
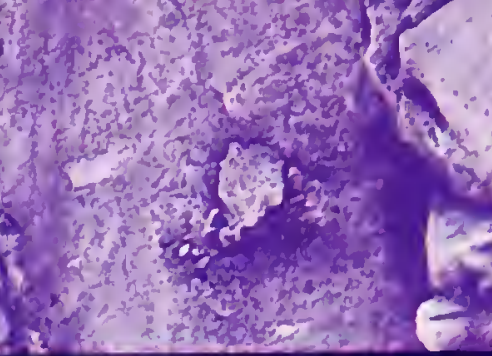

\title{
Cenozoic Mammals of Land and Sea: Tributes to the Career of Clayton E. Ray
}

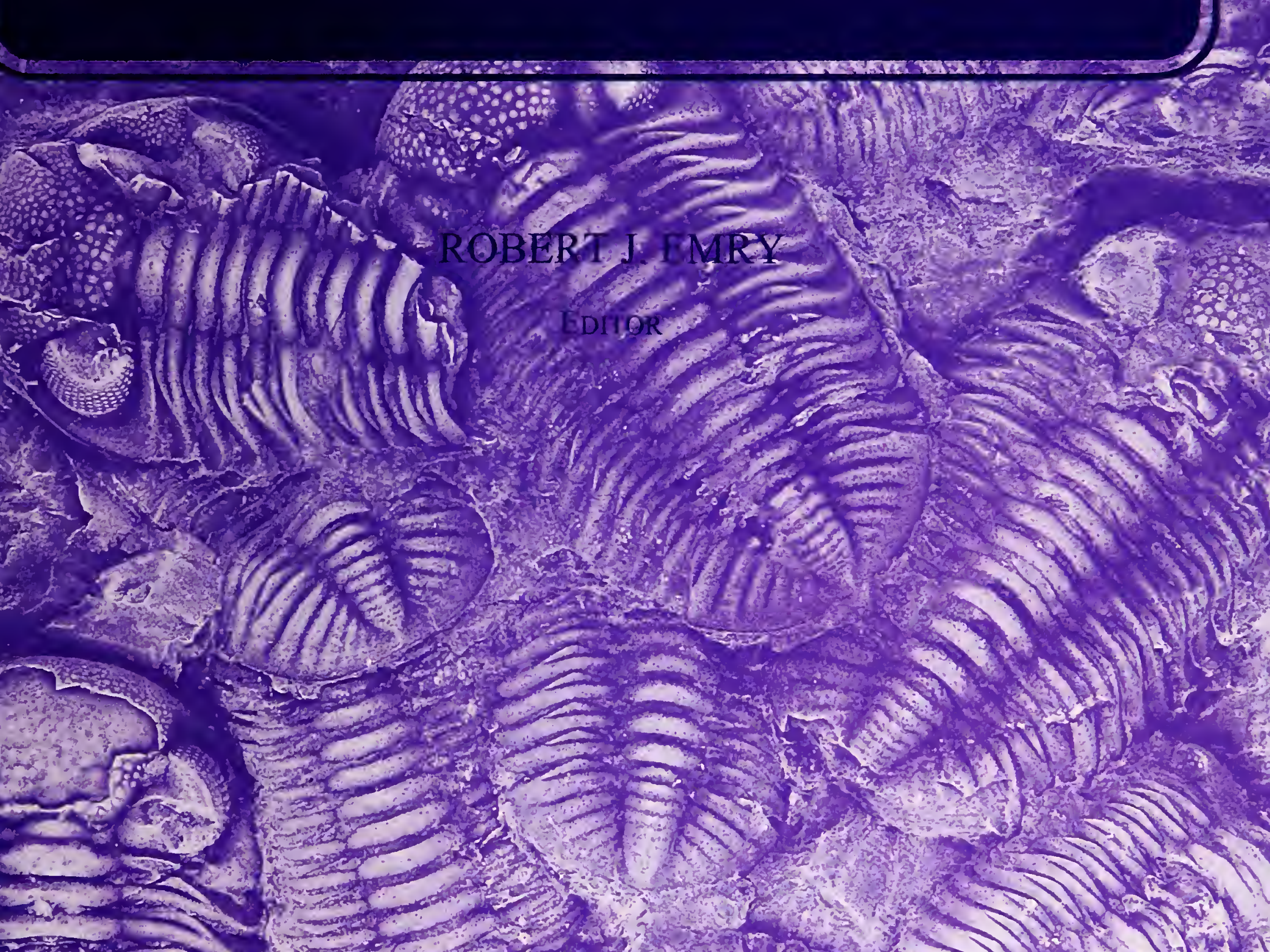
1 20 .

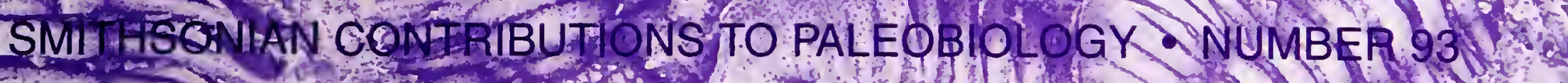




\title{
SERIES PUBLICATIONS OF THE SMITHSONIAN INSTITUTION
}

Emphasis upon publication as a means of "diffusing knowledge" was expressed by the first Secretary of the Smithsonian. In his formal plan for the Institution, Joseph Henry outlined a program that included the following statement: "It is proposed to publish a series of reports, giving an account of the new discoveries in science, and of the changes made from year to year in all branches of knowledge." This theme of basic research has been adhered to through the years by thousands of titles issued in series publications under the Smithsonian imprint, commencing with Smithsonian Contributions to Knowledge in 1848 and continuing with the following active series:

\author{
Smithsonian Contributions to Anthropology \\ Smithsonian Contributions to Botany \\ Smithsonian Contributions to the Earth Sciences \\ Smithsonian Contributions to the Marine Sciences \\ Smithsonian Contributions to Paleobiology \\ Smithsonian Contributions to Zoology \\ Smithsonian Folklife Studies \\ Smithsonian Studies in Air and Space \\ Smithsonian Studies in History and Technology
}

In these series, the Institution publishes small papers and full-scale monographs that report the research and collections of its various museums and bureaux or of professional colleagues in the world of science and scholarship. The publications are distributed by mailing lists to libraries, universities, and similar institutions throughout the world.

Papers or monographs submitted for series publication are received by the Smithsonian Institution Press, subject to its own review for format and style, only through departments of the various Smithsonian museums or bureaux, where the manuscripts are given substantive review. Press requirements for manuscript and art preparation are outlined on the inside back cover.

Lawrence M. Small

Secretary

Smithsonian Institution 


\title{
Cenozoic Mammals of Land and Sea: Tributes to the Career of Clayton E. Ray
}

\author{
Robert J. Emry \\ EDITOR
}

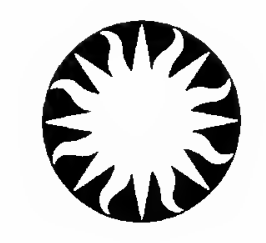

Smithsonian Institution Press

Washington, D.C.

2002 


\section{A B S T R A C T}

Emry, Robert J., editor. Cenozoic Mammals of Land and Sea: Tributes to the Career of Clayton E. Ray. Smithsonian Contributions to Paleobiology, 93, 372 pages, 197 figures, 11 plates, 46 tables, 2002.-This is a volume of collected papers published to honor the career of Clayton E. Ray, now Curator Emeritus in the Department of Paleobiology, National Museum of Natural History, Smithsonian Institution, and Curator of Late Cenozoic Mammals and of Fossil Marine Mammals in the same department for more than 30 years before his retirement in 1994. The volume includes a preface, a biography and bibliography of Clayton E. Ray, and 19 papers devoted principally to Pleistocene mammals and to fossil marine mammals. Gary Morgan describes late Pleistocene mammalian faunas from several sites in southernmost Florida and discusses the Neotropical influence in Florida's Pleistocene faunas. Richard H. Tedford describes the basicranium of the Pleistocene giant wombat Phascolonus gigas Owen and discusses its significance in marsupial phylogenetic reconstruction. Gerardo De Iuliis and A. Gordon Edmund describe Vassallia maxima Castellanos, the only pre-Pleistocene pampathere known in which a skull and mandible are associated with osteoderms; the range of osteoderm variation in one associated individual allows them to synonymize other taxa that had been based on osteoderm differences. Paul W. Parmalee and Russell Wm. Graham report additional records of the giant beaver, Castoroides, from the mid-South. Frederick Grady, Joaquin Arroyo-Cabrales, and E. Ray Garton report the northernmost known occurrence of vampire bats in the Pleistocene of eastern North America. H. Gregory McDonald reports the second known occurrence of the badger Taxidea taxus in the Pleistocene of Kentucky and discusses the paleoecological implications of the occurrence. Jerry N. McDonald and George E. Lammers describe Bison antiquus from Ontario and discuss the evolution of bison in the Holocene of North America. Daryl P. Domning presents a new analysis and interpretation of the terrestrial posture in desmostylians. Thomas A. Deméré and Annalisa Berta describe new material and present a phylogenetic analysis of the Miocene pinniped Desmatophoca oregonensis from Oregon. Irina A. Koretsky and Dan Grigorescu describe and evaluate the systematic position of the fossil monk seal Pontophoca sarmatica from the Miocene of eastern Europe. Irina A. Koretsky and Peter Holec describe a new, primitive, phocid pinniped from the early middle Miocene of Slovakia and discuss its bearing on the phylogeny and classification of pinnipeds. Irina A. Koretsky and Albert E. Sanders report remains of the oldest known phocid pinniped from the late Oligocene of South Carolina. R. Ewan Fordyce describes and discusses a bizarre archaic Oligocene dolphin from the eastern North Pacific, on which he bases a new species, genus, and subfamily. Christian de Muizon, Daryl P. Domning, and Darlene R. Ketten describe and discuss the paleobiology and behavior of an unusual walrus-convergent delphinoid cetacean from the early Pliocene of Peru. Susan D. Dawson and Michael D. Gottfried report paleopathologic conditions in a Miocene odontocete cetacean. Albert E. Sanders and Lawrence G. Barnes contribute two papers, both describing and analyzing new, primitive, cetotheriid mysticete cetaceans from the late Oligocene of South Carolina. James W. Westgate and Frank C. Whitmore, Jr., describe a new species of bowhead whale from the Pliocene Yorktown Formation in Virginia. James G. Mead and Rosemary G. Dagit present an account of the search for the I880s manuscript of J.A. Allen's unpublished monograph on the mammalian orders Cete and Sirenia; the manuscript was not found but the 12 plates that were prepared for it are published herein.

OFFICIAL PUBLICATION DATE is handstamped in a limited number of initial copies and is recorded in the Institution's annual report, Annals of the Smithsonian Institution. SERIES COVER DESIGN: The trilobite Phacops rana Green.

Library of Congress Cataloging-in-Publication Data

Cenozoie mammals of land and sea : tributes to the career of Clayton E. Ray / Robert J. Emry

p. cm.-(Smithsonian contributions to paleobiology; no. 93)

1. Mammals, Fossil. 2. Paleontology-Cenozoic. I. Emry, Robert J. II. Series.

QE881 .C46 $2002 \quad 569-\mathrm{dc} 2 \mathrm{I}$

The paper used in this publication meets the minimum requirements of the American National Standard for Permanence of Paper for Printed Library Materials Z39.48 - 1984. 


\section{Contents}

Page

Preface $\ldots \ldots \ldots \ldots \ldots \ldots \ldots \ldots \ldots \ldots \ldots \ldots \ldots \ldots \ldots \ldots \ldots$

Biography and Bibliography of Clayton Edward Ray

Ralph E. Eshelman, Robert J. Emry, Daryl P. Domning, and David J. Bohaska . . . . . 1

Late Rancholabrean Mammals from Southernmost Florida, and the Neotropical Influence in Florida Pleistocene Faunas

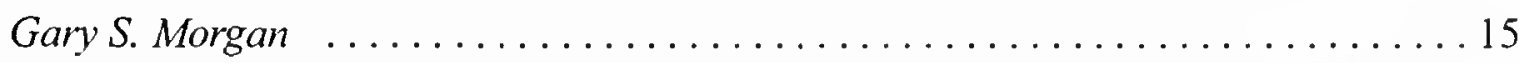

The Basicranium of the Giant Wombat Phascolonus gigas Owen (Vombatidae: Marsupialia) and Its Significance in Phylogeny

Richard H. Tedford $\ldots \ldots \ldots \ldots \ldots \ldots \ldots \ldots \ldots \ldots \ldots \ldots$

Vassallia maxima Castellanos, 1946 (Mammalia: Xenarthra: Pampatheriidae), from Puerta del Corral Quemado (Late Miocene to Early Pliocene), Catamarca Province, Argentina

Gerardo De Iuliis and A. Gordon Edinund . . . . . . . . . . . . . . . . . 49

Additional Records of the Giant Beaver, Castoroides, from the Mid-South: Alabama, Tennessee, and South Carolina

Paul W. Parmalee and Russell Wm. Graham ....................65

The Northernmost Occurrence of the Pleistocene Vampire Bat Desmodus stocki Jones (Chiroptera: Phyllostomatidae: Desmodontinae) in Eastern North America

Frederick Grady, Joaquin Arroyo-Cabrales, and E. Ray Garton . . . . . . . . . . 73

Second Record of the Badger Taxidea taxus (Schreber) from the Pleistocene of Kentucky and Its Paleoecological Implications

H. Gregory McDonald ............................ 77

Bison antiquus from Kenora, Ontario, and Notes on the Evolution of North American Holocene Bison

Jerry N. McDonald and George E. Lammers . . . . . . . . . . . . . . 83

The Terrestrial Posture of Desmostylians Daryl P. Domning . . . . . . . . . . . . . . . . . . . . . . . . . . . . 99

The Miocene Pinniped Desmatophoca oregonensis Condon, 1906 (Mammalia: Carnivora), from the Astoria Formation, Oregon

Thomas A. Deméré and Annalisa Berta ................... 113

The Fossil Monk Seal Pontophoca sarmatica (Alekseev) (Mammalia: Phocidae: Monachinae) from the Miocene of Eastern Europe

Irina A. Koretsky and Dan Grigorescu . . . . . . . . . . . . . . . . . . . . 149

A Primitive Seal (Mammalia: Phocidae) from the Early Middle Miocene of Central Paratethys

Irina A. Koretsky and Peter Holec . . . . . . . . . . . . . . . . . 163

Paleontology of the Late Oligocene Ashley and Chandler Bridge Formations of South Carolina, 1: Paleogene Pinniped Remains; The Oldest Known Seal (Carnivora: Phocidae)

Irina A. Koretsky and Albert E. Sanders . . . . . . . . . . . . . . . . . . . . 179

Simocetus rayi (Odontoceti: Simocetidae, New Family): A Bizarre New Archaic Oligocene Dolphin from the Eastern North Pacific

R. Ewan Fordyce ............... . . . . . . . . . . 185

Odobenocetops peruvianus, the Walrus-Convergent Delphinoid (Mammalia: Cetacea) from the Early Pliocene of Peru

Christian de Muizon, Daryl P. Domning, and Darlene R. Ketten . . . . . . . . . 223 
Paleopathology in a Miocene Kentriodontid Dolphin (Cetacea: Odontoceti)

Susan D. Dawson and Michael D. Gottfried .................... 263

Paleontology of the Late Oligocene Ashley and Chandler Bridge Formations of South Carolina, 2: Micromysticetus rothauseni, a Primitive Cetotheriid Mysticete (Mammalia: Cetacea)

Albert E. Sanders and Lawrence G. Barnes ..................... 271

Balaena ricei, a New Species of Bowhead Whale from the Yorktown Formation (Pliocene) of Hampton, Virginia

James W. Westgate and Frank C. Whitmore, Jr. . . . . . . . . . . . . . 295

Paleontology of the Late Oligocene Ashley and Chandler Bridge Formations of South Carolina, 3: Eomysticetidae, a New Family of Primitive Mysticetes (Mammalia: Cetacea)

Albert E. Sanders and Lawrence G. Barnes ........................ 313

Plates for Joel Asaph Allen's Unpublished Monograph on the Mammalian Orders

Cete and Sirenia and a Record of the Search for the Manuscript

James G. Mead and Rosemary G. Dagit . . . . . . . . . . . . . . . . . . . . 357 


\section{Preface}

When Clayton Ray retired from the National Museum of Natural History at the end of 1994, those of us who had been closely associated with him for many years, who had sat down to lunch with him several times each week, who had talked with him almost daily, were left with the feeling that we should do something to recognize his career and his contributions to his profession. Clayton, typically, had discouraged any kind of social event, such as a department party or luncheon, to celebrate the occasion of his retirement. So, mindful of what Clayton's advice would have been had we asked for it, we opted to do something useful instead: we invited some of his colleagues, mainly those who had worked closely with him on certain projects, who had been his coauthors, or who had studied groups of special interest to him, to contribute papers to be assembled as a festschrift. The process of completing this volume has gone on longer than intended (although not so much longer than expected), but this result surely makes the wait worthwhile. Although the "Contents" might suggest that a rather disparate range of topics is represented, in fact the contributions are all representative of Clayton's diverse interests during his career-late Cenozoic mammals, Caribbean/Neotropical mammalian biogeography, marine mammals.

There is hardly a paper in this volume to which Clayton hasn't contributed in some way, in some cases quite directly, and many of these papers would simply not have been possible without some kind of aiding and abetting by him. When we began to assemble this volume, some of the papers now included herein were in fact being prepared as individual Contributions to Paleobiology, with Clayton's encouragement, and in at least one instance, with his coauthorship. The authors of these contributions were eager to have them included in this tribute, even though some of the papers would undoubtedly have been published sooner as individual contributions. As editor, I take this opportunity to express my gratitude to all of the contributors for their patience in seeing this through the long process from conception to publication. I also want especially to thank David J. Bohaska, Irina A. Koretsky, and Robert W. Purdy, without whose ideas, encouragement, and assistance that long process might have been immeasurably longer. Irina A. Koretsky and Mary A. Parrish both stepped into the breach to help with illustration revisions during the final stage of production.

Early in the following biography, I mention that Clayton was born a Hoosier, which I am confident that readers will interpret in its usual meaning: the nickname for a native or resident of Indiana. The term sometimes also connotes a hayseed, a bumpkin, an unskilled rustic. Clayton's well-known sense of humor sometimes includes self-deprecation, so whereas he might not reject this meaning outright, it is hardly appropriate for a naturalized Virginian gentleman farmer. But there is a particular meaning of the term that applies to Clayton. The several office dictionaries that I consulted gave no etymology for hoosier, but the Webster's Third New International Dictionary, Unabridged does have this probable etymology: "alter. of E dial. hoozer anything large of its kind." So the word does fit. Although Clayton is not large in physical stature, he must have carried some weight; the breadth and depth of the imprints he has left through the course of his professional career are unmistakable evidence of "a large one of his kind," not the Hoosier by biogeographical chance, but the self-made Hoosier.

Robert J. Emry 


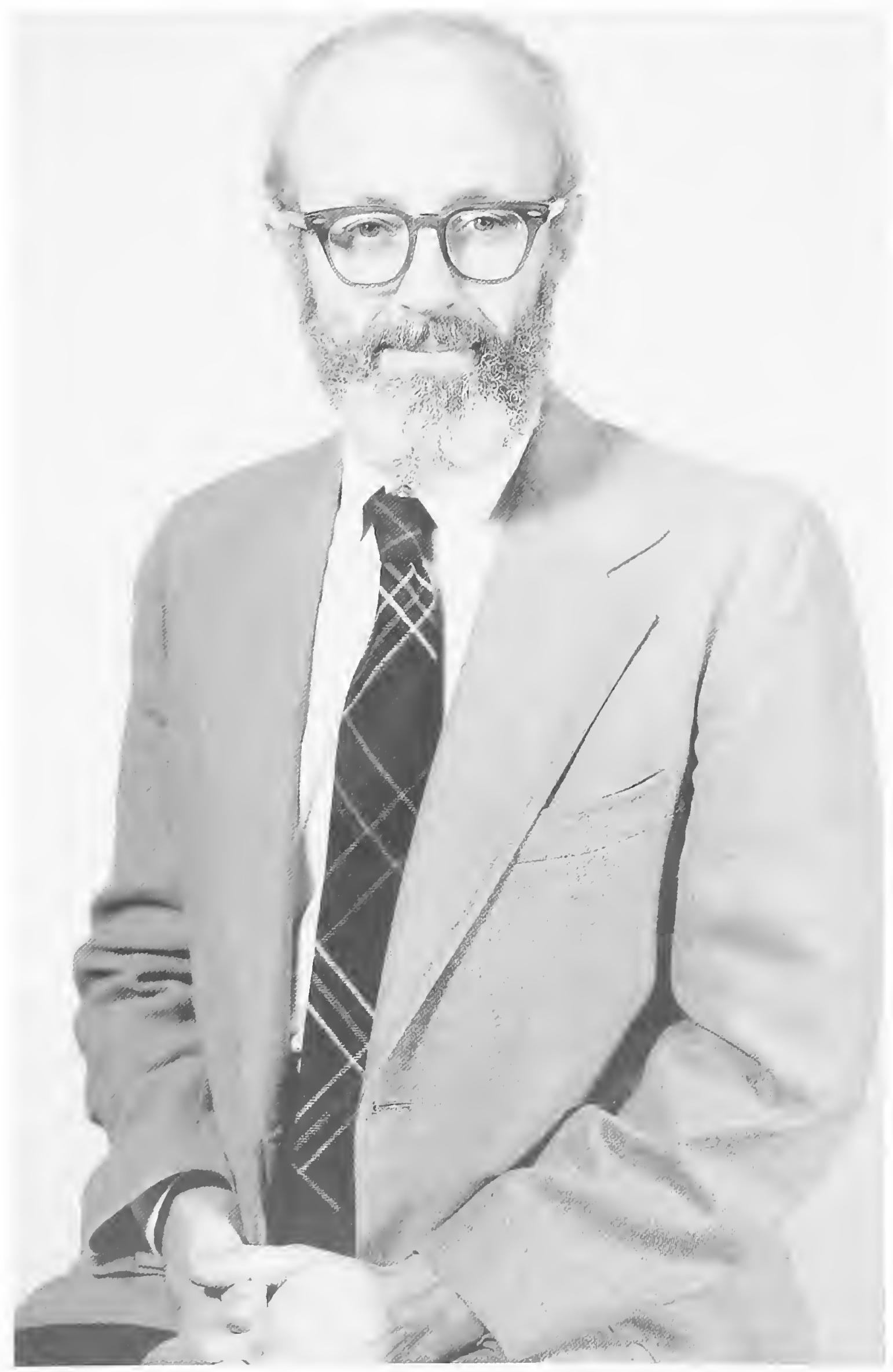

Clayton E. Ray, 1979. 


\title{
Biography and Bibliography of Clayton Edward Ray
}

\author{
Ralph E. Eshelman, Robert J. Emry, \\ Daryl P. Domning, and David J. Bohaska
}

With this volume we pay tribute to our mentor and colleague, Clayton E. Ray. Scientist, historian, ardent supporter of amateur and professional paleontologists alike, Clayton is most especially a sound advisor and a valued friend. One of the things we miss most as a result of his retirement is the benefit of his full-time good counsel: we counted on his instinct for the clearheaded, no-nonsense approach to problems, minor or major, and we relied upon him as a source for thoughtful, good advice, always strengthened with encouragement. In all of his personal interactions, Clayton is invariably perceptive, stimulating, helpful, patient, and kind. All of these qualities, combined with his quick wit and keen sense of humor, have enriched our long associations with him. We all hope that some of his attributes have been communicable - that something might have rubbed off on all of us to make us more like him.

When we began to organize this tribute, our intention was to publish it as a surprise to Clayton, but the process has now taken so long that the bigger surprise will be if Clayton does not find out what is afoot. One disadvantage of intending this as a surprise is that it inhibited our grilling him for biographical information, and thus limited our biography essentially to what is known or could be researched by all of us-the professional, public aspect. Consequently, this cannot be expected to be an in-depth biography, but a rather superficial review of the general trends in Clayton's professional career.

Clayton's wife, Donna, supplied us with a few of the basic facts of his pre-university days. Clayton was born a Hoosier, in Henry County, Indiana, to Lloyd and Ruth Ray, on 6 February 1933 and grew up in central Indiana. Clayton remembers

Ralph E. Eshelman and Darryl P. Domning, Research Associates, Department of Paleobiology, National Museum of Natural History, Smithsonian Institution, Washington, D.C. 20560-0121; Robert J. Emry and David J. Bohaska, Department of Paleobiology. National Museum of Natural History. Smithsonian Insttitution, Washington, D.C. 20560-0121. fondly the rural life he experienced around his boyhood home in Indiana, especially the summers spent on his grandparents' farm. He attended high school in Indianapolis, ranked third in his class at graduation, and was awarded a full scholarship to Harvard College. He married his high-school sweetheart, Donna, and together they raised four daughters.

Clayton enrolled at Harvard College, Cambridge, Massachusetts, in 1951 and received his A.B. degree in geology in 1955. He was elected to Phi Beta Cappa. His advisor as an undergraduate was Alfred $\mathrm{S}$. Romer, one of the most prominent and highly respected vertebrate paleontologists of his time. Toward the end of his senior year, as Clayton met with Romer to discuss graduate school possibilities, Romer revealed to him, in confidence, that Brian Patterson would be coming to Harvard and that Clayton might want to discuss graduate school possibilities with Patterson when he came to visit. Clayton believes that he was the first "civilian" (as he puts it) to know that Brian Patterson would be moving from Chicago to Harvard. Clayton followed Romer's advice, met with Patterson, and decided to remain at Harvard for advanced degrees with Patterson as his advisor. Clayton does stress, however, that, in the real, practical sense, it was Professor Ernest Williams who served as his graduate advisor and had the greatest impact on his career. It was Williams, for example, who steered Clayton's interests into Quaternary mammals of the Neotropics, and the Caribbean region in particular. Clayton was awarded his A.M. degree in 1958 and his Ph.D. in 1962 from Harvard, both in geology.

In September 1959 Clayton moved to the University of Florida, Gainesville, where he accepted the positions of Interim Assistant Professor in the Department of Biology and Interim Assistant Curator at the Florida State Museum (now the Florida Museum of Natural History). Upon receiving his doctorate from Harvard, he was promoted to Assistant Professor and Assistant Curator, positions he held until he moved to the Smithsonian Institution in 1963. 
Among his duties in Florida was, of course, fielding questions about fossils from visitors. One day he was manning the museum's front office in the old Seagle Building on Gainesville's main street when a high school student from Biloxi, Mississippi, named Daryl Domning walked in, his long-suffering parents in tow, seeking publications and tips on where to collect fossils in the area. Clayton patiently gave them directions to Paynes Prairie, an area on the edge of town where spoil piles from interstate highway construction offered bones of Pleistocene critters to the casual collector; afterward, he helped them identify their finds. This brief encounter was followed by countless more in subsequent years, as Clayton came to play a major role in fostering Domning's career as a vertebrate paleontologist. The two have since coauthored nearly a dozen publications on marine mammals.

Early in the 1960s, the National Museum of Natural History, Smithsonian Institution, began planning a major new exhibition hall devoted to Pleistocene mammals. When the museum decided in 1963 to hire a new curator to be in charge of developing these new exhibits, Clayton was the choice. Clayton's letter accepting the new position was typical of him in its thoughtfulness and clarity; he outlined prior obligations that he had to meet and asked to make his move to Washington, D.C., between school semesters to lessen the disruption to his children's education. On 18 December 1963, Clayton became Associate Curator of Later Cenozoic Mammals at the museum, where he remained until his retirement more than 30 years later.

It is probably not generally known that when research scientists (i.e., curators) are hired at the National Museum, they do not immediately become federal civil service employees, but must first complete a conditional, term appointment of at least one year. If all is well at the end of that term, the appointment is then converted to Career Civil Service status. C.L. (Lew) Gazin, senior vertebrate paleontologist at the Smithsonian at the time Clayton arrived, wrote the following evaluation of Clayton's first year:

\begin{abstract}
I have found him to be a highly intelligent and industrious worker. During the rather short time since receiving his doctorate at Harvard he has had published or has completed for publication a surprising number of well-written and carefully thought out papers. Much of the time of his first year here had been devoted, as anticipated, to planning with the exhibits staff renovation of Hall 6 for a new series of exhibits which are to depict the Pleistocene epoch in vertebrate paleontology. Nevertheless, this has not prevented him from carrying on field work in Mexico during the early part of the summer and in initiating at other times several short trips of profit to the museum. Moreover, in addition to keeping abreast of a rather considerable amount of examination and report work he has managed to squeeze in an appreciable amount of research and give a few lectures. Dr. Ray is a personable young man who gets along well with his colleagues and makes a good impression on outsiders. It gives me pleasure to report that we are entirely satisfied with his work.
\end{abstract}

So began Clayton's career of more than three decades as a Smithsonian Curator. Clayton officially retired at the end of September 1994 and is now a Curator Emeritus in the Department of Paleobiology.

\section{Fieldwork and Research}

Clayton's earliest publications were on modern mammals, including remains of mammals recovered from archeological sites, on Pleistocene mammals, and even on an osteological peculiarity of the extant gopher tortoise (see bibliography, following). In 1960 he cofounded, with two archeologists at the University of Florida, the first formally constituted museum program in archaeozoology. Elizabeth Wing, an early associate in the program, has gone on to become a leading figure in the field, and similar formal programs in archaeozoology are now common in other museums and universities. Clayton's interests in archaeozoology have continued throughout his career, even as his research evolved to focus more on Quaternary mammals and eventually on fossil marine mammals. The latter, however, had been prominent among his interests almost from the start. When Remington Kellogg, the preeminent curator of fossil marine mammals at the Smithsonian, passed away, Clayton's attention shifted progressively to marine mammals, and by the late 1970s this assumed priority over his work on Quaternary paleontology. The collections and research data on Quaternary mammals that Clayton had brought together were largely bequeathed to others. For example, bats were turned over to Gary Morgan, ungulates to Jerry McDonald, Caribbean oryzomyine rodents to Mike Carleton, and faunal studies to Ralph Eshelman. In concentrating on marine mammal fossils at the Smithsonian, Clayton continued a tradition that goes back almost as far as the Institution itself. In fact, the first vertebrate fossil cataloged in the Smithsonian's collections was a marine mammal bone, and work on fossil marine mammals has been conducted by scientists such as F.A. Lucas, Frederick True, Gerrit S. Miller, Jr., Remington Kellogg, and Frank C. Whitmore, Jr. Because of this long-standing emphasis, the fossil marine mammal collection at the Smithsonian is the largest in the United States and probably in the world; certainly it is one of the two most important fossil marine mammal collections in the world. Clayton's contributions have added substantially to this already strong collection; most important, he was the agent directly responsible for the Smithsonian's acquiring the Douglas Emlong collection of Tertiary marine mammals from the West Coast, and for nearly three decades he oversaw the collecting of the huge volume of material from the late Tertiary Lee Creek Mine in North Carolina. In his own research, Clayton has taken a lively interest in nearly every group of aquatic mammals, but pinnipeds most of all; among these, thanks largely to the gargantuan Lee Creek project, he has focused mainly on the phocid seals and on walruses (the subject of his first marine mammal paper, way back in 1960).

In the 1970s, Clayton and Charles Handley, Curator of Mammals in the Division of Mammalogy of the Department of Vertebrate Zoology, attempted to form a marine mammal study center for both fossil and modern marine mammals at the Smithsonian. An important objective was to bring the separate collections together both administratively and, especially, physically. As anyone who has studied whale skeletons knows, 


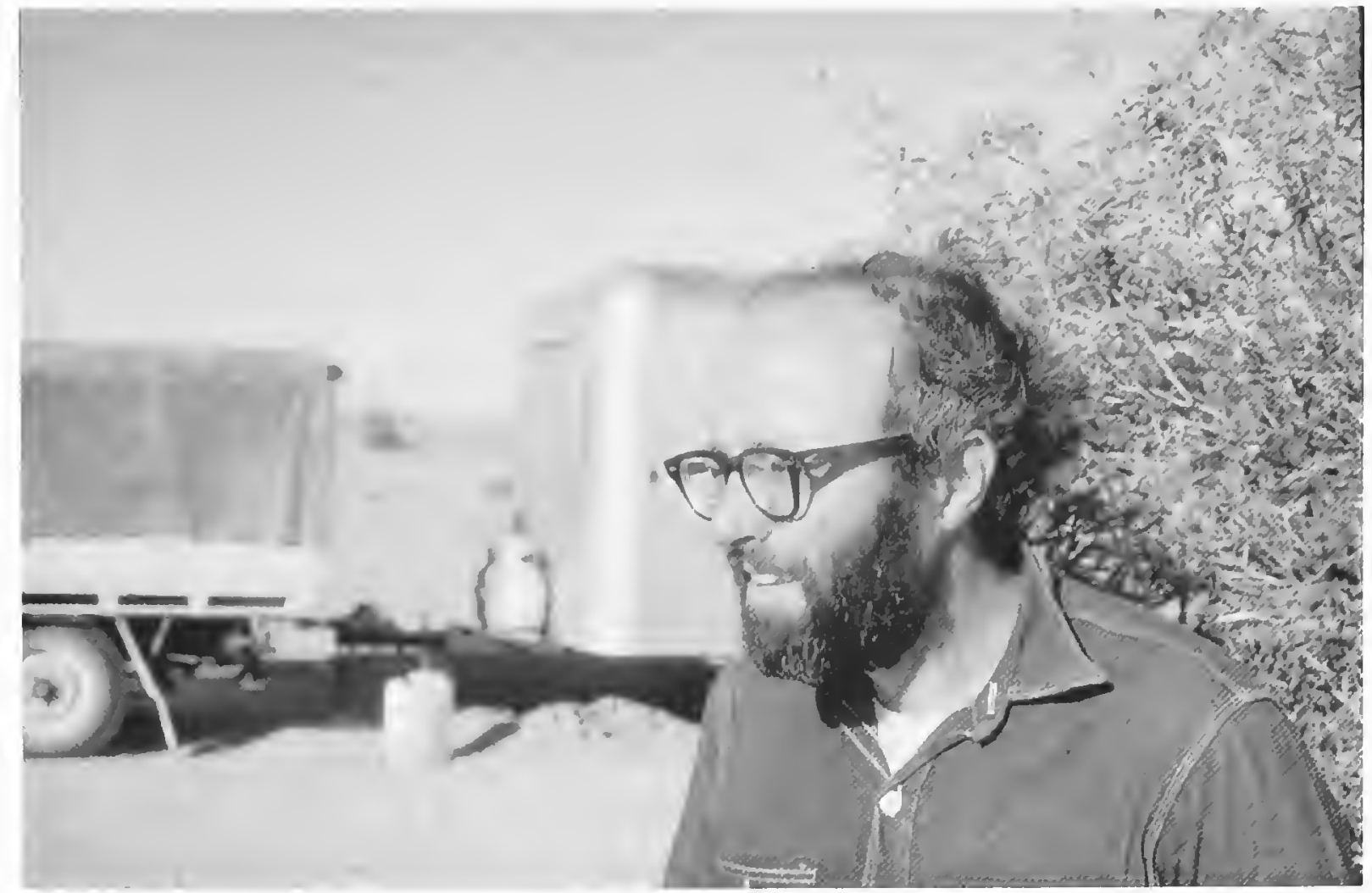

Figure 1.-Clayton E. Ray, ready for the long drive to Adelaide, after breaking camp at the end of field work, Lake Callabonna, South Australia, 19 September 1970. (Photograph by R.J. Emry.)

the specimens are immovable in any practical sense, and comparative studies could be greatly facilitated by having all material, fossil and modern, stored together. Space was temporarily obtained at a surplused U.S. Navy building (a World War II torpedo factory) in Alexandria, Virginia. The modern whale collections were moved there from the museum, but this space was lost before the fossil collections could be moved, and no other adequate space could be found. These efforts did result, however, in a unified library, the Remington Kellogg Library of Marine Mammalogy. A new curatorial position for modern whales was established, and a monthly seminar on marine mammals was begun in 1979. Now, in 2001, the goal of bringing the modern and fossil skeletal materials together has finally been partially realized; the fossil baleen whale material has followed the modern material to the Smithsonian's Garber Facility, a new storage facility in Silver Hill, Maryland.

Clayton's early fieldwork included numerous sites in Florida, which he worked from 1956 through 1964. In 1958 Clayton conducted fieldwork in the Dominican Republic and Puerto Rico, and in 1963 he went back to the Dominican Republic and also to the Lesser Antilles.

In 1964 Clayton conducted fieldwork at Ladds Quarry, Georgia, collecting an extensive fauna from a paleoecologically critical area that had not previously been studied; this collection represents one of the larger Pleistocene faunas of North America, with the bulk of the material now housed in the Smithsonian.

In 1964 and 1966 Clayton participated in a multidisciplinary study, sponsored by Harvard University and the National Science Foundation, at Valsequillo, Puebla, Mexico, where late Pleistocene deposits contained associated early humans and fossil vertebrates. Much of the material collected was retained by the Mexican government, but some of the fossil vertebrates were accessioned into the collections of the Smithsonian.

From 1964 through 1967, Clayton conducted fieldwork in the late Pleistocene deposits at Saltville, Virginia, supported by a grant from the National Science Foundation. Specimens resulting from this work, and associated specimens donated by Virginia Polytechnic Institute, now reside at the Smithsonian. Subsequently, Research Associate Jerry McDonald continued fieldwork at the site for a number of years.

In 1966 Clayton participated in fieldwork at Gate City, Virginia, where parts of a skeleton of Megalonyx were discovered in a cave. The specimen is now part of the Smithsonian collections. In 1967 Clayton oversaw fieldwork in borrow pits around the Norfolk, Virginia, area; this work produced about 200 late Pleistocene vertebrate specimens, which, for specimens from the Atlantic Coastal Plain, are unusual in having good stratigraphic control.

In 1968 Clayton worked in Sardinia, Sicily, Malta, and Majorca. One objective of this work was to acquire material for the new Pleistocene exhibits then being developed at the Smithsonian, but this work also produced microfaunal material for future research purposes.

In 1970 Clayton, accompanied by Chief Preparator Franklin Pierce, joined Dick Tedford and Bob Emry from the American Museum of Natural History for fieldwork in the dry northern interior of South Australia (Figure 1). A primary objective of that expedition was also to acquire material for the Pleistocene exhibits. Ten weeks of collecting in Pleistocene deposits exposed in the dry, deflating bed of Lake Callabonna produced numerous skeletons of extinct Australian megafauna, including 
giant marsupials and giant birds. Among the specimens personally collected by Clayton were two skeletons of the giant wombat Phascolonus; these specimens are the material basis of Dick Tedford's paper in the present volume. A cast of one of the skeletons is now exhibited at the American Museum of Natural History.

Since 1970, most of Clayton's fieldwork has been in connection with his long-term project at the Lee Creek Phosphate Mine in eastern North Carolina. This project has resulted in the majority of vertebrate fossil specimens accessioned into the Smithsonian's collections during this time. Clayton worked with and advised many amateur collectors who helped gather specimens, and he encouraged them to donate important material to the Smithsonian. He has also worked with nearly 50 authors to study and publish the findings. Thus far, three volumes have been published, covering the geology of the site, the plant and invertebrate fossils, and all non-mammalian vertebrates. Clayton is presently close to completing the editing of the fourth and final volume (this one covering mammals, marine and terrestrial) resulting from this research. The Lee Creek Phosphate Mine will certainly be the most comprehensively studied fossil site on the Atlantic Coastal Plain, and, when completed, the four volumes will record what is very likely the taxonomically most diverse fossil assemblage known from a single site.

In addition to his own work on Smithsonian collections, Clayton has actively promoted work on the collections by others. Much of this was accomplished by his taking full advantage of Smithsonian in-house funding sources, such as the Short-Term Visitor Awards Program, Pre- and Postdoctoral Fellowships, the Remington Kellogg Fund, and the Walcott Fund, as well as outside sources (e.g., the Marine Mammal Commission), to enable non-Smithsonian researchers to study and publish on the collections and thereby add to the knowledge about them.

Clayton was advisor to several Smithsonian Predoctoral and Postdoctoral Fellows whose research included using the Smithsonian collections. Among them are David Gillette, who reviewed the glyptodonts of North America; Russell Graham, who worked up the Valsequillo fauna of Mexico that Clayton had collected; Ewan Fordyce, from New Zealand, who studied primitive cetaceans in the Emlong collection; Kishor Kumar, from Pakistan, who also researched primitive cetaceans; Al Myrick, who studied Miocene porpoises; Jerry McDonald, then of Radford University, who worked on fossil ovibovines (musk oxen); and Irina Koretsky, a specialist on fossil phocid pinnipeds, who had emigrated to the United States from Kiev, Ukraine.

Under Clayton's sponsorship, many others received shortterm support for a variety of projects: Joaquín Arroyo-Cabrales, Mexico, worked on vampire bats; Oscar Carranza, Mexico, Mexican faunas; Pamela Rasmussen and Jonathan Becker, fossil birds from Lee Creek Mine; Castor Cartelle, Brazil, megatheres; Laszlo Kordos, Budapest, Miocene land and marine faunas; Guram Mchedlidze, Tbilisi, mid-Tertiary Cetacea; Irina Dubrovo, Moscow, fossil cetaceans; Christian de Muizon, Lima (now Paris), Pliocene pinnipeds; Oldrich Fejfar, Prague, Miocene rodents; Mario Cozzuol, Buenos Aires, fossil Cetacea; Annalisa Berta, Tom Deméré, and Sharon Messenger, all marine mammal workers from San Diego.

Clayton was an Adjunct Professor in the Department of Geological Sciences, Virginia Polytechnic Institute, in 1969. $\mathrm{He}$ also served on the doctoral committee of Gregory McDonald, University of Toronto, whose dissertation dealt with edentates.

Clayton has been the long-term sponsor of several Research Associates who have conducted collection-based research at the museum, have added materials to the collections, and have contributed substantially to curation of certain collections: Taseer Hussain, Neogene mammals; Annalisa Berta, fossil pinnipeds; Daryl Domning, fossil Sirenia and Desmostylia; Ralph Eshelman, Neogene faunas; Jerry McDonald, Pleistocene ungulates; Charles Repenning, fossil pinnipeds and microtines; and Frank Whitmore, Jr., fossil whales.

This collaborative work has resulted in important studies of such topics as faunas and stratigraphy of Paratethys, emphasizing fossil pinnipeds; archaic whales from New Zealand, Antarctica, and the west and southeast coasts of the United States; the most diverse nonmarine Miocene mammal fauna east of the Mississippi River outside of Florida; and a bizarre cetacean with convergent walrus-like morphology from the Pliocene of Peru. Clayton's recommendations made at the 1967 Darwin Conference led to the Quaternary cave studies conducted by Dave Steadman on the Galápagos Islands.

Since 1976, Clayton has been an author of nine publications of the Smithsonian Contributions to Paleobiology (nos. 28, 40, $51,52,53,59,61,66$, and 90). Number 59 (1986, coauthored with Daryl Domning and Malcolm McKenna), "Two New Oligocene Desmostylians and a Discussion of Tethytherian Systematics," reported a link among major groups of mammals, with important information bearing on relationships at the supraordinal level. The paper has since been widely cited by other authors discussing the higher-level classification of mammals.

Among Clayton's other more important contributions are his papers on the oldest known pinniped skeleton, which has stimulated and contributed to ongoing intensive debate on the definition, origin (or origins?), and relationships within and outside the Pinnipedia: is the Pinnipedia a natural monophyletic group or the result of convergence of two groups of carnivores with separate origins?

In addition to his scientific publications, Clayton has written book reviews and popular articles. Examples include reviews of the Sierra Club Handbook on Marine Mammals and Sutcliff's On the Track of Ice Age Mammals. Clayton served as a consultant on the Smithsonian-American Heritage book The Evidence of Evolution, and the Macmillan Company book 
Hunting for Fossils. Popular articles include "The time has come the walrus said..." in Virginia Explorer; "Outerbank Ovibovine Adds Link to Musk Ox Research," and "Catawba's wandering walrus: Case of peripatetic pinniped solved," both in Whalebones, Newsletter of the North Carolina State Museum of Natural History.

Clayton has been, of course, a frequent reviewer of proposals and manuscripts for the National Science Foundation, National Geographic Society, Sigma Xi, American Philosophical Society, Journal of Paleontology, Journal of Vertebrate Paleontology, and other similar journals and grant-awarding agencies. He has a well-deserved reputation as a thorough reviewer who not only finds mistakes but also offers solutions. He never met a split infinitive that he could not repair, and it is almost a sure bet that he will notice some in this volume.

\section{Service to His Profession}

During his freshman year at Harvard College, Clayton received a $\$ 50$ grant from a fund that had been established in the seventeenth century to enable students to return to their homes to be with their families during the Christmas holidays. To this event Clayton attributes the beginning of his continuing interest in establishing and supporting endowment funds. He was instrumental in establishing the Cooper Fund and the Kellogg Fund at the Smithsonian, and the Society of Vertebrate Paleontology Endowment Fund.

The Society of Vertebrate Paleontology Endowment Fund did not yet exist when Clayton became Chair of the Development Committee in 1986. Clayton had been concerned that the society might not be able to continue its long support of the Bibliography of Fossil Vertebrates, an important reference series within the field, but one that was becoming increasingly expensive to produce. Clayton urged the society to establish an endowment fund that would ensure the continuation of the bibliography, and this led to his being invited to chair an endowment committee. His committee organized a fund-raising campaign with a goal of $\$ 500,000$ within five years. That goal was surpassed within three years; by 1992 the balance was over $\$ 750,000$ and now is more than twice that amount. At the 1989 annual meeting, the Society of Vertebrate Paleontology presented Clayton with a special citation and plaque for his service on the committee. Clayton's response to the membership is so typical of him that it is worth quoting here for the insight it gives into his character:

On a personal note, as this is my last communication to you from the Development Committee, I was surprised at the business meeting and very pleased to receive a plaque from the Society in recognition of my service on the committee. Rather I owe thanks to the Society for enabling me to pursue on its behalf a cause that $I$ believe to be profoundly important to its future, for making that pursuit successful, and for affording me the opportunity to work closely with the best of the best in VP. Most of all I am proud of my good judgment as to the character of our members.
Clayton was also the leader in persuading the Society of Vertebrate Paleontology to assume responsibility for publishing the Journal of Vertebrate Paleontology. His effort began with an open letter to the society, which resulted in the formation of the Journal of Vertebrate Paleontology Committee. He was asked to chair this committee, and he did so from 1982 to 1985. Work toward this end involved distribution of a mail ballot to the membership for approval to take on such an effort, necessary revision of the society's constitution, and negotiations with the University of Oklahoma and with Jiri Zidek, the journal's first editor, who had founded the journal with support from the University of Oklahoma. The Journal of Vertebrate Paleontology has continued to grow as a professional, highly respected publication and has prompted renewed efforts to increase the society's endowment in order to ensure timely publication of accepted manuscripts.

From October 1975 through December 1977, Clayton served as Chairman of the Committee of Scientific Advisors on Marine Mammals for the Marine Mammal Commission. John Twiss, Executive Director of the Commission, wrote, in a letter to Bob Emry, 18 August 1999, that Clayton "was an able chairman who had considerable influence upon the Committee's activities. Particularly noteworthy were his efforts to focus attention on the plight of the West Indian manatee (Trichechus manatus). In no small measure as a result of his work, the Commission put into place aggressive research and management programs which succeeded in bringing greatly increased Federal and state resources to bear on this species' protection and conservation.'

In the 1960s, Clayton served on the American Geological Institute-Geological Society of America Geoscience Information Committee. Clayton served on the Advisory Panel on the Future of Mammalogy at the Museum of Comparative Zoology, Harvard University, in 1985; he was a member of the Search Committee for Curator of Vertebrate Paleontology, American Museum of Natural History, New York, in 1986.

Clayton was the keynote speaker at the first annual meeting of the Marine Mammal Society and authored a paper that was published in the first issue of its journal, Marine Mammal Science.

Many of Clayton's research papers exhibit a strong historical component, and he has a keen interest in the history of our profession and the lives and careers of its early practitioners, those giants whose shoulders we all stand on. Among the accomplishments that Clayton is most proud of is his proposal to name the auditorium at the National Museum of Natural History after Spencer Fullerton Baird, followed by a successful campaign to persuade the museum's administration to do so. Clayton was banquet speaker at the 1989 Florida Paleontological Society meeting on the occasion of the centennial of the first publication on Florida vertebrate paleontology by Joseph Leidy. He was also the invited speaker at the 1991 ceremony dedicating the Wagner Free Institute of Science, Philadelphia, as a National Historic Landmark on the centennial of Joseph Leidy's death. 


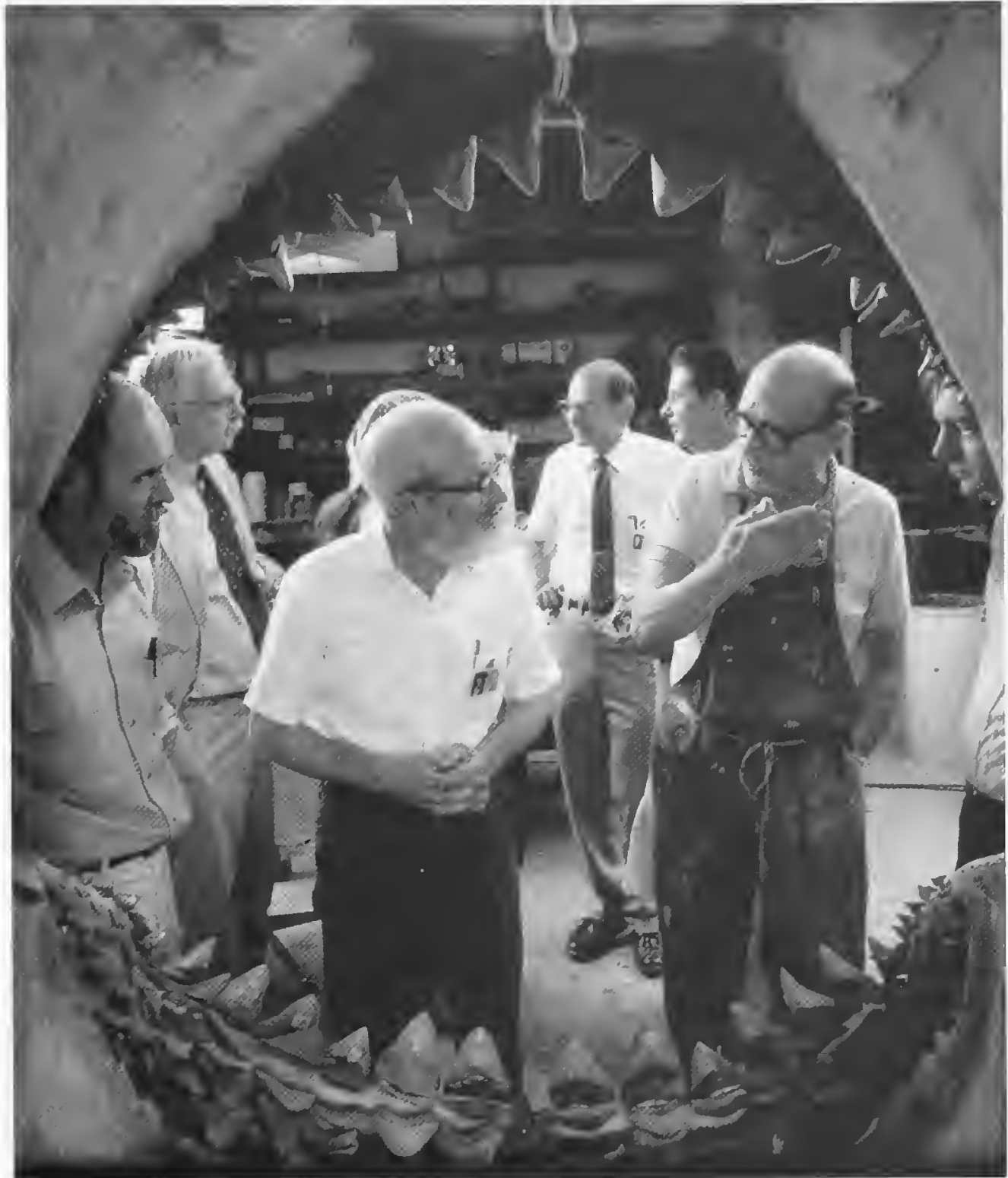

FIGURE 2 (left).-Clayton E. Ray reviewing the modeled jaws of Carcharodon megalodon containing actual fossil teeth from Lee Creek Mine, prior to installation in the paleontology exhibits at the National Museum of Natural History, 1985. From left: Robert J. Emry, Curator, Department of Paleobiology; Thomas R. Harney, Public lnformation Officer, Office of the Director; Clayton E. Ray, Curator, Department of Paleobiology; an unidentified person obscured by Clayton Ray; Victor G. Springer, Curator, Department of Vertebrate Zoology; Ian G. MacIntyre, Curator and then Chairman, Department of Paleobiology; Walter E. Hock, Sr., Modelmaker, Smithsonian Exhibits Central; Robert W. Purdy, Museum Specialist, Department of Paleobiology. All NMNH staff except Hock. (Photograph by Chip Clark, NMNH.)

\section{Professional Affiliations}

Clayton has been a Life Member of the American Society of Mammalogists since 1956. He is an Honorary Member of the Marine Mammal Society; a member of the Biological Society of Washington; Florida Paleontological Society; Georgia Academy of Science; Gruppo Grotte Nuorese, Associazione Speleologica; Paleontological Society of Washington; William Pengelly Cave Studies Association; and United States Association for Quaternary Research. He is the only Honorary Charter Member of the North Carolina Fossil Club. He is also a member of the Society of Vertebrate Paleontology, where he served as Chair of the Journal of Vertebrate Paleontology Committee, 1982-1985, Chair of the Development Committee, 1986-1989, and Vice President and President-Elect, 1990-1992.

\section{Exhibits}

Early in the planning phase of the Pleistocene Hall at the National Museum, Clayton suggested a multidisciplinary approach of using "living fossils" and introducing the relationship of early humans with the flora and fauna. During development of the Pleistocene Hall from 1964 through 1971,
Clayton advised on the preparation of all skeletal mounts and murals, and he also arranged for acquisition of specimens needed for the exhibit by exchange, gift, or field collection. For example, the Alaskan material (consisting of specimens from the Fairbanks area frozen gravels, including a composite skeleton of a woolly mammoth and a Bison mummy) and the Arizona glyptodont specimens, reputed to be the best examples from North America, were acquired by exchange from the American Museum of Natural History. Of the Australian material collected in 1970 by a joint Smithsonian Institution-American Museum of Natural History team, only a skull of the giant marsupial Diprotodon was eventually used. Clayton completed the gift of a composite skeleton of the rare goat-antelope, Myotragus balearicus, from the Deya Archeological Museum in Majorca. His fieldwork in the Mediterranean produced the material needed to make composite skeletons of the dwarf giant deer from Crete, Myotragus from Majorca, Prolagus from Sardinia, and giant dormouse from Sicily; these materials remain in the museum's collections but were not assembled for the exhibit. Clayton also coordinated the collection of dwarf hippo, lemur, tortoise, and elephant bird remains from the Pleistocene of Madagascar. 
Clayton proposed the "Jaws" exhibit on fossil sharks and was the primary advisor on its development (Figure 2). The original set of fossil teeth that were mounted in the reconstructed jaws of Carcharodon megalodon were acquired through Clayton's Lee Creek Mine project, mainly through the generosity of amateur collector Peter Harmatuk. The exhibit was completed in October 1985, and the poster that accompanied the exhibit, featuring members of the exhibit team framed by the reconstructed jaws, quickly became a collectors' item. Clayton also assisted in the acquisition of new fossils for the "Life in the Ancient Seas" exhibit, which opened in May 1990, and he supervised the mounting or remodeling of several marine mammal skeletons, plus creation of the mural, for this exhibit.

Clayton worked actively with the natural history museum community outside the Smithsonian. For example, he testified before the Virginia legislature in favor of the state establishing a museum of natural history, served first as an advisor in 1988, and was then appointed by the Governor of Virginia as a trustee of the Virginia Museum of Natural History in 1989. Among his other services, he helped write the collections policy manual for that museum. Because Thomas Jefferson was an early practitioner of our profession of vertebrate paleontology, and one of Clayton's heroes, Clayton was especially proud to be awarded the Jefferson Medal in 1993 by Governor Wilder and the Virginia state legislature for his outstanding contributions to science, and especially for his work with the Virginia Museum of Natural History.

Clayton is an Advisory Member of the Saltville Foundation and its Museum of the Middle Appalachians. He has served as an advisor to the Calvert Marine Museum in Solomons, Maryland, and its Calvert Cliffs fossil exhibit; to the Cincinnati Museum of Natural History on its Pleistocene exhibit; and to the Aurora Fossil Museum in Aurora, North Carolina.

\section{Library}

Anyone who has known Clayton for any time at all will know that he is an avid bibliophile and a strong advocate of building and maintaining good research libraries. He has served on a succession of Smithsonian Institution library committees through the years, and he served as the Department of Paleobiology Representative on the Library Liaison Committee before his retirement. Clayton was instrumental in arranging for the donation of Remington Kellogg's personal marine mammal library to the Smithsonian and establishing it as part of the Institution's library system, set up in a separate room near the fossil marine mammal collections. Clayton almost single-handedly has seen to it that the Kellogg Library has been properly cared for, that new literature and unpublished works are continually added, and that an active reprint exchange program is maintained. Clayton also facilitated the donation of the C.L. Gazin and R.H. Reinhart personal libraries to the vertebrate paleontology library holdings of the Smithsonian. He has made numerous donations to the Smithsonian Institution Archives and has arranged for all Society of Vertebrate Paleontology documents to be deposited in the Smithsonian Institution Archives as well.

Clayton's bibliophilia bore early fruit in one of his first publications, a bibliography of the fossil vertebrates of Florida (1957). He later remarked to Daryl Domning that having once produced such a work doomed one forever to be sought out as an advisor on other bibliographic projects. This destiny, however, he willingly embraced; nor did his warning dissuade Domning from using Clayton's Florida work as a model for his own first publication (a bibliography on fossil vertebrates of Louisiana and Mississippi, 1969). The Florida bibliographyalso served as an early inspiration for Domning's much later (1996) and much larger bibliography of the Sirenia and Desmostylia-another major (and Smithsonian-published) project to which Clayton for years lent his enthusiastic encouragement and tangible support.

\section{Extracurricular Pursuits}

Clayton in his extracurricular pursuits, and especially in his retirement, practices sustainable agriculture, animal husbandry, and silviculture on his farm near Fredericksburg, Virginia (Figure 3). He regards this as a natural extension of his career in natural history. Some might call him a purist in these pursuits, as he maintains "a holistic commitment to an environmental lifestyle." He eschews air conditioning, uses no motorized farm equipment, and practices organic farming methods. In line with this commitment, he collects and restores horse-drawn vehicles such as wagons, buggies, and bobsleds, as well as agricultural implements. To "power" this equipment he keeps and breeds Suffolk draft horses, maintaining at least one working team. He and Donna make frequent trips, mainly to southeastern Pennsylvania, to attend farm auctions and shows. He usually comes home with what he considers a prize. He loaned one of his farm wagons for a temporary Hidatsa Indian exhibit and helped the Smithsonian's Folklife Festival with information on an oatthreshing demonstration.

One of Clayton's major projects since he retired from the museum has been barn razing and barn raising. In 1995, a large ( 35 by 80 feet) dairy barn, built early in the last century, was about to be bulldozed to make way for construction of a shopping mall. Clayton was given the barn in exchange for removing it from the property. With the help of his extended family, Clayton dismantled the barn piece by piece and has since reassembled it on his own property.

Clayton still spends occasional days (typically one day each week) at the museum, continuing his research and finishing long-term research projects. The lunchtime gathering on those days is sometimes highlighted by new photographs, perhaps of his proud team of Suffolks pulling some new implement, or maybe of a pony recently acquired for the grandchildren, or, recently, baby pictures-a new foal born to one of his Suffolk 


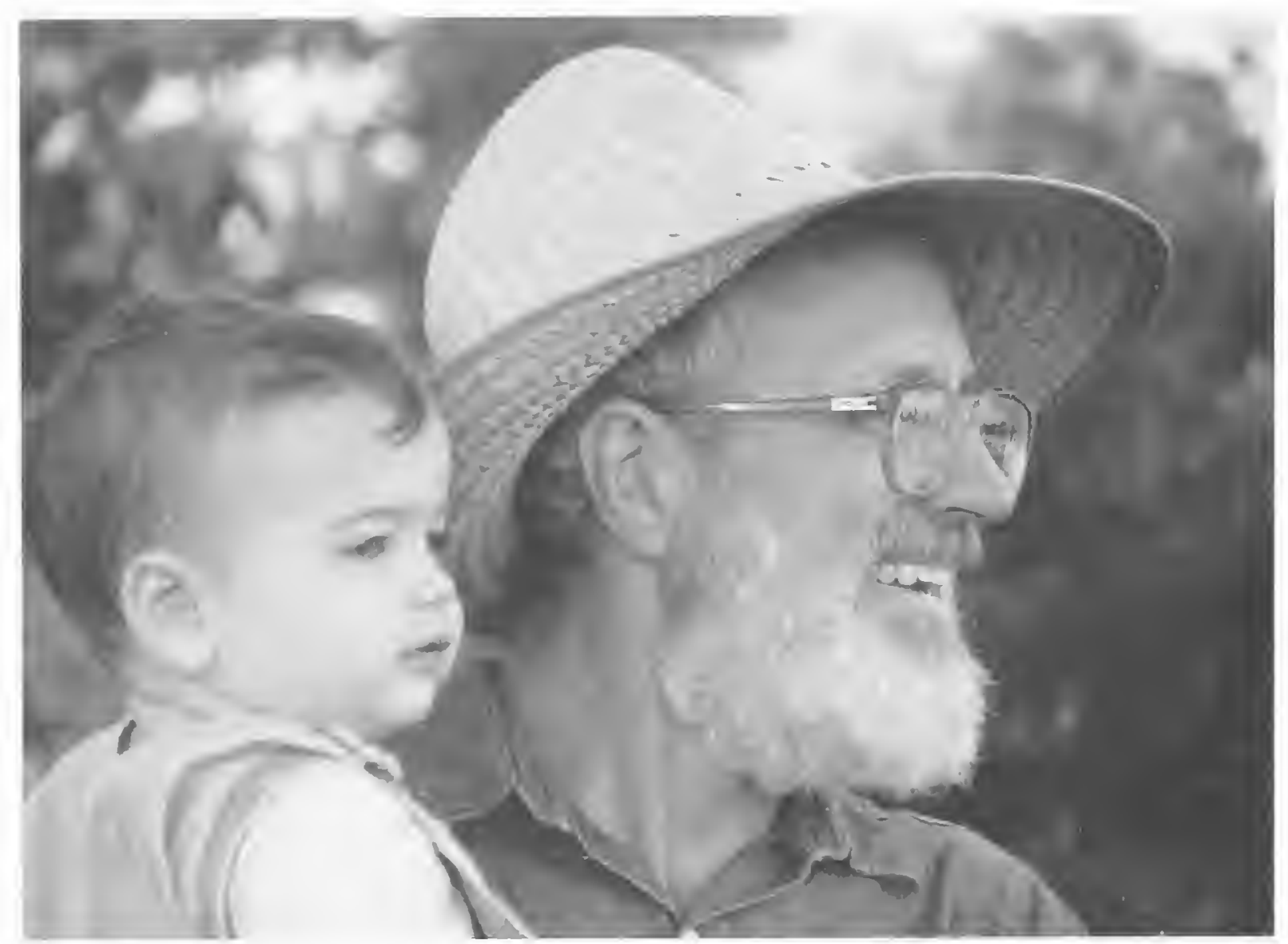

Figure 3.-Clayton E. Ray and grandson Danny afield in 1991, Stafford County, Virginia.

mares. We've learned that we cannot expect to see Clayton in the museum if there is new snow in Stafford County, because that far south in Virginia, any opportunity to hitch up the bobsled is too rare to be missed.

Finally, we take this opportunity to publish, this time complete and unexpurgated, a letter as written by Clayton to the editor of Smithsonian magazine (1995).

February first had begun in the dark as a humdrum day like many others with that somnambulant 50-mile drive up 1-95. Then right there in the middle of $\mathrm{M}$ Street, N.W., opposite my wife's office, suddenly materialized a beautiful tarcovered ball peen hammer with the handle only slightly split. 1 made it mine as her cautions about traffic echoed behind me. Then, in her office I find the new Smithsonian with John Neary's article about junk-this was a day to remember!

I always skim through Smithsonian eagerly to keep track of what you are doing (I am a curator in NMNH), to find your mistakes, and to sniff at the superficial potboilers written by hacks just for the money. Suddenly 1 realized why 1 have been so critical of you all these years and where you have gone wrong-so little of your stuff is written by real experts who know and love their subject. Neary's article is a sparkling exception.

I assure you that my assessment has nothing to do with why I gave up jogging to and from my officc back when we lived in South Arlington. The daily pickings in fender washers, bolts, and screw drivers alone were too heavy and their gleaning too time consuming, to say nothing of thc occasional chain or tool box that required phoning my wifc from the Jeffcrson Memorial to come and haul me home with what I had dragged from the 14th Street bridge. Nor is my judgment wcighted by my assemblage of blacksmith's vises $(8,9,10$, but who's counting); the next one auctioned at a bargain bid will certainly have some beautilitarian nuance to complement my holdings.
Congratulations on finally publishing something authoritative and of inherent interest to every reader.

As you might imagine, and to Clayton's chagrin, his letter was heavily edited and shortened when published in the magazine.

\section{Bibliography of Clayton E. Ray}

\section{7}

Pollock, H.E.D., and C.E. Ray. Notes on Vertebrate Animal Remains from Mayapan. Carnegie Institution of Washington, Department of Archaeology, Current Reports, 41: 633-656.

Ray, C.E. A List, Bibliography, and Index of the Fossil Vertebrates of Florida. Florida Geological Survey, Special Publication, 3: 175 pages.

Ray, C.E. Palaeontology. Vertebrate. In Walter Yust, editor, Britannica Book of the Year, 1957, pages 595-596. Chicago, London: Encyclopedia Britannica.

Ray, C.E. Pre-Columbian Horses from Yucatan. Journal of Mammalogy, 38(2):278.

\section{8}

Ray, C.E. Fusion of Cervical Vertebrae in the Erethizontidae and Dinomyidae. Breviora, 97:1-13, figures 1, 2.

Ray, C.E. Additions to the Pleistocene Mammalian Fauna 
from Melbourne, Florida. Bulletin of the Museum of Comparative Zoology, 119(7):419-450, figures 1-5.

Ray, C.E. A Sesamoid Bone in the Jaw Musculature of Gopherus polyphemus (Reptilia: Testudininae). Anatomischer Anzeiger, 107(1/5):85-91, figures 1-4.

\section{0}

Ray, C.E. Trichecodon huxleyi (Mammalia: Odobenidae) in the Pleistocene of Southeastern United States. Bulletin of the Museum of Comparative Zoology, 122(3):127-142, text figure 1, plates 1, 2 .

Ray, C.E. The Manatee in the Lesser Antilles. Journal of Mammalogy, 41(3):412-413.

1961

Ray, C.E. The Monk Seal in Florida. Journal of Mammalogy, $42(1): 113$.

Waters, J.H., and C.E. Ray. Former Range of the Sea Mink. Journal of Mammalogy, 42(3):380-383, figure 1.

\section{2}

Ray, C.E. New Finds of Old Bones. Florida Alumnus, University of Florida, 14(4):20-22, 3 figures.

\section{3}

Ray, C.E., S.J. Olsen, and H.J. Gut. Three Mammals New to the Pleistocene Fauna of Florida, and a Reconsideration of Five Earlier Records. Journal of Mammalogy, 44(3):373395 , text figures $1-7$, plates $1-4$.

\section{4}

Gut, H.J., and C.E. Ray. The Pleistocene Vertebrate Fauna of Reddick, Florida. Quarterly Journal of the Florida Academy of Sciences, 26(4):315-328.

Hooijer, D.A., and C.E. Ray. A Metapodial of Acratocnus (Edentata: Megalonychidae) from a Cave in Hispaniola. Proceedings of the Biological Society of Washington, 77: 253-258, figure 1.

Ray, C.E. A New Capromyid Rodent from the Quaternary of Hispaniola. Breviora, 203:1-4, figure 1.

Ray, C.E. A Small Assemblage of Vertebrate Fossils from Spring Bay, Barbados. Journal of the Barbados Museum and Historical Society, 31(1):11-22, figures 1-3.

Ray, C.E. Tapirus copei in the Pleistocene of Florida. Quarterly Journal of the Florida Academy of Sciences, 27(1): 59-66, plate 1 .

Ray, C.E. The Jaguarundi in the Quaternary of Florida. Journal of Mammalogy, 45(2):330-332, figure 1.

Ray, C.E. The Taxonomic Status of Heptaxodon and Dental Ontogeny in Elasmodontomys and Amblyrhiza (Rodentia:
Caviomorpha). Bulletin of the Museum of Comparative Zoology, 131(5): 107-127, figures 1, 2.

\section{5}

Hibbard, C.W., C.E. Ray, D.E. Savage, D.W. Taylor, and J.E. Guilday. Quaternary Mammals of North America. In H.E. Wright, Jr., and D.G. Frey, editors, The Quaternary of the United States, pages 509-525. Princeton: Princeton University Press.

Ray, C.E. A Glyptodont from South Carolina. Charleston Museum Leaflet, 27:1-12, plates 1-4.

Ray, C.E. A New Chipmunk, Tamias aristus, from the Pleistocene of Georgia. Journal of Paleontology, 39(5): 1016-1022, text figure 1.

Ray, C.E. The Relationships of Quemisia gravis (Rodentia: ?Heptaxodontidae). Smithsonian Miscellaneous Collections, 149(3): 1-12, text figures 1, 2, plate 1 .

Ray, C.E. Variation in the Number of Marginal Tooth Positions in Three Species of Iguanid Lizards. Breviora, 236: $1-15$, figures $1-5$.

Ray, C.E., and L. Lipps. An Assemblage of Pleistocene Vertebrates and Mollusks from Bartow County, Georgia. [Abstract.] Bulletin of the Georgia Academy of Science, 23(2):67.

1966

Ray, C.E. The Identity of Bison appalachicolus. Notulae Naturae of the Academy of Natural Sciences of Philadelphia, 384:1-7, figures 1, 2.

Ray, C.E. The Status of Bootherium brazosis. Pearce-Sellards Series, 5:1-7, figures 1, 2.

\section{7}

Lipps, L., and C.E. Ray. The Pleistocene Fossiliferous Deposit at Ladds, Bartow County, Georgia. Bulletin of the Georgia Academy of Science, 25(3):113-119, figures 1, 2.

Ray, C.E. Pleistocene Mammals from Ladds, Bartow County, Georgia. Bulletin of the Georgia Academy of Science, 25(3):120-150, figures 1-5.

Ray, C.E., B.N. Cooper, and W.S. Benninghoff. Fossil Mammals and Pollen in a Late Pleistocene Deposit at Saltville, Virginia. Journal of Paleontology, 41(3):608-622, text figures $1-4$, plates 65,66 .

1968

Ray, C.E., and L. Lipps. Additional Notes on the Pleistocene Mammals from Ladds, Georgia. Bulletin of the Georgia Academy of Science, 26(2):63.

Ray, C.E., A. Wetmore, D.H. Dunkle, and P. Drez. Fossil Vertebrates from the Marine Pleistocene of Southeastern Virginia. Smithsonian Miscellaneous Collections, 153(3): 1-25, text figures 1, 2, plates 1,2 .

Ray, C.E., D. Wills, and J.C. Palmquist. Fossil Musk Oxen of 
Illinois. Transactions of the Illinois Academy of Science, 61(3):282-292, figures 1-5.

Wing, E.S., C.A. Hoffman, Jr., and C.E. Ray. Vertebrate Remains from Indian Sites on Antigua, West Indies. Caribbean Journal of Science, 8(3-4):123-139, figures 1-4.

\section{0}

Ray, C.E., C.S. Denny, and M. Rubin. A Peccary, Platygonus compressus LeConte, from Drift of Wisconsinan Age in Northern Pennsylvania. American Journal of Science, 268(1):78-94, 1 text figure, 2 plates.

Ray, C.E., and L. Lipps. Southerly Distribution of Porcupine in Eastern United States during Late Quaternary Time. [Abstract.] Bulletin of the Georgia Academy of Science, 28(2):24.

\section{1}

Ray, C.E. Polar Bear and Mammoth on the Pribilof Islands. Arctic, 24(1):9-18, text figure 1.

\section{3}

Ray, C.E. Review of The Distributional History of the Biota of the Southern Appalachians, Perry C. Holt, editor. Systematic Zoology, 22(2):199-201.

Ray, C.E., and F.C. Whitmore, Jr. Paleontology. In T. Simkin, W.G. Reeder, and C. MacFarland, editors, Galapagos Science, 1972 Status and Needs, pages 67-68. Report of Galapagos Science Conference, October 6-8, 1972, Washington, D.C. [sponsored by the National Science Foundation, Smithsonian Institution, and the University of Wisconsin]. Washington, D.C.: Smithsonian Institution.

\section{5}

Ray, C.E. The Relationships of Hemicaulodon effodiens Cope 1869 (Mammalia: Odobenidae). Proceedings of the Biological Society of Washington, 88(26):281-304, plates $1-6$.

Ray, C.E. The Geography of Phocid Evolution. [Abstract.] American Zoologist, 15(3):812.

Ray, C.E. Field Conference in Marine Mammal Beds of Coastal Oregon, August 18-20, 1975. [Unpublished field guide], 33 pages, 2 tables, 7 maps.

\section{6}

Ray, C.E. Phoca wymani and Other Tertiary Seals (Mammalia: Phocidae) Described from the Eastern Seaboard of North America. Smithsonian Contributions to Paleobiology, 28: 36 pages, 3 text figures, 11 plates.

Ray, C.E. [Anonymous, with assistance and recommendations of others.] Marine Mammal Names. 8 pages. Washington, D.C.: Marine Mammal Commission. [A list of the marine mammals of the world, scientific and common names, published by the commission and distributed worldwide, to serve as a standard nomenclature.]

Ray, C.E. Procrastination Week [letter to the editor]. Washington Post, March 17, page A18.

Ray, C.E. The Gray Seal in U.S. Waters. 11 pages. [Unpublished "white paper" for Marine Mammal Commission.]

Repenning, C.A., and C.E. Ray. The Origin of the Hawaiian Monk Seal. Proceedings of the Biological Society of Washington, 89(58):667-688, plates 1-3.

1977

Ray, C.E. The Geography of Phocid Evolution. Systematic Zoology, 25(4):391-406, figures 1-6.

Ray, C.E. Fossil Marine Mammals of Oregon. Systematic Zoology, 25(4):420-436, figures 1, 2.

Ray, C.E. Seals and Walruses of Florida. Plaster Jacket, 27: $1-13$, figures $1-3$, cover illustration.

Ray, C.E. Chelonia couperi Harlan 1842, a Supposed Turtle Based on the Clavicle of a Megathere (Mammalia: Edentata). Notulae Naturae of the Academy of Natural Sciences of Philadelphia, 455: 16 pages, 4 figures.

Ray, C.E., and D.E. Wilson. Evidence for Macrotus californicus from Terlingua, Texas. Occasional Papers, The Museum, Texas Tech University, 57:1-10, 2 figures.

Repenning, C.A., C.E. Ray, and D. Grigorescu. Pinniped Biogeography. In J. Gray and A.J. Boucot, editors, Historical Biogeography, Plate Tectonics, and the Changing Environment: Proceedings of the 37th Annual Biology Colloquium and Selected Papers, pages 357-369. Corvallis: Oregon State University Press.

1980

Morgan, G.S., C.E. Ray, and O. Arredondo. A Giant Extinct Insectivore from Cuba (Mammalia: Insectivora: Solenodontidae). Proceedings of the Biological Society of Washington, 93(3):597-608, 1 figure.

Ray, C.E. Douglas Ralph Emlong, 1942-1980. [Obituary.] Society of Vertebrate Paleontology News Bulletin, 120:4546, 1 photograph.

\section{1}

Gillette, D.D., and C.E. Ray. Glyptodonts of North America. Smithsonian Contributions to Paleobiology, 40: 255 pages, 97 figures.

Ray, C.E. Catawba's Wandering Walrus: Case of Peripatetic Pinniped Solved. Whalebones [quarterly newsletter of the North Carolina State Museum of Natural History], 13(Fall):3, 1 figure [unnumbered pages].

Ray, C.E. Marine Mammal Information [guest editorial], December 1981, pages 1-3.

Ray, C.E., E. Anderson, and S.D. Webb. The Blancan Carni- 
vore Trigonictis (Mammalia: Mustelidae) in the Eastern United States. Brimleyana, 5:1-36, 7 figures.

Ray, C.E., and J.K. Ling. A Well Documented Early Record of the Australian Sea Lion. Archives of Natural History, 10(1):155-171, 7 figures.

Ray, C.E., and A.E. Spiess. The Bearded Seal, Erignathus barbatus, in the Pleistocene of Maine. Journal of Mammalogy, 62(2):423-427, 2 figures.

\section{2}

Domning, D.P., G.S. Morgan, and C.E. Ray. North American Eocene Sea Cows (Mammalia: Sirenia). Smithsonian Contributions to Paleobiology, 52: 69 pages, 34 figures.

Ray, C.E. The Journal of Vertebrate Paleontology and the SVP. Society of Vertebrate Paleontology News Bulletin, 125:5-7.

Ray, C.E. Review of "Handbook of Marine Mammals, Volume 1: The Walrus, Sea Lions, Fur Seals, and Sea Otter, and Volume 2: Seals," S.H. Ridgway and R.J. Harrison, editors. Journal of Mammalogy, 63(4):721-724.

Ray, C.E., F. Reiner, D.E. Sergeant, and C.N. Quesada. Notes on Past and Present Distribution of the Bearded Seal, Erignathus barbatus, around the North Atlantic Ocean. Memórias do Museu do Mar, Série Zoológica (Cascais, Portugal), 2(23): 1-32, 10 figures.

Steadman, D.W., and C.E. Ray. The Relationships of Megaoryzomys curioi, an Extinct Cricetine Rodent (Muroidea: Muridae) from the Galapagos Islands, Ecuador. Smithsonian Contributions to Paleobiology, 51: 23 pages, 11 figures.

\section{3}

Barnes, L.G., D.P. Domning, and C.E. Ray. Status of Studies on Fossil Marine Mammals. [Abstract.] Fifth Biennial Conference on the Biology of Marine Marnmals, November 27-December 1, 1983, Boston, Massachusetts, page 1.

Ray, C.E. Journal of Vertebrate Paleontology Committee Report. Society of Vertebrate Paleontology News Bulletin, 127:8-9, 17-19.

Ray, C.E. Outerbank Ovibovine Adds Link to Musk Ox Research. Whalebones [quarterly newsletter of the North Carolina State Museum of Natural History], 15(Spring):3, 1 figure [unnumbered pages].

Ray, C.E. [Anonymous.] President Robert L. Carroll's Report on Amendments and the JVP. Society of Vertebrate Paleontology News Bulletin, 128:1-2 [also pages 2-9, amendments to SVP constitution also written by C.E. Ray].

Ray, C.E. Hooded Seal, Cystophora cristata: Supposed Fossil Records in North America. Journal of Mammalogy, 64(3):509-512, 4 figures.

Ray, C.E., editor. Geology and Paleontology of the Lee Creek Mine, North Carolina, I. Smithsonian Contributions to Paleobiology, 53: 529 pages, frontispiece, 95 figures, 101 plates.

Ray, C.E. Prologue. In C.E. Ray, editor, Geology and Paleontology of the Lee Creek Mine, North Carolina, I. Smithsonian Contributions to Paleobiology, 53:1-14.

1984

Ray, C.E. Fossil Seals from the Calvert Formation of the Pamunkey River, Hanover County, Virginia. In L.W. Ward and Kathleen Krafft, editors, Stratigraphy and Paleontology of the Outcropping Tertiary Beds in the Pamunkey River Region, Central Virginia Coastal Plain: Guidebook for Atlantic Coastal Plain Geological Association 1984 Field Trips, pages 232-235. Atlantic Coastal Plain Geological Association.

Ray, C.E., and A.E. Sanders. Pleistocene Tapirs in the Eastern United States. In H.H. Genoways and M.R. Dawson, editors, Contributions in Quaternary Vertebrate Paleontology: A Volume in Memorial to John H. Guilday. Special Publication, Carnegie Museum of Natural History, 8:283315.

1985

Barnes, L.G., D.P. Domning, and C.E. Ray. Status of Studies on Fossil Marine Mammals. Marine Mammal Science, 1(1):15-53, 9 figures.

1986

Cifelli, R.L., and C.E. Ray. Review of Vertebrate Zoogeography and Evolution in Australasia, M. Archer and G. Clayton, editors. Journal of Vertebrate Paleontology, 6(2):203205.

Domning, D.P., and C.E. Ray. The Earliest Sirenian (Mammalia: Dugongidae) from the Eastern Pacific Ocean. Marine Mammal Science, 2(4):263-276, figures 1-6.

Domning, D.P., C.E. Ray, and M.C. McKenna. Two New Oligocene Desmostylians and a Discussion of Tethytherian Systematics. Smithsonian Contributions to Paleobiology, 59: iv +56 pages, 23 figures.

Ray, C.E. [Anonymous.] Development Committee Message. News Bulletin of the Society of Vertebrate Paleontology, 138:4 [also annual auction announcement, page 57].

Ray, C.E. [Anonymous.] Development Committee Report. Society of Vertebrate Paleontology News Bulletin, 137:5-6 [also raffle announcement, page 49].

Ray, C.E. [Letter to the Editor.] The Four Star SIWC [Smithsonian Institution Women's Council] Newsletter, 7(1):8.

Ray, C.E., and D.P. Domning. Manatees and Genocide. Marine Mammal Science, 2(1):77-78. [Letter to the editor regarding "Conservation and Protection of Marine Mammals...."]

\section{7}

Germon, R.N., Lauck W. Ward, and C.E. Ray. Ecphora: 
Important Fossil from the Miocene Strata on the Chesapeake Bay. Maryland Naturalist, 31(1):25-33, figures 111.

McDonald, J.N., and C.E. Ray. Bootherium bombifrons, the Autochthonous Low-Horned Musk Ox of Pleistocene North America. [Abstract.] Second International Muskox Symposium, October 1-4, 1987, University of Saskatchewan, page 22 .

Ray, C.E., editor. Geology and Paleontology of the Lee Creek Mine, North Carolina, II. Smithsonian Contributions to Paleobiology, 61: 283 pages, 49 figures, 80 plates.

Ray, C.E. Foreword. In C.E. Ray, editor, Geology and Paleontology of the Lee Creek Mine, North Carolina, II. Smithsonian Contributions to Paleobiology, 61:1-8.

Ray, C.E. Development Committee Message. Society of Vertebrate Paleontology News Bulletin, 139:24-25 [also SVP Archives, page 63].

Ray, C.E. Development Committee Activities. Society of Vertebrate Paleontology News Bulletin, 140:2.

1988

McDonald, J.N., and C.E. Ray. Zoogeography of the Musk Ox Genus Praeovibos Staudinger, 1908. [Abstract.] Journal of Vertebrate Paleontology, supplement, 8(3):21A22A.

Morgan, G.S., O.J. Linares, and C.E. Ray. New Species of Fossil Vampire Bats (Mammalia: Chiroptera: Desmodontidae) from Florida and Venezuela. Proceedings of the Biological Society of Washington, 101(4):912-928, 8 figures.

Ray, C.E. Development Committee Report and Second Development Workshop. Society of Vertebrate Paleontology News Bulletin, 142:3-7.

Ray, C.E. [Anonymous.] Development Committee Note. Society of Vertebrate Paleontology News Bulletin, 143:1-2.

Ray, C.E. Review of "A Short History of Vertebrate Palaeontology," by Eric Buffetaut. Earth Sciences History, 7(2): 162.

Ray, C.E., O.J. Linares, and G.S. Morgan. Paleontology. In A.M. Greenhall and U. Schmidt, editors, Natural History of Vampire Bats, pages 19-30 [Chapter 3]. Boca Raton, Florida: CRC Press.

\section{9}

Berta, A., C.E. Ray, and A. Wyss. Skeleton of the Oldest Known Pinniped, Enaliarctos mealsi. Science, 244(4900): 60-62, figures $1-3$.

McDonald, J.N., L.E. Freeman, and C.E. Ray. The Osteology of Bootherium bombifrons: A Comparative Osteological Atlas. [Abstract.] Journal of Vertebrate Paleontology, supplement, 9(3):32A.

McDonald, J.N., and C.E. Ray. Bootherium bombifrons, the Autochthonous Low-Horned Muskox of Pleistocene North America. [Abstract.] Canadian Journal of Zoology, 67(5): A64.
McDonald, J.N., and C.E. Ray. The Autochthonous North American Musk Oxen Bootherium, Symbos, and Gidleya (Mammalia: Artiodactyla: Bovidae). Smithsonian Contributions to Paleobiology, 66: 77 pages, 64 figures.

Ray, C.E. Development Committee Report. Society of Vertebrate Paleontology News Bulletin, 145:9.

1990

Berta, A., and C.E. Ray. Skeletal Morphology and Locomotor Capabilities of the Archaic Pinniped Enaliarctos mealsi. Journal of Vertebrate Paleontology, 10(2):141157, 7 figures, cover illustration.

Buffrénil, V. de, A. de Ricqlès, C.E. Ray, and D.P. Domning. Bone Histology of the Ribs of the Archaeocetes (Mammalia: Cetacea). Journal of Vertebrate Paleontology, 10(4): 455-466, 4 figures.

McDonald, H.G., and C.E. Ray. The Extinct Sloth, Megalonyx (Mammalia: Xenarthra), from the United States MidAtlantic Continental Shelf. Proceedings of the Biological Society of Washington, 103(1):1-5, 2 figures.

\section{1}

Borns, H.W., Jr., and C.E. Ray. Historic Bovid Teeth from Gardiner, Maine. Current Research in the Pleistocene, 8: $85-86$.

Domning, D.P., C.E. Ray, and M.C. McKenna. A New Specimen of Behemotops proteus (Mammalia: Desmostylia) from the Oligocene of Washington. [Abstract.] Journal of Vertebrate Paleontology, supplement, 11(3):26A.

McDonald, J.N., C.E. Ray, and C.R. Harington. Taxonomy and Zoogeography of the Musk Ox Genus Praeovibos Staudinger, 1908. In J.R. Purdue, W.E. Klippel, and B.W. Styles, editors, Beamers, Bobwhites, and Blue Points: Tributes to the Career of Paul W. Parmalee. Scientific Papers, Illinois State Museum, 23:285-314. [Also published as The University of Tennessee, Department of Anthropology, Report of Investigations, 52.]

Tedford, R.H., L.G. Barnes, and C.E. Ray. Earliest Miocene Littoral Arctoid, Kolponomos. [Abstract.] Journal of Vertebrate Paleontology, supplement, 11(3):57A.

Ubelaker, D.H., H.E. Berryman, T.P. Sutton, and C.E. Ray. Differentiation of Hydrocephalic Calf and Human Calvariae. Journal of Forensic Sciences, 36(3):801-812, 9 figures.

\section{2}

Inuzuka, N., D.P. Domning, C.E. Ray, and Y. Hasegawa. Summary of Taxa and Distribution of Desmostylia. Abstracts, 29th International Geological Congress, Kyoto, Japan, 24 August-3 September 1992, 2:349.

Koretsky, I.A., and C.E. Ray. Fossil True Seals (Family Phocidae) from the Lee Creek Mine of Southeastern USA. [Abstract.] Journal of Vertebrate Paleontology, supplement, 12(3):37A-38A.

Miyazaki, S., H. Horikawa, N. Kohno, K. Hirota, M. Kimura, 
Y. Hasegawa, Y. Tomida, L.G. Barnes, and C.E. Ray. Summary of the Fossil Record of Pinnipeds of Japan, and Comparisons with Those from the Eastern North Pacific. Abstracts, 29th International Geological Congress, Kyoto, Japan, 24 August-3 September 1992, 2:352.

Muizon, C. de, and C.E. Ray. A Walrus-Like Cetacean from the Early Pliocene of Peru. [Abstract.] Journal of Vertebrate Paleontology, supplement, 12(3):45A.

Ray, C.E. Foreword. In R.R. Reeves, B.S. Stewart, and S. Leatherwood, The Sierra Club Handbook of Seals and Sirenians, pages xi-xii. San Francisco: Sierra Club Books. Ray, C.E. "The time has come the walrus said...." The Virginia Explorer, 8(1):2-7.

1993

McDonald, J.N., and C.E. Ray. Records of Musk Oxen from the Atlantic Coastal Plain of North America. The Mosasaur, 5:1-18, figures 1-13.

Ray, C.E. [Letter to Editor.] Fossil Collecting and Government Regulation. Science, 259(5095):581.

\section{4}

Inuzuka, N., D.P. Domning, and C.E. Ray. Summary of Taxa and Morphological Adaptations of the Desmostylia. The Island Arc, 3(4):522-537.

Koretsky, I.A., and C.E. Ray. Cryptophoca, New Genus for Phoca maeotica (Mammalia: Pinnipedia: Phocinae), from Upper Miocene Deposits in the Northern Black Sea Region. Proceedings of the Biological Society of Washington, 107(1):17-26, figures 1-4.

Miyazaki, S., H. Horikawa, N. Kohno, K. Hirota, M. Kimura, Y. Hasegawa, Y. Tomida, L.G. Barnes, and C.E. Ray. Summary of the Fossil Record of Pinnipeds of Japan, and Comparisons with That from the Eastern North Pacific. The Island Arc, 3(4):361-372.

Ray, C.E. [Letter to the Editor]. The Junkoholic. Smithsonian, 25(1):12.

Ray, C.E. Presentation of the Harrell L. Strimple Award of The Paleontological Society to Peter J. Harmatuk. Journal of Paleontology, 68(4):920-923, 1 figure [with statements by F.C. Whitmore, Jr., and F.M. Huber; response by Peter J. Harmatuk].

Ray, C.E., D.P. Domning, and M.C. McKenna. A New Specimen of Behemotops proteus (Order Desmostylia) from the Marine Oligocene of Washington. Proceedings of the San Diego Society of Natural History, 29:205-222, figures $1-15$.

Tedford, R.H., L.G. Barnes, and C.E. Ray. The Early Miocene Littoral Ursoid Carnivoran Kolponomos: Systematics and Mode of Life. Proceedings of the San Diego Society of Natural History, 29:11-32, figures 1-15.

1996

McDonald, J.N., C.E. Ray, and F. Grady. Pleistocene Caribou (Rangifer tarandus) in the Eastern United States: New Records and Range Extensions. In K. Stewart and K. Seymour, editors, Paleoecology and Paleoenvironments of Late Cenozoic Mammals; Tributes to the Career of C. S. (Rufus) Churcher, pages 406-430. Toronto: University of Toronto Press.

1997

Arroyo-Cabrales, J., and C.E. Ray. Revisión de los Vampiros Fósiles (Chiroptera: Phyllostomidae, Desmodontinae) de México. In Joaquín Arroyo-Cabrales and Óscar J. Polaco, editors, Homenaje al Profesor Ticul Alvares, pages 69-86. México, D.F. [Mexico City]: Colección Cientifica, Instituto Nacional de Antropología e Historia.

2001

Ray, C.E., editor. Geology and Paleontology of the Lee Creek Mine, North Carolina, III. Smithsonian Contributions to Paleobiology, 90: 365 pages, 127 figures, 45 plates, 32 tables.

Ray, C.E. Prodromus. In C.E. Ray, editor, Geology and Paleontology of the Lee Creek Mine, North Carolina, III. Smithsonian Contributions to Paleobiology, 90:1-20. 



\title{
Late Rancholabrean Mammals from Southernmost Florida, and the Neotropical Influence in Florida Pleistocene Faunas
}

\author{
Gary S. Morgan
}

\section{ABSTRACT}

The Cutler Hammock and Monkey Jungle Hammock sites, both located near the Atlantic coast in Dade County at the southern tip of the Florida peninsula, have yielded the southernmost late Pleistocene (Rancholabrean) vertebrate faunas known from the continental United States. These two fossil assemblages were deposited in small sinkholes or sinkhole/cave systems that developed in the marine Pleistocene Miami Limestone when sea level was considerably lower than present, probably during the latter part of the Wisconsinan glacial interval between 20 and $11 \mathrm{Ka}$.

The mammalian fauna from Cutler Hammock consists of 47 species, including 16 members of the extinct Pleistocene megafauna. The most common larger mammals from Cutler Hammock are Mylohyus nasutus, Equus sp., Bison antiquus, and Canis dirus. Small vertebrates, including toads, snakes, birds, bats, rodents, and rabbits, are abundant in this site. The presence of a diverse fauna of large carnivores, particularly the dire wolf, Canis dirus, and the fragmentary condition of most ungulate long bones, some of which show clear evidence of gnawing, suggest that Cutler Hammock functioned, in part, as a carnivore den. Monkey Jungle Hammock has 41 species of mammals, nine of which are of extinct megafauna. Small mammals, including 12 species of rodents and eight species of bats, dominate the Monkey Jungle fauna.

Mammals from Cutler and/or Monkey Jungle that are unknown in Florida before the late Rancholabrean include Panthera atrox, Puma concolor, Ursus americanus, Sciurus niger, Pitymys pinetorum, Sigmodon hispidus, and Bison antiquus. The West Palm Beach site, located about $100 \mathrm{~km}$ north of Cutler and Monkey Jungle in Palm Beach County, has 11 species of extinct megafauna among its 17 species of mammals. The most common mammals in this fauna are the proboscideans Mammut americanum and Mammuthus columbi.

Mammals of South American origin, including species of ground sloths, armadillos, glyptodonts, vampire bats, and capybaras, are present in many Florida Pleistocene faunas. These South American species occur in Florida faunas along with species of North American origin that either are restricted to the Neotropics

Gary S. Morgan, New Mexico Museum of Natural History, 1801 Mountain Road NW, Albuquerque, New Mexico 87104. at the present time (e.g., jaguar, Panthera onca) or are closely related to living Neotropical species (e.g., extinct Florida cave bear, Tremarctos floridanus, and extinct tapir, Tapirus veroensis). The evolutionary history and biogeography of Florida's Pleistocene mammals with Neotropical affinities are thoroughly analyzed.

\section{Introduction}

Florida is well known for its rich Rancholabrean vertebrate faunas, most of which are concentrated in the northern half of the peninsula (Webb, 1974a; Kurtén and Anderson, 1980). The karst topography of northern Florida has strongly affected the distribution of Rancholabrean sites and has greatly increased their number, particularly faunas derived from sinkholes, fissures, or caves (e.g., Arredondo sites, Devil's Den, Haile sites, Reddick, and Sabertooth Cave) and faunas found in spring-fed rivers and streams (e.g., Aucilla River, Ichetucknee River, Santa Fe River, and Waccasassa River). The only diverse late Pleistocene sites previously reported from the southern half of the Florida peninsula (e.g., Melbourne, Seminole Field, and Vero) were deposited in marshes, ponds, or rivers along the Atlantic or Gulf coasts (Webb, 1974a; Kurtén and Anderson, 1980). Two deep, water-filled sinkholes located in southwestern Florida not far inland from the Gulf coast, Warm Mineral Springs (McDonald, 1990) and Little Salt Spring (Clausen et al., 1979; Holman and Clausen, 1984), have yielded limited late Rancholabrean faunas, including the ground sloth Megalonyx jeffersonii, the sabertooth cat Smilodon fatalis, and the extinct giant land tortoise Hesperotestudo (=Geochelone) cras siscutata.

This study reviews three late Pleistocene (late Rancholabrean) mammalian faunas from southernmost peninsular Florida: Cutler Hammock, Monkey Jungle Hammock, and West Palm Beach (Figure 1). Southernmost peninsular Florida is herein defined as the southern one-third of the peninsula from Lake Okeechobee southward (south of latitude $27^{\circ} \mathrm{N}$ ). The first 


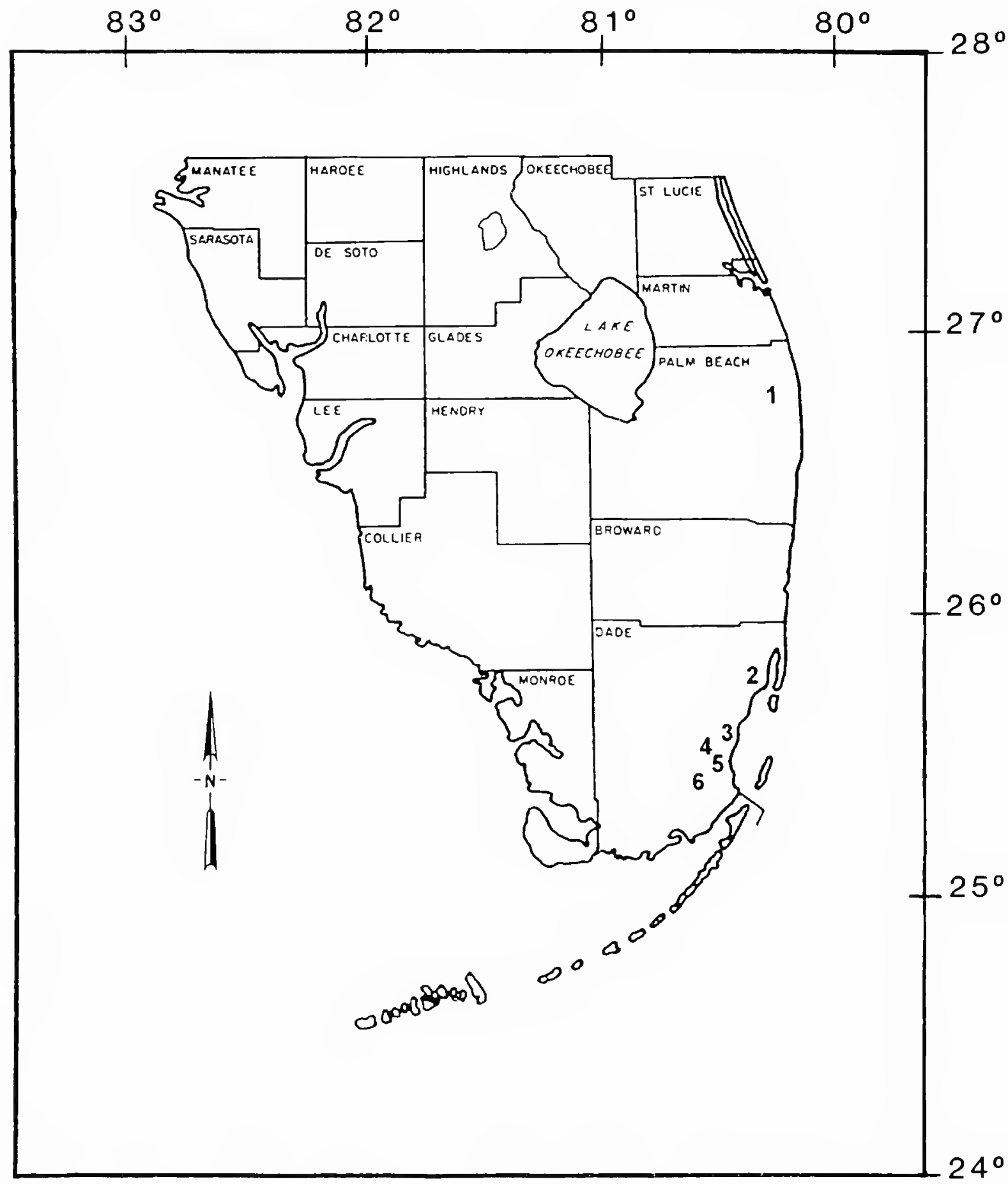

Figure 1.-Map of southernmost peninsular Florida showing location of Rancholabrean and Holocene fossil sites discussed in text: $1=$ West Palm Beach, late Rancholabrean; 2=Miami, late Rancholabrean; 3=Cutler Hammock, late Rancholabrean; 4=Monkey Jungle Hammock, late Rancholabrean, and Monkey Jungle 2, Holocene; $5=$ Nichol's Hammock, Holocene; $6=$ Florida City, late Rancholabrean.

fossil vertebrate fauna reported from this region was from Nichol's Hammock, a Holocene sinkhole site located south of Miami in Dade County (Hirschfeld, 1968). This site provides an interesting view of the vertebrate fauna of southern Florida prior to the extensive human impact of the last 500 years, but it completely lacks extinct species. Although located somewhat north of the study area covered in this paper, the Vero site, located not far inland from the Atlantic coast in Indian River County, is probably the best known Rancholabrean vertebrate fauna from the southern half of the Florida peninsula (Weigel, 1962; Webb and Wilkins, 1984; Morgan, 1985).

Fossils were found near West Palm Beach in Palm Beach County in 1969 during the excavation of a drainage ditch for a commercial development. Converse (1973) presented a preliminary faunal list and discussion of the West Palm Beach site. This site is similar in faunal composition and depositional setting to several other Florida coastal Rancholabrean sites, in particular Seminole Field, Melbourne, and Vero. Bones and teeth of extinct Pleistocene megafauna were recovered in 1969 from a small sinkhole at the Monkey Jungle tourist attraction about $25 \mathrm{~km}$ southwest of Miami. This discovery was summarized in a popular article (Ober, 1978), but until now only a few studies on selected vertebrate taxa have mentioned the Monkey Jungle Hammock site. Cutler Hammock is by far the largest of the three south Florida Rancholabrean sites, having produced literally thousands of vertebrate fossils. This site was discov- 
ered in 1985 by archaeologists conducting survey work near Perrine south of Miami. Like Monkey Jungle, the Cutler Hammock site was found in a small sinkhole on the Atlantic Coastal Ridge in an area now covered by a tropical hardwood hammock. Small terrestrial vertebrates, including toads, snakes, birds, and rodents, are abundant at Cutler Hammock. Sixteen species of Pleistocene megafauna occur in this fauna. Carr (1987) presented a popular account of the Cutler Hammock site, Morgan (1991) reviewed the bat fauna, Morgan and Seymour (1997) described the sample of Florida panthers (Puma concolor), and Emslie (1998) analyzed the avifauna. Emslie and Morgan (1995) summarized the taphonomy of this site, concluding that many of the large mammal remains were concentrated there as a result of the activities of large carnivores, particularly the dire wolf.

The Cutler Hammock and Monkey Jungle Hammock sites are the two southernmost Rancholabrean vertebrate faunas in the continental United States. This fact is integrally related to the second important aspect of these two faunas stressed in this study - the number of Florida Pleistocene vertebrate taxa that have affinities with the Neotropics. Morgan $(1985,1991)$ noted that many of the bat species from these two sites, and from Vero, were derived from either the West Indies or Middle America. Becker (1985), Emslie and Morgan (1995), and Emslie (1998) mentioned the Neotropical affinities of several species of birds from West Palm Beach and Cutler Hammock. The strong Neotropical component in the Cutler Hammock and Monkey Jungle Hammock vertebrate faunas has prompted an overview of all Florida Rancholabrean mammals that have affinities with the Neotropical Region.

All fossils discussed in this paper are housed in the vertebrate paleontology collections of the Florida Museum of Natural History (formerly the Florida State Museum), University of Florida, Gainesville, Florida. More detailed locality and map data, field notes, and additional information on Cutler Hammock, Monkey Jungle Hammock, West Palm Beach, and other sites described herein are available in the vertebrate paleontology locality files of the Florida Museum of Natural History. Names and distributions for Pleistocene mammals follow Kurtén and Anderson (1980) and Hulbert (2001); those for living mammals follow Wilson and Reeder (1992).

ACKNOWLEDGMENTs.-The Cutler Hammock site was excavated by archaeologists from the Metro-Dade Archaeology Division and the Dade County Archaeological Conservancy under the direction of Robert Carr. Their careful excavation techniques, screening of all sediments removed from the deposit, and detailed field notes greatly augmented the amount and quality of scientific data available from this important site. Access to the Cutler Hammock site was granted by the Deering family, who generously donated the entire Cutler collection of vertebrate fossils to the Florida Museum of Natural History. Lewis D. Ober, William G. Weaver, and several of their students from Miami-Dade Community College excavated the Monkey Jungle Hammock site and deposited the fossils in the
Florida Museum of Natural History. They screened much of the sediment from Monkey Jungle, which led to the recovery of important samples of bats and rodents. Frank Dumond, general manager of Monkey Jungle, kindly permitted access to the property. The West Palm Beach site was excavated by the late Howard H. Converse, Jr., and a large volunteer crew from the West Palm Beach area. The paleontological community owes a debt of gratitude to Howard for preserving the West Palm Beach fossils and for his many other important contributions to Florida paleontology. His untimely death saddened all of us who knew him. Russell W. Graham and S. David Webb provided helpful comments on the manuscript. Last, but certainly not least, I would like to thank my friend and colleague, Clayton E. Ray. Almost 30 years ago Clayton took time out from his always-too-busy schedule to give me a guided tour of the Smithsonian's vertebrate paleontology collection and preparation lab. At the time I was an impressionable undergraduate student considering graduate study in invertebrate paleontology. I was so captivated by vertebrate fossils that I went on to complete an undergraduate thesis on the Desmostylia, with much help and encouragement from Clayton, and then pursued graduate work and eventually a career in vertebrate paleontology. Clayton, many thanks for all your help through the years and congratulations on a long and productive career.

ABBREVIATIONS:

$\begin{array}{ll}\text { BP } & \text { before present } \\ \text { LF } & \text { local fauna } \\ \text { NALMA } & \text { North American land mammal age } \\ \text { Ka } & \text { thousands of years before present } \\ \text { Ma } & \text { millions of years before present } \\ \text { UF } & \text { Florida Museum of Natural History, University of Florida }\end{array}$

\section{Description of Fossil Sites}

\section{CUTLER HAMMOCK}

The Cutler Hammock site is located $13 \mathrm{~km}$ southwest of Miami and $4 \mathrm{~km}$ east of Perrine in Dade County $\left(25^{\circ} 37^{\prime} \mathrm{N}\right.$, $80^{\circ} 19^{\prime} \mathrm{W}$ ), near the southern tip of the Florida peninsula. Fossils were discovered at Cutler Hammock in 1985 and were excavated during 1985 and 1986 by the Historic Preservation Division of Dade County under the direction of Robert Carr and by personnel from the Florida Museum of Natural History. The fossils occur in a sinkhole in a tropical hardwood hammock on the Atlantic Coastal Ridge less than $5 \mathrm{~m}$ above sea level and only about $0.3 \mathrm{~km}$ inland from the Atlantic Ocean. This sinkhole formed in the oolitic facies of the marine late Pleistocene Miami Limestone. Since its formation in the late Pleistocene, the Cutler Hammock sinkhole has filled with sediments composed of sand, clay, and pieces of limestone eroded from the walls of the sinkhole, as well as with abundant vertebrate fossils.

The Cutler Hammock site was carefully excavated using a square-meter grid system over the entire surface of the sinkhole, which is approximately $6 \mathrm{~m}$ in diameter (Carr, 1987). 
Most of the $1 \times 1 \mathrm{~m}$ squares were excavated in arbitrary $10 \mathrm{~cm}$ levels to a depth of at least $2 \mathrm{~m}$. The excavation levels did not follow natural stratigraphic units. The majority of the fossils were derived from the lowermost stratigraphic unit, a layer composed of brownish silt and sand, bones, and limestone fragments. In places, this layer was semi-indurated by a calcareous cement. Cores indicated as much as $3 \mathrm{~m}$ of additional unexcavated sediment below the local water table. All sediments removed from Cutler Hammock, amounting to more than 5 metric tons, were washed through $1.5 \mathrm{~mm}$ mesh window screen. The screening resulted in the recovery of thousands of bones and teeth of small vertebrates, which provided an important addition to the abundant samples of large vertebrates removed using standard excavation techniques.

Emslie and Morgan (1995) provided a vertebrate faunal list for Cutler Hammock and discussed the taphonomy and paleoecology of the site, and Morgan (1991) reviewed the chiropteran fauna, Morgan and Seymour (1997) described and illustrated the Puma concolor fossils, and Emslie (1998) reviewed the avian fauna. The Cutler Hammock vertebrate fauna currently totals 119 species, including five fish, seven amphibians, nine reptiles, 51 birds, and 47 mammals. The faunal list almost certainly will increase as more work is conducted on the extensive microvertebrate sample, only a small fraction of which has been sorted and identified. In particular, additional species of toads, frogs, lizards, snakes, passerine birds, and bats almost surely will be added to the faunal list. Terrestrial vertebrates dominate the Cutler Hammock LF, both in number of species and individuals; however, the faunal list does include a few freshwater fish (gar and bowfin), salamanders (siren and amphiuma), aquatic turtles (mud turtle and pond turtle), water birds (loon, grebe, anhinga, and several ducks), and an otter. The most abundant species in the Cutler Hammock LF are the spadefoot toad (Scaphiopus holbrooki) and colubrid snakes, in particular the indigo snake (Drymarchon corais). Land tortoises are common, including the extant gopher tortoise (Gopherus polyphemus) and the extinct dwarf tortoise (Hesperotestudo incisa). The absence of the extinct giant land tortoise Hesperotestudo crassiscutata is notable, as it is one of the most abundant large vertebrates encountered in Pleistocene sinkhole, fissure, and cave sites in northern Florida. The large avifauna, which includes five extinct species, reflects a diversity of habitats (Emslie and Morgan, 1995; Emslie, 1998). Two large scavenging birds found at Cutler Hammock no longer occur in Florida; the California condor (Gymnogyps californianus) is found only in the western United States and the teratorn (Teratornis merriami) is extinct.

The Cutler Hammock mammalian fauna is composed of 47 species, including 16 members of the extinct Pleistocene megafauna (Table 1). The most abundant ungulates in the fauna are all extinct species, including the long-nosed peccary (Mylohyus nasutus), a small species of Equus, and the extinct bison Bison antiquus. Large carnivores are relatively common in the Cutler Hammock LF, in particular, the dire wolf (Canis dirus) and the
Florida cave bear (Tremarctos floridanus), both of which are extinct, and the extant jaguar (Panthera onca). The abundance of dire wolf remains and the fragmentary condition of most ungulate limb bones led Emslie and Morgan (1995) to hypothesize that the Cutler Hammock site was a carnivore den. Small mammals are common, in particular the eastern cottontail rabbit (Sylvilagus floridanus), the cotton rat, (Sigmodon hispidus), and the eastern woodrat (Neotoma floridana). Extant species in the fauna include two Neotropical taxa no longer found in Florida, the jaguar and the ghost-faced bat (Mormoops megalophylla), as well as two species of rodents, Geomys pinetis and Pitymys pinetorum, and two species of bats, Eptesicus fuscus and Myotis austroriparius, that are now restricted to the northern half of the Florida peninsula (Morgan, 1991).

\section{MONKEY JUNGLE HAMMOCK}

The Monkey Jungle Hammock site also is located in Dade County in southernmost peninsular Florida. The site is on the property of the Monkey Jungle tourist attraction, $5 \mathrm{~km}$ west of Goulds and $12 \mathrm{~km}$ southwest of Cutler Hammock $\left(25^{\circ} 34^{\prime} \mathrm{N}\right.$, $80^{\circ} 26^{\prime} \mathrm{W}$ ). The fossils were discovered in a small sinkhole less than $5 \mathrm{~m}$ above sea level and approximately $10 \mathrm{~km}$ inland from the Atlantic Ocean on the Atlantic Coastal Ridge. Like Cutler Hammock, the fossils at Monkey Jungle were found in a sinkhole in a tropical hardwood hammock developed in the marine late Pleistocene Miami Limestone. Both the Monkey Jungle and Cutler sites were formed during periods of much lower sea level and correspondingly lowered water tables. Consequently, a very late Pleistocene (late Rancholabrean) age is most likely.

Lewis D. Ober, William G. Weaver, and several students from Miami-Dade Community College first found fossils at Monkey Jungle in 1969. Through their efforts the fossiliferous organic sediments were removed from the sinkhole and washed through window screens to recover the rich microvertebrate fauna. No stratigraphic units were recorded. Ober (1978) discussed the discovery of vertebrate fossils at the Monkey Jungle Hammock site and provided a preliminary faunal list. Webb (1974b) mentioned isolated teeth of the stout-legged llama (Palaeolama mirifica) from Monkey Jungle, Martin (1977) and Morgan (1985) reported the large molossid bat Eumops glaucinus, Morgan (1991) reviewed the entire chiropteran fauna, and Morgan and Seymour (1997) described and illustrated a Puma concolor $\mathrm{P} 4$.

The presence of a diverse fauna of large mammalian carnivores and the fragmentary condition of most of the larger bones suggests that, like Cutler Hammock, the Monkey Jungle Hammock sinkhole may have been a carnivore den (Emslie and Morgan, 1995). The abundance of small vertebrates, including many species of frogs, lizards, snakes, birds, and small mammals, indicates that avian predators, most likely owls, roosted in the sinkhole/cave system and concentrated bones there as well. Three species of cave-dwelling bats, Mormoops megalophylla, Pteronotus cf. P. pristinus, and Myotis austroriparius, 
TABLE 1.-Mammalian faunas from the late Pleistocene (late Rancholabrean) Cutler Hammock, Monkey Jungle Hammock, and West Palm Beach local faunas, southem peninsular Florida. ( $x=$ present; $-=$ not present; $\dagger=$ extinct species; \#=extirpated in Florida, but still extant in Neotropical Region; ${ }^{*}=$ no longer found in southern Florida, but still occurring in northern half of state.)

\begin{tabular}{|c|c|c|c|c|c|c|c|}
\hline Taxa & \begin{tabular}{|c|} 
Cutler \\
Hammock
\end{tabular} & $\begin{array}{l}\text { Monkey Jun- } \\
\text { gle Hammock }\end{array}$ & $\begin{array}{l}\text { West Palm } \\
\text { Beach }\end{array}$ & Taxa & $\begin{array}{c}\text { Cutler } \\
\text { Hammock }\end{array}$ & $\begin{array}{l}\text { Monkey Jun- } \\
\text { gle Hammock }\end{array}$ & $\begin{array}{l}\text { West Palm } \\
\text { Beach }\end{array}$ \\
\hline Order MARSUPIALIA & & & & Glaucomys volans & $x$ & $x$ & - \\
\hline Family DIDELPHIDAE & & & & Sciurus carolinensis & $\mathrm{x}$ & $\mathrm{x}$ & - \\
\hline Didelphis virginiana & $x$ & $\mathrm{x}$ & $\mathrm{x}$ & Sciurus niger & $\mathrm{x}$ & $\mathrm{x}$ & - \\
\hline Order XENARTHRA & & & & Family CASTORIDAE & & & \\
\hline Family DASYPODIDAE & & & & Castor canadensis* & - & $\mathrm{x}$ & - \\
\hline Dasypus bellus $\dagger$ & $\mathrm{x}$ & $x$ & - & Family GEOMYIDAE & & & \\
\hline Family PAMPATHERIIDAE & & & & Geomys pinetis* & $\mathrm{x}$ & - & - \\
\hline Holmesina septentrionalis $\dagger$ & $\mathrm{x}$ & - & $\mathrm{x}$ & Family HYDROCHAERIDAE & & & \\
\hline Family MYLODONTIDAE & & & & Neochoerus pinckneyi $\dagger$ & - & - & $\mathrm{x}$ \\
\hline Paramylodon harlani $\dagger$ & $\mathrm{x}$ & - & $\mathrm{x}$ & Family MURIDAE & & & \\
\hline Order INSECTIVORA & & & & Subfamily ARVICOLINAE & & & \\
\hline Family SORICIDAE & & & & Neofiber alleni & $\mathrm{x}$ & $\mathrm{x}$ & - \\
\hline Cryptotis parva & $\mathrm{x}$ & $\mathrm{x}$ & - & Pitymys pinetorum* & $\mathrm{x}$ & $\mathrm{x}$ & - \\
\hline Family TALPIDAE & & & & Synaptomys australist & - & - & $\mathrm{x}$ \\
\hline Scalopus aquaticus & $\mathrm{x}$ & $\mathrm{x}$ & - & Subfamily SIGMODONTINAE & & & \\
\hline Order CHIROPTERA & & & & Neotoma floridana & $\mathrm{x}$ & $\mathrm{x}$ & - \\
\hline Family MORMOOPIDAE & & & & Oryzomys palustris & $\mathrm{x}$ & $\mathrm{x}$ & - \\
\hline Mormoops megalophylla\# & $\mathrm{x}$ & $x$ & - & Peromyscus gossypinus & $\mathrm{x}$ & $\mathrm{x}$ & - \\
\hline Pteronotus cf. P. pristinus $\dagger$ & - & $\mathrm{x}$ & - & Peromyscus polionotus & $x$ & $\mathrm{x}$ & - \\
\hline Family VESPERTILIONIDAE & & & & Podomys floridanus & $\mathrm{x}$ & $\mathrm{x}$ & - \\
\hline Eptesicus fuscus* & $\mathrm{x}$ & $\mathrm{x}$ & - & Sigmodon hispidus & $\mathrm{x}$ & $\mathrm{x}$ & $\mathrm{x}$ \\
\hline Lasiurus sp. & - & $\mathrm{x}$ & - & Order LAGOMORPHA & & & \\
\hline Myotis austroriparius* & $\mathrm{x}$ & $\mathrm{x}$ & - & Family LEPORIDAE & & & \\
\hline Nycticeius humeralis & $\mathrm{x}$ & $\mathrm{x}$ & - & Sylvilagus floridanus & $\mathrm{x}$ & $\mathrm{x}$ & $\mathrm{x}$ \\
\hline Family MOLOSSIDAE & & & & Order PERISSODACTYLA & & & \\
\hline Eumops glaucinus floridanus & - & $\mathrm{x}$ & - & Family TAPIRIDAE & & & \\
\hline Tadarida brasiliensis & - & $\mathrm{x}$ & - & Tapirus veroensis $\dagger$ & - & - & $\mathrm{x}$ \\
\hline Order CARNIVORA & & & & Family EQUIDAE & & & \\
\hline Family CANIDAE & & & & Equus small sp. $\dagger$ & $x$ & $x$ & $x$ \\
\hline Canis dirus $\dagger$ & $x$ & $x$ & $x$ & Equus large sp. $\dagger$ & $\mathrm{x}$ & - & - \\
\hline Canis latrans ${ }^{*}$ & $\mathbf{x}$ & $\mathrm{x}$ & - & Order ARTIODACTYLA & & & \\
\hline Urocyon cinereoargenteus & $\mathrm{x}$ & $\mathrm{x}$ & - & Family TAYASSUIDAE & & & \\
\hline Family URSIDAE & & & & Mylohyus nasutus $\dagger$ & $\mathrm{x}$ & $\mathrm{x}$ & $x$ \\
\hline Tremarctos floridanus $\dagger$ & $\mathrm{x}$ & $\mathrm{x}$ & - & Platygonus compressus $\dagger$ & $\mathrm{x}$ & $\mathrm{x}$ & - \\
\hline Ursus americanus & $\mathrm{x}$ & - & - & Family CAMELIDAE & & & \\
\hline Family PROCYONIDAE & & & & Hemiauchenia macrocephala $\dagger$ & $\mathrm{x}$ & $\mathrm{x}$ & - \\
\hline Procyon lotor & $\mathrm{x}$ & $x$ & $x$ & Palaeolama mirifica $\dagger$ & $x$ & $\mathbf{x}$ & $x$ \\
\hline Family MUSTELIDAE & & & & Family CERVIDAE & & & \\
\hline Lutra canadensis & $\mathrm{x}$ & - & - & Odocoileus virginianus & $\mathrm{x}$ & $\mathrm{x}$ & $\mathrm{x}$ \\
\hline Mephitis mephitis & $\mathrm{x}$ & - & - & Family BOVIDAE & & & \\
\hline Spilogale putorius & $\mathrm{x}$ & $\mathrm{x}$ & - & Bison antiquus $\dagger$ & $\mathrm{x}$ & - & $\mathbf{x}$ \\
\hline Family FELIDAE & & & & Order ProBoscideA & & & \\
\hline Lynx rufus & $\mathrm{x}$ & $\mathrm{x}$ & - & Family MAMMUTIDAE & & & \\
\hline Panthera atrox $\dagger$ & $\mathrm{x}$ & $\mathrm{x}$ & - & Mammut americanum $\dagger$ & $x$ & - & $\mathrm{x}$ \\
\hline Panthera onca\# & $\mathrm{x}$ & $\mathrm{x}$ & - & Family ELEPHANTIDAE & & & \\
\hline Puma concolor & $\mathrm{x}$ & $\mathrm{x}$ & - & Mammuthus columbi $\dagger$ & $\mathrm{x}$ & - & $x$ \\
\hline Smilodon fatalis $\dagger$ & $\mathrm{x}$ & - & - & & & & \\
\hline $\begin{array}{l}\text { Order RODENTIA } \\
\text { Family SCIURIDAE }\end{array}$ & & & & Total number of species & 47 & 41 & 17 \\
\hline
\end{tabular}

have been identified from Monkey Jungle, suggesting that this fossil site was a dry cave or sinkhole/cave system in the late Pleistocene. These three species no longer occur in southern Florida, presumably because there are currently no extensive dry cave systems in this region that would provide suitable roosting sites for cavernicolous bats. At present there are no caves in Florida south of Orange and Hernando Counties (about $28^{\circ} 30^{\prime} \mathrm{N}$ ) that are inhabited by bats (Rice, 1957; Jennings, 1958; Morgan, 1985, 1991). During the Wisconsinan glaciation, when both sea level and local water tables were much lower than present, southernmost peninsular Florida and the Florida Keys probably consisted of a low-relief carbonate platform as much as $100 \mathrm{~m}$ above sea level. It is likely that an extensive karst terrain developed in southern Florida at that 
time, as the Miami Limestone and Key Largo Limestone would have been highly susceptible to the formation of caves, sinkholes, and other karst features. The Monkey Jungle Hammock and Cutler Hammock sinkholes or sinkhole/cave systems almost certainly formed during the Wisconsinan and subsequently became filled with sediments near the end of this interval between 20 and $11 \mathrm{Ka}$.

The mammalian fauna from the Monkey Jungle Hammock site consists of 41 species, including nine extinct members of the Pleistocene megafauna (Table 1). Like Cutler Hammock, large carnivores are a common element of the fauna, particularly Canis dirus, Panthera onca, Puma concolor, and Tremarctos floridanus. Large ungulates are uncommon, and Bison antiquus and proboscideans are absent. Another similarity between the Monkey Jungle and Cutler faunas is the presence of two extant species of Neotropical mammals no longer found in Florida, Panthera onca and Mormoops megalophylla. Monkey Jungle records the southernmost Florida occurrence of four species of mammals that previously were unknown in the modern and late Pleistocene fauna south of Lake Okeechobee, the bats Myotis austroriparius and Eptesicus fuscus and the rodents Castor canadensis and Pitymys pinetorum. Monkey Jungle Hammock (Morgan, 1991) and Clark's Cave, Virginia (Guilday et al., 1977), each contain eight species of bats; thus they are the most diverse Pleistocene chiropteran faunas in North America (Kurtén and Anderson, 1980).

\section{West PaLM BEACH}

The West Palm Beach site was located in a shell rock pit near the city of West Palm Beach in Palm Beach County $\left(26^{\circ} 42^{\prime} \mathrm{N}\right.$, $80^{\circ} 10^{\prime} \mathrm{W}$ ), approximately $100 \mathrm{~km}$ north of the Cutler Hammock and Monkey Jungle Hammock sites (Figure 1). Like so much of southern Florida, this area was subsequently developed for residential housing, and the fossil site no longer exists. The site was discovered in 1969 when a dragline operator digging a drainage canal unearthed the partial skeleton of a mammoth. The late Howard H. Converse, Jr., and a large volunteer crew spent the following two months excavating the large sample of vertebrates that now constitute the West Palm Beach LF. All of the fossils were excavated from a small area of the pit that measured 27 meters by 16 meters. Converse (1973) discussed the discovery and excavation of the West Palm Beach locality and presented a preliminary vertebrate faunal list.

The vertebrate fauna from West Palm Beach differs from those of Cutler Hammock and Monkey Jungle Hammock in the dominance of aquatic vertebrates, the abundance of large ungulates, and the rarity of small mammals and carnivores. The aquatic component of the West Palm Beach fauna consists of rich samples of freshwater fish, including bowfin (Amia calva), gar (Lepisosteus sp.), and catfish (Ameiurus sp.), pond turtles (Trachemys scripta and Pseudemys nelsoni), and alligators (Alligator mississippiensis). Two large mammals from West Palm
Beach generally are associated with freshwater aquatic sites in Florida as well (Webb, 1974a), the giant capybara (Neochoerus pinckneyi) and the Vero tapir (Tapirus veroensis). The closest living relatives of these extinct species are presently restricted to the Neotropics and prefer aquatic habitats. Most of these aquatic vertebrates are either absent or rare at the Cutler and Monkey Jungle sites. The abundance of freshwater taxa, absence of estuarine and nearshore marine species, and presence of numerous well-preserved fossils of large terrestrial vertebrates suggest that the West Palm Beach site was deposited in a freshwater depositional environment, probably in a pond, marsh, or slow-moving stream located in a grassland savanna habitat.

The 17 species of mammals identified from the West Palm Beach LF are listed in Table 1. Large mammals dominate the fauna, in particular, American mastodont (Mammut americanum), Columbian mammoth (Mammuthus columbi), and Bison antiquils. Unlike Cutler and Monkey Jungle, there are numerous complete mandibles, limb bones, and a few skulls of large mammals from West Palm Beach. In addition to the partial mammoth skeleton mentioned above, an associated skeleton of a juvenile mastodont and a nearly complete skull and several mandibles of adult mastodonts also were collected. Two xenarthrans occur at West Palm Beach; the giant armadillo (Holmesina septentrionalis) is represented by a single osteoderm, whereas Harlan's ground sloth (Paramylodon harlani) is known from a complete mandible, humerus, and several other postcranial elements. Carnivores are rare, being represented by one identifiable element each of Canis dirus and raccoon (Procyon lotor). Neochoerus pinckneyi and Tapirus veroensis are the only large mammals from West Palm Beach that are absent at Cutler and Monkey Jungle (Table 1). A skull of $N$. pinckneyi from West Palm Beach is one of the most nearly complete known specimens of this species (Ahearn, 1981). This site was not extensively sampled for microvertebrates, but preliminary washing suggested that small mammals were uncommon. $D i$ delphis virginiana, Sylvilagus floridanus, Synaptomys australis, and Sigmodon hispidus are the only small mammals known in the fauna, and all of these species are represented by limited samples. The West Palm Beach LF is the southernmost record for the extinct bog lemming (Synaptomys australis), which also is the only small mammal from this locality that is absent from both the Cutler and Monkey Jungle sites.

Despite the importance of the West Palm Beach LF, it has received scant mention in the scientific literature. Besides Converse's (1973) semipopular account of the site, Robertson (1974) described a skull and two horn cores of Bison antiquus and Becker (1985) reported the avifauna. The fossil birds from West Palm Beach consist of eight species, two of which are extinct (a stork, Ciconia maltha, and a hawk eagle, Spizaetus $\mathrm{cf}$. $S$. grinnelli), and two species that now have very restricted ranges in western North America (the California condor, Gymnogyps californianus, and the whooping crane, Grus americanus). 
OTHER SOUTH FLORIDA RANCHOLABREAN AND HOLOCENE SITES

Although Cutler Hammock, Monkey Jungle Hammock, and West Palm Beach are the largest Rancholabrean faunas known from southern peninsular Florida, a few fossils are known from several other localities in this region. A few isolated vertebrate fossils of late Pleistocene age from Dade County are worthy of note (Figure 1). Two teeth of the extinct tapir, Tapirus veroensis (UF 1539), found in 1918 near Florida City in Dade County about $15 \mathrm{~km}$ southwest of Monkey Jungle, actually are the southernmost well-documented vertebrate fossils known from the Florida peninsula. A set of mandibles with both lower $\mathrm{m} 3 \mathrm{~s}$ of Mammuthus columbi (UF 12562) was collected in 1923 during the dredging of a ship basin within the city limits of Miami in northern Dade County. Although no associated fauna was recovered with the tapir or mammoth specimens, a late Rancholabrean age is most probable. Persistent rumors exist of mammoth teeth, presumably Mammuthus columbi, collected in shallow waters off the Florida Keys, but no specimens have yet been positively identified. There is every reason to believe that Rancholabrean vertebrate fossils eventually will be discovered in the Florida Keys, as these islands were directly connected to the Florida peninsula during the late Pleistocene low sea-level stand.

The Nichol's Hammock LF was collected $1 \mathrm{~km}$ northeast of Princeton, less than $5 \mathrm{~km}$ southeast of Monkey Jungle in southern Dade County $\left(25^{\circ} 32^{\prime} \mathrm{N}, 80^{\circ} 25^{\prime} \mathrm{W}\right)$. Hirschfeld (1968) reviewed the Nichol's Hammock vertebrate fauna. Like the Monkey Jungle and Cutler sites, the fossils from Nichol's Hammock were deposited in a small sinkhole in a tropical hardwood hammock. Unlike those two Rancholabrean sites, however, the Nichol's Hammock fauna consists exclusively of extant species and thus is almost certainly Holocene in age. The only mammals from Nichol's Hammock that do not currently occur in southeastern peninsular Florida are the eastern woodrat (Neotoma floridana) and the red wolf (Canis rufus). An endemic subspecies of $N$. floridana now occurs on Key Largo, but woodrats are otherwise absent south of Lake Okeechobee. The record of the red wolf is more problematic. The Nichol's Hammock record, a mandible with a nearly complete dentition, represents the only fossil occurrence in Florida of C. rufus, a species that inhabited the state until the early twentieth century. The complete absence of $C$. rufus from Rancholabrean fossil sites and Holocene archaeological sites in Florida suggests that the red wolf appeared in the state fairly recently. Judging from the occurrence of $C$. rufus, the Nichol's Hammock LF may be only a few hundred years old (Hirschfeld, 1968), although no radiocarbon dates from the site are currently available to confirm or refute this hypothesis.

The Monkey Jungle 2 LF and the Monkey Jungle Hammock LF are both located in the Monkey Jungle tourist attraction near Goulds in Dade County. Although both sites were depos- ited in small sinkholes, they are quite different in age and faunal composition. The Monkey Jungle $2 \mathrm{LF}$ is similar to Nichol's Hammock in its lack of extinct species. A late Holocene age is supported by the presence of the black rat (Rattus rattus), an Old World species introduced into Florida within the last 500 years. Morgan (1991) reported the large molossid bat Eumops glaucinus from Monkey Jungle 2, a species with Neotropical affinities that still occurs in the Miami area.

\section{Age of Rancholabrean Faunas from Southernmost Florida}

The vertebrate fossils from both the Cutler Hammock and Monkey Jungle Hammock sites accumulated in sinkholes in the marine Pleistocene Miami Limestone. Oolites from the Miami Limestone in nearby Coral Gables, Florida, have been dated at 140-110 Ka (Osmond et al., 1965). These and similar ages for the contemporaneous Key Largo Limestone of the Florida Keys indicate that the Miami Limestone was deposited during the last (Sangamonian) interglacial, when sea level was approximately $6 \mathrm{~m}$ higher than present (Bloom, 1983), completely inundating the Florida Keys and much of southern peninsular Florida. The last interglacial high sea-level stand, which corresponds to isotope substage $5 \mathrm{e}$, has been dated at many sites worldwide to between 130 and $120 \mathrm{Ka}$ (Harmon et al., 1983). The Cutler Hammock and Monkey Jungle Hammock sites accumulated during the subsequent Wisconsinan glacial interval between 120 and $10 \mathrm{Ka}$, a period during which sea levels were persistently lower than present.

The late Rancholabrean comprises the time interval from the beginning of the last interglacial $(130 \mathrm{Ka})$ until the end of the Pleistocene ( $10 \mathrm{Ka})$. The Cutler Hammock and Monkey Jungle Hammock local faunas are clearly late Rancholabrean by this definition and are most likely very late Pleistocene in age (20-11 Ka), corresponding to the $100 \mathrm{~m}$ drop in sea level during the late Wisconsinan glacial maximum. Further refinement of the ages of these two sites may not be possible because of the lack of directly associated radiocarbon dates. Tests performed by the University of Arizona radiocarbon laboratory confirmed that bones from both Cutler and Monkey Jungle are too highly leached (nitrogen content below $0.1 \%$ ) to yield accurate radiocarbon dates. The subtropical climate of Florida, which is characterized by high temperature, rainfall, and humidity, coupled with acidic soils, accounts for the nearly ubiquitous diagenetic alteration, particularly leaching, observed in bones from most Florida late Rancholabrean fossil sites. Many of these same processes, along with the intense activity of soil invertebrates, also have eliminated wood and other datable organic materials from Florida sites. The few late Rancholabrean sites from the state that have yielded accurate radiocarbon dates apparently have been continuously submerged since the end of the Pleistocene, including the Aucilla River sites in the eastern panhandle (Dunbar et al., 1989) and Little Salt Spring 
(Clausen et al., 1979) and Warm Mineral Springs (McDonald, 1990), both of which are deep, water-filled sinkholes located in southwestern Florida. These underwater sites often have excellent preservation of wood that has been dated to provide comparative radiocarbon ages for dates obtained from bone collagen.

Although no radiocarbon dates from Cutler Hammock were obtained from layers containing remains of extinct mammals, there is one reliable date from an overlying layer. A charcoal sample from a layer $1.25 \mathrm{~m}$ below the surface containing a hearth and human remains was radiocarbon dated at $9670 \pm 120$ years before present (BP) (Beta-16750), indicating a very early Holocene age (Carr, 1987). No extinct species of mammals were found in association with this radiocarbon date; however, many extinct megafaunal taxa were recovered from layers immediately below the hearth. This early Holocene date provides a minimum age for the Cutler Hammock LF.

A piece of mastodont rib from West Palm Beach was radiocarbon dated at $21,150 \pm 400$ years BP (Buckley and Willis, 1972; Converse, 1973), indicating a late Rancholabrean (Wisconsinan) age. This is a whole-bone date based upon the combined inorganic and organic carbon fractions of the bone. The more rigorous radiocarbon-dating techniques now applied to bones date only the bone collagen (i.e., the organic carbon fraction), which constitutes about $20 \%$ of the carbon in bones. The inorganic component of bone carbon is highly subject to diagenetic alteration and routinely gives erroneous radiocarbon dates. Although this radiocarbon date is suspect, it probably does provide a minimum date for the site.

Mammalian biochronology provides the most useful information on the age of the Cutler Hammock, Monkey Jungle Hammock, and West Palm Beach local faunas. The first appearance of Bison in North America at about $300 \mathrm{Ka}$ is generally used to define the base of the Rancholabrean NALMA (Savage, 1951; Lundelius et al., 1987). Although the presence of Bison is convenient for defining the Rancholabrean, this genus is often absent in Florida Rancholabrean faunas; therefore, other faunal criteria have been established for recognizing Rancholabrean faunas in Florida (Morgan and Hulbert, 1995). Mammals from the Cutler Hammock and/or Monkey Jungle Hammock local faunas (see faunal lists in Table 1) that are restricted to Rancholabrean faunas in Florida are Canis dirus, Tremarctos floridanus, Ursus americanus, Smilodon fatalis, Panthera atrox ( $=P$. leo atrox of Kurtén and Anderson, 1980), Puma concolor, Sciurus niger, Pitymys pinetorum, Oryzomys palustris, Sigmodon hispidus, and Bison antiquus. All of these species are known from Cutler Hammock, and all but three, Ursus americanus, Smilodon fatalis, and Bison antiquus, occur at Monkey Jungle Hammock. Three of these species, Canis dirus, Sigmodon hispidus, and Bison antiquus, have been identified from West Palm Beach. Furthermore, more than one-half of these species occur only in late Rancholabrean faunas in Florida (Morgan and Hulbert, 1995): U. americanus, P. atrox, P. concolor, S. niger, P. pinetorum, S. hispidus, and B. antiquus.

\section{Rancholabrean Mammals from Southernmost Florida}

MARSUPIALIA.-The opossum (Didelphis virginiana) is present in the West Palm Beach, Cutler Hammock, and Monkey Jungle Hammock local faunas. This species is common in many Florida Rancholabrean faunas and is currently widespread throughout the state. Didelphis virginiana is the only member of the Neotropical family Didelphidae found in Rancholabrean faunas north of Mexico. Marsupials went extinct in North America in the middle Miocene and did not reappear until Didelphis arrived from South America in the middle Pleistocene (late Irvingtonian). The earliest North American records of $D$. virginiana are from two Florida late Irvingtonian faunas, Coleman 2A in Sumter County (Martin, 1974) and Sebastian Canal in Brevard County (Morgan and Portell, 1996).

XENARTHRA.-The beautiful armadillo (Dasypus bellus) is the most common xenarthran in the two Dade County fossil sites, and it is the only member of this group present at Monkey Jungle. The giant armadillo or pampathere (Holmesina septentrionalis) and Harlan's ground sloth (Paramylodon harlani) both occur in the Cutler Hammock and West Palm Beach faunas, although neither species is common. The presence of $D$. bellus, H. septentrionalis, and P. harlani in southernmost Florida is not unexpected, as these are the three most common and widespread of the six species of xenarthrans known from Florida Rancholabrean faunas. The giant ground sloth Eremotherium laurillardi (see Cartelle and De Iuliis, 1995, for use of this species name rather than E. mirabile or E. rusconii) and the glyptodont Glyptotherium floridanum are found primarily in Florida coastal faunas and are rare in Rancholabrean sinkhole/ cave sites. Jefferson's ground sloth (Megalonyx jeffersonii) has a rather spotty distribution in Florida but occurs most often in sinkhole/cave and river sites in the northern part of the state. Five of these six genera (the cingulates Dasypus, Holmesina, and Glyptotherium and the ground sloths Eremotherium and Paramylodon=Glossotherium, in part; see McDonald, 1995) first entered Florida in the late Pliocene (late Blancan) as early participants in the Great American Faunal Interchange. The entire assemblage of xenarthrans found in Florida Rancholabrean faunas went extinct at the end of the Pleistocene. The ninebanded armadillo (Dasypus novemcinctus) is now common throughout the state but is unknown from Florida Rancholabrean faunas.

INSECTIVORA.-Two species of insectivores have been identified from Cutler Hammock and Monkey Jungle Hammock, the least shrew (Cryptotis parva) and the eastern mole (Scalopus aquaticus). Both species still inhabit southern peninsular Florida. The third insectivore currently found in southern Florida, the short-tailed shrew (Blarina carolinensis) is curiously absent from these two faunas. The only other insectivore known from Florida, the southeastern shrew (Sorex longirostris), is unknown from the southern two-thirds of the peninsula. Insectivores, in particular soricids, are more speciose in temperate and boreal regions, so their lack of diversity in the late Pleistocene and modern faunas of Florida is not unexpected. 
CHIROPTERA.-Eight species of bats representing three families are known from Monkey Jungle Hammock (Morgan, 1991): the mormoopids Mormoops megalophylla and Pteronotus $\mathrm{cf}$. P. pristinus; the vespertilionids Myotis austroriparius, Eptesicus fuscus, Lasiurus sp., and Nycticeius humeralis; and the molossids Tadarida brasiliensis and Eumops glaucinus floridanus. Four of these species, M. megalophylla, M. austroriparius, E. fuscus, and $N$. humeralis, have been identified from Cutler Hammock. No bats occur in the West Palm Beach LF. The two mormoopids are no longer found in Florida; P. pristi$n u s$ is extinct and M. megalophylla is now restricted to the southwestern United States and the Neotropics. Myotis austroriparius and E. fuscus are presently unknown in the southern one-third of the Florida peninsula. Mormoops megalophylla, $P$. pristinus, and $M$. austroriparius almost certainly inhabited caves in southern Florida. Eptesicus fuscus commonly roosts in caves as well, especially in the West Indies, although this species is currently rare in Florida caves. The bat faunas from both Monkey Jungle and Cutler indicate that extensive cave systems existed in southernmost Florida during the late Pleistocene, despite the absence of dry caves in this region at the present time. The disappearance of these four species of bats from southern Florida probably resulted from the rise in sea level and water tables since the end of the Pleistocene, which caused the flooding of formerly dry cave systems and the subsequent loss of suitable roosting sites (Morgan, 1991). Late Pleistocene and Holocene extinctions of cave-dwelling bats occurred throughout the West Indies as well, particularly on small, low limestone islands such as the Bahamas and Cayman Islands (Morgan and Woods, 1986; Morgan, 1989a, 1991, 1994a, 2001). These localized extinctions of bats in the Antilles also have been attributed to the post-glacial flooding of caves that were dry during the late Pleistocene low sea-level stand.

Fossils of Mormoops megalophylla from Cutler Hammock and Monkey Jungle Hammock constitute the second and third records of this species from the Pleistocene of Florida (Morgan, 1991). Ray et al. (1963) and Wilkins (1983) reported $M$. megalophylla from the Rancholabrean Rock Springs LF in Orange County about $350 \mathrm{~km}$ north of the Dade County fossil sites. Mormoops megalophylla is currently found in the United States only in southern Texas and Arizona. It is primarily a Neotropical species occurring from Mexico south throughout Central America to northern South America and Trinidad (Smith, 1972). Other late Pleistocene fossils of M. megalophylla from outside its modern range are known from Cuba, Hispaniola, Jamaica, Abaco, Andros, and Tobago (Silva Taboada, 1974; Eshelman and Morgan, 1985; Morgan and Woods, 1986; Morgan, 1989a, 2001). Two mandibles tentatively referred to Pteronotus pristinus, an extinct species described from late Quaternary cave deposits in Cuba (Silva Taboada, 1974), were reported from Monkey Jungle by Morgan (1991). No living or fossil species of Pteronotus had been recorded previously from the United States, although several species of Pteronotus are found in northern Mexico and Cuba
(Smith, 1972). Three Cuban species of Pteronotus were identified from late Quaternary cave deposits on Abaco, Andros, and New Providence, although all three are now extinct in the Bahamas (Morgan, 1989a, 2001). Considering the diversity of mormoopids in Cuba and Bahamas during the late Pleistocene (Silva Taboada, 1974; Morgan, 1989a, 2001), and the close proximity of these islands to Florida, it is not entirely unexpected to find an Antillean species of Pteronotus in a late Pleistocene fossil site in southern Florida.

Myotis austroriparius does not presently inhabit the southern half of the Florida peninsula. This is almost certainly related to the absence of dry caves in southern Florida, as this species usually roosts in caves for at least part of the year (Rice, 1957). Myotis austroriparius is the most abundant fossil bat in northern Florida, where it has been identified from more than 10 Rancholabrean cave, sinkhole, and fissure deposits (Martin, 1972). Eptesicus fuscus is common in both the Monkey Jungle Hammock and Cutler Hammock faunas. The big brown bat is one of the most widespread bats in North America, but it is currently unknown from the southern one-third of the Florida peninsula and is uncommon throughout the remainder of the state. Fossils of E. fuscus also are rare in Florida, having been reported from only three other Rancholabrean sites, Vero, Arredondo 2A, and Reddick 1A (Morgan, 1985). A small species of Lasiurus, either L. borealis or L. seminolus, occurs at Monkey Jungle. The fragmentary condition of the fossils does not permit a more precise identification. Lasiurus seminolus is the only small Lasiurus now found in southern Florida; however, the presence of E. fuscus and M. austroriparius at Monkey Jungle, both far south of their modern ranges, suggests that $L$. borealis also could have extended its range southward. Fossils of small Lasiurus are known from two other Florida Rancholabrean sites, Reddick 1A and Vero (Morgan, 1985). The evening bat (Nycticeius humeralis) now occurs throughout the Florida peninsula (Layne, 1974). In addition to the Monkey Jungle record, the only other Pleistocene fossils of $N$. humeralis are from Vero (Morgan, 1985) and Baker's Bluff Cave, Tennessee (Guilday et al., 1978).

The Mexican free-tailed bat (Tadarida brasiliensis) occurs in the Holocene Nichols Hammock LF (Morgan, 1991), as well as Monkey Jungle Hammock. Tadarida brasiliensis is now the most abundant bat in southern Florida (Layne, 1974). This species is not known to roost in caves in Florida (Jennings, 1958; Morgan, 1991), in marked contrast to the southwestern United States, where T. brasiliensis inhabits caves in huge numbers. Tadarida brasiliensis now roosts almost exclusively in humanmade structures in Florida, although before the twentieth century they probably lived in trees. The only other Florida Rancholabrean records of T. brasiliensis are from Reddick 1A and Vero (Morgan, 1985, 1991). A distal humerus of Tadarida from the late Blancan Macasphalt Shell Pit LF in Sarasota County in southwestern Florida is not identifiable to the species level (Morgan and Ridgway, 1987; Morgan, 1991). Wagner's mastiff bat (Eumops glancinus) occurs in both the Monkey Jungle 
Hammock and Holocene Monkey Jungle 2 faunas (Martin, 1977; Morgan, 1991). Other Florida fossil records of this species are from the Holocene stratum at Vero (Morgan, 1985) and the late Rancholabrean Melbourne LF (Allen, 1932; Ray et al., 1963; Koopman, 1971). Eumops glaucinus currently inhabits southernmost peninsular Florida, Cuba, Jamaica, and the mainland Neotropics from Mexico to tropical South America. All Neotropical representatives of E. glaucinus have been referred to the nominal subspecies. Only the Florida population is sufficiently distinct to be regarded as a different subspecies, $E$. glaucinus floridanus, which was first described as a fossil from Melbourne (Allen, 1932; Koopman, 1971; Eger, 1977).

CARNIVORA.-Diverse carnivore assemblages characterize Cutler Hammock and Monkey Jungle Hammock, whereas only two carnivores, Canis dirus and Procyon lotor, are known from West Palm Beach (Table 1). Fourteen species of mammalian carnivores have been identified from Cutler Hammock, 10 of which also occur at Monkey Jungle. Emslie and Morgan (1995) summarized the rich carnivore fauna from Cutler Hammock and concluded that the site represented a dire wolf den, at least in part. They identified 42 individuals of Canis dirus from Cutler Hammock, many of which were juveniles. Furthermore, the remains of the most abundant ungulates in the site, particularly small peccaries, consist almost entirely of isolated teeth and ends of limb bones, many of which appear to have been gnawed. Other common large carnivores at Cutler Hammock (in decreasing order of abundance) are Tremarctos floridanus, Canis latrans, Panthera onca, and Lynx rufus. Four other large carnivores are represented by one individual each: Ursus americanus, Panthera atrox, Puma concolor, and Smilodon fatalis. Cutler Hammock is one of the few Rancholabrean sites in North America that records the association of four large cats, Panthera atrox, Panthera onca, Puma concolor, and Smilodon fatalis. Among Florida's large Rancholabrean felids, only Homotherium serum is absent from Cutler Hammock. Homotherium serum has been reported from Reddick (Waldrop, 1974) but is unknown from the southern half of the state. Ursus americanus, Lutra canadensis, Mephitis mephitis, and Smilodon fatalis are the only carnivores in the Cutler fauna that are absent from Monkey Jungle.

There is some question about the identification of Canis latrans from Cutler and Monkey Jungle. The specimens tentatively identified as C. latrans from Cutler Hammock, including maxillae, mandibles, and isolated teeth, are considerably smaller than typical western coyotes. The presence of human remains in association with extinct Pleistocene megafauna in several stratigraphic levels at the Cutler Hammock site (Carr, 1987; Emslie and Morgan, 1995) suggests the intriguing possibility that the small Cutler Canis may actually represent an early domestic dog, C. familiaris. Only further careful study of the well-preserved fossils of small Canis from Cutler Hammock, as well as of the less complete fossils from Monkey Jungle and several other Florida Rancholabrean sites, will clarify their taxonomic status.
RODENTIA AND LAGOMORPHA.-Thirteen species of rodents have been identified from Cutler Hammock or Monkey Jungle Hammock (Table 1). Eleven of these species are shared between the two faunas, and each site has one rodent not found in the other. These latter two species are the beaver (Castor canadensis) from Monkey Jungle and the pocket gopher (Geomys pinetis) from Cutler Hammock. Both of these rodents are now restricted to the northern half of the Florida peninsula. Geomys pinetis has specialized habitat requirements, specifically dry, loose sandy soils for burrowing, that appear to be lacking in southern peninsular Florida (Wilkins, 1984). The pine vole (Pitymys pinetorum) occurs at both Cutler and Monkey Jungle, but like the beaver and pocket gopher it is now absent in southern Florida. Two other rodents identified from these two sites, the Florida mouse (Podomys floridanus) and the beach mouse (Peromyscus polionotus) are now absent or are very rare in southernmost peninsular Florida. The most abundant rodent in the Cutler and Monkey Jungle faunas is the cotton rat (Sigmodon hispidus), which also is one of the most common living rodents in southern Florida. Sigmodon hispidus also occurs in the West Palm Beach LF, as do two other rodents, Neochoerus pinckneyi and Synaptomys australis, neither of which is known from Cutler or Monkey Jungle. West Palm Beach is the southernmost Florida record for both of these extinct species.

The presence in the Cutler and Monkey Jungle sites of all three species of squirrels that currently inhabit the Florida peninsula is notable. Sciurids are generally rare or absent in most Florida Rancholabrean faunas. Sciurus carolinensis and S. niger are not particularly common in the two Dade County sites, but flying squirrels (Glaucomys volans) are second only to Sigmodon hispidus in abundance among rodents at Monkey Jungle and also are fairly common at Cutler. Flying squirrels are known from several other Florida late Pliocene and Pleistocene sinkhole or cave sites. A possible reason for the abundance of flying squirrels in sinkhole/cave sites is predation by owls, particularly the barn owl (Tyto alba).

The eastern woodrat (Neotoma floridana) is one of the most common rodents at both Cutler and Monkey Jungle. This species no longer occurs in the southern one-third of the Florida peninsula; however, an isolated endemic subspecies, $N$. floridana smalli, inhabits Key Largo, the northernmost of the Florida Keys, located about $30 \mathrm{~km}$ south of the Dade County sites. The Cutler and Monkey Jungle records of $N$. floridana, along with a Holocene record from Nichol's Hammock (Hirschfeld, 1968), indicate that the woodrat's range extended to the southern tip of the Florida peninsula until recently.

The cottontail rabbit (Sylvilagus floridanus) occurs in the Cutler Hammock, Monkey Jungle Hammock, and West Palm Beach faunas and is especially common in the Cutler site. The marsh rabbit ( $S$. palustris) has not been identified from any of these sites, even though it is fairly common in southern peninsular Florida and is one of the few indigenous mammals known from the Florida Keys (Lazell, 1989). The absence of marsh rabbits at Cutler and Monkey Jungle is probably related to this 
species' preference for wet-marshy or swampy-habitats. Most of the vertebrates from these two sites are more indicative of drier forested or savanna habitats.

PERISSODACTYLA.-Two species of horses of the genus Equus are known from Cutler Hammock, one of which also occurs in the Monkey Jungle Hammock and West Palm Beach faunas. Because of the taxonomic confusion that plagues the North American members of this genus, the Equus fossils from these three sites are not identified to species. The smaller horse from the Cutler site belongs to the E. alaskae group of Equus species, whereas the larger species belongs to the E. laurentius group, according to Winans's (1989) study of North American fossil Equus. The smaller Equus is the second most abundant ungulate at Cutler Hammock. The most interesting aspect of the Cutler horse fossils is that virtually the entire sample consists of isolated deciduous premolars and unerupted or newly erupted premolars and molars. Considering the abundance of Canis dirus in the Cutler fauna, Emslie and Morgan (1995) hypothesized that juvenile horses probably constituted a significant portion of the dire wolves' diet, exceeded in numbers only by peccaries. There is a small sample of Tapirus veroensis from West Palm Beach. Tapirs are absent from Cutler and Monkey Jungle, probably because conditions at these sites were more favorable to terrestrial taxa.

ARTIODACTYLA.-Six species of artiodactyls have been identified from the Cutler Hammock LF. Five of these species occur at Monkey Jungle and four are known from West Palm Beach. The most abundant large mammal from Cutler Hammock is the long-nosed peccary (Mylohyus nasutus). Emslie and Morgan (1995) counted 99 individuals of M. nasutus from Cutler Hammock; however, that number will increase substantially when the fauna is completely curated. The Cutler Mylohyus sample consists of hundreds of isolated adult and juvenile teeth, a small sample of mandibular and maxillary fragments, and numerous ends of long bones, carpals, tarsals, and phalanges. The fragmentary condition of most of the M. nasutus fossils from the Cutler site, as well as the large number of gnawed limb ends of this species, led Emslie and Morgan (1995) to hypothesize that peccaries composed a large portion of the diet of the carnivores that inhabited the cave, particularly Canis dirus. A few fossils of $M$. nasutus are known from Monkey Jungle Hammock and West Palm Beach. Florida's other Rancholabrean tayassuid, the flat-headed peccary, Platygonus compressus, is uncommon at Cutler and Monkey Jungle and is absent from West Palm Beach.

Camels are not particularly common in any of the three faunas under discussion. Both the large-headed llama (Hemiauchenia macrocephala) and the stout-legged llama (Palaeolama mirifica) are represented by small samples of isolated teeth from Cutler and Monkey Jungle. Webb (1974b) listed $P$. mirifica from Monkey Jungle, and Converse (1973) mentioned this species from West Palm Beach, the only species of camel from the latter fauna. White-tailed deer (Odocoileus virginianus) are fairly common in all three faunas. The extinct bison
Bison antiquus is among the most abundant large mammals in both the Cutler Hammock and West Palm Beach faunas. No horn core is known from the Cutler site, where the bison sample consists almost exclusively of isolated teeth, and thus the identification of $B$. antiquus is based upon the late Rancholabrean age of the fauna. A partial bison skull with both horn cores from West Palm Beach is definitely identifiable as B. antiquus (Robertson, 1974).

PROBOSCIDEA.-Both species of proboscideans found in Florida late Rancholabrean sites, the American mastodont (Mammut americanum) and the Columbian mammoth (Mammuthus columbi), occur at Cutler Hammock and West Palm Beach. No proboscideans are known from Monkey Jungle. The samples of these two species from Cutler Hammock are very sparse, consisting of isolated enamel plates and one deciduous premolar of $M$. columbi and a single enamel fragment of $M$. americanum. Both mastodonts and mammoths are common at West Palm Beach. The M. americanum sample includes the complete skeleton of a juvenile mounted at the West Palm Beach Science Center, as well as a complete skull and several mandibles in the UF collection. A partial M. columbi skeleton also was discovered at this site. The rarity of mastodonts and mammoths at Cutler and their absence at Monkey Jungle is not unexpected, as these two species are generally uncommon in Florida Rancholabrean sinkhole and cave sites.

\section{Florida Neogene and Recent Vertebrates with Neotropical Affinities}

Florida has long been known for its rich Pleistocene fauna of Neotropical mammals, including ground sloths, glyptodonts, giant armadillos, and capybaras, among others. All of these groups of mammals evolved in South America. Most of them first reached North America in the late Pliocene and early Pleistocene (late Blancan and early Irvingtonian) as participants in the Great American Faunal Interchange, which occurred during the million-year period following the final connection of these two continents at about 2.5 Ma. Late Blancan and early Irvingtonian sites from Florida document some of the earliest arrivals in North America of South American mammals that dispersed northward across the Panamanian isthmus following the onset of the Great American Faunal Interchange (Webb, 1976, 1985; Webb and Wilkins, 1984; Morgan and Hulbert, 1995). South American immigrants recorded from Florida Blancan and Irvingtonian sites include the armadillos Dasypus, Holmesina, and Pachyarmatherium; the glyptodont Glyptotherium; the ground sloths Eremotherium, Paramylodon (=Glossotherium, in part), and Nothrotheriops; the porcupine Erethizon; the capybaras Hydrochaeris and Neochoerus; and the giant flightless bird Titanis. After the northward flow of South American immigrants essentially ceased in the early Irvingtonian (after about 1.5 Ma), most of these genera became integral members of the temperate North American fauna and underwent evolutionary and biogeographic changes unrelated to 
their Neotropical origin. Some of these genera quickly spread throughout North America (e.g., Paramylodon and Erethizon), whereas others were restricted to more subtropical climates in the southeastern United States, particularly Florida (e.g., Holmesina, Pachyarmatherium, Eremotherium, Hydrochaeris, and Titanis). Among the 11 genera listed above, which constitute most of the South American contribution of large vertebrates to the Great American Interchange, all but two, Pachyarmatherium and Titanis, survived in Florida until the major megafaunal extinctions at the end of the Pleistocene. Dasypus and Erethizon are still extant in North America, although the porcupine is no longer found in Florida, and the capybara Hydrochaeris still inhabits parts of tropical Middle America and South America. The bizarre armadillo, Pachyarmatherium leiseyi, a new genus and species recently described from the Leisey Shell Pit and several other Florida sites (Downing and White, 1995), is known only from the late Blancan and early Irvingtonian. Titanis walleri, the only phorusrhacid bird known outside of South America, is restricted in Florida to three late Pliocene (late Blancan) sites (Brodkorb, 1963; Chandler, 1994). A specimen recently collected from the Gulf Coastal Plain of southern Texas (Baskin, 1995) represents the only Pleistocene record of the genus.

To better understand the geographic origin of Florida's mammals with Neotropical affinities, it is helpful to define the boundaries and subdivisions of the Neotropical Region. It should be emphasized that these boundaries are based upon the living fauna and flora, although many vertebrate paleontologists have used the term "Neotropical" to refer to extinct vertebrates originally derived from South America. The latter usage may be misleading because several species with South American origins are restricted to the Nearctic Region in the late Pleistocene. Hershkovitz (1958) divided the Neotropical Region into the Patagonian, Brazilian, and West Indian Subregions. The Patagonian Subregion is composed of temperate South America, the West Indian Subregion includes the Antillean islands, and the Brazilian Subregion comprises most of the mainland Tropics between Mexico and Brazil. Hershkovitz further subdivided the Brazilian Subregion into four provinces. The Middle American Province includes the northern boundary of the Neotropical Region in Mexico. The Nearctic Region incorporates all of temperate North America, including northern Mexico, the continental United States, Canada, and Alaska.

Koopman and Martin (1959) placed the northeastem boundary of the Neotropical mammal fauna between $23^{\circ} \mathrm{N}$ and $24^{\circ} \mathrm{N}$ latitude in the southern half of the state of Tamaulipas, Mexico, corresponding to the disappearance of tropical deciduous forests. Neotropical mammals, particularly bats, extend their ranges somewhat farther north along the Pacific coast of western Mexico, with the northern limit of the Neotropics at about $28^{\circ} \mathrm{N}$ in southern Sonora and southern Chihuahua. There is no strong faunal or floral evidence to suggest that the northern boundary of the Neotropical Region extended much farther north or east during the late Pleistocene. Another explanation must be proposed for the rather common occurrence of what are now considered Neotropical mammals, such as jaguar, ocelot, margay, and several bats, in Rancholabrean faunas in Florida. Either Neotropical species expanded their ranges northward into temperate North America in the late Pleistocene or they inhabited this region throughout the Pleistocene only to have their ranges retract southward into tropical America over the past 10,000 years. The Pleistocene and modern distributions of Florida Rancholabrean mammals should elucidate certain patterns, although many species, particularly bats and other small mammals, have inadequate fossil records to assess the full extent of their Pleistocene distribution accurately.

The evolutionary and biogeographic history of the numerous Florida mammals with Neotropical connections reveals some interesting trends. The most obvious species with Neotropical affinities are those of South American origin. These include Didelphis, all members of the Xenarthra, and all North American caviomorph rodents. This group can be further subdivided because South American mammals reached temperate North America during three widely separate time intervals: late $\mathrm{Mi}$ ocene, late Pliocene/early Pleistocene, and late Pleistocene/Holocene. Two unrelated ground sloths, the mylodont Thinobadistes and the megalonychid Pliometanastes, appeared in North American faunas at the beginning of the Hemphillian NALMA (late Miocene, about $9 \mathrm{Ma}$ ), long before the final connection of the two continents (Hirschfeld and Webb, 1968; Webb, 1989). These early arrivals apparently island-hopped or rafted across the water barrier separating North and South America in the late Miocene (Webb, 1976, 1985). At about this same time, procyonids dispersed from North America to South America (Baskin, 1989a). Earlier in the Miocene, megalonychid sloths from South America also reached the West Indies, where they are known from the early Miocene of Cuba (MacPhee and Iturralde-Vinent, 1994) and the late Quaternary of Cuba, Hispaniola, and Puerto Rico (Paula Couto, 1967; Morgan and Woods, 1986).

The genus Thinobadistes went extinct in North America in the late Hemphillian (Webb, 1989). The mylodonts that reached North America in the late Blancan, the GlossotheriumParamylodon lineage (see McDonald, 1995, for usage of Paramylodon for most North American mylodonts more commonly referred to Glossotherium), are unrelated to the older Thinobadistes. All temperate North American megalonychids, including two species of Pliometanastes and five species of Megalonyx, appear to be derived from the original megalonychid that emigrated to North America in the early Hemphillian. Although Thinobadistes, Pliometanastes, and Megalonyx were derived from South America, these three genera are unknown from that continent. Moreover, most species of North American mylodonts and megalonychids are restricted to fossil sites in the Nearctic Region. The only members of these two families known from tropical Middle America are two species of megalonychids, Megalonyx obtusidens and Meizonyx salvadorensis, described from the early Pleistocene of El Salvador 
(Webb and Perrigo, 1985), and the mylodont Glossotherium garbanii from central Mexico (Montellano-Ballesteros and Carranza-Castañeda, 1986).

Table 2 attempts to demonstrate both the origin and the biogeographic distribution of the mammals with Neotropical affinities recorded from Florida Rancholabrean sites. This table lists all species of Florida Rancholabrean mammals that have some connection with the Neotropical Region and evaluates their evolutionary origin (i.e., South America or North America) and present or late Pleistocene distribution. Many of these species have been lumped together in discussions of Florida Neotropical mammals, when they actually have quite different evolutionary and/or biogeographic histories. Florida's Neotropical mammals fall into three broad categories: (1) species of South American origin that either reached North America in the late Miocene after crossing the Central American Seaway or entered North America as participants in the Great American Faunal Interchange in the late Pliocene or early Pleistocene; (2) species of North American origin that have a predominantly Neotropical distribution at the present time; and (3) species of North American origin that now occur primarily in the Nearctic Region but do extend their ranges into the northernmost Neotropical Region in Mexico and Central America.

\section{MAMMALS OF SOUTH AMERICAN ORIGIN}

Didelphis virginiana is one of only two non-volant mammals of South American origin that reached temperate North America after the early Irvingtonian. The earliest North American records of $D$. virginiana are from two Florida late Irvingtonian sites, Coleman 2A (Martin, 1974) and Sebastian Canal (Morgan and Portell, 1996). Virtually all fossil occurrences of the Virginia opossum outside of Florida are from the late Rancholabrean (Kurtén and Anderson, 1980). Didelphis virginiana currently occurs widely throughout the Nearctic Region and in the Middle American Province of the Neotropical Region as far south as Costa Rica.

Most Rancholabrean Xenarthra found in Florida, although of South American origin, occur primarily in fossil sites in temperate North America. Two of the four species of Rancholabrean ground sloths, Megalonyx jeffersonii and Paramylodon harlani, are widespread throughout North America, and M. jeffersonii is known from sites as far north as central Alaska and the Yukon Territory of Canada (Kurtén and Anderson, 1980). A third species, the Shasta ground sloth (Nothrotheriops shastensis), is found principally in the arid southwest. The only North American Rancholabrean ground sloth that ranged widely into the Neotropics is the giant megatheriid Eremotherium laurillardi. Cartelle and De Iuliis (1995) synonymized all of the large late Pleistocene species of Eremotherium from North America, Central America, and South America, including $E$. mirabile and $E$. rusconii, under the oldest available name, $E$. laurillardi. A single Pan-American species of Eremotherium therefore occurred on the Atlantic and Gulf Coastal Plains in the southeastern United States from South Carolina to Florida to Texas, south through Middle America (Gazin, 1956; Webb and Perrigo, 1984), and throughout much of South America as far south as southern Brazil (Cartelle and De Iuliis, 1995). The three shelled xenarthrans recorded from Florida Rancholabrean faunas, Dasypus bellus, Holmesina septentrionalis, and Glyptotherium floridanum, are primarily found in fossil sites on the Atlantic and Gulf Coastal Plains in the southeastern United States. The last xenarthran to reach temperate North America, the living nine-banded armadillo (Dasypus novemcinctus), is unknown in the Nearctic Region before the Holocene. This armadillo dispersed naturally into the Florida panhandle in the 1970 s, although it was introduced into the peninsula earlier in the last century (Humphrey, 1974).

Eleven species of bats identified from Florida Rancholabrean sites are included in Table 2, as are two living bats unknown as fossils from the state. Morgan (1991) presented a detailed discussion of late Pliocene, Pleistocene, and extant bats from Florida with Neotropical affinities, so only a brief synopsis is presented herein. Bats are the only group of mammals listed in Table 2 for which the origin of some species may be in question. This uncertainty results from the poor Tertiary fossil record of bats in North and South America. Although the only pre-Pleistocene fossil record of the Mormoopidae is from the late Oligocene and Miocene of Florida (Morgan, 1989b), Mormoops megalophylla and Pteronotus cf. P. pristinus are listed as being of Neotropical origin in Table 2 because all living species of the family are restricted to the Neotropics. Molossids are known from the Miocene of Florida (Morgan, 1989b), but the great majority of New World members of this family are Neotropical in distribution. Molossids have been identified from the Oligocene and Miocene of South America (Czaplewski, 1997). The three molossids known from Florida Rancholabrean sites, Eumops glaucinus, E. underwoodi, and Tadarida brasiliensis, probably were derived from the Neotropics. The two Florida phyllostomids listed in Table 2, the extinct vampire bat (Desmodus stocki) and the living Jamaican fruit-eating bat (Artibeus jamaicensis), are almost certainly South American in origin. The five Florida vespertilionids that occur in the Neotropics, Eptesicus fuscus, Lasiurus borealis, $L$. intermedius, Nycticeius humeralis, and Pipistrellus subflavus, are clearly of North American origin. The Vespertilionidae is the best-represented bat family in the Tertiary of North America (Morgan, 1989b), whereas vespertilionids are unknown in South America prior to the Pleistocene (Czaplewski, 1997).

The late Pleistocene and modern distributions of the 13 species of bats in Table 2 are more indicative of the bats' biogeographic affinities than of their origins. Five of the bats, Mormoops megalophylla, Artibeus jamaicensis, Eumops glaucinus, Eumops underwoodi, and Molossus molossus, are living species that are principally restricted to the Neotropical Region. Mormoops megalophylla is now found in the United States only in southern Texas and Arizona. The majority of its range is in the Neotropics, from Mexico south throughout Central America to 
TABLE 2.-Florida Rancholabrean mammals with Neotropical affinities. With three exceptions, all species listed in this table have been identified, on the basis of Webb (1974a), Hulbert (2001), and Morgan and Hulbert (1995), from one or more Florida Rancholabrean faunas. For the sake of completeness, this list includes three species of mammals (Dasypus novemcinctus, Artibeus jamaicensis, and Molossus molossus) with Neotropical affinities that occur in the modern fauna of Florida but are unknown as fossils. Each species is evaluated according to its evolutionary origin (South America or North America) and its late Pleistocene or Holocene distribution. For extinct species, the distribution indicated is the late Rancholabrean distribution; for extant species it is the present distribution. Many of the distributional patterns of the individual species are not strictly Neotropical or Nearctic, hence the modifier "primarily." The third category is for species that occur widely in both biogeographic regions. A number of the species have peculiarities concerning their origin, distribution, or taxonomy. These are explained either in footnotes to this table or in the text. $(x=$ present; $-=$ not present; $\dagger=$ extinct species; $\#=$ extirpated in Florida, but still extant in the Neotropical Region.)

\begin{tabular}{|c|c|c|c|c|c|}
\hline \multirow[b]{2}{*}{ Taxa } & \multicolumn{2}{|c|}{ Origin } & \multicolumn{3}{|c|}{ Late Pleistocene/Holocene distribution } \\
\hline & $\begin{array}{l}\text { Neotropical (South/ } \\
\text { Middle America) }\end{array}$ & $\begin{array}{l}\text { Nearctic (North } \\
\text { America) }\end{array}$ & $\begin{array}{l}\text { Primarily } \\
\text { Neotropical }\end{array}$ & $\begin{array}{l}\text { Primarily } \\
\text { Nearctic }\end{array}$ & $\begin{array}{l}\text { Widely in both } \\
\text { regions }\end{array}$ \\
\hline \multicolumn{6}{|l|}{ MARSUPIALIA } \\
\hline Didelphis virginiana & $\mathrm{x}$ & & - & - & $x$ \\
\hline \multicolumn{6}{|l|}{ XENARTHRA } \\
\hline Dasypus bellus $\dagger$ & $\mathrm{x}$ & - & & $x$ & - \\
\hline Dasypus novemcinctus & $\mathrm{x}$ & - & & - & $\mathrm{x}$ \\
\hline Holmesina septentrionalis $\dagger$ & $x$ & - & - & $\mathrm{x}$ & - \\
\hline Glyptotherium floridanum $\dagger$ & $\mathrm{x}$ & - & - & $\mathrm{x}$ & - \\
\hline Eremotherium laurillardi ${ }^{1}$ & $\mathrm{x}$ & - & - & - & $\mathrm{x}$ \\
\hline Megalonyx jeffersonii $\dagger$ & $\mathrm{x}$ & - & - & $\mathrm{x}$ & - \\
\hline Paramylodon harlani† & $\mathrm{x}$ & - & - & $\mathrm{x}$ & - \\
\hline \multicolumn{6}{|l|}{ INSECTIVORA } \\
\hline Cryptotis parva & - & $\mathrm{x}$ & - & - & $\mathrm{x}$ \\
\hline \multicolumn{6}{|l|}{ CHIROPTERA } \\
\hline Mormoops megalophylla\# & $\mathrm{x}$ & - & $\mathrm{x}$ & - & - \\
\hline Pteronotus pristinus $\dagger$ & $x$ & - & $\mathrm{x}$ & - & - \\
\hline Artibeus jamaicensis & $\mathrm{x}$ & - & $\mathrm{x}$ & - & - \\
\hline Desmodus stocki† & $\mathrm{x}$ & - & - & $\mathrm{x}$ & - \\
\hline Eptesicus fuscus & - & $\mathrm{x}$ & - & - & $\mathrm{x}$ \\
\hline Lasiurus borealis & - & $\mathrm{x}$ & - & - & $\mathrm{x}$ \\
\hline Lasiurus intermedius & - & $\mathrm{x}$ & - & - & $\mathrm{x}$ \\
\hline Nycticeius humeralis & - & $\mathrm{x}$ & - & $x$ & - \\
\hline Pipistrellus subflavus & - & $\mathrm{x}$ & - & $x$ & - \\
\hline Eumops glaucinus & $\mathrm{x}$ & - & $\mathrm{x}$ & - & - \\
\hline Eumops underwoodi\# & $\mathrm{x}$ & - & $\mathrm{x}$ & & - \\
\hline Molossus molossus & $\mathrm{x}$ & - & $\mathrm{x}$ & & - \\
\hline Tadarida brasiliensis & $\mathrm{x}$ & - & - & & $\mathrm{x}$ \\
\hline \multicolumn{6}{|l|}{ CARNIVORA } \\
\hline Canis dirust & - & $\mathrm{x}$ & - & - & $\mathrm{x}$ \\
\hline Canis latrans ${ }^{2}$ & - & $\mathrm{x}$ & - & $\mathrm{x}$ & - \\
\hline Urocyon cinereoargenteus & - & $\mathrm{x}$ & - & - & $\mathrm{x}$ \\
\hline Tremarctos floridanus $\dagger^{3}$ & - & $\mathrm{x}$ & - & $\mathrm{x}$ & - \\
\hline Monachus tropicalis $\dagger$ & & $x ?$ & $x$ & - & \\
\hline Procyon lotor & - & $x$ & - & - & $\mathrm{x}$ \\
\hline Conepatus leuconotus\# & - & $x$ & - & - & $\mathrm{x}$ \\
\hline Conepatus robustus $†$ & - & $\mathrm{x}$ & - & $\mathrm{x}$ & - \\
\hline Mustela frenata & - & $\mathrm{x}$ & - & - & $\mathrm{x}$ \\
\hline Spilogale putorius & - & $\mathrm{x}$ & - & - & $\mathrm{x}$ \\
\hline Leopardus pardalis\# & - & $\mathrm{x}$ & $\mathrm{x}$ & - & - \\
\hline Leopardus wiediilamnicola\# $\dagger^{4}$ & - & $\mathrm{x}$ & $\mathrm{x}$ & $\mathrm{x}$ & - \\
\hline Lynx rufus & - & $\mathrm{x}$ & - & $\mathrm{x}$ & - \\
\hline Panthera atrox $\dagger$ & - & $x$ & - & - & $\mathrm{x}$ \\
\hline Panthera onca\# & - & $\mathrm{x}$ & $\mathrm{x}$ & - & - \\
\hline Puma concolor & - & $\mathrm{x}$ & - & - & $\mathrm{x}$ \\
\hline Sinilodon fatalis $\dagger$ & - & $\mathrm{x}$ & - & - & $x$ \\
\hline \multicolumn{6}{|l|}{ RODENTIA } \\
\hline Erethizon dorsatum 5 & $\mathrm{x}$ & - & - & $\mathrm{x}$ & - \\
\hline Hydrochaeris holmesi† & $\mathrm{x}$ & - & - & $x$ & - \\
\hline Neochoerus pinckneyi† & $\mathrm{x}$ & - & & $\mathrm{x}$ & - \\
\hline Glaucomys volans & - & $\mathrm{x}$ & & $\mathrm{x}$ & - \\
\hline
\end{tabular}


TABLE 2.-Continued.

\begin{tabular}{|c|c|c|c|c|c|}
\hline \multirow[b]{2}{*}{ Taxa } & \multicolumn{2}{|c|}{ Origin } & \multicolumn{3}{|c|}{ Late Pleistocene/Holocene distribution } \\
\hline & $\begin{array}{l}\text { Neotropical (South/ } \\
\text { Middle Amcrica) }\end{array}$ & $\begin{array}{l}\text { Nearctic (North } \\
\text { America) }\end{array}$ & $\begin{array}{c}\text { Primarily } \\
\text { Neotropical }\end{array}$ & $\begin{array}{l}\text { Primarily } \\
\text { Nearctic }\end{array}$ & $\begin{array}{l}\text { Widely in both } \\
\text { rcgions }\end{array}$ \\
\hline Oryzomys palustris ${ }^{6}$ & $\mathrm{x}$ & $\mathrm{x}$ & - & $\mathrm{x}$ & - \\
\hline Podomys floridanus & & $\mathrm{x}$ & & $\mathrm{x}$ & - \\
\hline Sigmodon hispidus & & $x$ & & - & $x$ \\
\hline LAGOMORPHA & & & & & \\
\hline Sylvilagus floridanus & & $\mathrm{x}$ & - & - & $\mathrm{x}$ \\
\hline PERISSODACTYLA & & & & & \\
\hline Tapirus veroensis $\dagger^{3}$ & - & $x$ & - & $\mathrm{x}$ & - \\
\hline ARTIODACTYLA & & & & & \\
\hline Mylohyus nasutus $\dagger^{3}$ & - & $\mathrm{x}$ & - & $\mathrm{x}$ & - \\
\hline Platygonus compressus $\dagger^{3}$ & - & $x$ & - & $x$ & - \\
\hline Hemiauchenia macrocephala $\dagger^{3}$ & - & $\mathrm{x}$ & - & $x$ & \\
\hline Palaeolama mirifica $\dagger^{3}$ & -. & $\mathrm{x}$ & - & $\mathrm{x}$ & \\
\hline Odocoileus virginianus & - & $\mathrm{x}$ & - & - & $\mathrm{x}$ \\
\hline Bison antiquus $\dagger$ & - & $\mathrm{x}$ & - & $x$ & - \\
\hline Bison latifrons $\dagger$ & - & $\mathrm{x}$ & - & $x$ & - \\
\hline PROBOSCIDEA & & & & & \\
\hline Mammut americanum $\dagger$ & - & $x$ & - & $x$ & - \\
\hline Cuvieronius tropicus $\dagger$ & - & $\mathrm{x}$ & - & - & $x$ \\
\hline Mammuthus columbi $\dagger$ & - & $\mathrm{x}$ & - & $x$ & - \\
\hline SIRENIA & & & & & \\
\hline Trichechus manatus & $\mathrm{x}$ & - & $\mathrm{x}$ & - & - \\
\hline
\end{tabular}

${ }^{1}$ Cartelle and Dc Iuliis (1995) recently synonymized all North, Central, and South American late Pleistocene Eremotherium under the single Pan-American species, E. laurillardi.

${ }^{2}$ May be referable to Canis familiaris instead of $C$. latrans; see discussion in text.

${ }^{3}$ These extinct species are known primarily from Rancholabrean sites in North America north of Mexico and are of Nearctic origin; they are included in this list because their closest living relatives are restricted to the Neotropical Region.

${ }^{4}$ There is some disagreement as to whether this small cat represents an extinct species, Leopardus amnicola, known only from the late Rancholabrean of Florida, or is an extinct subspecies of the Neotropical margay, $L$. wiedii.

${ }^{5}$ The porcupine Erethizon dorsatum is a caviomorph rodent of South American origin, but it is now restricted to the Nearctic Region and is unknown from the Holocene fauna of Florida.

${ }^{6}$ The genus Oryzomys is ultimately of North American origin, but the living rice rat, O. palustris, apparently evolved in Middle or South America and invaded the southeastem United States in the Rancholabrean.

northern South America and Trinidad (Smith, 1972). Lazell and Koopman (1985), Lazell (1989), and Frank (1997a) reported an isolated population of the Neotropical fruit bat Artibeus jamaicensis in the Florida Keys, substantiating a nineteenth-century record of this species from Key West. Artibeus jamaicensis is one of the most widespread of all Neotropical phyllostomids, ranging from the northern limits of the Neotropical Region in Mexico and the West Indies south to northern South America. Artibeus jamaicensis is unknown as a fossil in Florida, suggesting that this species dispersed to the Florida keys from Cuba sometime during the Holocene. With the exception of the records from southernmost peninsular Florida (Koopman, 1971; Eger, 1977; Belwood, 1981), Eumops glaucinus has a strictly Neotropical distribution. It occurs from southern Mexico to tropical South America, as well as in Cuba and Jamaica. Eumops underwoodi is found in the northern part of the Middle American Province from Nicaragua to Mexico and also extends its range northward into southern Arizona (Morgan, 1991). The small molossid Molossus molossus recently was reported from three islands in the Florida Keys, representing the first records of this bat from the United States (Frank, 1997b). Molossus molossus is a widespread Neotropical bat found from northern Mexico south to southern South America and throughout the West Indies. Frank (1997b) identified the bats from the Florida Keys as the Cuban subspecies M. molossus tropidorhynchus. Molossus molossus has no fossil record in Florida, indicating that, like Artibeus jamaicensis, this species probably reached the Florida Keys by overwater dispersal from Cuba during the Holocene. Each of these five bat species has a marginal range in the southernmost portion of the Nearctic Region, either in extreme southern Florida (A.jamaicensis, E. glaucinus, and M. molos$s u s)$ or in southern Arizona and/or Texas just north of the Mexican border (M. megalophylla and E. underwoodi). Tadarida brasiliensis also probably belongs with this group of bats. It has a wider distribution in the southern United States than the previous five bats and also occurs throughout most of the Neotropical Region from Mexico south to Argentina and Chile and on many islands in the West Indies.

One of the most interesting mammals of Neotropical origin recorded from Florida Rancholabrean faunas is Desmodus 
stocki, a large extinct species of vampire bat well known from Reddick and several other late Pleistocene faunas in the northern half of the state (Gut, 1959; Olsen, 1960; Morgan et al., 1988; Ray et al., 1988; Morgan, 1991). Desmodus stocki is considerably larger than the closely related living Neotropical vampire bat, $D$. rotundus, which is distributed throughout much of the Neotropical Region from its northern limits in Mexico south to Argentina and Chile. Desmodus rotundus does not presently occur in the West Indies, but it is known from late Quaternary deposits on Cuba (Koopman, 1958). Desmodus stocki is known primarily from late Pleistocene sites in the southern United States and northern Mexico (Ray et al., 1988), almost all of which are located in the Nearctic Region. The combination of the larger body size of $D$. stocki and the milder winters that characterized the southern part of the Nearctic Region in the late Pleistocene may account for the more temperate distribution of this extinct vampire, compared with the distributions of the three living species of vampire bats, all of which are confined to the Neotropics (McNab, 1973; Morgan, 1991). A smaller and more primitive species of Desmodus, D. archaeodaptes, was described from one latest Pliocene and two early Pleistocene localities in northern peninsular Florida (Morgan et al., 1988). Desmodus apparently was a participant in the Great American Faunal Interchange, presumably following one of its principal food supplies (large xenarthrans?) northward in the late Pliocene.

Before the discovery at Monkey Jungle Hammock of Pteronotus pristinus, a bat with indisputable Antillean affinities (Morgan, 1991), a Middle American origin was proposed for most species of Florida's Neotropical bats (Webb and Wilkins, 1984; Morgan, 1985). The occurrence of $P$. pristinus in the Rancholabrean of Florida suggests the possibility of a West Indian origin for several other bats found in the state (Morgan, 1991). Pteronotus pristinus is an extinct species known elsewhere only from the late Quaternary of Cuba (Silva Taboada, 1974), the most likely source for West Indian bats that may have dispersed to Florida. Cuba is almost certainly the source for populations of Artibeus jamaicensis and Molossus molossus that are known from the Florida Keys (Lazell and Koopman, 1985; Lazell, 1989; Frank, 1997a, 1997b), particularly considering how near Cuba is to the Florida Keys and the great distance separating Florida from the closest mainland populations of these two species. Two other Florida Neotropical bats, Mormoops megalophylla and Eumops glaucinus, may have been derived from the West Indies. Mormoops megalophylla is known from late Quaternary cave deposits in the Bahamas, Cuba, Hispaniola, Jamaica, and Tobago but is now extinct in the West Indies (Silva Taboada, 1974; Eshelman and Morgan, 1985; Morgan and Woods, 1986; Morgan, 1989a, 2001). The Florida $M$. megalophylla cannot be confidently assigned to either the extant mainland Neotropical or the extinct West Indian populations of this species, and its origin within the Neotropical Region is therefore unclear. Likewise, it is not possible to determine whether the endemic Florida subspecies, Eumops glaucinus floridanus, was derived from the mainland Neotropics or from the Greater Antilles, specifically Cuba, because both regions are inhabited by the nominal subspecies, $E$. $g$. glaucinus (Eger, 1977). Both Middle American and Antillean origins for E. glaucinus have been postulated (Layne, 1974; Baker and Genoways, 1978; Morgan, 1985). Tadarida brasiliensis also occurs throughout the Greater Antilles and Bahamas, but the various West Indian subspecies are smaller than the Florida race, which is more closely related to $T$. brasiliensis from the southwestern United States and Mexico. Tadarida is first recorded in Florida from the late Pliocene (late Blancan); thus, it appears likely that $T$. brasiliensis, or a very closely related species, reached Florida by way of Middle America as an early participant in the Great American Faunal Interchange (Morgan and Ridgway, 1987).

It is surprising that Antillean bats have not been reported from southern Florida more frequently considering the close proximity of Cuba and the Bahamas. The Florida Keys are 150 $\mathrm{km}$ north of Cuba, and less than $100 \mathrm{~km}$ would have separated Florida from Cuba and the Bahamas during the late Pleistocene low sea-level stand. Layne (1974) offered several suggestions for the rarity of West Indian bats in the modern fauna of southern Florida, including their inability to cross water barriers and the paucity of suitable tropical habitats. Layne's hypothesis may explain why some West Indian bats, particularly frugivorous phyllostomids, do not occur in southern Florida. The absence of dry caves in the southern two-thirds of the peninsula probably accounts for the absence of cave-dwelling bats, such as mormoopids, natalids, and brachyphylline phyllostomids.

The three genera of South American rodents known from Florida, Hydrochaeris, Neochoerus, and Erethizon, all first occurred in the state in the late Blancan (Webb, 1974a, 1976; Ahearn and Lance, 1980; Ahearn, 1981; Morgan and White, 1995). All three genera occur sporadically in Florida sites throughout the remainder of the Pliocene and Pleistocene and disappear at the end of the Rancholabrean. Hydrochaeris holmes $i$ is known from the late Pliocene through the Pleistocene in Florida. Neochoerus dichroplax occurs in several Florida late Blancan faunas (Ahearn and Lance, 1980), whereas $N$. pinckneyi appears to be restricted to the Rancholabrean (Ahearn, 1981 ; Morgan and White, 1995). The extant genus Hydrochaeris and the extinct Neochoerus also were widespread in South America in the Pleistocene, but the species $H$. holmesi and $N$. pinckneyi are found only in the southeastern United States. Erethizon is clearly of South American origin, although the genus is unknown from the Neotropical Region. Species of the prehensile-tailed porcupine, Coendou, are the typical Neotropical porcupines. The oldest Florida records of porcupines are Erethizon poyeri from the late Blancan Haile 7C LF (Hulbert, 1997) and the small endemic species, E. kleini, from the latest Blancan Inglis 1A LF (Frazier, 1981). The living porcupine (E. dorsatum) was fairly widely distributed in Florida during the Irvingtonian, but there are just three verified Rancholabrean records of this species from the state, Aucilla River, Seminole Field, and Wac- 
casassa River (Frazier, 1981; Morgan and White, 1995). Porcupines no longer occur in Florida; the nearest populations in central Texas and the Appalachian Mountains of eastern Tennessee. Erethizon dorsatum is now found primarily in temperate coniferous forests in the Nearctic Region, although porcupines also occur in the southwestern desert region.

\section{MAMMALS OF NORTH AMERICAN ORIGIN}

All species listed in Table 2 belonging to the Insectivora, Carnivora, Lagomorpha, Perissodactyla, Artiodactyla, and Proboscidea, as well as the sigmodontine rodents and vespertilionid bats, are of North American origin. The remainder of this discussion will attempt to characterize their evolutionary and biogeographic relationships. A few mammals of North American origin are widely distributed in the Nearctic Region and just barely extend their ranges into the northernmost portion of the Neotropical Region in Mexico. The vespertilionid bats Pipistrellus subflavus and Nycticeius humeralis fit this distributional pattern, as do Canis latrans and Lynx rufus. Other Florida mammals are widely distributed in both the Nearctic and Neotropical Regions. Some of these species range well into Middle America; among these are Lasiurus intermedius, Cryptotis parva, Glaucomys volans, and Spilogale putorius, as well as the extinct species Mammut americanum, Mammuthus columbi, Bison latifrons, and $B$. antiquus. Still other extant species, including Eptesicus fuscus, Lasiurus borealis, Urocyon cinereoargenteus, Procyon lotor, Mustela frenata, Puma concolor, Sigmodon hispidus, Sylvilagus floridanus, and Odocoileus virginianus, are widely distributed in both North America and South America. Canis dirus, Panthera atrox, and Smilodon fatalis are extinct species that occurred on both continents. These three large carnivores are known from numerous late Pleistocene faunas in North America and have been identified from sites west of the Andes as far south as Peru (Kurtén and Anderson, 1980; Kurtén and Werdelin, 1990). A second, larger species of Smilodon, S. populator, occurs in late Pleistocene faunas east of the Andes (Kurtén and Werdelin, 1990) and also is known from older (early to middle Pleistocene) faunas in South America (Berta, 1985). The gomphothere Cuvieronius was widespread in Middle and South America during the late Pleistocene and thus is generally considered a Neotropical genus, although it also occurred in the southern portion of the Nearctic Region (Kurtén and Anderson, 1980). The distribution of the various species of Cuvieronius is not well understood because the taxonomy of the genus is in need of revision. Cuvieronius tropicus occurs in a limited number of Rancholabrean sites in the southeastern United States along the Atlantic and Gulf coasts, and it ranged southward into Middle America. Even though many of the species listed in this paragraph are/ were widely distributed in the Neotropical Region, with a few exceptions (e.g., Cuvieronius) they are rarely included in discussions of Florida mammals with Neotropical affinities. Presumably this is a result of their widespread occurrence in the
Nearctic Region and their unambiguous North American origin.

Another biogeographic pattern observed in Florida Rancholabrean mammals with Neotropical affinities is shown by extant species that have been extirpated from Florida and are now primarily restricted to the Neotropical Region. The best examples of this pattern are the jaguar (Panthera onca), ocelot (Leopardus pardalis), margay (Leopardus wiedii), and hognosed skunk (Conepatus leuconotus). Conepatus leuconotus (including $C$. mesomelas) is fairly widespread from the southwestern United States southward into Middle America. It is included with this group because species of Conepatus are the typical Neotropical skunks. The jaguar and ocelot do occasionally wander northward into the extreme southern portion of the Nearctic Region, but for the most part these two species and the margay have Neotropical distributions. The occurrence of L. wiedii in Florida requires additional comment. Felis amnicola, an extinct species of small cat described from the Rancholabrean Aucilla River fauna in northern Florida (Gillette, 1976), was later regarded as an extinct subspecies of Felis (= Leopardus) wiedii by Werdelin (1985). Regardless of which author's interpretation is correct, it seems clear that amnicola is an extinct species or subspecies of small cat that is closely related to, if not conspecific with, the tropical American margay.

Two extinct species of large mammals of North American origin listed in Table 2, Tremarctos floridanus and Tapirus veroensis, belong to genera that are now principally restricted to the Neotropical Region. For this reason, these two species are almost always mentioned in discussions of Florida mammals with Neotropical affinities, despite the fact that they are known from fossil sites only in the Nearctic Region. Tremarctos floridanus occurs in many Rancholabrean sites in Florida and in a few other late Pleistocene localities in the southern United States and northern Mexico (Kurtén and Anderson, 1980). The only living member of the genus Tremarctos is the spectacled bear (T. ornatus), a species now restricted to the Andes Mountains in South America. Tapirus veroensis also is common in Florida Rancholabrean sites and occurs in scattered localities elsewhere in the southeastern United States (Kurtén and Anderson, 1980). The genus Tapirus has a long history in North America extending well back into the Miocene (Hulbert, 1995), but tapirs went extinct in the Nearctic Region at the end of the Pleistocene. Three species of Tapirus, T. bairdii, T. pinchaque, and T. terrestris, survive today in the Neotropics. The genera Tremarctos and Tapirus were far more widespread in the New World as recently as the late Pleistocene, but they are now restricted to the Neotropical Region because the temperate species in each genus went extinct. Conepatus robustus, a large extinct species of hog-nosed skunk known only from the Rancholabrean Haile 14A LF in northern Florida (Martin, 1978), may represent a third species with this same distributional pattern. As noted above, living members of the genus Conepatus occur primarily in the Neotropics, with only a single species 
making a small incursion into the southernmost portion of the Nearctic Region.

Four artiodactyls from the Florida Rancholabrean, the peccaries Mylohyus nasutus and Platygonus compressus and the camels Hemiauchenia macrocephala and Palaeolama mirifica, are often included in discussions of Neotropical taxa. These four species are known only from Nearctic fossil sites and belong to extinct genera. They are included in Table 2 and this discussion because, with one exception, all living members of the Tayassuidae and the llama tribe (Lamini) of the Camelidae are restricted to the Neotropical Region. Species of Platygonus, Hemiauchenia, and Palaeolama also are known from the Pleistocene of South America (Kurtén and Anderson, 1980; Webb, 1974b). Like tapirs, tayassuids and camelids have long evolutionary histories in North America and, except for one species, disappeared from the Nearctic Region in the late Pleistocene. One living species of tayassuid, the collared peccary or javelina (Dicotyles tajacu), barely enters the Nearctic Region in the southwestern United States and northern Mexico. This species is principally Neotropical in distribution, occurring throughout Middle America and much of South America. The absence of D. tajacu from North American late Pleistocene fossil sites (Kurtén and Anderson, 1980) suggests that the northward spread of this species occurred during the Holocene, after the extinction of Mylohyus and Platygonus. It had been suggested that Palaeolama mirifica evolved in South America and then reinvaded North America (Webb, 1974b); however, recent discoveries of early Irvingtonian Palaeolama in Florida (Webb and Stehli, 1995) indicate that this genus originated in North America, perhaps in tropical Middle America, and reached South America in the late Pliocene or early Pleistocene.

One of the sigmodontine rodents found in Florida Rancholabrean faunas, the cotton rat (Sigmodon hispidus), now occurs from the southern United States southward through Middle America to northern South America. The genus Sigmodon originated in North America during the early Pliocene (early Blancan) and then dispersed into South America after the onset of the Great American Interchange (Martin, 1979; Jacobs and Lindsay, 1981, 1984).

The two other sigmodontines listed in Table 2, the rice rat (Oryzomys palustris) and the Florida mouse (Podomys florida$n u s$ ), do not fit comfortably into any of the biogeographic patterns so far discussed. Although $O$. palustris is now found only in the southeastern United States, it is included in Table 2 because all other members of the genus Oryzomys are Neotropical in distribution. Neotropical sigmodontine rodents, including Oryzomys, had their origin in North America during the late Miocene and early Pliocene (Baskin, 1978, 1986, 1989b; Jacobs and Lindsay, 1981, 1984). These authors have documented that sigmodontines underwent their initial diversification in southern North America prior to the Great American Faunal Interchange. They further postulated that when these rodents first reached South America in the Pliocene they had already begun the explosive radiation that characterizes the evolutionary history of this group in the Neotropical Region.
Oryzomys palustris probably evolved in tropical Middle America and then invaded temperate North America in the Rancholabrean. The first appearance of $O$. palustris in Florida is one of the most reliable biochronological indicators for the beginning of the Rancholabrean NALMA (Morgan and Hulbert, 1995). This species is known from Bradenton, Oldsmar, and several other Florida early Rancholabrean faunas (Morgan, 1991; Morgan and White, 1995; Karrow et al., 1996), as well as many late Rancholabrean sites, but is unknown from Florida Irvingtonian faunas.

The Florida mouse, Podomys floridanus, is endemic to the peninsula and eastern panhandle of Florida. This species is included in Table 2 because the closest sister taxa of Podomys, the genera Habromys and Neotomodon (see Carleton, 1980), are Neotropical in distribution. The single species of Neotomodon and the four species of Habromys are all found at high elevations in Middle America (Hall, 1981). The oldest record of the genus Podomys is from the early Irvingtonian Leisey Shell Pit and Haile $21 \mathrm{~A}$ local faunas in Florida (Morgan and White, 1995). The living species, P. floridanus, first appeared in the late Irvingtonian Coleman 2A LF (Martin, 1974).

\section{MARINE MAMMALS}

Table 2 includes two marine mammals with Neotropical affinities recorded from Florida Rancholabrean faunas, the West Indian monk seal (Monachus tropicalis) and the West Indian manatee (Trichechus manatus). Ray (1958) identified M. tropicalis from the late Rancholabrean Melbourne LF, located along Florida's central Atlantic coast. Other fossils tentatively referred to $M$. tropicalis are known from the early Irvingtonian Leisey Shell Pit and Rigby Shell Pit local faunas along the Gulf coast in southwestern Florida (Morgan, 1994b; Morgan and Hulbert, 1995). Prior to its extinction within the last 40 years (Kenyon, 1977), the historic range of $M$. tropicalis included the southernmost portion of the Florida peninsula and the Florida Keys, as well as the Caribbean Sea and the southern Gulf of Mexico (Wing, 1992). Trichechus manatus is known from numerous Rancholabrean river and spring deposits in northern Florida (Domning, 1982). The oldest verified fossil record of $T$. manatus is from the early Pleistocene Leisey Shell Pit (Morgan, 1994b; Morgan and Hulbert, 1995). The current range of the West Indian manatee includes coastal marine habitats and freshwater rivers throughout the Florida peninsula, as well as the Greater Antilles, the Gulf and Caribbean coasts of Middle America, and northern and eastern South America.

\section{NeOtropical BiRds in Florida Plio-Pleistocene AND RECENT FAUNAS}

A strong Neotropical influence also is apparent in both the Plio-Pleistocene and modern avifaunas of Florida. The most spectacular Florida fossil bird of Neotropical origin is Titanis walleri, the only North American member of the otherwise strictly South American family Phorusrhacidae (Brodkorb, 
1963). Titanis first appears in Florida in the late Blancan along with a large suite of South American Interchange mammals (Webb, 1976; Chandler, 1994; Morgan and Hulbert, 1995). The rich Pleistocene record of fossil birds in Florida adds several more species with Neotropical affinities. The jacana (Jacana spinosa), a Neotropical waterbird found from Mexico south throughout much of Middle America, as well as the West Indies, is known from two Florida Rancholabrean faunas (Emslie, 1995, 1998). Two species of raptors found in Cutler Hammock and several other Florida Rancholabrean faunas, the extinct species Spizaetus grinnelli and the extant species Milvago chimachima, are members of genera that are now restricted to Middle and South America (Emslie, 1995, 1998). Spizaetus grinnelli also occurs in the West Palm Beach LF (Becker, 1985). Three species of jays described from Florida Rancholabrean sites belong to extinct genera that have their closest living relatives in Middle America, according to Brodkorb (1957) and Holman (1959). Protocitta, including the species $P$. ajax and $P$. dixi, is closely related to Middle American jays of the genus Calocitta, whereas Henocitta brodkorbi is related to Middle American jays of the genus Psilorhinos (Brodkorb, 1957; Holman, 1959). Likewise, two extinct genera of icterids known from Rancholabrean faunas in northern Florida, Cremaster and Pandanaris, have their closest living relatives in Middle America. Cremaster tytthus is an arboreal icterid most closely related to the living Neotropical oropendolas and caciques (Brodkorb, 1959). Pandanaris floridana has close affinities with Central American blackbirds (Hamon, 1964).

At least 12 species of extant land birds found in Florida have affinities with the Neotropical Region (Robertson and Kushlan, 1974). These birds exhibit the same general biogeographic patterns as Florida's Neotropical mammals discussed above, but birds have the added complication of migration. Many land birds that breed in Florida and elsewhere in temperate North America migrate to the Neotropics in the winter months. Only those land birds found in Florida that breed primarily in the Neotropical Region are discussed herein, including both migratory and nonmigratory species. Seven of these species are West Indian in origin, two species are found primarily in Middle America, and three species could have been derived from either the West Indies or Middle America. The seven land birds with Antillean affinities include white-crowned pigeon (Columba leucocephala), mangrove cuckoo (Coccyzus minor), smoothbilled ani (Crotophaga ani), Antillean nighthawk (Cordeiles gundlachii), gray kingbird (Tyrannus dominicensis), blackwhiskered vireo (Vireo altiloquus), and yellow warbler (Dendroica petechia). None of these species occur in Florida Rancholabrean fossil sites, suggesting that they may have dispersed northward from the West Indies fairly recently, perhaps during the Holocene. Two Florida birds probably were derived from Middle America, the short-tailed hawk (Buteo brachyurus) and the black-shouldered kite (Elanus caeruleus), although the latter species occurs in the southwestern United States as well. Three birds found in Florida, the snail kite (Rostrhamus sociabilis), caracara (Polyborus plancus), and burrowing owl
(Athene cunicularia), are widespread Neotropical species that occur throughout the West Indies, Central America, and South America. The caracara and burrowing owl also are known from several Florida Rancholabrean faunas. These two species also are found in the arid regions of the western United States but do not occur between peninsular Florida and Texas.

\section{Southwestern Vertebrates in Florida Plio-Pleistocene and Recent Faunas}

Coinciding with the appearance of Neotropical species in the Florida peninsula was an influx of species from the arid southwest. The dispersal of certain species of western vertebrates into the Florida peninsula probably was facilitated by the drier conditions, accompanied by more widespread grassland and scrub vegetation, that characterized the climate of glacial intervals in Florida (Watts and Hansen, 1988). Texas is the closest state where many of the western species found in Florida Pleistocene faunas still occur. Among mammals, these western forms include jackrabbits (Lepus), smooth-toothed pocket gophers (Thomomys), ground squirrels (Spermophilus), pallid bats (Antrozous), and possibly hog-nosed skunks (Conepatus). Western birds found in Florida fossil sites include two species of small owls of the genus Glaucidium (see Emslie, 1998), California condor (Gymnogyps californianus), prairie chicken (Tympanuchus cupido), and scrub jay (Aphelocoma coerulescens). All of these western genera and/or species of mammals and birds are known from Florida Irvingtonian and/or Rancholabrean faunas, but only the scrub jay survives there today (Emslie, 1996). Several of these taxa are known only from earlier glacials prior to the latest Pleistocene Wisconsinan glaciation.

The best-known pre-Wisconsinan fauna from Florida that clearly represents a glacial interval is the latest Blancan (latest Pliocene) Inglis $1 \mathrm{~A} \mathrm{LF}$, located just inland from the Gulf of Mexico in the north-central portion of the peninsula. Western species identified from Inglis (Meylan, 1982; Morgan, 1991; Emslie, 1996, 1998) include Lepus sp., Antrozous sp., two species of Glaucidium owls, scrub jay (Aphelocoma coerulescens), alligator lizard (Gerrhonotus sp.), and hog-nosed snake (Heterodon nasicus). None of these taxa are known from Florida Rancholabrean sites. Certain other species of mammals and birds found in Florida Pleistocene faunas occur in both the arid southwest and the Neotropics, including the bats Mormoops megalophylla, Eumops underwoodi, and Tadarida brasiliensis, the burrowing owl (Athene cunicularia), and the caracara (Polyborus plancus). For these species it is difficult to determine the geographic origin of the Florida fossil population. The two birds and T. brasiliensis still survive in Florida. The two other bats have been extirpated from the state. The burrowing owl and caracara are clearly relicts in Florida, as no other populations of these two species exist in eastern North America, whereas T. brasiliensis is more widespread in the southeastern United States. 


\section{Conclusions}

The most plausible explanation for the diversity of Neotropical vertebrates in Florida late Cenozoic faunas involves the combination of a subtropical climate and the intermittent presence of a broad savanna corridor connecting Florida with tropical Middle America around the northern and western margins of the Gulf of Mexico. This Gulf coastal corridor was a particularly important avenue of dispersal during glacial intervals in the late Pliocene and Pleistocene (Auffenberg and Milstead, 1965; Webb, 1976; Webb and Wilkins, 1984; Morgan, 1985, 1991; Emslie, 1998). The breadth of the Gulf coastal corridor increased during glacials as lower sea levels exposed the shallow continental shelf along the western and northern Gulf coast in Florida and westward around the Gulf of Mexico to southern Mexico. The dispersal of Neotropical vertebrates into Florida probably was facilitated by the more equable climate that characterized much of the unglaciated region of North America during glacial intervals, especially during the Wisconsinan glaciation (Graham and Lundelius, 1984). Perhaps the most important climatic factor influencing the occurrence of tropical vertebrates in Florida is the presence or absence of prolonged freezing temperatures in winter. The region south of the $10^{\circ} \mathrm{C}$ winter isotherm, which currently passes through the central portion of the Florida peninsula at about the latitude of Tampa and Orlando (between $27^{\circ} \mathrm{N}$ and $28^{\circ} \mathrm{N}$ ), only rarely experiences freezing temperatures in winter, and the freezes that do occur are of short duration. Prolonged freezes of several days to a week in northern Florida and along the northern Gulf coast may limit the dispersal of mainland Neotropical vertebrates into southern peninsular Florida, where many species of tropical vertebrates could survive. Introduced tropical vertebrates frequently occur in the wild in southern Florida; these include two species of monkeys, the rhesus macaque (Macaca mulata) and the squirrel monkey (Saimiri sciureus), and the red-bellied squirrel (Sciurus aureogaster), as well as numerous species of tropical birds and reptiles. During glacial intervals, when winters supposedly were somewhat milder, much of the Gulf Coastal Plain was probably frost-free, permitting tropical species to reach the Florida peninsula from Middle America.

Land tortoises of the genus Geochelone (now placed in the endemic New World genus Hesperotestudo; see Meylan, 1995) have long been used as indicators of Pleistocene climate (e.g., Hibbard, 1960). Living species of giant tortoises are restricted to tropical regions. They are intolerant of freezing temperatures and are too large to burrow and hibernate to escape the cold (Auffenberg and Milstead, 1965). The presence of giant tortoises (Hesperotestudo crassiscutata and related species) in North American late Cenozoic sites is therefore generally thought to indicate a frost-free climate (Hibbard, 1960). Two species of Hesperotestudo, $H$. crassiscutata and the extinct dwarf tortoise, $H$. incisa, were common throughout Florida in the Rancholabrean. The southernmost occurrence of H. incisa is at Cutler Hammock, whereas the southernmost Rancholabrean record of $H$. crassiscutata in Florida is from the West Palm Beach site. The occurrence of both species of Hesperotestudo throughout the northern half of the Florida peninsula during the late Rancholabrean indicates a frost-free climate for this region.

The principal dispersal route for Neotropical species that reached Florida was from tropical Middle America northward around the Gulf of Mexico. With several exceptions, most notably the armadillo (Dasypus novemcinctus), very few species of tropical vertebrates have reached Florida using the Gulf coastal corridor since the end of the Pleistocene. A second biogeographic pathway involved species that reached southern Florida by overwater dispersal from the West Indies, including several bats and birds discussed above, the green anole (Anolis carolinensis), and numerous plants (Long, 1974).

Most Florida mammals with Neotropical affinities disappeared at the end of the Pleistocene. Whatever the reason for these extinctions, the rich diversity of Neotropical mammals in Florida Rancholabrean faunas has been reduced to just a few species today. Southernmost peninsular Florida, one of the few subtropical regions in the continental United States, now supports only five Neotropical mammals, the large molossid bat Eumops glaucinus, the small molossid Molossus molossus, and the Jamaican fruit bat, Artibeus jamaicensis, as well as the more widely distributed Didelphis virginiana and Dasypus novemcinctus. Eumops glaucinus reached the Florida peninsula during the Rancholabrean, and it is known there from three sites, two of which are north of the species' current range (Morgan, 1985, 1991). Artibeus jamaicensis and Molossus molossus were almost certainly Holocene arrivals. The closest geographic region to Florida that supports a Neotropical fauna is the West Indies, the northernmost extensions of which, Cuba and the Bahamas, are separated from southernmost peninsular Florida by narrow (about $100 \mathrm{~km}$ wide), deep-water gaps. Not surprisingly, most Antillean species that apparently reached southern Florida in the Holocene are volant forms, including as many as seven species of birds (Robertson and Kushlan, 1974) and two bats. Most Neotropical vertebrates that arrived in Florida in the late Pliocene and Pleistocene traveled the much longer mainland route from Middle America, suggesting that distance is less of a barrier to dispersal than are oceanic water gaps. With the exception of the very recent arrival of Dasypus novemcinctus, post-Pleistocene dispersal of Neotropical vertebrates into Florida from tropical Middle America has almost entirely ceased, probably owing to inhospitable climatic conditions along the Gulf coastal corridor between southern Florida and northern Mexico. 


\section{Literature Cited}

Ahearn, M.E.

1981. A Revision of the North American Hydrochoeridae. 99 pages. Master's thesis, University of Florida, Gainesville.

Ahearn M.E., and J.F. Lance

1980. A New Species of Neochoerus (Rodentia: Hydrochoeridae) from the Blancan (Late Pliocene) of North Amcrica. Proceedings of the Biological Society of Washington, 93:435-442.

Allen, G.M.

1932. A Pleistocene Bat from Florida. Journal of Mammalogy, 13:256259.

Auffenberg, W., and W.W. Milstead

1965. Reptiles in the Quaternary of North America. In H.E. Wright, Jr., and D.G. Frey, editors, The Quaternary of the United States, pages 557-568. Princeton: Princeton University Press.

Baker, R.J., and H.H. Genoways

1978. Zoogeography of Antillean Bats. In F.B. Gill, editor, Zoogeography in the Caribbean. Academy of Natural Sciences of Philadelphia. Special Publication, 13:53-97.

Baskin, J.A.

1978. Bensonomys, Calomys, and the Origin of the Phyllotine Group of Neotropical Cricetines (Rodentia: Cricetidae). Journal of Mammalogy, 59:125-135.

1986. The Late Miocene Radiation of Neotropical Sigmodontine Rodents in North America. Contributions in Geology, University of Wyoming, Special Paper, 3:287-303.

1989a. Comments on New World Tertiary Procyonidae (Mammalia: Carnivora). Journal of Vertebrate Paleontology, 9:110-117.

1989b. The Initial Origin and Diversification of the Neotropical Sigmodontinae (Rodentia: Muridae): A Perspective from the North American Fossil Record. In Fifth International Theriological Congress, Rome, 22-29 August 1989. Abstracts of Papers and Posters, 1:263-264.

1995. The Giant Flightless Bird Titanis Walleri (Aves: Phorusrhacidae) from the Pleistocene Coastal Plain of South Texas. Journal of Vertebrate Paleontology, 15:842-844.

Becker, J.J.

1985. A Late Pleistocene (Wisconsinan) Avifauna from West Palm Beach, Florida. Bulletin of the British Ornithologists ' Club, 105(1):37-40.

Belwood, J.J.

1981. Wagner's Mastiff Bat, Eumops Glaucinus Floridanus (Molossidae), in Southwest Florida. Journal of Mammalogy, 62:411-413.

Berta, A

1985. The Status of Smilodon in North and South America. Contributions in Science, Natural History Museum of Los Angeles County, 370:1-15.

Bloom, A.L.

1983. Sea Level and Coastal Morphology of the United States through the Late Wisconsinan Glacial Maximum. In S.C. Porter, editor, Quaternary Environments of the United States, I: The Late Pleistocene, pages 215-229. Minneapolis: University of Minnesota Press.

Brodkorb, P.

1957. New Passerine Birds from the Pleistocene of Reddick Florida. Journal of Paleontology, 31:129-138.

1959. The Pleistocene Avifauna of Arredondo, Florida. Bulletin of the Florida State Museum, Biological Sciences, 4(9):269-291.

1963. A Giant Flightless Bird from the Pleistocene of Florida. Auk, 80:111-115.

Buckley, J., and E.H. Willis

1972. Isotopes' Radiocarbon Measurements, IX. Radiocarbon, 14:114 139.

Carleton, M.C.

1980. Phylogenetic Relationships in Neotomine-Peromyscine Rodents (Muroidea) and a Reappraisal of the Dichotomy within New World
Cricetinae. Museum of Zoology, University of Michigan, Miscellaneous Publications, 157:1-146.

Carr, R.S.

1987. Early Man in South Florida. Archaeology, November/Dccember: 62-63.

Cartelle, C., and G. De luliis

1995. Eremotherium laurillardi: The Panamerican Late Pleistocene Megatheriid Sloth. Journal of Vertebrate Paleontology, 15:830-841.

Chandler, R.M.

1994. The Wing of Titanis walleri (Aves: Phorusrhacidae) from the Late Blancan of Florida. Bulletin of the Florida Museum of Natural History, Biological Sciences, 36(6):175-180.

Clausen, C.J., A.D. Cohen, C. Emiliani, J.A. Holman, and J.J. Stipp

1979. Little Salt Spring, Florida: A Unique Underwater Site. Science, 203: 609-614.

Conversc, H.H., Jr.

1973. A Pleistocene Vertebrate Fauna from Palm Beach County, Florida. Plaster Jacket, 21:1-2.

Czaplewski, N.J.

1997. Chiroptera. In R.F. Kay, R.H. Madden, R.L. Cifelli, and J.J. Flynn, editors, Vertebrate Paleobiology in the Neotropics: The Miocene Fauna of La Venta, Colombia, pages 410-431. Washington, D.C.: Smithsonian Institution Press.

Domning, D.P.

1982. Evolution of Manatees: A Speculative History. Journal of Paleontology, 56:599-619.

Downing, K.F., and R. White

1995. The Cingulates (Xenarthra) of Leisey Shell Pit 1A (Irvingtonian) Hillsborough County, Florida. In R.C. Hulbert, Jr., G.S. Morgan, and S.D. Webb, editors, Paleontology and Geology of the Leisey Shell Pits, Early Pleistocene of Florida. Bulletin of the Florida Museum of Natural History, 37(2)12:375-396.

Dunbar, J.S., S.D. Webb, and D. Cring

1989. Culturally and Naturally Modified Bones from a Paleoindian Site in the Aucilla River, North Florida. In R. Bonnichsen and M.H. Sorg, editors, Bone Modification, pages 473-497. Orono, Maine: University of Maine, Center for the Study of the First Americans, Institute for Quaternary Studies.

Eger, J.L.

1977. Systematics of the Genus Eumops (Chiroptera: Molossidae). Life Sciences Contributions, Royal Ontario Museum, 110:1-69.

Emslie, S.D.

1995. An Early Irvingtonian Avifauna from Leisey Shell Pit, Florida. In R.C. Hulbert, Jr., G.S. Morgan, and S.D. Webb, editors, Paleontology and Geology of the Leisey Shell Pits, Early Pleistocene of Florida. Bulletin of the Florida Museum of Natural History, 37(1)10:299-344.

1996. A Fossil Scrub-Jay Supports a Recent Systematic Decision. Condor, 98:675-680.

1998. Avian Community, Climate, and Sea-Level Changes in the PlioPleistocene of the Florida Peninsula. Ornithological Monographs, 50: 113 pages.

Emslie, S.D., and G.S. Morgan

1995. Taphonomy of a Late Pleistocene Carnivore Den, Dade County Florida. In D.W. Steadman and J.1. Mead, editors, Late Quaternary Environments and Deep History: A Tribute to Paul S. Martin. The Mammoth Site of Hot Springs, South Dakota, Scientific Papers, 3:65-83.

Eshelman, R.E., and G.S. Morgan

1985. Tobagan Recent Mammals, Fossil Vertebrates, and Their Zoogeographical Implications. Research Reports, National Geographic Society, 21:137-143. 
Frank, P.A.

1997a. First Record of Artibeus jamaicensis Leach (1821) from the United States. Florida Scientist, 60:37-39.

1997b. First Record of Molossus inolossus tropidorhynchus Gray (1839) from the United States. Journal of Mammalogy, 78: 103-105.

Frazier, M.K.

1981. A Revision of the Fossil Erethizontidae of North America. Bulletin of the Florida State Museum, Biological Sciences, 27(1):1-76.

Gazin, C.L.

1956. Exploration for the Remains of Giant Ground Sloths in Panama. Annual Report of the Smithsonian Institution, pages 341-354.

Gillette, D.D.

1976. A New Species of Small Cat from the Late Quaternary of Southeastem United States. Journal of Mammalogy, 57:664-676.

Graham, R.W., and E.L. Lundelius, Jr.

1984. Coevolutionary Disequilibrium and Pleistocene Extinctions. In P.S. Martin and R.G. Klein, editors, Quaternary Extinctions: A Prehistoric Revolution, pages 223-249. Tucson: University of Arizona Press.

Guilday, J.E., H.W. Hamilton, E. Anderson, and P.W. Parmalee

1978. The Baker's Bluff Cave Deposit, Tennessee, and the Late Pleistocene Faunal Gradient. Bulletin of the Carnegie Museum of Natural History, 11:1-67.

Guilday, J.E., P.W. Parmalee, and H.W. Hamilton

1977. The Clark's Cave Bone Deposit and the Late Pleistocene Paleoecology of the Central Appalachian Mountains. Bulletin of the Carnegie Museum of Natural History, 2:1-87.

Gut, H.J.

1959. A Pleistocene Vampire Bat from Florida. Journal of Mammalogy, 40:534-538.

Hall, E.R.

1981. The Mammals of North America. Second edition, 2 volumes, $\mathrm{xv}+$ 1181 pages. New York: John Wiley and Sons.

Hamon, J.H.

1964. Osteology and Paleontology of the Passerine Birds of the Reddick, Florida, Pleistocene. Geological Bulletin, Florida Geological Survey, 44:1-210.

Harmon, R.S., R.M. Mitterer, N. Kriausakul, L.S. Land, H.P. Schwarcz, P. Garrett, G.J. Larson, H.L. Vacher, and M. Rowe

1983. U-Series and Amino-Acid Racemization Geochronology of Bermuda: Implications for Eustatic Sea-Level Fluctuation over the Past 250,000 Years. Palaeogeography, Palaeoclimatology, Palaeoecology, 44:41-70.

Hershkovitz, P.

1958. A Geographic Classification of Neotropical Mammals. Fieldiana, Zoology, 36(6):581-620.

Hibbard, C.W.

1960. An Interpretation of Pliocene and Pleistocenc Climates in North America. 62nd Annual Report of the Michigan Academy of Science, Arts and Letters, pages 5-30.

Hirschfeld, S.E.

1968. Vertebrate Fauna of Nichol's Hammock, a Natural Trap. Quarterly Journal of the Florida Academy of Sciences, 31:177-189.

Hirschfeld, S.E., and S.D. Webb

1968. Plio-Pleistocene Megalonychid Sloths of North America. Bulletin of the Florida State Museum, Biological Sciences, 12(5):213-296.

Holman, J.A.

1959. Birds and Mammals from the Plcistocenc of Williston, Florida. Bulletin of the Florida State Museum, Biological Sciences, 5(1):24

Holman, J.A., and C.J. Clausen

1984. Fossil Vertebrates Associated with Paleo-Indian Artifact at Little Salt Spring, Florida. Journal of Vertebrate Paleontology, 4: I46-154.

Hulbert, R.C., Jr.

1995. The Giant Tapir, Tapirus haysii, from Leisey Shcll Pit 1A and Other
Florida Irvingtonian Localities. In R.C. Hulbert, Jr., G.S. Morgan, and S.D. Webb, editors, Paleontology and Geology of the Leisey Shell Pits, Early Pleistocene of Florida. Bulletin of the Florida Museum of Natural History, 37(2)16:515-551.

1997. A New Late Pliocene Porcupine (Rodentia: Erethizontidae) from Florida. Journal of Vertebrate Paleontology, 17:623-626.

2001. The Fossil Vertebrates of Florida. 350 pages. Gainesville, Florida: University of Florida Press.

Humphrey, S.R

1974. Zoogeography of the Nine-Banded Armadillo (Dasypus novemcinc$(u s)$ in the United States. Bioscience, 24(8):457-462.

Jacobs, L.L., and E.H. Lindsay

1981. Prosigmodon oroscoi, a New Sigmodont Rodent from the Late Tertiary of Mexico. Journal of Paleontology, 55:425-430.

1984. Holarctic Radiation of Neogene Muroid Rodents and the Origin of South American Cricetids. Journal of Vertebrate Paleontology, 4: 265-272.

Jennings, W.L.

1958. The Ecological Distribution of Bats in Florida. 126 pages, doctoral dissertation, University of Florida, Gainesville.

Karrow, P.F., G.S. Morgan, R.W. Portell, E.H. Simons, and K. Auffenberg

1996. Middle Pleistocene (Early Rancholabrean) Vertebrates and Associated Marine and Non-Marine Invertebrates from Oldsmar, Pinellas County, Florida. In K.M. Stewart and K.L. Seymour, editors, Palaeoecology and Palaeoenvironments of Late Cenozoic Mammals. Tributes to the Career of C.S. (Rufus) Churcher, pages 97-133. Toronto: University of Toronto Press.

Kenyon, K.W.

1977. Caribbean Monk Seal Extinct. Journal of Mammalogy, 58:97-98.

Koopman, K.F.

1958. A Fossil Vampire Bat from Cuba. Breviora, 90:1-4.

1971. The Systematic and Historical Status of the Florida Eumops (Chiroptera, Molossidae). American Museum Novitates, 2478: 6 pages.

Koopman, K.F., and P.S. Martin

1959. Subfossil Mammals from the Gómez Farías Region and the Tropical Gradient of Eastern Mexico. Journal of Mammalogy, 40:1-12.

Kurtén, B., and E. Anderson

1980. Pleistocene Mammals of North America. 443 pages. New York: Columbia University Press.

Kurtén, B., and L. Werdelin

1990. Relationships between North and South Amcrican Similodon. Journal of Vertebrate Paleontology: 10:158-169.

Layne, J.N.

1974. The Land Mammals of South Florida. In P.J. Gleason, editor, Environments of South Florida: Present and Past. Miami Geological Society Memoir, 2:386-413.

Lazell, J.D.

1989. Wildlife of the Florida Keys: A Natural History. 253 pages. Washington, D.C.: Island Press.

Lazell, J.D., Jr., and K.F. Koopman

1985. Notes on Bats of Florida's Lower Kcys. Florida Scientist, 48:37-41.

Long, R.W.

1974. Origin of the Vascular Flora of South Florida. In P.J. Gleason, editor, Environments of South Florida: Prcsent and Past. Miami Geological Society Memoir, 2:28-36.

Lundclius, E.L., Jr., C.S. Churcher, T. Downs, C.R. Harington, E.H. Lindsay, G.E. Schultz, H.A. Semken, S.D. Webb, and R.J. Zakrzewski

1987. The North American Quaternary Sequence. In M.O. Woodburne, editor, Cenozoic Maminals of North America: Geochronology and Biostratigraphy, pages 211-235. Berkelcy: University of California Press.

MacPhcc, R.D.E., and M.A. Iturralde-Vinent

1994. First Tertiary Land Mammal from Greater Antillcs: An Early Mioccne Sloth (Xenarthra, Megalonychidae) from Cuba. American Museum Novitates, 3094: 13 pages. 
Martin, R.A.

1972. Synopsis of Late Pliocene and Pleistocene Bats of North America American Midland Naturalist, 87:326-335.

1974. Fossil Mammals from the Coleman IIA Fauna, Sumter County, In S.D. Webb, editor, Pleistocene Mammals of Florida, pages 35-99. Gainesville, Florida: University Presses of Florida.

1977. Late Pleistocene Eumops from Florida. Bulletin of the New Jersey Academy of Science, 22:18-19.

1978. A New Late Pleistocene Conepatus and Associated Vertebrate Fauna from Florida. Journal of Paleontology, 52:1079-1085.

1979. Fossil History of the Rodent Genus Sigmodon. Evolutionary Monographs, 2:1-36.

McDonald, H.G.

1990. Understanding the Paleoecology of Fossil Vertebrates: Contributions of Submerged Sites. In W.C. Jaap, editor, Diving for science...1990. Proceedings of the American Academy of Underwater Sciences Tenth Annual Scientific Diving Symposium. October 4-7. 1990, St. Petersburg, Florida, pages 273-292.

1995. Gravigrade Xenarthrans from the Early Pleistocene Leisey Shell Pit 1A, Hillsborough County, Florida. In R.C. Hulbert, Jr., G.S. Morgan, and S.D. Webb, editors, Paleontology and Geology of the Leisey Shell Pits, Early Pleistocene of Florida. Bulletin of the Florida Museum of Natural History, 37(2)11:345-373.

McNab, B.K.

1973. Energetics and the Distribution of Vampires. Journal of Mammalogv, 54:131-144.

Meylan, P.A.

1982. The Squamate Reptiles of the Inglis IA Fauna (Irvingtonian: Citrus County, Florida). Bulletin of the Florida State Museum, Biological Sciences, 27(3): 1-85.

1995. Pleistocene Amphibians and Reptiles from the Leisey Shell Pit, Hillsborough County, Florida. In R.C. Hulbert, Jr., G.S. Morgan, and S.D. Webb, editors, Paleontology and Geology of the Leisey Shell Pits, Early Pleistocene of Florida. Bulletin of the Florida Museum of Natural History, 37(1)9:273-297.

Montellano-Ballesteras, M., and O. Carranza-Castañeda

1986. Descripción de un mílodóntido del Blancano temprano de la Mesa Central de México. Universidad Nacional Autonoma de México. Instituto de Geología, Revista, 6:193-203.

Morgan, G.S.

1985. Fossil Bats (Mammalia: Chiroptera) from the Late Pleistocene and Holocene Vero Fauna, Indian River County, Florida. Brimleyana. 11:97-117.

1989a. Fossil Chiroptera and Rodentia from the Bahamas, and the Historical Biogeography of the Bahamian Mammal Fauna. In C.A. Woods, editor, Biogeography of the West Indies: Past, Present, and Future, pages 685-740. Gainesville, Florida: Sandhill Crane Press.

1989b. New Bats from the Oligocene and Miocene of Florida and the Origins of the Neotropical Chiropteran Fauna. Journal of Vertebrate Paleontology, supplement, 9(3):33A.

1991. Neotropical Chiroptera from the Pliocene and Pleistocene of Florida. Bulletin of the American Museum of Natural History, 206: 176-213.

1994a. Late Quaternary Fossil Vertebrates from the Cayman 1slands. In M.A. Brunt and J.E. Davies, editors, The Cayman Islands: Natural History and Biogeography, pages 465-508. Dordrecht, Netherlands: Kluwer Academic Publishers.

1994b. Miocene and Pliocene Marine Mammal Faunas from the Bone Valley Formation of Central Florida. In A. Berta and T.A. Deméré, editors, Contributions in Marine Mammal Paleontology Honoring Frank C. Whitmore, Jr. Proceedings of the San Diego Society of Natural History, 29:239-268.

2001. Patterns of Extinction in West Indian Bats. In C.A. Woods, editor, Biogeography of the West Indies: New Patterns and Perspectives, pages 367-405. Boca Raton, Florida: CRC Press.
Morgan, G.S., and R.C. Hulbert, Jr.

1995. Overview of the Geology and Vertebrate Biochronology of the Leisey Shell Pit Local Fauna, Hillsborough County, Florida. In R.C. Hulbert, Jr., G.S. Morgan, and S.D. Webb, editors, Paleontology and Geology of the Leisey Shell Pits, Early Pleistocene of Florida. Bulletin of the Florida Museum of Natural History, 37(1)1:1-92.

Morgan, G.S., O.J. Linares, and C.E. Ray

1988. New Species of Fossil Vampire Bats (Mammalia: Chiroptera: Desmodontidae) from Florida and Venezuela. Proceedings of the Biological Society of Washington, 101:912-928.

Morgan, G.S., and R.W. Portell

1996. The Tucker Borrow Pit: Paleontology and Stratigraphy of a PlioPleistocene Fossil Sitc in Brevard County, Florida. Papers in Florida Paleontology, 7:1-25.

Morgan, G.S., and R.B. Ridgway

1987. Late Plioccne (Late Blancan) Vcrtebrates from the St. Petersburg Times Site, Pinellas County, Florida, with a Brief Review of Florida Blancan Faunas. Papers in Florida Paleontology, 1:1-22.

Morgan, G.S., and K.L. Seymour

1997. Fossil History of the Panther (Puma concolor) and the Cheetah-Like Cat (Miracinonyx inexpectatus) in Florida. Bulletin of the Florida Museum of Natural History, 40(2): 177-219.

Morgan, G.S., and J.A. White

1995. Small Mammals (Insectivora, Lagomorpha, and Rodentia) from the Early Pleistocene (Early Irvingtonian) Leisey Shell Pit Local Fauna, Hillsborough County, Florida. In R.C. Hulbert, Jr., G.S. Morgan, and S.D. Webb, editors, Paleontology and Geology of the Leisey Shell Pits, Early Pleistocene of Florida. Bulletin of the Florida Museum of Natural History, 37(2)13:397-461.

Morgan, G.S., and C.A. Woods

1986. Extinction and the Zoogeography of West Indian Land Mammals. Biological Journal of the Linnean Society, 28:167-203.

Ober, L.D.

1978. The Monkey Jungle, a Late Pleistocene Fossil Site in Southern Florida. Plaster Jacket, 28:1-13.

Olsen, S.J.

1960. Additional Remains of Florida's Pleistocene Vampire. Journal of Mammalogy, 41:458-462.

Osmond, J.K., J.R. Carpenter, and H.L. Windom

1965. $\mathrm{Th}^{230} / \mathrm{U}^{234}$ Age of Pleistocene Corals and Oolites of Florida. Journal of Geophysical Research, 70:1843-1847.

Paula Couto, C. de

1967. Pleistocene Edentates of the West Indies. American Museum Novitates, 2304: 55 pages.

Ray, C.E.

1958. Additions to the Pleistocene Mammalian Fauna from Melbourne, Florida. Bulletin of the Museum of Comparative Zoology, 119(7): $421-449$.

Ray, C.E., O.J. Linares, and G.S. Morgan

1988. Paleontology. In A.M. Greenhall and U. Schmidt, editors, Natural History of Vampire Bats, pages 19-30. Boca Raton, Florida: CRC Press.

Ray, C.E, S.J. Olsen, and H.J. Gut

1963. Three Mammals New to the Pleistocene Fauna of Florida, and a Reconsideration of Five Earlier Records. Journal of Mammalogy, 44: 373-395.

Rice, D.W.

1957. Life History and Ecology of Myotis austroriparius in Florida. Journal of Mammalogy: 38:15-32.

Robertson, J.S., Jr.

1974. Fossil Bison of Florida. In S.D. Webb, editor, Pleistocene Mammals of Florida, pages 214-246. Gainesville, Florida: University Presses of Florida.

Robertson, W.B., Jr., and J.A. Kushlan

1974. The Southern Florida Avifauna. In P.J. Gleason, editor, Environ- 
ments of South Florida: Present and Past. Miami Geological Society Memoir, 2:414-452.

Savage, D.E.

1951. Late Cenozoic Vertebrates of the San Francisco Bay Region. University of California Publications, Bulletin of the Department of Geological Sciences, 28:215-314.

Silva Taboada, G.

1974. Fossil Chiroptera from Cave Deposits in Central Cuba, with Description of Two New Species (Genera Pteronotus and Mormoops), and the First West Indian Record of Mormoops megalophylla. Acta Zoologica Cracoviensia, 19(3):33-73.

Smith, J.D.

1972. Systematics of the Chiropteran Family Mormoopidae. University of Kansas Museum of Natural History, Miscellaneous Publication, 56: 132 pages.

Waldrop, J.S

1974. The Scimitar Cat, Homotherium serum, from the Florida Late Pleistocene. In S.D. Webb, editor, Pleistocene Mammals of Florida, pages 154-157. Gainesville, Florida: University Presses of Florida.

Watts, W.A., and B.C.S. Hansen

1988. Environments of Florida in the Late Wisconsin and Holocene. In B.A. Purdy, editor, Wet Site Archaeology, pages 307-323. Caldwell, New Jersey: Telford Press.

Webb, S.D.

1974a. Chronology of Florida Pleistocene Mammals. In S.D. Webb, editor, Pleistocene Mammals of Florida, pages 5-31. Gainesville, Florida: University Presses of Florida.

1974b. Pleistocene Llamas of Florida, with a Brief Review of the Lamini. In S.D. Webb, editor, Pleistocene Mammals of Florida, pages 170-213. Gainesville, Florida: University Presses of Florida.

1976. Mammalian Faunal Dynamics of the Great American Interchange. Paleobiology, 2:220-234.

1985. Late Cenozoic Mammal Dispersals between the Americas. In F.G Stehli and S.D. Webb, editors, The Great American Biotic Interchange, pages 357-386. New York: Plenum Press.

1989. Osteology and Relationships of Thinobadistes segnis, the First Mylodont Sloth in North America. In K. Redford and J.F. Eisenberg, editors, Advances in Neotropical Mammalogy, pages 469-532. Gainesville, Florida: Sandhill Crane Press.

Webb, S.D., and S.C. Perrigo

1984. Late Cenozoic Vertebrates from Honduras and El Salvador. Journal of Vertebrate Paleontology, 4:237-254.

1985. New Megalonychid Sloths from El Salvador. In G.G. Montgomery, editor, The Evolution and Ecology of Armadillos, Sloths, and Vermilinguas, pages 113-120. Washington, D.C.: Smithsonian Institution Press.

Webb, S.D., and F.G. Stehli

1995. Selenodont Artiodactyla (Camelidae and Cervidae) from the Leisey Shell Pits, Hillsborough County, Florida. In R.C. Hulbert, Jr., G.S. Morgan, and S.D. Webb, editors, Paleontology and Geology of the Leisey Shell Pits, Early Pleistocene of Florida. Bulletin of the Florida Museum of Natural History, 37(2)19:621-643.

Webb, S.D., and K.T. Wilkins

1984. Historical Biogeography of Florida Pleistocene Mammals. In H.H. Genoways and M.R. Dawson, editors, Contributions in Quaternary Vertebrate Paleontology: A Volume in Memorial to John E. Guilday. Special Publication, Carnegie Museum of Natural History, 8:370383.

Weigel, R.D.

1962. Fossil Vertebrates of Vero, Florida. Florida Geological Survey, Special Publication, 10:1-59.

Werdelin, L.

1985. Small Pleistocene Felines of North America. Journal of Vertebrate Paleontology, 5:194-210.

Wilkins, K.T

1983. Pleistocene Mammals from the Rock Springs Local Fauna, Central Florida. Brimleyana, 9:69-82.

1984. Evolutionary Trends in Florida Pleistocene Pocket Gophers (Genus Geomys), with Description of a New Species. Journal of Vertebrate Paleontology, 3:166-181.

Wilson, D.W., and D.M. Reeder, editors

1992. Mammal Species of the World: A Taxonomic and Geographic Reference. 1206 pages. Washington, D.C.: Smithsonian lnstitution Press.

Winans, M.C.

1989. A Quantitative Study of North American Fossil Species of the Genus Equus. In D.R. Prothero and R.M. Schoch, editors, The Evolution of Perissodactyls, pages 262-297. New York: Oxford University Press.

Wing, E.S

1992. West Indian Monk Seal, Monachus tropicalis. In S.R. Humphrey, editor, Rare and Endangered Biota of Florida, I: Mammals, pages 35-40. Gainesville, Florida: University Presses of Florida. 


\title{
The Basicranium of the Giant Wombat Phascolonus gigas Owen (Vombatidae: Marsupialia) and Its Significance in Phylogeny
}

\author{
Richard H. Tedford
}

\begin{abstract}
The availability of two skulls of the giant wombat Phascolonus gigas Owen, from Pleistocene deposits of Lake Callabonna, South Australia, allows characters from the basicranium to contribute to the phylogenetic resolution of the Vombatidae. In agreement with previous work, this study confirms that Phascolonus is a part of the clade containing the living hairy-nosed wombat, Lasiorhinus, and other large fossil wombats. Phascolonus retains some plesiomorphies seen only in the Miocene wombats (large, bilobed premolars) but also exhibits a number of autapomorphies of the skull and dentition, the most striking of which are the great breadth of the upper incisors, the peculiar arcuate ectotympanic, and the enclosure of the facial canal within the mastoid process of the periotic.
\end{abstract}

\section{Introduction}

In 1913, E.C. Stirling announced the discovery at Lake Callabonna, South Australia, of the first associated upper and lower dentitions and most of the major skeletal elements of Phascolonus gigas (Owen, 1858). This association demonstrated that the mandibular remains first described by Owen in 1858, as Phascolomys gigas (made the genotypic species of Phascolonus Owen in 1872), pertained to the same taxon as the peculiar, flattened, central upper incisors described as Sceparnodon stephensii by Ramsay in 1880 . In 1970, nearly sixty years after Stirling's announcement, a joint Smithsonian InstitutionAmerican Museum of Natural History-South Australian Museum expedition to Lake Callabonna discovered two partial skeletons of Phascolonus gigas at Site 4 in the northern part of the fossil field (Wells and Tedford, 1995:110, fig. 2). The skeletons included two crushed, but nearly complete, adult skulls

Richard H. Tedford, Department of Vertebrate Paleontology, American Museum of Natural History, Central Park West at 79th Street, New York, New York 10024. now housed at the National Museum of Natural History (the former United States National Museum), USNM 214696 and 215139 , of which the former supplied most of the basicranial morphology described below.

Shortly after the field shipment was received at the Smithsonian, these specimens were skillfully prepared by Frank Pearce, who had been a member of the field party. He used a wax-impregnation technique, which avoided problems of drying and fragmentation by salt crystal growth that so plagued the preparation of Callabonna fossils owing to their long burial within the saline water table. Study and photographic illustration of material prepared in this way are best effected under ultraviolet light, as the wax-impregnated bone fluoresces strongly in contrast to the matrix.

This study of the basicranial morphology is intended to help clarify the phylogenetic relationship of Phascolonus. Comparisons are limited to living wombats because the only comparable cranial material available from fossil species is from forms closely related to those living.

In addition to the living wombats, Lasiorhinus and Vombatus, the following outgroup taxa were examined: Ilaria illumidens Woodburne and Tedford (AMNH 102651), casts of the Alcoota diprotodontids and the diprotodontid Ngapakaldia tedfordi Stirton, and a cranium of Thylacoleo carnifex Owen from Victoria Cave (SAM P16681).

ACKNOWLEDGMENTS.-This paper is dedicated to Clayton Ray who not only lovingly collected the principal specimen used in this study but also throughout the sandstorms and flies of a successful though trying field season in Australia in 1970, contributed more than his share of enthusiasm and good cheer in the best "she'll be right" spirit of Australia. I also owe a debt of gratitude to my other companions in the field, namely, Bob Emry, Frank Pearce, and Neville Pledge, who also made that trip memorable, and to our institutions and the National Science Foundation (grant number GB 18273x 1). The work would never have been so productive without the superb logistic skills 
of Paul Lawson of the South Australian Museum, who kept a consistent stream of vital supplies arriving on time and who later expedited their shipment to the United States. We are eternally grateful to Mick and Audrey Sheehan of Moolawatana Station, who put up with our intrusion. Lorraine Meeker and Chester Tarka of the American Museum of Natural History provided the innovative ultraviolet/white-light stereophotos that illustrate this paper. Frank Pearce developed the equally innovative wax-impregnation technique that enabled the preservation and preparation of the well-preserved, but frustratingly fragile, Callabonna fossils.

ABBREVIATIONS.-The following abbreviations are used:

\section{AMNH American Museum of Natural History, New York}

NMNH National Museum of Natural History, Smithsonian Institution, Washington, D.C.

SAM South Australian Museum, Adelaide

USNM Collections of the National Museum of Natural History, Smithsonian Institution, which include the collections of the former United States National Museum

\section{Description of the Basicranium}

\section{FIGURES 1,2}

EXOCCIPITAL.-This element of the most posterior part of the basicranium includes the foramen magnum, the occipital condyles, the condyloid foramina, the posterior rim of the posterior lacerate foramen, and the foramina for the transverse sinus within the lateral wall of the foramen magnum. The occipital condyles are more salient than in living wombats and are laterally separated from the body of the exoccipital by grooves. As in Vombatus, there is an occipital foramen just lateral to the condyles that appears to be open and probably communicates with the transverse sinus. The exoccipital forms only the medial base of the paroccipital process, whereas in both living wombat species the entire process is formed by the exoccipital.

BASIOCCIPITAL.-The precise limits of this element are difficult to discern because of its fusion with adjacent basicranial bones. The basioccipital bears a low median keel that separates two shallow depressions for insertion of the rectus capitus muscles. No foramina pierce this bone.

BASISPHENOID.-The precise limits of this bone are also difficult to determine owing to the advanced ontogenetic age of the specimens available. The anterior end probably lies at the level of the posterior end of the palatine bar, which closes the palatine fenestra. The basioccipital is penetrated by the carotid foramen, which enters the body of the basioccipital near the posterior limit of the bone. The transverse canal appears to be absent or tiny in Phascolonus, as it is in Lasiorhinus, rather than large, as in Vombatus.

PTERYGOID.-The pterygoid wing ascends from the posterior end of the palate and passes backward to the level of the foramen ovale. It forms the floor of the opening of the carotid canal as in Vombatus, rather than passing lateral to the canal as in Lasiorhinus.
ALISPHENOID.-As in other vombatiforms, the extension of the squamosal into the anterior part of the tympanic space has largely limited the alisphenoid to the medial side of the temporal opening. In the living wombats, the alisphenoid forms the anterior and ventral rim of the foramen ovale, which lies on the suture between these two cranial elements. In Phascolonus, damage in this area limits observation to the left side of USNM 214696 , where the foramen is situated astride the squamosalalisphenoid suture and opens into the braincase on the lateral side of the median lacerate foramen, as in both species of living wombats.

SQUAMOSAL.-Phascolonus lacks the prominent squamosal tympanic wings seen in Vombatus. Instead, the hypotympanic sinus extends deeply anterolaterally into the squamosal, as in Lasiorhinus, without the ventral processes underlying the ectotympanic as seen in both living wombats. Also, there is no extensive hollowing of the epitympanic fossa of the squamosal, as in Lasiorhinus. The morphology more nearly resembles that in Vombatus. The posterior part of the epitympanic fossa is more deeply excavated than in the living genera, forming a chamber into which the external auditory meatus opens. One or two postglenoid foramina lie deep within the fossa above the dorsal process of the ectotympanic, as in Vombatus. A single large subsquamosal foramen lies just above the posterior root of the zygoma. In contrast, living wombats, especially Vombatus, have a suite of small foramina in this position. The squamosal forms the lateral rim of the mastoid process, and its distribution resembles that of Lasiorhinus.

ECTOTYMPANIC.- This bone has a unique form in Phascolonus; rather than being tubular, as in most diprotodont marsupials, it is flattened into a body that bridges the external opening of the tympanum between the squamosal and the mastoid process of the periotic. In ventral view, the ectotympanic forms an anteriorly concave, curved structure. It is united with the mastoid process by a large squamous suture but apparently only touches the squamosal tympanic wing. The pointed anteromedial process of the ectotympanic underlies the squamosal wing. The crista tympanica surrounds the slit-like porus acousticus on the anteromedial surface of the ectotympanic. The external auditory meatus is a very small dorsoventrally oriented slit, deeply contained within the epitympanic fossa. The convex posterior surface of the ectotympanic is cupped within a comparably curved surface of the mastoid medial to the tip of the mastoid process and partially separated from the mastoid by a narrow space.

PERIOTIC.-As in some other vombatiforms (thylacoleonids, ilariids, diprotodontids), the paroccipital process in Phascolonus is formed mainly from the mastoid process of the periotic. In the living wombats, the parocciptial process is formed entirely by the exoccipital. A prominent stylomastoid foramen is enclosed by the mastoid process and opens onto the ventral surface behind the ectotympanic. In living wombats, the facial nerve passes, by way of a canal on the ectotympanic-mastoid suture, ventral to the promontorium posteriorly and medially, 

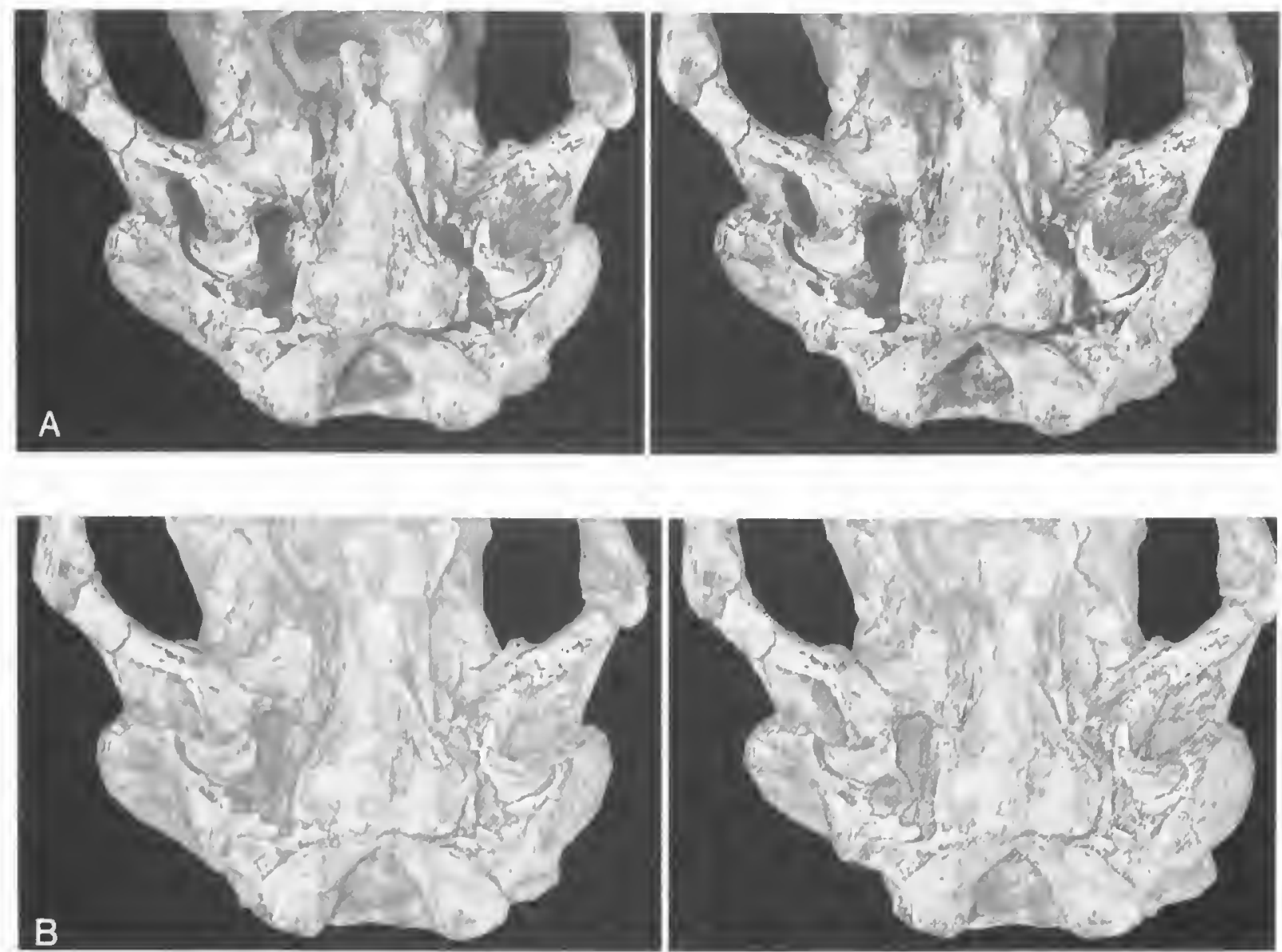

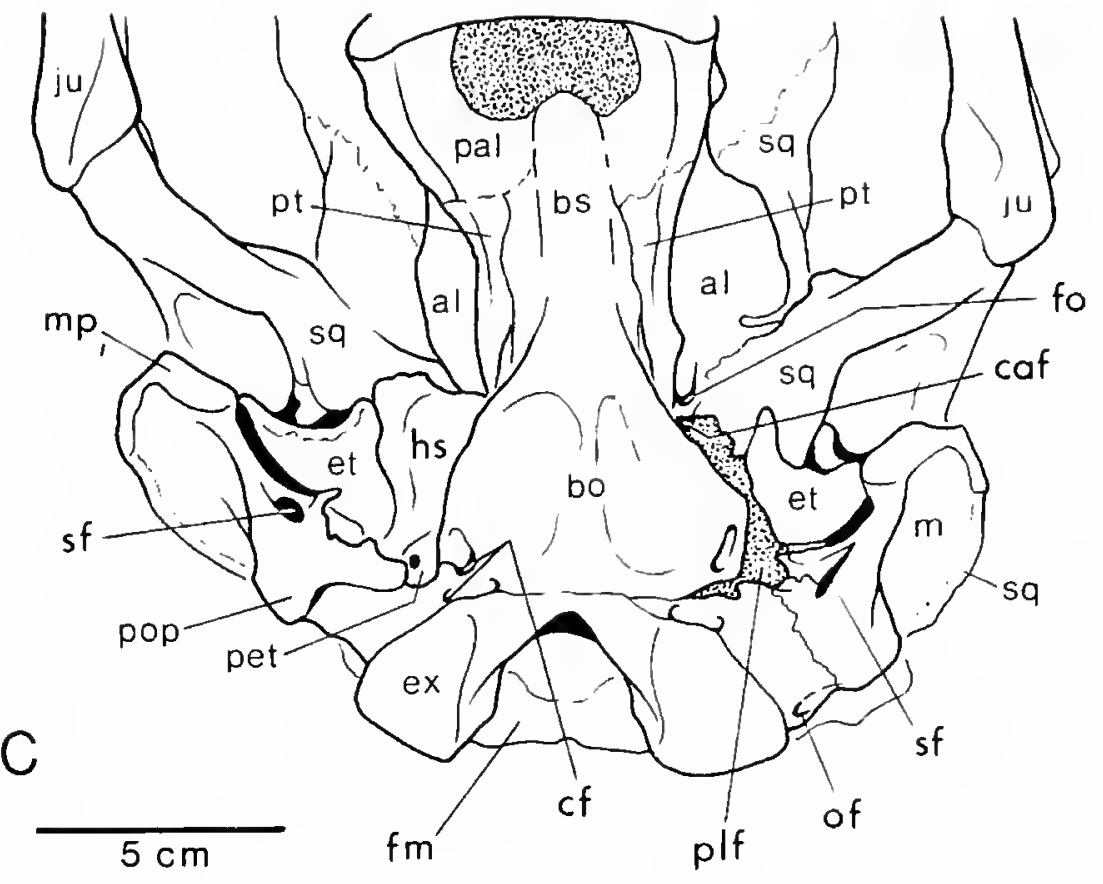

and exits posterior to the external auditory meatus. A similar lateral course for the facial nerve also seems to be the case in other vombatiforms. The mastoid process of the periotic is laterally produced into a thin flange, backed by the squamosal. This plate-like structure is similar in form and composition to that seen in other vombatiforms. At its posteriormost extent, medial to the stylomastoid foramen, it bears a fossa for reception of the hyoid apparatus.

Thepf petrosal is remarkably small and deeply sunken into the hypotympanic space to the level of the crista tympani. In its anteroposteriorly elongate form it closely resembles the petro-
FIGURE 1 - - Ventral view of the basicranium of Phascolonus gigas, USNM 214696 , taken in ultraviolet $(A)$ and composite white and ultraviolet light (B). The associated outline at the same scale (C) identifies the structures discussed in the text. (al=alisphenoid; bo=basioccipital; $b s=b a s i s p h e n o i d$; $c a f=$ carotid foramen; $\mathrm{cf}=$ condyloid foramina; $\mathrm{et=ectotympanic;} \mathrm{ex=exoccipital;fm=fora-}$ men magnum; fo=foramen ovale; hs=hypotympanic sinus; ju=jugal; $m=$ mastoid; $\mathrm{mp}=$ mastoid process; of=occipital foramen; $\mathrm{pal}=$ palatine; pet=petrosal; $\mathrm{plf}=$ posterior lacerate foramen; $\mathrm{pop}=$ paroccipital process; $\mathrm{pt}=\mathrm{pterygoid;} \mathrm{sf}=$ stylomastoid foramen; sq=squamosal.)

sal of living wombats. In the living wombats, the petrosal lies more superficially in the hypotympanic space, not far above the level of the basicranial bones. Although the petrosals in both skulls of Phascolonus appear to be displaced, they are confined to a relatively narrow space behind the squamosal hypotympanic sinus.

In reviewing the salient points of the basicranium of Phascolonus, two aspects appear to be unique to this taxon among known vombatiforms. The first is the form of the ectotympanic. The second is the facial nerve, which exits from a canal in the mastoid, rather than from a groove or canal at the ecto- 

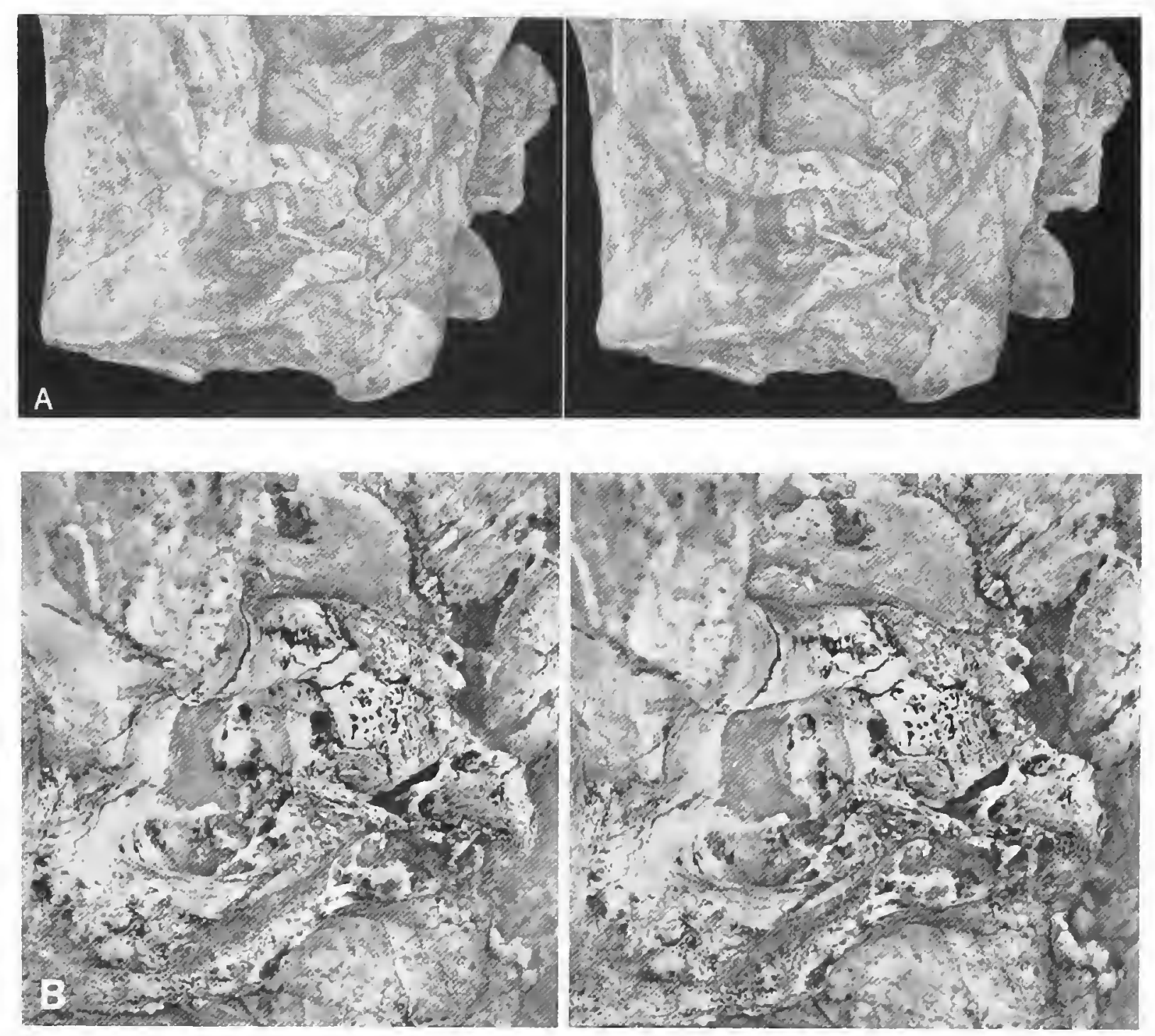

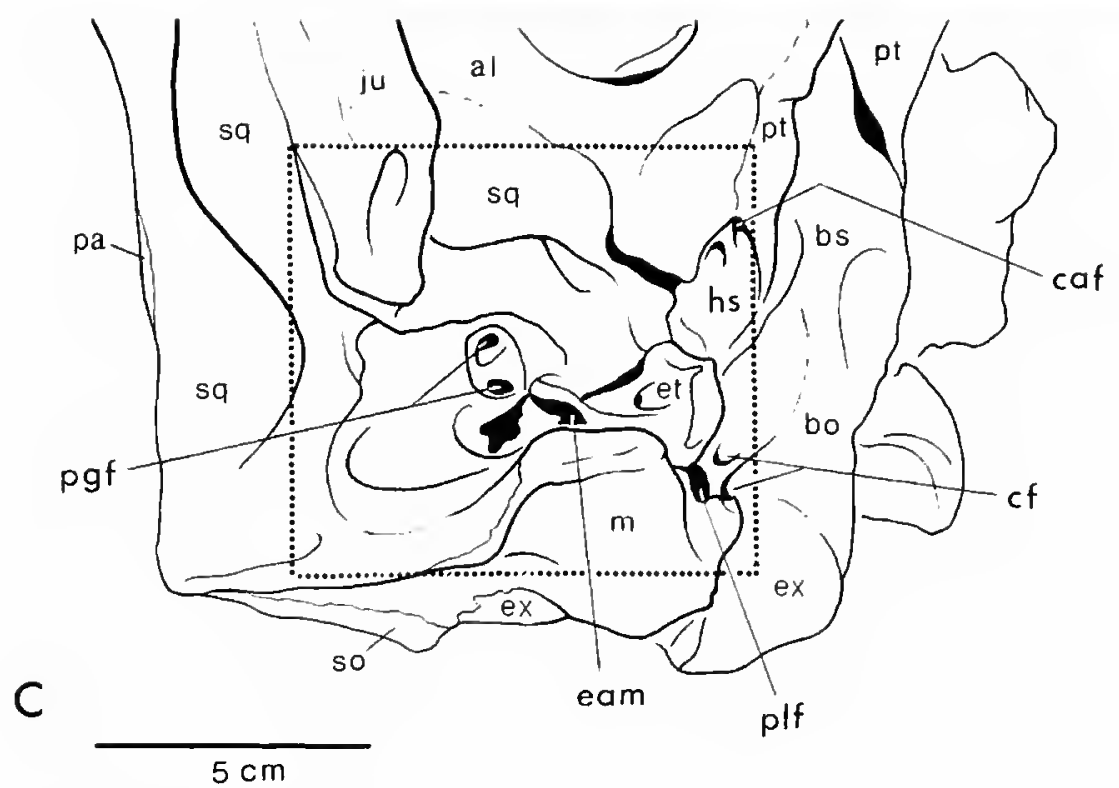

tympanic-mastoid suture as in all other diprotodontians. Otherwise, the basicranium closely resembles living wombats; it lacks only the ventral inflation of the squamosal hypotympanic sinus and the dorsal position of the petrosal in the narrow space between the basioccipital and the ectotympanic.

\section{Discussion}

The distinctive suite of synapomorphies that characterize the Vombatidae, especially the gliriform incisive battery and the
FIGURE 2-Oblique view of the posterior part of the right side of the cranium of Phascolonus gigas, USNM 214696, taken in composite white and ultraviolet light (A) and detailed view (B). The associated outline at the same scale identifies the structures discussed in the text. The rectangle encloses the detailed view. (eam=external auditory meatus; $\mathrm{pa}=$ parietal; $\mathrm{pgf}=$ postglenoid foramina; $\mathrm{so}=$ supraoccipital. Other abbreviations as in Figure 1.)

strong modification of the skeleton for fossorial existence, has long justified the hypothesis of wombat monophyly. Possession of a squamosal tympanic process has clearly grouped the Vombatidae with the other vombatoid families, all of which are extinct (Marshall et al., 1990). With the inclusion of the fossil record, the recognition of their sister group has been less universally acknowledged.

In one of the earliest cladistic analyses, Archer (1984, fig. $310)$ placed the wombats in an unresolved trichotomy with "diprotodontoids" (Diprotodontidae + Palorchestidae) and the 


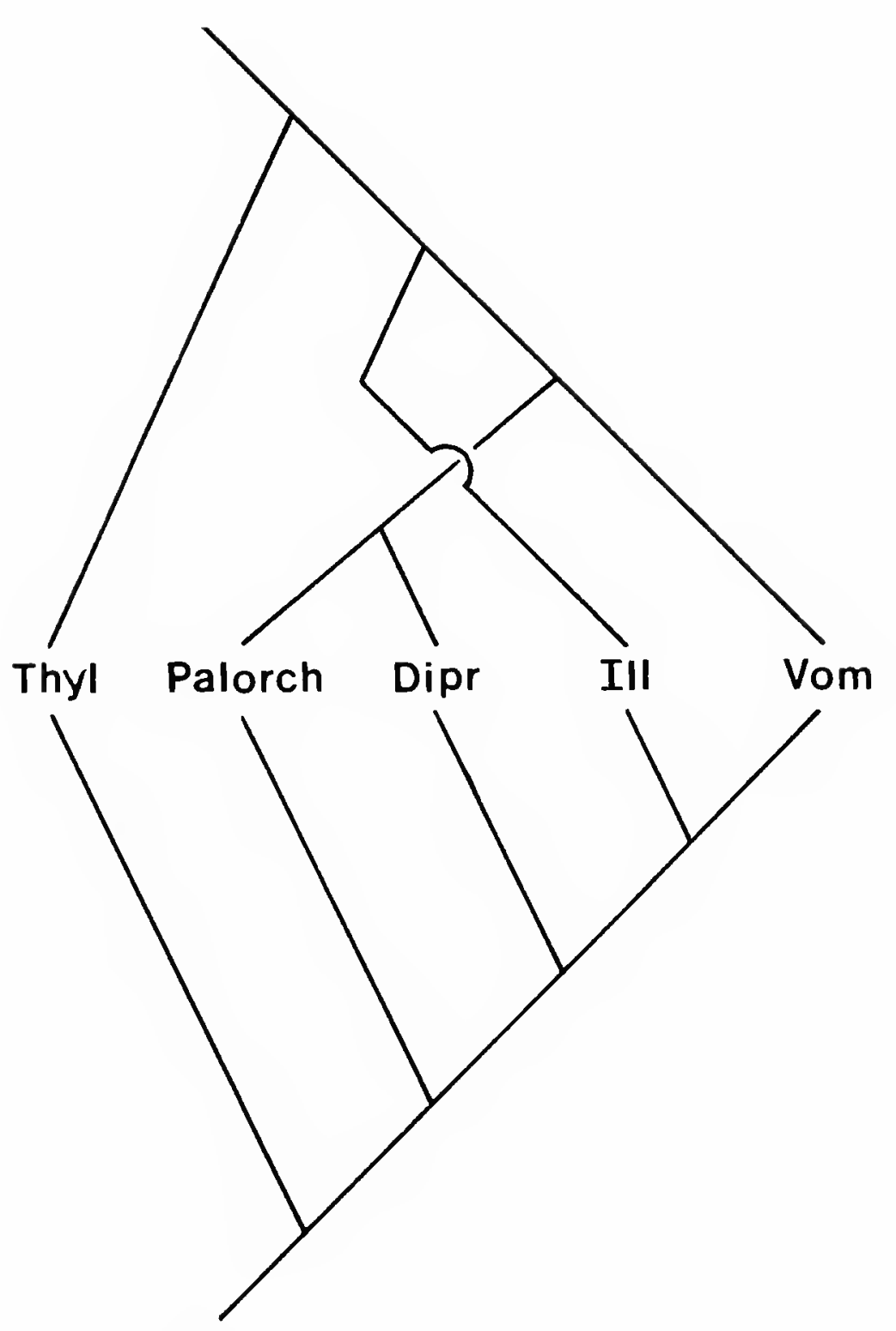

FIGURE 3.-Comparison of the resolution of vombatimorph phylogeny of Marshall et al. (1990), based upon cranial and dental features (top), versus that of Munson (1992), based upon postcranial features (bottom).

Thylacoleonidae based on cranial and dental features. Later, Marshall et al. (1990), on the basis of shared loss of the upper canine and of elongation and increased ankylosis of the mandibular symphysis, placed the vombatids specifically as sister taxa of the diprotodontids + palorchestids. Other vombatoids were arranged in pectinate fashion below these terminal sister taxa, with the marsupial-lions being the least-derived relative to the suite of cranial and dental characters used.

Munson's (1992) study of vombatiform (phascolarctids + vombatoids of Marshall et al., 1990) relationships focused on Ngapakaldia (Diprotodontidae) and Ilaria (Ilariidae). Munson (1992) considered 100 postcranial characters of the families of vombatiforms and successive outgroups, including several species within the phalangeriforms, peramelids, dasyurids, and microbiotheres. The analysis was generalized to the family level, and a parsimony algorithm (PHYLIP 2.8 of Felsinstein, 1987) yielded a single tree (no statistics were given) that grouped Vombatidae with Ilariidae as the crown group of a pectinate cladogram in which the Diprotodontidae, Palorchestidae, and
Thylacoleonidae were successive taxa included in the Vombatiformes. When this tree is compared with cranial-dental results of Marshall et al. (1990), the only discordance among equivalent taxa is the placement of the ilariids and the relationships among the diprotodontoid taxa (Figure 3).

These conclusions represent conflicts that pit a hypothetical dental transformation series against modification of the skeleton for digging. Because the ilariids are primitive in possessing a selenodont dentition and the living wombats retain this pattern in the unworn teeth, it seems likely that the postcranial skeleton contains the more phylogenetically valuable signal of phylogeny. Munson (1992) used the skeleton of Phascolonus gigas in her analysis, but she did not find that it diverged markedly from that of living wombats, except in size and features related to size.

Phascolonus gigas thus makes no particular contribution to the questions of within-wombat relationships in the postcranial skeleton. Nonetheless, divergent views have been advanced regarding the phylogenetic position of Phascolonus within the Vombatidae. Dawson (1981) used cladistic arguments to investigate the phylogeny of the giant wombats, Phascolonus gigas, Ramsayia magna Owen, and "Phascolomys" medius Owen. Using the distribution of five dental and two cranial characters, she specifically examined the relationships of these three to the two living species. The "Palorchestidae" (now allocated to the Diprotodontidae) were used as an outgroup to establish the polarity of these features. The result was a single cladogram (Figure 4A) (Hypothesis A herein) that grouped Phascolonus with Vombatus and Ramsayia with Lasiorhinus (including "Phascolomys" medius, following Marcus, 1976).

In 1983, using new material that more clearly showed the palatal features, Dawson returned to the subject of wombat phylogeny and the phylogenetic position of L. medius. In this revised analysis (Dawson, 1983) she used two more characters of the anterior palate; these continued to group "Phascolomys" medius with Lasiorhinus but shifted the position of Phascolonus from a sister taxon of Vombatus (involving four parallelisms, as in Figure 4A) to a sister taxon of the Lasiorhinus group, which included Ramsayia and L. medius (two parallelisms and two reversals, as shown in Figure 4B).

Subsequently, Archer (1984) presented a cladogram (Figure 5) of wombat phylogeny that included the Pleistocene Warendja and the Miocene Rhizophascolonus as successive outgroups. Determination of character polarity was assisted by consideration of other "diprotodontians." This view was supported by 17 characters, including those considered by Dawson (1983), and favored the arrangement of Phascolonus + "P." medius as a sister taxon of Lasiorhinus and Ramsayia and more distantly Vombatus.

A recent analysis by Murray (1998) used a suite of 28 cranial and dental characters in an ostensibly cladistic analysis (Figure 6), which essentially reinforced Archer's (1984) view. Accepting the monophyly of the Vombatidae as having been well sub- 

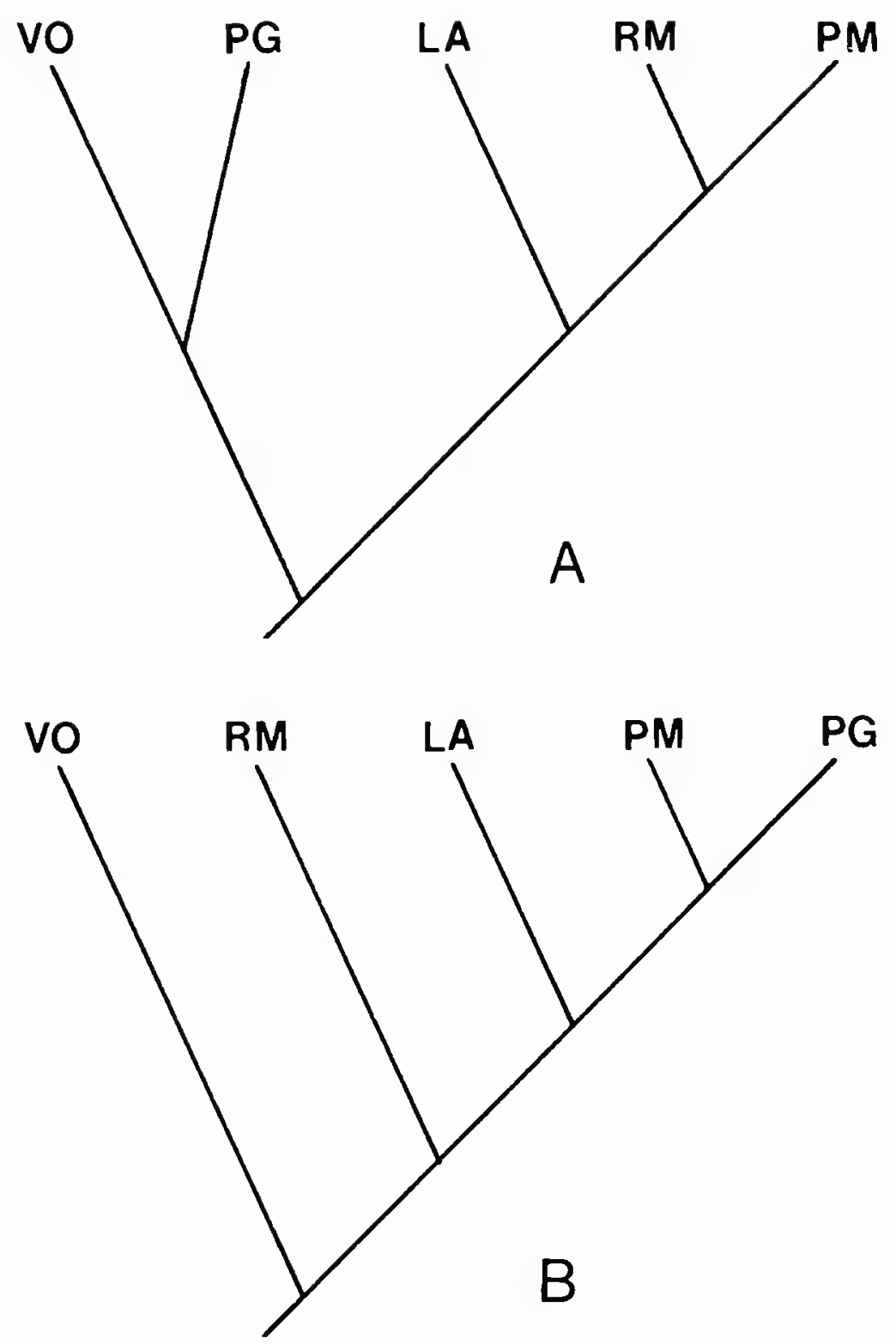

FIGURE 4.-Altemative phylogenies for the Vombatidae proposed by Dawson: A, Hypothesis A (1981); B, Hypothesis B (1983). Both are based upon cranial and dental features. (LA=Lasiorhinus; $\mathrm{PG}=$ Phascolonus gigas; $\mathrm{PM}="$ Phascolomys" medius; $\mathrm{RM}=$ Ramsayia magna: $\mathrm{VO}=$ Vombatus.)

stantiated by the data reviewed by Murray, we examine a smaller suite of characters (including 10 of those used by Murray) to analyze the phylogeny of wombat species. The characters used by Murray are not explicitly polarized, but they can be if other vombatiforms - diprotodontids, palorchestids, ilariids, and thylacoleonids - are used as outgroups. The following characters and their polarities were used: (1) The highly modified Il of Phascolonus is "transversely implanted" (sensu Murray, 1998); in the primitive condition, the Il is obliquely implanted, as seen in Vombatus. (2) The Il in Phascolonus is autapomorphic in its extreme breadth compared with its dorsoventral depth; the enamel is restricted to the anterior face. (3) The $\mathrm{P} 3$ has a labial and a lingual groove in the primitive form of this tooth, but in wombats both grooves may be reduced or lacking. Both conditions are usually accompanied by reduction in the size of the tooth relative to the size of the molar rows. Phascolonus retains both grooves. (4) A small P3, shorter than

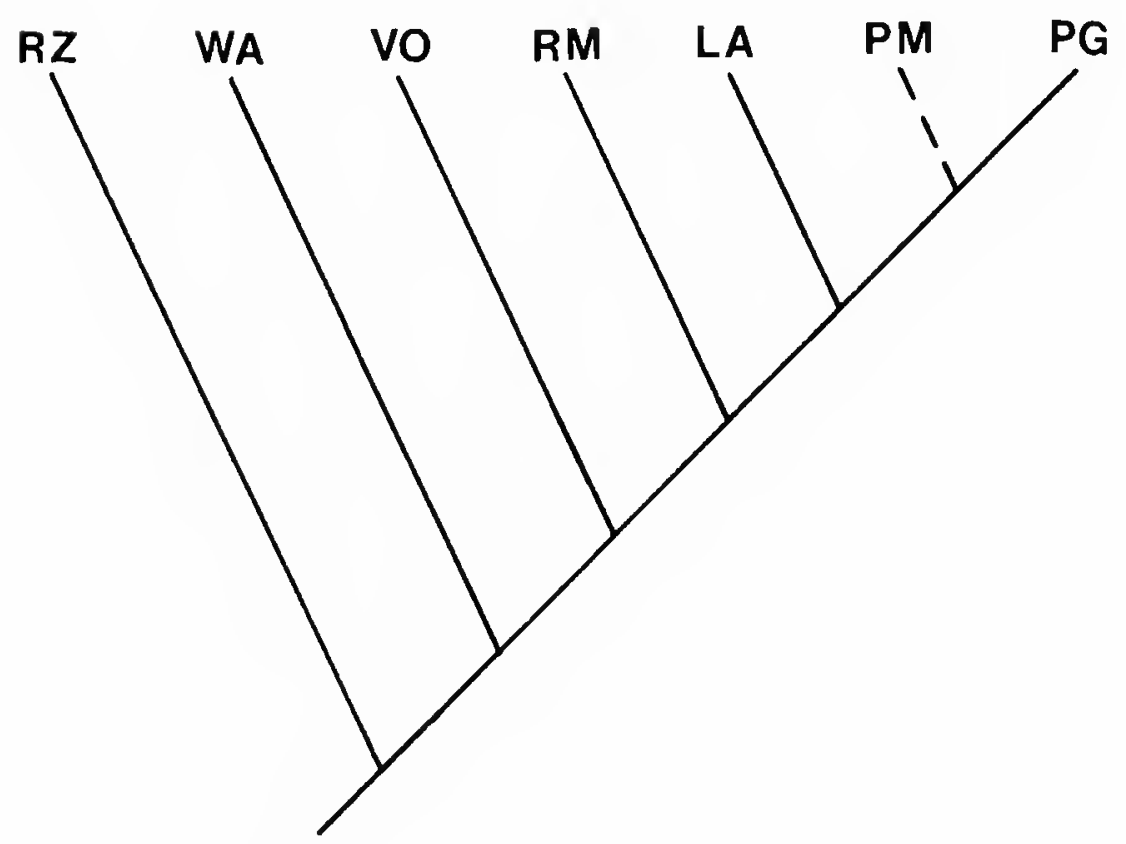

FIGURE 5.-Archer's (1984) phylogeny of the Vombatidae, based upon cranial and dental characters. (Taxa abbreviated as in Figure 4, with RZ (Rhizophascolonus) and WA (Warendja) added.)

M1, characterizes all wombats except Phascolonus, in which the P3 is nearly as long as the M1, and possibly the Miocene wombat Rhizophascolonus, which has rooted teeth. (5) An il that is deeper than it is broad is the primitive form in the vombatiforms. A flattened lower incisor that either is broader than it is deep or is equidimensional appears to be derived (contrary to the polarity assignment of Dawson, 1981, 1983). (6) The diastemal palate widens anteriorly in derived taxa, whereas the primitive anteriorly narrowing or parallel-sided condition is seen in Vombatus and other vombatiforms. (7) The incisive fo-

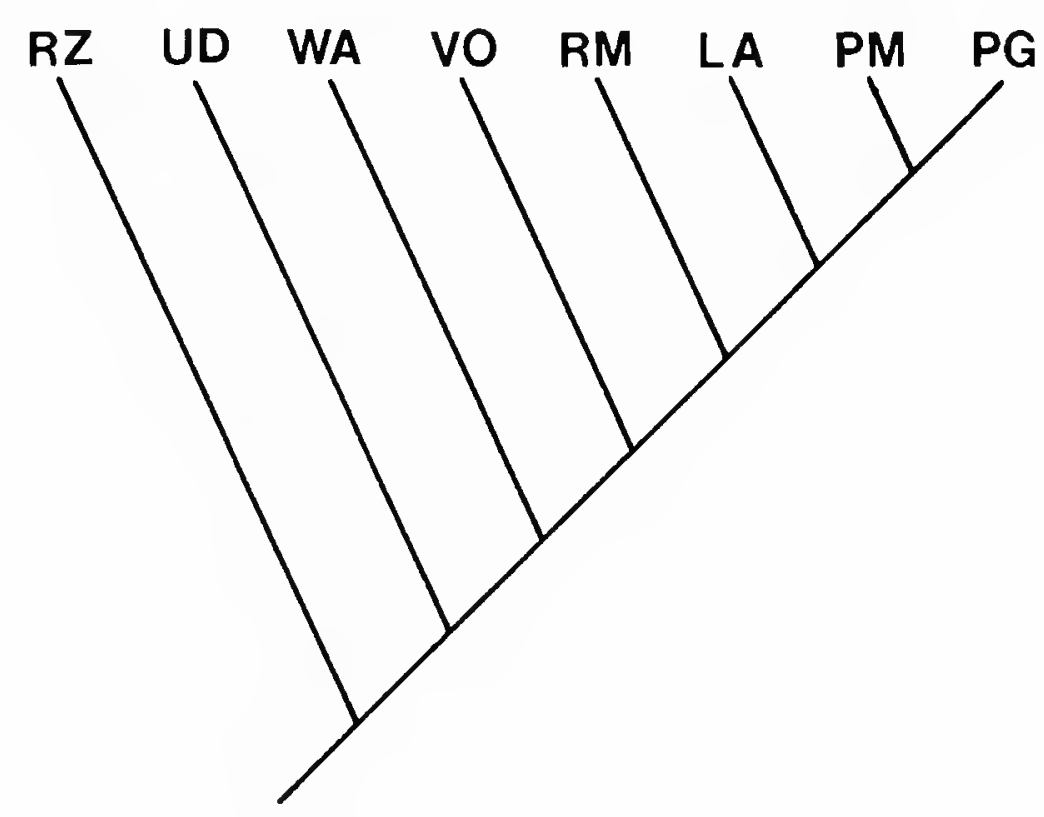

FIGURE 6.-Murray's (1998) phylogeny of the Vombatidae, based upon cranial and dental characters. (UD=undescribed Riversleigh (Miocene) form; other abbreviations of taxa as in Figures 4 and 5.) 
TABLE 1.-Distribution of character states among taxa of Vombatidae discussed in the text.

\begin{tabular}{|c|c|c|c|c|c|c|c|}
\hline Character & $\begin{array}{c}\text { Other vombati- } \\
\text { morphs }\end{array}$ & Warendja & Vombatus & Lasiorhinus & $\begin{array}{c}\text { Ramsayia } \\
\text { magna }\end{array}$ & $\begin{array}{c}\text { "Phascolomys" } \\
\text { medius }\end{array}$ & $\begin{array}{l}\text { Phascolonus } \\
\text { gigas }\end{array}$ \\
\hline 1. Il transversely implanted & 0 & 0 & 0 & 1 & 1 & 1 & 1 \\
\hline 2. Il broad & 0 & 0 & 0 & 0 & 0 & 0 & 1 \\
\hline 3. P3 lab/ling grooves shallow or lacking & 0 & 1 & 1 & 1 & 1 & 1 & 0 \\
\hline 4. P3 small & 0 & 1 & 1 & 1 & 1 & 1 & 0 \\
\hline 5. il broad & 0 & 0 & 1 & 0 & 0 & 0 & 0 \\
\hline 6. Palate wide anteriorly & 0 & 0 & 0 & 0 & 1 & I & 1 \\
\hline 7. Incisive foramen in deep fossa & 0 & 0 & 0 & 1 & 0 & 1 & 1 \\
\hline 8. Incisive foramen posterior & 0 & 0 & 0 & 1 & 0 & 1 & 1 \\
\hline 9. Palate emarginated & 0 & 0 & 0 & 1 & 0 & 1 & 1 \\
\hline 10. Upper tooth rows converge & 0 & 0 & 1 & 0 & 0 & 0 & 1 \\
\hline 11. Fossa superficial. masseter dorsal & 0 & 0 & 0 & $?$ & 1 & 1 & 1 \\
\hline 12. Median premaxillary process & 0 & 0 & 0 & 1 & 1 & 0 & 1 \\
\hline 13. Masseteric foramen large & 0 & 1 & 1 & 0 & 0 & 0 & 0 \\
\hline 14. Squamosal epitympanic wings inflated & 0 & 1 & 1 & $?$ & 1 & $?$ & 0 \\
\hline 15. Hypotympanic sinus large & 0 & $?$ & 0 & $?$ & 1 & $?$ & I \\
\hline 16. Epitympanic fossa small & 0 & 1 & 1 & $?$ & 0 & $?$ & 1 \\
\hline
\end{tabular}

ramina lie in a concavity in the diastemal palate in Lasiorhinus and the giant wombats. The primitive anterior palate of Vombatus is nearly flat. (8) In the giant wombats, the incisive foramina lie posteriorly, just anterior to $\mathrm{P} 3$, in a deep pocket at the rear of the diastema. This posterior position of the foramina correspondingly displaces the premaxillary-maxillary suture to a position just anterior to the cheek-tooth row. This is a highly derived condition that is not clearly foreshadowed in Lasiorhinus. It is present in both Phascolonus and Ramsayia, even though the latter lacks the diastemal flare associated with the wide incisors that is so prominent in the former. (9) In the giant wombats, the strong emargination of the palate between the cheek teeth forms a trough that passes dorsally into the deep diastemal trench. (10) The upper cheek teeth are strongly convergent anteriorly, particularly across the anterior part of M1. Although the cheek-tooth rows of Lasiorhinus do converge, the condition in Vombatus and Phascolonus is extreme in its narrowing palate. (11) The fossa for the superficial masseter anterior to the orbit rises to the dorsal surface of the skull in Lasiorhinus, Phascolonus, and "Phascolomys" medius. This condition gives rise to a strong notch in front of the zygomatic root in these taxa. The masseter origin lies mostly below the orbit in Vombatus and other vombatiforms. (12) A median premaxillary process is well developed in Phascolonus and Ramsayia and is present as a low spine at the midline dorsal surface of the premaxillaries in Lasiorhinus. This feature is shared only with Diprotodon among other vombatiforms. (13) In Vombatus and Warendja the masseteric foramen is enlarged. This foramen pierces the masseteric fossa and opens in the vicinity of the mandibular foramen on the medial side of the ascending ramus of the mandible. It is small or lacking in other wombats and in other vombatiforms. (14) The squamosal epitympanic processes, or "wings," are inflated and terminate in pointed processes in the living wombats. This derived condition con- trasts with the lack of inflation in Phascolonus and other vombatiforms. (15) The hypotympanic sinus extends anterolaterally into the zygomatic root of the squamosal in Lasiorhinus and Phascolonus. This is a derived condition relative to Vombatus and other vombatiforms. (16) The epitympanic fossa lies above the ectotympanic and lateral to the hypotympanic sinus and is extensive in Lasiorhinus. This condition is widely present in other vombatiforms and therefore seems primitive for that group as a whole. In Vombatus and Phascolonus this structure is shallow, and the division between the posterior segment, into which the external auditory meatus opens, and the larger anterior segment is marked by a low ridge.

These characters are distributed as shown in Table 1. Analysis using the maximum parsimony program of Hennig86 (Farris, 1988) and the distribution of synapomorphies found by ClaDos (Nixon, 1992) resulted in three trees of equivalent length (23 steps) and statistics (Consistency Index $=69$ and Rescaled Consistency Index=66) (Figure 7). All three trees confirm essentially the same phylogenetic hypotheses and differ only in the resolution of relationships among the giant wombats. They also agree with Dawson (1983, Hypothesis B), Archer (1984, fig. 64), and Murray (1998) in grouping the giant wombats with Lasiorhinus. Support for this relationship on all trees lies with three synapomorphies: the transversely implanted I1 (1); the dorsal extension of the origin of the superficial masseter (11); and a large hypotympanic sinus (15). The program assumed that the last two features would be found in Ramsayia. The more-resolved cladograms assume either that the wide anterior palate (6) was acquired twice in this clade or that it was lost in Ramsayia. In fact, however, the structure of the anterior palate in Lasiorhinus, although wider than in Vombatus, may not be homologous with the condition in the giant forms, in which this state is reinforced by the depth and position of the incisive foramina. A number of reversals to the 

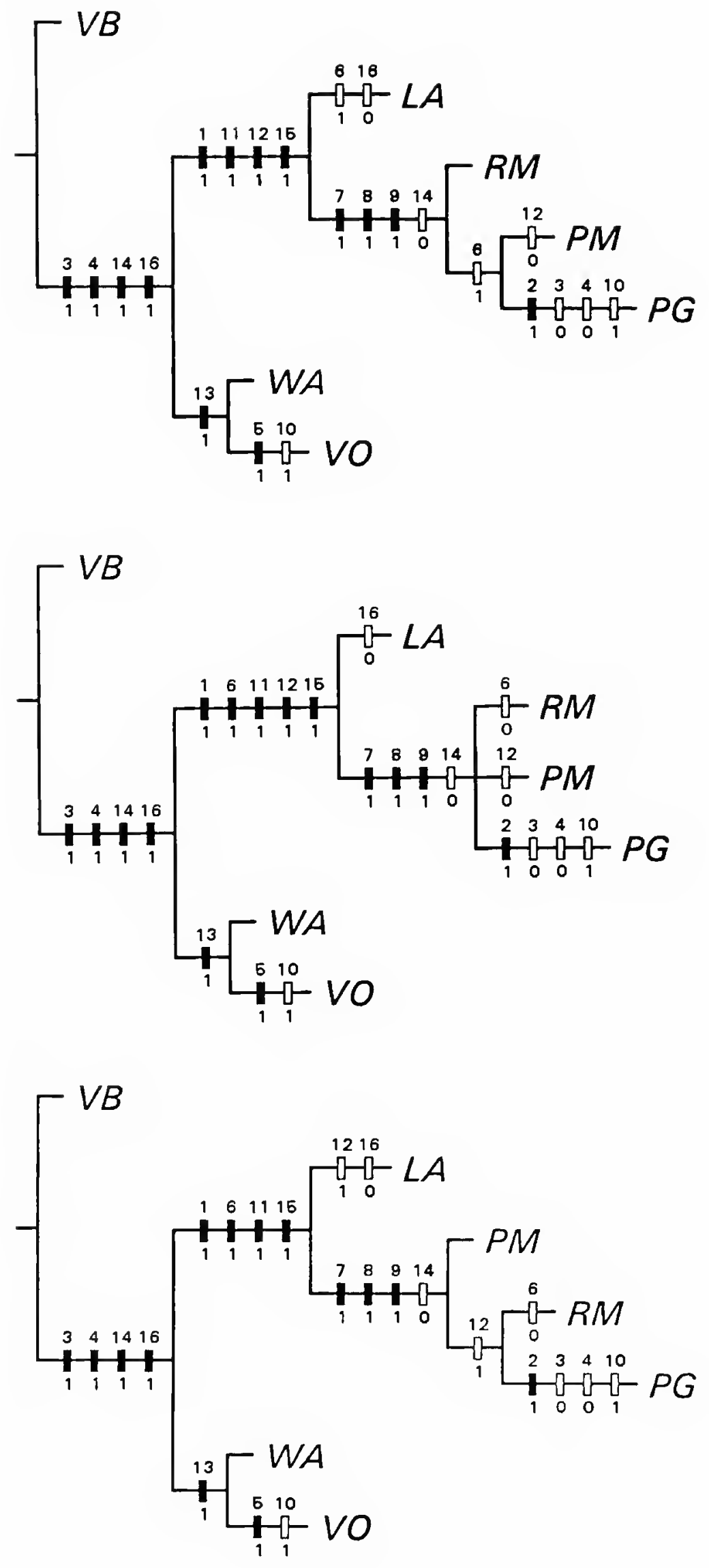

FIGURE 7 (Ieft).-Alternative cladograms of relationships of vombatid taxa discussed in the text. These trees have identical statistics (length 23, Consistency Index $=69$, Rescaled Consistency Index $=66$ ) but differ in the resolution of relationships of the giant wombats. Cladograms were generated by the parsimony algorithm of Hennig86 (Farris, 1988), and the distribution of character states used by ClaDos (Nixon, 1992). (VB=other vombatiforms; other abbreviations of taxa as in Figures 4 and 5.)

primitive state (five, nearly one-third of the data, in the best-resolved arrangements) must be assumed in grouping Lasiorhinus with the giant wombats, an arrangement that reinforces the phyletic isolation of this clade from Vombatus. Phascolonus, with its large, bilobed $\mathrm{P} 3$, remains primitive in some respects. Its converging upper tooth rows may be, like its uniquely wide Il, an autapomorphy. Additional unique features are the platelike ectotympanic (primitive) and enclosed stylomastoid foramen, both of which serve to further isolate this taxon phylogenetically.

\section{Conclusions}

Acquisition of two crania of the giant wombat Phascolonus gigas from the Pleistocene of Lake Callabonna by a joint Smithsonian Institution-American Museum of Natural HistorySouth Australian Museum expedition in 1970 allowed description of the basicranium and a reevaluation of previous attempts to place this taxon in wombat phylogeny. The basicranium reveals a unique combination of features; some of these are synapomorphies with other wombats, whereas others appear to be autapomorphies of Phascolonus. The new data, and those advanced by previous studies, can be used in a cladistic analysis of phylogeny to reinforce previous conclusions that Phascolonus and the other giant wombats, Ramsayia and "Phascolomys" medius, form a clade with the living hairy-nosed wombat, Lasiorhinus. They are united with their sister taxathe living naked-nosed wombat, Vombatus, and the fossil Warendja-by a single synapomorphy of a mandible bearing a large masseteric foramen. The well-established monophyletic wombat clade is based upon four characters noted herein and is reinforced by many others in the skeleton, soft anatomy, and biochemistry noted by previous authors (summarized by Murray, 1998). 


\section{Literature Cited}

Archer, M.

1984. The Australian Marsupial Radiation. In M. Archer and G. Clayton, editors, Vertebrate Zoology and Evolution in Australasia: Animals in Space and Time, pages 633-808. Carlisle, Western Australia: Hesperian Press.

Dawson, $\mathrm{L}$.

1981. The Status of the Taxa of Extinct Giant Wombats (Vombatidae: Marsupialia) and a Consideration of Vombatid Phylogeny. Australian Mammalogy, 4:65-79.

1983. On the Uncertain Generic Status and Phylogenetic Relationships of the Large Extinct Vombatid Species Phascolomys medius Owen, 1872 (Marsupialia: Vombatidae). Australian Mammalogy, 6:5-13.

Farris, J.S.

1988. Hennig86, Version I.5. New York: Port Jefferson Station.

Felsinstein, J.

1987. PHYLIP Manual, Version 2.8. Berkeley: University Herbarium, University of California.

Marcus, L.F.

1976. The Bingara Fauna: A Pleistocene Vertebrate Fauna from Murchison County, New South Wales, Australia. University of California Publications in Geological Sciences, 114: 145 pages.

Marshall, L.G., J.D. Case, and M.D. Woodburne

1990. Phylogenetic Relationships of the Families of Marsupials. In H.H. Genoways, editor, Current Mammalogy, 2:433-505. New York: Plenum Press.

Munson, C.J.

1992. Postcranial Description of Ilaria and Ngapakaldia (Vombatiformes, Marsupialia) and the Phylogeny of the Vombatiforms Based on
Postcranial Morphology. University of California Publications in Zoology, 125:1-99.

Murray, P.F.

1998. Palaeontology and Palaeobiology of Wombats. In R.T. Wells and P.A. Pridmore, editors, Wombats, pages 1-33. Chipping Norton, New South Wales: Surrey Beatty and Sons in association with the Royal Zoological Society of South Australia.

Nixon, K.C.

1992. ClaDos, Version I.2. Ithaca, New York: Comell University.

Owcn, R.

1858. Odontology. In The Encyclopedia Britannica, or Dictionary of Arts, Sciences and General Literature. Eighth edition, 16:447, 450, text figure 80 .

1872. On the Fossil Mammals of Australia, Part VII; Genus Phascolomys: Species Exceeding the Existing Ones in Size. Philosophical Transactions of the Royal Society of London, 162:241-258, plates 32-40.

Ramsay, E.P.

1880. [Untitled.] The Sydney Morning Herald, 13286, 30 October 1880 , page 5 , column 4 .

Stirling, E.C.

1913. On the ldentity of Phascolomys (Phascolonus) gigas, Owen, and Sceparnodon ramsayi, Owen, with a Description of Some Parts of the Skeleton. Memoirs of the Royal Society of South Australia, 1:127-178, plates 40-58.

Wells, R.T., and R.H. Tedford

1995. Sthenurus (Macropodidae: Marsupialia) from the Pleistocene of Lake Callabonna, South Australia. Bulletin of the American Museum of Natural History, 225: 112 pages. 



\title{
Vassallia maxima Castellanos, 1946 (Mammalia: Xenarthra: Pampatheriidae), from Puerta del Corral Quemado (Late Miocene to Early Pliocene), Catamarca Province, Argentina
}

\author{
Gerardo De Iuliis and A. Gordon Edmund
}

\begin{abstract}
A specimen in the Field Museum of Natural History is the first record of a pre-Pleistocene South American pampathere that preserves the skull, dentary, and numerous osteoderms of a single individual. We confidently assign the specimen, FMNH P14424, to Vassallia maxima Castellanos after comparing it with the mandible and osteoderms of the type of this species and with other material in South American museums. FMNH Pl4424 is from fossiliferous deposits near Puerta del Corral Quemado, Catamarca Province, Argentina. Field notes are ambiguous with regard to its precise stratigraphic level, and therefore age, but the section from which it was recovered includes both the Huayquerian and the Montehermosan.

The range of osteodermal variation of $V$. maxima FMNH P14424 encompasses that of Plaina intermedia Ameghino and $P$. subintermedia Rovereto, which suggests that these genera and species may not justifiably be distinguished. If this is confirmed, then Vassallia is the valid genus and $V$. intermedia (Ameghino, 1888) is the valid specific name for the species; however, until the status of these taxa is unambiguously demonstrated, we maintain $V$. maxima.
\end{abstract}

\section{Introduction}

The pampatheres represent a distinct lineage of cingulates (Hulbert and Morgan, 1993) and are known with certainty from the late Miocene to late Pleistocene of South and North America (Scillato-Yané, 1980). Traditionally, they have been consid-

Gerardo De Iuliis, Department of Zoology, University of Toronto, 25 Harbord Street, Toronto, Ontario M5S 3G5, Canada, and Faculty of Community Services and Health Sciences, George Brown College of Applied Arts and Technology, 200 King Street East, Toronto, Ontario M5A 1J5, Canada. A. Gordon Edmund, Department of Geology, Earth Sciences Centre, University of Toronto, 22 Russell Street, Toronto, Ontario M5S 1A1, Canada. ered to be intermediate in general morphology between dasypodids and glyptodonts, although Simpson (1930) rejected this concept. Pampatheres bear pectoral and pelvic bucklers, formed from sutured osteoderms; the bucklers are separated by only three transverse movable or imbricating bands, whereas dasypodids usually possess more than three movable bands. Furthermore, each osteoderm bears only a single keratinized scute in pampatheres, whereas more than one scute usually contributes to the keratinized covering of an osteoderm in other cingulates. Edmund (1987) listed additional pampathere characters.

Pampatheres have long been regarded as distinct from both dasypodids and glyptodonts, although Ameghino (1889), followed by various authors (e.g., Castellanos, 1927), considered them probably ancestral to the glyptodonts but more closely related to the true armadillos. Patterson and Pascual (1972) and Engelmann (1985), however, believed that they were more closely related to glyptodonts, and the latter author formally placed pampatheres with glyptodonts and eutatine armadillos in a group termed the Glyptodonta.

For much of the last century, researchers (e.g., Paula Couto, 1954; Hoffstetter, 1958; Robertson, 1976; Scillato-Yané, 1980; Cartelle and Bohórquez, 1985; Patterson et al., 1989; Cartelle et al., 1991) have usually followed Lydekker (1894) in classifying the Pampatheriinae (=Chlamydotheriinae) within the Dasypodidae. Earlier workers, such as Moreno and Mercerat (1891) and Ameghino (1889), recognized pampatheres as the family Pampatheriidae (=Chlamydotheriidae or Chlamydotheridae). Bordas (1939), exceptionally, raised them to superfamilial rank as the Chlamydotherioidea. More recently, there has been a tendency among researchers (e.g., Edmund, 1985a, 1987; Downing and White, 1995; Edmund and Theodor, 1997) to consider them a separate family. We follow this, pending a comprehensive phylogenetic analysis of cingulates. 
The Pleistocene pampatheres are represented by eight species distributed in the genera Pampatherium and Holmesina (including the North American Blancan H. floridanus Robertson; see also Morgan and Hulbert, 1995). They are reasonably well represented by osteoderms and other skeletal elements, and their taxonomy, based largely upon osteoderms, is reviewed by Edmund (1996). Except for some of these Pleistocene species, particularly $H$. septentrionalis Simpson and $H$. floridanus, pampatheres are not well defined. Little is known or published of their osteological variation at the specific or generic levels, although much of the research has focused on osteoderms. For example, Edmund (1987) and Hulbert and Morgan (1993) documented changes in the size and morphology of osteoderms and various postcranial elements; and Edmund (1996) recognized Pleistocene species solely on the basis of osteodermal characters. Among the reasons that workers have relied on osteoderms is that these elements are frequently recovered. Unfortunately, however, they are rarely found in association with skull or postcranial remains (Edmund, 1996).

Other than $H$. floridanus from the late Blancan, pre-Pleistocene pampatheres are South American and are known mainly from Argentina and Colombia. Four genera (see Edmund and Theodor, 1997) are currently recognized: Kraglievichia, Plaina, Scirrotherium, and Vassallia (excluding the fragmentary remains from the Patagonian Eocene assigned to Machlydotherium; see Edmund, 1985a). Ameghino (1883) described $K$. paranense from isolated osteoderms. Castellanos (1927) amplified the description and included unassociated skull and postcranial material from the type area. Plaina and Vassallia are based upon sparse remains, mostly isolated osteoderms. Among the difficulties with relying on osteoderms from different localities is that intraspecific or age variation, or even differences between osteoderms of a single individual, may be accorded taxonomic importance. Ultimately one must learn for each taxon the range of osteodermal variation. That goal is complicated by the fact that the armor of pampatheres "consists of specialized osteoderms covering the head, body, tail, and limbs" that vary dramatically in size, shape, and ornamentation, depending upon the type of osteoderm and its precise location (Edmund, 1985a:6). Identification or erection of new taxa based upon small samples of osteoderms is unreliable.

The specimen described herein, FMNH P14424, is assigned to V. maxima Castellanos on the basis of its dentary and osteoderms. It is the first record of a pre-Pleistocene South American pampathere that preserves nearly completely the skull and dentary of a single individual, along with a large number and variety of almost certainly associated osteoderms of the same individual. Thus, it expands the knowledge of variation in pampatheres and permits a considerably more complete description and understanding of pre-Pleistocene genera. FMNH P14424 was assigned to Plaina sp. by Marshall and Patterson (1981) and Marshall et al. (1983). Patterson et al. (1989) referred it tentatively to $P$. subintermedia Rovereto, and Edmund (1985a) referred it to Plaina sp. but incorrectly cited FMNH P14414 as its catalog number.

ABBREVIATIONS.-The following museum abbreviations are used:
AMNH
FMNH
IFG
INSP
American Museum of Natural History, New York
Field Museum of Natural History, Chicago
Instituto de Fisiografia y Geología, Rosario, Santa Fé, Argentina
Instituto Nacional Superior del Profesorado, Paraná, Entre Ríos, Argentina
MACN Museo Argentino de Ciéncias Naturales "Bemardino Rivadavia," Buenos Aires
MLP Museo de La Plata, La Plata, Argentina
MMP Museo Municipal de Ciencias Naturales "Lorenzo Scaglia," Mar del Plata, Argentina
MNA Museum of Northern Arizona, Flagstaff
ROM Royal Ontario Museum, Toronto
UF Florida Museum of Natural History, Gainesville, Florida

In the description of material, the following abbreviations are used:

$\begin{array}{ll}\text { D } & \text { digit } \\ \text { L } & \text { left } \\ \text { M or } m & \text { molariform upper or lower, respectively (for convenience molar- } \\ & \text { iform is used for all teeth even though not all are such) } \\ \mathrm{Mt} & \text { metatarsal } \\ \mathrm{Ph} & \text { phalanx } \\ \mathrm{R} & \text { right. }\end{array}$

ACKNOWLEDGMENTS.-We thank the numerous curators of the various institutions for allowing us to examine specimens in their care. We appreciate the efforts of D.D. Gillette (MNA), S.F. Vizcaíno (MLP), and S.D. Webb (UF) in reviewing the manuscript; their comments and suggestions significantly improved the quality of this paper. We benefited greatly from discussions with G.J. Scillato-Yané (MLP), who freely shared his insights on and knowledge of pampatheres. We are grateful to W.F. Simpson (FMNH) for his research on the stratigraphic position of the specimen; to E. Knapp and L. Yuik (Department of Zoology, University of Toronto), for their help with the photography; to M.J. Lo Presti, V.A. Stock, D. Stonehouse, and N. Taccogna for accommodating the schedule of GDI; and to P. Gisondi for various logistic support during many years. This paper was funded in part by National Science and Engineering Research Council Grants A1760 to C.S. Churcher and A1810 to A.G. Edmund.

\section{TAXONOMIC HISTORY}

Castellanos $(1927,1937)$ created the generic names Kraglievichia, Vassallia, and Plaina for pampatheres of the late Miocene and early Pliocene of Argentina using materials previously assigned by others to Chlamydotherium (=Pampatherium; see Edmund, 1985b). Kraglievichia is based upon the posterior part of a right dentary, which Ameghino (1883) used to erect $C$. paranense, from the left bank of the Río Paraná, Entre Ríos Province, Argentina. The deposits in the Argentinian Mesopotamia were commonly considered as "Mesopotamian" 
but are now assigned to the Huayquerian or Montehermosan on the basis of geographic position (Marshall et al., 1983). Castella-nos (1927:2; 1937:15) considered Ameghino's specimen a "metatypo" and stated that it was housed in MLP. Scillato-Yané (1980, 1982) and Mones (1986:231), however, listed the type of C. paranense as "INSP ?"; the latter author indicated that the type is lost and that MLP has casts of the type (MLP M-112, M-227, M-228).

Using comparisons with the posterior end of a right dentary (i.e., Ameghino's metatypo, according to Castellanos, 1927, 1937), Castellanos $(1927,1937)$ referred additional remains to $K$. paranense, including a nearly complete, but edentulous, skull (MACN 2617), a left palatal fragment (MACN 8943), a large part of a left dentary (MACN 8968), and other remains. These were recovered from the "Mesopotamiense de la Formación Entrerriana de la margen izquierda del río Paraná" (Castellanos, 1927:2). Castellanos (1937) provided more precise locality information for MACN 2617, which indicates, according to criteria suggested by Marshall et al. (1983), that the skull is of Huayquerian age. Kraglievich (1934) assigned an osteoderm from the Chapadmalal region to Kraglievichia. Pascual et al. (1966) reported $K$. paranense from the Monte Hermoso Formation and the Chapadmalal Formation in Buenos Aires Province. Castellanos (1927) transferred C. intermedium Ameghino, 1888, and C. subintermedium Rovereto, 1914, to Kraglievichia (vide infra).

Vassallia Castellanos, 1927, is based upon the species $C$. minutum from the "Araucanian" of Catamarca. Moreno and Mercerat (1891) had described this species from a right dentary and three questionably associated osteoderms, which were illustrated by Lydekker (1894, pl. 33: figs. 1, 1a, and figs. 2, 3a, respectively). Scillato-Yané (1980, 1982) and Mones (1986) listed the dentary, MLP 29-IV-15-4, as the type of the species. Marshall and Patterson (1981) suggested that the remains were recovered from the Andalhualá Formation, to which Marshall et al. (1983) assigned a Huayquerian age.

Castellanos (1946:6) described the larger V. maxima from remains recovered from various localities "del Araucanense medio y superior" in the Valle de Yocavil (=Santa María; Marshall and Patterson, 1981), Tucumán and Catamarca Provinces, Argentina. The type, IFG 500, preserves the anterior part of a right dentary and a few imbricating osteoderms "de la margen derecha del arroyo de la Totora, al N.W. de 'Los Nacimientos,' Valle de Yocavil, provincia de Tucumán" (Castellanos, 1946:6). These remains are reasonably considered Huayquerian by Marshall et al. (1983). It is worth noting that some of the referred osteoderms are from Loma Rica, near Andalhualá, probably very close to the deposits yielding $V$. minuta.

Castellanos (1937) erected Plaina to include P. intermedia and $P$. subintermedia. Ameghino (1888) based the former species upon isolated osteoderms from Monte Hermoso. Mones (1986) listed the type as MACN?, suggesting that it is lost, although the title of the article in which Ameghino (1887) first mentioned the osteoderms suggests that the type was in MLP.
Edmund, in 1986, located a single buckler osteoderm, MACN A7799, labeled by F. Ameghino, which is possibly the type. Ameghino (1895) incorrectly identified " $C$." minutum as a synonym of this species (Castellanos, 1937). Anaya and MacFadden (1995) assigned pampathere remains from the Pliocene Inchasi fauna of Bolivia to $P$. intermedia.

Rovereto (1914) erected the species $P$. subintermedia on the basis of various osteoderms, MACN 8473 (Mones, 1986), and described and figured them as from the Huayquerías region of Mendoza Province, Argentina. Pascual and Odreman Rivas (1973) and Marshall et al. (1983) noted that these remains (i.e., those listed by Rovereto, 1914:214-224) are actually from the Tunuyán Formation and are of Montehermosan age. Plaina was listed as a Montehermosan mammal by Marshall et al. (1983). Castellanos (1958) typified $P$. brocherense Castellanos on various osteoderms (IFG 769) from Los Reartes Valley, Córdoba Province, Argentina. The fauna from Los Reartes and Nono Valleys are now believed, however, to "represent a mixture of Montehermosan and Ensenadan taxa" (Marshall et al., 1984:26). Robertson (1976) proposed that Plaina be synonymized with Kraglievichia.

FMNH P14424 is assigned to Vassallia maxima on the basis of its similarity in size and morphology to a partial dentary and osteoderms of the type of this species, IFG 500. Vassallia maxima is approximately twice the linear size of $V$. minuta, although the osteoderms of these species are similarly ornamented. The dentary of $V$. maxima is considerably more robust, with a relatively larger angular process, than that of $V$. minuta.

\section{GEOLOGY}

FMNH P14424 was recovered from the fossiliferous deposits near the Puerta del Corral Quemado, Catamarca Province during the 1926 FMNH field expedition to South America under the supervision of E.S. Riggs (Marshall and Patterson, 1981). These authors listed FMNH P14424 as being from units 15-23 of the section, but W.F. Simpson (pers. comm., 1995) of the FMNH stated that the original field notes suggest less precision and indicate only that these remains may have been recovered from the section between units 16 and 32. This is essentially the entire fossiliferous section of the Corral Quemado section and includes the upper part of Stahlecker's Araucanense and his Corral Quemado Formation (Riggs and Patterson, 1939), which are currently considered Huayquerian (late Miocene) and Montehermosan (early Pliocene), respectively.

Marshall and Patterson (1981:71) listed FMNH P14424 as including "skull, paired mandibles, ... leg scutes, and foot bones" among its skeletal elements. These elements and a few additional osteoderms were originally, and for a considerable time, labeled with this catalog number; their field number is 334. W.F. Simpson's investigation of original FMNH documents, however, strongly suggests that numerous additional osteoderms and the axis, which had remained uncataloged, were part of field number 334, and thus that these additional ele- 


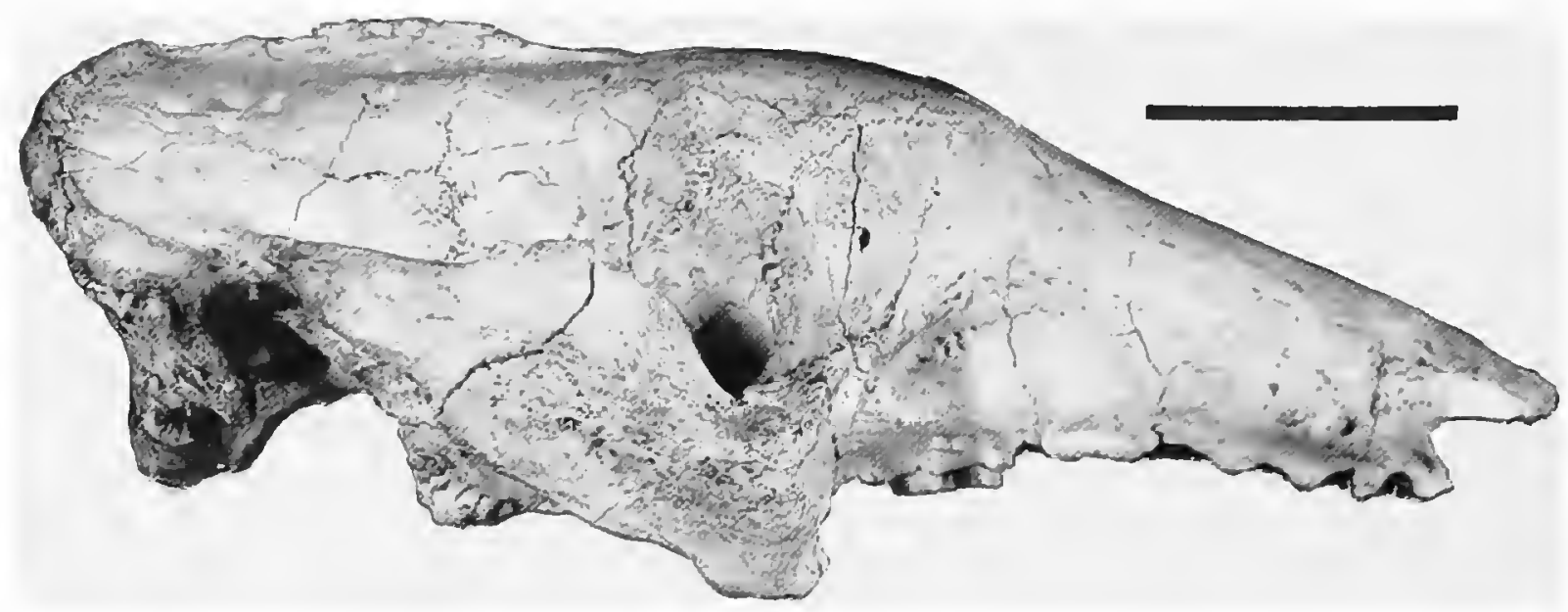

FIGURE 1.-Lateral view of the skull of Vassallia maxima FMNH P14424. (Scale bar=50 mm.)

ments, which are identical in preservation, were also found in association and probably belong to the same individual. These element were recently labeled as FMNH P14424.

FMNH P15302 includes three osteoderms of similar ornamentation to that of FMNH P14424 but different preservation. They were recovered from the same locality, but the horizon was unrecorded (Marshall and Patterson, 1981), and they are not associated with FMNH P14424.

\section{Systematics}

\section{Infraorder Cingulata Illiger, 1811}

\section{Family PampatheriIDae Paula Couto, 1954}

\section{Genus Vassallia Castellanos, 1946}

\section{Vassallia maxima Castellanos, 1946}

D1AGNOSIS.-Medium-sized pampathere, with marked palatal flexion, prominently inflated frontals, strongly tapered rostrum, and robust zygomatic arches. Sagittal crest weak, but more prominent than in other pampatheres. Temporal fossa large. Lacrimal large, with elongated dorsal portion. Cranial length relative to facial length approximately intermediate between condition in Kraglievichia, in which cranium is relatively longest, and Holmesina and Pampatherium. Hard palate

TABLE 1.-Skull measurements (in mm) for FMNH P14424.

\begin{tabular}{l|c}
\hline \multicolumn{1}{c|}{ Skull feature } & Measurement \\
\hline Greatest width across zygomatic processes of squamosal & $69 \times 2=138$ \\
Greatest width across anterior part of zygomatics & $64 \times 2=128$ \\
Greatest width across pterygoid processes & 51 \\
Occipital width & 97 \\
Bicondylar width & 75 \\
Postorbital constriction & 52 \\
Width across postorbital processes & 79 \\
Maximum width across palate (between M6s) & 28 \\
Tooth-row length & 140 \\
Length of temporal fenestra and orbit & 49 \\
Occipital height & 59 \\
Maximum height of zygomatic & 42 \\
\hline
\end{tabular}

extending farther posteriorly than in Kraglievichia, but not as far as in Holmesina and Pampatherium. Dentary robust, with relatively short but deep horizontal ramus and prominent angular process, in comparison with those of Holmesina and Pampatherium. Axis possibly, but not certainly, fused to other cervical vertebrae (if so, this complex is morphologically distinct from cervical tube of other pampatheres and dasypodids); element compressed anteroposteriorly and very large in relation to size of skull; axis apparently bearing transverse processes.

DESCRIPTION.-Skull: The skull of FMNH P14424 is nearly complete and only slightly distorted (Figures 1,2 ). Measurements of the skull and upper dentition are presented in Tables 1 and 2, respectively. The skull lacks the posterior part of the left zygomatic arch, the posterior one-third of the margin of the sagittal crest, and most of the molariform teeth. Its longitudinal axis veers anteriorly to the right because the left temporal region is damaged, but the right side is virtually intact. The dorsal midline is clearly indicated by the nasal suture, which is

TABLE 2.-Dental measurements for FMNH P14424. Transverse widths for M4-M9 and m5-m9 include widths of mesial and distal lobes on the left and right sides, respectively, of the slash. $\left({ }^{*}=\right.$ alveolar. $)$

\begin{tabular}{l|ccc}
\hline \multicolumn{1}{c|}{ Tooth } & Medio distal length & Transverse width & $\begin{array}{c}\text { Minimum width } \\
\text { between alveoli }\end{array}$ \\
\hline M1 $^{*}$ & 6.8 & 4.5 & 5.0 \\
M2* $^{*}$ & 8.0 & 5.5 & 8.5 \\
M3* $^{*}$ & 8.5 & 6.1 & 13.0 \\
M4* $^{*}$ & 14.5 & $5.5 / 6.6$ & 16.3 \\
M5* & 18.5 & $7.9 / 8.0$ & 19.6 \\
M6 & 19.0 & $8.4 / 8.6$ & 22.0 \\
M7* & 17.5 & $8.0 / 8.5$ & 26.3 \\
M8 & 16.7 & $7.7 / 7.5$ & 25.7 \\
M9 & 13.7 & $6.0 / 7.0$ & 25.4 \\
m2 & 7.2 & 5.1 & - \\
m3* & 7.4 & 5.1 & - \\
m4* & 11.5 & 5.5 & - \\
m5* & 18.5 & $5.7 / 7.0$ & - \\
m6 & 19.5 & $8.3 / 7.0$ & - \\
m7 & 17.0 & $7.8 / 7.0$ & - \\
m8 & 15.7 & $6.2 / 6.2$ & - \\
$\mathrm{m} 9$ & 12.8 & $5.3 / 5.1$ & - \\
\hline
\end{tabular}




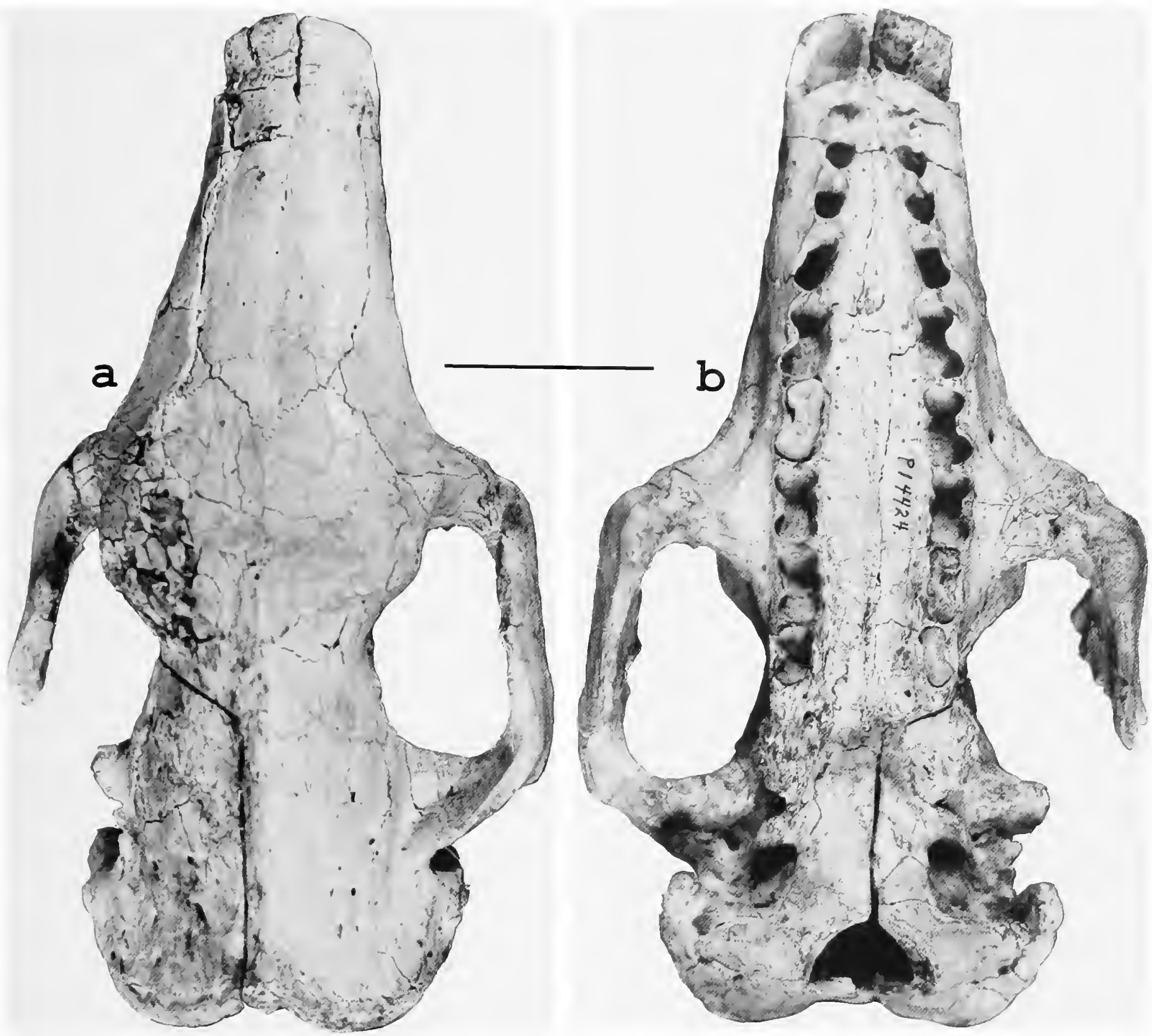

FiGURE 2.-Skull of Vassallia maxima FMNH P14424: $a$, dorsal view; $b$, ventral view. (Scale bar $=50 \mathrm{~mm}$.)

open at its anterior one-third, and the prominent sagittal crest. Dorsoventral distortion is not apparent.

In lateral view (Figure 1) the outline resembles those of Holmesina (ROM 3881) and Pampatherium (Bordas, 1939, figs. 1, 2, pls. 1, 2; Winge, 1915, pls. 9, 10), compared with the lower, elongated, and more strongly tapered skull of Kraglievichia (MACN 2617; Castellanos, 1937, fig. 8). The palate of FMNH P14424 is longitudinally concave anterior to the alveolar septum between M7 and M8, owing to its anteroventral inclination anterior to the distal margin of the M5 alveolus. Pala- tal flexion is less in Holmesina and Pampatherium and is slight in Kraglievichia.

The nasals are broad and long but widen slightly posteriorly (Figure $2 a$ ). Their anterior tips appear to turn slightly ventrally, but this may be the result of the considerable fracturing and reconstruction in this area of FMNH P14424. The naso-frontal suture is nearly rectilinear and extends posteromedially at an angle of approximately $42^{\circ}$ to the midline. In Holmesina the lateral part of the suture passes medially and then curves abruptly posteromedially to the midline, so that the posterome- 
dial tips of the nasals taper markedly posteriorly. Furthermore, the nasals in Holmesina are narrower posteriorly and widen anteriorly. The lateral margin of the external naris is formed by the premaxilla, which is deeply embayed between its dorsal and ventral rami. The lateral surface of the rostrum is raised and rugose from the middle of M2 to the distal end of M4, presumably for the attachment of the buccinator. Posterior to this, the surface of the maxilla is depressed between the middle of M5 and the infraorbital canal, which lies over the distal onehalf of M6.

The rostrum tapers more strongly in FMNH P14424 than in known crania of Holmesina, Pampatherium, and Kraglievichia. This appearance may be partly caused by the strongly inflated frontals, although in anterior view the narial opening is considerably flattened relative to that of Holmesina. Anterior to the temporal lines, the frontals and adjacent parts of the nasals, lacrimals, and maxillae form a low dome over the orbital region, approximately between the distal end of M5 and the middle of M8 (Figure 1). The frontals in Kraglievichia and Pampatherium are considerably less domed; Holmesina is approximately intermediate between these and FMNH P14424. Anterior to and between the temporal lines, the frontals of FMNH P14424 are nearly flat, whereas they are depressed in Holmesina.

The frontals continue posteriorly past the postorbital constriction and meet the parietals along a nearly transverse suture approximately at the level of the anterior margin of the posterior zygomatic root (Figure $2 a$ ). The frontal forms the anterior part of the temporal fossa and the posterior part of the orbit.

The parietals bear nearly all of the sagittal crest, which is apparently more prominent and raised in FMNH P14424 than in other pampatheres. They meet the occipitals dorsally and laterally at the posterior margin of the temporal fossae, and they are excluded from the nuchal crest. The parietals and squamosals meet in a gently sinuous suture and form the posterior part of the temporal fossa. The surface of the fossa, including all of the parietal and adjacent part of the squamosal, is penetrated by numerous, large vascular foramina.

The nuchal crests, formed mostly from the occipitals, are prominent and more robust than in Holmesina. In Holmesina and Pampatherium, however, the crests extend farther posteriorly, so that the dorsolateral surfaces of the occiput are concave, whereas in FMNH P14424 they are nearly flat. In lateral view the crests slope more markedly posterodorsally in Holmesina and Pampatherium than in FMNH P14424 and Kraglievichia. The crest becomes less robust ventrally as it extends into the mastoid process.

The squamosal and occipital meet for about $10 \mathrm{~mm}$ on the posteroventral surface of the fossa. Ventral to this, a small, rectangular expansion of the squamosal onto the occiput forms a small part of the nuchal crest (Figure 1). The ventral part of this expansion forms the dorsal margin of the mastoid foramen. A similar, though larger and ventrolaterally more elongated, expansion occurs in Dasypus (e.g., ROM R676, R948, R2019).
In dorsal view the temporal fossa is relatively larger in FMNH P14424, particularly anteromedially, than in other known pampatheres. The size of the fossa is reflected in the form of the temporal lines and the width across the frontal region. In FMNH P14424 the temporal line extends nearly medially from the postorbital process and then curves abruptly posteromedially into the sagittal crest (Figure 1). In Holmesina it curves posteromedially in a gradual curve. The frontal region is wider in Holmesina, and it is reflected in dorsal view in the form of the margin of the anterolateral skull wall, which is convex, or bulging, and elongated between the postorbital process and the postorbital constriction. The condition in Pampatherium resembles that of Holmesina. In FMNH P14424 and Kraglievichia this wall is concave and shorter.

The postorbital constrictions in FMNH P14424, Holmesina, Kraglievichia, and Pampatherium are expressed about equally, but the positions of the constrictions differ. In dorsal view the braincase of FMNH P14424 is longer relative to the facial region. The length of the cranium is nearly $92 \mathrm{~mm}$, measured parasagittally from the postorbital constriction to the nuchal crest. An equivalent distance measured anteriorly from the postorbital constriction almost reaches the mesial part of M5, which is well anterior to the anterior zygomatic root. A similar condition occurs in Kraglievichia, although the equivalent length may reach even farther anteriorly. In Holmesina the equivalent length reaches only to near the alveolar septum between M6 and M7, as is also the condition in Pampatherium.

The zygomatic arch is more robust in FMNH P14424 than in Holmesina and Pampatherium (the arch is not preserved in specimens of Kraglievichia), so that the ventral margin of the orbit, formed by the descending process of the maxilla, the maxillary process of the zygomatic, and the lacrimal is shallower.

The ventral margin of the arch is sculptured and anterolaterally wider in FMNH P14424, whereas in Holmesina it is relatively smooth and thin, and it tapers ventrally. The anteroventral surface of the arch of FMNH P14424, as in Holmesina and Pampatherium, bears a prominent, expanded, and rugose tuberosity, probably for the origin of the superficial masseter muscle (Figures 1, 2b). In FMNH P14424 the tuberosity is more robust and crescentic in ventral view, curving anteromedially. In Holmesina and Pampatherium the tuberosity is oriented nearly anteroposteriorly. In Holmesina the zygomatic extends posterior to the tuberosity as a thinner plate. The arch of FMNH P14424 is also more robust posteriorly. For example, the anteroposterior length of the posterior root is almost equal in FMNH P14424 and H. occidentalis Hoffstetter (ROM 3881), although the latter is considerably larger. The more robust characteristics of the arch, larger temporal fossae, and more prominent sagittal crest of FMNH P14424 suggest a larger, more powerful masseteric musculature than in other pampatheres. The relationship between form and function of the masticatory system in pampatheres was discussed by Vizcaino et al. (1998) and De Iuliis et al. (2000). 
An additional difference is that the squamoso-zygomatic suture occurs more anteriorly in Holmesina and in Pampatherium, so that the squamosal and zygomatic contribute almost equally to the arch in lateral view. In FMNH P14424 the squamosal makes a smaller contribution to the arch. It is worth noting that the posterodorsal tip of the zygomatic, at the squamoso-zygomatic suture, projects dorsally beyond the zygomatic process of the squamosal, as occurs also in other pampatheres for which this character is known. This is not apparent in Figure 1, because the tip of the zygomatic is broken, but it is preserved on the left side of the skull.

The lacrimal is large and contributes ventrally to the anterior root of the zygomatic process (Figures 1,2a). Its tapered dorsal margin extends farther dorsally and is longer dorsally in FMNH P14424 than in Holmesina and Kraglievichia. The lacrimal foramen is quite small in FMNH P14424, as is that of Kraglievichia. Dorsal to the foramen, the lacrimal bears a raised, rugose, and nearly circular protuberance in FMNH P14424. The homologous surface in Holmesina is somewhat rugose, but a protuberance is not developed. The ventral margin of the lacrimal extends posteroventrally across the lateral surface of the anterior zygomatic root, as occurs in the dasypodine Dasypus (ROM R2019).

The premaxillo-maxillary suture is not visible, although various cracks are present anteroventrally on the palate (Figure $2 b$ ). Presumably it ran between the alveoli of M1 and M2 and perhaps contributed to the mesial part of the M2 alveolus. Edmund (1985b) stated that this was the general condition in pampatheres, and he rejected the supposed presence (as by Winge, 1915; Castellanos, 1927) of M1 and M2 in the premaxilla of Pampatherium. The maxillae form most of the hard palate (Figure $2 b$ ). Right and left Ml alveoli are very close together, so that their lingual walls are separated by about $2 \mathrm{~mm}$ and largely cover the medial processes of the premaxillae. In Kraglievichia, Holmesina, and Pampatherium the M1s are farther apart. The tooth rows diverge posteriorly to the distal walls of the alveoli of the M6s, which are separated by approximately $28 \mathrm{~mm}$; between the M7s and M9s they are then nearly parallel or converge very slightly posteriorly.

The maxilla, zygomatic, and lacrimal meet lateral to the infraorbital canal and the anterior surface of the zygomatic root. The maxillo-zygomatic suture extends nearly ventrally to the masseteric tuberosity (Figure 1). Medially these bones meet along an almost vertical suture at about the level of the deepest part of the orbit, but ventrally this turns anteroventrally onto the tuberosity. The course of the suture on the tuberosity is unclear, but it probably resembles that of Dasypus, in which both bones contribute to the tuberosity.

The maxilla, lacrimal, and frontal meet at the large ethmoid foramen, about $17 \mathrm{~mm}$ posterior to the lacrimal foramen. The maxillo-frontal suture, well preserved in FMNH P14424, undulates gently posteriorly. The maxilla has a large lateral exposure. It extends posteriorly to the level of the sphenopalatine foramen, where it meets the small orbitosphenoid, and then turns abruptly ventrally into the margin of the foramen. This relationship is odd, yet the sutures are sufficiently distinct. Usually, as in Dasypus and Choloepus, the frontal contacts the anterior margin of the orbitosphenoid, which has a broader lateral exposure and contains various foramina, such as the optic canal and orbital fissure. The palatine meets the ventral margin of the orbitosphenoid and forms the posterior and ventral margins of the sphenopalatine foramen; the maxilla forms its anterior margin. This usual condition is indeed present in Holmesina (ROM 3881); ventral to the postorbital process the fronto-maxillary suture descends posteroventrally into the anterodorsal margin of the sphenopalatine foramen. The condition in FMNH $\mathrm{P} 14424$, if correctly interpreted, is therefore not characteristic of pampatheres and may be unique to this taxon or perhaps to this individual. Confirmation of this pattern by additional specimens and detailed study of the region in Kraglievichia (MACN 2617) are desirable.

In FMNH P14424 the orbitosphenoid is small and apparently consists of an anterodorsal and a posteroventral wing. The former has a short suture with the frontal. In lateral view, the orbitosphenoid is mostly covered by the curved, crest-like, anterior margin of the alisphenoid, which ends ventrally at the sphenopalatine foramen. The surface medial to the margin of the alisphenoid is depressed and contains various foramina, but their morphology is partly obscured by matrix. Some of the matrix has been removed, but the osseous partitions are delicate and preclude further preparation.

A dorsal, elongated groove almost surely represents the optic canal. Its dorsal margin is formed by the margin of the alisphenoid posteriorly and a crest of the frontal (which is confluent with that of the alisphenoid) anteriorly. Ventrally the margin of the optic canal is formed by a nearly horizontal and raised ridge that nearly coincides with the suture between the maxilla and the anterodorsal wing of the orbitosphenoid.

Ventral to this ridge the depressed surface bears at least two passages: a large, apparently single, canal leading posteromedially and the smaller sphenopalatine foramen, leading ventromedially. The former possibly represents the confluent orbital fissure and foramen rotundum. This morphology is apparently the same as in other pampatheres. The sphenopalatine foramen is single in FMNH P14424, but on the left side of Holmesina (ROM 3881) a second smaller foramen lies dorsal to the main foramen and becomes confluent with it. The sphenopalatine is thus closely associated with the orbital foramen in pampatheres, whereas it is farther anterior in dasypodines.

The lateral suture between the maxilla and palatine is unclear, but it may be represented by a weak ridge between the ventral margin of the sphenopalatine foramen and a fine groove lying ventrally and some $5 \mathrm{~mm}$ posteriorly to the distal margin of the M9 alveolus. A second fine groove $3-4 \mathrm{~mm}$ posterior to the first may represent the palatopterygoid suture. On the palate, the suture between the palatine and maxilla is distinct only anteriorly. The suture strongly resembles that of Kraglievichia and is unlike that in Holmesina and Dasypus, in which the su- 
ture curves gradually posterolaterally from the midline. In FMNH P14424 and Kraglievichia the suture extends anterolaterally from the ventral midline, approximately between the distal and mesial ends of M8. The suture then turns abruptly posteriorly and lies very near the margins of the alveoli.

At the ventral midline the palatines and posterior parts of the maxillae form a median crest between the middle of M6 and the posterior margin of the hard palate in FMNH P14424. The crest is most prominent on the maxilla, approximately between the distal one-half of M6 and mesial one-half of M7. In Holmesina the crest is shorter and less prominent. It arises anteriorly from the maxillae at about the middle of M7 as a very weak ridge, is most prominent posteriorly, and ends about $15 \mathrm{~mm}$ anterior to the margin of the hard palate. The condition in $\mathrm{Kra}$ glievichia cannot be clearly distinguished from Castellanos's (1937, fig. 7) illustration, but it apparently resembles more closely that of Holmesina.

In FMNH P14424 the mastoid has a wide occipital exposure. It is approximately $\mathrm{Y}$-shaped, with the mastoid foramen lying at the knee of the $Y$. Its medial branch rises more dorsally than the lateral, and the stem of the $Y$ is oriented ventrolaterally in occipital view. The mastoid in Holmesina is also Y-shaped, but the lateral arm is higher and the stem curves markedly ventromedially.

The paroccipital process is more robust in Holmesina, particularly ventrally. That of FMNH P14424 extends anteroventrally at about the same angle as in Holmesina but tapers ventrally to a blunt process (the right process is distorted so that its ventral end is displaced anterodorsally). In Holmesina the paroccipital process is expanded and elongated, with its long axis oriented anteromedially.

The paroccipital process of FMNH P14124 lies adjacent to the lateral margin of the occipital condyle. It projects ventrally a short distance past the levels of the condyle and mastoid process as a blunt process (Patterson et al., 1989). A deep, narrow cleft lies between the paroccipital and mastoid processes. In Holmesina the paroccipital process extends laterally, rather than ventrally, at about the level of the dorsal one-half of the occipital condyle. It contacts the root of the mastoid process, thereby enclosing a short, anteroposteriorly oriented canal that lies a short distance ventral to the mastoid foramen on the occiput.

The occipital condyles project slightly more ventrally and posteriorly relative to the mastoid process in FMNH P14424 than in Holmesina and Pampatherium. In these genera, however, the basicranium lies higher relatively to the pterygoid processes and alveolar margins. In FMNH P14424 the condyles lie slightly above the plane of the alveolar margins. In Kraglievichia they are apparently even lower. The pterygoid bone cannot be identified with confidence in this specimen and may have been lost postmortem, as is common in other pampathere specimens.

The basicranium is relatively short and wide in Holmesina and Pampatherium but is relatively elongated in FMNH
P14424 and Kraglievichia. The auditory region of FMNH P14424 was described by Patterson et al. (1989). Ventrally the pterygoid process is expanded and rugose and bears three or four prominent ridges. This condition also occurs in Holmesina and Pampatherium, but the process is apparently considerably less expanded and rugose. The position of the posterior end of the hard palate differs in these taxa. In Kraglievichia it ends slightly posterior to M9; in FMNH P14424, slightly farther posteriorly, approximately midway between the distal surface of M9 and the posterior end of the pterygoid process; in $\mathrm{Hol}$ mesina, about two-thirds of the way between these structures; and in Pampatherium, near the posterior part of the pterygoid process.

Mandible: The mandibles are of similar form in all known pampatheres (Figure 3). FMNH P14424 includes a right dentary, missing only its anterior portion and $\mathrm{m} 3-\mathrm{m} 5$. Measurements of the lower dentition and dentary are presented in Tables 2 and 3, respectively. The angular region is expanded and bears near its margin various tuberosities laterally and ridges medially for insertion of the masseteric musculature. The dentary of FMNH P14424 differs from that of Holmesina (ROM 4954, 4955, 4956, AMNH 26856), Pampatherium (Bordas, 1939, fig. 2; Winge, 1915, pls. 9, 10), and Kraglievichia (MACN 8968) in that the horizontal ramus is less elongated relative to the ascending ramus and angular region, so that it appears short and robust (Figure $3 a$ ). The horizontal ramus is relatively deep, however, and the ventral margin below the symphysis inclines more abruptly. The masseteric fossa is barely indicated in FMNH P14424, in contrast to the small but distinct fossa in Holmesina and Pampatherium.

The medial surface of the dentary differs in minor ways from that described by Castellanos (1946). For example, the scar line for the mylohyoid lies somewhat farther dorsally and is more prominent in FMNH P14424. Also, the various depressed regions dorsal and ventral to it (e.g., fovea submaxillaris, fovea sublingualis) are apparently deeper and their surfaces are more heavily scarred. It is probable, however, that these features are not taxonomically significant. These features vary considerably in two dentaries of subequal size (ROM 4954, 4955) of H. occidentalis from a single locality.

The ascending ramus rises steeply, as indicated by James (1957). A prominent, curved crest lies on the dorsolateral surface of the coronoid process (Figure $3 a$ ). The crest is highest posteriorly and diminishes gradually as it extends anteroventrally to become confluent with the anterior edge of the process. The crest possibly marks the separation between the insertions of the temporal and masseteric musculatures, although Smith and Redford (1990) indicated that a similar crest in Euphractus sexcinctus Linnaeus is associated only with the temporal.

The anterior margin of the ascending ramus begins to rise just lateral to the mesial part of M8, although this tooth is sometimes entirely visible (e.g., K. paranense, MACN 8968). It slopes rapidly dorsally in a regular curve and in lateral view 


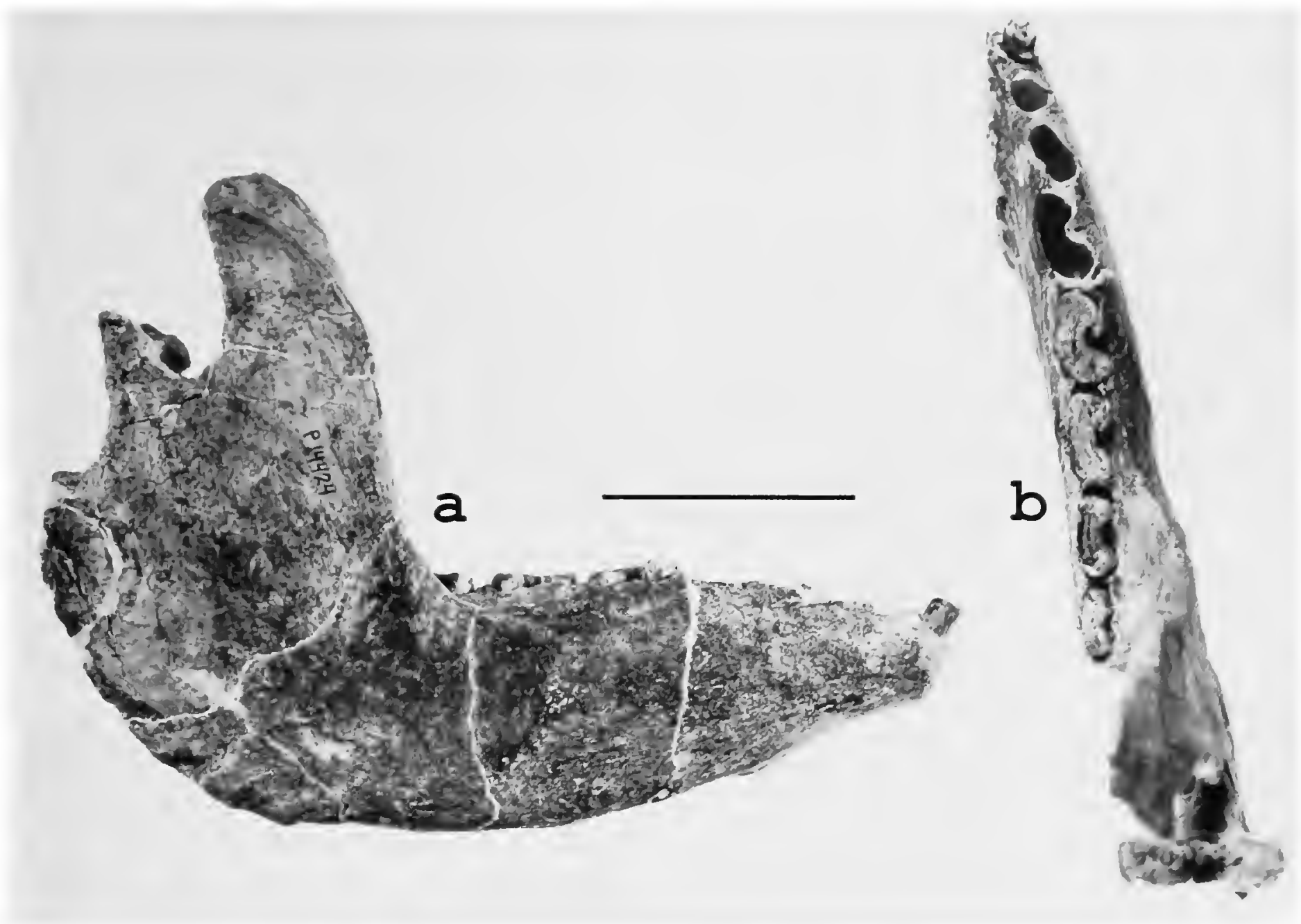

FIGURE 3. - Right dentary of Vassallia maxima FMNH P14424: $a$, lateral view; $b$, occlusal view. (Scale bar $=50$ $\mathrm{mm}$.)

covers most of the distal one-half of M8. This morphology is present in all pampatheres. Castellanos $(1927,1937)$ claimed, even though M9 is broken at the alveolar margin, that in $V$. minuta the anterior edge of the ramus lies somewhat posteriorly farther and therefore left part of this tooth uncovered. This is apparently incorrect, however. Although it is not clear from Castellanos's illustrations (1927, fig. 5; 1937, fig. 5), a cast (ROM 29580) of its type, MLP 29-IV-15-4, indicates that the position of the ascending ramus is precisely as in other pampatheres. It is evident from the position of M9 that its exposed part would have to have been extraordinarily high for the ramus to have left part of it uncovered.

Dentition: Only three upper teeth are preserved in situ: the right M6, nearly complete; the left M8, broken at the alveolar margin; and M9, broken below the alveolar margin. The shapes of the teeth in section therefore are interpreted largely from the form of the alveoli (Figure $2 b$ ).

M1-M3 are not lobate. M1 is nearly circular; M2 and M3 are slightly and successively more elliptical. M4 is reniform, with a relatively weak labial sulcus. M5 is strongly bilobate, with a deep labial sulcus. Its lingual margin is not regularly curved but undulates slightly owing to a weak anterior groove, which is inferred from the correspondingly weak ridge of the alveolar margin. M6 and M7 are also strongly bilobate. Their lingual margins bear two weak grooves, and the alveoli bear two weak ridges. M8 and M9 are similar, but the mesial and distal lobes are relatively narrower transversely. M5 is the largest tooth, judging from its alveolus, but M6 was probably almost as large, followed in size by M7 and M8. M9 and M4 are approximately equal in size, followed by M3, M2, and M1.

The upper teeth of other pampatheres differ in various details. M2 is subreniform in Holmesina and probably in Pampatherium, with the long axis oriented markedly obliquely. M3 is elliptical, and M4 is subreniform and longer than M2. In M2

TABLE 3.-Dentary measurements (in mm) for FMNH P14424.

\begin{tabular}{l|c}
\hline \multicolumn{1}{c|}{ Dentary feature } & Measurement \\
\hline Ramus height at m5 & 37.0 \\
Ramus height at m6 & 43.3 \\
Ramus height at m7 & 47.5 \\
Ramus height at m8 & 48.0 \\
Ramus height at m9 & 50.0 \\
Height coronoid process to angular process & 80.0 \\
Height coronoid process to ventral margin of dentary & 132.0 \\
Height condyle to angular process & 47.0 \\
Height condyle to ventral margin of dentary & 96.4 \\
Condyle, transverse length & 31.2 \\
Condyle, anteroposterior width & 11.0 \\
Symphysis length & 54.0 \\
Symphysis thickness & 16.0 \\
\hline
\end{tabular}


and M4, however, the sulcus lies on the lingual surface, rather than on the labial as in FMNH P14424. In Kraglievichia, M1-M4 are nearly elliptical, with the long axis of M2 oriented nearly as in Holmesina. M5-M9 in these other pampatheres are similar to those of FMNH P14424.

The dentary of FMNH P14424 preserves $\mathrm{m} 2$ and $\mathrm{m} 6-\mathrm{m} 9$, the alveoli for $\mathrm{m} 3-\mathrm{m} 5$, and the distal one-half of the $\mathrm{ml}$ alveolus (Figure $3 b$ ). The $\mathrm{ml}$ alveolus is insufficiently preserved to permit recognition of the shape of the tooth; however, it is assumed to be circular in section, as indicated by Castellanos (1927, 1937). Tooth $\mathrm{m} 2$ is elliptical, with the long axis oriented obliquely, and its distolingual surface is flattened, as described by Castellanos (1946) for V. maxima. The alveolus of $\mathrm{m} 3$ is elliptical. This is in contrast to the shape of the right $\mathrm{m} 3 \mathrm{de}-$ scribed by Castellanos (1946, figs. 5, 6, 7b), in which the distolingual surface is concave and the distal part of the tooth is keeled in section. It is worth noting, however, that the preserved lingual one-half of the left alveolus of Castellanos's specimen (IFG 500) does not indicate a concave surface. In FMNH P14424, m4 is elongated and reniform or possibly slightly bilobate, with weak sulci present on the lingual and labial surfaces. Castellanos (1946) described and figured the corresponding tooth in IFG 500 as prominently keeled. The preserved one-half of the left alveolus of $\mathrm{m} 4$ in Castellanos's specimen suggests, however, that the lingual surface was probably semi-elliptical. The differences between left and right teeth in IFG 500 suggest that the features described by Castellanos (1946) for the right $\mathrm{m} 3$ and $\mathrm{m} 4$ reflect individual variation. $\mathrm{m} 5$ of FMNH P14424 is strongly bilobate, with a deep labial sulcus; $\mathrm{m} 6-\mathrm{m} 8$ are also markedly bilobate, each with a deep and flattened labial sulcus; $\mathrm{m} 9$ is weakly bilobate, with mesial and distal lobes subequal in width. The alveolus of $\mathrm{m} 5$ is slightly larger than that of $\mathrm{m} 6$, which is followed in size by $\mathrm{m} 7, \mathrm{~m} 8, \mathrm{~m} 9, \mathrm{~m} 4, \mathrm{~m} 3, \mathrm{~m} 2$, and presumably $\mathrm{m} 1$. In size and form of the teeth, FMNH P14424 essentially follows Kraglievichia and Pampatherium (Castellanos, 1927, 1937). It differs from Holmesina (Simpson, 1930) in that $\mathrm{m} 4$ in the latter is reniform, with a slightly angular distal surface, and from $V$. minuta (Castellanos, 1927, 1937) in that $\mathrm{m} 4$ is subelliptical.

Hoffstetter (1958) characterized the teeth of cingulates as composed of a small central portion of osteodentine surrounded by compact dentine, which forms most of the tooth, and finally by a layer of cementum. He indicated that in some lineages, most notably glyptodonts, the osteodentine may be harder and structurally resembles vasodentine. This condition is present in the three molariform teeth $(\mathrm{M} 6, \mathrm{~m} 7, \mathrm{~m} 8)$ of FMNH P14424 for which the occlusal surfaces are preserved. The central osteodentine is a narrow, elongate strip that widens slightly mesially and distally. It is raised in relief (as is the periphery of the tooth), is convex lingually, and strongly resembles the form illustrated by Hoffstetter (1958, fig. 22b) for m 1 and $\mathrm{m} 2$ of the glyptodont Eucinepeltus petesatus Ameghino. The osteodentine is not well preserved in Holmesina septentrionalis (Edmund, 1985a, figs. 5, 6) or H. occidentalis (ROM
$3881,4964)$, suggesting that it was considerably softer. The central portion of the tooth tends to split longitudinally (see Edmund, 1985a, fig. 7), creating a cavity (presumably filled in life by osteodentine) that often divides the tooth in half. In some teeth, single or multiple fractures radiate from the mesial or distal end of the cavity toward the periphery of the tooth. In Kraglievichia paranense (MACN 8968, 8943) and Pampatherium typum Ameghino (MLP 81-x-30-1) osteodentine is present and stands in relief.

Cervical Vertebrae: Perhaps the most peculiar part of FMNH P14424 is the axis, which may be either separate or fused with additional elements (Figure 4). The form of this element is unexpected in a pampathere or dasypodid. Although possibly it is not part of the individual assigned to $\mathrm{FMNH}$ P14424, the state of its preservation and the nature of the adherent matrix are identical with those of the remaining suite of elements constituting FMNH P14424. Furthermore, we are unable to reconcile its morphology with that of any known mammal.

It is generally known that in dasypodids and other pampatheres the axis is fused to two or three succeeding cervical vertebrae to form a cervical tube. Utaetus is the only dasypodid genus, to our knowledge, in which the axis is free (Simpson, 1948; Hoffstetter, 1958). In Holmesina, for example, the tube includes the axis and cervical vertebrae $3-5$, with intervertebral foramina clearly delimiting each vertebra. The length of the tube clearly reflects the presence of multiple elements. In dorsal view, it is constricted posterior to the lateral facets for the atlas, forming what may be termed a neck. The slender, transverse processes of cervical vertebrae 3-5, fused lateral to the intervertebral foramina, extend lateroventrally and end in expanded, somewhat rugose tuberosities. The tube in dasypodines (e.g., Dasypus, ROM R948) is extremely similar.

The element in FMNH P14424 clearly includes the axis, with its high, overhanging neural spine, dens, and three anterior facets for the atlas (Figure $4 a$ ). These facets are smaller than those in Holmesina, and the dens is relatively shorter. The element is extremely large and robust for the size of the skull and is strongly compressed anteroposteriorly (Figure $4 b$ ). It is approximately as long, posterior to the facets, as the axis in the cervical tube of Holmesina ROM 3856. Two very long and robust processes extend laterally on either side immediately posterior to the articular facets, i.e., the position of the neck. Intervertebral foramina are absent from the dorsolateral surface of these processes, in contrast to the condition in ROM 3856, but one large foramen and two very small foramina anterior to it open from the ventral surface of the process; two large, subequal foramina lie ventrally in ROM 3856.

This element possibly represents the axis only. In dasypodids and other pampatheres, however, the axis, although fused to other cervical vertebrae, does not bear transverse processes $_{2}$ a condition that also occurs in the free axis of Pilosa (sloths and vermilinguas). It more closely resembles the fused axis and cervical vertebrae 3-5 of the glyptodont Propalaeohoplopho- 


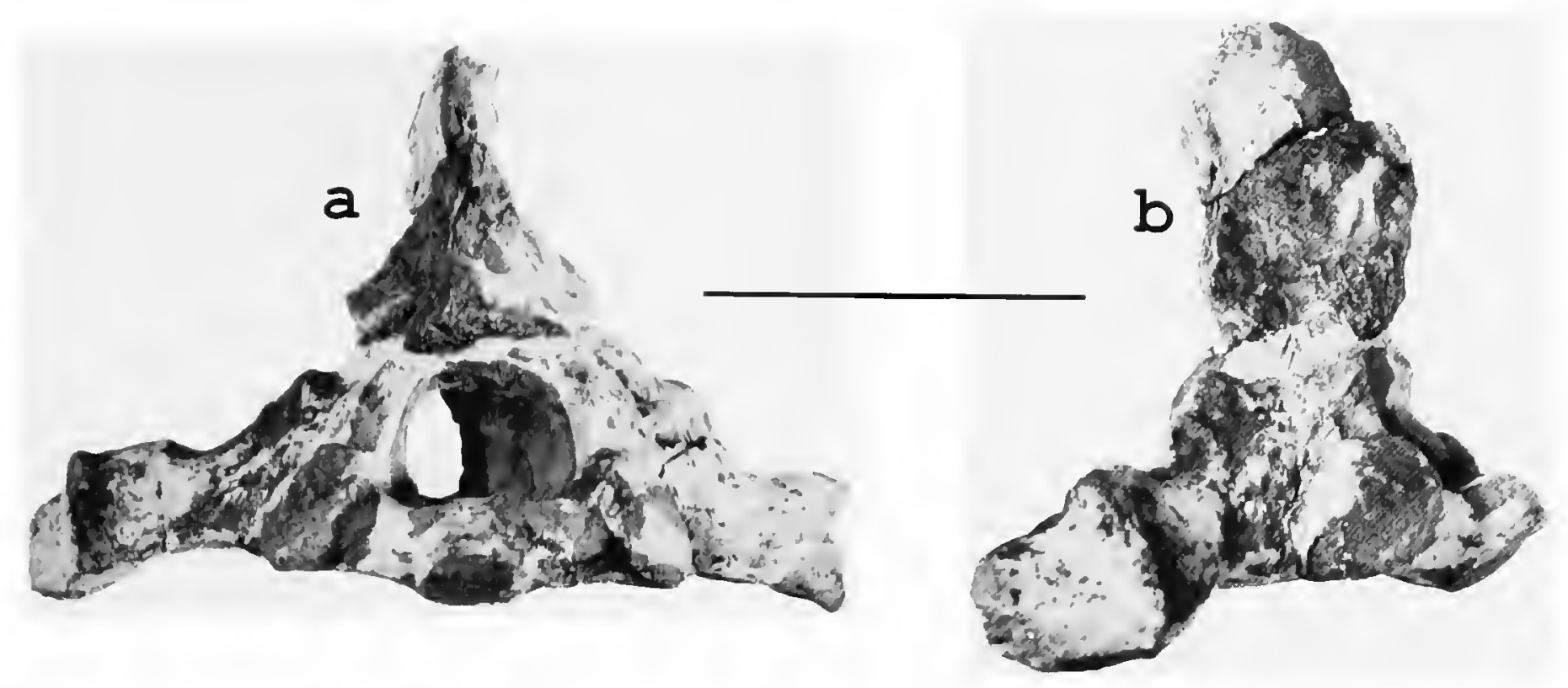

FIGURE 4.-Axis (or axis complex) of Vassallia maxima FMNH P14424: $a$, anterior view; $b$, lateral view. (Scale bar $=50 \mathrm{~mm}$.)

rus australis Ameghino (Scott, 1903, pl. 25: fig. 1) in the shape, compression, and relationship of the transverse processes to the articular facets. In this species, however, the facets are oriented differently and three intervertebral foramina identify the cervicals. The element in FMNH P14424 differs considerably from the tube of Glyptotherium arizonae Gidley (Gillette and Ray, 1981, fig. 22). The transverse processes of FMNH P14424 resemble those of the free axis of Manis pentadactyla Linnaeus (ROM R589), although they are less expanded laterally in the latter.

Manus: FMNH P14424 preserves the R unciform, $\mathrm{L}$ and $\mathrm{R}$ Ph 1 of D II, L Ph 2 of D III, L Ph 1 of D IV, and L Ph 1 of D V. The elements were compared with casts (ROM 5000) of those of $H$. septentrionalis, UF 9336 . Those of FMNH P14424 are smaller, but they differ mostly in minor ways from those of Holmesina. The unciform is missing a small mediopalmar portion. It is relatively deeper proximodistally than that of Holmesina.

$\mathrm{Ph} 1$ of D II differs markedly. It is considerably shorter proximomedially, and the articular surface for Mc II is flatter. In Holmesina, this surface is extended by mediolateral and mediopalmar articular shelves, probably for sesamoids, which are separated by a deep notch. The shelves are rudimentary, and the notch is replaced by a sulcus in FMNH P14424. Distally the articular condyles in FMNH P14424 are reduced and flattened, and the median palmar protuberance of the articular surface is more distal relative to the atrophied condyles. The articular surfaces of $\mathrm{Ph} 1$ suggest relatively restricted movement.

In proximal view the articular surface of Ph 2 of D III has a less excavated palmar margin because the palmomedian sulcus is less prominent; however, the dorsal margin is more convex, and its median portion projects farther distally than in Holmesina. Ph 1 of D IV closely resembles that of Holmesina, but its proximal and distal articular surfaces have less relief. Ph 1 of D
$\mathrm{V}$ is relatively elongated and thus more gracile. Its shaft is less triangular in section, and its dorsal surface is more rounded. In proximal view, $\mathrm{Ph} 1$ of Holmesina is distinctly triangular, whereas that of FMNH P14424 has two short and two long margins.

Pes: Nearly all of the pes is represented in FMNH P14424, including $\mathrm{L}$ astragalus, calcaneum, navicular, cuboid, entocuneiform, mesocuneiform, and ectocuneiform; L Mt I, L and R Mt II, R Mt III, L Mt IV; L and R proximal phalanges, R Ph 2 and ungual phalanx of digit III, $\mathrm{L}$ ungual phalanx of digit IV, $\mathrm{L}$ and $R$ phalanges 1 and 2 , and $R$ ungual phalanx of digit $V ; L$ plantar sesamoid. As with the manus, the pedal elements are smaller than those of $H$. septentrionalis (compared with casts, ROM 5000, of UF 9336).

The neck of the astragalus is not as well defined as that of Holmesina, and the neck and the facet for the navicular taper more strongly anteriorly. The trochlea tali is relatively larger because its anterior margin extends farther distovolarly. Also, this margin is not as prominently notched. The calcaneum lacks the tuber. The facet for the cuboid is relatively larger and wider, but in other respects the calcaneum strongly resembles that of Holmesina. The navicular differs mainly in that the bony rugosities are less prominent and the facet for the cuboid is elongate compared with that of Holmesina. The cuboid is more robust because it is relatively compressed dorsovolarly. Its calcaneal facet is wider dorsovolarly, and its lateral portion approaches the volar sesamoid facet much more closely than in Holmesina. The cuneiforms are very similar to those in Holme$\sin a$; however, the proximal and distal surfaces are subequal in dorsovolar length, whereas in Holmesina the distal surface is elongated.

Mt I is relatively compressed dorsovolarly, and the keel of the distal trochlear surface is poorly defined. Mt I of Holmesina is relatively expanded mediovolarly. Mt II and Mt III are more 

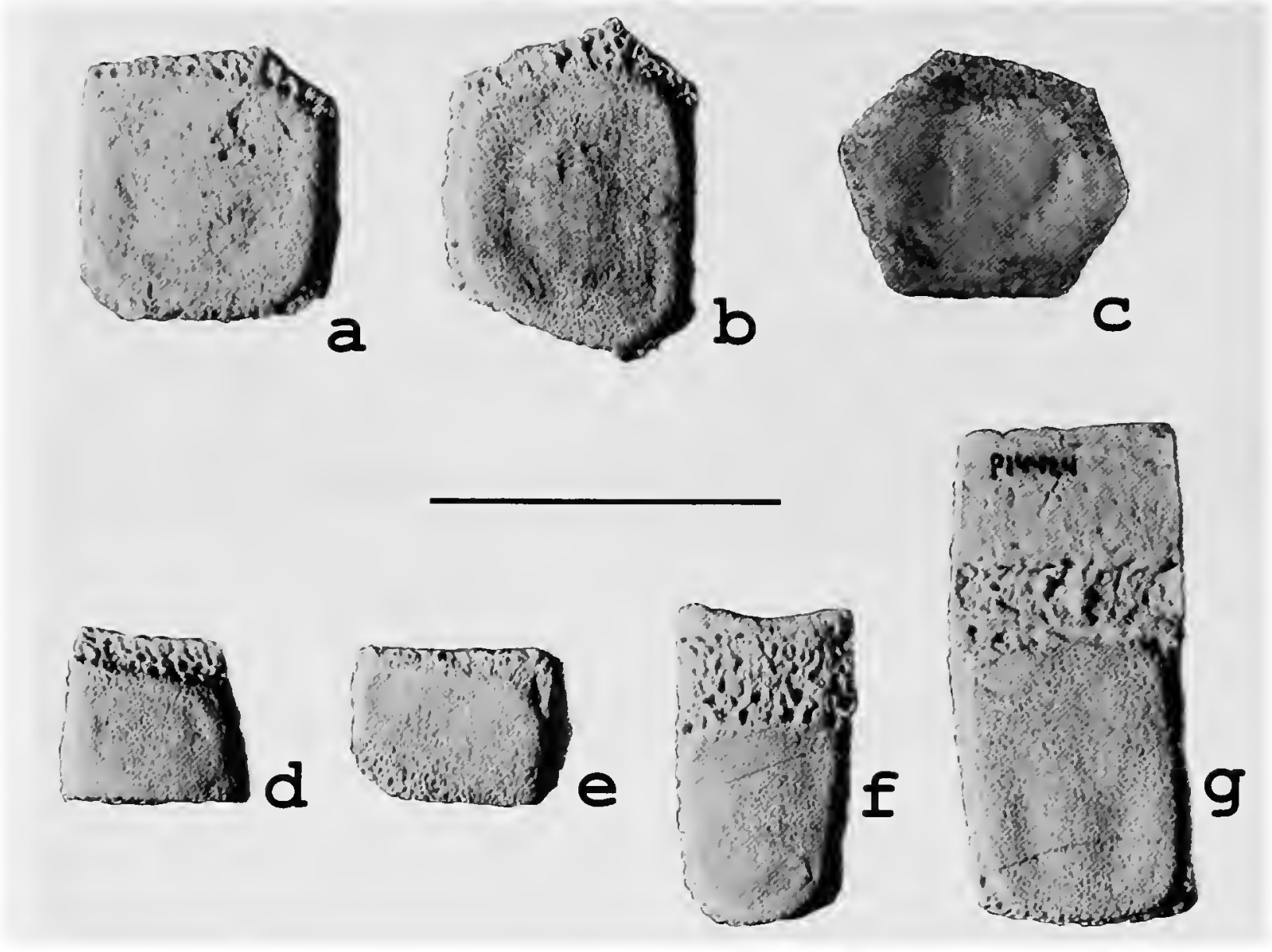

FIGURE 5.-Dorsal views of osteoderms of Vassallia maxima FMNH P14424: $a-c$, osteoderms probably from the anterior buckler; $d, e$, osteoderms from the margin of the buckler; $f$, osteoderm probably from a limb; $g$, imbricating osteoderm. (Scale bar $=50 \mathrm{~mm}$.)

gracile, and their shafts are relatively narrower mediolaterally just distal to the proximal articular surfaces. This also occurs in Mt IV, and the median keel of the distal trochlear surface is nearly semicircular, whereas in Holmesina it is truncated.

$\mathrm{Ph} 1$ of $\mathrm{D} 1$ is relatively elongate proximodistally. $\mathrm{Ph} 2$ of $\mathrm{D}$ III is nearly as long as that of Holmesina but is markedly compressed mediolaterally. The ungual phalanx of D III is relatively elongate and less spatulate than that of Holmesina. The ungual phalanx of D IV is relatively elongated, less spatulate, and less dorsovolarly flattened. The bony projections on the perimeter of the proximal articular surfaces are markedly less prominent, particularly laterally. $\mathrm{Ph} 1$ of D V is relatively compressed mediolaterally, and its distal articular surface has less relief. $\mathrm{Ph} 2$ of $\mathrm{DV}$ is more robust, apparently because it is relatively thicker dorsovolarly. The bony core of the ungual is similar in shape, but there is greater development of bony projections posterovolarly and laterally in Holmesina.

The plantar sesamoid bears two articular facets dorsally, which meet along a straight line at an angle of approximately $120^{\circ}$.ne facet, probably for the cuboid, is elongate, hexagonal, and nearly flat. The other is somewhat larger and articulated with the navicular; it is partially concave, but it becomes convex on two of its edges. The remainder of the bone is rugose and bears a prominent almond-shaped protuberance on the side nearest the cuboid facet. In Holmesina this swelling is less prominent and is nearly centered on the rugose surface.
Osteoderms: The suite of osteoderms associated with the skeletal and dental material make FMNH P14424 a pivotal specimen in the study of late Miocene and early Pliocene pampatheres, especially those assigned to the genera Vassallia (Figure 5), Plaina, and Kraglievichia, and to the Pleistocene genus Pampatherium.

The feeble ornamentation of the osteoderms of Vassallia distinguishes the genus from Kraglievichia, although their size ranges overlap (Table 4). Some isolated buckler osteoderms assigned to Kraglievichia, however, have an ornamentation not unlike that of some in the series of FMNH P14424, raising doubts regarding the identification of isolated osteoderms.

Plaina intermedia (MACN A7799) and P. subintermedia (MACN 8473) are based upon inadequate osteodermal material that is similar in size and morphology to that of Vassallia sp., and their generic validity is questionable, as suggested by Edmund in Patterson et al. (1989). The material assigned to Plaina brocherense (IFG 769; Castellanos, 1958) is larger than that of any species of Vassallia so far described. The ornamentation of the osteoderms is not unlike that of FMNH P14424, and other series referred to Vassallia, except that it is larger and the buckler osteoderms have wide margins made up of large follicular pits. Vassallia minuta, as typified by MLP 69-VIII$25-7$, strongly resembles $V$. maxima morphologically but is smaller (Table 4). 
TABLE 4.-Length, width, and thickness of non-marginal buckler osteoderms of pampatheres. $(\mathrm{Mx}=$ maximum; $\mathrm{Mn}=$ minimum; $\mathrm{Me}=$ mean.)

\begin{tabular}{|c|c|c|c|c|c|c|c|c|c|c|c|}
\hline \multirow{2}{*}{ Species } & \multirow[b]{2}{*}{ Specimen } & \multirow[b]{2}{*}{$\mathrm{N}$} & \multicolumn{3}{|c|}{ Length } & \multicolumn{3}{|c|}{ Width } & \multicolumn{3}{|c|}{ Thickness } \\
\hline & & & $M x$ & Mn & $\mathrm{Me}$ & $M x$ & $\mathrm{Mn}$ & $\mathrm{Me}$ & $\mathrm{Mx}$ & Mn & $\mathrm{Me}$ \\
\hline Vassallia maxima & FMNH PI4424 & 15 & 29 & 29 & 39 & 40 & 29 & 34 & 13 & 7 & 8.7 \\
\hline V. maxima & IFG $502-515^{1}$ & 8 & 45 & 33 & 39 & 34 & 23 & 28 & 7 & 55 & 6.1 \\
\hline V. maxima & PVL $3205^{2}$ & 10 & 49 & 31 & 40 & 46 & 23 & 33 & 8 & 4 & 6.2 \\
\hline V. maxima & MLP 29-X-10-123 & 3 & 39 & 33 & 37 & 36 & 26 & 30 & 7 & 6 & 6.3 \\
\hline V. maxima & MLP 52-IX-30-2 $1^{4}$ & 5 & 43 & 31 & 39 & 36 & 30 & 33 & 8 & 5 & 6.4 \\
\hline V. minuta & MLP 69-XII-26-175 & 15 & 36 & 22 & 28 & 24 & 20 & 22 & 6 & 4 & 4.8 \\
\hline Plaina subintermedia & MACN $8473^{6}$ & 3 & 34 & 22 & 30 & 26 & 12 & 20 & 7 & 6 & 6.7 \\
\hline P. intermedia & MACN A-77997 & I & - & 40 & - & - & 26 & - & & 7 & - \\
\hline$P$. intermedia & MLP 69-VIII-25-1 ${ }^{8}$ & 8 & 43 & 37 & 40 & 39 & 28 & 33 & 9 & 6 & 7.3 \\
\hline P. brocherense & IFG $769^{9}$ & 6 & 50 & 44 & 47 & 43 & 35 & 38 & 10 & 6 & 8.5 \\
\hline Pampatherium typum & IFG $110^{10}$ & 12 & 51 & 30 & 39 & 34 & 27 & 30 & 10 & 7 & 8.1 \\
\hline P. typum & MLP 69-VIII-22- I I11 & 7 & 49 & 28 & 36 & 32 & 25 & 28 & 7 & 6 & 6.7 \\
\hline P. typum & MMP $216 \mathrm{~S}^{12}$ & 6 & 37 & 32 & 36 & 35 & 26 & 29 & 8 & 7 & 7.3 \\
\hline P. typum & MLP 69-V111-25-713 & 8 & 43 & 37 & 40 & 34 & 31 & 33 & 4 & 6 & 7.1 \\
\hline Kraglievichia paranense & $\mathrm{MACN}^{14}$ & 18 & 44 & 23 & 39 & 32 & 17 & 24 & 9 & 5 & 6.6 \\
\hline
\end{tabular}

'Series including type of Vassallia maxima in Castellanos (1946).

${ }^{2}$ Identified as V. maxima by Scillato-Yané (1982); Andalhualá Formation, Caspinchango, Valle de Santa Maria, Tucumán Province, Huayquerian.

${ }^{3}$ Identified as V. maxima by Scillato-Yané (1982); San Femando, Catamarca Province.

${ }^{4} \mathrm{~V}$. maxima according to museum label, Tiopunco, Valle de Santa Maria, Tucumán Province.

${ }^{5}$ Identified as V. minuta by Scillato-Yané (1982); "Araucanense," Catamarca Province.

${ }^{6}$ Plaina subintermedia, holotype of Rovereto (1914); Montehermosan (Marshall and Patterson, 1981); we consider this morphologically inseparable from osteoderms of $V$. maxima

${ }^{7}$ Plaina intermedia, labeled by Ameghino as Chlamydotherium intermedium; Monte Hermoso, Buenos Aires Province.

${ }^{8}$ Identified by Scillato-Yané (1982), P. subintermedia according to museum label; Monte Hermoso, Buenos Aires Province, no stratigraphic data.

${ }^{9}$ Plaina brocherense, type series of Castellanos (1958); Valle de los Reartes, Córdoba Province, Formacion Brocherense (Castellanos, 1958) cf. Huayquerian (Marshall et al., 1983).

${ }^{10}$ Pampatherium typum according to museum label; Rio Cararañá, Santa Fé Province, referred to upper Pleistocene by A.G. Edmund.

${ }^{11}$ Identified by Scillato-Yané (1982); no stratigraphic or locality data.

${ }^{12}$ Pampatherium typum according to museum label; Ensenadan.

${ }^{13}$ Identified as $P$. typum by Scillato-Yané (1982); no stratigraphic or locality data.

${ }^{14}$ Kraglievichia paranense, includes a series of MACN specimens (MACN 1637, 2639, 3951, 4056, 4076, $4693,4700,4758,5053,8944$ ) according to Scillato-Yané, and MACN 4858, 12278 according to museum label; all are from Entre Ríos, Paraná Province.

Vassallia is generally believed to be the precursor of Pampatherium, and indeed it has essentially identical morphology but is larger in size. Usually members of the the genus Vassallia, especially $V$. maxima, have been confined to the late Miocene and much of the Pliocene. Some suites of osteoderms supposedly of Pleistocene age, however, have been assigned to P. typum and have typical Vassallia morphology. Their sizes are equal to, or sometimes smaller than, those of $V$. maxima, the latter including the type specimen and a series of osteoderms confidently identified as being of the Huayquerian age (Table 4). Vassallia maxima and smaller individuals of $P$. typum may therefore be confused, at least on the basis of osteoderms.

Osteoderms of the type and referred specimens of $V$. maxima (e.g., IFG 505-528; Castellanos, 1946) agree well with those of FMNH P14424, except that the latter are somewhat thicker (Table 4). This may be an age-related variation. A typical nonmarginal buckler osteoderm of P14424 has most of the hair fol- licles confined to the anterior end, in a band up to $5 \mathrm{~mm}$ wide. In some specimens the follicles continue down the sides in a very narrow margin. The marginal band (Edmund 1985b) is approximately $5-8 \mathrm{~mm}$ wide and is smooth and slightly rounded. It is separated from the central figure by a sulcus usually less than $1 \mathrm{~mm}$ deep and approximately $5-8 \mathrm{~mm}$ wide. The sulcus is usually horseshoe shaped, with the central figure reaching the submarginal band posteriorly. The central figure is highly variable, usually a flat, rounded, almost impalpable boss, but in some specimens it is slightly raised, tapering posteriorly to join the submarginal band.

Some osteoderms of FMNH P 14424 lack a sulcus or central figure and instead have a distinct central depression approximately $2 \mathrm{~mm}$ deep and $10 \mathrm{~mm}$ in diameter. In others the sulcus is represented by two narrow furrows that are subparallel to the central figure and are barely united at the anterior end. Within the range of variability of the osteoderms of FMNH P14424, 
however, one can find examples of the surface morphology given in the literature for all species of Plaina and Vassallia. With regard to the illustrations of the type description of $V$. maxima (Castellanos, 1946), one should be cautious of the half-tone illustrations. Castellanos, who had impaired vision, highlighted the central figures with a soft pencil. In fact, these figures are barely palpable, and the markings were intended only for Castellanos's personal reference.

In the sample of osteoderms of FMNH P14424, there are numerous specialized osteoderms from the nuchal notch, the margins of the buckler, and the rows adjacent to the imbricating bands. These are similar to those illustrated by Holmes and Simpson (1931) and by Edmund (1985a), except that they bear little surface ornamentation.

In the large sample represented by P14424, one would expect to find numerous rectangular buckler osteoderms, representing the posterior buckler. Instead, there are only a few, suggesting that this area had been lost either before becoming fossilized or by subsequent erosion. No part of the skeleton underlying this area was recovered. Most suites of randomly collected osteoderms of Vassallia sp. or Pampatherium sp. contain approximately $50 \%$ rectangular buckler osteoderms (Edmund, 1996).

Specimen P14424 includes 176 nearly complete osteoderms, distributed as follows:

$\begin{array}{lr}\text { Non-marginal buckler } & 68 \\ \text { Posterior margin of pectoral buckler } & 15 \\ \text { Anterior margin of pelvic buckler } & 5 \\ \text { Nuchal notch } & 6 \\ \text { Lateral margins } & 6 \\ \text { Buckler, imbricating } & 20 \\ \text { Tail and possibly leg, imbricating } & 36 \\ \text { Small, non-imbricating } & 20\end{array}$

\section{Discussion and Conclusions}

FMNH P14424 is from the Puerta del Corral Quemado, Catamarca Province, but the field notes are sufficiently vague that its age may be Huayquerian or Montehermosan. The type specimen of Vassallia maxima was recovered from the Valle de Santa María, Tucumán Province. Castellanos (1946) considered these strata as middle and upper Araucanian; Marshall et al. (1983) suggested that they are probably of Huayquerian age. These localities are reasonably close to each other, and both are well removed from deposits typically yielding remains of Krag-lievichia, Pampatherium, and Holmesina. Although the localities are not identical, their proximity supports the possibility that FMNH P14424 belongs to V. maxima.

The morphological and mensural differences between the left dentary of FMNH P14424 and the partial right dentary of the type of $V$. maxima (IFG 500) are few and minor. The osteoderms of FMNH P 14424 agree well morphologically and mensurally with those of the type series of V. maxima. Morphologically, the osteoderms also strongly resemble those of the Huayquerian (late Miocene) V. minuta and the Pleistocene Pampatherium. On the basis of comparable morphological and, apparently, stratigraphic criteria, there is no obvious justification for separating FMNH P14424 from V. maxima; we therefore assign it to this species.

The only identifiable vertebral material of FMNH P14424 is the axis or axis complex. Although it was apparently associated in the field with the remaining and typically pampathere material of FMNH P14424, its morphology renders an association questionable.

The extensive suite of osteoderms of FMNH P14424 demonstrates a moderate degree of variation, suggesting that the identification of material, and more importantly the erection of taxa, on the basis of small series of isolated osteoderms is essentially futile. The range of variation in FMNH P14424 also encompasses the descriptions of Plaina intermedia and P. subintermedia, and indeed of some suites identified as Pampatherium typum. This suggests that the validity of $P$. intermedia and $P$. subintermedia, which were described from inadequate material, is probably unjustified, and that the genus Plaina should perhaps be considered a synonym of Vassallia. The size and morphology of the type specimens for these species fall within the range of the osteoderms of FMNH P 14424, suggesting that $P$. intermedia, $P$. subintermedia, and $V$. maxima are conspecific. That this is probably the case for the species of Plaina has alredy been suggested by Paula Couto (1979), who indicated that Plaina was a monotypic genus with $P$. intermedia being the valid name. Although direct comparison between FMNH P14424 and the Bolivian material assigned to $P$. intermedia by Anaya and MacFadden (1979) was not possible, the resemblance of the remains illustrated and described by those authors to FMNH P14424 seems sufficiently close to support a hypothesis of conspecifity of $P$. intermedia and $V$. maxima. If this is demonstrated to be true, then the epithet intermedia is the earliest available name. Its type is apparently lost, and the description is vague but is probably sufficient for its time of publication. The valid name for the species would thus be $V$. intermedia (Ameghino 1888), and the epithets subintermedia and maxima would fall as junior synonyms. We do not propose this formally at this time, however, because of the paucity of data for the two earlier species. The thickness of the osteoderms of $P$. brocherense suggests that the latter may be a distinct species, but the morphology of the osteoderms suggests that it also may possibly be referred to Vassallia. 


\section{Literature Cited}

Ameghino, F.

1883. Sobre una colección de mamíferos fósiles del piso mesopotámico de la formación patagónica recogidos en las barrancas del Paraná por el Prof. Pedro Scalabrini. Boletin de la Academia Nacional de Ciencias en Córdoba, 5:101-116.

1887. Apuntes preliminares sobre algunos mamíferos extinguidos del yacimiento de "Monte Hermoso" existentes en el "Museo de La Plata." Boletin del Museo La Plata, 1:1-20.

1888. Lista de las especies de mamiferos fósiles del Mioceno superior de Monte-Hermoso, hasta ahora conocidas. 21 pages. Buenos Aires: P.E. Coni.

1889. Contribución al conocimiento de los mamíferos de la República Argentina. Actas de la Academia Nacional de Ciencias en Córdoba, 6:1-1027.

1895. Sur les édentés fossiles de l'Argentine. Revista del Jardin Zoológico, 3(4):97-192.

Anaya, F., and B.J. MacFadden

1995. Pliocene Mammals from Inchasi, Bolivia: The Endemic Fauna Just before the Great American Interchange. Bulletin of the Florida Museum of Natural History, 39(3):87-140.

Bordas, A.F.

1939. Craneometria y región auditiva de Chlamytherium typum Ameghino. Physis, 14:447-460.

Cartelle, C., and G. Bohórquez

1985. Pampatherium paulacoutoi, una nova espécie de tatu gigante da Bahia, Brasil (Edentata, Dasypodidae). Revista Brasileira de Zoologia, 2:229-254

Cartelle, C.A., B.G. Câmara, and P.1.L. de Prado

1991. Estudo comparativo dos esqueletos da mão e pé de Pampatherium humboldti (Lund 1839) e Holmesina paulacoutoi (Cartelle \& Bohórquez 1985); Edentata Pampatheriinae. Anais do XI Congresso Brasileiro de Paleontologia, 2:621-634.

Castellanos, A.

1927. Breves notas sobre los clamidoterios. Publicación del Centro de Estudiantes de Ingenieria de Rosario, 8 pages.

1937. Anotaciones sobre las líneas filogenéticas de los clamiterios. Publicaciones del Instituto de Fisiografia y Geologia, Universidad $\mathrm{Na}$ cional del Litoral (Rosario, Argentina), Serie Técnico-Cientifica, 8: 35 pages.

1946. Una nueva especie de clamiterio, Vassallia maxima n. sp. Publicaciones del Instituto de Fisiografia y Geologia, Universidad Nacional del Litoral (Rosario, Argentina), Serie Técnico-Cientifica, 26: 47 pages.

1958. Nota preliminar sobre nuevos restos de mamíferos fósiles en el Brocherense de Valle de los Reartes (Provincia de Córdoba, Argentina). XX Congreso Geológico Internacional, México, section 7, pages 217-233, figures $1-7$.

De Iuliis, G., M.S. Bargo, and S.F. Vizcaino

2000. Variation in Skull Morphology and Mastication in the Fossil Giant Armadillos Pampatherium spp. and Allied Genera (Mammalia: Xenartha: Pampatheriidae), with Comments in Their Systematics and Distribution. Journal of Vertebrate Paleontology, 20(4):743-754.

Downing, K.F., and R.S. White

1995. The Cingulates (Xenarthra) of the Leisey Shell Pit Local Fauna (Irvingtonian), Hillsborough County, Florida. Bulletin of the Florida Museum of Natural History, 37:375-396.

Edmund, A.G.

1985a. The Fossil Giant Armadillos of North America (Pampatheriinae, Xenarthra=Edentata). In G.G. Montgomery, editor, The Evolution and Ecology of Armadillos, Sloths, and Vermilinguas, pages 83-94. Washington, D.C.: Smithsonian Institution Press.

1985b. The Armor of Fossil Giant Armadillos (Pampatheriidae, Xenarthra,
Mammalia). Pearce-Sellards Series, Texas Memorial Museum, 40 20 pages.

1987. Evolution of the Genus Holmesina (Pampatheriidae, Mammalia) in Florida, with Remarks on Taxonomy and Distribution. Pearce-Sellards Series, Texas Memorial Museum, 45: 20 pages.

1996. A Review of Pleistocene Giant Armadillos (Pampatheriidae, Xenarthra, Mammalia). In K.M. Stewart and K.L. Seymour, editors, Palaeoecology and Palaeoenvironments of Late Cenozoic Mammals: Tributes to the Career of C.S. (Rufus) Churcher, pages 300-321. Toronto: University of Toronto Press.

Edmund, A.G., and J.M. Theodor

1997. A Giant New Pampatheriid Armadillo. In R.F. Kay, R.H. Madden, R.L. Cifelli, and J.J. Flynn, editors, Vertebrate Paleontology in the Neotropics: The Miocene Fauna of La Venta, Colombia, pages 227-232. Washington, D.C.: Smithsonian Institution Press.

Engelmann, G.F.

1985. The Phylogeny of the Xenarthra. In G.G. Montgomery, editor, The Evolution and Ecology of Armadillos, Sloths, and Vermilinguas, pages 51-64. Washington, D.C.: Smithsonian Institution Press.

Gillette, D.D., and C.E. Ray

1981. Glyptodonts of North America. Smithsonian Contributions to Paleobiology, 40:1-255.

Hoffstetter, R.

1958. Xenarthra. In J. Piveteau, editor, Traité de Paléontologie, 6:534 636. Paris: Masson.

Holmes, W.W., and G.G. Simpson

1931. Pleistocene Exploration and Fossil Edentates in Florida. Bulletin of the American Museum of Natural History, 59:383-418.

Hulbert, R.C., Jr., and G.S. Morgan

1993. Quantitative and Qualitative Evolution in the Giant Armadillo Holmesina (Edentata: Pampatheriidae) in Florida. In R.A. Martin and A.D. Bamosky, editors, Morphological Change in Quaternary Mammals of North America, pages 134-177. New York: Columbia University Press.

James, G.T.

1957. An Edentate from the Pleistocene of Texas. Journal of Paleontology, 31:796-808.

Kraglievich, $\mathrm{L}$.

1934. La antigüedad pliocena de las faunas de Monte Hermoso y Chapadmalal, deducidas de su comparación con las que le precedieron y sucedieron. 133 pages. Montevideo: El Siglo Ilustrado.

Lydekker, $\mathrm{R}$.

1894. Contributions to a Knowledge of the Fossil Vertebrates of Argentina, Part II(2): The Extinct Edentates of Argentina. Anales del Museo de La Plata, Paleontologia Argentina, III: 118 pages.

Marshall, L.G., A. Berta, R. Hoffstetter, R. Pascual, O.A. Reig, M. Bombin, and A. Mones

1984. Mammals and Stratigraphy: Geochronology of the Continental Mammal-Bearing Quaternary of South America. Palaeovertebrata (Montpellier), Mémoire Extraordinaire, 1984: 76 pages.

Marshall, L.G., R. Hoffstetter, and R. Pascual

1983. Mammals and Stratigraphy: Geochronology of the Continental Mammal-Bearing Tertiary of South America. Palaeovertebrata (Montpellier), Mémoire Extraordinaire, 1983: 93 pages.

Marshall, L.G., and B. Patterson

1981. Geology and Geochronology of the Mammal-Bearing Tertiary of the Valle de Santa Maria and Rio Corral Quemado, Catamarca Province, Argentina. Fieldiana, new series (Geology), 9:1-80.

Mones, $\mathrm{A}$.

1986. Palaeovertebrata Sudamericana, Catálogo Sistemático de los Vertebrados Fósiles de América del Sur, Parte I: Lista Preliminar y Bibliografia. Courier Forschungsinstitut Senckenberg, 82:1-625. 
Moreno, F.P., and A. Mercerat

1891. Paleontología. Revista del Museo de La Plata, 1:222-236.

Morgan, G.S., and R.C. Hulbert, Jr.

1995. Overview of the Geology and Vertebrate Biochronology of the Leisey Shell Pit Local Fauna, Hillsborough County, Florida. Bulletin of the Florida Museum of Natural History, 37:1-92.

Pascual, R., and O. Odreman Rivas

1973. Las unidades estratigráficas del terciario portadores de mamíferos, su distribución y sus relaciones con las acontecimentos diastróficos. Actas del Quinto Congreso Geológico Argentino, 3:293-338.

Pascual, R., E.J. Ortega Hinojosa, D. Gondar, and E.P. Tonni

1966. Vertebrata. In A.V. Borrello, editor, Paleontografia Bonaerense, 4 202 pages. La Plata: Comisión de Investigaciones Científicas.

Patterson, B., and R. Pascual

1972. The Fossil Mammal Fauna of South America. In A. Keast, F.C. Erk, and B. Glass, editors, Evolution, Mammals, and Southern Continents, pages 247-309. Albany: State University of New York Press.

Patterson, B., W. Segall, and W.D. Turnbull

1989. The Ear Region in Xenarthrans (=Edentata: Mammalia), Part I: Cingulates. Fieldiana, new series (Geology), 18:1-46.

Paula Couto, C. de

1954. Sôbre um gliptodonte do Uruguai e um tatú fóssil do Brasil. Notas Preliminares e Estudos, Divisão de Geologia e Mineralogia, 80: $1-10$.

1979. Tratado de Paleomastozoologia. 590 pages. Rio de Janeiro: Academia Brasileira de Ciências.

Riggs, E.S., and B. Patterson

1939. Stratigraphy of Late Miocene and Pliocene Deposits of the Province of Catamarca (Argentina) with Notes on the Faunae. Physis, 14: 143-162.

Robertson, J.S

1976. Latest Pliocene Mammals from Haile 15A, Alachua County, Florida. Bulletin of the Florida State Museum, Biological Sciences, 20: 111-186.
Rovereto, C.

1914. Los estratos araucanos y sus fósiles. Anales del Museo Nacional de Historia Natural (Buenos Aires), 25: 250 pages.

Scillato-Yané, G.J.

1980. Catálogo de los Dasypodidae fósiles (Mammalia, Edentata) de la República Argentina. Actas del Segundo Congreso Argentino de Paleontologia y Bioestratigrafia y Primero Congreso Latinoamericano de Paleontologia, Buenos Aires, 1978, 3:7-36.

1982. Los Dasypodidae (Mammalia, Edentata) del Plioceno y Pleistoceno de Argentina. 159 pages. Doctoral dissertation, Facultad de Ciencias Naturales y Museo, Universidad Nacional de La Plata. La Plata, Argentina.

Scott, W.B.

1903. Mammalia of the Santa Cruz Beds, Part I: Edentata; Part ll: Glyptodontia and Gravigrada. Reports of the Princeton University Expeditions to Patagonia, 1896-1899. Palaeontology, 5:107-227.

Simpson, G.G.

1930. Holmesina septentrionalis, Extinct Giant Armadillo of Florida. American Museum Novitates, 442: 10 pages.

1948. The Beginning of the Age of Mammals in South America, Part 1: Introduction; Systematics: Marsupialia, Edentata, Condylarthra, Litopterna and Notioprogonia. Bulletin of the American Museum of Natural History, 91(1):1-232.

Smith, K.K., and K.H. Redford

1990. The Anatomy and Function of the Feeding Apparatus in Two Armadillos (Dasypoda): Anatomy ls Not Destiny. Journal of Zoology (London), 222:27-47.

Vizcaíno, S.F., G. De luliis, and M.S. Bargo

1998. Skull Shape, Masticatory Apparatus, and Diet of Vassallia and Holmesina (Mammalia: Xenartha: Pampatheriidae): When Anatomy Constrains Destiny. Journal of Mammalian Evolution, 5(4): 291-322.

Winge, $\mathrm{H}$.

1915. Jordfunde og nulevende Gumlere (Edentata) fra Lagoa Santa, Minas Geraes, Brazilien. E Museo Lundii, 3(2): 321 pages, 42 plates. 


\title{
Additional Records of the Giant Beaver, Castoroides, from the Mid-South: Alabama, Tennessee, and South Carolina
}

\author{
Paul W. Parmalee and Russell Wm. Graham
}

\begin{abstract}
Four previously unreported records of Castoroides provide supportive evidence that the giant beaver probably occurred throughout the southeastern United States, especially along the middle stretch of the Tennessee River. A distal section of an upper right incisor and an incisor fragment of the extinct Pleistocene giant beaver, Castoroides, were recovered from Bell Cave, Colbert County, Alabama. Cave ACb-3, also in Colbert County and containing an extensive deposit of late Pleistocene megafauna, yielded a single incisor enamel fragment. A fragment of a left ilium of this beaver was found in a dry stream bed in Ruby Falls Cave, Lookout Mountain, Hamilton County, Tennessee. These four specimens are referred to Castoroides sp.

A relatively complete skull of Castoroides has been recovered from the Cooper River, near Strawberry Hill, Charleston County, South Carolina. The cranial characters of this specimen make it referable to Castoroides leiseyorum Morgan and White, 1995, which was described from the Irvingtonian Leisey Shell Pit, Hillsborough County, Florida. The taxonomy of Castoroides from the southeastem United States is uncertain, and at least two different interpretations are possible.
\end{abstract}

\section{Introduction}

The extinct giant beaver, Castoroides Foster, 1838, was the largest rodent known in North America during the Pleistocene, reaching a length of about $2.5 \mathrm{~m}$ and a weight between 150 and $200 \mathrm{~kg}$ (Kurtén and Anderson, 1980). The animal possessed huge convex incisors that in adult individuals extended 75 to $100 \mathrm{~mm}$ beyond the gum line. Longitudinal grooves and ridges on the exterior enamel make even small fragments diagnostic.

Paul W. Parmalee, Frank H. McClung Museum, University of Tennessee, Knoxville, Tennessee 37996. Russell Wm. Graham, Earth Sciences, Denver Museum of Natural History, 2001 Colorado Boulevard, Denver, Colorado 80205.
The rounded and blunt tips of the incisors, along with certain features of the skull and relative proportions of postcranial elements, have led several researchers (e.g., Barbour, 1931; Stirton, 1965) to conclude that Castoroides, unlike the modern beaver, Castor canadensis Kuhl 1820, would not have been effective at felling trees. Considered to have been an inhabitant of lakes and ponds bordered by swamps, the giant beaver was probably more similar in habits to the muskrat, Ondatra zibethicus (Linnaeus, 1766), than to C. canadensis. "The teeth were used in cutting off and grinding up the coarse swamp vegetation on which the giant beaver fed" (Kurtén and Anderson, 1980:236).

Cahn (1932) summarized distribution records of the giant beaver, based upon reported specimens by state, known at that time. Nearly 50 years later Kurtén and Anderson (1980) noted that it had been reported from 30 local faunas as well as from hundreds of isolated sites. Although its remains have been found as far north as Alaska and as far south as Florida, and from Nebraska to the East Coast, Castoroides apparently occurred most abundantly in the region immediately south of the Great Lakes (Faunmap Working Group, 1994). Relatively abundant remains of Castoroides also have been recorded in Florida (Martin, 1969, 1975; Morgan and White, 1995). There are, however, few records of this extinct beaver (Faunmap Working Group, 1994) for the mid-South $\left(\sim 33^{\circ} \mathrm{N}-36^{\circ} \mathrm{N}\right)$ east of the Mississippi River. The most recent record of Castoroides from Alabama, and apparently the first for the state, is of an incisor fragment from the Bogue Chitto Creek site, a late Pleistocene vertebrate assemblage in the coastal plain west of Selma, Dallas County (McCarroll and Dobie, 1994). A large portion of a right lower jaw with full dentition from Shelby County, Tennessee, was first described by Wyman (1850) and was referred to as the "Memphis specimen" by Cahn (1932:234). Parmalee et al. (1976) reported isolated cheek teeth from two caves in east Tennessee: Baker Bluff Cave (Sullivan County) and an unnamed cave along the Clinch River 


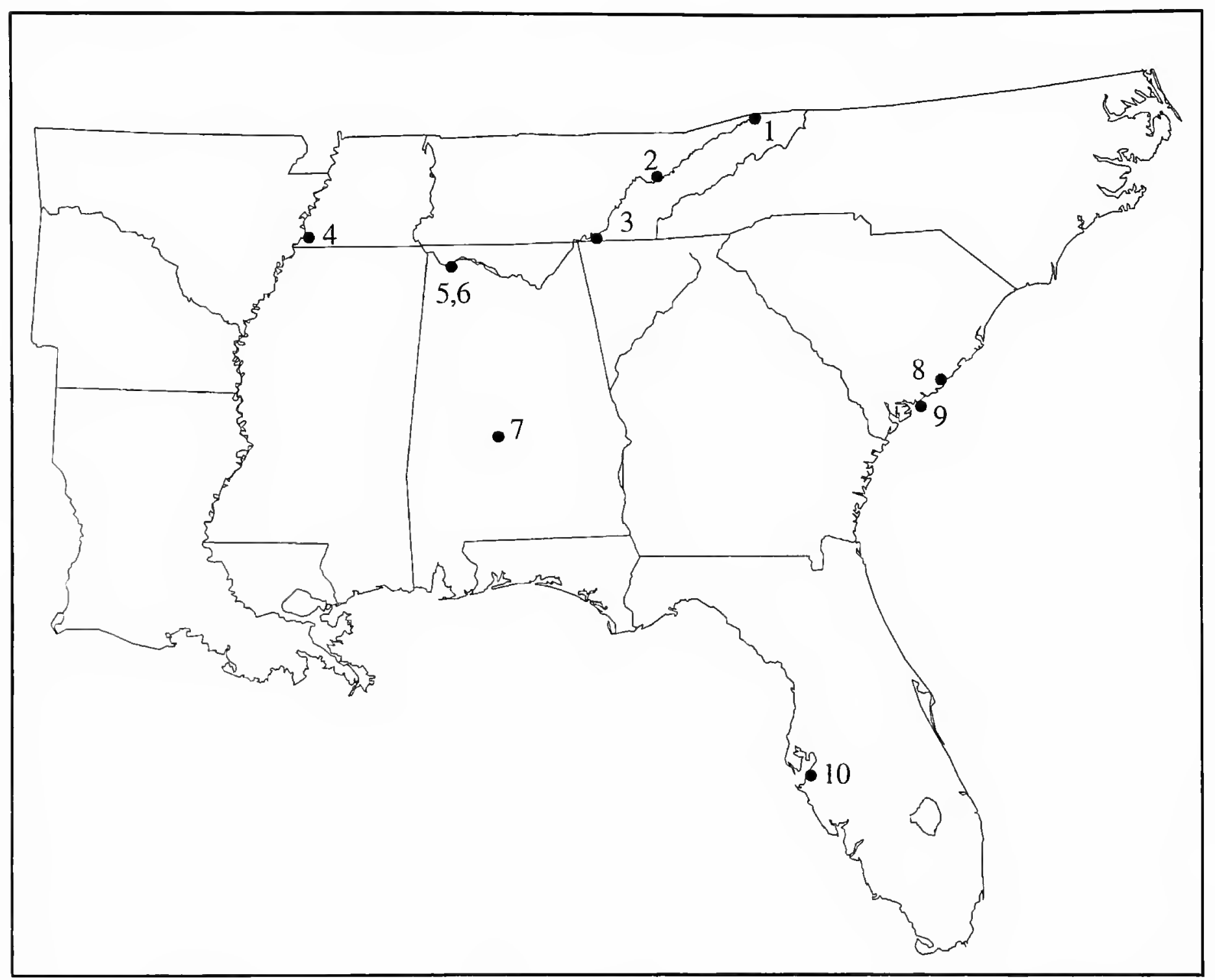

FIGURE 1.-Map showing the location of Castoroides localities mentioned in the text: $1=$ Baker Bluff Cave, Sullivan County, Tennessee; $2=$ Clinch River Unnamed Cave, Roane County, Tennessee; $3=$ Ruby Falls Cave, Hamilton County, Tennessee; $4=$ "Memphis specimen," Shelby County, Tennessee; $5=$ Bell Cave, Colbert County, Alabama; $6=$ Cave ACb-3, Colbert County, Alabama; $7=$ Bogue Chitto Creek, Dallas County, Alabama; $8=$ Strawberry Hill, Charleston County, South Carolina; $9=$ Edisto Island, Charleston County, South Carolina; $10=$ Leisey Shell Pit, Hillsborough County, Florida.

(Roane County). Castoroides $\mathrm{cf}$. ohioensis also has been reported from Edisto Island, a barrier island located $34 \mathrm{~km}$ southwest of Charleston, South Carolina (Roth and Laerm, 1980). We herein report four new records for the mid-South region (Figure 1): one from Tennessee (Hamilton County), two from Alabama (Colbert County), and one from South Carolina (Charleston County).

ACKNOWLEDGMENTS.- - Special appreciation is extended to Kent Ballew for bringing to our attention bone deposits he discovered in Ruby Falls Cave and for collecting samples for study. We thank Jack Steiner and Ronnie Burk for granting permission to examine the vertebrate material and to publish this record of Castoroides from Ruby Falls Cave. Gorden L. Bell and James P. Lamb, directors of the Bell and ACb-3 cave excavations, and Susan Henson, Discovery 2000 (formerly known as Red Mountain Museum), are acknowledged with gratitude for the loan of the giant beaver specimens from these caves and for permission to publish the records. We acknowledge with thanks Patricia P. Adams for assisting with the collection of specimens in Ruby Falls Cave. We appreciate the assistance of Maria Wilson and Malinda Aiello for typing drafts of the manuscript. We thank Jeffrey Saunders for providing access to the Castoroides innominate from the Hopwood Farm site. We extend our gratitude to Ruth Holmes Whitehead for bringing to our attention the skull from Strawberry Hill. We also thank James Knight for access to the Strawberry Hill specimen and for permission to describe it. We appreciate the efforts of W. Miles Wright and Marlin Roos for preparation of the photographs. We thank R. Bruce McMillan for his valuable comments on an earlier draft of the manuscript and we appreciate reviews by William Korth and Fred Grady.

\section{Material}

During 1991-1993, Kent Ballew from Hixon, Tennessee, was able to investigate several extensive unexplored passage- 


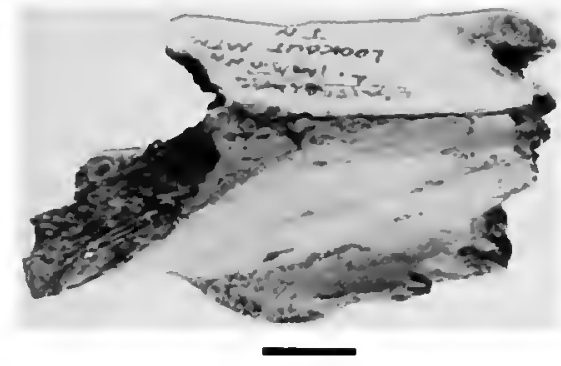

FIGURE 2.--Section of left ilium of Castoroides sp. from Ruby Falls Cave, Hamilton County, Tennessee.

ways forming a complex multilevel system of corridors in Ruby Falls, a commercially operated cave in Lookout Mountain, Chattanooga, Hamilton County, Tennessee. This cave, overlooking the Tennessee River, has been inhabited by animals since late Pleistocene times. Many of the more accessible passageways have been greatly modified by human activity in historic times, including mining for saltpeter during the Civil War, and more recently by enlarging and straightening passages to accommodate visitors.

Animal remains occur in many of the passageway floors and streambeds; a varied extant fauna is represented, as well as extinct Pleistocene taxa, such as jaguar (Panthera onca (Linnaeus, 1758)) and tapir (Tapirus (Brunnich, 1772)). In the fall of 1993, Mr. Ballew recovered a $63.5 \mathrm{~mm}$ long section of a left ilium broken just anterior of the acetabulum (Figure 2). It was found lying on the surface of a dry streambed, but the original site of deposition could not be determined. The specimen was compared with a complete Castoroides innominate from the Hopwood Farm site, Montgomery County, Illinois (King and Saunders, 1986), housed in the paleontological collections of the Illinois State Museum, Springfield, Illinois. Although

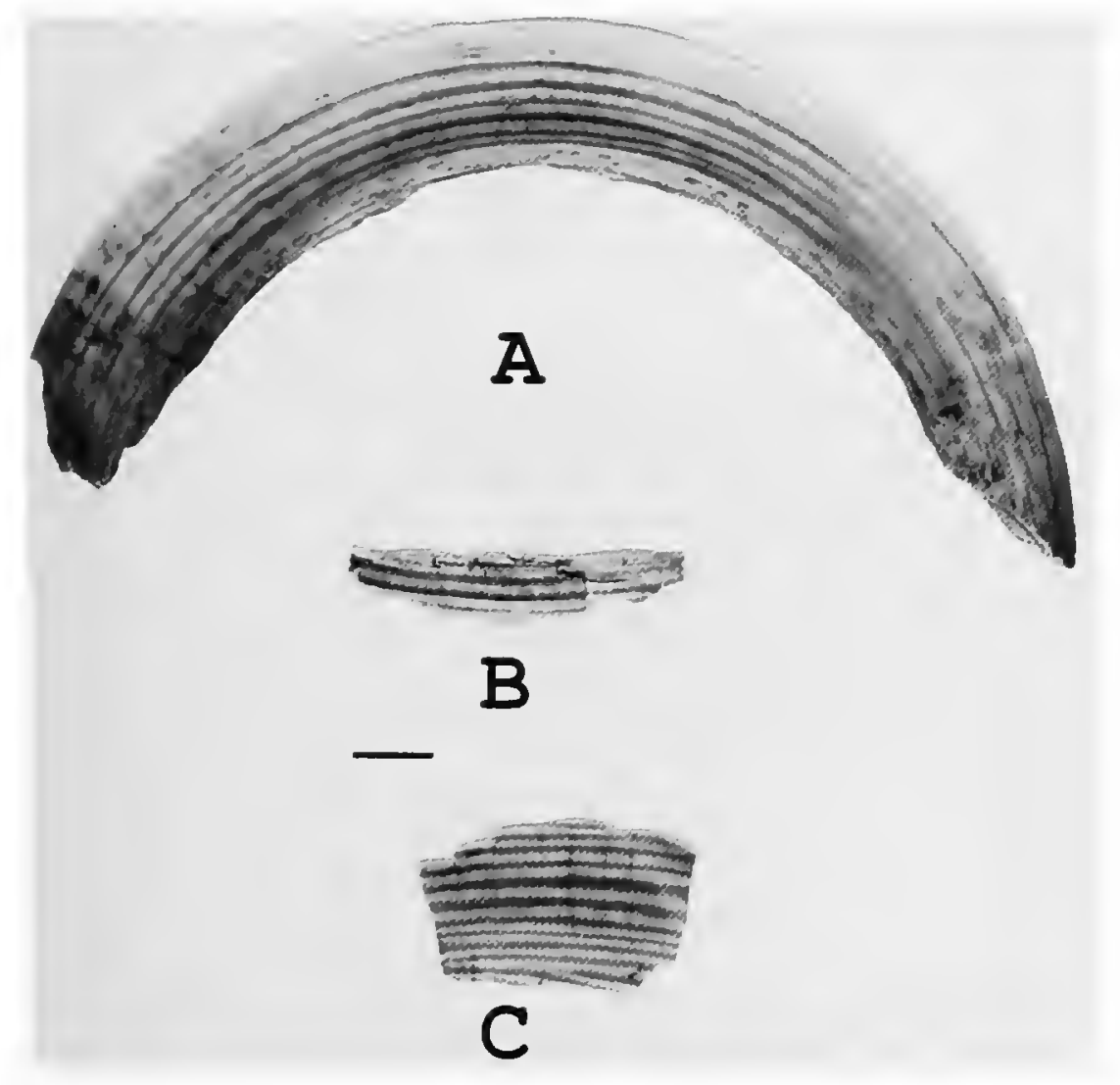

FIGURE 3.-Castoroides sp. from Bell Cave, Colbert County, Alabama: A, upper right incisor (RMM 4000); B, incisor fragment (RMM 5547); C, incisor fragment (RMM 6223). slightly smaller and less rugose, the Ruby Falls specimen can be assigned to Castoroides with certainty. The size differences in these two specimens may be attributed to sexual dimorphism, ontogenetic development, or geographic variation.

During the summers of 1984 and 1987, paleontologists from the Red Mountain Museum (RMM) dug six excavation units (1 $\times 1 \mathrm{~m}$ ) into the floor of Bell Cave, located in the south bluff of the Tennessee River (Tennessee River Mile 248.2 (km 397.1) $\sim 11 \mathrm{~km}$ west of Tuscumbia, Colbert County, Alabama). A species-rich vertebrate assemblage was recovered, which included remains of fish, turtles, birds (Parmalee, 1992), and mammals. Many of the extant species, such as fisher (Martes pennanti Erxleben, 1777) and caribou (Rangifer tarandus (Linnaeus, 1758)) (Churcher et al., 1989), have boreal affinities and no longer occur in the area. In addition to extant mammals, extinct species including tapir (Tapirus sp.) and long-nosed peccary (Mylohyus nasutus Leidy, 1869) also were represented. Remains of the giant beaver from Bell Cave consisted of a 195.0 $\mathrm{mm}$ external section of an upper right incisor (RMM 4000) and a $44.0 \times 10.5 \mathrm{~mm}$ incisor fragment (RMM 5547) (Figure 3A,B). Radiocarbon dates indicate that the accumulation of vertebrate remains occurred between ca. 25,000 and 11,500 radiocarbon years before present (RCYBP).

Lively et al. (1992) reported Uranium (U)-series dates from travertines associated with a late Pleistocene megafauna recovered in a cave designated as ACb-3 (Colbert County, Alabama). This cave is $\sim 70 \mathrm{~m}$ long $\times 15 \mathrm{~m}$ wide and has several huge open rooms. It is situated $\sim 0.5 \mathrm{~km}$ west of Little Bear Creek (Tennessee River Mile 249.5 ( $\mathrm{km}$ 399.2)). ACb-3 was excavated by paleontologists from RMM during the summers of 1985 and 1987. Like Bell Cave, it contained remains of both extant and extinct taxa; included in the latter group were Tapirus sp., $M$. nasutus, sabertooth (Smilodon fatalis (Leidy, 1868)), beautiful armadillo (Dasypus bellus (Simpson, 1930)), and Jefferson's ground sloth (Megalonyx jeffersonii (Desmarest, 1822)). Jefferson's ground sloth was represented by a minimum of six individuals, including old adults and infants. Castoroides was represented in the assemblage by a single incisor enamel fragment (RMM 6223) measuring $36.5 \times 22.0 \mathrm{~mm}$ (Figure 3C). According to the U-series dates, ACb-3 "was accumulating small vertebrate remains as early as 228,000 B.P. and was visited by large vertebrates from about 170,000 years to at least 115,000 years B.P. and probably later" (Lively et al., 1992:1).

A skull of Castoroides (Figure 4) was recovered by divers from the Cooper River, near Strawberry Hill, Charleston County, South Carolina. It has been reposited under the number SC75.33.1 in the South Carolina State Museum, Columbia, South Carolina. The skull is relatively complete, but both zygomatics (Figure 4A) and both incisors (Figure 4B) have been broken. In addition, the right maxilla and the right palatine bones have been broken just posterior to the alveolus for P4, but the left maxilla is complete with alveoli for the left P4-M3 (Figure 4C). All of the molar and premolar teeth are missing. The left palatine bone is broken and missing. Most of the su- 

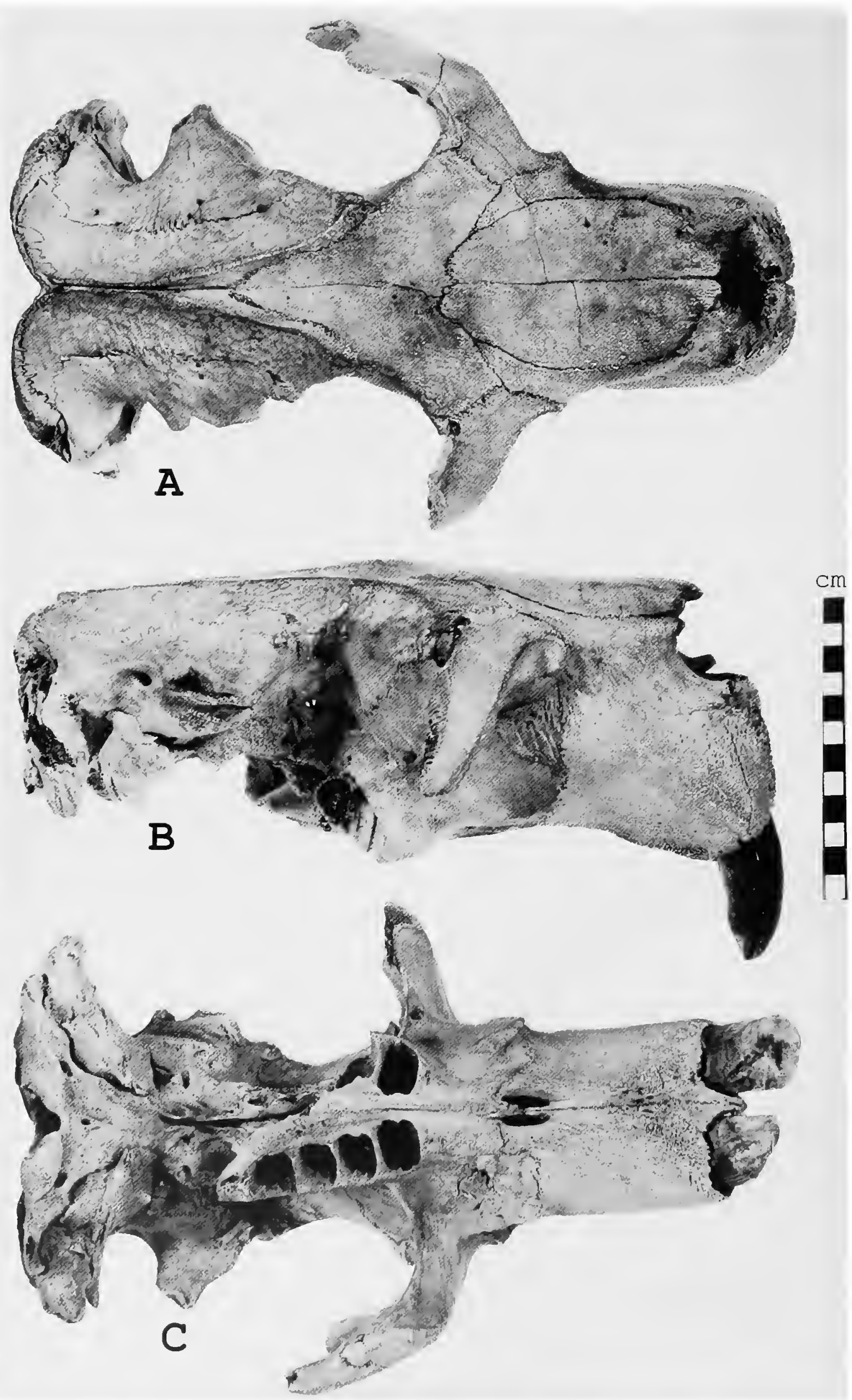

FIGURE 4.-Cranium (SC75.33.1) of Castoroides leiseyorum from Cooper River, Strawberry Hill, South Carolina: A, dorsal view; B, right lateral view; C, ventral view. 
TABLE 1.-Measurements (in mm) of the cranium (SC75.33.1) of Castoroides leiseyorum from Cooper River, Strawberry Hill, South Carolina.

\begin{tabular}{|c|c|c|c|}
\hline Cranial feature & Unsided & Right side & Left side \\
\hline $\begin{array}{l}\text { 1. Greatest length from anterior end of premaxillary to posterior end of occipital } \\
\text { condyles }\end{array}$ & 289.4 & - & - \\
\hline $\begin{array}{l}\text { 2. Basal length from anterior end of premaxillary to inferior notch between occipi- } \\
\text { tal condyles }\end{array}$ & 275.2 & - & - \\
\hline $\begin{array}{l}\text { 3. Greatest length from anterior end of premaxillary to posterior edge of palatine } \\
\text { wing of interpterygoid at dorsal choana }\end{array}$ & 238.3 & - & - \\
\hline $\begin{array}{l}\text { 4. Greatest length from anterior end of premaxillary to anterior edge of incisive fo- } \\
\text { ramen }\end{array}$ & 83.5 & - & - \\
\hline $\begin{array}{l}\text { 5. Greatest length from anterior end of nasals to dorsomedial notch of lamboidal } \\
\text { crest }\end{array}$ & 248.6 & - & - \\
\hline $\begin{array}{l}\text { 6. Greatest length from anterior end of premaxillary to posterior edge of lamboidal } \\
\text { crest }\end{array}$ & - & 284.8 & 283.8 \\
\hline 7. Chord from posterior edge of incisor alveolus to anterior edge of $\mathrm{P} 4$ alveolus & 112.9 & - & - \\
\hline $\begin{array}{l}\text { 8. Length of alveolar tooth row from anterior edge of } \mathrm{P} 4 \text { alveolus to posterior edge } \\
\text { of } \mathrm{M} 3 \text { alveolus }\end{array}$ & - & 67.4 & - \\
\hline $\begin{array}{l}\text { 9. Length of alveolar molar row from anterior edge of } \mathrm{M} 1 \text { alveolus to posterior } \\
\text { edge of } \mathrm{M} 3 \text { alveolus }\end{array}$ & - & - & 49.8 \\
\hline 10. Greatest mediolateral diameter of 11 alveolus & - & 33.6 & 33.4 \\
\hline 11. Greatest anterodorsal diameter of 11 alveolus & - & 31.2 & 31.8 \\
\hline 12. Width from lateral anterior edges of alveoli for $\mathrm{P} 4 \mathrm{~s}$ & 39.6 & - & - \\
\hline 13. Greatest width across rostrum from lateral edges of the alveoli for the incisors & 74.3 & - & - \\
\hline 14. Greatest width of anterior nares at premaxillo-nasal sutures & 41.5 & - & - \\
\hline 15. Greatest height of anterior nares from nasal suture to premaxillary suture & 42.7 & - & - \\
\hline $\begin{array}{l}\text { 16. Greatest width across rostrum at the maxillo-premaxillary suture at anteroven- } \\
\text { tral edge of the infraorbital foramen }\end{array}$ & 80.9 & - & - \\
\hline 17. Least width of postorbital constriction at fronto-parietal sutures & 66.1 & - & - \\
\hline 18. Greatest width across postorbital processes & 85.9 & - & - \\
\hline 19. Least width of postzygomatic constriction across squamosals and parietals & 81.6 & - & - \\
\hline 20. Greatest width between outer edges of mastoid processes & 150.6 & - & - \\
\hline 21. Greatest width between outer edges of parocciptal processes & 115.6 & - & - \\
\hline 22. Greatest diameter of foramen magnum at medial edges of occipital condyles & 28.0 & - & - \\
\hline 23. Greatest height of foramen magnum & 19.0 & - & - \\
\hline 24. Height of occiput from base of basioccipital to middle of lamboidal crest & 68.5 & - & - \\
\hline 25. Height of rostrum above incisive foramen & 98.0 & - & - \\
\hline
\end{tabular}

tures in the skull have not fused completely, although the size of the skull indicates that the individual was an adult. Cranial measurements are given in Table 1.

Morgan and White (1995) described a new species, Castoroides leiseyorum, from the Irvingtonian Leisey Shell Pit, Hillsborough County, Florida. Castoroides leiseyorum is biometrically and morphologically similar to $C$. ohioensis (Morgan and White, 1995). Castoroides leiseyorum is distinguished from $C$. ohioensis, in part, however, by the absence of the palatine wing of the interpterygoid fossa and the mesopterygoid fossa (Morgan and White, 1995:416). Specifically, Castoroides species are unique in possessing two separate openings for the posterior internal nares (see Stirton, 1965:280, fig. 3 for a detailed description). These two openings are referred to as the dorsal and ventral choanae. A large, deep, ovate fossa in the basisphenoid just posterior of the dorsal choana is known as the mesopterygoid fossa, and it is one of the most unusual characters of C. ohioensis (Stirton, 1965:280). The mesopterygoid fossa is clearly apparent in figured specimens of $C$. ohioensis from New York (Stirton, 1965, fig. 3) and Iowa (Hay, 1914, pl. 71: fig. 1).
Castoroides leiseyorum has both ventral and dorsal choanae but lacks the mesopterygoid fossa. Instead, the basisphenoid bears a slightly concave, elongated groove along the midline that connects anteriorly to the dorsal choana (Morgan and White, 1995:416). Although the posterior palatine region of the South Carolina specimen (SC75.33.1) is broken, the basisphenoid and dorsal choana are well preserved. The South Carolina specimen, like the Florida specimens of $C$. leiseyorum, lacks a deep, ovate mesopterygoid fossa, but it has a slight concave groove extending into the dorsal choana (Figure 4C).

Morgan and White (1995:420) also stated that "there is a slight ridge along the midline of the basioccipital in the Leisey crania and the portion of the basioccipital lateral to this ridge is only slightly concave." The same is true for the basioccipital of the South Carolina specimen (Figure 4C). In "typical" specimens of $C$. ohioensis, the median ridge is higher and the lateral fossae are well developed (more concave) (Morgan and White, 1995:420).

In addition, the lamboidal crests in C. leiseyorum form a distinct $V$-shaped outline, whereas in $C$. ohioensis the lamboidal crest is sharper and more vertical, and it meets the sagittal crest 
at nearly a right angle (Morgan and White, 1995). The lamboidal crest of the South Carolina specimen is V-shaped like that of C. leiseyorum (Figure 4A). Because the South Carolina skull shares diagnostic characteristics with $C$. leiseyorum Morgan and White, 1995, it is assigned to this taxon.

\section{Discussion}

Because of its size, the distinctive occlusal pattern of the cheek teeth, the unique longitudinally grooved enamel on the anterior and labial surfaces of the huge incisors, and its former extensive range, the giant beaver is one of the most intriguing species constituting the late Pleistocene megafauna of eastern North America. It is thought to have been more like the muskrat in its habits than the modern beaver, inhabiting river bottom lakes, embayments, and associated bogs and swamplands where it probably fed on coarse marsh vegetation. Kurtén and Anderson (1980:236) stated that "there is no evidence that the giant beaver built dams or felled trees." Castoroides ohioensis appears to have reached its greatest abundance in areas adjacent to the Great Lakes, especially the region that is now Michigan, Illinois, Indiana, and Ohio. The animal apparently was able to adapt well to a wide variety of environments with aquatic habitats, as evidenced by its extensive temporal (Blancan to Rancholabrean) and geographic (Alaska to Florida and Nebraska to East Coast) ranges.

Just as for the majority of the megafauna species, reasons for extinction of the giant beaver at the end of the Pleistocene are unclear (e.g., Martin and Klein, 1984). In the northern latitudes a combination of a gradual increase in the annual mean temperature, resulting in replacement of a spruce/pine/hemlock forest with a deciduous one, and reduction of backwater marsh and swamp habitat may have brought about the animal's demise. The natural reorganization of biological communities at the end of the Pleistocene may have resulted in the destruction of habitats for many mammal species (Graham and Lundelius, 1984). Cahn (1932) noted that a radical change would not have been required for climatic, biotic, or hydrographic conditions to have a profound effect on a highly specialized form such as Castoroides. Competition for habitat with $C$. canadensis as a factor, as has been suggested by Cahn (1932) and others, is questionable in light of apparent differences between the two relative to foods, feeding behavior, and general adaptations to aquatic habitat. Furthermore, these two taxa appear to have coexisted throughout much of the Pleistocene (Kurtén and Anderson, 1980).

Remains of Castoroides sp. from Ruby Falls, Bell, and ACb3 caves provide new records of this extinct beaver for the midSouth and establish its former presence along the middle stretch of the Tennessee River. During the late Pleistocene, floodplain lakes and marshes bordering the middle (northwestern Georgia, northern Alabama) and lower stretches of the Tennessee River were probably extensive. These environments probably persisted into the Holocene. Parmalee (1993:81), in reporting an avian assemblage from Smith Bottom Cave, Lauderdale County, Alabama, (approximately opposite Bell and ACb-3 caves), a primarily Archaic aboriginal deposit $8950 \pm$ 950 RCYBP, commented that "the predominance of remains of ducks such as the mallard (Anas platyrhynchos), teal and closely related species suggests considerable expanses of backwater sloughs, embayments and floodplain lakes within close vicinity to the site."

The taxonomy of Castoroides in the southeastern United States is not clear. Morgan and White (1995:420) indicated that the Leisey specimens may represent the early stages in the evolution of Castoroides, especially with regard to the development of the basicranial region of the skull. The Leisey fauna correlates most closely with the late early Irvingtonian, 1.6 to 1.0 million years ago (Morgan and Hulbert, 1995). The age of the South Carolina specimen is unknown, but it is quite likely late Pleistocene. It is, therefore, possible that the basicranial features of $C$. leiseyorum are actually geographic variants within $C$. ohioensis rather than characters diagnostic of a chronospecies. The lack of a mesopterygoid fossa may, consequently, be characteristic of a southeastern phenon of Castoroides. This hypothesis could be tested, if the South Carolina specimen could be dated by radiocarbon methods (e.g., Stafford et al., 1991). It is interesting to note that all specimens of Castoroides documented to have a mesopterygoid fossa, a high median ridge and well-developed lateral fossa on the basioccipital, and a strong lamboidal crest that joins the sagittal crest at right angles (typical C. ohioensis features) come from northern states (e.g., New York, Illinois, Iowa).

Martin (1969) described, on the basis of dental parameters, an extinct subspecies of $C$. ohioensis, $C$. o. dilophidus, from Florida. Castoroides ohioensis dilophidus has been found throughout Florida and may persist from the Blancan into the late Rancholabrean (Martin, 1969, 1975). Morgan and White (1995:421), however, noted that the presumed Blancan specimens of C. o. dilophidus are from the Santa Fe 1B fauna, which may be a heterochronic mixture of Blancan and Irvingtonian vertebrates. The diagnostic character of $C$. $o$. dilophidus is the occurrence of two isolated lophs (ids) in place of a single anterior loop in the upper third molar and the lower fourth premolar (Martin, 1969:1035).

Martin (1969) also assigned some postcranial elements to this subspecies, but cranial material of this taxon apparently was not known. In their later review, Morgan and White (1995: 420-421) indicated that other than the two Leisey specimens, there are no crania of Castoroides from Florida with a basicranial region. Different diagnostic criteria have been used for the various Florida taxa, so it is difficult to compare $C$. leiseyorum (cranial characters) with C. o. dilophidus (dental characters). The only lower fourth premolar from Leisey lacks the isolated lophid characteristic of C. o. dilophidus (Morgan and White, 1995:416). Martin (1969:1035), however, indicated that not all upper third molars and lower fourth premolars of C.o. dilophidus have the diagnostic isolated lophs (ids). In the original 
samples he studied, Martin (1969:1035) found that only $83 \%$ $(n=6)$ and $29 \%(n=7)$ of the lower fourth premolars and upper third molars, respectively, had the diagnostic feature. Absence of the diagnostic feature in the only lower fourth premolar from Leisey therefore does not significantly distinguish the Leisey sample of $C$. leiseyorum from $C$. o. dilophidus.

Two different interpretations of current knowledge of the taxonomy and evolutionary history of Castoroides in the Southeast are possible. On the one hand, it may be that the more typical $C$. ohioensis morphology (sensu stricto Stirton, 1965 ) is characteristic of more northern populations, and that C. leiseyorum and C. o. dilophidus are the same southern geographic variant of $C$. ohioensis. Under this scenario, C. leisey- orum represents cranial characters and $C$. o. dilophidus typifies dental features of this southeastern phenon. If this proves to be the case, then $C$. leiseyorum should be synonymized with $C$. ohioensis, and, depending upon additional taxonomic evaluations, either $C$. o. dilophidus or $C$. dilophidus would be the appropriate name. On the other hand, if $C$. leiseyorum is shown to be distinct from $C$. o. dilophidus, then it appears that two different phena ( $C$. leiseyorum and $C$. o. dilophidus) may have persisted throughout the southeastern United States (at least Florida and South Carolina) for most of the Pleistocene. Further studies of associated cranial and dental material are required before either of these interpretations can be refuted.

\section{Literature Cited}

Barbour, E.H.

1931. The Giant Beaver, Castoroides, and the Common Beaver, Castor, in Nebraska. Nebraska State Museum Bulletin, 20(1):171-186.

Cahn, A.R.

1932. Records and Distribution of the Fossil Beaver, Castoroides ohioensis. Journal of Mammalogv, 13(3):229-241.

Churcher, C.S., P.W. Parmalee, G.L. Bell, and J.P. Lamb

1989. Caribou from the Late Pleistocene of Northwestern Alabama. Canadian Journal of Zoology, 67:1210-1216.

Faunmap Working Group

1994. FAUNMAP: A Database Documenting Late Quaternary Distributions of Mammal Species in the United States. Illinois State Museum Scientific Papers, 25(1-2): 690 pages.

Graham, R.W., and E.L. Lundelius, $\mathrm{J}_{\mathrm{r}}$.

1984. Coevolutionary Disequilibrium and Pleistocene Extinctions. In P.S. Martin and R.G. Klein, editors, Quaternary Extinctions: A Prehistoric Revolution, pages 223-249. Tucson: University of Arizona Press.

Hay, O.P.

1914. Pleistocene Mammals of lowa. Iowa Geological Survey Annual Report, 1912:22

King, J.E., and J.J. Saunders

1986. Geochelone in Illinois and the Illinoian-Sangamonian Vegetation of the Type Region. Quaternary Research, 25(1):89-99.

Kurtén, B., and E. Anderson

1980. Pleistocene Mammals of North America. 442 pages. New York: Columbia University Press.

Lively, R.S., G.L. Bell, and J.P. Lamb, Jr.

1992. Uranium-Series Dates from Travertines Associated with a Late Pleistocene Megafauna in ACb-3, Alabama. Southeastern Geology, 33(1):1-8.

Martin, P.S., and R.G. Klein, editors

1984. Quaternary Extinctions: A Prehistoric Revolution. 892 pages. Tucson: University of Arizona Press.

Martin, R.A.

1969. Taxonomy of the Giant Beaver Castoroides from Florida. Journal of Paleontology, 43(4):1033-1041.

1975. Giant Pleistocene Beavers and the Waccasassa River, Levy County, Florida. Bulletin of the New Jersey Academy of Science, 20(1): 26-30.
McCarroll, S.M., and J.L. Dobie

1994. Additional Pleistocene Mammals from Bogue Chitto Creek, Dallas County, Alabama. Journal of the Alabama Academy of Science 65(1):16-27

Morgan, G.S., and R.C. Hulbert, Jr.

1995. Overview of the Geology and Vertebrate Biochronology of the Leisey Shell Pit Local Fauna, Hillsborough County, Florida. Bulletin of the Florida Museum of Natural History, 37(I)1:1-92.

Morgan, G.S., and J.A. White

1995. Small Mammals (Insectivora, Lagomorpha, and Rodentia) from the Early Pleistocene (Irvingtonian) Leisey Shell Pit Local Fauna, Hillsborough County, Florida. Bulletin of the Florida Museum of Natural History, 37(II) 13:397-461.

Parmalee, P.W.

1992. A Late Pleistocene Avifauna from Northwestern Alabama. Natural History Museum of Los Angeles County, Science Series, 36: 307-318.

1993. An Archaeological Avian Assemblage from Northwestern Alabama. ArchaeoZoology, 5(2):77-92.

Parmalee, P.W., A.E. Bogan, and J.E. Guilday

1976. First Records of the Giant Beaver (Castoroides ohioensis) from Eastern Tennessee. Journal of the Tennessee Academy of Science. $51(3): 87-88$

Roth, J., and J. Laerm

1980. A Late Pleistocene Vertebrate Assemblage from Edisto Island, South Carolina. Brimleyana, 3:1-29.

Stafford, T.W., Jr., P.E. Hare, L. Currie, A.J.T. Jull, and D.J. Donahue

1991. Accelerator Radiocarbon Dating at the Molecular Level. Journal of Archaeological Science, 18:35-72.

Stirton, R.A.

1965. Cranial Morphology of Castoroides. In A.G. Jhingran et al., editors, Dr. D.N. Wadia Commemorative Volume, pages 273-285. Calcutta: Mining, Geological and Metallurgical lnstitute of India.

Wyman, J.

1850. Remarks on Finding Bones of Megalonyx, Castor and Castoroides at Memphis, Tennessee. Proceedings of the Boston Society of Natural History, 3:281. 



\title{
The Northernmost Occurrence of the Pleistocene Vampire Bat Desmodus stocki Jones (Chiroptera: Phyllostomatidae: Desmodontinae) in Eastern North America
}

\author{
Frederick Grady, Joaquín Arroyo-Cabrales, \\ and E. Ray Garton
}

\begin{abstract}
Four bones of the extinct vampire bat Desmodus stocki Jones were recovered from New Trout Cave, Pendleton County, West Virginia. Three of the four elements were located in a level $30 \mathrm{~cm}$ below a level radio-carbon dated to $29,400 \pm 1700$ years before present (BP); the fourth was located in a younger layer but is suspected to have been redeposited. This is the first record of Desmodus stocki from the central Appalachians.
\end{abstract}

\section{Introduction}

The Pleistocene vampire bat Desmodus stocki Jones, 1958, occurs in several localities in the southwestern and southeastern United States, northern Mexico (Ray et al., 1988), and as far south as the valley of Mexico (Alvarez, 1972). Most of the known localities are outside the range of the extant vampire bat, Desmodus rotundus, and these two vampire bats have been considered allopatric species (Alvarez, 1972).

The occurrence of the extinct Desmodus stocki to the north of the common vampire bat's present range has attracted the attention of paleontologists (Ray et al., 1988). The extant vampire bats are intolerant of cold temperatures, and their northernmost occurrence is limited by the $10^{\circ} \mathrm{C}$ winter isotherm (McNab, 1973). Morgan (1991) offered two explanations for

Frederick Grady, Department of Paleobiology, National Museum of Natural History, Smithsonian Institution, Washington, D.C. 205600121, United States. Joaquín Arroyo-Cabrales, Museum of Texas Tech University, Lubbock, Texas 79409-3191, United States, and Subdirección de Servicios Academicos, I.N.A.H., Col. Centro, Distrito Federal 06060, Mexico. E. Ray Garton, P.O. Box 200, Barrackville, West Virginia 26559, United States. the occurrences of Desmodus stocki north of the present range of Desmodus rotundus: (1) the larger D. stocki could withstand somewhat cooler temperatures, and (2) climatic conditions were more equable during the late Pleistocene, with warmer winters and cooler summers (Graham and Mead, 1987:371). Identification of Pleistocene vampire bat remains in West Virginia is therefore important for our understanding of these highly specialized mammals, as well as of the historical biogeography of the Appalachian region.

ACKNOWLEDGMENTS.-Clayton Ray first identified the Desmodus remains from New Trout Cave and encouraged the authors to write this paper. Many cavers assisted in collecting and processing $2000 \mathrm{~kg}$ of cave earth. Thomas Stafford made the new carbon-14 dates available. Two anonymous reviewers provided many useful comments, which greatly improved this manuscript. The second author thanks the Smithsonian Institution Office of Fellowships and Grants for two Short-Term Visitor Program Awards (1987, 1990).

\section{STUDY SITE}

New Trout Cave is located in a low escarpment $20 \mathrm{~m}$ above U.S. Highway $220,5.5 \mathrm{~km}$ southwest of Franklin, Pendleton County, West Virginia. The cave is located on the Sugar Grove quadrangle, $38^{\circ} 39^{\prime} 09^{\prime \prime} \mathrm{N}, 79^{\circ} 22^{\prime} 98^{\prime \prime} \mathrm{W}$, and the entrance is at an elevation of $570 \mathrm{~m}$. The cave developed in the Coeymans-New Scotland limestones of Devonian age.

In February 1979, a party of explorers from the Monongahela Grotto of the National Speleological Society discovered a deposit of bones in the cave. Samples discovered at that time and during subsequent trips indicated that the deposit was Pleistocene in age. A total of 12 collecting trips were made. The deposit was collected in $30 \mathrm{~cm}$ intervals to a depth of 220 $\mathrm{cm}$ and wet-screened through $5 \mathrm{~mm}$ and $1.5 \mathrm{~mm}$ mesh (Grady, 
TABLE 1.-Measurements (in mm) of humeri of Desmodus stocki from different localities (after Arroyo-Cabrales and Ray, 1997 (AR); or Morgan, 1991 (M)), of two specimens of Desmodus draculae (paratype and Loltun Cave, (Arroyo-Cabrales and Ray, 1997)) and of the specimens from West Virginia. Mean measurements are presented first, followed by ranges given in parentheses.

\begin{tabular}{l|ccc}
\hline \multicolumn{1}{c|}{ Locality } & Proximal width & Distal width & Shaft width \\
\hline Desmodus stocki & & & \\
San Josecito Cave (M) & $6.3(5.8-6.8)$ & $6.8(6.4-7.3)$ & $2.5(2.0-2.9)$ \\
San Josecito Cave (AR) & $6.4(5.9-6.8)$ & $7.0(6.6-7.6)$ & $2.6(2.0-2.9)$ \\
Reddick 1, Florida (M) & $6.3(6.0-6.7)$ & $6.8(6.4-7.2)$ & $2.6(2.2-2.7)$ \\
New Trout Cave, West Virginia & 6.6 & 7.7 & 3.8 \\
Desmodus draculae & & & 4.0 \\
$\quad$ Paratype & 6.5 & 7.2 & 3.1 \\
Loltun Cave, Mexico & 7.6 & 7.7 & \\
\hline
\end{tabular}

1984) at the field laboratory facilities of the Carnegie Museum of Natural History in New Paris, Pennsylvania. Cleaned materials were sorted to separate bones, teeth, mollusk shells, and other biological elements. All samples were deposited in the National Museum of Natural History, Smithsonian Institution, which subsumed the collections of the former United States National Museum (USNM).

One of the important features of the excavations at New Trout Cave is the stratigraphic control provided by $\mathrm{C}-14$ dating of the units. Arbitrary $30 \mathrm{~cm}$ levels were designated $\mathrm{A}-\mathrm{H}$ from top to bottom of the excavation. Dates of three units were obtained from $100 \mathrm{gm}$ samples of bone collagen: level A, 17,060 \pm 220 years before present (yrs BP); level B, 28,250 \pm 850 yrs BP; and level C, 29,400 \pm 1700 yrs BP. All dating was performed by the Carbon Dating Section, Smithsonian Radiation Biology Laboratory (no longer in operation). Additional dating by T. Stafford, University of Colorado (pers. comm., 1995) indicated that level $\mathrm{B}$ ranges from about $13,000 \mathrm{yrs} \mathrm{BP}$ to more than 40,000 yrs BP and that level D is older than 50,000 yrs BP.

The fauna includes fish, amphibians, reptiles, birds, and at least 60 species of mammals. Several studies have already been published about some of the taxa, including amphibians and reptiles (Holman and Grady, 1987), mollusks (Bogan and Grady, 1991), gophers (Grady, 1984), and collared lemming (Grady and Garton, 1981), and Grady and Gorton (1982) produced a general synthesis of the faunal elements. Vampire bat remains from New Trout Cave were briefly noted by Ray et al. (1988), who assigned them to Desmodus sp., although they are morphologically close to $D$. draculae Morgan, Linares, and Ray. Our study indicates that the specimens pertain to Desmodus stocki.

\section{Taxonomic Account}

\section{Order CHIROPTERA}

\section{Family Phyllostomidae}

\section{Subfamily DESMODONTINAE}

\section{Desmodus stocki Jones, 1958}

MATERIAL EXAMINED.-One right cochlea (USNM 374284), level D; one left humerus, distal end (USNM
374285), level D; one right humerus, proximal epiphysis (USNM 374286), level D; one right metacarpal III, proximal end (USNM 3742870), level B.

The specimens clearly pertain to the genus Desmodus. They compare satisfactorily with the extant species, $D$. rotundus, but are much larger. They were compared with the bones available for specimens of $D$. stocki collected from the type locality of the species, San Josecito Cave, Nuevo Leon, Mexico, and with the paratype of $D$. draculae from Cueva del Gaucharo, Venezuela. The specimens from West Virginia were found to be within the range of variation of $D$. stocki or close to it, as shown by the series of specimens from San Josecito Cave. The proximal humeral epiphysis from New Trout Cave measured $3.30 \mathrm{~mm}$ in length and $3.27 \mathrm{~mm}$ in width, whereas three specimens of $D$. stocki measured 3.27-3.40 in length and 3.23-3.40 in width. The distal epiphysis from New Trout Cave, including the lower part of the shaft, is slightly larger than available specimens of D. stocki (Table 1). Arroyo-Cabrales and Ray (1997) pointed out that the San Josecito Cave vampire bat series was presumably formed by specimens from both sexes, males being of larger size; therefore, it is possible that the West Virginian specimen was a male of extreme size for the species. Although it might be argued that the distal humeral end of our specimen, especially when the remainder of the shaft is included, overlaps with measurements for $D$. draculae (Arroyo-Cabrales and Ray, 1997), the two species can be separated by a diagnostic character of the humerus: in D. stocki, including the New Trout specimen, the crest on the lateral epicondyle of the capitulum is low and rounded; in $D$. draculae and D. rotundus, the crest is well developed and sharp-pointed. The $D$. draculae paratype is also abraded, and its measurements likely underestimate its actual size.

One of the New Trout specimens was collected from level B, but it may have been intrusive, even though the available date for that level is still within the previously reported time range for Desmodus stocki: late Pleistocene (ca. 120,000 yrs BP) to Holocene (2500-5000 yrs BP) (Arroyo-Cabrales and Ray, 1997). Most of the bone from the lower levels (D-H) of New Trout Cave is reddish in color, whereas most of the bone from levels A-C is ivory to tan. All four New Trout vampire bones are reddish in color. Three specimens were collected from level D, $30 \mathrm{~cm}$ below level C, which dated at $29,400 \mathrm{yrs}$ BP. New 
dates (R.W. Graham pers. comm., 1995) suggest considerably older dates, especially for the D and lower levels of New Trout Cave.

The herpetofauna found below level C in New Trout Cave was interpreted by Holman and Grady (1987) to be consistent with mild winters and warm summers. This interpretation is supported by the presence of the water rat, Neofiber alleni, which is found in level D (Grady and Garton, 1982). The presence of the extinct vampire bat Demodus stocki in association with these taxa suggests that consistently mild winters, which have been hypothesized as necessary to accommodate the physiological constraints of this bat, prevailed at that time. These associations also suggest that Desmodus stocki was not more cold tolerant than the extant vampire bat, Desmodus rotundus. Rather, the extinct vampire bat and its associated fauna suggest that the late Pleistocene climatic conditions in West Virginia were substantially more equable than the tundra and boreal environments reported as typical for the late Pleistocene (e.g., Graham and Mead, 1987).

\section{Literature Cited}

Alvarez, Ticul

1972. Nuevo Registro para el Vampiro del Pleistoceno, Desmodus stocki del Tlapacoya, Mexico. Anales de Ciencias Biologicas, México. 19:163-165.

Arroyo-Cabrales, Joaquín, and Clayton E. Ray

1997. Revisión de los Vampiros Fósiles (Chiroptera: Phyllostomidae, Desmodontinae) de México. In Joaquín Arroyo-Cabrales and Óscar J. Polaco, editors, Homenaje al Profesor Ticul Alvarez, pages 69-86. México, D.F. [Mexico City]: Colección Cientifica, Instituto Nacional de Antropologia e Historia.

Bogan, Arthur E., and Frederick V. Grady

1991. Two Pleistocene Molluscan Faunas from Eastern West Virginia. In James R. Purdue, Walter E. Klippel, and Bonnie W. Styles, editors, Beamers, Bobwhites, and Blue-points: Tributes to the Career of Paul W. Parmalee. Illinois State Museum, Scientific Papers, 23:189-213. Grady, Frederick

1984. A Pleistocene Occurrence of Geomys (Rodentia: Geomyidae) in West Virginia. In Hugh H. Genoways and Mary R. Dawson, editors, Contributions in Quatemary Vertebrate Paleontology: A Volume in Memorial to John E. Guiday. Special Publication, Carnegie Museum of Natural History, 8:161-163.

Grady, Fred, and E. Ray Garton

1981. The Collared Lemming Dicrostonyx hudsonius (Pallas) from a Late Pleistocene Deposit in West Virginia. Proceedings of the Eighth In- ternational Congress of Speleology, pages 279-281. Americus, Georgia: National Speleological Society.

1982. Pleistocene Fauna from New Trout Cave. Capital Area Cavers Bulletin, 1:62-69.

Graham, Russell W., and Jim l. Mead

1987. Environmental Fluctuations and Evolution of Mammalian Faunas during the Last Deglaciation in North America. In W.F. Ruddiman and H.E. Wright, Jr., editors, The Geology of North America, K-3. North America and Adjacent Oceans during the Last Deglaciation, pages 371-402. Boulder, Colorado: Geological Society of America.

Holman, J. Alan, and Frederick Grady

1987. Herpetofauna of New Trout Cave. National Geographic Research, 3(3):305-317.

McNab, Brian K.

1993. Energetics and the Distribution of Vampires. Journal of Mammalogy, 54(1):131-144.

Morgan, Gary S.

1991. Neotropical Chiroptera from the Pliocene and Pleistocene of Florida. Bulletin of The American Museum of Natural History, 206: 176-213.

Ray, Clayton E., Omar J. Linares, and Gary S. Morgan

1988. Paleontology. In Arthur M. Greenhall and Uwe Schmidt, editors, Natural History of Vampire Bats, pages 19-30. Boca Raton, Florida: CRC Press. 



\title{
Second Record of the Badger Taxidea taxus (Schreber) from the Pleistocene of Kentucky and Its Paleoecological Implications
}

\author{
H. Gregory McDonald
}

\begin{abstract}
A small fauna of late Pleistocene age from Great Saltpetre Cave, Rockcastle County, Kentucky, includes the lower jaw of a juvenile badger, Taxidea taxus (Schreber). The badger is not currently present in Kentucky, and the Great Saltpetre specimen is only the second known occurrence for the state. The badger is one of a number of taxa that was present during the Pleistocene in the eastern United States but whose modern distributions are restricted to the central and western United States.
\end{abstract}

\section{Introduction}

The badger Taxidea taxus (Schreber) presently inhabits the central and western United States. The eastern part of its distribution includes southwestern Ohio, south-central Indiana and Illinois, southeastern Missouri, northwestern Arkansas, and eastern Texas. Late Pleistocene records of the badger outside its present range are few, and the recent discovery of a badger specimen from Great Saltpetre Cave, Rockcastle County, Kentucky, provides additional information regarding its former distribution.

ACKNOWLEDGMENTS.-It is with great pleasure that I include this paper in a volume dedicated to my friend and colleague Clayton Ray. I would like to thank George Turner, Bill Simpson, John Agnew, and other members of the Greater Cincinnati Grotto who collected the skeletal material from Great Saltpetre Cave, graciously donated the specimen to the museum, and generously shared their knowledge of the cave. Charles A. Long of the Museum of Natural History, University of Wisconsin at Stevens Point (UWSP), kindly loaned the juvenile badgers used for comparison. $\mathrm{X}$-rays of fossil and modern specimens were provided through the courtesy of Malcolm

H. Gregory McDonald, Geologic Resources Division, National Park Service, P.O. Box 25287, Denver, Colorado 80225.
Meyn and Mary Thompson. Cliff Dickey photographed the specimens. Maryann Graham of the Illinois State Museum drafted Figure 2 using the FAUNMAP database. Anita Buck read the manuscript, Philip R. Bjork, South Dakota School of Mines and Technology, Rapid City, SD; and Elaine Anderson (deceased) reviewed it, and all provided many useful comments. Any errors are the responsibility of the author.

\section{CAVE LOCATION}

The badger and associated fauna were recovered by members of the Greater Cincinnati Grotto during excavation of a side passage near the Pig Pen portion of Great Saltpetre Cave, Rockcastle County, Livingston Quadrangle, Kentucky. This portion of the cave is close to the south entrance, $37^{\circ} 22^{\prime} 04^{\prime \prime} \mathrm{N}$, $84^{\circ} 12^{\prime} 12^{\prime \prime} \mathrm{W}$. Elevation near the south entrance is $305 \mathrm{~m}$ above sea level. The cave is located next to Crooked Creek, which drains into the Rockcastle River. Crooked Creek previously flowed through the main passage until it was diverted by a meander cutoff. The cave is a solution feature in the St. Genevieve Member of the Mississippian Newman Limestone. Great Saltpetre Cave is located on the eastern edge of the Mississippian Plateau physiographic province. Present habitat in the vicinity of the cave is mixed mesic deciduous forest.

The earliest recorded mention of Great Saltpetre Cave was in 1798, when it was first explored by John Baker and his family. Saltpeter mining was initiated in late 1800, and in April 1805 bones reported to be those of the sloth Megalonyx jeffersonii (Demarest) were found in the cave. In November of the same year the skull and jaw of a peccary, believed to be Platygonus compressus LeConte, were found by Samuel Brown and saltpeter miners in the cave (Barton, 1805; George, 1994). The present location of the sloth bones is unknown. According to Harlan (1825), the skull and jaw of the peccary were deposited in the cabinet of the American Philosophical Society. The collections of the American Philosophical Society were later transferred to the Academy of Natural Sciences in Philadel- 
phia. The specimens are not presently in the Academy's collections (T. Daeschler, pers. comm., 1994), and their present location is unknown. The first published description of the cave was by Brown in 1809. Following these initial discoveries no other fossil vertebrate material was reported from the cave until the discoveries made by the Greater Cincinnati Grotto. All of the recently discovered fossil material from Great Saltpetre Cave is housed in the vertebrate paleontology collections of the Cincinnati Museum of Natural History (CMNH).

A late Pleistocene age for the badger is indicated by its association with skeletal material of the extinct peccary, Platygonus compressus. Platygonus compressus is known only in faunas of Rancholabrean age (Wright, 1993). Repenning (1987) considered the Irvingtonian/Rancholabrean boundary to be at about 400,000 years before present (yrs BP). Most records of Platygonus compressus are late Pleistocene (Wisconsinan), with the youngest carbon- 14 date for the species at $11,900 \pm 750 \mathrm{yrs} B P$ (Ray et al., 1970). Until more work is done on the Saltpetre Cave material, nothing more precise than a Rancholabrean age for the fauna can be determined. In addition to the badger mandible and peccary bones, the group recovered the skulls of long-tailed weasel (Mustela frenata) and woodchuck (Marmota monax) and bones of unidentified bird species. The specimens were buried in a reddish silty-clay that had filled the cave passageway. Further excavation of the silty-clay may greatly expand the fauna.

\section{Description of Material}

The specimen is the right dentary (CMNH 3681) of a juvenile, with permanent canine in place but not erupted, and third and fourth deciduous premolars fully erupted. An X-ray of the specimen indicates that the crowns of the permanent third and fourth premolars and first and second lower molars are fully formed although not yet erupted (Figure $1 b$ ). The mandibular symphysis is unfused and the two halves of the mandible had separated at this point. Mandible length is $76.1 \mathrm{~mm}$; height at coronoid process, $31.0 \mathrm{~mm}$; width of condyle, $14.9 \mathrm{~mm}$; alveolar length of premolar series, $21.8 \mathrm{~mm}$; length of deciduous lower third premolar (dp3), $6.0 \mathrm{~mm}$; width of dp3, $3.5 \mathrm{~mm}$; length of deciduous lower fourth premolar (dp4), $9.0 \mathrm{~mm}$; and width of talonid of dp4, $4.6 \mathrm{~mm}$.

The eruption of the permanent canine is anterior to the alveolus of the deciduous canine, a feature used by Long (1965) to distinguish Taxidea from Meles. The presence of two distinct alveoli also indicates that the deciduous lower second premolar (dp2) was double-rooted, another feature of Taxidea noted by Long (1965).

The crown of the dp3 has two distinct cusps-a prominent protoconid and a small accessory cusp on the posterolabial side of the protoconid - and the $\mathrm{dp} 3$ has a well-developed talonid. In these features the $\mathrm{dp} 3$ resembles the permanent lower fourth premolar, although it is not as massive, rather than the perma- nent lower third premolar, which has a single cusp and no talonid.

In the dp4 the protoconid, paraconid, and metaconid are prominent and distinct, with the protoconid the largest of the three. The paraconid, the second largest cusp, constitutes the mesial portion of the tooth. The metaconid is the smallest of the three cusps and is positioned posterolingually to the protoconid. Although the dp4 is similar to the permanent lower first molar in relative positioning of the cusps, the talonid of the dp4 is less well developed and lacks the entoconid.

Comparison of the Saltpetre Cave specimen with another juvenile badger (UWSP M-5318) shows identical features in the morphology of the deciduous premolars.

\section{Discussion}

The only previous record of the badger in Kentucky is a portion of the left temporal from Welsh Cave, Woodford County (Guilday et al., 1971). Great Saltpetre Cave is about $100 \mathrm{~km}$ southeast of Welsh Cave and approximately $200 \mathrm{~km}$ southeast of the present range of badger in southwestern Ohio.

The fossil record of Taxidea in the eastern United States extends from the middle Pleistocene (Irvingtonian) deposits of Cumberland and Port Kennedy Caves to Holocene archaeological records. Gidley and Gazin (1933) originally described the material from Cumberland Cave as a distinct species, Taxidea marylandica, but Long (1964) considered it a subspecies of $T$. taxus. Material from Port Kennedy Cave was referred by Cope (1899) to the modern species. Reference of all Pleistocene badger material to the modern species has been followed by subsequent workers (Hall, 1936; Anderson, 1977; Kurtén and Anderson, 1980).

Late Pleistocene and early Holocene localities of Taxidea outside its present range in the eastern United States include Baker Bluff Cave, Sullivan County, Tennessee (Guilday et al., 1978); Peccary Cave, Newton County, Arkansas (Semken, 1984); Bootlegger Sink, York County, Pennsylvania (Guilday et al., 1966); Meyer Cave, Monroe County, Illinois (Parmalee, 1967); and New Trout Cave, Pendleton County, West Virginia (Grady, 1984).

During the Pleistocene, the ranges of the many species expanded and contracted in response to environmental changes (FAUNMAP Working Group, 1994). Taxidea forms part of a suite of species associated with grasslands and prairie whose distributions are currently restricted to the central and western United States but at one time included portions of the eastern United States (Figure 2). Other now-western species that share similar habitat preferences with the badger and have extraliminal eastern records include plains pocket gopher, Geomys bursarius (Parmalee and Klippel, 1981); thirteen-lined ground suqirrel, Spermophilus tridecemlineatus (Guilday et al., 1978); northern grasshopper mouse, Onychomys leucogaster (Semken, 1984); and birds such as the black-billed magpie, Pica pica (Parmalee, 1992), and prairie chicken, Tympanuchus 


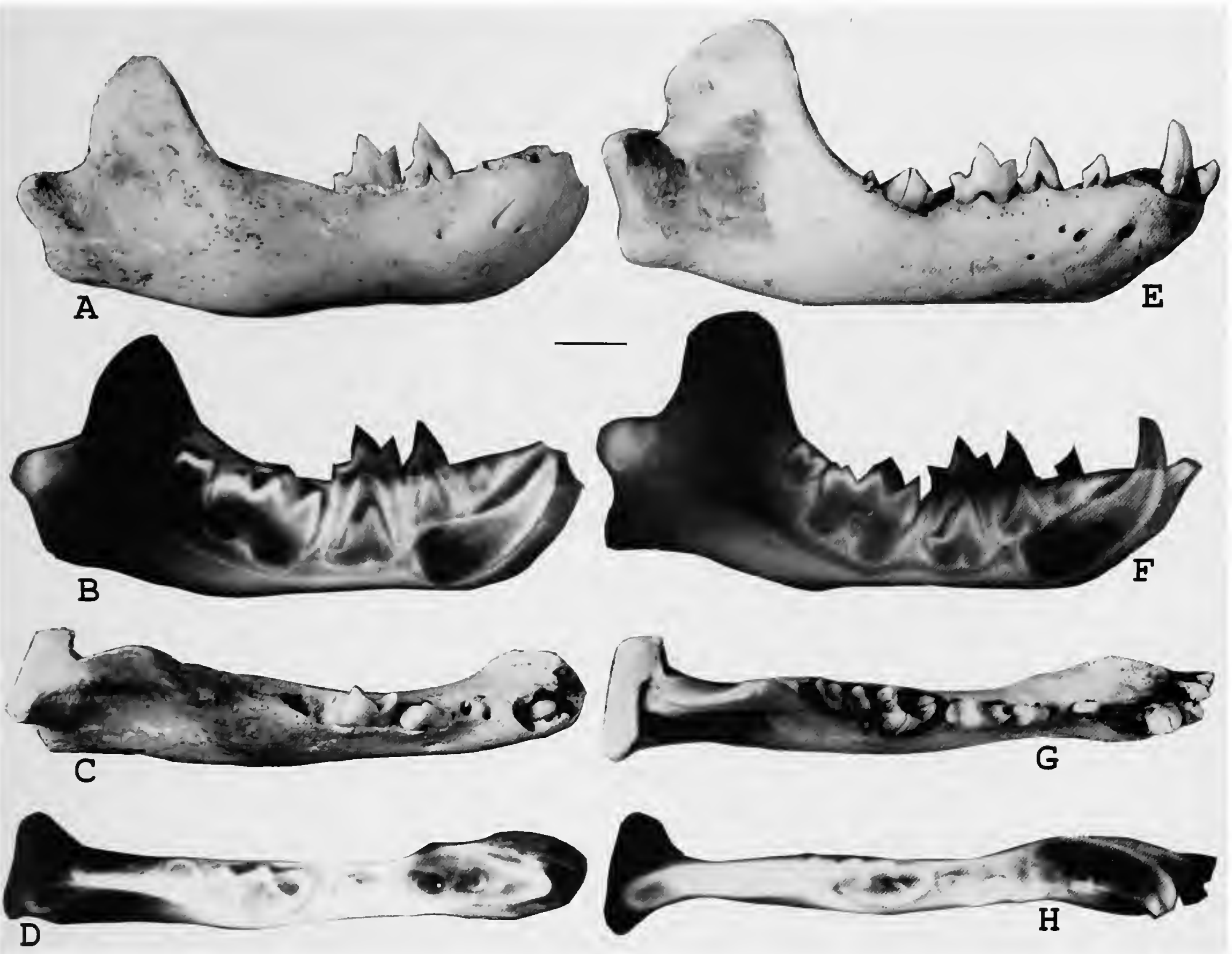

FIGURE 1.-Taxidea taxus juvenile jaws: A-D, Great Saltpetre Cave (CMNH 3681); E-H, modern (UWSP M5318). A,E, lateral view; B,F, X-ray, lateral view; C,G, occlusal view; D,H, X-ray, occlusal view.

cupido (Guilday and Parmalee, 1971). Many of these taxa have been found together in Pleistocene sites in the eastern United States (Table 1). Mammalian species with western affinities still present in Kentucky include prairie vole, Microtis ochrogaster (which is still present in Rockcastle County); prairie deer mouse, Peromyscus maniculatus bairdii; spotted skunk, Spilogale putorius; and coyote, Canis latrans (Barbour and Davis, 1974).

Compared with these other species, the badger is generally not a common species in fossil assemblages in the eastern United States. This spotty record permits two alternative interpretations with regard to historical changes in the distribution of badger and its presence in the eastern United States. Under the first scenario, an initial widespread distribution in the early and middle Pleistocene (Irvingtonian) may have been followed by a gradual but continuous reduction in range, from its maxi- mum extent as far east as Maryland and Pennsylvania to the more limited western distribution of today. This pattern is seen in Ochotona, which is known from middle Pleistocene sites in the east but whose present distribution is limited to western North America (Guilday, 1979; Mead, 1987).

Alternatively, the range of the badger could have become restricted farther west earlier in the Pleistocene, with the late Pleistocene and early Holocene records representing a secondary, short-term, eastward expansion of range during more optimal environmental conditions, possibly related to the development of prairie conditions. Grady (1984) suggested that the presence of Geomys in New Trout Cave, West Virginia, which also includes Taxidea in the fauna, represents a range expansion during a dry, probably glacial interval before the latest Wisconsinan glaciation.

Spermophilus tridecemlineatus is considered to be typically 
TABLE 1.-Late Pleistocene and Holocene records of western species found outside of their present range in eastern sites. Age assignments are taken from FAUNMAP (1994): Wisconsinan (10-110 Ka), middle Wisconsinan (35-65 Ka), late Wisconsinan (10-35 Ka), Glacial (9.5-20.5 Ka), late Glacial (9.5-15.5 Ka), Holocene $(0-10 \mathrm{Ka})$, early Holocene $(8-10 \mathrm{Ka})$, middle Holocene $(4-8 \mathrm{Ka})$, late Holocene $(0-4 \mathrm{Ka}) .(\mathrm{Tt}=$ Taxidea taxus; $\mathrm{Gb}=$ Geomys bursarius; $\mathrm{St}=$ Spermophilus tridecemlineatus; $\mathrm{Ol}=$ Onychomys leucogaster; $\mathrm{Pp}=$ Pica pica; $\mathrm{Tc}=$ Tympanuchus cupido.)

\begin{tabular}{|c|c|c|c|c|c|c|}
\hline Location & $\mathrm{Tt}$ & $\mathrm{Gb}$ & St & Ol & $\mathrm{Pp}$ & $\mathrm{Tc}$ \\
\hline 1. New Paris No. 4, Pennsylvania (late Glacial) & - & - & * & - & - & - \\
\hline 2. Bootlegger Sink, Pennsylvania (late Wisconsinan/Holocene) & * & - & * & - & - & - \\
\hline 3. Eagle Cave, West Virginia (Holocene) & - & - & * & - & - & - \\
\hline 4. Trout Cave, West Virginia (Wisconsinan) & - & - & * & - & - & - \\
\hline 5. New Trout Cave, West Virginia (late Wisconsinan) & * & * & * & - & - & - \\
\hline 6. Natural Chimneys, Virginia (late Wisconsinan) & - & - & * & - & * & - \\
\hline 7. Clark’s Cave, Virginia (Glacial) & - & - & * & - & - & - \\
\hline 8. Strait Canyon Fissure, Virginia (late Pleistocene) & - & - & - & - & * & - \\
\hline 9. Welsh Cave, Kentucky (late Glacial) & * & * & * & - & - & - \\
\hline 10. Savage Cave, Kentucky (Wisconsinan) & - & * & - & - & - & * \\
\hline 11. Great Saltpetre Cave, Kentucky (Wisconsinan) & * & - & - & - & - & \\
\hline 12. Guy Wilson Cave, Tennessee (late Wisconsinan) & - & - & * & - & - & \\
\hline 13. Baker Bluff, Tennessee (Glacial) & * & - & * & - & * & - \\
\hline 14. Robinson Cave, Tennessee (late Wisconsinan) & - & - & * & - & - & - \\
\hline 15. Cheek Bend Cave, Tennessee (Glacial) & & * & * & - & - & * \\
\hline 16. First American Bank Site, Tennessee (Wisconsinan/Holocene) & & * & - & - & & - \\
\hline 17. Harrodsburg Crevice, Indiana (Wisconsinan) & & * & - & - & - & - \\
\hline 18. Riverton Site, Illinois (late Holocene) & & * & - & - & - & - \\
\hline 19. Meyer Cave, Illinois (Wisconsinan/Holocene) & * & * & - & - & - & - \\
\hline 20. Modoc Rock Shelter, lllinois (middle Holocene) & - & * & - & - & - & - \\
\hline 21. Black Earth Site, Illinois (late Holocene) & - & * & - & - & - & - \\
\hline 22. Kingston Lake, lllinois (late Holocene) & - & - & - & & - & * \\
\hline 23. Crankshaft Cave, Missouri (Wisconsinan) & - & * & * & * & - & - \\
\hline 24. Brynjulfson Caves, Missouri (Wisconsinan/Holocene) & - & * & * & - & - & * \\
\hline 25. Zoo Cave, Missouri (Wisconsinan/Holocene) & - & * & - & - & - & - \\
\hline 26. Herculaneum Crevice, Missouri (Wisconsinan) & - & * & & - & - & - \\
\hline 27. Bat Cave, Missouri (Holocene) & - & * & & - & - & - \\
\hline 28. Kingston Saltpeter Cave, Georgia (Wisconsinan) & - & - & & - & * & - \\
\hline 29. Bell Cave, Colbert County, Alabama (late Wisconsinan) & - & - & * & - & * & * \\
\hline 30. Peccary Cave, Arkansas (Glacial) & * & * & * & * & - & - \\
\hline 31. Zebree Site, Arkansas (late Holocene) & - & - & * & - & - & * \\
\hline
\end{tabular}

a grassland inhabitant, and throughout its present range it is found predominantly on moderately high prairies and knolls (Streubel and Fitzgerald, 1978). The plains pocket gopher, Geomys bursarius, lives mostly in open lands such as prairie grasslands and meadowlands, where it will range from river bottoms to hill tops as long as the soil has a low water-holding capacity (Schwartz and Schwartz, 1981). Semken (1984) considered the presence of Geomys bursarius and Spermophilus tridecemlineatus at Peccary Cave (which also includes Taxidea as a member of the fauna) as indicative of prairie conditions. He surmised that their subsequent disappearance in the region resulted from loss of habitat with closure of the deciduous forest. Guilday et al. (1971) suggested that during the Pleistocene the range of Geomys was continuous from the Midwest to Florida and that the present, more limited distribution of Geomys was a post-Pleistocene event. Given the similarity of habitat preference of badger and these species, this may have been the pattern followed by the badger.
The degree of association between Taxidea taxus, Geomys bursarius, and Spermophilus tridecemlineatus from the sites listed in Table 1 can be calculated using the formula for the Index of Association: $100 \mathrm{C} / \mathrm{N} 1+\mathrm{N} 2-\mathrm{C} . \mathrm{N} 1$ is the total number of sites for species 1, N2 is the total number of sites for species 2 , and $\mathrm{C}$ is the number of sites in common for the two species. The data in Table 1 indicate that in eastern faunas Taxidea taxus and Geomys bursarius are found together $21 \%$ of the time, Taxidea taxus and Spermophilus tridecemlineatus are found together $26 \%$ of the time, and Geomys bursarius and Spermophilus tridecemlineatus are associated $22 \%$ of the time. From this analysis it appears that the three species have an equal probability of association with each other.

Platygonus compressus, the extinct peccary, has been interpreted as an inhabitant of open country (Guilday et al., 1971). The association of $P$. compressus with badger at Great Saltpetre Cave supports the interpretation of former prairie, or at least open woodland, habitat in Rockcastle County during the Pleistocene. 


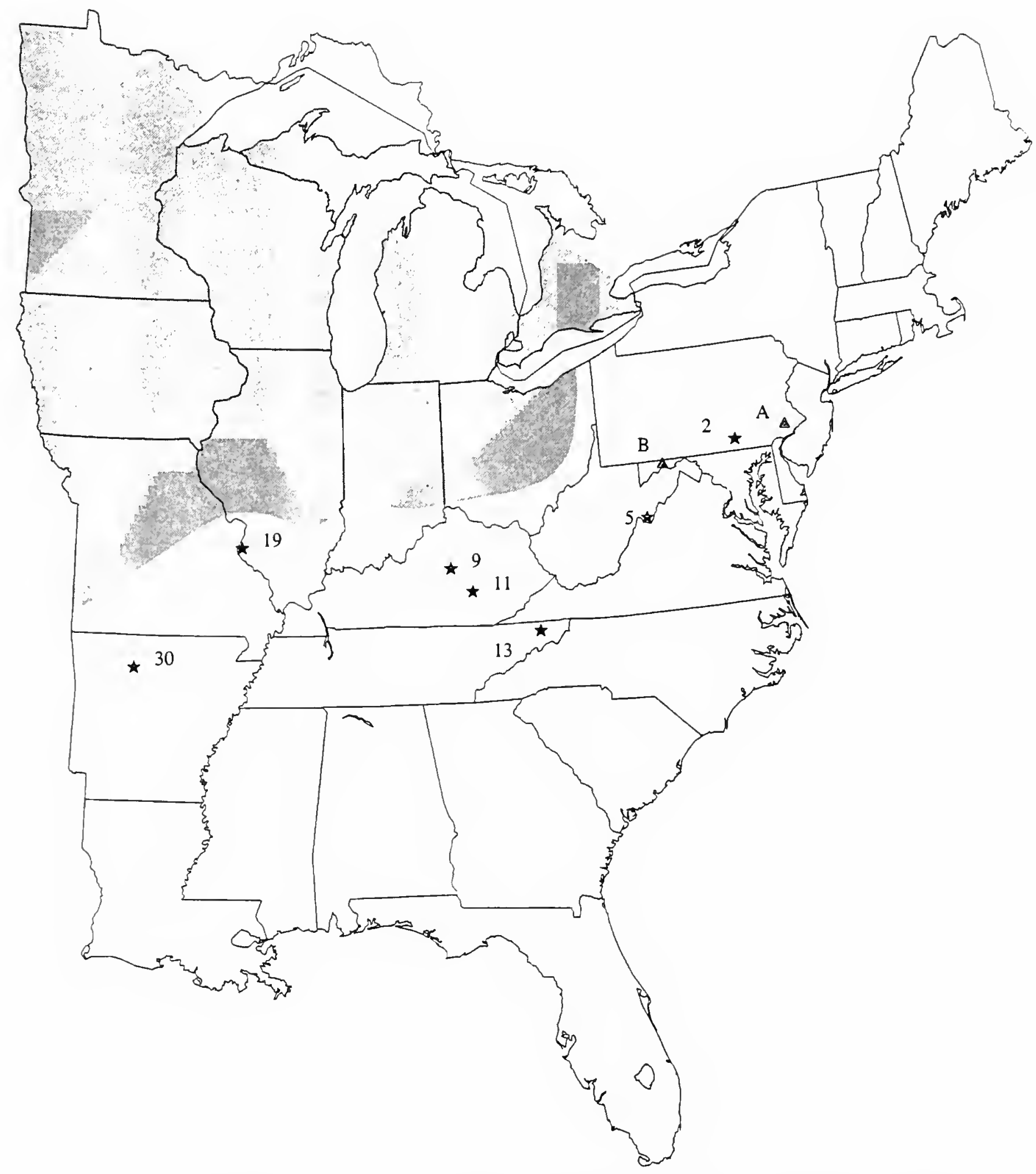

FIGURE 2.-Modern distribution of Taxidea taxus (shaded) and extralimital records during the Pleistocene. Numbers refer to late Pleistocene localities listed in Table 1. Irvingtonian localities are designated by letters: A, Port Kennedy Cave; B, Cumberland Cave.

This is in contrast to the mesic forest present in the area today.

Whether the present distribution of badger represents a continuous unidirectional reduction in range or one of many fluctuations of its range during the Pleistocene and early Holocene, its presence or absence in a fauna may not be a direct indication of long-term environmental change, either unidirectional or fluctuating. As noted by Long (1973), badgers are labile in habitat preference; they range from below sea level (Death Valley) to above $3660 \mathrm{~m}$ in elevation and are found from the Arctic-alpine to lower Austral life zones. Given its ecological position as a predator, expansion or contraction of its range may not be the direct result of environmental changes but rather may reflect changes in the distribution of prey, such as Geomys bursarius and Spermophilus tridecemlineatus. It may be the prey species that are sensitive to changes in available habitat, and that climatic change results in changes in their distribution. Expansion or reduction in the range of Taxidea may be merely a secondary consequence. 


\section{Literature Cited}

Anderson, E.

1977. Pleistocene Mustelidae (Mammalia, Carnivora) from Fairbanks, Alaska. Bulletin of the Museum of Comparative Zoology, 148(1): $1-21$.

Barbour, R.W., and W.H. Davis

1974. Mammals of Kentucky. 322 pages. Lexington, Kentucky: University of Kentucky Press.

Barton, B.S.

1805. Miscellaneous Facts and Observations. The Philadelphia Medical and Physical Journal, 1(2):158.

Brown, S.

1809. A Description of a Cave on Crooked Creek with Remaks and Observations on Nitre and Gunpowder. Transactions of the American Philosophical Society, 6:235-247.

Cope, E.D.

1899. Vertebrate Remains from the Port Kennedy Bone Deposit. Journal of the Academy of Natural Sciences of Philadelphia, 11:193-267.

FAUNMAP Working Group

1994. FAUNMAP: A Database Documenting Late Quaternary Distributions of Mammal Species in the United States. Illinois State Museum Scientific Papers, 1-2: 690 pages.

George, A.I.

1994. Interim Chronology of Historic Events at Great Saltpetre Cave, Rockcastle County, Kentucky. The Electric Caver, 31(2):10-14.

Gidley, J.W., and C.L. Gazin

1933. New Mammalia in the Pleistocene Fauna from Cumberland Cave. Journal of Mammalogy, 14:343-357.

Grady, F.V.

1984. A Pleistocene Occurrence of Geomys (Rodentia: Geomyidae) in West Virginia. Special Publication, Carnegie Museum of Natural History, 8:161-163.

Guilday, J.E.

1979. Eastern North American Pleistocene Ochotona (Lagomorpha: Mammalia). Annals of the Carnegie Museum, 48(24):435-444

Guilday, J.E., H.W. Hamilton, E. Anderson, and P.W. Parmalee

1978. The Baker Bluff Cave Deposit, Tennessee, and the Late Pleistocene Faunal Gradient. Bulletin of the Carnegie Museum of Natural History, 11:1-67.

Guilday, J.E., H.W. Hamilton, and A.D. McCrady

1966. The Bone Breccia of Bootlegger Sink, York County, Pennsylvania. Annals of the Carnegie Museum, 38(8):145-163.

1971. The Welsh Cave Peccaries (Platygonus) and Associated Fauna, Kentucky Pleistocene. Annals of the Carnegie Museum, 43(9): 249-320.

Guilday, J.E., and P.W. Parmalee

1971. Thirteen-lined Ground Squirrel, Prairie Chicken and Other Vertebrates from an Archaeological Site in Northeastern Arkansas. American Midland Naturalist, 86(1):227-229.

Hall, E.R.

1936. Mustelid Mammals from the Pleistocene of North America with Systematic Notes on Some Recent Members of the Genera Mustela,
Taxidea and Mephitis. Carnegie Institution of Washington Publication, 473:41-119.

Harlan, R.

1825. Fauna Americana, Being a Description of the Mammiferous Animals Inhabiting North America. 318 pages. Philadelphia: Anthony Finley.

Kurtén, B., and E. Anderson

1980. Pleistocene Mammals of North America. 442 pages. New York: Columbia University Press.

Long, C.A.

1964. Taxonomic Status of the Pleistocene Badger, Taxidea marylandica. American Midland Naturalist, 72:176-180.

1965. Comparison of Juvenile Skulls of the Mustelid Genera Taxidea and Meles, with Comments on the Subfamily Taxidiinae Pocock. American Midland Naturalist, 74(1):225-232.

1973. Taxidea taxus. Mammalian Species, 26: 4 pages.

Mead, J.I.

1987. Quaternary Records of Pika, Ochotona, in North America. Boreas, $16: 165-171$

Parmalee, P.W.

1967. A Recent Cave Deposit in Southwestern Illinois. Bulletin of the $\mathrm{Na}$ tional Speleological Society, 29(4):119-147.

1992. A Late Pleistocene Avifauna from Northwestern Alabama. Natural History Museum of Los Angeles County Science Series, 36: 307-318.

Parmalee, P.W., and W.E. Klippel

1981. A Late Pleistocene Population of the Pocket Gopher, Geomys cf. bursarius, in the Nashville Basin, Tennessee. Journal of Mammalogy, 62(4):831-835.

Ray, C.E., C.S. Denny, and M. Rubin

1970. A Peccary, Platygonus compressus LeConte, from Drift of Wisconsinan Age in Northern Pennsylvania. American Journal of Science, 268:78-94.

Repenning, C.A.

1987. Biochronology of the Microtine Rodents of the United States. In M.O. Woodburne, editor, Cenozoic Mammals of North America: Geochronology and Biostratigraphy, pages 236-268. Berkeley: University of California Press.

Schwartz, C.W., and E.R. Schwartz

1981. The Wild Mammals of Missouri. 356 pages. Columbia: University of Missouri Press.

Semken, H.A.

1984. Paleoecology of a Late Wisconsinan/Holocene Micromammal Sequence in Peccary Cave, Northwestern Arkansas. Special Publication. Carnegie Museum of Natural History, 8:405-431.

Streubel, D.P., and J.F. Fitzgerald

1978. Spermophilus tridecemlineatus. Mammalian Species, 103: 5 pages.

Wright, D.B.

1993. Evolution of Sexually Dimorphic Characters in Peccaries (Mammalia, Tayassuidae). Paleobiology, 19(1):52-70. 


\title{
Bison antiquus from Kenora, Ontario, and Notes on the Evolution of North American Holocene Bison
}

\author{
Jerry N. McDonald and George E. Lammers
}

\begin{abstract}
An associated skeleton of an adult male Bison antiquus occidentalis from Kenora, Ontario, is radiocarbon dated at $4270 \pm 65 \mathrm{yrs}$ $\mathrm{BP}$, making it the youngest unequivocal record for the species. It also extends the range $280 \mathrm{~km}$ north and $65 \mathrm{~km}$ east of the previously documented limits for the genus in the western Great Lakes area. The Kenora bison died in a shallow pond in an oak-pine woodland; it was experiencing nutritional stress at the time of its death. Both halves of the mandible had been fractured by trauma earlier in life.

A review of morphological change in bison during the Holocene shows that later bison, Bison bison, were absolutely smaller, had absolutely shorter limbs, and had more robust upper limbs and more gracile lower limbs, relative to length, than did the earlier bison, Bison antiquus. Compared with that of Bison antiquus, the thoracic limb of Bison bison became elongated relative to the pelvic limb, and limb length increased relative to skull size. Relative to the norm in Bison antiquus, these traits diverged further in the wood bison, Bison bison athabascae, than in the plains bison, Bison bison bison. The patterns of pelage development and social behavior in Bison bison bison, however, are more distant from parallel pattems postulated for Bison antiquus antiquus than are patterns of pelage development and social behavior in Bison bison athabascae.
\end{abstract}

\section{Introduction}

The skull, mandible, 14 teeth, and 58 postcranial bones of an adult male bison were collected late in the 1970s during dredging operations in a peat bog near Kenora, Ontario. This bison, now in the collections of the Manitoba Museum of Man and Nature, and cataloged as MMMN V-1914, has been referred to

Jerry N. McDonald, Research Associate, Department of Paleobiology, National Museum of Natural History, Smithsonian Institution, Washington, D.C. 20560-0121; and McDonald \& Woodward Publishing Company, 431-B East College Street, Granville, Ohio 43023. George E. Lammers (deceased).
Bison antiquus occidentalis, an extinct taxon that was the evolutionary link between the late Pleistocene North American steppe bison, Bison antiquus, and the extant North American bison, Bison bison. Sediment from within the cranium of the Kenora bison was radiocarbon dated at $4850 \pm 60$ years before present (yrs BP) (Beta-3779) and ribs of the bison were radiocarbon dated at $4270 \pm 65 \mathrm{yrs}$ BP (DIC-3381). Sediment from the site yielded pollen, plant macrofossils, and mollusks, which provided information about the regional environment at the time the bison lived.

The Kenora bison is significant for several reasons. Associated skeletons of Bison antiquus occidentalis are uncommon from other than archaeological contexts, and descriptions of the postcranial bones of such associated specimens are rare. The Kenora bison was found farther north and east than any bison previously known in the western Great Lakes region, and it is a rare record of bison in Ontario. The radiocarbon age of $4270 \pm$ $65 \mathrm{yrs} \mathrm{BP}$ is the youngest known for Bison antiquus. Pathologies of the face and teeth provide information about the life history of this animal and its biophysical condition at the time of death, and contribute information about patterns of pathology in the taxon. Although most characters of the Kenora bison skull are of average to greater-than-average size for Bison antiquus occidentalis, the postcranial bones are smaller than might be expected, a circumstance that raises questions about the pattern of coevolution of the postcranial skeleton and skull in bison during the Holocene.

In this paper we (1) describe the partial bison skeleton, pollen spectrum, and invertebrate remains from the Kenora site; (2) review the zoogeographical, paleoecological, and evolutionary context of the Kenora bison; (3) document the pattern of skull and limb coevolution seen in North American Holocene Bison, and, on the basis of the observed pattern of coevolution, (4) comment upon the position of the wood bison, Bison bison athabascae, in the evolutionary sequence of North 


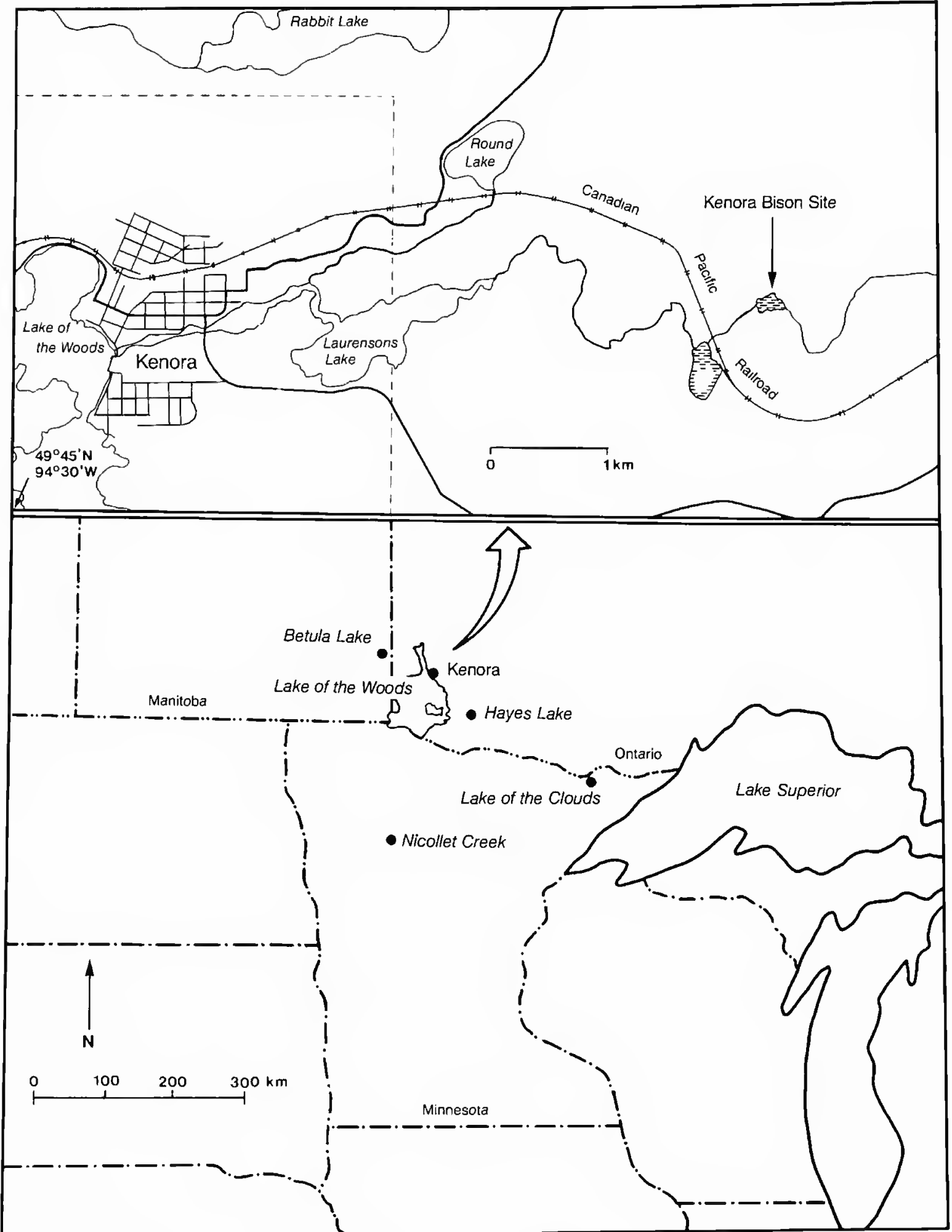

FIGURE 1.-Top: The Kenora, Ontario, area showing the location of the Kenora bison site. Bottom: Southwestem Ontario and adjacent regions showing the Kenora bison site and other places mentioned in the text in regional context.

American Bison. All dates are given in uncalibrated radiocarbon years before present.

ACKNOWLEDGMENTS.-We extend our appreciation to Nick Serduletz of Kenora, Ontario, for salvaging the Kenora bison skeleton and donating it to the Manitoba Museum of Man and Nature. Gary Haynes and Clayton E. Ray reviewed this paper and provided many helpful comments, but the authors retain full responsibility for the facts and opinions as finally presented.

ABBREVIATIONS.-The following museum abbreviations are used:
MMMN Manitoba Museum of Man and Nature, Winnipeg, Manitoba PIN Paleontological Institute, Russian Academy of Sciences, Moscow.

\section{The Kenora Bison}

\section{LOCATION AND DESCRIPTION OF THE KENORA SITE}

The bison skeleton was recovered during a period of several years by Nick Serduletz while dredging a peat bog located in the watershed of Laurensons Creek $3.0 \mathrm{~km}$ east of Kenora. The dredging extended to a depth of approximately $4.5 \mathrm{~m}$, at which 

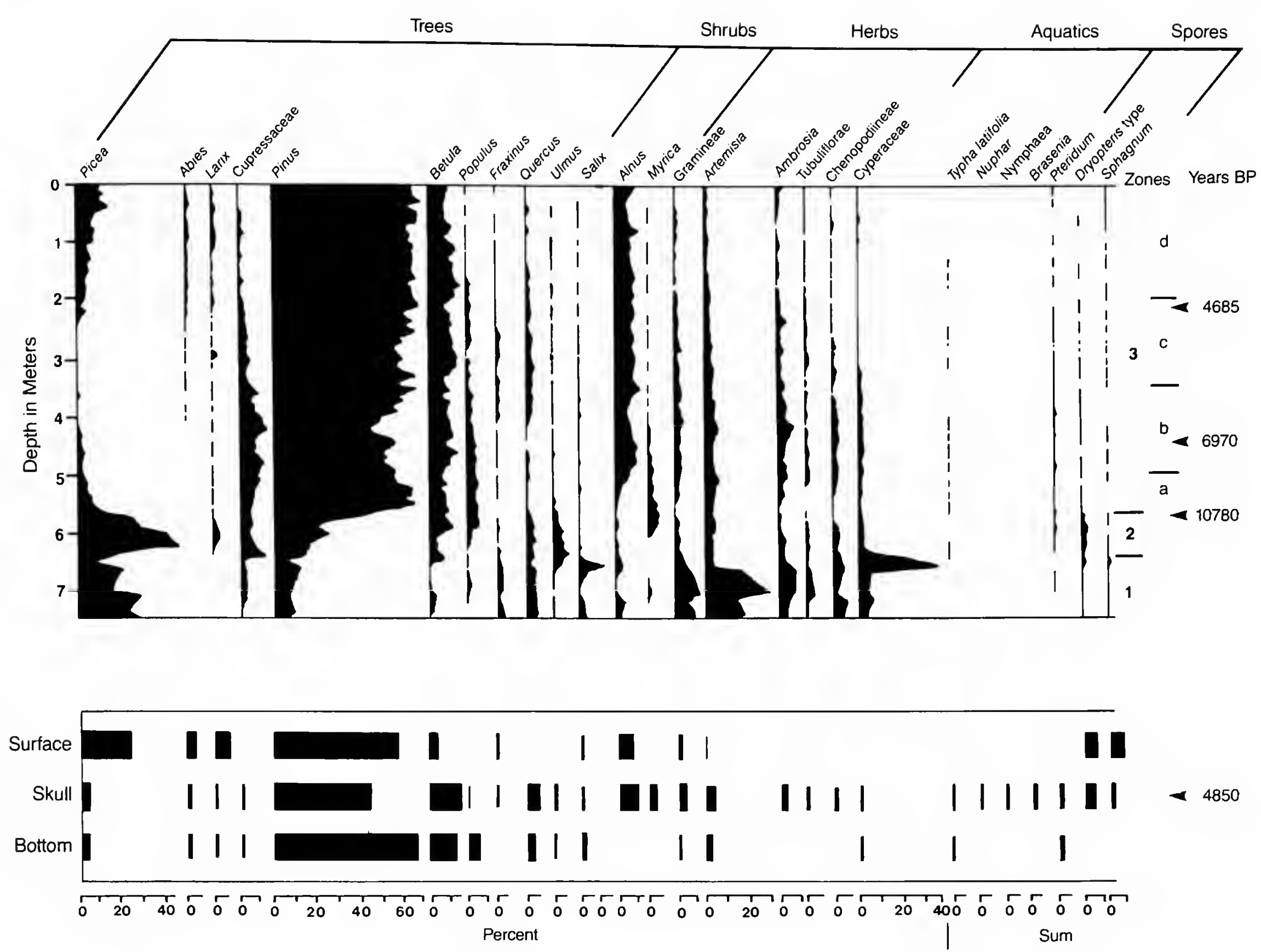

FIGURE 2.-Pollen and spore diagrams for Hayes Lake and the Kenora bison site, Ontario, simplified from McAndrews (1982).

level the skeleton was found. The technical description of the bog location is Lot K101, Concession 4J, Township Jaffray; this site is mapped on the Kenora 52E/16 quadrangle, 1:50,000 series (Figure 1).

\section{PALEOENVIRONMENT OF THE KENORA Site}

McAndrews (1982) analyzed pollen, spores, and plant macrofossils from three samples of sediment from the Kenora bison site. One sample was from the bottom of the bog, another was from within the skull, and the third was from near the upper surface of the bog. McAndrews's analyses indicated that the pattern of vegetation composition and change at Kenora (Figure 2) was similar to patterns at nearby Hayes Lake, Ontario, and the more distant Lake of the Clouds, Minnesota (Figure 1).
The bog began to fill about 10,000 yrs BP, when the regional vegetation was essentially pine forest. Between about $9200 \mathrm{yrs}$ $\mathrm{BP}$ and $5000 \mathrm{yrs} \mathrm{BP}$, in response to warming and drying associated with the Boreal and Atlantic climatic episodes, deciduous broadleaf species became more prominent than conifers in the regional forest, and open areas supporting grasses and other herbs presumably reached their maximum. The return of somewhat cooler and more mesic conditions with the onset of the Sub-Boreal climatic episode (ca. 5000-2750 yrs BP), initiated a return to a more closed pine forest. By about $3600 \mathrm{yrs} B P$ this forest was well established (Wendland, 1978; McAndrews, 1982; Webb et al., 1983; Dykev and Prest, 1987; Wendland et al., 1987).

The bison skeleton was entombed in organic-rich mud deposited in a lentic aquatic environment. Sediment from the skull yielded "a variety of marsh shrubs and herbs and pond plants... This evidence suggests the bison died in a water-lily- 


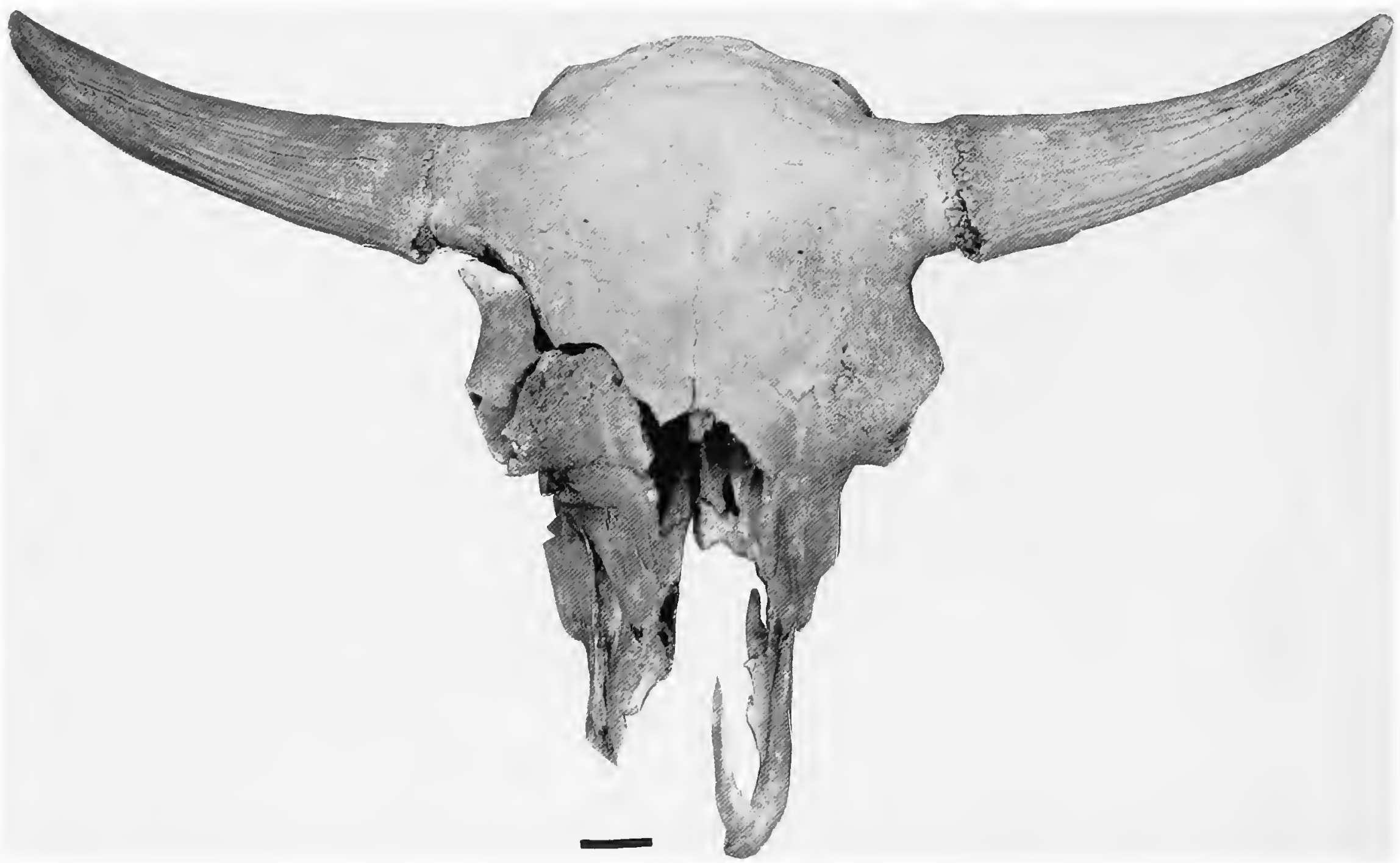

FIGURE 3,-Kenora bison skull in dorsal view. (Scale bar $=5 \mathrm{~cm}$.)

covered pond one or two meters deep that was bordered with a marsh dominated by shrubs; wetland conifers (spruce, larch) grew nearby" (McAndrews, 1982:47-48).

Five species of mollusks were collected from within the cranium of the bison. These included the small spire (Amnicola walkeri), three-keeled valve (Valvata tricarinata), ribbed valve (Valvata sincera sincera), modest gyraulus (Gyraulus parvus), and shiny pea clam (Pisidium nitidum). Although the pond of 4270 yrs BP probably was intimately associated with upper Laurensons Creek, similar to the situation of the depression today, the gastropods from the bison skull suggest that the body of water containing the skeleton was relatively slow moving and pond-like. The Kenora site is within the present range of the five mollusks (Clarke, 1981), and their presence $4270 \mathrm{yrs}$ BP does not require ecological conditions substantially different than exist today. At the same time, these mollusks are widespread today, and their sympatry $4270 \mathrm{yrs}$ BP would have been possible even under environmental conditions somewhat different than those of today.

\section{Skeletal and Dental Material Collected}

The skull, mandible, 14 teeth, and 58 complete or partial postcranial skeletal elements of the Kenora bison have been re- covered. The skull is nearly complete, lacking only the nasals, most of the right premaxilla, and most of the palatine process of the left maxilla (Figures 3-5). Minor fragments are missing from other bones of the skull. Both halves of the mandible are complete (Figures 6-9). Teeth present include RP4-M3, LM2-M3, Rp4-m3, and Lp4-m3. Postcranial elements present include the atlas; axis; cervical vertebrae 3,5 , and 7 ; thoracic vertebrae (1), 2, 4, 5, ?7, 9, and ?10; lumbar vertebrae (2), (3), (4), and (5); sacrum; ribs R1, (R?2), (R3), (R4), (?R5), R6, R7, (R8), R11, (R12), L1, (L2), (L3), (L4), (L5), L6, L8, L9, L10, L11, L13 or L14; manubrium; (sternebrae); R scapula; $\mathrm{R}$ radioulna; $\mathrm{R}$ radial carpal; $\mathrm{R}$ metacarpal; $\mathrm{L}$ scapula; $\mathrm{L}$ radioulna; $\mathrm{L}$ fused $2+3$ carpal; proximal thoracic sesamoid; proximal thoracic first phalanx; medial thoracic phalanx; bony pelvis, $\mathrm{R}$ femur, R tibia, R calcaneum; L femur, L tibia, two proximal pelvic phalanges. Specimens in parentheses are incomplete; those not in parentheses are either complete or nearly complete. Cranial, vertebral, and rib measurements are given in Tables 1-3; those for other elements are given in the Appendix.

The bones and teeth of the Kenora bison are well preserved and exhibit no evidence of pre-entombment or diagenetic weathering, abrasion, trampling, crushing, or chew-gnaw damage. The bones do vary in color, ranging from light to dark brown, which suggests exposure during diagenesis to different 


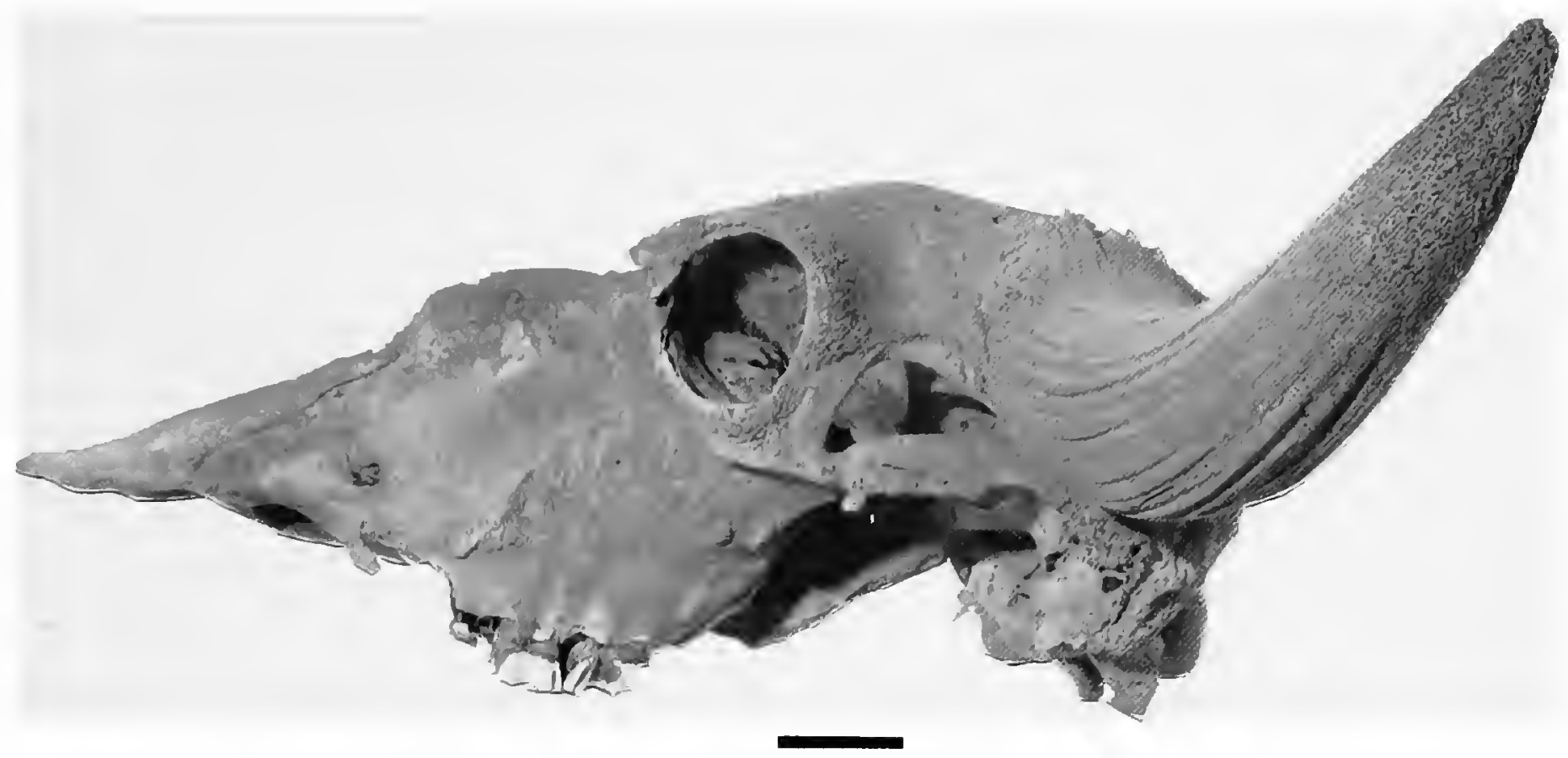

Figure 4.-Kenora bison skull in lateral view, left side. (Scale bar $=5 \mathrm{~cm}$.)

concentrations of decaying organic matter or to groundwater with differing concentrations of oxygen. All breakage of the bones can be attributed to damage during excavation.

AGE AND SEX.-The Kenora bison was approaching senescence at the time of its death. All teeth were in full to advanced wear. The RMl and both mls either had lost or were losing, by wear, the enamel fossettes within the dentine field.

Several morphological features identify this specimen as a male. The skull is robust, the frontal and fronto-parietal sutures are obscured by fusion over most of the dorsal surface of the cranium, the supraorbital foramina are bridged by bone at the level of the orbits, the horn cores possess distinct burrs at the base, the horn core growth is spiraled posteriorly around the longitudinal axis, and the anteroposterior plane of the base of the horn cores is rotated rearward relative to the frontal plane.
Females of all species of North American bison have relatively gracile skulls. Typically, among the short-horned North American bison, the frontal and fronto-parietal sutures are unfused over most or all of their length, the supraorbital foramina are not bridged by bone at the level of the orbits, the horn cores do not possess burrs at the base, the horn cores grow straight or spiral anteriorly around the longitudinal axis, and the anteroposterior plane of the bases of the horn cores is either rotated forward relative to the plane of the frontals or parallel with the plane of the frontals (McDonald, 1981).

TAXONOMIC IDENTITY.-The Kenora bison is referred to $\mathrm{Bi}$ son antiquus occidentalis on the basis of diagnostic criteria given in McDonald (1981). The horn cores of the Kenora bison are triangular in cross-section and symmetrical about the dorsoventral axis at the base. The tips of the horn cores are ellipti-

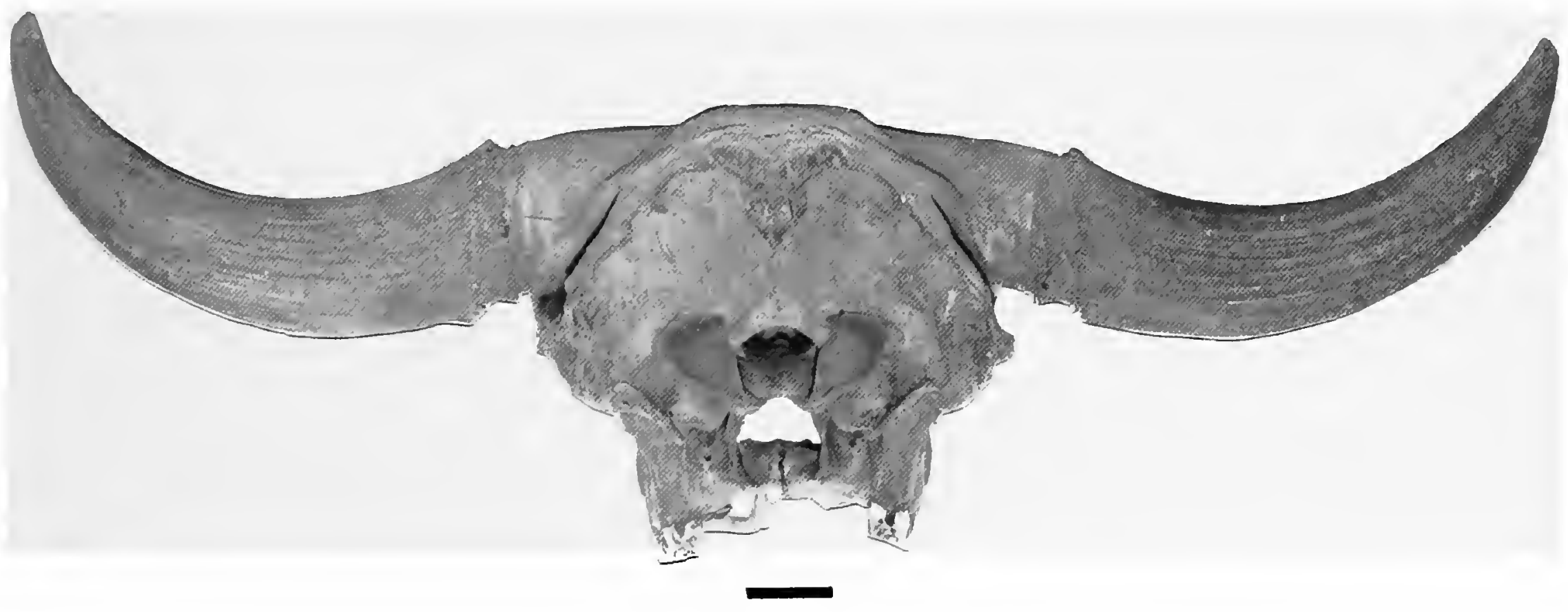

FigurE 5.-Kenora bison skull in caudal view. (Scale bar $=5 \mathrm{~cm}$.) 
TABLE 1.-Skull (linear measurements in $\mathrm{mm}$, angular measurements in degrees) of Kenora bison (Bison antiquus occidentalis) compared with the means of similar measurements for other shorter-horned North American bison. (Data are from McDonald, 1981, except measurements for Banff bison, which are from Harington, 1984; values in single parentheses are estimated dimensions for the complete character; values in double parentheses are for incomplete characters and are provided solely to describe the amount of bone present.)

\begin{tabular}{|c|c|c|c|c|c|c|c|c|c|c|}
\hline \multirow{2}{*}{ Measurement } & \multirow[b]{2}{*}{ Kenora bison } & \multirow[b]{2}{*}{ Banff bison } & \multicolumn{2}{|c|}{ B. a. antiquus ${ }^{1}$} & \multicolumn{2}{|c|}{ B. a. occidentalis ${ }^{2}$} & \multicolumn{2}{|c|}{ B.b.bison ${ }^{3}$} & \multicolumn{2}{|c|}{ B.b. athabascae } \\
\hline & & & $\overline{\bar{x}}$ & $s$ & $\overline{\bar{x}}$ & $s$ & $\overline{\bar{x}}$ & $s$ & $\overline{\bar{x}}$ & $\mathrm{~s}$ \\
\hline Spread of horn cores, tip to tip & $(850.0)$ & - & 870.0 & 71.0 & 779.3 & 76.9 & 603.9 & 44.7 & 681.2 & 92.0 \\
\hline Horn core length, upper curve, tip to burr & $(315.0)$ & 265.0 & 279.2 & 35.1 & 277.8 & 39.1 & 190.7 & 24.7 & 235.1 & 43.9 \\
\hline $\begin{array}{l}\text { Straight-line distance, tip to burr, dorsal surface of } \\
\text { horn core }\end{array}$ & 275.0 & - & 249.7 & 29.2 & 248.1 & 31.8 & 172.4 & 21.4 & 207.0 & 34.4 \\
\hline Dorsoventral diameter, horn core base & 88.6 & $(82.0)$ & 101.9 & 9.7 & 94.6 & 8.4 & 81.9 & 6.4 & 91.5 & 8.7 \\
\hline Rostro-caudal diameter, horn core base & 93.7 & 85.0 & 105.6 & 12.2 & 98.8 & 10.0 & 83.4 & 6.3 & 97.2 & 9.5 \\
\hline Minimum circumference, horn core base & 286.0 & $(260.0)$ & 324.4 & 32.6 & 300.3 & 27.7 & 255.4 & 19.5 & 289.1 & 22.9 \\
\hline Width of occiput at auditory opening & 269.9 & - & 287.9 & 18.6 & 262.0 & 13.2 & 243.9 & 9.7 & 273.6 & 15.3 \\
\hline Width of occipital condyles & 138.5 & - & 143.7 & 8.4 & 135.0 & 7.7 & 126.6 & 5.7 & 130.1 & 6.4 \\
\hline $\begin{array}{l}\text { Depth of occiput, nuchal line to dorsal edge of fora- } \\
\text { men magnum }\end{array}$ & 99.0 & - & 111.6 & 9.2 & 104.0 & 7.0 & 98.7 & 6.2 & 99.6 & 6.6 \\
\hline Least width of frontals, between horn cores and orbits & 274.1 & 301.0 & 314.7 & 19.4 & 296.6 & 16.8 & 271.1 & 12.6 & 293.4 & 10.5 \\
\hline Greatest width of frontals at orbits & 317.0 & - & 371.3 & 18.6 & 348.0 & 16.7 & 324.6 & 12.9 & 354.0 & 14.8 \\
\hline Distance, nuchal line to rostral end of premaxillae & 545.0 & - & $629.0^{*}$ & - & 564.3 & 24.8 & 535.3 & 17.0 & 578.6 & 15.2 \\
\hline $\begin{array}{l}\text { Angle of divergence of horn cores forward from sagit- } \\
\text { tal }\end{array}$ & 70.0 & - & 72.9 & 4.8 & 72.1 & 5.2 & 67.7 & 4.4 & 71.0 & 5.0 \\
\hline Angle between foramen magnum and occipital plane & 135.0 & - & 125.4 & 1.6 & 129.6 & 7.3 & 133.8 & 7.6 & 129.4 & 8.8 \\
\hline $\begin{array}{l}\text { Angle between foramen magnum and basioccipital } \\
\text { plane }\end{array}$ & 119.0 & - & 115.6 & 1.7 & 113.4 & 5.6 & 110.5 & 5.0 & 113.8 & 6.6 \\
\hline
\end{tabular}

\footnotetext{
1 Number of specimens measured varies from 1 to 41 .

${ }^{2}$ Number of specimens measured varies from 25 to 91 .

${ }^{3}$ Number of specimens measured varies from 56 to 142 .

${ }^{4}$ Number of specimens measured varies from 7 to 11 .

*Denotes sample containing only 1 specimen.
}

cal in cross-section. Growth along the longitudinal axis is modestly spiraled posteriorly, the posterior margins of the horn cores are slightly concave in dorsal view, and the anteroposterior plane of the horn core is rotated rearward relative to the plane of the frontals. The length along the upper surface of the horn core, tip to burr, is approximately $315 \mathrm{~mm}$, well within the range of 186-392 $\mathrm{mm}$ known for the taxon. In Bison antiquus antiquus, the tips of the horn cores are typically cordiform to triangular in cross-section and possess a distinct groove on the dorsal surface, growth is straight (not spiraled) around the arched longitudinal axis of the core, the posterior margin is straight, and the anteroposterior plane of the hom cores is parallel with the frontal plane. The horn cores of Bison bison grow straight along the longitudinal axis, they are straight along their posterior margins, and they are less slender (i.e., length: basal circumference ratio is less) than in Bison antiquus occidentalis.

PATHOLOGIES.-Pathological conditions are apparent in the bones and teeth of the skull and in both halves of the mandible. The RP2 and P3 were missing during at least the later part of the life of the Kenora bison, as evidenced by the ossified alveo-

TABLE 2.-Measurements (in $\mathrm{mm}$ ) of vertebrae (exclusive of atlas and axis) of Kenora bison. (Measurements conform to those described for bovids in von den Driesch, 1976. Measurements in parentheses are estimated dimensions for the complete character.)

\begin{tabular}{|c|c|c|c|c|c|c|c|c|c|c|c|c|c|c|}
\hline Measurement & C3 & $\mathrm{C5}$ & $\mathrm{C} 7$ & $\mathrm{~T} 1$ & $\mathrm{~T} 2$ & T4 & T5 & ?T7 & T9 & ?T 10 & $\mathrm{~L} 2$ & L3 & L4 & L5 \\
\hline $\mathrm{H}$ & $(155.0)$ & 168.0 & 385.0 & - & - & & - & - & - & - & 158.9 & 160.5 & 155.9 & 148.1 \\
\hline GL & 66.0 & 62.0 & 57.0 & 59.0 & 61.0 & 62.0 & 59.0 & 60.0 & 61.0 & 62.0 & 64.0 & 65.0 & 64.0 & 65.0 \\
\hline $\mathrm{GLPa}$ & 100.2 & 89.5 & 94.3 & 70.2 & 66.3 & 63.7 & 63.2 & 63.9 & 60.7 & 63.5 & 99.6 & 100.6 & 94.8 & 96.9 \\
\hline Bpacr & 97.0 & 113.2 & 109.5 & - & - & & - & - & - & - & 65.6 & 75.1 & 78.1 & 78.2 \\
\hline Bpacd & 101.7 & 102.6 & 86.3 & - & - & - & - & - & - & - & 47.6 & 46.5 & 49.5 & 60.1 \\
\hline Bfcr & 45.5 & 41.0 & 43.0 & 65.4 & 58.7 & 57.1 & 59.8 & 48.7 & 59.2 & 55.2 & 48.0 & 49.1 & 49.9 & 50.8 \\
\hline Bfcd & 51.1 & 48.1 & 79.4 & 77.5 & 77.9 & 74.9 & 70.2 & 62.6 & 77.1 & 67.3 & 52.7 & 53.6 & 55.8 & 66.2 \\
\hline $\mathrm{Hfcr}$ & 53.1 & 55.1 & 59.0 & 51.7 & 53.5 & 52.7 & 49.6 & 47.2 & 53.1 & 47.3 & 45.9 & 47.0 & 47.8 & 47.1 \\
\hline Hfcd & 53.6 & 57.7 & 54.8 & 50.3 & 51.1 & 50.1 & 44.4 & 45.1 & 52.2 & 43.3 & 43.4 & 46.3 & 45.7 & 42.0 \\
\hline $\mathrm{MinBr}$ & 59.1 & 80.1 & 93.1 & 67.6 & 66.9 & 44.6 & 43.3 & 37.2 & 48.4 & 43.8 & 42.8 & 44.2 & 52.5 & 60.9 \\
\hline Bptr & - & - & 139.8 & 129.4 & 119.0 & 110.5 & 110.4 & 107.8 & 112.5 & 107.5 & $(242.0)$ & 317.0 & $(358.0)$ & $(369.2)$ \\
\hline Height of spine & - & 69.9 & 326.0 & - & 472.0 & - & 285.0 & 214.0 & 391.0 & 141.0 & $(101.0)$ & 93.6 & 87.4 & 80.8 \\
\hline
\end{tabular}




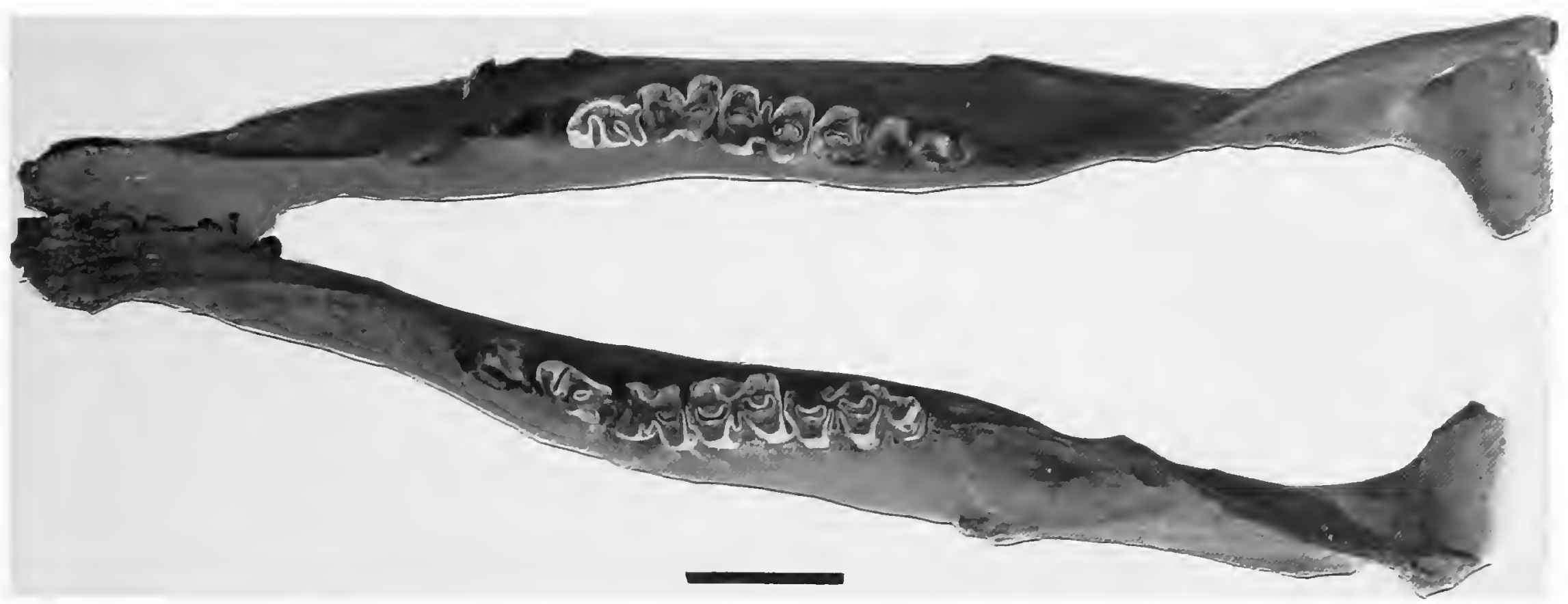

FIGURE 6. -Kenora bison mandible in dorsal view. (Scale bar $=5 \mathrm{~cm}$.)

lar trough that would have accommodated the roots of these teeth (Figure 6). A hole is present in the dentine fields of LM3. The insertion tubercle for the masseteric muscle on the right mandible is conspicuously larger than the same tubercle on the left mandible (Figure 7). Both the right and left halves of the mandible had been fractured and healed. The fractures were centered approximately below the right $\mathrm{p} 2-\mathrm{p} 3$ and left $\mathrm{p} 4-\mathrm{m} 1$ (Figures 6-9). The right mandibular body contains roughened

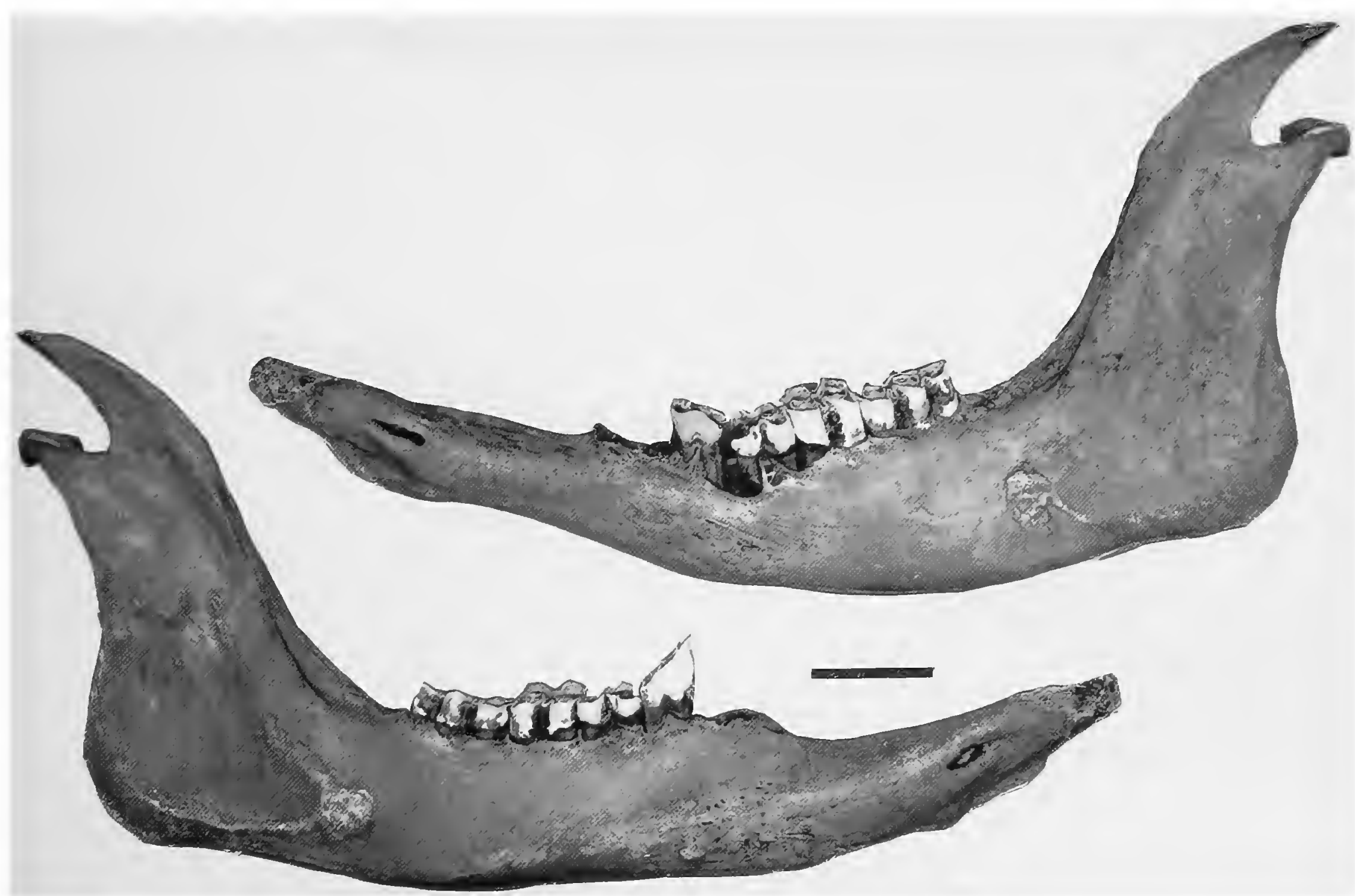

FIGURE 7.-Left (top) and right (bottom) halves of Kenora bison mandible in lateral view. (Scale bar=5 cm.) 


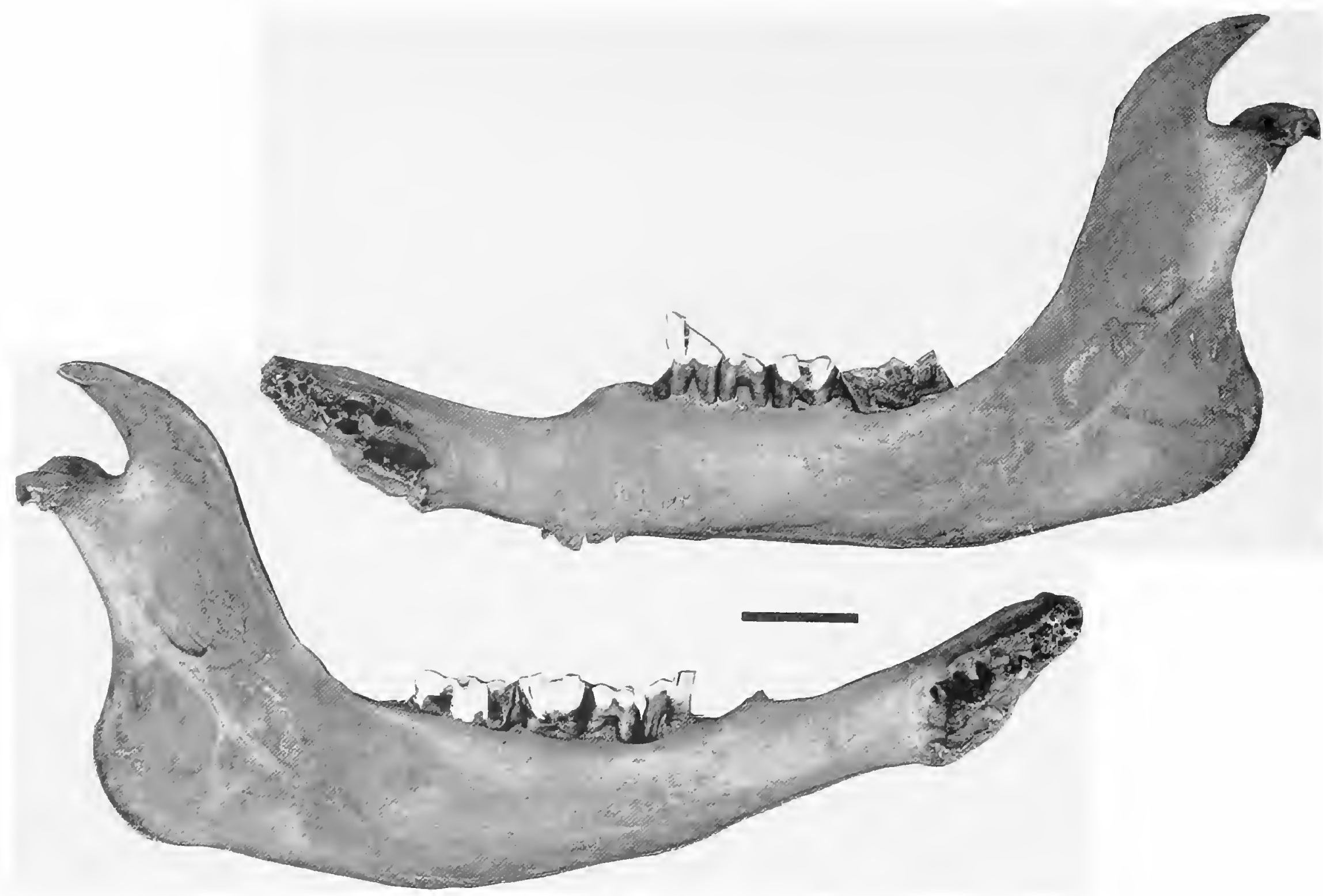

FIGURE 8. - Left (top) and right (bottom) halves of Kenora bison mandible in medial view. (Scale bar $=5 \mathrm{~cm}$.)

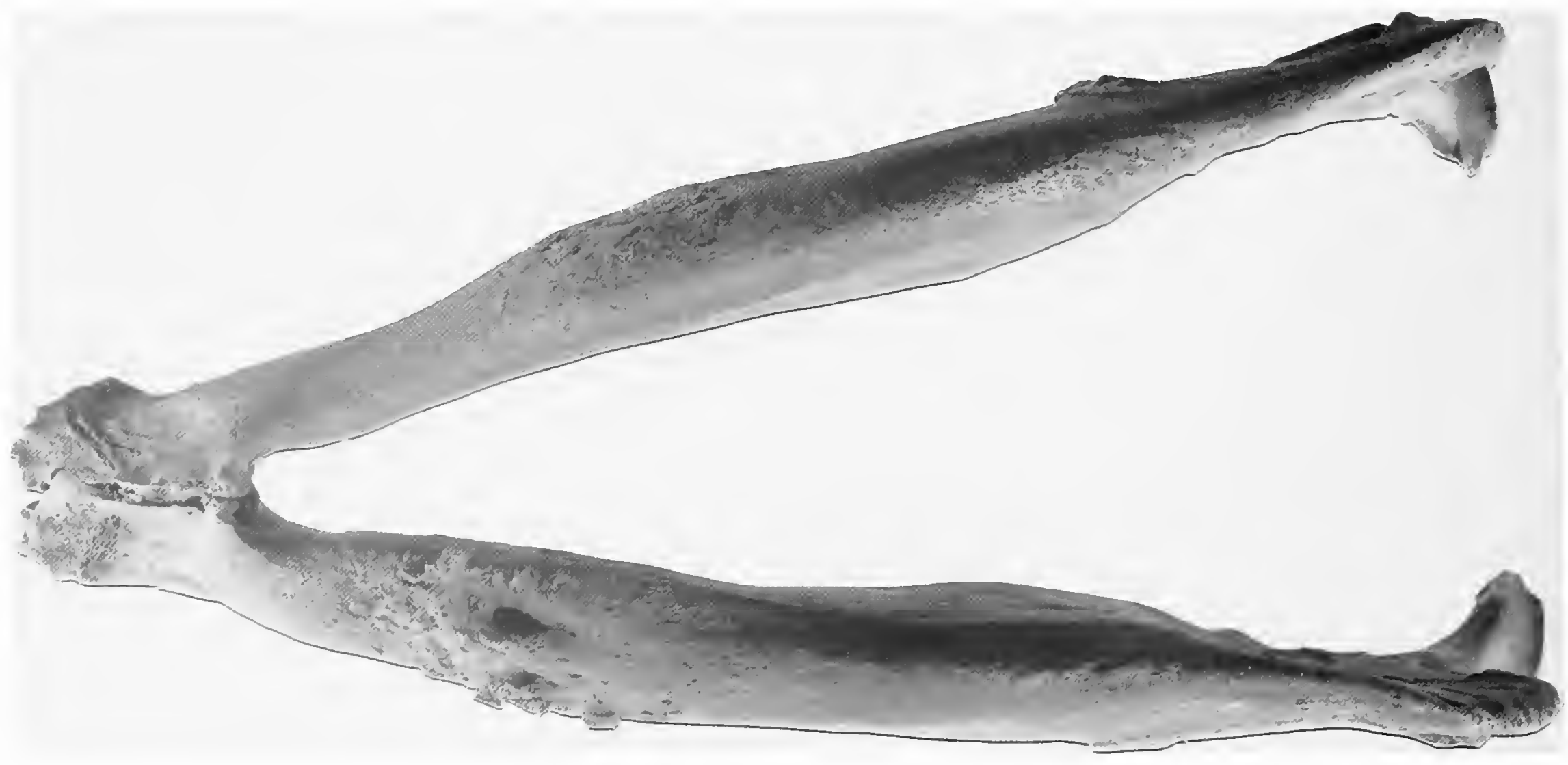

FIGURE 9.-Kenora bison mandible in ventral view. (Scale bar $=5 \mathrm{~cm}$.) 
TABLE 3.- Measurements (in $\mathrm{mm}$ ) of ribs of Kenora bison. (Measurements in double parentheses are for incomplete elements and are provided solely to describe the amount of the element that is present.)

\begin{tabular}{c|ccc}
\hline Rib number & Length & $\begin{array}{c}\text { Minimum anteropos- } \\
\text { terior diameter }\end{array}$ & $\begin{array}{c}\text { Minimum } \\
\text { circumference }\end{array}$ \\
\hline R1 & 316 & 27.6 & 73.0 \\
?R2 & $((210))$ & - & - \\
R3 & 360 & 26.1 & 64.0 \\
R4 & 466 & 26.7 & 70.0 \\
?R5 & $((84.9))$ & - & - \\
R6 & 604 & 27.3 & 74.0 \\
R7 & 630 & 25.1 & 69.0 \\
R8 & $((400))$ & - & - \\
R11 & 563 & 19.6 & 62.0 \\
R12 & $((460))$ & 19.9 & 57.0 \\
L1 & 309 & 27.4 & 74.0 \\
L2 & $((229))$ & 25.4 & 63.0 \\
L3 & $((260))$ & - & - \\
L4 & $((135))$ & - & - \\
L5 & $((224))$ & 29.7 & 76.0 \\
L6 & 609 & 27.6 & 76.0 \\
L8 & 644 & 25.8 & 69.0 \\
L9 & 645 & 21.6 & 61.0 \\
L10 & 618 & 18.2 & 61.0 \\
L11 & 568 & 18.8 & 61.0 \\
L13 & 396 & 17.9 & 56.0 \\
\hline
\end{tabular}

bone on the lateral, ventral, and medial surfaces of the healed fracture, and a subcircular hole leading to the interior of the bone opens through the ventral surface of the fractured area. Rostral to the level of Rm1, the body of the right ramus of the mandible is conspicuously wider than that of the left, and the diastema is displaced ventral to its normal position. Root canals for the missing Rp2 and Rp3 are present in the alveolar trough, indicating that these teeth were present at, or at least shortly before, the time of death. The medial side of $\mathrm{Rm} 3$ was shorn away in life, and the dentine surface thus exposed was worn smooth by use. The surface of the healed left body of the mandible is much smoother than that of the right, and no displacement of the diastema occurred. A circular opening is located between and below Lp4-Lm1; both of these teeth are loosely rooted in the alveolus, and an abnormally long gap separates the two teeth. The bone surrounding the opening is dense and does not appear to have been affected by infection at the time of death. Root canals for the missing Lp2 and Lp3 are present, but they are shallow-a condition that suggests either displacement of the teeth or modification of the roots by the trauma to the mandible or by its subsequent healing. Enamel on the medial surfaces of Lp4, Lm1, and Lm3 had been chipped, part of the medial wall of the rostral cusp of $\operatorname{Lm} 3$ is missing, and holes are present in the dentine fields of $\mathrm{Lm} 3$ and $\mathrm{Lp} 4$. The tooth rows of both halves of the mandible are unusually sinuous, probably reflecting modification of the tooth alignment by the fractures and subsequent healing.

No pathologic conditions were noted in any of the postcranial bones.

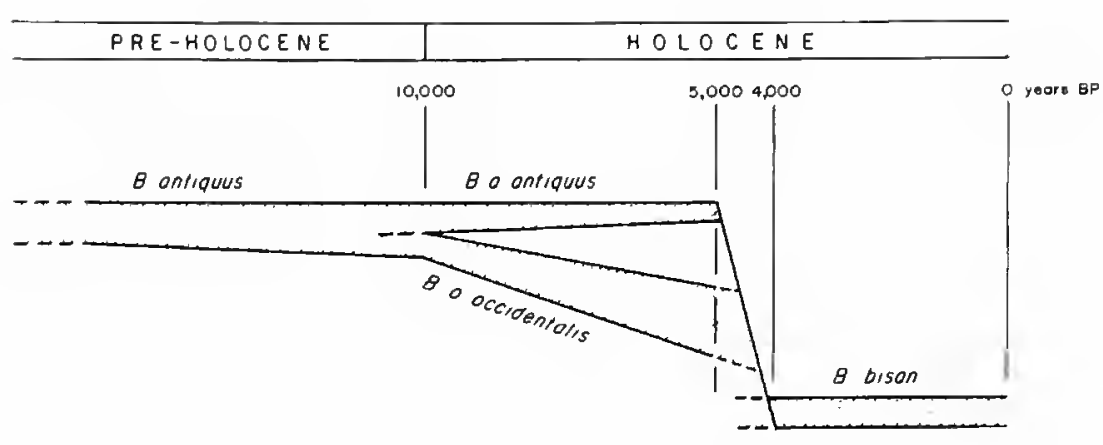

FIGURE 10.--The evolutionary fold of 5000-4000 radiocarbon yrs BP, when the evolution of Bison bison from Bison antiquus was rapidly completed (from McDonald, 1981).

\section{DISCUSSION}

The Kenora bison lived at the time when the nucleus of the North American bison range was anchored on the northern Great Plains and when the final, rapid steps in the evolution of Bison bison from Bison antiquus were taking place (Figure 10) (McDonald, 1981). The radiocarbon age of $4270 \pm 65$ yrs BP is the youngest such date of which we are aware for a specimen that can be assigned with confidence to Bison antiquus occidentalis. Harington (1984) reported a partial cranium from Banff, Alberta, dated at $3240 \pm 90$ yrs BP (I-11638), which he referred to Bison bison occidentalis, equivalent to Bison antiquus occidentalis as used in this paper. Having examined the Banff cranium, we believe that this specimen is referable to $B i$ son bison. All measurements that can be obtained from the skull of the specimen are within the range of Bison bison (Table 1), and the qualitative aspects of characters still visible on the specimen also are consistent with those typical of Bison bison.

Measurements of the Kenora bison skull are all within the range documented for Bison antiquus occidentalis, but some are outside the observed ranges for Bison antiquus antiquus and Bison bison (Table 1; cf. tables 21, 25, 29, and 34 in McDonald, 1981). Most features of the Kenora bison skull conform harmoniously with both qualitative and quantitative attributes of the skull typical of Bison antiquus occidentalis. The horn cores are longer and more slender (i.e., long relative to diameter at base), and the dorsal part of the cranium is narrower than typical specimens, however. The breadth of the base of the cranium is near the mean for the taxon.

All measured dimensions of the long bones of the Kenora bison are smaller than the observed means for the limbs of Bison antiquus occidentalis except the anteroposterior diameter of the femur, which is slightly larger (within one standard deviation $(s)$ ) than the observed mean for the taxon (Table 4). The length of the radius is $>2 s$, and that of the femur and tibia are between $1 s$ and $2 s$, of the mean for Bison antiquus occidentalis long bone lengths, whereas the length of the metacarpal in the Kenora bison is smaller than the heretofore-documented minimum for the taxon. The transverse diameters of all four limb 
TABLE 4.-Limb measurements (in mm) for shorter-horned North American bison, males only. (For each taxon, top row is mean measurement, bottom row is standard deviation. Data from McDonald, 1981. AP=anteroposterior diameter; $\mathrm{TR}=$ transverse diameter; $\mathrm{L}=$ rotational length; ${ }^{*}=$ sample with only $\mathrm{l}$ specimen.)

\begin{tabular}{|c|c|c|c|c|c|c|c|c|c|c|c|c|c|c|c|c|c|c|c|}
\hline \multirow{2}{*}{ Species } & \multirow[b]{2}{*}{$n$} & \multicolumn{3}{|c|}{ Humerus } & \multicolumn{3}{|c|}{ Radius } & \multicolumn{3}{|c|}{ Metacarpal } & \multicolumn{3}{|c|}{ Femur } & \multicolumn{3}{|c|}{ Tibia } & \multicolumn{3}{|c|}{ Metatarsal } \\
\hline & & $\mathrm{L}$ & $\mathrm{AP}$ & $\mathrm{TR}$ & $\mathrm{L}$ & $\mathrm{AP}$ & $\mathrm{TR}$ & $\mathrm{L}$ & $\mathrm{AP}$ & TR & $\mathrm{L}$ & $\mathrm{AP}$ & $\overline{\mathrm{TR}}$ & $\mathrm{L}$ & $\mathrm{AP}$ & TR & $\mathrm{L}$ & $\mathrm{AP}$ & TR \\
\hline Bison antiq & $1-28$ & $339.0 *$ & 69.7 & 58.7 & 343.0 & 33.7 & 54.5 & 222.0 & 30.7 & 52.3 & 429.0 & 56.2 & 58.8 & 412.0 & 42.5 & 59.0 & 273.9 & 35.2 & 40.9 \\
\hline antiquus & & $S=-$ & 2.8 & 0.5 & 7.7 & 0.9 & 1.2 & 6.6 & 1.2 & 3.5 & 14.0 & 4.2 & 2.1 & 14.7 & 2.9 & 3.2 & 8.3 & 2.3 & 2.7 \\
\hline Bison antiquus & $38-161$ & 356.9 & 66.4 & 55.0 & 343.8 & 35.5 & 58.5 & 219.8 & 30.1 & 51.4 & 403.7 & 50.0 & 49.3 & 403.5 & 38.9 & 53.5 & 270.3 & 33.1 & 39.2 \\
\hline occidentalis & & $S=21.6$ & 4.5 & 4.2 & 14.7 & 2.1 & 3.3 & 8.6 & 1.8 & 3.7 & 18.0 & 3.2 & 2.3 & 17.6 & 2.2 & 3.0 & 10.0 & 1.8 & 2.9 \\
\hline $\begin{array}{l}\text { Kenora bison } \\
\text { (MMMN V-1914) }\end{array}$ & 1 & - & - & - & 309.0 & 32.0 & 57.8 & 190.0 & 28.2 & 48.3 & 383.0 & 51.8 & 48.8 & 370.0 & 35.0 & 51.7 & - & - & - \\
\hline Bison bison & $37-118$ & 325.9 & 61.5 & 50.6 & 320.5 & 32.2 & 53.9 & 206.3 & 27.2 & 45.4 & 380.7 & 47.9 & 47.3 & 371.9 & 34.7 & 49.1 & 255.2 & 30.3 & 35.3 \\
\hline bison & & $S=11.1$ & 3.1 & 3.1 & 9.2 & 1.7 & 2.8 & 7.1 & 1.6 & 3.4 & 10.4 & 2.4 & 2.4 & 10.0 & 1.4 & 2.2 & 7.7 & 1.3 & 1.9 \\
\hline Bison bison & $2-3$ & 354.5 & 67.5 & 58.5 & 341.3 & 35.0 & 59.7 & 228.7 & 30.3 & 52.0 & 421.3 & 54.0 & 51.7 & 414.3 & 38.0 & 53.3 & 275.7 & 33.0 & 39.0 \\
\hline athabascae & & $S=6.3$ & 0.7 & 0.7 & 14.0 & 1.0 & 3.5 & 4.1 & 1.1 & 2.0 & 11.5 & 4.3 & 0.5 & 12.6 & 1.7 & 1.5 & 5.5 & 1.0 & 1.7 \\
\hline
\end{tabular}

bones, and the anteroposterior diameter of the femur, are near the mean for Bison antiquus occidentalis, whereas the anteroposterior diameters of the shaft of the radius, metacarpal, and tibia are $>1 s$ from the observed mean for Bison antiquus occidentalis. At the same time, however, the dimensions of the Kenora bison long bones are also within the ranges observed for Bison bison bison. The two thoracic limb bones of the Kenora bison are $>1 s$ shorter than the mean, whereas the two pelvic limb bones are very near the mean for Bison bison bison. The diameters of all four bones are near the mean for Bison bison bison. All of the long bones of the Kenora bison are smaller than the documented range for equivalent characters in male Bison bison athabascae.

The fact that the Kenora bison lived near the end of the Bison antiquus lineage, as Bison antiquus was changing rapidly into Bison bison (Figure 10), suggests that the Kenora bison should be relatively small bodied compared with the mean for Bison antiquus occidentalis. Except for the horn cores, which are relatively long for the subspecies, the cranium of the Kenora bison generally conforms to this expectation of small size. The long bones are shorter than might be expected when compared with the size of the skull. If the evolutionary reduction in all skeletal elements were taken to be isometric, these long bones would probably be identified casually as those of Bison bison bison had they been found without the associated skull. In general, however, the long bones are broad and robust relative to their length, a condition suggesting that the Kenora bison was more heavily built than Bison bison bison. In addition, the bones of the thoracic limb are shorter relative to those of the pelvic limb, a condition resembling more nearly the limb proportions of Bison antiquus antiquus than Bison bison bison. (The thoracic limb:pelvic limb ratio was lowest $(0.81)$ in Bison antiquus antiquus, greater $(0.83)$ in Bison bison athabascae, still greater (0.846) in Bison bison bison, and greatest (0.854) in Bison antiquus occidentalis (i.e., the thoracic limb, relative to the pelvic limb, was shortest in Bison antiquus antiquus and longest in Bison bison occidentalis). Bison bison occidentalis also demonstrated the greatest variation in limb dimensions, which is not unexpected given its dynamic role as a decanalized evolutionary bridge between two relatively canalized species (Tables 5, 6).

ZOOGEOGRAPHIC SigNiFiCANCE.-The Kenora bison is a range record for the subspecies, species, and genus. The nearest known remains of bison from natural contexts are of Bison antiquus antiquus from Betula Lake, Whiteshell Provincial Park, Manitoba, and Bison antiquus occidentalis from Nicollet Creek, Itasca State Park, Minnesota, respectively $65 \mathrm{~km}$ west and $280 \mathrm{~km}$ south of Kenora (Figure 1) (Cleland, 1966; Shay, 1971; McDonald, 1981). Prehistoric Bison bison remains have been recovered from the Hungry Hall archaeological site along the east side of Rainy River near where it discharges into Lake of the Woods, Ontario (Moore, 1975). Bison from Hungry Hall are north and east of the known natural range of Bison bison; they probably were imported by Indians from the nearby bison range.

TABLE 5.-Ratios of anteroposterior and transverse diameters to lengths of long limb bones. (Data from McDonald, 1981, as presented in Table 4. $\mathrm{AP}=$ anteroposterior diameter; $\mathrm{TR}=$ transverse diameter; $\mathrm{L}=$ rotational length; * =sample with only 1 specimen.)

\begin{tabular}{|c|c|c|c|c|c|c|c|c|c|c|c|c|c|}
\hline \multirow{2}{*}{ Species } & \multirow[b]{2}{*}{$n$} & \multicolumn{2}{|c|}{ Humerus } & \multicolumn{2}{|c|}{ Radius } & \multicolumn{2}{|c|}{ Metacarpal } & \multicolumn{2}{|c|}{ Femur } & \multicolumn{2}{|c|}{ Tibia } & \multicolumn{2}{|c|}{ Metatarsal } \\
\hline & & $\overline{\mathrm{AP}: L}$ & $\overline{T R: L}$ & $\overline{\mathrm{AP}: \mathrm{L}}$ & TR:L & $\overline{\mathrm{AP}: \mathrm{L}}$ & TR:L & $\overline{\mathrm{AP}: \mathrm{L}}$ & $\overline{\text { TR:L }}$ & $\overline{\mathrm{AP}: \mathrm{L}}$ & $\overline{\text { TR:L }}$ & $\overline{\mathrm{AP}: \mathrm{L}}$ & $\overline{\text { TR:L }}$ \\
\hline Bison antiquus antiquus & $1-28$ & $0.206^{*}$ & 0.173 & 0.098 & 0.159 & 0.138 & 0.236 & 0.131 & 0.137 & 0.103 & 0.143 & 0.129 & 0.149 \\
\hline Bison antiquus occidentalis & $38-161$ & 0.186 & 0.154 & 0.103 & 0.170 & 0.137 & 0.234 & 0.124 & 0.122 & 0.096 & 0.133 & 0.122 & 0.145 \\
\hline Kenora bison (MMMN V-1914) & 1 & - & - & 0.104 & 0.187 & 0.148 & 0.254 & 0.135 & 0.127 & 0.095 & 0.140 & - & - \\
\hline Bison bison bison & $37-118$ & 0.180 & 0.155 & 0.100 & 0.168 & 0.132 & 0.220 & 0.126 & 0.124 & 0.093 & 0.132 & 0.119 & 0.138 \\
\hline Bison bison athabascae & $2-3$ & 0.190 & 0.165 & 0.103 & 0.175 & 0.132 & 0.227 & 0.128 & 0.123 & 0.092 & 0.129 & 0.120 & 0.141 \\
\hline
\end{tabular}


TABLE 6.- Ratios between selected cranial and limb biometrics for shorter-horned North American Bison, males only. (Data from McDonald, 1981. FW=least frontal breadth; N-Pm=nasion to premaxilla; BW=breadth across base of skull at mastoid processcs; $\mathrm{TL}=$ combined rotational length of humerus, radius, and metacarpal; $\mathrm{PL}=$ combined rotational length of femur, tibia, and metatarsal; HCL=horn core length.)

\begin{tabular}{l|ccccccc}
\hline \multicolumn{1}{c|}{ Species } & FW/N-Pm & BW/N-Pm & TL/PL & HCL/TL & HCL/PL & FW/TL & FW/PL \\
\hline Bison antiquus antiquus & 0.500 & 0.457 & 0.811 & 0.308 & 0.250 & 0.348 & 0.283 \\
Bison antiquus occidentalis & 0.526 & 0.464 & 0.854 & 0.302 & 0.258 & 0.322 & 0.275 \\
Kenora bison (MMMN V-1914) & 0.503 & 0.495 & - & - & - & - & - \\
Bison bison bison & 0.506 & 0.455 & 0.846 & 0.224 & 0.189 & 0.318 & 0.269 \\
Bison bison athabascae & 0.507 & 0.472 & 0.832 & 0.254 & 0.212 & 0.317 & 0.264 \\
\hline
\end{tabular}

Paleoecological Significance.-During the Atlantic climatic episode (ca. 8500-5000 yrs BP) the regional vegetation of extreme southwestern Ontario was dominated by a mixed forest. Early in the episode, when conditions were cooler and more mesic, conifers dominated. By the end of the episode, when the warming and drying trend reached its maximum, deciduous broadleaf species were more prominent than conifers in the regional forest, and open areas supporting grasses and other herbs presumably reached their maximum. The onset of the Sub-Boreal climatic episode (ca. 5000-2750 yrs BP) brought a cooler, more mesic climate, which led to a closed forest with conifers increasing in importance relative to deciduous broadleaf species.

The parkland vegetation that characterized the Kenora region around 5000 yrs BP, with the deciduous browse and sparse grasses, would have afforded the best local environmental conditions available during the Holocene for supporting populations of bison. This does not mean that the population of bison in the Kenora region was either large or permanent. The Kenora bison does not possess morphological characteristics suggesting inbreeding depression in the population (McDonald, 1981), but it does show evidence of extended nutritional stress.

McAndrews's (1982) interpretation of the death of the Kenora bison-that it died in a shallow pond-is consistent with taphonomic evidence as well as paleobotanic and sedimentary evidence. Similarly, the bones recovered consist of a random array of elements, not the patterned collection that would be expected had the bison been killed by predators or its carcass scavenged, or had flowing water sorted the bones (Voorhies, 1969; Haynes, 1980, 1982; Shipman, 1981). All breakage in the bones appears to be the result of excavation by heavy machinery rather than the result of battering in a highenergy fluvial environment. Some of the elements appear to have weathered after excavation.

INTERPRETATION OF PATHOLOGIES.--Two pathologic conditions appear to be represented in the Kenora bison. A trauma to the face appears to have broken the bodies of both halves of the mandible and dislodged the R/L? P2 and P3. A sharp blow to the right half of the mandible, along or immediately caudal to the diastema, could have produced the fractures that broke the bone completely through, allowing it to become displaced, and bent the body of the left side of the mandible to the left, producing a green-stick fracture that separated the medial and ven- tral parts but not the dorsolateral part. The incompletely severed left body could have functioned as the splint that held the rostral parts of both halves of the mandible in place while they healed. Healing occurred with slight ventral displacement of the diastema of the right body.

In addition to the pathologic conditions discussed above, the broken teeth conform to a pattern of tooth pathology seen in the dentition of numerous musk oxen (Ovibos moschatus) from Greenland, the Arctic islands of Canada, and Alaska (Henrichsen, 1981, 1982; Anne Gunn, pers. comm., 1987; McDonald, unpub. data). The usual pattern of this pathology is that holes exist in the dentine field in correlation with broken teeth. In musk oxen, the enamel walls of teeth are often conspicuously thin in individuals exhibiting the condition. The etiology of this condition is not known, but it is believed to result from inadequate or imbalanced intake of (=access to) essential nutrients, such as calcium or phosphorus. The hypoplastic condition of the dentine and enamel appears to weaken the teeth to the extent that normal use results in tooth breakage. In musk oxen exhibiting hypoplasia and subsequent breakage, irritation of the alveolar bone is common, and teeth frequently are loosely rooted and have nodulated roots.

In the Kenora bison, the medial wall of the $\mathrm{Rm} 3$ was broken to below the gum line (Figure 8), but no irritation of the alveolar bone is apparent. Indeed, the alveolar bone is dense and most of the teeth, except those near the fractures, are well rooted. The fact that some teeth exhibit hypoplasia and are chipped or more extensively broken suggests that the Kenora bison was experiencing modest long-term nutritional stress. This stress could have been caused by the inadequate supplies of the requisite nutrients in the formerly glaciated, shallowsoiled Kenora area.

\section{Gross Allometry in Holocene Bison Evolution}

The evolution of limb length and proportions in North American Holocene bison is summarized in Tables 4 and 5. The most general tendency was toward absolutely shorter limbs, with more robust (i.e., greater shaft:length ratio) upper limb bones and more gracile (i.e., lesser shaft:length ratio) metapodials, relative to length. Superimposed on this pattern was a trend toward the evolution of longer thoracic limbs relative to pelvic limbs. Both of these observations apply to the derivation of the late Holocene Bison bison from the late Wisconsinan Bison an- 
tiquus. In other ways, the pattern of limb evolution in Bison bison athabascae diverged from that in Bison bison bison. The latter evolved to absolutely smaller size, with the greatest relative reduction of length taking place in the upper limb bones and the least occurring in the metapodials. In Bison bison athabascae, the femur and humerus evolved to be only slightly $(1 \%-3 \%)$ shorter than in Bison antiquus antiquus, the radius and tibia remained about the same size, and the metapodials became longer.

The skull of bison became smaller during the Holocene, and the proportions of some characters altered, which produced changes in shape. The most obvious changes were those involving the horn cores, which became smaller, directed more caudally, and rotated caudally. The cranium became more domed on the dorsal surface, and the occipital condyles projected less far from the occiput. The skull became shorter and, on the dorsal surface, narrower in nearly equal proportions; but the rate of shortening exceeded the rate at which the base of the cranium narrowed, leaving the ventral side of the cranium proportionately wider in Bison bison than it had been in Bison antiquus.

When the evolutionary changes in the limbs and skull of bison are correlated, the pattern that emerges is a trend toward a relatively smaller head (with conspicuously allometrically shorter horns) set relatively lower on a body whose limbs, especially the thoracic limbs, were becoming relatively longer (Table 6). Bamforth (1988), drawing upon data in McDonald (1981), observed that limb length in North American bison increased relative to overall body size during the early Holocene.

The relative lengthening of the thoracic limbs and the changes in the robustness of the limb bones are probably associated with the evolution of relatively more cursorial habits in Bison bison than characterized Bison antiquus antiquus. The musculature of the upper limbs was exaggerated, relative to that of Bison antiquus antiquus, paralleling the increased relative robustness of the upper limb bones, and the metapodials developed into support structures carrying absolutely less weight and better equipped for more frequent and versatile mobility than had typified Bison antiquus antiquus. The length of the thoracic limb, relative to the pelvic limb, in Bison bison bison is greater than in Bison bison athabascae, probably because of selection for greater cursoriality, more frequent or specialized agonistic encounters during the rut (which selected for greater forebody strength, focused on the thoracic limb, for delivering and enduring head-to-head clashes and various headthrusting movements), and the essentially obligatory grazing feeding behavior (requiring regular raising and lowering of the relatively low-slung but massive head) of the former, all as discussed at greater length in McDonald (1981). Bison bison athabascae, on the other hand, is less cursorial, probably has less frequent or less specialized agonistic encounters during the rut, and has greater opportunity to browse at higher than ground level with its relatively high-placed head; it has therefore developed a relatively lower hump and shorter thoracic limb.

\section{The Evolutionary Place of Bison bison athabascae}

The evolutionary position of Bison bison athabascae has been a subject of scholarly and practical concern for a century. The existence of a form of extant bison in north-central Canada different from the plains bison, Bison bison, has been known to science since at least 1829 (Richardson, 1829; Hind, 1859). Most early writers regarded the northern bison as little more than a phenotypic variant, or merely a marginal population, of the plains bison. Rhoads (1897), however, regarded the northern, or wood, bison to be taxonomically distinct and gave it the name Bison bison athabascae. Scientific and political opinion on the taxonomic status of the wood bison has vacillated frequently during the last century. There is no question, however, that the bison native to the parklands of north-central Canada during the nineteenth and twentieth centuries were demonstrably larger than the contemporary plains bison. Here we follow McDonald's (1981) premise that it is scientifically useful and valid to designate the wood bison as taxonomically distinct, a position recently reinforced by van Zyll de Jong and others (1995).

The wood bison became protected by law in 1891, and two years later a preserve was created as a refuge for the remaining populations. The total population of wood bison was about 1500-2000 when, between 1925 and 1928-at a time when wood bison were considered by responsible authorities as not distinct taxonomically from the plains bison-6673 plains bison were introduced into Wood Buffalo National Park. Today, most zoologists familiar with North American bison recognize only a single extant North American species-Bison bisoncontaining the two subspecies Bison bison bison (the plains bison) and Bison bison athabascae (the wood bison) (e.g., Skinner and Kaisen, 1947; McDonald, 1981; Nowak and Paradiso, 1983; Meagher, 1986; van Zyll de Jong, 1986; van Zyll de Jong et al., 1995). Flerow (1971) considered the wood bison to belong to a separate species, Bison priscus, and he identified it as Bison priscus athabascae. Geist (1990), however, recently argued that the wood and plains bison are taxonomically identical.

Interpretations of the evolutionary origins of Bison bison athabascae have fallen generally into two categories. The first interpretation is that Bison bison athabascae represents a descendant (either changed or unchanged) form of bison derived from ancestral populations that originated in eastern Siberia or Beringia and dispersed southward. Bison bison athabascae then represents either (1) the evolutionary and geographic endpoint of that parent dispersal or (2) an arrested phase of the evolutionary trajectory that continued as the parent dispersal continued southward to produce, either alone or with introgression with more southerly bison, the plains bison (Skinner and Kaisen, 1947; Guthrie, 1970; Flerow, 1971; Harington, 1984; van Zyll de Jong, 1986). A second interpretation is that Bison bison athabascae represents a (changed) descendant form of bison derived from ancestral populations that originated in 
midlatitude North America and dispersed northward during the early and middle parts of the Holocene (McDonald, 1981).

Elsewhere, McDonald (1981) has argued against the Beringian origin of Bison bison athabascae and Bison bison bison and for the common origin of both of these subspecies from $B i$ son antiquus. McDonald relied upon the dense and continuous factual record documenting both the spatial, temporal, and morphological continuity among midlatitude North American bison throughout the Holocene and the absence of any such spatial and morphological continuity among bison in, or those coming from, Beringia. Quite simply, the vast body of factual evidence still demonstrates that Bison bison athabascae is morphologically, temporally, and spatially nearer to Bison bison bison than to the late Pleistocene bison of eastern Siberia. Opinions to the contrary are based upon antiquated concepts of either (1) progressive diminution of body size or (2) periodic radiation of new taxa into North America from Siberia, or both (e.g., Allen, 1876; Gromova, 1935; Schultz and Frankforter, 1946; Skinner and Kaisen, 1947; Guthrie, 1970; Wilson, 1975, 1996; Harington, 1986).

Van Zyll de Jong (1986) argued the case for a Beringian origin for Bison bison athabascae and supported his thesis with a well-preserved skull (PIN 835-624-39) from the Bolshaya Chukochya River in Siberia. He considered this skull to be representative of "athabascae-like bison in eastern Siberia at the close of the last glaciation." "The similarity of this bison to North American occidentalis and to athabascae is strong evidence of the former existence of an ancestral Beringian population" (van Zyll de Jong, 1986:53). Van Zyll de Jong did not examine the specimen personally, and he provided no absolute age for the specimen or the population it represented. Nor did he figure the specimen, describe any diagnostic characteristics that would allow it to be accepted unequivocally as resembling Bison bison athabascae or Bison antiquus occidentalis more nearly than a Eurasian form of Bison, or provide measurements. To diagnose this specimen, he relied upon linear measurements alone (which were sunk in his quantitative summaries and never presented, in the 1986 paper, as raw data); but measurements alone frequently are insufficient to diagnose most bison specimens, especially those representing taxa that obviously overlap others in size. It is quite possible to obtain identical measurements from two or more bison specimens that possess substantially different qualitative (and genetically controlled) characteristics. It also is theoretically possible for convergent evolution to produce similar phenotypes from generally similar ancestral stock even in the absence of recent genetic unity. The morphological, behavioral, and ecological similarities between Bison bison and the Eurasian bison or wisent, Bison bonasus, is a case in point. Although these species differ in morphological detail, they evolved generally via pathways that resulted in convergence of size, form, and function; it is obvious from the fossil record that Bison bonasus had a larger ancestor that could have passed through a stage during which linear features of its skull morphology resembled those of Bison bison athabascae. Lastly, bison collected from along the Bolshaya Chukochya River span nearly 1.7 million years, and most specimens have been collected without stratigraphic context and have not been radiocarbon dated (Sher, 1974, 1986, pers. comm., 1992; McDonald et al., 1991). Thirty years ago, Sher cautioned against the assignment of bison to a given geological age based upon the size and shape of horn cores, noting that this practice "is risky to say the least" (Sher, 1974:207).

Our position is that the weight of factual evidence supports the view that Bison bison athabascae originated in North America from the same lineage that gave rise to Bison bison bison. McDonald (1981:260-261) was of the opinion that Bison bison athabascae could have attained its morphological characteristics by either "(1) suspended equilibrium, in which case $B$. b. athabascae retained large body size as it evolved characters from $B$. antiquus adapted to the new r-type forest/woodland selection regime; or (2) more recent adaptive differentiation, in which case $B . b$. athabascae has increased in body size from $B$. b. bison.... Elements of both alternatives could have operated in the origin and continuation of $B$. b. athabascae, but the second has probably been more important over time...."

Considering the evolutionary trends in the size, shape, and proportions of skeletal elements, as documented for bison during the Holocene, one is left with the realization that Bison bison athabascae may be considered the most "advanced" or "furthest evolved" form of Holocene bison in several important respects. When the skull and limb morphology typical of the ancestral Bison antiquus antiquus is compared with that of the derivative taxa, Bison bison bison and Bison bison athabascae, the integrated skeleton of Bison bison athabascae is less like that of Bison antiquus antiquus than is Bison bison bison. Specifically, in Bison bison athabascae, the skull is smaller, the upper limb bones are relatively more robust, and the metapodials are relatively more gracile than in Bison bison bison. Relative to head size, Bison bison athabascae is the most longlimbed of short horned North American bison, whereas Bison antiquus antiquus is the shortest limbed.

In other respects, Bison bison athabascae is probably not as distant from Bison antiquus antiquus as is Bison bison bison. The evolutionary lengthening of the front limb relative to the hind limb has progressed further in Bison bison bison than in Bison bison athabascae. Also, the forebody pelage used to effect social rank and breeding success during the rut is less exaggerated and seasonally pronounced in Bison bison athabascae than in Bison bison bison (Geist and Karsten, 1977; Lott, 1979). The horns therefore perhaps have relatively greater importance for establishing social rank or dominance in Bison bison athabascae than in Bison bison bison.

The interpretation of skeletal measurements presented herein suggests that the evolution of the skeleton of Bison bison athabascae has, collectively, proceeded further than has that of $\mathrm{Bi}$ son bison bison, whereas the opposite is true for evolution of selected morphological features and behavior of social signifi- 
cance. Claims that Bison bison athabascae is more or less far evolved from its ancestral morph should, therefore, indicate exactly which parameter of evolution is being considered. It is not necessary that all parameters evolve the same distance, at the same time, or in the same direction. As environments change, the multitude of selective pressures that act on individ- ual organisms also change. The skeleton of Bison bison athabascae appears to have differed allometrically from Bison antiquus to a greater extent than has the skeleton of Bison bison bison, but behaviorally and ecologically Bison bison athabascae might differ less from Bison antiquus than from Bison bison bison.

\section{Appendix}

\section{Measurements (in mm) of limb bones of Kenora Bison}

(Measurements and abbreviations follow those given for bovids in von den Driesch, 1976)

1. Atlas: $\mathrm{GB}=199.9 ; \mathrm{GL}=129.5 ; \mathrm{BFcd}=111.3 ; \mathrm{BFcr}=$ 123.8; $\mathrm{H}=102.1$.

2. Axis: $\mathrm{LCDe}=122 ; \mathrm{H}=162.1 ; \mathrm{LAPa}=122.6 ; \mathrm{BFcd}=67.7$; $\mathrm{BPtr}=132.8 ; \mathrm{BPacd}=88.5 ; \mathrm{BFcr}=113.6 ; \mathrm{SBV}=75.3$.

3. Manubrium: Dorsoventral depth $=92.3$; length $=104.5$; breadth at articular surfaces $=47.2$; minimum breadth $=$ 17.5 .

4. Sacrum: $B F c r=72.0 ; \mathrm{HF} c r=35.3$.

5. Scapula (right): $\mathrm{Ld}=276$; $\mathrm{HS}=504 ; \mathrm{DHA}=487 ; \mathrm{SLC}=$ 79.2; $\mathrm{GLP}=95.4 ; \mathrm{LG}=75.0 ; \mathrm{BG}=69.8$; transverse breadth of neck $=37.9$; breadth, lateral border of spine to medial border of neck $=76.7$.

6. Radius (left): Approximate rotational length $=309$; GL (radius) $=333$; GL (radioulna) $=452$; minimum anteroposterior diameter of diaphysis $=32.0$; minimum transverse diameter of diaphysis $=57.8$.

7. Ulna (left): $\mathrm{GL}=425 ; \mathrm{DPA}=98.9 ; \mathrm{SDO}=68.5 ; \mathrm{LD}=$ 145.7; minimum transverse breadth of diaphysis $=21.3$.

8. Radial carpal (right): $\mathrm{GB}=48.2$.

9. Fused $2+3$ carpal (left): $G B=47.4$.

10. Metacarpal (right): $\mathrm{GL}=190.0 ; \mathrm{SD}=48.3 ; \mathrm{DD}=28.2 ; \mathrm{BD}$ $=76.8$; anteroposterior diameter, proximal epiphysis $=46.0$; anteroposterior diameter, distal epiphysis $=40.3 ; \mathrm{Bp}=77.5$.

11. Proximal sesamoid, thoracic limb: length $=26.1$; transverse breadth $=17.8$; anteroposterior depth $=15.8$.

12. Proximal phalanx, thoracic limb: GLpe $=65.3 ; \mathrm{Bp}=39.7$; $\mathrm{SD}=35.8 ; \mathrm{Bd}=39.6$.

13. Medial phalanx, thoracic limb: $G L p e=43.3 ; B p=38.1$; $\mathrm{SD}=31.3 ; \mathrm{Bd}=35.9$.

14. Bony pelvis: $\mathrm{GL}=526 ; \mathrm{GBT}=279 ; \mathrm{SBI}=180 ; \mathrm{GBA}=$ $268 ; \mathrm{SB}=37.0 ; \mathrm{GBTc}=503 ; \mathrm{LS}=208.6 ; \mathrm{LA}=89.6$.

15. Femur (right): $\mathrm{GL}=436 ; \mathrm{GLC}=405$; rotational length $=$ 383; $\mathrm{Bp}=154.1 ; \mathrm{SD}=48.8 ; \mathrm{Bd}=119.3 ; \mathrm{DC}=56.4$; anteroposterior diameter of diaphysis $=51.8$.

16. Tibia (right): Rotational length $=370 ; \mathrm{GL}=403 ; \mathrm{Bp}=$ 127.4; $\mathrm{Bd}=103.4 ; \mathrm{SD}=51.7$; minimum anteroposterior diameter of shaft $=35.0 ; \mathrm{Bd}=75.7 ; \mathrm{Dd}=53.0$.

17. Calcaneum (right): $\mathrm{GL}=158.9 ; \mathrm{GB}=56.7$; transverse breadth of neck $=23.0$.

18. Proximal phalanx 1, pelvic limb: $\mathrm{GLpe}=69.7 ; \mathrm{Bp}=34.2$; $\mathrm{SD}=31.6 ; \mathrm{Bd}=35.2$.

19. Proximal phalanx 2, pelvic limb: $\mathrm{GLpe}=70.3 ; \mathrm{Bp}=34.7$; $\mathrm{SD}=31.4 ; \mathrm{Bd}=35.6$.

\section{Literature Cited}

Allen, J.A.

1876. The American Bisons, Living and Extinct. Memoirs of the Museum of Comparative Zoology at Harvard College, 4(10): 246 pages.

Bamforth, D.B.

1988. Ecology and Human Organization on the Great Plains. 216 pages. New York: Plenum Prcss.

Clarke, A.H., Jr.

1981. The Freshwater Molluscs of Canada. 446 pagcs. Ottawa: National Muscum of Canada.

Cleland, C.E.

1966. The Prehistoric Animal Ecology and Ethnozoology of the Upper Great Lakes Region. Anthropological Papers, University of Michigan, Museum of Anthropology, 29: 294 pages.

Driesch, A. von den

1976. A Guide to the Measurement of Animal Bones from Archaeological Sites. Bulletin of the Peabody Museum of Archaeology and Ethnol- ogy, Harvard University, 1: $\mathrm{x}+138$ pages.

Dykcv, A.S., and V.K. Prest

1987. Paleogeography of Northern North America; 18,000-5000 Years Ago [Map 1703A, scale 1:12,500,000]. Ottawa: Geological Survey

Flerov, C.C. of Canada.

1971. The Evolution of Certain Mammals during the Late Cenozoic. In K.K. Turekian, editor, The Late Cenozoic Glacial Ages, pages 479-491. New Haven: Yale University Press.

Gcist, V.

1990. [Letter to the Editor.] Conservation Biology, 4(4):345-346.

Geist, V., and P. Karsten

1977. The Wood Bison (Bison bison athabascae Rhoads) in Relation to Hypotheses on the Origin of the American Bison (Bison bison Linnaeus). Zeitschrift für Säugetierkunde, 42:119-127. 
Gromova, V.l.

1935. Pervobtnyi zubr (Bison priscus Bojanus) $\vee$ SSSR. Trudy Zoological Institute, Academy Nauk SSSR, 2:77-204.

Guthrie, R.D.

1970. Bison Evolution and Zoogeography in North America during the Pleistocene. Quarterly Review of Biology, 45(1):1-15.

Harington, C.R.

1984. Mammoths, Bison and Time in North America. In W.C. Mahaney, editor, Quaternary Dating Methods, pages 299-309. Amsterdam: Elsevier.

Haynes, G.

1980. Prey Bones and Predators: Potential Ecologic Information from Analysis of Bone Sites. Ossa, 7:75-97.

1982. Utilization and Skeletal Disturbances of North American Prey Carcasses. Arctic, 35:266-281.

Henrichsen, $\mathbf{P}$.

1981. Dental Anomalies in Muskoxen from Greenland. Videnskabelige Meddelelser fra Dansk Naturhistorisk Forening, 143:113-123.

1982. Population Analysis of Muskoxen, Ovibos moschatus (Zimmermann 1780), Based on Occurrence of Dental Anomalies. Säugetierkundliche Mitteilungen, 30(4):260-280.

Hind, H.Y.

1859. Report on the Assiniboine and Saskatchewan Exploring Expedition of 1858. Toronto: The Legislative Assembly.

Lott, D.F.

1979. Hair Display Loss in Mature Male American Bison: A Temperate Zone Adaptation? Zeitschrift für Tierpsychologie, 49:71-76.

McAndrews, J.H.

1982. Holocene Environment of a Fossil Bison from Kenora, Ontario. Ontario Archaeology, 37:41-51.

McDonald, J.N.

1981. North American Bison: Their Classification and Evolution. 315 pages. Berkeley: University of California Press.

McDonald, J.N., C.E. Ray, and C.R. Harington

1991. Taxonomy and Zoogeography of the Musk Ox Genus Praeovibos Staudinger, 1908. In J.R. Purdue, W.E. Klippel, and B.W. Styles, editors, Beamers, Bobwhites, and Blue-Points: Tributes to the Career of Paul W. Parmalee. Illinois State Museum, Scientific Papers, 23: 285-314

Meagher, $\mathrm{M}$.

1986. Bison bison. Mammalian Species, 266:1-8.

Moore, L.

1975. The Presence of Bison Bones at Hungry Hall Site, Rainy River Northwest Ontario. [Abstract.] In Eighth Annual Meeting, I975, Canadian Archaeological Association, Abstracts, page 24.

Nowak, R.M., and J.L. Paradiso

1983. Walker's Mammals of the World. Fourth edition, 1362 pages. Baltimore: Johns Hopkins University Press.

Rhoads, S.N.

1897. Notes on Living and Extinct Species of North American Bovidae. Proceedings of the Academy of Natural Sciences of Philadelphia, 49:483-502.

Richardson, J.

1829. Fauna Boreali-Americana; Or the Zoology of the Northern Parts of British America. 140 pages. London: John Murray.
Schultz, C.B., and W.D. Frankforter

1946. The Geologic History of the Bison in the Great Plains: A Preliminary Report. Bulletin of the Nebraska State Museum, 3:1-10.

Shay, C.T.

1971. The Itasca Bison Kill Site: An Ecological Analysis. 133 pages. Saint Paul: Minnesota Historical Society.

Sher, A.V.

1974. Pleistocene Mammals and Stratigraphy of the Far Northeast USSR and North America. International Geological Review, 16(7-10): 284 pages. [Original in Russian, published by Nauka Press, Moscow, 1971, 310 pages.]

1986. Olyorian Land Mammal Age of Northeastern Siberia. Palaeontographica Italica, 74:97-112.

Shipman, $\mathrm{P}$

1981. Life History of a Fossil: An Introduction to Taphonomy and Paleoecology. 222 pages. Cambridge, Massachusetts: Harvard University Press.

Skinner, M.F., and O.C. Kaisen

1947. The Fossil Bison of Alaska and a Preliminary Revision of the Genus. Bulletin of the American Museum of Natural History, 89: 123-256.

van Zyll de Jong, C.G.

1986. A Systematic Study of Recent Bison, with Particular Consideration of the Wood Bison (Bison bison athabascae Rhoads 1898). Publications in Natural Sciences, National Museum of Canada, National Museum of Natural Sciences, 6: 69 pages.

van Zyll de Jong, C.G., C. Gates, H. Reynolds, and W. Olson

1995. Phenotypic Variation in Remnant Populations of North American Bison. Journal of Mammalogy, 76:391-405.

Voorhies, M.R

1969. Taphonomy and Population Dynamics of the Early Pliocene Vertebrate Fauna, Knox County, Nebraska. Contributions to Geology [University of Wyoming], Special Paper, 1: 69 pages.

Webb, T., 11l, E.J. Cushing, and H.E. Wright, Jr.

1983. Holocene Changes in the Vegetation of the Midwest. In H.E. Wright, $\mathrm{J}_{\mathrm{r}}$, editor, Late-Quaternary Environments of the United States, 2: The Holocene, pages 142-165. Minneapolis: University of Minnesota Press.

Wendland, W.M.

1978. Holocene Man in North America: The Ecological Setting and Climatic Background. Plains Anthropologist, 23:273-287.

Wendland, W.M., A. Benn, and H.A. Semken, Jr.

1987. Evaluation of Climatic Changes on the North American Great Plains Determined from Faunal Evidence. In R.W. Graham, H.A. Semken, Jr., and M.A. Graham, editors, Late Quaternary Mammalian Biogeography and Environments of the Great Plains and Prairies. Illinois State Museum, Scientific Papers, 22:460-472.

Wilson, M.C.

1975. Holocene Fossil Bison from Wyoming and Adjacent Areas. xiv + 276 pages. Master's thesis, University of Wyoming, Laramie, Wyoming.

1996. Late Quaternary Vertebrates and the Opening of the lce-Free Corridor, with special Reference to the Genus Bison. Quaternary International, 32:97-105. 



\title{
The Terrestrial Posture of Desmostylians
}

\author{
Daryl P. Domning
}

\begin{abstract}
An attempt to reconstruct a skeleton of Paleoparadoxia Reinhart, 1959 (Mammalia, Desmostylia), suggests that desmostylian terrestrial posture deviated from that of typical ungulates much less than has been supposed by other authors. Desmostylians probably had a quadrupedal stance, with the body well off the ground and the limbs more or less under the body; a strongly arched spine and steeply inclined pelvis; slightly abducted elbows and more strongly abducted knees; and a digitigrade foot posture with an extended but not hyperextended wrist and hyperextended toes, the front toes pointing anterolaterad and the hind toes pointing forward. Most peculiarities of the skeleton have parallels in certain large, slow-moving terrestrial mammals, such as ground sloths and chalicotheres. The desmostylian skeleton was apparently well suited to supporting the body's weight on the hindquarters, perhaps while the animal clambered slowly over very uneven ground. This most likely occurred while it foraged for marine algae or sea grasses in rocky intertidal areas of the North Pacific shoreline, and while it crossed these areas en route to and from the water. Locomotion in the water probably resembled that of polar bears, with alternate pectoral paddling as the principal means of propulsion and the hind limbs used for steering. Surprisingly, desmostylianlike features of the tibia and ankle also are found in many other primitive ungulates and deserve closer study.
\end{abstract}

\section{Introduction}

Before and even since the discovery that desmostylians were quadrupedal, apparently amphibious marine mammals rather than wholly aquatic sirenians, their outward appearance and, in particular, their terrestrial posture have been controversial (see the remarkable collection of artists' reconstructions compiled by Inuzuka (1982)). Not even the more recent studies, based upon complete postcranial skeletons, have led to a consensus on this latter issue (cf. Repenning, 1965; Shikama, 1966, 1968; Inuzuka, 1984, 1985; Halstead, 1985; Repenning and Packard, 1990).

Daryl P. Domning, Research Associate, Department of Paleobiology, National Museum of Natural History, Smithsonian Institution, Washington, D.C. 20560-0121, and Laboratory of Evolutionary Biology, Department of Anatomy, College of Medicine, Howard University, Washington, D.C. 20059.
In March 1986, I was asked to design a new mount of $\mathrm{Pa}$ leoparadoxia Reinhart, 1959, in a terrestrial pose for a planned exhibit gallery at the National Museum of Natural History, Smithsonian Institution. (The mount was never actually constructed because of a change in the exhibit plan.) The specimen to be mounted was a cast of the neotype skeleton of Paleoparadoxia tabatai (Tokunaga, 1939), known in the literature as the Izumi specimen. Available for comparison were several other specimens and casts of various desmostylian genera and species (see below). Because some of these (notably the Stanford specimen) have not been formally described, most original specimens were not then accessible, and time and resources were limited, a thorough morphological or biomechanical study of the desmostylian skeleton was infeasible. Features critical for mounting the skeleton, however, were sufficiently clear from the available material, and the observations seemed worth recording as a contribution to the ongoing debate.

These conclusions were first presented at the Society of Vertebrate Paleontology annual meeting in Philadelphia in 1986. Subsequent discussions and collaboration with N. Inuzuka and others (see Inuzuka et al., 1995) have encouraged further refinement of these observations, which are offered herein for future testing as yet another alternative hypothesis on the fascinating subject of desmostylian locomotion.

ACKNOWLEDGMENTS.-I thank R.J. Emry and C.E. Ray for stimulating this study by inviting me to design the proposed mount of Paleoparadoxia, D. Chaney for logistical help in the course of the work, and M. Cole, M.C. Coombs, and R.J. Emry for useful discussions. J.M. Clark, M. Cole, M.C. Coombs, N. Court, N. Inuzuka, C.E. Ray, and C.A. Repenning commented on various drafts of the manuscript or parts thereof. I take great pleasure in dedicating this paper to Clayton E. Ray, friend, model, and mentor throughout my professional career.

ABBREVIATIONS.-The following museum abbreviations are used:

PV National Science Museum, Tokyo

UCMP University of California Museum of Paleontology, Berkeley

USNM Collections of the National Museum of Natural History, Smithsonian Institution, Washington, D.C., which include the collections of the former United States National Museum 


\section{MATERIAL AND METHODS}

1. Cast (USNM 26375) of nearly complete skeleton of subadult Paleoparadoxia tabatai (PV-05601; Izumi specimen) from Japan, partly described by Shikama $(1966,1968)$.

2. Cast (USNM 25899) of nearly complete skeleton of mature adult Paleoparadoxia sp. (UCMP 81302; Stanford specimen) from California.

3. Cast (USNM 24727) of nearly complete skeleton of adult Desmostylus Marsh, 1888 ("D. mirabilis" Nagao, 1935; Hokkaido University, Sapporo; Keton specimen), from Sakhalin, described by Shikama (1966) and Inuzuka (1980-1982).

4. Partial skeleton of immature Desmostylus (USNM 186891) from Oregon.

Also in existence are two partial skeletons possibly referable to Behemotops Domning, Ray, and McKenna, 1986 (the Ashoro specimens; Inuzuka, 1989); a well-preserved skeleton of Desmostylus (the Utanobori specimen, described in part by Inuzuka (1988)); two partial skeletons of Paleoparadoxia tabatai from the Chichibu Basin in the Saitama Prefectural Museum, Japan (Sakamoto, 1983); and the anterior one-half of an immature skeleton of Paleoparadoxia weltoni Clark, 1991 (UCMP 114285). The last three specimens do not appear to show any biomechanically significant postcranial differences from the Izumi specimen. Behemotops, Paleoparadoxia, and Desmostylus seem to have differed little, if at all, in their locomotor specializations (Shikama, 1966; Inuzuka et al., 1995), so observations made herein apply to all three genera unless otherwise stated.

I reached my conclusions mainly by manipulating the casts of the Stanford specimen, the well-preserved skeleton of a mature adult of the largest known species of Paleoparadoxia. Its joint surfaces are accordingly both fully developed and adapted to bear the maximum stresses that would have occurred in any known desmostylian. This makes the Stanford specimen the most sensitive indicator of the biomechanical constraints on desmostylian locomotion. The conclusions derived from this individual were then applied to the Izumi specimen, which is smaller, immature (judging from degree of epiphyseal fusion), less well preserved, and somewhat distorted, and which apparently represents a different species. No evidence was encountered, however, that would invalidate the assumption of biomechanical similarity.

The skeleton was built literally from the ground up, by assembling the feet in their most probable poses and then placing the limbs, girdles, and axial skeleton on top of them, with as litthe deviation as possible from a "normal" terrestrial ungulate or subungulate stance. Recent reconstructions that differed greatly from such a stance were not satisfactory. For example, Repenning's (1965) reconstruction, which was reproduced by Romer (1966, fig. 367), Barnes et al. (1985, fig. 3a), Inuzuka (1984, pl. 9: fig. 2), and others, placed the animal in a frog-like squatting pose with the dorsal surface of the manus against the ground. Inuzuka $(1984,1985)$ advocated a "herpetiform" posture with the limbs sprawled to the sides. In contrast, my work- ing assumption, or null hypothesis, was that Paleoparadoxia did not differ essentially in posture from typical large land mammals such as hippopotamuses or rhinoceroses. (No single species of mammal, however, was used as a model.) When (as often happened) peculiarities of the joints demanded a departure from this assumption, other mammals provided analogies to demonstrate the mechanical feasibility of the posture. The aim of this study was to clarify the terrestrial posture of desmostylians and not their aquatic adaptations, so these examples were sought among land mammals; however, this is not meant to imply that desmostylians were other than largely aquatic in habits and habitat.

It is somewhat reassuring that this eclectic method, although applied separately to different parts of the skeleton, repeatedly led to comparisons with animals that share a similar habitus: heavy-bodied, presumably slow-moving quadrupedal forms resembling ground sloths. Perhaps Paleoparadoxia was not a paradox after all.

\section{Results}

PES.- The key observation of this study was made on the hind foot, which has always posed the most vexing problems for desmostylian functional anatomy. The axis of the ankle joint inclines ventromedially about $30^{\circ}-40^{\circ}$ from normal to the long axis of the tibia, and it slopes ventrolaterally about $10^{\circ}$ from the plantar plane of the foot. If the foot is placed plantigrade on a horizontal surface, as it has been in some reconstructions (see Inuzuka, 1982), the tibia is thereby inclined about $40^{\circ}-50^{\circ}$ from the sagittal plane. Together with the torsion in the tibia itself (see below), this necessitates strong abduction of the knee, and awkward positions of other joints, in order to assume the plantigrade pose during the weight-bearing portion of the stride. This pose, however, is certainly incorrect, as is shown by the form of the metatarsals and, especially, the metatarso-phalangeal joints.

The pes as a whole is paddle-like; the tarsus-metatarsus is rigid and planar, rather than forming a half-cone as in an elephant. From digit II to digit $\mathrm{V}$ the metatarsals increase significantly in length, and the form of curvature of the phalangeal articular surface varies (Figure $1 a-d$ ). This surface lies on the dorsal side of the bone at its distal end and is nearly flat on metatarsal II, corresponding to the equally flat proximal surface of the proximal phalanx. The transition from this flat dorsal surface to the distal part of the articular surface is abrupt and much more strongly curved than the very slight proximal concavity of the phalanx. The latter can stably articulate with the metatarsal in either the maximally (about $75^{\circ}$ ) hyperextended position (the more stable position; Figure $1 a$ ) or the typical extended position, i.e., in line with the metatarsal. The metatarsal's palmar joint surface is slightly keeled and articulates with a pair of large sesamoids, so flexion of the phalanx onto this surface is impossible. The most likely terrestrial pose 

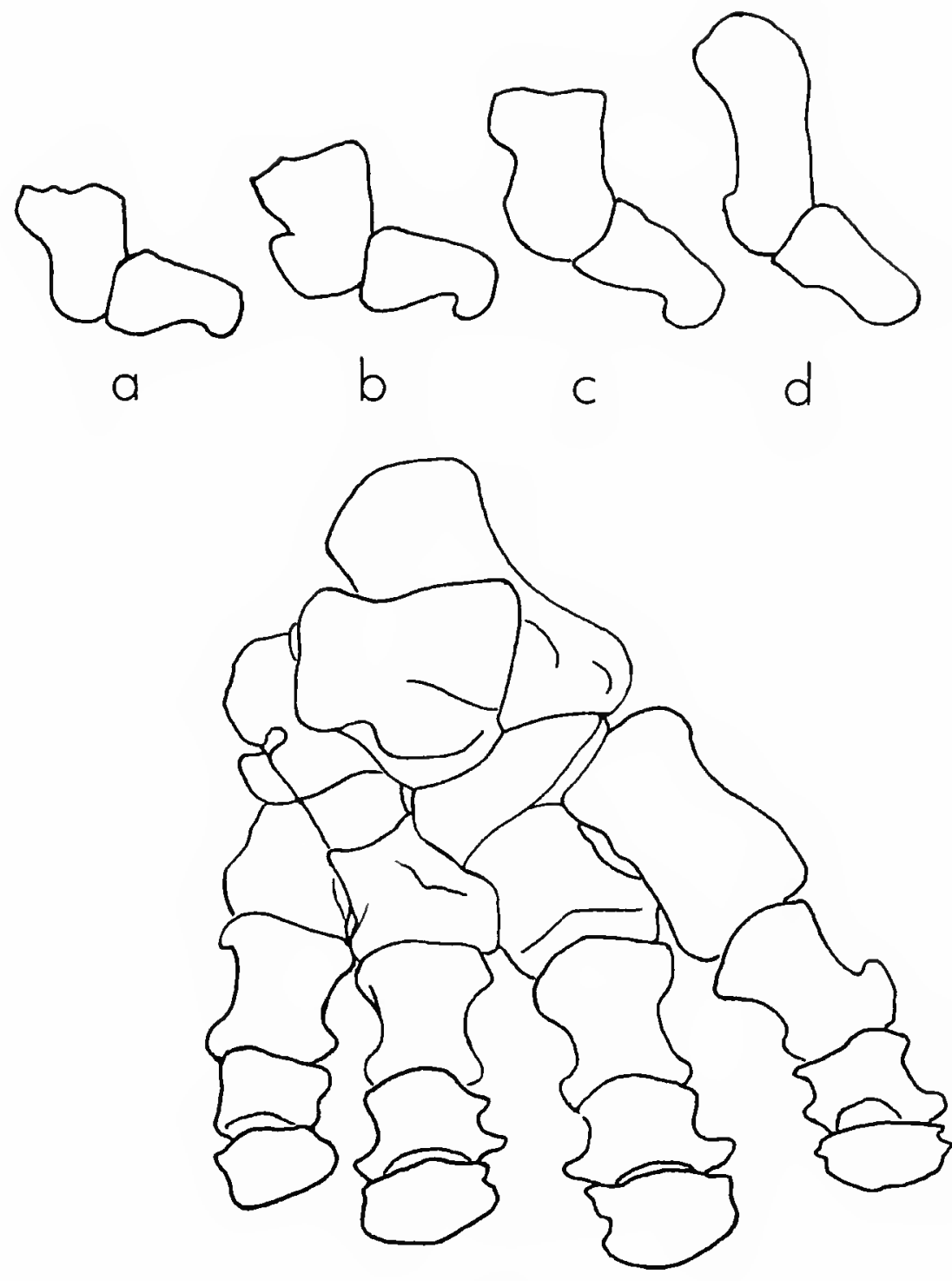

e

FIGURE 1.-Paleoparadoxia sp. (UCMP 81302), left pes: $a-d$, metatarsals and proximal phalanges of digits II-V, respectively, in medial views, each showing maximum degree of hyperextension possible; $e$, left pes in anterodorsal view. Note that the tibial-astragalar joint axis is horizontal, the metatarsals lie in a nearly vertical plane, the weight-bearing axis passes through digit III, and the toes are maximally hyperextended.

of the second digit is therefore the hyperextended one, with the phalanx nearly perpendicular to the metatarsal (Figure $1 a$ ).

The same observations hold for the more lateral toes to a progressively lesser extent. The dorsal-to-distal curvature of the metatarsal surface gradually becomes less abrupt, and the proximal articular concavity of the phalanx deepens. The degree of hyperextension required (or even possible) at these joints, after increasing slightly from digit II to III, correspondingly diminishes from about $80^{\circ}$ on III to $60^{\circ}$ on IV and $50^{\circ}$ on V (Figure $1 b-d)$.

This pattern becomes intelligible when the foot is placed in a digitigrade position, with the plane of the metatarsals at an angle to the ground and the phalanges flat on the substrate (Figure le). Then the short, almost cuboidal medial metatarsals (especially metatarsal III) support the body's weight on their flat distal ends and their sesamoids. The greater lengths of the more lateral metatarsals require them to extend distally and laterally at progressively greater angles to the sagittal plane. Conse- quently they bear less weight; the end of metatarsal $\mathrm{V}$ may almost have been free of the ground, and not only is its digit the least hyperextended (Figure $1 d$ ), but its proximal phalanx has a canted distal articulation, causing the toe to curve medially and making the distal phalanges lie parallel to those of the other digits (Figure 1e).

When the metatarsals and phalanges are in this pose, one finds that, despite the peculiar shapes of the tarsals and metatarsals (1) the foot posture can be digitigrade during weightbearing (i.e., when the hip is directly over the ankle) and would be within usual limits for a large land mammal; (2) both the axis of the ankle joint and the plane of the sole are nearly perpendicular to the sagittal plane; (3) the toes point forward; and (4) the axis of the ankle joint is horizontal (Figure 1e), so the ankle joint is not prone to dislocation by the body"s weight. The calcaneal tuberosity does have a strong medial inclination (Figure le), but this can be seen as an adjustment to the torsion of the tibia (see below) and of the muscles of plantar flexion. A line from the apex of the calcaneal tuberosity perpendicular to the axis of the tibial-astragalar joint passes approximately through digit III, and therefore probably along the central weight-bearing axis of the foot. If the animal were to take a long stride, the hind foot might initially be placed in a plantigrade pose, becoming digitigrade only as the hip moved above it. Such a bulky animal as a desmostylian may have habitually taken only short strides, however, throughout which the foot could have been digitigrade or nearly so.

On the whole, in view of its strange morphology, the posture of the hind foot is surprisingly normal. An elastic pad, such as exists in elephants, may have supported the foot in this digitigrade posture (although in elephants the foot bones surround the pad with a half-conical structure that is not seen in desmostylians, and the posture of the digits themselves is actually unguligrade; Osborn, 1942:1336). Alternatively, desmostylians may have managed without such a supporting pad because they were smaller than elephants, probably spent more time supported by water, and when hauled out probably took weight off their feet by squatting or lying on the ground as do sea lions. The modern Hippopotamus, for example, maintains a digitigrade posture on land without an elephant-like supporting pad in the foot.

TiBIA.-The tibia has two major peculiarities: lateral torsion of the proximal end about $45^{\circ}-50^{\circ}$ relative to the distal end, and mediodistal inclination of the distal joint surface about $30^{\circ}-40^{\circ}$ from normal to the long axis of the shaft. If the shaft is held vertically with its anteroposteriorly flattened distal portion perpendicular to a sagittal plane, the knee and femur must be strongly abducted and the sole of the foot must face both distally and laterally. Conversely, with the foot in the digitigrade position described above, the tibia is inclined outward from the ankle about $30^{\circ}-40^{\circ}$ from a sagittal plane. The abduction of the knee largely compensates for this, however, so that the ankle lies not far outboard of the parasagittal plane of the hip joint (Figure 2). 


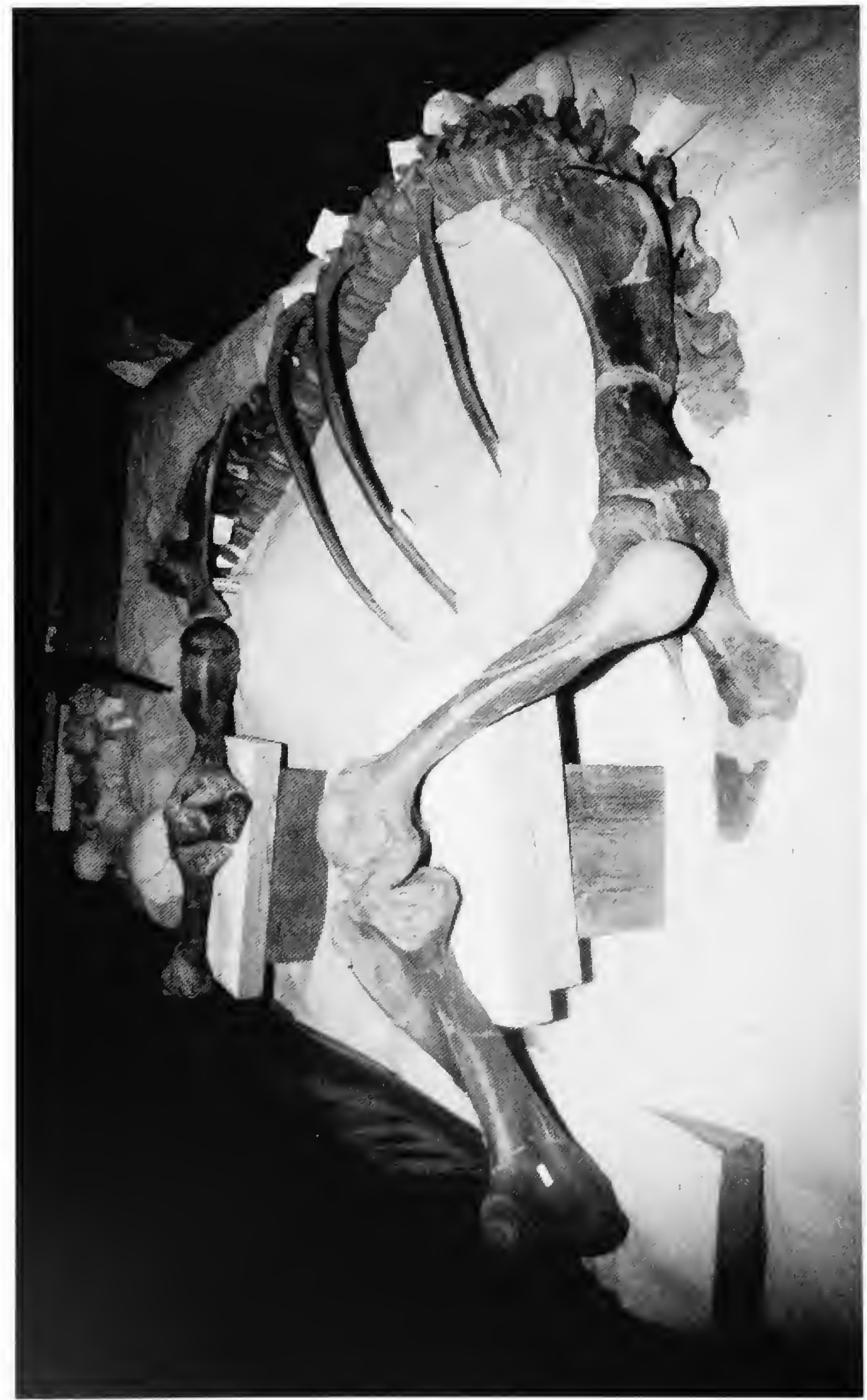

FIGURE 2.-Paleoparadoxia tabatai (Izumi specimen, cast, USNM 26375), skeleton partly assembled in sandbox in postcrolateral view to show limb positions and spinal curvature postulated in this study. The three representative ribs shown are not in correct anatomical position; their ventral ends should be abducted much farther from the midline. 


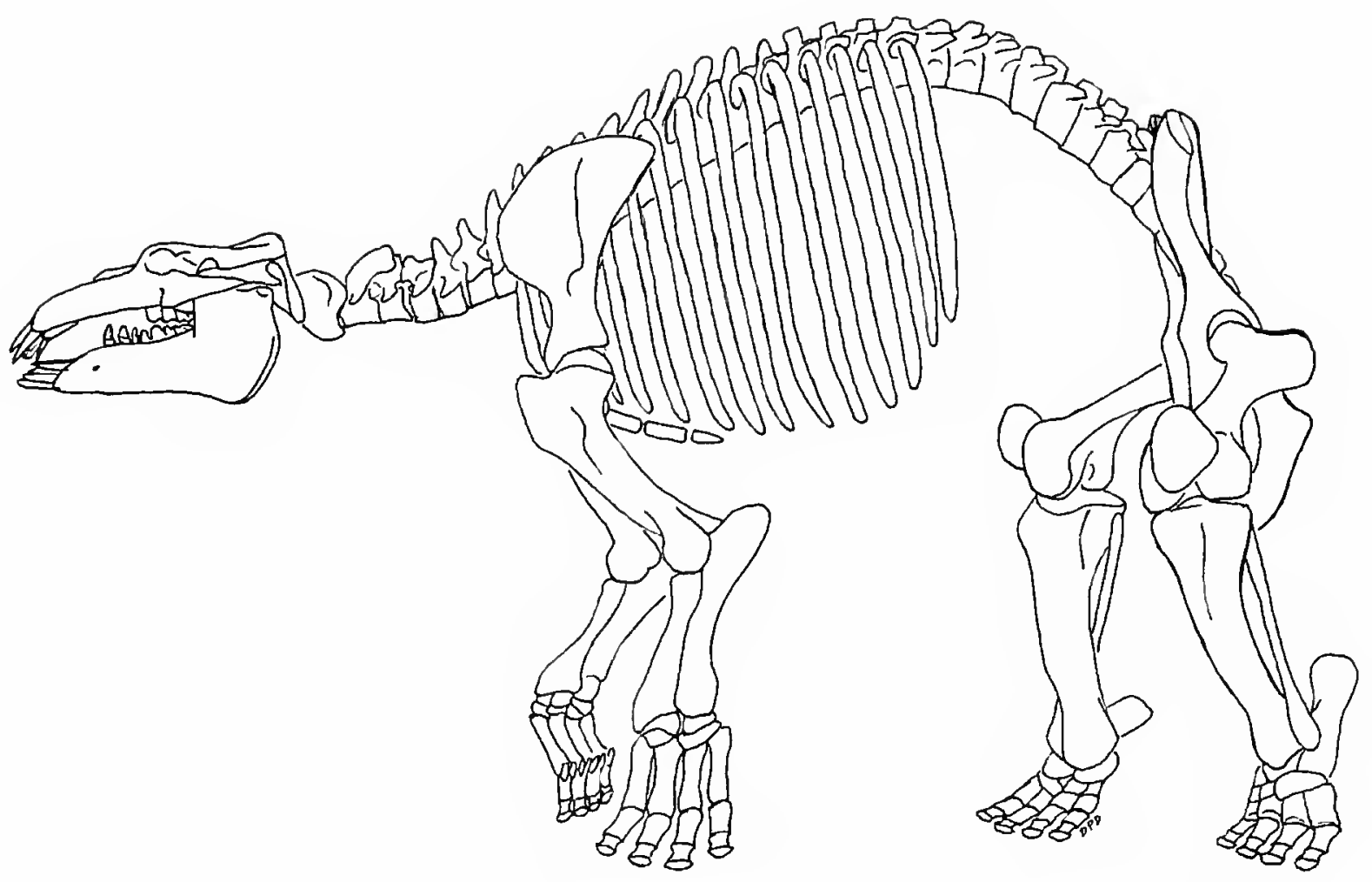

FIGURE 3.-Paleoparadoxia tabatai (lzumi specimen, PV-05601), reconstructed skeleton in lateral view, showing probable terrestrial posture. Note hyperextension and anterolateral direction of front toes, anterior direction of hind toes, and strong abduction of knees.

FEMUR.-The shaft of the femur is broad and greatly flattened anteroposteriorly. The neck protrudes anteromedially from the plane of flattening of the shaft. The head rises slightly above the level of the greater trochanter and lacks a fovea capitis. A line connecting the proximal and distal margins of the articular surface of the head forms an angle of about $50^{\circ}-65^{\circ}$ with the femoral shaft. With the foot bones in the position described above, with the tibia inclined outward $30^{\circ}-40^{\circ}$ from a sagittal plane and lying in a transverse plane inclined perpendicular to the sole of the foot, and with the knee joint bent at a right angle, the posterior (now ventral) edge of the femoral head lies barely inside the acetabulum; a $2-3 \mathrm{~cm}$ wide strip of the head's articular surface is exposed dorsally; and although the femur is laterally rotated, there remains clearance between the greater trochanter and the ischium (Figures 2,3). This leg posture would seem to provide adequately for support and movement of the hindquarters. The medial condyle is somewhat larger than the lateral in the Izumi specimen and extends farther distally and posteriorly; in the Stanford specimen, probably representing a different species, they are more nearly equal in development. Court (1994:324) stated that "[i]n medial view, a line drawn from the posterior-most extent of the inner condyle to its anterior margin, when orientated in the horizontal plane, reflects the position of maximum articular congruence at the knee and the likely habitual posture of the femur." By this criterion, the femur of Paleoparadoxia would have habitually inclined about $67^{\circ}-69^{\circ}$ from the vertical. The crural index (lengths of tibia/femur $\times 100$ ) is 88 in the Izumi and 77 in the Stanford specimen. The ratios of lengths of meta- tarsal III/femur $\times 100$ are 19 and 15 , respectively. These differences might be ontogenetic, interspecific, or both.

INNOMINATE.-As others have noted, the innominate is primitive looking, even rodent-like, being very long and narrow for such a large mammal. The ilium in particular lacks the degree of lateral expansion typical of heavy ungulates. The vertical angle between innominate and sacrum is slight (about $10^{\circ}-15^{\circ}$ ), as in primitive mammals, and, given the length of the ilium, would seem to be disadvantageous for weight-bearing. The strong spinal curvature (see below), however, makes possible (indeed, necessitates) a very steep inclination of both sacrum and pelvis (Figures 2,3). This accomplishes the same purpose as the short, almost vertical ilium of most other graviportal mammals, namely, to bring the hip joint nearly underneath the sacroiliac joint. In caudal view, the posterior part of the pelvis has a pronounced $U$-shape, with the pubes forming an almost flat floor of the pelvic canal and the ischia lying in almost parallel, parasagittal planes (cf. Inuzuka, 1985, fig. 1). The acetabulum is relatively wide and shallow. This is reflected in the extremely acute angle seen in ventral view between its superolateral and ventrolateral margins (cf. Jenkins and Camazine, 1977, fig. 7), which indicates that the superolateral margin does not extend very far laterally. Also, a line connecting the medial and lateral margins of the upper, weight-bearing articular surface of the acetabulum forms an angle of about $70^{\circ}-75^{\circ}$ with the vertical, as nearly could be estimated for the disarticulated Izumi and Stanford skeletons.

VERTEBRAL COLUMN.-The desmostylian neck is short for an ungulate, and, although the head is fairly large, the anterior thoracic neural spines are normally inclined and not unusually 
enlarged, so the nuchal ligament was evidently not relied upon much for cranial support. The cervical and anterior thoracic centra, largely missing from the Izumi specimen but restored by its preparators, give a distinct secondary (concave-dorsal) curvature to this region.

Fifteen thoracic and six lumbar vertebrae are present in the restored Izumi skeleton (although Shikama (1966) mentioned only 14 thoracics); the last 13 thoracics are preserved in the Stanford specimen. The posterior thoracics and lumbars have short, vertical spines, and there is no anticlinal vertebra. The fourth thoracic from the rear (?T12) in the Stanford specimen comes closest to being a diaphragmatic vertebra; the zygapophyseal articular planes shift from near-horizontal to near-vertical in the region of ?T11-13 but then return to an intermediate inclination in the lumbar region. This shift suggests more vertical flexibility in the posterior thorax than in the adjacent regions.

The most-posterior thoracic and most-anterior lumbar centra are distinctly wedge shaped, thicker dorsally, and thinner ventrally in both the Stanford and the Izumi Paleoparadoxia specimens (this, however, is not very evident in Desmostylus). This shape indicates a strong dorsal convexity of the spine in this region, with the summit of the backbone lying near the rear of the ribcage. From this point the lumbar and sacral vertebrae descend at a rather steep angle, with the pelvis in an almost vertical position (Figures 2,3 ). The sacrum is fairly long and robust but is not fused to the pelvis, and sacral vertebrae 1 and 2 are not fused to one another, even in the Stanford adult (although sacrals $2-5$ are fused).

MANUS.-The metacarpals are about twice as long as the metatarsals. The metacarpo-phalangeal articulations are fairly uniform in shape and do not show a mediolateral gradient of change analogous to that seen in the hind foot. The long axis of the lunar articular surface lies at approximately a $65^{\circ}$ angle to the plane of the palm. With the metacarpals vertical, the radius can easily be balanced upright on the lunar without any other support and with its shaft tilted backward some $15^{\circ}$ from the vertical (Figure 3 ). The large radial styloid process thus would not have prevented wrist extension sufficient for digitigrade posture. In this position, the axis of the elbow joint is at about a $75^{\circ}$ angle to the plane of the palm. Even with the elbow abducted $30^{\circ}$ from the body, the front toes could not have pointed straight forward; at best the palm might have been "pronated" some $45^{\circ}$ from a parasagittal plane when the animal stood on land. (True pronation and supination, however, were prevented by the firm articulation of the radius and ulna; this angle of "pronation" was controlled instead by movement at the shoulder joint.) The weight of the forequarters therefore appears to have been carried on metacarpals held essentially vertically, with the foot in a digitigrade stance; the toes presumably were hyperextended and pointed as much laterad as anterad, and the wrist joint was extended straight. From this position the wrist could have been flexed, but the very large styloid process of the radius would have prevented any significant hyperextension.
RADIUS AND ULNA.-As mentioned above, the radius and ulna are tightly articulated, although not fused, and the radius bears a massive styloid process that overlaps the anterior side of the wrist joint. The radius forms almost the entire distal part of the semilunar notch and is, therefore, the main weight-bearing bone. The ulna also bears considerable weight, however, and has an even thicker shaft than the radius. The olecranon is very long, equal to one-half the length of the radius (excluding the styloid process) in the Izumi specimen and to about twothirds of the length of the radius in the Stanford specimen.

HUMERUS.-The humerus is long and slender in the Izumi specimen. The trochlea is deeply constricted at its middle, and a corresponding ridge on both radial and ulnar parts of the semilunar notch renders the elbow joint very stable. The notch, however, opens more anteriorly than proximally, so the elbow could not have been extended as straight as in graviportal forms such as elephants. The entepicondyle is short and stout, protruding more posterad than mediad. The trochlea is canted only about $80^{\circ}$ to the long axis of the shaft, so the shafts of the humerus and radius are only $10^{\circ}$ out of alignment when the elbow is extended. This alignment indicates a very slight degree of abduction of the elbow and nearly parasagittal forelimb movement in terrestrial locomotion (Jenkins, 1973). The supinator crest shows little or no expansion, but there is a long and fairly prominent deltopectoral crest reaching almost to the distal end of the shaft. The lesser tuberosity is weakly developed in the immature Izumi specimen, but the greater tuberosity is robust. The head is expanded anteromedially. The brachial index (lengths of radius/humerus $\times 100$ ) is 62 in the Izumi skeleton; the intermembral index (lengths of (humerus + radius)/(femur + tibia) $\times 100$ ) is 88 ; the ratio of lengths of metacarpal III/ humerus $\times 100$ is 41 ; and the ratio of lengths of metacarpal III/ radius $\times 100$ is 65 (64 in the Stanford skeleton).

SCAPULA.-The distal end of the scapula is not preserved in the Stanford specimen, and that of the Izumi specimen has the coracoid process detached; on the cast it has been restored as extending rather far anteriorly and distally. Although this prevents the humerus from being extended straight downward from the glenoid, such extension almost certainly would not have taken place. At maximum extension of the shoulder, the humerus would have made perhaps a $140^{\circ}$ angle with the spine of the scapula. In a normal standing pose the angle would have been smaller, perhaps $120^{\circ}-130^{\circ}$ (Figure 3 ).

\section{Comparisons}

PES.-The desmostylian hind foot has been thought to be completely without parallel, but it shows surprising resemblances to the pes of the perissodactyl Chalicotherium (Figure 4; Zapfe, 1979): the latter is digitigrade, the metatarsals increase markedly in length from medial to lateral, the calcaneal tuberosity has a strong medial inclination, and the toes point forward despite the strong abduction of the knee (see below). There are also differences from Paleoparadoxia: the axis of the 


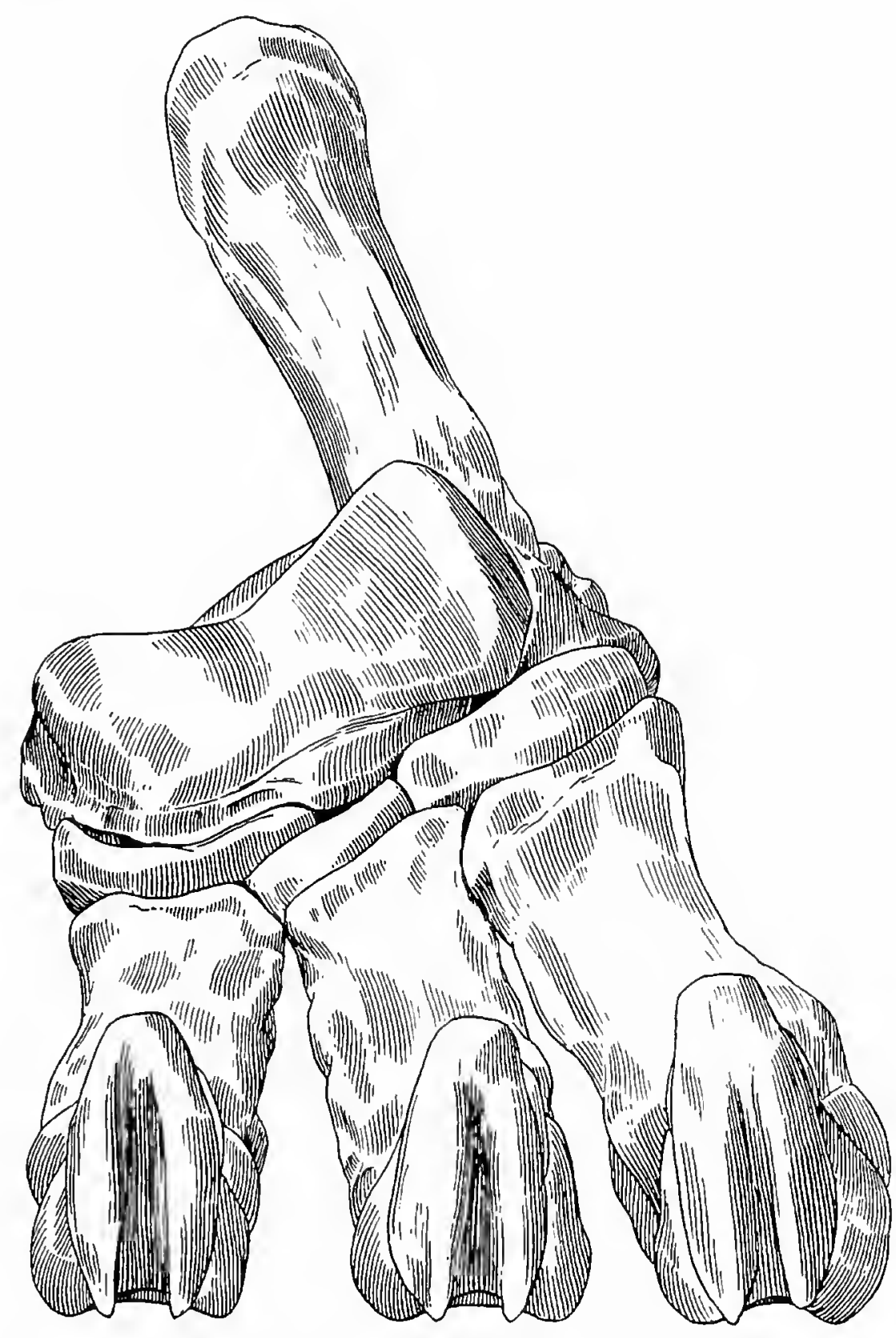

FIGURE 4.-Chalicotherium grande, left pes in anterior view, after Zapfe (1979).

astragalus is sloping rather than horizontal, and of course the feet have only three toes, which bear claws rather than the small hooves that desmostylians presumably possessed. Nonetheless, we see in Chalicotherium a large quadruped of unquestioned terrestrial habits that bore its weight mainly on the medial side of a hind foot that resembled in obvious ways the foot of Paleoparadoxia. The notoungulate Homalodotherium also has longer lateral than medial metatarsals, but the medial ones are thin rather than stout, and the animal evidently walked on the lateral rather than medial edge of its foot (Scott, 1930).

TIBIA.-Again, Chalicotherium approaches Paleoparadoxia in the torsion of the tibial shaft, although not in the tilt of the ankle joint. Even closer matches to Paleoparadoxia are found in the giant armadillo (Priodontes), the collared anteater (Tamandua), pangolins (Manis), various bears (including $\mathrm{Hel}$ arctos and Ursus spelaeus Rosenmüller and Heinroth), and the giant panda (Ailuropoda). Indeed, one giant panda (USNM 258835, a wild-caught specimen) is identical to the Stanford
Paleoparadoxia in values of both variables (Domning, 2001). These two features (and especially the tilt of the ankle joint) also are seen to different degrees in a variety of other, extinct forms, including the most primitive sirenians (Prorastomidae; Domning, 2001) and proboscideans (Numidotherium; Court, 1994, and below), ground sloths (Megalonyx), Coryphodon, and "condylarths," including Hyopsodus (Gazin, 1968) and Meniscotherium (Gazin, 1965; Williamson and Lucas, 1992; see also Domning, 2001). Hyopsodus and Meniscotherium belong to the group of primitive ungulates from which tethytheres or pantomesaxonians emerged (Thewissen and Domning, 1992), so these features of the tibia may well have been inherited from the ancestors of desmostylians. Their function is unclear, and their taxonomic distribution (or indeed, their very existence) within this group has attracted negligible attention. Meniscotherium (which exhibits much less tibial torsion but an even greater tilt of the ankle joint than Paleoparadoxia) has, however, been characterized as "adapted for ambulatory, habitual travel on an irregular terrestrial substrate" and as suited to negotiating "a rugged and obstacle-filled terrain" (Williamson and Lucas, 1992:32-33), as was also probably the case for desmostylians (see below). The desmostylians' short tibia, relative to the femur, is characteristic of graviportal quadrupeds in general as well as the above-mentioned "condylarths."

PATELLA.—Coombs (1983:38) suggested that a large patella (indicative of powerful knee extensors) was associated with body erection in Chalicotherium; this bone is proportionately much larger in the Stanford Paleoparadoxia than in chalicotheres.

FEMUR.--The flattened desmostylian femur is strikingly reminiscent of that of large ground sloths, but some flattening of the shaft is seen in most large land animals, including Chalicotherium and Homalodotherium as well as elephants, rhinoceroses, and sauropod dinosaurs. (This flattening is more pronounced in sauropods thought to have routinely used a bipedal posture; Wilson and Carrano, 1999.) The femur of Paleoparadoxia, like that of elephants and ground sloths, lacks a fovea capitis. The posture suggested herein for Paleoparadoxia, with the knees strongly abducted from the body, is likewise not unprecedented among large mammals, including the largest ground sloths and Chalicotherium. Bears adopt a similar pose when supporting themselves on their hind legs. Jenkins and Camazine (1977) described the form and kinematics of the hip joint in three other carnivores (raccoon, cat, and fox) that show progressively lesser degrees of hip abduction. The angle between the margin of the articular surface of the head and the femoral shaft is greater in desmostylians than in raccoons, in which it is about $50^{\circ}$ (Jenkins and Camazine, 1977:363), suggesting a greater degree of femoral abduction in the former. When desmostylian bones are manipulated in the fashion advocated herein, the portions of the femoral articular surface enclosed within the acetabulum at each stage of the stride correspond well with the observations of Jenkins and Camazine (1977:359-360) on the raccoon, cat, and fox, indicating that the 
present reconstruction does not involve a pattern of hip articulation unusual for terrestrial mammals.

INNOMINATE.- - In most large terrestrial mammals, including Chalicotherium, Homalodotherium, and ground sloths, the ilium is much broader than in desmostylians. This broadening provides attachment area for enlarged gluteal muscles, which extend the hip against gravity. The absence of this graviportal adaptation in desmostylians may be because of their more amphibious habits; in any case, it does not rule out body erection. The long innominate and relatively narrow ilium of Paleoparadoxia, as noted above, resemble those of rodents, but they also strongly resemble those of the giant panda, Ailuropoda (see Davis, 1964). Desmostylians are probably the largest mammals to display this form of pelvis. Davis (1964:110) listed seven features that he believed to characterize the pelvis "in mammals in which forces parallel to the long axis of the pelvis predominate, i.e., those that stand erect and those that use their hind legs for bracing while digging." Of these seven features (which do not include a broadened ilium), at least five are seen in desmostylians: the wings of the ilia tend to be shifted into the frontal plane; the corpus of the ilium is nearly circular in cross section; the pubo-ischiadic symphysis is reduced in its anterior part (i.e., the front of the symphysis lies posterior to the acetabulum); the number of sacral vertebrae is relatively high (five); and the tail is shortened. (Although Davis (1964:113) pointed out that Ailuropoda exhibits these features "to a far greater degree than any other carnivore," he nonetheless believed that pandas do not stand erect more than bears and that the contrast in pelvic shape between these forms is due to nonadaptive factors. In any case, both bears and pandas frequently assume a bipedal posture, in contrast to most mammals.) Desmostylians also lack the noticeably enlarged ischial tuberosity that is typically seen in large ungulates, including Chalicotherium and Homalodotherium. In Chalicotherium, however, these tuberosities were thought by Zapfe (1979) to reflect the use of a sitting posture during feeding. The $U$-shape of the desmostylian pelvis in caudal view is outside the range of variation of the carnivores studied by Jenkins and Camazine (1977:368, fig. 7), but they generalized that "the ischial surface is approximately perpendicular to the middle of the range of abduction." The nearly parasagittal ischial surface in desmostylians implies very pronounced abduction at the hip, as is agreed by most authors. The relatively shallow, open desmostylian acetabulum and the inclination of its upper articular surface likewise tend toward the end of the raccoon-to-fox spectrum that indicates relatively great hip abduction (Jenkins and Camazine, 1977:361-363, figs. 6, 7).

VERTEBRAL COLUMN AND BODY FORM.-The strongly curved backbone of Paleoparadoxia was explained above as an adjustment to supporting a heavy body by way of an elongate pelvis. A similar degree of spinal curvature and verticality of the pelvis can be observed in rodents as large as the giant beaver Castoroides (see Romer, 1966, fig. 442), which of course is still much smaller than Paleoparadoxia. A somewhat similar overall body form (albeit with different osteological details) is seen in the giant panda, however (Davis, 1964, fig. 15), and even in some very heavy mammals, such as the notoungulate Toxodon and the edentate Glyptodon (Romer, 1966, figs. 374, 427). The last two forms share a bulky body, low forequarters, a high rump, and (as in nearly all graviportal mammals) a nearly vertical ilium, although they lack a pronounced lumbar curvature. Spinal curvatures more similar to that of Paleoparadoxia, as well as more equal limb lengths, occur in the sloth Hapalops and the marsupial Diprotodon (see Coombs, 1983, figs. 5a, 7e). Chalicotherium and Homalodotherium, on the other hand, have long front legs, low hindquarters, and straighter spines, although the schizotheriine chalicothere Moropus shows a distinct dorsal convexity of the spine at the front of the lumbar region (Coombs, 1983, fig. 7a).

MANUS.-Several large land mammals have longer metacarpals than metatarsals, including Chalicotherium and Homalodotherium. The latter used a digitigrade stance of the forefoot, but Chalicotherium, like anteaters, walked on the dorsal surfaces of the flexed and heavily clawed toes, with the palm in a parasagittal plane (an orientation also seen, to a lesser extent, in Paleoparadoxia).

RADIUS AND ULNA.-A strong radial styloid process (albeit not so strong as in Paleoparadoxia) is found in Chalicotherium; Toxodon; the smaller toxodont, Nesodon (Scott, 1912); and the polar bear, Thalarctos (as well as other ursids), in combination with digitigrade or even (in ursids) plantigrade posture. The olecranon is short in Chalicotherium and Homalodotherium; a closer match to that of Paleoparadoxia is seen in Toxodon, Nesodon, and Glyptodon, which used the forelimbs for support and not for pulling down tree limbs (see below).

HUMERUS. - The humerus of Chalicotherium is long, but with a more markedly tilted trochlea and a more expanded distal end than in Paleoparadoxia. Sloths, bears, and Nesodon also have relatively long and slender humeri.

STERNUM.-Chalicotherium shows a slight broadening and dorsoventral flattening of the sternebrae, but the double row of broad, flat plates forming the desmostylian sternum (Shikama, 1966 ) is unique. It is worth noting, however, that in large ground sloths, such as Paramylodon and Eremotherium, the costal cartilages are ossified. This arrangement and the desmostylian sternum both could be ways of providing a solid area of origin for massive pectoral muscles, used in ground sloths for pulling down branches and in desmostylians for swimming. This notion unfortunately is not readily testable, for such muscles generally have fleshy proximal attachments that leave no evidence in the form of distinct scars on the bones.

\section{Discussion}

TERRESTRIAL LOCOMOTION.-The foregoing is not intended to be an exhaustive catalog of the desmostylian-like features found among terrestrial mammals. Its purpose is merely to show that nothing in the present reconstruction is wholly un- 


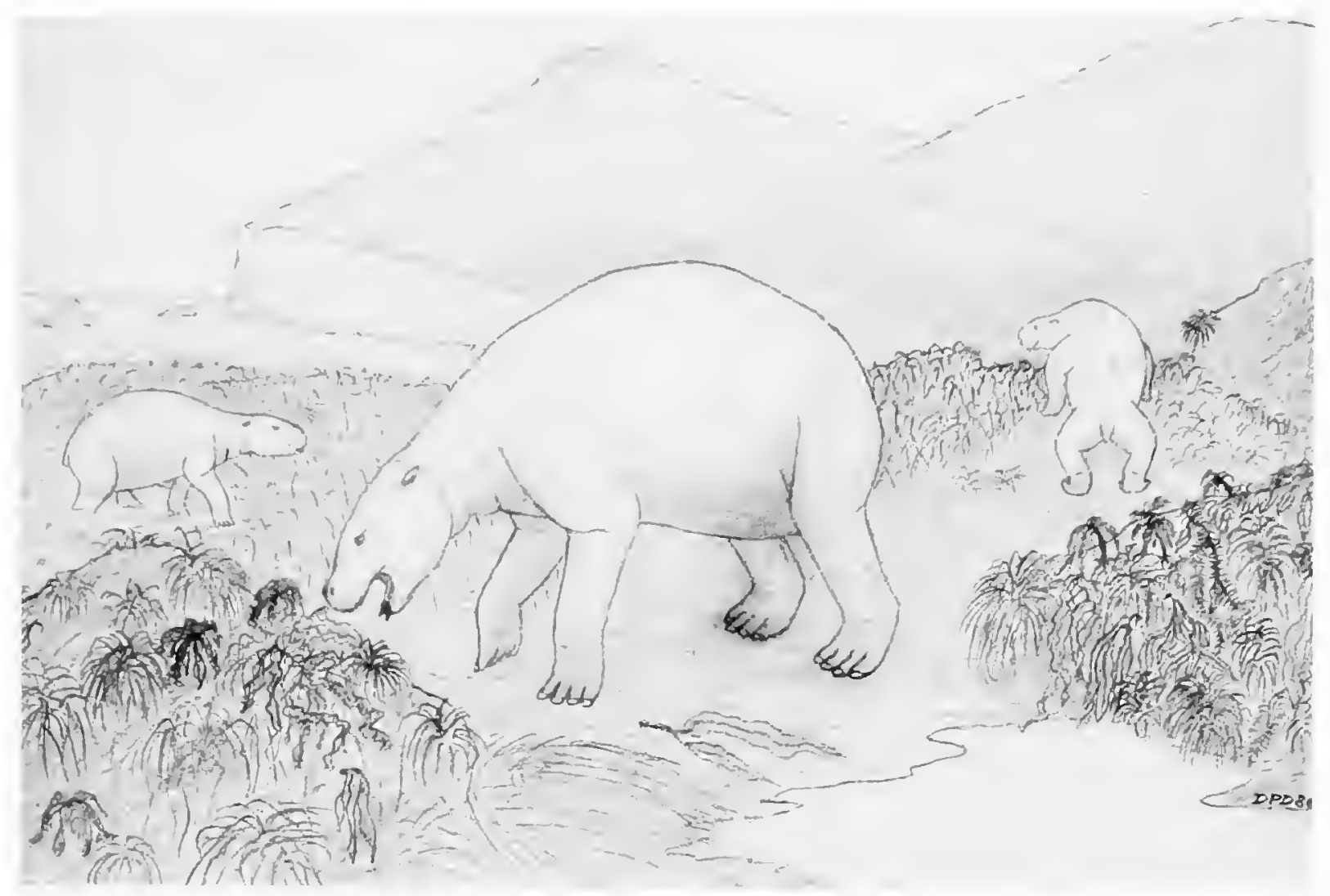

FIGURE 5.-Reconstruction of Paleoparadoxia, showing postures that it probably used while standing or traveling in the intertidal zone of North Pacific shorelines

precedented among large land mammals. On the contrary, $P a$ leoparadoxia presents a coherent suite of features that repeatedly appear in mammals believed to share a particular range of lifestyles: large, slow-moving herbivores that browsed (often bipedally) on leafy vegetation, in many cases by pulling it down from overhanging branches. These forms include ground sloths in addition to chalicotheres and Homalodotherium, both of which have been compared with sloths as well as with each other.

I do not suggest that desmostylians browsed on trees or even used their forelimbs to gather food. Apart from their marine habitat, their lack of claws and their non-elongated forelimbs, among other features, clearly rule this out. The sloth-like forms, however, are believed to have shared a less obvious trait, namely, the habit of supporting themselves on their hind legs while feeding. Large sloths had massive tails to help support them in this pose, but even the practically tailless Chalicotherium is thought to have behaved similarly (Zapfe, 1979). The essential requirement is a broad, stable base formed by the hind appendages. These forms all share an abducted posture of the knees (which steadies the upright body against falling sideways) and striking modifications of the hind feet-to support weight on the lateral edge of the foot in sloths and Homalodotherium, and on the medial side in Chalicotherium and desmostylians. The similarities in metatarsal, ankle, and tibial structure between the latter two seem too striking to reflect wholly different selective pressures.
Coombs (1983, figs. 3, 4, table 4) summarized in more detail the osteological features that appear to characterize diggers and bipedal browsers. The majority of these are features of the forelimbs, and judged on these alone, Paleoparadoxia resembles a digger more than a bipedal browser. This similarity, however, is surely due to its use of the forelimb for digging-like movements while swimming, because the front feet are not at all suited to efficient digging or food-gathering. Most features of the desmostylian hindlimb, in contrast, are consistent with the pattern Coombs described for semi-bipedal forms. These features-most of which also are well exemplified by humansinclude a vertical ilium, a large acetabulum, a heavy femur, differing stance of manus and pes, a long calcaneal tuber, short metatarsals with rigid articulations, and splayed hind toes. Although Coombs's comparisons were designed to distinguish bipedal browsers from diggers and climbers rather than from swimmers or amphibious quadrupeds, and although they covered such a diversity of mammals that they are necessarily very generalized, these resemblances nonetheless show that the present interpretation of desmostylians is not without anatomical precedent.

Consequently, Paleoparadoxia likely was a slow, heavy, quadrupedal herbivore that often had to support much of its weight on its hindquarters when climbing over extremely uneven, rocky, slippery ground. This would have been especially true while it fed in the North Pacific intertidal zone, presumably on marine algae and sea grasses (see Domning et al., 1986:47-48; Figure 5), and while it traveled to and from the 
water. Such a scenario fits well with Repenning and Packard's (1990) explanation for the bilateral hind-limb fractures seen in the Stanford skeleton, which also envisions a rocky seashore habitat.

Although it is possible that the peculiarities of the hind limbs were instead adaptations for swimming (see below), it is not necessary to look beyond the realm of purely terrestrial mammals to find detailed resemblances to the limbs of desmostylians. The latter, once envisioned as an aberrant group of sirenians or "sea cows," might more accurately be thought of as "sea sloths." (Interestingly, on the Pacific coast of Peru, where desmostylians apparently never occurred, Thalassocnus natans Muizon and McDonald, 1995, a newly discovered genus and species of megalonychid ground sloth, apparently filled an ecological niche much like that suggested herein for desmostylians.)

These parallels with semi-bipedal terrestrial browsers have been drawn from a diverse group of land mammals. The test, then, is whether the salient features of desmostylian osteology really fit together coherently. The hind feet and legs would provide stable support for most or all of the body's weight during slow, deliberate movements over rough ground. The almost vertical pelvis is appropriate for four-footed weight-bearing. The strongly arched back, although well suited for supporting a heavy trunk, is flexible enough for raising the forequarters without greatly changing the slope of the lumbosacral region. In quadrupedal stance, the base of the short neck is carried relatively low to the ground, which could easily be reached by the elongated rostrum. The scapula and forelimbs are in a normal ungulate pose, and the manus is peculiar only in its "semi-pronated" orientation. Although its gait was doubtless slow, nothing would seem to have prevented the animal from traveling with ease across dry, level ground.

A further and more rigorous test is to examine the moments of resistance against bending of the vertebral centra. Slijper (1946) and Coombs (1983) calculated these quantities by multiplying the width (b) of the caudal surface of the centrum by the square of the height $\left(\mathrm{h}^{2}\right)$. Calculated moments for each vertebra were graphed, as in Figure 6. A curve peaking in the lumbar region (Figure $6 a$ ) was interpreted to indicate use of an erect or semi-erect posture (cf. Coombs, 1983, fig. 2). Humans and bears (including Ailuropoda, Figure $6 b$ ) display this pattern. The results for the Stanford Paleoparadoxia (Figure 6c) agree for the most part with Slijper's theoretical curve for quadrupedal mammals (Figure $6 d$ ), but they also show bipedal tendencies in that the highest moments seen in the preserved portion of the vertebral column are relatively posterior, lying mostly in the lumbar region. Among the seven forms compared by Coombs (1983, fig. 2), this combination of a peak at the front of the thorax and one in the lumbar region is most closely matched by the chalicothere Moropus, the gerenuk (Litocranius), which often feeds in a bipedal pose (Figure $6 e$ ), and a goat (Capra) that was born without forelimbs and learned to walk bipedally. A normal goat did not show any lumbar or pos-
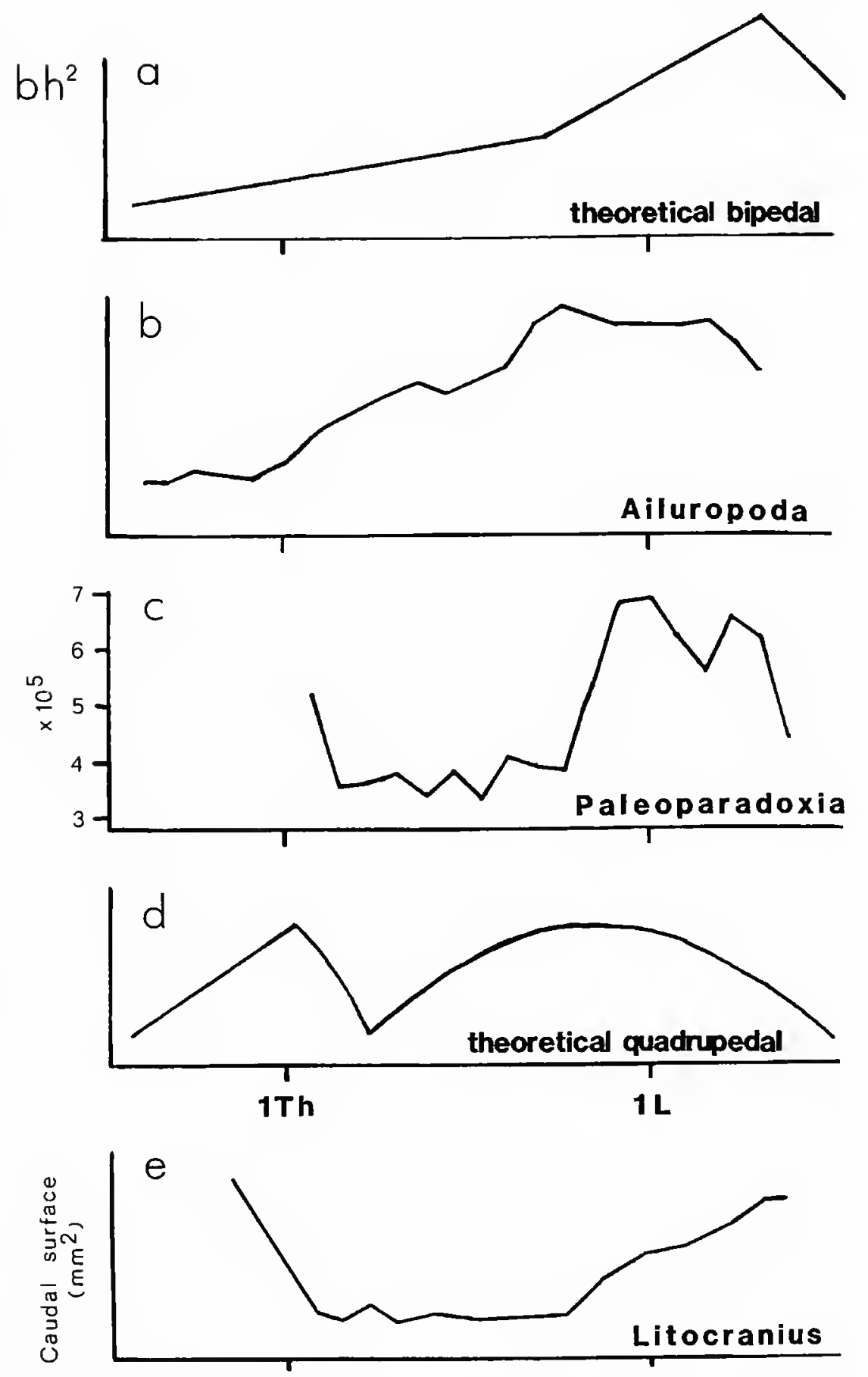

FIGURE 6. $-a-d$, Graphs of moments of resistance ( $b h^{2} ; b=$ greatest caudal width of centrum in $\mathrm{mm} ; \mathrm{h}=$ greatest caudal height) against bending of vertebral centra, redrawn after Slijper (1946) and Coombs (1983): $a$, Slijper's theoretical curve for mammals with erect or semi-erect posture; $b$, curve for giant panda (Ailuropoda); c, curve for Paleoparadoxia sp. (Stanford specimen, UCMP 81302); $d$, Slijper's theoretical curve for quadrupedal mammals. $e$. Comparable curve for gerenuk (Litocranius), from Coombs (1983) after Richter; $y$-axis $=$ caudal surface of centra, in $\mathrm{mm}^{2}$. For all curves, the $\mathrm{x}$ axis represents the vertebral series, with 1Th indicating first thoracic and iL indicating first lumbar vertebra Where scales are omitted, the $y$-axis just indicates lesser to greater.

terior thoracic peak. Although this evidence seems to support the concept of desmostylians as quadrupeds with semi-bipedal habits, it cannot be considered conclusive because patterns somewhat resembling that of Paleoparadoxia also are seen in Hippopotamus and even in horses and cows (Slijper, 1946, table 2). This body of data clearly needs to be analyzed in more detail.

Yet another possible test is to compare the limb and joint proportions of desmostylians with those of other large ungulates 
and subungulates, in order to find phenetic resemblances that give clues to locomotor habits. An ongoing study will use multivariate ordination of dissimilarity (M. Cole, unpub. data) to assess patterns of overall similarity among taxa based upon relative joint size and limb shape. The study incorporates numerous osteological measurements from a variety of extinct and living taxa: Desmostylus, Paleoparadoxia, Elephas, Loxodonta, Tapirus, Moropus, Dicerorhinus, Rhinoceros, Bos, Hippopotamus, Choeropsis, Eremotherium, and Paramylodon.

Preliminary results of this principal coordinates analysis (M. Cole, pers. comm., 1999) show the two desmostylians linked together, then to the two ground sloths and to the pygmy hippopotamus and hippopotamus. The remaining taxa, in turn, are linked to the two hippos. Although the functional reasons for these linkages have yet to be interpreted, and the possible role of facultative bipedality remains unclear, it is interesting that the closest resemblances of desmostylians are with hippos on the one hand and ground sloths on the other. Although desmostylians have often been compared with hippos, no one has heretofore seen in desmostylians any resemblance to sloths. This independent result tends to corroborate my conclusion based upon the comparisons offered above.

AQUATIC LOCOMOTION.-Although Paleoparadoxia, like other desmostylians, seems to have been capable of fully terrestrial locomotion, it displays some features that seem best explained by, or at least consistent with, a partially aquatic mode of life. These include the retracted external nares, raised orbits, peculiar sternum, long, robust olecranon process, and unusual "semi-pronated" position of the manus. The toes are not obviously adapted for digging, so the powerful forelimb must have had other uses. Toxodon shows that weight-bearing alone might explain the large olecranon; this and large pectoral muscles also would have been of use in clambering over rocky ground. Nonetheless, the combination of characters cited also makes sense in the context of aquatic locomotion. Nothing in the desmostylian skeleton demands an aquatic interpretation, however, and aquatic habits might not have been postulated were desmostylian remains not found exclusively in marine deposits.

Repenning (in Shikama, 1966:145; Repenning and Packard, 1990, fig. 183) and Shikama (1966:148, fig. 114) visualized Paleoparadoxia as swimming with the broad, somewhat paddle-like forefeet while using the hind limbs as rudders. This swimming method (alternate pectoral paddling; Fish, 1996) is essentially the one used by polar bears (Thalarctos), which (although they do not possess a greatly enlarged olecranon or enlarged pectoral muscle attachments) have limb proportions similar to those of desmostylians (intermembral index of Thalarctos $=87$ ), are fully capable of both aquatic and terrestrial locomotion, and nonetheless show no obvious aquatic adaptations in the skeleton. This swimming method is entirely consistent with the comparatively short hind legs and metatarsals and powerfully developed forelimbs of a desmostylian, and it readily explains the features mentioned above. With the elbow strongly abducted, the manus could have been effectively re- tracted underneath the trunk in a sweeping motion with the palm facing posteromediad, by means of movement at the shoulder permitted by the anteromedial expansion of the humeral head. Large pectoral muscles arising from the broad sternum and inserting on the long deltopectoral crest would have played an important role in this. With the elbow adducted against the ribcage, the manus, held almost parasagittally as in sirenians and other marine mammals, could have been feathered for the recovery stroke. The deeply grooved elbow joint would have resisted dislocation during the power stroke, with the huge olecranon enabling forceful extension of the elbow at the end of the stroke. The large radial styloid process would simultaneously have resisted hyperextension of the wrist. With their dorsoventrally flattened digits, whose lateral processes at the distal ends of the phalanges may have supported webbing (Figure 1e; Repenning and Packard, 1990), both front and hind feet would have been effective paddles.

Shikama (1966) described the desmostylians' probable mode of locomotion when feeding on the seafloor. The procumbent tusks would have been used for uprooting and raking in aquatic vegetation; the hind limbs, with the knees adducted and the soles directed posterolaterad against the substrate, would have driven the animal forward; and the forelimbs would have steadied and helped steer the body. The posterolaterad-directed hind feet might be likened to the anti-recoil spades of a split-trail field artillery carriage. The overall posture would have somewhat resembled that of a bottom-feeding walrus, although the hind limbs would have propelled the animal in a different manner.

\section{Critique of Alternative Reconstructions}

INUZUKA'S RECONSTRUCTION.-Inuzuka's "herpetiform mammal" reconstruction has been described several times in both Japanese and English, most recently and succinctly in Inuzuka et al. (1995). He defended his interpretation mainly on the basis of anatomical arguments, although the splayed-limb postmortem position of the Utanobori skeleton was also a factor (possibly the dominant one) in his original formulation of the idea.

Inuzuka postulated a highly unusual, horizontal orientation of the scapula, based only upon its position in the partly disarticulated, fossilized skeleton-a questionable source of information at best, and certainly not decisive. The broad sternum may well have served for the origin of large pectoral muscles, but a herpetiform stance is not needed to explain such muscles, as they also would be important in swimming. As evidence for a laterally extending humerus, he cites the semi-pronated position of the mutually immobile radius and ulna, on the assumption that the front toes would have had to point forward. As noted above, however, this latter constraint is sometimes relaxed-as in Chalicotherium - and it then becomes possible to bring the elbow and front feet much closer to the midline than Inuzuka shows.

As for the hind limb, the evidence Inuzuka cited for an abducted femur and strong adductor and quadriceps musculature 
is equally consistent with a sloth-like pose, as is the inclination of the calcaneal tuber when the tibial torsion is taken into account. His reconstruction of the entire hind limb, including a digitigrade pes with the toes pointing forward, is basically in agreement with the interpretation presented herein for a semibipedal stance, although a normal walking stance would probably involve more extended hip and knee joints and less separation of the hind feet. The pelvis, however, should be more steeply inclined to accommodate a stronger dorsal convexity of the spine than he shows (e.g., Inuzuka, 1984, pl. 11: fig. 2). This also would bring the base of the neck closer to the ground.

In short, no feature of the skeleton demands a herpetiform posture; all features are at least equally explicable in the context of a sloth-like restoration, which has the major advantage for weight-bearing of keeping the feet (especially the front feet) much closer to the midline.

Also relevant to this discussion is Numidotherium, possibly the most prmitive proboscidean (Court, 1994). Given that proboscideans have been proposed as the sister group of desmostylians (Domning et al., 1986), Court's (1994) conclusion that Numidotherium had a semisprawling posture might support Inuzuka's reconstruction. The resemblances between Numidotherium and desmostylians are relatively few, however: the femur was habitually abducted, laterally rotated, and posteriorly inclined; the cnemial crest is deflected laterally; the tibial shaft is twisted; and the talocrural joint surface of the tibia faces laterodistad. There are, on the other hand, many points of contrast: in desmostylians the lateral part of the humeral trochlea protrudes more distally; the spiral elbow joint is designed for forceful medial rotation of the humerus, as in most sirenians (cf. Domning, 1978:125-127, fig. 32c), and is dislocated by lateral rotation; the forefeet were evidently digitigrade rather than plantigrade; the head of the femur is nearly spherical and lacks a fovea, and its shaft is not bowed; the femoral condyles are much more nearly equal in size; the femur was habitually held in a more nearly horizontal position; the proximal tibia faced anterolaterad rather than anterad and lacks an interarticular eminence; movements of the talocrural joint do not seem to involve significant inversion/eversion or abduction/adduction; the calcaneal tuber is inclined; and a rugose plantar tubercle is present on the calcaneum, indicating strong plantar ligaments and possibly implying a digitigrade rather than a plantigrade pedal stance.

Numidotherium apparently was specialized in a direction rather different from that of desmostylians, a condition that provides no support for the idea of semisprawling posture in the latter. Furthermore, at least some of the few shared characters may merely reflect a common tethythere heritage, for example, the twisted tibial shaft and inclined talocrural joint surface, as discussed above.

REPENNING'S RECONSTRUCTION.-Repenning's (1965) "frog-like" or "sealion-like" reconstruction also can be reconciled with my own by means of a simple adjustment. Although Paleoparadoxia could doubtless have squatted in that position when at rest, it would not necessarily have been confined to such a posture (with the belly "on or very close to the ground," Repenning and Packard, 1990:202) while moving about on land; again the key feature is the hind foot.

Repenning and Packard (1990) envisioned desmostylian terrestrial locomotion as resembling the "humping" or "hopping" gait of an otarioid pinniped, in which the front feet move in unison followed by the back feet moving in unison. This movement also would involve strong extension and flexion of the spine. They viewed the sole of the hind foot as being nearly vertical and the toes hyperextended against the substrate during this action. They further stated that lifting the body by greater extension of the hind-limb joints (i.e., so that the femur and tibia approached vertical, as in an elephant; C.A. Repenning, pers. comm., 1996) would result in "rotating the foot from a plantar position to one in which the plantar plane was approaching $45^{\circ}$ from horizontal; ... concentrating the weight ... on the medial edge of the paddle-like foot, and ... rotating the tibial-astragalar articular surface toward the maximum of $45^{\circ}$ from horizontal and toward possible dislocation" (Repenning and Packard, 1990:202-203).

The latter statement concerning ankle dislocation is true if the tibia is visualized in an elephant-like vertical position. There is, however, a less extreme possibility that also permits an alternating terrestrial gait. Repenning and Packard's interpretation overlooks the features of the metatarso-phalangeal joints described above, and the fact that the pes could adopt a digitigrade stance with the axis of the ankle joint level. This stance would allow the body's weight to be stably supported on moderately flexed hip, knee, and ankle joints and with abducted knees as shown in Figure 3. With the hip joint directly above the ankle, the weight would indeed fall on the medial side of the digitigrade foot, but this is just what the foot is built for. The hindquarters could thus have been lifted well off the ground, with the hind feet beneath the hip joint, and an alternating gait could have been used.

Repenning and Packard (1990) correctly noted the vertebral articulations allowing arching of the back, and they stated that the front legs "could be held vertically for support." Apparently, then, they did not regard as obligatory the front-limb posture shown by Repenning (1965), with the dorsum of the manus resting on the ground. In any case, the radial styloid process, although preventing hyperextension, does not prevent full extension of the wrist. Their anatomical interpretation and the present one therefore are essentially compatible, given the reinterpretation of the hind foot outlined above. Their conclusion that "Paleoparadoxia was well adapted to swimming and was as poorly adapted to terrestrial locomotion as are modern otarioid pinnipeds" (Repenning and Packard, 1990:203) appears incorrect, however. Paleoparadoxia was distinctly less aquatically specialized than otarioids: it swam more on a par with a polar bear, whereas it moved on level ground more like a typical ungulate or other terrestrial mammal than an otarioid, and most like a ground sloth. 


\section{Literature Cited}

Barnes, L.G., D.P. Domning, and C.E. Ray

1985. Status of Studies on Fossil Marine Mammals. Marine Mammal Science, 1(1):15-53.

Coombs, M.C

1983. Large Mammalian Clawed Herbivores: A Comparative Study. Transactions of the American Philosophical Society, 73(7):1-96.

Court, N.

1994. Limb Posture and Gait in Numidotherium koholense, a Primitive Proboscidean from the Eocene of Algeria. Zoological Journal of the Linnean Society, 111(4):297-338.

Davis, D.D.

1964. The Giant Panda: A Morphological Study of Evolutionary Mechanisms. Fieldiana: Zoology Memoirs, 3:1-339.

Domning, D.P.

1978. Sirenian Evolution in the North Pacific Ocean. University of California Publications in Geological Sciences, 118: xi + 176 pages.

2001. Supposedly Unique Features of the Desmostylian Tibia Are Also Found in Other Mammals. Bulletin of the Ashoro Museum of Paleontology, 2:39-42.

Domning, D.P., C.E. Ray, and M.C. McKenna

1986. Two New Oligocene Desmostylians and a Discussion of Tethytherian Systematics. Smithsonian Contributions to Paleobiology, 59: iii +56 pages

Fish, F.E

1996. Transitions from Drag-Based to Lift-Based Propulsion in Mammalian Swimming. American Zoologist, 36:628-641.

Gazin, C.L.

1965. A Study of the Early Tertiary Condylarthran Mammal Meniscotherium. Smithsonian Miscellaneous Collections, 149(2): iv + 98 pages.

1968. A Study of the Eocene Condylarthran Mammal Hyopsodus. Smithsonian Miscellaneous Collections, 153(4): iv + 90 pages.

Halstead, L.B.

1985. On the Posture of Desmostylians: A Discussion of lnuzuka's "Herpetiform Mammals." Memoirs of the Faculty of Science, Kyoto University, Biology, 10(2):137- 144.

Inuzuka, $\mathrm{N}$.

1980-1982. [The Skeleton of Desmostylus mirabilis from South Sakhalin, [Parts] I-V.] Chikyu Kagaku [Earth Science], 34:205-214, 247-257; 35:1-18, 240-244; 36:117-127. [In Japanese with English summary.]

1982. [Atlas of Reconstructed Desmostylians.] Abstracts, 36th Annual Meeting, Association for the Geological Collaboration in Japan, Saitama, pages 44-61. [In Japanese.]

1984. Skeletal Restoration of the Desmostylians: Herpetiform Mammals. Memoirs of the Faculty of Science, Kyoto University, Biology, 9(2):157-253.

1985. Are "Herpetiform Mammals" Really lmpossible? A Reply to Halstead's Discussion. Memoirs of the Faculty of Science, Kyoto University, Biology, 10(2): 145-150

1988. [The Skeleton of Desmostylus from Utanobori, Hokkaido, 1: Cranium.] Bulletin of the Geological Survey of Japan, 39(3):139-190. [In Japanese with English summary.]

1989. [Desmostylus and Behemotops.] In Ashoro Educational Committee, editors, Research Report on the Ashoro Marine Mammal Fauna, pages 40-76. [In Japanese.]

Inuzuka, N., D.P. Domning, and C.E. Ray

1995. Summary of Taxa and Morphological Adaptations of Desmostylia. The Island Arc, 3:522-537.

Jenkins, F.A., Jr.

1973. The Functional Anatomy and Evolution of the Mammalian Humero-
Ulnar Articulation. American Journal of Anatomy, 137(3):281-298.

Jenkins, F.A., Jr., and S.M. Camazine

1977. Hip Structure and Locomotion in Ambulatory and Cursorial Carnivores. Journal of Zoology, 181:351-370.

Muizon, C. de, and H.G. McDonald

1995. An Aquatic Sloth from the Pliocene of Peru. Nature, 375:224-227. Osborn, H.F.

1942. Proboscidea, a Monograph of the Discovery, Evolution, Migration and Extinction of the Mastodonts and Elephants of the World. Volume 2, pages xxvii $+805-1675$. New York: American Museum Press.

Repenning, C.A.

1965. [Drawing of Paleoparadoxia Skeleton, with Caption.] Geotimes, $9(6): 1,3$

Repenning, C.A., and E.L. Packard

1990. Locomotion of a Desmostylian and Evidence of Ancient Shark Predation. In A.J. Boucot, editor, Evolutionary Paleobiology of Behavior and Coevolution, pages 199-203. Amsterdam: Elsevier.

Romer, A.S.

1966. Vertebrate Paleontology. Third edition, 468 pages. Chicago: University of Chicago Press.

Sakamoto, $\mathrm{O}$

1983. On the Occurrence of the Two Skeletons of Paleoparadoxia tabatai (Tokunaga) from Chichibu Basin, Central Japan. Bulletin of the Saitama Museum of Natural History, 1:17-26.

Scott, W.B.

1912. Mammalia of the Santa Cruz Beds, Part 11: Toxodonta. Reports of the Princeton University Expedition to Patagonia, 6:111-238, 287-300.

1930. A Partial Skeleton of Homalodontotherium from the Santa Cruz Beds of Patagonia. Geology Memoirs, Field Museum of Natural History, 1:7-34

Shikama, T.

1966. Postcranial Skeletons of Japanese Desmostylia: Limb Bones and Sternum of Desmostylus and Paleoparadoxia, with Considerations on Their Evolution. Palaeontological Society of Japan, Special Papers, 12: iii +202 pages.

1968. Additional Notes on the Postcranial Skeletons of Japanese Desmostylia. Science Reports of the Yokohama National University, section 2, 14:21-26.

Slijper, E.J.

1946. Comparative Biologic-Anatomical Investigations on the Vertebral Column and Spinal Musculature of Mammals. Verhandelingen der Koninklijke Nederlandsche Akademie van Wetenschappen, Afdeeling voor Natuurkunde, series 2, 42:1-128.

Thewissen, J.G.M., and D.P. Domning

1992. The Role of Phenacodontids in the Origin of the Modern Orders of Ungulate Mammals. Journal of Vertebrate Paleontology, 12: 494-504.

Williamson, T.E., and S.G. Lucas

1992. Meniscotherium (Mammalia, "Condylarthra") from the PaleoceneEocene of Western North America. Bulletin of the New Mexico Museum of Natural History and Science, 1: iv +75 pages.

Wilson, J.A., and M.T. Carrano

1999. Titanosaurs and the Origin of "Wide-Gauge" Trackways: A Biomechanical and Systematic Perspective on Sauropod Locomotion. Paleobiology, 25:252-267.

Zapfe, $\mathrm{H}$.

1979. Chalicotherium grande (Blainv.) aus der miozänen Spaltenfüllung von Neudorf an der March (Devinska Nova Ves), Tschechoslowakei. Neue Denkschriften des Naturhistorischen Museums in Wien, 2:1-282. 



\title{
The Miocene Pinniped Desmatophoca oregonensis Condon, 1906 (Mammalia: Carnivora), from the Astoria Formation, Oregon
}

\author{
Thomas A. Deméré and Annalisa Berta
}

\begin{abstract}
New crania, dentitions, mandibles, and postcrania of the fossil pinniped Desmatophoca oregonensis Condon, 1906, are described from the Miocene Astoria Formation of the Newport Embayment, Lincoln County, Oregon. This relatively large sample includes specimens of different developmental ages and genders and permits documentation of the range of variation in this Miocene pinniped. This variation suggests that several characters previously considered diagnostic of different species are in fact the result of sexual dimorphism. Reevaluation of the status of Desmatophoca supports recognition of only two species, $D$. brachycephala Barnes, 1987, and D. oregonensis. A cladistic analysis, using 30 cranial and dental characters, supports the monophyly of the genus Desmatophoca and suggests a close sister-group relationship with a monophyletic Allodesmus clade. The parsimony analysis also confirms the monophyly of the Desmatophocidae, which is herein defined as the clade containing the most recent common ancestor of Desmatophoca and Allodesmus and all of its descendants. Phocids are shown to be the sister group to the desmatophocids in a redefined monophyletic Phocoidea.
\end{abstract}

\section{Introduction}

The fossil pinniped genus Desmatophoca was founded on the basis of a partially prepared skull, a partial mandible, and postcranial bones collected from the middle Miocene portion of the Astoria Formation at Newport, Lincoln County, Oregon, and was described by Condon (1906) as Desmatophoca oregonensis. A second species known only by a skull was described by Barnes (1987) as Desmatophoca brachycephala. This specimen was collected from the lower Miocene portion

Thomas A. Deméré, Department of Paleontology, San Diego Natural History Museum, P.O. Box 121390, San Diego, California 92112. Annalisa Berta, Research Associate, Department of Paleobiology, $\mathrm{Na}$ tional Museum of Natural History, Smithsonian Institution, Washington, D.C. 20560-0121; and Department of Biology, San Diego State University, San Diego, California 92182. of the Astoria Formation as exposed in southwestern Washington, across the Columbia River from the stratotype at Astoria, Oregon.

Desmatophoca has been variously classified in the family Desmatophocidae (Hay, 1930) or the subfamily Desmatophocinae (Mitchell, 1966; Barnes, 1972), the content of which has included (Repenning, 1976; Repenning and Tedford, 1977; King, 1983) or excluded (Mitchell, 1968, 1975; Barnes, 1987, 1989) the genus Allodesmus. More recently, Barnes (1987, $1989)$ has followed Mitchell $(1968,1975)$ in recognizing the Allodesminae and Desmatophocinae as separate monotypic subfamilies within the Otariidae sensu lato (=Otarioidea fide Repenning and Tedford, 1977). According to Barnes (1989), the Desmatophocinae are the sister group of walruses and the Allodesminae are more closely linked with Pinnarctidion in a group that includes all other "non-walnus otariids" (i.e., Enaliarctos, sea lions, and fur seals) (Figure 1). In the classification arrangement adopted herein, the family Desmatophocidae is defined as the monophyletic group containing the most recent common ancestor of Desmatophoca and Allodesmus and all of its descendants. The Otarioidea (Enaliarctidaet Desmatophocidae + Odobenidae+Otariidae) of Repenning and Tedford (1977) and the Otariidae (Enaliarctinae+ Desmatophocinae +Allodesminae+Odobeninae+Otariinae) of Barnes (1989) were rejected by Wyss (1987), Berta (1991), and Berta and Wyss (1994) as nonmonophyletic groupings that are based largely upon shared primitive characters. Berta (1991) proposed a close relationship between Desmatophoca and the "enaliarctine" pinniped Pinnarctidion in a clade that included Allodesmus + Phocidae, whereas Berta and Wyss (1994) supported a slightly different arrangement in which Pinnarctidion, Desmatophoca, and Allodesmus formed a polytomy with a sister-group relationship to the Phocidae, referring to the entire clade as the Phocoidea (Figure 1).

Although Desmatophoca oregonensis was named more than 90 years ago, the original description was minimal and ham- 
Other Otariidae (incl. Otariinae, Pinnarctidien. Allodesmus, Pteronarctos. Enaliarctos)

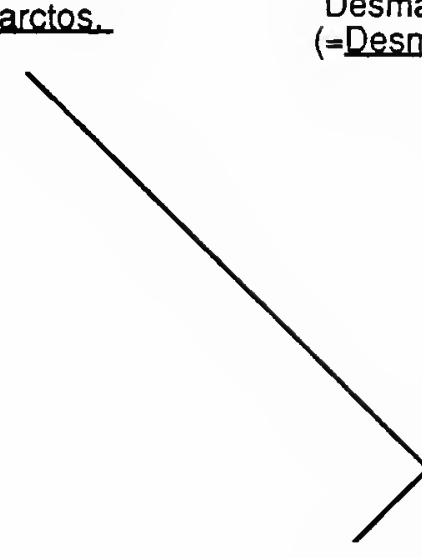
Desmatophocinae
(=Desmatophoca)

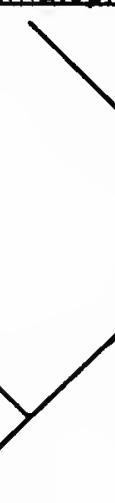

Barnes, 1989

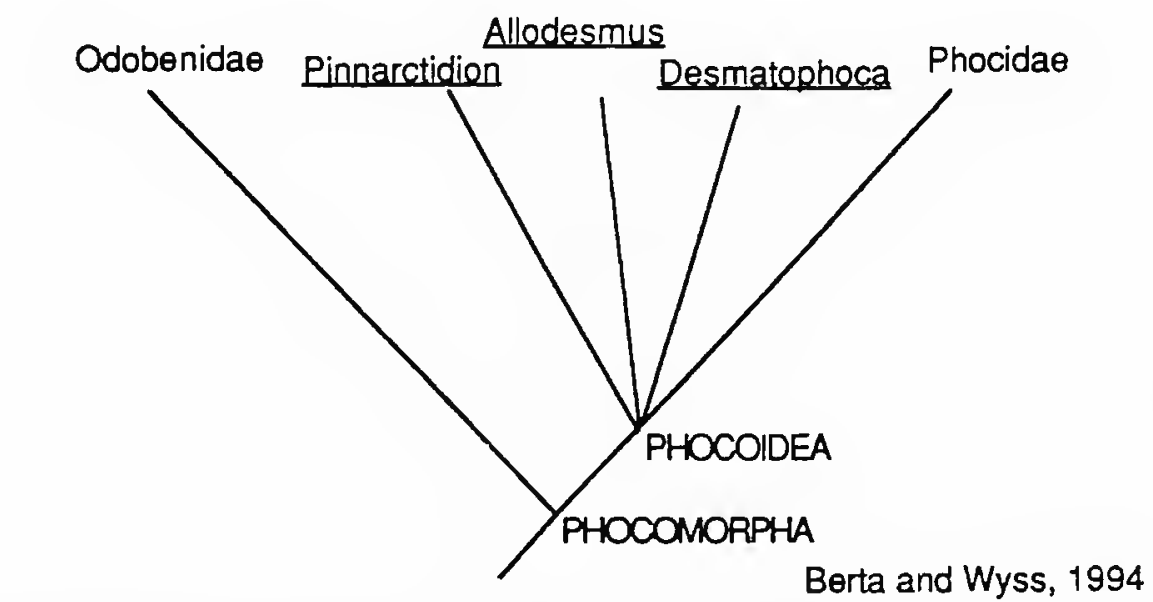

FIGURE 1.-Alternative phylogenetic hypotheses of phocoid and desmatophocid relationships.

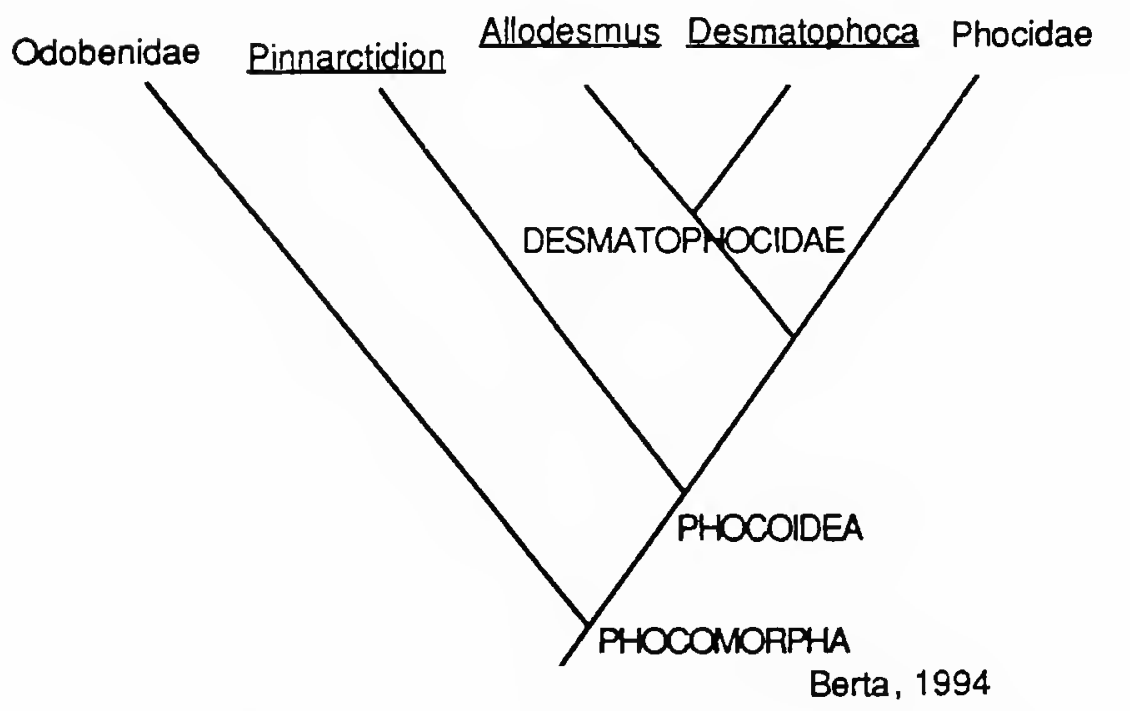

pered by the incomplete preparation of the holotype skull. Mitchell $(1966,1975)$ prepared and illustrated additional portions of the holotype but did not provide more complete osteological descriptions or comparisons. Such a redescription is critical to an understanding of the phylogenetic significance of this important early pinniped. Unfortunately, the holotype skull is not currently available for study. Among the large number of fossil pinnipeds collected by Douglas Emlong from the Astoria Formation along the Oregon coast near Newport (Ray, 1977), however, are several undescribed specimens referable to Desmatophoca oregonensis. These specimens, which form the basis of this report, include new cranial, mandibular, dental, and postcranial material. New insights derived from the study of this material provide evidence for a close phylogenetic rela- tionship between $D$. oregonensis, $D$. brachycephala, and species of Allodesmus.

ABBREVIATIONS.-The abbreviations for institutions and collections are as follows:

BVM Buena Vista Museum of Natural History, Bakersfield, California

LACM Natural History Museum of Los Angeles County, Los Angeles, California

SDSNH San Diego Natural History Museum, San Diego, Califomia

SICC Sado lsland Community Center, Ogi-machi, Sado Island, Japan

UCMP Museum of Paleontology, University of Califomia, Berkeley, California

UOMNH University of Oregon, Museum of Natural History, Eugene, Oregon

USNM Collections of the National Museum of Natural History (NMNH), Smithsonian Institution, Washington, D.C., which include collections of the former United States National Museum 
TABLE 1.-Suture closure scoring for specimens of Desmatophoca oregonensis. Suture classification follows terminology of Doutt (1942) and Siversten (1954).

\begin{tabular}{c|ccccccccc}
\hline Specimen & I & Il & IIl & lV & V & V1 & V1I & V1ll & lX \\
\hline USNM 335478 & 4 & 1 & 3 & 1 & 1 & 1 & 1 & 1 & 1 \\
USNM 314645 & - & - & - & - & - & 1 & - & & 1 \\
USNM 335451 & - & 1 & 4 & 1 & 2 & - & 1 & - & 1 \\
USNM 335702 & 4 & 2 & - & - & 3 & 4 & 2 & 4 & - \\
USNM 243694 & - & - & - & - & - & - & 4 & & 2 \\
USNM 250283 & 4 & 4 & - & - & 4 & 4 & - & 4 & - \\
\hline
\end{tabular}

ACKNOWLEDGMENTS. - We thank Lawrence G. Barnes (LACM), Michael Metz (BVM), and Clayton E. Ray (NMNH) for allowing us to study specimens under their care. We also thank Lawrence G. Barnes for providing casts of comparative specimens. Naoki Kohno of the National Science Museum, Tokyo, Japan, facilitated study of Japanese pinniped specimens during a research trip supported by National Science Foundation (NSF) international programs grant 9417088 to AB. Robert Ernst of Bakersfield, California, donated specimens of $\mathrm{Al}$ lodesmus kernensis to SDSNH. Robert L. Clark (SDSNH) skillfully prepared several of the Emlong Desmatophoca skulls. Research was supported in part by NSF grant BSR 9006535 to $\mathrm{AB}$.

\section{METHODS}

To determine the degree of closure for cranial sutures, we used the procedures of Doutt (1942) and Siversten (1954); the resulting scores are provided in Table 1. Measurements, to the nearest tenth of a millimeter, of crania, dentitions, and mandibles were taken using digital calipers; these measurements are provided in Tables 2 and 3 and for the most part represent the standard measurements of Siversten (1954). All specimens in the photographic figures, with the exception of Figure 6B, were coated with a sublimate of aluminum chloride.

\section{MATERIAL}

In addition to the referred specimens listed below, the following specimens were examined during the course of this study:

TABLE 2.-Cranial and upper dentition measurements for specimens of Desmatophoca oregonensis and $D$. brachycephala. ( $\mathrm{a}=$ measurement for alveolus; $\mathrm{e}=$ estimated measurement; *=measurement doubled for missing half; +=broken specimen; -= no data. Measurements of Siversten (1954) indicated by numbers in parentheses.)

\begin{tabular}{|c|c|c|c|c|c|c|c|}
\hline Measurements & $\begin{array}{l}\text { USNM } \\
335478\end{array}$ & $\begin{array}{l}\text { USNM } \\
335702\end{array}$ & $\begin{array}{l}\text { USNM } \\
335451\end{array}$ & $\begin{array}{l}\text { USNM } \\
314645\end{array}$ & $\begin{array}{l}\text { USNM } \\
243694\end{array}$ & $\begin{array}{l}\text { Cast of holotype } \\
\text { SDSNH } 61143\end{array}$ & $\begin{array}{l}\text { Holotype of } D \text {. } \\
\text { brachycephala } \\
\text { LACM } 120199\end{array}$ \\
\hline Condylobasal length $(0)$ & 230.0 & - & - & $255.0^{\mathrm{e}}$ & - & 326.0 & $282.0^{e}$ \\
\hline Palatal length & 117.1 & - & - & $136.0^{\mathrm{e}}$ & $141.8+$ & 172.7 & $144.0^{e}$ \\
\hline Postpalatal length & 99.7 & 123.3 & - & 101.9 & - & 135.0 & 119.9 \\
\hline Facial length & $125.0^{\mathrm{e}}$ & - & - & $139.0^{\mathrm{e}}$ & $170.0^{e}$ & $195.0^{e}$ & $169.0^{e}$ \\
\hline Braincase length & $99.0^{e}$ & $114.0^{e}$ & - & $102.0^{e}$ & - & $120.0^{e}$ & $106.0^{\mathrm{e}}$ \\
\hline C-M2 length & $63.2^{\mathrm{a}}$ & - & 96.3 & - & 99.5 & - & $97.7^{e}$ \\
\hline Orbit length & $48.0^{e}$ & $64.0^{e}$ & $59.0^{e}$ & $48.0^{e}$ & $48.0^{e}$ & $64.0^{e}$ & $54.0^{e}$ \\
\hline Temporal fossa length & $34.0^{e}$ & $49.0^{e}$ & $42.0^{e}$ & $41.0^{e}$ & $38.0^{\mathrm{e}}$ & $54.0^{e}$ & $46.0^{e}$ \\
\hline Greatest width anterior nares (3) & 23.8 & - & 26.7 & - & - & 28.8 & \\
\hline Greatest length nasals (4) & 59.2 & - & 55.8 & - & - & - & - \\
\hline Rostral width at C (12) & 52.7 & - & $59.8^{*}$ & 61.3 & $65.3+$ & $76.7+$ & $76.0+e$ \\
\hline Palate width at P4 (anterior root) & 46.9 & 55.4 & 53.2 & 59.4 & 47.6 & $68.0^{*}$ & 63.1 \\
\hline Width at supraorbital processes (7) & 32.4 & $35.0^{*}$ & 35.4 & - & - & $36.0+$ & - \\
\hline Least interorbital width & 28.7 & 33.0 & 33.2 & - & - & $36.1+$ & - \\
\hline Width of braincase (8) & 78.6 & $77.6+$ & 80.1 & $84.6+$ & - & $77.3+$ & $88.0^{* e}$ \\
\hline Zygomatic width (17) & 132.9 & 176.3 & $165.0^{*}$ & 153.8 & $152.0^{*}$ & $188.0^{*}$ & 182.3 \\
\hline Auditory width (19) & 103.9 & 135.1 & 130.5 & 119.1 & $128.0^{*}$ & 144.1 & 143.8 \\
\hline Mastoid width (20) & 116.2 & 157.4 & $139.0^{*}$ & 133.3 & $148.0^{*}$ & 161.9 & 168.6 \\
\hline Greatest width of occipital condyles & 60.3 & 70.4 & - & $72.0^{*}$ & - & 70.6 & 70.9 \\
\hline Greatest width of foramen magnum & 30.0 & 29.8 & - & $32.5+$ & - & 31.7 & 31.6 \\
\hline Greatest height of foramen magnum & 16.9 & 30.0 & - & 21.0 & - & 18.5 & 23.5 \\
\hline $\mathrm{I} 1 ; \mathrm{AP} / \mathrm{T}$ & $3.0 / 5.3^{\mathrm{a}}$ & $-1-$ & $-1-$ & $-1-$ & $-1-$ & $-1-$ & $-1-$ \\
\hline $12 ; \mathrm{AP} / \mathrm{T}$ & $3.4 / 6.1^{\mathrm{a}}$ & $-1-$ & $-1-$ & $-1-$ & $-1-$ & $-1-$ & $-1-$ \\
\hline $\mathrm{I} 3 ; \mathrm{AP} / \mathrm{T}$ & $7.2 / 10.7^{\mathrm{a}}$ & $-1-$ & $-1-$ & $-1-$ & $9.6 / 8.2$ & $11.4 / 8.1$ & $-1-$ \\
\hline $\mathrm{Cl} ; \mathrm{AP} / \mathrm{T}$ & $14.4 / 8.0$ & $-1-$ & $17.1 / 13.4$ & $16.8 / 11.8$ & $20.2 / 13.4$ & $18.2 / 13.7$ & $-1-$ \\
\hline $\mathrm{P} 1 ; \mathrm{AP} / \mathrm{T}$ & $6.8 / 6.1^{\mathrm{a}}$ & $9.9 / 9.0$ & $9.8 / 8.1$ & $8.8 / 8.4^{\mathrm{a}}$ & $9.2 / 7.5$ & $8.1 / 8.3^{e}$ & $-1-$ \\
\hline $\mathrm{P} 2 ; \mathrm{AP} / \mathrm{T}$ & $12.1 / 8.9$ & $11.8 / 8.0$ & $10.4 / 7.8$ & $13.3 / 8.9$ & $10.2 / 8.2+$ & $12.9 / 9.9$ & $-1-$ \\
\hline $\mathrm{P} 3 ; \mathrm{AP} / \mathrm{T}$ & $11.6 / 8.7$ & $10.7 / 8.1$ & $10.5 / 7.8$ & $12.8 / 8.9^{\mathrm{a}}$ & $10.2 / 7.9+$ & $15.9 / 8.0^{\mathrm{a}}$ & $-/ 11.5^{\mathrm{a}}$ \\
\hline $\mathrm{P} 4 ; \mathrm{AP} / \mathrm{T}$ & $10.0 / 8.3$ & $12.8 / 8.2^{\mathrm{a}}$ & $9.5 / 8.0$ & $9.7 / 7.2^{\mathrm{a}}$ & $8.9 / 6.8$ & $13.4 / 10.1$ & $13.2 / 12.3^{\mathrm{a}}$ \\
\hline $\mathrm{Ml} ; \mathrm{AP} / \mathrm{T}$ & $6.9 / 7.2$ & $7.3 / 6.7$ & $6.6 / 6.4$ & $6.6 / 3.7^{\mathrm{a}}$ & $5.6 / 4.8+$ & $10.5 / 5.5^{a}$ & $6.2 / 6.0$ \\
\hline $\mathrm{M} 2 ; \mathrm{AP} / \mathrm{T}$ & $4.9 / 4.2$ & $6.0 / 4.1^{\mathrm{a}}$ & $5.2 / 3.1^{\mathrm{a}}$ & $-1-$ & $7.5 / 5.3^{\mathrm{a}}$ & $-1-$ & $6.8 / 4.2^{\mathrm{a}}$ \\
\hline
\end{tabular}


TABLE 3.--Mandibular and lower dentition measurements for specimens of Desmatophoca oregonensis. $(\mathrm{a}=$ measurement for alveolus; $b=$ measurement for base of root; $c=$ measurement for $\mathrm{c}-\mathrm{ml} ;+=$ broken specimen; -= no data.)

\begin{tabular}{l|ccccc}
\hline \multicolumn{1}{c|}{ Measurements } & USNM & USNM & USNM & USNM & USNM \\
& 335478 & 335694 & 314536 & 335457 & 335430 \\
\hline Ramus total length & 147.1 & 188.7 & 161.8 & - & - \\
c-m2 length & $67.2^{\mathrm{c}}$ & 95.6 & 83.9 & 93.7 & 117.5 \\
Greatest length symphysis & 52.0 & 54.1 & 50.4 & 60.9 & $63.6^{+}$ \\
Greatest width symphysis & 18.6 & 23.4 & 22.1 & 25.2 & $32.6^{\circ}$ \\
Angle of symphysis to alveoli & $48^{\circ}$ & $49.5^{\circ}$ & $41^{\circ}+$ & $47.5^{\circ}$ & $59^{\circ}$ \\
Depth ramus at p3 & 34.4 & 37.7 & 30.2 & 25.0 & 43.7 \\
Depth ramus at coronoid process & 65.9 & 83.7 & 59.3 & - & - \\
c AP/T & $13.4 / 8.9$ & $18.2 / 11.8$ & $12.2 / 9.0$ & $17.5 / 10.9$ & $19.0 / 14.0$ \\
p1 AP/T & $8.6 / 7.4$ & $8.6 / 6.9^{\mathrm{a}}$ & - & $9.1 / 4.7^{\mathrm{a}}$ & $12.5 / 8.5^{\mathrm{a}}$ \\
p2 AP/T & $9.8 / 7.6$ & $12.7 / 6.9^{\mathrm{a}}$ & $10.7 / 7.7$ & $11.6 / 8.5$ & $15.2 / 6.3^{\mathrm{b}}$ \\
p3 AP/T & $11.5 / 8.0$ & $13.5 / 5.9^{\mathrm{a}}$ & $11.1 / 7.8$ & $11.8 / 8.5$ & $15.4 / 8.3^{\mathrm{b}}$ \\
p4 AP/T & $11.1 / 7.8$ & $11.1 / 7.6$ & $11.3 / 7.8$ & $11.3 / 8.0$ & $16.8 / 7.1^{\mathrm{b}}$ \\
m1 AP/T & $11.2 / 7.4$ & $10.1 / 6.7$ & $10.5 / 7.2$ & $11.1 / 8.0$ & $18.2 / 6.3^{\mathrm{b}}$ \\
m2 AP/T & - & $6.0 / 3.4^{\mathrm{a}}$ & $6.7 / 4.3^{\mathrm{a}}$ & $9.5 / 3.0^{\mathrm{a}}$ & $9.0 / 4.4^{\mathrm{a}}$ \\
\hline
\end{tabular}
1979

1. UCMP 86334, holotype of Pinnarctidion bishopi Barnes,

2. LACM 1376, skeleton on slab of Allodesmus courseni (Downs, 1956)

3. LACM 4320, complete skeleton of Allodesmus kernensis Kellogg, 1922 (=holotype of Allodesmus kelloggi Mitchell, 1966)

4. SDSNH 54801, referred braincase of Allodesmus kernensis

5. SDSNH 54802, referred right squamosal of Allodesmus kernensis

6. BVM 0163, associated complete skull and mandible of Allodesmus kernensis

7. BVM 0164, complete skull of Allodesmus kernensis

8. USNM 205315, cast of holotype of Allodesmus packardi Barnes, 1972

9. SICC 0001, holotype of Allodesmus sadoensis Hirota and Barnes, 1995

10. SDSNH 61143, cast of holotype of Desmatophoca oregonensis Condon, 1906

11. LACM 120199, holotype of Desmatophoca brachycephala Barnes, 1987

12. USNM 314325, holotype of Pinnarctidion rayi Berta, 1994

13. USNM 250345, holotype of Enaliarctos emlongi Berta, 1991

\section{LOCATION, STRATIGRAPHY, AND CORRELATION}

All but one of the pinniped fossils described in this report were collected by the late Douglas Emlong from the marine Astoria Formation in the Newport Embayment near Newport, Oregon. The majority of these fossils were recovered from a single stratigraphic horizon, the "Iron Mountain bed" (Armentrout, 1981), as exposed along Moolack Beach, north of Yaquina Head (Ray, 1977).
In addition to Desmatophoca oregonensis, four other pinniped taxa have been described from the Astoria Formation of the Newport Embayment: Pteronarctos goedertae Barnes, 1989; P. piersoni Barnes, 1990; Pacificotaria hadromna Barnes, 1992; and Proneotherium repenningi Barnes in Kohno et al., 1995. Cetaceans known from these exposures include the mysticete Cophocetus oregonensis Packard and Kellogg, 1934, and an undescribed new species of squalodontid odontocete (Dooley, 1994). A desmostylian, Desmostylus hersperus Marsh, 1888, also is reported from the Newport Embayment exposures of the Astoria Formation (Packard and Kellogg, 1934).

The molluscan and foraminiferal biostratigraphy of the Astoria Formation is rather complex and suggests an age range from early to early middle Miocene. In the type area at Astoria, Oregon, the formation contains molluscs typical of the provincial Pillarian Stage (Addicott, 1976), whereas outcrops in the Newport Embayment have served as the stratotype for the younger Newportian Stage. Foraminiferal assemblages from the Astoria Formation at Astoria are correlated with the provincial Saucesian Stage, whereas those from the Newport Embayment suggest correlation with the upper Saucesian through Relizian Stages (Armentrout, 1981). The dome-headed chalicothere recovered from the "Iron Mountain bed" in the Astoria Formation of the Newport Embayment suggests correlation with the Hemingfordian or early Barstovian North American Land Mammal Age (Munthe and Coombs, 1979). At Depoe Bay (Newport Embayment), the Astoria Formation is overlain and intruded by the Depoe Bay Basalt (Snavely et al., 1973), which at Cape Meares near Tillamook Head, Oregon, yielded wholerock K/Ar dates of $14.5 \pm 1.0$ million years ago (Ma) and $15.2 \pm$ 0.6 Ma (Turner, 1970). Exposures of the Depoe Bay Basalt near Ecola, Oregon, yielded a whole-rock K/Ar date of $14 \pm 2.2$ Ma (Turner, 1970). These dates represent a minimum age for the Astoria Formation. Barnes (1989) suggested that the exposures in the type area near Astoria may be as old as $23-20 \mathrm{Ma}$, 
and that those in the Newport Embayment probably range from 19 to $15 \mathrm{Ma}$.

The type species of Desmatophoca, D. oregonensis, is known only from the Astoria Formation of the Newport Embayment (Newportian, Saucesian-Relizian, Hemingfordian/ Barstovian), whereas $D$. brachycephala is known only from the Astoria Formation in the type area near Astoria (Pillarian, Saucesian). The geochronologic range of the genus Desmatophoca thus extends from the early Miocene through the early middle Miocene, approximately from 23 to $15 \mathrm{Ma}$.

\section{Family DESMATOPHOCIDAE (Hay, 1930)}

\section{Genus Desmatophoca Condon, 1906}

TYPE SPECIES.-Desmatophoca oregonensis Condon, 1906.

DisTRIBUTION.-Early Miocene to early middle Miocene of Oregon and Washington.

INCLUDED SPECIES.-Desmatophoca oregonensis Condon, 1906; Desmatophoca brachycephala Barnes, 1987.

DEFINITION.- The monophyletic group containing the most recent common ancestor of D. brachycephala and D. oregonensis and all of its descendants.

EMENDED DIAGNOS1S.-Desmatophocine pinnipeds with posteriorly expanded zygomatic process of squamosal (autapomorphy of Desmatophoca), enlarged but not excavated paroccipital process, raised strut separating stylomastoid foramen from tympanohyal, and $\mathbf{3}$ procumbent and laterally directed (synapomorphies shared with Allodesmus). Laterally expanded pterygoid process (convergent with Pinnarctidion), mortised jugal-squamosal contact, acutely $V$-shaped nasal-frontal suture, and well-developed marginal process of mandible (synapomorphies at the level of the common ancestry of desmatophocids and phocids).

REMARKS.- - Repenning and Tedford (1977:74) listed the following features as diagnostic of the genus Desmatophoca: large size; double-rooted cheek teeth; well-developed internal cingulum on cheek teeth; large incisive foramina (for a desmatophocid); weak mortising of jugal-squamosal articulation; relatively small orbits (for a desmatophocid; $17 \%$ of condylobasal length); and dental formula (I1-3, C, P1-4, M1,2, il ,2, c, $\mathrm{pl}-4, \mathrm{ml}$ ). It is acknowledged that this "diagnosis" was meant to be dichotomous between Desmatophoca and Allodesmus; however, all of these character states are primitive at the level of Desmatophoca, so they are uninformative for resolving intrafamilial relationships.

Barnes (1989) listed five characters as diagnostic of his monotypic subfamily Desmatophocinae (includes only the genus Desmatophoca): orbit enlarged; cheek-tooth crowns bulbous, with smooth enamel; paroccipital process enlarged; tympanic crest reduced, not projecting into tympanic cavity; and pterygoid process (palatine process) of maxilla expanded laterally beneath orbit. Of these characters, none is unique to Desmatophoca. Although large orbits are diagnostic at the Pinnipedimorpha level, very large orbits are recognized as a secondary transformation of this character shared by Desmatophoca, Allodesmus, and most phocids. Bulbous cheek-tooth crowns (i.e., crowns rounded and swollen) with smooth enamel occur in both Allodesmus and Desmatophoca. A large paroccipital process is diagnostic at the Pinnipediformes level; the secondary transformation - paroccipital process greatly enlarged posterolaterally - is seen in both Allodesmus and Desmatophoca. Another purported diagnostic feature of this genus, reduced tympanic crest, was actually listed by Barnes (1989, fig. 9, caption) as originating independently in Desmatophoca, Allodesmus, and his Otariinae. Finally, expansion of the palatine process of the maxilla beneath the orbit is a feature shared by Pinnarctidion, Allodesmus, and Desmatophoca.

These previous attempts at diagnosing the genus Desmatophoca have essentially provided a characterization of this taxon following the usage of Deméré (1994; i.e., a listing of distinguishing characters, both shared-derived and shared-primitive homologous characters, and their taxonomic distributions). Under the phylogenetic system as proposed by Rowe (1988) and de Queiroz and Gauthier (1990), diagnosis of a clade is a listing of shared-derived homologous character states and the level of generality at which they occur, whereas definition of a taxon is based upon ancestry and taxonomic membership. Our diagnosis and definition of the Desmatophoca clade is based upon the phylogenetic analysis discussed later in this report.

\section{Desmatophoca oregonensis Condon, 1906}

FIGURES $2-4,6 a, 8,10-14$

Desmatophoca oregonensis Condon, 1906:1-14._Kellogg, 1922:107.—Packard and Kellogg, 1934:20.-Mitchell, 1966:36-39, pl. 29; 1968:1883-1886; 1975:12-14, fig. 2.-Bames, 1972:60-65; 1987:4-6.-Repenning and Tedford, 1977:74.

EMENDED Diagnosis.-A species of Desmatophoca with incisive foramina undivided by medial septum, angle formed by long axis of external auditory meatus and sagittal plane of skull less than or equal to $62^{\circ}$ (autapomorphies of $D$. oregonensis), well-developed cingula and cuspules/crenations on P1-3, conical anterior and posterior cuspules on $\mathrm{p} 2-4$ (derived character states that also may apply to $D$. brachycephala), no prenarial shelf, distinct carinae on $\mathrm{Cl}$, and thick lateral wall of alisphenoid canal (symplesiomorphies shared with basal pinnipeds).

HOLOTYPE.-UOMNH F735, nearly complete skull (missing the left zygomatic arch) with right and left $13, \mathrm{C}, \mathrm{P} 2$, and right $\mathrm{P} 4$, and partial left mandible with $\mathrm{c}$ and $\mathrm{p} 2$. Size of skull suggests probable mature male.

TYPE LOCALITY AND HORIZON.-On the coast near Newport, Lincoln County, Oregon; UOMNH locality 1153 (Condon, 1906; Packard and Kellogg, 1934).

REFERRED SPECIMENS.-LACM 123285, anterior part of skull with right $\mathrm{C}, \mathrm{P} 2,3$, and left $\mathrm{I} 3, \mathrm{C}$, and P1-3. Size and degree of suture closure (Table 1) suggest probable immature male. Collected by D.J. Martel, 18 April 1983, from Astoria 


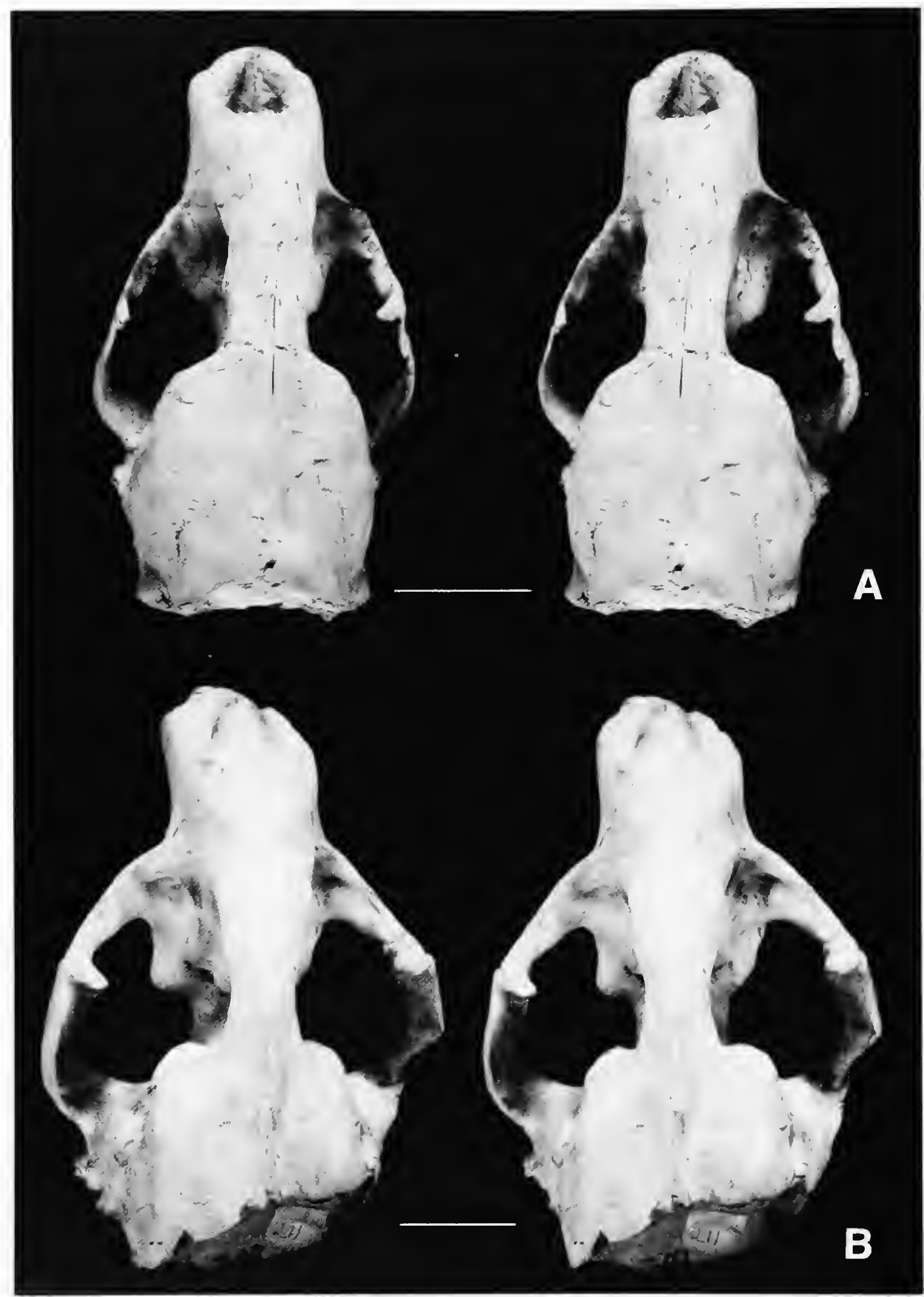

FIGURE 2.-Desmatophoca oregonensis: A, USNM 335478, dorsal aspect, immature female skull (stereophotographs); B, USNM 335451, dorsal aspect, mature male skull (stereophotographs). (Scale bars $=5 \mathrm{~cm}$.)

Formation, LACM locality 4851 , among boulders on beach midway between mouths of Schooner and Moloch Creeks, approximately $6.5 \mathrm{~km}$ north of Newport, Lincoln County, Oregon (Barnes, 1987)

USNM 250283, posterior portion of sectioned skull preserving basicranium, occipital region, and left and right squamosal portions of zygomatic arches. Development of rugose lambdoi- dal crest suggests probable mature male. Collected by Douglas Emlong from drift concretion in Astoria Formation approximately $1.2 \mathrm{~km}$ north of Yaquina Head lighthouse, Lincoln County, Oregon.

USNM 243694, complete palate with right zygomatic arch and mastoid region, left $\mathrm{I} 3, \mathrm{C}, \mathrm{P} 1-4, \mathrm{M} 1$ and right $\mathrm{I} 3, \mathrm{C}, \mathrm{P} 1,2$, $\mathrm{P} 4$. Canine size and degree of postcanine tooth wear suggest 


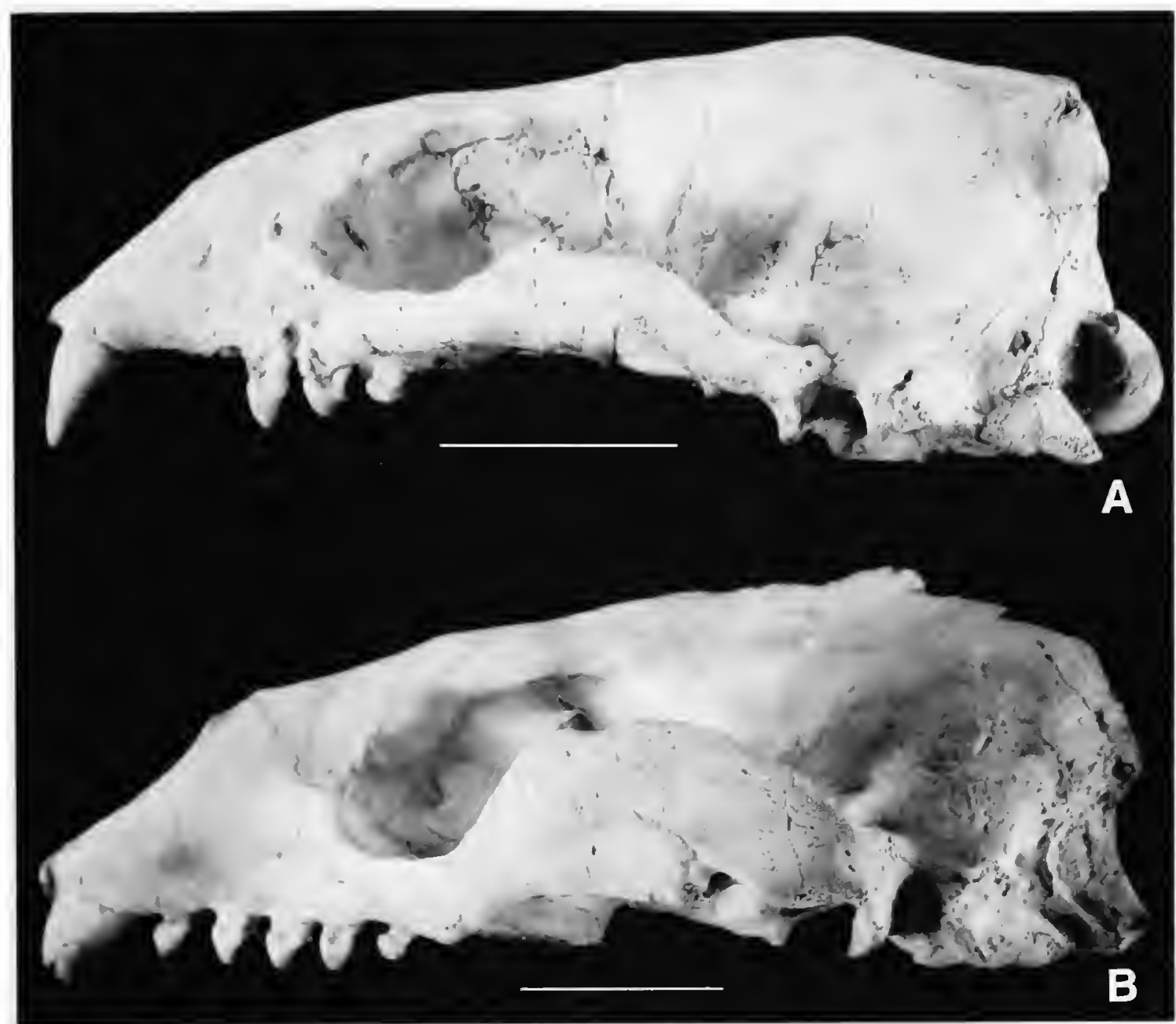

FIGURE 3.-Desmatophoca oregonensis: A, USNM 335478, lateral aspect, immature female skull; B, USNM 335451 , lateral aspect, mature male skull. (Scale bars $=5 \mathrm{~cm}$.)

probable mature male. Collected by Douglas Emlong, 1961, from "Iron Mountain bed," 7.2-8 km north of mouth of Yaquina River, Lincoln County, Oregon.

USNM 335478, complete skull with left C, P3,4, Ml and right $\mathrm{P} 2, \mathrm{P} 4, \mathrm{M} 1$; right mandible with $\mathrm{p} 3$ and $\mathrm{ml}$ and left mandible with i3, c, p1-4; isolated teeth (right P3, M2, p1; left P1, $\mathrm{ml}$ ); and atlas vertebra. Size, degree of suture closure (Table 1, suture age of 14), laterally placed temporal crests, and canine size indicate probable immature female. Collected by Douglas Emlong, April 1970, in place in "Iron Mountain bed," Astoria Formation, approximately $0.5 \mathrm{~km}$ north of Moolack Beach State Park, $75 \mathrm{~m}$ south of mouth of Wade Creek, Lincoln County, Oregon.

USNM 314645, complete skull with canines and left P2. Size, incomplete canine enuption, and degree of suture closure (Table 1) suggest probable immature female. Collected by Douglas Emlong in place in Astoria Formation, "Fogarty Creek block," Lincoln County, Oregon.

USNM 335702, skull with right and left P2,3, M1; anterior portion of rostrum missing. Size, degree of suture closure (Table 1), and development of rugose lambdoidal crests indicate probable mature male. Collected by Douglas Emlong, spring 1961, in drift from "Iron Mountain bed," Astoria Formation, approximately $100 \mathrm{~m}$ north of mouth of Schooner Creek, Lincoln County, Oregon.

USNM 335451, nearly complete skull missing the incisive margin of rostrum, occipital shield, and occipital condyles; includes left $\mathrm{C}$, left and right $\mathrm{P} 1-4, \mathrm{M} 1$, and associated left mandible with $\mathrm{p} 2-4, \mathrm{~m} 1$. Canine size and degree of suture closure (Table 1) suggest probable mature male. Collected by Douglas Emlong, spring 1964, from Astoria Formation, approximately $100 \mathrm{~m}$ south of mouth of Spencer Creek, Lincoln County, Oregon.

USNM 335457, partial left mandible with c, p2-4, m1. Collected by Douglas Emlong from Astoria Formation, approximately $800 \mathrm{~m}$ north of Beverly Beach, Lincoln County, Oregon.

USNM 335723, partial left mandible with p4. Collected by Douglas Emlong from "Iron Mountain bed," Astoria Formation, approximately $1.6 \mathrm{~km}$ north of Agate Beach, Lincoln County, Oregon.

USNM 314536, associated right and left mandibles with right p2-4, m1. Collected by Douglas Emlong in float from "Iron Mountain bed," Astoria Formation, approximately $800 \mathrm{~m}$ south of Moolack Beach State Park, Lincoln County, Oregon. 


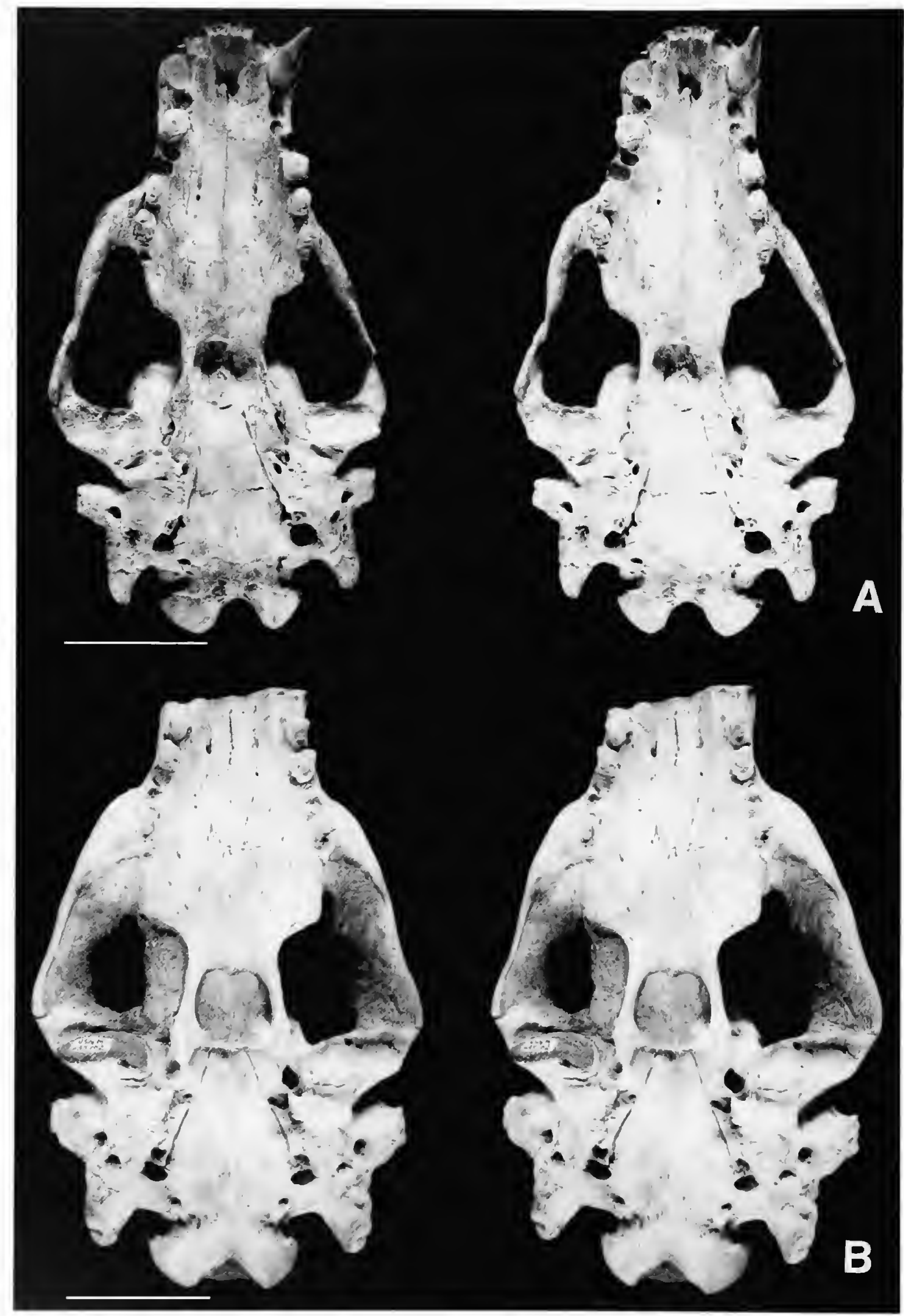

FIGURE 4.-Desmatophoca oregonensis: A, USNM 335478, ventral aspect, immature female skull (stereophotographs); B, USNM 335702, ventral aspect; mature male skull (stereophotographs). (Scale bars $=5 \mathrm{~cm}$.)

USNM 335721, worn partial right edentulous mandible. Collected by Douglas Emlong from special concretion in "Iron Mountain bed," Astoria Formation, Lincoln County, Oregon.

USNM 335694, complete right mandible with c, p4, ml. Collected by Douglas Emlong from "Iron Mountain bed," Astoria Formation, approximately $1.6 \mathrm{~km}$ north of Agate Beach,
Lincoln County, Oregon.

USNM 335430, associated right and left mandibles with extremely worn right and left $\mathrm{p} 2-4$ and $\mathrm{m} 1$, isolated right $\mathrm{C}$, $\mathrm{P} 1(?), \mathrm{P} 3($ ?), and M1(?); damaged right radius; head of left femur; proximal end of left tibia; right scapholunar; left patella; cervical vertebra (C7?); thoracic vertebra (T1?); fused sacral 


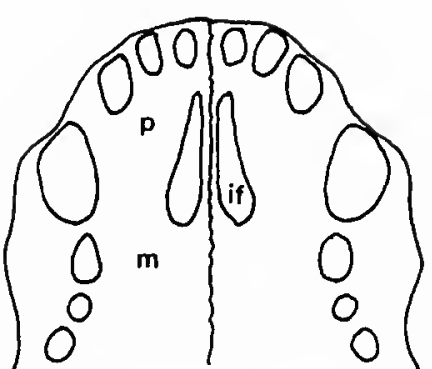

A

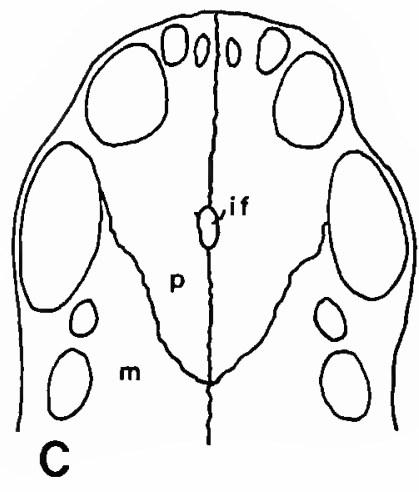

FIGURE 5.-Anterior portion of palate in pinnipeds: A, Enaliarctos emlongi; B, Desmatophoca oregonensis; C, Allodesmus kernensis; D, Monachus schauinslandi. (if=incisive foramen; $m=$ maxilla; $\mathrm{p}=$ premaxilla.)

vertebrae (S1-3); eight ribs; and sternebra. Collected by Douglas Emlong, March 1967, from several drift concretions, Astoria Formation, approximately $1.6 \mathrm{~km}$ south of mouth of Big Creek, Lincoln County, Oregon.

USNM 335246, associated right and left humeri, left scapula, right ulna, and metacarpals. Collected by Douglas Emlong from drift concretion, Astoria Formation, $0.8 \mathrm{~km}$ north of mouth of Spencer Creek, Lincoln County, Oregon.

DESCRIPTION.-Skull: The Emlong specimens provide important new information on the anatomy of Desmatophoca oregonensis, especially the dentition, palate, orbital wall, occipital shield, basicranium, and mandible. The number of available specimens together with the occurrence of individuals of different developmental ages and genders provides an opportunity to document the range of variation in this Miocene pinniped. The following descriptions include discussions of this variation.

Analysis of sutural closure (Table 1), tooth wear, and secondary sexual characteristics (e.g., development of sagittal crest and lambdoidal crests) suggests that USNM 335478 and 314645 are immature females, and that USNM 335451 and 335702 are mature males. USNM 243694, 250283, and LACM 123285 , all incomplete crania, also are probably males as judged by canine size, sutural wear, and/or lambdoidal crest development.

Overall, the skull of Desmatophoca oregonensis is elongate (Figure 2). The condylobasal lengths (CBL) of SDSNH 61143 (plaster cast of holotype, UOMNH F735), USNM 335478, and 314645 are $327 \mathrm{~mm}, 231 \mathrm{~mm}$, and $250 \mathrm{~mm}$, respectively (Table
2). Barnes (1987) estimated the CBL of Desmatophoca brachycephala (holotype, LACM 120199) to be $283 \mathrm{~mm}$. The CBL dimension in Allodesmus kernensis ranges from 370 to 400 mm (Mitchell, 1966; Barnes, 1972; pers. obs.).

The facial length (i.e., approximate level of cribriform plate to prosthion) in proportion to the $\mathrm{CBL}$ is variable in the Emlong sample of $D$. oregonensis, ranging from $54 \%$ in USNM 335478 (immature female) to $60 \%$ in the cast of the holotype (mature male). This variation is ascribed to the different developmental ages of these skulls and follows the observations of King (1972) that the braincase in phocid pinnipeds ceases growth earlier than the face. In the adult skull of $D$. brachycephala, the facial length is approximately $60 \%$ of the CBL, whereas in A. kernensis (LACM 4320) this percentage is $65 \%$ and in Enaliarctos emlongi (USNM 250345), 54\%.

The orbit (i.e., antorbital rim of maxilla to postorbital process of jugal $)$ is large, approximately $19 \%-21 \%(x=20 \%, n=2)$ of the CBL. The percentage of $17 \%$ given by Repenning and Tedford (1977) was presumably based upon the holotype, which has an incomplete postorbital region. In $D$. brachycephala, this measure is 19\%, and in Allodesmus kernensis it is $25 \%$ (in agreement with the conclusions of Repenning and Tedford, 1977). The temporal fossa (for operational purposes defined herein as the cranial opening between the anterior border of the preglenoid process of the squamosal and the postorbital process of the jugal) is anteroposteriorly shorter than the orbit, approximately $71 \%-79 \%(x=75 \%, n=4)$ of the orbit length in $D$. oregonensis, compared with $85 \%$ in D. brachycephala, $61 \%$ in A. kernensis, and $92 \%$ in E. emlongi.

In lateral aspect (Figure 3), the interorbital region is high and at the same level as the dorsal surface of the braincase. The preorbital portion of the rostrum descends slightly $\left(20^{\circ}-24^{\circ}\right.$ from the horizontal; $x=21.7^{\circ}, n=3$ ) from the interorbital region to the level of the posterodorsal margin of the external nares, at which point there is an abrupt flexure of the facial profile, which then descends anteroventrally $\left(41^{\circ}-44^{\circ} ; x=42.7^{\circ}, n=3\right)$ to the incisive margin of the rostrum. The facial profile of $D$. brachycephala, although distorted, appears to possess a nearly horizontal $\left(2^{\circ}\right)$ preorbital region, a more marked flexure, and an incline of $42^{\circ}$ at the narial margin. The facial profile of $\mathrm{Al}$ lodesmus kernensis lacks the abrupt flexure at the posterodorsal margin of the external nares and instead consists of a nearly uniformly $\left(30^{\circ}\right)$ descending dorsal margin from the interorbital region to the incisive margin of the rostrum.

Palate: The palate of Desmatophoca oregonensis preserves a pair of large ovoid incisive foramina (for transmission of the incisive duct and the rostral septal branch of the palatine artery) that coalesce medially to create a single palatal opening (Figure 4). The anterior margin of this common opening extends to the lingual border of the incisor alveoli. This unique structure of the incisive foramina is seen in the mature male skulls, USNM 335451 and 243694 , and in the immature female skull, USNM 335478. In these latter two specimens, small wedges of bone aligned with the intermaxillary suture extend 
from the posterior margin of the foramen a short distance into the incisive opening (Figure 5B). In Enaliarctos emlongi, Pinnarctidion rayi, and Desmatophoca brachycephala, the large incisive foramina remain medially separated by a thin maxillary septum (Figure 5A). In Allodesmus kernensis, the incisive foramina are extremely reduced and coalesce to form a very small circular to ovoid opening on the intermaxillary suture (Figure 5C). This extreme reduction of the incisive foramina also is seen in species of the extant phocids Monachus and Mirounga and is presumably correlated with possession of a prenarial shelf.

The palatal segment of the premaxillary-maxillary suture, as preserved in USNM 335478 and LACM 123285 emerges from the posterolateral corner of each incisive foramen and makes an anteriorly concave arc to intersect the posteromedial corner of the canine alveolus (Figure 5B). This suture is closed and not visible in the holotype of $D$. brachycephala. In Allodesmus kernensis, this suture is considerably longer and leaves the intermaxillary suture well posterior to the reduced incisive foramen and runs anterolaterally to join with the anteromedial corner of the canine alveolus (Figure 5C).

Large anterior palatine foramina (for transmission of the major palatine artery) are positioned on either side of the intermaxillary suture at the level of the anterior root of P4. Each foramen lies at the posterior end of an elongate channel that extends anteriorly along either side of the flattened medial portion of the palate. Several smaller foramina are scattered on the palate posterior to the anterior palatine foramina. These smaller palatine foramina appear to increase in number with sexual maturity (e.g., USNM 335702). In D. brachycephala, the anterior palatine foramina are positioned more posteriorly, at the level of $\mathrm{M} 1$.

Overall, the palate of $D$. oregonensis is narrow anteriorly and broad posteriorly (Figure 4 ). The width between the canine alveoli (lingual borders) ranges from 27.1 to $39.4 \mathrm{~mm}$ ( $x=32.1$ $\mathrm{mm}, n=6$ ), whereas the width between the anterior alveoli (lingual borders) of M1 ranges from 54.8 to $82.2 \mathrm{~mm}$ ( $x=66.4 \mathrm{~mm}$, $n=7$ ). For both measurements, the greatest width was found in the cast of the holotype skull. Expressed as a ratio (i.e., intercanine width/inter-Ml width), the range for $D$. oregonensis is 0.48 to $0.52(x=0.49, n=6)$. This ratio will be greatest in species with nearly parallel tooth rows and least in species with posteriorly broadened palates. Allodesmus kernensis (LACM 4320) has a ratio of 0.58 , A packardi (USNM 205315), 0.43, Pinnarctidion rayi (USNM 314325), 0.53, and Enaliarctos emlongi (USNM 250345), 0.65. In D. brachycephala (LACM 120199), the intercanine and inter-Ml widths are 31.8 and 70.8 $\mathrm{mm}$, respectively, yielding a ratio of 0.45 . These values fall within the range of variation seen in $D$. oregonensis and suggest that there is no significant difference in palate shape between these two species of Desmatophoca.

The palate of $D$. oregonensis is slightly arched transversely and longitudinally. The degree of transverse arching was quantified, and a ratio of palate depth to width (i.e., arch of palate) was calculated (see Appendix, character 4). Ratios computed at the level of each maxillary tooth position reveal that the greatest arching occurs on the anterior portion of the palate between the canine and $\mathrm{P} 2$. The $\mathrm{P} 1-\mathrm{M} 2$ palate arch ratios range from only 0.15 to 0.26 and average about 0.19 . In D. brachycephala, the greatest palatal arching also is anteriorly placed and the ratios average only 0.18. In Allodesmus kernensis (LACM 4320), the greatest transverse arching occurs on the posterior portion of the palate between $\mathrm{P} 4$ and $\mathrm{M} 1$, and the P1-M2 palate arch ratios range from 0.21 to 0.30 and average 0.26 .

Desmatophoca oregonensis, D. brachycephala, and Allodesmus kernensis lack all traces of the embrasure pits between P3 and P4 and between P4 and M1 that are preserved on the palates of species of Enaliarctos, Pinnarctidion, and Proneotherium.

The palatine process of the maxilla (=pterygoid process of maxilla of Bames, 1987) is well developed in LACM 123285 , USNM 335451, 335702, 335478, and 314645 and extends as a thin and broad shelf behind M2 and beneath the orbit (Figure 4). In USNM 335478 (Figure 4A), the lateral margin of the palatine process makes a sharp flexure as it curves posteromedially to merge with the narrow palatines in the vicinity of the angle for the descending minor palatine artery. In USNM 335702 (Figure $4 \mathrm{~B}$ ), the lateral margin of the palatine process is elongate and extends $22 \mathrm{~mm}$ behind the $\mathrm{M} 2$ alveoli. The broad palatine process in Desmatophoca oregonensis is similar to that in D. brachycephala, Pinnarctidion rayi, and P. bishopi. In Allodesmus kernensis, the lateral margin of the palatine process is broadly convex and not as abruptly flexed. A variation in this feature in the Emlong specimens of $D$. oregonensis is seen in USNM 243694, in which the palatine process lacks a prominent lateral flexure, especially on the right side. The palatine process is broken in the cast of the holotype but presumably was also broad. In LACM 123285, the palatine process is eroded on its posterolateral corner but still forms a shelf behind M2 (Barnes, 1987, fig. 1B).

The maxillary-palatine suture in Desmatophoca oregonensis is transverse medially and occurs at the level of the posterior root of Ml in USNM 335478 and 335702 and the anterior root of M2 in USNM 243694 and 335451. In all specimens, the suture then curves posterolaterally to intersect the lateral margin of the palatine process of the maxilla just medial to its posterolateral corner.

The palatines are transversely broad and generally flattened. The anterior border of the internal nares is smooth, bluntly rounded, and positioned at the level of the cribriform plate. The lateral margins of the internal nares are formed by the palatines anteriorly and the pterygoids posteriorly. The palatine-pterygoid suture is not visible on any specimen.

Pterygoid and Alisphenoid: The pterygoid hamuli, best preserved on USNM 335702, are slender and laterally recurved, terminating in anteroposteriorly flattened (not transversely flattened) processes (Figure 4B) for origination of pharyngeal muscles (e.g., pterygopharyngeus). The laterally 
recurved portion of the hamulus marks the position of the tensor veli palatini. The pterygoids of USNM 335702 are tightly co-ossified with the alisphenoid, thus obscuring all sutures. The form of the alisphenoid, however, is discernible on other specimens and is short on the pterygoid strut where it contacts the pterygoid and palatine. The area on the strut for origination of the internal pterygoid muscle is planar to slightly convex and is marked neither by a depression, as in Allodesmus kernensis, nor by a broad concave shelf, as in Pinnarctidion rayi and fossil odobenids (e.g., Imagotaria downsi Mitchell, 1968). In lateral aspect, the pterygoid strut is relatively thicker than in Pinnarctidion bishopi or A. kernensis, but it is not as thick as in later-diverging odobenids (e.g., I. downsi). The posterior end of the pterygoid strut is penetrated by the alisphenoid canal (for transmission of the maxillary artery), which lies in a common pit with the foramen ovalis. In USNM 335702 and 335451, this common pit is short and deep as in D. brachycephala, whereas in USNM 335478 the pit is anteroposteriorly elongate and shallow. On some specimens (USNM 335451 and 250283), a distinct pit-like fossa is located immediately anterolateral to the posterior alisphenoid canal and dorsal to the base of the pterygoid strut. This fossa is presumably for origination of the external pterygoid muscle. Such a fossa does not occur in $D$. brachycephala or A. kernensis.

The lateral wall of the alisphenoid canal is thick and well defined in both species of Desmatophoca, unlike the condition in Allodesmus kernensis in which the lateral wall is quite thin and usually not preserved. In such specimens of $A$. kernensis, there is often no obvious trace of the lateral wall of the canal. This condition "mimics" the condition in phocids in which the alisphenoid canal typically is missing.

The temporal wing of the alisphenoid extends dorsally onto the sharply angled anterolateral corner of the braincase, as in Allodesmus kernensis, early-diverging odobenids, otariids, and presumably species of Enaliarctos.

Basicranium: The presphenoid-basisphenoid suture, as preserved in USNM 335478 and the cast of the holotype, is unfused and allows recognition of the presphenoid, which is acutely triangular anteriorly and broader posteriorly than in $\mathrm{Al}$ lodesmus kernensis. The basisphenoid-basioccipital suture is unfused in USNM 335478 and 314645 but fused in all other skulls. This suture is straight in the transverse plane and is positioned midway between the anterior and posterior openings of the carotid canal. The basisphenoid is a narrow trapezoidal bone with a broad sagittal sulcus. The basioccipital is broadly trapezoidal with a low sagittal ridge separating the raised insertions for the longus capitis muscle anteriorly and the shallow fossae for insertion of the rectus capitis lateralis muscle posteriorly (Figure 4). In more mature specimens (e.g., USNM 335702), the basioccipital and basisphenoid are strongly co-ossified, the rectus capitis insertions are more rugose, the sagittal ridge is more keeled, and the posterior fossae are broader and deeper. The hypoglossal foramina, for passage of cranial nerve XII, are small (relative to those in $A$. kernensis) and positioned midway between the posterior lacerate foramen and the occipital condyles.

The auditory bulla in $D$. oregonensis is moderately inflated relative to the distinctly inflated bullae in Enaliarctos and Pinnarctidion and the flattened bullae in Allodesmus and many fossil odobenids. Unlike the condition in Allodesmus kernensis, there is no clear distinction between the ectotympanic and entotympanic portions of the bulla, even on immature skulls. Anteriorly, the bulla is closely appressed to the posterior side of the postglenoid process. Medially, the entotympanic is distinct from the basioccipital and descends to a level below the basioccipital. The carotid canal runs through a short, swollen tube, the posterior opening of which is retracted from the posterior lacerate foramen, and forms a distinct dorsal bony shelf between these two foramina as in Pinnarctidion and Allodesmus (Figure $6 \mathrm{~B})$. The ectotympanic has a rugose transverse crest that extends from the medial portion of the bulla to a point ventral to the external auditory meatus (Figure 4). The portion of the ectotympanic anterior to this crest is smoother than that posterior to it. An elongate styliform process at the anteromedial edge of the bulla projects anterior to the anterior opening of the carotid canal. In USNM 335478, the styliform processes on both the left and right sides are marked by a small, but deep anteroposteriorly, oval pit (Figure 4A) measuring 2.4 by $4.5 \mathrm{~mm}$. This pit does not penetrate into the carotid canal. Although similar pits were not observed in other specimens of Desmatophoca oregonensis or $D$. brachycephala, or in outgroup taxa, they were seen in specimens of Allodesmus kernensis (SDSNH 54801 and LACM 4320) (Figure 6B). A distinct styloid process underlies the opening for the eustachian canal and is best developed in the cast of the holotype and in USNM 250283 and 335702. In A. kernensis, there is no such styloid process; instead this region of the bulla is marked by a distinct medially directed embayment or retraction of the anterior margin of the median lacerate foramen (Figure 6B). In the latter taxon and D. oregonensis, there is no bony meatal tube, and the external auditory meatus (EAM) is long and anterolaterally directed. The long axis of the EAM forms an angle of $56^{\circ}-61^{\circ}\left(x=57.8^{\circ}, n=\right.$ 4) with the sagittal plane. In D. brachycephala, the EAM is more laterally directed and forms an angle of $75^{\circ}$. In A. kernensis, this angular measurement is $66^{\circ}$

Posterolateral to the bulla, the circular and ventrolaterally directed stylomastoid foramen is separated from the tympanohyal pit by either a thin bony septum (USNM 250283) or a broader bony strut (as in all other USNM specimens). The tympanohyal pit in this taxon is circular and directed posteroventrally. In D. brachycephala, the two openings are small, closely appressed, and separated by a thin bony septum, and the tympanohyal pit is circular and faces posterolaterally. In $A$. kernensis, the stylomastoid foramen is anteroposteriorly elongate and the tympanohyal pit is larger (relative to D.oregonensis), circular, and posterolaterally directed (Figure 6B). In $D$. oregonensis the posterior lacerate foramen is large and transversely oval, not circular as in $D$. brachycephala and $A$. kern- 


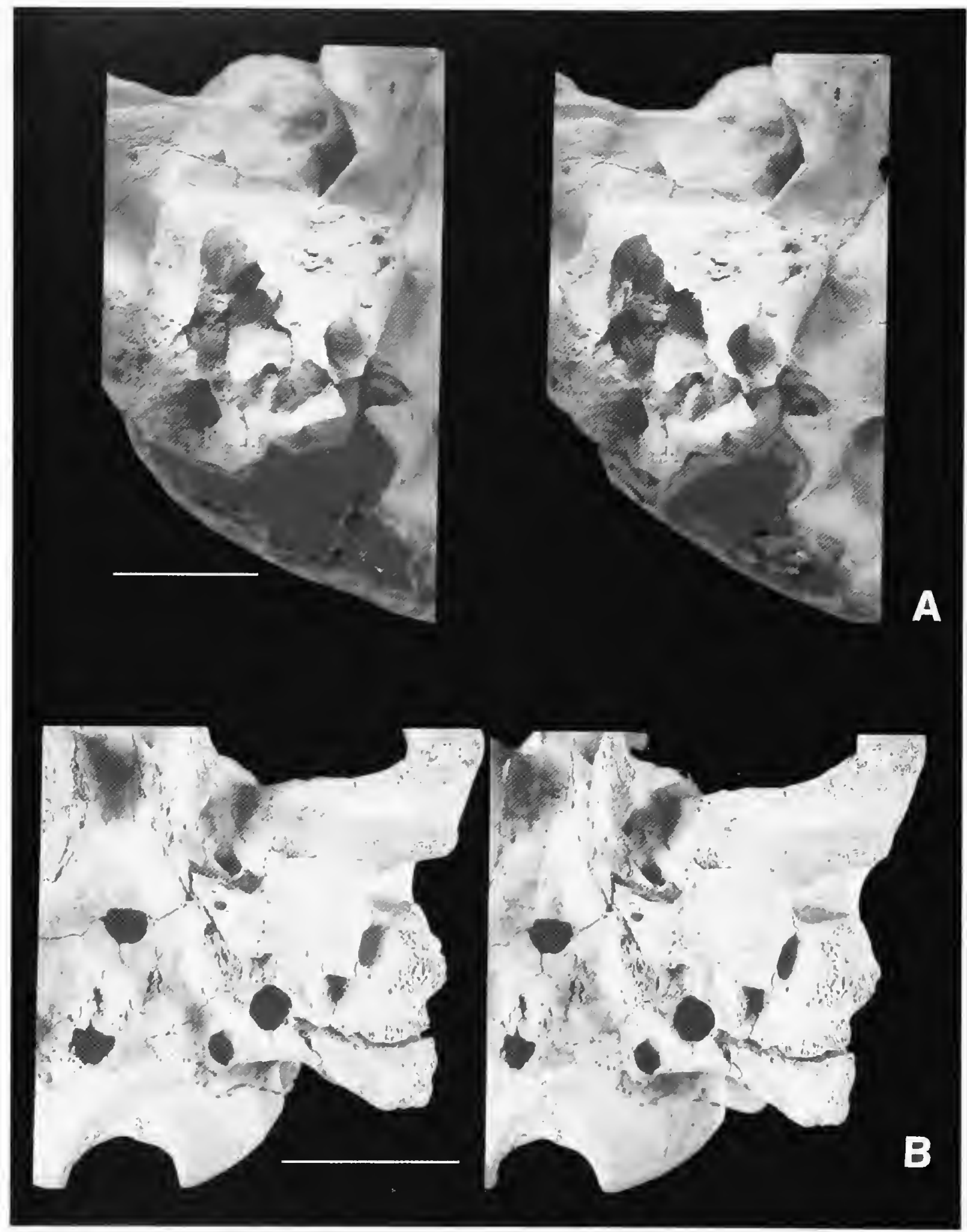

FIGURE 6. A, Desmatophoca oregonensis, USNM 33545I, right middle ear region (stereophotographs); B, Allodesmus kernensis, SDSNH 54801, basicranium, left side (stereophotographs). (Scale bar in $\mathrm{A}=2 \mathrm{~cm}$; scale bar in $\mathrm{B}=5 \mathrm{~cm}$.)

ensis. In all three taxa, the posterior margin of the petrosal is exposed in ventral aspect at the anterior end of the posterior lacerate foramen.

In Desmatophoca oregonensis, the paroccipital process for insertion of the rectus capitis lateralis muscle (flexor of the atlanto-occipital joint) and origination of the digastricus muscle (mandible depressor) is large (relative to that of Enaliarctos) and dorsoventrally flattened. In ventral aspect it projects posteriorly and slightly posteroventrally (Figure $4 \mathrm{~A}$ ) and is roughly parallel to the sagittal plane. The ventral surface of this process in mature skulls (USNM 250283 and 335702) is marked by several low crests and fossae (Figure 4B). In D. brachycephala, the paroccipital processes are constructed as in $D$. oregonensis except that they project more posterolaterally, forming an angle of $62^{\circ}$ with the sagittal plane. Ventrally, the exoccipital-squamosal suture reveals that the paroccipital process in $D$. oregonensis is formed entirely from the exoccipital (Figure 7C). This suture is open and discernible even in mature skulls and can be traced from the lateral border of the posterior lacerate foramen laterally around the paroccipital process and onto the lateral 
A
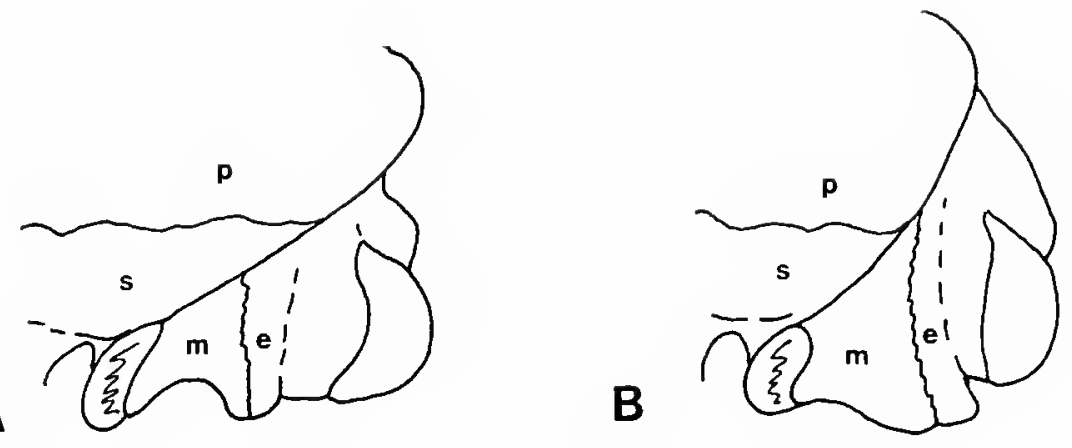

C
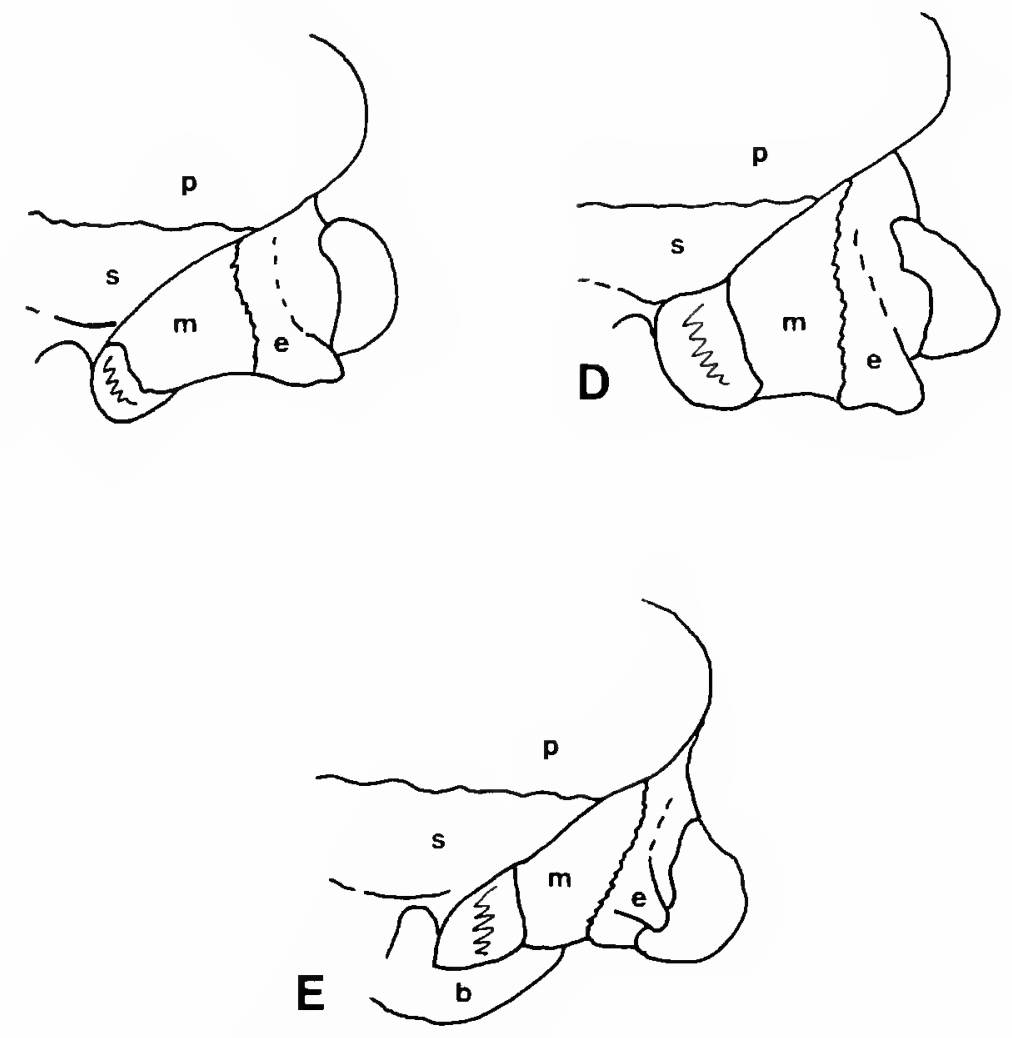

FIGURE 7.-Mastoid region in pinnipeds: A, Enaliarctos emlongi: B, Pinnarctidion bishopi (after Barnes, 1979); C, Desmatophoca oregonensis; D, Allodesmus kernensis; E, Piscophoca pacifica (after Muizon, 1981). (b=auditory bulla; $\mathrm{e}=$ exoccipital; $\mathrm{m}=$ mastoid; $\mathrm{p}=$ parietal; $\mathrm{s}=$ squamosal.)

surface of the skull to join dorsally with the lambdoidal crest. In lateral aspect, the paroccipital process is anteroposteriorly thick, rather than thin and splint-like as in odobenids (Figure 3). Species of Allodesmus also have posteriorly elongate paroccipital processes (best discerned in ventral aspect), but these are relatively shorter than in $D$. oregonensis and are more transversely broader along the exoccipital-squamosal suture (Figure 6B). As in D. oregonensis, this suture remains open even in mature skulls of $A$. kernensis. In lateral aspect, the lateral fossa on the side of the braincase between the mastoid and paroccipital processes (here called the mastoid fossa) is deeper and more anteroposteriorly elongate in $D$. oregonensis and $D$. brachycephala than in $A$. kernensis. In all three taxa, however, the paroccipital process (as viewed in lateral aspect) is separated from the mastoid process by a continuous horizontal shelf as in the type of Pinnarctidion bishopi (Figure 78). In species of Enaliarctos, the two processes are separated by a dorsally arched ridge (Figure 7A). In lateral aspect, the mastoid process in D. oregonensis is lunate in mature skulls (USNM 335451 and 335702) and cubic in immature skulls (USNM 335478). In $D$. brachycephala, the mastoid process also is lunate, but the entire process is more laterally extended (Barnes, 1987). The rugosity on the ventrolateral process of the mastoid surface marks the origination of lateral flexors of the head (e.g., sternomastoid). In $A$. kernensis, the mastoid process appears to be less rugose laterally and is cubic in mature skulls (SDSNH 54801); immature skulls have more lunate processes (Figure 7D).

Occiput: The occipital condyles are set off from the exoccipitals by well-developed ventral condyloid fossae and variably developed dorsal condyloid fossae (Figure 8B). Ventrally, the articular surfaces of the right and left condyles are either continuous (USNM 335702) or separated by a smooth saddle (USNM 335478 and 250283) (Figure 3). A segment of the exoccipital lies in the saddle between the ventromedial articular surfaces of the condyles. Dorsally, the condyles tilt between $35^{\circ}$ and $40^{\circ}$ from the vertical axis. In the cast of the holotype and in USNM 335478, a large circular opening (condyloid canal) lies on the lateral wall of the foramen magnum.

The lambdoidal (nuchal) crests are variably developed in the sample of Emlong skulls, a reflection of different developmental ages. In immature individuals (USNM 335478 and 314645), the lambdoid suture is marked by a low and wide rugose surface that is nearly flush with the surface of the occipital shield (Figure 3A). In mature male skulls (USNM 335702 and 250283), the rugose surfaces are enlarged into the lambdoidal crests for insertion of the splenius muscle and other neck extensors (Figure 3B). From the interparietal suture the crests diverge posterolaterally to overhang the occipital shield before curving laterally and descending in a keeled anteroventral arc to merge with the mastoid processes. In these specimens, the occipital shield is deeply embayed dorsomedially with distinct fossae on either side of the midline for insertion of the rectus capitis dorsalis muscle and other neck extensors. The occipital surface also is distinctly rugose in these mature male skulls.

Premaxillary: The anterior termini of the premaxillae in the cast of the holotype and LACM 123285 have weak nasal processes relative to those seen in fossil and living otariids and odobenids. These weak processes are not seen in USNM 335478 (Figure 8A) and probably develop with age. The narial basin (i.e., the region of the rostrum from the incisive margin of the premaxillae to the nasal-premaxilla contact; King, 1972) is not enlarged, and the snout is not elongate. In most species of Allodesmus (A. kernensis, A. sadoensis Hirota, A. sinanoensis Nagao, A. packardi Barnes, and $A$. naorai Kohno), there are no nasal processes; instead the premaxillae (and maxillae) are developed into an elongate "prenarial shelf" (Kohno, 1996) that serves to enlarge the narial basin.

A shallow fossa is positioned on the premaxillary-maxillary suture between the incisive margin and the external narial 


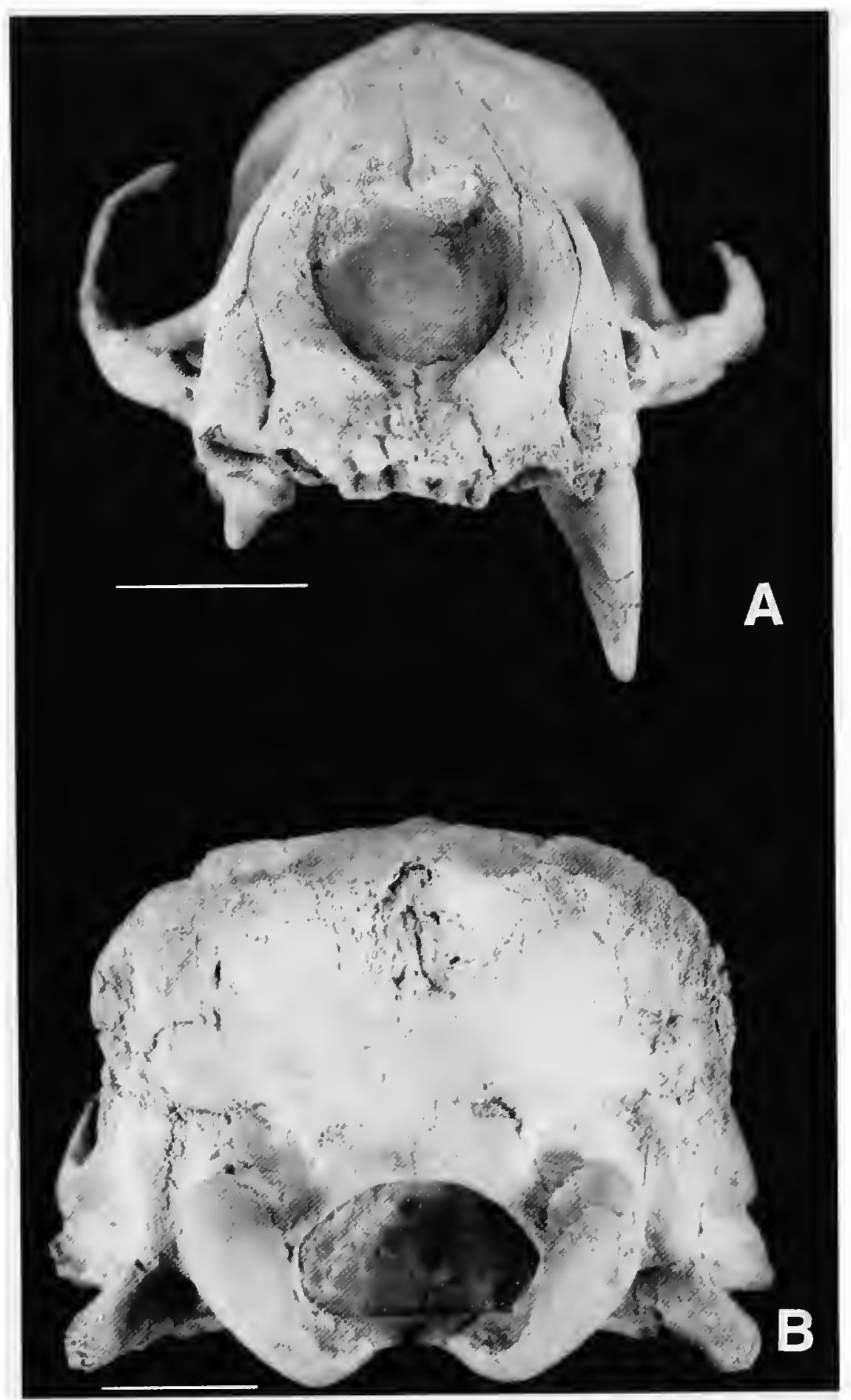

FIGURE 8.-Desmatophoca oregonensis, USNM 335478: A, anterior aspect; B, posterior aspect.

opening. Similar fossae occur in Enaliarctos, Pinnarctidion, Prototaria, and Allodesmus. The ascending processes of the premaxillae curve around the external nares and have a short overlap with the nasals medially (Figure 2A). In USNM 335478 and 335451 , this overlap is $36 \%$ and $27 \%$, respectively, of the total nasal length. The posterodorsal corner of the ascending process of the premaxilla, adjacent to the dorsolateral corner of the narial opening, is marked by a small keeled process that projects anteriorly. These processes (one right and one left) are especially well developed in LACM 123285 and to a lesser extent in USNM 335451. In USNM 335478, an immature female skull, the processes are weakly developed, suggesting that they probably increase in size with age and/or gender.
The position of these processes suggests that they may represent attachment sites for ligaments of the nasal cartilages.

Nasal: Posteriorly the nasals extend between the frontals in an acute V-shaped termination (Figure 2A), as in Allodesmus kernensis and phocids (Deméré, 1994). Medially the frontalmaxillary suture is characterized by a narrow, anteriorly directed, $V$-shaped segment of the frontal that invades the maxilla immediately adjacent to the nasals (the anterior process of the frontal after Kohno, 1996). This configuration also occurs in Enaliarctos, Pteronarctos, Prototaria, and Neotherium (Deméré, 1994). In A. kernensis, the $V$-shaped frontal segment is indistinct. Lateral to the $\mathrm{V}$-shaped frontal segment in $D$. oregonensis, the frontal-maxillary suture turns anteroventrolaterally to descend into the orbit. Anterior to the suture on the dorsomedial side of the maxilla is a low, rugose longitudinal crest that marks the origination of the naso-labialis muscle. This crest is absent in species of Allodesmus and is not preserved in the holotype of $D$. brachycephala.

Maxillary and Zygomatic Arch: The zygomatic arch is horizontally oriented and only slightly arched dorsally at the midpoint. The maxillary root of the zygomatic arch is at the level of M1-2, and it is penetrated by a transversely elliptical infraorbital foramen of moderate size (relative to the larger foramina in odobenids). As described by Barnes (1987), the anterior dorsal margin of the maxillary root of the zygomatic arch flares anteriorly over the anterior opening of the infraorbital canal to form an orbital cup for the eye. This structure is seen in most pinnipeds, except for species of Allodesmus, which possess dorsal margins that are retracted posteriorly from the anterior opening of the infraorbital foramen (Barnes, 1972). The anteroventral margin of the zygomatic arch is elevated above the tooth row, as in species of Enaliarctos and Pinnarctidion, and is not excavated or pitted for origination of the maxillonaso-labialis muscle. In Allodesmus, the ventral margin of the maxillary root also is smooth, but it is lower and at the level of the tooth row.

There is no evidence of a lacrimal bone, even on the immature female skull (USNM 335478). The anterior border of the orbit is thus made up entirely of maxilla as in all other pinnipeds (Berta and Wyss, 1994). There are no antorbital processes. The maxillary and jugal meet in a deep foliate suture, with the jugal sending dorsal and ventral processes anteriorly to overlie and underlie the zygomatic process of the maxilla. In USNM 335451 , the lateral portions of the dorsal and ventral processes of the jugal overlap and underlap $34 \mathrm{~mm}$ and $17 \mathrm{~mm}$, respectively, the posteriorly tapering zygomatic process of the maxilla. This same construction of the jugal is seen in Allodesmus, odobenids, and otariids. In phocids, there is no ventral process of the jugal. Instead, the jugal has a split-like contact with the maxillary (jugal above maxillary; Muizon, 1981). Posteriorly, in $D$. oregonensis, the jugal ascends the anterior border of the zygomatic process of the squamosal and terminates dorsally in a sharply pointed and anteroposteriorly compressed postorbital process (Figures 3, 9E,F). The posterior portion of the jugal 

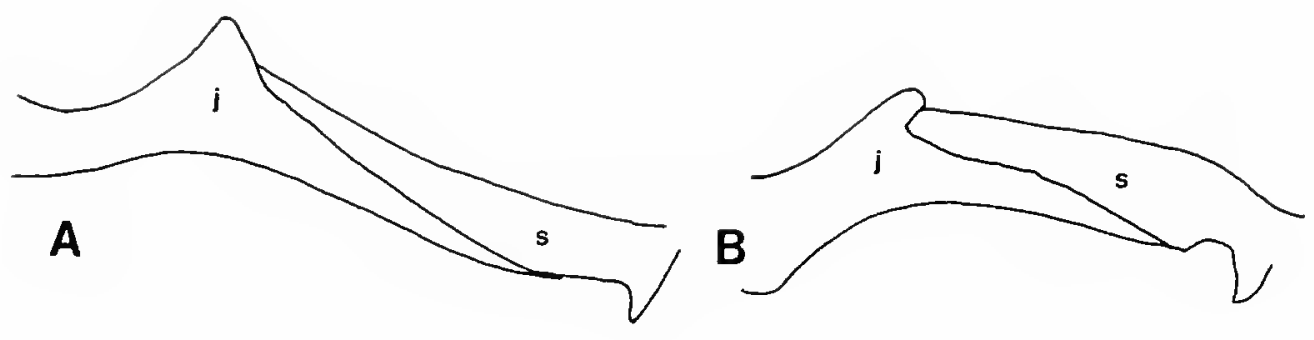

FIGURE 9 (right).- -Jugal-squamosal suture pattern in pinnipeds: A, Enaliarctos emlongi; B, Pinnarctidion bishopi (after Barnes, 1979); C, Allodesmus packardi (after Barnes, 1972); D, Piscophoca pacifica (after Muizon, 1981); E, Desmatophoca oregonensis (female); $\mathrm{F}, \mathrm{D}$. oregonensis (male). ( $\mathrm{j}=\mathrm{jugal} ; \mathrm{s}=$ squamosal.)
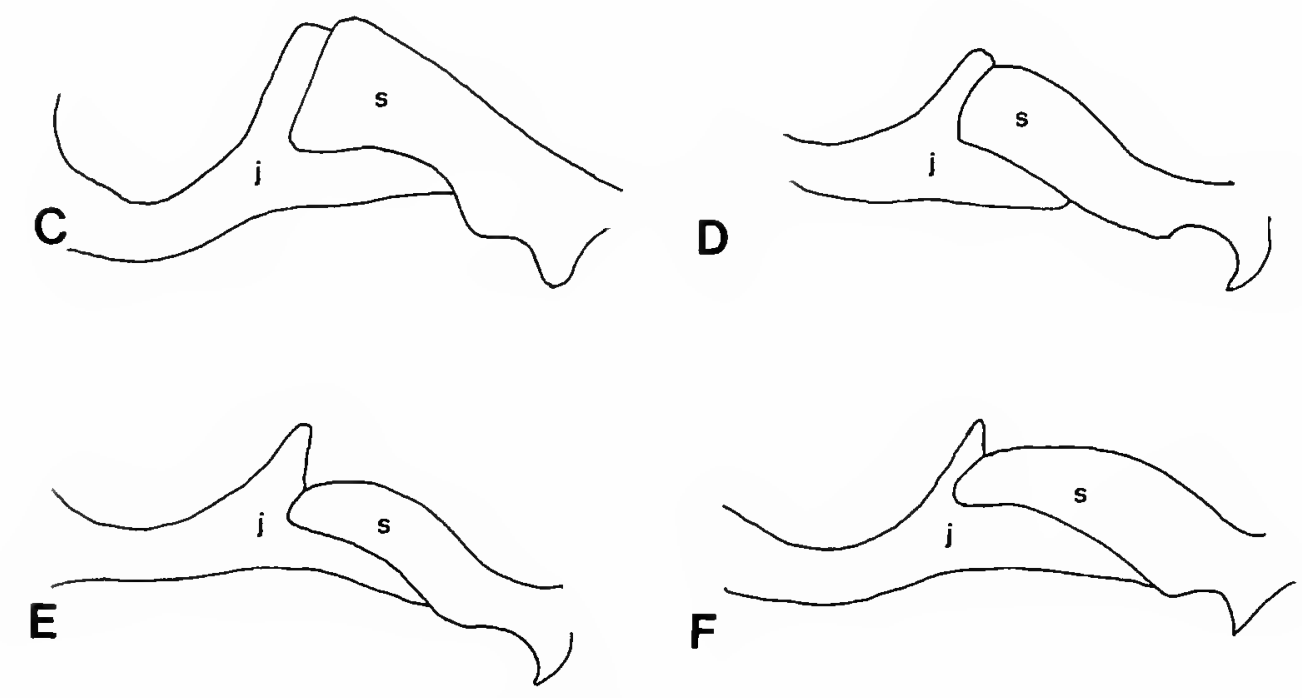

broadly underlies the zygomatic process of the squamosal in a splint-like suture and extends posteriorly to the anterior border of the glenoid fossa, as in Enaliarctos and Pinnarctidion (Figure 9A). In Allodesmus, the postorbital process of the jugal is lower than the zygomatic process of the squamosal (Figure 9C), and the posteroventral portion of the jugal is short, not reaching the glenoid fossa. In $D$. oregonensis and $D$. brachycephala, the jugal is transversely compressed, as in Enaliarctos, Pinnarctidion, and odobenids, and contrasts with the nearly circular cross section seen in Allodesmus kernensis. In D. oregonensis, the zygomatic process of the squamosal is transversely compressed and variable in dorsoventral thickness. In USNM 335451, the anterior portion of the process is deep and forms a distinctly mortised contact with the jugal (Figures 3B, 9F). In USNM 335478 , the process is narrower (Figures $3 \mathrm{~A}, 9 \mathrm{E}$ ), which consequently limits the extent of mortising. This variation in mortising in $D$. oregonensis, also seen in phocids of different developmental ages, is suggested to be ontogenetic in the fossil species (see Ronald and Healey, 1981, fig. 9). A mortised contact also is well developed in species of Allodesmus and in phocids (Figure 9C,D). In these groups, however, the zygomatic process of the squamosal is deeper anteriorly adjacent to the jugal. In $D$. oregonensis, the zygomatic process is deeper posteriorly (Figure 9E,F).

Frontal: The frontals are narrow along the interorbital constriction and preserve small but distinct supraorbital processes or crests for attachment of the orbital ligament (Figure 2). These processes are similarly developed in Enaliarctos, Pinnarctidion, Allodesmus, and basal odobenids (e.g., Prototaria and Neotherium). In Allodesmus, however, the position of the processes relative to the condylobasal dimension is more posterior than in Desmatophoca (Kohno, 1996). This is most likely correlated with the greatly enlarged orbits of the former taxon.

The orbital wall as preserved in USNM 335478 is solid bone and lacks any obvious vacuities. In USNM 335451 and 335702 , however, a small horizontally oval opening ( 9.4 and $9.8 \mathrm{~mm}$ in length, respectively) occurs on the orbital wall posterodorsal to the sphenopalatine foramen. In USNM 335702 , the ventral margin of this opening is smooth, which suggests that it is a true orbital vacuity rather than a preservational artifact. Its position at the frontal-palatine suture on the orbital wall is similar to that of small vacuities in certain phocids (e.g., Mirounga and Monachus). The oval sphenopalatine foramen in USNM 335451 measures $4.4 \mathrm{~mm}$ in length and is positioned $4.5 \mathrm{~mm}$ dorsal to the maxillary-palatine suture. The frontalmaxillary suture as preserved in USNM 335478 enters the anterodorsal border of the orbit and traverses the ventral onequarter of the orbital wall. In USNM 335451 and 335702, the suture can be traced to the junction with the palatine bone. In the latter specimen, the frontal-palatine suture appears to be preserved and is marked posteriorly by the small orbital vacuity discussed above. The sutural boundaries of the orbitosphenoid cannot be reliably discerned. In USNM 335702, however, a distinct horizontal break in the orbital wall aligns with the predicted position of the ventral margin of this bone. Posteriorly, the circular optic foramen, within the orbitosphenoid, lies almost directly anterior and slightly dorsal to the foramen rotundum. Both foramina are positioned beneath the anterior end of the braincase, as in Allodesmus kernensis and Pinnarctidion rayi. The medial wall separating the right and left optic foramina is solid and not perforate as in A. kernensis and certain otariids. The alisphenoid canal is merged with the foramen rotundum externally, forming a large orbital fissure. In USNM 250283 , there is a deeply recessed septum dividing the two fo- 
ramina internally. The lateral wall of the alisphenoid canal is thick and well formed, unlike the thin and variably preserved lateral wall described above for $A$. kernensis.

Parietal: The braincase is transversely inflated and has a sharply angled anterolateral margin composed of the frontal dorsally and the alisphenoid ventrally. The coronal suture as preserved in USNM 335478 is transverse dorsomedially and curves slightly anteriorly as it descends to the alisphenoid. Oblique depressions marking the position of the pseudosylvian sulcus occur on the parietal behind the anterolateral corners of the braincase just above the squamosal fossa. In USNM 335478 , these depressions are shallow, relative to the deep depressions preserved in USNM 335702. Such depressions also occur in D. brachycephala, Pinnarctidion, and Enaliarctos but are absent in Allodesmus. The parasagittal fossae located on the midline of the dorsal part of the braincase in the holotype of $D$. oregonensis discussed by Barnes (1987:11) are not present on any of the Emlong Desmatophoca specimens, suggesting that these fossae may be pathologic.

Development of a sagittal crest is variable in specimens of Desmatophoca and has not been noted by previous workers. In USNM 335478, the immature female skull, there is no sagittal crest; instead the temporal crests marking the dorsal extent of the temporalis muscle on the parietal are clearly visible and well separated from the interparietal suture (Figures 2A, 3A). These crests converge anteriorly on the interparietal suture and merge with it on the posterior portion of the frontal. This structure is typical of immature carnivorans and reflects the early stage in the progressive medial migration of the temporal crests, which eventually join in the well-developed sagittal crests of mature individuals. USNM 335451, a mature male skull, has a distinct sagittal crest that measures $10 \mathrm{~mm}$ in height at the coronal suture and extends from the posterior portion of the frontal to the broken posterior extremity of the parietal (Figures 2B, 3B). As expected, there are no traces of temporal crests on this specimen (they have merged medially to form the sagittal crest).

Petrosal (Inner Ear): Preparation of the cerebral surface of the petrosal in USNM 335451 reveals a distinctly bilobed, dorsoventrally compressed internal auditory meatus (IAM) similar to that reported in Enaliarctos mitchelli Barnes by Berta (1991), Pinnarctidion bishopi by Barnes (1979), Prototaria planicephala Kohno by Kohno (1994), Imagotaria downsi Mitchell by Repenning and Tedford (1977), Odobenus by Wyss (1987), and fossil odobenines by Deméré (1994). Specimens of Allodesmus kernensis (SDSNH 54801 and 54802) show the same type of IAM morphology, suggesting that a bilobed and compressed internal auditory meatus with separate canals for the facial and vestibulocochlear nerves is primitive for pinnipeds.

Internally, the IAM in $D$. oregonensis is incompletely divided by a low septum that rises from the petrosal but does not reach the meatal roof. The posterior margin of the petrosal is thick and broadly triangular in dorsal aspect, as in $A$. kernensis.
The apex of this triangle aligns with the dorsal lip of the internal auditory meatus. The floccular fossa is domed and only slightly smaller (USNM 335451, approximately $5.4 \mathrm{~mm}$, as measured from a cast of the middle ear) than the fossa in a similarly sized specimen of $A$. kernensis (SDSNH 54802, $6.8 \mathrm{~mm}$ ).

Petrosal (Middle Ear): The middle ear region as prepared in USNM 335451 and 250283 reveals a small but inflated promontorium (Figure 6A) as in Allodesmus kernensis (SDSNH 54802). In Pinnarctidion bishopi and Enaliarctos mealsi Mitchell and Tedford, the promontorium also is inflated (relative to otariids and odobenids) but slopes gradually anteriorly instead of having an abrupt flexure as in $D$. oregonensis. A shallow groove crosses the promontorium from the posterolateral corner to the anteromedial corner. This groove also is seen in A. kernensis and was reported by Barnes (1979) for P. bishopi. Barnes (1979) suggested that this groove marked the course of the promontory branch of the internal carotid artery.

The round window and oval window in USNM 250283 measure $4.3 \mathrm{~mm}$ and $2.2 \mathrm{~mm}$ in width, respectively. The former faces posteriorly and the latter faces laterally. The anterolateral wall of the tympanic cavity in $D$. oregonensis and $A$. kernensis is smooth and broadly concave. A narrow crest is evident on this wall beginning at the septum between the tympanic opening and the epitympanic recess. This crest extends anterodorsally toward the promontorium. Its posterior origination is similar in position to that of the tympanic crest in Enaliarctos (Mitchell and Tedford, 1973:228; Berta, 1991) and Pinnarctidion (Barnes, 1979), except that in these taxa the crest maintains a roughly horizontal orientation and does not converge dorsally on the promontorium. It is unclear if these two crests are homologous.

The process of the anterior tympanic septum described by Mitchell and Tedford (1973:228) in Enaliarctos mealsi and by Barnes (1979) in Pinnarctidion bishopi is not present in D. oregonensis and A. kernensis. The taxonomic distribution of this character state is not known in fossil odobenids, otariids, or phocids. The epitympanic recess in USNM 335451 is damaged but appears to have been deep relative to its length; it is small relative to the large and hemispherical condition in a specimen of $A$. kernensis (SDSNH 54802) of similar size.

Endocranium: Special preparation of USNM 250283 reveals the right half of an endocranial cast. This cast preserves a broad, deep, and vertically oriented pseudosylvian sulcus. This differs from the condition in Enaliarctos mealsi, which has a narrower and shallower sulcus (Mitchell and Tedford, 1973). Anterior to the pseudosylvian sulcus the cerebrum of $D$. oregonensis is more elongate than in E. mealsi. Although more morphology is represented in USNM 250283, further description of the braincase must await comparative study of other fossil and Holocene pinniped endocrania.

Upper Dentition: The upper incisor alveoli are arranged in an arc and represent $\mathrm{I} 1-3$ (Figure 5B). As judged from the alveoli, the roots of $I 1,2$ were transversely compressed. The crowns of $I 1,2$ are not preserved in any of the skulls of $D$. oregonensis. 


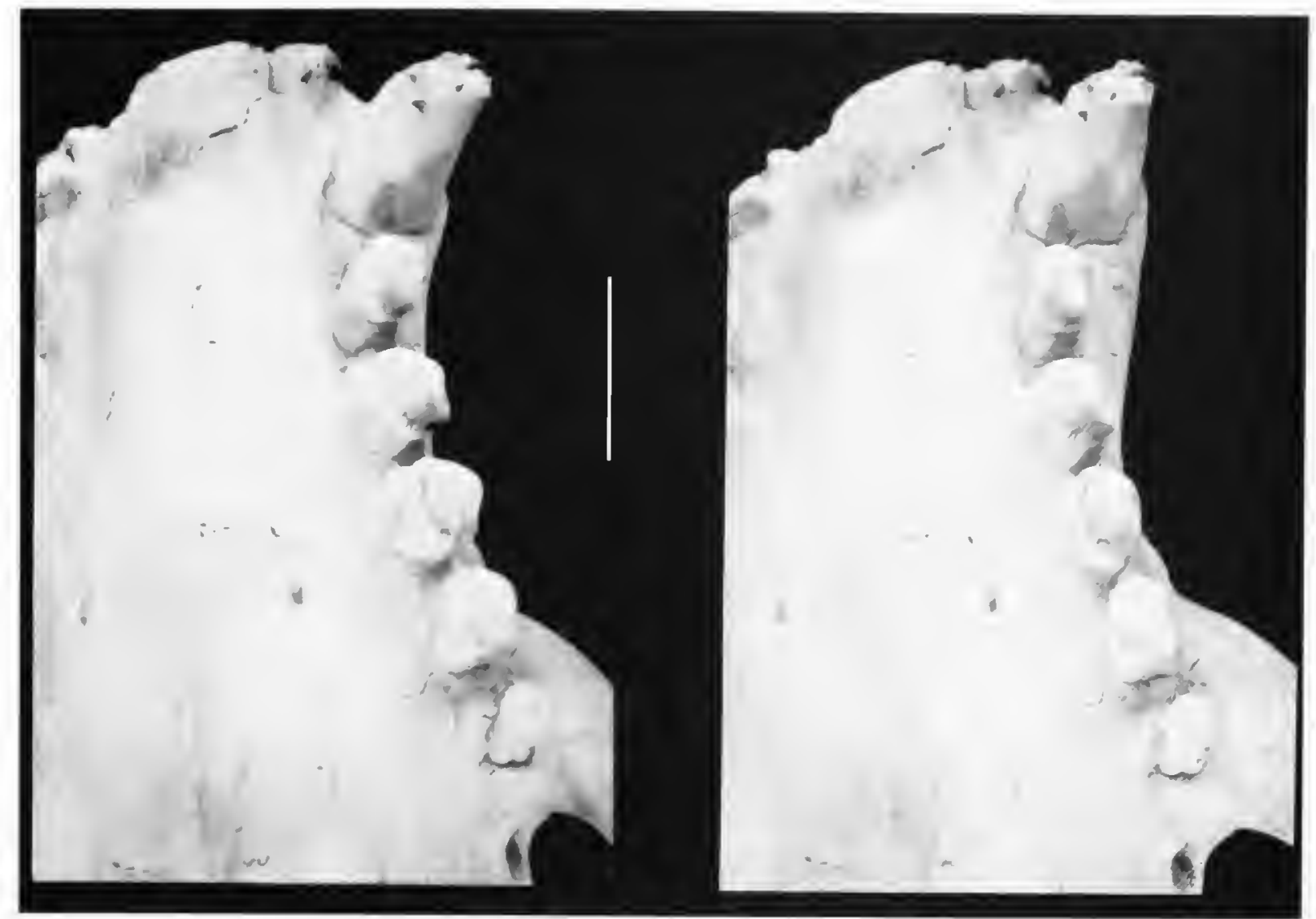

FIGURE 10.-Desmatophoca oregonensis, USNM 33545I, left tooth row and palate (stereophotographs). (Scale bar $=2 \mathrm{~cm}$.)

The root of 13 is larger than the roots of the medial incisors (Figure 4A). The tooth is procumbent and has an ovoid cross section. As preserved in the cast of the holotype and in LACM 123285 , the crown of 13 is a single conical, anterolaterally directed cusp with smooth enamel. In USNM 243694, the crown of I3 is heavily worn, presumably from occlusion with the lower canine. With the exception of the young female skull (USNM 335478), a short (4.4-6.6 mm, $x=5.8 \mathrm{~mm}, n=3$ ) diastema is present between I 3 and the canine. Similar diastemata are present in species of Enaliarctos and Allodesmus, as well as in D. brachycephala.

The canine in USNM 335478 is shorter and more slenderly proportioned than in the cast of the holotype or in USNM 243694 (Table 2). A longitudinal crista is prominent posteriorly in USNM 243694, 335451, and 335478. In USNM 314645, 335451 , and LACM 123285, a second crista occurs on the anteromedial side of the crown and merges tangentially with the base of the crown. The enamel on the canine is typically smooth except in LACM 123285 where the posteromedial corner of the crown between the anteromedial and posterior cristae is marked by dorsoventrally elongate enamel "wrinkles." In USNM 243694 and 314645 apical wear is present. In addition, USNM 243694 and 335478 preserve vertical wear facets developed anteromedially on the canine crown, presumably by occlusion with the lower canine.

The postcanine teeth possess smooth enamel crowns that have been described by other workers as bulbous. Presumably, this description means that the crowns are swollen and rounded relative to the more secodont dentitions of Enaliarctos and Pinnarctidion. By this definition of bulbous, the postcanine teeth of Desmatophoca are less bulbous than those of species of $\mathrm{Al}$ lodesmus. With the exception of P1 and M2, all of the upper postcanine teeth are double rooted.

$\mathrm{Pl}$ is single rooted and its crown, as preserved in USNM 335451 and 335478 , has a single principal cusp and anterior and posterior cristae (Figure 10). The cingulum is nearly circumferential except for a small area on the labial side of the crown above the principal cusp. The lingual margin of the cingulum is crenulated with at least five unequally sized crenations. Wear facets are developed on the posterolingual portion of the tooth at the base of the crown. The root of P1 is long (19.6 mm in USNM 335478) and closely appressed to and underlying the canine root.

The crown of $\mathrm{P} 2$ has a single large principal cusp with a tiny cuspule on its posterior flank (Figure 10). A weak crista extends from this cuspule to the apex of the crown, which is slightly posteriorly directed. As preserved in USNM 335451, 335478 , and 335702 , the crenulated cingulum (with up to nine crenations) is developed only lingually. USNM 314645 differs from other specimens in possessing an additional small cuspule on the anterior margin of the principal cusp just ventrad of the cingulum. Large vertical wear facets are seen on the posterolingual margins of P2 in USNM 243694 and 335451. In USNM 314645 and 335478 the anteroposterior axis of $\mathrm{P} 2$ is oblique to the tooth row. In all other specimens $\mathrm{P} 2$ has a more anteropos- 
terior alignment. The distinct anterior and posterior roots are circular in cross section and are of nearly equal size.

The crown of $\mathrm{P} 3$ consists of a single large principal cusp with weak anterior and posterior cristae (Figure 10). The principal cusp has smooth enamel and is about the same size as P2 but is less apically pointed. A tiny cuspule is positioned on the posterodorsal flank of the principal cusp. The lingual margin of the crown base is marked by a continuous and crenulated cingulum (with up to nine unequal-sized crenations), which in occlusal aspect is expanded posterolingually. This expansion is correlated with the transversely elongate and superficially bilobed posterior root. The separate anterior root is smaller and nearly circular in cross section.

The crown of P4, as seen in USNM 335451 and 335478, has a lower and more bulbous principal cusp, a larger posterior cuspule, and a stronger posterior crista than P2,3 (Figure 10). In occlusal aspect, the principal cusp is not as expanded posterolingually, and the lingual cingulum is less crenulated (five crenations on the posterolingual corner). Wear facets are developed on the posterior edge of the crown. The tooth has two separate roots; the posterior one is transversely bilobed, whereas the smaller anterior root is nearly circular in cross section. A short (4.5-6.5 mm; $x=5.7 \mathrm{~mm}, n=4)$ diastema separates P4 from $\mathrm{M} 1$.

The crown of $\mathrm{Ml}$ is triangular to quadrate in occlusal aspect and smaller than in Pl-4 (Figure 10). The paracone, metacone, and protocone are low-crowned and separate in USNM 335702; there is no talon. In USNM 335478 and 335451 , the paracone is larger than the metacone and is connected to it by a crest. The protocone is indistinct. A well-developed cingulum nearly encircles the crown in USNM 335478 but is confined to the anterolateral margin in USNM 335702. The number of roots is variable in M1: M1 is single-rooted in USNM 243694, 335451 , and probably 335702 ; weakly bilobed in USNM 314645; and distinctly double rooted as shown by alveoli in the cast of the holotype and LACM 123285 (Barnes, 1987). This degree of variability may herald the single-rooted condition seen in divergent species of Allodesmus. A short (3.7-6.0 mm; $x=4.8 \mathrm{~mm}, n=4$ ) diastema separates M1 from M2.

An isolated right M2 is associated with USNM 335478 and preserves a circular crown (in occlusal aspect) with a low, centrally placed cusp. A cingulum extends from the posterior edge around the lingual margin to the anterior edge. A faint crista extends medially from the crown apex to the lingual margin of the cingulum. The tooth has a single, short, transversely compressed root. The presence of M2 is variable in Desmatophoca oregonensis; it occurs in USNM 335451, 335478, 335702, and LACM 123285 and is absent in USNM 243694 and 314645.

The postcanine upper dentition of Desmatophoca oregonensis differs from that of species of Enaliarctos and Pinnarctidion in having (1) principal cusps that are bulbous rather than bladelike, (2) small posterior cuspules on the principal cusps rather than large cuspules, (3) anterior and posterior cristae that are faint rather than sharp, and (4) lingual cingula that are finely crenulated rather than smooth. The derived states of these characters appear to be characteristic of $D$. oregonensis. Relative to species of Allodesmus, however, the condition in $D$. oregonensis is primitive for many of these characters. The bulbous crowns of the postcanine dentition of Allodesmus consist of only the large principal cusp without cuspules, cristae, cingula, or crenations. In addition, $\mathrm{P} 2-\mathrm{M} 2$ are all single rooted in $A$. kernensis, A. sadoensis, A. packardi, and A. naorai. The double-rooted condition reported (Barnes, 1972) in $A$. courseni is actually only observable on $\mathrm{p} 2,3$ and cannot be confirmed for the upper dentition.

Mandible: The Emlong collection contains seven mandibles herein referred to Desmatophoca oregonensis. This material provides information, previously unreported, on the morphology of the lower jaw and lower dentition. The new specimens include right and left dentaries associated with the mature female skull (USNM 335478), a partial left dentary associated with the mature male skull (USNM 335451), and right and left dentaries of a mature male individual (USNM 335430). Table 2 summarizes measurements of dentaries and individual teeth for the five most complete specimens. The largest specimen (USNM 335430) is compatible in size with the holotype skull. The postcanine teeth with this specimen have large wear facets on the anterior and posterior crown margins and emergent and distally flared roots.

The ramus is deep relative to that in species of Enaliarctos and has a teardrop-shaped, unfused, bony symphysis (Figure $11 \mathrm{~B})$. The symphysis extends in most specimens to the level of the posterior root of $\mathrm{p} 2$ and is marked in older individuals (USNM 335430) by a thickened genial tuberosity. Mental foramina are positioned on the midline of the jaw, one below $\mathrm{p} 3$ and two to three smaller ones located below p2 and p1 (Figure 11A). In lateral aspect, the ventral margin of the horizontal ramus is straight (not curved) and extends posteriorly as a conspicuous bony flange (the marginal process of Davis, 1964) for insertion of the digastricus muscle. This flange provides the mandible with a distinctly angled posterior margin as is seen also in species of Allodesmus, as well as in phocids. Enaliarctos, Pteronarctos, and basal odobenids lack a well-developed marginal process. A shelf-like, anteroposteriorly elongate angular process is positioned above the marginal process and marks the area of insertion for the internal pterygoid muscle. This process is reduced and not shelf-like in species of Allodesmus. The mandibular condyle in $D$. oregonensis is transversely elongate and conspicuous in its elevated position above the tooth row. The condyle is closely appressed to the posterior margin of the coronoid process and does not extend as posteriorly as it does in Allodesmus kernensis. The coronoid process is broad and low with a rounded dorsal margin (Figure 11A). The masseteric fossa is shallow with a smooth surface. The small mandibular foramen is positioned directly above the marginal process at the level of the angular process. In occlusal aspect the mandible has a weakly sinuous outline, broadly concave laterally between $\mathrm{cl}$ and $\mathrm{p} 4$ and broadly convex laterally 


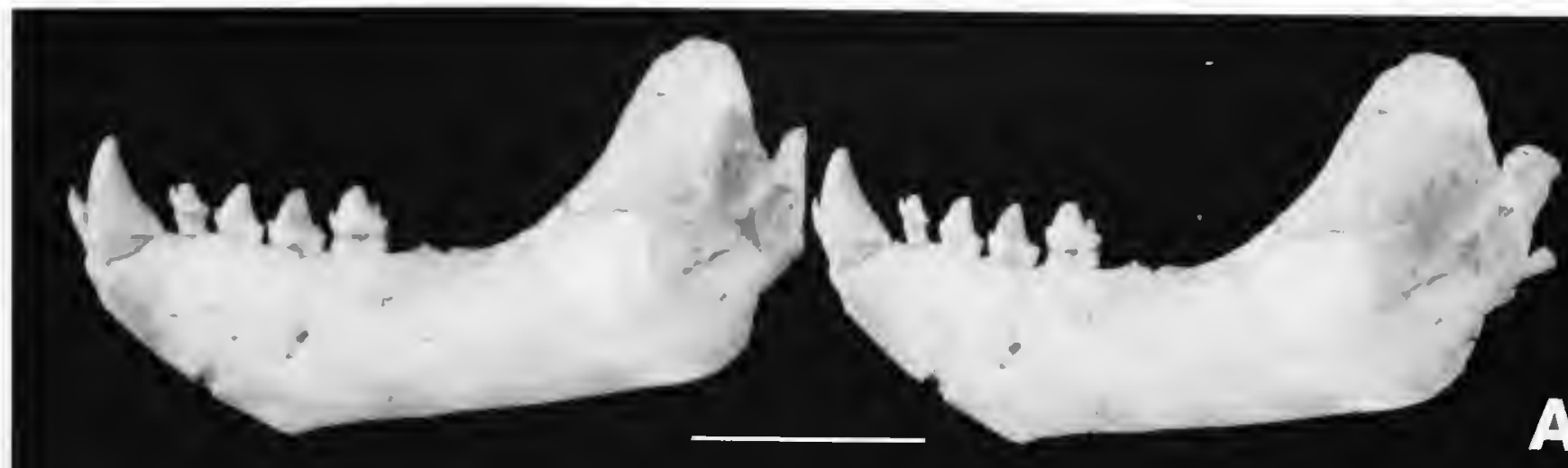

$\mathbf{A}$
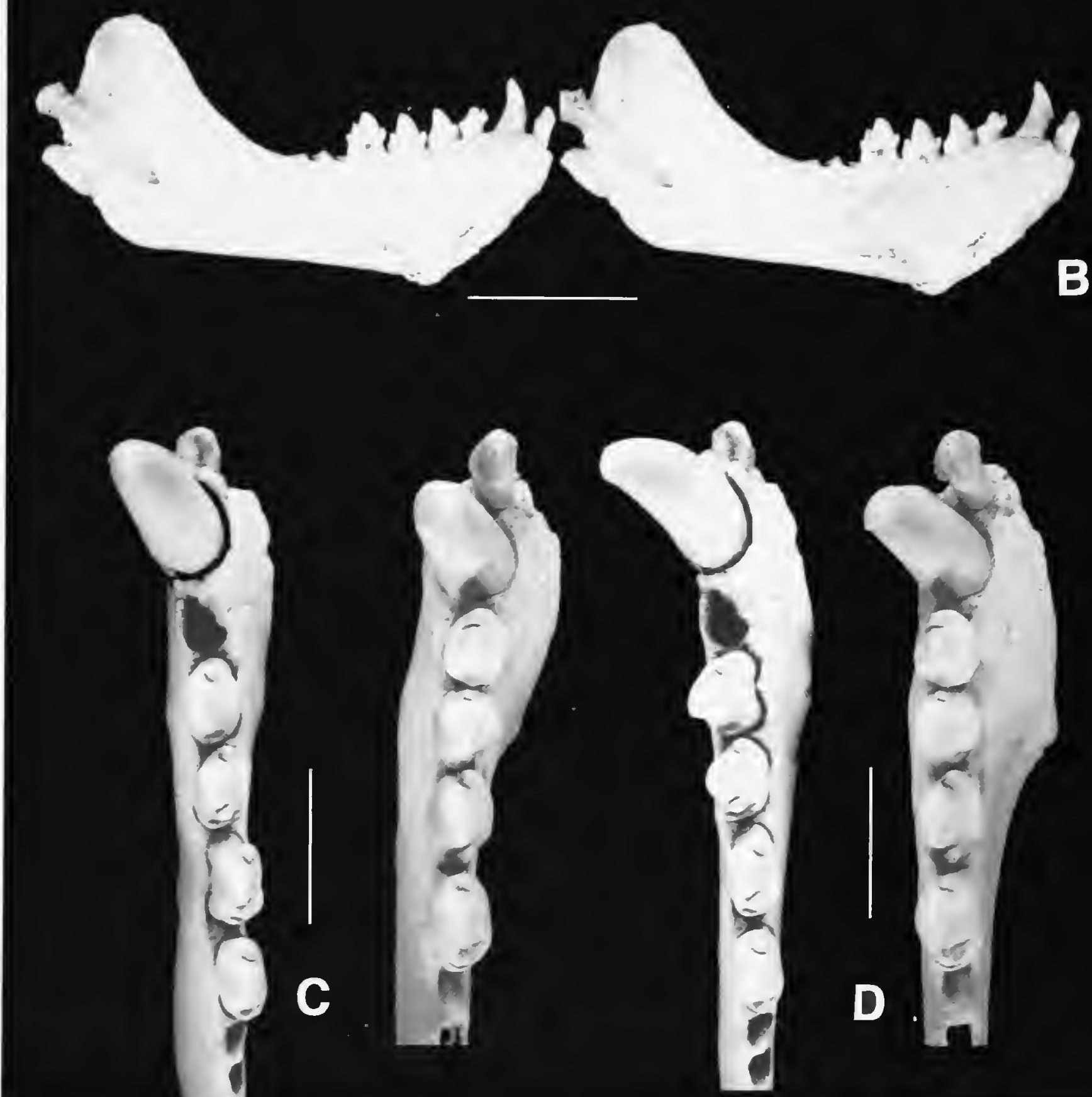

FIGURE 11.-Desmatophoca oregonensis: A,B, USNM 335478, left mandible: A, lateral aspect; B, medial aspect (stereophotographs). C, USNM 335457, left mandible, occlusal aspect (stereophotographs). D, USNM 335478, left dentary, occlusal aspect (stereophotographs). (Scale bars in $A$ and $B=5 \mathrm{~cm}$; scale bars in $C$ and $D=2 \mathrm{~cm}$.)

between $\mathrm{p} 4$ and the mandibular condyle. The postcanine alveoli are closely appressed and lack diastemata.

Lower Dentition: The lower dentition consists of i2?,3, c1, $\mathrm{pl}-4, \mathrm{ml}, 2$. Variation in this formula is seen in USNM 335430 , which lacks all incisive alveoli, and in USNM 335478, which lacks alveoli for right and left $\mathrm{m} 2$ (compare $\mathrm{C}$ and $\mathrm{D}$ of Figure $11)$.

The incisive region of USNM 335694 has an anterolaterally 
elongate and bilobed alveolus that suggests the presence of two incisors, presumably, i2,3 (i2 posterior to i3). No specimens preserve i2. The left $i 3$ is preserved in USNM 335478 (Figure 11D). The root is transversely compressed in cross section. The crown consists of a well-formed central cusp that is triangular in anterior aspect, and it has a weak and incomplete lingual cingulum. A small wear facet on the medial side of the cusp indicates occlusion with $\mathrm{I} 1$ or $\mathrm{I} 2$.

The lower canine is slenderly proportioned in the young female specimen (USNM 335478) and preserves a large vertical wear facet positioned posterolaterally and extending from the apex to the middle of the crown (Figure 11D). A weak vertical crista is present posteriorly on the thickly enameled crown. The canine teeth in USNM 335430, 335457, and 335694 (all presumably male specimens) are longer with broader bases (Table 3 ). The latter two specimens also preserve weak posterior cristae. Variation in crown wear noted within the sample includes a single apical wear facet (USNM 335694), apical and posterolateral wear facets, and no wear facet (USNM 335457). The root of $\mathrm{c}$ as preserved in USNM 335430 (presumably an old male) is distinctly fluted with longitudinal furrows and ridges.

The postcanine teeth are closely positioned in the tooth row. Except for pl, the premolars possess two separate roots that are circular in cross section. The crowns of $\mathrm{p} 2-\mathrm{ml}$ are characterized by strong principal cusps with convexly curved anterior margins and concavely curved posterior margins. In labial and occlusal aspects, the enamel surfaces of the principal cusps are rounded and swollen and not secodont as in Enaliarctos and Pinnarctidion.

The crown of $\mathrm{p} 1$ is nearly circular in occlusal aspect and consists of a small, low, and rounded principal cusp positioned slightly anterior of center (Figure 11D). Two low, tiny cuspules are located on the labial cingulum, one anterior to the principal cusp and the other posterolateral to it. The lingual portion of the crown is broad and encircled by a cingulum. The tooth has a single conical root and is closely appressed to the canine root.

The principal cusp of $\mathrm{p} 2$ is larger and more apically pointed than on $\mathrm{pl}$ and is flanked by a low and tiny anterior cuspule positioned on the anterior corner of the lingual cingulum (Figure $11 C, D)$. A second tiny cuspule is positioned on the posterior margin of the cingulum in line with the principal cusp. The lingual cingulum is continuous from the anterior cuspule to the posterior cuspule and is irregularly crenulated especially at the posterolingual corner. There is no labial cingulum. As seen in USNM 335457 and 335694, p2 has two separate roots that are circular in cross section. Large oblique wear facets on the $\mathrm{p} 2$ in USNM 335430 occur on both the anterior and posterior margins of the tooth and expose the dentine core.

The crown of $\mathrm{p} 3$ also is characterized by a large, apically pointed principal cusp. Relative to $\mathrm{p} 2$, the anterior cuspule is taller and more conical and is positioned more lingually on the anterior margin of the lingual cingulum (Figure 11C,D). A tiny cuspule is positioned on the posterior corner of the cingulum. As preserved in USNM 335457, this posterior cuspule appears to be just the largest in a series of fine crenations that mark the posterior portion of the lingual cingulum. This cingulum, as preserved in USNM 335457, is crenulated, the crenation on the posterolabial corner being the largest. In other specimens (USNM 314536 and 335478), the cingulum is smooth. Between the tiny posterior cingular cuspule and the principal cusp is a large conical cuspule whose base is not on the cingulum but rather is positioned on the posterolingual flank of the primary cusp (Figure 11B). There is no labial cingulum. The tooth has two separate roots that are circular in cross section.

The crown morphology of $\mathrm{p} 4$ is similar to that of $\mathrm{p} 3$ except that the principal cusp is lower and the conical posterior cuspule occurs farther up its posterolingual flank (Figure 11C,D). The lingual cingulum is well developed and in USNM 335457 has a finely crenulated margin. The tall and conical, anterior cuspule at the anterior corner of the lingual cingulum is well separated from the principal cusp and is positioned on its anteromedial flank. The tooth has two separate roots that are circular in cross section.

The crown of $\mathrm{m} 1$ differs from the premolar crowns in lacking a well-developed and continuous lingual cingulum, in possessing a lower principal cusp, and in lacking the prominent conical cuspule on the posteromedial flank of the principal cusp (Figure 11C). Instead, there is a prominent, transversely elongated, posterior cuspule located in the position of the small, posterior, cingular cuspule of $\mathrm{p} 3,4$. In one specimen (USNM 335457), a slight swelling on the posterior flank of the principal cusp may be homologous with the conical posterior cuspule of $\mathrm{p} 3,4$. Anterior to the principal cusp is a well-developed, conical cuspule of slightly larger size than the cuspule located on the posterior extremity of the crown. The bases of these cuspules are positioned on incomplete lingual cingula. The tooth has two separate roots that are circular in cross section.

None of the mandibles studied preserves the crown of $m 2$, and of the seven mandibles available only one (USNM 335478) lacks alveoli for this tooth. Of the six specimens with $\mathrm{m} 2$ alveoli, five preserve a single oval alveolus and one (USNM 335457) preserves two separate circular alveoli (Figure 11C). This degree of variation is reminiscent of the condition in modern otariids (King, 1983).

The lower dentition of Desmatophoca oregonensis differs from that of all other pinnipeds in possessing the combination of distinctly conical anterior and posterior cuspules, finely crenulated lingual cingula, and broadly rounded principal cusps.

Atlas: USNM 335478 includes a nearly complete atlas vertebra (Figure 12A,B). This element measures $68 \mathrm{~mm}$ across the widely spaced anterior articulation and $105 \mathrm{~mm}$ across the nearly complete transverse process. The anterior articular facets are deeply concave and are separated medially by a 12.4 $\mathrm{mm}$ wide ventral notch. The posterior articular facets are damaged but appear to have been relatively planar. There is no distinct fovea for the dens of the axis vertebra. There is also no tu- 


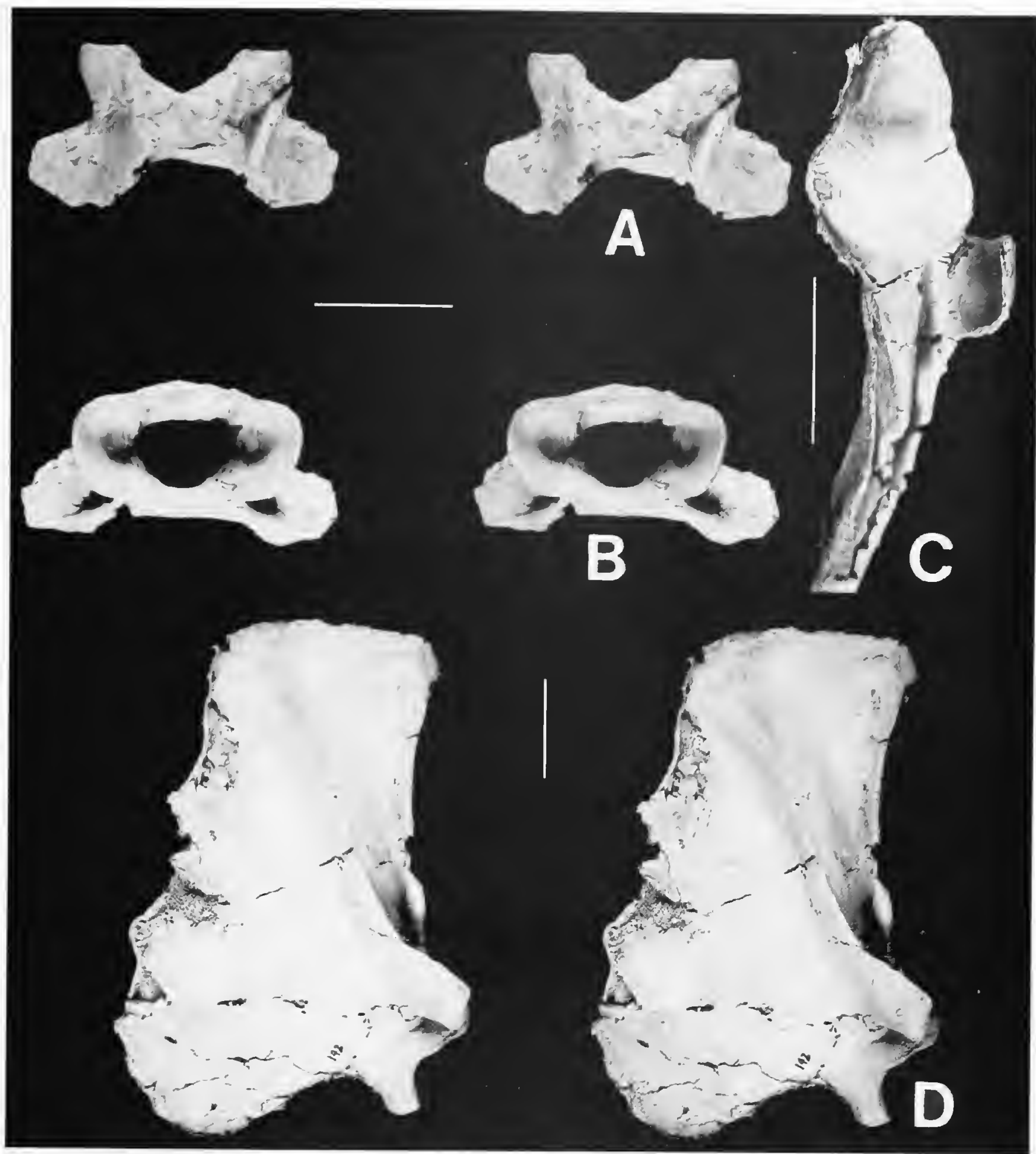

FIGURE 12.-Desmatophoca oregonensis, USNM 335478, atlas vertebra: A, dorsal aspect (stereophotographs); B, anterior aspect (stereophotographs). C,D, USNM 335246, left scapula: C, anterior aspect; D, lateral aspect (stereophotographs). (Scale bars $=5 \mathrm{~cm}$.)

bercle on the ventral border of the atlas vertebral body. The transverse processes descend from the body of the vertebra at an angle of $53^{\circ}$ to the horizontal plane. In dorsal aspect the processes diverge laterally from the sagittal plane at an angle of $50^{\circ}$ to $60^{\circ}$. The matrix-filled, left lateral vertebral foramen for passage of the vertebral artery measures approximately $9 \mathrm{~mm}$ wide by $11 \mathrm{~mm}$ high. The transverse foramen for passage of the vertebral artery exits the posteromedial side of the transverse process above the ventral border of the posterior articular facet. A deep, oval fossa on the ventral side of the transverse process marks the exit of the artery. In comparison with the atlas verte- bra of Allodesmus kernensis (Kellogg, 1931, figs. 9-12), USNM 335478 is actually smaller, the dorsal surfaces of the transverse processes are planar rather than broadly excavated, and the transverse foramen is positioned more ventrally on the posterior side of the transverse process.

Scapula: USNM 335246 includes a nearly complete left scapula with a broken vertebral border (Figure 13C,D). Referral of this element to $D$. oregonensis is based upon its association with humeri showing strong affinities with the referred humerus of Packard (1947; see below). Overall, the blade is otariid-like in shape and lacks the transverse elongation of pho- 


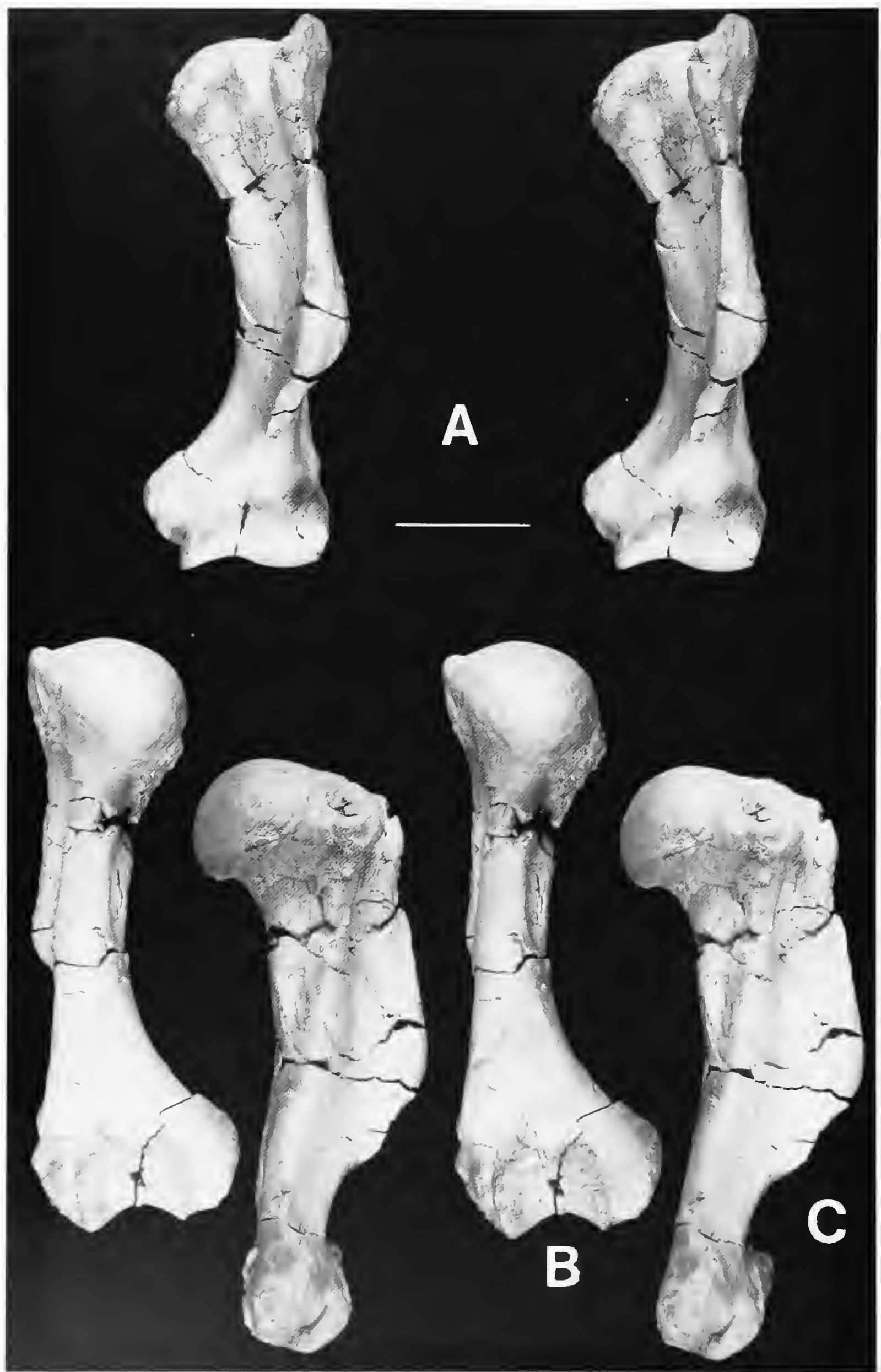

FIGURE 13.-Desmatophoca oregonensis, USNM 335246, left humerus: A, anterior aspect (stereophotographs); B, posterior aspect (stereophotographs); C, medial aspect (stereophotographs). (Scale bars $=5 \mathrm{~cm}$.)

cine scapulae and the longitudinal elongation of odobenine scapulae. The supraspinous fossa is very large, roughly twice the size of the narrow, triangular infraspinous fossa. The latter shows no obvious morphology indicating the origins of the infraspinatus or teres minor muscles. The scapular spine is keellike, is not thickened apically, and is strongly tilted caudally to 
overhang the cranial portion of the infraspinous fossa (Figure 13B). The axis of the spine meets the glenoid fossa at an angle of approximately $40^{\circ}$ from the perpendicular. The acromion is large, flange-like, curved caudally, and positioned on the proximal edge of the spine. In Allodesmus kernensis, the acromion is blunt and knob-like and does not overhang the infraspinous fossa (Mitchell, 1966). The caudal angle of the blade has a distinct flange-like process for the teres major. This process is not apparent on the scapula of Allodesmus illustrated by Mitchell (1966, pl. 15). The caudal border is distinctly raised and keeled on its lateral margin and not blunt as in $A$. kernensis. The glenoid fossa is deeply embayed. The coracoid process is robust and rounded, and on the anteromedial corner it shows a slight indication of a bump for the origination of the biceps muscle. The medial surface of the scapular blade is broadly concave and marked by at least five low longitudinal ridges with intervening broadly concave furrows.

Humerus: USNM 335246 includes both humeri. These are referred to Desmatophoca oregonensis on the basis of their overall size and morphological similarity to the left humerus referred to $D$. oregonensis by Packard (1947). The proximodistal length of the right humerus of USNM 335246 is $218 \mathrm{~mm}$, about $10 \mathrm{~mm}$ longer than the referred humerus of Packard. The greater tuberosity is higher than the lesser tuberosity and equal to the level of the humeral head (Figure 13A-C). The deltopectoral crest is transversely broad and longitudinally elongate and meets the humeral shaft proximal to the level of the entepicondyle. The longitudinal axis of the deltopectoral crest is directed toward the middle of the distal trochlea. The area for insertion of the deltoid muscle is large and well defined, extending along the entire lateral border of the crest (Figure 13A). The distal end of this insertion is developed as a laterally projecting knob. Caudal to the deltoid insertion is a conspicuous sulcus for origination of the brachialis muscle. The bicipital groove is deep and broadly open. The humeral head is rounded and extended caudally. The entepicondyle is robust and extends medially to produce a broad distinct concave outline to the humeral shaft. The supinator ridge is indistinct. The radial capitulum is broader than the medial ulnar lip of the distal trochlea. Mitchell (1961:15) briefly discussed the morphology of the referred left humerus of Packard (1947), mentioning its slender proportions, laterally bowed shaft, and high degree of shaft torsion. Comparison of a cast of this humerus with the humeri of USNM 335246 suggests that the bowing and torsion are the result of diagenetic distortions. Humeri of Allodesmus kernensis display many features distinct from the humeri of Desmatophoca oregonensis, including the following: the overall size is larger; the humeral head is higher than either tuberosity; the bicipital groove is shallow and open; the supinator portion of the distal end is stronger, resulting in a more central position of the shaft relative to the entepicondyle and the ectepicondyle; the medial portion of the distal ulnar condyle is not flared as a lip; the deltopectoral crest is relatively longer and meets the shaft at the level of the entepicondyle; and the del- topectoral crest is laterally inclined and directed toward the medial margin of the ulnar facet. The taxonomic distribution of these various character states was not investigated for the present report.

Ulna: A nearly complete right ulna (Figure 14A-C) missing only the extreme distal end and styloid process is associated with the scapula and humeri of USNM 335246. As preserved, the proximodistal length of the ulna is $208 \mathrm{~mm}$, which suggests that the complete element would likely have been longer than the associated humerus. The proximal end is transversely compressed and is developed anteroposteriorly into the broad fan-shaped olecranon process characteristic of all pinnipeds (Howell, 1929). The proximal crest of the olecranon process for insertion of the triceps muscle is broadly curved in lateral aspect and terminates in a distinct posterior or ulnar process (Howell, 1929); the olecranon crest in Allodesmus is relatively shorter and less falcate and has a broader triceps insertion proximomedially. Anteriorly, the height of the olecranon crest above the trochlear or sigmoid notch is $45 \mathrm{~mm}$. The lateral surface of the olecranon process has a low longitudinal ridge adjacent to the midpoint of the olecranon crest. This ridge blends distally with the main area of the extensor fossa and presumably marks the division between the extensor metacarpi pollicis and the extensor pollicis longus. Its position is more posteriorly placed than in modern otariids (Howell, 1929). The anterior portion of the extensor fossa adjacent to the sigmoid notch is longitudinally excavated into a conspicuous depression. The distal terminus of this depression lies at the proximal edge of a raised, oblong rugosity on the anterolateral margin of the ulnar shaft. This rugosity, as discussed by Howell (1929), is the site in Phoca of origination of a strong interosseous ligament that binds the ulna to the radius. Well-developed rugosities like these are not recorded for Allodesmus kernensis. The shaft in the distal region of the ulna is transversely compressed into an elongate oval.

The medial surface of the olecranon process is broad for origination of the flexor musculature. This flexor fossa is flattened, as in Allodesmus kernensis, and not deeply concave, as in modern otariids. The greater sigmoid cavity for articulation with the humerus is taller than it is broad and has a uniformly convex trochlear facet. The lesser sigmoid cavity for articulation with the radius is lunate in shape and only slightly concave. Ulnae of Allodesmus kernensis are larger than in USNM 335246 , have a relatively shorter and less falcate olecranon crest, and have a more quadrate greater sigmoid cavity.

\section{Desmatophoca brachycephala Barnes, 1987}

EMENDEd Diagnosis.-A species of Desmatophoca with widely flared zygomatic arches, posterior portion of squamosal fossa smaller than anterior fossa (autapomorphies of $D$. brachycephala), paroccipital process oriented at an angle greater than $50^{\circ}$ to the sagittal plane (possible autapomorphy), angle formed by long axis of external auditory meatus and sagittal plane of skull greater than $62^{\circ}$, no prenarial shelf, distinct 


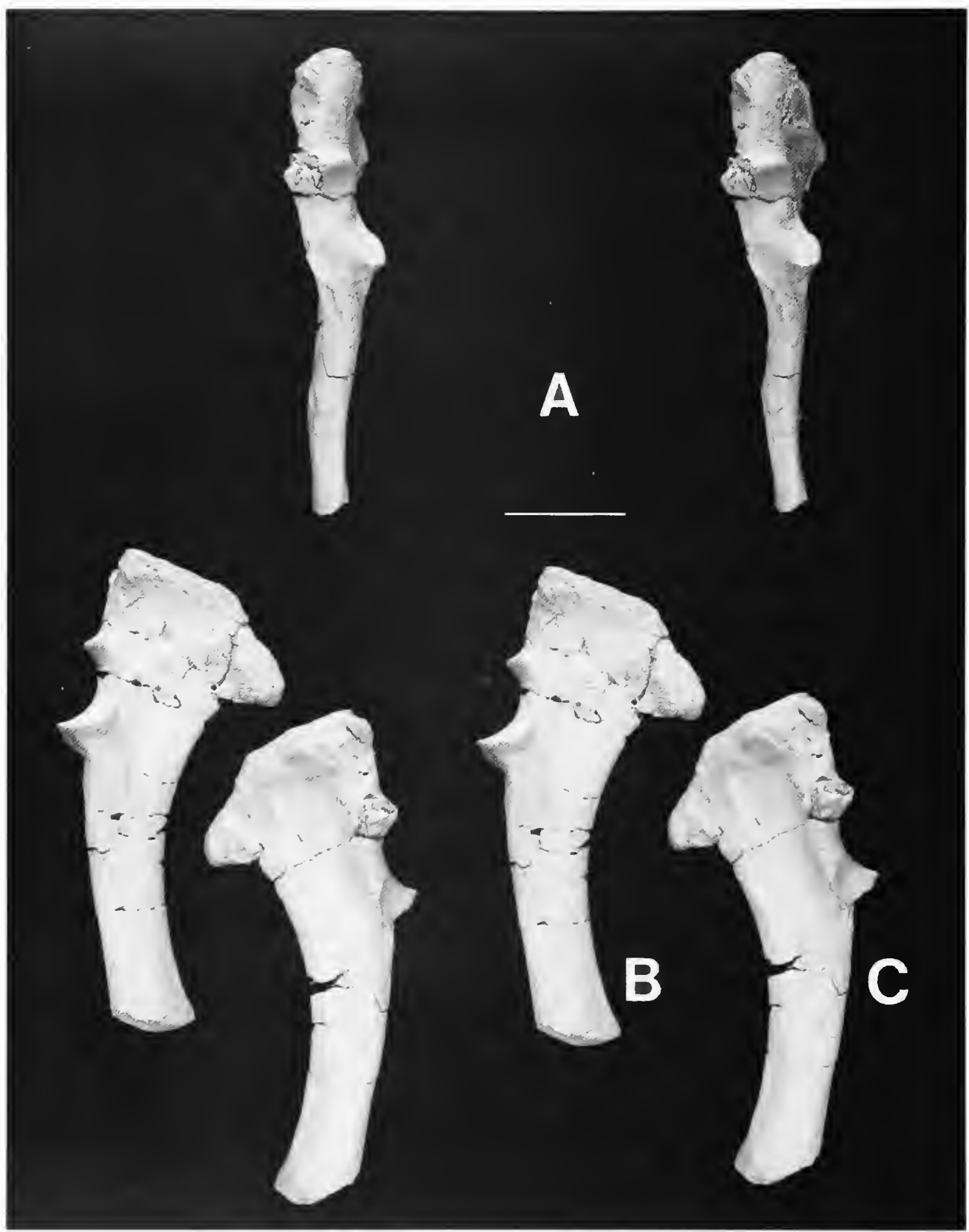

FIGURE 14.-Desmatophoca oregonensis, USNM 335246, right ulna: A, anterior aspect (stereophotographs); B, medial aspect (stereophotographs); $\mathrm{C}$, lateral aspect (stereophotographs). (Scale bars $=5 \mathrm{~cm}$.)

carinae on $\mathrm{C}$, and thick lateral wall of alisphenoid canal (symplesiomorphies shared with basal pinnipeds).

HOLOTYPE.-LACM 120199, incomplete skull with parts of both canines and crowns of left Il-3 and M1, collected by J.L. Goeddert and G.H. Goeddert in 1979 (Barnes, 1987).

TYPE LOCALITY.-LACM 4584, east of Knappton, Pacific County, Washington.
DISCUSSION.-Desmatophoca brachycephala is represented solely by the holotype skull, which is damaged in the rostral region and lacks all postcanine teeth except the left M1. Preserved alveoli include those for the right $\mathrm{P} 1, \mathrm{P} 4$, and $\mathrm{M} 1$ and the left P1 (lingual margin only), P3 (posterior root only), P4, and $M 1,2$. The size and morphology of the right and left canines is extrapolated from a small preserved portion of the dor- 
solingual surface of the crowns. The well-developed lambdoidal crests suggest that the skull belongs to a mature male individual.

Barnes (1987) listed 12 characters to distinguish $D$. brachycephala from $D$. oregonensis. Subsequent to the description of $D$. brachycephala, the remainder of the right palate with the M2 alveolus intact was discovered, negating one of the characters (M2 absent) initially used to diagnose this taxon (L.G. Barnes, pers. comm., 1998). Of Barnes's remaining 11 characters, seven are not exclusive to $D$. brachycephala but are also characteristic of $D$. oregonensis given the larger sample now available. Those characters determined not to be diagnostic of $D$. brachycephala include the following: the pterygoid process beneath the orbit is larger (also seen in USNM 335702, 335478 , and 335451); the interorbital region is wider, especially in the anterior part (also seen in USNM 335451 and 335702); the zygomatic arch is more slender (also seen in USNM 335478; as discussed above, this character is age and sex dimorphic); the optic foramina are located more posteroventrally within the orbits (variable in $D$. oregonensis, similarly positioned in USNM 335478 and 335451 ); and the posterior lacerate foramen is larger and more circular in outline (variable in $D$. oregonensis, similar size and shape in USNM 335451).

Another purported diagnostic character that we could not confirm given the larger sample is the size and orientation of the mastoid process. According to Barnes (1987:6) the mastoid process is "larger and extended more posterodorsally" in $D$. brachycephala. This character is actually a combination of both size and orientation of the mastoid process, so our discussion is divided accordingly. Although mastoid size has not been quantified, in a qualitative sense it is clear that some specimens of $D$. oregonensis (e.g., USNM 335702) possess mastoid processes that are the same size as those of $D$. brachycephala. Size, therefore, is not a distinguishing feature.

Orientation of the mastoid process involves at least two aspects, lateral orientation of the long axis of the process as viewed in ventral aspect and vertical orientation of the rugose lateral face of the process as viewed in posterior aspect. The former is correlated with orientation of the EAM and, as discussed below, D. brachycephala has an EAM (and mastoid process) that are directed more laterally than anterolaterally. Orientation of the rugose lateral face of the mastoid process is generally the same in both species, although $D$. brachycephala tends to have a broader lateral surface area compared with the more ventrally placed surface of $D$. oregonensis.

Three of Barnes's characters purported to be diagnostic for $D$. brachycephala were not quantified by Barnes and, when quantified by us, could not be confirmed as dichotomous: (1) the skull has a shorter and wider rostrum, more expanded laterally around the canines, and the palate is wider, especially in posterior part; (2) the external auditory meatus is wider and directed more laterally, and (3) the paroccipital process is di- rected more laterally, instead of posteriorly. We redefined these characters so that they could be quantified.

Rostrum length is defined herein as the distance from the anterior border of the orbital rim to the prosthion. Comparing measurements of rostrum length to CBL we found that in both Desmatophoca oregonensis and D. brachycephala this measurement was $28 \%$ of CBL, thus failing to confirm the dichotomous nature of this character. A further modification of rostrum size is the degree of lateral expansion around the canines. As discussed by Barnes (1987), D. brachycephala is distinguished from $D$. oregonensis by its relatively short rostrum that flares around the roots of the canine teeth. The holotype of the former is missing the lateral portion of the maxilla, however, so it is not possible to precisely determine the extent of expansion of the rostrum around the canines. Palate width was measured at two points-the interalveolar distance at P1 and at M1 (lingual borders) - and a ratio of the former to the latter was calculated. Thus quantified, a uniformly narrow palate would have a ratio close to 1.00 , whereas a posteriorly broadened palate would have a ratio closer to 0.50 . In $D$. oregonensis, the palate width ratio is $0.44-0.54(x=0.49, n=4)$ compared with 0.42 in D. brachycephala. This ratio is 0.46 in Allodesmus packardi, 0.60 in Allodesmus kernensis (LACM 4320), and 0.70 in Enaliarctos emlongi. Quantification of this character reveals that $D$. brachycephala has only a slightly broader palate than $D$. oregonensis. Unfortunately, the sample size is not large enough to determine if this difference is significant.

The orientation of the EAM was quantified by measuring the angle that the axis of the EAM makes with the sagittal plane of the skull in ventral aspect. Desmatophoca brachycephala possesses the primitive condition also seen in outgroup taxa, in which the axis of the EAM is oriented at an angle greater than $62^{\circ}$ from the sagittal plane of the skull. In $D$. oregonensis, this angular measurement is less than $62^{\circ}$ (see Appendix, character 19), thus confirming the characterization of Barnes (1987). This is also true for Barnes's identification of the more lateral orientation of the paroccipital process in Desmatophoca brachycephala. This character was quantified by measuring the angle between the long axis of the paroccipital process and the sagittal plane of the skull in ventral aspect. Desmatophoca oregonensis possesses the primitive condition also seen in outgroup taxa, in which the paroccipital process is oriented at an angle less than $25^{\circ}$ from the sagittal plane of the skull. In $D$. oregonensis this angular measurement is $17^{\circ}-22^{\circ}\left(x=20^{\circ}, n=4\right)$, whereas in D. brachycephala the angle is $54^{\circ}$ and in $A$. kernensis, $52^{\circ}-62^{\circ}\left(x=57^{\circ}, n=3\right)$.

Although only two of Barnes's purported dichotomous characters for Desmatophoca brachycephala were confirmed (EAM oriented at an angle greater than $62^{\circ}$ from the sagittal plane, and paroccipital process oriented at an angle greater than $50^{\circ}$ from the sagittal plane), the present analysis recognizes an additional apomorphy useful in diagnosing this taxon: zygomatic arches more widely flared (see also Appendix, character 15). Zygomatic width, defined relative to $\mathrm{CBL}$, was $65 \%$ of 
condylobasal length in D. brachycephala, compared with values ranging from $54 \%$ to $60 \%$ in other pinnipeds.

\section{Phylogenetic Relationships of Desmatophoca}

As previously mentioned, recent hypotheses for higher-level relationships of species of Desmatophoca can be summarized as two major alternative topologies (Figure 1). In one arrangement, proposed by Barnes (1989), species of Desmatophoca are more closely related to odobenids than to other "otarioids," including Allodesmus. In the other arrangement proposed by Repenning and Tedford (1977), species of Desmatophoca and Allodesmus are sister taxa. Building on this lattter arrangement, Wyss and Flynn (1993), Berta and Wyss (1994), and Berta (1994) further suggested that the Desmatophoca + Allodesmus clade is more closely related to phocids than to odobenids.

To analyze the phylogenetic relationships of species of Desmatophoca, we evaluated 30 cranial and dental characters ( 20 binary and 10 multistate) (Table 4). We used the branch-andbound search option of PAUP*4.0b8 (Swofford, 1998) with all multistate characters treated as unordered. Using the higherlevel relationships summarized above, we considered the following as ingroup taxa: Desmatophoca oregonensis, Desmatophoca brachycephala, Pinnarctidion rayi, Pinnarctidion bishopi, Allodesmus courseni, Allodesmus sadoensis, Allodesmus packardi, Allodesmus kernensis, and the Phocidae (basal phocids Homiphoca capensis Hendey and Repenning, 1972, and Piscophoca pacifica Muizon, 1981, and a living basal monachine, Monachus schauinslandi Matschie). We used the following taxa as successive outgroups: Odobenidae (basal odobenids Proneotherium repenningi and Prototaria planicephala Kohno, 1994), Otariidae (basal otariid Thalassoleon mexicanus Repenning and Tedford, 1977), Pteronarctos goedertae Barnes, 1989, and Enaliarctos emlongi Berta, 1991.

The cladistic analysis produced five equally parsimonious trees that differed only in the relationships among outgroup taxa. A strict consensus tree yielded a tree length of 49 steps and a rescaled consistency index of 0.785 (Figure 15). A clade consisting of species of Allodesmus and Desmatophoca was consistently recognized as the sister group to phocids. An unexpected result (not figured) was the consistent position of the Otariidae (not Odobenidae) as the sister taxon to the ingroup. This arrangement can be explained if one considers that basal otariids (i.e., Thalassoleon) possess character states that are derived relative to those of the earliest identified odobenids (i.e., Proneotherium and Prototaria). Another contributing factor for the unusual sister-group placement of otariids involves the limited character data set employed, which because of the focus of our study does not include many characters relevant to interpreting the relationships of otariids. For a more inclusive study of pinniped relationships, see Berta and Wyss (1994).

The position of Pinnarctidion as a member of the Phocoidea clade (see Figure 1, middle and bottom) was not confirmed using this character data set. In this analysis Pinnarctidion was variously placed among outgroup taxa, and we do not consider it to be a member of the ingroup.

On the basis of this analysis, we recognize the monophyletic groups/taxa presented below together with our evaluation of previous arrangements of these clades/taxa. Bootstrap percentages based upon 500 replicates were calculated and are summarized in Figure 15. With one exception (the $D$. oregonensis$D$. brachycephala clade), taxonomic associations are well supported.

Phocoidea (Allodesmus +Desmatophoca+Phocidae): This monophyletic group is diagnosed by three unequivocal synapomorphies (Figure 15): premaxilla-nasal contact reduced (1), squamosal-jugal articulation mortised with zygomatic process expanded anteriorly (transformation to state 1 in Desmatophoca) (11), and flange (=marginal process) below ascending ramus well developed (22). An additional five equivocal synapomorphies are potentially diagnostic of this clade: paroccipital process enlarged and not excavated (9), posterior portion of squamosal fossa smaller than anterior portion (18), angular process reduced or absent (21), and p2-4 crowns with conical cuspules (transformation to state 2 in Allodesmus) (27).

Bames and Hirota (1995) argued against the validity of recognizing the Phocoidea clade (Allodesmus + Desmatophoca + Pinnarctidion + Phocidae) as proposed by Berta and Wyss (1994). As evidence, they refuted the seven synapomorphies used by Berta and Wyss to support this clade. We respond to their conclusions in the following discussion.

1. Nasals extending posterior to frontal-maxillary contact. We have modified the definition of this character following Deméré (1994). The significant morphology is the shape of the nasal-frontal suture and not merely its posterior position. The derived condition, a narrowly acute, $\mathrm{V}$-shaped nasal-frontal suture is seen in Desmatophoca, Allodesmus, and phocids (see Appendix, character 2). Dusignathine odobenids possess $V$ shaped nasal-frontal sutures (Deméré, 1994), but the sutures are broadly $\mathrm{V}$-shaped and are not posteriorly placed. Pinnarctidion was incorrectly coded by Berta and Wyss (1994) and actually has the primitive condition in which the suture is blunt and nearly transverse. This character thus does not support a close relationship between Pinnarctidion and the Phocoidea. It does, however, support the grouping of Desmatophoca, Allodesmus, and phocids.

2. Pterygoid process with flat, concave lateral margin. Barnes and Hirota (1995) considered this character actually to be a combination of two characters - the form of the pterygoid strut (i.e., rounded and convex; excavated; or flat and rugose) and the arrangement of the bones (i.e., palatine, pterygoid, and alisphenoid) making up the strut. Although this distinction is valid, Berta and Wyss (1994:48) were only concerned with the form of the pterygoid strut, which they noted was flat with a concave lateral margin in Pinnarctidion, Desmatophoca, Allodesmus, and phocids. We have determined that this is not a useful character at this taxonomic level (also see below), but we disagree with the specific reasons given by Barnes and $\mathrm{Hi}$ - 


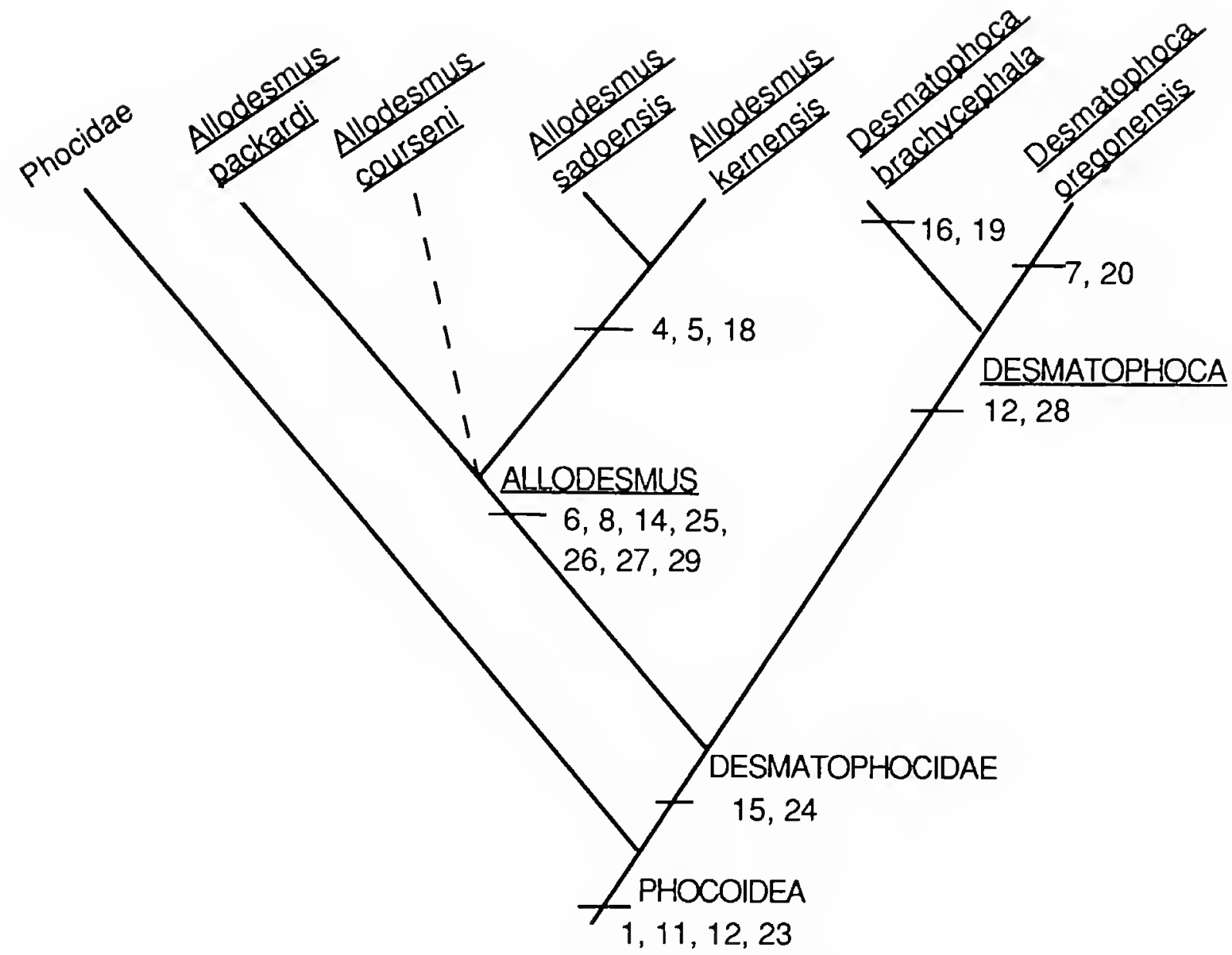

FIGURE 15.-Phylogenetic hypothesis of phocoid and desmatophocid relationships. (Plain numbers indicate character support for selected nodes; numbers in bold are bootstrap values discussed in text; dashed lines for Allodesmus courseni branch were added a posteriori, as discussed in text.)

rota. The implication that in all phocids there is no well-formed hamulus and that the palatine does not contact the alisphenoid bone is incorrect (see for example Mirounga).

3. Mastoid process distant from paroccipital process. According to Barnes and Hirota, this character was neither correctly described nor quantified. Although Berta and Wyss did oversimplify the complex states for this character and did not quantify it, the discussion offered by Barnes and Hirota also was oversimplified and also failed to quantify the character. We agree that the character is complex and requires a more detailed description (see Figure 7).

4. IAM absent and canals for vestibulocochlear nerve completely separated. According to Barnes and Hirota, this character was incorrectly described and attributed by Berta and Wyss (1994). As reevaluated in this study, a bilobed IAM with separate canals for cranial nerves VI and VII occurs in Enaliarctos, Pinnarctidion, Desmatophoca, Allodesmus, and Imagotaria and is primitive for pinnipedimorphs.

5. Auditory bulla underlaps basioccipital. According to Barnes and Hirota, this character was incorrectly described and attributed by Berta and Wyss (1994). We agree.

6 . Bony flange below ascending ramus. Barnes and Hirota (1995:356) claimed that this is an incorrectly described and attributed character. This character, they argued, is "related to the musculature and functional morphology of the dentary and not of phylogenetic significance." They offered no evidence to support this assertion, however. Clearly, this flange (the marginal process of Davis, 1964) is correlated with the jaw abduction musculature, but this does not negate any phylogenetic significance. In fact, our proposed phylogeny (Figure 15) indicates that the derived condition (character 22) evolved only once in the common ancestor of phocoids.

7. Pericardial plexus well developed. As Barnes and Hirota (1995:356) wrote, "soft anatomical structures that are not reflected by bone morphology cannot elucidate the relationships of fossil taxa." This is, of course, true. We wish to point out, however, that this character was identified by parsimony analysis (Berta and Wyss, 1994) as a potential synapomorphy of this clade. Because it was scored as "?" in fossil taxa, it should be treated as apomorphic for phocids, the minimum level at which observation confirms its distribution.

In summary, we agree with Barnes and Hirota that the Phocoidea as originally defined (i.e., Pinnarctidion, Allodesmus, Desmatophoca, and phocids) is not supported by our revised character evidence. Our analysis, however, does recognize a monophyletic Phocoidea, but one that we redefine as the clade containing Desmatophoca, Allodesmus, and phocids.

Desmatophocidae (Allodesmus +Desmatophoca): This monophyletic group is diagnosed by four unequivocal synapomorphies (Figure 15): stylomastoid foramen separated by raised strut from tympanohyal (14), tympanic crest present and dorsally convergent with petrosal (16), I3 procumbent and lat- 
erally directed (23), and Pl-3 with well-developed cingula with numerous cuspules/crenations (26). One equivocal synapomorphy is potentially diagnostic of this clade: laterally expanded pterygoid process of the maxilla ( 3 , also independently derived in basal odobenids and species of Pinnarctidion).

Recognition of this clade differs from Barnes's (1979) arrangement in which Allodesmus was removed from the Desmatophocidae because of the presence of three "derived" characters shared between Pinnarctidion and Allodesmus: (1) extreme lateral excavation of the palatine-pterygoid strut between the palate and the braincase; (2) more dorsally flattened posterior narial opening; and (3) more posterior and ventral position of the orbital aperture of the optic foramen. The possession of the "primitive" states of these characters in species of Desmatophoca was sufficient to convince Barnes (1979) that Allodesmus evolved directly from the "enaliarctine" Pinnarctidion without "passing through" a Desmatophoca ancestor. Our evaluation of these characters suggests that they are more variable than observed by Barnes (1979) and not seen in $\mathrm{Al}$ lodesmus and Pinnarctidion exclusively. First, several of the Emlong specimens of Desmatophoca oregonensis (USNM 335451 and 335478) have a pterygoid strut that is shelf-like and roughly as wide as in Pinnarctidion bishopi, whereas another specimen (USNM 314645) has a narrow, rounded pterygoid strut. Second, although Barnes claims that the internal narial opening is more compressed in Pinnarctidion bishopi and Allodesmus kernensis, this character also is variable in Desmatophoca oregonensis and in some cases is probably related to diagenesis. Third, we observed variability in the position of the optic foramen. In the cast of the holotype of $D$. oregonensis the foramen is more anterior; however, in USNM 335702 , the foramen is posteriorly placed.

In a recent phylogenetic study of Allodesmus from Japan, Kohno (1996) supported recognition of the Desmatophocidae as a monophyletic clade including Desmatophoca and Allodes$m u s$. Although he did not discuss specific character evidence for this arrangement, the data in his character-taxon matrix (his table 3) do provide support.

Desmatophoca: Diagnosis of this monophyletic taxon is based upon two synapomorphies (Figure 15): mortised contact with the zygomatic process expanded posteriorly (11) and p2-4 crowns with anterior and posterior cuspules conical (27). A posteriori character analysis recognizes another possible synapomorphy: P1-3 crowns with well-developed cingula and numerous cuspules (26). The derived state evolved first in Desmatophoca; absence of cingula or cuspules represents a secondary transformation (derived state 2) in Allodesmus. If correct, this transformation series predicts that well-developed cingula and cuspules should be found in D. brachycephala.

Desmatophoca brachycephala is diagnosed on the basis of the following autapomorphies (Figure 15): widely flared zygomatic arch (15) and squamosal fossa divided, with anterior and posterior portions of equal size (18). Desmatophoca oregonensis is distinguished from Desmatophoca brachycephala by two unequivocal autapomorphies (Figure 15): incisive foramen without medial septum (7) and external auditory meatus axis oriented less than or equal to $62^{\circ}(19)$.

Allodesmus: Diagnosis of a monophyletic Allodesmus is based upon six synapomorphies (Figure 15): dorsal margin of zygomatic arch retracted dorsal to infraorbital foramen (6), supraorbital processes of frontals developed as a posteriorly positioned swelling (8), styloid process of auditory bulla absent (13), upper canine crowns lacking posterior and medial carinae (24), upper postcanine teeth single rooted (25), and upper postcanine tooth roots inclined (28).

Although recent work by Barnes and Hirota (1995) and Kohno (1996) recognized as many as nine species of allodesmines from the Miocene of California and Japan, a review of their evidence suggests that the taxa are probably oversplit. This is especially true for species of Allodesmus from California, three of which alone are reported from a very limited stratigraphic interval within the middle Miocene, Round Mountain Silt. Because of this oversplitting and the fact that resolution of phylogenetic relationships within this clade was not a primary goal of our study, we decided to include only four species of Allodesmus in the present analysis. These four species (Allodesmus kernensis, A. packardi, A. courseni, and A. sadoensis) were selected in part for their long taxonomic standing and/or representation by fairly complete fossil material. The results reveal that $A$. kernensis and $A$. sadoensis are sister taxa, distinguished from $A$. packardi by four unequivocal synapomorphies (Figure 15): palate transversely arched (4), lateral wall of alisphenoid canal thin (5), infraorbital canal small (17), and moderately sized orbit (20). Allodesmus courseni was omitted from the computer analysis because it could only be scored for eight of 30 characters (see Table 4). This taxon does possess certain synapomorphies, however, so it could be manually placed in an unresolved position within the Allodesmus clade. A basal position within this clade is suggested by possession of the primitive condition for one character: multiple rooted upper postcanine teeth (25). For a more complete analysis of phylogenetic relationships among species of Allodesmus see Kohno (1996).

\section{Conclusions}

Analysis of new fossil skulls, mandibles, and postcrania of Desmatophoca oregonensis from the Astoria Formation of the Newport Embayment of coastal Oregon, USA, documents the range of morphologic variation in this taxon and concludes that several characters previously considered diagnostic of different species are actually the result of sexual dimorphism and/or developmental age. As a basal desmatophocid, Desmatophoca oregonensis has an elongate skull and upper postcanine teeth characterized by bulbous crowns with prominent central cusps, small posterior cuspules, and distinct crenulated lingual cingula. The lower postcanine teeth have distinctly conical ante- 
TABLE 4.-Character-taxon matrix showing distribution of cranial, dental, and mandibular character states among selected fossil and modern pinnipeds. Character state 0 rcpresents the ancestral state; states 1-3 represent the derived statcs. Missing data are scorcd as?

\begin{tabular}{|c|c|c|c|c|c|c|c|c|c|c|c|c|c|c|c|c|c|c|c|c|c|c|c|c|c|c|c|c|c|c|}
\hline \multirow{2}{*}{ Taxon } & \multicolumn{30}{|c|}{ Character } \\
\hline & 1 & 2 & 3 & 4 & 5 & 6 & 7 & 8 & 9 & 10 & 11 & 12 & 13 & 14 & 15 & 16 & 17 & 18 & 19 & 20 & $2 !$ & 22 & 23 & 24 & 25 & 26 & 27 & 28 & 29 & 30 \\
\hline Enaliarchos spp. & 0 & 0 & 0 & 0 & 0 & 0 & 0 & 0 & 0 & 0 & 0 & 0 & 0 & 0 & 0 & 0 & $?$ & 0 & 0 & 0 & 0 & 0 & 0 & 0 & 0 & 0 & 0 & 0 & 0 & 0 \\
\hline Pteronarchos spp. & 0 & 0 & 0 & 0 & 0 & 0 & 0 & 0 & 1 & 0 & 0 & 0 & 0 & 0 & 0 & 0 & $?$ & 0 & 0 & 0 & $?$ & $?$ & 0 & 0 & 0 & 0 & 0 & 0 & 0 & 0 \\
\hline Otariidae & 0 & 2 & 0 & 0 & 0 & 0 & 0 & 3 & 1 & 1 & 0 & 0 & 0 & 0 & 0 & 0 & 0 & 0 & 0 & 0 & 0 & 0 & 0 & 0 & 0 & 0 & 0 & 0 & 1 & 1 \\
\hline Odobenidae & 0 & 0 & 1 & 0 & 0 & 0 & 0 & 0 & 1 & l & 0 & 0 & 0 & 0 & 0 & 0 & 0 & 0 & 0 & 0 & 0 & 0 & 0 & 0 & 0 & 0 & 0 & 0 & 0 & 0 \\
\hline Phocidae & 1 & 1 & 0 & 0 & 2 & 0 & 0 & 1 & 3 & 2 & 2 & 1 & 2 & 0 & 0 & 0 & 0 & $0 / 2$ & 0 & 1 & 1 & 1 & 0 & $0 / 1$ & 0 & 0 & $0 / 2$ & 0 & 1 & 1 \\
\hline Pinnarctidion bishopi & $?$ & $?$ & 1 & 0 & 0 & 0 & $?$ & 0 & 1 & 0 & 0 & 0 & 0 & 0 & 0 & 0 & $?$ & 0 & 0 & 0 & $?$ & $?$ & 0 & $?$ & 0 & 0 & $?$ & 0 & 0 & 0 \\
\hline P. rayi & 0 & 0 & 1 & 0 & 0 & 0 & 0 & 0 & 1 & 0 & 0 & 0 & $?$ & 0 & 0 & 0 & 0 & $?$ & $?$ & 0 & $?$ & $?$ & 0 & 0 & 0 & 0 & $?$ & 0 & 0 & 0 \\
\hline Desmatophoca oregonensis & 1 & 1 & 1 & 0 & 0 & 0 & 1 & 0 & 2 & 1 & 1 & 0 & 0 & 1 & 0 & 1 & 0 & 2 & 1 & 0 & 0 & 1 & 1 & 0 & 0 & 1 & 1 & 0 & 1 & 1 \\
\hline D. brachycephala & $?$ & $?$ & 1 & 0 & 0 & 0 & 0 & 0 & 2 & 1 & 1 & 0 & 0 & 1 & 1 & $?$ & 0 & 1 & 0 & 0 & $?$ & $?$ & 1 & 0 & 0 & $?$ & $?$ & 0 & $?$ & $?$ \\
\hline Allodessmus kernensis & 1 & 1 & 1 & 1 & 1 & 1 & 2 & 2 & 2 & 1 & 2 & 0 & 1 & 1 & 0 & 1 & 1 & 2 & 0 & 1 & 1 & 1 & 1 & 1 & 1 & 2 & 2 & 1 & 1 & 1 \\
\hline A. courseni & $?$ & $?$ & $?$ & $?$ & $?$ & $?$ & $?$ & $?$ & $?$ & 1 & 2 & $?$ & 0 & $?$ & 0 & $?$ & $?$ & $?$ & $?$ & $?$ & $?$ & 1 & $?$ & $?$ & 0 & $?$ & $?$ & $?$ & 1 & 1 \\
\hline A. packardi & 1 & 1 & 1 & 0 & 0 & 1 & $?$ & 2 & $?$ & 1 & 2 & 0 & 1 & 1 & $?$ & $?$ & 0 & 2 & 0 & 0 & $?$ & $?$ & $?$ & $?$ & 1 & $?$ & $?$ & 1 & $?$ & $?$ \\
\hline A. sadoensis & $?$ & $?$ & ? & 1 & 1 & 1 & 2 & 2 & 2 & 1 & $?$ & 0 & 1 & 1 & 0 & $?$ & 1 & 2 & $?$ & $?$ & $?$ & $?$ & 1 & 1 & 1 & 2 & $?$ & 1 & 1 & 1 \\
\hline
\end{tabular}

rior and posterior cuspules, finely crenulated lingual cingula, and broadly rounded principal cusps.

Phylogenetic analysis confirms the monophyly of the desmatophocids, which represent a group of early and middle Miocene North Pacific endemic pinnipeds with enlarged paroccipital processes and bulbous-crowned postcanine teeth. The family includes two genera, Desmatophoca and Allodesmus, which together contain at least six described species from the early and middle Miocene. The oldest record of Desmatophocidae is currently established by Desmatophoca brachycephala Barnes, 1987, from the early Miocene (Aquitanian correlative) Astoria Formation of Washington, USA, suggesting that divergence of desmatophocids from phocids likely occurred sometime before $18 \mathrm{Ma}$, probably in the North Pacific Ocean basin.

\title{
Appendix
}

\section{Characters and Character-states for Desmatophocid Pinnipeds and Related Taxa}

\author{
$(0=$ primitive $; 1-3=$ derived $; ?=$ missing $)$
}

1. Premaxilla-nasal contact. $0=$ extensive, $1=$ reduced (Wyss 1987:7, 15, fig. 5).

In Enaliarctos, Pteronarctos, and Pinnarctidion, the premaxilla has a broad area of contact with the nasals on the rostrum (primitive condition). A short, narrow contact between the premaxilla and nasal occurs in Desmatophoca, Allodesmus, and the Phocidae (derived condition) and represents a phocoid synapomorphy.

2. Nasal-frontal suture. $0=$ transverse, $1=V$-shaped, $2=W$ shaped (Deméré, 1994:105, fig. 3).

As discussed by Deméré (1994) the posterior border of the nasal is blunt and nearly transverse in Enaliarctos, Pteronarctos, and Pinnarctidion. Although two derived states are recognized, the homology of the first, a $V$-shaped naso-frontal suture (point of $V$ directed posteriorly between frontals) is questionable. Two variations of this condition are seen: In the dusignathine odobenids (e.g., Gomphotaria and Dusignathus), there is a broad V-shaped suture. In Desmatophoca, Allodesmus, and phocids there is an acute $V$-shaped naso-frontal suture. Otariids display a $W$-shaped naso-frontal suture, in which the frontals extend anteriorly between the nasals at the midline (King, 1983:151, fig. 6.4), identified as derived state 2 .
A posteriori character analysis suggests the evolution of character state 1 in phocoids + Otariidae with transformation to state 2 occurring in the Otariidae (ACCTRAN optimization). Another possibility is the independent evolution of state 1 in the Phocoidea clade with the independent evolution from state 0 to state 2 in the Otariidae (DELTRAN optimization).

3. Laterally expanded pterygoid process of the maxilla. $0=$ absent, 1=present (Barnes, 1979:23).

The pterygoid process of the maxilla is defined by Barnes (1979:23) as a "wide, thin, squared posterolaterally projecting shelf of the palate beneath each orbit." This structure in Desmatophoca brachycephala is described as an expansive pterygoid process of the maxilla that forms a thin infraorbital shelf with a prominent posterolateral comer (Barnes, 1987). Lateral expansion of the pterygoid process also is seen among basal odobenids (e.g., Prototaria; Kohno, 1994). Berta (1991) defined this character differently. She identified the presence of a "palatine shelf' in Pinnarctidion, Desmatophoca, and Allodesmus but recognized it as a further modification (derived state 2) of derived condition 1 , in which the palatine process of the maxilla extends posterior to the last molar. Without further in- 
formation about the homology of these character states, it seems best to represent them as separate characters.

A posteriori character analysis suggests that the derived condition, a laterally expanded pterygoid process of the maxilla evolved at least three times: in basal odobenids, Pinnarctidion, and desmatophocids (Allodesmus and Desmatophoca). The primitive condition seen in all other pinnipeds is the lack of a laterally expanded pterygoid process of the maxilla.

4. Palate. $0=$ relatively flat (palatal arch means of $0.18-0.19$ ), $1=$ transversely arched (palatal arch means greater than 0.25 ) (Deméré, 1994:106; this study).

The palate of pinnipeds varies from relatively transversely flattened to transversely arched. Palatal arch can be quantified as the ratio of the depth of the palate at the midline to the chord length of the transverse arch measured between the lingual alveolar borders of individual right and left tooth positions. Taking ratios for each tooth position (i.e., C, P1-4, M1,2) and computing the mean ratio provides a means for comparison. Palatal arch ratios of $0.15-0.26(x=0.19)$ occur in Desmatophoca oregonensis, $0.14-0.21$ in Desmatophoca brachycephala $(x=$ 0.18 ), and $0.21-0.30$ in Allodesmus kernensis $(x=0.26)$. Palatal arch in $A$. sadoensis measures 0.30 (based upon a single measurement taken at P4). Given these ratios, we define the derived condition, a transversely arched palate as having a palatal arch mean greater than 0.25 . The derived condition occurs in Allodesmus kernensis and A. sadoensis. All other pinnipeds, with the exception of the later-diverging odobenine walruses and the divergent otariid Otaria, are characterized by relatively flat palates (Deméré, 1994) with palatal arch means that range between 0.18 and 0.19 .

5. Lateral wall of alisphenoid canal. $0=$ thick and well defined, $1=$ thin, 2=absent (Barnes and Hirota, 1995; this study).

The lateral wall of the alisphenoid canal is thick and well defined in species of Enaliarctos, Pteronarctos, Pinnarctidion, Desmatophoca, odobenids, and otariids. In the derived condition seen in Allodesmus kernensis and A. sadoensis, the lateral wall is extremely thin when preserved, and it is often lost through postmortem abrasion and/or diagenesis. In those specimens with non-preservation, there is no obvious trace of the wall. Allodesmus packardi retains the primitive condition (Barnes and Hirota, 1995). In phocids, the alisphenoid canal is always absent, identified as derived condition 2 .

6. Dorsal margin of maxillary root of zygomatic arch. $0=$ not retracted dorsal to infraorbital foramen, $1=$ retracted dorsal to infraorbital foramen (Barnes, 1989).

Barnes (1989) observed that species of Allodesmus could be distinguished from those of Desmatophoca by having the dorsal margin of the maxillary root of the zygomatic arch posteriorly retracted dorsal to the infraorbital foramen. Associated with the receding dorsal margin of the zygomatic arch in $\mathrm{Al}$ lodesmus are very large orbits. In Desmatophoca and all other pinnipeds, the dorsal margin of the zygomatic arch flares anteriorly above the anterior opening of the infraorbital canal and forms a "cup" for the eyeball (Barnes, 1987). The derived con- dition is interpreted as a synapomorphy for species of Allodesmus.

7. Incisive foramina. $0=$ divided by medial septum, $l=$ medial septum absent, 2 =foramina reduced (this study).

The incisive foramina in Enaliarctos, Pinnarctidion, Pteronarctos, basal odobenids, and otariids are divided by a distinct medial bony septum. This configuration, representing the primitive condition, also occurs in Desmatophoca brachycephala. In $D$. oregonensis, there is no medial septum developed, and the right and left foramina are joined into a single incisive opening, derived state I. This condition also occurs in the laterdiverging odobenid Dusignathus seftoni. In Allodesmus kernensis and $A$. sadoensis, the incisive foramina are very small and positioned nearly on the intermaxillary suture; derived condition 2.

DELTRAN optimization indicates that the transformation from state 0 to state 2 is a synapomorphy for Allodesmus kernensis and A. sadoensis. ACCTRAN optimization holds that this transformation occurred at the level of Allodesmus and predicts its occurrence in $A$. packardi.

8. Supraorbital process of frontals. $0=$ small, distinct ridge, 1 $=$ extreme reduction or complete absence, $2=$ posteriorly positioned swelling, $3=$ strongly developed (King, 1983, fig. 6.7; Berta and Wyss, 1994; this study).

A small but distinct supraorbital ridge is seen in species of Enaliarctos, Pteronarctos, Desmatophoca, Pinnarctidion, and basal odobenids (e.g., Prototaria). Later-diverging odobenids and phocids are characterized by extreme reduction or complete absence of the supraorbital process, derived state 1 . Allodesmus is characterized by a supraorbital process that is developed as a posterior-placed swelling, derived state 2 . A strongly developed supraorbital process, derived state 3 , occurs only in otariids.

A posteriori character analysis suggests that each of the three derived character states evolved independently from the primitive condition.

9. Paroccipital process. $0=$ small, blunt, $1=$ enlarged and excavated, $2=$ enlarged and not excavated, $3=$ unenlarged and crest-like (this study, Figure 7).

The shape, size, orientation, and relationship of the paroccipital process to surrounding bones have been variously used to distinguish among pinnipeds (e.g., Mitchell, 1968; Repenning and Tedford, 1977). In the primitive condition seen in Enaliarctos, the paroccipital process is small and blunt. Three derived states are recognized. Pteronarctos, Pinnarctidion, basal odobenids, and otariids are characterized by having an enlarged paroccipital process with an excavated ventral surface (derived state 1). Although the paroccipital process in Desmatophoca and Allodesmus is enlarged, the ventral surface is not excavated (derived state 2). The paroccipital process in phocids is unenlarged and crest-like (Muizon and Hendey, 1980:110) (derived state 3 ), a condition that is not homologous with other pinnipeds. 
DELTRAN optimization indicates independent transformations from state 1 to state 0 in Enaliarctos, from state 1 to 2 in the Desmatophocidae, and from state 1 to state 3 in the Phocidae. ACCTRAN optimization indicates transformations from state 1 to state 2 in the Phocoidea and from state 2 to state 3 in the Phocidae.

10. Auditory bulla. $0=$ ectotympanic inflated, $1=$ ectotympanic flattened, $2=$ =ntotympanic inflated (King, 1983, fig. 6.3).

In Enaliarctos, Pteronarctos, and Pinnarctidion, the ectotympanic portion of the bulla is slightly inflated (primitive condition). In Allodesmus, Desmatophoca, the Otariidae, and the Odobenidae, the ectotympanic is flattened, derived condition 1. Only phocids have a greatly inflated entotympanic, derived condition 2 (Wyss, 1987).

11. Squamosal-jugal articulation. $0=$ splint-like, $1=$ mortised zygomatic process expanded posteriorly, $2=$ mortised zygomatic process expanded anteriorly (this study, Figure 9).

Barnes (1979) described the splint-like arrangement of the squamosal and jugal in which the zygomatic portion of the squamosal tapers to a sharp point anteriorly but does not touch the postorbital process of the jugal. This condition, seen in Enaliarctos and otariids, is identified as the primitive condition. In Allodesmus, Desmatophoca, and phocids, the squamosal jugal contact is mortised, an arrangement in which both the postorbital process of the jugal and the zygomatic process of the squamosal are expanded dorsally to form a broad contact. The condition in Pinnarctidion, in which the zygomatic process of the squamosal is only slightly expanded and fits into a shallow notch in the postorbital process of the jugal, has been interpreted as an intermediate stage of mortising (Barnes, 1987; Berta, 1994; Berta and Wyss, 1994). We do not support this earlier conclusion, however, because there is no mutual expansion of both the jugal and squamosal.

Among those pinnipeds that display a mortised contact of the squamosal and jugal, two derived states are recognized. In Desmatophoca, the greatest dorsal expansion of the zygomatic process is positioned posteriorly (derived state 1), whereas in both Allodesmus and phocids the greatest dorsal expansion of the zygomatic process of the squamosal is positioned anteriorly (derived state 2).

A posteriori character analysis suggests that anterior placement of the dorsal expansion evolved in the common ancestor of phocids and desmatophocids, with evolution of the posterior position representing a secondary transformation in Desmatophoca.

12. Jugal-maxillary suture. $0=$ jugal with anterodorsal and anteroventral splints, $1=$ jugal with anterodorsal splint only (Kohno, 1996, listed but not described).

The jugal contacts the maxillary in a deeply interdigitating foliate suture with anterodorsal and anteroventral splints. This is the primitive condition, which occurs in all pinnipeds except phocids. In phocids, the suture is a simple splint with the anterodorsal splint overriding the posteroventral splint of the maxillary, the derived condition. There is no anteroventral splint of the jugal.

13. Styloid process of auditory bulla. $0=$ present, $1=$ absent, 2 = ectotympanic reduced (this study).

The primitive condition of a distinct styloid process of the ectotympanic ventral to the Eustachian tube occurs in all outgroup taxa and Desmatophoca. In Allodesmus kernensis, the styloid process is absent (derived condition 1) and instead the anterior corner of the ectotympanic is retracted posteriorly in the region of the eustachian tube (Figure 6B). In phocids, the entotympanic is greatly enlarged, resulting in reduction of the ectotympanic and reconfiguration of the exit of the eustachian tube (derived state 2 ).

14. Stylomastoid foramen. $0=$ in a common fossa with tympanohyal pit, $1=$ separated by raised strut from tympanohyal (Berta, 1994, listed but not described; this study).

In Desmatophoca and Allodesmus, the stylomastoid foramen is separated from the tympanohyal by a raised bony strut, the derived condition. In all other pinnipeds, the stylomastoid foramen and the tympanohyal lie very close to one another in a common fossa. The derived condition of this character was incorrectly reported in Pinnarctidion (Berta, 1994).

15. Zygomatic arch. $0=$ not widely flared (less than $62 \%$ of condylobasal length), $1=$ widely flared (greater than or equal to $62 \%$ of condylobasal length) (this study).

Although widely flared zygomatic arches have been used to distinguish Desmatophoca brachycephala from all other pinnipeds (Barnes, 1987), this character has not previously been quantified. We redefine this character as zygomatic width relative to condylobasal length (CBL). Zygomatic width measures $65 \%$ of CBL in Desmatophoca brachycephala, $58 \%-60 \%$ in Desmatophoca oregonensis ( $x=59 \%, n=3$ ), $56 \%$ in Enaliarctos emlongi, 54\%-57\% in Allodesmus kernensis ( $x=55 \%, n=3)$, $61 \%$ in Homiphoca capensis (measured from a photograph in Muizon and Hendey, 1980, fig. 3), and 57\% in Piscophoca pacifica (measured from a photograph in Muizon, 1981, pl. 1: fig. 2). Given this range of measurements among fossil pinnipeds, we defined the derived condition as zygomatic arches measuring greater than or equal to $62 \%$ of CBL. By this definition only Desmatophoca brachycephala possesses the derived condition.

16. Tympanic crest. $0=$ present and horizontally continuous, 1 $=$ present and dorsally convergent with petrosal (Mitchell and Tedford, 1973:228).

The tympanic crest (crista tympani) is described as occurring along the lateral wall of the auditory bulla in Enaliarctos mealsi (Mitchell and Tedford, 1973). This is the primitive condition seen in outgroup taxa and Pinnarctidion bishopi (Barnes, 1979). In Desmatophoca oregonensis and Allodesmus kernensis, a narrow crest is evident on the lateral wall of the bulla, beginning at the same position as the tympanic crest (septum between the tympanic opening and the epitympanic recess) and extending anterodorsally toward the promontorium. Although there is some question about the homology of these crests, we 
have coded the condition in Desmatophoca and Allodesmus as derived.

DELTRAN optimization indicates independent characterstate transformations for Desmatophoca oregonensis and for Allodesmus kernensis. ACCTRAN optimization indicates that the derived condition is a synapomorphy for the Desmatophocidae.

17. Infraorbital foramen. $0=$ large, $1=$ small (this study).

The primitive condition, infraorbital foramen large relative to condylobasal length, occurs in Enaliarctos, Pinnarctidion, Desmatophoca, and Allodesmus packardi. The derived condition, a small infraorbital foramen, occurs in Allodesmus kernensis and Allodesmus sadoensis.

18. Squamosal fossa. $0=$ undivided, $1=$ divided, posterior and anterior portions of equal size, 2 =divided, with posterior portion smaller than anterior portion (Barnes, 1987; this study).

As defined by Barnes (1987:11), the squamosal fossa is "the broad recess in the squamosal between the braincase and the zygomatic arch, dorsal to the glenoid fossa, and which floors the temporal fossa." Barnes further noted that the squamosal fossa is relatively wider in Desmatophoca brachycephala than in $D$. oregonensis and other pinnipeds.

We redefine this character as the recess between the anterior border of the preglenoid process of the squamosal and the lambdoidal crest portion of the mastoid process. In addition, we further divide the fossa into anterior and posterior portions. The anterior portion is dorsal to the glenoid fossa and is roughly equivalent to Barnes's characterization of the squamosal fossa. The posterior portion of the squamosal fossa lies above the mastoid process and the external auditory meatus. In the primitive condition seen in Enaliarctos, Pteronarctos, Pinnarctidion, odobenids, and otariids, the squamosal fossa is transversely narrow and continuous (i.e., anterior and posterior portions undivided). In Desmatophoca and Allodesmus, the two portions are divided by a transverse raised bony strut that extends from the lateral wall of the braincase to the middle of the squamosal root of the zygomatic arch. In D. brachycephala, the posterior portion of the fossa is roughly equivalent in size to the anterior portion (derived condition 1 ). In D. oregonensis and Allodesmus kernensis, the posterior portion of the fossa is relatively smaller than the anterior portion (derived condition 2). Basal phocids possess both the primitive condition (e.g., Monachus schauinslandi, SDSNH 18711) and the derived state (e.g., Piscophoca pacifica; Muizon, 1981, pl. 1: fig. 3) (derived condition 2) of this character.

19. External auditory meatus (EAM). $0=$ axis oriented greater than $62^{\circ}, 1=$ axis oriented less than or equal to $62^{\circ}$ (Barnes, 1987; this study).

We quantified this character by measuring the angle that the axis of the EAM makes with the sagittal plane of the skull. This angle measures $75^{\circ}$ in the holotype of D. brachycephala and ranges between $56^{\circ}$ and $61^{\circ}$ in four skulls of $D$. oregonensis ( $x$ $=57.8^{\circ}$ ). Polarization of this character is difficult to assess because of the shortness of the EAM in species of Enaliarctos (the angle measures approximately $72^{\circ}$ in Enaliarctos mitchelli and $70^{\circ}$ in Enaliarctos mealsi). This angle measures $73^{\circ}$ in Pteronarctos, about $67^{\circ}$ in Pinnarctidion bishopi, $64^{\circ}$ in $\mathrm{Al}$ lodesmus kernensis, $70^{\circ}$ in Allodesmus packardi, $78^{\circ}-84^{\circ}$ in otariids ( $84^{\circ}$ in Thalassoleon mexicanus, measured from a photograph in Repenning and Tedford (1977, pl. 20)), and at least $77^{\circ}-85^{\circ}$ in phocids ( $77^{\circ}$ in Mirounga angustirostris (Gill), and $85^{\circ}$ in Homiphoca capensis, measured from a photograph in Muizon and Hendey (1980, fig. 2).

Using these measurements, we define the primitive condition as an EAM axis oriented greater than $62^{\circ}$ to the sagittal plane and the derived condition as an EAM axis oriented less than or equal to $62^{\circ}$. Following this definition, the derived condition occurs only in Desmatophoca oregonensis.

20. Orbit size. $0=$ small (less than or equal to the temporal fossa length, $1=$ intermediate $(110 \%$ to $130 \%$ of temporal fossa length), $2=$ large (greater than $130 \%$ of temporal fossa length) (this study).

We define the orbit as the region from the antorbital rim of the maxilla to the postorbital process of the jugal. We define the temporal fossa as the opening between the anterior border of the preglenoid process of the squamosal and the postorbital process of the jugal. In the primitive condition, the orbit is small, measuring $98 \%$ of the temporal fossa length in Enaliarctos emlongi. In derived condition 1 , the orbit size is $110 \%-130 \%$ of the temporal length (approximately $125 \%$ of the orbit length in D. oregonensis and $119 \%$ in D. brachycephala). In derived condition 2, seen in species of Allodesmus and phocids, the orbit size is greater than $130 \%$ of the temporal fossa length (139\% in A. kernensis, 161\% in A. packardi, 193\% in Piscophoca pacifica (measured from a photograph in Muizon, 1981, pl. 1), and 261\% in Homiphoca capensis (measured from a photograph in Hendey and Repenning, 1972, fig. 5)).

Correlated with relative size of the orbit and temporal fossa is the relative position of the supraorbital process along the interorbital/temporal bar. We have chosen not to recognize this as a separate character because it is directly related to orbit size. Kohno (1996) originally defined this character and distinguished two character states. In the primitive condition, the supraorbital process is located relatively anterior to the orbital rim, whereas in the derived condition the supraorbital process is positioned far posterior on the postorbital bar. The position of the supraorbital process is best described relative to the midpoint of the postorbital bar. In all pinnipeds except species of Allodesmus, the supraorbital process is positioned anterior to the midpoint of the postorbital bar. Allodesmus possesses the derived condition in having the supraorbital process positioned posterior to the midpoint of the postorbital bar.

A posteriori character analysis suggests that derived state 2 evolved independently in phocids and species of Allodesmus. 21. Angular (=pterygoid) process. $0=$ well developed, $1=$ reduced or absent (Berta and Wyss, 1994). 
The angular process is the area for insertion of the internal pterygoid muscle. A well-developed angular process positioned near the base of the mandibular condyle characterizes terrestrial carnivorans, Enaliarctos, Pteronarctos, otariids, odobenids, and Desmatophoca oregonensis. The derived condition of a reduced or absent angular process occurs in monachine phocids and Allodesmus (Berta and Wyss, 1994).

DELTRAN optimization indicates independent transformations of this character state in Allodesmus kernensis and the Phocidae. ACCTRAN optimization indicates that this character transformation evolved in the Phocoidea and that a reversal occurred in Desmatophoca.

22. Flange (=marginal process) below ascending ramus. $0=$ small or absent, l=well developed (Berta, 1991; Deméré, 1994).

The marginal process (Davis, 1964) is the area for insertion of the digastricus muscle on the medioventral margin of the mandible. The process is small in species of Enaliarctos (Berta, 1991), Pteronarctos (Berta, 1994), and basal odobenids (Deméré, 1994). A well-developed flange-like marginal process occurs in Desmatophoca and Allodesmus.

23. I3. $0=$ not procumbent, $1=$ procumbent and laterally directed (this study).

The I3 in Enaliarctos, Pinnarctidion, and Pteronarctos is vertically directed. In Desmatophoca, I3 is procumbent and laterally directed. This tooth is not present among published specimens of Allodesmus, although Barnes (1972:14) mentioned the procumbent roots of this tooth. In a complete skull of Allodesmus kernensis (BVM 0163) with preserved right and left I3, the roots are strongly procumbent and the crowns are laterally directed. The derived condition is a synapomorphy linking Desmatophoca and Allodesinus.

24. Upper canine, crowns with posterior and medial carinae. 0 =present, $1=$ absent (Barnes, 1987).

The posterior and medial margins of the upper canine in Enaliarctos, Pteronarctos, Pinnarctidion, and Desmatophoca are characterized by distinct longitudinal carinae, the primitive condition. Carinae are absent in Allodesmus (Barnes, 1987) and later-diverging odobenids (i.e., Alachtherium, Valenictis, Odobenus), the derived condition. Basal phocids vary in their possession (e.g., Monachus schauinslandi; pers. obs.) or lack of carinae (e.g., Piscophoca pacifica; Muizon, 1981:22).

DELTRAN optimization indicates that the derived condition is a synapomorphy linking Allodesmus kernensis and Allodesmus sadoensis. ACCTRAN optimization indicates that the derived condition is a synapomorphy uniting species of Allodesmus.

25. Upper postcanine teeth. $0=$ triple/double rooted, $1=$ single rooted (Barnes, 1972).

The derived condition, single-rooted upper postcanine teeth (except for P1, which is always single rooted) occurs in $\mathrm{Al}$ lodesmus kernensis, $A$. packardi (Barnes, 1972), and $A$. sadoensis. All other pinnipeds (except later-diverging odobenids and otariids) retain the primitive condition of having multiple- rooted cheek teeth. Although the upper postcanine teeth are not present (or are hidden in matrix) in the holotype of $A$. courseni, the left $\mathrm{p} 4$ and right $\mathrm{p} 3$ are clearly double rooted, suggesting that the upper teeth also were double rooted (pers. obs.).

26. $\mathrm{Pl}-3$ crowns. $0=$ narrow lingual cingula without numerous cuspules/crenations, $1=$ well-developed cingula with numerous cuspules/crenations, $2=$ no cingula, no cuspules/crenations (this study).

In Enaliarctos emlongi and E. mitchelli, P1-3 have distinct but narrow lingual cingula without any cingular cuspules, the primitive condition. In Desmatophoca oregonensis, these teeth have well-defined cingula surrounding the lingual border of the principal cusp, and a series of small cuspules/crenations characterizes the edge of these cingula (derived condition 1). In Allodesmus kernensis, there is no cingulum nor cuspules/crenations on P1-3 (derived condition 2). Instead, the lingual profile of the crown is smoothly concave from tip to base. Barnes (1972) and other workers have described the postcanine teeth of this taxon as bulbous, referring to the swollen base of the tooth crown. The term is misleading, however, and the more significant feature is the lack of a cingulum.

DELTRAN optimization indicates independent character transformations from state 0 to state 1 in Desmatophoca oregonensis and from state 0 to state 2 in Allodesmus kernensis + A. sadoensis. ACCTRAN optimization indicates transformation from state 0 to state 1 as a synapomorphy for the Desmatophocidae clade, with transformation from state 1 to state 2 as a synapomorphy supporting the monophyly of the genus $\mathrm{Al}$ lodesmus.

27. $\mathrm{p} 2-4$ crowns. $0=$ anterior and posterior cuspules trenchant, $1=$ cuspules conical, $2=$ cuspules absent (this study).

In Enaliarctos emlongi, the crowns of p2-4 are characterized by a principal cusp (protoconid?) flanked by an anterior (paraconid?) and posterior (metaconid?) trenchant cusp/cuspule. This represents the primitive condition. In Desmatophoca oregonensis, the anterior and posterior cusps/cuspules are conical (derived condition 1). In Allodesmus kernensis, the tooth crowns are smooth and lack cusps/cuspules (derived condition 2). Derived condition 2 also applies to later-diverging members of other pinniped groups except phocids.

DELTRAN optimization indicates independent transformations from state 0 to state 1 in Desmatophoca oregonensis and from state 0 to state 2 in Allodesmus kernensis. ACCTRAN optimization indicates transformation from state 0 to state 2 as a synapomorphy uniting the Phocoidea clade with a second transformation from state 2 to state 1 occurring in the Desmatophocidae.

28. Upper postcanine tooth roots. $0=$ vertical, $1=$ inclined (Barnes, 1989; this study).

In all outgroup taxa, as well as in Desmatophoca and phocids, the roots of the upper postcanine teeth are oriented vertically in the maxillary, the primitive condition. In the derived condition seen in Allodesmus kernensis, A. packardi, and A. sadoensis, the postcanine roots are ventrolaterally inclined. 
29. P4 metacone. $0=$ distinct, $1=$ reduced or absent $($ Berta, 1994).

In Enaliarctos, Pteronarctos, Pinnarctidion, and basal odobenids, $\mathrm{P} 4$ has a distinct metacone, representing the primitive condition. In Allodesmus, Desmatophoca, otariids and phocids, as well as later-diverging odobenids, the metacone is reduced or absent on the upper carnassial (Berta, 1994), the derived condition.

30. P4, protocone shelf. $0=$ present $1=$ absent (Barnes, 1979).
The presence of a protocone shelf on the upper carnassial has been used to distinguish Enaliarctos and Pteronarctos from all other pinnipedimorphs (Barnes, 1979, 1989). The shelf-like protocone is an ursid+pinnipedimorph synapomorphy (Flynn et al., 1988; Berta et al., 1989) seen in Enaliarctos, Pteronarctos, Pinnarctidion, and basal odobenids. The derived condition, absence of the $\mathrm{P} 4$ protocone shelf, occurs in otariids, Desmatophoca, Allodesmus, later-diverging odobenids, and phocids.

\section{Literature Cited}

Addicott, W.A.

1976. Neogene Molluscan Stages of Oregon and Washington. In A.E. Fritsche, H. Ter Best, Jr., and W.W. Wornardt, editors, The Neogene Symposium. Society of Economic Paleontologists and Mineralogists, Annual Meeting, Pacific Section, pages 95-116.

Armentrout, J.M.

1981. Correlation and Ages of Cenozoic Stratigraphic Units in Oregon and Washington. Geological Society of America Special Paper, 184: 137-148.

Barnes, L.G.

1972. Miocene Desmatophocinae (Mammalia: Carnivora) from California. University of California Publications in Geological Sciences. 89: 68 pages.

1979. Fossil Enaliarctine Pinnipeds (Mammalia: Otariidae) from Pyramid Hill, Kern County, California. Contributions in Science, Natural History Museum of Los Angeles County, 318: 41 pages.

1987. An Early Miocene Pinniped of the Genus Desmatophoca (Mammalia: Otariidae) from Washington. Contributions in Science, Natural History Museum of Los Angeles County, 382: 20 pages.

1989. A New Enaliarctine Pinniped from the Astoria Formation, Oregon, and a Classification of the Otariidae (Mammalia: Carnivora). Contributions in Science, Natural History Museum of Los Angeles County, 403: 26 pages.

Barnes, L.G., and K. Hirota

1995. Miocene Pinnipeds of the Otariid Subfamily Allodesminae in the North Pacific Ocean: Systematics and Relationships. The Island Arc, 3:329-360.

Berta, A

1991. New Enaliarctos (Pinnipedimorpha) from the Oligocene and Miocene of Oregon and the Role of "Enaliarctids" in Pinniped Phylogeny. Smithsonian Contributions to Paleobiology, 69:1-33.

1994. A New Species of Phocoid Pinniped Pinnarctidion from the Early Miocene of Oregon. Joumal of Vertebrate Paleontology, 14:405-413.

Berta, A., C.E. Ray, and A.R. Wyss

1989. Skeleton of the Oldest Known Pinniped, Enaliarctos mealsi. Science, 244:60-62.

Berta, A., and A.R. Wyss

1994. Pinniped Phylogeny. In A. Berta and T.A. Deméré, editors, Contributions in Marine Mammal Paleontology Honoring Frank C. Whitmore, Jr. Proceedings of the San Diego Society of Natural History, 29:33-56.

Condon, $\mathrm{T}$.

1906. A New Fossil Pinniped (Desmatophoca oregonensis) from the Miocene of the Oregon Coast. University of Oregon Bulletin, suppleDavis, D.D. ment, 3(3): 14 pages.

1964. The Giant Panda: A Morphological Study of Evolutionary Mechanisms. Fieldiana: Zoology Memoirs, 3: 334 pages.
Deméré, T.A.

1994. The Family Odobenidae: A Phylogenetic Analysis of Fossil and Living Taxa. In A. Berta and T.A. Deméré, editors, Contributions in Marine Mammal Paleontology Honoring Frank C. Whitmore, Jr. Proceedings of the San Diego Society of Natural History, 2:99123.

Dooley, A.C., Jr.

1994. The First Well Preserved Squalodont (Cetacea) from the West Coast of North America. Journal of Vertebrate Paleontology, supplement, 14(3):23A.

Doutt, J.K.

1942. A Review of the Genus Phoca. Annals of the Carnegie Museum, 29:61-125.

Downs, T.D.

1956. A New Pinniped from the Miocene of Southem California. Journal of Paleontology, 30:115-131.

Flynn, J.J., N.N. Neff, and R.H. Tedford

1988. Phylogeny of the Carnivora. In M.J. Benton, editor, The Phylogeny and Classification of the Tetrapods, 2:73-116. Oxford: Clarendon Press.

Hay, O.P.

1930. Second Bibliography and Catalogue of the Fossil Vertebrata of North America. Two volumes, 1074 pages. Washington, D.C.: Carnegie lnstitution of Washington.

Hendey, Q.B., and C.A. Repenning

1972. A Pliocene Phocid from South Africa. Annals of the South African Museum. 59:71-98.

Howell, A.B.

1929. Contribution to the Comparative Anatomy of the Eared and Earless Seals (Genera Zalophus and Phoca). Proceedings of the United States National Museum, 73:1-142.

1930. Aquatic Mammals. 338 pages. Springfield, Illinois: Charles C. Thomas.

Kellogg, R.

1922. Pinnipeds from the Miocene and Pleistocene of California. University of California Publications in Geological Sciences, 13:23-132.

1931. Pelagic Mammals from the Temblor Formation of the Kern River Region, California. Proceedings of the California Academy of Sciences, series 4, 19:217-397.

King, $\mathrm{J}$.

1972. Observations on Phocid Skulls. In R.J. Harrison, editor, Functional Anatomy of Marine Mammals, 1:81-115. London: Academic Press.

1983. Seals of the World. Second edition, 240 pages. Ithaca, New York: Cornell University Press.

Kohno, N.

1994. A New Miocene Pinniped in the Genus Prototaria (Camivora: Odobenidae) from the Moniwa Formation Miyagi, Japan. Journal of Vertebrate Paleontology, 14:414-426. 
1996. Miocene Pinniped Allodesmus (Mammalia: Carnivora); with Special Reference to the "Mito Seal" from Ibaraki Prefecture, Central Japan. Transactions and Proceedings of the Palaeontological Society of Japan, new series, 181:388-404.

Kohno, N., L.G. Bames, and K. Hirota

1995. Miocene Fossil Pinnipeds of the Genera Prototaria and Neotherium (Carnivora; Otariidae; Imagotariinae) in the North Pacific Ocean: Evolution, Relationships, and Distribution. The Island Arc, 3: 285-308.

Mitchell, E.

1961. A New Walrus from the Imperial Pliocene of Southern California: with Notes on Odobenid and Otariid Humeri. Contributions in Science, Los Angeles County Museum, 44: 28 pages.

1966. The Miocene Pinniped Allodesmus. University of California Publications in Geological Sciences, 61:1-46.

1968. The Mio-Pliocene Pinniped Imagotaria. Journal of the Fisheries Research Board of Canada, 25:1843-1900.

1975. Parallelism and Convergence in the Evolution of Otariidae and Phocidae. Rapports et Proces-verbaux des Réunions Conseil International pour l'Exploration de la Mer, 169:12-26.

Mitchell, E.D., and R.H. Tedford

1973. The Enaliarctinae, a New Group of Extinct Aquatic Camivora and a Consideration of the Otariidae. Bulletin of the American Museum of Natural History, 151:201-284.

Muizon, C. de

1981. Les vertébrés fossiles de la formation Pisco (Pérou); Recherche sur les grandes civilisations. Mémoires de l'Institut Français d'Études Andines, 6: 150 pages.

Muizon, C. de, and Q.B. Hendey

1980. Late Tertiary Seals of the South Atlantic Ocean. Annals of the South African Museum. 82:91-128.

Munthe, J., and M.C. Coombs

1979. Miocene Dome-Skulled Chalicotheres (Mammalia, Perissodactyla) from the Western United States: A Preliminary Discussion of a Bizarre Structure. Journal of Paleontology, 53:77-91.

Packard, E.L.

1947. A Pinniped Humerus from the Astoria Miocene of Oregon. Oregon State Monographs, Studies in Geology (Oregon State College, Corvallis), 7:23-32

Packard, E.L., and R. Kellogg

1934. A New Cetothere from the Miocene Astoria Formation of Newport, Oregon. Carnegie Institution of Washington Publication, 447:1-62.
Queiroz, K. de, and J. Gauthier

1990. Phylogeny as a Central Principle in Taxonomy: Phylogenetic Definitions of Taxon Names. Systematic Zoology, 39:307-322.

Ray, C.E.

1977. Fossil Marine Mammals of Oregon. Systematic Zoology, 25:420-436.

Repenning, C.A.

1976. Adaptive Evolution of Sea Lions and Walruses. Systematic Zoology 25:375-390.

Repenning, C.A., and R.H. Tedford

1977. Otarioid Seals of the Neogene. U.S. Geological Survey Professional Paper, 992:1-93.

Ronald, K., and P.J. Healey

1981. Harp Seal, Phoca groenlandica Erxleben, 1777. In S.A. Ridgway and R.J. Harrison, editors, Handbook of Marine Mammals, 2: Seals, pages 55-87. San Francisco: Academic Press.

Rowe, $\mathrm{T}$.

1988. Definition, Diagnosis, and Origin of Mammalia. Journal of Vertebrate Paleontology, 8:241-264.

Siversten, E.

1954. A Survey of Eared Seals (Family Otariidae) with Remarks on the Antarctic Seals Collected by M/K "Norvegia" in 1928-1929. Det Vorske Videnskaps-Akademii Oslo, 36:1-76.

Snavely, P.D., Jr., N.S. MacLeod, and H.C. Wagner

1973. Miocene Tholeiitic Basalts of Coastal Oregon and Washington and Their Relations to Coeval Basalts of the Columbia Plateau. Bulletin of the Geological Society of America, 84:387-424.

Swofford, D.L.

1998. PAUP*: Phylogenetic Analysis Using Parsimony ( ${ }^{*}$ and Other Methods), Version 4.0. Sunderland, Massachusetts: Sinauer Associates.

Turner, D.L.

1970. Potassium-Argon Dating of Pacific Coast Miocene Foraminiferal Stages. In O.L. Bandy, editor, Radiometric Dating and Paleontological Zonation. Geological Society of America Special Paper, 124: $91-129$

Wyss, A.R.

1987. The Walrus Auditory Region and Monophyly of Pinnipeds. American Museum Novitates, 2924: 38 pages.

Wyss, A.R., and J.J. Flynn

1993. A Phylogenetic Analysis and Definition of the Carnivora. In F.S. Szalay, M.J. Novacek, and M.C. McKenna, editors, Mammal Phylogeny, pages 32-52. Berlin: Springer-Verlag. 



\title{
The Fossil Monk Seal Pontophoca sarmatica (Alekseev) (Mammalia: Phocidae: Monachinae) from the Miocene of Eastern Europe
}

\author{
Irina A. Koretsky and Dan Grigorescu
}

\begin{abstract}
We present a phylogenetic analysis of the middle Miocene European seal Pontophoca sarmatica (Alekseev) based upon characters of the mandible, humerus (both described herein for the first time), and femur. The diagnoses of the subfamily Monachinae and the genus Pontophoca are emended to include the postcranial characters. Pontophoca, as revised, is proposed as the sister group of the modern Monachus and is included in the monophyletic subfamily Monachinae. We also include in this subfamily two extinct taxa that occur in both the eastern United States and western Europe: Callophoca and Pliophoca.
\end{abstract}

\section{Introduction}

The purpose of this study is to clarify the taxonomic status of Pontophoca sarmatica (Alekseev, 1924) in light of new material found in the last 30 years and of previously undescribed bones in various European collections.

The most numerous fossil remains of true, or earless, seals (Phocidae) in the Old World have been found in the middle Sarmatian-Maeotian, and probably Pontian, deposits of the European part of the former USSR, especially in the northern coastal region of the Black Sea in Ukraine, Moldavia, and Romania. In this study we seek to improve the state of knowledge of Monachinae of the middle Sarmatian and Maeotian, and possibly of the early Sarmatian and Pontian, as well as (within limits) of the subfamily as a whole. We also present a phylogenetic analysis and classification based upon morphological characters of the mandible, humerus, and femur of the Monachinae.

The age of the material of Pontophoca sarmatica was con-

Irina A. Koretsky, Research Associate, Department of Paleobiology, National Museum of Natural History. Smithsonian Institution, Washington, D.C. 20560-0121, United States. Dan Grigorescu, Faculty of Geography-Geology, Laboratory of Paleontology-Stratigraphy. University of Bucharest, Romania. sidered to be late Tertiary by Eichwald (1850) and von Nordmann (1858-1860), whereas Andrusov (1893) specified the age more precisely as Upper Miocene (Sarmatian).

Further studies on Sarmatian marine mammals were made early in the last century. Alekseev $(1924,1926)$ described two new species, Phoca sarmatica and Phoca novorossica. About the same time, in his study of true seals of the northern littoral region of the Black Sea, Simionescu (1925) also described two other species-P. maeotica and $P$. pontica. As can be judged by the illustrations of the femur in his study (pl. 1: fig. 2), Simionescu included in "P." pontica the seal described previously by Alekseev (1924) as $P$. sarmatica and noted that these finds date from the Sarmatian period. Following Simionescu (1925), Macarovici and Oescu (1942) and Macarovici (1942) published short reviews of information on fossil seals of the European Sarmatian, which only confused the picture.

Meanwhile, Kretzoi (1941), who tried to classify the Neogene seals of this region, proposed three new genera: Praepusa, Pontophoca, and Monachopsis. The importance of Kretzoi's work is that he attempted for the first time to make comparisons of previously known fossil material. Unfortunately, he did not succeed completely.

King (1956), in her monographic review of monk seals, presented the first description of bones of the postcranial skeleton as well as descriptions and measurements of the skulls and mandibles of modern species of Monachinae. Of special interest in this context is an article by McLaren (1960), who, on the basis of previous publications, revised the two subfamilies of true seals of the northern Black Sea coastal region of the former USSR. King (1964), in the first edition of her monograph on seals of the world, presented her conception of fossil seals of the Miocene of the northern Black Sea coastal region, separating them into four species of Phoca and two other species referred to Monotherium and Pontophoca. Subsequently, King (1983) changed her views on classification of the true seals, but she considered only their classification above the rank of tribe. Grigorescu (1977), in his article on the seals of 
Paratethys, presented a detailed description of postcranial bones from southern Romania. He also discussed the evolution and phylogeny of Sarmatian seals. Miocene seals in the Northern Hemisphere were reviewed by Ray (1977), who also considered routes of penetration of Phocidae into the North Atlantic during the Neogene.

ACKNOWLEDGMENTS. - The authors thank all persons and scientific organizations who permitted access to paleontological and osteological materials, helped on expeditions, and aided in the writing of this study, especially Y.A. Semenov and S.I. Ivanova, both from the Paleontological Museum of the Ukrainian Academy of Sciences, Kiev, Ukraine, and A.A. Antoniuk from the Military Medical Academy, Saint Petersburg, Russia. We thank Ann Forstén and Mikael Fortelius, both of the Museum of Zoology, Helsinki, Finland, for loan of fossil seals from the Nordmann collection. D. Domning, of Howard University, Washington, D.C., and Diana Lipscomb, of George Washington University, Washington, D.C., reviewed the manuscript at various stages and made many helpful suggestions.

REPOSITORIES.-The following abbreviations are used for institutions housing specimens used in this study:

\begin{tabular}{|c|c|}
\hline IZUAN & $\begin{array}{l}\text { Institute of Zoology (named after I.I. Shmalhausen) of the } \\
\text { Academy of Sciences of the Ukraine, Kiev }\end{array}$ \\
\hline $\mathrm{JaU}$ & Department of Geology, University of Jassy, Romania \\
\hline MZHF & Museum of Zoology, Helsinki, Finland \\
\hline OGUM & $\begin{array}{l}\text { Paleontological Museum (named after I.I. Mechnikov), } \\
\text { Odessa State University, Ukraine }\end{array}$ \\
\hline PIN & $\begin{array}{l}\text { Paleontological Institute of the Academy of Sciences of Rus- } \\
\text { sia, Moscow }\end{array}$ \\
\hline TGPI & ate Pedagogical Institute, Moldavia \\
\hline UBFG & $\begin{array}{l}\text { Ity of Geography-Geology, University of Bucharest, Ro- } \\
\text { a }\end{array}$ \\
\hline USNM & $\begin{array}{l}\text { Collections of the National Museum of Natural History, } \\
\text { Smithsonian Institution, Washington, D.C. (includes collec- } \\
\text { tions of the former United States National Museum) }\end{array}$ \\
\hline ZIN & $\begin{array}{l}\text { Zoological Institute of the Academy of Sciences of Russia, } \\
\text { Saint Petersburg }\end{array}$ \\
\hline ZKM & $\begin{array}{l}\text { Zaporozhye Museum of Regional Studies, Zaporozhye, } \\
\text { Ukraine }\end{array}$ \\
\hline
\end{tabular}

\section{MATERIAL AND METHODS}

For solving diagnostic problems, we used the methods of Astanin (1936), Chapskii (1952, 1967), and Antoniuk (1970, 1972). Morphometric analysis of skulls and mandibles was based upon the methods of Chapskii $(1955,1974)$, Semenov (1981), Andreescu and Murariu (1985), and the methods described below. Bones of the postcranial skeleton and skulls of both Miocene and extant Monachinae were measured according to the schemes of Marcoci and Popa (1957), Dornesco and Marcoci (1958), Sergienko (1967), Piérard (1971), Driesch (1976), Muizon (1981), Antoniuk and Koretsky (1984), Koretsky (1987), and Koretsky and Ray (1994). Anatomical terminology follows the International Anatomical Nomenclature edited by Michaylov (1980), the Anatomical Atlas by Sinelnikov (1963), and Piérard (1971).
The information presented below on geographic location and geologic age of the finds as well as on collectors and institutional repositories is compiled from data published by Kellogg (1922), Pidoplichko (1956), Gromova et al. (1962), Godina (1973), Dubrovo and Kapelist (1979), Korotkevich et al. (1985), and Semenenko (1987) and from our unpublished data.

In this study we use the stratigraphic scheme of eastern Paratethys published by Chepalyga et al. (1985).

This cladistic study is intended to clarify the phylogenetic relationships among modern and fossil species of monachine seals. Six species of Monachinae were analyzed, along with one species of Cystophorinae (Cystophora cristata) and one species of Phocinae (Leptophoca lenis) as outgroups, using 48 cranial and postcranial morphological characters. Originally, 62 characters were examined, but 14 were eliminated because they could not be examined in the fossil taxa. The 48 informative characters were analyzed with the Hennig 86 computer program (Farris, 1988).

\section{Systematic Paleontology}

\section{Superfamily PHOCOIDEA Smirnov, 1908}

\section{Family PhOCIDAE Gray, 1825}

\section{Subfamily MonaCHINAE Trouessart, 1897}

TYPE GENUS.-Monachus Fleming, 1822; present distribution: Mediterranean Basin, Atlantic Ocean (North Africa), Hawaiian Islands, Gulf of Mexico, Caribbean Sea (probably extinct in the last two areas).

DisTRIBUTION.-Middle Miocene to the present; Mediterranean Basin, North Atlantic, North Pacific, Antarctic region.

EMENDED DIAGNOSIS.-Large seals with eight incisors (I= $2 / 2$ ). Mastoid with wide convexity; convexity not strongly laterally protruding and not turned abruptly downward behind mastoid process (King, 1966). Maxilla anterior to orbits slightly concave. Anterior palatal foramen tending to disappear, according to Chapskii (1974). Mandibular chin prominence present; posterior symphysis border reaching at least to middle of alveolus for $\mathrm{p} 3$. Middle of internal crest of humeral trochlea raised arch-like over coronoid fossa; width of distal epiphysis exceeding width of proximal epiphysis by one-fifth to one-sixth. Width of distal femoral epiphysis greater than that of proximal epiphysis by one-quarter to one-fifth; minimum width of femoral shaft more than two-thirds of the proximal epiphysis width; intertrochanteric crest weakly developed.

INCLUDED TRIBES.-Monachini Scheffer, 1958; Lobodontini Scheffer, 1958.

COMPARISONS.-The interorbital width at the frontal bones in Monachinae is wider than in Phocinae, although not as wide as in Cystophorinae. The anterior part of the frontal has a fossa that is directed medially. On the midline at the fronto-nasal suture is the origin of the very low sagittal crest, which is completely absent in the other two subfamilies. In contrast to the 
condition in Cystophorinae, the part of the maxilla located between the nares and orbits is wide. Just as in Phocinae, an interval is present between the external auditory meatus and the postglenoid process. The jugal bone, as in Cystophorinae, has an antero-orbital process. The bolster-like convexity of the mastoid is strongly compressed and is directed laterally. The anterior palatal foramina tend to disappear.

The symphyseal part of the mandible is very strongly developed; it is straight and its posterior edge is considerably displaced posteriorly relative to its position in the other subfamilies.

The middle of the crest of the humeral trochlea, unlike that in Phocinae, is arch-like in shape and raised over the coronal foramen.

Both distal condyles of the femur are of equal dimensions, unlike those in Phocinae. The difference in width of the distal and proximal epiphyses is significant.

DISCUSSION.-Up to the present there has been no clear conception of the relationships within this subfamily. Previously, in accordance with the classification of Trouessart (1897), the subfamily Monachinae contained the genera Lobodon Gray, 1844; Ommatophoca Gray, 1844; Hydrurga Gistel, 1848; and Leptonychotes Gill, 1872. Simpson (1945), however, placed Lobodon and the other three genera mentioned above in the subfamily Lobodontinae. Placement of these four genera is still a controversial problem. One group of investigators has assigned them to a single subfamily (Ognev, 1935; Grassé, 1955; King, 1964, 1983; Tedford, 1977; Muizon, 1982), whereas others (Wyss, 1988; Muizon, 1992) have separated them into two subfamilies. Finally, some investigators (Sokolov, 1979; Pavlinov and Rossolimo, 1987; Wozencraft, 1989) have chosen not to separate true seals (Phocidae) into subfamilies at all.

Chapskii $(1955,1961,1971,1974)$ presented a comprehensive series of analyses of the suprageneric systematics of pinnipeds. Analyzing the crania, he clearly described diagnostic characters that separate true seals into three subfamilies: Phocinae, Monachinae, and Cystophorinae, which he in turn divided into tribes and subtribes. This is also true for the tribes Monachini and Lobodontini. Chapskii's (1974) detailed analysis proved King's (1966) hypothesis to be untenable; however, King (1983) persisted in her hypothesis that the genus Cystophora should be transferred from the subfamily Cystophorinae into the subfamily Phocinae, and that the genus Mirounga should be moved into the subfamily Monachinae. It may be assumed that Muizon (1982) was unaware of the study by Chapskii (1974) because he accepted the systematics of King $(1964,1966)$ without any reservations, and thus he returned to the concept of subdivision of the subfamily Cystophorinae.

Chapskii's concept is supported by the conclusion of Robinette and Stains (1970) in their comparative study of the pinniped calcaneus. These authors emphasized that it is inadmissible to separate the hooded seal and the elephant seal taxonomically. This point of view was supported by Anbinder $(1980: 76)$ who noted that "modern analytical methods of chro- mosome investigations actually do not permit the separation of genera Cystophora and Mirounga, and this contrasts with the concept of their separate taxonomic status and of inclusion of Cystophora in Phocinae." In our view, the problem of the status of the Cystophorinae is solved, and we support Chapskii's point of view that the subfamily Cystophorinae is valid.

\section{Tribe Monachini Scheffer, 1958}

TYPE GenUS.-Monachus Fleming, 1822; present distribution: Mediterranean Basin, southern North Atlantic, North Pacific.

DISTRIBUTION.-Middle Miocene to the present; Europe, southern North Atlantic, North Pacific.

DIAGNOSIS.-Maxillary process of jugal bone clearly outlined. Lower edge (masseteric margin) of jugal bone arched upward, elevated to greatest degree in middle part of bone. Antero-upper process of jugal bone reaching level of infraorbital foramen, terminating almost over inferior edge of infraorbital foramen. Lower edge of orbit at same level as infraorbital foramen.

Nasal bones not united with each other; frontal contact of nasals not longer than maxillary contact. Turbinals (fontanelles) in presphenoid region huge and round (see Chapskii, 1971:311).

INCLUDED GENERA.—Monachus Fleming, 1822; Monatherium Van Beneden, 1877; Callophoca Van Beneden, 1877; Pliophoca Tavani, 1941; Pontophoca Kretzoi, 1941.

COMPARISONS.-Representatives of the Monachini are distinguished from the Lobodontini by (1) an arch-like bending of the jugal bone, (2) the position of the infraorbital foramen on a level with the greatest deflection of the upper border of the jugal bone, and (3) separate nasal bones.

DISCUSSION.-Several other genera were earlier included in the Monachinae, but now these assignments are considered uncertain or even wrong. We review the status of some of them below; Mesotaria Van Beneden (1877) and Pristiphoca Gervais and Serres (1847) will be discussed in detail by Koretsky and Ray (in prep.).

Although the author of "Miophoca" vetusta (Zapfe, 1937), as well as Simpson (1945), Thenius (1950, 1952), King (1964), and Holec et al. (1987), assigned this western European genus to the subfamily Monachinae and dated it to the middle Miocene, other investigators (Kirpichnikov, 1961; Ray, 1977; Muizon, 1982; Savage and Russell, 1983) did not mention this genus at all in their reviews of Tertiary seals of Europe. Thenius $(1950,1952)$ assigned this species to Pristiphoca, and Holec et al. (1987) supported the opinion of Thenius with new cranial remains from Devinská Nová, Slovakia. The uncertainty of the taxonomic position is because of the incompletely known morphology of "Miophoca," which also precludes a detailed comparison between "Miophoca" and Pontophoca. It should be pointed out, however, that in accord with the opinion of Zapfe (1937), the very distinctive, characteristic morphotype 
of the mandible shows that representatives of the genus "Miophoca" are undoubtedly ancestral to Cystophora. The problem of whether "Miophoca" belongs in the subfamily Monachinae still remains open, however.

\section{Genus Monachus Fleming, 1822}

EMENDED Diagnosis.-Condylobasal length of skull not exceeding $200 \mathrm{~mm}$. Facial part of skull markedly lower than occipital part, and with large infraorbital processes. P1 single rooted. Diastemata between teeth absent. Basal cingulum well developed. Main cusp on all cheek teeth sharp-triangular in form. Supplementary cusps weakly developed. Carotid canal displaced almost to bottom of triangular tympanic bulla. Bony blade of external auditory meatus relatively weakly developed. Foramen ovale more or less covered by hamular process of sphenoid bone. Transverse measurement of glenoid fossa of mandible equal to or slightly exceeding longitudinal dimension of tympanic bulla. Jugular process not conjoined with mastoid process, and with a convexity on anterolateral part.

Deltoid crest of humerus short, not reaching middle of the shaft, and distended in proximal quarter; lesser tubercle oval shaped, with height exceeding height of head; head flattened proximodistally; ratio of width to height of head greater than 0.90 ; intertubercular sulcus narrow and deep; epicondyles strongly developed; distal epiphysis wider than the proximal epiphysis; coronoid fossa shallow.

Greater trochanter of femur slightly higher than femur head and square in form; slightly distended in proximal part; trochanteric fossa shallow, rounded, and ending in anterior onethird of trochanter. Minimal width of shaft in middle of femur. Distal condyles similar in size and placed widely apart; maximal distance across epicondyles 0.61 times length of femur; intercondylar area flat; distal end of femur wider than proximal end by $\sim 115 \%$.

DISCUSSION.- This is the first time that characters of the humerus and femur have been included in the diagnosis of Monachus, except for the short general description by King (1956: $239,241)$. Because the material of the other fossil taxa needed for analysis is totally lacking or is fragmentary, we cannot make a more detailed comparison with genera in the tribe Monachini. For example, there is no information on skull fragments, mandibles, or femora of the genus Monatherium, and the fossils assigned to Paleophoca represent a cetacean (Koretsky and Ray, in prep.).

\section{Genus Pontophoca Kretzoi, 1941}

TYPE SPECIES._Phoca sarmatica Alekseev, 1924; middle Sarmatian of Kishinev.

Distribution.-Middle Miocene of eastern Europe.

EMENDED DIAGNOSIS. - p3 and p4 double rooted, placed parallel to the tooth-row axis. Protoconid on $\mathrm{p} 4$ triangular. Di- astemata present. Metaconid and basal cingulum weakly developed.

Deltoid crest of humerus terminating lower than middle of shaft; proximal part of crest recurved posterodorsally; distal end of bone considerably wider than proximal end; lesser tubercle located higher than proximal end of deltoid crest and head; ratio of width to height of head about 1.00; supracondylar crest strongly developed.

Greater trochanter of femur slightly higher than head and very oblique; distal end of greater trochanter narrower than proximal end. Distal end of femur broader than proximal end by $111 \%-114 \%$; trochanteric fossa shallow and elongated along femur axis; head of femur very small relative to massive bone and seated on narrow neck; minimal width of shaft located in proximal part of femur between head and distal part of greater trochanter; distal condyles widely separated; maximal distance across epicondyles $\sim 70 \%$ of femur length.

INCLUDED SPECIES.-In the middle Sarmatian of the northern Black Sea littoral region, only one monachine species (the type species) is recorded-"Phoca" sarmatica from Moldavia and possibly from the middle part of the Don River (Alekseev, 1924).

COMPARISONS.-Among the modern and fossil representatives of the subfamily Monachinae, the extinct genus Pontophoca can be compared only with Monachus, Pliophoca, Callophoca, and partly with Monatherium. It differs from all of these taxa as follows: (1) The teeth are oriented parallel to the axis of tooth row, with diastemata between the teeth; cheek teeth have one anterior and one posterior accessory cusp (except in $M$. monachus); basal cingulum is weakly developed (except in Monachus). (2) The deltoid crest of the humerus is shorter (except in Monachus); the distal part of the deltoid crest is narrow, and the proximal part is averted posterodorsally; the development of a coronoid fossa and intertubercular sulcus is rudimentary (except in Callophoca and Monatherium); the lesser tubercle is elongated; the head is more spherical; the development of the medial supracondyles is relatively stronger. (3) The medial border of the femoral body is distended; the supracondyles are of different heights and are thickened at the points of attachment of both heads of the gastrocnemius muscle; the lateral supracondyle, however, is thickened only at the point of attachment of $m$. extensor digitorum longus.

Apart from these characters, this genus differs from Monatherium as follows: the width of the distal end of the humerus is greater than that of the proximal end; the lesser tubercle extends above the head and above the proximal part of the deltoid crest; and development of the lateral epicondyloid crest is considerably stronger.

It differs from Pliophoca as follows: The body of the mandible is higher. The lesser tubercle extends above the head of the humerus; the radial sulcus is absent; the deltoid crest is widest in its proximal part. The trochanteric fossa of the femur is shallow and wide; the least width of the shaft is in the proximal part of the bone; and the condyles are widely spaced and flat. 


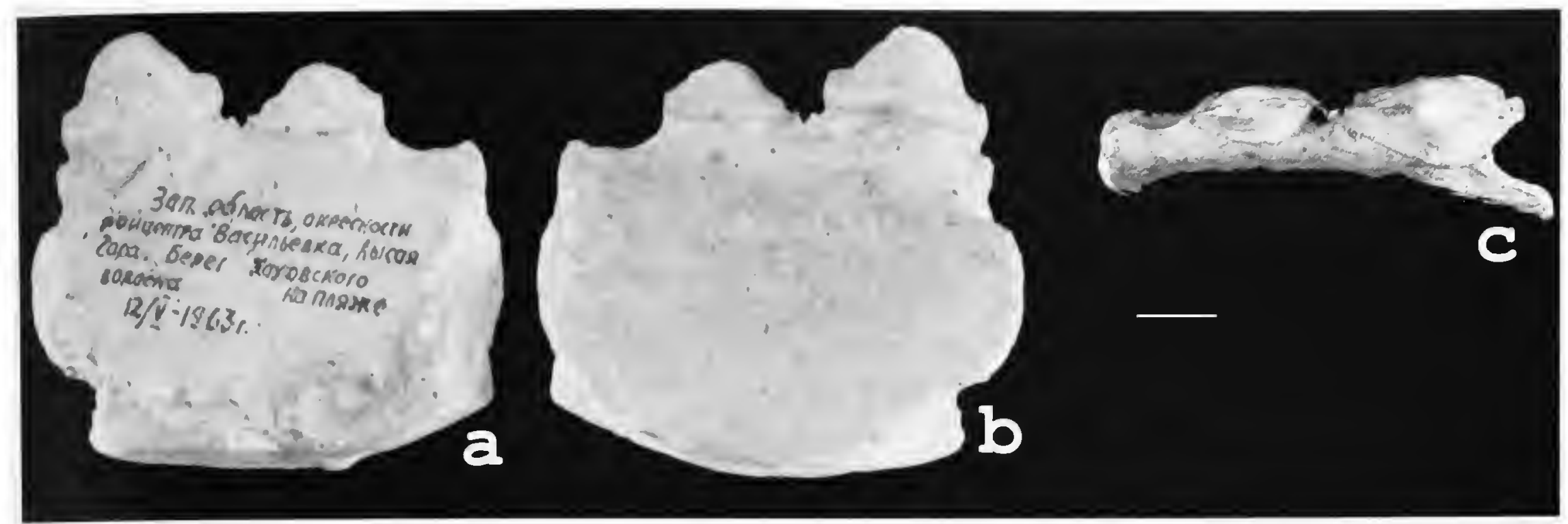

Figure 1.-Mandible of Pontophoca sarmatica. Cast of fragment of R. mandible, collection of ZKM, unnumbered (with p3, p4) from village of Vasilyevka, Zaporozhye Region, bank of Kachovka Reservoir (Mount Lysaya), Ukraine. In labial $(a)$, lingual $(b)$, and occlusal $(c)$ aspects. (Scale bar $=1 \mathrm{~cm}$.)

It differs from Callophoca in the following characteristics: the greater trochanter of the femur extends higher above the head, and the condyles are flat.

DISCUSSION.-Like most taxa erected by Kretzoi, the genus Pontophoca was not diagnosed satisfactorily. For this reason, until recently this genus was recognized by only a few specialists, such as McLaren (1960) and Kirpichnikov (1961). Representatives of this genus were usually assigned either to Phoca or to Monachus. Some species included in these genera undoubtedly belong to Pontophoca.

Von Nordmann (1858) was the first investigator who analyzed the bones of the extremities of Pontophoca sarmatica, but he described them under the name Phoca maeotica, together with the remainder of his material. Alekseev (1924) separated these specimens from the Nordmann collection, supplemented them with material kept at Odessa University (Ukraine), and described them as Phoca sarmatica. Some authors (Grigorescu, 1977; Trelea and Simionescu, 1985; Muizon, 1992) still use the name Phoca when referring to them. We view this assignment as incorrect, because the femur and humerus differ so distinctly from those of Phoca that the possibility of confusion is practically excluded. The importance of Grigorescu's (1977) work is that he recognized characters diagnostic of the Monachinae in bones of Pontophoca sarmatica. In his opinion, the strong development of the gastrocnemius muscle and the location of its attachment stimulated considerable expansion of the distal part of the femur. Our material confirms this, but all femora that we studied also have a very well developed plantar fossa, the place for attachment of the plantaris muscle, so we can add that not only the gastrocnemius muscle but also the plantaris contributed to expansion of the distal part of the femur.

To remove some doubts on the correctness of the assignment of Pontophoca to the subfamily Monachinae, we compared its femora with those of young individuals of Monachus mona- chus. These femora are very similar to those of Pontophoca sarmatica in the form of the bone, the obliqueness of the greater trochanter, the narrow neck, and the relatively small head. For these reasons we consider the assignment of "Phoca" sarmatica to the Monachinae to be well founded.

In the "Comparisons" section above we drew attention to the common structural features of the mandibles in P. sarmatica, M. monachus, $M$. tropicalis, and $M$. schauinslandi. These common features are evidence of the common origin of these four species (Repenning and Ray, 1977) and also suggest that Pontophoca might be ancestral to the genus Monachus. The cladistic analysis below confirms this (Figure 5).

\section{Pontophoca sarmatica (Alekseev, 1924) McLaren, 1960}

\section{FIGURES 1-4; TABLES $1-3$}

Phoca maeotica Nordmann, 1860:356-357, pl. 23: figs. 3, 7; pl. 24: fig. 1. Phoca moeotica [sic].-Nordmann, 1860:317.

Phoca pontica.-Kellogg, 1922:120 [in part].-Simionescu, 1925:180, 188, 190-191, fig. 5P; pl. 1: fig. 2.-Macarovici and Oescu, 1942:351-352, 363367, 378-379, figs. 7, 8; pl. 2: figs. 18, 19.-Macarovici, 1942:262-263.McLaren, 1960:51.

Phoca sarmatica.-Alekseev, 1924:203, figs. 4-7.-Friant, 1947:12.-Pidoplichko, 1956:142.-McLaren, 1960:57.--Kirpichnikov, 1961:29, 32, 34, 36.Aslanova, 1965:52.-Grigorescu, 1977:407-411, 413-418, fig. 5D.-Dubrovo and Kapelist, 1979:36.-Trelea and Simionescu, 1985:19.-Muizon, 1992: 35.

Phoca pontica var. sarmatica.-Macarovici, 1942:263, 267, pl. 2: fig. 18.1 . Pontophoca simionescui.-Kretzoi, 1941:354, fig. 3.2.

Monachus [sic].-Friant, 1947:6, 16, 47-50, pl. 1: fig. la-c.

Pontophoca sarmatica.-McLaren, 1960:47, 52, 57, fig. lg,h,i.-King, 1964 131.

HOLOTYPE.-Femur described and illustrated by Alekseev (1924:202, fig. 6). Phoca sarmatica (McLaren, 1960:57); collection of OGUM, Moldavia, middle Sarmatian.

DisTRIBUTION.-Middle Sarmatian of northern Black Sea coastal region (southern Ukraine and possibly Russia). 
TABLE 1.-Measurements (mm) of mandible and lower dentition of Pontophoca sarmatica, collection of ZKM, unnumbered, incomplete right ramus with $\mathrm{p} 3$ and $\mathrm{p} 4$.

\begin{tabular}{l|c}
\hline \multicolumn{1}{c|}{ Character } & Measurement \\
\hline p3 length & 14.0 \\
p4 length & 20.0 \\
Ramus depth under p4 & 36.5 \\
p3 height & 8.7 \\
p4 height & 15.0 \\
p3 width & 7.0 \\
p4 width & 10.0 \\
Diastema length between p3 and p4 & 4.5 \\
\hline
\end{tabular}

REFERRED MATERIAL.-Kishinev: PIN 1713/10, R. humerus and L. femur from one individual; PIN 1713/23, femur from another individual; OGUM 23, two humeri, eight femora ( $R$. and L.); OGUM 53-57, one scapula, two fused tibiae and fibulae, five isolated tibiae, three isolated fibulae, and two pelvic bones (this material was described by Alekseev (1926)); ZIN 4, one femur, collection of von Nordmann; ZIN 8, one femur, collection of von Nordmann; UBFG 259, L. and R. femora, collection of Simionescu; USNM 214980, cast of R. femur (original UBFG 259, collection of Simionescu); JaU MS20L, femur, collection of Simionescu (this material was described and illustrated as Phoca pontica by Macarovici and Oescu (1942: 351-352, 363-367, 378-379, figs. 7, 8, pl. 2: figs. 18, 19);
TABLE 2.-Measurements (in mm) of humeri of Pontophoca sarmatica.

\begin{tabular}{l|ccc}
\hline \multicolumn{1}{c|}{ Character } & $n$ & $x$ & Range \\
\hline Total length & 7 & 111.1 & $100.5-120.0$ \\
Length of deltoid crest & 7 & 67.0 & $64.0-73.0$ \\
Height of head & 5 & 25.8 & $25.5-28.0$ \\
Height of trochlea & 5 & 20.1 & $19.5-23.0$ \\
Width of head & 5 & 25.1 & $23.0-27.5$ \\
Width of deltoid crest & 5 & 30.8 & $27.0-33.0$ \\
Width of proximal epiphysis & 7 & 33.3 & $28.0-38.0$ \\
Width of distal epiphysis & 7 & 36.1 & $30.1-47.0$ \\
Width of trochlea distally & 5 & 20.1 & $20.0-24.0$ \\
Width of trochlea, anteriorly & 5 & 17.0 & $16.5-18.0$ \\
Transverse width of diaphysis & 8 & 16.9 & $15.3-19.1$ \\
Thickness of proximal epiphysis & 7 & 38.7 & $37.3-43.0$ \\
Thickness of medial condyle & 7 & 18.1 & $15.0-22.0$ \\
Thickness of lateral condyle & 5 & 18.2 & $16.5-22.0$ \\
Diameter of diaphysis with deltoid crest & 8 & 35.2 & $31.0-45.0$ \\
\hline
\end{tabular}

MZHF 1811, R. humerus, illustrated by von Nordmann (1858, pl. 23: fig. 3) and described by him $(1860: 317,356-357)$ as Phoca maeotica; UBFG unnumbered, two L. and one R. femora; UBFG 249, L. humerus; MZHF unnumbered, five R. femora, collection of von Nordmann.

Vicinity of Tiraspol, Moldavia: OGUM 6, 23-25, six humeri (two of which are unnumbered).

Stanitsa Tsymlyansk on the Don River: OGUM 9, humerus.

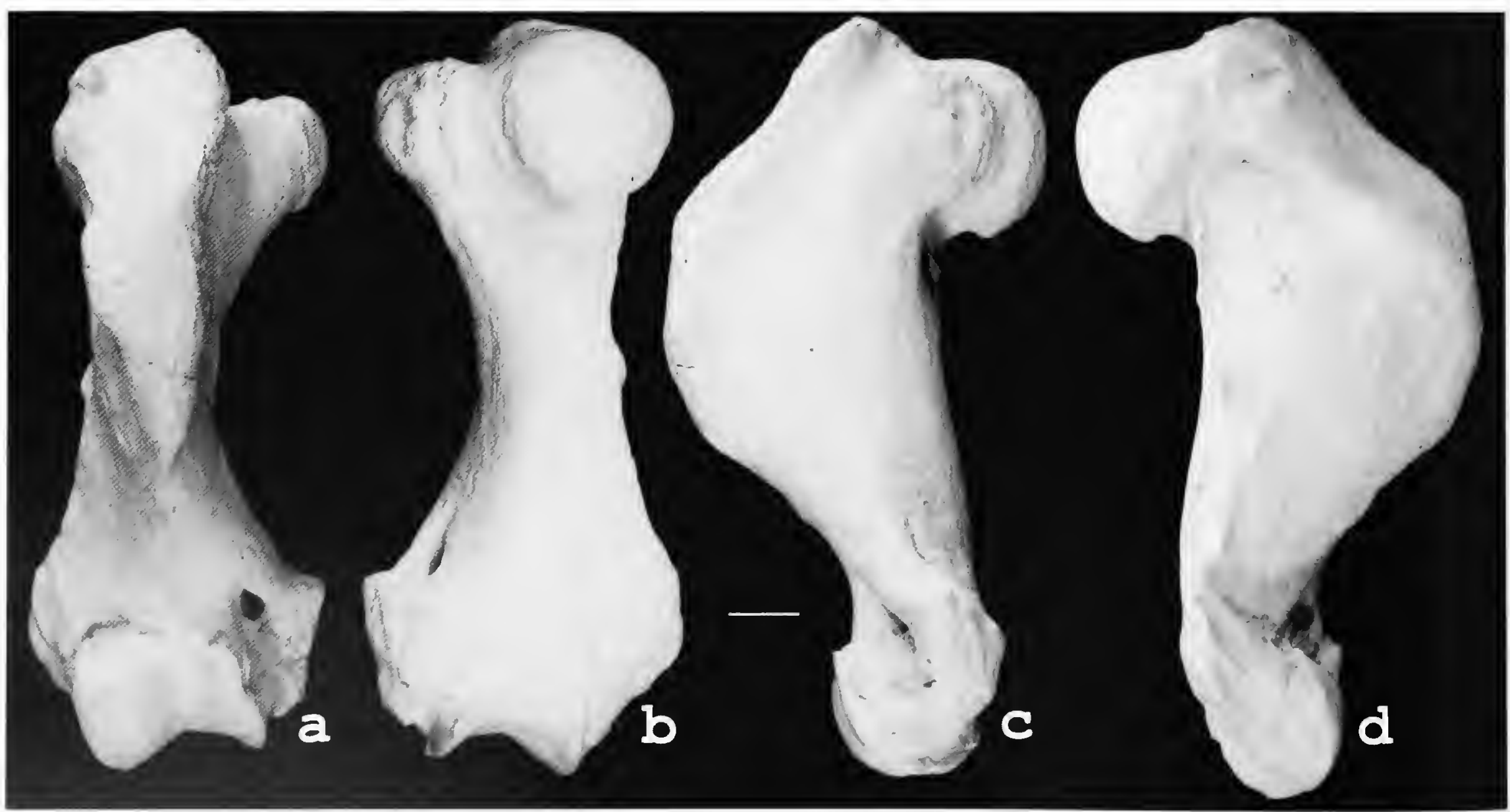

FIGURE 2.- Humerus of Pontophoca sarmatica. Cast of R. humerus, collection of MZHF 1811, from Kishinev, Moldavia. This was illustrated by von Nordmann (1858, pl. 23: fig. 3) and described by him (1860:317, 356-357) as Phoca maeotica. In cranial (a), caudal (b), medial (c), and lateral $(d)$ aspects. (Scale bar $=1 \mathrm{~cm}$.) 


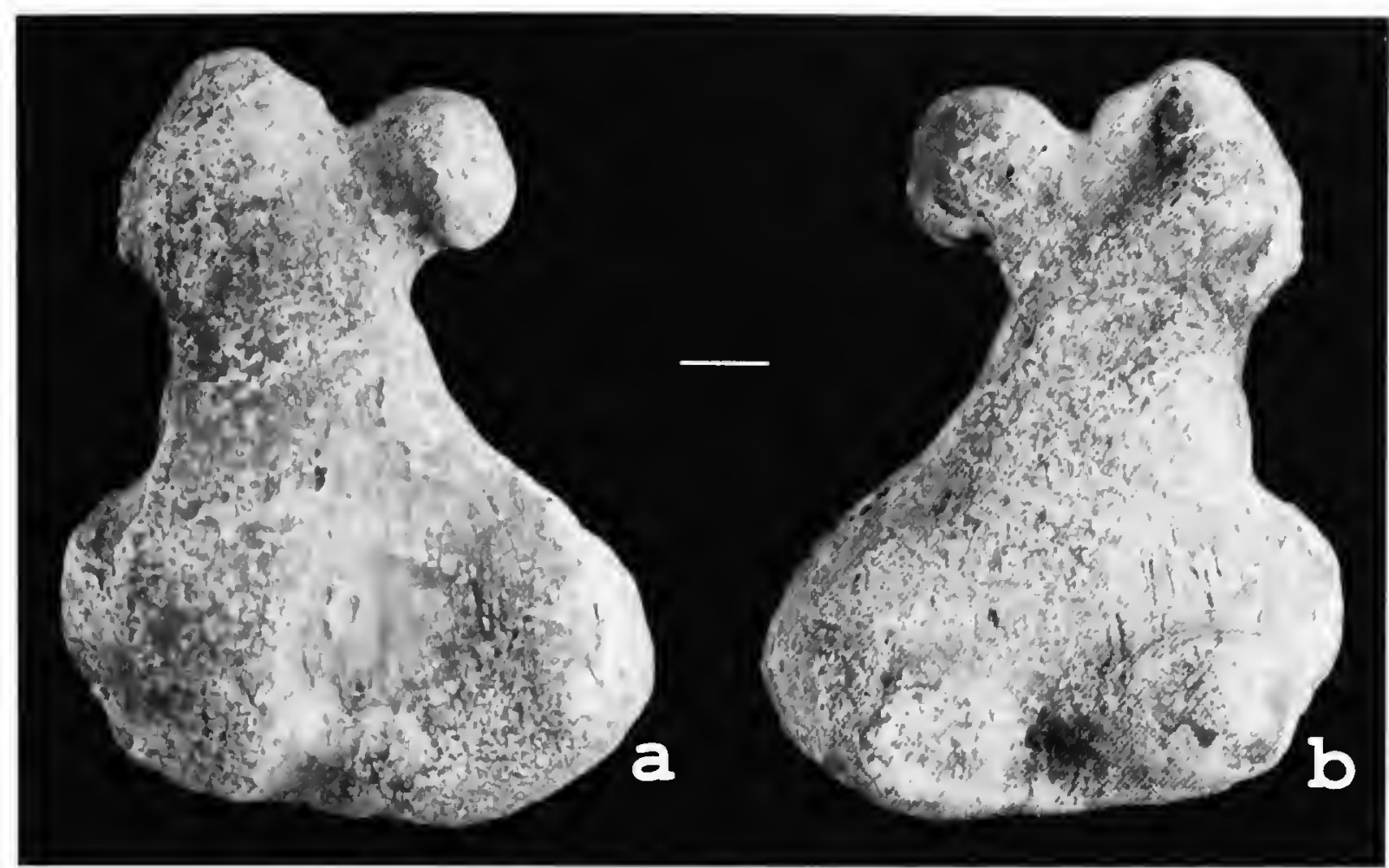

Figure 3.-Femur of Pontophoca sarmatica. Cast of R. femur, USNM 214980 (original UBFG 259, collection of Simionescu), from Kishinev, Moldavia. In cranial $(a)$ and caudal $(b)$ aspects. (Scale bar $=1 \mathrm{~cm}$.)

Like the material from the foregoing localities, this material was described by Alekseev (1924).

Kerch Peninsula (Kamysh-Burun): IZUAN 64-357, 64-361, 64-362, three femora.

Village of Vasilyevka, Zaporozhye region; bank of Kachovka Reservoir (Mount Lysaya): ZKM unnumbered, incomplete R. ramus of mandible with $\mathrm{p} 3$ and $\mathrm{p} 4$.

DIAGNOSIS.-Same as for the genus.

DESCRIPTION.-Mandible (Figure 1, Table 1): The long axes of the teeth are parallel to the tooth-row axis. The diastema between $\mathrm{p} 3$ and the alveolus of $\mathrm{p} 2$ is longer than the diastema between $\mathrm{p} 3$ and $\mathrm{p} 4$ Lower $\mathrm{p} 4$ is considerably larger than $\mathrm{p} 3$. The height of $\mathrm{p} 3$ exceeds by only $3.0 \mathrm{~mm}$ the paraconid on $\mathrm{p} 4$. The basal cingulum and metaconid are weakly developed on both teeth.

Scapula: "Its distinctive features are the strong development of the muscular spine, thickened summit and thick, massive acromion. The articular surface is very narrow; the tuberculum supraglenoidale and cervix scapulae are very weakly pronounced" (Alekseev, 1924:202).

Humerus (Figures 2, 4, Table 2): The lesser tubercle is large, elongate parallel to the bone's axis, and proximally higher than the head, practically on the same level as the proximal border of the deltoid crest. The intertubercular sulcus is absent. The head is spherical. In well-preserved specimens, the ratio between the length and the width of the head is almost 1.00. The deltoid crista ends in the distal one-third of the bone. This crest is markedly convex, and the deltoid tuberosity is strongly swollen. The coronoid fossa is barely outlined in smaller (i.e., juvenile) bones; in larger individuals it is absent. The radial sulcus is absent. In well-preserved bones, significant distention of the two epicondyles is clearly seen. The lateral epicondyle is wide; in height it practically reaches the distal part of the deltoid crest. The medial epicondyle in a large individual (evidently an adult) barely reaches the height of the lateral supracondyle. The entepicondylar fossa is seen on all specimens, but in sexually mature individuals this fossa is covered on its medial side by a thicker and wider wall.

Pelvis: The ilia are considerably thickened and distended. "The acetabulum is very deep. Its diameter is rather small, less than in "Phoca" maeotica and with very pronounced borders" (Alekseev, 1924:202; 1926:138-143).

Femur (Figures 3, 4, Table 3): The femora are closely similar in size to those of the living seal of the genus Histriophoca. The greater trochanter is higher than the head, very obliquely oriented, and elongated along the bone's long axis. In smaller individuals from the Kerch Peninsula (these individuals probably were younger; see Astanin, 1936; Heptner, 1947), it is less oblique and, consequently, more protruding. In its distal part the greater trochanter has a $V$-shaped end. The length of the greater trochanter varies considerably (from $19.5 \mathrm{~mm}$ to 52.0 $\mathrm{mm}$ ), depending upon the individual's age. The trochanteric fossa is shallow and wide and reaches the middle of the greater trochanter's length. This fossa is open on the proximal side of the greater trochanter. Relative to the bone's mass, the femoral head is very small and is placed on a narrow, long neck. The least width of the shaft is located in the proximal part of the bone. The distal condyles are flat and very widely spaced. The maximum distance between them $(10.0-15.5 \mathrm{~mm})$ is $60 \%-80 \%$ of the bone's length. In young individuals a plantar fossa is present on top of the lateral epicondyle. In adult individuals a considerable swelling of the bone is seen at this loca- 

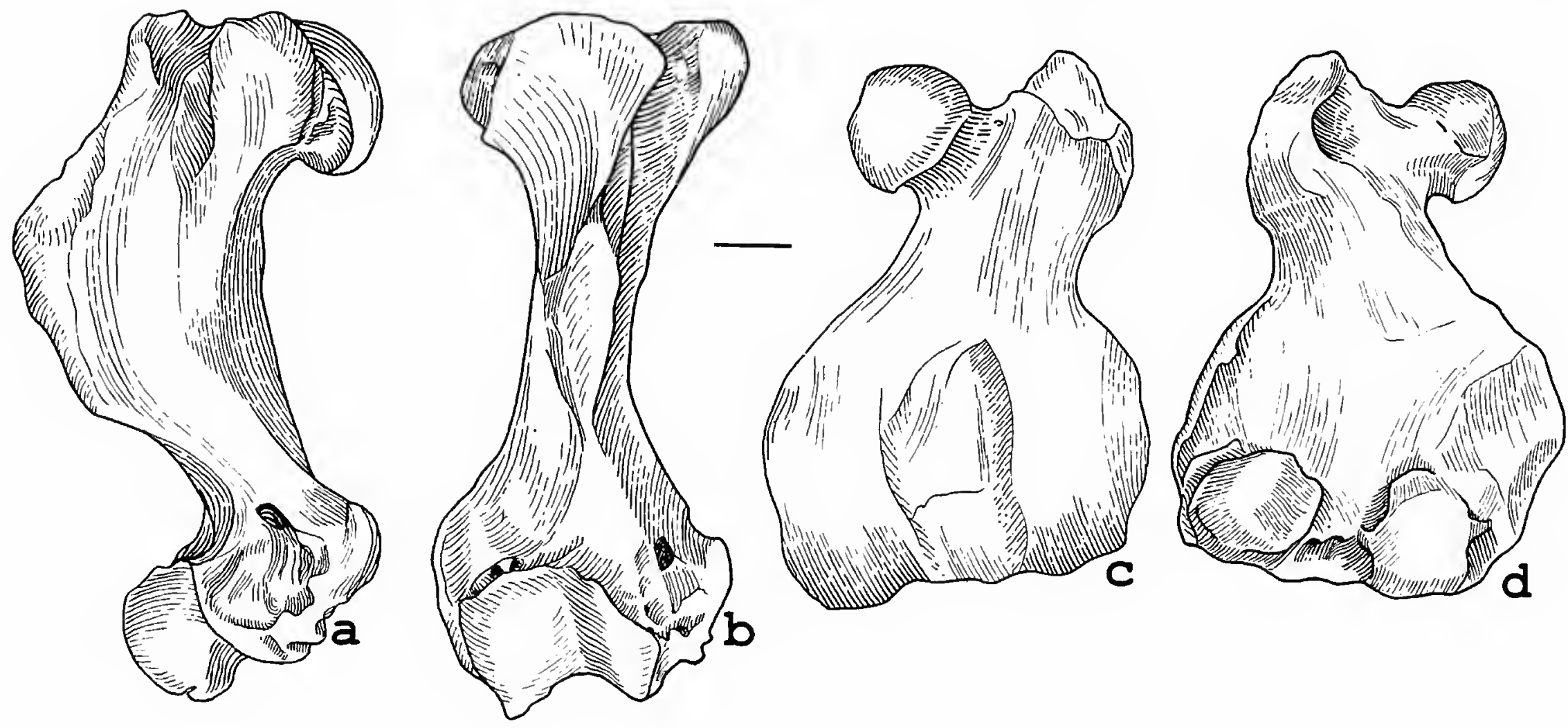

FIGURE 4.-Humerus and femur of Pontophoca sarmatica from one individual, originals, collection of PIN $1713 / 10$, from Kishinev, Moldavia. Illustrations of R. humerus in medial $(a)$ and cranial $(b)$ aspects; L. femur in cranial (c) and caudal $(d)$ aspects. (Scale bar $=1 \mathrm{~cm}$.)

tion. The characteristic, distinctive feature of this species is significant distention (expansion) of the distal part of the bone, which in adult individuals is $1.4-1.5$ times wider than the proximal part (in juveniles 1.2 times).

Tibia and Fibula: Distinctive features are a narrower diaphysis and markedly thickened epiphysis; "the distal condyles of the femur are, consequently, widely placed; the articular surface bordering this distal end of the femur is significantly distended" (Alekseev, 1924:202).

Discussion.-According to published data, this type species is a widely known representative of the Monachinae. It has not, however, been adequately described. In particular, the limits of its dimensions are unknown, as are most of the bones of its skeleton. McLaren (1960) thus stated that it is of smaller dimensions than Cryptophoca maeotica (formerly Phoca maeotica), which was revised by Koretsky and Ray (1994); but Alekseev (1924) stated that some bones (pelvis) are of equal dimensions with those of the latter species. Kretzoi (1941) illustrated the femur of Pontophoca sarmatica as being smaller than that of "Phoca" pontica. According to our information, however, $P$. sarmatica is considerably larger than $C$. maeotica, and even more so than Phoca pontica. Although detailed studies were made of femora of $P$. sarmatica, no one except Alekseev has studied other skeletal parts. We have described herein for the first time a humerus and femur belonging to one individual (PIN 1713/10 from Kishinev). The fact that these bones have the same pathology (not described) and were found not far from each other in one bed supports our opinion that they belong to the same individual. The skeletal parts (the scapula, pelvis, tibia, and fibula) described and illustrated by Alekseev
$(1924,1926)$ were not cited as associated and were never studied by other authors (e.g., Kretzoi, 1941; Friant, 1947; McLaren, 1960); therefore, at present we cannot supplement their descriptions by our materials or confirm their species assignment. To describe this species more completely, we used the description of Alekseev for these missing skeletal parts of Pontophoca sarmatica. Future analysis of supplementary materials may show this hypodigm to be a composite, particularly in view of the considerable intraspecific variability of the humerus and femur, and of the rather narrow geographic distribution (eastern Europe) of this seal as herein recognized. Also, there are no reliable records from the banks of the Don River, although Alekseev reported finding this species in the Lower Don. In addition, more than one large seal is known from the Sarmatian deposits. Alekseev's scapula, pelvis, tibia, and fibula can be questionably assigned to the same species.

\section{Cladistic Analysis}

\section{Characters Used For Subfamily MonachinaE}

The data matrix for the 48 included characters is shown in Table 4. Characters and character states for Monachinae are listed below; 0 designates the most primitive state among the taxa studied; 1 and 2 are derived states; -indicates unknown or missing data.

\section{Skull}

1. Mastoid process: (0) not strongly pronounced; (1) pronounced. 
TABLE 3.- Measurements (in mm) of femora of Pontophoca sarmatica.

\begin{tabular}{|c|c|c|c|c|c|c|}
\hline \multirow{2}{*}{ Measurement } & \multicolumn{3}{|c|}{ Adult } & \multicolumn{3}{|c|}{ Juvenile } \\
\hline & $n$ & $x$ & Range & $\bar{n}$ & $x$ & Range \\
\hline Total length & 16 & 82.5 & $76.5-96.0$ & 2 & - & $68.0 ; 68.5$ \\
\hline Medial length & 8 & 78.3 & $74.0-88.0$ & 2 & - & $64.5 ; 68.0$ \\
\hline Lateral length & 9 & 75.3 & $71.5-80.5$ & 3 & 60.7 & $58.0-62.5$ \\
\hline Length of medial condyle & 13 & 16.6 & $15.0-21.0$ & 2 & - & $12.0 ; 12.0$ \\
\hline Length of lateral condyle & 17 & 18.0 & $16.0-22.0$ & 3 & 16.8 & $16.0-18.0$ \\
\hline Length of grcater trochanter & 15 & 28.0 & $25.0-30.0$ & 3 & 21.3 & $20.5-22.0$ \\
\hline Height of head & 6 & 18.5 & $17.2-23.0$ & 2 & - & $15.0 ; 15.5$ \\
\hline Height of articular area of patella surface & 6 & 17.2 & $15.9-22.0$ & 2 & - & $16.5 ; 20.0$ \\
\hline Intertrochanteric width & 9 & 29.0 & $28.5-38.0$ & 3 & 25.5 & $25.0-26.0$ \\
\hline Width of proximal cpiphysis & 13 & 40.8 & $36.0-44.0$ & 2 & - & $34.0 ; 35.0$ \\
\hline Width of distal epiphysis & 19 & 59.2 & $54.5-66.0$ & 2 & - & $39.0 ; 39.5$ \\
\hline Width of condyles & 13 & 46.8 & $42.6-50.5$ & 2 & - & $33.0 ; 35.0$ \\
\hline Width of greater trochanter & 16 & 16.1 & $14.5-18.0$ & 3 & 13.7 & $13.0-14.0$ \\
\hline Width of head & 11 & 18.9 & $17.5-20.7$ & 2 & - & $15.0 ; 15.5$ \\
\hline Width of shaft & 15 & 26.0 & $24.5-29.5$ & 3 & 18.7 & $18.0-19.0$ \\
\hline Anteroposterior thickness of shaft & 12 & 11.7 & $11.0-12.5$ & 3 & 11.2 & $10.5-12.0$ \\
\hline Thickness of medial condyle & 8 & 17.5 & $16.0-20.0$ & 2 & - & $15.0 ; 15.5$ \\
\hline Thickness of lateral condyle & 13 & 25.3 & $24.0-27.0$ & 2 & - & $17.0 ; 23.0$ \\
\hline Distance between condyles & 16 & 12.7 & $12.0-15.5$ & 2 & - & $11.0 ; 11.0$ \\
\hline Diameter of head & 13 & 15.9 & $14.0-17.5$ & 2 & - & $12.5 ; 14.0$ \\
\hline
\end{tabular}

2. Mastoid process: (0) narrow; (1) wide (Chapskii, 1974:301; polarity opposite to Berta and Wyss, 1994:48).

3. Maxilla: (0) convexity anterior to the orbits; (1) short concavity; (2) long concavity (polarity opposite that of Berta and Wyss, 1994:46).

4. Anterior palatine foramina: (0) faintly marked; (1) oval and shallow (Burns and Fay, 1970:372).

5. Interorbital width: (0) less than $25.0 \%$ width of skull across mastoids; (1) less than $30.0 \%$, but equal to or greater than $25.0 \%$ of mastoid width; (2) equal to or greater than $30.0 \%$ of mastoid width (Burns and Fay, 1970:370; Chapskii, 1974:299).

6. Jugular process: (0) poorly developed; (1) well developed.

7. Rostrum: (0) elongate; (1) short, compared with cranium (Chapskii, 1974:300).

8. Diameter of infraorbital foramen: (0) less than diameter of alveolus of maxillary canine; (1) approximately equal to diameter of alveolus of maxillary canine; (2) greater than diameter of alveolus of maxillary canine (polarity opposite that of Berta and Wyss, 1994:47).

9. Anteroposterior length of auditory bullae: (0) greater than distance between them; (1) less than distance between them; (2) about equal to distance between them (Burns and Fay, 1970:382; Chapskii, 1974:300) (unordered character).

\section{Mandible}

10. Symphyseal part: (0) continues at least to the middle of the alveolus of $\mathrm{p} 3 ;$ (1) reaches only to the alveolus of $\mathrm{p} 2 ;(2)$ reaches only to the alveolus of $\mathrm{p} 1$.

11. Lateral outline of symphyseal region: (0) square, symphysis thin; (1) rounded, symphysis thick; (2) straight, symphysis thick.
12. Chin prominence: (0) pronounced; (1) absent or weakly outlined.

13. Chin prominence: (0) extends from the anterior or posterior alveolus of $\mathrm{p} 2$ to the posterior or anterior alveolus of $\mathrm{p} 4$; (1) extends from the anterior alveolus of $\mathrm{p} 2$ to anterior alveolus of $\mathrm{p} 3$.

14. Maximum height of body of mandible: ( 0 ) between $\mathrm{p} 2$ and $\mathrm{p} 3$; (1) in the middle or at the posterior portion of $\mathrm{p} 2$ (Koretsky and Ray, 1994:21); (2) situated between alveoli of p4$\mathrm{m} 1$.

15. Diastemata and tooth alveoli: (0) alveoli small, with equal diastemata; (1) alveoli round and large, with equal diastemata between them; (2) alveoli shallow, and diastemata unequal.

16. Alveoli of $\mathrm{p} 4$ and $\mathrm{ml}$ : (0) alveoli similar in size; (1) alveoli of $\mathrm{p} 4$ smaller than alveoli of $\mathrm{m} 1$; (2) alveoli of $\mathrm{p} 4$ larger than alveoli of $\mathrm{ml}$ (unordered character).
17. Retromandibular space: (0) long; (1) short.

\section{Teeth}

18. Number of incisors: (0) $3 / 2$; (1) $2 / 2$; (2) $2 / 1$ (Chapskii, 1974:289; polarity opposite that of Burns and Fay, 1970:380).

19. Roots of postcanine teeth (P,p 2-P,p 4): (0) one root, divided partially at the base; (1) two (polarity opposite that of Berta and Wyss, 1994:51).

20. Crowns of postcanine teeth: (0) single cusped; (1) multicusped (polarity opposite that of Berta and Wyss, 1994:51) (reversal to primitive condition, unordered character).

21. Relative dimensions of postcanine teeth: (0) large; (1) small.

22. Relative dimensions of canine: (0) large; (1) small.

23. Basal cingulum of postcanine teeth: (0) well developed; (1) not developed. 
TABLE 4.- Matrix of character-state data for monachine taxa and outgroups analyzed. ( ${ }^{*}=$ outgroup.)

\begin{tabular}{|c|c|c|c|c|c|c|c|c|c|c|c|c|c|c|c|c|c|c|c|c|c|c|c|c|}
\hline \multirow[b]{2}{*}{ Species } & \multicolumn{24}{|c|}{ Character } \\
\hline & 1 & 2 & 3 & 4 & 5 & 6 & 7 & 8 & 9 & 10 & 11 & 12 & 13 & 14 & 15 & 16 & 17 & 18 & 19 & 20 & 21 & 22 & 23 & 24 \\
\hline Leptophoca lenis* & 0 & 0 & 0 & 1 & 0 & 0 & 0 & 1 & 1 & 1 & 1 & 1 & 1 & 0 & 0 & 0 & 0 & 0 & 1 & 1 & 1 & 1 & 0 & 1 \\
\hline Cystophora cristata* & 1 & 1 & 1 & 0 & 1 & 0 & 0 & 0 & 0 & 0 & 1 & 1 & 0 & 2 & 1 & 1 & 0 & 2 & 0 & 0 & 1 & 0 & 0 & 2 \\
\hline Pontophoca sarmatica & - & - & - & - & - & - & - & - & - & - & - & - & - & - & 1 & & - & - & 1 & 0 & 0 & - & 0 & 0 \\
\hline Monachus monachus & 1 & 1 & 2 & 0 & 0 & 1 & 1 & 0 & 2 & 1 & 2 & 1 & 1 & 2 & 2 & 2 & 1 & 1 & 1 & 1 & 1 & 0 & 0 & 0 \\
\hline Monachus schauinslandi & 1 & 1 & 2 & 0 & 0 & 0 & 1 & 1 & 1 & 2 & 1 & 1 & 1 & 1 & 2 & 2 & 1 & 1 & 1 & 1 & 1 & 1 & 0 & 1 \\
\hline Monachus tropicalis & 1 & 0 & 2 & 1 & 0 & 1 & 1 & 2 & 2 & 2 & 1 & 0 & 1 & 1 & 0 & 2 & 1 & 1 & 1 & 1 & 0 & 0 & 0 & 1 \\
\hline Pliophoca etrusca & 0 & 0 & 2 & 0 & 2 & 0 & 0 & 1 & 0 & 1 & 2 & 0 & 0 & 0 & 1 & 0 & 0 & 1 & 1 & 1 & 0 & 1 & 0 & 1 \\
\hline \multirow[t]{2}{*}{ Callophoca obscura } & 0 & 0 & 2 & 0 & 1 & 0 & 0 & 0 & 0 & 1 & 0 & 1 & 1 & 0 & 2 & 0 & 0 & 1 & 0 & 1 & 0 & 0 & 0 & 1 \\
\hline & \multicolumn{24}{|c|}{ Character } \\
\hline Species & 25 & 26 & 27 & 28 & 29 & 30 & 31 & 32 & 33 & 34 & 35 & 36 & 37 & 38 & 39 & 40 & 41 & 42 & 43 & 44 & 45 & 46 & 47 & 48 \\
\hline Leptophoca lenis* & 0 & 0 & 0 & 0 & 1 & 0 & 0 & 0 & 0 & 1 & 1 & 1 & 0 & 0 & 1 & 0 & 0 & 1 & 0 & 0 & 1 & 1 & 0 & 0 \\
\hline Cystophora cristata* & 0 & 1 & 1 & 1 & 1 & 1 & 2 & 1 & 1 & 0 & 0 & 1 & 0 & 0 & 2 & 1 & 0 & 1 & 2 & 0 & 0 & 1 & 1 & 1 \\
\hline Pontophoca sarmatica & 0 & - & - & 0 & 0 & 1 & 1 & 1 & 0 & 0 & 0 & 1 & 0 & 0 & 0 & 0 & 0 & 0 & 0 & 0 & 0 & 1 & 1 & 0 \\
\hline Monachus monachus & 1 & 0 & 1 & 1 & 0 & 1 & 0 & 0 & 2 & 1 & 1 & 2 & 1 & 1 & 0 & 0 & 1 & 1 & 0 & 1 & 1 & 0 & 0 & 1 \\
\hline Monachus schauinslandi & 1 & 0 & 1 & 1 & 0 & 1 & 0 & 0 & 1 & 1 & 1 & 1 & 1 & 1 & 0 & 1 & 1 & 1 & 0 & 1 & 0 & 1 & 1 & 1 \\
\hline Monachus tropicalis & 0 & 0 & 1 & 1 & 0 & 1 & 0 & 0 & 1 & 1 & 1 & 2 & 1 & 1 & 0 & 0 & 1 & 1 & 0 & 1 & 1 & 1 & 1 & 1 \\
\hline Pliophoca etrusca & 1 & 0 & 1 & 1 & 0 & 0 & 1 & 2 & 2 & 1 & 0 & 0 & 0 & 0 & 0 & 0 & 1 & 1 & 1 & 0 & 0 & 0 & 0 & 1 \\
\hline Callophoca obscura & 1 & 0 & 2 & 1 & 0 & 0 & 1 & 1 & 1 & 2 & 0 & 1 & 0 & 0 & 0 & 0 & 1 & 0 & 1 & 1 & 1 & 0 & 0 & 1 \\
\hline
\end{tabular}

24. Number of additional cusps of premolars: (0) two; (1) more than two; (2) no additional cusps (unordered character).

25. Premolars: (0) seated parallel to axis of tooth row; (1) seated obliquely.

26. Upper incisors: (0) form a curved line; (1) form a straight line.

27. Second and third (or first) upper incisors: (0) third larger than second; (1) second larger than third (or first); (2) incisors equal in size (unordered character).

\section{Humerus}

28. Lesser tubercle: (0) pronounced; (0) not pronounced (polarity opposite that of Berta and Wyss, 1994:52).

29. Trochlear crest: (0) raised arch-like over coronoid fossa; (1) not separated from coronoid fossa by a distinct lip.

30. Lesser tubercle and head: (0) equal in height or tubercle insignificantly higher than head; (1) tubercle very much higher than head.

31. Lesser tubercle: (0) rounded; (1) extended along the bone's axis; (2) oval.

32. Head: (0) mediolaterally compressed; (1) rounded; (2) flattened proximodistally.

33. Deltoid crest: (0) maximal enlargement is in its proximal part; (1) neither part noticeably enlarged; (2) maximal enlargement is in its middle part.

34. Deltoid crest: (0) shorter than one-half length of the bone, confined to the proximal half of the bone; (1) longer than one-half length of the bone but not reaching coronoid fossa; (2) reaches coronoid fossa (in contrast to that of Berta and Wyss, 1994:52).

35. Coronoid fossa: (0) deep; (1) shallow.

36. Head and trochlea: (0) head wider than trochlea; (1) head almost equal in width to trochlea; (2) trochlea wider than head (polarity opposite that of Berta and Wyss, 1994:53).

\section{Femur}

37. Lesser trochanter: (0) present; (1) absent (Berta and Wyss, 1994:54).

38. Condyles: (0) different in size; (1) similar in size.

39. Epiphyses: (0) distal epiphysis wider than proximal by one-fourth to one-fifth; (1) widths of proximal and distal epiphyses about equal; (2) proximal epiphysis wider than distal one.

40. Shaft: (0) minimum width less than or about equal to two-thirds width of proximal epiphysis; (1) minimum width more than two-thirds width of proximal epiphysis.

41. Intertrochanteric crest: (0) well developed; (1) absent or poorly developed.

42. Intertrochanteric crest: (0) reaches lower than head; (1) short, ends on same level as distal edge of head or fovea capitis.

43. Head: (0) rounded; (1) flattened in proximodistal direction; (2) compressed in mediolateral direction.

44. Intercondylar area: (0) narrow, deep; (1) wide, flattened.

45. Greater trochanter: (0) maximum width in its middle part; (1) maximum width in its proximal part (Koretsky, 1987: 75).

46. Head and greater trochanter: (0) same height; (1) greater trochanter higher than head.

47. Neck: (0) long, slender; (1) short, wide.

48. Shaft: (0) minimum width in its proximal part; (1) minimum width in its middle part.

\section{RESULTS}

The analysis of these taxa using Hennig86 and the 48 unweighted characters shown above produced a single tree, 45 steps long, with consistency index of 0.84 and retention index 
of 0.83 (Figure 5). The matrix of character-state data for six species of fossil and living monachine seals is given in Table 4, together with data on two outgroup taxa. Leptophoca lenis is representative of the oldest known Phocinae (Repenning and Ray, 1977), and Cystophora cristata represents the Cystophorinae (as mentioned above).

The nodes of the tree corresponding to taxa recognized by us are indicated; only one new name, Pontophoca sarmatica, has been added to those previously recognized: inclusion of Pontophoca sarmatica within the Monachinae supports the recognition of the monotypic genus Pontophoca. The nodes of the cladogram shown in Figure 5 are supported by the following character transformations:

Node 1. (Subfamily Monachinae) one branch forms the possibly paraphyletic subfamily: 3(2); 18(1); 32(1.2).

Node 2. 41(1) (intertrochanteric crest of the femur poorly developed).

Node 3. 43(1) (head of the femur flattened in dorsoventral direction).

Node 4. (Genus Monachus): 7(1); 16(2); 17(1); 37(1); 38(1). Also, character 10(2) is homoplasious in $M$. tropicalis and $M$. schauinslandi; character 35(1) shares the homoplasy of L. lenis.

Node 5. 6(1); 9(2); 36(2). Also, character 45(1) shares the homoplasy of Callophoca obscura and Leptophoca lenis.

As can be seen from the tree (Figure 5), the assignment of Pontophoca to the Monachinae is confirmed. Thus, the characters and their polarities that we used on every level of taxonomy are working. Moreover, Pontophoca sarmatica (consisting of a new description of the mandible and humerus) is a closely related sister group to Monachus and other Monachinea.

In contrast to Berta and Wyss (1994:43), we treated Monachus schauinslandi as a not-so-close sister taxon (Flynn, 1988). At the same time, we agree with their conclusion that the subfamily Monachinae is monophyletic (tribe Lobodontini not considered). In this subfamily we include just the three Holocene species of Monachus, as well as two Pliocene fossil genera (Callophoca and Pliophoca) and one middle Miocene genus (Pontophoca).

\section{Conclusions}

The family Phocidae separated from Carnivora, probably in the early Oligocene (Davies, 1958), became widely distributed during the middle and (especially) late Miocene, and practically ceased to exist in the European part of the former USSR (Black Sea region) in the early Pliocene (Chapskii, 1955, 1970, 1971, 1975; Repenning et al., 1979). Shared derived features of the morphology of the skull, and the relatively early geological age of these Miocene seals, allow the conclusion that these animals are broadly ancestral forms of presently living true seals. A direct relationship between known Miocene seals and modern genera is very uncertain, however. Probably, together with other Phocidae, monachine seals are descendants of some Oligocene or even Eocene semiaquatic mustelid. It should be

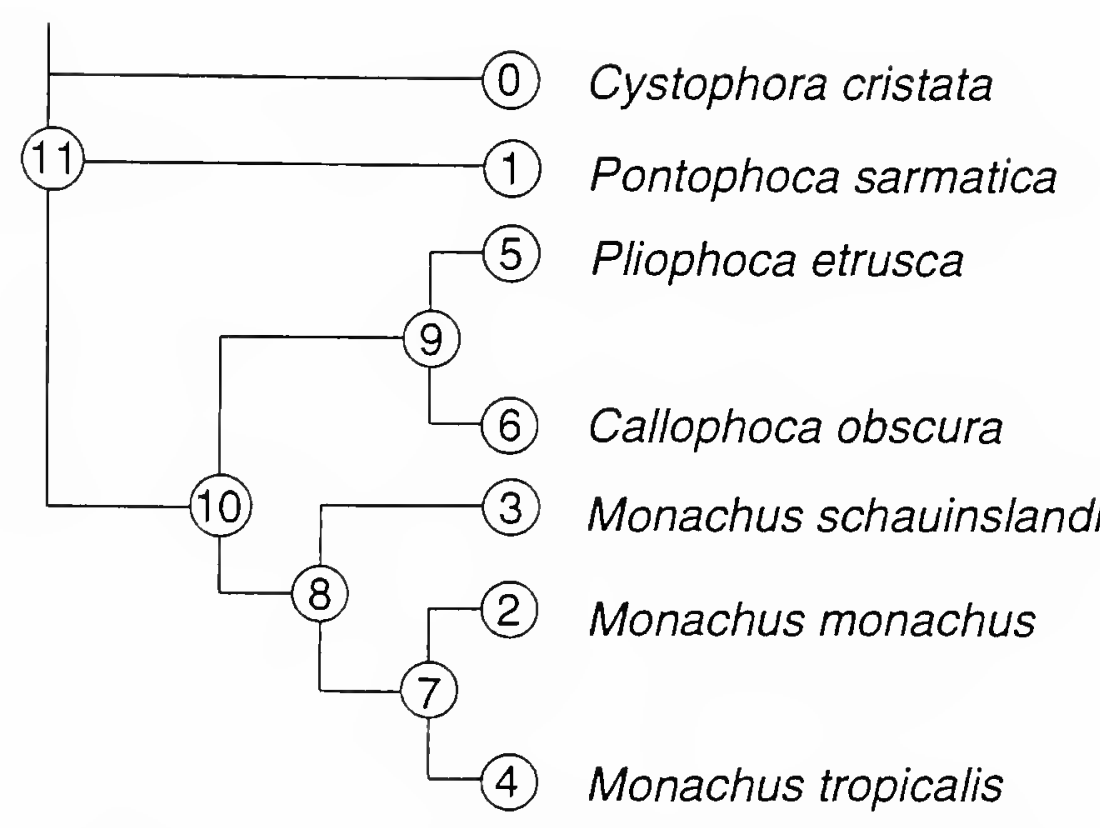

FIGURE 5.-Single most-parsimonious tree of monachine taxa and two outgroups, generated by Hennig86 using 48 unweighted characters. Tree length, 45 steps; consistency index, 0.84 ; retention index, 0.83 .

pointed out, however, that the only Oligocene representatives of this family yet found are two fragments of femora from the late Oligocene of South Carolina (see Koretsky and Sanders, 2002). The most ancient fossil phocids known from good, informative material are from the early middle Miocene (Holec et al., 1987; Koretsky and Holec, 2002). By that time these animals were fully recognizable members of subfamilies to which modern pinnipeds belong.

Middle Miocene seals did not differ very much from modern species, and in most morphological characteristics they are not especially similar to any of the terrestrial or semiaquatic carnivorans that might have been the ancestors of phocids. The analysis of the dentition allows us to conclude that monachines have long been separated from the common stem of pinnipeds and formed a separate phylogenetic branch that has existed until now.

Clearly, the geographical and geological distributions of taxa are of considerable interest for biostratigraphy and for correlations of middle Miocene to early Pliocene marine deposits of Eurasia. At present, however, in view of insufficient investigation of Western European and Asiatic materials, these findings may be used mainly for more precise control of the geological age of the true seals in the European part of the former USSR, and of the stratigraphic distribution of Monachinae in the middle Sarmatian to Pontian of this region.

Moreover, the majority of problems of systematics and morphology of Monachinae are not solved completely (Barnes et al., 1985). In this respect the present study is of a preliminary character that opens up new perspectives in investigations of the groups of predators analyzed. We hope that the results presented herein will draw the specialist's attention and will allow the investigation, from new and different viewpoints, of many problems of classification of both ancient and modern representatives of the subfamily Monachinae. 


\section{Literature Cited}

Alekseev, A.K.

1924. [Seals in the Sarmatian Deposits of Southem USSR.] Journal Nauchno-Issledovatelskich Kafedr v Odesse, 1(10-11):201-205. [ln Russian.]

1926. [Seals in the Sarmatian Deposits of the South of the USSR.] Journal Nauchno-Issledovatelskich Kafedr v Odesse, 11(4):138-143. [ln Russian.]

Anbinder, E.M.

1980. Karyologia e Evolucia Lastonogich [Karyology and Evolution of the Pinnipeds]. 452 pages. Moscow: Nauka. [In Russian.]

Andreescu, 1., and D. Murariu

1985. Contribution à l'étude du crâne de quelques représentants des families des Otariidae et Phocidae (Mammalia: Pinnipedia). Travaux du Muséum d'Histoire Naturelle "Grigore Antipa" (Bucharest), 27: 317-324.

Andrusov, N.I.

1893. Geotektonika Kerchenskogo poluostrova [Geotectonics of the Kerch Peninsula]. In Materialy dlia Geologii Rossii [Material on the Geology of Russia], 16:91-113. [1n Russian.]

Antoniuk, A.A.

1970. [Comparative Morphological Research on the Vertebrae of Pinnipedia.] Trudy Ticloookeanskogo Instituta Rybnogo Khoziaistva (TINRO), 17:87-95. [ln Russian.]

1972. [The Morphology of the Vertebral Column of Genus Pusa.] Fifth All-Union Conference on Marine Mammals, Machatchkala, 2:24-26. [In Russian.]

Antoniuk, A.A., and 1.A. Koretskaya [Koretsky]

1984. [A New Seal from the Middle Sarmatian Deposits of the Crimean District of the Ukraine.] Vestnik Zoologii, 4:26-31. [In Russian.]

Aslanova, S.M

1965. [Seal in Lower Miocene Deposits in Azerbaijan.] Doklady Akademii

Astanin, L.P. Nauk, Azerbaizhanskoy SSR, 21(6):46-48, 4 figures. [1n Russian.]

1936. [Ontogenetic Dimorphism of the Skeleton of Mammals in Connection with the Question of Age Determination.] Izvestia Nauchnogo Instituta, 19(2):203-231. [In Russian.]

Bames, L.G., D.P. Domning, and C.E. Ray

1985. Status of Studies on Fossil Marine Mammals. Marine Mammal Science, 1(1):15-53.

Berta, A., and A.R. Wyss

1994. Pinniped Phylogeny. In A. Berta and T.A. Deméré, editors, Contributions in Marine Mammal Paleontology Honoring Frank C. Whitmore, Jr. Proceedings of the San Diego Society of Natural History 29:33-57, 6 figures, 3 tables, 2 appendices.

Burns, J.J., and F.H. Fay

1970. Comparative Morphology of the Skull of the Ribbon Seal, Histriophoca Fasciata, with Remarks on Systematics of Phocidae. Journal of Zoology (London), 161(3):363-394, 3 figures, 4 plates.

Chapskii, K.K.

1952. [Age-Sexual Dimorphism of the Cranial Features and Its Effect on the Diagnoses of Some Pinnipedia.] Izvestia Instituta Estestvenich Nauk, Moscow, 25:78-96. [In Russian.]

1955. [Contribution to the Problem of the History of Development of the Caspian and Baikal Seals.] Trudy Zoologicheskogo Instituta Akademii Nauk SSSR, 17:200-216. [In Russian. English translation by Fisheries Research Board of Canada, Translation Series, 174, 26 pages, 1958.]

1961. [Current Status and Problems in the Systematics of Pinnipeds.] Trudy Soveschanii Ikhtiologicheskoi Komissii, Akademii Nauk SSSR (Moscow), 12:138-149. [In Russian. English translation by Sayer, U.S. Fish and Wildlifc Service, Seattle, Washington.]

1967. [Morphology-Taxonomic Structurc of Phoca largha of the Bering
Sea.] In Research in Marine Mammals. Trudy Poliarnogo NauchnoIssledovatelskogo Instituta Rybnogo Khoziaistva e Okeanography (PINRO), 21:147-177. [In Russian.]

1970. [The Concept of the Arctic Origin of Pinnipeds and Another Solution to This Problem.] In A.I. Tolmachev, editor, Severnyi Ledovityi Okean i ego poberezh'e $v$ Kainozoe [Northem Arctic Ocean and Its Coast in the Cenozoic], pages 166-173. Leningrad: Hydrometeorological Publishers. [In Russian.]

1971. [The Systematic Rank and Suprageneric Differentiation of the Eight-Incisor Seals (Monachinae).] Trudy Atlantic Nauchno-Issledovatelskogo Instituta Rybnogo Khoziaistva e Okeanography (AT. LANTNIRO) (Kaliningrad), 39:305-316. [In Russian. English translation, Fisheries Research Board of Canada, Translation Series, $3185,1974)$

1974. [In Defense of Classical Taxonomy of the Seals of the Family Phocidae.] In [Theoretical Questions on the Systematics and Phylogeny of Animals]. Trudy Zoologicheskogo Instituta Akademii Nauk SSSR. 53:282-334. [In Russian.]

1975. Taxonomy of the Seals of the Genus Phoca Sensu Stricto. In Marine Mammals. Materials for the Sixth All-Union Conference, Naukova Dumka, Kiev, 2:159-162.

Chepalyga, A.L., E.L. Korotkevich, and Y.A. Semenov

1985. Paratethys Regional Stages and Hipparion Faunas According to Paleomagnetic Data. In Abstracts of the Seventh Congress of the Regional Committee on Mediterranean Neogene Stratigraphy, Budapest. pages 137-139.

Davies, J.L.

1958. The Pinnipedia: An Essay in Zoogeography. Geographical Review, 48:474-493

Dornesco, G.-T., and G.-V. Marcoci

1958. Étude comparative du crâne des pinnipèdes. Annales des Sciences Naturelles, Zoologie, 11: xx + 158-182, 9 figures, 2 tables.

Driesch, A. von den

1976. A Guide to the Measurement of Animal Bones from Archeological Sites. Bulletin of the Peabody Museum of Archaeology and Ethnology, Harvard University, 1:1-137.

Dubrovo, 1.A., and K.V. Kapelist

1979. Katalog mestonachozdeniy tretichnuch pozvonochnuch Ykrainu [Catalog of the Localities of the Tertiary Vertebrates of the Ukrainian SSR]. 159 pages. Moscow: Nauka. [In Russian.]

Eichwald, E

1850. [Paleontology of Russia.] 520 pages, atlas, 13 plates. Saint Petersburg: Edward Pratz. [In Russian.]

Farris, J.S.

1988. Hennig86, Version 1.5. New York: Port Jefferson Station.

Fleming, J.

1822. Philosophy of Zoology, or a General View of the Structure, Function, and Classification of Animals. Volume 2, 187 pages. Edinburgh.

Flynn, J.J.

1988. Ancestry of Sea Mammals. Nature, 334:383-384

Friant, $M$.

1947. Recherches sur la fémur des Phocidae. Bulletin du Musée Royal d'Histoire Naturelle de Belgique, 23(2):1-51, 4 plates.

Gervais, P., and M. de Serres

1847. Sur les mammifères fossiles des sables marins tertiaires de Montpellier. Comptes Rendus des Séances de l'Académie des Sciences (Paris), 28(8):799-801.

Gill, T.N.

1872. Arrangement of the Families of Mammals, with Analytical Tables. Smithsonian Miscellaneous Collections, 11(1): vi +98 pages. 
Gistel, J.

1848. Naturgeschichte des Tierreichs. xvi +216 pages, 32 leaves of color plates. Stuttgart: Scheitlin \& Krais.

Godina, A.Y

1973. Pozvonochnue neogenovuch otlozheniy na territorii Moldavii [Neogene Vertebrate Localities in the Territory of Moldavia]. 107 pages. Kishinev: "Shtiintsa." [In Russian.]

Grassé, P.-P.

1955. Mammifères: Les Ordres-Anatomie, Ethologie, Systématique. In Traité de Zoologie: Anatomie, Systématique, Biologie, 17:568-668. Paris: Masson.

Gray, J.E.

1825. Outline of an Attempt at the Disposition of the Mammalia into Tribes and Families with a List of the Genera Apparently Pertaining to Each Tribe. Annals of Philosophy, new series, 10:337-344.

1844-1875. The Zoology of the Voyage of H.M.S. Erebus \& Terror, under the Command of Captain Sir James Clark Ross, R.N., F.R.S., during the Years 1839 to 1843. Part 1: Mammalia. 12 pages, 17 plates. London: Longman, Brown, Green, and Longmans. [See Scheffer, 1958, for dates.]

Grigorescu, D

1977 ("1976"). Paratethyan Seals. Systematic Zoology, 25(4):407-419. [Date on title page is 1976; actually published 1977.]

Gromova, V.I., 1.A. Dubrovo, and N.M. Janowskaya

1962. [Order Pinnipedia: Seals.] In V.l. Gromova, editor, Osnovy Paleontologii [Fundamentals of Paleontology], 13 [Mammals]: pages 234-235. Moscow. [1n Russian. English translation by lsrael Program for Scientific Translations, Jerusalem, 1968.]

Heptner, V.G, K.K. Chapskii, B.A. Arsen'ev, and V.E. Sokolov

1996. Pinnipeds and Toothed Whales. In V.G. Heptner and N.P. Naumov, editors, Mammals of the Soviet Union, 2(3): xxx + 995 pages. Washington, D.C. [Originally published in Russian as Mlekopitayushchie Sovetskogo Soyuza. Moscow: Vysshaya Shkola, 1976.]

Holec, P., J. Klembara, and S. Meszáros

1987. Discovery of New Fauna of Marine and Terrestrial Vertebrates in Devínska Nová Ves. Geologický Zbornik. Geologica Carpathica (Bratislava), 38(3):349-356

Kellogg, R.

1922. Pinnipeds from Miocene and Pleistocene Deposits of California. University of California Publications, Bulletin of the Department of Geological Sciences, 13(4):23-132, 19 figures, folding table.

King, $J$.

1956. The Monk Seals (Genus Monachus). Bulletin of the British Museum (Natural History), Zoology, 3:201-256, 5 plates

1964. Seals of the World. 154 pages, 17 figures, 14 plates, frontispiece, 30 maps. London: Trustees of the British Museum (Natural History).

1966. Relationships of the Hooded and Elephant Seals (Genera Cystophora and Mirounga). Journal of Zoology (London), 148(4): 385-398, 7 figures.

1983. Seals of the World. Second edition, 240 pages. London: British Museum (Natural History).

Kirpichnikov, A.A.

1961. [Sketch of the History of Study of Marine Mammals from Sarmatian Localities in the USSR and Neighboring Countries.] Trudy Ikhtiologicheskoi Komissii Akademii Nauk Ukrainskoi SSR, 12:25-39. [1n Russian.]

Koretskaya [Koretsky], I.A

1987. [Sexual Dimorphism in the Structure of the Humerus and Femur of Monachopsis pontica (Pinnipedia: Phocinae).] Vestnik Zoologii, 4:77-82. [1n Russian.]

Koretsky, I.A., and P. Holec

2002. A Primitive Seal (Mammalia: Phocidae) from the Early Middle Miocene of Central Paratethys. In R. Emry, editor, Cenozoic Mammals of Land and Sea: Tributes to the Career of Clayton E. Ray. Smithsonian Contributions to Paleobiology, 93:163-178.
Koretsky, 1.A., and C.E. Ray

1994. Cryptophoca, New Genus for Phoca Maeotica (Mammalia: Pinnipedia: Phocinae) from Upper Miocene Deposits in the Northern Black Sea Region. Proceedings of the Biological Society of Washington, 107(1):17-26, 4 figures, 3 tables.

In prep. Phocidae of the Pliocene of Eastern North America. Smithsonian Contributions to Paleobiology.

Koretsky, 1.A., and A.E. Sanders

2002. Paleontology of the Late Oligocene Ashley and Chandler Bridge Formations of South Carolina, 1: Paleogene Pinniped Remains; The Oldest Known Seal (Carnivora: Phocidae). In R. Emry, editor, Cenozoic Mammals of Land and Sea: Tributes to the Career of Clayton E. Ray. Smithsonian Contributions to Paleobiology, 93:179-183.

Korotkevich, E.L., V.N. Kushniruk, Y.A. Semenov, and A.P. Chepalyga

1985. [New Localities of Middle Sarmatian Vertebrates in the Ukraine.] Vestmik Zoologii, 3:81-82. [In Russian.]

Kretzoi, M

1941. Seehund-Reste aus dem Sarmat von Érd bei Budapest. Földtani Közlöny, 71(7-12):350-356

Macarovici, N.

1942. Sur les phoques fossiles du Sarmatien de l'Europe. Annales Scientifiques de l'Université de Jassy, section 2, 28(10):260-268.

Macarovici, N., and C.V. Oescu

1942. Quelques vértebrés fossiles trouvés dans les calcaires récifales de Chişinau (Bessarabia). Analele Academiei Romāne, Memoriile Sect, iunii Știinjifice, series 3, 17(6):351-382, 7 plates.

Marcoci, G.V., and M. Popa

1957. Contribution à la description du crâne de Monachus monachus Herm., le phoque de la mer Noire. Revue de Biologie, Académie de la République Populaire Roumaine, 2(2):277-295.

McLaren, I.A.

1960. On the Origin of the Caspian and Baikal Seals and Their Paleoclimatological Implications. American Journal of Science, 258:47-65.

Michaylov, S.S.

1980. Mezdynarodnaya anatomicheskaya nomenklatyra [International Anatomical Nomenclature]. Fourth edition, 239 pages. Moscow: Medicinskaya Literatura [Medical Literature]. [ln Russian.]

Muizon, C. de

1981. Les vertébrés fossiles de la formation Pisco (Perou), Première partie: Deux nouveaux Monachinae (Phocidae: Mammalia) du Pliocène de Sud-Sacaco. Travaux de l'Institut Français d'Études Andines, 22: 161 pages.

1982. Phocid Phylogeny and Dispersal. Annals of the South African Museum (Cape Town), 89(2):175-213, 9 figures, 1 table

1992. Paläontologie. In Raymond Duguy and Daniel Robineau, editors, Meeressäuger: Robben-Pinnipedia. In Jochen Niethammer and Franz Krapp, editors. Handbuch der Säugetiere Europas, 6(2) 34-41. Wiesbaden: AULA-Verlag.

Nordmann, A.D. von

1860 [1858]. Palaeontologie Südrusslands. 360 pages, atlas of 24 plates Helsingfors: H.C. Friic. [Plates published 1858. Text to accompany plates published 1860.]

Ognev, S.1.

1935. [Fissipedia and Pinnipedia.] In [Mammals of the USSR and Adjacent Countries], 3: 752 pages. Moscow, Leningrad: Glavpushnina. [In Russian. English translation by A. Birron and Z.S. Coles for lsrael Program for Scientific Translations, Washington, D.C., 1962.]

Pavlinov, 1.J., and O.L. Rossolimo

1987. [Systematics of Mammalia of the Soviet Union.] 282 pages. Moscow: Moscow University. [In Russian.]

Pidoplichko, I.G.

1956. [Materials for the Study of the Faunas of the Ukrainian SSR.] Second edition, 225 pages. Kiev: Naukova Dumka. [In Ukrainian.]

Piérard, J.

1971. Osteology and Myology of the Weddell Seal (Leptophoca weddelli 
(Lesson, 1826). In W.H. Burt, editor, Antarctic Pinnipedia. Antarctic Research Series, 18:53-108. Washington, D.C.: National Academy of Sciences, National Research Council.

Ray, C.E.

1977 (“1976"). Geography of Phocid Evolution. Systematic Zoology, 25(4): 391-406. [Date on title page is 1976; actually published 1977.]

Repenning, C.A., and C.E. Ray

1977. The Origin of the Hawaiian Monk Seal. Proceedings of the Biological Society of Washington, 89(58):667-688.

Repenning, C.A., C.E. Ray, and D. Grigorescu

1979. Pinniped Biogeography. In J. Gray and A.J. Boucot, editors. Historical Biogeography, Plate Tectonics, and the Changing Environment: Proceedings of the 37th Annual Biology Colloquium and Selected Papers, pages 357-369. Corvallis: Oregon State University Press.

Robinette, H., and H.J. Stains

1970. Comparative Study of the Calcanea of the Pinnipedia. Journal of Mammalogy, 51(3): 527 pages.

Savage, D.E., and D.E. Russell

1983. Mammalian Paleofaunas of the World. 432 pages. Reading, Massachusetts: Addison-Wesley.

Scheffer, V.B.

1958. Seals, Sea Lions and Walruses: A Review of the Pinnipedia. 179 pages, 32 plates, 15 figures. Stanford, California: Stanford University Press.

Semenenko, V.N.

1987. Sytratigraficheskaya korrelacia verchnego Miocena i Pliocena, Vostochnuy Paratetis $i$ Tetis [Stratigraphical Correlation of Upper Miocene and Pliocene, Eastern Paratethys and Tethys]. 230 pages. Kiev: Naukova Dumka. [In Russian.]

Semenov, Y.A.

1981. [On the Question of the Systematic Situation of the Genus Palhyaena Gervais, 1859 (Carnivora, Hyaenida).] In [Ecological-Morphological Specialization of the Animals and Their Environmental Habitats], pages 58-61. Sbornik Nauchnykh Trudov. Kiev: Naukova Dumka. [ln Russian.]

Sergienko, N.I.

1967. [On the Taxonomic Significance of Some Parts of the Postcranial Skeleton of the Genus Pusa.] Trudy Poliarnogo Institute Morskogo Rybnogo Khoziaistva e Okeanography (PINRO) (Murmansk), 21:185-193. [In Russian.]

Simionescu, I.

1925. Foci fosile din Sarmatecul de la Chişinau. Academia Romänâ Memoriile, Secţiunii Ştiinţifice, 3(3)4:179-191, 4 plates.

Simpson, G.G.

1945. The Principles of Classification and a Classification of Mammals. Bulletin of the American Museum of Natural History, 85: 350 pages. Sinelnikov, R.D.

1963. Atlas anatomii cheloveka [Atlas of the Anatomy of Man]. Second edition, volume 1, 477 pages. Moscow: Medicinskaya Literatura

Sokolov, V.E. [Medical Literature]. [In Russian.]

1979. [Cetacea, Pinnipedia, Carnivora, Tubulidentata, Tylopoda, Perissodactyla]. In Sistematika mlekonitauzchich [Systematics of Mammals], 3: 528 pages. Moscow: "Vischaya Schkola" [High School]. [In Russian.]

Tavani, G.

1941. Revisione dei resti del pinnipede conservato nel Museo di Geologia di Pisa. Paleontographica Italica, Memorie di Paleontologia, 40: 97-113, 15 plates, 23 figures. [Volume 40 dated 1942.]

Tedford, R.H.

1977 ("1976"). Relationship of Pinnipeds to Other Camivores (Mammalia). Systematic Zoology, 25(4):363-374. [Date on title page is 1976; actually published 1977.]

Thenius, E.

1950. Ergebnisse der Neuuntersuchung von Miophoca vetusta (Zapfe) (Phocidae, Mammal.) aus dem Torton des Wiener Beckens. Anzeiger der Österreich Akademie der Wissenchaften, Vienna, Mathematisch-Naturwissenschaftliche Klasse, 5:1-9.

1952. Die Säugetierfauna aus dem Torton von Neudorf an der March (CSR). Neues Jahrbuch für Geologie und Paläontologie, Abhandlungen (Stuttgart), 96(1):27-136, 70 figures.

Trelea, N., and T. Simionescu

1985. Au sujet de quelques formes de vertébrés des formations sarmatiennes de Şchelia du département Jassy. Analele Ştiinţifice ale Universitatii Jasi, Geologie-Geografic, 31:18-20.

Trouessart, E.-L.

1897. Carnivora, Pinnipedia, Rodentia I. In Catalogus mammalium tam viventium quam fossilium. New edition, volume 2, pages 219-452. Berlin: R. Friedländer and Son

Van Beneden, P.-J.

1877. Description des ossements fossiles des environs d'Anvers, première partie: Pinnipèdes ou Amphithèriens. Annales du Musée Royal d'Histoire Naturelle de Belgique, 1: 88 pages, 18 plates, 17 figures, 9 maps.

Wozencraft, W.C.

1989. The Phylogeny of the Recent Carnivora. In John L. Gittleman, editor, Carnivore Behavior, Ecology, and Evolution, pages 495-593. 1thaca, New York: Comell University Press.

Wyss, A.R.

1988. On "Retrogression" in the Evolution of the Phocinae and Phylogenetic Affinities of the Monk Seals. American Museum Novitates, 2924: 38 pages.

Zapfe, $\mathrm{H}$.

1937. Ein bemerkenswerter Phocidenfund aus dem Torton des WienerBeckens. Verhandlungen der K.K. Zoologisch-Botanischen Gesellschaft (Vienna), 86/87:271-276, 2 figures. 


\title{
A Primitive Seal (Mammalia: Phocidae) from the Early Middle Miocene of Central Paratethys
}

\author{
Irina A. Koretsky and Peter Holec
}

\section{ABSTRACT}

A well-preserved skull from the early middle Miocene (approximately $15 \mathrm{Ma}$ ) at Devinska Nova Ves (formerly Neudorf an der March), Slovakia, herein named Devinophoca claytoni, new genus and new species, is morphologically the closest common ancestor of all true seals. It shows a mixture of subfamilial characters. Features shared with Phocinae are the number of incisors and the lack of a strongly pronounced mastoid process. Characters similar to Monachinae are the shape of maxillae and the ratio between frontal and maxillary contacts of nasal bones. Characters shared with Cystophorinae are the ratio between interorbital width and mastoid width and (also shared with Phocinae) the ratio between length of auditory bullae and distance between them. Moreover, this skull has primitive features that are not known in any of the three subfamilies: M1 is triangular, with three cusps and three roots; in P2-P4 the larger posterior roots are clearly made up of two fused roots; the incisors form a curved line; the anterior palatal foramina are deep and oval; and the sagittal crest is very well developed.

The traditional separation of the family Phocidae into the subfamilies Phocinae, Monachinae, and Cystophorinae has been intensively debated during the past 40 years and debate continues today, but we herein follow the traditional classification. The plesiomorphic $D$. claytoni is thus considered a sister taxon to the three extant subfamilies of Phocidae and is referred to a new subfamily, Devinophocinae. Because of its late age, $D$. claytoni cannot be ancestral to the more advanced phocids. Its primitive characters in combination with the characters it shares with the other subfamilies suggest, however, that it might approximate the common ancestral morphotype.

\section{Introduction}

Around Devínska Kobyla Hill near Bratislava, Slovakia (Figure 1), fossil mammals are found at eight localities. A brief

Irina A. Koretsky, Research Associate, Department of Paleobiology, National Museum of Natural History, Smithsonian Institution, Washington, D.C. 20560-0121, United States. Peter Holec, Department of Geology and Paleontology, Faculty of Natural Sciences, Comenius University, Mlynská Dolina, 84215 Bratislava, Slovakia. description and a list of all vertebrate species from these localities were given by Holec and Sabol (1996). These assemblages contain a mixture of marine and terrestrial vertebrates. Fossil seals are found at three of the localities at Devínska Nová Ves: Sandberg, Bonanza (a newly discovered fissure-filling at the quarry of the former Stokerau limekiln), and Wait's Quarry. The first locality discovered was Sandberg, the history of which was discussed in detail by Thenius (1952). The original independent township Devínska Nová Ves (Neudorf an der March in the earlier literature) is now a suburb of Bratislava.

In the quarry of the former Stokerau limekiln, two localities with mammalian faunas are found. The first is Zapfe's classical locality, consisting of two fissures in the western part of the quarry filled with terra fusca with many fossil bones of terrestrial mammals; marine mammals have never been found there. At present, only the more western of the two fissures can be seen. At the eastern end of the limestone quarry a new, second locality, called Bonanza, was discovered more recently; there, abundant fossil bones of terrestrial and marine vertebrates (fishes and seals) are mixed in the same deposit.

The knowledge of the mammalian assemblage found in the two western fissures at the Stokerau limekiln is the result of the efforts of Helmuth Zapfe. His father, I.B. Zapfe, saved the fossils that were discovered in the fissure-filling during exploitation of the limestones in 1943. From the large-mammal fauna, Zapfe (1953) determined the age of the filling to be "Helvetian." Fejfar (1974) also carried out research there, focused mainly on the small mammals. He identified five species of insectivores and fifteen species of rodents, on the basis of which he determined the age of the assemblage to be early Badenian. Some species of rodents were mentioned also by Holec (1986).

The Bonanza locality was discovered in 1984 by the amateur paleontologist Š. Mészároš. Its vertebrate fauna was described by Holec et al. (1987). In addition to the mammals, abundant remains of fishes and frogs also were found there.

Remains of seals also were found at Wait's Quarry; a short description of the locality by Holec and Sabol (1996) mentioned the occurrence. 


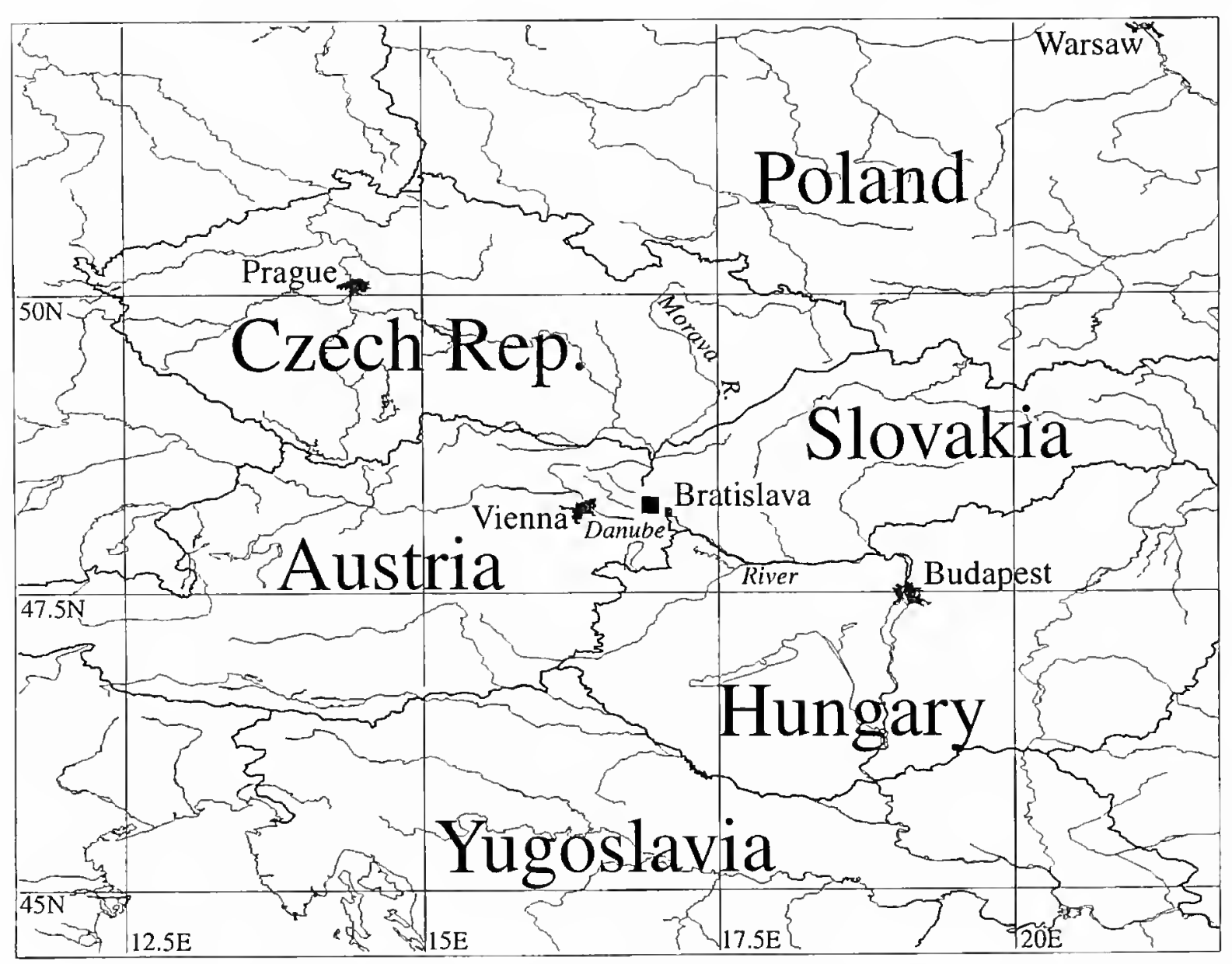

FIGURE 1.- Map of Central Europe. Study area indicated by black square.

Zapfe's (1937) description of Miophoca vetusta from the Sandberg locality (early middle Miocene; Badenian) was based upon a mandible. He noted that this specimen may be related to Pristiphoca Gervais, 1848-1852, and also is very close to the living Monachinae. Later, Thenius (1950), using Zapfe's hypothesis, transferred this material to the genus Pristiphoca. As explained below, we do not accept this transfer because this genus is a nomen dubium.

A preliminary description of the pinniped skull described herein has already been published by Holec with a list of the other fossil mammals from the early Miocene of Slovakia (Holec et al., 1987). When Koretsky visited the Slovak National Museum in Bratislava in 1995, she recognized the unusual morphology of a this skull and its importance to phocid evolution.

In this paper, we accept a traditional classification (Simpson, 1945; Chapskii, 1955, 1974; Scheffer, 1958; King, 1966; Heptner et al., 1976) in which the family Phocidae is divided into three subfamilies: Phocinae, Monachinae, and Cystophorinae.

For our morphometric analysis of the skull, we used the methods of Dornesco and Marcoci (1958), Piérard (1971), von den Driesch (1976), and Trelea and Simionescu (1985). Osteological terminology in this paper follows the Illustrated Veterinary Anatomical Nomenclature (Schaller, 1992).

ACKNOWLEDGMENTS.-We thank Clayton E. Ray and Robert J. Emry, National Museum of Natural History (NMNH), Smithsonian Institution, and Daryl P. Domning, Howard University, for their critical reviews and discussion of several drafts of this work; Steven J. Jabo and Victor Krantz, NMNH, for the photographs presented in this paper; Jennifer Emry for illustrations; Peter Kroehler, NMNH, for providing casts for study; James G. Mead and Charles W. Potter, NMNH, for permission to study the modern pinnipeds in the National Museum collections; and R. Ewan Fordyce, Department of Geology, University of Otago, Dunedin, New Zealand, for his help with the cladistic analysis. The authors express their sincere thanks to I. Iablonský for critical reading of the manuscript and for encouraging remarks; to V. Matlàkovà for the geological map; and to Anna Durišová and Branislav Matoušek, both from the Slovak National Museum of Natural History, Bratislava, and Michael Ková, Department of Geology and Paleontology, Faculty of Sciences, Comenius University, Bratislava, for their cooperation and permission to study material under their care.

We would like to thank two anonymous reviewers and Lawrence G. Barnes from the Natural History Museum of Los Angeles County for constructive critical reviews of the manuscript.

Most of the financial support for the travel and research for this project was provided by the Remington and Marguerite Kellogg Fund of the Smithsonian Institution.

\section{GeOLOGY}

Rising to $514 \mathrm{~m}$ above sea level, Mt. Devinska Kobyla is the highest peak in the Devínske Karpaty Mountains, which constitute the southernmost tip of the Male Karpaty Mountains in 
Slovakia. Devinska Kobyla lies near the southern edge of the mountains, close to the Vienna Basin. The Devínske Karpaty range is bounded by the Danube River on the south and southeast, the Morava River on the west, Dúbravský Potok creek on the north, and the Lamaè Fault, which separates these mountains from the rest of the Malé Karpaty, on the north-northeast. The whole area lies in the territory of greater Bratislava City, which includes once-separate villages such as Devínska Nová Ves, near which are several important fossil vertebrate localities, and the village of Devin (Figures 1, 2).

The Devínska Kobyla area was emergent at the beginning of the late Miocene, and terrestrial sediments being produced by erosion were sometimes trapped and preserved in fissures and caverns in the subjacent limestones. This is exemplified by loamy fillings in a quarry of the former Stockerau lime plant. The early middle Miocene (early Badenian, 16.0-13.6 Ma) fillings contain many bones of various vertebrates, described mainly by Zapfe between 1949 and 1983. The terrestrial loam in these fissures is overlain by transgressive sandy marine sediments of late Badenian age.

Late Badenian sediments occur (along with early and middle Badenian sediments) in drillhole DNV-1 (Bonanza locality), as well as in outcrops. The lithostratigraphic unit, Sandberg Sands, had been defined there by Baráth et al. (1994). The base of this formation consists of gravels with pebbles of variable size intercalated with sands. The sands reflect a transgressive stage of deposition on the eastern edge of the Vienna Basin. Calcareous clays and friable siltstones, which account for the entire late Badenian in the basin are found in a brick plant in Devínska Nová Ves. These sediments are typically rich in micro- and macrofauna and include terrestrial flora (Holec, 1987; Holec and Sabol, 1997).

The late Badenian marine transgression reached the slopes of Devínska Kobyla, whose summit at that time protruded as an island or peninsula. Littoral deposits (carbonate breccias) of late Badenian age are found in numerous outcrops: sands, sandstones, algal limestones, and carbonate breccia. Coarse breccia and conglomerates, with clasts as much as $1 \mathrm{~m}$ in size, are exposed in the former Wait's Quarry on the western slope of Devínska Kobyla, where they were deposited on the inundated ridge (Andrusov, 1969). The signs of a seacoast also are very clearly visible at the renowned Sandberg locality, where almost 300 species of fossils including marine algae, invertebrates, marine vertebrates, and terrestrial mammals have been found (Holec, 1985; Holec and Sabol, 1996; Švagrovský, 1981). The presence of red algal sandy limestones at Sandberg proves that the sea here was shallow during the time of late Badenian deposition.

The whole Devinska Kobyla area is rich in fossil remains of invertebrates and vertebrates alike. The three Badenian localities yielding fossil seals (Figure 2) are (1) Wait's Quarry, an abandoned quarry on the western slope of Devínska Kobyla, (2) Sandberg, a sand pit located about $700 \mathrm{~m}$ north of Wait's Quarry, and (3) the Bonanza sublocality of the Stockerau limekiln.

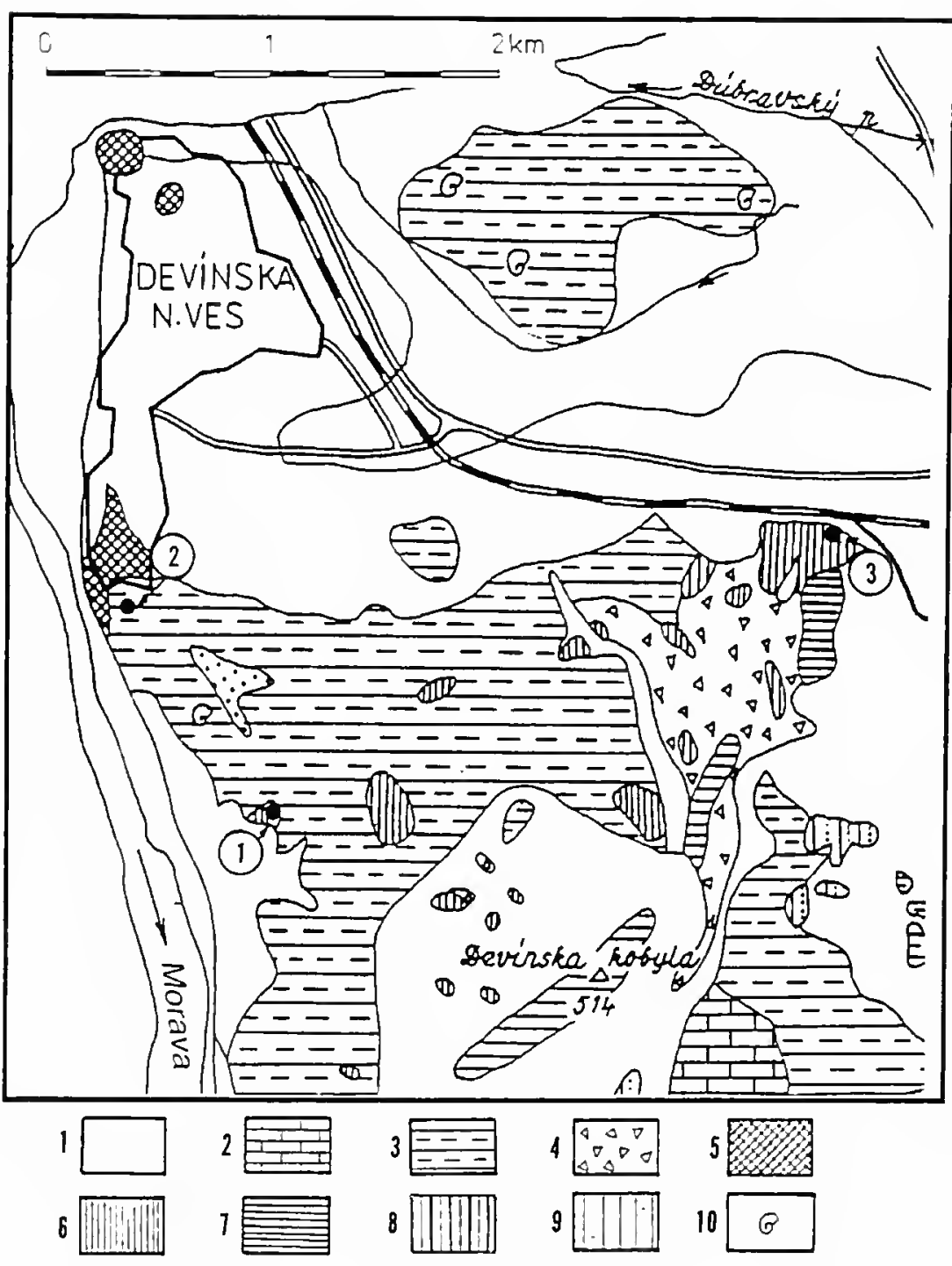

FIGURE 2.-Geological map of Devinska Kobyla: $1=$ Quatemary, undifferentiated: fluvial, proluvial, and man-made sediments. $2=$ Sarmatian: Bryozoan-serpulid limestones, oolitic sands, calcareous and variegated clays, sands. $3=$ Studienka Formation, late Badenian: algal limestones, sands with sandstone beds and gravel intercalations, conglomerates dominated by granite pebbles. $4=$ Devínska Nová Ves, middle Badenian and undifferentiated Badenian: granite conglomerates, carbonate breccias cemented by sinter, conglomerates. $5=$ Mesozoic, Albian?: shales; Neocomian: mildly marly, cherty limestones; Dogger-Malm: siliceous limestones and silicites; Lias: brecciated limestones with carbonate extraclasts. $6=$ Envelope unit, Middle Triassic: massive, locally dolomitic limestones, massive intraclast breccia dolomites interlayered with limestones. $7=$ Early Triassic: bedded siliceous limestones and dolomites. $8=$ Late Devonian-Early Carboniferous: aplite and pegmatite dikes. 9=Pre-Devonian: crystalline schists, primarily metapelites. $10=$ Fossil occurrences. Localities (circled numbers): Wait's Quarry (1), Sandberg (2), Bonanza (3).

The former Stockerau lime plant and its quarry are situated on the northern slope of Devínska Kobyla. Dark gray, fairly strongly recrystallized limestone of Jurassic age is exposed there. It is dissected by north-south trending fissures, many of them filled with sinter, terra rossa, and terra fusca. Overlying all of these is late Badenian marine sand. A rich vertebrate fauna was described largely by Zapfe (1937-1983) from two of these fissures in the western part of the Stockerau quarry. Bonanza is a third fissure located nearby on the quarry's eastern edge. Unlike the preceding two fissures, which yielded only terrestrial vertebrates, this one also contains a wealth of remains of fish, seals, and marine invertebrates (Holec et al., 
1987). The holotype skull of Devinophoca claytoni described below was found there.

\section{Systematic Paleontology}

\section{Superfamily PHOCOIDEA Smirnov, 1908}

\section{Family PhOCIDAE Gray, 1825}

\section{Subfamily DEVINOPHOCINAE, new subfamily}

DiAGNOSIS.-Upper dental formula I3, Cl, P4, M1 (shared with Phocinae). Incisors forming U-shaped arcade; P2-P4 double rooted (as in Phocinae and Monachinae, in contrast to Cystophorinae), with posterior root larger than anterior; P4 with two fused posterior roots and with carnassial notch on metastyle blade; M1 triangular with three cusps and three roots (no other phocid has teeth with three cusps and three roots in triangular arrangement); preorbital part of maxilla with very short, pronounced concavity (similar to Monachinae); antorbital process well defined; frontal contact of nasal bones much shorter than maxillary contact (shared with Phocinae); interorbital space slightly broader anteriorly than posteriorly; interorbital width less than $25 \%$ of width of skull at mastoid processes (as in Cystophorinae); sagittal crest very well developed (more than in Monachinae) and not forming triangle with lambdoidal crests; diameter of infraorbital foramen less than diameter of alveolus of upper canine (as in Monachus schauinslandi, unlike Phocinae and Cystophorinae); anterior palatal foramina ovalshaped and deep (as in Cystophorinae), with well-pronounced palatal groove; anteroposterior length of tympanic bullae greater than distance between them (similar to Phocinae and Cystophorinae); width of mastoid process less than one-half length of tympanic bulla; mastoid convexity not turned down behind mastoid process (as in Phocinae).

TYPE AND ONLY INCLUdED GENUS.-Devinophoca, new genus

\section{Genus Devinophoca, new genus}

Pristiphoca.-sensu Holec et al., 1987:350, fig. 3.-[Not Pristiphoca Gervais, 1852:272 (nomen dubium)].--[Not Pristiphoca Thenius, 1950:1-9; 1952: 60-63; 1969:402, figs. 420, 421; 1979:171; 1992:73].

TYPE SPECIES.-Devinophoca claytoni, new species.

ETYMOLOGY.-From Devin, in reference to Devínska Nová Ves, Slovakia; and phoca (Latin), seal.

DIAGNOSIS.-As for the subfamily until other genera are described.

REMARKS.-According to Koretsky and Ray (in prep.), the name Pristiphoca occitana Gervais and Serres, 1847, in Gervais, 1848-1852 is a nomen dubium because it was based upon an illustration of the canine tooth of an indeterminate carnivore.

\section{Devinophoca claytoni, new species}

FiguRES 3-8, TABLES 1,2

Miophoca velusta Zapfe, 1937.-Holec et al., 1987:350, fig. 3 [assignment to Pristiphoca].

HOLOTYPE.-Incomplete skull with right M1 and left P2-M1; collected by the amateur paleontologist Š. Mészároš in 1984; catalog number Z14523 of the Museum of Natural History, Slovak National Museum, Bratislava, Slovak Republic.

TYPE Locality.-Stokerau lime quarry, Bonanza Hill, Devínska Kobyla, Slovak Republic.

ETYMOLOGY.-Named in honor of Clayton E. Ray, in recognition of his numerous contributions to the study of fossil pinnipeds.

AGE AND DisTRIBUTION.-Badenian, early middle Miocene, 14.8 Ma (Steininger and Nevesskaya, 1975; Steininger et al., 1989; Rögl and Daxner-Höck, 1996); Vienna Basin of Slovakia.

DIAGNOSIS.-As for the subfamily and genus.

DESCRIPTION AND COMPARISON.-The obliterated sutures and heavily worn premolars indicate that the holotype cranium of D. claytoni represents an adult individual. All of the incisors and both canines have fallen out. On the right side of the skull all teeth have fallen out except Ml. The anterior part of the premaxillae around the incisors, the palatine, parts of the palatine processes of the maxilla, and much of the orbital parts of the frontal bones are missing. Part of the basicranium is broken away also, and the vomer, pterygoid, presphenoid, and basisphenoid bones are missing. Both jugal (=zygomatic) bones are missing, the paroccipital (=jugular) processes are broken away, and the supraoccipital part of the occipital shield is largely absent.

The pre- and postorbital parts of the skull are approximately equal in length (Figure 3 ). The lateral outline of the braincase is rounded. In lateral profile, the top of the skull is slightly concave. The braincase is widest $(84.5 \mathrm{~mm})$ above the external auditory meatus. The preorbital parts of the maxillae, between the nasal aperture and the orbits, are short and concave, the same shape as in the Monachinae (Chapskii, 1974). The palatal parts of the premaxilla-maxillary sutures are fused and completely obliterated, but lateral to the nares, near the nasal bones, the sutures are clear. The tongue-like ascending process (pnp) of the premaxilla has a short (at least $4.0 \mathrm{~mm}$ ) contact with the lateral edge of the nasal bones (Figure 4A,B); it cannot be determined with certainty whether this process of the premaxilla is complete.

The supraorbital process (sop) of the frontal bone is represented only by a small tubercle (Figure $3 \mathrm{~A}, \mathrm{~B}$ ). On the maxilla at the anterior margin of the orbit is a small but distinct antorbital process (aop). The fronto-maxillary suture is slightly forward of the anterior rim of the orbit. 


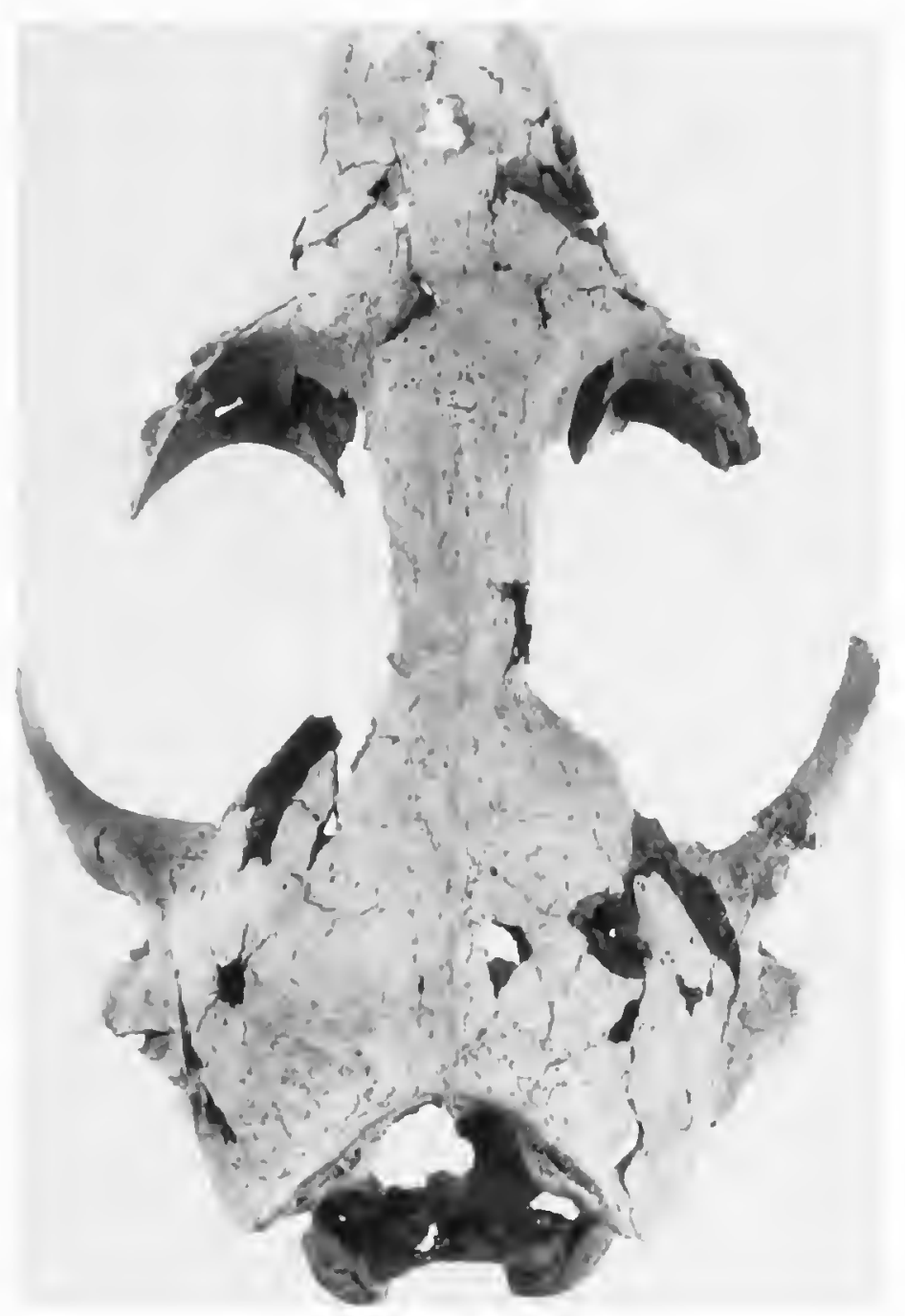

A

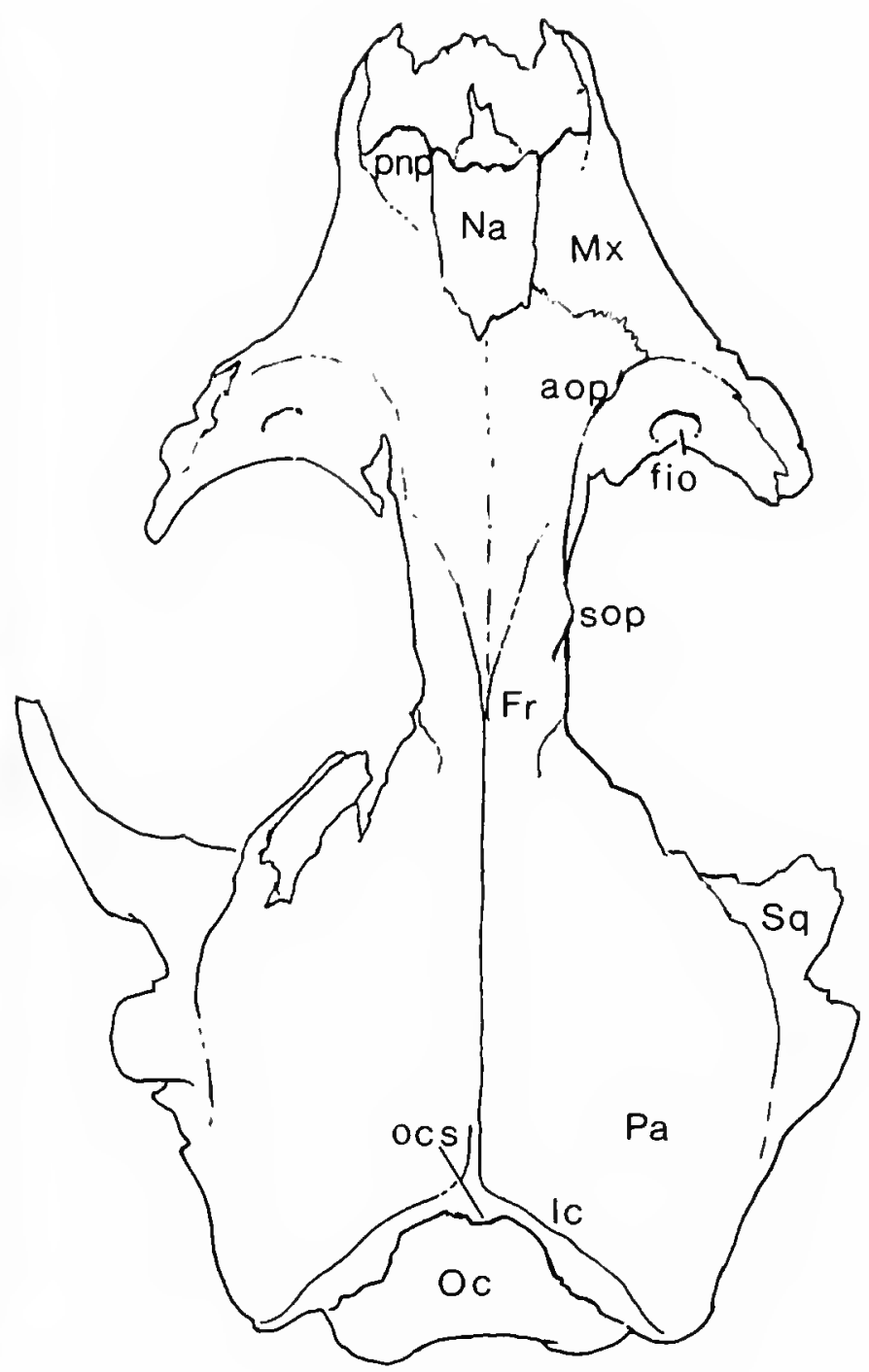

B

FIGURE 3,-Devinophoca claytoni, new genus and species, holotype skull Z14523: A, dorsal view; scale bar= $0.75 \mathrm{~cm}$; B, outline drawing of the photograph of dorsal view. (Abbreviations for Figures 3-7: aop=antorbital process; $\mathrm{Bo}=$ basioccipital; $\mathrm{cc}=$ carotid canal; $\mathrm{cf}=$ carotid foramen; $\mathrm{ch}=$ hypoglossal canal; $\mathrm{cma}=$ anterior musculotubular canal; $\operatorname{coc}=$ condyloid canal with transverse venous sinus; eam=external acoustic meatus; ec=ectotympanic; en=entotympanic; $f i=$ incisive foramen; fio=infraorbital foramen; flp=posterior lacerate foramen; fml= median lacerate foramen; fpal=palatine foramen; $f p g=$ postgelenoid foramen; $\mathrm{Fr}=$ frontal; fsm=stylomastoid foramen; $\mathrm{g}=$ glenoid fossa; $\mathrm{ju}=$ jugal process of squamosal; $\mathrm{lc}=$ lambdoidal crest; $\mathrm{mp}=$ mastoid process; $\mathrm{mt}=$ meatal tube of the bulla; $\mathrm{Mx}=$ maxilla; $\mathrm{Na}=$ nasal; $\mathrm{Oc}=$ occipital; occ=occipital condyle; ocs=supraoccipital crest; $\mathrm{Pa}=$ parietal; $\mathrm{Pal}=$ palatine; $\mathrm{Pmx}=$ premaxilla; $\mathrm{pnp}=$ nasal process of the premaxilla; $\mathrm{pp}=$ paroccipital process; $\mathrm{Sq}=$ =squamosal; sips=sulcus for inferior petrosal sinus; sop=supraorbital process; $\mathrm{spt}=$ transverse palatal suture; tb=tympanic bulla.)

Neither jugal bone is present, but the maxillary-jugal suture is complete on the left side; it slopes posterolaterally from the anteroventral edge of the orbit.

The nasal bones (Figures 3,4A) are very short and completely fused to each other along the midline; their frontal contact is much shorter than their maxillary contact. Posteriorly the nasal bones together form a $V$-shaped projection about $5 \mathrm{~mm}$ long inserted between the frontal bones. The posterior limit of the nasal bones is immediately behind the broad frontal-maxillary contact. The width of the nasal bones is approximately constant for their whole length except for the small pointed frontal process. The nasal opening is circular (Figure 4A,B).
The lateral edge of each nasal bone projects farthest anteriorly; the anterior edge of each nasal bone is concave, and together the two nasals form a short median anterior projection. This shape of the anterior border of the nasal bones is more similar to that of the Phocinae (especially Erignathus) than to that of other members of the Phocidae. The ratio between the lengths of the frontal and maxillary contacts of the nasal bones, however, is more similar to that of Monachinae.

The interorbital region is slightly wider anteriorly and narrows posteriorly to where the braincase begins. The least interorbital width occurs in the most posterior portion of the interorbital area. Berta and Wyss (1994) noted that this very primitive 

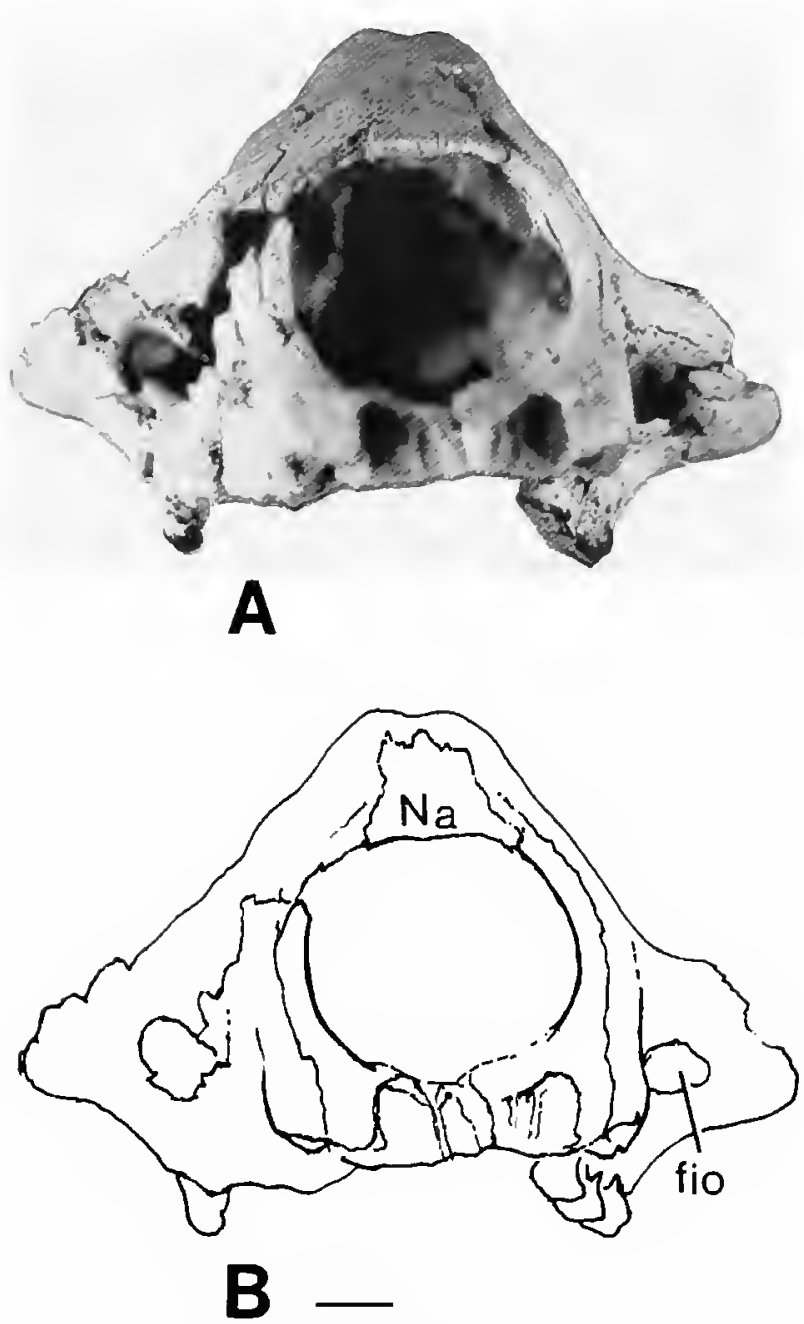
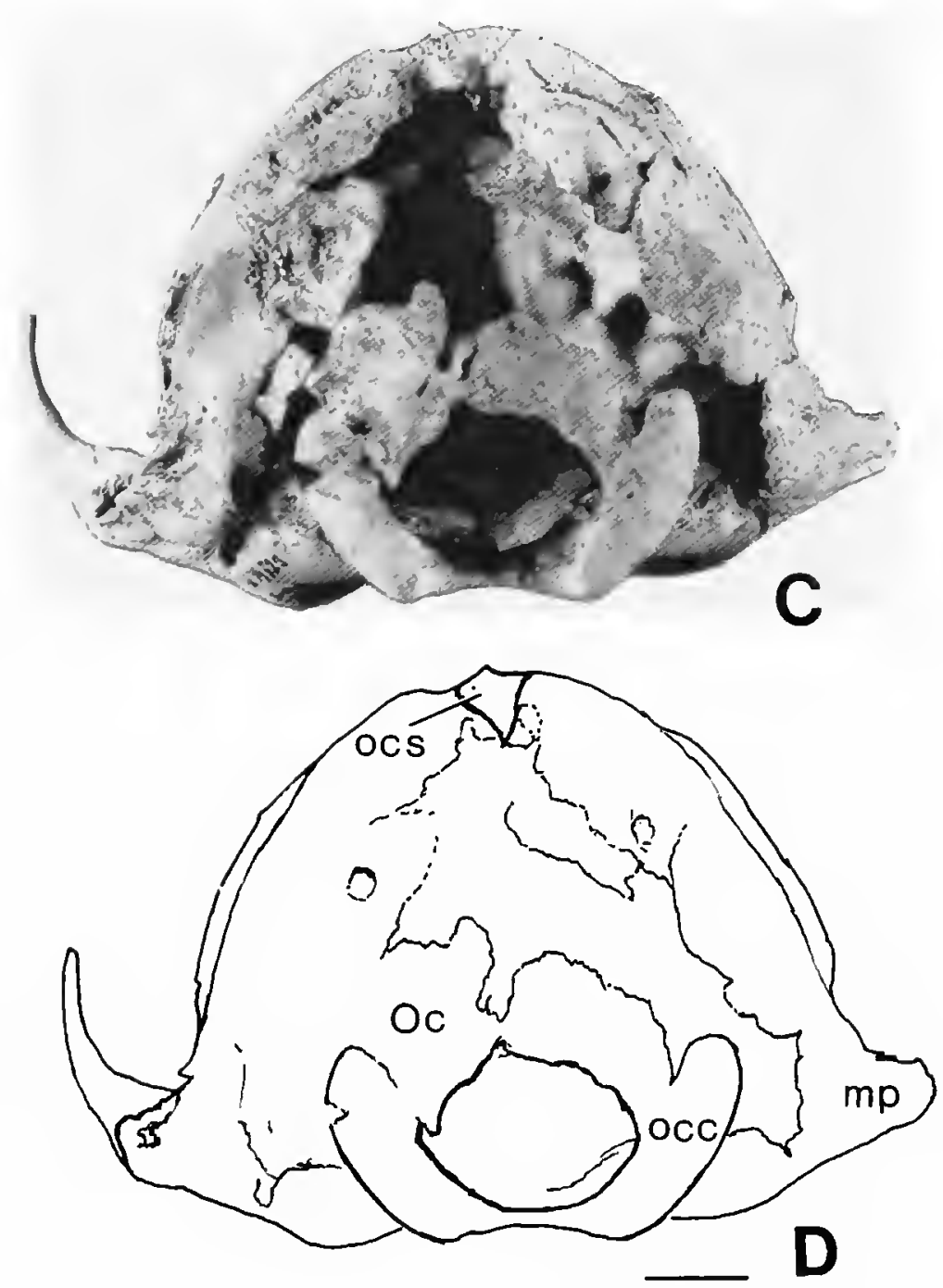

FIGURE 4.-Devinophoca claytoni, new genus and species, holotype skull Z14523: A, anterior view; B, outline drawing of the photograph of anterior view; scale bar $=0.75 \mathrm{~cm}$; C, posterior view; $D$, outline drawing of the photograph of posterior view, scale bar $=1.0 \mathrm{~cm}$. For explanation of abbreviations see Figure 3.

feature is typical for terrestrial camivorans. The widest part of the interorbital area $(24.0 \mathrm{~mm})$ is about $21 \%$ of the width of the skull across the mastoid processes $(113.0 \mathrm{~mm}$; Table 1$)$, which is very similar to the ratio in Cystophorinae (including Cystophora and Mirounga).

The sagittal crest is much better developed than in other Phocidae; it begins at the narrowest part of the interorbital area, even with the posterior ends of the orbit, and continues to the lambdoidal crest. At its anterior end the sagittal crest divides into two much smaller, indistinct temporal crests that disappear at the dorsal edge of the orbit. The depressions on either side of the sagittal crest become deeper where they meet the lambdoidal crests. The sagittal and lambdoidal crests join at a point, without the triangle seen in the monachines. The maximum height of the sagittal crest is about $2 \mathrm{~mm}$.

The infraorbital foramen (Figures $4 \mathrm{~A}, \mathrm{~B}, 6 \mathrm{~B}$ ) is located above the posterior $\mathrm{P} 4$-anterior $\mathrm{Ml}$; it is circular and relatively small. The diameter of the alveolus of the upper canine $(13.2 \mathrm{~mm})$ is greater than the diameter of the infraorbital foramen, in contrast to Phocinae. When the skull is viewed dorsally, the posterior opening of the infraorbital canal cannot be seen in the orbits. The ventral root of the zygomatic process of the maxilla originates posterolateral to $\mathrm{Ml}$, at the same level as the palatal process of the maxilla. The medial wall of the infraorbital canal is continued posteriorly by the vertical interorbital plate of the maxilla, which is very similar to the condition in Enaliarctos mealsi Mitchell and Tedford, 1973.

The palatine process of the maxilla (Figure 6) is a flat plate. The anterior palatal foramina (=fissurae palatinae) are located between the canines and are oval and deep, in contrast to the condition stated by Wozencraft (1989) for other phocids. Between the canines the palate is narrow and concave $(18.5 \mathrm{~mm}$ wide and $11 \mathrm{~mm}$ high) and descends abruptly to the posterior margin of the incisor arcade. The lingual alveolar margins of the canines and incisors are at the same level as those of the cheek teeth (Figure 5). From the anterior palatal foramina to the level of $\mathrm{P} 2$ the palate is broken; posterior to $\mathrm{P} 2$ the palate is flattened transversely. The maxillary-palatine suture (=sutura palatina transversa, spt) lies medial to $\mathrm{Ml}$; the palatine bones are missing. The posterior palatine foramina (=canali palatine major, fpal) are medial to P4 (Figure 6), anterior to the palatine/ maxilla suture; each is divided into two openings by a tiny bridge. The anterior and posterior palatine foramina are connected by a relatively shallow anteroposteriorly aligned groove (=sulcus palatinus) (Figure 6A). Wyss and Flynn (1993) theorized that this primitive condition characterized phocid ances- 
TABLE 1.-Cranial measurements (in mm) in the holotype skull Z14523 of Devinophoca claytoni, new genus and new spccies.

\begin{tabular}{l|c}
\hline \multicolumn{1}{c|}{ Character } & Mcasurement \\
\hline 1. Total length & 119.9 \\
2. Condylobasal length & 119.3 \\
3. Length of processus palatinus & 71.0 \\
4. Length of rostral part, measurcd from antero-upper corner of orbit & 49.0 \\
5. Length of braincase, measured from anterior corner of orbit & 93.5 \\
6. Length of bulla tympanica & 38.5 \\
7. Length of tooth row, Pl to M1 & 49.0 (L), 53.2 (R) \\
8. Length of tooth row, P2 to P4 & 32.5 (L), 34.5 (R) \\
9. Maximum diameter of infraorbital foramcn & 7.5 (L), $11.2(\mathrm{R})$ \\
10. Length of temporal fossa & 61.5 \\
11. Width of rostrum across canincs & 40.0 \\
12. Maximal infraorbital width & 25.5 \\
13. Minimal infraorbital width & 14.0 \\
14. Width of skull across of processus zygomaticus of squamosal & 124.0 \\
15. Width of braincase & 88.0 \\
16. Mastoid width & 113.0 \\
17. Width of processus palatinus between Pls & 10.5 \\
18. Maximum width of processus palatinus & 55.5 \\
19. Maximum width of foramen infraorbitale & 9.0 (L), $10.0(\mathrm{R})$ \\
20. Width of bulla tympanica & 49.3 \\
21. Width of rostrum & 37.0 \\
22. Height of skull in region of bulla tympanica & 80.0 \\
23. Distance from center of stylomastoid foramen to center of postglenoid foramen & 15.1 \\
Ratios of measurements & \\
character 14/ character 1 & 103.4 \\
character 4/ character 5 & 52.4 \\
character 18/ character 9 & 160.9 \\
\hline
\end{tabular}

tors. The posterior border of the horizontal plate of the maxilla is sharp edged, turning ventrally about $2 \mathrm{~mm}$ behind Ml. Posterior to M1, the ventrolateral border of the maxilla (inside the orbits) is flattened, and a very distinct separation can be defined between the horizontal and vertical surfaces of the palatine bones. The thickness of the maxilla between the posterior alveolus of $\mathrm{Ml}$ and the ventral border of the infraorbital canal is about $12.5 \mathrm{~mm}$.

The anterior edge of the orbit is above the middle of P4 (Figure 5). The jugal process (ju) of the squamosal ascends anteriorly, as a long tapered process; the length of this process in front of the glenoid fossa is at least $36 \mathrm{~mm}$. The glenoid fossa (g) measures $11 \mathrm{~mm}$ anteroposteriorly and $23.5 \mathrm{~mm}$ transversely. The postglenoid process itself is located about $4 \mathrm{~mm}$ forward of the meatal tube. A postglenoid foramen ( $\mathrm{fpg}$ ) is present in the fossa between the postglenoid process and the meatal tube (Figures 6,7B). In contrast to the opinion of Wyss and Flynn (1993), we consider the presence of this foramen to be primitive in Phocidae; it is present and large in terrestrial carnivorans. Between the meatal tube and the postglenoid foramen is a deep, narrow groove in the tympanic bone; this groove is parallel to the meatal tube and floored by the tympanic. The presence or absence of a suprameatal fossa cannot be determined.

Laterally, the bulla (Figure 6) is extended as a long tube, with a prominent ventral lip forming the ventral margin of the exter- nal auditory meatus (eam); this opening is slightly oval (Figures 5,6 ). The rim of the external auditory meatus is separated by a shallow notch from the mastoid process on the left side (as in other carnivorans), whereas on the right side these are in contact, with no notch present. The middle part of the auditory tube (on both sides) is completely fused to the anteromedial portion of the mastoid. A distinct shallow groove extends anterolaterally from the stylomastoid foramen ( $\mathrm{fsm}$ ) between the meatal tube of the bulla and the mastoid process (mp); this groove is present in all phocids and absent in all otarioids, including the enaliarctines. The groove has a different prolongation on the two sides of the skull: it starts from the vagina processus hyoidei (for this terminology see Mitchell, 1966, and Burns and Fay, 1970); on the right side of the skull this groove disappears at the middle of the meatal tube $(\mathrm{mt})$, whereas on the left side, the groove continues to the lateral one-third of the tube, where it disappears. A deep cleft continues from the hyoid fossa around the posterolateral border of the bulla; this is the typical phocid structure, unlike any otarioid pinniped. The pit for the tympanohyal ligament is separated from the stylomastoid foramen (Figure 6B) and is medial to the latter (a primitive character).

In ventral view (Figure 6), the tympanic bulla (tb) is roughly triangular in outline, has a smoothly convex ventral surface, is slightly inflated in its anterolateral (=ectotympanic) parts, and slopes uniformly toward the external auditory meatus (eam). 

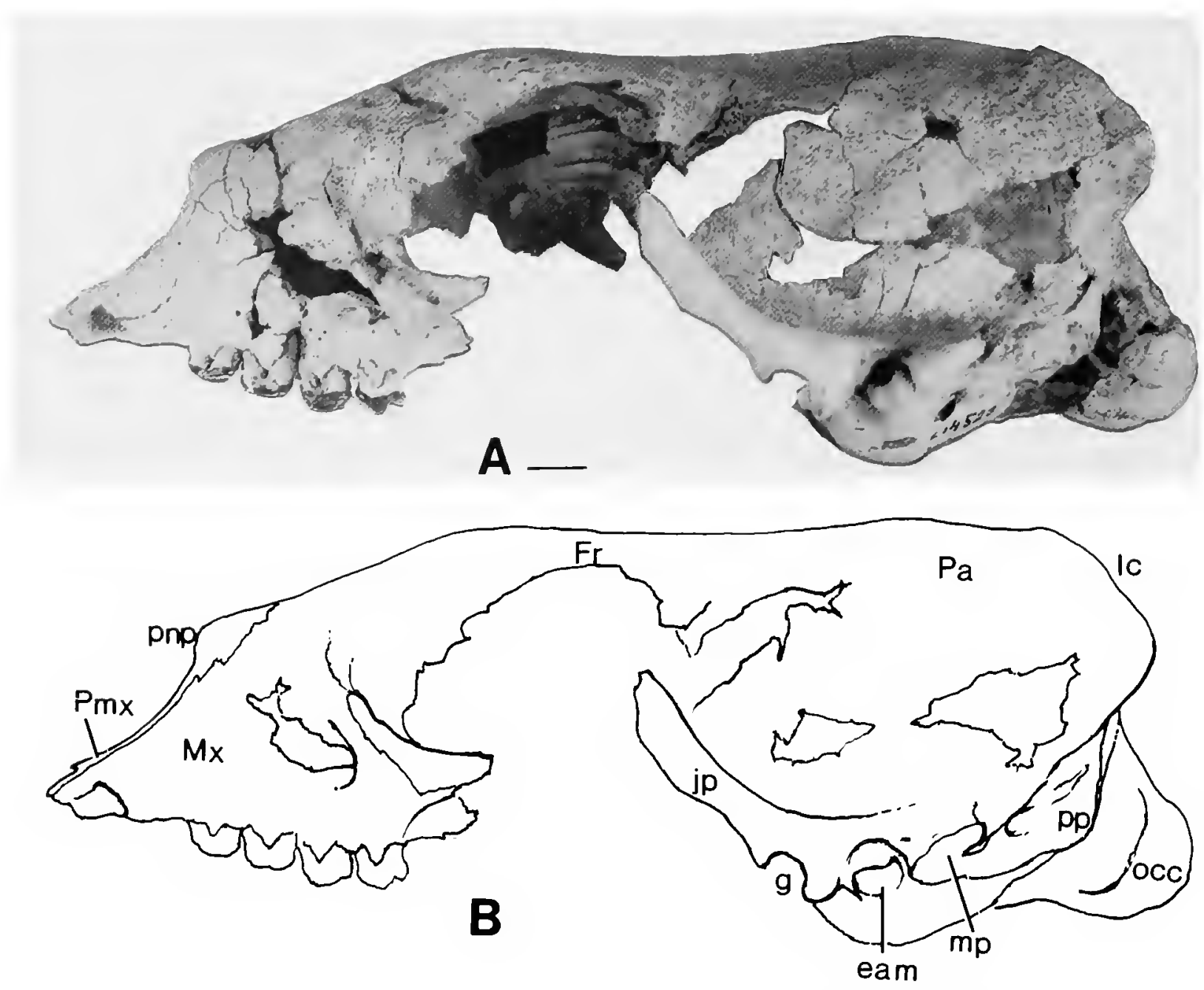

FIGURE 5.-Devinophoca claytoni, new genus and species, holotype skull Z14523: A, left lateral view, scale bar= $0.75 \mathrm{~cm}$; B, outline drawing of the photograph of left lateral view. For explanation of abbreviations see Figure 3.

The anteroposterior length of the tympanic bulla is 1.38 times greater than the distance between the bullae $(27 \mathrm{~mm})$; this size relationship is similar to that of Cystophorinae and Phocinae. The length of the auditory bulla $(37.5 \mathrm{~mm})$ is 3.4 times the anteroposterior width of the glenoid fossa $(11 \mathrm{~mm})$, whereas in phocines it is 2.5-3.0 times this width. The long axis of the bulla is slightly oblique to the midline of the skull. The median lacerate foramen $(\mathrm{fml})$ and musculotubular canal (=canalis musculotubaris, $\mathrm{cma}$ ) are internally separated by a septum above the anteromedial corner of the bulla (Figures 6,7B). The entotympanic part is much larger (more than two-thirds of the bulla) than the ectotympanic (ec). Caudally, the entotympanic (en) is more flattened than the ectotympanic along an anteroposterior axis, and it is separated from the ectotympanic part of the bulla by a distinct ridge instead of a sulcus. The flatter entotympanic is in contrast to the more inflated entotympanic of Mustelinae and other Phocidae, as noted by Wozencraft (1989).

The medial portion of the entotympanic close to the petrosal forms a deep, long fissure around the medial side of the bulla, and the carotid foramen ( $\mathrm{cf}$ ) is separated from the posterior lacerate foramen by a tiny lip. The carotid canal (cc) (Figures $6,7)$ is partially concealed in the posteromedial wall of the bulla, considerably anterior to the posterior lacerate foramen (the primitive state; see Tedford, 1977). In contrast to phocines (Berta and Wyss, 1994), in Devinophoca claytoni the posterior opening and the posteromedial process of the carotid canal (cc) are visible in ventral view. In $D$. claytoni the posterior aperture of the carotid canal is horizontal by lateral to the basioccipital, opens in a posteroventral direction, and has a fully formed margin on the right bulla at its medial side. This is the primitive condition, in contrast to that of other phocids, in which the posterior opening of the carotid canal is directed ventrally. It can be seen clearly on an X-ray (Figure 7) that the carotid canal is quite long; on the right side of the skull it is parallel to the sagittal plane of the skull, but on the left side the canal curves in an anterolateral direction. In the wall of bone dividing the carotid canal from the basioccipital bone (Bo) on the left bulla is a small canal (=inferior tympanic canaliculus), whereas on the right bulla this canaliculus is found inside (medial to) the posteromedial process of the carotid foramen.

The posterior lacerate foramen (flp) does not reach the base of the paroccipital process (pp) as it does in other phocids (Mitchell and Tedford, 1973). The posterior lacerate foramen (flp) at the posteromedial corner of the bulla is transversely bilobed and formed of two fenestrae; through the posterior lacerate foramen a septum is visible (Figure 6A). The posterior carotid foramen (cf) (Figure 6B) does not open into a common fossa with the posterior lacerate foramen (such a common opening is characteristic of ursids, otariids, and also of primitive musteloids) (see Mitchell and Tedford, 1973; Tedford, 


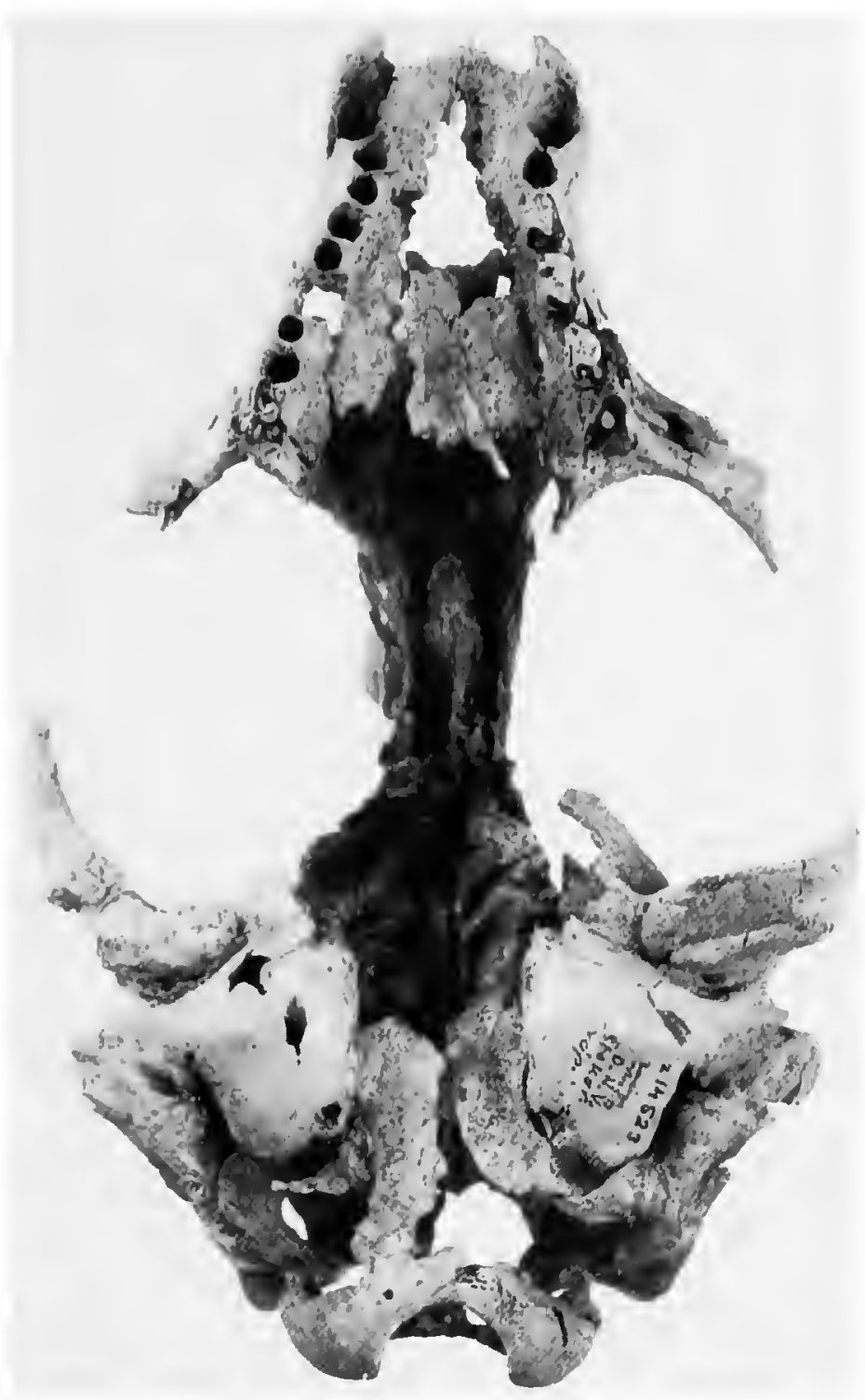

A

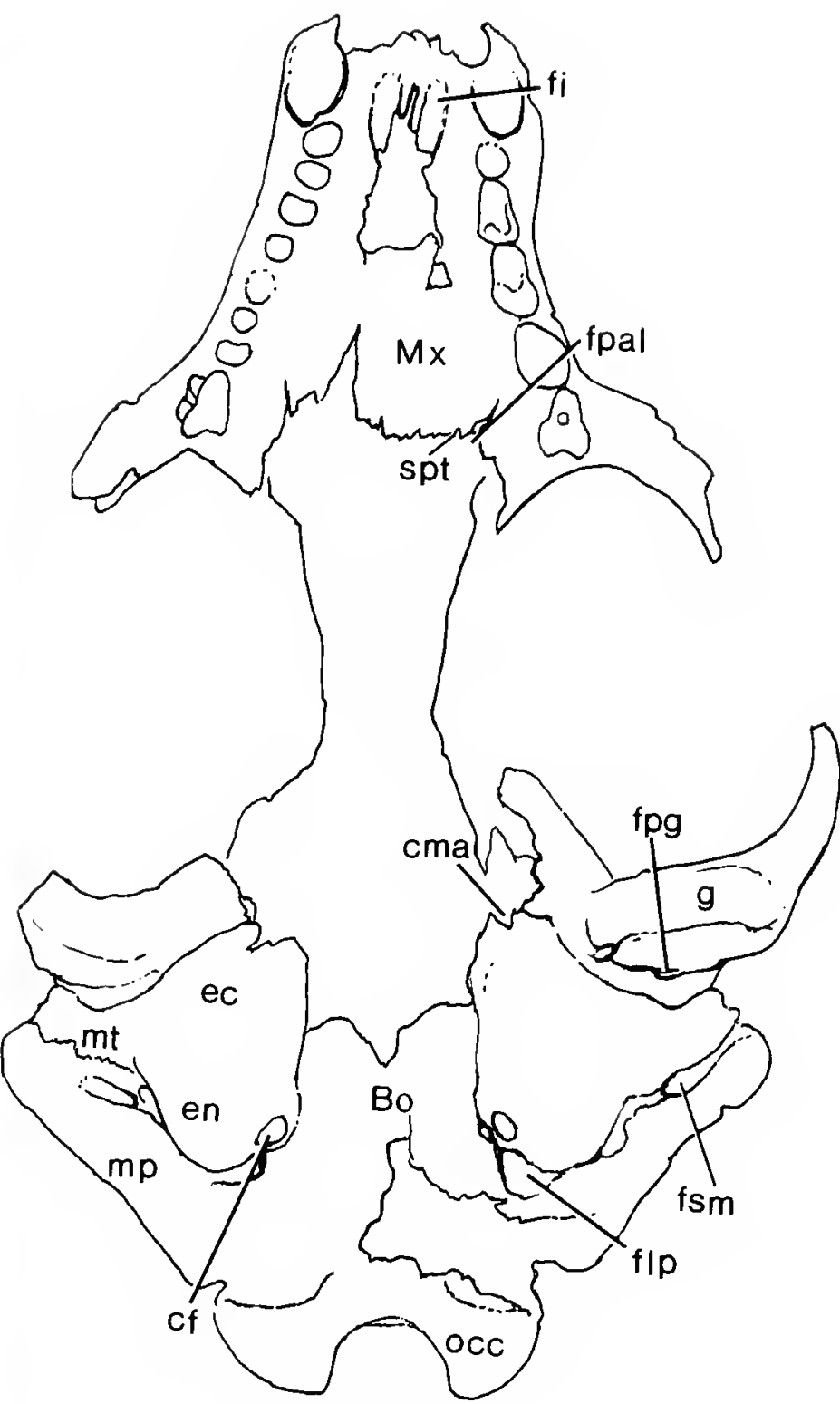

B

FIGURE 6.-Devinophoca claytoni, new genus and species, holotype skull Z14523: A, in ventral view scale bar= $0.75 \mathrm{~cm}$; B, outline drawing of the photograph of ventral view. For explanation of abbreviations see Figure 3 .

1977; Wolsan, 1993). The anterior part of the posterior lacerate foramen is expanded anteroposteriorly, whereas its posterior part extends mediolaterally (=transversely), a condition unknown in any other phocid (Wyss, 1988; Barnes, 1989; Berta and Wyss, 1994) (Figure 6). The posterior extremity of the petrosal is visible inside the posterior lacerate foramen, behind the bulla (King, 1966; Burns and Fay, 1970; Ray, 1976; Berta and Wyss, 1994) (Figure 6A). On the lateral margin of the basioccipital is a sulcus for the inferior petrosal sinus (sips) (see outline drawing from the X-ray on Figure 7B).

The mastoid process (mp) does not extend far laterally as it does in Monachinae, but it does form a pronounced prominence lateral to the auditory bulla. The mastoid is not so inflated that it obscures the bulla in lateral view; this is the condition described by Chapskii (1974) and King (1983) for phocines. According to Mitchell and Tedford (1973), a unique phocid feature, especially well developed in the Phocinae, is the inflation of the lateral side of the squamosal between the paroc- cipital and mastoid processes, joining the two in a crest (Figure 6A). This is present also in Devinophoca claytoni. A continuous crest extends from the mastoid process over the paroccipital process (pp; jugular process in the terminology of Burns and Fay, 1970) to the supramastoid crest and connects to the lambdoidal crest (lc); it is rounded and weakly developed. Posteriorly the bulla is separated from the base of the paroccipital process by a distance of $10 \mathrm{~mm}$, whereas it contacts both mastoid and exoccipital bones. The bases of the paroccipital (= jugular) processes are small, but the processes themselves are broken away.

In his analysis of the functional morphology of the inner and middle ear regions, Repenning (1972) concluded that phocids, otariids, and odobenids have different patterns of environmental adaptation in their auditory apparatus. Unfortunately, the middle ear cavity of $D$. claytoni is impossible to examine directly without destroying the tympanic bulla. An X-ray (Figure $7 \mathrm{~A}$ ) does not adequately display the middle ear cavity, but it 


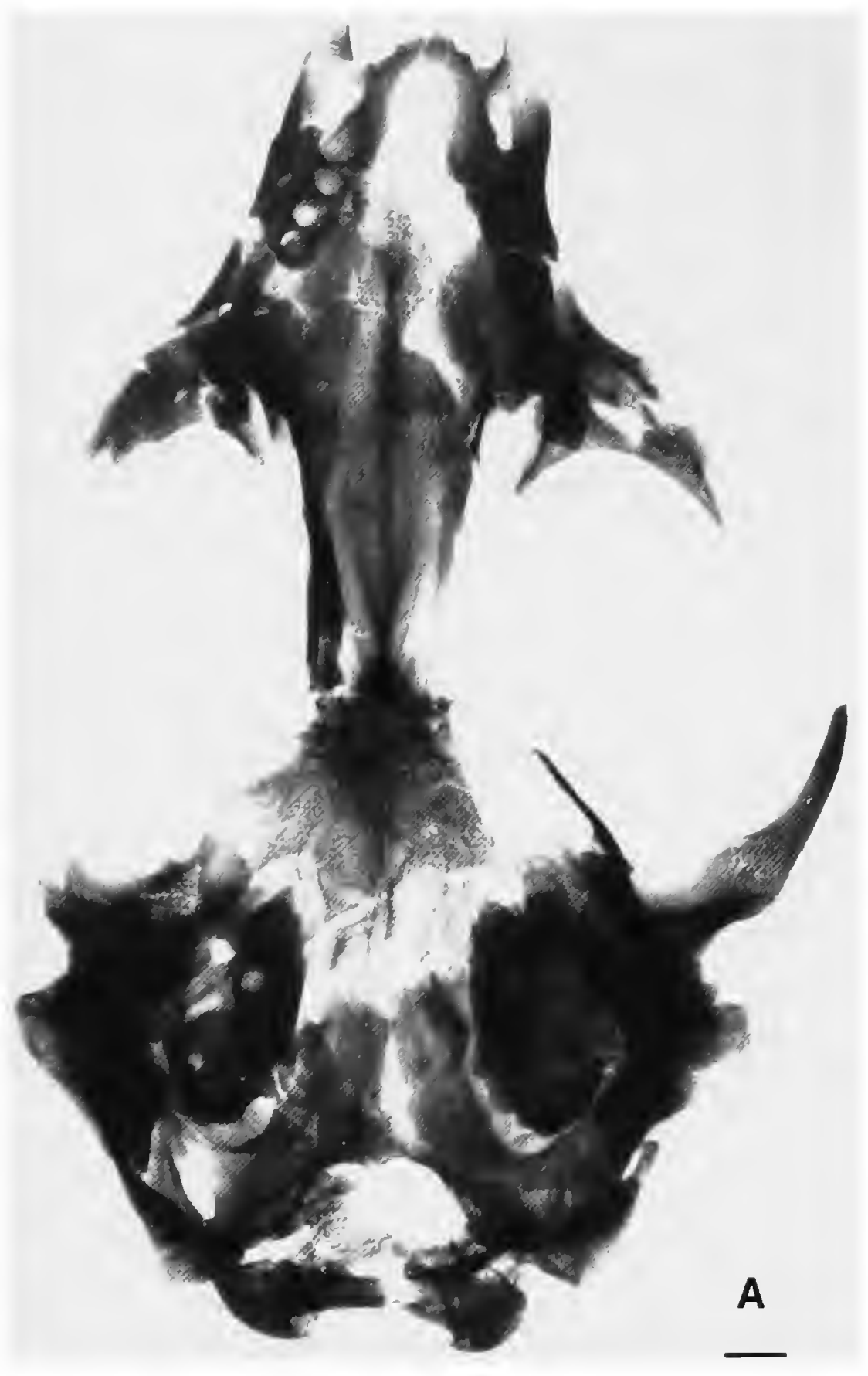

does allow us to learn that in Devinophoca claytoni the inner ear has a phocid construction; i.e., the oval window is a small, slim fissure, not round as in otariids. Along its ventral path to the oval window, the basal whorl of the cochlea extends transverse to the orientation of the skull as in other phocids, rather than posterolaterally as in otariids and odobenids. The fossa of the round window is partially shielded by the bony lip of the entotympanic.

The occipital shield (oc) is partially broken away (Figure $4 C, D$ ). A thin, median supraoccipital crest (ocs), only the dorsal part of which is preserved, extends dorsally to meet the thick lambdoidal crest. Lateral to the occipital condyles, the lambdoidal crests become very thin and continue as sharp ridges to the posterodorsal comers of the mastoid processes. The occipital condyles are $27 \mathrm{~mm}$ apart in the upper part of the foramen magnum and are approximately $18 \mathrm{~mm}$ apart below the foramen. The border of the intercondylar notch is thick $(4.5 \mathrm{~mm})$. The dorsal border of the foramen magnum is semicircular. The foramen for the transverse venous sinus is located medially in-
FIGURE 7.-Devinophoca claytoni, new genus and species, holotype skull Z14523: A (left), X-ray of skull in ventral view; B (below), outline drawing based upon Figure 7A and other $\mathrm{X}$-rays of skull in ventral view. Scale bars $=1.0$ $\mathrm{cm}$. For explanation of abbreviations see Figure 3.

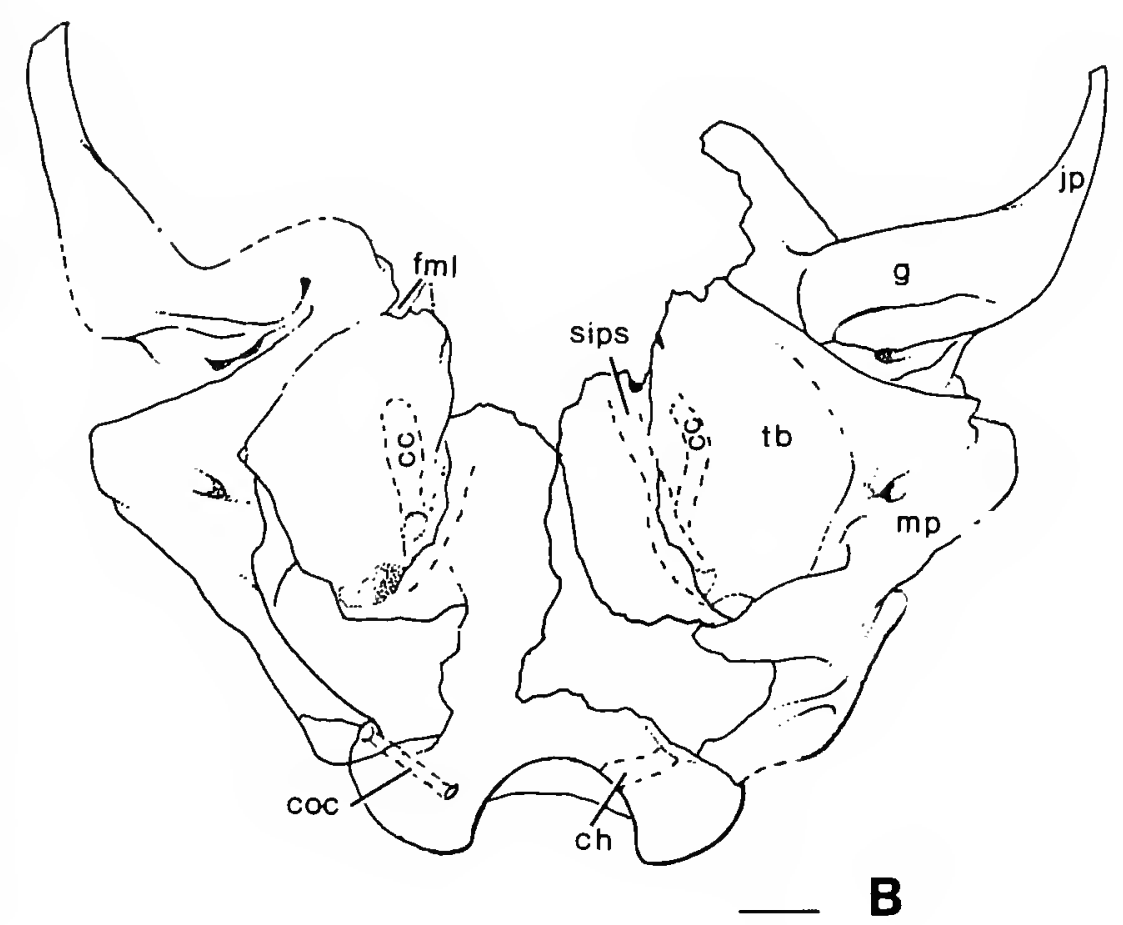

side of the occipital condyle, and the condyloid canal runs anterolaterally (Figure 7B).

The upper dental formula is I3, C1, P4, Ml (Figures 5B, 8). The incisor alveoli form a narrow $U$-shaped arcade. Cingula traverse the lingual sides of the crowns of the maxillary teeth and extend around to the buccal sides both anteriorly and pos-

TABLE 2.-Measurements (in mm) of the upper dentition in the holotype skull Z14523 of Devinophoca claytoni, new genus and new species.

\begin{tabular}{l|cc}
\hline \multicolumn{1}{c|}{ Teeth } & length & width \\
\hline II alveolus & - & 3.0 \\
I2 alveolus & - & 3.0 \\
I3 alveolus & - & 5.7 \\
C alveolus & 13.2 & 10.5 \\
P1 alveolus & 6.5 & 5.6 \\
P2 crown & 10.0 & 6.5 \\
P3 crown & 10.0 & 8.0 \\
P4 crown & 10.6 & 8.2 \\
M1 crown & 9.3 & 7.5 \\
\hline
\end{tabular}




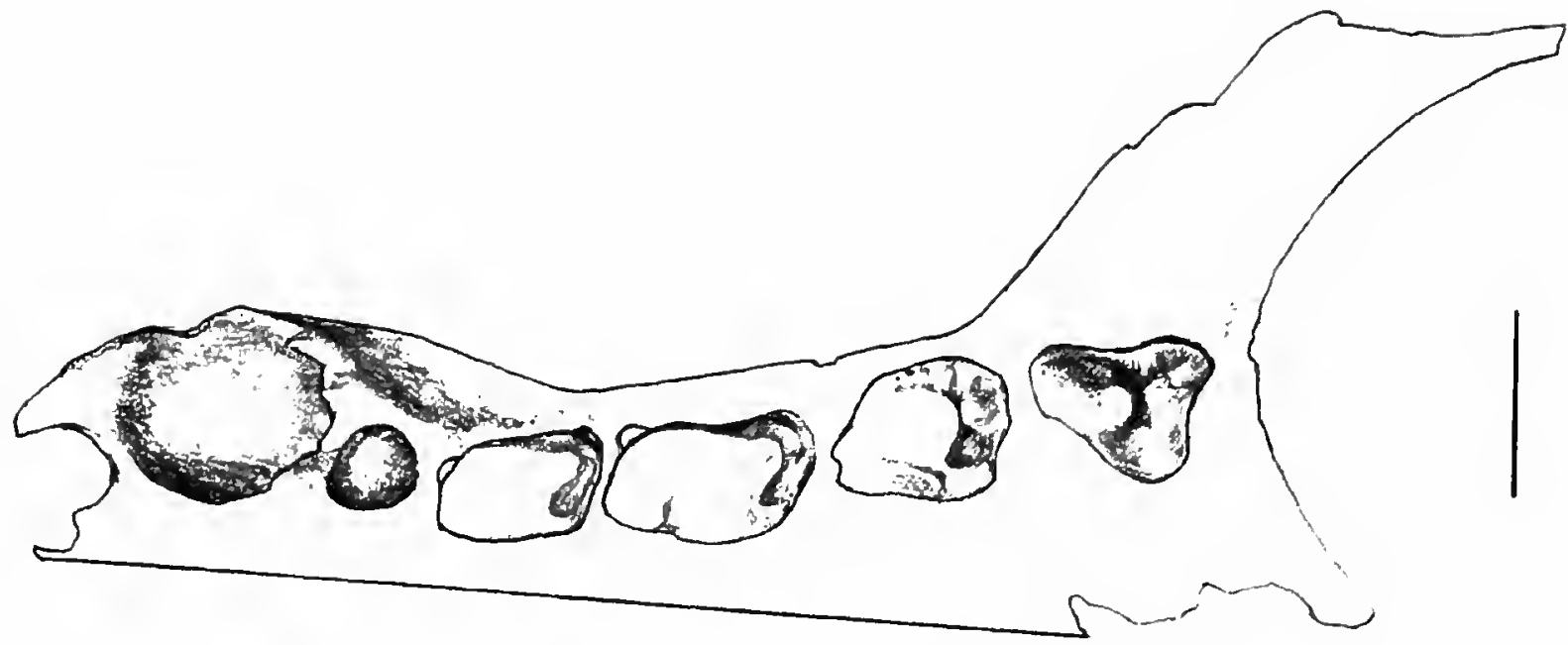

FigURE 8.-Devinophoca claytoni, new genus and species, holotype skull Z14523: Drawing of teeth in occlusal view. Scale bar $=1.5 \mathrm{~cm}$.

teriorly. As a result, the cingula nearly encircle the crowns of the teeth, as in the Enaliarctinae (Barnes, 1992), in Kolponomos (Tedford et al., 1994), and in other primitive arctoid carnivorans (Wolsan, 1993). The number of upper incisors is six, the same as in Phocinae, whereas Monachinae and Cystophorinae have four. Preserved alveoli indicate that $\mathrm{I} 3$ is much larger than both $\mathrm{I} 1$ and $\mathrm{I} 2$, and that $\mathrm{I} 1$ and $\mathrm{I} 2$ are approximately equal in size (Table 2). The canines were relatively small and projected ventrally more than forward, judging from the curvature of the anterior surfaces of their alveoli. P1 has a single root, circular in cross section. $\mathrm{P} 2$ and $\mathrm{P} 3$ each have two roots; the anterior roots are round in cross section, but the posterior roots are expanded transversely and bilobed in cross section. The crowns of P2 and P3 are oval in occlusal view and heavily worn. P3 has a distinct lingual cusp (protocone).

The crown of P4 is subtriangular in occlusal view, and the buccal side is convex. Its metacone is present as a distinct cusp; the paracone and protocone are heavily worn. $\mathrm{P} 4$ has two roots, with the posterior alveolus bigger than the anterior and bilobate in cross section, indicating that the posterior root is made up of two fused roots, one above the protocone and one above the metacone. The bilobed posterior roots of $\mathrm{P} 4$ are very similar to the primitive condition in terrestrial carnivores (Berta and Wyss, 1994), unlike most pinniped teeth. A shallow notch (carnassial notch) is present between the paracone and metacone (Figure 8). The protocone of $\mathrm{P} 4$ and $\mathrm{M} 1$ is posteromedial to the paracone, and its buccal side is longer than the lingual, as in terrestrial arctoid carnivorans (Wolsan, 1993; Wyss and Flynn, 1993).

The $\mathrm{M} 1$ of $D$. claytoni is unlike that of any other known pinniped, but some similarity can be seen with the same tooth in the Enaliarctinae (Mitchell and Tedford, 1973; Barnes, 1979, 1992). The crown is triangular in occlusal view and is composed principally of the paracone, which is flanked by the much smaller metacone and protocone (Figure 8). These three cusps are supported respectively by the three roots. A threerooted M1 has not been reported previously in any phocid. The paracone is long anteroposteriorly and compressed transversely, and the small metacone lies posterolateral to it. The protocone is smaller than on the $\mathrm{P} 4$ but equal in size to those on $\mathrm{P} 2$ and P3. It is separated from the paracone by a trigon basin (as in enaliarctines, according to Barnes, 1989). The metacone and protocone connect to the paracone by sharp ridges, but a stronger ridge connects the apex of the paracone to the anterior angle of the tooth where it joins the anterior end of the buccal cingulum without a parastyle. The axis of this ridge is parallel to the sagittal plane.

\section{Cladistic Analysis}

\section{CHARACTERS USED IN FAMILY PHOCIDAE}

For this cladistic analysis, 32 characters were scored (Table 3). 0 designates the most primitive state among the taxa studied; 1 and 2 are alternate derived states; - indicates unknown or missing data.

1. Tympanic bulla: (0) small; (1) large (Chapskii, 1974:300, fig. 12).

2. External auditory meatus: (0) inframeatal lip well developed; (1) poorly developed.

3. Mastoid process: (0) not united with paroccipital process; (1) united with paroccipital process.

4. Mastoid process: (0) axis of mastoid convexity not directed ventrally; (1) directed ventrally.

5. Mastoid process: (0) prominence lateral to auditory bullae not strongly pronounced; (1) pronounced.

6. Mastoid process: (0) narrow (width of process less than length of process itself); (1) wide (Chapskii, 1974).

7. Mastoid process: (0) bulbous; (1) cylindrical.

8. Mastoid process: (0) width less than or equal to one-half of length of tympanic bulla; (1) width greater than one-half of length of tympanic bulla.

9. Mastoid convexity: (0) not turned down; (1) moderately turned down behind mastoid process; (2) directed sharply downward behind mastoid process. 
TABLE 3.- Matrix of character-state data for Phocidae taxa and outgroups analyzed. $\left({ }^{*}=\right.$ outgroup taxa.)

\begin{tabular}{|c|c|c|c|c|c|c|c|c|c|c|c|c|c|c|c|c|c|c|c|c|c|c|c|c|c|c|c|c|c|c|c|c|}
\hline \multirow{2}{*}{ Species } & \multicolumn{32}{|c|}{ Character number } \\
\hline & 1 & 2 & 3 & 4 & 5 & 6 & 7 & 8 & 9 & 10 & 11 & 12 & 13 & 14 & 15 & 16 & 17 & 18 & 19 & 20 & 21 & 22 & 23 & 24 & 25 & 26 & 27 & 28 & 29 & 30 & 31 & 32 \\
\hline Allodesmus kelloggi* & 0 & 1 & 0 & 1 & 0 & 0 & 1 & 1 & 1 & 1 & 0 & 2 & 2 & 1 & 0 & 1 & 0 & 0 & 1 & 0 & 0 & 0 & 0 & 2 & 1 & 0 & 0 & 1 & 1 & 0 & 1 & 0 \\
\hline Lutra canadensis ${ }^{*}$ & 1 & 0 & 0 & 0 & 1 & 1 & 1 & 0 & 2 & 0 & 1 & 0 & 0 & 1 & 0 & 1 & 2 & 1 & 0 & 0 & 0 & 0 & 1 & 0 & 0 & 1 & 1 & 0 & 0 & 0 & 0 & 0 \\
\hline Devinophoca claytoni & 0 & 0 & 1 & 0 & 0 & 0 & 0 & 0 & 0 & 0 & 1 & 2 & 1 & 0 & 0 & - & 1 & 1 & 0 & 0 & 0 & 0 & 1 & 0 & 0 & 1 & 0 & 0 & 0 & 0 & 0 & 0 \\
\hline Cystophora cristata & 1 & 0 & 1 & 1 & 0 & 1 & 1 & 1 & 2 & 0 & 0 & 1 & 1 & 1 & 0 & 0 & 1 & 1 & 0 & 0 & 0 & 2 & 0 & 1 & 1 & 0 & 1 & 1 & 1 & 0 & 1 & 1 \\
\hline Mirounga leonina & 1 & 0 & 1 & 1 & 1 & 1 & 0 & 0 & 2 & 1 & 0 & 1 & 0 & 1 & 0 & 0 & 2 & 1 & 0 & 0 & 0 & 2 & 0 & 1 & 1 & 0 & 0 & 1 & 1 & 0 & 1 & 1 \\
\hline Monachus monachus & 0 & 0 & 1 & 0 & 1 & 1 & 0 & 1 & 1 & 1 & 1 & 2 & 2 & 0 & 1 & 0 & 0 & 0 & 0 & 0 & 0 & 1 & 1 & 1 & 0 & 1 & 0 & 0 & 0 & 1 & 0 & 0 \\
\hline Monachus schauinslandi & 0 & 0 & 1 & 0 & 1 & 1 & 0 & 1 & 0 & 1 & 1 & 2 & 2 & 0 & 1 & 0 & 0 & 0 & 0 & 1 & 1 & 1 & 1 & 1 & 0 & 0 & 0 & 0 & 0 & 1 & 0 & 0 \\
\hline Callophoca obscura & 1 & 1 & 1 & 0 & 0 & 0 & 1 & 1 & 1 & 0 & 1 & 2 & 2 & 0 & 0 & 0 & 1 & 0 & 1 & 0 & 0 & 1 & 1 & 1 & 0 & 0 & 1 & 0 & 0 & 1 & 0 & 2 \\
\hline Phoca vitulina & 1 & 0 & 1 & 0 & 0 & 0 & 0 & 0 & 1 & 0 & 0 & 0 & 1 & 0 & 0 & 0 & 0 & 1 & 0 & 2 & 1 & 0 & 1 & 1 & 0 & 0 & 1 & 1 & 0 & 0 & 0 & 0 \\
\hline Erignathus barbatus & 1 & 1 & 1 & 1 & 0 & 1 & 0 & 0 & 0 & 0 & 0 & 0 & 1 & 0 & 1 & 0 & 0 & 1 & 0 & 2 & 1 & 0 & 1 & 1 & 1 & 1 & 1 & 1 & 0 & 1 & 0 & 0 \\
\hline Leptophoca lenis & 0 & 0 & - & 0 & 0 & 0 & 1 & 1 & 1 & 0 & 0 & 0 & 0 & 0 & 0 & 1 & 0 & 1 & 1 & 1 & 1 & 0 & 1 & 1 & 0 & 1 & 0 & 0 & 0 & 0 & 0 & 0 \\
\hline
\end{tabular}

10. Nasal bones: (0) anterior ends form one common termination; (1) anterior ends separated.

11. Nasal bone: (0) maxillary contact longer than frontal contact; (1) frontal and maxillary contacts almost equal in length.

12. Maxilla: (0) very pronounced convexity anterior to orbits; (1) short concavity; (2) long concavity (Chapskii, 1974).

13. Anterior palatine foramina: (0) round and deep; (1) oval and shallow; (2) indistinctly marked (Burns and Fay, 1970).

14. Palatal groove: (0) present; (1) absent.

15. Palatal process of maxillary bone: (0) flat; (1) convex.

16. Foramen ovale: (0) hidden under hamular process of pterygoid bone; (1) exposed.

17. Interorbital width: (0) less than $25.0 \%$ of mastoid width of skull; (1) less than $30.0 \%$ but equal to or greater than $25.0 \%$ of mastoid width; (2) equal to or greater than $30.0 \%$ of mastoid width (Burns and Fay, 1970; Chapskii, 1974).

18. Paroccipital process: (0) well developed, large, hookshaped; (1) poorly developed or absent, small conical projection.

19. Rostrum: (0) short, relative to cranium; (1) elongated (Chapskii, 1974).

20. Diameter of infraorbital foramen: (0) less than diameter of alveolus of upper canine; (1) equal to diameter of alveolus of upper canine; (2) greater than diameter of alveolus of upper canine.

21. Length of auditory bullae: (0) equal to or greater than distance between them; ( 1 ) less than distance between them (Burns and Fay, 1970; Chapskii, 1974).

22. Number of incisors: (0) $3 / 2$; (1) $2 / 2$; (2) $2 / 1$ (Chapskii, 1974).

23. Roots of postcanine teeth (P2, P3): (0) one (fused); (1) two (according to Berta and Wyss, 1994).

24. Roots of P4: (0) three; (1) two; (2) one.

25. Crowns of postcanine teeth: (0) multicusped; (1) single cusped.

26. Relative dimensions of postcanine teeth as compared with longitudinal diameter of alveolus of upper canine: more than $60 \%$ of longitudinal diameter of upper canine; (1) less than $60 \%$ or subequal.

27. Longitudinal diameter of alveolus of upper canine compared with maximal width of infraorbital foramen: (0) subequal in size; (1) more than one-half of maximal width.

28. Basal cingulum of postcanine teeth: (0) well developed; (1) not developed.

29. Number of additional cusps of premolars: (0) more than two; (1) no additional cusps.

30. Premolar crown: (0) aligned parallel to axis of tooth row; (1) seated obliquely.

31. Upper incisors: (0) arranged in a curved arcade; (1) arranged in a straight line.

32. Second and third upper incisors: (0) third larger than second; (1) second larger than third, (2) all upper incisors subequal in size.

The matrix of character-state data for nine species of fossil and modern phocids is given in Table 3; in addition, these characters were scored for two outgroup taxa. These outgroup taxa are the fossil otarioid Allodesmus and the living mustelid Lutra, reflecting the competing hypotheses of pinniped relationships, monophyly (Wyss and Flynn, 1993; Berta and Wyss, 1994) or diphyly (McLaren, 1960; Mitchell, 1966; Tedford, 1977). Allodesmines are highly evolved otariids, widely diversified in the middle Miocene, and possess many derived marine carnivore features (Barnes and Hirota, 1995).

The analysis of the phocid taxa using these 32 unweighted cranial and dental characters and the $\mathrm{bb}^{*}$; ie* routines in Hennig86 (Farris, 1988) produced two maximally parsimonious trees, each 79 steps long with a consistency index of 0.51 and a retention index of 0.68 .

Use of Hennig86's successive-weighting option reduced the number of trees from two to one, leaving this part of the tree much better resolved (Figure 9). Points where the nodes of the present tree correspond, the clades, traditionally recognized as subfamilies, are indicated. Only one new higher taxon name is introduced here: inclusion of Devinophoca within the Phocidae requires recognition of the new subfamily Devinophocinae.

The nodes of the cladogram shown in Figure 9 are supported by the following character transformations: 


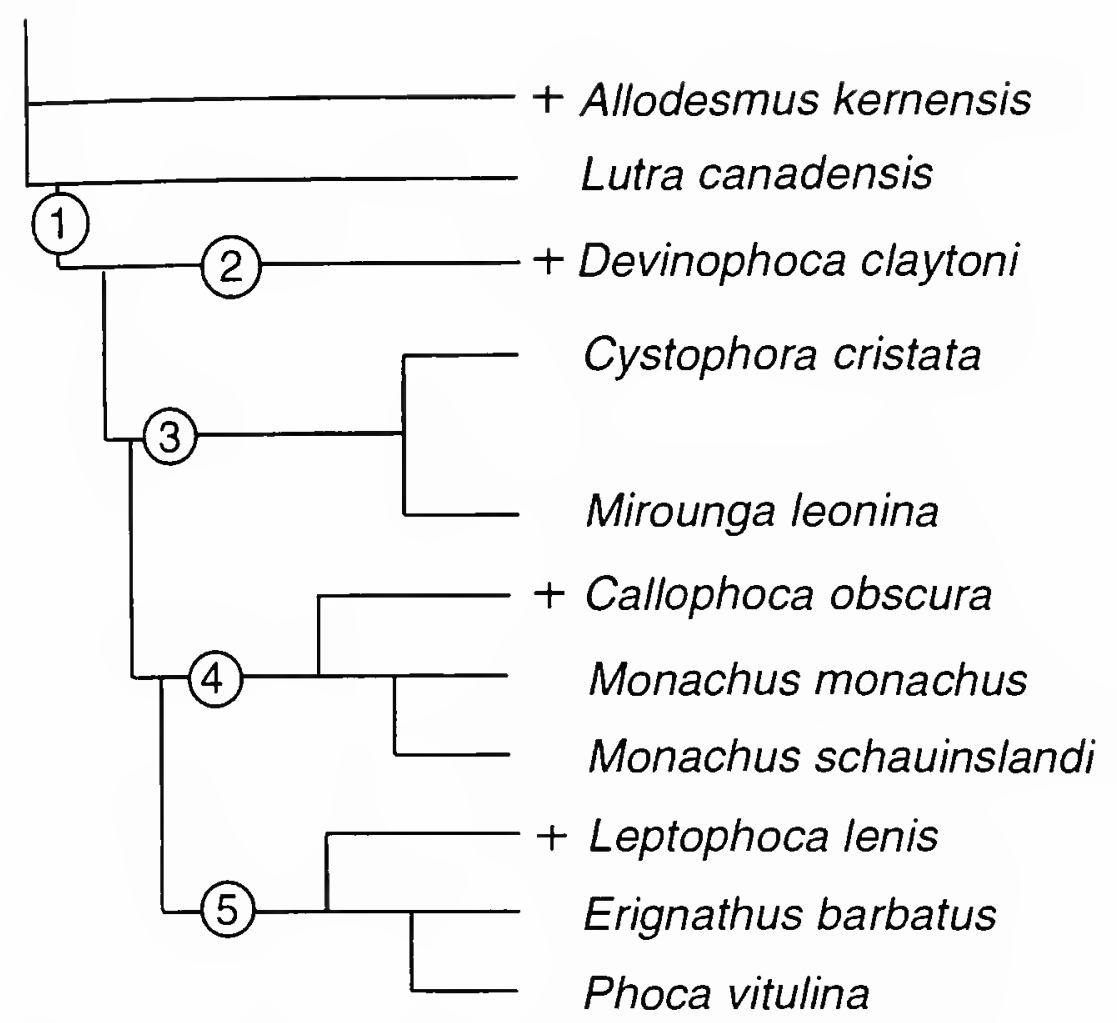

FIGURE 9.-Nelson consensus tree of two trees of the hypothesized phylogenetic relationships among taxa of true seals and two outgroups, generated by Hennig86 using 32 cranial characters and the successive weighting option. Tree length, 79 steps; consistency index, 0.51 ; retention index, 0.68 . Character states are given in Table 3.

Node 1 (Family Phocidae): 3(1); 23(1); 24(1). These apomorphic characters (relative size of the mastoid process and its lack of union with the paroccipital process; two roots on postcanine teeth ) are treated as synapomorphies of the family Phocidae.

Node 2 (subfamily Devinophocinae, possibly paraphyletic): $24(0)$. Autapomorphy of $D$. claytoni: three roots of the posterior postcanine teeth fused.

Node 3 (subfamily Cystophorinae): 9(2); 22(2); 29(1). The mastoid convexity directed sharply downward behind the mastoid process; reduced number of incisors; no additional cusps on premolars.

Node 4 (subfamily Monachinae): 11(1); 13(1). The relative dimensions of the frontal and maxillary parts of the nasal bones; the shape of the anterior palatine foramina. Also, character 13(2) is homoplasious in Phoca vitulina and Erignathus barbatus.

Node 5 (subfamily Phocinae): $20(1,2) ; 21(1)$. The diameter of the infraorbital foramen is equal to or greater than the diameter of the alveolus of the maxillary canine; the length of the auditory bullae is less than the distance between them. Also, character 20(1) is homoplasious in Monachus schauinslandi and Leptophoca lenis.

\section{Discussion and Conclusions}

The traditional separation of Phocidae into subfamilies Phocinae, Monachinae, and Cystophorinae has been inten- sively debated during the past 40 years, but overall it is the system still used today.

The well-preserved skull of Devinophoca claytoni from the early middle Miocene (16.4 Ma) shows a mix of subfamilial characters. The features it shares with Phocinae are weakly pronounced mastoid process, $5(0)$; six incisors, 22(0); and poorly developed paroccipital process, $18(1)$ (also shared with Cystophorinae). The characters similar to Monachinae are the shape of maxillae, 12(2) and the ratio between frontal and maxillary contacts of the nasal bones, 11(0) (shared with Phocinae also). Characters shared with Cystophorinae are ratio between interorbital space and mastoid width, 17(1); ratio between the length of auditory bullae and distance between them, 21(0); and oval-shaped and deep anterior palatine foramina, 13(1).

Moreover, this skull has primitive features that are not known in any of the three subfamilies: M1 is triangular, with three cusps and three roots; in $\mathrm{P} 2-\mathrm{P} 4$ the larger posterior roots are clearly made up of two fused roots; and the sagittal crest is very well developed for a phocid, though weak compared with some carnivorans. This plesiomorphic pinniped is therefore considered a sister taxon to the other three subfamilies of Phocidae. Because of its late geologic age, Devinophoca might represent a very primitive relict of the common ancestor of the groups of Phocidae.

Wozencraft (1989) identified the shortened and narrowed contact between the premaxilla and the nasal, as seen in phocids and lutrines, as a primitive condition. Barnes (1989), Berta and Wyss (1994), and Wyss and Flynn (1993) had the opposite opinion and suggested that this character is derived. The supraorbital process of the frontal is a small, rounded knob that is the primitive condition seen in terrestrial carnivorans (Berta and Wyss, 1994).

In Devinophoca claytoni, the nasals bones end near the frontal-maxillary contact. According to Berta and Wyss (1994), this is a primitive condition among terrestrial carnivorans, and among otariids and odobenids, as exemplified by the enaliarctine otarioids Enaliarctos and Pteronarctos. In the more-derived phocids, the nasals extend far posterior to the frontalmaxillary suture between the frontals, and they share this feature convergently with the otarioids Desmatophoca and $\mathrm{Al}$ lodesmus. Our material supports that statement; this plesiomorphic representative of phocids, i.e., Devinophoca, shares the primitive form of the nasals with terrestrial carnivorans, especially with Mustelidae.

Computer-assisted phylogenetic analysis of some fossil and living phocids supports the monophyly of the family and recognizes four principal clades, including the new subfamily Devinophocinae. This phylogenetic framework supports the classification used by Chapskii $(1955,1974)$, Scheffer (1958), and Koretsky and Grigorescu (2002), and it conflicts with the various arrangements proposed by King (1966), Burns and Fay (1970), Wyss (1994), and McKenna and Bell (1997). We are reluctant to name a new higher-level taxon, but the very unusual morphology of Devinophoca does not allow us to assign 
it to any known subfamily. We thus erect a new taxon at the subfamilial level.

The interorbital construction in Devinophoca claytoni, the large size of the orbits, and the loss of the lacrimal bone also are found in other aquatic species, including the Enaliarctinae among the otarioids, as advanced aquatic adaptations (Howell, 1928; Savage, 1957; Mitchell and Tedford, 1973). The development of the dorsal sagittal sinus (as clearly seen in the Xray; Figure 7) for venous drainage of the brain is suggested by Mitchell and Tedford (1973) to be related to diving adaptations.

Striking similarities between the skulls of Devinophoca and Enaliarctos include a short rostrum. Although the ventral part of the skull is not preserved in Devinophoca, we presumed that the interorbital part of the skull has the shape of an I-beam, as seen in Enaliarctos and other Phocidae. Mitchell and Tedford (1973) suggested that this construction is an adaptation for structural rigidity, while accommodating the large eyes (as in desmatophocines also). The presence of a sagittal crest and strong lambdoidal crests, the complexity of the teeth, and the short rostrum all indicate that the feeding mechanism of Devinophoca claytoni was adapted for slower and more powerful closing of the jaws, rather than the rapid action of the fish-eating pinnipeds. We conclude that Devinophoca claytoni was adapted to eating mollusks and crustaceans.

Some of the features mentioned above, such as the paroccipital process separated from the mastoid and a single-chambered bulla with large entotympanic and much smaller ectotympanic, are more similar to the primitive Mustelidae or Procyonidae than to Ursidae (in accord with Tedford, 1977).

\section{Literature Cited}

Andrusov, D.

1969. Chaines enterrées, méganticlinaux et horst dans la région des Carpathes occidentales. Geologický Zbornik SAV, Bratislava, 20(1): $39-45$.

Baráth, I., A. Nagy, and M. Ková

1994. [Sandberg Member-Late Badenian Marginal Sediments on the Eastern Margin of the Vienna Basin.] Geologické Práce, Sprâvy (Bratislava), 99:59-66. [In Slovak.]

Barnes, L.G.

1979. Fossil Enaliarctine Pinnipeds (Mammalia: Otariidae) from Pyramid Hill, Kern County, California. Contributions in Science, Natural History Museum of Los Angeles County, 318:1-41.

1989. A New Enaliarctine Pinniped from the Astoria Formation, Oregon, and Classification of the Otariidae (Mammalia: Carnivora). Contributions in Science, Natural History Museum of Los Angeles County, 403:1-26.

1992. A New Genus and Species of Middle Miocene Enaliarctine Pinniped (Mammalia, Carnivora, Otariidae) from the Astoria Formation in Coastal Oregon. Contributions in Science, Natural History Museum of Los Angeles County, 431:1-27.

Barnes, L.G. , and K. Hirota

1995. Miocene Pinnipeds of the Otariid Subfamily Allodesminae in the North Pacific Ocean: Systematics and Relationships. In L.G. Barnes, N. Inuzuka, and Y. Hasegawa, editors, Evolution and Biogeography of Fossil Marine Vertebrates in the North Pacific. Island Arc, 3(4):329-360.

Berta, A., and A.R. Wyss

1994. Pinniped Phylogeny. In A. Berta and T.A. Deméré, editors, Contributions in Marine Mammal Paleontology Honoring Frank C. Whitmore, Jr. Proceedings of the San Diego Society of Natural History. 29:33-57.

Burns, J.J, and F.H. Fay

1970. Comparative Morphology of the Skull of the Ribbon Seal, Histriophoca Fasciala, with Remarks on Systematics of Phocidae. Journal of Zoology (London), 161(3):363-394.

Chapskii, K.K.

1955. [An Attempt at Revision of the Systematics and Diagnostics of Seals of the Subfamily Phocinae.] Trudy Zoologicheskogo Instituta Akademii Nauk SSSR, 17:160-199. Leningrad. [In Russian. English translation by T.F. Jeletzky, Fisheries Research Board of Canada, Translation Series, 114, 57 pages, 1957.]
1974. [In Defense of Classical Taxonomy of the Seals of the Family Phocidae.] In [Theoretical Questions on the Systematics and Phylogeny of Animals]. Trudy Zoologicheskogo Instituta Akademii Nauk SSSR, 53:282-334. [In Russian.]

Dornesco, G.-T., and G.-V. Marcoci

1958. Étude comparative du crâne des pinnipèdes. Annales des' Sciences Naturelles, Zoologie, 11: $\mathrm{xx}+158-182$.

Driesch, Angela von den

1976. A Guide to the Measurement of Animal Bones from Archeologica Sites. Bullet in of the Peabody Museum of Archaeology and Ethnology [Harvard University], 1:1-137.

Farris, J.S.

1988. Hennig86, Version I.5. New York: Port Jefferson Station.

Fejfar, 0 .

1974. Die Eomyiden und Cricetiden (Rodentia, Mammalia) des Miozäns der Tschechoslowakei. Palaeontographica, Part A, 16: 146 pages.

Gervais, $P$.

1848-1852. Zoologie et paléontologie Françaises (animaux vertébres) ou nouvelles recherches sur les animaux vivants et fossiles de la France, 1 [text]:18-141.

Gervais, P., and M. de Serres

1847. Sur les mammifères fossiles des sables marins tertiaires de Montpellier. Comptes Rendus de l'Académie des Sciences (Paris), 28(8): 799-801.

Heptner, V.G, K.K. Chapskii, B.A. Arsen'ev, and V.E. Sokolov

1996. Pinnipeds and Toothed Whales. In V.G. Heptner and N.P. Naumov, editors, Mammals of the Soviet Union, 2(3): xxx + 995 pages. Washington, D.C. [Originally published in Russian as Mlekopitayushchie Sovetskogo Soyuza. Moscow: Vysshaya Shkola, 1976.]

Holec, P.

1985. Finds of Mastodon (Proboscidea, Mammalia) Relics in Neogene and Quaternary Sediments of Slovakia (SSR). Západny Karpaty, Paleontologia, 10:13-53.

1986. Neueste Resultate der Untersuchungen von neogenen und quartaeren Nashornen, Baeren und Kleinsaeugern im Bereich der Westkarpaten (Slowakei). Acta Universitatis Carolinae, Geologica (Prague), 2:223-231.

Holec, P., J. Klembara, and Š. Meszároš

1987. Discovery of New Fauna of Marine and Terrestrial Vertebrates in Devinska Nová Ves. Geologický Zbornik, Geologica Carpathica, 38(3):349-356. Bratislava. 
Holec, P., and M. Sabol

1996. [The Tertiary Vertebrates from Devinska Kobyla.] Mineralia Slovaca, 28:519-522. [In Slovak.]

1997. [Fossils of the Dévinska Kobyla Hill.] In V. Feráková, editor, Flora of the Dévinska Kobyla Hill. 639 pages. Bratislava: APOP-Edition. [ln Slovak.]

Howell, A.B.

1928. Contribution to the Comparative Anatomy of the Eared and Earless Seals (Genera Zalophus and Phoca). Proceedings of the United States National Museum, 3(15):1-42.

King, J.

1966. Relationships of the Hooded and Elephant Seals (Genera Cystophora and Mirounga). Journal of Zoology, London, 148(4):385-398.

1983. Seals of the World. Second edition, 240 pages. Ithaca, New York: Cornell University Press.

Koretsky, 1.A., and D. Grigorescu

2002. The Fossil Monk Seal Pontophoca sarmatica (Alekseev) (Mammalia: Phocidae: Monachinae) from the Miocene of Eastern Europe. In R. Emry, editor, Cenozoic Mammals of Land and Sea: Tributes to the Career of Clayton E. Ray. Smithsonian Contributions to Paleobiology, 93:149-162.

McKenna, M.C., and S.K. Bell

1997. Classification of Mammals above the Species Level. 631 pages. New York: Columbia University Press.

McLaren, I.A.

1960. Are the Pinnipedia Biphyletic? Systematic Zoology, 9:18-28.

Mitchell, E.D.

1966. The Miocene Pinniped Allodesmus. University of California Publications in Geological Sciences, 61:1-105.

Mitchell, E.D., and R.H. Tedford

1973. The Enaliarctinae, a New Group of Extinct Aquatic Carnivora and Consideration of the Origin of the Otariidae. Bulletin of the American Museum of Natural History, 151(3):203-284.

Piérard, J.

1971. Osteology and Myology of the Weddell Seal, Leptonychotes weddelli (Lesson, 1826). In W.H. Burt, editor, Antarctic Pinnipedia. Antarctic Research Series, 18:53-108.

Ray, C.E.

1976. Phoca wymani and Other Tertiary Seals (Mammalia: Phocidae) Described from the Eastern Seaboard of North America. Smithsonian Contributions to Paleobiology, 28: 36 pages.

Repenning, C.A.

1972. Underwater Hearing in Seals: Functional Morphology. In R.J. Harrison, editor, Functional Anatomy of Marine Mammals, pages 307331. London and New York: Academic Press.

Rögl, F., and G. Daxner-Höck

1996. Late Miocene Paratethys Correlations. In R.L. Bernor, V. Fahlbusch, and H.-W. Mittmann, editors, Evolution of Western Eurasia Neogene Mammal Faunas, pages 46-56. New York: Columbia University Press.

Savage, R.J.G.

1957. The Anatomy of Potamotherium, an Oligocene Lutrine. Proceedings of the Zoological Society of London, 129(2):151-244.

Schaller, O., editor

1992. Illustrated Veterinary Anatomical Nomenclature. 617 pages. Stuttgart: Ferdinand Enke Verlag.

Scheffer, V.B.

1958. Seals, Sea Lions and Walruses: Review of the Pinnipedia. 179 pages. Stanford, California: Stanford University Press.

Simpson, G.G.

1945. The Principles of Classification and a Classification of Mammals. Bulletin of the American Museum of Natural History, 85: xvi +350 pages.

Steininger, F.F., and L.A. Nevesskaya

1975. Stratotypes of Mediterranean Neogene Stages. Volume 2, 364 pages.
Bratislava: Committee on Mediterranean Neogene Stratigraphy.

Steininger, F.F., R.L. Bcrnor, and V. Fahlbusch

1989. European Neogene Marine/Continental Chronologic Correlation. In E.H. Lindsay, V. Fahlbusch, and P. Mein, editors, European Neogene Mammal Chronology, pages 15-46. New York: Plenum Press.

Švagrovský, J.

1981. Lithofazielle Entwicklung und Molluskenfauna des oberen Badenien (Miozän M4d) in dem Gebiet Bratislava-Devinska Nová Ves. Západny Karpaty, Paleontologia, 7: 203 pages. Bratislava: GÚDŠ.

Tedford, R.H.

1977. Relationship of Pinnipeds to Other Carnivores (Mammalia). Systematic Zoology, 25(4):363-374.

Tedford, R.H., L.G. Barnes, and C.E. Ray

1994. The Early Miocene Littoral Ursoid Carnivoran Kolponomos: Systematics and Mode of Life. In A. Berta and T.A. Deméré, editors, Contributions in Marine Mammal Paleontology Honoring Frank C. Whitmore, Jr. Proceedings of the San Diego Society of Natural History, $29: 1-32$.

Thenius, E.

1950. Ergebnisse der Neuuntersuchung von Miophoca vetusta Zapfe (Phocidae, Mammal.) aus dem Torton des Wiener Beckens. Anzeiger der Österreichischen Akademie der Wissenschaften, Vienna, Mathematisch-Naturwissenschaftlichen Klasse, 5:1-9.

1952. Die Säugetierfauna aus dem Torton von Neudorf an der March (SR) Neues Jahrbuch für Geologie und Paläontologie, Abhandlungen, 96(1):27-136

1969. Stammesgeschichte der Säugetiere (einschliesslich der Hominiden) In J.-G. Helmcke, D. Starer, and H. Wermuth, editors, Handbuch der Zoologie, pages 393-405. Berlin: Walter De Gruyter \& Co.

1979. Die Evolution der Säugetiere: Eine Übersicht über Ergebnisse und Probleme. 270 pages. Stuttgart, New York: Gustav Fischer Verlag.

1992. Neue Befunde und Erkenntnisse zur Verbreitungsgeschichte der Robben (Mammalia: Carnivora: Pinnipedia). Anzeiger der Österreichischen Akademie der Wissenschaften, Sitzungsberichte der Mathematisch-Naturwissenschaftlichen Klasse, 129:67-73.

Trelea, N., and T. Simionescu

1985. Au sujet de quelques formes de vertébrés des formations sarmatiennes de chelia du département Jassy. Analele Stiintifice ale Universitatii "Al. I. Cuza" din lasi, Geologie-Geografie, 31(2):18-20.

Wolsan, M.

1993. Phylogeny and Classification of Early European Mustelidae (Mammalia: Carnivora). Acta Theriologica, 38(4):345-384.

Wozencraft, W.C.

1989. The Phylogeny of the Recent Carnivora. In J.L. Gittleman, editor, Carnivore Behavior, Ecology, and Evolution, pages 495-593. Ithaca, New York: Cornell University Press.

Wyss, A.R.

1988. On "Retrogression" in the Evolution of the Phocinae and Phylogenetic Affinities of the Monk Seals. American Museum Novitates, 2924: 38 pages.

1994. The Evolution of Body Size in Phocids: Some Ontogenetic and Phy logenetic Observations. In A. Berta and T.A. Deméré, editors, Contributions in Marine Mammal Paleontology Honoring Frank C. Whitmore, Jr. Proceedings of the San Diego Society of Natural History, 29:69-75.

Wyss, A.R., and J.J. Flynn

1993. A Phylogenetic Analysis and Definition of the Camivora. In F.S. Szalay, M.J. Novacek, and M.C. McKenna, editors, Mammal Phylogeny: Placentals, pages 32-52. New York: Springer-Verlag.

Zapfe, $\mathrm{H}$.

1937. Ein bemerkenswerter Phocidenfund aus dem Torton des WienerBeckens. Verhandlungen der Zoologisch-Botanischen Gesellschaft in Wien, 86/87:271-276.

1949. Eine mittelmiozäne Säugetierfauna aus einer Spaltenfüllung bei 
Neudorf an der March (SR). Anzeiger der Österreichischen Akademie der Wissenschaften, Sitzungsberichte der Mathematisch-Naturwissenschaftlichen Klasse, 86(7):173-181.

1950. Die Fauna der miozänen Spaltenfüllung von Neudorf an der March (CSR), Chiroptera, Camivora. Anzeiger der Österreichischen Akademie der Wissenchaften, Sitzungsberichte der Mathematisch-Naturwissenschaftlichen Klasse, 159:51-64, 109-141.

1952. Die Pliopithecus-Funde aus der Spaltenfüllung von Neudorf an der March. Verhandlungen der Geologoschen Bundesanstadt (Wien), special issue $C: 126-130$.

1953. Das geologische Alter der Spaltenfüllung von Neudorf an der March. Verhandlungen der Geologischen Bundesanstalt (Wien), 3: 195-202.

1960. Die Primatenfunde aus der Miozän Spaltenfüllung von Neudorf an der March, Tschechoslowakei. Schweizerische Paleontologische Abhandlungen, 78:1-293.

1976. Die Fauna der miozänen Spaltenfüllung von Neudorf a.d. March (SSR), Chalicotherium grande (BLV.). Anzeiger der Österreichischen Akademie der Wissenschaften, Sitzungsberichte der Mathematisch-Naturwissenschaftlichen Klasse, Part 1, 185(7):91-112.

1979. Chalicotherium grande (Blainv.) aus der miozänen Spaltenfüllung von Neudorf an der March (Dèvínská Nová Ves), Tschechoslowakei. Neue Denkschriften des Naturhistorischen Museums in Wien, 2: 282 pages.

1983. Die Fauna der miozänen Spaltenfüllung von Neudorf an der March (SSR). Suidae. Anzeiger der Österreichischen Akademie der Wissenschaften, Sitzungsberichte der Mathematisch-Naturwissenschaftlichen Klasse, Part 1, 192(7):167-182. 


\title{
Paleontology of the Late Oligocene Ashley and Chandler Bridge Formations of South Carolina, 1: Paleogene Pinniped Remains; The Oldest Known Seal (Carnivora: Phocidae)
}

\author{
Irina A. Koretsky and Albert E. Sanders
}

\begin{abstract}
The proximal halves of two femora from the Chandler Bridge and Ashley Formations (early Chattian, late Oligocene) near Charleston, South Carolina, provide the earliest evidence to date of true seals. They are clearly referable to the Phocidae and furnish information regarding osteological and myological features that had evolved in early phocids by early Chattian time. Although not determinate to the generic level, these specimens represent a taxon closely comparable to the most specialized phocid, the modern genus Cystophora.
\end{abstract}

\section{Introduction}

The long-standing question of phylogenetic relationships among the Odobenidae, Otariidae, and Phocidae is still open. The debates about the monophyletic or diphyletic origin of pinnipeds from a series of ancestors (mustelid- or ursid-like animals) are not yet resolved. The new material reported herein, the proximal parts of two femora from the late Oligocene of South Carolina, now in The Charleston Museum (ChM), helps little in solving the problems of phylogeny, but we have for investigation the earliest and most primitive remnants of Phocidae. Herein we refer to the two partial femora from the late Oligocene as the "Oligocene seal." The two new specimens appear to represent the same taxon, but they are so incomplete that any taxonomic assignment below the family level would be mere speculation. This material nonetheless does provide information concerning some derived (=apomorphic) and primitive (=plesiomorphic) characters of the Phocidae.

Irina A. Koretsky, Research Associate, Department of Paleobiology, National Museum of Natural History, Smithsonian Institution, Washington, D.C. 20560-0121. Albert E. Sanders, Department of Natural Sciences, The Charleston Museum, 360 Meeting Street, Charleston, South Carolina 29430.
For comparisons we used postcranial material from several living and fossil representatives of aquatic and semiaquatic carnivores, including Mustelidae (the genera Lutra, Enhydra, and Potamotherium); Otariidae (the genera Zalophus and Allodesmus, the latter the most controversial eared seal (Berta and Wyss, 1994; Barnes and Hirota, 1994)); and Phocidae (for example, the genus Cystophora as the most specialized representative of the family).

ACKNOWLEDGMENTS.- The authors are grateful to James Mead and Charles Potter for access to modern comparative material, to Clayton E. Ray for access to fossil pinniped collections, to Victor Krantz and Steven Jabo for specimen photography (all National Museum of Natural History (NMNH), Smithsonian Institution, Washington, D.C.), and to Robert J. Emry (NMNH), Daryl Domning (Howard University, Washington, D.C.), and Mieczyslaw Wolsan (Institute of Paleobiology, Warsaw, Poland) for their helpful comments on several versions of this manuscript.

MATERIAL AND LOCALITY.-Proximal portion of right femur (ChM PV5712), from a ditch in the Irongate subdivision, approximately $3.9 \mathrm{~km}$ (2.4 mi.) SW of Summerville, Dorchester County, South Carolina, collected by Vance McCollum, summer 1978; cast of ChM PV5712 (USNM 299831) in the NMNH (which subsumed the collections of the former United States National Museum). Proximal portion of right femur (ChM PV5713), from a ditch on Trolley Road (County Road 199), approximately $3.0 \mathrm{mi}$. (4.8 km) SW of Summerville, Dorchester County, South Carolina, collected by Chris Kenney, 6 December 1978; cast of ChM PV5713 (USNM 306508).

FORMATION AND AGE.-ChM PV5712: Chandler Bridge Formation, early Chattian (late Oligocene). ChM PV5713: Ashley Formation, early Chattian (late Oligocene).

The Chandler Bridge Formation, an unconsolidated noncalcareous marine unit rich in vertebrate fossil remains, occurs at numerous disjunct localities in Berkeley, Charleston, and Dorchester Counties, South Carolina. It unconformably over- 


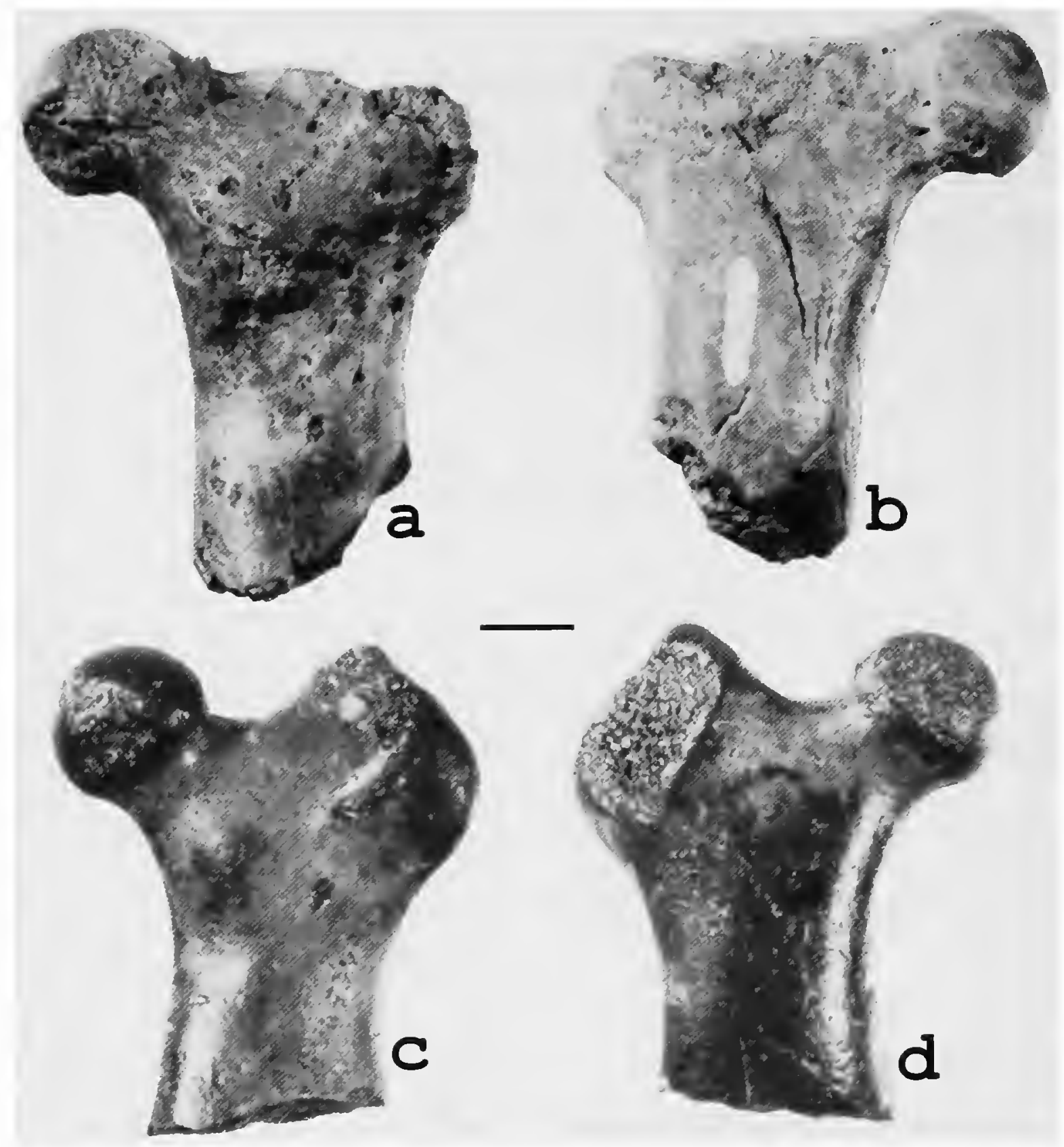

FIGURE 1.-Femora of Oligocene seals $(\times 1)$. Right femur, original ChM PV 5712, cast USNM 299831, from Chandler Bridge Formation, early Chattian, late Oligocene: $a$, caudal view; $b$ cranial view. Right femur, original ChM PV 5713, cast USNM 306508, from Ashley Formation, lower Chattian, late Oligocene: $c$, caudal view; $d$, cranial view.

lies the Ashley Formation, a highly indurated calcarenite underlying most of the area encompassed by the aforementioned counties (Sanders, 1980; Sanders et al., 1982). E. Martini has found the nannoplankton of the Ashley Formation to be referable to zone NP24 (Sanders and Barnes, 2002). Sanders et al. (1982) have estimated the Chandler Bridge Formation to be approximately 28 million years old and the Ashley Formation to be about 30 million years in age. Both units have yielded abundant remains of sharks; bony fishes; sea turtles (Carolinachelys, Procolpochelys, Syllomus, two dermochelyids); three nonmarine turtle taxa; a large, newly described estuarine crocodile, Gavialosuchus carolinensis Erickson and Sawyer (1996); marine birds (including a large pseudodontorn with a wingspan of about six meters); sirenians; and more than 20 taxa of primitive cetaceans. Now a pinniped is added to the impressive faunas of marine vertebrates from these two formations.

\section{Phocidae}

\section{Genus and Species Indeterminate}

DESCRIPTION.-The femora (Figure 1, Table 1) are similar in size to those of the modern harp seal, Pagophilus groenlandicus. The shaft of the bone is flattened in the cranial-caudal direction. The greater trochanter extends proximally slightly higher than the head and is slender, although not well developed. The trochanteric fossa is shallow and wide open, actually not reaching the middle of the greater trochanter. The intertrochanteric crest is not expanded. The lesser trochanter is very well developed and is located on the posteromedial side of the bone at the same level as the distal border of the greater trochanter. The cervix is short but narrow relative to the bone's mass. The head is damaged, but it clearly has an indentation for attachment of the ligamentum teres in the center of the head. 
TABLE 1.-Measurements (in $\mathrm{mm}$ ) of the late Oligocene seal femora from the Chandler Bridge Formation (ChM PV5712) and the Ashley Formation (ChM PV5713), Dorchester County, South Carolina.

\begin{tabular}{l|cc}
\hline \multicolumn{1}{c}{ Character } & \multicolumn{2}{c}{ Measurements } \\
\cline { 2 - 3 } & ChM PV5712 & ChM PV5713 \\
\hline Length of greater trochanter & 29.5 & - \\
Intertrochanteric length & 42.0 & - \\
Height of head & 20.5 & 21.5 \\
Width of proximal epiphysis & 54.0 & 56.5 \\
Width of head & 18.0 & 19.0 \\
Narrowest part of diaphysis & 27.0 & 28.0 \\
Maximum thickness of greater trochanter & 13.5 & - \\
Anteroposterior thickness of diaphysis & 16.0 & 18.0 \\
Diameter of cervix & 17.0 & 20.0 \\
\hline
\end{tabular}

This insertion of the ligamentum teres is not a completely developed fovea as it is in most terrestrial mammals. In phocids this fovea is absent.

The slight difference in bone morphology of the two Oligocene femora perhaps could be ascribed to sexual dimorphism (Koretsky, 1987), but the limitations of the material preclude a more precise interpretation.

According to authors who have studied the functional morphology and myology of the limbs of different carnivores (Howell, 1928, 1930; Savage, 1957; Mori, 1958; Mitchell, 1966; Piérard, 1971; Tarasoff, 1972; Sokolov et al., 1974), the lesser trochanter is the point of insertion of the iliopsoas muscle. These authors also noted, however, that if the lesser trochanter is absent, then the pectineus and adductor muscles insert on this place; that is true for all comparatively aquatic and semiaquatic mammals. The iliopsoas muscle is a large, heavy muscle connecting the lumbar spine and ilium with the femur. The actions of this muscle are to flex and laterally rotate the femur, tilt the pelvis forward, flex the thigh upon the pelvis, and adduct the femur (working as a synergist with the adductor brevis) (Gordon, 1983).

The quadratus femoris muscle is absent in extant phocids. In the otter, this reduced and weakened muscle inserts on the distal part of the greater trochanter, on the caudal border of the femur (Sokolov et al., 1974). In sea lions (otariids), the insertion of the $\mathrm{m}$. quadratus femoris is along the entire laterocaudal border of the femur (Howell, 1928). The action of the quadratus femoris muscle is to extend the hip joint.

Howell (1928, 1930), Piérard (1971), and other researchers described the trochanteric fossa as a place of attachment of the obturator internus and externus muscles, together with the two gemelli muscles, the superior and inferior. The gemelli and obturator externus muscles arise from the lateral border of the obturator foramen and its membrane. The two gemelli join with the obturator internus muscle to form a common tendon for insertion. (Piérard at the same time (1971:68) mistakenly stated that the origin of the tendon of the obturator internus muscle is a shallow groove in the middle one-third of the pubic edge.) The action of the obturator externus muscle is to rotate the fe- mur laterally. The actions of the gemelli and obturator internus are to abduct the femur and also to rotate it laterally.

COMPARISONS.-The Oligocene seal differs from other carnivores we examined (except for Cystophora and Zalophus) in its shallow and poorly defined trochanteric fossa, from all except Cystophora by its slight extension of the greater trochanter above the head, and from all except Lutra and Potamotherium in having a pit for attachment of the ligamentum teres.

Other distinct differences between this seal and other genera also exist. It differs from Cystophora (the hooded seal) in having a lesser trochanter (but this is always absent in females of Cystophora); a narrower and less prominent greater trochanter; and a more delicate, not massive, overall bone structure. So far as they can be determined, the muscle attachments for the Oligocene seal are in general the same as for Cystophora, but with one exception: in female hooded seals, which lack a lesser trochanter, the tendons of the pectineus and adductor cranialis muscles are inserted on the same spot on the bone, and the iliopsoas muscle inserts upon the medial tuberosity of the tibia (Howell, 1928).

From Lutra this seal differs in the presence of a well-developed and distinct lesser trochanter and a much broader shaft. In general, there are no differences between these two taxa in insertion of the described muscles; gemelli, obturator externus, and internus muscles all insert into the trochanteric fossa, and the iliopsoas muscle inserts onto the lesser trochanter (Sokolov et al., 1974).

The Oligocene seal differs from Enhydra in the shorter cervix and smaller size of the head compared with the rest of the bone. Insertions of the muscles into the fossa trochanterica are almost the same in Enhydra and Lutra, but the mass of these muscles is apparently greater in Enhydra. In contrast to the Oligocene seal, Enhydra lacks the ligamentum teres (Sokolov et al., 1974; Howard, 1975).

Its differences from Potamotherium are the more medial location of the lesser trochanter and the absence of the intertrochanteric crest. In Potamotherium the tendon of the obturator internus did not merge with the common tendon of the obturator externus and gemelli; the quadratus femoris was located on the intertrochanteric crest (Savage, 1957).

The Oligocene seal differs from Zalophus in having a more medially located lesser trochanter and in lacking an intertrochanteric crest. Presumably the insertion of the obturator externus in the Oligocene seal is located distal to the trochanteric fossa on the posteromedial side of the greater trochanter; the tendons of the two gemelli muscles were not joined together. In Zalophus, the tendon of the gemellus superior muscle does not join with the tendon of the obturator internus muscle; the tendon of the adductor brevis muscle inserts into the intertrochanteric crest (Howell, 1928; Lyon, 1937); and the ligamentum teres is absent.

From Allodesmus, the Oligocene seal differs in its smaller and thinner greater trochanter and its lack of the intertrochanteric crest. By analogy to the living otariids, the adductor brevis 
TABLE 2.-Comparative diagnostic characters of the femora of the Oligocene seal and some other members of Carnivora. $(+=$ character present; $-=$ character absent; $+/=$ character variable. $)$

\begin{tabular}{|c|c|c|c|c|c|c|c|}
\hline Character & Olig. seal & Cystophora & Lutra & Enhydra & Potamotherium & Zalophus & Allodesmus \\
\hline 1. Shallow and open trochanteric fossa & + & + & - & - & - & + & - \\
\hline 2. Greater trochanter slightly extended over head & + & + & - & - & - & - & - \\
\hline 3. Lesser trochanter present & + & $+1-$ & - & - & + & + & + \\
\hline 5. Cervix short and narrow & + & - & + & + & + & - & + \\
\hline 6. Intertrochanteric ridge absent & + & + & + & + & - & - & - \\
\hline 7. Fovea for ligamentum teres present & + & - & + & - & + & - & - \\
\hline
\end{tabular}

muscle in Allodesmus inserted on the intertrochanteric crest (Mitchell, 1966; Hirota, 1983), which is not present in the Oligocene seal. The fovea capitis, and hence presumably the ligamentum teres, is absent also in Allodesmus.

\section{Discussion}

The osteology and interpreted myology of these proximal femora indicate that these remains are definitely more closely related to the Phocidae than to other carnivores (Table 2). In addition, the functional morphology of even these proximal femora can suggest whether this Oligocene seal used its hind limb predominantly for propulsion in water or to some degree for terrestrial movement as well.

For example, the diaphysis of the femur of Lutra is almost circular in cross-section and is better prepared for terrestrial locomotion than for aquatic movement. Increasing the surface area for insertion of the adductor muscle makes the shaft of the femur broader. The enlarged adductor muscle also helps prevent rotation and movement of the femur. The diaphysis in the Oligocene seal is flatter and wider than in Lutra, Potamotherium, and Enhydra; similar to that of Allodesmus; and narrower than in Cystophora and Zalophus.

The literature and observation of living animals both indicate that terrestrial locomotion in Lutra (and presumably in Potamotherium) is only slightly impaired. The increased surface area of the femur suggests that Enhydra, Zalophus, and the Oligocene seal have more limitations on land. Cystophora has lost the ability to turn its hind limbs forward on solid ground, as have other modern Phocidae, in contrast to the Otariidae and Odobenidae. When the animal is on land, the ligamentum teres allows rotational movement of the femur and helps to fix the head of the femur to the acetabular fossa. This ligament disappears when the animal spends less time on land (Tarasoff, 1972) and has greater freedom of movement of the femur. In the Oligocene seal there is morphological evidence for a higher degree of terrestriality than in Cystophora and Zalophus but much less than in Lutra and Potamotherium.

The distribution among carnivore taxa of osteological features associated with lower-limb propulsion can assist in interpreting the specific method of locomotion in both aquatic and terrestrial movement. The main effect of the flattening and expansion of the greater trochanter is thus to increase the area of insertion of the muscles that rotate the femur (Howell, 1928; Tarasoff, 1972; Gordon, 1983). The Oligocene seal, with its greater trochanter only slightly expanded, used its hind limb in lateral movement and with some flexion and adduction (similar to Cystophora) for aquatic movement. This involved little rotation of the femur, suggesting that these Oligocene animals were not as good swimmers as later phocids.

As the antagonistic muscle to those lateral rotators, the iliopsoas muscle, located on the caudal side of the femur, becomes very much reduced and weakened. In parallel to the decrease in its stress on the lesser trochanter, the latter is reduced and finally disappears. In those mammals that do not bring their hind limbs forward, the lesser trochanter is less and less developed. We can observe this progressive reduction from Lutra, to the Oligocene seal, to Cystophora (where it is small in males and absent in females), and finally to Phoca, where it is completely absent. The lateral rotation of the lower limb results in turning the hind foot so that it can move in a horizontal plane.

The anatomy of Enhydra and Zalophus shows that the feet of these animals are adapted predominantly for lateral movement, but that vertical and horizontal movement also is possible for body support and locomotor activity on land. On the other hand, the anatomy of the pelvic limb of Lutra is similar to that of completely terrestrial carnivores. Phocids have undergone major morphological changes that are closely correlated with their specialized methods of aquatic locomotion. In its patterns of aquatic locomotion, Enhydra shows analogy to both Lutra and Cystophora and to the Oligocene seal. Moreover, Enhydra has a convergent similarity to the seal in its elongated hind limb as the major organ of propulsion.

The primary result of this study is that, from the viewpoint of adaptation to the water, the numerous modifications of the Oligocene seal correspond most closely with Cystophora. From a taxonomic viewpoint, the relationship between the Oligocene seal and other phocids is supported both osteologically and, by inference, myologically.

Within the range of taxa compared herein, the Oligocene seal is closer in several characters (see Table 2) to the semiaquatic Mustelidae than to the representative of the eared seals. These characters are primitive (e.g., the lesser trochanter), indicating its derivation from land carnivores. At the same time, the Oligocene seal has derived characters (for example, the much en- 
larged greater trochanter) that place it within the Phocidae rather than as an ancestor of this taxon. The morphology of these partial femora, and the functional myology interpreted from the osteology, shows that the locomotor adaptations of the Oligocene seal were much closer to the pinniped type (especially the phocids) than to that of the semiaquatic mustelids. This, along with its occurrence in marine deposits, associated with other fully marine vertebrates, suggests that the Oligocene seal was well adapted to a marine environment.

Savage (1957:235) concluded that the Phocidae "evolved from a lutra-like mustelid in the Oligocene. The Otariidae and Odobenidae may have had a separate origin." The material of this Oligocene seal is not sufficient to either support or falsify the hypothesis of mustelid ancestry, but it is sufficient to conclude that the ancestor of Phocidae must be sought in deposits older than the late Oligocene.

\section{Literature Cited}

Barnes, L.G., and K. Hirota

1994. Miocene Pinnipeds of the Otariid Subfamily Allodesminae in the North Pacific Ocean: Systematics and Relationships. Island Arc. $3(4): 329-360,13$ figures.

Berta, A., and A.R. Wyss

1994. Pinniped Phylogeny. In A. Berta and T.A. Demeré, editors, Contributions in Marine Mammal Paleontology Honoring Frank C. Whitmore, Jr., Proceedings of the San Diego Society of Natural History; 29:33-57, 6 figures, 3 tables, 2 appendices.

Erickson, B.R., and G.T. Sawyer

1996. The Estuarine Crocodile Gavialosuchus carolinensis n. sp. (Crocodylia: Eusuchia) from the Late Oligocene of South Carolina, North America. Monograph of the Science Museum of Minnesota (St. Paul), 3: 47 pages, 30 figures.

Gordon, K.R.

1983. Mechanics of the Limbs of the Walrus (Odobenus rosmarus) and the California Sea Lion (Zalophus californianus). Journal of MorpholHirota, K.M. ogy, 175:73-90, 7 figures, 2 appendices.

1983. Notes on the Miocene Sea-Lion Allodesmus. 128 pages. Masters thesis, Department of Geology and Mineralogy, Faculty of Sciences, Howard, L.D. Kyoto University, Japan.

1975. Muscular Anatomy of the Hind Limb of the Sea Otter (Enhydra lutris). Proceedings of the California Academy of Sciences, 40(12): Howell, A.B. $335-416,59$ figures.

1928. Contribution to the Comparative Anatomy of the Eared and Earless Seals (Genera Zalophus and Phoca). Proceedings of the United States National Museum, 73(15):1-42, 1 plate.

1930. Aquatic Mammals: Their Adaptations to Life in the Water. vii +338 pages, 54 figures. Springfield, lllinois, and Baltimore, Maryland: Charles $\mathrm{C}$. Thomas.

Koretsky, I.A.

1987. [Sexual Dimorphism in the Structure of the Humerus and Femur of Monachopsis pontica (Pinnipedia: Phocinae).] Vestnik Zoologii, 4: Lyon, G.M 77-82. [In Russian.]

1937. Pinnipeds and a Sea Otter from the Point Mugu Shell Mound of California. Publications of the University of California at Los Angeles
Mitchell, E.D.

in Biological Sciences, 1(8):133-168, 11 figures.

1966. The Miocene Pinniped Allodesmus. University of California Publications in Geological Sciences, 61:1-46, 29 plates.

Mori, Masaru

1958. The Skeleton and Musculature of Zalophus. Folia Anatomica Japonica. 31(3-4):203-284, 54 figures, 4 plates.

Piérard, Jean

1971. Osteology and Myology of the Weddell Seal Leptonychotes weddelli (Lesson, 1826). In W.H. Burt, editor, Antarctic Pinnipedia. Ant-

Sanders, A.E. arctic Research Series, 18:53-108, 59 figures.

1980. Excavation of Oligocene Marine Fossil Beds near Charleston, South Carolina. National Geographic Society Research Reports, 12: $601-621$.

Sanders, A.E., and L.G. Barnes

2002. Paleontology of the Late Oligocene Ashley and Chandler Bridge Formations of South Carolina, 2: Micromysticetus rothauseni, a Primitive Cetotheriid Mysticete (Mammalia: Cetacea). In R. Emry, editor, Cenozoic Mammals of Land and Sea: Tributes to the Career of Clayton E. Ray Smithsonian Contributions to Paleobiology, 93:271-293.

Sanders, A.E., R.E. Weems, and E.M. Lemon, Jr.

1982. Chandler Bridge Formation: A New Oligocene Stratigraphic Unit in the Lower Coastal Plain of South Carolina. U.S. Geological Survey Bulletin, 1529-H:105-124, figures 24-27.

Savage, R.J.G.

1957. The Anatomy of Potamotherium, an Oligocene Lutrine. Proceedings of the Zoological Society of London, 129(2):151-244, 38 figures, 3 plates, 8 tables.

Sokolov, I.1., A.S. Sokolov, and E.A. Klebanov

1974. [The Morphological Specialization of the Organs of Movement of Some Mustelidae, in Connection with Their Life-Style.] In [Functional Morphology of the Mammals.] Trudy Zoologicheskogo Instituta, Akademii Nauk SSSR (Leningrad), 54:4-103, 24 figures, 13

Tarasoff, F.J. tables. [1n Russian.]

1972. Comparative Aspect of the Hind Limbs of the River Otter, Sea Otter and Seals. In R.J. Harrison, editor, Functional Anatomy of Marine Mammals, pages 333-359. London and New York: Academic Press. 



\title{
Simocetus rayi (Odontoceti: Simocetidae, New Family): A Bizarre New Archaic Oligocene Dolphin from the Eastern North Pacific
}

\author{
R. Ewan Fordyce
}

\begin{abstract}
Simocetus rayi (new genus, new species) is based upon a skull and mandible of a small archaic dolphin (Cetacea: Odontoceti) from the upper Oligocene Alsea Formation of Oregon, bordering the northeast Pacific. The species shows many primitive features reminiscent of the archaic odontocete family Agorophiidae: the cheek teeth appear nonpolydont, the nares and premaxillary sac fossae lie anteriorly, the orbit and facial fossa are elevated above the level of the rostrum, the ascending processes of premaxillae are narrow and long, the supraorbital processes of the maxillae are narrow, the intertemporal constriction is prominent, and the pterygoid sinus fossae are restricted to the basicranium. These features are consistent with a basal position among the odontocetes, but they do not justify placement in the paraphyletic- and probably polyphyletic-grade family Agorophiidae. Simocetus rayi shows some unusual autapomorphies (toothless premaxillae, anterior of rostrum and mandible downturned) that exclude it from described taxa of odontocetes, and for this reason it is placed in a new and currently monotypic family, Simocetidae. Broader relationships are uncertain; some cranial features hint at affinities with Eurhinodelphinidae. For now, $S$. rayi is regarded as a specialized archaic odon-tocete that lies stemward (more basal) to all extant groups of Odontoceti (namely, Physeteroidea, Ziphiidae, Platanistoidea, and Delphinida).

Simocetus rayi was perhaps a bottom feeder that preyed through suction feeding on soft-bodied invertebrates. The inferred presence of nasal turbinals and a vomeronasal organ contrasts with the situation in living odontocetes. Features of the face and basicranium point to echolocation abilities comparable to those of extant Odontoceti. Simocetus rayi and other contemporaneous archaic odontocetes from Oregon and Washington indicate that odontocetes were taxonomically and ecologically diverse by the late Oligocene.
\end{abstract}

R. Ewan Fordyce, Department of Geology, University of Otago, Dunedin, New Zealand; and Research Associate, Department of Vertebrate Zoology, National Museum of Natural History, Smithsonian Institution, Washington, D.C. 20560-0121, United States.

\section{Introduction}

Odontocetes, which include toothed whales, dolphins, and porpoises, have an extensive fossil record from the late Oligocene to Holocene. In the last decade, sound progress has been made in understanding the relationships between many living groups, particularly those with a Miocene to Holocene record (Muizon, 1987, 1988a, 1988b, 1991). In contrast, the morphology and relationships of archaic odontocetes-heterodont dolphins that retain an intertemporal constriction-are understood poorly. The so-called primitive odontocetes have nonetheless been pivotal in helping develop basic concepts of odontocete evolution. Indeed, one species, Agorophius pygmaeus (Müller, 1849), is the basis for the family Agorophiidae Abel, 1913, from which, according to many authors, later odontocetes evolved. This article describes and discusses a new species and new genus of archaic odontocete that has been mentioned previously (Muizon, 1991:303) as a species of Agorophiidae, but that is herein placed in a new group, Simocetidae. The fossil, USNM 256517, shows many details of cranial structure not recorded previously for archaic odontocetes. It is the first archaic odontocete from the northeastern Pacific margin to be described formally. Although the species shows a wide range of primitive features, consistent with its late Oligocene age and rather basal position in the Odontoceti, it is too specialized, particularly in terms of feeding apparatus, to have been directly ancestral to any other described odontocete.

Specimen USNM 256517 is one of several hundred fossil vertebrates assembled by the late Douglas R. Emlong, which now constitute the Emlong collection (Ray, 1977, 1980; Domning et al., 1986) in the National Museum of Natural History. The Emlong collection comprises fossils from a thin sequence of marine Oligocene and Neogene rocks along the eastern coast of the North Pacific Ocean, mainly from Oregon and Washington. Other unnamed species of archaic odontocete are repre- 
sented by undescribed specimens in the Emlong collection; mentioned below are USNM 205491 ("non-squalodontid odontocete" of Whitmore and Sanders, 1977, fig. 2b, from Alsea Formation, Oregon), USNM 243979 ("non-squalodontid odontocete" of Whitmore and Sanders, 1977, fig. 2a, from ?Pysht Formation, Washington), and USNM 299482 (?Pysht Formation, Washington), all of which are of Oligocene age.

Descriptions below are based upon the right or left side, whichever is more nearly complete. Some comparisons are offered in the descriptive text to clarify homologies, but fuller systematic comparisons follow the description. Absences are noted for some cranial features that are present in archaeocete cetaceans but are enigmatic or missing in most odontocetes. Unreferenced statements about cetacean anatomy are based upon personal observations. Nomenclature follows that used by Kellogg (1936), Kasuya (1973), Fordyce (1994), and others, with modifications and synonyms (following Sisson and Grossman, 1953; Davis, 1964; Novacek, 1986; Evans, 1993) to better identify cetacean homologs with those of other mammals. The few postcranial elements are rather uninformative and are not described.

Line diagrams are from $35 \mathrm{~mm}$ photographs (Asahi Pentax camera, $50 \mathrm{~mm}$ macro lens) and are not corrected for parallax. Illustrations are by the author.

F.V. Grady carried out most of the preparation using mechanical tools. The author prepared fine details under a low-power binocular microscope using pneumatic scribe and an air-abrasive unit. Much of the matrix is a leached (formerly calcareous) mudstone that bonds tightly to bone, and still obscures some sutures and foramina.

ABBREVIATIONS.- The following abbreviations are used:

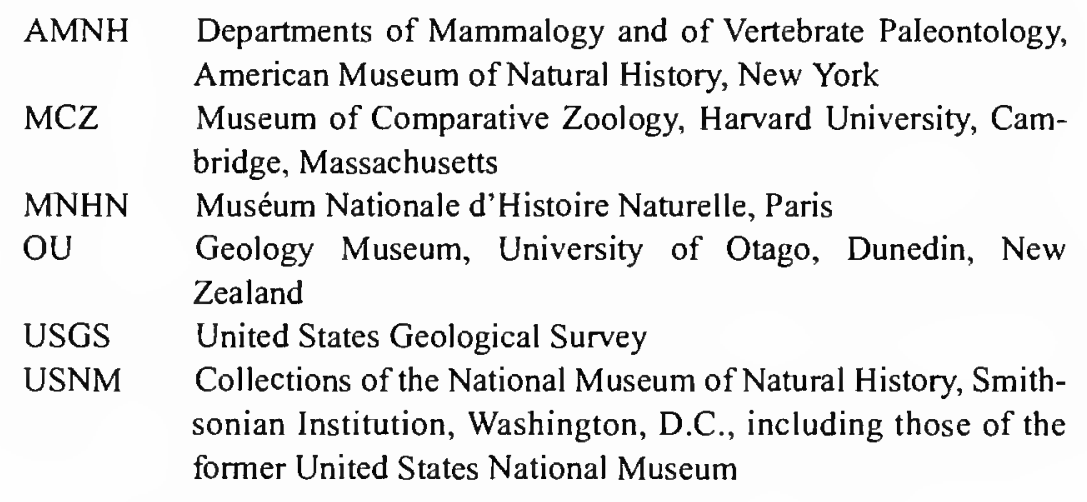

ACKNOWLEDGMENTS.-Work was started during the tenure of a Smithsonian Postdoctoral Fellowship in the Department of Paleobiology from early 1979 to mid-1980 and was continued with support from Smithsonian short-term visiting fellowships. The University of Otago supported visits to the Smithsonian Institution in 1984, 1988-1989, 1994, and 1996. I am indebted to Frank C. Whitmore, Jr., for his valuable guidance and advice over the years. I gratefully thank Clayton E. Ray for facilitating diverse aspects of this study, and Frederick V. Grady for preparation. Lawrence G. Barnes, Hiroto Ichishima, Richard Köhler, James G. Mead, Mark D. Uhen, and Frank C. Whitmore, Jr., reviewed different versions of the manuscript. Barnes, Mead, Whitmore, and Christian de Muizon also provided fruitful ongoing discussion of cetacean systematics. Lawrence G. Barnes,
David J. Bohaska, Andrew P. Currant, John T. Darby, Anton van Helden, Jerry J. Hooker, James G. Mead, Clayton E. Ray, Thomas H. Rich, Richard H. Tedford, and Albert E. Sanders kindly arranged access to specimens studied as part of this work.

\section{Class Mammalia}

\section{Order CeTACEA}

\section{Suborder ODONTOCETI}

DIAGNOSIS.-Odontoceti are recognized herein as Cetacea with the following combination of osteological features: supraorbital process of maxilla telescoped posteriorly over frontal; one or more dorsal infraorbital (=maxillary) foramina open posteriorly in supraorbital process of maxilla; premaxillary sac fossa, premaxillary sulci, and premaxillary foramen (or foramina) present; infraorbital process of maxilla reduced; posteriormost teeth inserted anterior to antorbital notch; orbitotemporal crest displaced posterodorsally relative to postorbital ridge and partly roofing temporal fossa; distinct antorbital notch faces anteriorly to anterolaterally; pterygoid hamulus partly excavated for the pterygoid sinus system; ossified mesethmoid present between bony nares; and parietal and squamosal dorsointernally override periotic to occlude the cranial hiatus.

REMARKS.- These features are seen in or inferred for $S$. rayi. They are modified in some other odontocetes. Many of the facial features listed appear to be linked to the presence of a posteriorly displaced and hypertrophied maxillo-naso-labialis (nasofacial) muscular complex, and thus to the ability to generate high-frequency sound that might be used in echolocation. See "Discussion," below.

\section{Superfamily Incertae Sedis \\ SiMOCETIDAE, new family}

DiAGNOSIS.-As for Simocetus rayi, at present the only included species; see remarks under species diagnosis.

TYPE GENUS.-Simocetus new genus.

INCLUDED GENERA.—Simocetus new genus only.

\section{Simocetus, new genus}

ETYMOLOGY.-From simus, pug-nosed, and cetus, whale (Greek). In allusion to the prominent medial "snout" posterior to the external nares.

DiAGNOSIS.-As for Simocetus rayi, at present the only included species; see remarks under species diagnosis.

TYPE SPECIES.-Simocetus rayi new species.

INCLUDED SPECIES.-Simocetus rayi only.

\section{Simocetus rayi, new species}

Agorophius sp., Muizon, 1991:303.

HYPODIGM.-USNM 256517 (Emlong collection number 


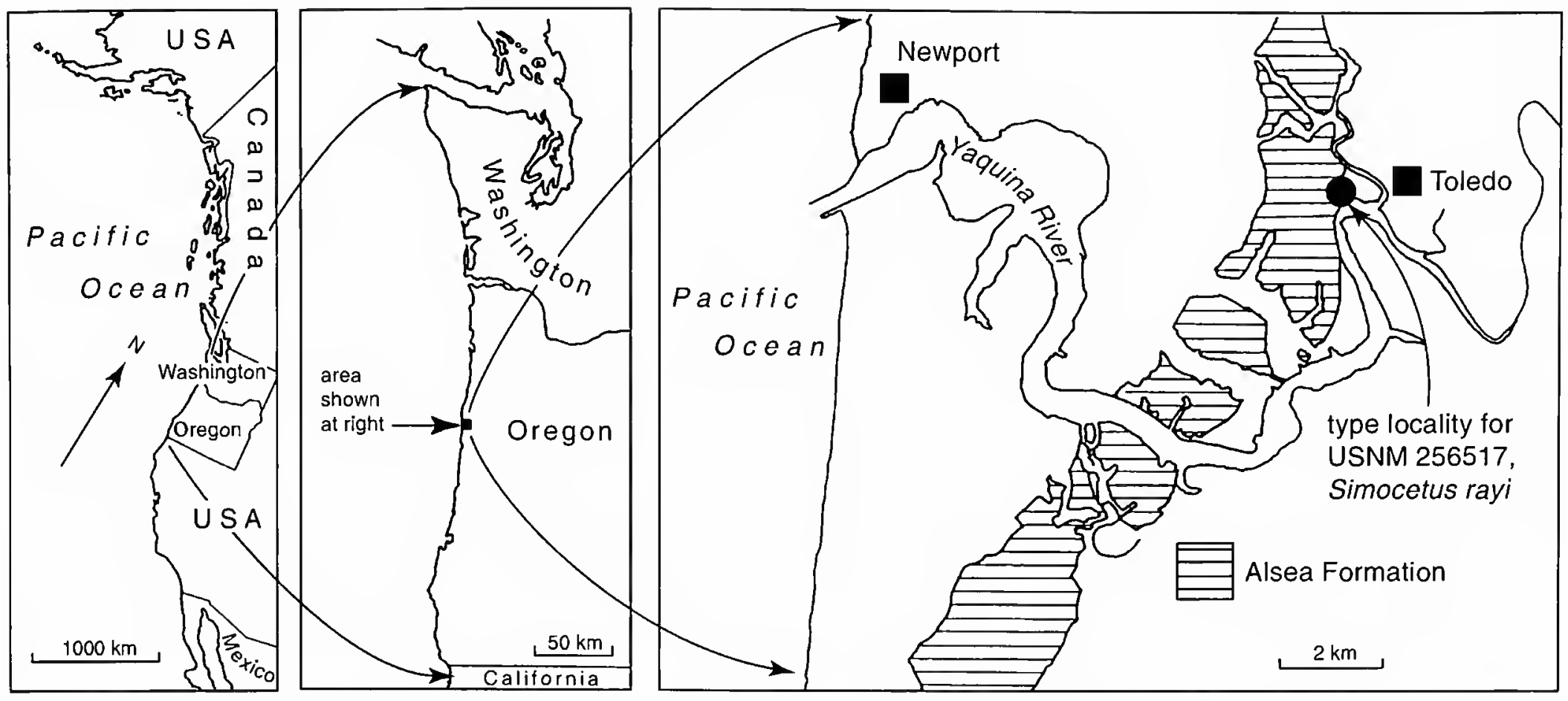

FIGURE 1.-Locality map of Pacific Northwest. The detailed map is based upon Snavely et al. $(1975,1976)$.

E77-32), holotype, only. Almost-complete skull, right periotic in place on skull, incomplete right mandible, three anterior teeth, 10 cheek teeth (four in place in rostrum, four in place in mandible), two incomplete presumed lumbar vertebrae, one chevron, eight or more incomplete ribs. Collected by D.R. Emlong, 3 August 1977.

DIAGNOSIS.-Small odontocete. More primitive than described species of Squalodontidae, Waipatiidae, Squalodelphinidae, Platanistidae, Dalpiazinidae, Eoplatanistidae, Eurhinodelphinidae, Lipotidae, Pontoporiidae, Iniidae, Albireonidae, Kentriodontidae, Delphinidae, Phocoenidae, Monodontidae, Ziphiidae, Physeteridae, and Kogiidae. Primitive features as follows: premaxillary sac fossa located well forward on rostrum; lateral margin of rostrum (rostral base) located well ventral to level of elevated roof of orbit; rostrum with well-developed fossa for nasofrontal muscles; ventral infraorbital foramen and sphenopalatine foramen opening in a large infundibulum in anterior wall of orbit; external nares open well forward of level of antorbital notch; median facial elements (nasals plus frontals) form an elongate "snout"; multiple supraorbital foramina open on frontal; elongate palatine forms much of palate; and parietals and interparietal form elongate intertemporal constriction.

Similar to Agorophius pygmaeus (Agorophiidae) only in plesiomorphic features including heterodont teeth; premaxillary sac fossa and associated foramina and sulci lying well forward on rostrum; lateral margin of rostrum (rostral base) lying ventral to level of elevated roof of orbit; and parietals contributing to an elongate intertemporal constriction. Differs from Agorophius pygmaeus in derived features as follows: rostrum more dorsoventrally compressed; supraorbital process of maxilla not expanded far laterally; braincase more inflated at base of zygomatic process, with deep cleft between process and braincase; supraoccipital more hemispherical; and cheek teeth smaller, asymmetrical, and with diastemata.

Similar to Eurhinodelphinidae in having toothless premaxilla, elongate conical pterygoid hamulus, and thick postglenoid process. Similar to some extant Delphinidae in having well-developed interparietal and unfused mandibular symphysis. Similar to Waipatiidae and Squalodelphinidae in having pronounced cleft, presumably representing foramen spinosum, arising near foramen ovale and trending posterolaterally toward periotic along or near parieto-squamosal suture. Similar to some Delphinidae and Squalodontidae in having palate with scattered multiple small palatine foramina.

Presumed autapomorphies include thin spatulate edentulous rostral apex, formed by premaxillae, deflected ventrally, resulting in down-turned rostrum; relatively short rostrum; supraorbital process of maxilla not expanded laterally over supraorbital process of frontal; deep, narrow optic infundibulum; complex fine sutures between alisphenoid and squamosal; posterior maxillary cheek teeth occluding into facing diastemata between mandibular cheek teeth; and vestigial lower I1.

ETYMOLOGY.--After Clayton E. Ray, in recognition of his enduring and influential contributions to the study of fossil marine mammals.

TYPE LOCALITY.-Near intersection of North Yaquina Bay Road and Toledo Road, Lincoln County, Oregon, USA. Grid reference: SW 1/4, NE 1/4, Section 18, T 11S, R 10W on Toledo 15 -minute quadrangle map (USGS) or about $44^{\circ} 37^{\prime} 06^{\prime \prime} \mathrm{N}$, $123^{\circ} 56^{\prime} 50^{\prime \prime} \mathrm{W}$. See Figure 1, and Snavely et al. (1976).

HORIZON.-Gray calcareous to brown leached massive mudstone of the Alsea Formation of Snavely et al. (1975). The specimen came from the most eastern exposure of Alsea Formation mapped by Snavely et al. $(1975,1976)$, near Toledo, Oregon. 
TABLE 1.-Skull Measurements (in mm) of the standard skull measurements used by Perrin (1975), as well as measurements more appropriate for archaic odontocetes.

Condylobasal length, from tip of rostrum to posterior of occipital condyles

Length of rostrum, from tip to line across posterior limits of antorbital notches (right and left notch, respectively)

Width of rostrum at base, along line across posterior limits of antorbital notches

Width of rostrum at $60 \mathrm{~mm}$ anterior to line across posterior limits of antorbital notches

Width of rostrum at mid-length, at $\sim 120 \mathrm{~mm}$ anterior to line across posterior limits of antorbital notches

Width of premaxillae at mid-length of rostrum

Width of rostrum at $3 / 4$ length, measured from posterior end

Distance from tip of rostrum to posterior of prenarial constriction

Distance from tip of rostrum to anterior of bony naris

Distance from tip of rostrum to most anterior portion of external wall of choana, immediately dorsal to pterygoid hamulus

Distance from tip of rostrum to broken tip of pterygoid hamulus

Preorbital width, at level of frontal-lacrimal suture

Supraorbital width, at middle of orbit

Postorbital width, across apices of postorbital processes

Depth from vertex to roof of orbit

Maximum width across narial aperture

Maximum width across zygomatic processes of squamosals

(width from right process to midline)

Maximum width of premaxillae

Maximum width between posterolateral sulci

Distance from antorbital notch to apex of ascending process of right premaxilla

Distance from antorbital notch to apex of supraorbital process of right maxilla

Maximum distance between posterior apices of supraorbital processes of maxillae

Distance from midline of right internal ventral infraorbital foramen

Depth from vertex of right internal ventral infraorbital foramen

Median length of nasals on vertex

Maximum length of right nasal on vertex

Distance anterior to antorbital notch of anterior border of nasals

Median length of frontals on vertex

Distance behind antorbital notch of anterior of frontals on vertex

Median length of parietals/interparietals on vertex

Minimum parietal/interparietal width, at level of temporal lines

Parietal width, at dorsoventral midpoint of intertemporal region ( $35 \mathrm{~mm}$ ventral to vertex) and halfway along intertemporal region

Distance from posterior of occipital condyle to anterior apex of supraoccipital

Vertical external height of braincase, from midline of basioccipital to dorsal extremity of supraoccipital

Maximum length of right temporal fossa, point to point from most anterior portion of orbitotemporal crest on frontal to most posterior boundary of fossa

Minimum length of right temporal fossa, point to point from postorbital ridge on frontal to most anterior portion of base of zygomatic process

Maximum dorsoventral depth of right temporal fossa, from dorsal surface of intertemporal region to temporal angle

Maximum transverse width, from apex of right zygomatic process to braincase wall

Projection of premaxillae beyond maxillae, measured from tip of rostrum to line across anteriormost tips of maxillae in dorsal view

Distance from posteriormost end of median suture between nasals to anteriormost apex of supraoccipital

Length of right orbit, from anterior apex of orbit to ventral apex of postorbital process

Median length of palatines

Maximum transversc width across palatines

Maximum length of left pterygoid

Distance from tip of hamulus of left pterygoid to posteriormost portion of occipital condyle

Maximum width of choanae

Distance from most anterior portion of wall of left choana to most posterior portion of occipital condyle

Distance from hindmost portion of vomer to hindmost portion of occipital condyle

Width across paroccipital processes

(width from right process to midline)

Distance from most anterior portion of right pterygoid sinus fossa to most posterior portion of occipital condyles

Length of upper right tooth-row, from hindmost margin of most posterior alveolus to tip of rostrum

Distance from upper right caninc to tip of rostrum

Distance from position of postcrior tooth to antorbital notch

$449+$

$235 ; 241$

142

112

75

est. 61

$51+($ est. 57)

$\sim 198$

$\sim 203$

340

361

173

183

207

41

31

est. 238

119

89

71

63

80

125

36

19

$23+$

46

$\sim 18$

$\sim 81$

86

$\sim 39$

36

82

99

107

125

88

64

55

$-24$

139

51

72

91

$67+$

$78+$

est. 48

105

49

est. 216

108

$\sim 143$

206

est. 61

59 
TABLE 2.-Measurements of periotic. Not all the standard measurements suggested by Kasuya (1973) for odontocete periotics could be made. Measurements for the right periotic are to the nearest $0.5 \mathrm{~mm}$.

\begin{tabular}{l|r}
\hline Maximum anteroposterior length of exposed portion of periotic, from anterior apex of anterior process & 37.0 \\
to level of posterior of pars cochlearis & \\
Maximum anteroposterior length of pars cochlearis & 23.0 \\
Maximum transverse width of pars cochlearis, from internal edge to fenestra ovalis & -9.5 \\
Maximum dorsoventral depth of anterior process & $\sim 16.5$ \\
Length of anterior process, from anterior apex of anterior process to level of anterior of pars cochlearis & 14.0 \\
Maximum transverse width of periotic, internal face of pars cochlearis to apex of lateral tuberosity & 21.0 \\
Maximum width of anterior process at base & 13.0 \\
\hline
\end{tabular}

AGE AND CORRELATION.- Upper Zemorrian Stage, late Oligocene. The Alsea Formation at the locality of USNM 256517 is faulted against the underlying upper Eocene Nestucca Formation, so that stratigraphic position of the specimen relative to the base of the Alsea Formation cannot be determined. Ellen J. Moore (USGS, pers comm., 1981) stated that foraminifera collected about $200 \mathrm{~m}$ south of the odontocete locality indicate an upper Zemorrian or late Oligocene age, and that molluscs collected about $300 \mathrm{~m}$ northwest of the odontocete locality indicate "Blakeley" Stage or late Oligocene. Domning et al. (1986) gave more details of the stratigraphy of vertebrate-bearing strata of this part of Oregon. Absolute ages for international units have been refined since 1986, so that the age for the Alsea Formation is presumably in the range of 30-23 Ma.

DESCRIPTION.-General Features of Skull (Figures 2-17; measurements in Tables 1-3): The skull is telescoped, with a plate-like supraorbital process of maxilla present dorsal to the supraorbital process of the frontal, the supraoccipital is thrust forward, and the short parietal is present in a distinct intertemporal constriction. Teeth are heterodont. Apart from the apex of the rostrum, there is little obvious postmortem distortion, and the asymmetry at the base of the rostrum appears to be real.

Cranium: The cranial portion of the skull, behind the antorbital notches, is long relative to the condylobasal length (Figure 2A). In lateral view (Figure 8A,C), the dorsal profile of the cranium is roughly straight, without an obvious raised vertex, and the dorsal and ventral profiles are more or less parallel. Viewed thus, the orbit clearly lies dorsal to the level of the lateral border of the rostral part of the maxilla (base of rostrum), the remnant of infraorbital process of maxilla, and the jugal. Presumably, the nasofacial (maxillo-naso-labialis) muscle originated from the maxilla both on the rostrum and dorsal to the orbit. In dorsal view (Figures $2 \mathrm{~A}, 3$ ), the posterior limit of the origin of nasofacial muscles is marked by the ridge that runs from the apex of each postorbital process smoothly medially and dorsally onto the fronto-parietal suture. Seen thus, the profile of the posterior of the face is anteriorly concave.

In dorsal view (Figures 2A, 3), the maxilla and frontal cover little of the temporal fossa, and the intertemporal constriction, formed by parietal and interparietal, is prominent. A long snout of nasal and frontal roofs the nares and olfactory cavity. A prominent orbitotemporal crest (temporal crest of Fordyce, 1994) delimits the dorsal edge of the fossa. Within the fossa, the lateral wall of the braincase is not particularly inflated except toward the base of the zygomatic process of the squamosal.

In lateral view (Figures $8 \mathrm{~A}, \mathrm{C}, 9$ ), the external nares open more than $20 \mathrm{~mm}$ anterior to the level of the antorbital notch. The internal nares (choanae) open level with the apex of the supraoccipital and the middle of the pterygoid sinus fossa, indicating inclined rather than subvertical narial passages. Anteroposterior separation between internal and external nares also is emphasized by the long ventral exposure of the palatines (Figures 2D, 4).

Rostrum: The triangular rostrum is short, about as long as the cranium, and is broad at the base. The apex is blunt, with its apical $10 \mathrm{~mm}$ formed only by premaxillae (Figures $2 \mathrm{~A}, 3,5 \mathrm{C}$ ) that are dorsoventrally thin and, individually, spatulate. Farther posteriorly, the rostral edges are straight until $20-35 \mathrm{~mm}$ anterior to the dorsoventrally deep antorbital notches. Here, at point of maximum width, the rostrum is asymmetrical, with the incomplete right side flared out laterally more than the complete left side. The antorbital notches, which appear wide and shallow in dorsal view, are asymmetrical, with the left notch more open than the right. In lateral view (Figures 8A,C, 9), the anterior half of the rostrum is thin, but rostral depth increases markedly toward the cranium as the premaxillae and maxillae become more elevated, and the rostrum is steep sided behind the external nares.

As viewed laterally (Figure $8 \mathrm{~A}$ ), the ventral profile of the rostrum is concave, with its tip depressed relative to the basicranial axis. A postmortem break distorts the tip dorsally, but the mandible (Figure 8B,D) indicates the original profile of the rostrum. In transverse profile, the maxillary part of the palate is flat to slightly convex (Figure $8 \mathrm{E}$ ), but for a slightly concave region posterolaterally.

TABLE 3.-Measurements of mandible. Standard measurements of the right mandible, after Perrin (1975) are to the nearest $1 \mathrm{~mm}$.

\begin{tabular}{l|c}
\hline Tooth-row length, from posterior margin of most posterior alveolus to tip of mandible & 221 \\
Maximum length of mandible & $334+($ est. 380) \\
Maximum height of mandible, perpendicular to maximum length & $90+$ \\
\hline
\end{tabular}




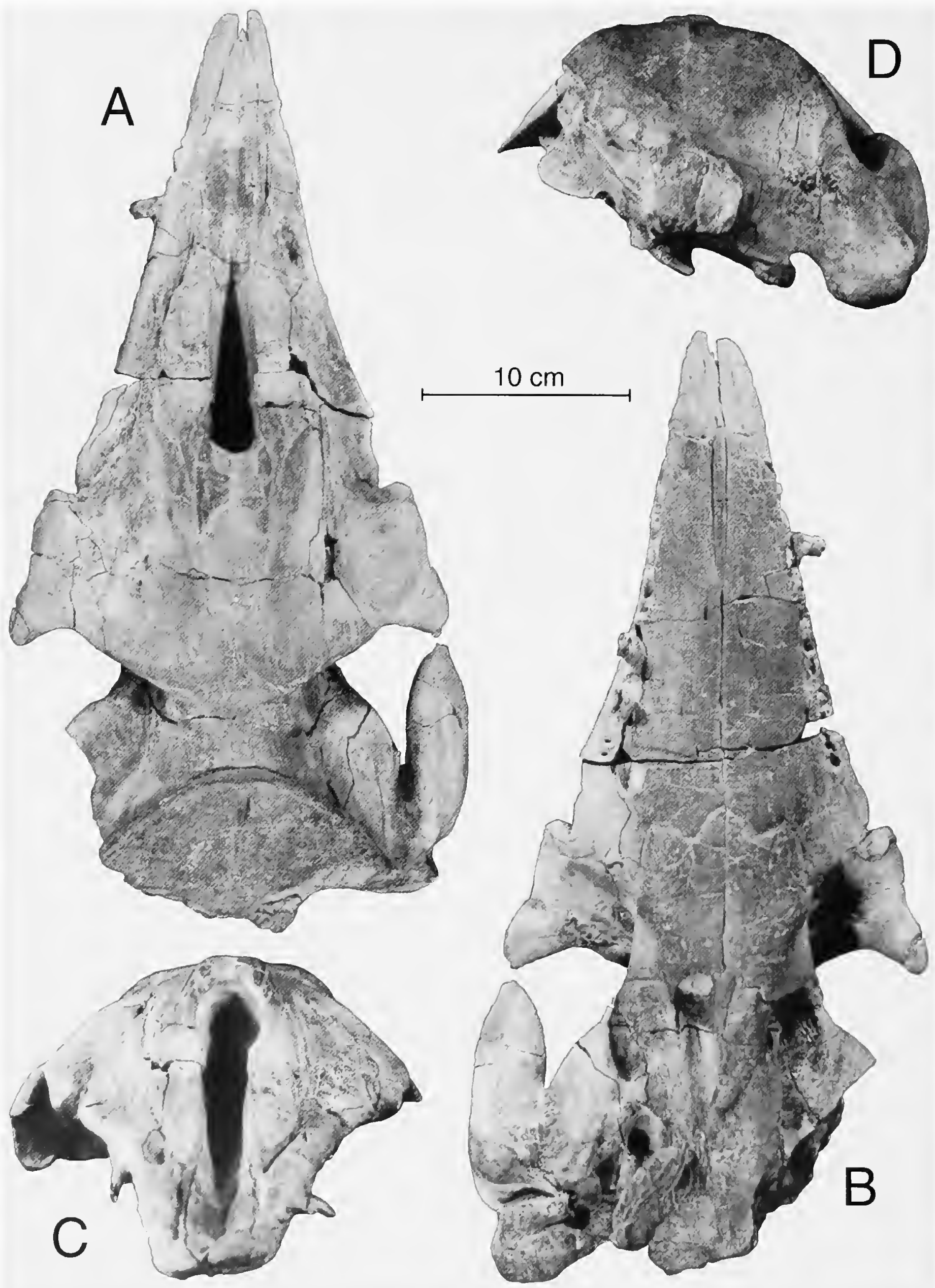

FIGURE 2.-Simocetus rayi, USNM 256517, holotype skull: A, dorsal; B, ventral; C, anterior; D, posterior. (Scale bar $=10 \mathrm{~cm}$.)

A prominent mesorostral groove dominates the rostrum anterior to the nasals. The groove is wide and shallow anteriorly, but it deepens and narrows behind the premaxillary foramina to become about as wide as deep at the mid-length of the rostrum.
Farther posteriorly, the groove is narrow, deep, parallel-sided, and $U$-shaped, with a minimum width at an indistinct prenarial constriction about $35 \mathrm{~mm}$ in front of the nasals (Figures $2 \mathrm{~A}, 3$ ). (The prenarial constriction was inadvertently termed internarial 


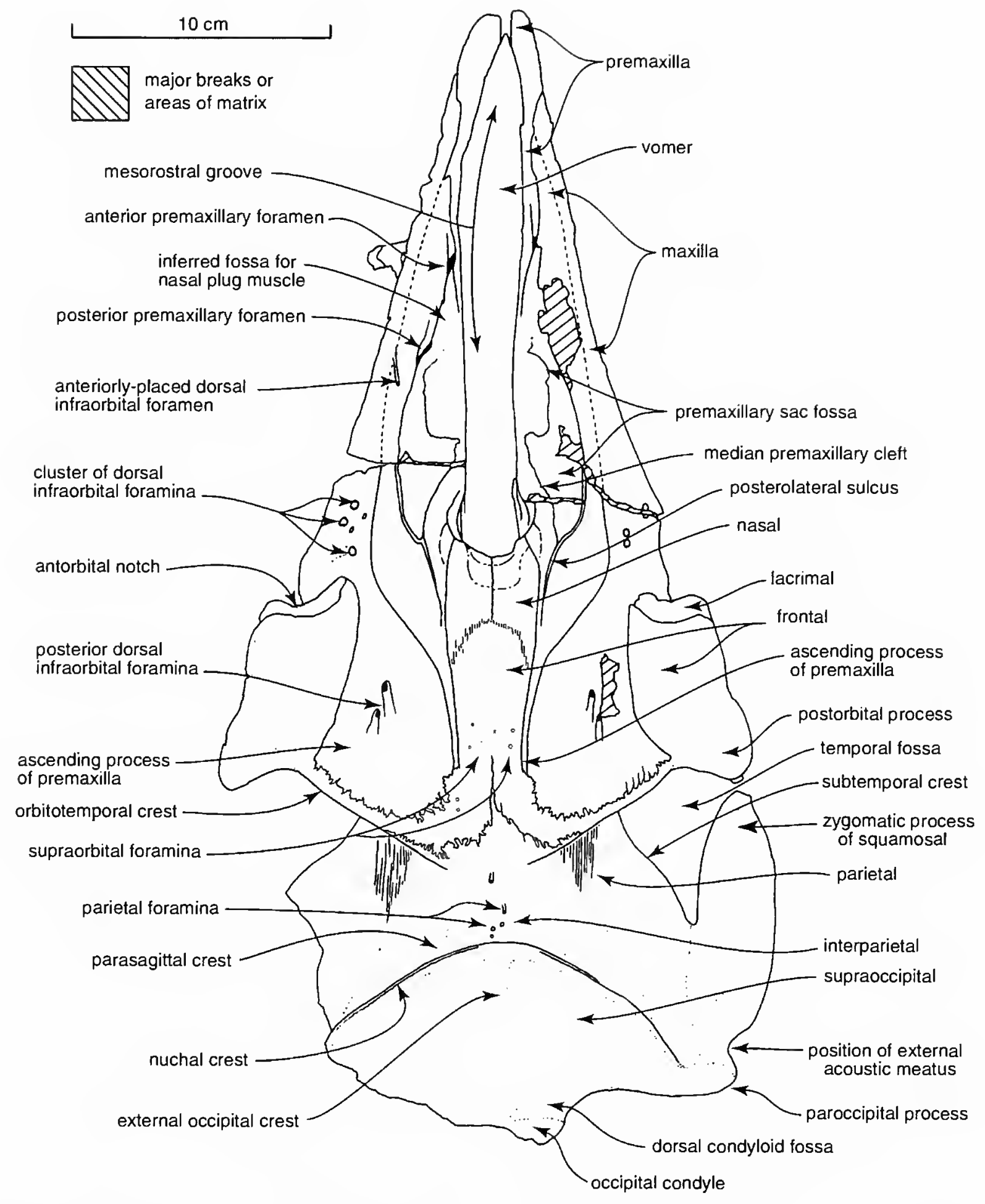

FIGURE 3.-Simocetus rayi. USNM 256517, dorsal view of holotype skull, based upon Figure 2A, showing main features. (Scale bar $=10 \mathrm{~cm}$.)

constriction by Fordyce (1994:149.)

Premaxilla: Three regions of the premaxilla command attention: the rostral apex, the premaxillary sac fossa, and the portion at and posterior to the nares. Most of the premaxilla lies on the rostrum, anterior to the antorbital notch. Anteriorly, the premaxillae lie close together for their apical $10 \mathrm{~mm}$, separated by only a few millimeters at the open incisive suture (Figures $2 \mathrm{~A}, \mathrm{~B}, 3,4,5 \mathrm{C})$. Each premaxilla forms the thin spatulate anterior about $27 \mathrm{~mm}$ of the dorsal surface and margin of the rostrum. Apically, the well-preserved ventral (or palatal) surface of the premaxilla lacks alveoli and is interpreted as edentulous (Figure 5c). Ventrally, about $5 \mathrm{~mm}$ from the medial edge, each premaxilla carries a long, shallow, narrow groove that originates posteriorly at a feature presumed to be the palatine fissure. This fissure lies at the junction of premaxilla, maxilla, and vomer, about $58 \mathrm{~mm}$ posterior to the rostral apex. (Formerly, it was suggested that the palatine fissure is absent in Cetacea; Kellogg, 1936.) Anteriorly, the groove ends at a shallow depression presumed to be for the vomeronasal (Jacobson's) organ, about $8 \mathrm{~mm}$ behind the apex of the rostrum (Figure 5C).

Dorsally, the premaxillary sac fossa (premaxillary plate or spiracular plate of some authors), associated sulci, and foramina dominate the premaxilla. The premaxillary sac fossa is the long, elevated, and rather tabular dorsal surface of the premaxilla bounded by the posterolateral sulcus and the mesorostral groove (Figures $2 \mathrm{C}, 6$ ). In living odontocetes, this surface carries a lobe of the nasal passages, the premaxillary sac (Mead, 1975). The fossa is narrow and pointed anteriorly. Its depressed lateral edge between $115 \mathrm{~mm}$ and $140 \mathrm{~mm}$ from the rostral apex perhaps marks the origin for the nasal plug muscle, al- 


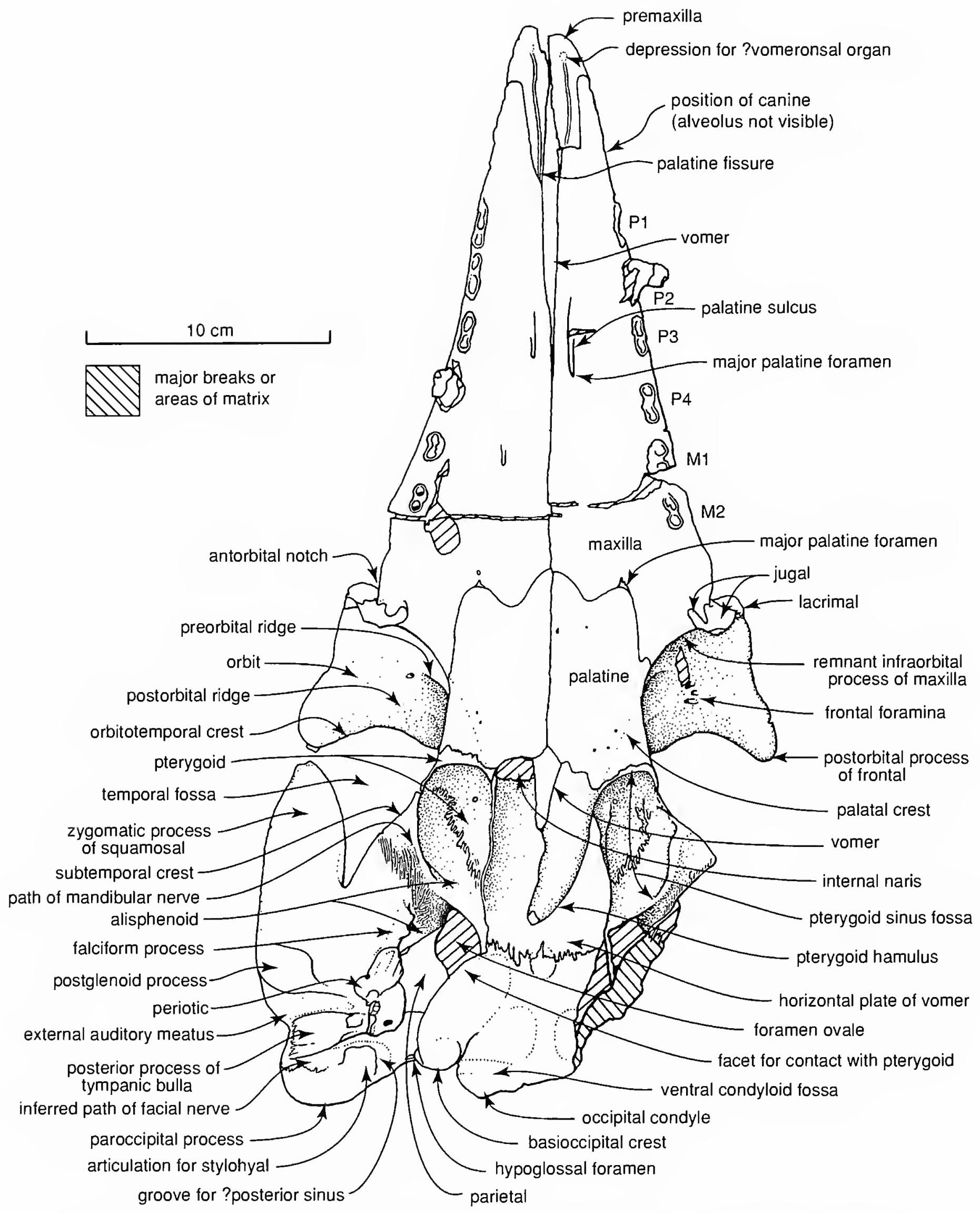

FIGURE 4.-Simocetus rayi, USNM 256517, ventral view of holotype skull, based upon Figure 2B, showing main features. (Scale bar $=10 \mathrm{~cm}$.)

though the bone here is smooth rather than rough. Farther posteriorly, the premaxillary sac fossa widens as its tabular dorsal surface rises above the level of the rest of the rostrum. The fossa reaches a width of about $25 \mathrm{~mm}$ level with the indistinct prenarial constriction, then narrows abruptly as the premaxilla rises toward the nasal.

Immediately lateral to the anterior part of the premaxillary sac fossa are two large premaxillary foramina, inferred to transmit branches of the internal maxillary artery and associated nerves. The anterior premaxillary foramen opens within the premaxilla (seen on the right, obscured on the left) into an anteromedial sulcus (sensu Barnes, 1978) on the dorsal surface, about $95 \mathrm{~mm}$ behind the apex of the rostrum and just lateral to the mesorostral groove. The posterior premaxillary foramen 


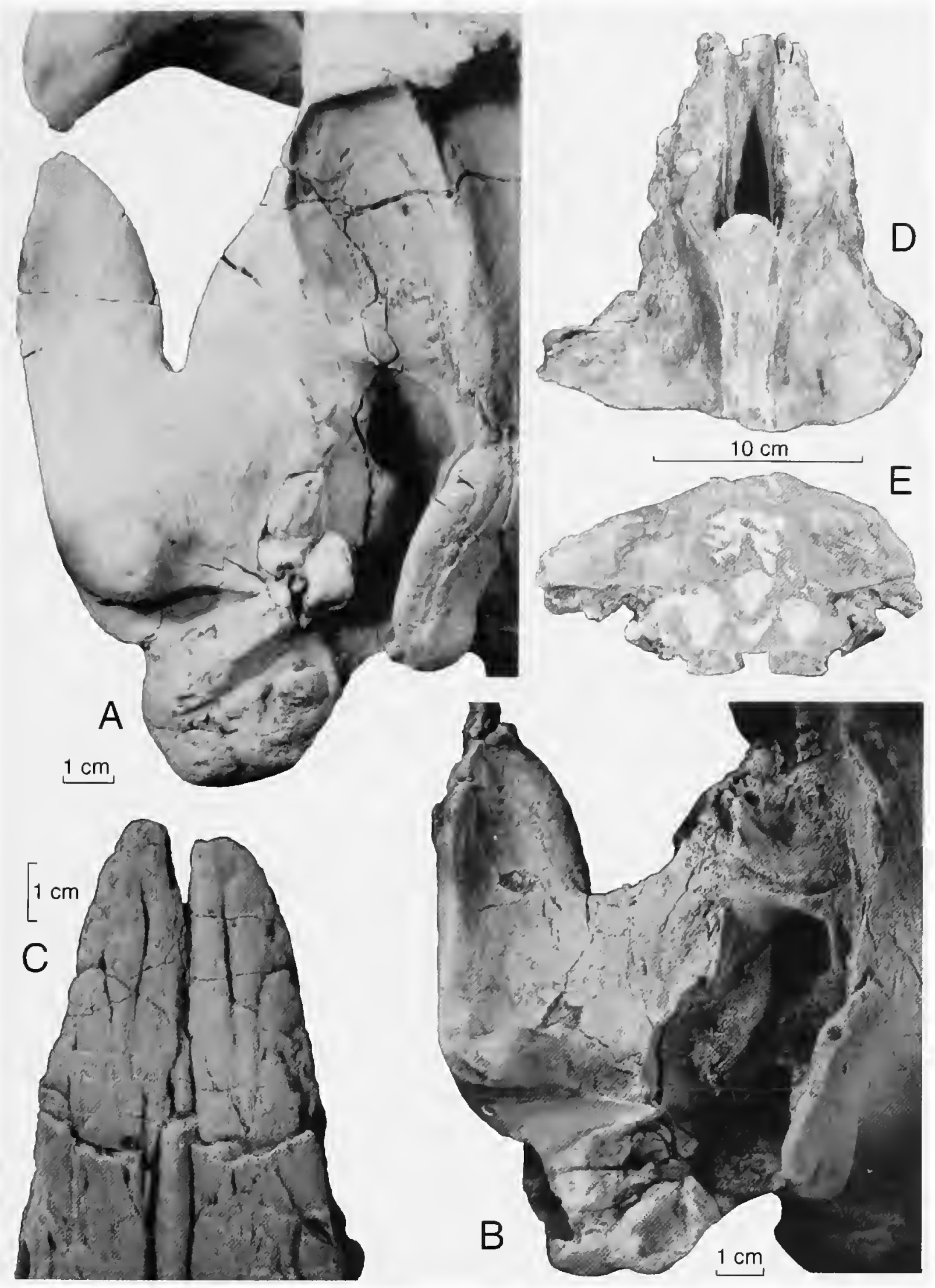

FIGURE 5.-Simocetus rayi, USNM 256517, and unnamed odontocetes USNM 205491 (Oligocene, Oregon) and USNM 299482 (Oligocene, Washington): A-C, whitened with ammonium chloride; A, holotype skull of $S$ rayi, USNM 256517, right basicranium; B, skull of unnamed odontocete USNM 205491 (Oligocene, Oregon), for comparison with Simocetus rayi; C, holotype skull of S. rayi, USNM 256517, detail of ventral surface of rostrum; D,E, incomplete skull of unnamed odontocete USNM 299482 (Oligocene, Oregon); D, dorsal view, showing elongate nasals over snout; E, posterior view of eroded section through olfactory cavity showing turbinals within olfactory cavity. (Scale bar $=10 \mathrm{~cm}$.)

(best preserved on the left) opens lateral and slightly ventral to the apex of the premaxillary sac fossa, $135-150 \mathrm{~mm}$ from the rostral apex (Figures 2A, 3). Posteriorly, the posterolateral sulcus deepens and narrows as it rises dorsomedially toward the nasals; it can be traced about $25 \mathrm{~mm}$ behind the level of the ex- ternal nares. The posteromedian sulcus is possibly represented by an indistinct, wide, shallow groove that originates laterally near the apex of the fossa and trends posteromedially toward the elevated internal edge of the premaxilla.

Another fine sulcus, interpreted as the median premaxillary 


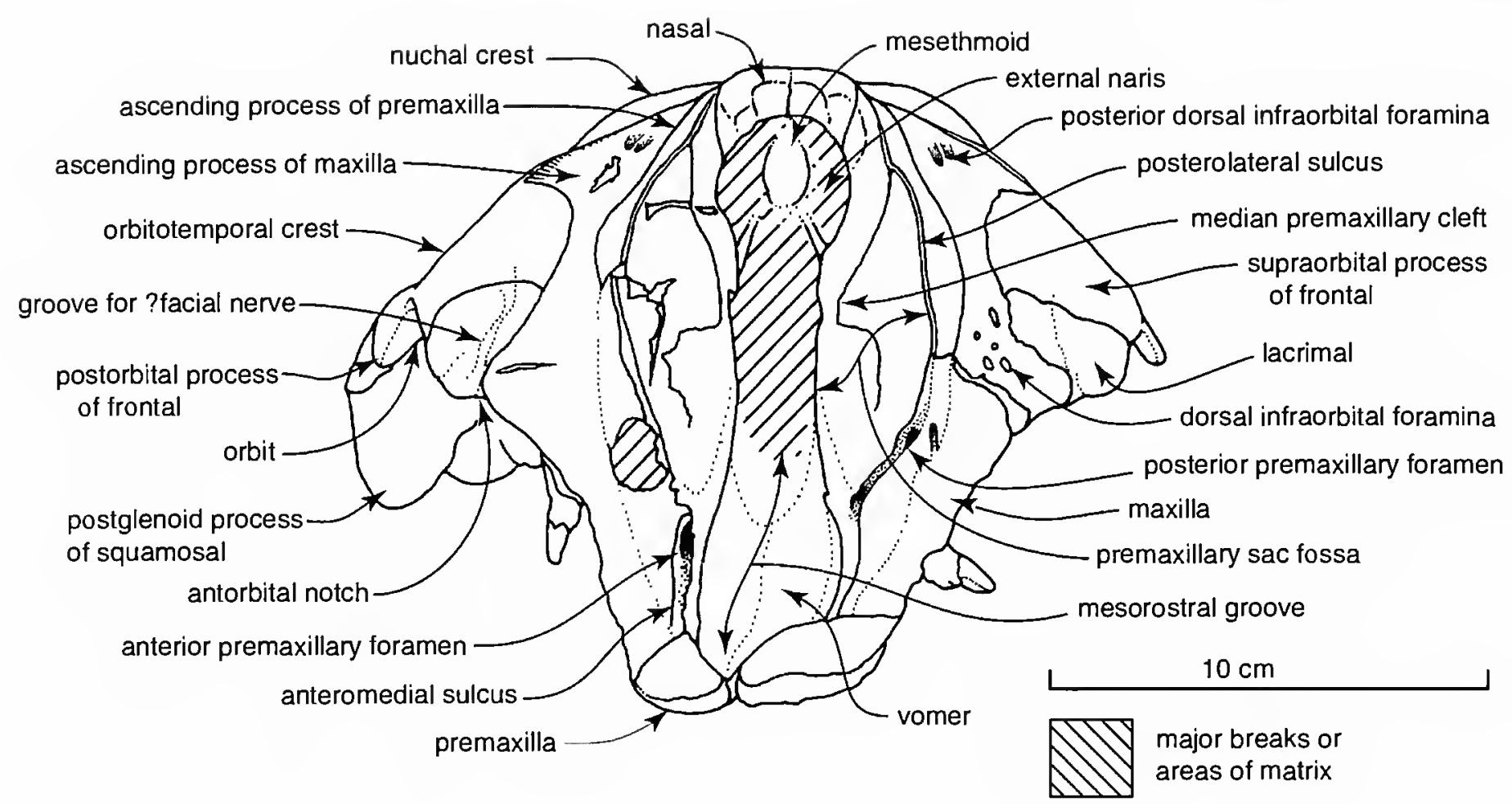

FIGURE 6.-Simocetus rayi, USNM 256517, anterior view of holotype skull, based upon Figure 2C, showing main features. (Scale bar $=10 \mathrm{~cm}$.)

cleft of Fordyce (1994:149), appears as a fissure in the otherwise smooth dorsal surface of the premaxillary sac fossa. In $S$. rayi, the anterior origin of the median premaxillary cleft is obscure, but in USNM 299482 (an undescribed archaic odontocete; Figure 5D), the median premaxillary cleft appears to originate at the posterior premaxillary foramen. It meanders posteriorly then diverges abruptly toward the internal edge of the premaxillary sac fossa at about the mid-length of the fossa; thence it trends farther posteriorly and slightly externally to contact the posterolateral sulcus at about the level of the anterior end of the nasal. Broken sections through the median premaxillary cleft in USNM 299482 indicate that it extends far ventrally within the premaxilla, and the same is inferred for $S$. rayi. The function of this sulcus is uncertain.

Lateral to the premaxillary sac fossa and the posterolateral sulcus are remnants of a thin, elongate flange of premaxilla

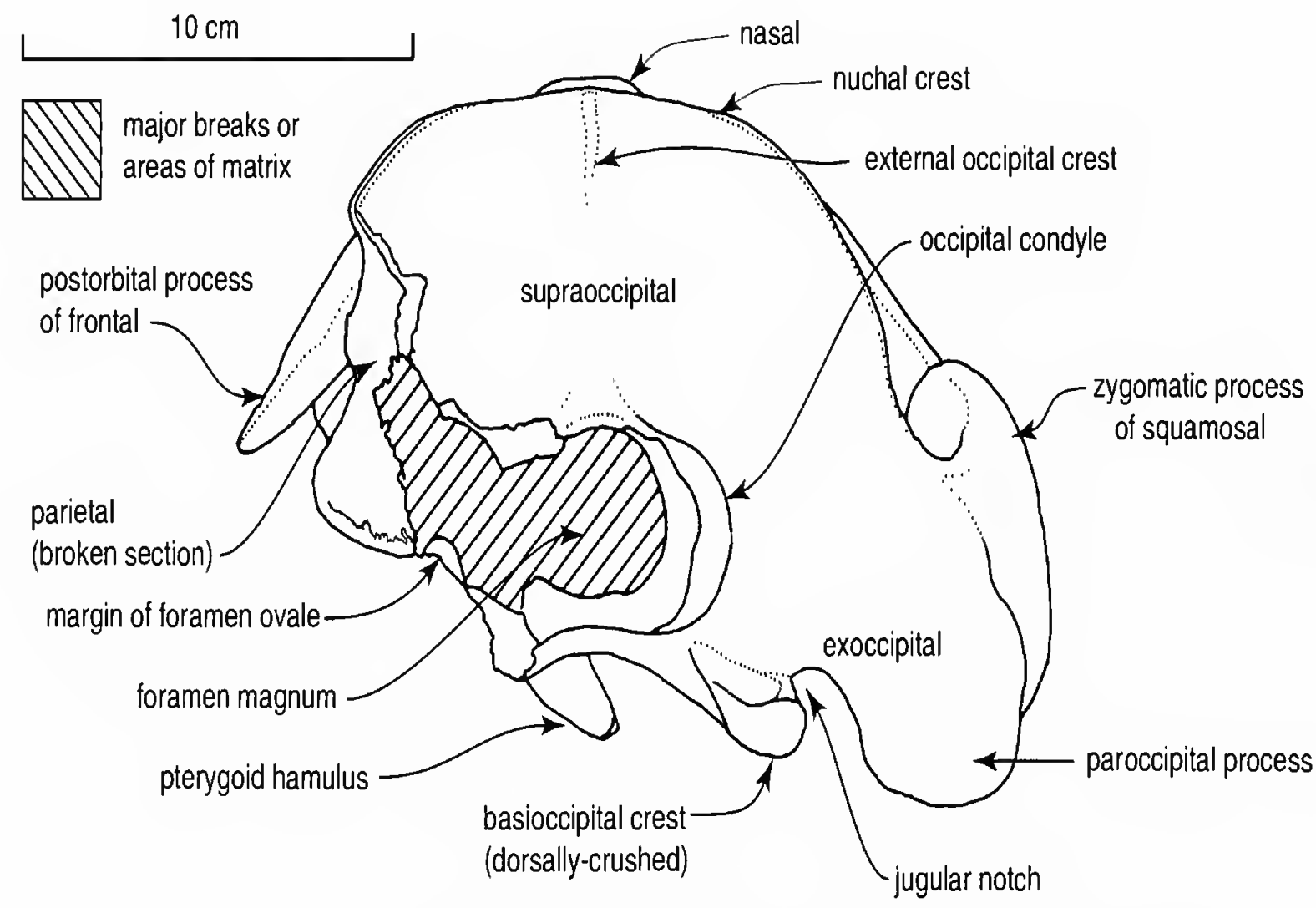

FIGURE 7.-Simocetus rayi. USNM 256517, posterior view of holotype skull, based upon Figure 2D, showing main features. (Scale bar $=10 \mathrm{~cm}$.) 


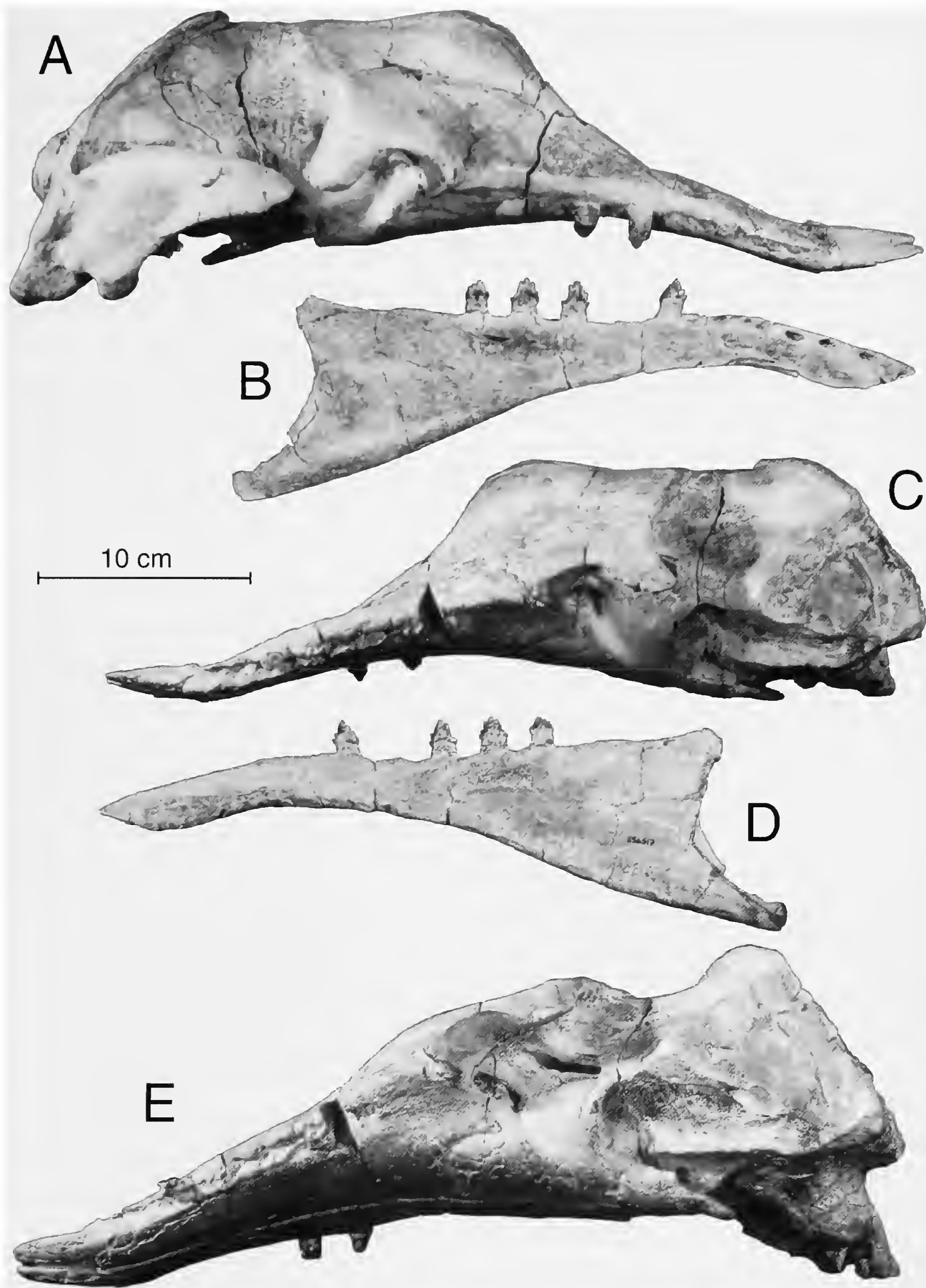

FIGURE 8.-Simocetus rayi, USNM 256517, holotype skull and right mandible: A, skull, right lateral; B, right mandible, lateral (buccal) view; C, skull, left lateral view; D, right mandible, medial (lingual) view; E, skull, oblique ventrolateral view, left side. (Scale bar $=10 \mathrm{~cm}$.)

that, before being eroded, originally overlay the dorsal surface of the maxilla (Figure $2 \mathrm{~A}, \mathrm{C}$ ). Posteriorly, at the level of the nasal, this thin portion of premaxilla becomes the posterolateral plate; the plate is conspicuous in lateral view (e.g., Figure 9). Dorsally, the posterolateral plate passes into the posteromedial process. The left and right posteromedial processes are sym- 


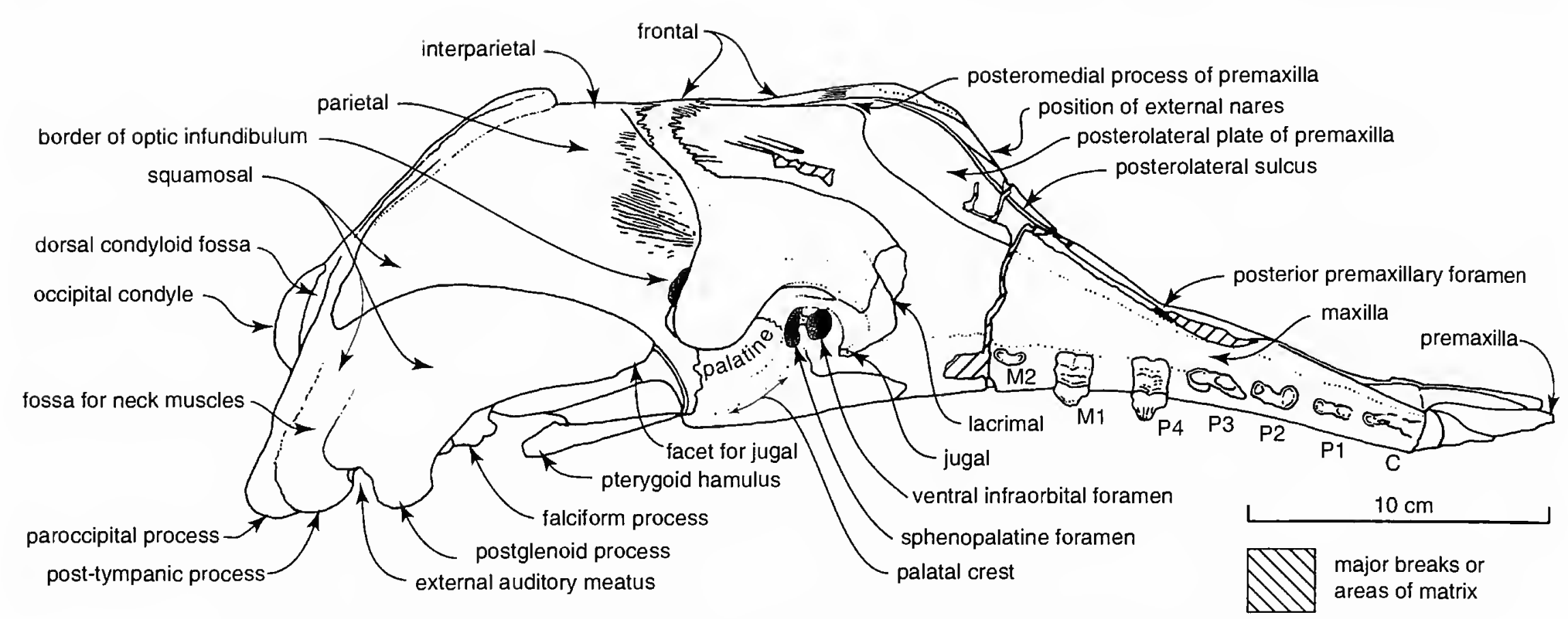

FIGURE 9.-Simocetus rayi, USNM 256517, right lateral view of holotype skull, based upon Figure 8A, showing main features. (Scale bar $=10 \mathrm{~cm}$.)

metrical; each is narrow ( $<2 \mathrm{~mm}$ wide), parallel sided, and long, extending far posteriorly between the maxilla and the nasal-frontal. The right process reaches about $95 \mathrm{~mm}$ behind the nares, well posterior to the naso-frontal suture and the orbit (Figures 2A, 3, 9).

Maxilla: Ventrally, the maxilla forms most of the rostrum, including the massive thick dorsoventrally rounded lateral edge, which extends to within about $25 \mathrm{~mm}$ of the rostral apex. Anterior teeth lie at the edge of the maxilla, but the posterior teeth lie a little medially (Figures $2 \mathrm{~B}, 4$ ). There are alveoli for a canine (matrix-filled with eroded borders, on the rostral margin of the maxilla and not readily seen in figures) and six cheek teeth, identified as P1-4 and M1-2; teeth are detailed below. Anteriorly, the alveoli on the rostral margin are too eroded to be sure of orientations and fine structure, but posterior alveoli are separated by diastemata (interdental spaces) long enough to accommodate crowns of lower cheek teeth. An indistinct embrasure pit lies between and slightly medial to right $\mathrm{P} 4$ and $\mathrm{M} 1$ (Figure 2B). M2 lies about $35 \mathrm{~mm}$ anterior to the antorbital notch (Figures 2B, 4). There are no obvious alveolar juga, and the alveolar process is not distinct from the rest of the maxilla.

Most of the rostral (oral, ventral) surface (palatine process) of the maxilla is gently convex in transverse profile, but, posterolaterally near the antorbital notch, the surface is concave

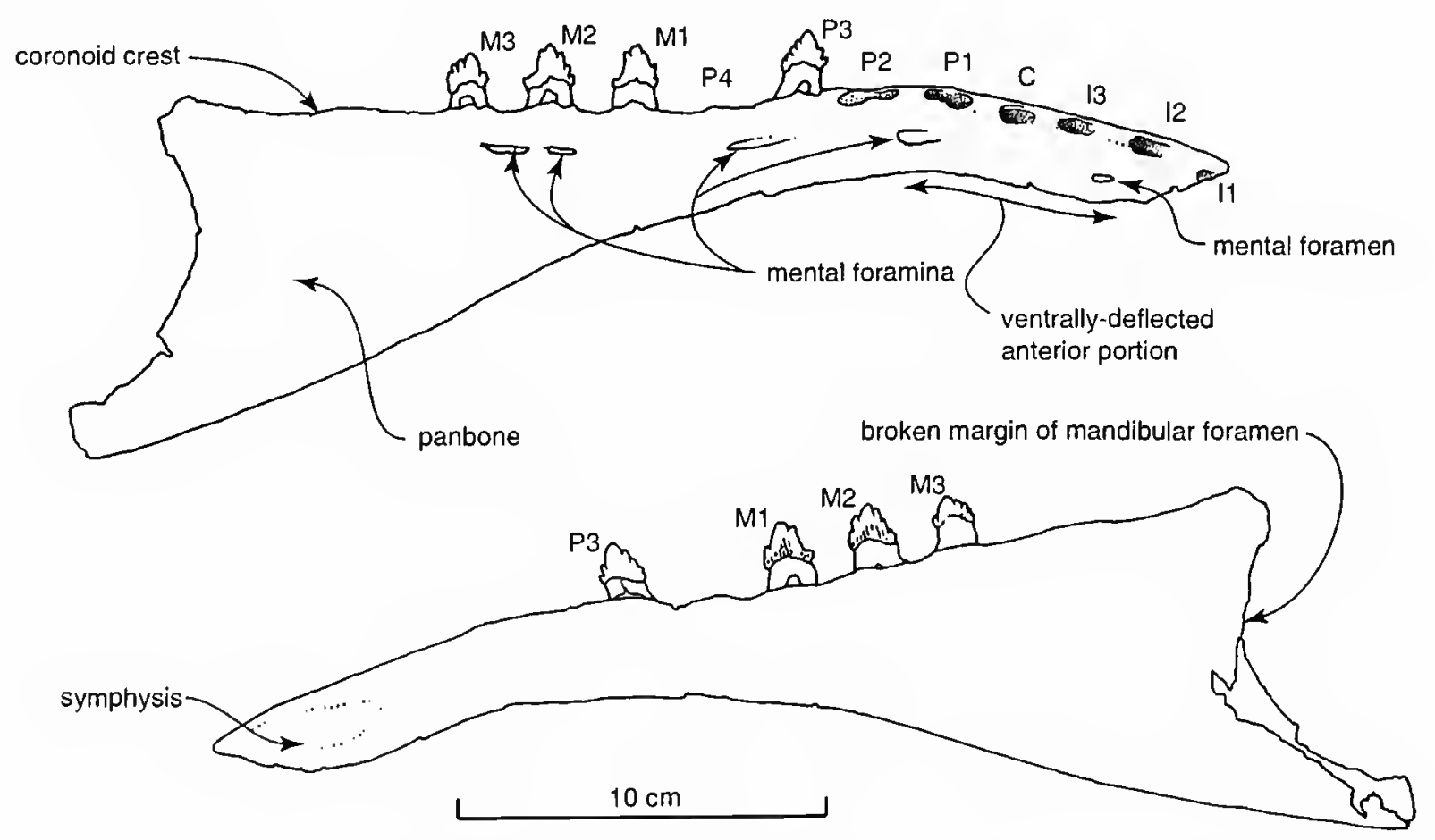

FIGURE 10.-Simocetus ravi, USNM 256517, right mandible, showing main features: A, lateral (buccal), based upon Figure 8A; B, medial (lingual), based upon Figure 8C. (Scale bar $=10 \mathrm{~cm}$.) 


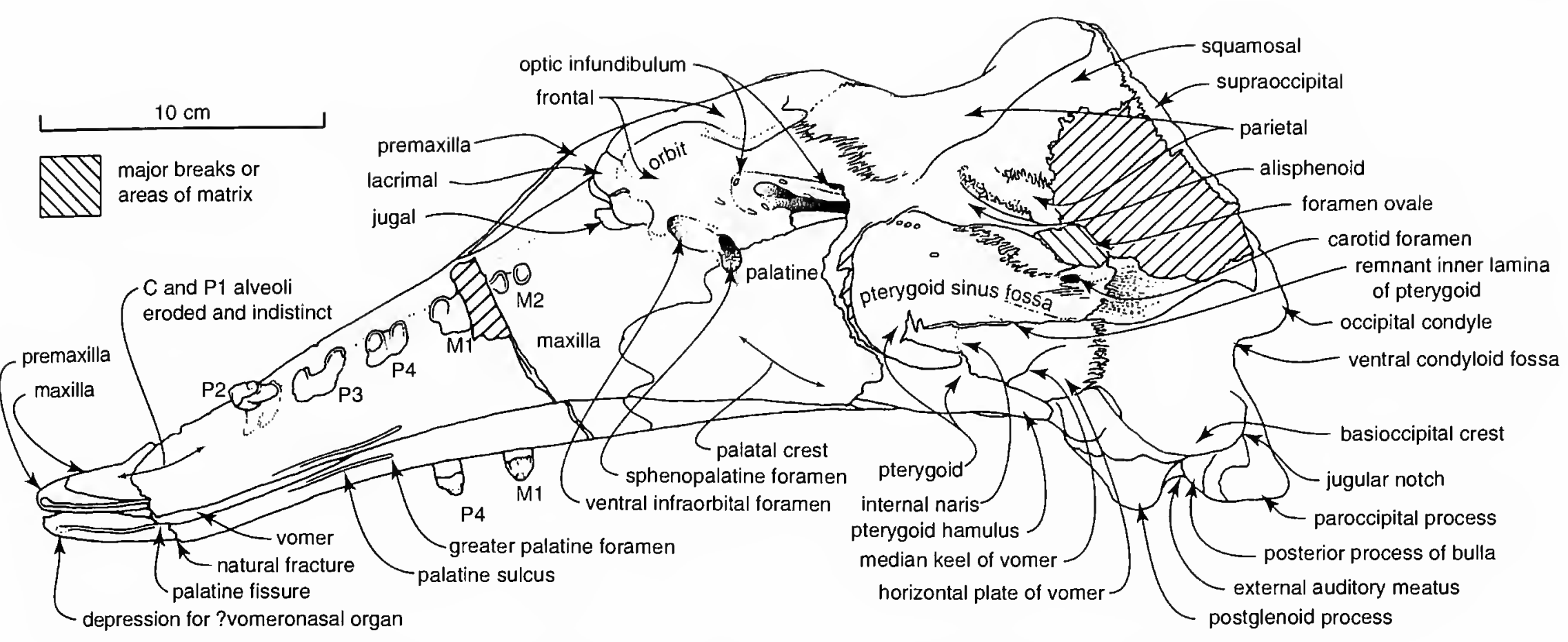

FIGURE 11.-Simocetus rayi, USNM 256517, oblique ventrolateral view of holotype skull, based upon Figure

$8 \mathrm{E}$, showing main features. (Scale bar $=10 \mathrm{~cm}$.)

(Figures 2B, 8E). Nearby, the conspicuous and simple maxillary-palatine suture (Figure $2 \mathrm{~B}$ ) traces an S-shaped profile as it runs laterally from the midline. A short and narrow major (or greater) palatine sulcus at the maxillary-palatine suture (Figure 4) indicates a major palatine foramen. Farther anteriorly, another aperture of the major palatine foramen opens into a palatine sulcus medially, about level with P3 and P4. Smaller foramina that open ventrally on the maxilla probably represent other multiple openings for the palatine foramina.

Posteriorly, the maxilla has only a small orbital surface. Here, a prominent transverse ridge of the maxilla in the orbital wall, immediately below the ventral infraorbital foramen (orbital opening of infraorbital canal, or maxillary foramen of authors) is a vestigial infraorbital process. Because the ridge is not prolonged posteriorly, there is neither a maxillary tuberosity nor a pterygopalatine fossa. Medially, a stout projection of the maxilla partly separates the ventral infraorbital foramen from the sphenopalatine foramen (Figures 11, 12).

The ventral infraorbital and sphenopalatine foramina open within a common infundibulum anterior to the preorbital ridge (Figures 8E, 11-13) and topographically within the orbit. Within the infundibulum, the larger infraorbital portion lies

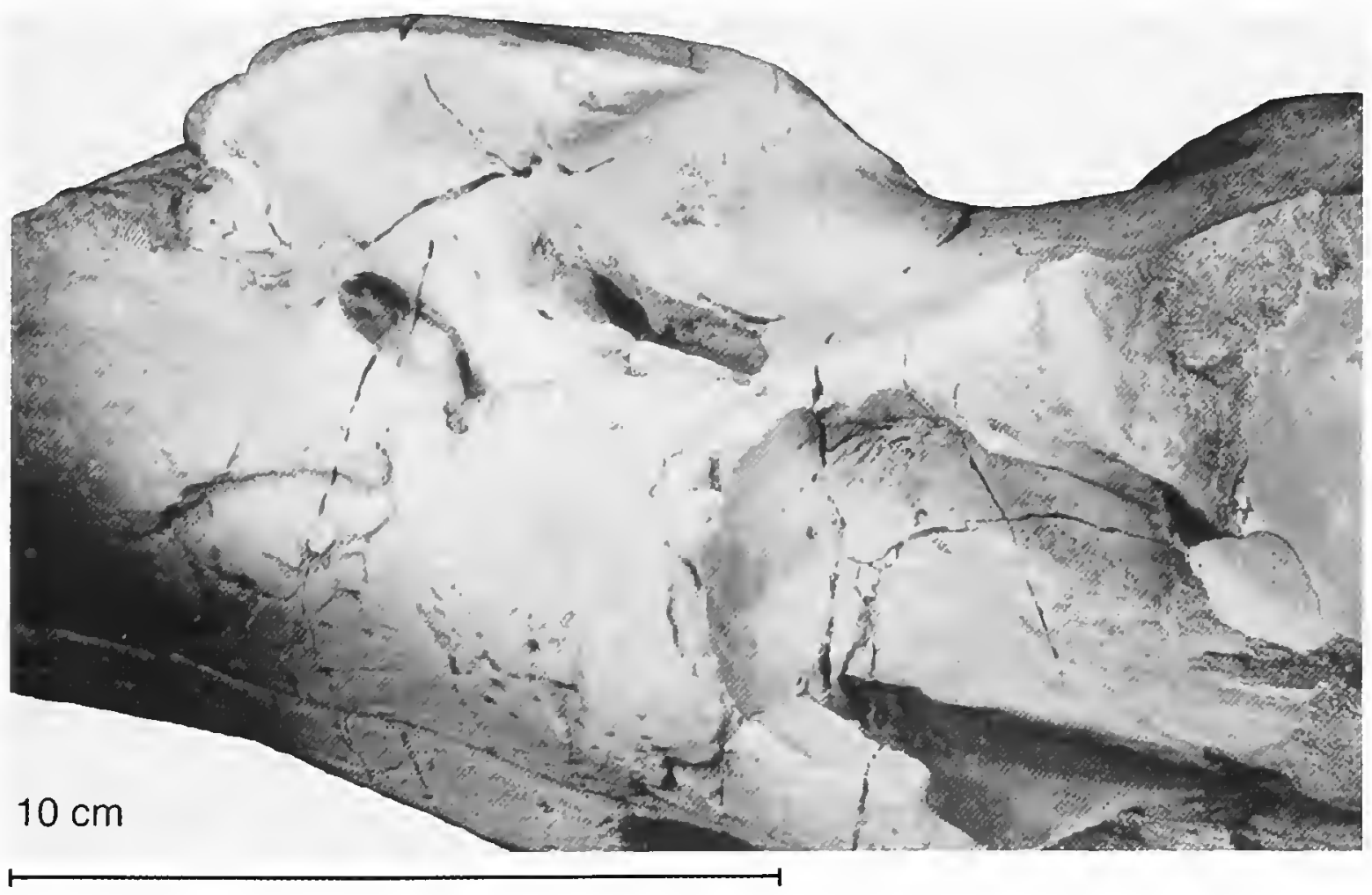

FIGURE 12.-Simocetus rayi, USNM 256517, oblique ventrolateral view of left orbit of holotype skull. Skull whitened with ammonium chloride. (Scale bar $=10 \mathrm{~cm}$.) 


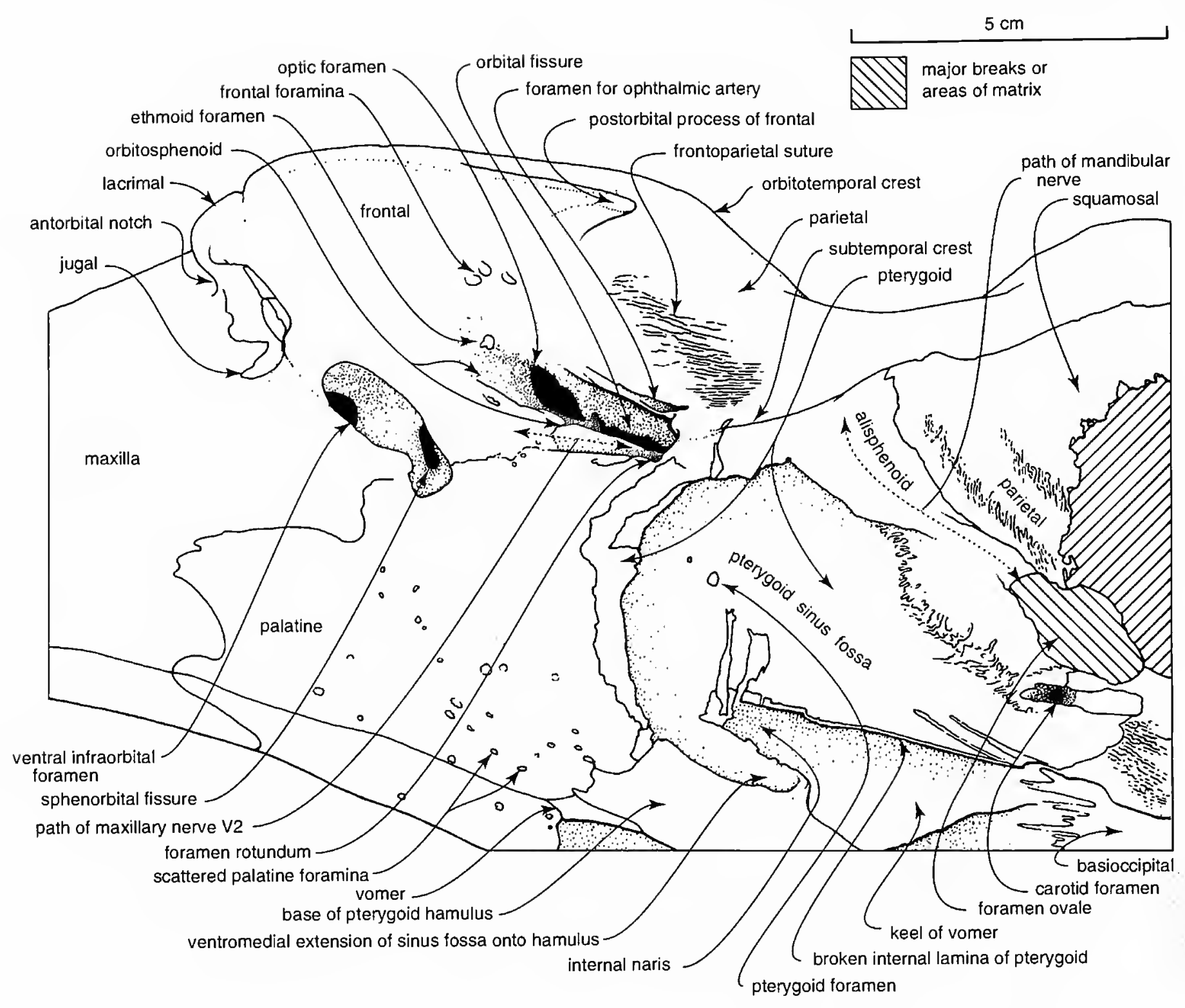

FIGURE 13.-Simocetus rayi, USNM 256517, oblique ventrolateral view of left orbit of holotype skull, based upon Figure 12, showing main features. (Scale bar $=5 \mathrm{~cm}$.)

medially in the anterior wall of the orbit, whereas the smaller sphenopalatine portion lies posteroventrally on the lateral wall of the skull below the orbit. The infundibulum is bounded ventrally by the maxilla, dorsally and anterolaterally by the frontal, and posteriorly and posteroventrally by the palatine; it is uncertain if the lacrimal contributes to the lateral border. Anteriorly, the large ventral infraorbital foramen gives rise to the infraorbital canal from which the dorsal infraorbital foramina (maxillary foramina of authors) and premaxillary foramen open on the dorsal surface of the skull. The small sphenopalatine foramen lies posteriorly in the roof of the infundibulum, where it is directed dorsomedially.

As seen ventrally, the maxilla at the antorbital notch is invaded by two small lobes of the jugal (zygomatic bone), a shorter lateral lobe and a longer medial lobe. That part of the maxilla bounded by the two lobes of the jugal may represent the zygomatic process of the maxilla, although the zygomatic process in other mammals usually lies laterally on the skull wall. There is no clear evidence in the maxilla here of an ante- rior lacrimal crest, lacrimal notch, lacrimal sulcus, or lacrimal canal.

Dorsally on the rostrum, the maxilla is rounded in transverse profile until about the level of the posterior premaxillary foramen, behind which its surface becomes slightly concave. Dorsal infraorbital foramina open on the maxilla; on the left, the anteriormost foramen opens near the posterior premaxillary foramen ( $150 \mathrm{~mm}$ behind the rostral apex), and a prominent cluster of foramina lies farther posteriorly near the antorbital notch. Because of poor surface detail on the right side, it is not clear whether the number and size of foramina is symmetrical from left to right, although the two maxillae clearly are asymmetrical in profile. These large, multiple, dorsal infraorbital foramina are taken to indicate that parts of the nasofacial muscles originated on the rostrum anterior to the antorbital notch.

The lacrimal bisects the maxilla at the antorbital notch, separating the rostral from the more-posteromedial facial parts of the maxilla (Figures 2C,6). At the base of the supraorbital process, the maxilla does not expand laterally over the lacrimal; thus, it lacks an antorbital process. 
Posterior to the lacrimal, the maxilla forms a long, roughly parallel-sided supraorbital process (ascending process, frontal process) that extends across the frontal and rises medially toward the vertex (Figures 2A, 3). Here, the maxillary surface is slightly concave from side to side, forming an indistinct facial fossa for nasofrontal muscles. Seen dorsally, the supraorbital process has a lateral margin that is gently concave rather than convex. Further, the supraorbital process is not expanded outward over the frontal. Because the left and right supraorbital processes are symmetrical, and there is no evidence of erosion or abnormal bone surface on maxilla and frontal, the lack of lateral expansion is taken as an original condition. Two posterior dorsal infraorbital foramina open posterodorsally in the supraorbital process of each maxilla; they lie about level with the mid-orbit as viewed laterally, about $15 \mathrm{~mm}$ below the level of the vertex, and about $40 \mathrm{~mm}$ lateral to the cranial midline. Each foramen opens posteriorly into a shallow widening groove; the anterior foramen is the larger. These foramina are taken to indicate that the maxilla here formed an origin for a significant volume of facial muscles. Nearby, the posterolateral corner of the supraorbital process is sharp, whereas the posteromedial corner is rounded. Posteriorly, the supraorbital process does not reach the level of the orbitotemporal crest of the frontal. By analogy with an undescribed archaic odontocete, USNM 299482 (Figure 5D), the straight and slightly raised medial border of the supraorbital process of maxilla probably overlies part of the posteromedial process of the premaxilla. Preservation is too poor to tell if the maxilla has a nasal crest within the bony naris.

Vomer: The vomer lines the prominent mesorostral groove where, in dorsal view, it reaches to within about $10 \mathrm{~mm}$ of the rostral apex (Figures 2A, 3). The vomer, and thus the mesorostral groove, is widest (about $28 \mathrm{~mm}$ ) about $70 \mathrm{~mm}$ behind the rostral apex. Ventrally, the vomer is exposed as a short thin sliver (up to $7 \mathrm{~mm}$ wide) anteriorly on the palate, wedged between the premaxillae anteriorly and the maxillae posteriorly. A cross section of rostrum seen during preparation indicates that each side of the vomer widens to more than $25 \mathrm{~mm}$ within the rostrum. Farther posteriorly, a diamond-shaped medial exposure of vomer lies between the palatines and pterygoids (Figures 2B, 4); compared with most odontocetes, this exposure of vomer is quite large. Posterodorsally, this diamondshaped exposure rises into a long median keel of vomer, which separates the choanae back to about the level of the foramen ovale (Figures 8E, 11-13). The slightly outward-flared horizontal plate of vomer, which roofs the choanae, extends back about $20 \mathrm{~mm}$ farther, about level with the anterior of the basioccipital crests. Presumably, the horizontal plate of vomer originally contacted the now-missing internal lamina of the pterygoid here.

Palatine: The broadly exposed palatine forms much of the posterior flat ventral surface (horizontal lamina) of the palate, and it is inferred to contribute to the hard palate as seen in other mammals but in contrast to living odontocetes. The prominent median interpalatine suture is about $71 \mathrm{~mm}$ long, and each pa- latine is more than $84 \mathrm{~mm}$ long, so that the pterygoid is separated widely from the maxilla. Anteriorly, the palatine extends well forward of the antorbital notch, whereas posteriorly the palatine reaches behind the level of the postorbital process of the frontal. Ventral and lateral faces of the palatine are separated by a gently rounded palatal crest that arises at the infundibulum for the infraorbital and sphenopalatine foramina and descends posteroventrally toward the pterygoid. There is no obvious pterygopalatine fossa. Above this palatal crest, the palatine carries a smoothly rounded surface posterior to the infraorbital infundibulum and ventral to the optic infundibulum; this surface is presumed to be the origin of the internal pterygoid muscle. Dorsally, there is no sphenopalatine notch, so that the orbital process and spheno-ethmoid lamina are continuous; sutures with frontal and orbitosphenoid are prominent. Posterodorsally, a few millimeters of the palatine contacts the parietal. Posteriorly, the suture with the pterygoid is conspicuous, without a lateral lamina of palatine, and the pterygoid sinus does not invade the palatine. Ventral sutures with the pterygoid and vomer are deep.

Grooves at the anterolateral corner of the maxillo-palatine suture form the major palatine sulcus and associated (matrixfilled) major palatine foramen, and small foramina scattered on the horizontal lamina represent minor palatine foramina. The palatine carries other scattered small foramina, some localized on the palatal crest.

At its anterodorsal limit, and within the orbit, the palatine contributes to a large common infundibulum for the more posteriorly placed sphenopalatine foramen and anteriorly placed ventral infraorbital foramen. The caudal palatine foramen (proximal opening of canal for palatine vessels and nerves) probably also opens here, although it is not visible.

Nasal: The small, dorsally convex, and anteriorly deflected nasals form the vertex of the skull at the prominent "snout," where they lie well forward of the orbits. In dorsal view, each nasal is sculptured anteromedially and is longer than it is wide. The gently convex laterai border is markedly longer than the medial border, which is marked by a slightly depressed internasal suture. The nasals are slightly asymmetrical in shape and sculpture, but it is uncertain if this is original or postmortem. Anteriorly, each nasal forms a thin downturned roof over the bony nares. The two nasals are separated posteriorly by the blunt narial process of the frontals, and the naso-frontal suture is slightly depressed.

Mesethmoid: The mesethmoid occurs in the posterior of the mesorostral groove (Figure 6), where it is some $32 \mathrm{~mm}$ high and $10-12 \mathrm{~mm}$ wide. Matrix obscures details. Presumably, the mesethmoid (mesorostral or septal) cartilage originally filled the mesorostral groove anterior to the ossified mesethmoid. A round element seen in cross section in the narial cavity above the large exposure of the mesethmoid could be a dorsal part of the mesethmoid; it is about $14 \mathrm{~mm}$ high and 9-10 $\mathrm{mm}$ wide. The ectethmoid is not apparent. 
Frontal: On the vertex, the frontals form a long, narrow ( $\sim 28 \mathrm{~mm}$ wide), median exposure posterior to the nasals and medial to the ascending processes of the premaxillae. Anteriorly, the frontals are fused to form a broad, bluntly rounded narial process, which partly separates the nasals. Posteriorly, a median interfrontal suture arises from the fronto-parietal suture to separate the frontals for about $30 \mathrm{~mm}$. The frontals at the vertex carry at least 12 small $(\leq 1 \mathrm{~mm}$ diameter) scattered foramina, interpreted as remnant supraorbital foramina comparable with those of some Dorudontinae and archaic Mysticeti.

From the posterior limit on the vertex, a narrow continuous strip of frontal descends laterally toward the orbit, bounded by the supraorbital process of the maxilla (anterior) and parietal (posterior). The parietal margin has a well-developed foliate fronto-parietal suture, on which the orbitotemporal crest originates. In a dorsal or anterodorsal view (Figures $2 \mathrm{C}, 6$ ) of the skull, the two orbitotemporal crests form a conspicuous semicircular posterior border of the face; the crests probably indicate the posterior limit of the origin of the nasofacial muscles. Each orbitotemporal crest grades laterally onto the supraorbital region, where it forms a strong ridge at the base of the postorbital process. The postorbital process is a wide, thin plate that descends steeply toward the apex of the zygomatic process of the squamosal; it does not extend far posteriorly. Farther anteriorly is the thick and robust orbital (supraorbital) part of the frontal, which is overlapped medially by the rather narrow ascending or supraorbital process of the maxilla. The preorbital process of the frontal appears blunt in dorsal view and is dorsoventrally thick, but it is the lacrimal that here forms the anterolateral part of the cranium at the antorbital notch.

As seen laterally, the orbit is strongly arched dorsally, contrasting with the shallow, long orbit in most odontocetes. Furthermore, its anterior profile is strongly concave posteriorly. The orbit lies above the level of the lateral border of the rostral part of the maxilla (above the base of the rostrum), but a little below the dorsoventral midpoint of the skull. The frontal forms most of the orbit, with some contribution of the lacrimal, jugal, and maxilla to the anterior wall. At least two presumed frontal foramina open in the roof of the left orbit about $30 \mathrm{~mm}$ internal to the edge of the orbit, just anterior to the postorbital ridge. Medially, the orbit passes into the deep groove of the optic infundibulum, where the narrow, slit-like ethmoid foramen (see left side; Figures 12,13) for the ethmoidal vessel and nerve opens immediately anterior to orbitosphenoid-frontal suture. Other details of the optic infundibulum are given under the orbitosphenoid.

Posteriorly, the orbit is bounded by a strong postorbital ridge (crista orbitalis superior; Figures 2B, 4), which is indistinct laterally on the postorbital process but which becomes more distinct medially as it grades into the dorsal edge of the optic infundibulum (sensu Fraser and Purves, 1960). This ridge marks the anteroventral limit of origin of the temporalis on the frontal. The preorbital ridge (ventral orbital crest, crista orbitalis inferior), which normally delimits the anteroventral part of the orbit in mammals (Davis, 1964; Evans, 1993), is not developed laterally, but it is thick and low medially where it separates the optic infundibulum from the infraorbital infundibulum. There is no obvious pterygopalatine fossa.

Anteroventrally, the orbit is delimited by a strong ridge of jugal and maxilla at the posterior limit of the rostrum, to which the frontal does not contribute. Laterally, this ridge involves only the jugal (the lacrimal lies more dorsally), whereas farther posteromedially, the maxilla forms the ridge just ventral to the infundibulum for the infraorbital and sphenopalatine foramina. This ridge is a vestigial equivalent of the infraorbital process of the maxilla of other mammals.

Lacrimal: The lacrimal is unexpectedly prominent, and the facial surface is exposed well to dorsal view and not covered by the maxilla. It is transversely elongate and dorsoventrally thick in the anterior wall of the orbit but does not contribute to the roof of the anterior part of the orbit (posterodorsal limits of the lacrimal within the orbit are not clear). Medially, the lacrimal extends beyond the antorbital notch onto the rostrum; the left side is well preserved. There is no evidence of a fossa for the lacrimal sac, fossa for oblique muscle, or lacrimal canal, and an orbital crest cannot be identified.

Jugal: The jugal (zygomatic bone) is identified provisionally by analogy with the situation in young specimens of extant Ziphiidae, the only group of extant Odontoceti in which limits of the normally fused jugal and lacrimal can be determined easily. As seen ventrally, the left jugal in $S$. rayi has two anteriorly directed processes that invade the maxilla; the medial process is the larger. (Limits to the right jugal are obscure.) In the absence of a clear suture between the jugal and the more dorsal lacrimal, these two bones are presumed to be fused fully. Originally, a thin process of the jugal presumably underlay the orbit, passing posteriorly to contact the apex of the zygomatic process of the squamosal.

Parietal and Interparietal: The prominent, short, and transversely rounded intertemporal region is formed by the parietals and interparietal. The interparietal has a narrow medial exposure, is bounded by ill-defined serrate to foliate sutures with the parietal, and fully separates the parietals; it extends from the supraoccipital to the frontal. There is a low, indistinct median ridge but no sagittal crest. Anteriorly directed parietal foramina open on the interparietal.

Immediately lateral to the interparietal, each parietal is smooth with two indistinct subparallel parasagittal temporal crests (temporal lines, supratemporal crests of Novacek, 1986) developed posterolaterally (Figures 2A, 3). Anteriorly, about 17 $\mathrm{mm}$ from the midline, each parietal gives rise to a sharp orbitotemporal crest that passes laterally and slightly anteriorly onto the frontal. Here, at its frontal border, the parietal dorsally buttresses the supraorbital process of the frontal (Figure 2A). Farther ventrally, where, on the left, a prominent serrate suture is present (Figures 12, 13), the parietal extends a little anteriorly along the cranial wall. Anteroventrally, the parietal forms the posterior margin of the optic infundibulum, thus contributing to 
the postorbital ridge, and it also contacts the palatine and pterygoid immediately ventral to the optic infundibulum (Figures $12,13)$. Farther posteriorly, the parietal extends ventrally to the infratemporal crest (=subtemporal crest; Fordyce, 1994), but details of contact here with the alisphenoid are uncertain. Also within the temporal fossa, the posterior suture with the squamosal at the squamous border cannot be localized; on the broken left side, the parieto-squamosal suture is not identifiable on the preserved part of the braincase wall. The suture with the supraoccipital cannot be localized at the nuchal crest. Ventrally and posteroventrally, within the temporal fossa, the braincase widens markedly.

The parietal appears to be present in the basicranium dorsal and medial to the periotic. This identification is not certain because the in situ periotic covers the area where the parietosquamosal suture is expected, and it is possible that the element here may be squamosal only. The parietal is, however, known to be present in the identical position in an archaic odontocete USNM 205491 (Figure 5B), which is comparable in basicranial grade to $S$. rayi. The parietal also occurs in this position in Waipatia maerewhenua Fordyce (holotype, OU 22095; see Fordyce, 1994, for discussion) and in a wide range of other odontocetes. Identified thus, the parietal forms the lateral border to the posterior lacerate foramen. Although the parietal extends medially toward the basioccipital, it does not contact the latter; thus the posterior lacerate foramen and more anteriorly placed foramen ovale are confluent, with a constricted apostrophe-like profile. The posterior suture of the parietal with the exoccipital can be localized only to within a few millimeters. Anteromedially, this basicranial part of the parietal forms a wedge that extends forward, bounded laterally by the alisphenoid, to form part of the foramen ovale.

Supraoccipital: The broad supraoccipital slopes forward at about $45^{\circ}$ from horizontal. It is roughly hemispherical in dorsal or posterior view (Figures $2 \mathrm{~A}, \mathrm{D}, 3,7$ ), whereas in lateral view the longitudinal profile is convex, more so laterally than medially. Anterodorsally, the surface of the supraoccipital is raised, but there is no distinct projecting external occipital protuberance. Also anterodorsally, a short low external occipital crest lies just to the right of the midline (Figure 7), but there is no significant asymmetry. Below the external occipital crest is a faint median depression that passes ventrally into a raised region, without nuchal tubercles, just above the foramen magnum. The anterolateral quadrants of the supraoccipital are gently convex dorsally.

The apex of the supraoccipital at the nuchal crest rises dorsally about $6 \mathrm{~mm}$ above the adjacent interparietal and parietals. Laterally, the nuchal crest (here sometimes termed the lambdoidal crest) overhangs the parietal and squamosal by up to 10 $\mathrm{mm}$. The crest descends steeply toward the exoccipital and, at the posterior of the temporal fossa, swings abruptly forward onto the zygomatic process of the squamosal (forming the temporal crest of some authors).
Exoccipital: Dorsally, the exoccipital is fused completely with the supraoccipital, so that the limits of these elements are uncertain. The right condyle lacks the medial border, so that its outline is incomplete; as preserved it is reniform and transversely narrow in posterior view. Enough remains to show that, originally, the condyles formed an articular surface with a primitively wide and oblate (rather than subcircular) profile (Figures 2D, 7), with a circular foramen magnum. The dorsal intercondylar notch is broad and shallow, although remnants indicate a more narrow ventral notch. The condyle lacks an elevated pedicle, but the dorsal condyloid fossa is prominent and deep. The ventral condyloid fossa is open and spacious but less clearly delimited. Preservation is too poor to judge the state of the condyloid foramen (in other mammals, for condyloid vein between basilar sinus and sigmoid sinus), but presumably the foramen is small or absent as in other odontocetes.

The long axis of the rather tabular and roughly parallel-sided paroccipital process extends ventrolaterally and posteriorly (Figures 2D, 6, 14B, 16) to almost reach the level of the outer face of the zygomatic process of the squamosal. Ventrally, the apex reaches below the level of the basioccipital crest (although the latter is pushed dorsally by postmortem crushing) and, viewed dorsally, extends posteriorly almost to the level of the posterior of the condyle.

In lateral view, the paroccipital process appears mostly thin, but distally, at its contact with the post-tympanic process of the squamosal, it thickens markedly. This thick apex, seen ventrally, is nodular, wider than it is long, and roughly oval in profile. The diffuse articulation for the stylohyal lies ventral to a horizontal, anteriorly facing, narrow groove or notch interpreted as the fossa for a posterior sinus, which originated from the elliptical foramen of the bulla. Immediately dorsally, between the exoccipital and posterior process of the tympanic bulla, is an open groove that probably carried the facial nerve externally; it is not clear whether the paroccipital process contacts the posterior process of the bulla in the roof of this groove, or whether 1-2 mm of squamosal lies between these elements. Farther dorsomedially, the anterior face of the paroccipital process is convex, without any excavated fossa, but the open region between the paroccipital process and the pars cochlearis of the periotic probably held a lobe of the peribullary sinus. This interpretation, based upon study of extant odontocetes, differs from that of previous authors (e.g., Fraser and Purves, 1960), who have identified this open region in diverse odontocetes as the fossa for the posterior sinus. Farther medially, the exoccipital bounds all of the jugular notch and descends onto the base of the basioccipital crest. The notch is wide and shallow, and the small hypoglossal foramen (for nerve XII and perhaps the vein of the hypoglossal canal) opens anteromedially. Immediately anterodorsal to the hypoglossal foramen, the exoccipital is grooved, presumably for vessels that exited via the posterior lacerate foramen.

Basioccipital: Broken and compressed bone obscures some details of the basioccipital; sutures with the exoccipital 


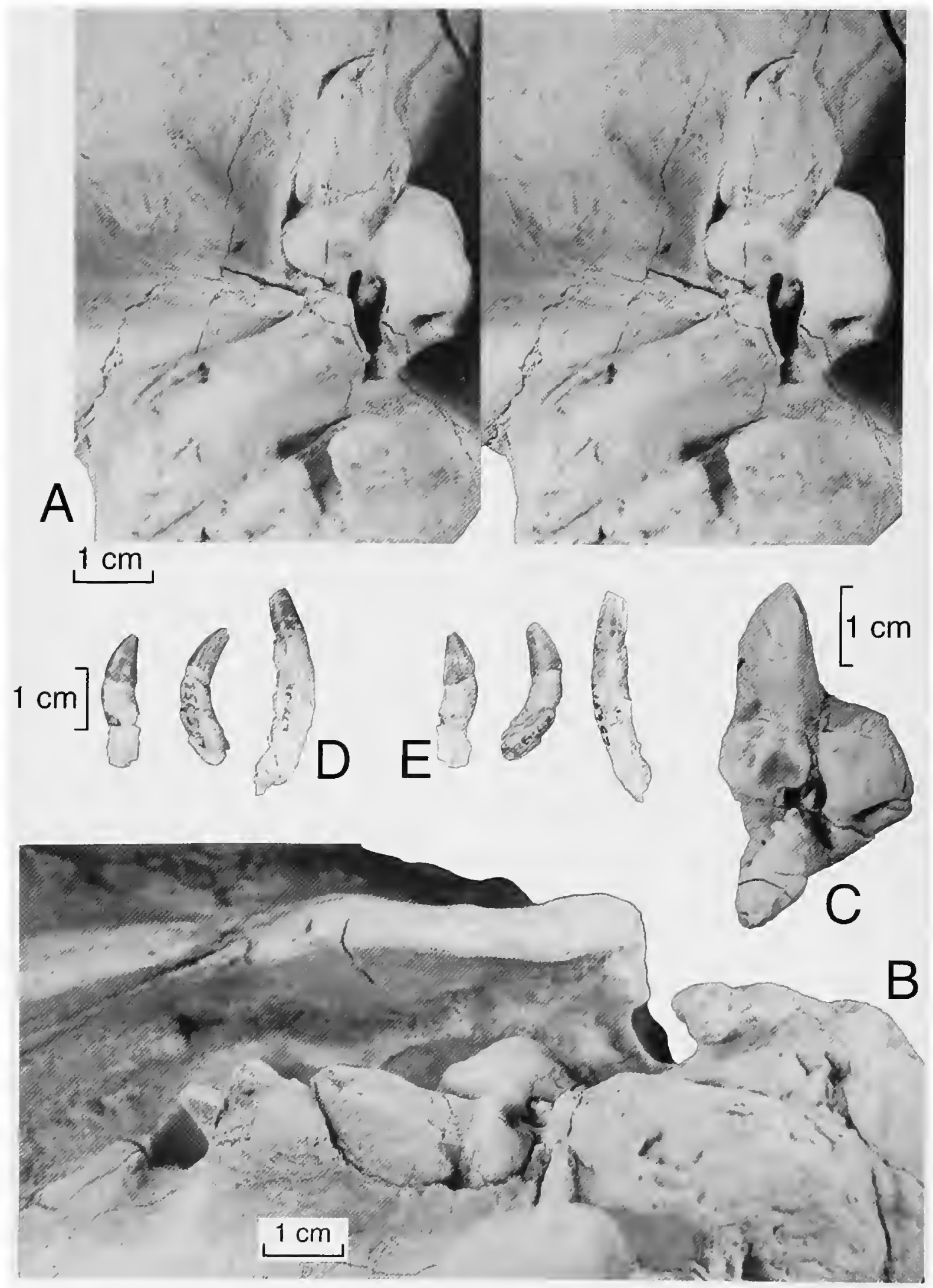

FIGURE 14.-Simocetus rayi, USNM 256517, holotype elements, and unnamed odontocete USNM 205491: A, stereophotographs of right periotic of holotype skull of S. rayi. USNM 256517, ventral view (skull whitened with ammonium chloride); B, lateral view of right periotic of holotype skull of $S$. rayi. USNM 256517, with ventral surface upper (skull whitened with ammonium chloride); C, right periotic of unnamed odontocete USNM 205491, to show anteroexternal sulcus and posterior process; D,E, isolated anterior teeth associated with holotype skull of $S$. rayi, USNM 256517; D, buccal view; E, lingual view. (Scale bar $=1 \mathrm{~cm}$.)

are fused except at a crushed contact at the posterior of the basioccipital crest. The right basioccipital crest is robust and anteroposteriorly short, reaching forward to about the mid-level of the foramen ovale. Its current posteroventral and markedly lateral orientation probably reflects postmortem crushing; originally the crest extended farther ventrally and less posteriorly or laterally, with the posterior lacerate foramen better exposed to ventral view. Rough bone medially near the thickened apex of the crest probably marks the insertion for the longus capitis. Anteriorly, the basioccipital contacts the vomer medially; laterally, the basioccipital crest carries a small, narrow, oval facet interpreted as the suture for the medial lamina of the pterygoid. 
An indistinct tubercle lies medially at the contact with the vomer, anterior to a gentle elevation that runs transversely between the bases of the two basioccipital crests. Posteromedially, bilateral ridges that flare back toward each condyle delimit the insertions for the rectus capitis ventralis.

Dorsolaterally, opposite to the periotic, the basioccipital crest lacks any obvious fossa for a peribullary sinus, although such a sinus probably was present. Dorsally, near the border for the posterior lacerate foramen, the basioccipital carries a narrow elongate shelf and an associated groove; because the region between the tympanic bulla and basioccipital is equivalent to the petro-occipital canal of other mammals, the groove may be for the ventral (inferior) petrosal sinus.

The basioccipital contributes little to the margin of the laterally directed posterior lacerate foramen ( $=$ cranial hiatus in part of Fraser and Purves, 1960; see Fordyce, 1994), which otherwise is bounded by the exoccipital (posterior) and, particularly, the parietal (lateral). The foramen is long and narrow $(\sim 20 \mathrm{~mm}$ $x \sim 10 \mathrm{~mm}$ ), and anteriorly it is confluent with the much larger foramen ovale. Presumably the foramen transmitted cranial nerves IX-XI and any vessels from the sigmoid sinus. The region ventral to the posterior lacerate foramen includes the tympano-occipital fissure and jugular foramen of other mammals, now indistinct because the bulla and periotic are effectively extra-cranial, displaced ventrolaterally from the braincase.

Squamosal: The squamosal appears to form the posterolateral wall of the temporal fossa at and posterior to a prominent bulge in the braincase, although the parieto-squamosal suture cannot be localized here. A long, deep, narrow cleft in the dorsal surface of the squamosal floors the temporal fossa and separates the braincase from the zygomatic process (Figure 2A, right side). Anteroventrally, the cleft is particularly narrow, confined anteriorly by the convex subtemporal crest and by the medial edge of the zygomatic process, as if to form a channel for a tendinous part of temporalis.

The zygomatic process of the squamosal parallels the skull axis and forms the most lateral part of the skull (dorsal view; Figures $2 \mathrm{~A}, \mathrm{~B}, 3,4)$ ). Its dorsal crest is abruptly rounded transversely, and the medial wall is steeper than the lateral. The zygomatic process is deeper than it is wide, with a roughly comma-shaped cross section, and the thin ventral margin extends a little laterally. In lateral view (Figures 8A, 9), the dorsal margin of the process is subhorizontal, descending gently to a sharp apex below which is an elongate small facet for the contact with the jugal.

Posteriorly, the base of the zygomatic process has a deep, rough fossa for muscles of the neck. Subdivisions are not obvious; the muscles included some or all of the sternomastoideus, splenius, longissimus capitis, and mastohumeralis (see Schulte and Smith, 1918; Howell, 1927). The fossa extends anterodorsally above the external auditory meatus, is pitted deeply in its midpoint, and extends ventrally onto the post-tympanic process of the squamosal (lateral view; Figure 8A). By analogy with ar- tiodactyls, the post-tympanic part of the fossa is inferred to be an origin for the sternomastoideus.

The ventral surface of the squamosal is complex. The lateral edge of the zygomatic process has a marked crest, but limits to the glenoid cavity otherwise are not clear except at the robust postglenoid process. Here the tympano-squamosal recess for the middle sinus (fide Fraser and Purves, 1960) descends onto the postglenoid process, with the distal part of the recess bounded by a distinct ridge on the anterolateral part of the postglenoid process (Figure 5A). Although there is no excavated tympano-squamosal recess anteriorly, the structure of the squamosal between the zygomatic process and steep-sided falciform process is compatible with a well-developed middle sinus (sensu Fraser and Purves, 1960) originating at the lower tympanic aperture between the periotic and tympanic bulla. Farther anteriorly (Figure 5A), the squamosal forms a broad shelf on which a thick rounded subtemporal crest ("projecting...temporal rim" of squamosal, of Kellogg, 1936:101) separates the temporal fossa from the basicranium. As in Waipatia maerewhenua, the squamosal lacks the anterior transverse ridge and the vestigial (nonpatent) postglenoid (retroarticular, retroglenoid) foramen seen in Basilosauridae; see also the discussion of postglenoid foramen and foramen spinosum below.

Anteriorly, between the pterygoid sinus and the groove for the mandibular nerve, the alisphenoid-squamosal suture is foliate and complex, with multiple fine interdigitation.

The falciform process is thin, with a long base; it projects ventrally, skewing slightly anteromedially, and is bifurcated distally. On the skull in modern odontocetes in which the tympanic bulla is articulated (e.g., growth series of Tursiops truncatus (Montagu) in USNM), the anteroventral or distal part of the falciform process lies close to the descending anterior edge of the outer lip of the bulla. This distal part is missing in $S$. rayi, presumably through postmortem loss. A second, more anterodorsal, division of the falciform process often is identifiable in odontocetes, immediately ventral to the path of the mandibular nerve. This division may contact the bony lateral lamina of the pterygoid sinus fossa. There no evidence that any extensive sheet of outer lamina of pterygoid contacted the falciform process in S. rayi. Posteriorly, the falciform process lies closely against the anterolateral face of the anterior process of the periotic, but farther posteriorly, the squamosal rises rapidly to expose much of the anterior process of the periotic to lateral view (Figures 14B, 16). A large foramen between the squamosal and the fovea epitubaria of the periotic, immediately anterior to the lateral tuberosity, marks the ventral opening of the anteroexternal sulcus, which in turn is presumably for the middle meningeal artery (see Fordyce, 1994). The in situ periotic obscures the squamosal within the periotic fossa.

The external auditory meatus is more deep than wide distally, with the anterior and posterior walls roughly parallel for the distal half of its length, and is bounded by the steep posterior face of the postglenoid process. Medially, the meatus is more open and is separated from the tympano-squamosal recess by a 


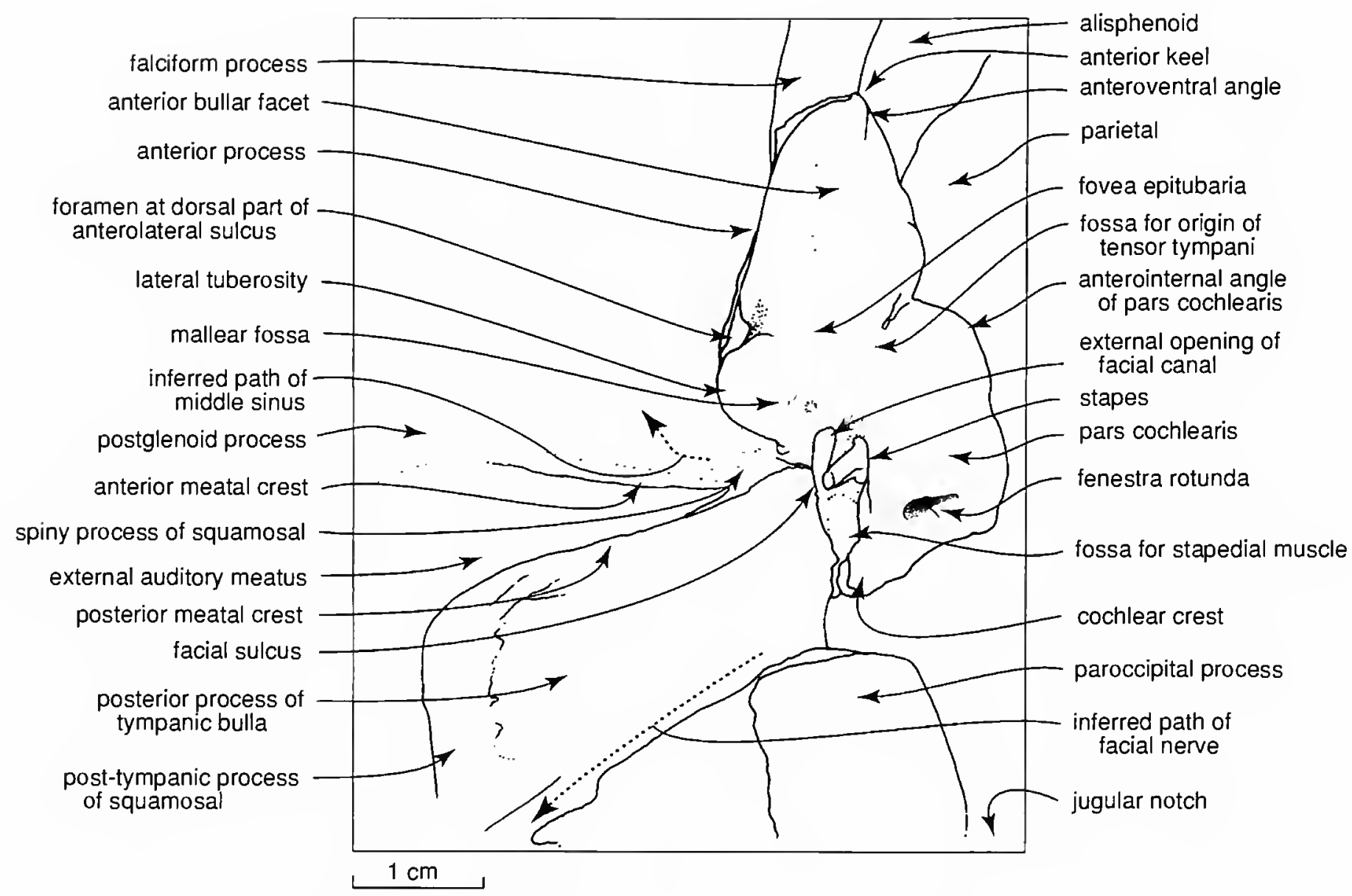

FIGURE 15.-Simocetus rayi, USNM 256517, ventral view of right periotic of holotype skuIl, based upon Figure $14 \mathrm{~A}$, showing main features. (Scale bar $=1 \mathrm{~cm}$.)

sharp anterior meatal crest. The latter extends from the postglenoid process to the apex of the spiny process (sensu Muizon, 1987), in the hiatus epitympanicus of the periotic, immediately posterior to the lateral tuberosity (Figures 14A,B, 15, 16). Here the spiny process of the squamosal carries two grooves, of which the anterior marks the path of the middle sinus and the posterior is the meatus. The suture between the squamosal and tympanic bulla here is obscure, but the posterior meatal crest forms at least the dorsal few millimeters of the wall of the meatus, with the rest formed by the posterior process of the bulla. The latter covers the squamosal that is presumed to have a post-tympanic process comparable to that of Waipatia maerewhenua. The amastoid state of the skull (posterior process of the periotic not visible on the skull wall) is consistent with the interpretation of a substantial post-tympanic process.

Periotic: The right periotic (Figures 14A, B, 15, 16) is preserved in situ and is applied closely to the squamosal (lateral, anterior), alisphenoid (anterior), parietal (anteromedial and medial), exoccipital (posterior), and tympanic bulla (posterolateral and ventral). There is no clear evidence of original intimate sutural contact with these elements, other than at and near the posterior process of the bulla. Details of the lateral and dorsal surfaces of the periotic cannot be seen.

The anterior process, body, and pars cochlearis are all skewed anteromedially relative to the skull axis. The anterior process is about as long as the body, is more narrow than deep, and has a convex lateral face and flatter medial face. As viewed medially, the anterior process is dorsoventrally deepest near its apex. Also, the anterior keel is curved as seen in medial view, with the anteroventral angle apparently more rounded than the anterodorsal angle, which, together with the medial face, is prolonged dorsomedially. The anterodorsal angle approaches a groove (at the parietal-alisphenoid suture) interpreted to lead toward the foramen spinosum. There are several subhorizontal fine grooves (anterointernal sulci of Fordyce, 1994) ventrally on the medial face of the anterior process, and one of these may be for the lesser petrosal nerve. Another groove traverses the medial face toward the anterodorsal angle. Fine details on this face of the periotic (e.g., presence or absence of a vertical canal) are obscured by resistant adhering matrix. Posteriorly, the medial face of the anterior process meets the perpendicular face of the pars cochlearis at an open groove; a fissure, which in odontocetes commonly accompanies an inflated pars cochlearis, is absent. Fordyce (1994) and others, following Kellogg (1936), have interpreted the grooved contact of the anterior process with the pars cochlearis as representing the origin for the tensor tympani; however, it seems likely that the origin for the tensor tympani lies farther ventrally, within the shallow and more subhorizontal groove between the fovea epitubaria and the ventral surface of the pars cochlearis. A long $(\sim 9 \mathrm{~mm})$, shallow, grooved anterior bullar facet lies on the ventral surface of the anterior process. The facet is bounded posteriorly by a wide shallow fovea epitubaria for the anterior pedicle and accessory ossicle of the bulla. The fovea is slightly deeper later- 


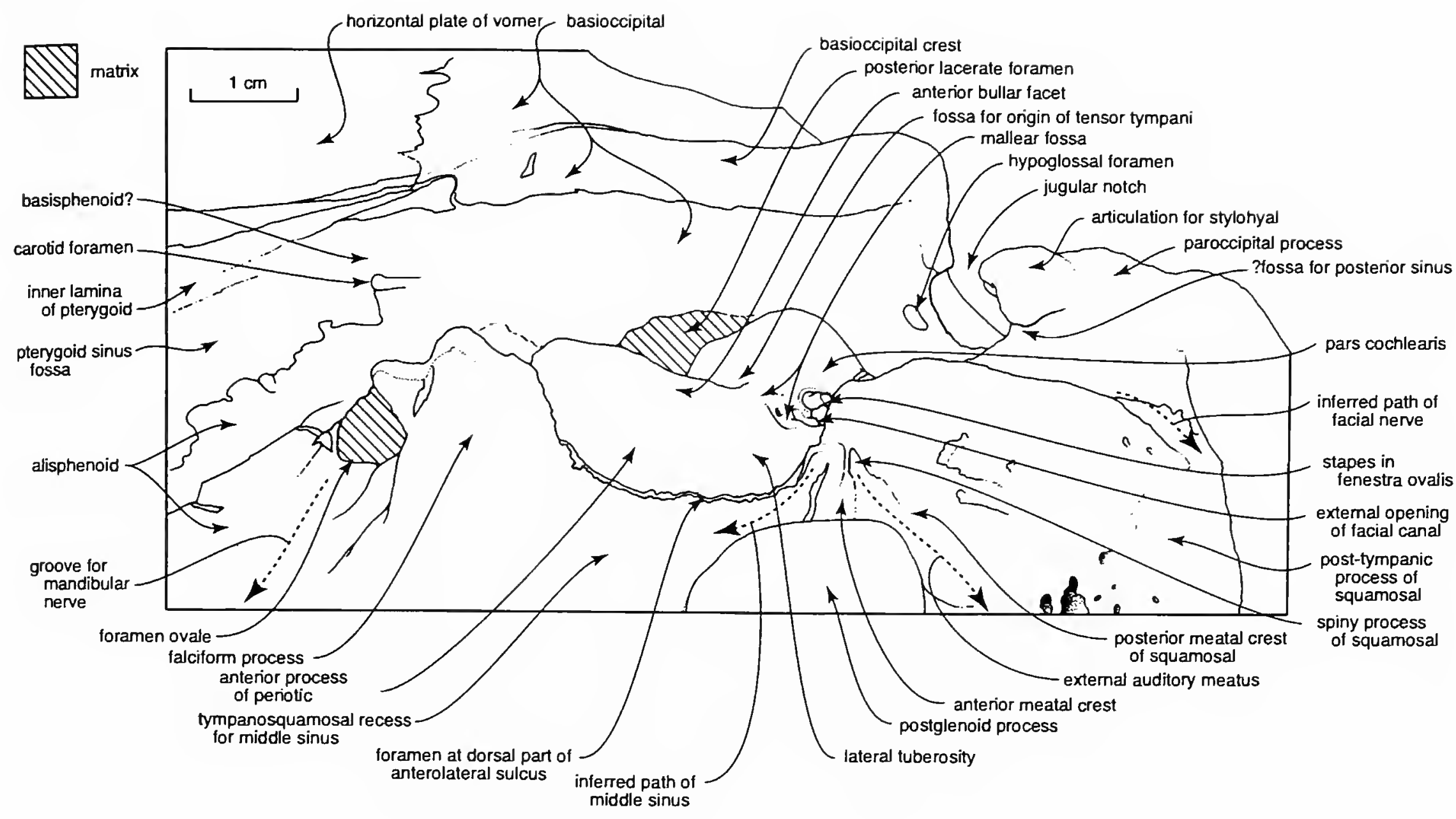

FIGURE 16.- Simocetus ravi. USNM 256517, lateral view of right periotic of holotype with ventral surface upper, based upon Figure 14B, showing main features. (Scale bar $=1 \mathrm{~cm}$.)

ally, where it is succeeded by the prominent dorsal end of the anterolateral (or anteroexternal) sulcus. The indistinct ventral part of this sulcus is curved, as seen also in some platanistoids and eurhinodelphinids. Comparisons with other archaic Cetacea (e.g., Zygorhiza kochii (Reichenbach), Waipatia maerewhenua, and archaic odontocete USNM 205491 of Figures 5B, $14 \mathrm{C})$ suggest that this groove, bounded laterally by the squamosal, trends toward the anterodorsal angle on the anterior process of the periotic and marks the path of the middle meningeal artery.

The body is delimited anteriorly by the lateral tuberosity and by the transverse ridge that anteriorly bounds the mallear fossa. The latter ridge is indistinctly tuberculate both medially and laterally, and its relationship with the now-lost anterior pedicle of the bulla is uncertain. Posterodorsally, the large hemispherical lateral tuberosity is undercut deeply. An indistinct facet on the ventrolateral face of the tuberosity probably marks the point where the sigmoid process of the bulla originally lay close to the periotic. The irregularly subspherical mallear fossa is shallow and large, deepest dorsomedially, and faces obliquely posteroventrally. Medially, the fossa merges smoothly onto the pars cochlearis without an obvious groove. There is no distinct fossa incudis, although whether this is an original absence or a postmortem loss is uncertain. The spiny process of the squamosal and, posteriorly, posterior process of bulla, obscure the hiatus epitympanicus. The fenestra ovalis, with in situ stapes, faces posterolaterally and ventrally; its anterior margin is just visible in a lateral view from the skull margin into the external auditory meatus (Figures 14B, 16). The facial canal opens lateral and just anterior to the fenestra ovalis. Because of broken bone, details are uncertain about the facial sulcus (groove for facial nerve), the deep fossa for the stapedial muscle, and the condition of the tympanohyal. The stapes is unrevealing.

The pars cochlearis is long and narrow, is not inflated, and has a smooth, somewhat tabular ventral surface. Its narrow anterior face passes via a rounded anterointernal angle onto the long, steep, irregular medial face. There is a sharp posterointernal angle. The gently concave posterior face is prolonged ventrolaterally into a laterally compressed, blunt, posterior cochlear crest (new term) that closely approaches the posterior process of the bulla. Laterally, the pars cochlearis rises abruptly toward the fenestra ovalis but does not obscure the latter from ventral view. Posteriorly, the indistinctly reniform fenestra rotunda is only just visible to ventral view. A slight nodule at the dorsal lip of the fenestra rotunda merges into a ridge directed toward the presumed position of the aperture for the cochlear aqueduct. 
The posterior process of the periotic is directed laterally, as seen from the jugular notch, but is not exposed on the skull wall; hence, the skull is amastoid. There is no evidence on the skull wall of a mastoid foramen.

Tympanic Bulla: Most of the bulla is missing. The long, narrow, posterior process of the bulla is directed posterolaterally, forming the ventral part of the posterior wall of the external auditory meatus (Figures 14A, 15). The proximal two-thirds of the process has a smooth crest that separates the rounded anterior surface from the tabular posterior surface. There is no obvious groove for the facial nerve on the bulla, and there is no stylomastoid foramen laterally; rather, the facial nerve probably lay in the groove between the posterior process of the bulla and the paroccipital process. Laterally the process thins to a distal apex. Sutures between the dorsal surface of the posterior process and adjacent elements, which can be localized to within a few millimeters, indicate contacts similar to those in Waipatia maerewhenua and other archaic odontocetes (e.g., Squalodontidae, Eurhinodelphinidae), namely, with the posterior meatal crest anteriorly, with the posterior process of the periotic posteriorly, and with the post-tympanic process of the squamosal laterally.

Pterygoid and Fossa for Pterygoid Sinus: The pterygoid lines part of the fossa for the pterygoid sinus, and it forms a prominent hamulus. Unsurprisingly, delicate parts of the pterygoid are absent; the bone is inferred to have had lateral, ventral, and medial laminae (sensu Fraser and Purves, 1960), which mostly were lost postmortem. The long left hamulus, skewed to the right after death, forms the ventral extremity of the skull just below the level of the palate and basicranium. Ventrally, the transversely rounded anterior surface of the hamulus passes back into a broad-based conical distal portion, broken apically. Although this distal part is dorsoventrally compressed, it is robust and not invaded by the pterygoid sinus. The hamulus extends posteriorly at least to a level with the falciform process. Originally, the medially apposed hamuli formed a prominent posterior spine on the palate.

More-lateral and more-dorsal features of pterygoid are interpreted next in terms of the pterygoid sinus fossa, which here is a large, dorsoventrally deep, compressed cavity lateral and, in part, ventral to the choana (Figures 2B, 4, 8E, 11-13). Remnants at the hamulus indicate that the medial lamina of the pterygoid arose from the anterior half of the hamulus to flank the internal naris at the nasopharyngeal surface. $\mathrm{A}$ facet on the anterior face of the basioccipital crest (Figures 4, 5A) indicates that the medial lamina of the pterygoid extended posteriorly to contact the basioccipital, as in other odontocetes. Judging from the remnant of preserved profile at the hamulus, the eustachian notch opened at a level slightly posterior to the midpoint of the pterygoid sinus fossa. Part of the fossa for the pterygoid sinus invades the base of the hamulus, so that in life the sinus underlay the external half of the narial passage. A remnant of ventral lamina arises from the hamulus; in life, the ventral lamina probably extended outward to merge dorsally into the lateral lamina of the pterygoid. Remnants of the lateral lamina occur at the suture with the palatine (at the anterior of the pterygoid sinus fossa) and dorsally along the outer margin of the sinus fossa. A broken surface of lateral lamina indicates a posterior extent at least to the point where the subtemporal crest bulges laterally away from the adjacent pterygoid sinus fossa, and it is possible that the lamina reached farther back, to within $30 \mathrm{~mm}$ of the falciform process. The indifferently preserved thin dorsal lamina of the pterygoid forms the anterior and anteromedial roof of the oval elongate sinus fossa, with the alisphenoid forming the posterolateral surface. Anteriorly, the fossa is excavated dorsally above the level of the foramen ovale and subtemporal crest, but it is shallower posteriorly. A small foramen (diameter $\sim 2 \mathrm{~mm}$ ) placed medially near the apex of the fossa may be the pterygoid foramen, which opens dorsally into the foramen rotundum (Figure 13). The dorsal roof of the fossa, in the region of the pterygoid-alisphenoid suture, possesses many small foramina. Posteriorly, the fossa is bounded by a low ridge that marks the path of the mandibular nerve (V3) from the foramen ovale. There is no evidence that the pterygoid sinus extended beyond the skull base and into the orbit, or that it had medial or posteromedial lobes.

Alisphenoid: Most sutures of the alisphenoid are fused or obliterated, and their limits are determinable only to within a few millimeters. The foramen ovale identifies the posterior border of the alisphenoid. The alisphenoid also forms the posterior and posterolateral parts of the roof of the pterygoid sinus fossa (Figures $5 \mathrm{~A}, 12,13$ ). The large subcircular foramen ovale is not occluded posteriorly by the parietal and basioccipital, so it is confluent posteriorly with the cranial hiatus. The posteromedial limit of the alisphenoid is indicated by the carotid foramen in the adjacent basioccipital. Relationships with the squamosal are uncertain because they are obscured by complex sutures; the alisphenoid apparently forms only a small medial part of the groove for the mandibular nerve. A splint of alisphenoid extends posteriorly between the squamosal and parietal to reach the anterodorsal angle of the anterior process of the periotic (Figure 5A). The deep groove here between the parietal and alisphenoid is real, not a postmortem artifact; its position and orientation, and comparisons with other odontocetes (Waipatia maerewhenua and the unnamed odontocete USNM 205491 of Figure $5 \mathrm{~B}$ ), suggest that it is a fissure for the middle meningeal artery and that its anterior limit represents the foramen spinosum.

Basisphenoid: The carotid foramen, which opens level with but ventromedial to the foramen ovale, indicates the posterior extent of the basisphenoid (Figures 12,13). Limits to the basisphenoid otherwise are obscured by the vomer ventrally, and by the inner lamina of the pterygoid laterally. The carotid foramen is small and elongate. This foramen is thought not likely to transmit an internal carotid artery in adult living mysticetes and odontocetes (Fraser and Purves, 1960; Vogl and Fisher, 1981), although an artery may be present in juveniles (Melnikov, 1997). 

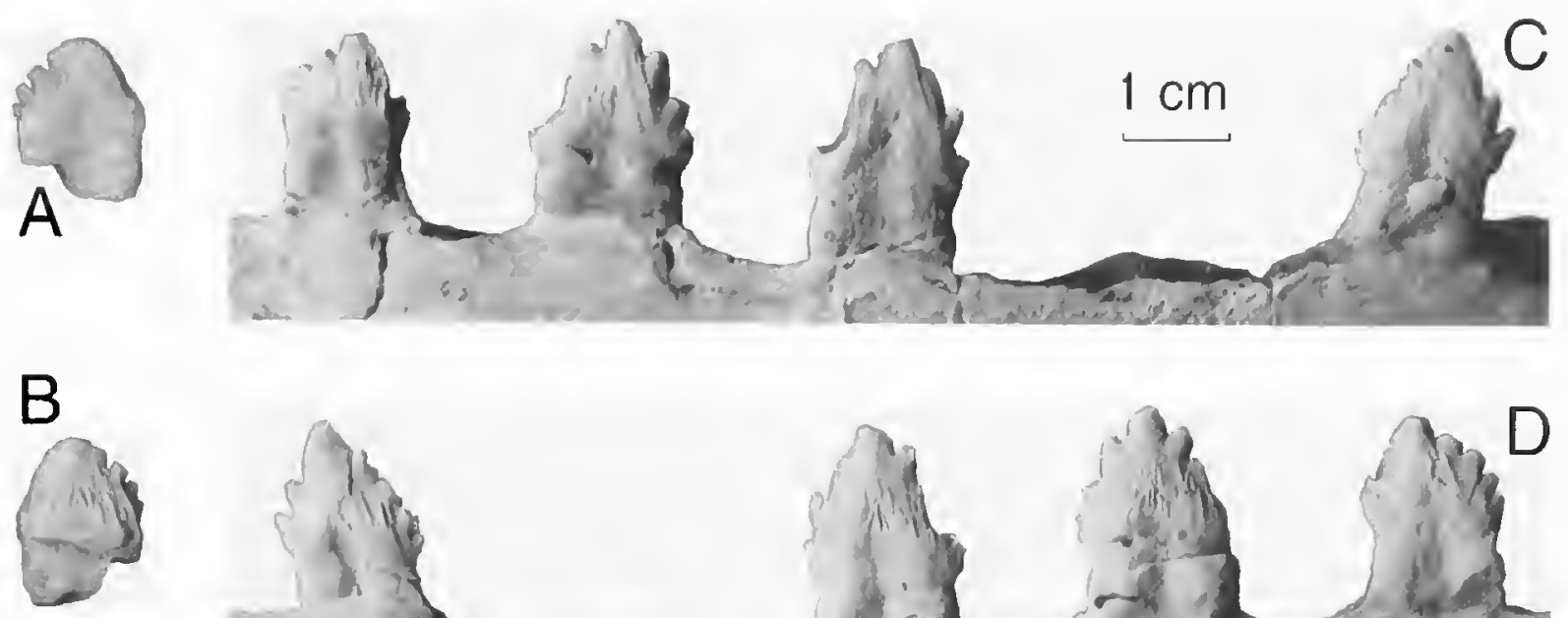

$1 \mathrm{~cm}$

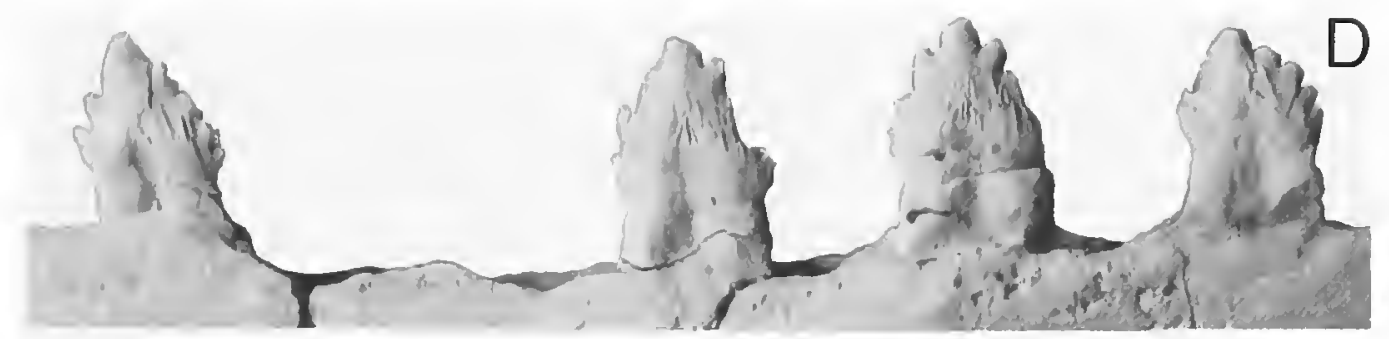

FiGURE 17.-Simocetus rayi, USNM 256517, teeth, whitened with ammonium chloride: A,B, isolated crown of a cheek tooth; A, buccal; B, lingual; C,D, mandibular teeth; C, buccal; D, lingual. (Scale bar $=1 \mathrm{~cm}$.)

Orbitosphenoid: Details are seen best in the left orbit (Figures 11-13) in which, however, proximal parts of foramina could not be exposed fully. Kellogg's (1936, fig. 31c) illustration of Zygorhiza kochii helps interpret this region. The orbitosphenoid surrounds much of the elongate deep cleft of the optic infundibulum but cannot be identified positively in the anterior wall. The optic foramen opens anteriorly in the roof of the infundibulum, which is level with but posteromedial to the ethmoid foramen. The path for the optic nerve is perpendicular to the condylobasal axis. The orbital fissure (=portion of optic foramen for V1 of Kellogg, 1936, fig. 31c) is not seen, but it is inferred to open farther posteriorly, deep within the infundibulum. A small foramen presumably for the ophthalmic artery lies at the junction of the orbitosphenoid, frontal, and parietal, immediately dorsal to the optic infundibulum. Also on the orbitosphenoid is the path of the maxillary nerve (V2) that arises from the foramen rotundum (hidden) and runs anteriorly in a shallow groove that is lateral and ventral to the deeper part of the infundibulum. A low horizontal ridge bounds the groove dorsally, and the ventral edge of the groove is close to the suture with the palatine.

Mandible: Notable features of the incomplete right mandible (Figures 8B,D, 10A,B, 17C,D include its gracile, laterally compressed and ventrally deflected anterior portion, and ventrally and laterally inflated panbone (lateral wall of the mandibular foramen). There are alveoli for 11 teeth, presumably i1-3, $\mathrm{c}, \mathrm{pl}-4$, and $\mathrm{m} 1-3$. Missing are the apex of the coronoid process, maxillary notch, condyle, condylar crest, angular process, and angle.

Anteriorly, the tooth-bearing body has a sharp apex that passes back into the subparallel dorsal and ventral surfaces. Depth increases markedly about the level of $\mathrm{m} 1-\mathrm{m} 3$, as the panbone becomes laterally and ventrally inflated. The dorsal profile behind the posteriormost cheek tooth is barely elevated above the level of tooth insertion, but not enough of the dorsal profile remains to judge the shape of the now-missing apex of the coronoid process. In dorsal view, the mandible becomes inflated posterior to about $\mathrm{m} 3$. Overall, the mandible is suboval in cross section, although the crests are developed anteroventrally below about il-c; posterodorsally, a sharp, narrow coronoid crest is developed behind $\mathrm{m} 3$. The apical $85 \mathrm{~mm}$ of the mandible, from $\mathrm{pl}$ forward, is deflected ventrally to complement the inferred original profile of the now-distorted rostrum.

In dorsal view, the mandible is roughly straight except anteriorly where it is slightly recurved medially toward the symphysis. A left mandible, if reconstructed to comparable profiles and articulated with the right, would result in an acutely pointed lower jaw with a narrow mandibular space. Proportions of the rostrum, however, point to a broader mandibular space. It thus seems likely that the orientations of the mandible and symphysis were distorted postmortem.

The mandibular symphysis is short, indistinct, and not particularly prominent in dorsal or internal views. It extends from the apex of the mandible posteriorly to about level with the alveolus of i3. Surface detail is too poor to tell patterns of symphyseal ridges and grooves, if any. There is no evidence that the left and right mandibles were fused.

Four single alveoli with prominent diastemata occupy the anterior $67 \mathrm{~mm}$ of the mandible. These, and the alveolus for $\mathrm{pl}$, lie toward the lateral (buccal) face of the mandible, whereas the more-posterior alveoli are on the dorsal surface. The forwardpointing tiny alveolus for il lies ventral to the apex. Much larger alveoli for $\mathrm{i} 2$ and $\mathrm{i} 3$ are suboval and directed anterolaterally, so that these teeth probably were procumbent. A more rounded alveolus for the canine indicates a more vertically oriented, single-rooted tooth. Here and farther posteriorly, there are no alveolar juga. A fine longitudinal ridge links the medial (lingual) margins of the alveoli.

Two-rooted alveoli lie farther posteriorly; the seventh and ninth through 11 th teeth (p3, ml-3) are in situ (Figure 17C,D). The shortest diastemata are between $\mathrm{p} 1$ and $\mathrm{p} 3$; posteriorly thereafter, the diastemata lengthen enough to have accommo- 
dated the crowns of opposing maxillary teeth. Poorly preserved shallow pits in the diastemata may be embrasure pits for the apices of upper cheek teeth. Five small elongate mental foramina open on the buccal face (Figure 10A) between i2,3, level with the anterior of $\mathrm{p} 2$, level with the anterior of $\mathrm{p} 4$, level with the anterior of $\mathrm{m} 2$, and between $\mathrm{m} 2,3$.

Only the crushed anterior margin of the mandibular foramen is preserved. As viewed laterally, the pan-bone is markedly inflated ventrally, relative to the rather straight dorsal profile between $\mathrm{p} 1$ and the broken base of the coronoid process. As seen posteriorly, the medial (lingual) face of the mandible is gently concave. The mandibular canal is at least $70 \mathrm{~mm}$ deep and 20 $\mathrm{mm}$ wide, and its walls are less than $1 \mathrm{~mm}$ thick.

Teeth: The teeth (Figures 14D,E, 17A-D) are heterodont and apparently not polydont. The tooth complement appears to be $\mathrm{I} 0 / 3, \mathrm{Cl} / 1, \mathrm{P} 4 / 4, \mathrm{M} 2 / 3$, based upon the count of teeth, roots in place, and the alveoli, with the proviso that anterior alveoli are eroded and the matrix is filled. There is no evidence of deciduous teeth. It is uncertain whether premolars and molars can be differentiated on the basis of crown structure; in this specimen they are identified by position. Premaxillary teeth are not recognizable and, furthermore, each premaxilla lacks alveoli. Teeth preserved in the skull (Figure 2B) are the right $\mathrm{P} 4$ and $\mathrm{M} 1$, left P2, and roots of left P3 and M1; none of these upper teeth is preserved well enough to warrant detailed illustrations. Mandibular teeth are listed above. Isolated teeth are three anterior teeth (i and/or c; Figure 14D,E), one cheek-tooth crown (perhaps left m1; Figure 17A,B), and a fragment of one cheektooth crown.

The isolated, slender, single-rooted teeth with simple crowns are incisors and possibly a canine. All are rather small in absolute size and also in size relative to the mandible. The longest, with a relatively small crown, may represent the procumbent lower right i2, for which the alveolus is large and directed forward. Of the two smaller teeth, the straighter is perhaps the lower left $\mathrm{i} 3$; the more recurved could represent the lower left or upper right $C$. In each single-rooted tooth, the crown is acutely pointed with a small apical angle (sensu Rothausen, 1968), is recurved slightly to markedly lingually, and is anteroposteriorly keeled. The basal cross section is oval and transversely compressed, and the buccal face is more convex than the lingual face; transverse compression is pronounced apically. The enamel is smooth or has microscopic vertical striae buccally, whereas the lingual face has a few low, vertical, subparallel ridges. In each tooth, the root has a smooth surface, is thicker below the crown, and is roughly circular in cross section.

Features of the cheek teeth are shown in Figure 17A-D. On the skull, only the right $\mathrm{P} 4$ appears to be in undistorted original position, facing ventrally and slightly laterally (buccally) (Figure $8 \mathrm{~A}$ ). The cheek teeth in place are emergent, with the crown well clear of the alveolus. Generally, the triangular crowns are laterally compressed, are recurved lingually in the upper teeth, and have a triangular main (apical) denticle and two or more accessory (anterior and posterior) denticles. In other archaic odontocetes, the apical denticle becomes smaller posteriorly in the tooth row relative to the accessory denticle(s); in $S$. rayi the apical denticle in the lower $\mathrm{p} 3$ is larger than in the $\mathrm{m} 1$, but more teeth are needed to determine the real trend. Accessory denticles are small, compressed, free-standing, and keeled. They are arranged anteroposteriorly along the keels of each tooth. In the lower teeth, an occlusal view shows that this arrangement is roughly linear, but for the upper teeth, the anterior and posterior keels, and their associated denticles, trend buccally as they descend from the main denticle. Some accessory denticles are preserved well enough to show apical wear. There are large facets on the left P2 (anterolingual face), right M1 (anterobuccal edge), $\mathrm{m} 1$ (posterior keel), $\mathrm{m} 2$ (posterior keel), and on the isolated crown, resulting from tooth-to-tooth wear that has removed denticles. The right $\mathrm{m} 3$ lacks large anterior denticles and is clearly asymmetrical in lateral view. Anteriorly, the keel on $\mathrm{m} 3$ carries a flat face bounded by two distinct ridges, similar to the anterior vertical groove bounded by ridges in the lower molars of basilosaurids (see Kellogg, 1936:124125).

Ornament is present on all cheek teeth, less marked buccally than lingually. The buccal ornament (Figure 17C) comprises coarse, low, broad-based ridges that arise in the midline toward the crown base and converge apically toward the main denticle. The ridges are shorter and coarser basally. The buccal ornament is most pronounced on the posterior mandibular teeth. The lingual ornament (Figure 17D) is more raised, is longer, has sharper crests, and is distributed farther apically and anteroposteriorly along the crown than for the buccal ornament. A faint papillate cingulum, in the shape of an inverted open $\mathrm{V}$, is present lingually on lower $\mathrm{m} 2,3$. There is no cingulum on the more-anterior lower cheek teeth or the in situ upper cheek teeth, although ornament is more pronounced toward the crown base as if forming an incipient cingulum. In all cheek teeth, a vertical median sulcus extends onto the crown base buccally and lingually from between the roots, so that a cross section near the crown base has a compressed figure- 8 shape. The enamelocementum boundary varies in profile (lateral view) from gently convex apically to an inverted $V$ shape, with the apex of the $V$ marking the median sulcus on the crown base.

Cheek-tooth roots are subparallel and fused for all of their exposed length out of the alveoli. In the slightly displaced upper left $\mathrm{P} 2$, the exposed roots curve posteriorly. The right $\mathrm{P} 4$ has what may be a lingual third root, fused to the face of the posterior root and skewed posteriorly into the alveolus. Some roots have a prominent basal swelling near the crown base. Roots of the right $\mathrm{P} 4$ and $\mathrm{Ml}$ also have conspicuous lines, presumably growth lines, on the cementum parallel to the surface of insertion in the alveolus. 


\section{Discussion of Morphology, Homology, and Function}

The skull of Simocetus rayi helps us understand the early evolution of cranial functional complexes in odontocetes. Previously, patterns of odontocete cranial evolution have been inferred mainly from Neogene and living odontocetes (Miller, 1923; Kellogg, 1928). The few archaic odontocetes described, such as Agorophius pygmaeus (Müller, 1849) and Archaeodelphis patrius Allen, 1921, have given tantalizing glimpses of primitive morphologies, which, however, need to be put into modern context. For Simocetus rayi, the functional complexes discussed below are the face, olfactory complex, orbit, feeding apparatus, and basicranium.

Face: Simocetus rayi may be interpreted in light of the facial structure in living odontocetes. In odontocetes, the unique posteriorly expanded supraorbital or ascending process of the maxilla (Winge, 1921; Miller, 1923) forms an origin for hypertrophied maxillo-naso-labialis (nasofacial) muscles (Lawrence and Schevill, 1956; Schenkkan, 1973; Mead, 1975; Heyning, 1989; Curry, 1992). Nasofacial muscles and the associated nasal diverticula and melon are thought to produce and transmit high frequency sounds used in echolocation (Mead, 1975; Wood and Evans, 1980; Heyning, 1989; Cranford et al., 1996). On the basicranium, the pterygoid sinuses may help receive and process high-frequency sounds (Norris, 1968). Mysticetes lack an odontocete-like supraorbital process of the maxilla; they also lack hypertrophied nasofacial muscles, nasal diverticula, and a large melon (Heyning and Mead, 1990). Further, mysticetes are not known to produce and use high-frequency sounds in the manner of odontocetes (Heyning and Mead, 1990).

The face of Simocetus rayi shows some broad sutural and topographic patterns similar to those of extant odontocetes. Indeed, such features are critical in identifying $S$. rayi as an odontocete. Furthermore, the skull structure points to $S$. rayi as having essentially the same facial soft tissues as are seen in extant odontocetes. Below is a generalized summary about facial structures in living odontocetes that might also apply to $S$. rayi. This summary is based upon Lawrence and Schevill (1956), Moris (1969), Schenkkan (1973), Schenkkan and Purves (1973), Mead (1975), Heyning (1989), Curry (1992), and Cranford et al. (1996).

In odontocetes, the external nose is a dorsal single blowhole, generally median and well posterior to the apex of the rostrum. Complex nasal diverticula are developed in the soft tissues of the face between the blowhole and the skull. Generally, for the nasal diverticula, it is only the premaxillary sac that has a distinct bony origin (on the premaxillary sac fossa). Proximally, nasal plugs occlude the nasal passages at the external nares.

Nasofacial muscles originating from the premaxilla, and particularly the maxilla, open and close the nostril (blowhole) and manipulate the nasal diverticula. Nasofacial muscles have distinct origins on the premaxilla (nasal plug muscle), on rostral and facial parts of the maxilla, and on some of the frontal. Posteriorly, the hypertrophied nasofacial muscles commonly oc- cupy a distinct depressed facial fossa, with little, if any, bony differentiation of muscle origins in the facial fossa. Anterior limits of the nasofacial muscles on the rostrum are diffuse. A melon is present anteriorly, although without a consistent discrete bony fossa, so that it is difficult to predict size and shape of the melon from skull form alone.

The premaxillary foramina transmit branches of the internal maxillary artery and the maxillary nerves to parts of the nasofacial muscles anteriorly and posteriorly on the rostrum (see, e.g., Schenkkan, 1973, fig. 5, on Mesoplodon bidens (Sowerby)). More posteriorly placed dorsal infraorbital foramina supply branches of the internal maxillary artery and maxillary nerves to the region near the antorbital notch and the facial fossa. There is little bony evidence of venous drainage from the face (Mead, 1975). The odontocete face is innervated by sensory infraorbital branches of the maxillary division (V2) of the trigeminal nerve, which issue from the dorsal infraorbital foramina, and the facial nerve, which passes dorsally to the face via the antorbital notch (Huber, 1930, 1934; Mead, 1975).

Within each bony naris is a diagonal membrane, a soft tissue structure that may have a role in sound production (Mead, 1975). The membrane lies in the posterolateral corner of each bony naris and is inserted at the posterior of the nasal septum distal to small foramina in the mesethmoid that may be a vestigial olfactory foramina or a foramina for the nasal nerve.

The orbit is displaced ventrolaterally to become functionally independent of the rest of the face. Mysticetes and archaeocetes, which lack an enlarged facial fossa, have a similar orbital form, so that such changes probably are not caused solely by development of the nasofacial muscles.

All the above features are inferred for $S$. rayi. There is no reason to think that bone and soft tissues had a fundamentally different structure from that of living odontocetes. Facial topography, detailed suture patterns, and positions of foramina differ from those of living species, however, and require comment. For example, $S$. rayi has a prominent depression laterally on the maxilla immediately anterior to the antorbital notch; this rostral area perhaps held a substantial volume of nasofacial muscles that inserted around the nose. Extant odontocetes, in contrast, have nasofacial muscles arising mainly on the cranium, with a limited rostral component (Mead, 1975; Heyning, 1989; Cranford et al., 1996). Simocetus rayi also differs in facial topography in having a long rounded "snout," presumably for a well-developed olfactory complex (discussed below).

The internal and external borders of the premaxillary sac fossa are obvious in $S$. rayi, as in extant odontocetes. The lack of a distinct roughened origin for the nasal plug muscle does not preclude this muscle's presence; the bony origin is indistinct, for example, in the living Platanista spp. and mysticetes that have nasal plugs but lack a discrete roughened fossa on the premaxilla. Simocetus rayi has only an indistinct prenarial constriction, with the premaxillae barely expanded over the mesorostral groove anterior to the narial opening; a cartilaginous median septum was probably developed here and farther poste- 
riorly, to form a median border for the nasal plugs. The premaxillary sacs would have lain anterolateral rather than anterior to the bony nares, with posteromedial rather than posterior openings into the narial cavity. Extant adult odontocetes generally have one, not two, premaxillary foramina, in contrast to $S$. rayi, but double foramina do occur sporadically. For example, an adult of Lipotes vexillifer Miller has a second premaxillary foramen in the anteromedian sulcus (AMNH 57333; see also Brownell and Herald, 1972, fig. 1), and neonatal delphinids may show two closely associated premaxillary foramina that become confluent in adults. Two well-developed premaxillary foramina occur in the premaxilla of some extinct odontocetes (e.g., Patriocetus ehrlichi (Van Beneden) of Rothausen, 1968, fig. 2a; Squalodon bariensis (Jourdan) of Muizon, 1991, fig. $7 \mathrm{a})$. In these fossils, the posterior premaxillary foramen lies within the posterolateral sulcus, as in $S$. rayi.

A posteromedian sulcus, which is well developed at the premaxillary sac fossa of many other odontocetes (e.g., Lophocetus repenningi Barnes (1978:4); Mesoplodon bidens (Schenkkan 1973:5)), is not obvious in S. rayi, but another sulcus, the median premaxillary cleft, is notable. A comparable feature occurs in the fossils Waipatia maerewhenua Fordyce, 1994 (holotype OU 22095) and Lomacetus ginsburgi Muizon, 1986 (holotype MNHN PPI 104; fissure originally interpreted as a taxonomically important median suture between the premaxilla and maxilla—see Muizon, 1988c:33: "fissure longitudinale"). On the left premaxilla of the unnamed odontocete USNM 299482 , the median premaxillary cleft meets the eroded remnant of the posterolateral sulcus at a premaxillary foramen. Similar clefts arise from the premaxillary foramen in some extant odontocetes (Mesoplodon densirostris (Blainville), USNM 486173; Mesoplodon hectori (Gray), USNM 504260; Phocoena phocoena (Linnaeus), USNM 550843 and USNM 550844).

Simocetus rayi differs dramatically from extant odontocetes in the structure of its bony nares. The nasal passages of $S$. rayi are directed obliquely, with the bony nares roofed by long and dorsoventrally thin nasals and frontals, so that the external bony nares are more similar in position and orientation to those of extant mysticetes than to extant odontocetes. The nasal region in $S$. rayi could not be prepared, but some other structures may be inferred. In the unnamed archaic odontocete USNM 299482, which is similar in external topography and bone contacts to $S$. rayi, well-developed turbinal bones (Figure 5D) are exposed in the broken cross section at the posterior of a long nasal cavity (Figure 5E). Vestigial turbinals also occur in mysticetes (Edinger, 1955) and are developed well in archaeocetes (Stromer, 1908); among odontocetes, Squalodontidae may possess small cribriform plates, turbinals, and prominent olfactory peduncles within the cranium (e.g., Dart, 1923, fig. 19; Kellogg, 1928:198-202; Flynn, 1948). Turbinals are inferred, therefore, in $S$. rayi. Also in unnamed archaic odontocete USNM 299482, as in mysticetes and, presumably, S. rayi, the external bony nares are rather removed from the anteroposteriorly elongate olfactory cavity and turbinals. In contrast, most Neogene and living odontocetes have near-vertical narial passages, and anteroposteriorly short and nodular nasals that rarely roof the nares, and they lack an capacious olfactory cavity with the turbinals. Small foramina that could be vestigial olfactory foramina are nearly ubiquitous in the mesethmoid of extant odontocetes; alternatively, some of these foramina could mark the path of the nasal nerve and associated vessels. Simocetus rayi thus probably had soft tissues of the face that functioned around a snout more similar in shape to that of modern mysticetes than to modern odontocetes.

It is not clear how the prominent snout in $S$. rayi would have constrained the structure and operation of the nasal plugs, the diagonal membrane, and the nasal diverticula. Retracted nasals, a reduced olfactory complex, and development of a roughly vertical narial passage have been regarded as functionally linked to the telescoped odontocete skull (Miller, 1923; Norris, 1968). Structures in S. rayi, however, indicate that, during odontocete history, the nasofacial muscles migrated posteriorly first, and the olfactory complex was reduced later.

FACIAL ASYMMETRY.-Bilateral asymmetry at the flared rostral margins of the maxillae and antorbital notches in S. rayi is comparable to that in some other archaic odontocetes (Waipatia maerewhenua, Microcetus sharkovi Dubrovo, Squaloziphius emlongi Muizon) discussed by Fordyce (1994:165). Because this maxillary and rostral asymmetry occurs in a range of archaic odontocetes, it is presumed to be directional, with functional implications, and not merely fluctuating or random asymmetry that might be ascribed to ontogenetic "noise." Bony rostral asymmetry probably reflects asymmetry in overlying muscles, although study of living species does not help to understand which of the rostral muscles are involved (Mead, 1975; Heyning, 1989; J.G. Mead, pers. comm., 2001). Nasal asymmetry is seen in $S$. rayi; the right nasal has a more convex lateral border and blunter posterolateral profile, but whether this is fluctuating or directional asymmetry is uncertain.

Asymmetrical nasofacial muscles and/or nasal diverticula are ubiquitous in living odontocetes (Schenkkan, 1973; Mead, 1975; Heyning, 1989), even those with apparently symmetrical skulls (e.g., Pontoporia blainvillei (Gervais and d'Orbigny); cf. Kellogg, 1928, fig. 11, and Schenkkan, 1973, fig. 13). It seems likely that the largely symmetrical $S$. rayi probably also had asymmetrical facial soft tissues.

GRADES OF EVOLUTION OF THE FACE.-The grade of facial structure for Simocetus rayi is intermediate between that of the most archaic odontocete described, Archaeodelphis patrius Allen, 1921, and the rather more modern Waipatia maerewhenua Fordyce, 1994. A comparison between these species helps to understand changes in the grade of evolution of nasofacial muscles. Two other widely cited archaic taxa are not considered in this section but are discussed under "Phylogenetic Relationships," below. One, Agorophius pygmaeus (Müller) 
(see True, 1907), is known certainly only from a single, nowlost, skull for which details are unknown; it is similar in grade to $S$. rayi. Another, the enigmatic Xenorophus sloani Kellogg (1923b), is rather similar to Archaeodelphis patrius.

In $A$. patrius, the supraorbital or ascending process of the maxilla extends back little, the orbit is elevated with a prominent infraorbital process of the maxilla, development of a facial fossa on the cranium is minimal, and the dorsal infraorbital foramen lies rather anteriorly about level with the antorbital notch. Such features indicate that the nasofacial muscles originated far anteriorly on the cranium and on the base of the rostrum. Because the supraorbital process of the maxilla extends posteriorly well beyond the facial fossa and dorsal infraorbital foramina, "telescoping" of the maxilla is perhaps more than just a simple response to posterior migration of the nasofacial muscles. Anteriorly, the premaxilla is lost, so that details are not known for the premaxillary sac fossa and associated sulci.

In S. rayi, the supraorbital process extends posteriorly toward the orbitotemporal crest but not far laterally over the supraorbital process of the frontal; this condition is presumed to be intermediate between that seen in $A$. patrius and most other odontocetes. The orbit is elevated rather less than in $A$. patrius, the infraorbital process of the maxilla is minimal, and a facial fossa lies above the orbit. Multiple dorsal infraorbital foramina open both on the base of the rostrum near the antorbital notch and on the supraorbital process of the maxilla. Judging from the topography of the supraorbital region, the facial portion of the nasofacial muscles was better developed than in A.patrius. The prominent lateral crest on the supraorbital process of the frontal probably marks the limits of origins of the nasofacial muscles; interestingly, a substantial part of the supraorbital origin of the nasofrontal muscles lies on the frontal, rather than mainly on the maxilla. The premaxillary sac fossa and associated sulci lie well anterior to the antorbital notch.

Waipatia maerewhenua shows a more advanced grade, comparable to that of many extant groups: the facial fossa is large; the roof of the shallow orbit is about level with the lateral border of the rostral part of the maxilla, so that the origins of the rostral muscle 5 and facial muscle 5 are roughly on the same plane; and the maxilla does not contribute to the orbit. Well-developed premaxillary foramina and sulci are associated with a broad "spiracular plate" for the premaxillary sac fossa. Fordyce (1994) concluded that $W$. maerewhenua, with facial structure fundamentally the same as in extant Odontoceti, was probably capable of echolocation.

FEEDING APPARATUS.-Teeth in $S$. rayi contrast with the dentitions of archaeocetes in that the teeth are absolutely and relatively small, the cheek teeth are separated by marked diastemata, and the posteriormost cheek teeth are inserted far anterior to the antorbital notch. Such features also occur in the archaic mysticete genus Aetiocetus (see Barnes et al., 1995). The tooth complement of $S$. rayi is unusual for an odontocete in that upper incisors are absent and the dentition is not polydont.
The lack of alveoli in the premaxillae suggests that $11-3$ either were lost or were tiny and embedded only in the gums. In contrast, upper incisors are well developed in other archaic odontocetes, such as squalodontids and kentriodontids, and in basilosaurid archaeocetes, all of which have three premaxillary teeth. Incisors also occur in archaic mysticetes. In extant odontocetes, functional incisors are retained if functional maxillary teeth also are present. Upper incisors are absent in some living species of odontocete (e.g., Grampus griseus (Cuvier) and many Ziphiidae) that lack a functional upper dentition. Among fossil taxa, only eurhinodelphinids reportedly have toothless premaxillae. A special explanation, below, seems warranted for incisor loss in Simocetus.

Polydonty, or increase in tooth number above the usual mammalian complement, previously has been interpreted as a synapomorphy for Odontoceti (e.g., Fordyce, 1983a; Barnes, 1990:21, item 10), so that the lack of polydonty in S. rayi, an archaic odontocete, is unexpected. All extant Odontoceti, and fossil Odontoceti for which complete dentitions are known, either are polydont or have dentitions plausibly reduced from a polydont condition. For example, Xenorophus sloani Kellogg (1923b), perhaps the most archaic odontocete for which the dentition is documented, has 10 maxillary teeth. Among other Cetacea, archaic mysticetes and embryos of some living mysticetes are polydont, whereas archaeocetes and a few archaic mysticetes are not polydont (Kellogg, 1936; Barnes et al., 1995). For Simocetus, tooth complement could be plesiomorphic with archaeocetes, or it could reflect a secondary reversal to a nonpolydont state.

The feeding apparatus of $S$. rayi is quite unlike that described for other odontocetes, thereby allowing a novel interpretation of function. Alveolar form for il-c suggests that these lower teeth were procumbent, with il vestigial. Anteriorly, the dorsal surface of the conjoined mandibles at the symphysis is narrow and flat, without teeth that protrude above the jawline, so that the apically downturned mandibles probably occluded against the similarly downturned, flat, edentulous anterior of the palate. Analogs are not seen in other Cetacea, but among Sirenia, Domning (1978) observed that the degree of deflection of the sirenian rostrum appears to correlate directly with the degree to which bottom feeding is used. Sirenia generally lack functional anterior teeth and use horny pads instead to crop and crush vegetation. The apices of the rostrum and mandible are strengthened, the mandible by thickening of the dorsal edges of the horizontal bodies and lateral edges of the masticatory surface (partly developed in S. rayi), and the snout by buttressing of the dorsal outline (not in $S$. rayi). Therefore, Simocetus rayi may have been a bottom feeder. In view of the relatively delicate cheek teeth and nonbuttressed rostral apex, a durophagous diet (e.g., molluscs) seems unlikely; soft-bodied benthic invertebrates were probably taken.

Further evidence in support of bottom feeding is provided by the presence of indistinct large, shallow, paired pits at the ros- 
tral apex, presumed to be for the vomeronasal (Jacobson's) organ. A groove from each pit leads toward the presumed palatine fissure. The vomeronasal organ is a branch of the olfactory complex that is functional in some other mammals (e.g., Evans, 1993) and has been reported in extant mysticetes (Quay and Mitchell, 1971). A vomeronasal organ could have functioned in $S$. rayi as a chemoreceptor in bottom feeding.

The cheek teeth are delicate, with small denticles, and are widely spaced. Occlusal wear is on the anterior (mesial) and posterior (distal) faces, rather than on the buccal or lingual. Carnassial-like shearing seems unlikely; rather, teeth probably functioned in simple grasping or perhaps in a sieve-feeding system like that of the extant crab-eater seal, Lobodon carcinophagus (Hombron and Jacquinot) (see King, 1961). The combination of a broad palate, short mandibular symphysis, and long mandibular space indicates a voluminous mouth that could have functioned to hold water during suction feeding or filter feeding. Simocetus rayi perhaps fed on small epifaunal or shallow infaunal invertebrates detected with the aid of the vomeronasal organ. Perhaps it was a mud-grubber and used teeth to filter food from a substrate-water slurry.

The long, robust, conical unexcavated proximal portions of the pterygoid hamuli possibly functioned as secondary posterior extensions of the hard palate. Similar long hamuli occur in a few other extinct odontocetes (e.g., unnamed problematic archaic odontocete USNM 243979, the eurhinodelphinids Eurhinodelphis bossi Kellogg, 1925, Argyrocetus joaquinensis Kellogg, 1932, and the presumed eurhinodelphinid Squaloziphius emlongi Muizon, 1991), but the functional significance is not clear. Accounts of the nasopharyngeal muscles in extant odontocetes (Fraser and Purves, 1960) indicate that enlarged hamuli could play a major role in the function of the palatopharyngeal muscles.

FEEDING MUSCLES.-Skull proportions indicate that the temporalis was the largest masticatory muscle, which suggests a simple hinge closure of the mandible as in archaic eutherians, where the temporal is dominant (Turnbull, 1970). The proportions of cranium to rostrum, and to temporal fossa, indicate a lever action of the mandible that was powerful and slow; in contrast, Waipatia maerewhenua had proportionally smaller temporal fossa, longer forceps-like jaws, and an inferred faster but weaker snap (Fordyce, 1994). Other features related to the temporalis are puzzling; examples are the long tabular postorbital process (implicated in the action of the temporalis; Perrin, 1975); the straight, long inner face of the zygomatic process; and the deep cleft on the squamosal in the posterior floor of the temporal fossa. The masseter and zygomatico-mandibularis muscles were probably small, given the reduced infraorbital process of the maxilla and the small zygomatic arch of the jugal. The palatine, perhaps aided by the lateral lamina of the pterygoid, formed a large origin for the pterygoid muscles, but there is no evidence of hypertrophied pterygoideus or significant lateral $/$ medial movements of the mandibles in feeding.
The paroccipital process is large, potentially providing a large origin for the digastric muscle. Alternatively, large size could relate to articulation of the stylohyal.

ORBIT.-Key features of the orbit are the arched profile extending well above the level of the lateral border of the rostral part of the maxilla, a deep optic infundibulum, an indistinct preorbital ridge, a large infraorbital infundibulum, and a limited contribution of the maxilla to the anterior wall. In archaeocetes, the orbit is arched more strongly, with a more distinct preorbital ridge (so that the sphenopalatine foramen is better separated from the orbit); in contrast, the orbit in Neogene and living odontocetes lies about level with the alveoli and usually is flattened from above by the facial fossa. In archaeocetes, the optic infundibulum is shallower, with contributing foramina placed more posteromedially in a much narrower interorbital region than in Simocetus; possibly the depth of the optic infundibulum in $S$. rayi relates to relative interorbital width, although the functional significance of change in interorbital width is uncertain. There is no reason to think that the voluminous optic infundibulum held a rete. Simocetus rayi differs from the dorudontine archaeocete Zygorhiza kochii (see Kellogg, 1936, fig. 31c) in that the foramen rotundum for the maxillary branch of the trigeminal nerve, V2 (=sphenorbital fissure of Kellogg), opens within the optic infundibulum, together with the optic foramen and orbital fissure. Change in the position of the foramen rotundum relative to other orbital foramina may reflect shortening of the intertemporal region. Mysticetes, which have a shortened intertemporal region, also have a foramen rotundum that opens within the optic infundibulum. The relative importance of the orbital and associated foramina is hard to judge from their size; foramen size in extant Cetacea does not always correlate with size of the nerve or vessel that issues from it, and some foramina may be enlarged through the development of retia (Breathnach, 1960).

In terms of maxillary contribution to the orbit, $S$. ravi is intermediate between archaeocetes and modern odontocetes. In archaeocetes, the maxilla forms the anterior wall of the strongly arched orbit, whereas there is minimal contribution in modern odontocetes. In living species, the orbit and ventral infraorbital foramen are in about the same horizontal plane as the lateral border of the rostral part of the maxilla. The maxilla effectively forms the anterodorsal roof of the orbit. A preorbital ridge (inferior orbital crest) may be present. These changes in the orbital region perhaps reflect the posterior movement of facial muscles and development of an enlarged facial fossa, rather than major changes in eye function.

PTERYGOID SINUS.-Norris (1968) suggested that air sinuses in the basicranium may isolate the auditory region from selfproduced sound and may help to channel external sound to the periotic. Therefore, the development of sinuses may give a guide to hearing capabilities. In S. rayi, the fossae for the pterygoid sinuses are more derived than those of basilosaurid archaeocetes; they are longer relative to cranial length, extend 
relatively farther forward, are relatively more excavated dorsally, and extend ventromedially into the pterygoid hamuli. Relative to modern odontocetes, however, the fossae in $S$. rayi are more primitive in many respects. They do not extend as far anteriorly on the cranium and appear to be relatively smaller than, for example, the superficially similar but large sinus fossae of Ziphiidae and Physeteroidea. Further, the sinuses in $S$. rayi are restricted to the basicranium, in contrast to many other odontocete groups in which the sinuses invade the orbit (Fraser and Purves, 1960) through dorsal expansion, often with loss of a bony wall on the pterygoid sinus fossae.

In $S$. rayi, the alisphenoid forms the posterodorsal and posterolateral parts of the pterygoid sinus fossa, as in basilosaurid archaeocetes and the archaic mysticete Mammalodon colliveri Pritchard. None of these cetaceans is preserved well enough to see clearly how alisphenoid relates to the pterygoid at the lateral wall of the fossa.

Of the more-posterior parts of the pterygoid sinus complex, little can be said about the middle sinus, other than to emphasize that bone topography is consistent with the presence of that sinus. Proportions of the peribullary sinus (e.g., volume between bulla and basioccipital) cannot be judged because the tympanic bulla is missing. The basioccipital crest is relatively deeper and narrower than in archaeocetes, possibly contributing to an enlarged fossa for the peribullary sinus. The crest is not excavated to form a thin plate, however, as in some species of Delphinidae, for example.

Concepts of the posterior sinus among odontocetes and mysticetes are confused. Many odontocetes carry a fossa, commonly termed the fossa for the posterior sinus, on the anterior face of the paroccipital process dorsal to the apex of this process. The cavity may be deeply concave, e.g., as in Phocoena phocoena and Pontoporia blainvillei, or may be shallow but well delimited, as in Tursiops truncatus. In many odontocetes, there is a less distinct excavation anteriorly at the apex of the paroccipital process, right at the articulation of the stylohyal and clearly distal to the position of the often more distinct larger fossa. In heads of extant delphinids, injections of the pterygoid sinus complex with silicone rubber (Stenella longirostris (Gray), USNM 396173; Lagenodelphis hosei Fraser, USNM 396079) revealed that this less distinct excavation carries a small lobe of sinus that originates from the eustachian cavity via the elliptical foramen of the tympanic bulla. This lobe must be the posterior sinus sensu stricto (Fraser and Purves, 1960:9). Accordingly, the subtle fossa that lies more ventrally (more distally), near the apex of the paroccipital process, is the posterior sinus fossa sensu stricto, whereas the cavity that lies more dorsally in the paroccipital process is probably for a lobe of the peribullary sinus.

Overall, structures seen in $S$. rayi give no new insight into the function of the pterygoid sinus system, but they indicate that the basicranial sinuses were comparable in structure and hence function to those of extant odontocetes.
EAR, Hearing, and Basicranial CirCulation.-Comment on these aspects is limited, because the periotic is indifferently preserved and obscures the adjacent squamosal, and because most of the tympanic bulla is missing. The bony groove for the external auditory meatus is primitively larger than the narrow vestigial cleft of most extant odontocetes. Squamosal-bulla-periotic contacts are similar to those of Waipatia maerewhenua, Notocetus vanbenedeni Moreno, and the extant Platanista gangetica (Roxburgh) (see Muizon, 1987; Fordyce, 1994), judging from the amastoid skull wall and from contact relationships of the posterior process of the bulla with the squamosal at both the external auditory meatus and posttympanic process. It is notable that, in all extant and fossil odontocetes studied during this project, the posterior meatal crest of the squamosal articulates with the anterior face of the posterior process of the tympanic bulla. The articulation is present even in Delphinidae (although very reduced); delphinids commonly are regarded as having the tympanoperiotic disarticulated from the adjacent skull.

Some inferences may be made about cranial circulation in $S$. rayi, but with important provisos: (1) Details of arterial circulation are known reliably for only a few extant species of cetaceans (see below). (2) General features of venous circulation were described by Fraser and Purves (1960; see also their summary of Boenninghaus, 1904), but there are no detailed modern accounts of paths of individual vessels from the cranial cavity to the basicranium. (3) There seem to be no accounts of the relative contributions of nerves, arteries, and veins for any one of the major cranial foramina in odontocetes, so that it is difficult to infer vascular or neural anatomy for fossils from the form of cranial foramina alone. Comments below focus on the braincase; the face, orbit, and rostrum are not considered.

In extant Cetacea, the main arterial supply to the brain appears to be from a thoracico-spinal rete via spinal meningeal arteries that enter the foramen magnum. The internal carotid artery is small (Fraser and Purves, 1960). In fetal Physeter catodon Linnaeus, the internal carotid enters the cranium to participate in the carotid rete mirabile (Melnikov, 1997), but in adult Physeter catodon, Tursiops truncatus, and Monodon monoceros Linnaeus the vessel is occluded (McFarland et al., 1979; Vogl and Fisher, 1981; Melnikov, 1997). Nonetheless, a patent carotid foramen is a persistent feature in Cetacea. The role of arteries other than the spinal meningeal and internal carotid is not clear; Fraser and Purves (1960:26) noted that, in one injected unnamed odontocete, the middle meningeal artery, a branch of the internal maxillary artery, was involved in intracranial supply.

Cranial drainage in Odontoceti is understood less well. Fraser and Purves (1960) identified the pterygoid vein, supplemented by the internal maxillary and the internal jugular veins, as important in draining the basicranium. Apparently, none of these veins is associated with foramina that might otherwise be used to judge venous size and function. Furthermore, some 
vessels that are intracranial in other mammals are extracranial in extant odontocetes (Fraser and Purves, 1960, fig. 13), through movement of the tympanoperiotic away from the braincase. Now-extracranial features in extant species, and presumably in $S$. rayi, include the ventral and dorsal petrosal venous sinuses and the cavernous sinus. There is no petro-occipital canal for the ventral petrosal sinus, and the squamosal and/or parietal occludes the posterior lacerate foramen dorsal to the periotic (e.g., Fraser and Purves, 1960, pls. 13, 19, 26, 28). Of other venous foramina, the mastoid foramen, for the occipital emissary vein, is obscured or lost through change in contribution of the periotic to the braincase wall. The structure of the ethmoid foramen, orbital fissure, and foramen ovale in $S$. rayi are unrevealing about venous drainage.

In non-cetacean mammals, the most notable foramen that has a venous function alone is probably the postglenoid foramen (also known as the retroarticular, retroglenoid, temporal, or spurious jugular foramen). This lies at the ventral opening of the temporal canal, for passage of the temporal sinus (or dorsal cerebral vein) from the transverse sinus (Sisson and Grossman, 1953; Whitmore, 1953; Padget, 1957, pl. 6; Evans, 1993). In non-cetacean mammals, including Artiodactyla (the presumed sister group to Cetacea), the temporal canal lies wholly within the squamosal. A comparable foramen is absent in Odontoceti and Mysticeti, suggesting that the temporal sinus is lost. It could be claimed that the pathway that Fordyce (1994) identified in $W$. maerewhenua (and, here, in $S$. rayi) as that for the middle meningeal artery actually represents the path of the temporal sinus and, thus, the temporal canal and postglenoid foramen, but this seems unlikely. First, in archaeocetes, a vestigial (non-patent) postglenoid foramen lies at the base of the postglenoid process on the squamosal, posterolateral to the well-developed foramen between the periotic and squamosal that is inferred to mark the path for the middle meningeal artery. Second, the temporal canal in non-cetacean mammals lies within the squamosal, whereas the pathway for the presumed middle meningeal artery in $W$. maerewhenua is a groove on the ventromedial surface of the squamosal, dorsal and lateral to the periotic and associated with a small subcircular fossa (Fordyce, 1994).

Some features of $S$. rayi are similar to those of $W$. maerewhenua. A prominent foramen opens between the squamosal and the lateral wall of the periotic at the fovea epitubaria. More internally (cranially), a foramen, presumably for the middle meningeal artery, lies at the posterior of the parietal-alisphenoid suture near the apex of the anterior process of the periotic; this foramen is presumed to be the homolog of the subcircular fossa as seen in Squalodelphinidae and, as a small cavity, in $W$. maerewhenua. Muizon (1994:137) discussed the broader significance of the subcircular fossa in Platanistoidea, identifying it as present in the squamosal of some species of Squalodontidae, but that homology is questionable. In one well-preserved specimen referred to Squalodon calvertensis Kellogg (USNM 23537), a large foramen is present in the ventral surface of the squamosal dorsal to the periotic, but it is directed dorsally into the squamosal; it is not associated with sutures with adjacent bones, and it lacks an associated groove leading toward the foramen ovale. Such a situation contrasts with the combination of foramen (foramen spinosum) and fissure (path for presumed middle meningeal artery, associated with the parietal-alisphenoid-squamosal) that runs toward the foramen ovale from above the periotic in Waipatia (Waipatiidae) and from the subcircular fossa above the periotic in Notocetus (Squalodelphinidae) and Zarhachis (Platanistidae). In Platanista, the foramen opens in the squamosal lateral to the periotic, which is visible in ventral view. The feature in $S$. calvertensis thus is probably not related to the subcircular fossa; it could be a nutrient foramen for the squamosal, or it may indicate venous drainage of the posterior of the temporal fossa. Because of its position dorsal to the periotic, it is unlikely that this is the temporal canal. Comparable foramina occur sporadically in other odontocetes, but their taxonomic patterns and function are uncertain.

Other basicranial foramina on odontocete skulls also are problematic. Kellogg (1925) noted small foramina in the basicranium of Zarhachis flagellator (Cope), and possibly homologous foramina occur in W. maerewhenua (see Fordyce, 1994, fig. 8, foramina 1 and 2). Ridewood (1922) named the squamosal cleft in some mysticetes, where it is a deep fissure that extends ventrally from the temporal fossa to a point on the squamosal opposite the periotic. Comparable features in some extant odontocetes (Monodontidae) are associated with the squamosal/parietal suture in the temporal fossa and may indicate venous drainage; such a pathway is not seen in $S$. rayi.

\section{Phylogenetic Relationships}

CLADISTIC ANALYSIS.-Simocetus rayi shows derived structures representative of the Odontoceti, and it is not an archaeocete or a mysticete. Further, the overall primitive condition of many features in $S$. rayi suggests a basal position in the clade Odontoceti. Traditionally, basal odontocetes are placed in the family Agorophiidae, a group reviewed below. Archaic form in an organism, however, does not rule out relationships with a more-crownward taxon, and with this in mind extensive pointby-point comparisons of $S$. rayi were made with representatives of all other major odontocete clades. No single features or, notably, structural complexes, were identified that placed $S$. rayi convincingly close to one or more of the Physeteroidea, Ziphiidae, Delphinida, Eurhinodelphinidae, or Platanistoidea. A few ambiguous similarities between $S$. rayi and some of the latter taxa (e.g., toothless premaxilla, elongate conical pterygoid hamulus) are of uncertain value in placing Simocetus (see below).

To explore relationships further, $S$. rayi was included in computer-assisted cladistic analyses of odontocetes, which used the taxa, characters, and matrix of Fordyce (1994) as a starting point and added the few derived features (such as toothless premaxilla, elongate conical pterygoid hamulus, and persistent in- 
terparietal) that $S$. rayi shares with some more-crownward odontocetes. (Although comparisons are needed with other archaic "agorophiid" odontocetes, none of the latter provide enough information to warrant their inclusion in a cladistic analysis; see below.) In all analyses, $S$. rayi plotted consistently toward the base of the Odontoceti. On the cladogram of Fordyce (1994, fig. 15), it plotted immediately crownward from Archaeodelphis patrius but stemward from representative Physeteroidea, Ziphiidae, Delphinida, Eurhinodelphinidae, and Platanistoidea. Figure 18 summarizes the latter relationships. Other than positioning $S$. rayi toward the base of the odontocetes, the cladistic analyses added no new information about patterns among more-crownward odontocetes. For this reason, the characters, procedures, and results offered by Fordyce (1994) are not presented again herein, and the cladistic analysis is not taken any further.

As mentioned above, archaic odontocetes comparable with Simocetus previously have been put in the widely debated family Agorophiidae. On this point, several issues immediately require attention. Should the Agorophiidae be used as a clade based upon Agorophius pygmaeus, as Fordyce (1981) suggested? Or should Agorophiidae be used more broadly (e.g., Whitmore and Sanders, 1977) as a grade, forming a paraphyletic and perhaps polyphyletic receptacle for enigmatic archaic odontocetes? The latter seems undesirable, although $S$. rayi is still compared below with other described "agorophiid" odontocetes.

On broader relationships, some authors have suggested that the family Agorophiidae belongs with the Squalodontidae in a superfamily Squalodontoidea and, further, that the Squalodontidae may be a near-basal group of odontocetes whence some living groups evolved (e.g., Abel, 1913:221; Simpson, 1945; Slijper, 1979, fig. 36). Rothausen (1968) recognized the desirability of a cladistic approach to the Squalodontidae, and Muizon (1987, 1988a, 1988b, 1991, 1994) later convincingly argued that squalodontids are related closely to Platanista and cther Platanistoidea. The conclusion herein follows Muizon (and also Fordyce, 1994), and Squalodontoidea is regarded as a synonym of Platanistoidea. There is no reason to think that $S$. rayi is related closely to Squalodontidae. Relationships between A. pygmaeus and Squalodontidae have yet to be resolved.

Finally, despite the basal position of Simocetus rayi, the species does have a few highly specialized features of the feeding apparatus. These features preclude $S$. rayi from being ancestral to any other described species and indicate that it was an early side branch in odontocete history. For such reasons the species is placed in a new family. All these points are elaborated below.

Simocetus As AN ODONTOCETE.-Simocetus rayi shows a range of features unique to odontocetes, including a posteriorly telescoped supraorbital (ascending) process of the maxilla that is broadened laterally behind the level of the antorbital notch, a posteriorly placed dorsal infraorbital (maxillary) foramen, and the presence of a premaxillary sac fossa, premaxillary sulci,

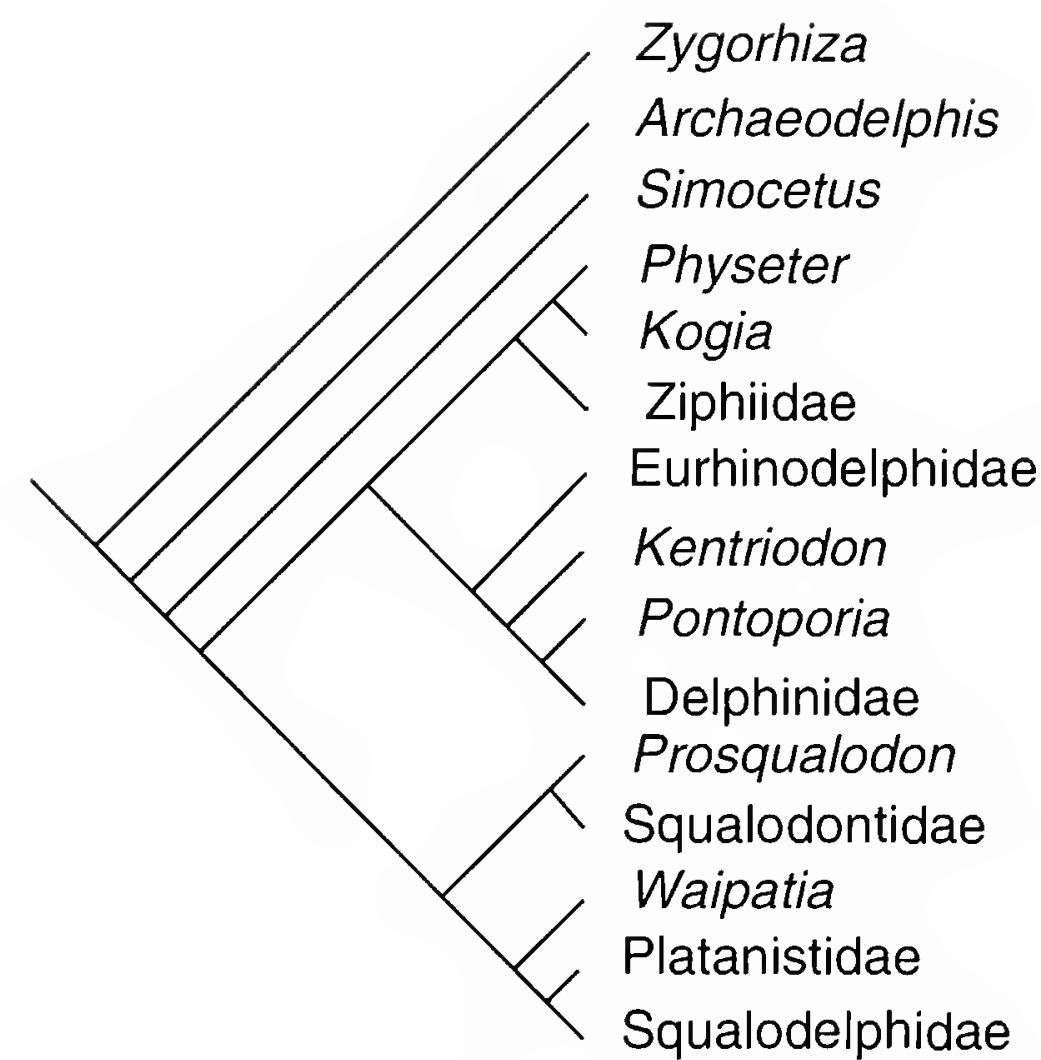

FIGURE I8.-Cladogram showing inferted relationship of Simocetus rayi to other major groups of Odontoceti. $(\dagger=$ extinct taxa.)

and premaxillary foramen (or foramina). In the orbit, the infraorbital process of the maxilla is greatly reduced, rather than conspicuous (archaeocetes) or large and plate-like (mysticetes). At the posterior of the face, the orbitotemporal crest is displaced posterodorsally relative to the postorbital ridge, so that the posterior of the face partly roofs the temporal fossa. In contrast, the orbitotemporal crest in archaeocetes (and in the odontocete family Physeteridae) lies immediately dorsal to the postorbital ridge, whereas in mysticetes the orbitotemporal crest is lost or migrates anterodorsally. The distinct antorbital notch forms a vertical groove that faces anteriorly to anterolaterally; this grooved notch is probably a concomitant of the facial fossa developed above the orbit (see comparisons with the archaic odontocetes Archaeodelphis and Xenorophus, below). An ossified mesethmoid lies between the bony nares. In the basicranium, the parietal lies dorsomedial to the periotic to occlude the cranial hiatus, and the squamosal is presumed to lie above the periotic. Finally, the region of the mandibular foramen is relatively large and ventrally inflated.

SIMILARITIES WITH MYSTICETI.-Odontocetes and mysticetes do share features not seen in archaeocetes, pointing to their sister-group relationship. Some of these features are conspicuous in $S$. rayi. For example, a cluster of dorsal infraorbital foramina opens at the base of the rostrum in $S$. rayi and in the archaic mysticete Mammalodon colliveri. The mesorostral groove in S. rayi and mysticetes is well developed anteriorly on the rostrum, but there is no anterior groove in archaeocetes; rather, the premaxillae contact each other here at a planar median suture. Simocetus rayi, other odontocetes, and Mysticeti are amastoid, with the posterior (mastoid) process of the peri- 
otic not exposed laterally on the skull wall. This may be linked with the reduced or lost contact between the periotic and exoccipital, which, in turn, perhaps reflects the development of the peribullary sinus. Teeth in odontocetes and toothed mysticetes lie anterior to the antorbital notch, but in all described odontocetes they are farther forward than in archaic mysticetes of the genus Aetiocetus (see Barnes et al., 1995). The short mandibular symphysis in $S$. rayi is reminiscent of that seen in mysticetes, but the structure in $S$. rayi is more extensive anteroposteriorly. As in mysticetes, there is an indistinct longitudinal groove toward the ventral surface of the symphysis, but whether the groove is homoplasious or synapomorphic is uncertain. The large mandibular foramen and its associated thin lateral wall ("panbone") are similar between odontocetes and archaic mysticetes, apart from the ventral inflation seen in odontocetes. Comparable structures occur in basilosaurid archaeocetes; more study of homology and function is needed.

CURRENT CONCEPTS AND PROBlems OF OdONTOCETE PHYLOGENY.--Recent cladistic analyses by Muizon (1987, 1988a, 1988b, 1991), Heyning (1989, 1997), Barnes (1990), and Fordyce (1994) help to elucidate family-level patterns within the Odontoceti and help to interpret the relationships of $S$. rayi. Sperm whales, Physeteroidea (Physeteridae and Kogiidae), are odontocetes (cf. Milinkovitch, 1995) that form a sister group to Ziphiidae. Physeteroidea and Ziphiidae together represent the Physeterida (see Muizon, 1991; Fordyce, 1994). Alternatively, sperm whales may constitute a sister group to all other odontocetes (Heyning, 1989, 1997; Barnes, 1990). The Platanistoidea (sensu Muizon, 1987, 1991; Fordyce 1994) encompasses Platanistidae, Squalodelphinidae, Waipatiidae, Squalodontidae, and perhaps Dalpiazinidae. Delphinida (sensu Muizon, 1988b) includes the Delphinoidea (Delphinidae, Phocoenidae, Monodontidae, Albireonidae, and Kentriodontidae) along with some of the "river dolphins" (Iniidae, Pontoporiidae, and the uncertainly distinct Lipotidae). Less clear are the relationships of Eurhinodelphinidae and Eoplatanistidae, which Muizon (1991) included in Eurhinodelphinoidea, a sister group to Delphinida.

Despite recent efforts, the cladistic relationships between the major groups Physeteroidea, Ziphiidae, Delphinida, Eurhinodelphinoidea, and Platanistoidea seem weakly resolved. Characters cited by Muizon and Barnes in support of their cladograms are debatable in terms of distribution among taxa (homoplasy was not always identified), applicability (a state was not always seen in all members of a clade), and polarity (the primitive versus derived states were not always clear, and transition series were not always clear-cut). Fordyce (1994) attempted to circumvent such problems through a computer analysis of an explicit matrix of characters, but even then (Fordyce, 1994, fig. 15) some of the key nodes among the Odontoceti were supported by rather few characters including reversals and features of debatable polarity (e.g., ossified lateral lamina of pterygoid sinus fossa). Heyning (1989, without data matrix; 1997, with data presented) considered only extant odontocetes, yet fossils in general are known to influence cladograms profoundly (Donoghue et al., 1989). Is there hope to get beyond this situation by using traditional anatomy, as opposed to molecular phylogeny? The described species of odontocetes, fossil and recent, have been studied in such detail and for so long that it is difficult to imagine new insights into higher relationships arising from more studies of described material. Rather, new discoveries of well-preserved fossil skulls will more likely provide the key. This is particularly the case for Oligocene fossils; material in the largely unstudied Emlong collection offers great promise.

FAMILY AgOROPHIIDAE.-The Family Agorophiidae has long been considered to encompass the phylogenetically and geologically oldest odontocetes. Supposed diagnostic features of the family (e.g., Kellogg, 1923b, and other references reviewed by Fordyce, 1981) include the presence of heterodont teeth and a primitively telescoped skull with a large intertemporal constriction. Such features occur in Simocetus, which might, therefore, be viewed as an agorophiid. These supposed diagnostic features of agorophiids, however, are plesiomorphies of no value in assessing immediate relationships. To judge the relationship between Simocetus and Agorophiidae, the latter family first should be rediagnosed on the basis of derived characters. Any rediagnosis must be based initially upon Agorophius pygmaeus (Müller, 1849), which is the type species and only species in the genus Agorophius Cope, 1895, and in turn is the type genus of the family Agorophiidae Abel, 1913.

Agorophius pygmaeus is known with certainty only from the holotype skull, from the Cooper Marl (Chattian, late Oligocene) of South Carolina (Whitmore and Sanders, 1977). No other described fossils undoubtedly belong to this species or in Agorophius, although Albert E. Sanders recently collected an apparently conspecific skull. One species possibly close to $A$. pygmaeus is "Squalodon (Microzeuglodon?)" wingei Ravn, 1926, the hypodigm of which consists of teeth, a bulla, and undescribed skull fragments from the upper Oligocene of Denmark. (Rothausen (1970) indicated that this species does not belong to Squalodon, and used the new generic name "Oligosqualodon," a nomen nudum, for the species.) Like $A$. pygmaeus, "Squalodon (Microzeuglodon?)" wingei has a cheek tooth with a high crown, indistinctly elevated denticles, and limited ornament. Relationships between these species could be elucidated if other topotypic material is found.

The holotype skull of $A$. pygmaeus is lost, and only a cheek tooth remains (specimen MCZ 8761; Fordyce, 1981), but some details of the lost skull appear in a lithograph (True, 1907, pl. 6). Clearly, Agorophius pygmaeus is an archaic odontocete. The lithograph shows overall profiles and some sutures and foramina; the skull has a prominent supraorbital process of the maxilla, a marked intertemporal constriction, a robust zygomatic process, and a moderately large, denticulate, smooth, high-crowned cheek tooth. The basicranium, tympanoperiotic, most teeth, and the mandible appear to be missing, however, and few or no details can be seen for the supraorbital process of 
the maxilla, dorsal infraorbital foramen, premaxillary sac fossa and sulci, anterior of rostrum, antorbital notch, lacrimal, nasals, orbit, and palate. Overall, the lithograph seems good enough to judge whether any new topotypic fossils might be conspecific with the lost holotype skull, and it allows limited comparisons with $S$. rayi and other archaic odontocetes. It appears, however, not to provide enough information to allow the Agorophiidae to be rediagnosed in a cladistic sense. Should we then maintain a grade family Agorophiidae for archaic odontocetes such as Xenorophus sloani, Archaeodelphis patrius, and Simocetus rayi? Perhaps not; although grade families offer easy classification of incomplete specimens, and limit the numbers of monotypic high-level basal clades, they also obscure relationships and thus oversimplify phylogenetic history. For now, the broad traditional use of Agorophiidae is not followed, and the family is used herein only for $A$. pygmaeus.

Beyond Agorophius pygmaeus, odontocetes previously referred to the Agorophiidae include Archaeodelphis patrius Allen (1921), Atropatenocetus posteocenicus Aslanova (1977), Microzeuglodon caucasicum (Lydekker, 1893), Mirocetus riabinini Mchedlidze (1970), and Xenorophus sloani Kellogg (1923b). Kellogg (1923a), Simpson (1945), Whitmore and Sanders (1977), Barnes (1978), and Fordyce (1981), among others, have commented on the family placement of these species. Comparisons with all, below, are based largely upon published accounts.

COMPARISONS OF Simocetus AND Agorophius.-Conspicuous primitive (plesiomorphic) features on the skull of $S$. rayi provide superficial similarity with $A$. pygmaeus, and, indeed, Muizon (1991:303) identified USNM 256517 (the holotype of $S$. rayi) as belonging in Agorophius. Shared primitive features include a facial fossa that is only moderately developed, a large temporal fossa open to dorsal view rather than roofed by adjacent bones, an intertemporal constriction with the parietals exposed dorsally, prominent nuchal crests, and heterodont teeth. ( $S$. rayi does show other plesiomorphies, such as the broadly exposed palatine and a pterygoid sinus fossa that is restricted to the basicranium, but comparable features cannot be seen in $A$. pygmaeus.)

More importantly, S. rayi is more derived than A.pygmaeus in some features. Its rostrum is quite dorsoventrally compressed and anteriorly deflected, with a transversely convex ventral surface, whereas that of $A$. pygmaeus appears to be straight. The braincase is more inflated at the base of the zygomatic process, and there is a deep cleft between the zygomatic process and the braincase. The outline of the supraoccipital is more hemispherical (dorsal view), the postglenoid process is thicker (lateral view), and the exoccipital extends farther laterally. Notably, Agorophius pygmaeus is more derived than $S$. rayi in its more laterally expanded supraorbital process of the maxilla and greater number of maxillary teeth (eight or more).

Comparisons of teeth also reveal differences, although it is not easy to judge their taxonomic significance. Mandibular cheek teeth in S. rayi differ from the one upper middle cheek tooth of $A$. pygmaeus in the (presumably) derived states of smaller absolute size, relatively lower crowns, relatively smaller main denticle and more free-standing accessory denticles, and more transversely compressed crowns. In S. rayi, also, tooth crowns are more asymmetrical (lateral view) and ornamented, with the main denticles displaced relatively anteriorly, but whether these conditions are primitive or derived is uncertain.

In summary, the plesiomorphies seen in these two species do not demonstrate close relationships. Furthermore, each species shows specialized features that seem to rule out close relationships. For this reason, $S$. rayi is excluded from the Agorophiidae. Differences with other archaic odontocetes, elaborated below, reinforce the suggestion that $S$. rayi belongs in its own family Simocetidae.

COMPARISONS OF Simocetus AND Archaeodelphis.-The enigmatic, monotypic small species Archaeodelphis patrius Allen, 1921, is perhaps the most archaic odontocete described. Whitmore and Sanders (1977:305) assigned it to the Cetacea incertae sedis, whereas Fordyce (1994, fig. 15) placed it at the base of the Odontoceti. Its age is possibly Oligocene (Whitmore and Sanders, 1977).

Brief examination of the holotype and only specimen of $A$. patrius (MCZ 15749; skull lacking rostrum and bullae) revealed notable differences from $S$. rayi. Simocetus rayi is more derived in having facial structures more posteriorly displaced (facial fossa, supraorbital process of the maxilla, an ascending process of the premaxilla, and dorsal maxillary foramina), a posteriorly bifurcated premaxilla, a more elevated lateral margin of the rostrum, the relatively shorter nasals, a relatively longer and more delicate postorbital process of the frontal, a robust and transversely thickened zygomatic process of the squamosal, larger pterygoid sinus fossae, long, medially apposed pterygoid hamuli into which the pterygoid sinuses extend, a more prominent basioccipital crest, a more anteroposteriorly thickened postglenoid process, and a more posterodorsally displayed orbitotemporal crest on the frontal.

Despite its overall archaic form, Archaeodelphis patrius seems quite specialized in its relatively large lacrimal, deep medial cleft between the palatines posteriorly, and thick, platelike extensions of the medial lamina of the pterygoid that meet medially to roof the choanae. As in most other odontocetes (cf. $S$. rayi), the foramen ovale is not confluent with the posterior lacerate foramen. The structure of the medial lamina of the pterygoid is so unusual that, despite its archaic structure, $A$. patrius is probably not ancestral to any other known odontocete, although perhaps the enlarged lacrimal indicates affinity with Xenorophus sloani. There is no evidence to support a close relationship with $S$. rayi.

COMPARISONS OF Simocetus AND Xenorophus.-The late Oligocene species Xenorophus sloani Kellogg (1923b) is known from the holotype (USNM 11049), an incomplete skull that lacks the tip of the rostrum, the region around the premaxillary sac fossa, and the braincase posterior to the orbits. Other 
specimens referable to Xenorophus were mentioned and figured by Whitmore and Sanders (1977), but they have not been described formally. Comparisons below are based upon study of the holotype skull and upon published illustrations (Miller, 1923, pl. 5: fig. 6; Whitmore and Sanders, 1977, fig. 1a).

There are major differences between $S$. rayi and X. sloani. As with $A$. patrius, $S$. rayi is more derived in its posteriorly displaced facial structures (facial fossa, supraorbital process of the maxilla, ascending process of the premaxilla, and posterodorsally oriented dorsal maxillary foramina), posteriorly bifurcated premaxilla, and more elevated lateral margin of the rostrum (resulting in a less abruptly elevated orbit). The antorbital notch is more prominent (dorsoventrally more shallow, anteroposteriorly deeper), the premaxillary sac fossa is broader and more tabular (although the premaxilla in X. sloani is broken, a narrow long fossa is indicated), the premaxillary sulci are more prominent, and the anterior of the mesorostral groove is more open. The cheek teeth are relatively smaller, more transversely compressed, and more emergent from the alveoli, and they have large diastemata. The palate is ventrally convex rather than flat in transverse profile and the anterior of the rostrum is dorsoventrally thin and deflected ventrally (what remains in $X$. sloani does not indicate deflection). The rostrum is relatively shorter, wider, and less abruptly attenuated, and ventrally, the posterior of the palate is relatively wider and less abruptly attenuated. The postorbital process of the frontal is relatively longer and more delicate, and the intertemporal area is shorter and wider. Finally, the supraoccipital is produced more anteriorly.

Despite its generally archaic form, Xenorophus sloani shows some intriguing derived features. A very large lacrimal dominates the preorbital and supraorbital parts of the cranium, and the supraorbital process of the maxilla is large and produced far posteriorly. Also notable are the prominent prenarial constriction, nares that open well behind the level of the antorbital notch, multiple cheek teeth with a triangular low crown and multiple small denticles, and a relatively short exposure of the frontals on the vertex. Lacrimal size alone seems to rule out affinities with any more-crownward odontocete, and there is no evidence to support a close relationship with $S$. rayi.

COMPARISONS OF Simocetus AND Atropatenocetus.-Atropatenocetus posteocenicus Aslanova, 1977, was described as a new genus and species of Agorophiidae. The holotype and only described specimen is a quite incomplete skull with fragmentary mandibles presumably from the upper Oligocene of Apsheron Peninsula, Azerbaijan. The supraorbital process of the maxilla appears to be displaced posterodorsally over the frontal. The cheek teeth are relatively larger and lower crowned than $S$. rayi, and they possess papillate ornament on the cingula. Otherwise, more meaningful comparisons are difficult. There is no hint of features that would placc this species close to Simocetus rayi or, for that matter, Agorophius pygmaeus.

COMPARISONS OF Simocetus AND Microzeuglodon.-Microzeuglodon caucasicum (Lydekker, 1893) is known only from the holotype: a posterior fragment of the left mandible with four cheek teeth, an unfigured second fragment of the jaw with five broken teeth, a left humerus, and an incomplete caudal vertebra, from an uncertain horizon in the Oligocene of Azerbaijan (Kellogg, 1923a; Mchedlidze, 1964). The species has been discussed widely without consensus as to its affinities. The large size of the mandible and teeth, relatively high crowns, prominent lingual cingula and level of insertion of the teeth, and relatively narrow diastemata suggest that $M$. caucasicum is not related closely to $S$. rayi.

COMPARISONS OF Simocetus AND Mirocetus.-Mirocetus riabinini Mchedlidze, 1970, is known only from the holotype skull and associated partial postcranial skeleton from the upper Oligocene of Caucasus. (Initially, Riabinin (1938) identified the holotype as Microzeuglodon aff. caucasicus.) The skull is distorted, albeit with basic topography preserved (Riabinin, 1938), but sutural details are unclear (K. Rothausen, pers. comm., 1980). Of note, the skull appears to possess posteriorly displaced facial fossae, which suggests that $M$. riabinini is an odontocete, rather than a species of Aetiocetidae (cf. Mchedlidze, 1976). Some features in $M$. riabinini suggest at least that it is not conspecific with $S$. rayi; for example, the skull and teeth are notably larger, the rostrum is more narrow (plesiomorphy), the supraorbital process extends farther laterally, the postorbital process is robust with a widened apex, a sagittal crest appears to be present (plesiomorphy), the zygomatic process is relatively shorter and possesses a more recurved ventral surface (plesiomorphy), the braincase is not markedly inflated anteroexternally, the supraoccipital apex is sharp, and the teeth are not inserted at the lateral edge of the rostrum. Mirocetus riabinini is similar to $S$. rayi in that the cheek teeth appear to be emergent, with parallel roots united by an isthmus, and diastemata are prominent. No features clearly indicate close relationship between $M$. riabinini and $S$. rayi or, for that matter, A. pygmaeus.

COMPARISONS WITH OTHER HETERODONT ODONTOCETES.Other named species of heterodont odontocetes might be compared with $S$. rayi. Among these are many so-called Squalodontidae based upon isolated teeth; examples from the middle Tertiary of the North American Atlantic Coastal Plain include "Phoca" debilis, "Phoca" modesta, Colophonodon holmesii, and "Squalodon" protervus. Arguably, such names based upon isolated teeth are nomina dubia, although it is always possible that such teeth will be found in place in topotypic skulls, which, in turn, might elucidate relationships. For now, these taxa cannot be compared usefully with $S$. rayi.

RELATIONSHIPS WITH OTHER GROUPS OF ODONTOCETES.A few other comparisons warrant attention. Although $S$. rayi is dramatically different from Eurhinodelphinidae in overall skull form, it is similar to some eurhinodelphinids in having a toothless premaxilla, an elongate conical pterygoid hamulus, a thick postglenoid process, and a recurved anteroexternal sulcus on the periotic. In all species of Eurhinodelphis (e.g., E. bossi Kellogg, 1925), the toothless premaxillae are elongate, forming 
a tapered distal part to the rostrum similar to that of longirostral teleosts, and in marked contrast to the short flattened distal toothless premaxillae of $S$. rayi. Simocetus rayi has elongate conical pterygoid hamuli, similar to those of Argyrocetus joaquinensis (figured in Kellogg, 1932). Elongate subcylindrical hamuli also occur in an unnamed archaic odontocete USNM 243979 (the so-called non-squalodontid odontocete of Whitmore and Sanders, 1977, fig. 2a, from ?Pysht Formation, Washington) that is not demonstrably a eurhinodelphinid. Hamular structure is known too poorly among basal odontocetes to allow reliable use in higher taxonomy. The postglenoid process in $S$. rayi is anteroposteriorly thick, as seen also in species of Eurhinodelphis (e.g., Kellogg, 1925). A thick postglenoid process, however, also occurs in the enigmatic Squaloziphius emlongi Muizon, 1991 (a possible eurhinodelphinid), and in some ziphiids; the functional significance of such thickening is uncertain. On the periotic, the ventral part of the anteroexternal sulcus is recurved forward, as seen in some eurhinodelphinids (Fordyce, 1983b), but the sulcus is shallow and indistinct in contrast to the deep sulcus of eurhinodelphinids. In this respect, the anteroexternal sulcus is more similar to that of the platanistoid groups Waipatia and Squalodelphinidae. For now, eurhinodelphinid relationships cannot be ruled out, but they are not supported strongly.

Simocetus rayt is similar to some extant Delphinidae (such as Orcaella brevirostris (Owen)) in having an identifiable or incompletely sutured interparietal in the adult. Sutures between the interparietal and adjacent elements sometimes persist in adults of other species of delphinid. This condition may be interpreted as paedomorphic. An interparietal is distinct also in late fetal stages of some mysticetes (Ridewood, 1922). Many delphinids, as with $S$. rayi, also have a short unfused mandibular symphysis. Some delphinids (e.g., Gramptus griseus) also have a palate with scattered multiple small palatine foramina, although this condition also is seen in Squalodontidae. Such features might indicate a relationship with Delphinidae or other Delphinoidea, but more convincing similarities (involving, e.g., the pterygoid sinus complex, premaxillae, and periotic) are lacking.

As with the platanistoids Waipatia maerewhenua and Squalodelphinidae, $S$. rayi has a pronounced cleft-associated with or representing the foramen spinosum, and thus presumably for the middle meningeal artery-arising near the foramen ovale and trending posterolaterally toward the periotic along or near the parieto-squamosal suture. Even in the rather archaic $W$. maerewhenua, however, the foramen spinosum lies dorsal to and is obscured by the periotic, and the foramen in Squalodelphinidae is transformed into a large subcircular fossa, whereas in $S$. rayi a foramen opens medial to the periotic and is clearly visible in ventral view. The condition in $S$. rayi could be interpreted as trending toward that of some platanistoids. Similar forms of the anteroexternal sulcus of the periotic were noted above. Beyond these, there is little particular support for platanistoid relationships.

\section{Summary}

Morphological comparisons do not clearly indicate relationships. This was emphasized during cladistic analyses, when, despite the above similarities, $S$. rayi did not cluster with any particular more-crownward clade. A more-crownward position might have been forced by character weighting, or by invoking an ordered transition series for some supposed key characters, or by invoking accelerated character transformation, but such techniques seem inappropriate given the poor understanding of the anatomy of archaic odontocetes.

Superimposed on the archaic skull of this peculiar ancient taxon are some features that are, unexpectedly, highly specialized: the premaxilla is toothless and dorsoventrally flattened, the rostrum is relatively short and broad, and the anterior of the rostrum and mandible are markedly downturned. Such attributes indicate specialized feeding behavior. Other unusual features are plausibly but less clearly autapomorphies; these include the nonpolydont tooth complement (primitive, or secondarily reduced from polydont state?), broad diastemata between posterior cheek teeth, narrow rather than laterally expanded supraorbital process of the maxilla (again, primitive, or secondarily reduced from a broader state?), and the mediolaterally deep optic infundibulum. Previously published literature might give the impression that archaic odontocetes-"agorophiids"are primitive overall, but Simocetts demonstrates that archaic taxa may indeed represent specialized side branches in odontocete history that are not close to modern clades. Simocetus rayi nevertheless shows the distinctive facial structure seen in most other odontocetes, emphasizing the early development-presumably in the most archaic of the odontocetes-of the nasofacial soft tissues and probably of echolocation abilities.

\section{Literature Cited}

Abel, $O$.

1913. Die Vorfahren der Bartenwale. Denkschriften der Akademie der Wissenschaften, Wien, Mathematisch-Naturwissenschaftliche Klasse, $90: 155-224,12$ plates.

Allen, G.M.

1921. A New Fossil Cetacean (Archaeodelphis patrius gen. et sp. nov.).
Bulletin of the Museum of Comparative Zoology at Harvard College. $65: 1-14$.

Aslanova, S.M.

1977. [A New Genus of Cetaceans (Atropatenocetus posteocenicus gen. et sp. nov.) from the Oligocene of Azerbaijan.] Doklady Akademia Nauk Azerbaidzhanskoi SSR, 33:60-64. [In Russian.] 
Barnes, L.G.

1978. A Review of Lophocetus and Liolithax and Their Relationships to the Delphinoid Family Kentriodontidae (Cetacea: Odontoceti). Science Bulletin of the Natural History Museum of Los Angeles County, 28:1-35.

1990. The Fossil Record and Evolutionary Relationships of the Genus Tursiops. In S. Leatherwood and R.R. Reeves, editors, The Bottlenose Dolphin, pages 3-26. San Diego: Academic Press.

Barnes, L.G., M. Kimura, H. Furusawa, and H. Sawamura

1995. Classification and Distribution of Oligocene Aetiocetidae (Cetacea; Mysticeti) from Western North America and Japan. The Island Arc, 3(4):392-431

Boenninghaus, $\mathrm{G}$.

1904. Das Ohr des Zahnwales. Zoologische Jahrbücher, Abteilung für Anatomie und Ontogenie der Tiere, 19:189-360.

Breathnach, A.S.

1960. The Cetacean Nervous System. Biological Review, 35:187-230.

Brownell, R.L., and E.S. Herald

1972. Lipotes vexillifer. Mammalian Species, 10: 4 pages.

Cope, E.D.

1895. Fourth Contribution to the Marine Fauna of the Miocene Period of the United States. Proceedings of the American Philosophical Society, 34:135-155.

Cranford, T.W., M. Amundin, and K.S. Norris

1996. Functional Morphology and Homology in the Odontocete Nasal Complex: Implications for Sound Generation. Journal of Morphology, 228:223-285.

Curry, B.E.

1992. Facial Anatomy and Potential Function of Facial Structures for Sound Production in the Harbor Porpoise (Phocoena phocoena) and Dall's Porpoise (Phocoenoides dalli). Canadian Journal of Zoology. 70:2103-2114.

Dart, R.A.

1923. The Brain of the Zeuglodontidae (Cetacea). Proceedings of the Zoological Society of London, 1923:615-648.

Davis, D.D.

1964. The Giant Panda: A Morphological Study of Evolutionary Mechanisms. Fieldiana, Zoology Memoirs, 3:1-339.

Domning, D.P.

1978. Sirenian Evolution in the North Pacific. University of California Publications in Geological Sciences, 118:1-176.

Domning, D.P., C.E. Ray, and M.C. McKenna

1986. Two New Oligocene Desmostylians and a Discussion of Tethytherian Systematics. Smithsonian Contributions to Paleobiology, 59: $1-56$.

Donoghue, M.J., J.A. Doyle, J. Gauthier, A.G. Kluge, and T. Rowe

1989. The lmportance of Fossils in Phylogeny Reconstruction. Annual Reviews of Ecology and Systematics, 20:431-460.

Edinger, $\mathrm{T}$.

1955. Hearing and Smell in Cetacean History. Monatschrift für Psychiatrie und Neurologie, 129:37-58

Evans, H.E., editor

1993. Miller's Anatomy of the Dog. Third edition, 1113 pages. Philadclphia: W.B. Saunders

Flynn, T.T.

1948. Description of Prosqualodon davidi Flynn, a Fossil Cetacean from Tasmania. Transactions of the Zoological Society of London, 25: 153-197.

Fordyce, R.E.

1981. Systematics of the Odontocete Agorophius pygmaeus and the Family Agorophiidae (Mammalia: Cetacea). Journal of Paleontology 55: 1028-1045.

1983a. Dental Anomaly in a Fossil Squalodont Dolphin from New Zealand, and the Evolution of Polydonty in Whales. New Zealand Journal of Zoology, 9:419-426. 1983b. Rhabdosteid Dolphins (Mammalia: Cetacea) from the Middle Miocene, Lake Frome Area, South Australia. Alcheringa, 7:27-40.

1994. Waipatia maerewhenua, New Genus and New Species (Waipatiidae, New Family), an Archaic Late Oligocene Dolphin (Cetacea: Odontoceti: Platanistoidea) from New Zealand. Proceedings of the San Diego Museum of Natural History, 29:147-176

Fraser, F.C., and P.E. Purves

1960. Hearing in Cetaceans: Evolution of the Accessory Air Sacs and the Structure of the Outer and Middle Ear in Recent Cetaceans. Bulletin of the British Museum (Natural History), Zoology, 7:1-140 pages, frontispiece, plates 1-53.

Heyning, J.E.

1989. Comparative Facial Anatomy of Beaked Whales (Ziphiidae) and a Systematic Revision among the Families of Extant Odontoceti. Contributions in Science, Natural History Museum of Los Angeles County, 405:1-64.

1997. Sperm Whale Phylogeny Revisited: Analysis of the Morphological Evidence. Marine Mammal Science, 13(4):596-613.

Heyning, J.E., and J.G. Mead

1990. Evolution of the Nasal Anatomy of Cetaceans. In J. Thomas and R. Kastelein, editors, Sensory Abilities of Cetaceans, pages 67-69. New York: Plenum Press.

Howell, A.B.

1927. Contribution to the Anatomy of the Chinese Finless Porpoise Neomeris phocaenoides. Proceedings of the United States National Museum, 70(13): 43 pages [publication 2662].

Huber, E.

1930. Evolution of Facial Musculature and Cutaneous Field of Trigeminus. Quarterly Review of Biology, 5:133-187.

1934. Anatomical Notes on Pinnipedia and Cetacea. Carnegie Institution of Washington Publication, 447:105-136.

Kasuya, T.

1973. Systematic Consideration of Recent Toothed Whales Based on the Morphology of Tympano-Periotic Bone. Scientific Reports of the Whales Research Institute, Tokyo, 25:1-103.

Kellogg, $\mathrm{R}$

1923a. Description of Two Squalodonts Recently Discovered in the Calvert Cliffs, Maryland; and Notes on the Shark-Toothed Dolphins. Proceedings of the United States National Museum, 62(6):1-69.

1923b. Description of an Apparently New Toothed Cetacean from South Carolina. Smithsonian Miscellaneous Collections, 76(7): 7 pages, 2 plates.

1925. On the Occurrence of Remains of Fossil Porpoises of the Genus Eurhinodelphis in North America. Proceedings of the United States National Museum, 66(26): $1-40$.

1926. Supplementary Observations on the Skull of the Fossil Porpoise Zarhachis flagellator. Proceedings of the United States National Museum, 67(28): 18 pages, 5 platcs.

1928. History of Whales: Their Adaptation to Life in the Water. Quarterly Review of Biology, 3:29-76, 174-208.

1932. A Miocene Long-Beaked Porpoise from California. Smithsonian Miscellaneous Collections, 87(2): 11 pages, 4 plates.

1936. A Review of the Archaeoceti. Carnegie Institution of Washington Publication, 82: 366 pages, 37 plates.

King, J.E

1961. The Feeding Mechanism and Jaws of the Crabeater Seal (Lobodon carcinophagus). Mammalia, 25:462-466.

Lawrence, B., and W.E. Schevill

1956. The Functional Anatomy of the Delphinid Nose. Bulletin of the Museum of Comparative Zoology at Harvard College, 114:103-151.

Lydckker, R

1893. On Zeuglodont and Other Cetaccan Remains from the Tertiary of the Caucasus. Proceedings of the Zoological Society of London, 1892:558-564. 
McFarland, W.L., M.S. Jacobs, and P.J. Morgane

1979. Blood Supply to the Brain of the Dolphin, Tursiops truncatus, with Comparative Observations on Special Aspects of the Cerebrovascular Supply of Other Vertebrates. Neuroscience and Biobehavioural Reviews, supplement 1, 3:1-93.

Mchedlidze, G.A.

1964. [Fossil Cetaceans of Caucasus.] 144 pages. Tbilisi, Georgia: Izdatel'stvo Metsniereba. [In Russian.]

1970. [Some Features of the Historical Development of the Cctacea, Part 1.] 112 pages. Tbilisi, Georgia : Metsniereba. [In Russian.]

1976. [The Basic Features of the Paleobiological History of the Cetacea.] 136 pages. Tbilisi, Georgia: Metsniereba. [In Russian.]

Mead, J.G.

1975. Anatomy of the External Nasal Passages and Facial Complex in the Delphinidae (Mammalia: Cetacea). Smithsonian Contributions to Zoology, 207:1-72.

Melnikov V.V.

1997. The Arterial System of the Sperm Whale (Physeter macrocephalus). Journal of Morpholog: 234(1):37-50.

Milinkovitch, M.C.

1995. Molecular Phylogeny of Cetaceans Prompts Revision of Morphological Transformations. Trends in Ecology and Evolution, 10(8): 328-334.

Miller, G.S.

1923. The Telescoping of the Cetacean Skull. Smithsonian Miscellaneous Collections, $76(5)$ : 70 pages, 8 plates.

Moris, $\mathrm{F}$.

1969. Étude anatomique de la région céphalique du marsouin Phocaena phocaena L. (Cetacé: Odontocete). Mammalia, 33:666-726.

Müller, J.

1849. Über die fossilen Reste der Zeuglodonten von Nordamerica, mit Rucksicht auf die europäischen Reste aus dieser familie. 38 pages. Berlin: Reimer.

Muizon, C. de

1986. Un nouveau Phocoenidae (Odontoceti, Cetacea) du Miocène supérieur de la Formation Pisco (Pérou). Comptes Rendus de l'Academie des Sciences, series 2, 303:1509-1512.

1987. The Affinities of Notocetus vanbenedeni, an Early Miocene Platanistoid (Cetacea, Mammalia) from Patagonia, Southern Argentina. American Museum Novitates, 2904: 27 pages.

1988a. Le polyphylétisme des Acrodelphidae, Odontocètes longirostres du Miocène européen. Bulletin du Muséum Nationale d'Histoire Naturelle (Paris), series 4, section C, 10(1):31-88.

1988b. Les relations phylogénétiques des Delphinida (Cetacea, Mammalia). Annales de Paléontologie, 74(4):159-227.

1988c. Les vertébrés fossiles de la Formation Pisco (Pérou), Troisième partie: Les odontocètes (Cetacea, Mammalia) du Miocène. Mémoires del'Institut Français d'Études Andines, 78:1-244.

1991. A New Ziphiidae (Cetacea) from the Early Miocene of Washington State (USA) and Phylogenetic Analysis of the Major Groups of Odontocetes. Bulletin du Muséum Nationale d'Histoire Naturelle, Paris, series 4, section C, 12(3-4):279-326.

1994. Are the Squalodonts Related to the Platanistoids? Proceedings of the San Diego Museum of Natural History, 29:135-146.

Norris, K.S.

1968. The Evolution of Acoustic Mechanisms in Odontocete Cetaceans. In E.T. Drake, editor, Evolution and Environment, pages 297-324. New Haven: Yale University Press.

Novacek, M.J.

1986. The Skull of Leptictid Insectivorans and the Higher-Level Classification of Eutherian Mammals. Bulletin of the American Museum of Natural History, 183(1):1-112.

Padget, D.H.

1957. The Development of the Cranial Venous System in Man, from the Viewpoint of Comparative Anatomy. Contributions to Embryology,
Perrin, W.F.

$$
\text { Carnegie Institution of Washington, 36:79-140. }
$$

1975. Variation of Spotted and Spinner Porpoise (Genus Stenella) in the Eastern Tropical Pacific and Hawaii. Bulletin of the Scripps Institution of Oceanography, 21:1-206.

Quay, W.B., and E.D. Mitchell

1971. Structure and Sensory Apparatus of Oral Remnants of the Nasopalatine Canals in the Fin Whale (Balaenoptera physalus L.). Journal of Morphology, 34:271-280.

Ravn, J.P.J.

1926. On a Cetacean, Squalodon (Microzeuglodon?) wingei nov. sp., from the Oligocene of Jutland. Meddelelser fra Dansk Geologisk Forening, 7:45-54.

Ray, C.E.

1976. Fossil Marine Mammals of Oregon. Systematic Zoology, 25:420436. [Date on title page is 1976; actually published in 1977.]

1980. [Obituary] Douglas Ralph Emlong 1942-1980. News Bulletin of the Society of Vertebrate Paleontology, 120:45-46.

Riabinin, A.N.

1938. Microzeuglodon aff. caucasicum Lyd. iz verkne-Maikopskikh otlozhenii Kabristana. Problemy Paleontologii, 4:137-185.

Ridewood, W.G.

1922. Observations on the Skull in Foetal Specimens of Whales in the Genera Megaptera and Balaenoptera. Philosophical Transactions of the Royal Society of London, series B, 211:209-272.

Rothausen, $\mathrm{K}$

1968. Die systematische Stellung der europäischen Squalodontidae (Odontoceti: Mamm.). Paläontologische Zeitschrift, 42:83-104.

1971. Marine Reptilia and Mammalia and the Problem of the OligoceneMiocene Boundary. Giornale di Geologia, series 2, 35:181-189.

Schenkkan, E.J.

1973. On the Comparative Anatomy and Function of the Nasal Tract in Odontocetes (Mammalia, Cetacea). Bijdragen Tot de Dierkunde, 43:127-159.

Schenkkan, E.J., and P.E. Purves

1973. The Comparative Anatomy of the Nasal Tract and the Function of the Spermaceti Organ in the Physeteridae (Mammalia, Odontoceti). Bijdragen Tot de Dierkunde, 43(1):93-112.

Schulte, H. von, and M. de F. Smith

1918. The External Characters, Skeletal Muscles, and Peripheral Nerves of Kogia breviceps (Blainville). Bulletin of the American Museum of Natural History, 38:7-72.

Simpson, G.G

1945. The Principles of Classification, and a Classification of Mammals. Bulletin of the American Museum of Natural Histon: 85:1-350.

Sisson, S., and J.D. Grossman

1953. The Anatomy of the Domestic Animals. Fourth edition, 972 pages. Philadelphia: W.B. Saunders.

Slijper, E.J.

1979. Whales. Second edition, 511 pages. London: Hutchinson. [Translated from the original, Walvissen, by A.J. Pomerans.]

Snavely, P.D., N.S. McLeod, W.W. Rau, W.D. Addicott, and J.W. Pearl

1975. Alsea Formation: An Oligocene Marine Sedimentary Sequence in the Oregon Coast Range. Bulletin of the U.S. Geological Survey, 1395F:1-21.

Snavely, P.D., N.S. MacLeod, H.C. Wagner, and W.W. Rau

1976. Geology of the Yaquina and Toledo Quadrangles, Oregon. U.S. Geological Survey, Miscellaneous Investigations Series, 1:62,500, map 1-867:1-21.

Stromer, E.

1908. Die Archaeoceti des ägyptischen Eocäns. Beiträge zur Geologie und Paläontologie von Österreich-Ungarn, 21:106-178

True, F.W.

1907. Remarks on the Type of the Fossil Cetacean Agorophius pygmaeus (Müller). Smitlisonian Institution Publication, 1694:1-8. 
Turnbull, W.D.

1970. Mammalian Masticatory Apparatus. Fieldiana, Geology 18:147- 356. Vogl, A.W., and H.D. Fisher

1981. The Internal Carotid Artery Does Not Directly Supply the Brain in the Monodontidae (Order Cetacea). Journal of Morphology, 170: 207-214.

Whitmore, F.C.

1953. Cranial Morphology of Some Oligocene Artiodactyla. U.S. Geological Survey Professional Paper, 243-H:117-160.
Whitmore, F.C., and A.E. Sanders

1977. Review of the Oligocene Cetacea. Systematic Zoology, 25:304-320. Winge, $\mathrm{H}$.

1921. A Review of the Interrelationships of the Cetacea. Smithsonian Miscellaneous Collections, 72(8):1-97.

Wood, F.G., and W.E. Evans

1980. Adaptiveness and Ecology of Echolocation in Toothed Whales. In R.G. Busnel and J.F. Fish, editors, Animal Sonar Systems, pages 381-425. New York: Plenum Press. 


\title{
Odobenocetops peruvianus, the Walrus-Convergent Delphinoid (Mammalia: Cetacea) from the Early Pliocene of Peru
}

\author{
Christian de Muizon, Daryl P. Domning, \\ and Darlene R. Ketten
}

\begin{abstract}
Odobenocetops peruvianus Muizon, 1993 (early Pliocene, southern Peru), is a bizarre cetacean that is convergent in its skull, general aspect, and presumably feeding habits with the modern walrus Odobenus rosmarus (Linnaeus). Its cranial specializations are unique among cetaceans and include loss of the elongated rostrum, development of large premaxillary processes housing asymmetrical tusks, forward migration of the bony nares, reversal of the typical cetacean telescoping of the skull, dorsal binocular vision, large vaulted palate, and an inferred upper lip. The structure of the basicranium (possession of palatine expansions of the pterygoid sinus and presence of a large cranial hiatus) and face (possession of a medial portion of the maxillae at the anterior border of the nares) indicates that it belongs to the odontocete infraorder Delphinida and to the superfamily Delphinoidea. Within this group Odobenocetops is related to the Monodontidae because of the lateral lamina of its palatine flooring the optic groove, the anteroposterior elongation of the temporal fossa, and the thickness of the alisphenoid and squamosal in the region of the foramen ovale. We hypothesize that Odobenocetops, like the walrus, fed upon shallow-water benthic invertebrates and probably used its tongue and upper lip jointly in extracting the soft parts of bivalves or other invertebrates by suction. The highly modified morphology of the rostrum indicates that there was no melon as in all other odontocetes, and therefore that Odobenocetops was probably unable to echolocate; binocular vision could have compensated for this inability. The most probable function of the tusks themselves was social, as in the living walrus, but we suggest that the historically primary function of both the premaxillary processes of Odobenoc-
\end{abstract}

Christian de Muizon, UMR 8569 CNRS, Laboratoire de Paléontologie, Muséum National d'Histoire Naturelle, 75005 Paris, France. Email:muizon@cimrsI.mnhn.fr.Daryl P.Domning,Research Associate, Department of Paleobiology, National Museum of Natural History, Smithsonian Institution, Washington, D.C. 20560-0121, and Laboratory of Evolutionary Biology, Department of Anatomy, College of Medicine, Howard University, Washington, D.C. 20059, United States.Email:ddomning@fac.howard.edu.Darlene R. Ketten, Massachusetts Eye and Ear Infirmary, Harvard Medical School, Boston, Massachusetts 02114, United States.Email:dketten@whoi.edu. etops and the tusks of Odobenus was as orientation guides in feeding. This reopens the question of whether the tusks of walruses play a role in feeding, as it seems that these also may be useful as orientation guides for the mouth and vibrissal array.

\section{Introduction}

Abundant remains of fossil odontocete cetaceans have been found in the rocks of the Pisco Formation near the southern coast of Peru. Although the occurrence of cetacean bones in this area has been known for more than one hundred years (Lisson, 1890), the first odontocete described from this formation was Incacetus brogii Colbert, 1944. Subsequently, Hoffstetter (1968) was the first to show the importance of the faunal assemblage (fish, reptiles, birds, and mammals) of the locality of Sacaco, in the southern outcrops of the Pisco Formation, 540 $\mathrm{km}$ south of Lima. Further studies by Muizon (1981, 1983a, 1983b, 1983c, 1984, 1986, 1988), Pilleri (1989, 1990), and Cheneval (1992) have described part of the vertebrate fauna of the Pisco Formation, but abundant material still remains unstudied (work in progress includes that of C. de Muizon and G. McDonald on mammals, and J. Cheneval on birds). As established by Marocco and Muizon (1988), the Sacaco vertebrate fauna was deposited under shallow waters in a littoral and beach environment. The preservation of the fossils is exceptional, and associated skeletons are not rare; both characteristics indicate calm waters.

In 1990, the skull of an unexpected walrus-like cetacean (Muizon, 1993a) was found in the locality called "Sud-Sacaco" by Muizon (1981). In the Sacaco area, Muizon (1981, 1984, 1988a), Muizon and DeVries (1985), and Muizon and Bellon (1986) recognized five vertebrate horizons, which range from the late Miocene to the late Pliocene (approximately $9 \mathrm{Ma}$ to 3 Ma). The specimen came from the Sud-Sacaco (SAS) horizon, earliest Pliocene, which has yielded an abundant vertebrate fauna (Muizon, 1981, 1984). Cetaceans are represented there 
by balaenopterids, cetotheriids, pontoporiids (Pliopontos littoralis), ziphiids (Ninoziphius platirostris), and phocoenids (Piscolithax longirostris). The walrus-like cetacean, named Odobenocetops peruvianus, was briefly described by Muizon (1993a, 1993b), who concluded that its feeding adaptations were convergent with those of the walrus. Herein we describe that specimen more thoroughly and present a more detailed study of its features as a foundation for observations on the paleobiology of this unique cetacean. Its phylogenetic relationships with delphinoid odontocetes are confirmed.

INSTITUTIONAL ABBREVIATIONS.-The following abbreviations for institutions have been used:

\section{MNHN Muséum National d'Histoire Naturelle, Paris}

NMNH National Museum of Natural History, Smithsonian Institution, Washington, D.C.

SMNK Staatliches Museum für Naturkunde, Karlsruhe, Germany

USNM Collections of the NMNH, which include those of the former United States National Museum

ACKNOWLEDGMENTS. - This research was supported by funds from the Centre National de la Recherche Scientifique (CNRS), Paris, in 1991; by two short-term visitor awards from the Smithsonian Institution, Washington D.C., in 1992 and 1993; and by funds from the Institut Français d'Études Andines (Lima, Peru) in 1994 (to C. de Muizon). CT scanning and periotic analyses were supported by Office of Naval Research contracts N00014-2-J-4000 and N00014-93-1-0940 (to D.R. Ketten) and by the Three-Dimensional Head and Neck Imaging Service, Department of Otolaryngology, Massachusetts Eye and Ear Infirmary. Beluga periotics were provided by S. Ridgway, Naval Research and Development (NRD, San Diego. We thank C. Martín, who found the specimen, and P.L. Larson, who collected it and donated it to the Smithsonian Institution. P. Kroehler prepared the specimen. Illustrations, including the life reconstruction (Figure 20), are by Mary Parrish (NMNH); photographs are by Vic Krantz and Chip Clark (both NMNH), and D. Serrette (MNHN). Irina Koretsky helped greatly with the illustrations. Valuable insights through discussion were provided by L.G. Barnes, T.A. Deméré, R.E. Fordyce, J.G. Mead, C.E. Ray, J.S. Reidenberg, and A. Werth. Ray and Werth also provided detailed formal reviews of the manuscript.

We are pleased to dedicate this paper to Clayton E. Ray, who invited us to study the specimen under his care and who greatly helped and encouraged us in our work.

\section{Systematic Paleontology}

\section{Superfamily DELPHINOIDEA}

\section{Family ODOBENOCETOPSIDAE Muizon (1993a)}

TYPe Genus.-Odobenocetops Muizon (1993a).

Diagnosis.-As for the single known species, $O$. peruvianus Muizon (1993a).

\section{Genus Odobenocetops Muizon (1993a)}

TYPE SPECIES.—Odobenocetops peruvianus Muizon (1993). DIAGNOSIS.-As for the species.

\section{Odobenocetops peruvianus Muizon (1993a)}

\author{
FIGURES 1-18, TABLE 1
}

TYPE SPECIMEN.-USNM 488252 (originally numbered USNM 460306), an incomplete skull lacking much of the left side and all of the auditory bones.

REFERRED SPECIMENS.-MNHN SAS 1613, a left periotic and partial tympanic; and MNHN SAS 1614, a left periotic.

One other, recently discovered specimen (MNHN SAO 202) is relevant to this study but is not described herein in detail; it will be described in a separate report (Muizon and Domning, 2002). It is a badly weathered partial skeleton with a partial skull, including the left tympanic, periotic and asymmetrical tusk; the distal half of a humerus; a complete radius; several dorsal and caudal vertebrae; and rib fragments. It was found in the SAO horizon of the Pisco Formation (ca. 3.5 Ma), which is younger than the SAS horizon (ca. $5 \mathrm{Ma}$ ), and is provisionally referred herein to Odobenocetops sp. (see "Addendum," below; Muizon et al., 1999).

ETYMOLOGY.-From odon, tooth, and baino, walk (Greek); and from cetus (Latin, from Greek ketos), whale, and ops (Greek, masculine), like: "the cetacean that seems to walk on its teeth," to refer to its feeding position (see below) and also to its similarity to the walrus (Odobenus). Species: peruvianus, from Peru.

DiAGNOSIS.-Delphinoid cetacean characterized by loss of elongate cetacean rostrum and concomitant probable absence of melon; development of large, ventrally directed premaxillary alveolar processes housing straight tusks; right tusk longer than $55 \mathrm{~cm}$, cylindrical, with oval section, with long, open pulp cavity $23 \mathrm{~cm}$ deep; left tusk probably unerupted and probably no longer than $20 \mathrm{~cm}$, with short conical pulp cavity $1.5 \mathrm{~cm}$ deep; important muscular insertion and numerous neurovascular foramina on anterior side of premaxillae and on anterior extremity of palate, suggesting presence of strong upper lip and possible vibrissae; regression in telescoping of skull by forward migration of nares and anterior withdrawal of maxillae and frontals; nasal on vertex of skull, contacting occipital and right maxilla, lying upon frontals but separated from mesethmoid, which followed bony nares in their forward migration; large temporal fossa open dorsally; large dorsal exposure of parietals and concomitant development of temporalis muscle origin; large orbits facing dorsally and not laterally as in other odontocetes; large pre- and postorbital processes expanded anterolaterally; maxillae articulating behind nares; large, deep, and vaulted palate; maxillae excluded from palate but forming part of lateral wall of skull; no maxillary teeth; no jugal; vomer very large and lanceolate; lateral lamina of palatine flooring the anteroposteriorly oriented optic gutter; pterygoid with flattened 
subhorizontal hamular process and large rounded lateral crest for origin of pterygoid muscle; ventral surface of zygomatic process of squamosal forming large and deep anteroposteriorly elongated, trough-like glenoid fossa; large cranial hiatus; alisphenoid and squamosal strongly thickened on anterolateral region of cranial hiatus. Periotic with relatively small pars cochlearis and long and thickened anterior process with small bullar facet; ventral process with relatively flattened ventral rim and large ventral tuberosity; very large dorsal aperture of aqueductus vestibuli; periotic tympanic with clearly sigmoidshaped involucrum.

GeOlOgicAl Formation AND AgE.-Pisco Formation, SAS (Sud-Sacaco) level as defined by Muizon (1981) and Muizon and DeVries (1985). As stated by these authors, the age of the Sud-Sacaco beds is early Pliocene, probably basal Pliocene, approximately $5 \mathrm{Ma}$.

TYPE LOCALITY.-Sud-Sacaco, southern coast of Peru, on the west side of the Panamerican Highway at km 542.

\section{DESCRIPTION}

GENERAL FEATURES.-The general morphology of the skull of Odobenocetops peruvianus is far from that of a typical cetacean. The hyperspecialization of this species (within the cetaceans) has resulted in the modification of the characteristic telescoping of the cetacean skull. The skull is bilobate in dorsal view, with a large braincase posteriorly and an anterior part made up of the narial, orbital, and rostral regions. These are separated by a well-marked constriction situated behind the supraorbital processes of the frontals. Such a condition is not observed in the other Neogene odontocetes, where the posterior expansions of the frontals and maxillae cover the braincase and the temporal fossa. In some primitive odontocetes (Xenorophus, Archaeodelphis, and Agorophius) and in archaeocetes, a similar condition can be observed because of the slight telescoping of the skull; in Odobenocetops, the condition described above is the result of a character reversal that considerably reduces the telescoping. Related to this reversal is the anterior position of the nares and of the orbits. The nares are very large compared with those in the Holocene Delphinoidea. They are anteroposteriorly elongate, and their length is more than double their width. The left naris is slightly larger than the right. The dorsal openings of the nares are horizontal (contrary to other Delphinoidea, where they are anterodorsally oriented), and they are not partially overhung in their anterior part by the maxillae and the premaxillae. In Odobenocetops the anterior walls of the narial passages face posterodorsally (posteroventrally in other delphinoids) and their contact with the dorsal surface of the premaxillae is a gently rounded surface, whereas it is a sharp crest in the other delphinoids. In lateral view, the dorsal profile of the skull is markedly concave; the nuchal crest and the rounded anterior part of the snout clearly overhang the much lower narial fossae and the posterior portion of the maxillae. Another obvious characteristic of Odobenocetops is the reduction of the rostrum and the development of large premaxillary alveolar processes housing the tusks that give the skull a strong, although superficial, resemblance to that of the modern walrus. As preserved, the skull is large, with an anteroposterior length of approximately $46 \mathrm{~cm}$ (the posterior part of the only condyle preserved is missing) and an estimated bizygomatic width of $18 \times 2=36 \mathrm{~cm}$ (Figure 1).

Premaxilla: The premaxillae are certainly the most amazing bones of the skull of $O$. peruvianus. Compared with other odontocetes, the elongate rostrum has disappeared, and the premaxillae show long ventral processes just anterior to the preorbital notch that form an angle of approximately $60^{\circ}$ with the horizontal plane of the skull (Figures 2,3). This condition defines a small dorsal horizontal portion of the premaxillae, situated between the anterior edge of the naris and the apex of the snout, and a large subvertical portion, the alveolar process, located almost entirely on the ventral part of the skull (i.e., below the supraorbital process of the frontal). The ventral extremity of the alveolar process is posterior to its dorsal extremity and below the postorbital process of the frontal. It is hollowed by large alveoli housing the tusks (see below). The right premaxilla is almost complete, but the left is broken and lacks most of the alveolar process.

On the dorsal side of the skull (Figures 1,2), the premaxillae form the anterolateral edges of the nares; in that region, the bones have a conspicuous posterolateral process that runs along the anterior half of the lateral border of the nares on the left side, and along nine-tenths of its length on the right side. The anterior border of each naris is formed medially by a small medial portion of the maxilla and laterally by the premaxilla. Anterior to the nares the premaxillae become narrower, being narrowest just behind the fairly large premaxillary foramina. In that region they are thick and each bears a dorsolateral rounded keel that runs anteriorly from the posterolateral process, passes lateral to the premaxillary foramen (forming its lateral border), and converges with the other keel in the anteriormost region of the snout.

These keels mark the limits of an elongate triangle just anterior to the bony nares; in this area, in other odontocetes, are located the premaxillary sacs (posterior to the premaxillary foramina) and the origins of the nasal plug muscles (medial and anterior to the premaxillary foramina). The premaxillary sacs of the other Delphinoidea are generally situated upon the part of the premaxilla posterior to the premaxillary foramina and anterior and lateral to the nares; in Odobenocetops there was very little space for such air sacs and, if present, they must have been extremely reduced. The origin of the nasal plug muscle on the premaxillae of other delphinoids is generally a rugose lozenge-shaped or triangular area located medial and mostly anterior to the premaxillary foramina; in Odobenocetops, this part of the premaxilla is small, suggesting that the nasal plug muscle, if present, would have been fairly weak.

Demarcating the lateral edges of the triangular surface, and anterior to the premaxillary foramina, the rounded keels men- 

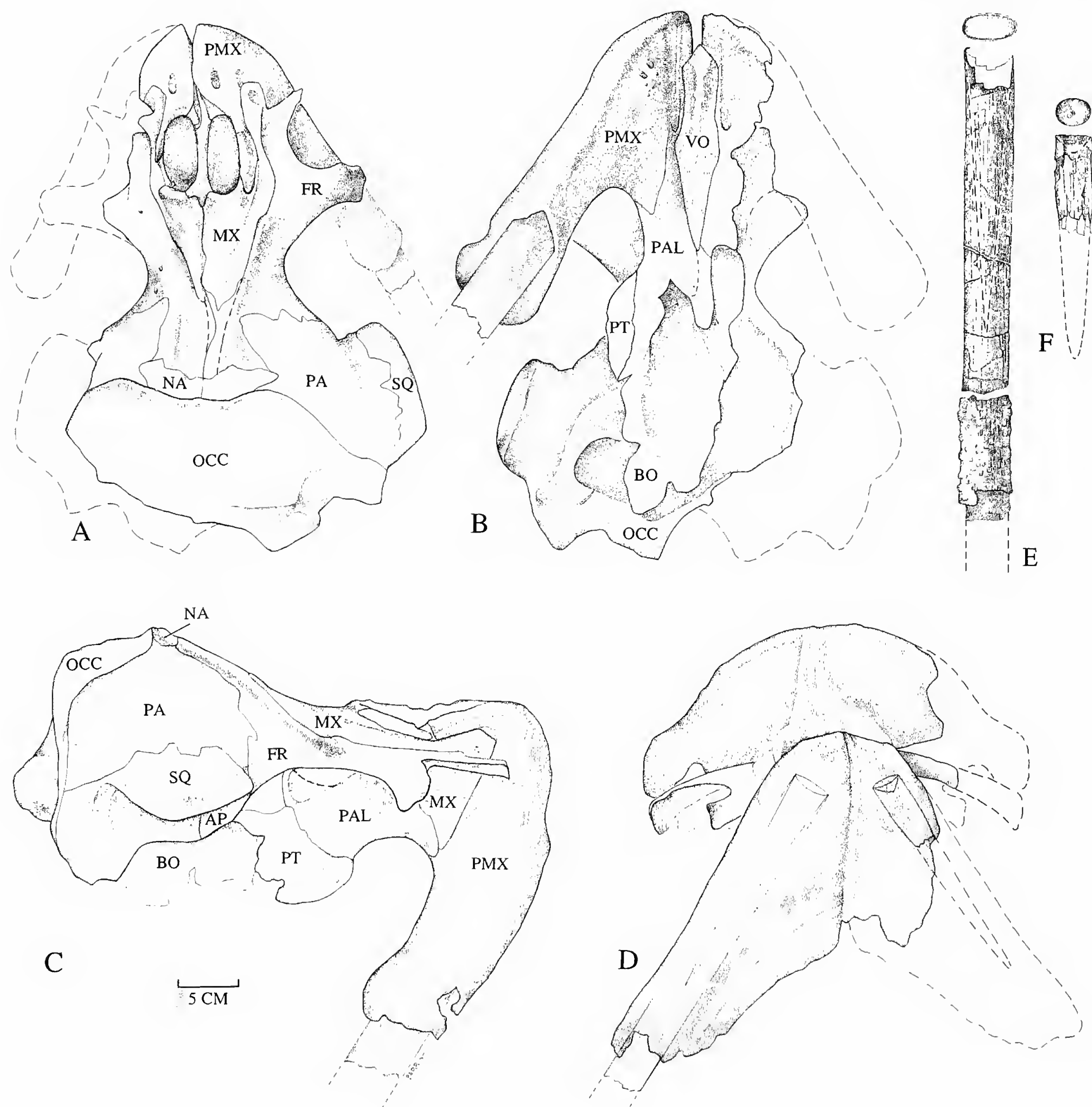

FIGURE 1.-Odobenocetops peruvianus, holotype (USNM 488252): skull in dorsal view (a), ventral view (b), lateral view $(c)$, and anterior view $(d)$; right premaxillary tusk $(e)$ in lateral view (bottom) and proximal view (top); left premaxillary tusk $(f)$ in lateral view (bottom) and proximal view (top).

tioned above are very thickened and most probably represent strong muscular attachments. These strong attachments are not in the position of the nasal plug muscle of other delphinoids, however, and consequently are not related to it. In fact, in the other delphinoids the two rounded keels of the premaxillae lat- eral to the origin of the nasal plug muscle receive fibers of the medial portion of the rostral muscle (Lawrence and Schevill, 1956; Mead, 1975). In Odobenocetops, they probably represent part of the rostral muscle modified for movements of a very strong upper lip (see below and "Discussion"). 


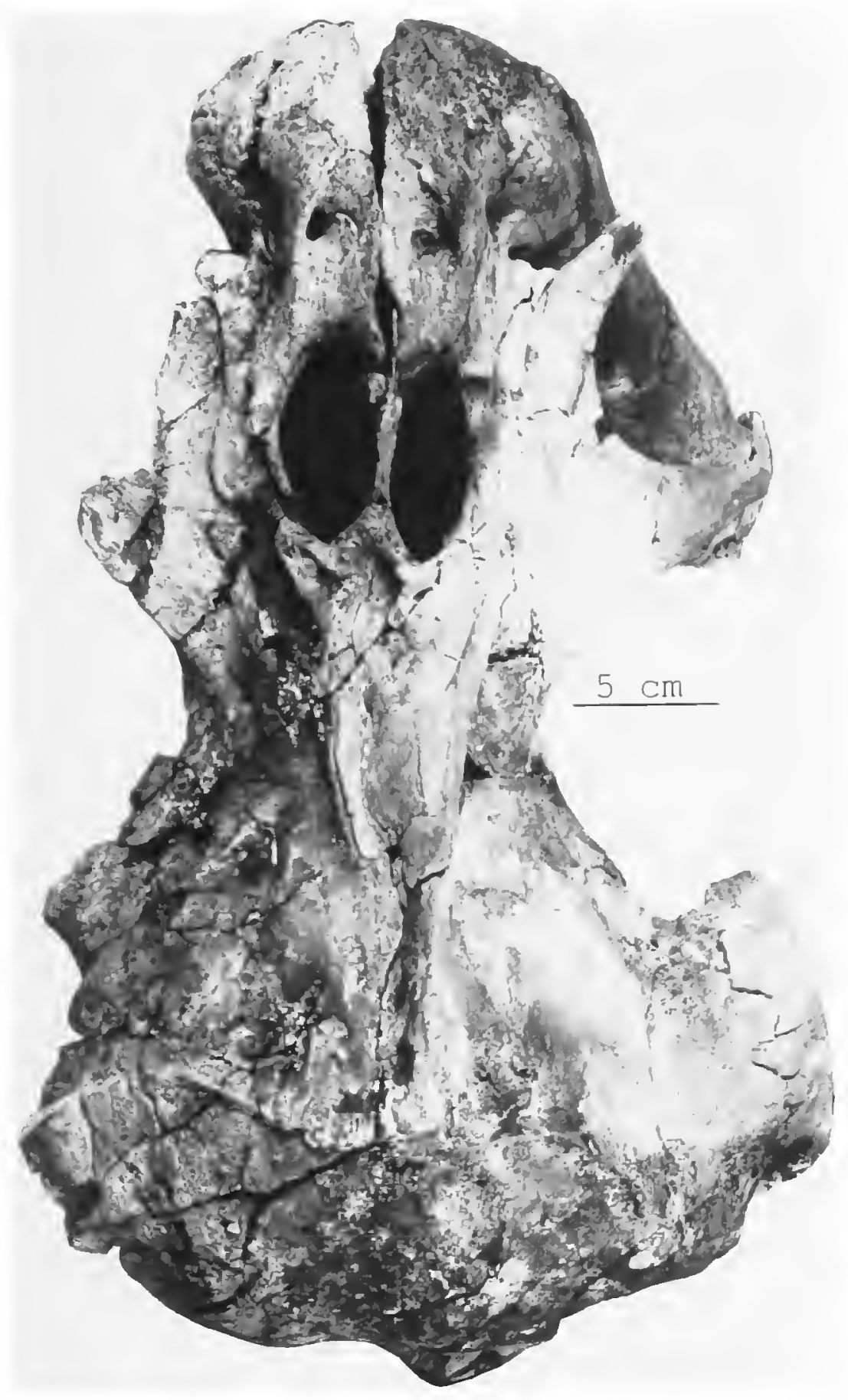

FIGURE 2.-Odobenocetops peruvianus, holotype (USNM 488252): dorsal view of the skull.

Anterior to the premaxillary foramina, the premaxillae are strongly expanded transversely; at the level of the preorbital process they are approximately twice as wide as at the level of the premaxillary foramina. On the dorsal portion, the right premaxilla is slightly wider and larger than the left, resulting in asymmetry of the skull. The two premaxillae are separated by a prominent premaxillary groove, which is partially filled in its posterior part by the mesethmoid. The anterior region of the snout is formed by the premaxillae only; it is very wide, massive, and rounded. In anterior view, the apex of the snout is a high and nearly vertical wall, fissured vertically by the premaxillary groove (Figures 4, 5). From that massive apex, two large alveolar processes are directed ventrolaterally and diverge at an angle of approximately $60^{\circ}$. In anterior view, the rounded apex of the snout shows an irregular and spongy surface that seems to indicate strong muscular attachments (Figure 4). The ante- rior sides of the premaxillae show a very spongy structure and several large and small foramina (also seen on the anterior part of the palate), which indicate extensive vascularization and innervation.

The anterior edge of the alveolar process of the premaxilla presents a strong crest along its whole length (Figure 4). This crest is a long and irregular surface of bone, concave medially, 1-2 cm wide, which might have carried a long and narrow horny pad or, more likely, strong connective tissue for attachment of the upper lip. Several large vascular foramina are observable on the dorsomedial portion of this attachment area. Its morphology is very similar to what is observed on the dorsal side of the walrus mandible, between the first mandibular tooth and the apex of the symphysis. Fay (1982:167) mentioned that, in the walrus, "the incisive area is covered by an extraordinarily tough firm gingiva, unlike that on any other part of the mouth but closely resembling the skin on the palms and soles of the flippers." Furthermore, Howell (1927:21) mentioned the presence of a very hard horny tissue surrounding the lips of Neophocaena phocaenoides, and Kleinenberg et al. (1969:80) noted in the lips of Delphinapterus leucas a "many-layered keratinized epithelium" indicating that such structures are not uncommon in other delphinoids. Given the important modification of the superior edge of its mouth, however, it is likely that the keratinization was much more pronounced in Odobenocetops than in the other delphinoids.

The condition of the anterior face of the premaxilla suggests the presence of a well-developed upper lip, and given the vascularization of the bone, it is possible that it possessed strong vibrissae, as observed in the walrus. Hair is known to occur on the snouts of various fetal and newborn odontocetes (Yablokov and Klevezal, 1962; Tomilin, 1967; Brownell, 1989) and on the apex of the rostrum of the living Amazon dolphin Inia geoffrensis (Best and da Silva, 1989).

The rough and vascularized area mentioned above is restricted to the upper one-third of the alveolar process, except for the anterior crest, and may mark the limit of muscle origin and vibrissae.

In anterior view, the upper part of the mouth opening had a wide and elevated parabolic shape (Figure 5). In lateral view, the alveolar process of the right premaxilla is in sutural contact along the proximal one-half of its length with the maxilla, whereas its distal half is free. It is slightly concave posteriorly and widened at its apex; the posterior border of its free portion is rounded in cross section, differing therefore from the anterior crest, which received muscular and/or tendinous attachment of the upper lip. The lateral surface of the alveolar process is clearly convex and gently rounded, whereas its medial side is slightly convex at the apex and distinctly concave in its proximal portion, where it forms most of the anterior bony palate. The section of the alveolar process on its proximal two-thirds is teardrop-shaped, having a wide, convex, and rounded posterior edge and a thin, narrow, angular anterior edge. On the posterior side of the alveolar process, a small ridge runs from the poster- 


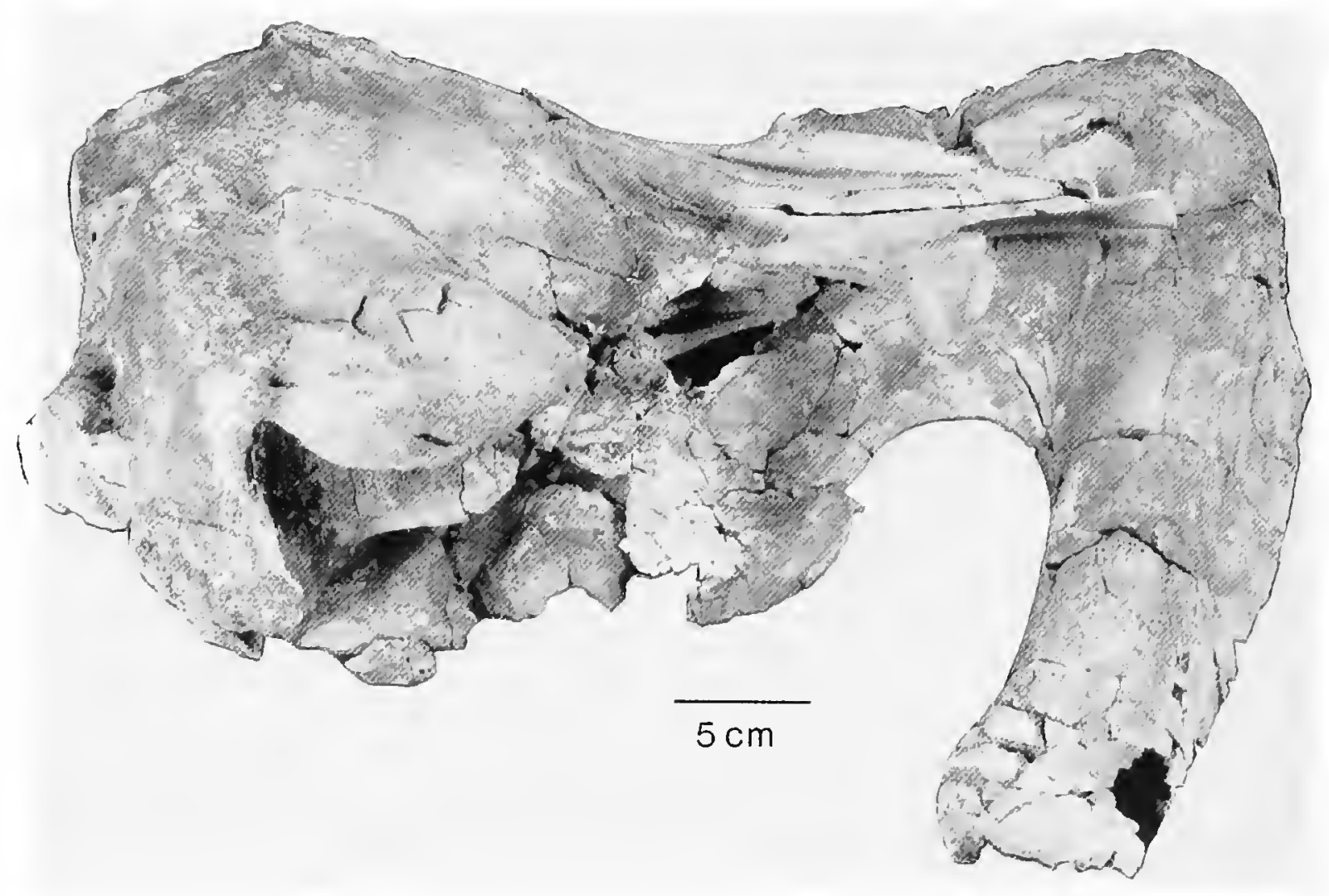

FIGURE 3.-Odobenocetops peruvianus, holotype (USNM 488252): lateral view of the skull.

omedial point of junction of the alveolar process with the palate (exactly at the anteroventral angle of the maxilla) to the posterolateral extremity of the process.

On the palate, the premaxilla is in contact with the vomer medially and with the palatine posteriorly. The maxilla does not participate in formation of the bony palate. Along its medial suture with the vomer, the premaxilla shows a deep, anteroposteriorly elongated fossa with a very large foramen (7-8 $\mathrm{mm}$ in diameter) posteriorly; this foramen, which opens in the palatine, is the anterior opening of a canal originating in the infraorbital canal and extending into the premaxillary fossa via a well-marked gutter. This greatly enlarged foramen corresponds to the palatine foramen that is commonly observed, but very reduced and sometimes nearly closed, in the other Delphinoidea (Figure 6). On the lateral edge of the premaxillary fossa and lateral to it, several other smaller (but still $2-4 \mathrm{~mm}$ in diameter) foramina perforate the premaxilla. There is little doubt that these particularly large foramina contained blood vessels for the abundant vascularization of the upper lip. The fossa is limited medially by the vomer, which forms its medial wall.

The significance of this fossa is not apparent, but in many other mammals, it is the location of a chemical sense organ (the vomeronasal organ). Chemoreception organs in living dolphins, however, are located on the tongue (Fried et al., 1990; Kuznetzov, 1990). Nothing definite can be said about the possibility of homology of the premaxillary fossae with the incisive foramina of terrestrial mammals (these foramina are absent in cetaceans), but the various pieces of evidence given below that Odobenocetops is a cetacean would favor the hypothesis that

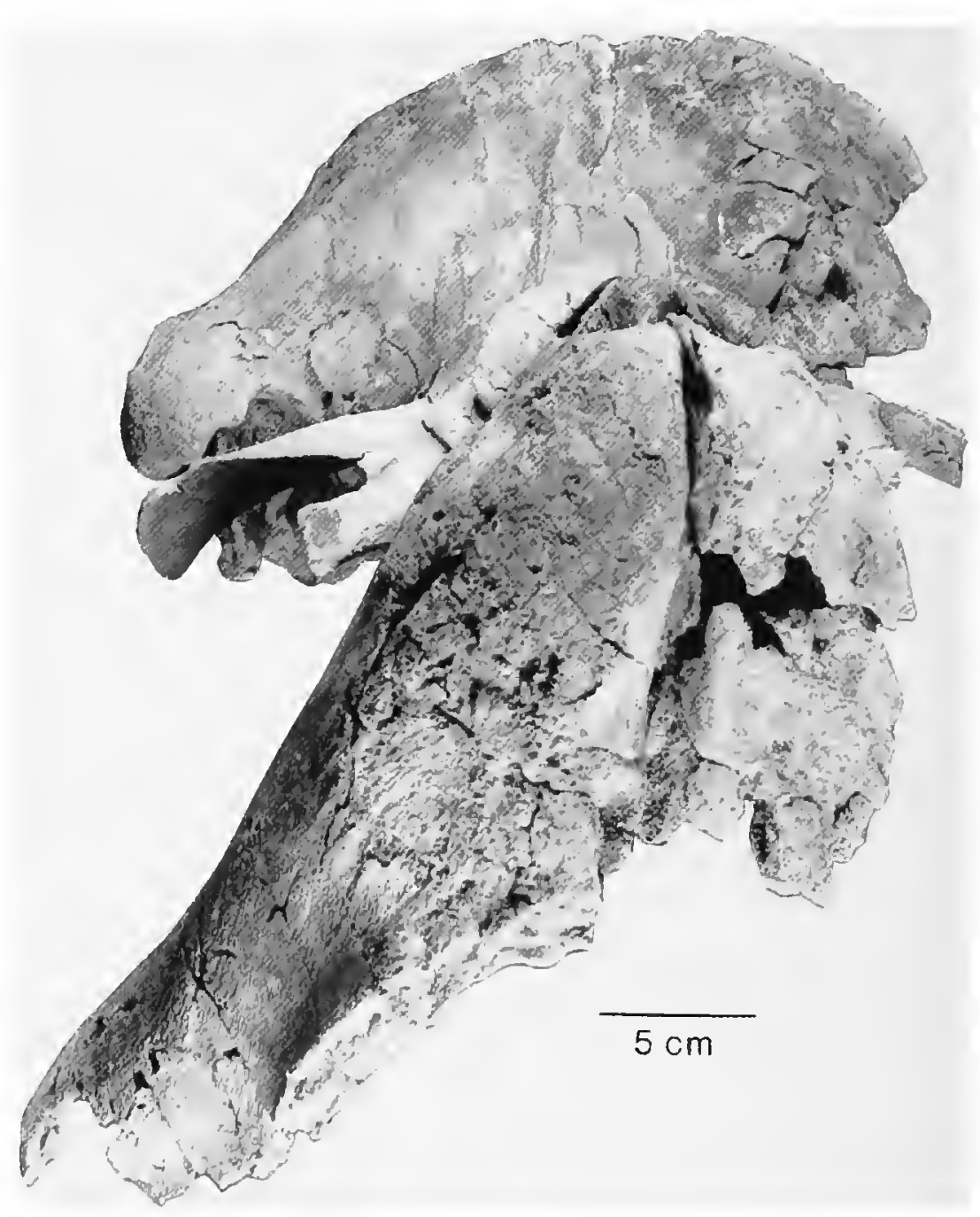

FIGURE 4.-Odobenocetops peruvianus, holotype (USNM 488252): anterior view of the skull approximately perpendicular to a horizontal swimming position. 


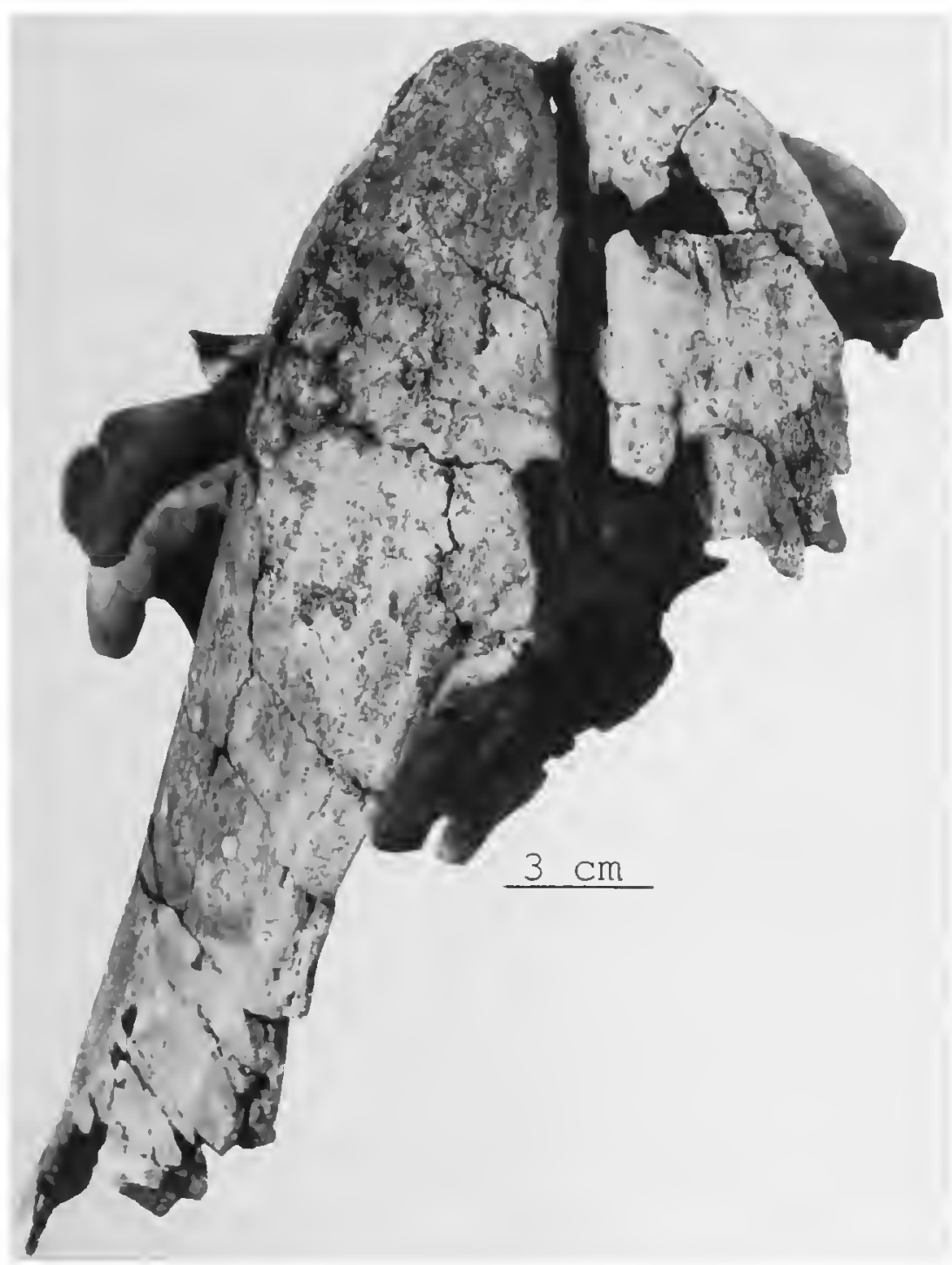

FIGURE 5.-Odobenocetops peruvianus, holotype (USNM 488252): anterior view of the skull approximately parallel to the plane made by the alveolar processes (i.e., to the plane parallel to the bottom in a feeding position).

these structures are not homologous.

The premaxilla extends onto the palate in a triangular posterior expansion that is in contact with the palatine; the contact between the two bones is flat and nearly horizontal, and the suture on the palate forms a large $\mathrm{V}$-shape, opening anteriorly.

The alveolus of the right premaxilla is straight, transversely flattened (i.e., oval in section), and $30 \mathrm{~cm}$ deep; the left alveolus is not completely preserved, but it is clear that it had a much smaller diameter than the right.

Tusks: The right tusk (Figure 7) as preserved is not complete; however, a $39 \mathrm{~cm}$ long portion of it indicates that it was a straight cylindrical tooth with a transversely flattened section (at $10 \mathrm{~cm}$ from the base of the tusk, the two diameters are 38 $\mathrm{mm}$ and $30.5 \mathrm{~mm}$ ). Its cross section is constant along the length of the whole fragment available, although it is possible that the section of the (badly crushed) anterior extremity of the fossil is slightly smaller than the intra-alveolar portion. The tusk is made of dentine only and does not show any enamel; its surface is regular and only shows fine and regular longitudinal striation. A $23 \mathrm{~cm}$ long pulp cavity indicates that the tooth had

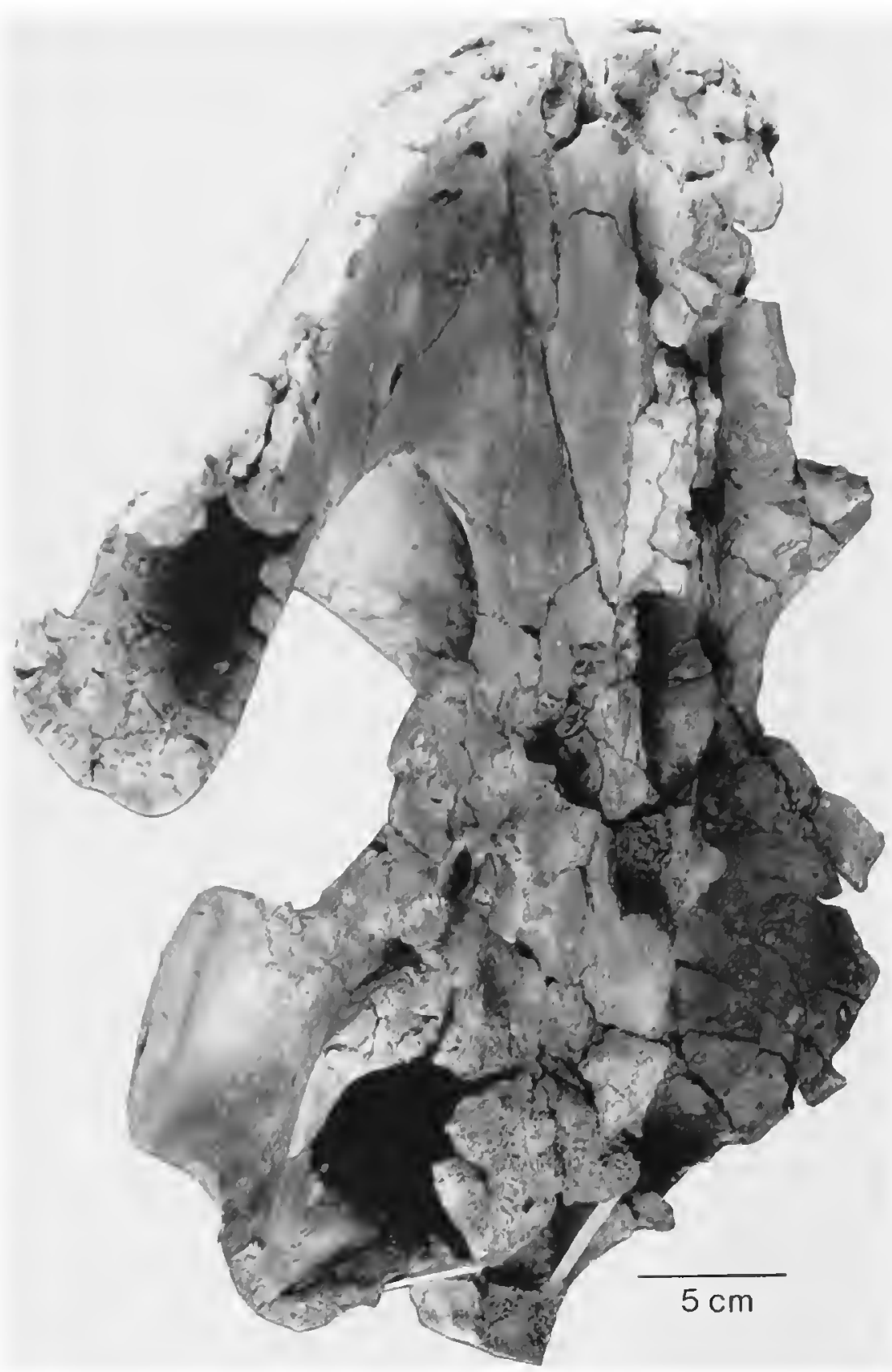

FIGURE 6.-Odobenocetops peruvianus, holotype (USNM 488252): ventral view of the skull.

continuous growth; at its base the tooth itself is only a thin layer of dentine surrounding the pulp cavity, whose diameter decreases toward the apex. A tentative reconstruction of the tooth shows that it could not have been shorter than $45 \mathrm{~cm}$ and possibly was no longer than $55 \mathrm{~cm}, 15-25 \mathrm{~cm}$ of the tusk thus being external to the alveolus.

The left tusk (Figure 8) is known from a small, $8 \mathrm{~cm}$ long fragment. It has a much smaller diameter than the right tusk (approximately 20\% smaller); its section also is flattened transversely, and at its base the section is $30 \mathrm{~mm}$ long and $24 \mathrm{~mm}$ wide. Like the right tusk, it has no enamel and its surface shows very fine longitudinal striations. Unlike the right, its section is not constant and at its apex, as preserved, the diameters are $27 \mathrm{~mm}$ and $25 \mathrm{~mm}$; in the middle part of the fragment the tooth is slightly inflated, and its diameters are $32 \mathrm{~mm}$ and 27 $\mathrm{mm}$. Consequently, the tooth shows a slight but distinct taper- 
FIGURE 7 (left).-Odobenocetops peruvianus, holotype (USNM 488252), right tusk: $a$, lateral view; $b$, proximolateral view, showing the deep pulp cavity.

FIGURE 8 (right).-Odobenocetops peruvianus, holotype (USNM 488252), left tusk: $a$, lateral view; $b$, proximolateral view, showing the small pulp cavity.

a

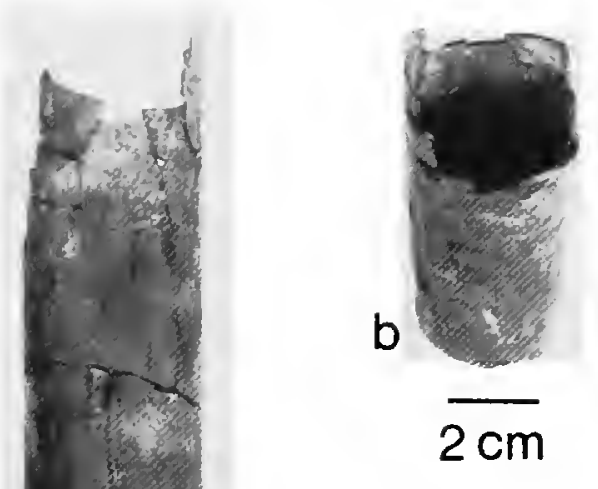

ing toward its apex. By projecting apically the edges of the fragment, it is possible to estimate the original length of the tusk to be between $15 \mathrm{~cm}$ and $20 \mathrm{~cm}$. A wide-open but very short pulp cavity is present at the base of the tooth; it has a small conical opening, $15 \mathrm{~mm}$ deep, $30 \mathrm{~mm}$ long, and $24 \mathrm{~mm}$ wide at its base. This condition indicates that the tooth was still growing, although obviously much more slowly than the right tusk.

Evidence of continued growth does not prove that the tooth was erupted, as indicated by the presence of a deeper pulp cavity on an unerupted incisor of a 17-year-old female Dugong dugon (Marsh, 1980). The condition of the unerupted teeth of the narwhal, however, favors the hypothesis of an erupted tooth (Hay, 1980). In the newborn narwhal, the unerupted teeth (the right in the male and both in the female) have a long pulp cavity that occupies almost the entire length of the tooth; the cavity closes after deposition of approximately eight to nine dentine layers, which generally corresponds to an age younger than
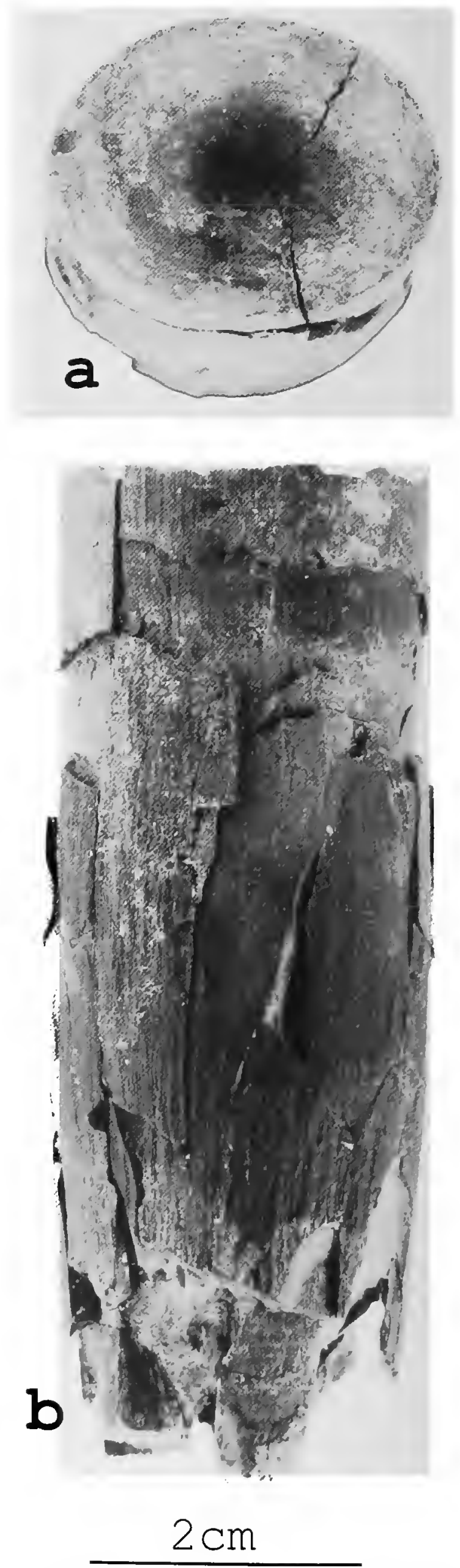

sexual maturity. With the closure of the cavity, the root of the tooth develops a knot made of dentine and irregular cementum. Consequently, the narwhal's unerupted tusk stops growing before the animal has attained its full size and sexual maturity. In the skull of Odobenocetops, the pulp cavity is small but clearly 
open, the knot at the root of the tooth is lacking, and the individual described herein is a relatively old adult, considering the state of fusion of its cranial bones. If the tusk was erupted, therefore, the premaxillae of Odobenocetops could have been strongly asymmetrical and the alveolar process of the left premaxilla should not have been longer than $18 \mathrm{~cm}$, considering that a small portion of the tusk had to be external to the premaxilla; the alveolar process of the left premaxilla would therefore have been, at a minimum, almost $10 \mathrm{~cm}$ shorter than the right. Such asymmetry, which strongly modifies the external aspect of the head, is unknown in mammals, however; consequently we conclude that the left tusk of Odobenocetops was unerupted and that, as in the female dugong, it was still growing very slowly in the closed alveolus. The alveolar process of the left premaxilla could, therefore, have had a length similar to that of the right side (or only slightly smaller) and the $\sim 20 \mathrm{~cm}$ long left tusk could still have grown for a long time in its $30 \mathrm{~cm}$ long alveolus.

Furthermore, it is noteworthy that the right tusk of Odobenocetops differs from all other tusks found among mammals in being straight and cylindrical.

Maxilla: The maxillae of Odobenocetops peruvianus are considerably reduced in comparison with those of other delphinoids; they do not cover the braincase posteriorly or the frontals laterally, and they do not participate in the construction of the bony palate. They form the posterolateral borders of the narial openings, and they are in contact behind the nares; between that region and the occipital crest they are reduced to a narrow strip of bone in the median area of the skull. The right maxilla is two to three times as wide as the left. They lie upon the frontals, and at their posterior ends they contact the nasals. On the specimen described herein, they are only preserved for two-thirds of the distance between the nares and the nasals, but their sutures with the frontals are clearly visible. Lateral to the nares, the maxilla forms a very narrow flange, no more than 2 $\mathrm{cm}$ wide, that is strongly withdrawn medially from the lateral edge of the frontal. Its lateral border is sigmoid and more or less follows the lateral profile of the frontal, being wider above the pre- and postorbital processes and narrower above the deep orbital notch. At the level of the preorbital process of the frontal, the maxilla shows a small lateral spine, which corresponds to the preorbital process of the maxilla in the other delphinoids, and which overhangs the jugolacrimal and is lateral to the antorbital notch. In Odobenocetops the jugolacrimal has disappeared. The maxillary rim, which forms the posterolateral border of the nares, continues posteriorly $(4 \mathrm{~cm}$ behind the nares on the right side and 3 on the left side) and overhangs the flat lateral portion of the maxillae that overlaps the base of the supraorbital process of the frontal.

Three maxillary foramina are found on the right maxilla: (1) a small foramen at the level of the posterior edge of the nares, located between the maxilla and the frontal and opening posteriorly; (2) the anterodorsal opening of the infraorbital canal at the contact of the premaxilla and maxilla, which is preceded by a deep groove in the maxilla, communicating with the premaxillary foramen; and (3) a third small foramen anteromedial to the antorbital notch and distinctly pinched in the "folding" of the rostrum. On the left maxilla, the dorsal opening of the infraorbital canal is divided into four foramina, and through a broken portion of the lateral wall of the alveolus it is possible to see that one or two of these foramina gave passage to blood vessels for irrigation of the tusk pulp cavity.

The portion of the maxilla ventral to the supraorbital process of the frontal is a small triangle of bone bordered anteriorly by the premaxilla, posteriorly by the palatine, and dorsally by the frontal. A large posterior opening of the infraorbital canal is present in this ventral portion of the maxilla, just below the suture with the frontal. As mentioned above, the maxillae of $O d o$ benocetops have been excluded from the palate and no maxillary teeth are present. The ventral portions of the maxillae are tightly fused to the premaxillae, thus indicating that the individual was not a young adult.

Mesethmoid: The mesethmoid is a large, relatively thick blade of bone separating the nares. In dorsal view its posterior extremity presents a $\mathrm{Y}$-shaped relief that overhangs a lower portion, posterior to the nares and partially overlapped by the maxillae. This condition is unique among odontocetes and is related to important modifications of the skull, such as the long contact of the maxillae behind the nares, among others. The nares are large and anteroposteriorly elongated (almost three times longer than wide); the left naris is wider than the right and is located a little more anteriorly. The right naris is $\sim 28$ $\mathrm{mm}$ wide and $\sim 62 \mathrm{~mm}$ long, and the left naris is $\sim 31 \mathrm{~mm}$ wide and $\sim 62 \mathrm{~mm}$ long.

On the dorsal face of the nasal passage, at the same level as the anteriormost point of the brain but slightly more lateral, is a group of small foramina that are directed posteromedially. Those foramina are most probably related to the small olfactory lobes of the brain (see below).

Frontal: The frontals have the typical cetacean trait of enlarged supraorbital processes, composed of the preorbital process and the postorbital process separated by a deep orbital notch. The preorbital process is an elongate, flat, and horizontal wing; its anterior extremity is square, and its lateral angle is distinctly twisted dorsally. It has a marked anterior orientation and runs along the posterolateral edge of the base of the alveolar process of the premaxilla. The antorbital notch is long (40 $\mathrm{mm})$ and narrow $(8 \mathrm{~mm})$ and does not widen anteriorly as it does in most delphinoids. The postorbital process is large and much stouter than the preorbital process. It is a large triangular plate whose apex faces posterolaterally and not laterally as in other delphinoids. Like the preorbital process, it is markedly stretched anterolaterally. It is improbable that the masseter muscle, which arises partly from the postorbital process in the other odontocetes (Howell, 1927), originated on that process in Odobenocetops (see below for discussion). These two processes are separated by a deep and wide orbital notch that faces dorsally and not laterally as in other delphinoids, therefore in- 
dicating very good dorsal binocular vision. The eyes were very large, probably the size of a tennis ball, and abutted the posterolateral side of the base of the alveolar process of the premaxilla.

In dorsal view, the posterior edge of the supraorbital process is almost straight and oblique, and it forms the anterior border of the temporal fossa. The supraorbital process does not cover the temporal fossa as it does (at least partially) in all Neogene and Holocene odontocetes. In those forms its posterior edge is anteroposteriorly oriented and not oblique as in Odobenocetops. As the supraorbital process is not (or only slightly) covered by the maxilla, it is widely exposed dorsally on the anterolateral region of the braincase. As a consequence of the reduction of the telescoping of the skull, the frontal of Odobenocetops does not cover the parietal posteriorly and does not participate in the formation of the roof of the temporal fossa as it does in all the other delphinoids. Consequently, this bone also is widely exposed on the posterolateral region of the braincase. The anterolateral portion of the suture with the parietal is transverse, but it shows two big indentations, which are clearly visible on the right side where it is completely preserved. Medially, each frontal is exposed, like the maxilla, in a long median strip that apparently joins the occipital posteriorly (sutures in the vertex are not easy to determine as the bones are badly encrusted with iron oxide). In that region, therefore, the classical relationships of the telescoped odontocete skull are preserved, as the maxillae overlap the frontals, which overlap the parietals.

On the right frontal, the narrow posterior portion is elevated medially and presents a strong keel that runs as far as the occipital; the strip formed by the right maxilla lies on the medial side of this frontal keel and reaches the nasals posteriorly. In fact, lateral to the maxilla-frontal suture there is a deep, elongate fossa located medial to the bottom of the temporal fossa and running from the posterior edge of the supraorbital process to approximately the middle of the braincase. This fossa is absent on the left side of the skull and could be interpreted as a pathological deformation. The keel mentioned above also could be a pathological structure related to the first one; in the middle region of the braincase, the right frontal appears to have been pinched transversely and thus elevated. It is possible that the animal suffered a minor skull trauma when young, the traces of which are still observable on the skull. Because of that deformation, the posterior median strip of the frontal clearly appears to be, in dorsal view, narrower than the left frontal at that level. In fact, however, if one "unfolds" the right frontal, both frontals have approximately the same width.

Another interpretation would be that the asymmetry of these structures is related to the asymmetry that characterizes the delphinoids. If this were the case, however, the asymmetry pattern observed in Odobenocetops would be unique among cetaceans. In delphinoids, the asymmetry is always manifested by larger size of the right maxilla and premaxilla and a displacement of the vertex to the left side of the skull. A possible interpretation of that morphology would therefore be that the right elongated fossa and the crest serve as muscular attachments for part of the maxillonasolabialis. In odontocetes the pars nasalis of this muscle is the blowhole muscle, which arises from the maxilla and part of the frontal; the withdrawal of these bones from the roof of the braincase would have forced the fibers to concentrate in that fossa and on that crest. It would, however, be surprising if this phenomenon occurred only on the right side. Until new material is discovered, the first interpretation seems more reasonable. Consequently, it is likely that the maxillonasolabialis was relatively reduced in Odobenocetops. This muscle is related to the movements of the blowhole and of the nasal air sac complex, two structures related to ultrasonic sound production, so it is probable that Odobenocetops had a relatively reduced air sac system (already observed in the reduction of the premaxillary sacs) and consequently reduced ultrasonic sound production consistent with loss of echolocation. The posterior extremities of the frontals articulate with the nasals.

Ventrolaterally, the frontals contact the alisphenoid and the palatine posteriorly. In ventral view, the supraorbital process of the frontal is in a subhorizontal plane that meets the lateral wall of the palate at a right angle; along this angle, the frontals articulate successively with the orbitosphenoid (optic gutter), with the palatine, and anteriorly with the maxilla.

Nasal: The nasals are small plates of bone that have been pushed posteriorly; they articulate with the frontals anteriorly and with the occipital posteriorly. The nasals apparently lie upon the parietals, whereas in other odontocetes they always lie upon the frontals. The lateral half of the right nasal is preserved in situ, but its medial half, as well as the left nasal, have been lost during fossilization. The sutures, however, are clearly visible in numerous small anteroposteriorly directed grooves that mark the skull in that region. The nasals were more wide than long, and apparently the left nasal was larger than the right.

Parietal: The parietal forms most of the dorsal face of the braincase as a smooth bony plate that is covered only by the frontal medially. It contacts the squamosal by a very strong interdigitated suture, which differs from the squamous suture generally found in mammals. As seen below, this condition is probably related to the feeding adaptations of Odobenocetops. Ventrally, the parietal shows a small expansion in the anterior part of the glenoid cavity.

Palatine: The palatine forms an important part of the palate; it is located posterior to the premaxilla, medial to the pterygoid, and lateral to the vomer. As mentioned above, a very large palatine foramen opens anteriorly in a deep elongate fossa on the anteromedial border of the premaxilla. The palate is very large and deeply arched transversely, as well as longitudinally. Very wide anteriorly, at the level of the premaxillae, it narrows posteriorly at the level of the palatines and widens again at its posterior extremity at the level of the pterygoids. The anterior portion of the palatines is located in the narrowest part of the palate, and consequently the anterior part of the palatine (on the palate) is much narrower than the posterior. On 
the lateral side of the skull, below the supraorbital process, the palatine forms a subvertical wall with a deeply concave ventral border. The suture with the maxilla is markedly concave posteroventrally. Above the lateral edge of the palate and just anterior to the suture with the pterygoid, the palatine presents an elongate fossa that also extends onto the pterygoid. That fossa is deeper on the palatine and gradually shallows and disappears on the pterygoid posteriorly. It follows the lateral edge of the palate and consequently is oriented anterodorsally-posteroventrally. Boenninghaus (1904), referring to Phocoena, and Fraser and Purves (1960), referring to Delphinus, mentioned that the origin of the internal pterygoid muscle was on the lateral edge of the maxilla, palatine, pterygoid, and (in the case of Phocoena) basioccipital. The elongated fossa observed on the lateral edge of the palatine, therefore, probably corresponds to a strong attachment of the internal pterygoid muscle, which also attaches on the pterygoid hamulus and on the medial lamina of the pterygoid (see below).

Although the palatine is partially broken in its dorsal portion, it clearly had an important contact with the frontal. Ventral to the optic gutter of the orbitosphenoid, the dorsal edge of the palatine shows a small curvature (concave dorsally), which we regard herein as the medial part of the lateral lamina that was covering the optic gutter and contacting the frontal dorsally. Posterodorsally, the palatine also contacts the anterior edge of the alisphenoid.

Pterygoid: The pterygoid is excavated by a relatively small pterygoid sinus and, therefore, is divided into lateral and medial laminae. On the palate, its suture with the palatine is an anteroposterior line observable at the posterolateral corner of the palate. The suture between the two bones on the palate is actually a horizontal plane, as the large backward expansion of the palatine covers the pterygoid posteriorly. Because of this morphology of the palatine, the pterygoids are laterally displaced and widely separated, and the palatine must have formed the major part of the posterior edge of the bony palate. Widely separated pterygoids are known in the Holocene Monodontidae and Phocoenidae and in some living Delphinidae.

The pterygoid hamulus is only partially excavated by the pterygoid sinus and possesses a large ventrolateral crest, probably for the insertion of the pars lateralis of the pterygoid muscle. The outline of the crest is strongly convex in ventral view, in contrast to the markedly concave lateral border of the palatine anteriorly. The anteriormost extremity of the palatinepterygoid suture is on the lateral edge of the palate at the inflexion point of the curve.

Although the apex of the pterygoid hamulus is broken on the specimen, it is probable that only a small part is missing. The medial lamina of the pterygoid, posterior to the hamulus, is strongly thickened relative to other odontocetes. Its lateral edge shows a sort of semicylindrical crest, which delimits a semicircular cupule. Probably an extremely strong pterygoid muscle originated partly on this structure. On its medial side and ventral to this muscle attachment is an anteroposteriorly directed notch excavated in a very thickened and dense bony wall. This structure is in the location of the passage of the eustachian tube observed in the other odontocetes, although it is never as conspicuous in the latter. The pterygoid forms the dorsal wall of the choanae and partially overlaps the vomer medially, contrary to the condition in other odontocetes, where the vomer generally overlaps the medial border of the medial lamina of the pterygoid. The lateral lamina of the pterygoid contacts the palatine anteriorly and the alisphenoid posteriorly. It is large and smooth and participates in the formation of a continuous bony bridge between the palate and the frontal, a condition that strongly recalls that observed in the Monodontidae.

Vomer: The vomer is very large, and its participation in the palate is much more extensive than in any other odontocete. On the palate the vomer has the characteristic lanceolate shape observed in those odontocetes in which the vomer participates in the formation of the palate. It is long and occupies approximately two-thirds of the midline of the palate. Its maximum width is at the level of the anteriormost point of the palatinepremaxillary suture; its anterior half contacts the premaxilla, and its posterior half contacts the palatine. The posterior part of the bone, in the basicranial basin, is relatively narrow but much thicker than in the other delphinoids.

Orbitosphenoid: The orbitosphenoid has a long and wide optic canal, whose anterior opening is situated below the posterior edge of the supraorbital process and above the inflexion point of the sigmoid lateral border of the palate. It has an almost anteroposterior orientation and faces laterally, whereas in the other odontocetes it faces ventrally and forms an angle of approximately $45^{\circ}$ with the anteroposterior axis of the skull. A large optic foramen opens in the optic canal just below the narrowest part of the temporal fossa; lateral to it, the large sphenorbital fissure (anterior lacerate foramen) is walled laterally by the lateral laminae of the palatine and pterygoid. The morphology of this region of the skull is related to the strong anterior displacement of the nares and the orbits, which have dragged the optic canal anteriorly (above the palatine-pterygoid suture); in most delphinids and phocoenids, the optic canal lies posterior to the lateral lamina of the pterygoid. It is noteworthy, however, that a condition intermediate between that of Odobenocetops and that of most of the other Delphinoidea is observed in Delphinapterus, in which the orbits are located fairly far anteriorly.

Alisphenoid: The alisphenoid is a very thick bone located just anterior to the large squamosal gutter. It contacts the frontal dorsally, the squamosal and parietal posteriorly, and the pterygoid ventrally. On its ventral edge can be observed the dorsal border of an enormous foramen ovale. This foramen was not closed and was confluent with the cranial hiatus of the auditory region, contrary to what is observed in the other delphinoids. Apart from this feature, the major characteristic of the alisphenoid is its thickness, which, among the delphinoids, also is found in the Monodontidae (Muizon, 1988b). 
Basioccipital: The basioccipital is almost totally broken away, and only the anterior portion of the right side is preserved. On its ventrolateral side, a small and shallow gutter very probably represents the passage for the internal carotid. The carotid foramen was, therefore, confluent with the foramen ovale and with the cranial hiatus. On the dorsal side of the basioccipital, the carotid gutter reaches the lateral edge of the sella turcica, as in the other delphinoids. The carotid gutter has a strong anteroposterior orientation, however, and the internal carotid entered the skull at a point well posterior to the sella turcica. In the other delphinoids the carotid foramen is located approximately at the same level as the sella turcica.

Squamosal: The squamosal is a relatively small bone whose entire morphology is conditioned by a wide, deep, and anteroposteriorly elongate gutter, which is formed mainly by the highly modified zygomatic process. The gutter is open anteriorly and posteriorly and is approximately cylindrical. It corresponds in other delphinoids to the depression observed between the lateral wall of the zygomatic process and the crest that joins the falcate process to the posteromedial origin of the fossa for the middle sinus. The lateral edge of the squamosal gutter of Odobenocetops is very thick, and its anterior extremity represents the greatly shortened zygomatic process. It is likely that the glenoid cavity did not occupy the whole volume of the gutter. A comparison with the position of the glenoid fossa in a beluga or narwhal shows that in Odobenocetops it probably occupied the posterolateral quarter of the squamosal gutter. The articulation of the condyle was therefore on the posterior half of the medial side of the lateral wall of the gutter. The posterior region of the gutter bears a posterodorsally extroverted saddle-like crest, which strongly suggests the presence, anterior to it, of a very mobile articulation. The prominence of this saddle-shaped crest also indicates the mature development of the articulation, in agreement with the extensive fusion of the bones of the skull, and indicates a relatively old animal. It is therefore likely that the condyle articulated only with the posterolateral extremity of the squamosal gutter.

The squamosal gutter (and consequently the glenoid fossa) is located in a much higher position than in the other delphinoids. It is well above the lateral wall of the cranial hiatus, and its bottom is approximately at the same level as the posterior edge of the postorbital process of the frontal. In the other delphinoids, the glenoid cavity is at the same level as the lateral wall of the cranial hiatus and well below the posterior edge of the postorbital process of the frontal.

The ventral edge of the medial wall of the gutter is rounded, very thick, and dense, and it forms the lateral edge of the enormous cranial hiatus; it is related anteriorly to the extremely thickened medial edge of the alisphenoid. Immediately behind the suture with the alisphenoid, on the thickened medial wall of the squamosal gutter, a small crest probably represents the very reduced falciform process of the squamosal. At the posterior extremity of the medial wall of the squamosal is the medial extremity of the middle sinus fossa; the sinus was probably fairly well developed and may have extended onto most of the medial wall of the squamosal gutter. At the posteromedial corner of the bone, on the suture with the occipital, there is no articulation area for the periotic but rather some squamous and spongy bone for attachment of the ligament that, as in the other Delphinida, held the periotic in place.

Behind the saddle-shaped posterior extremity of the squamosal gutter, and squeezed between it and the exoccipital, the passage for the external auditory meatus is long but very reduced; it opens dorsolaterally in the ventral part of the very small sternomastoid fossa. The latter is reduced and occupies the posterodorsal corner of the zygomatic process (or of the lateral wall of the squamosal gutter). It is limited dorsally by a small crest, which is much more reduced than its homologue in other delphinoids. The lateral side of the zygomatic process is wide and elongated anteroposteriorly. In other delphinoids this surface gives rise to the masseter muscle; therefore, the condition observed in Odobenocetops suggests a strong masseter (for a cetacean).

On the lateral wall of the braincase, the suture of the squamosal with the parietal is very unusual. In most other mammals, and certainly in all the other odontocetes, the squamosalparietal suture is mainly a subvertical plane facing laterally, and the part of the squamosal contacting the parietal is a squamous lamina, which gives its name to the bone. In Odobenocetops, the articulation is a rough zigzag line, and the joint surface faces dorsally. This articulation, together with the general stoutness of the squamosal, suggests that large muscular tensions were applied to the bone. In the posterolateral region of the squamosal, just anterior to the paroccipital process, the entire region of the external auditory meatus is tremendously thickened, further exemplifying the exceptional stoutness of this bone in Odobenocetops peruvianus.

Periotic: One isolated left periotic (MNHN SAS 1614) and one partial tympanic associated with another left periotic (MNHN SAS 1613) are referred to Odobenocetops peruvianus (Figures 9, 10). The taxonomic assignment of these isolated elements is clearly confirmed by the recent discovery of a partial skeleton of Odobenocetops sp. (MNHN SAO 202) that includes, associated in situ with the skull, a tympanic and periotic like those described herein. In the following description the tympanic side of the periotic will be called ventral; the cerebral side, dorsal; the cochlear promontory side, medial; and the side opposite to the cochlear side, lateral. The nomenclature of the external anatomy of odontocete periotics follows Fordyce (1994). Both periotics are morphologically as unusual as the skull and do not closely resemble those of any other cetacean. The periotic of Odobenocetops is a large and stout bone whose proportions are in agreement with the very large cranial hiatus of the skull. It has a large, long, and robust anterior process with a blunt rounded apex. On the ventral side of the anterior process, a large lateral tuberosity is located lateral to the mallear fossa. From the tuberosity, a wide and flat ventral rim extends anteriorly as far as the apex of the anterior process. It is 

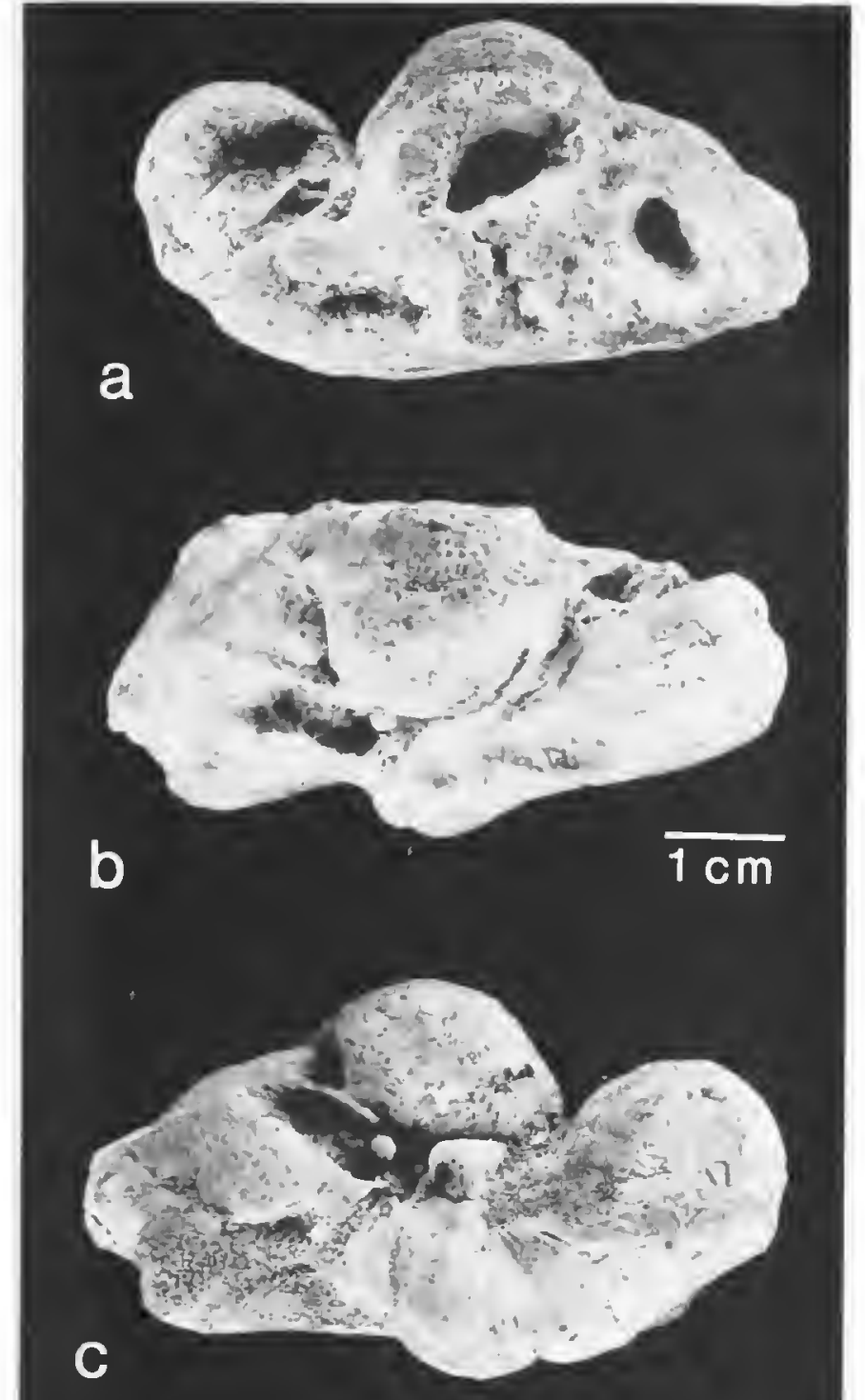

d

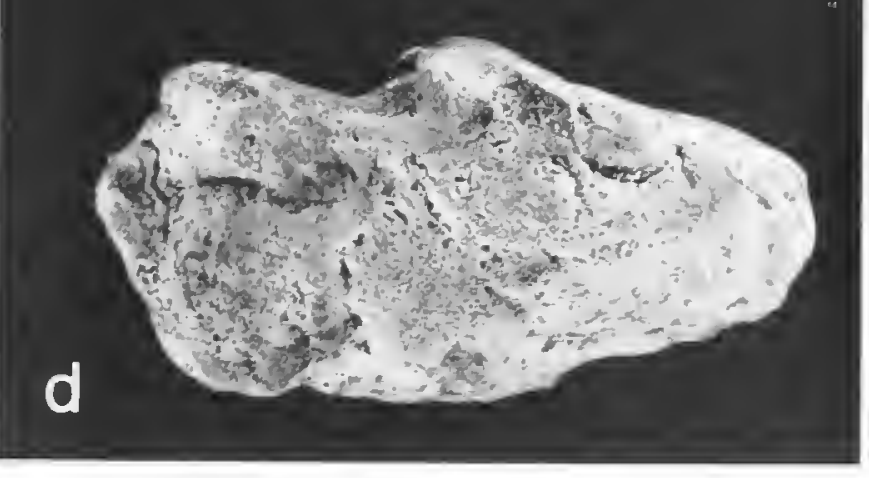

FIGURE 9.-Odobenocetops peruvianus, left periotic (referred specimen, MNHN 1613): $a$, dorsal view; $b$, medial view; $c$, ventral view; $d$, lateral view.

wider and flatter than in other delphinoids, especially in its anterior portion. This rim bears numerous fine parallel wrinkles, which are slightly concave anteriorly and oblique to the axis of the bone. This structure, although flattened, corresponds to the "bourrelet ventral" defined by Muizon (1988b), which is a synapomorphy of the Delphinida.

Three small fossae are observed on the ventral face of the anterior process, medial to the ventral rim. They are, from rear to front, the mallear fossa (or fossa capitis mallei), the epitubarian fossa, and the bullar facet. The mallear fossa receives the head of the malleus; it is oriented more ventrally than in the other Delphinoidea, especially the Monodontidae where the orienta-
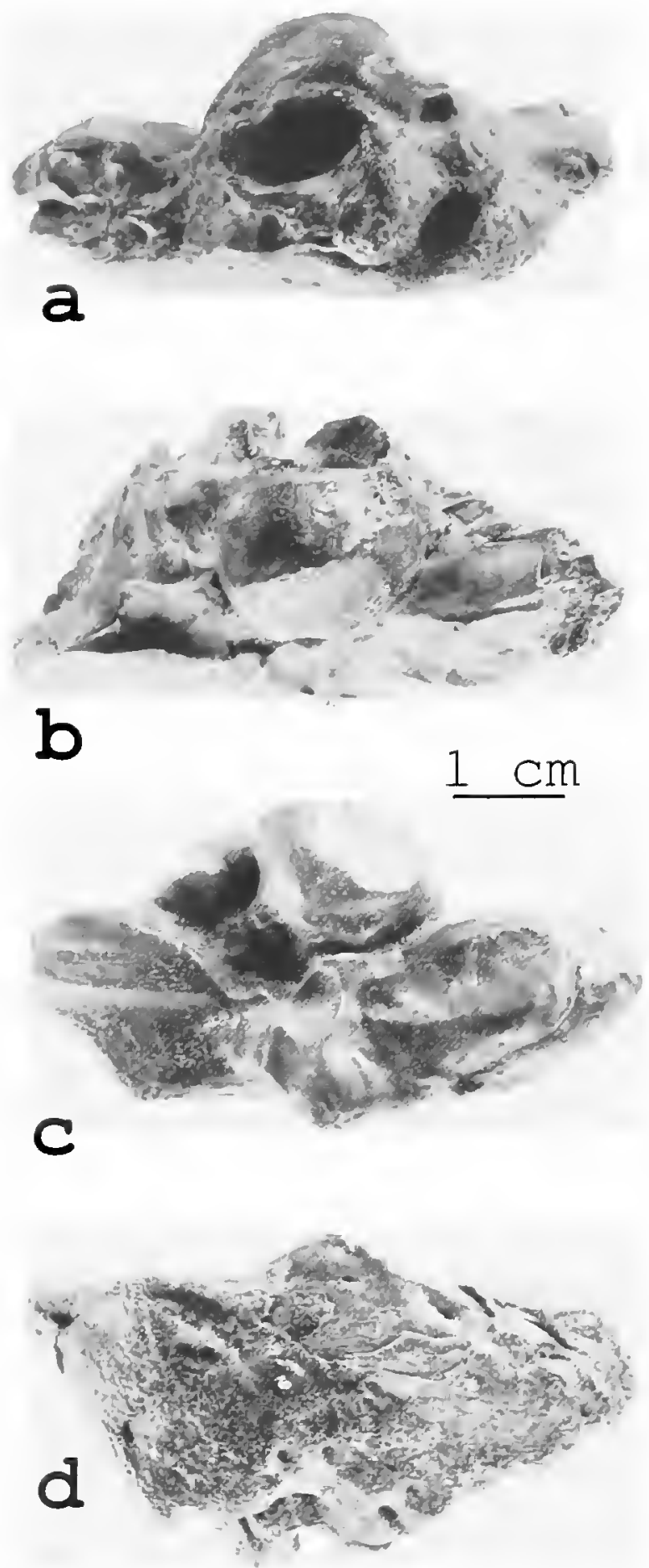

FIGURE 10.-Odobenocetops peruvianus, left periotic (referred specimen, MNHN 1614): $a$, dorsal view; $b$, medial view; $c$, ventral view; $d$, lateral view.

tion is almost medial. The epitubarian fossa receives the processus tubarius of the tympanic, also called the accessory ossicle, unciform process, or uncinate process. When compared with that in other delphinoids, the epitubarian fossa is small relative to the size of the bone, but it is more concave. The third and most anterior fossa is the bullar facet, as defined by Fordyce (1994), and erroneously termed epitubarian fossa by Muizon (1987, 1988a, 1988b, 1988c, 1991). The bullar facet is a shallow fossa, slightly longer than it is wide, which occupies approximately the anterior one-third of the ventral face of the process.

The bullar facet is surprisingly well developed for a delphinoid; however, it is noteworthy that a small bullar facet also is 
observed in some Kentriodontidae (Muizon, 1988b:172), such as Liolithax. The bullar facet is a common structure in several groups of odontocetes (Squalodontidae, Squalodelphidae, Platanistidae, Waipatiidae, Ziphiidae, Physeteridae, and Lipotidae). The loss of the bullar facet (=epitubarian fossa sensu Muizon, 1987, 1988a, 1988b, 1988c, 199l) has been considered a synapomorphy of the monophyletic clade Delphinoidea +Inioidea (Muizon, 1988b). This clade is defined by three other synapomorphies (Muizon, 1988b:165), so it is possible that loss of the bullar facet occurred several times in the evolution of the Delphinida. It also is possible that the presence of a bullar facet in Odobenocetops is related to the increase in length and thickness of the anterior process of the periotic, which is as highly specialized as the rest of the skull.

In dorsal view, the anterior process shows several slits, foramina, and fissures, as is often the case in the Monodontidae. The fossa incudis (or fossa crus breve incudis) is located just posterior to the mallear fossa and anterior to the anterior extremity of the tympanic articular facet of the posterior process. It is small and shallow, and it faces more anteroventrally than in other delphinoids.

Anterolateral to the fossa incudis is the ventral (or tympanic) opening of the facial canal, which transmits the facial nerve (VII). This foramen is small, approximating the size of that observed in Delphinapterus, although the periotic of Odobenocetops is almost twice the size of that of Delphinapterus. Between the mallear fossa, the fossa incudis, and the ventral opening of the facial canal is a small elongate fossa that faces posteriorly. Such a fossa is not present in all Delphinoidea; among the Holocene species, we have observed it in Pseudorca. In some periotics of an undescribed fossil delphinapterid and of a fossil kogiine (Luo and Marsh, 1996) from Lee Creek Mine (North Carolina), a very small pit is observed ventrolateral to the ventral opening of the facial canal.

The fossa for the stapedial muscle is large but shallow and faces almost ventrally. It differs in this respect from the condition in Delphinapterus and most other odontocetes, where the fossa faces laterally or ventrolaterally. The groove for the facial nerve is not well separated from the stapedial muscle fossa as is generally observed in other Delphinoidea. Posteromedial to the ventral opening of the facial canal is the fenestra ovalis. Contrary to what is observed in Delphinapterus, Monodon, and generally in the Delphinoidea, where the fenestra ovalis is oval-shaped, in Odobenocetops it is almost circular, and the stapes (preserved in MNHN SAS 1613) is a small conical bone, inflated at its ventral extremity for articulation with the incus (Figure 12). It is not flattened as in most other odontocetes.

Posteromedial to the fenestra ovalis is the fenestra rotunda, which is clearly reniform in MNHN SAS 1613. The posterolateral wall of the fenestra rotunda is thickened and shows a conspicuous elevation responsible for its oval shape. That morphology is not observed in the other Delphinoidea, but it is common in Squalodon and in the Eurhinodelphidae (Muizon, 1988c, 1991). In MNHN SAS 1614, the fenestra rotunda is wider than in MNHN SAS 1613, a condition that could be pathologic or related to erosion.

The pars cochlearis is extremely small considering the large size of the periotic. It is very low and somewhat recalls that of Squalodon, although it is not as compressed dorsoventrally in medial view, is not ventrally shifted, and has a rounded overall shape in ventral view. It differs strongly from the much higher profile (in dorsal or ventral view) pars cochlearis of other Delphinoidea and especially that of the Monodontidae. The posterior process is relatively slender and bears a narrow, anteroposteriorly elongate articular facet for the tympanic. Lateral to the tympanic facet is a conspicuous anteroposteriorly oriented crest that bordered the external auditory meatus dorsally.

On the dorsal face of the bone is the internal auditory window, composed of the tractus spiralis foraminosus (or fundus of the internal auditory meatus) (posteromedially), the foramen singulare, and the dorsal aperture of the facial canal for the facial nerve (anterolaterally). The window is large but relatively smaller than in the other Delphinoidea. It is approximately the size of that of Delphinapterus, although the periotic of Odobenocetops is twice as large. In particular, the tractus spiralis foraminosus is smaller than that of most large delphinoids. The window in Odobenocetops, however, differs from that of the other delphinoids in being much deeper, probably because of the thicker (in medial view) pars cochlearis. The same can be said concerning the aperture for the endolymphatic duct (dorsal opening of the vestibular aqueduct), which is a large conical pit posterolateral to the window. It is larger than that of Delphinapterus but resembles it in being widely open. The aperture for the cochlear aqueduct is a small pit facing dorsally, anteromedial to the aperture for the endolymphatic duct. The dorsal face of the periotic has an irregular aspect and presents numerous exostoses made of dense bone; it does not show the smooth and regular morphology generally observed in the other Delphinoidea. In this respect, it resembles the periotics of Physeteridae. In lateral view, the periotic of Odobenocetops shows a very large and relatively flat surface.

\section{CT SCANS OF THE PERIOTICS}

METHODS.-The two periotics of Odobenocetops peruvianus were scanned with an ultra-high resolution protocol developed for analysis of fossil material. The technique provides fine-level differentiation of mineralization characteristics, which in turn provides good delineation of inner-ear structures in CT images. Simple surface reconstruction algorithms were used to obtain three-dimensional reconstructions of the periotic shell. Segmentation algorithms were used to visualize particular features, e.g., the cochlear canal, vestibular aqueduct, facial nerve, and auditory nerve. In live ears, these algorithms utilize the attenuation coefficients for cochlear fluids and neural tis- 


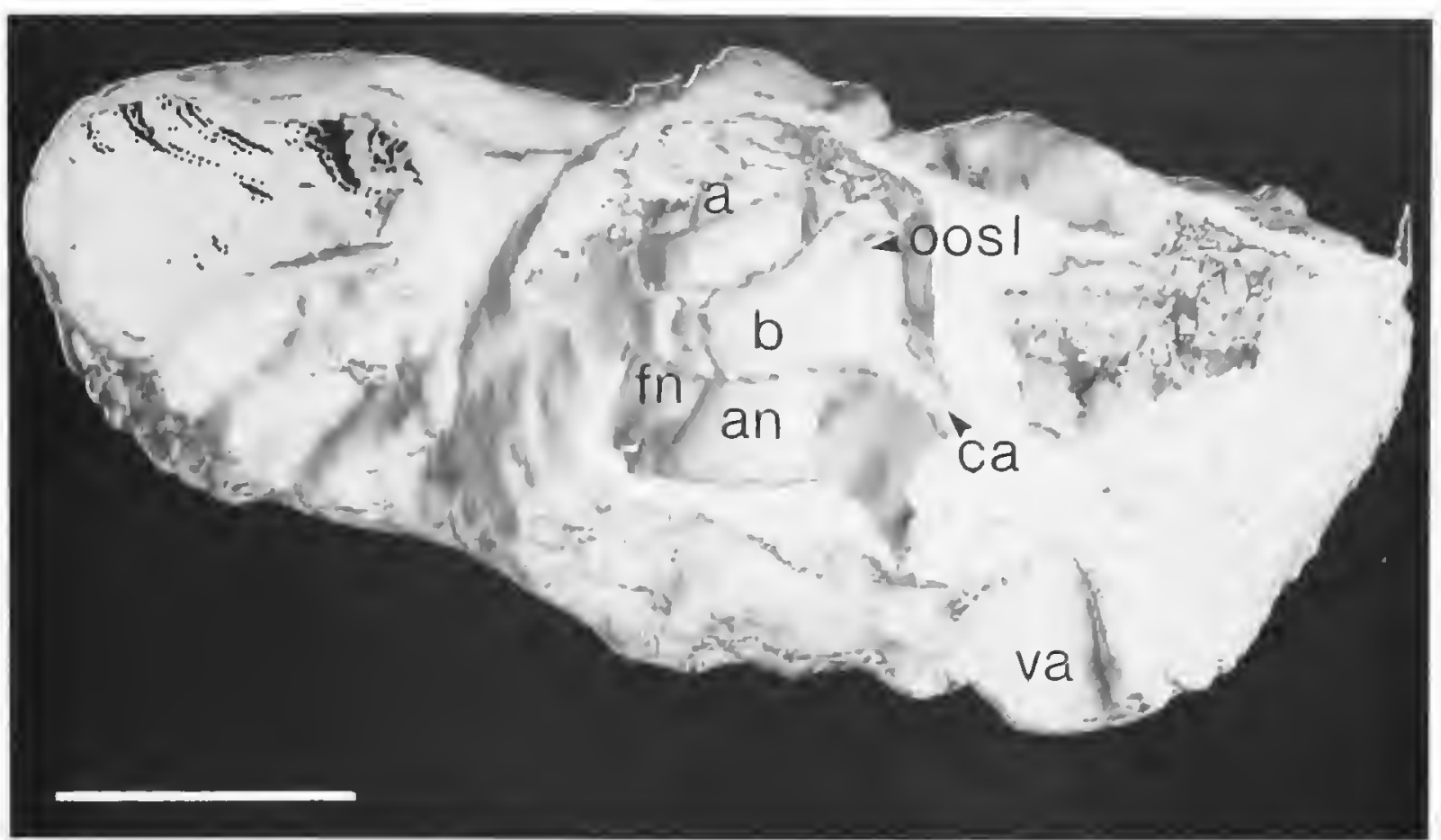

FIGURE 11.-Odobenocelops peruvianus, left periotic (referred specimen, MNHN SAS 1613): reconstruction of inner ear spaces from CT data. (Scale bar $=1 \mathrm{~cm} ; \mathrm{a}=$ apex of cochlea; an=auditory nerve canal; $\mathrm{b}=$ basal turn; $\mathrm{ca}=$ cochlear aqueduct; $\mathrm{fn}=$ facial nerve canal; oosl=outer osseous spiral laminar ridge; va=vestibular aqueduct.)

sues to produce three-dimensional representations of inner-ear anatomy; in fossils, the differences in X-ray attenuations of sediments or mineralization of bone versus neural and inner ear areas are used for the reconstructions.

RESULTS.-Inner Ear: Both specimens are left periotics with well-preserved inner ears. Small differences in cochlear dimensions and turn number (Table 2) between these specimens are within the range of normal interindividual variability for modern odontocete inner ears (Ketten and Wartzok, 1990). The cochleae have approximately 2.5 turns with the three classic hallmarks of odontocete cochleae: a ventrolateral apical orientation, a substantial outer osseous lamina in the basal turn, and an exceptionally large cochlear aqueduct (Figure 11). The cochlear canal follows a conventional odontocete type II format (Ketten, 1984; Ketten and Wartzok, 1990), with closest morphometric affinities to Delphinapterus leucas and Monodon monoceros. The three-dimensional cochlear canal length for each specimen is approximately $44.4 \mathrm{~mm}$, implying an animal length of $360-400 \mathrm{~cm}$, assuming that the ratio of canal length to body mass follows the same allometry as extant odontocetes (Table 1). A substantial outer osseous lamina (as indicated by the laminar indentation in Figure 11) is present throughout the first $16 \mathrm{~mm}$ of the lower basal turn in both specimens and is a clear indication of some ultrasonic hearing in Odobenocetops. The outer lamina covers approximately $35 \%$ of the cochlear length, again consistent with a type II odontocete cochlear format. Cochleae of this type have maximum peak ultrasonic sensitivities below $80 \mathrm{kHz}$. In fact, the cochlear profile of these Odobenocetops cochleae is best approximated by species at the lower end of the type II group of odontocete ears, which have a peak frequency of $35-50 \mathrm{kHz}$.

Although Odobenocetops, judging from its cochlear configuration, could (like most mammals) perceive frequencies above $20 \mathrm{kHz}$, it is important to note that having ultrasonic hearing abilities is not synonymous with echolocation. Echolocation per se requires not only perception but also synchronized production of ultrasonic signals coupled with the ability to analyze target features from the returning echoes.

A notable deviation from typical extant odontocete inner ear configuration is the presence of well-defined semicircular canals (Figure 12), a large, reniform vestibular aqueduct, and, judging from the diameter of the residual VIIIth nerve canal (Table 3), relatively large vestibular and facial nerve fiber counts (Figure 13). Extant Odontoceti have vestibular volumes that are substantially less than their cochlear canal volumes. In

TABLE 1.-Measurements (in $\mathrm{cm}$ ) of holotype of Odobenocetops peruvianus (USNM 488252).

Total length of skull from anteriormost extremity of premaxillae to posterior border of occipital condyle

Width of postorbital constriction

Width of orbit from apex of antorbital process to apex of postorbital process

Length of right premaxillary sheath from its apex to antero-dorsal hump of premaxilla

Depth of right alveolus

Bizygomatic width (estimated)

Anteroposterior length of braincase

Width of braincase (estimated)

Length of mandibular gutter
45.7

11.6

10.5

31.7

30.7

$15.4 \times 2=30.8$

18.3

$10.2 \times 2=20.4$

10.2 


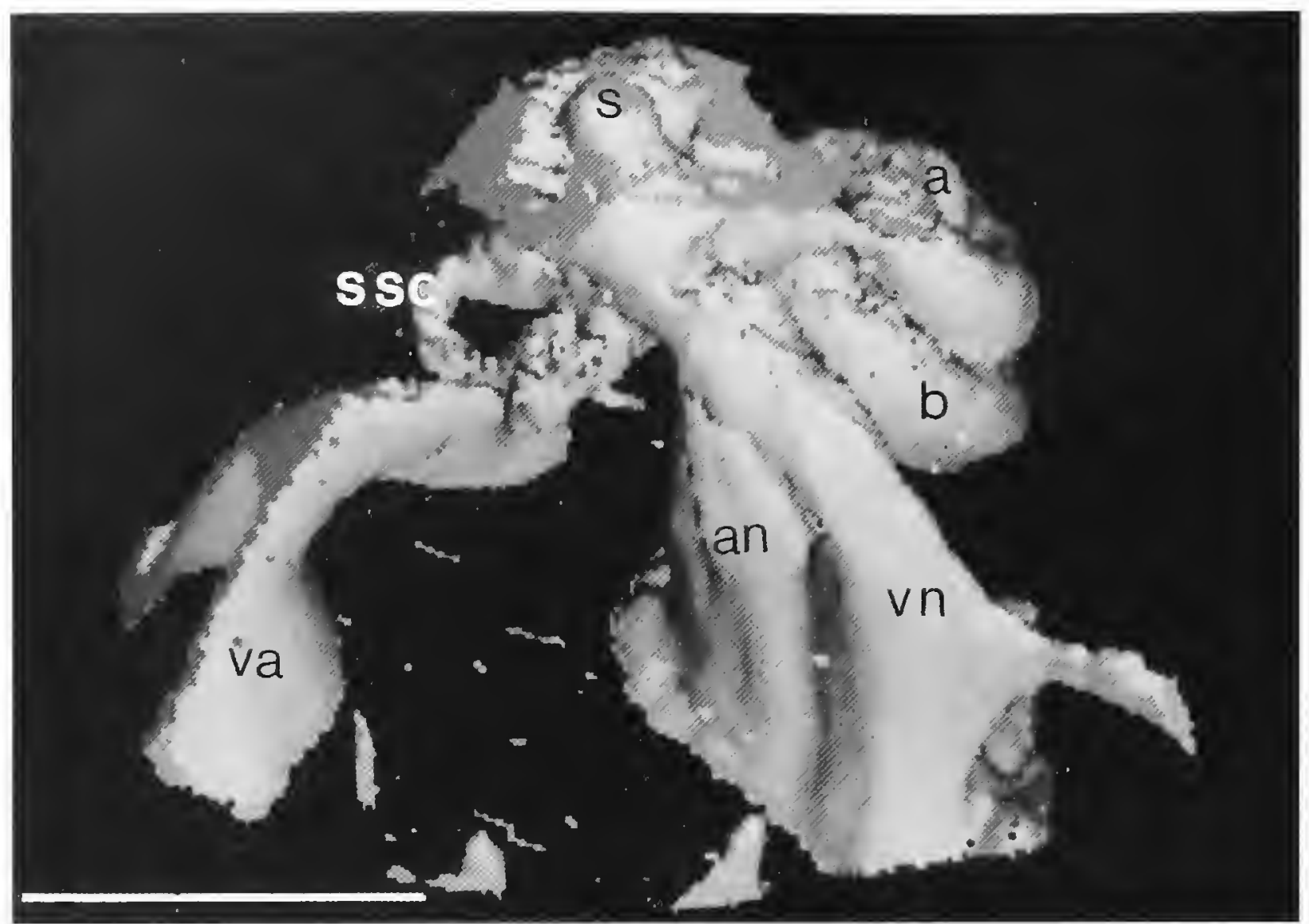

FIGURE 12.-Odobenocetops peruvianus, left periotic (referred specimen, MNHN SAS 1613): reconstruction of inner ear spaces from CT data. (Scale $b a r=1 \mathrm{~cm}$; $a$ =apex of cochlea; an=auditory nerve canal; $b=$ basal turn; $s=$ head of stapes; ssc=semicircular canal; va=vestibular aqueduct; vn=vestibular nerve bundle.)

many species, the semicircular canals are sufficiently small and thread-like that the complete canal system cannot be traced in periodic histologic sections, much less detected by high-resolution CT (Gray, 1951; Ketten, 1992). This contrasts sharply with the condition in land mammals, in which vestibular canal volumes rival cochlear volumes and are readily imaged by even conventional CT (Gray, 1951; Spoor, 1993). Although size is not a criterion for vestibular function, the majority of cetaceans appear to have uniquely small semicircular canals that are significantly shorter and narrower than their cochlear canals (Gray 1951; Jansen and Jansen, 1969). This anomalous vestibular de-

TABLE 2.-Cochlear morphometry of cetaceans. Measurement are in millimeters. (e=estimated.)

\begin{tabular}{l|llccc}
\hline \multicolumn{1}{c|}{ Species } & Turns & $\begin{array}{c}\text { Scalae } \\
\text { length }\end{array}$ & $\begin{array}{c}\text { Basal } \\
\text { diameter }\end{array}$ & $\begin{array}{c}\text { Axial } \\
\text { height }\end{array}$ & $\begin{array}{c}\text { Body } \\
\text { length }\end{array}$ \\
\hline Delphinapterus leucas & 1.75 & 41.99 & 10 & 4.21 & 325 \\
Grampus griseus & 2.5 & 40.5 & 8.73 & 5.35 & 228 \\
Lagenorhynchus albirostris & 2.5 & 34.9 & 8.74 & 5.28 & 207 \\
Monodon monoceros & 2.5 & 45.12 & 11.6 & 5.3 & 425 \\
Phocoena phocoena & 1.5 & 25.93 & 5.25 & 1.47 & 133 \\
Physeter catodon & 1.75 & 72.21 & 14.3 & 3.12 & 1361 \\
Stenella attenuata & 2.5 & 36.9 & 8.61 & 4.36 & 185 \\
Tursiops truncatus & 2.25 & 40.65 & 9.45 & 5.03 & 259 \\
$\begin{array}{l}\text { Odobenocetops peruvianus } \\
\quad \text { (MNHN SAS 1613) }\end{array}$ & 2.5 & 44.37 & 10.1 & 4.31 & $380 \mathrm{e}$ \\
$\begin{array}{l}\text { Odobenocetops peruvianus } \\
\text { (MNHN SAS 1614) }\end{array}$ & 2.25 & 44.41 & 10 & 4.5 & $380 \mathrm{e}$ \\
\hline
\end{tabular}

velopment is underscored by the fiber distributions of cetacean acoustovestibular nerves. Recent data show that the majority of odontocetes have $3 \%-5 \%$ of the total of VIII ${ }^{\text {th }}$ nerve fibers devoted to vestibular components, as compared with an average of $45 \%$ in land mammals-percentage ranges from about $20 \%$ in bats to about $60 \%$ in brachiating primates (Gao and Zhou, 1995).

The three readily imaged semicircular canals and the welldefined vestibule of Odobenocetops are similar in dimensions to those of the beluga (Delphinapterus leucas) (Figure 12). Delphinapterus leucas has the highest semicircular canal ratio of any extant odontocete studied. In all mammals, cochlear size is best correlated with body mass, but the exact correlates of the semicircular-canal size in most mammals remain unclear. For primates, a positive relationship to locomotory behavior appears relatively robust (Spoor, 1993). It has been suggested that fusion of the cervical vertebrae in Cetacea resulted in limited head movements and substantially fewer inputs to the vestibular system, leading to a loss of related receptors (Ketten, 1992). Better-developed semicircular canals in D. leucas are consistent with this species having a well-defined neck and greater rotational and lateral head movements (a full right angle) than other living odontocetes. The diameters of the auditory and vestibular canals in Delphinapterus, Monodon, and Odobenocetops are very close but not substantially different from those of other odontocetes. Cross-sectional areas of the canals for the vestibular component versus the auditory compo- 


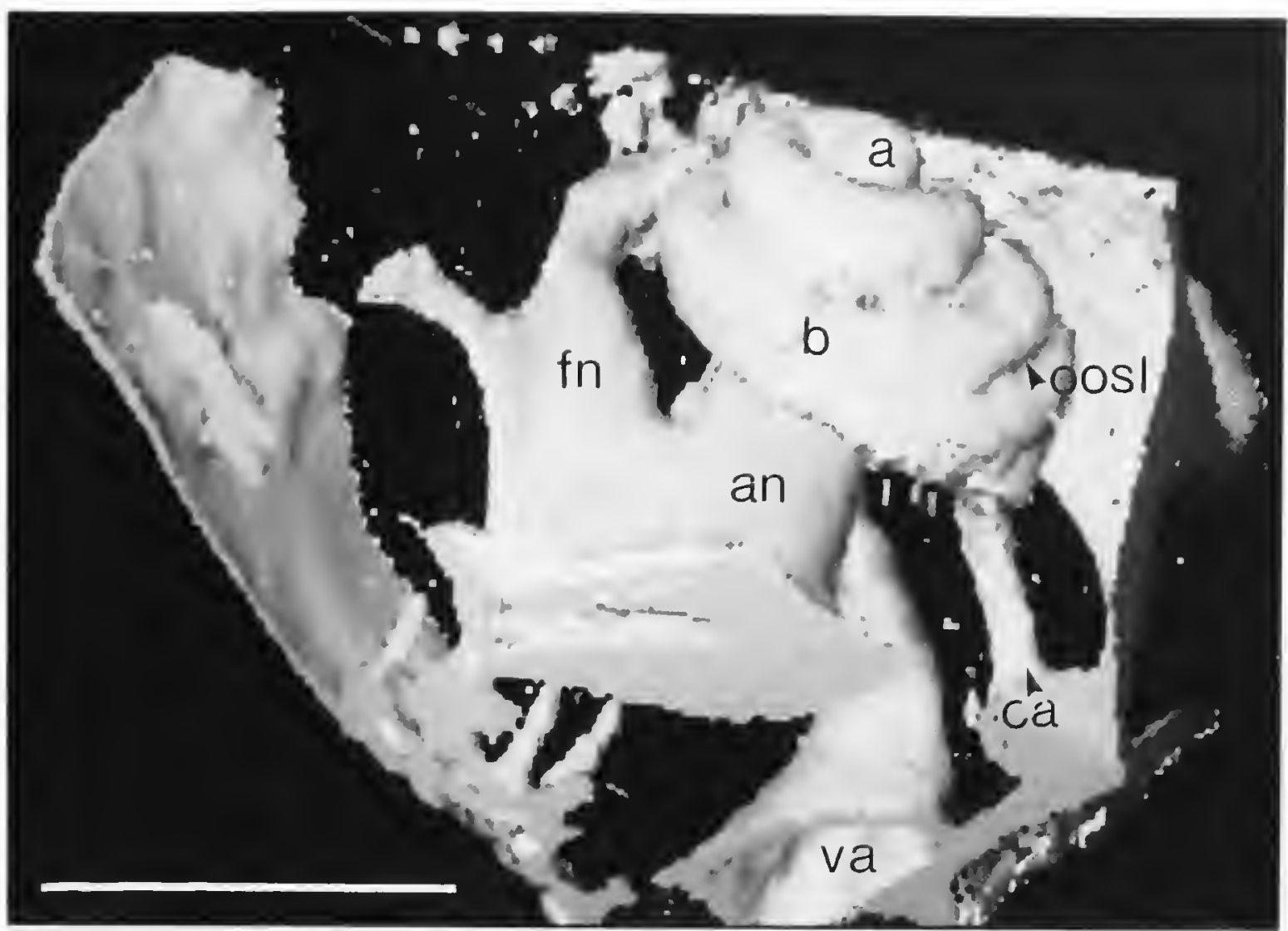

FIGURE 13.-Odobenocetops peruvianus, left periotic (referred specimen, MNHN SAS 1613): reconstruction of inner ear spaces from CT data. (Scale bar $=1 \mathrm{~cm}$; abbreviations as in Figure 11.)

nent of the VIII ${ }^{\text {th }}$ nerve are somewhat higher for both Delphinapterus $(7 \%)$ and Odobenocetops (6\%-9\%) than for most delphinids. Assuming that the diameters of neural fibers occupying those cross sections were equivalent in extinct and extant species, we speculate that Odobenocetops had a vestibular-ganglion cell population between 4500 and 7000 neurons, with an average auditory ganglion population of approximately 75,000 to 80,000 . There are, however, a great many caveats to this speculation, chief among them being that the available database is too small for explicit conclusions about exact neuronal levels. At this point, the most appropriate interpretation is that the exceptionally close morphometric resemblance between the Delphinapterus and Odobenocetops vestibular systems is striking and consistent with the idea that Odobenoce- tops also may have had substantially greater head motions than most modern cetaceans. This motility could be related to the benthic feeding adaptations proposed herein.

The significance of an enlarged vestibular aqueduct and presumably equally large endolymphatic duct is unclear. Large reniform aqueducts are found in some baleen whales, e.g., Balaena mysticetus. No detailed comparative studies of the aqueduct across a variety of species are currently available for aquatic mammals, however.

Equally striking is the relative size of the facial nerve canal in Odobenocetops compared with that of most odontocetes. With the exception of Monodon monoceros, the facial nerve is typically less than $1.5 \mathrm{~mm}$ in diameter. The facial nerve of the specimen of $M$. monoceros examined for this study, an adult

TABLE 3.-Neural canal morphometry of cetaceans. Measurements are in millimeters.

\begin{tabular}{l|cccc}
\hline \multicolumn{1}{c|}{ Species } & $\begin{array}{c}\text { Vestibular } \\
\text { nerve diameter }\end{array}$ & $\begin{array}{c}\text { Facial } \\
\text { nerve diameter }\end{array}$ & $\begin{array}{c}\text { Internal auditory } \\
\text { canal diameter }\end{array}$ & $\begin{array}{c}\text { Auditory } \\
\text { nerve diameter }\end{array}$ \\
\hline Delphinapterus leucas & 1.20 & 1.47 & 5.6 & 4.4 \\
Grampus griseus & - & - & 4.7 & 3.7 \\
Lagenorhynchus albirostris & - & - & 4.6 & 3.6 \\
Monodon monoceros & 1.50 & 3.04 & 6.22 & 4.92 \\
Phocoena phocoena & 0.52 & 1.09 & 3.7 & 2.78 \\
Physeter catodon & - & - & 11.3 & - \\
Stenella attenuata & - & - & 4.9 & - \\
Tursiops truncatus & 1.00 & 1.41 & 5.6 & 4.5 \\
Odobenocetops peruvianus & 1.15 & 2.7 & 5 & 3.85 \\
$\quad$ (MNHN SAS 1613) & & & & 4.0 \\
Odobenocetops peruvianus & 1.00 & 2.5 & 5 & \\
(MNHN SAS 1614) & & & & \\
\hline
\end{tabular}




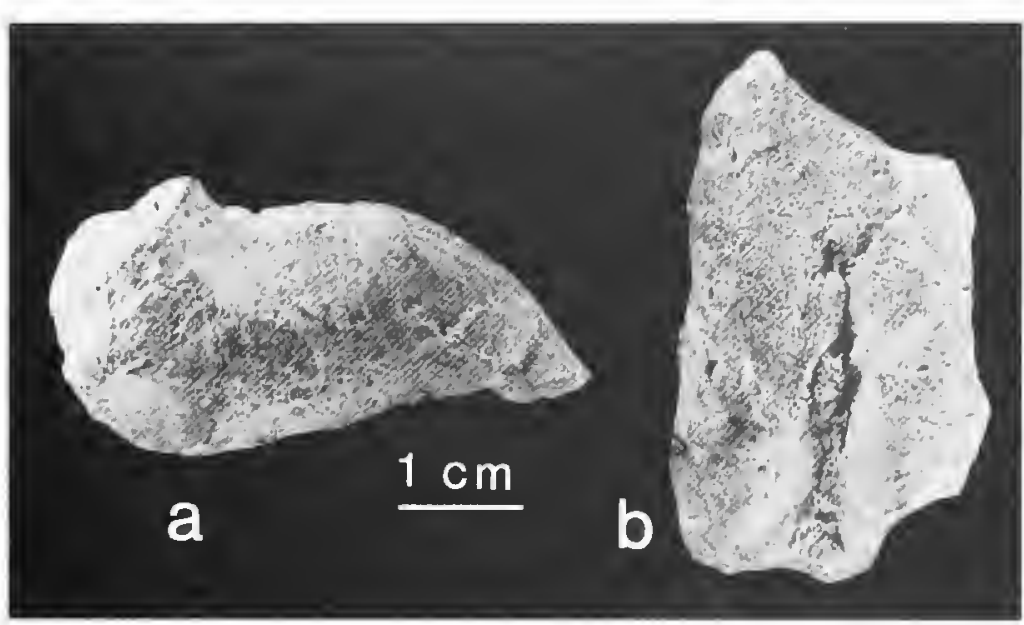

FIGURE 14.-Odobenocetops peruvianus, left tympanic (referred specimen, MNHN 1613): $a$, medial view; $b$, ventral view.

male, measured $3.1 \mathrm{~mm}$, or approximately double the odontocete average. The Odobenocetops facial nerve canals averaged $2.6 \mathrm{~mm}$ at mid-periotic level. Once again, it is not possible to draw definitive neural conclusions from the anatomy of one or two animals; however, it is noteworthy that in each of these species the tusks coincide with an unusually large volume of facial nerves.

Middle Ear: Little can be said about the middle ear because of the lack of complete tympanics. One stapes remains in situ. It is monocrural with a large head and footplate, a configuration common among both Odontoceti and Sirenia. The distal facet has a surface area that is large in comparison with the stapes footplate and is more ventrally directed in this specimen than in other odontocetes.

Tympanic: The tympanic is incomplete, as only the involucrum and a small portion of the ventral side are preserved (Figure 14). It shows, however, a typical feature of the Delphinida (Muizon, 1988b), namely the sigmoid morphology of the involucrum in medial view. This feature is very clear in the Lipotidae, Inioidea, and Delphinoidea. It is absent in the Platanistoidea (sensu Muizon 1987, 1991) and in the Physeterida. The involucrum is much more robust and stout in Odobenocetops than in any other Delphinoidea. It is not dorsoventrally flattened as in the Holocene Delphinoidea, even in the most robust forms such as Orcinus. In some Kentriodontidae, such as Atocetus, the involucrum is relatively robust but much smaller.

Occipital: The occipital is relatively lower than in other Delphinoidea but is very wide and convex (Figure 15). It has undergone some slight postmortem deformation, but this apparently had little effect on the overall shape of the bone. The portion of the bone lateral to the occipital condyle is much wider and lower than in the Delphinidae and Phocoenidae and is strongly expanded laterally. It somewhat resembles the condition in the Monodontidae, where the posterior crest of the temporal fossa (the lambdoid crest) is oblique and not vertical. In Odobenocetops the lambdoid crest is assimilated into the nuchal crest as a consequence of the strong modification of the temporal fossa. The paroccipital process, although partially broken, seems to have been very well developed, robust, and

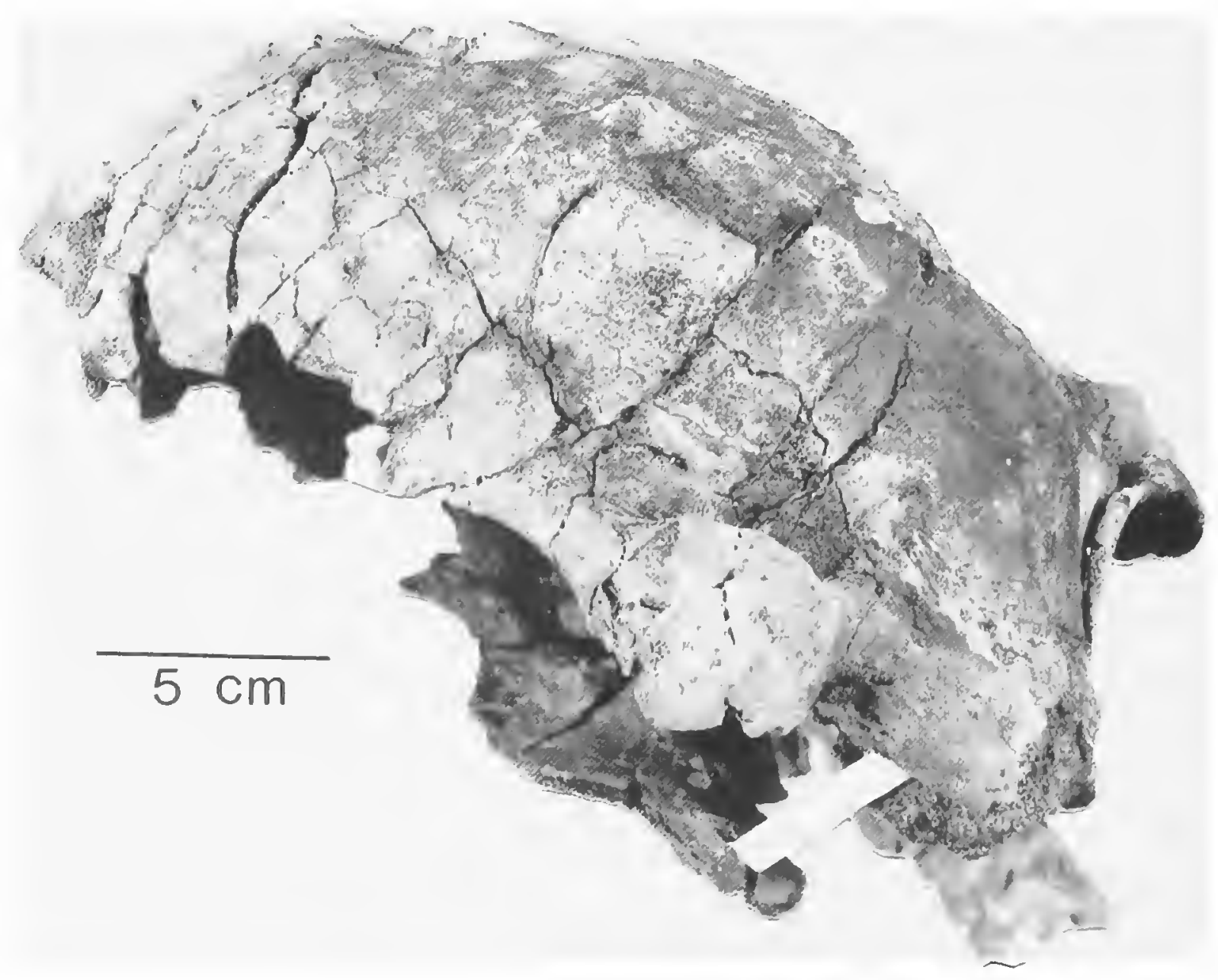

FIGURE 15.-Odobenocetops perwianus, holotype (USNM 488252): occipital view of the skull. 
markedly expanded laterally. Its anterior face very probably received a posterior sinus. It is thickened and fused to the posterior thickened region of the squamosal. The very stout morphology of this squamoso-paroccipital angle of the skull, as well as the robustness of the zygomatic process of the squamosal, seems to indicate very strong musculature inserted on this region of the skull: the scalenus ventralis and scalenus dorsalis, which insert on the anteroventral and posteroventral regions of the paroccipital process respectively, and possibly the costohumeralis and sternomastoideus, which insert in part on the posterolateral border of the process. In its dorsal region, the occipital crest does not seem to have been more prominent than in other delphinoids, and the muscle insertions are not as marked as in some Monodontidae (in some males of Monodon). The occipital shield is strongly convex, much more so than in other Delphinoidea. It differs from the somewhat flattened condition observed in the Monodontidae and is closer to the more convex condition of the Delphinidae and Phocoenidae.

The right condyle only is preserved, and that not totally. It is much more convex and salient than in any Holocene delphinoid and adjoins a very deep supracondylar fossa. These structures are much more developed than in Delphinapterus, which is well known for having a very well-defined and flexible neck for a cetacean. Consequently, the morphology of the occipital condyle of Odobenocetops obviously indicates that it was capable of very ample movements of its head, which was certainly much more mobile and flexible than in Delphinapterus.

Endocranial Cavity: The endocranial cavity is widely opened, as major parts of the posterolateral and ventrolateral regions of the left side of the skull are missing, allowing observation of the internal morphology of the braincase (Figure 16). Its major characteristic is the presence of ethmoidal fossae for a pair of small olfactory bulbs, separated by a small bony wall. The fossae are horizontal, slightly higher than they are wide, and approximately $4 \mathrm{~mm}$ wide, $6 \mathrm{~mm}$ high, and $8 \mathrm{~mm}$ deep. Such structures are very uncommon in the living odontocetes but have been mentioned in the Delphinidae (Sinclair, 1966) and Eoplatanistidae (sensu Pilleri and Ghir, 1981, 1982; Muizon, 1988c), and Muizon observed them in the Eurhinodelphidae, in the Platanistidae (cf. Pomatodelphis sp., USNM 214759), and in the Squalodontidae (Squalodon tiedemani). Kellogg (1926) observed, in the posterior wall of the bony nares of the platanistid Zarhachis flagellator, two crescentic foramina that represent the exits of the olfactory nerves. Furthermore, Oelschläger and Buhl (1985a, 1985b) noted, in early ontogenetic stages of Phocoena phocoena, an olfactory bulb that becomes reduced in later growth stages.

The groove for the optic chiasma is located just below the ethmoidal fossae, and the optic nerves exited the skull at the very front of the brain, as in the living Monodontidae but unlike the condition in the other odontocetes. The exits of the optic nerves are located more medially (much closer to the midsagittal plane of the skull) and the chiasmatic groove is much narrower than in the other delphinoids, however. In Delphi- napterus the distance between the exits of the optic nerves is generally two to three times greater in absolute value than in Odobenocetops.

Posterolateral to the optic canal are the sphenorbital fissure and the foramen rotundum. They are large and the latter is superposed to the former. They are separated by a bony wall (partially broken) where they exit the skull. Among the Delphinoidea this morphology is present in Monodon. In the Delphinidae and Phocoenidae, the sphenorbital fissure and the foramen rotundum are most commonly confluent with the optic foramen. In Delphinapterus the optic foramen is isolated, but the sphenorbital fissure and foramen rotundum are confluent.

The sphenorbital fissure of Odobenocetops is much larger than in Delphinapterus and approaches the size observed in the much larger Monodon, although in that genus the foramen rotundum is smaller than in Odobenocetops. The sphenorbital fissure is the passage for the nerves and blood vessels that provide innervation and blood supply to the anterior part of the skull, including the oculomotor nerve (III), trochlear nerve (IV), ophthalmic branch of the trigeminal nerve (V1), abducens nerve (VI), anastomotic artery, and cavernous sinus. The foramen rotundum is the passage for the maxillary branch of the trigeminal nerve (V2). The large size of these apertures in the skull of Odobenocetops is certainly related to the major modifications of the rostrum (large mobile eyes, premaxillary tusks, and inferred large upper lip), which would have required extensive blood and nerve supplies. The very large sphenorbital fissure in the walrus and the narwhal is very probably related to the growth of the tusks (and to the large upper lip, in the case of the walrus).

The remainder of the internal view of the braincase shows mainly the cavities for the cerebral hemispheres, which appear to be proportionally shorter and wider than in the other Delphinoidea. Immediately dorsal to the lateral border of the foramen ovale, on the internal side of the braincase, is a longitudinal groove that seems to reach the foramen rotundum; it is absent from the other Delphinoidea, and its function is not clear.

\section{COMPARISONS AND AFFINITIES}

Comparing Odobenocetops peruvianus with other taxa is not easy, as most of the typical odontocete characters have been strongly modified. As already stated (Muizon, 1993a, 1993b), Odobenocetops is a delphinoid odontocete cetacean. Within the Delphinoidea, comparisons are not very productive because Odobenocetops differs from the other Delphinoidea in almost all the features observed. The exceptional morphology of the cetacean described herein, however, requires a statement of which characters allow a precise taxonomic definition of Odobenocetops. Five major features allow assignment of Odobenocetops to the Cetacea:

1. The presence of large air sinuses in the auditory region, connected to well-developed pterygoid sinuses. All cetaceans have a peribullary sinus, but pterygoid sinuses are not found in all members of the order. Although they are absent in Pakicetus 


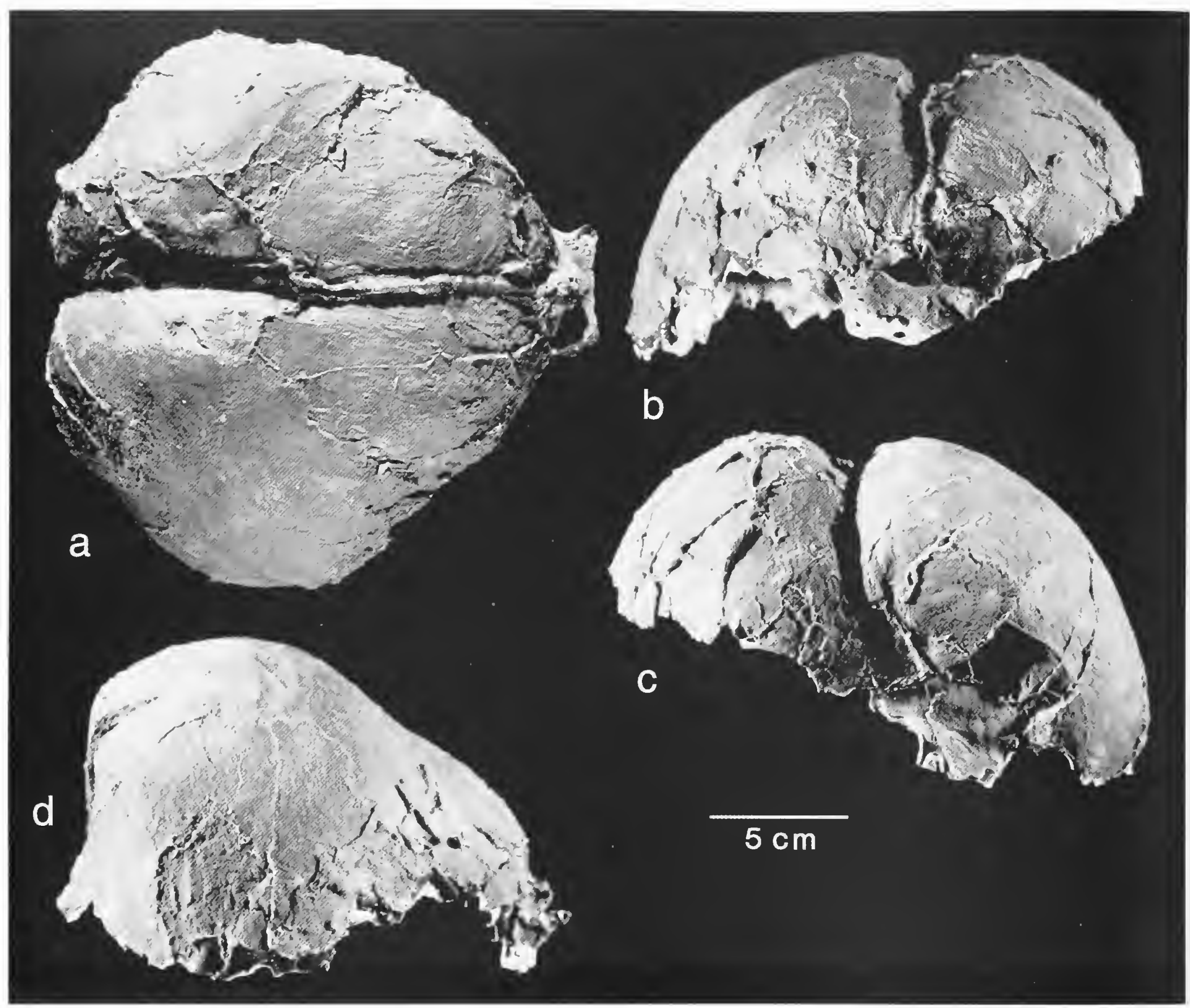

FIGURE 16.-Endocranial cast of the holotype of Odobenocetops peruvianus (USNM 488252): $a$, dorsal view; $b$, anterior view; $c$, posterior view; $d$, lateral view.

and in Protocetus, they are present in all other cetaceans. Air sinuses surrounding the auditory region and invading the pterygoid are not known in any other mammals. A pterygoid duplicated into two laminae also is found in the Erinaceidae, the Macroscelidae, and the Tupaiidae. In these families, however, the fossa is always opened anteriorly, unlike what is observed in all cetaceans, and there are no peribullary sinuses.

2. The large supraorbital process of the frontal, which widely overhangs the orbital region. This feature is present in all adequately known cetaceans; however, it has not been observed in Pakicetus because that part of the skull is unknown in this genus.

3. The narial fossae of Odobenocetops, which open dorsally and are not located at the apex of the skull. In the Sirenia the condition of the bony nares is significantly different from that in the cetaceans; the nares open anteriorly in a wide narial basin that opens dorsally and is located in the anterodorsal region of the skull. In the proboscideans, the narial fossae are not located at the anterior end of the skull but they open anteriorly. A condition convergent with that of the cetaceans is found, however, in Macrauchenia, a Pleistocene South American litoptern. The cetacean condition is not found in any carnivores.

4. The absence of a true cribriform plate. This structure is located in the mesethmoid, at the anterior region of the cranial cavity, and gives passage to the olfactory nerves. The olfactory nerves have not totally disappeared in the cetaceans, however; small olfactory bulbs have been observed in several cetaceans, and Odobenocetops still retains small ethmoidal fossae (see 
above). The loss of the cribriform plate is obviously related to the aquatic life habits of the cetaceans. A well-developed cribriform plate is present in all the aquatic carnivores, but it is reduced in the Sirenia.

5. An immobile elbow. Although archaeocetes do not have an immobile elbow, this feature is constant in mysticetes and odontocetes. The partial forelimb illustrated in Figure 17 was found associated with a partial skull of Odobenocetops (as mentioned above) and shows the characteristic immobility of the elbow seen in the modern cetacean forelimb.

Several other features allow us to classify Odobenocetops among the odontocetes, although the hyperspecialization of the skull partially hides the key character of the suborder. It has been noted elsewhere (Muizon, 1994) that the odontocetes are diagnosed by a posterior projection of the maxilla that covers the supraorbital process of the frontal totally or partially. In Odobenocetops, the maxillae have withdrawn medially and the supraorbital process is almost totally uncovered dorsally. Nonetheless, this key character of the odontocetes is still observable in Odobenocetops. The following features allow the assignment of Odobenocetops to the odontocetes.

1. Although strongly withdrawn, the maxillae still cover part of the medial part of the supraorbital processes medially, are expanded far backwards behind the nares, and are in contact with each other medially in that region. This condition is found neither in the Archaeoceti nor in the Mysticeti.

2. The fossa for the pterygoid sinus of Odobenocetops is greatly expanded dorsoventrally, and its dorsal limit is dorsal to the floor of the braincase. This condition is never found in any Archaeoceti or Mysticeti but is common in the odontocetes. In some very early taxa, such as agorophiids and Waipatia, the pterygoid fossa is not as developed as in the Holocene forms, but it is still clearly more developed than in the archaeocetes and mysticetes.

3. The premaxillary foramina are large. The premaxillary foramen of odontocetes is a supplementary passage for branches of the external carotid artery and for the maxillary division of the trigeminal nerve. This need for supplementary blood supply and innervation is related to the major specializations of the odontocete head, namely the melon and the air sac system. Enlarged premaxillary foramina are observed neither in the archaeocetes nor in the mysticetes.

4. The bones of the skull in the facial region are asymmetrical, especially the premaxillae and the maxillae; the right bone is always more developed than the left. Although this asymmetry is lacking or extremely reduced in several fossil groups (among others, Squalodontidae, Eurhinodelphidae, and Agorophiidae), this pattern of asymmetry is known among mammals only in the odontocetes. Furthermore, Odobenocetops presents a strong asymmetry of the tusks, as in the narwhal.

5. The narial passages are more vertical than those of archaeocetes and mysticetes. In Odobenocetops, because of the forward migration of the nares, this feature is not so well marked as in the other odontocetes. This is not a very satisfac-

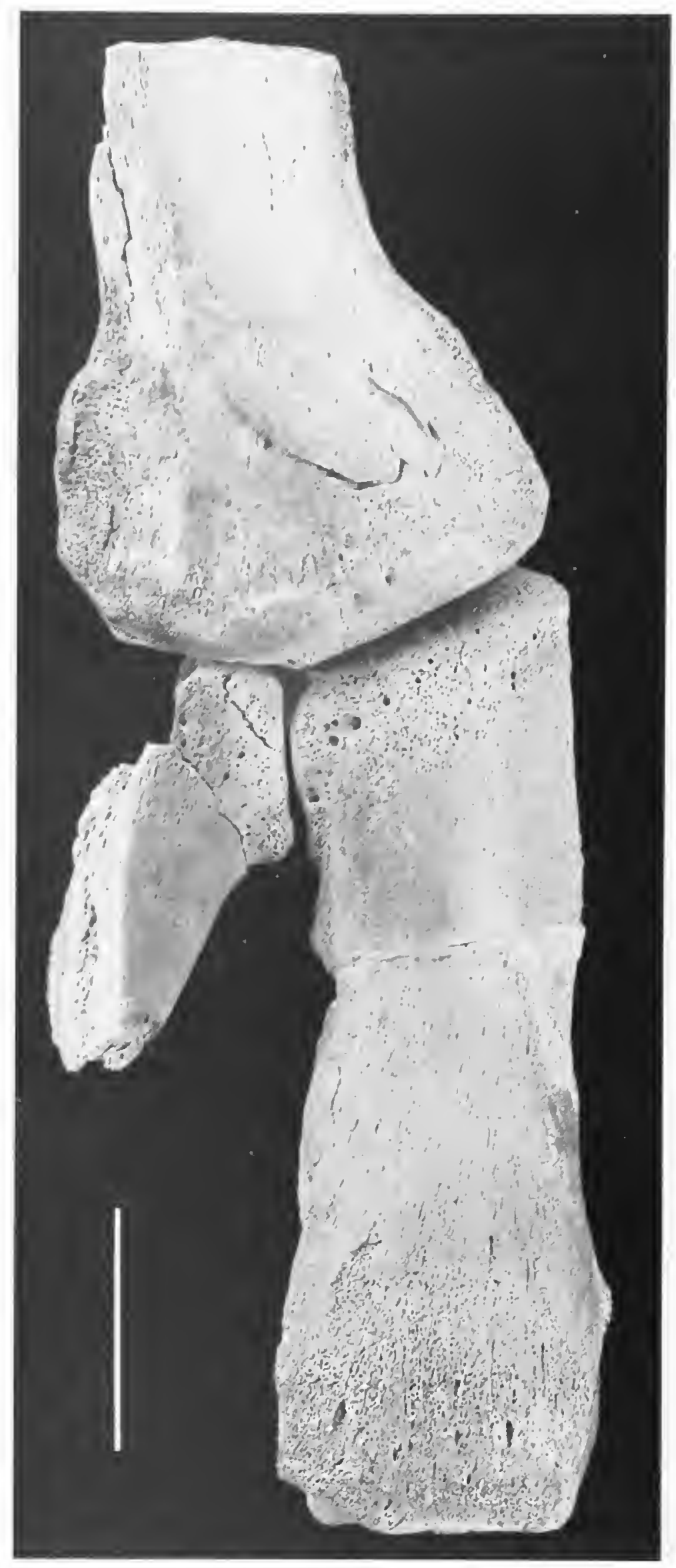

FIGURE 17.-Odobenocetops sp. (MNHN SAO 202): left forelimb, with partial humerus, partial ulna, and complete radius, in medial view. (Scale bar $=3 \mathrm{~cm}$.)

tory character, however; in the early-diverging odontocetes it also is little developed, because the telescoping of the skull has not yet proceeded very far.

As to the position of Odobenocetops within the odontocetes, some features allow its classification within the infraorder Delphinida (sensu Muizon, 1988c). The major synapomorphy of 
the Delphinida is the protrusion of the pterygoid sinus within the palatine, which is thereby divided into a medial and a lateral lamina. Such a structure is present in all eight families of the group (Lipotidae, Iniidae, Pontoporiidae, Kentriodontidae, Albireonidae, Monodontidae, Phocoenidae, and Delphinidae). The Delphinida also share the presence of a cranial hiatus that greatly enlarges the posterior lacerate foramen, which in turn is coalescent with the median lacerate foramen; in the Delphinida the periotic hangs in the hiatus, because it is connected to the skull by ligaments only. As mentioned above, Odobenocetops has a very large cranial hiatus. Furthermore, if the tympanic described above actually belongs to Odobenocetops, the sigmoid morphology of its involucrum in medial view leaves little doubt that the walrus-like dolphin belongs to the Delphinida (see Muizon, 1988c:163, fig. 3). The sigmoid involucrum of the tympanic of the Delphinida contrasts with the olive shape observed in the Platanistoidea (sensu Muizon 1987, 1991) and with the indented involucrum of the Eurhinodelphoidea and Ziphiidae.

Odobenocetops peruvianus is a delphinoid because it bears a medial maxilla-premaxilla suture in the anterolateral edge of each narial fossa, which is formed by the maxilla. This character, which was analyzed by Muizon (1988c:199), is present in all the living Delphinoidea (with some individual variation), but it is not constant in the fossil groups, such as the Kentriodontidae. This feature is found only in the Delphinoidea, however, so its presence in Odobenocetops is evidence for its classification in that superfamily.

Among the Delphinoidea, Odobenocetops is related to the Monodontidae by three derived features that have been regarded as synapomorphies of the Monodontidae (Muizon, 1988b:191):

1. A lateral lamina of the palatine that passes below the optic gutter and joins the frontal laterally.

2. An alisphenoid and adjacent portions of the squamosal that are very thickened lateral to the foramen ovale and medial to the zygomatic process.

3. The presence of a very long and low temporal fossa (contrary to what Muizon (1988b:207) stated, it is clearly present in Denebola (Barnes, 1984, fig. 6)). This morphology corresponds to an anteroposterior elongation of the middle region of the skull. Related to this modification are the anterior stretching of the supraorbital process of the frontal, the less transverse orientation of the optic gutter than in the other delphinoids, and the position of the exits of the optic nerves at the most anterior region of the brain and not posteroventral to the apex of the brain as in the other delphinoids. In fact, the transformation in the Monodontidae seems to be the consequence of the anterior migration of the eyes. That original modification is present to an extreme degree in Odobenocetops, where the supraorbital process of the frontal is tremendously stretched anteriorly, the optic gutter is oriented almost anteroposteriorly, the exits of the optic nerves are located at the anterior extremity of the brain, and the temporal fossa is greatly elongated anteroposteriorly. The morphology of Odobenocetops is obviously a much more derived stage of the condition observed in the Monodontidae.

The Monodontidae also were diagnosed by two additional features: the extension of the maxilla-premaxilla suture on the lateral side of the nares (in the other Delphinoidea, the suture always remains on the anterior edge of the nares) and the reduction of the lateral lamina of the hamular process of the pterygoid (all the other delphinoids have well-developed lateral laminae) (Muizon, pers. obs.). These characters are not observed in Odobenocetops, which is therefore less derived than the living Monodontidae for those features.

The Monodontidae are further characterized by widely separated pterygoid hamuli. This monodontid condition is greatly accentuated in Odobenocetops, where the pterygoids are very widely separated. This feature, however, also is known in some Delphinidae (generally as an individual variation) and in the Holocene Phocoenidae (it is absent in Piscolithax, a Tertiary phocoenid).

In addition to the above evidence, the discovery of a partial skeleton (including skull and forelimb) of Odobenocetops sp. (MNHN SAO 202) in a slightly younger level at Sacaco confirms both that $O$. peruvianus is a cetacean and that its affinities lie with the Monodontidae. The forelimb shows the typical cetacean modifications (immobility of the elbow), and its overall morphology recalls that of the Monodontidae (Muizon and Domning, 2002) (Figure 17). The monodontid affinities of Odobenocetops are clearly reinforced by the morphology of the inner ear, as shown above.

In view of the exceptional specializations of Odobenocetops peruvianus, it was referred (Muizon, 1993a) to a new family, the Odobenocetopsidae, regarded as the sister group of the Monodontidae. Odobenocetops peruvianus shows obvious autapomorphies, the most important of which are (1) loss of the typical cetacean rostrum and enormous thickening of the premaxillae at the anterior region of the skull, (2) development on the premaxillae of large, downturned alveolar processes housing one large erupted right tusk and a small, probably unerupted left tusk, (3) extreme anterior position of the enlarged nares and the dorsally facing orbit, (4) withdrawal of the frontal and maxilla from the posterodorsal angle of the skull, a condition that opens the temporal fossa dorsally, (5) reduction of the maxillae, which are excluded from the bony palate and only form part of the lateral wall of the skull, (6) extensive modification of the zygomatic process of the squamosal into the thick lateral wall of a large, anteroposteriorly elongated squamosal gutter, part of which houses the glenoid cavity and the middle sinus, (7) great reduction or absence of the premaxillary sacs, and (8) a strongly thickened posteroventral region of the squamosal and a very solid, interdigitated parietal-squamosal suture.

The occurrence of tusks in Odobenocetops is a convergence with Monodon; in the latter genus the large tusk of the male is 
implanted in the left maxilla, whereas in Odobenocetops the large tusk is implanted in the right premaxilla. Consequently, the tusk of Monodon and that of Odobenocetops are not homologous.

Enlarged apical teeth or tusks are known in some other cetaceans. Enlargement of apical teeth is common in squalodonts, where the anteriormost tooth of the premaxilla and of the dentary are enlarged and protrude anteriorly, being almost horizontal (Dal Piaz, 1916; Kellogg, 1923). A similar condition is found in Kentriodon pernix from the middle Miocene of the Calvert Formation of Maryland. These teeth, in squalodonts and Kentriodon, do not show asymmetry. Kharthlidelphis diceros from the Oligocene of Georgian Republic (Mchedlidze and Pilleri, 1988) also possesses one pair of enlarged apical upper teeth that protrude anteriorly and horizontally. In this case the left tooth has a diameter approximately twice that of the right one, and the teeth are implanted in the maxillae. This condition is basically similar to that of the narwhal, but the size difference between the teeth is much less and the right tusk is erupted. Kharthlidelphis is therefore very different from Odobenocetops, where the tusks are implanted in the premaxillae and the right tusk is much larger than the left one. Furthermore, the downturned tusks of Odobenocetops are unique among cetaceans.

\section{Functional Anatomy}

When compared with the other delphinoids, Odobenocetops shows drastic modifications of the skull that have been mentioned in the description above. These can be classified in three groups: (1) those related to the nasal sacs, basicranial sinuses, and auditory region, and consequently to sound production and reception; (2) those related to feeding; and (3) the tusks. In the following sections we analyze each of these groups of specializations.

\section{NaSAl SaCs, Basicranial SinUSES, AND AUDITORY REGION}

Several authors have stated that the nasal sacs are at least partially implicated in sound production (Lawrence and Schevill, 1956; Lilly, 1961; Lilly and Miller, 1961; Evans and Prescott, 1962; Norris, 1964, 1968, 1969; Norris and Evans, 1967). Mead (1975) critically reviewed the literature on the relations between the nasal diverticula and sound production and reached the conclusion that "the structures more likely to be involved in sound production are those in the vicinity of the nasal plugs." Mead (1975) also stated that the premaxillary sacs could be used as sources for air during phonation.

The role of the basicranial air sinus has been debated. Fraser and Purves (1960) stated that their function is the phonic isolation of the periotic from bone-conducted sounds. The sound waves transmitted by bone conduction are reflected on the in- terfaces between bone and soft tissues (which behave like liquid in sound transmission) and the foamy filling of the air sinus (which behaves like air in sound transmission). The sound waves are therefore forced to enter the cochlea through the external auditory meatus, thus providing good directional hearing. McCormick et al. (1970) rejected this idea, however, stating that the acoustic vibrations reach the ear through the tissues of the head, and Norris $(1964,1968,1969)$ and Brill et al. (1988) proposed that the echolocation sounds may return to the body "by the way of the intramandibular fat body which acts as a passive wave guide and enter the middle ear via the tympanic bulla which transmits sounds directly to the ossicular chain and cochlea through the processus gracilis," which attaches the malleus to the tympanic.

The melon is a fatty organ located on the dorsal side the rostrum anterior to the nasal complex. In some species, the melon reaches the apex of the rostrum; this is generally true, for example, in the Globicephalinae. The melon is embraced by the medial portion of the rostral muscle (Mead, 1975), also called the pars labialis of the maxillonasolabialis (Lawrence and Schevill, 1956) and the nasolabialis profundus pars lateralis (Rodinov and Markov, 1992). Below the posterior part of the melon are the nasal plug muscle and the premaxillary sacs (Mead, 1975), in which it is partially imbricated. The most commonly suggested function of the melon is as an acoustic lens (Lilly, 1961; Norris, 1964, 1968, 1969; Wood, 1964). Although it seems clear that the melon is involved in sound reception and transmission (Norris and Harvey, 1974; Mead, 1975), its function remains unclear.

On the skull of Odobenocetops, three features can be observed that denote lesser ability in sound production and/or transmission than in the other delphinoids: (1) the premaxillary sacs and nasal plug muscles were either absent or very reduced; (2) the melon was vestigial or absent; and (3) apparently the nasal diverticula of the nasal passages were very reduced or absent. The latter statement requires explanation.

The nasal diverticula of the Delphinidae have been well described by Lawrence and Schevill (1956) and Mead (1975). The nasal sacs and the communication between them are controlled by the various layers of the pars nasalis of the maxillonasolabialis muscle. Most of that muscle is attached to the dorsal side of the skull, lateral to the nasal opening and to the premaxilla, and posterior to the antorbital notch and the nuchal crest. It is divided into six layers according to Lawrence and Schevill (1956), and five layers according to Mead (1975). Rodinov and Markov (1992) recognized nine muscles, four in their nasolabialis group (which includes the nasal plug muscle, their nasolabialis profundus pars anterior medialis) and five in their maxillonasalis group. None of these layers or muscles is attached to the parietal. In Odobenocetops, the anterior withdrawal of the frontal and maxilla and the loss of the roof of the temporal fossa are supposed to have considerably reduced the attachment area of the pars nasalis of the maxillonasolabialis. 
This statement assumes that very few or no muscle fibers would have migrated onto the broadly uncovered parietal, posteriorly. The five layers recognized by Mead (1975) are the pars posteroexternus (PE), the pars intermedius (I), the pars anteroexternus $(\mathrm{AE})$, the pars posterointernus $(\mathrm{PI})$, and the pars anterointernus (AI). The first four layers (PE, I, AE, PI) attach to the lateral edge of the supraorbital process and to the temporal crest. The pars AI attaches mainly to the ascending process of the maxilla and to the lateral border of the premaxilla.

Consequently, we can assume that the great reduction of the maxilla would have resulted in an extreme reduction (or loss) of AI. Furthermore, the disappearance of the temporal crest and the reduction of the lateral edge of the supraorbital process (which is very thin and strongly notched in dorsal view) also suggest a great reduction of the four layers PE, I, AE, and PI. Even if all the nasal diverticula totally disappeared, however, it is obvious that at least part of the maxillonasolabialis (pars anteroexternus) must have been retained, as this layer is involved in opening the blowhole.

Furthermore, Odobenocetops has large nasal apertures, and the problem is to determine whether it had nasal plugs or not. Given the size of the bony nasal passages, if nasal plugs were present, they would have been very large and consequently would have been moved by equally developed muscles. We observed, however, that the nasal plug muscle, if present, was very small. Furthermore, Mead (1975:53) stated that the "PI and $\mathrm{AI}$ also serve to seat the nasal plugs in the orifice of the bony nasal passage." The AI originates on the posterior border of the supraorbital process and on the temporal crest, and the PI originates on the ascending process of the maxilla. As stated above, these layers were probably very reduced in Odobenocetops, a condition that would be in agreement with the absence of nasal plugs. Furthermore, Lawrence and Schevill (1956) and Mead (1975) have shown that the nasal plugs are tightly imbricated with the dorsal surface of the premaxillary sacs and with the melon and that there is a sort of histological continuity among these organs. Consequently, the absence or great reduction of the premaxillary sacs and the absence of a melon would be consistent with the absence or reduction of the nasal plugs. If the nasal plugs were actually present and well developed, there would be an inconsistency between their large size on the one hand and the reduction of the nasal plug muscle, premaxillary sacs, and melon on the other. From this discussion it therefore follows that the nasal plugs were very probably absent or vestigial in Odobenocetops.

There seems to be a consensus that the nasal plugs and the nasal diverticula are related to sound production (Lilly, 1961; Lilly and Miller, 1961; Norris, 1964, 1968, 1969; Norris and Evans, 1967; Kleinenberg et al., 1969; Diercks et al., 1971; Norris et al., 1971; Evans and Maderson, 1973; Mead 1975; Dormer, 1979; Ridgway et al., 1980). It also is possible that sound could be produced by the larynx (Lawrence and Schevill, 1956; Purves, 1967; Schenkkan, 1973). Some authors have suggested that both the nasal sac system and the larynx are implicated in sound production (Lilly and Miller, 1961; Evans and Prescott, 1962; Schevill, 1964; Evans, 1967). Ridgway et al. (1980), however, clearly rejected the possibility of any sound production in the larynx and stated that sounds are produced by the nasal system only.

Consequently, Odobenocetops probably had no (or vestigial) nasal plugs, no (or vestigial) melon, and very reduced premaxillary sacs, if any; and, as the maxillonasolabialis was apparently very reduced in comparison to the other delphinoids, it also is likely that the other nasal diverticula were either reduced or totally absent. If so, then Odobenocetops had little (or no) ability to produce sounds (in the usual cetacean way) and therefore to echolocate.

As indicated earlier, the inner-ear structure implies that $O d o$ benocetops, like most mammals, was capable of perceiving ultrasonic sounds (frequencies $>20 \mathrm{kHz}$ ), but whether Odobenocetops could echolocate cannot be determined from ears alone. High-frequency facility is not synonymous with echolocation. The ability to echolocate implies the production of self-generated, beamed, gated signals and analysis of the corresponding echoes. Analysis of ambient sound is passive listening and is common to all mammals. Passive listening clearly provides considerable information about the immediate environment (e.g., directionality or the relative distance of two sound sources), but it does not provide spatial or textural information with the level of resolution commonly obtained through biosonar. Biosonar is an extraordinarily sophisticated acoustic imaging system that conventionally uses very high frequencies because the level of detail that can be transduced is related to the wavelength of the ensonifying signal. The stronger the evidence against the presence of a melon, which is directly implicated in outgoing signal generation and control, the less support there is for functional echolocation by Odobenocetops. The absence of nasal plugs would be critical evidence against echolation, as that structure and the diagonal membrane seem to represent the major sound producers in odontocetes, although it is not possible to refute definitively the hypothesis that Odobenocetops had a reduced air sac system and nasal plugs.

Whatever the morphology was, it is very probable that $O d o$ benocetops had little echolocational ability, if any-a condition that may have been compensated for by good binocular vision. The orbit of Odobenocetops is proportionally much larger than in any other cetacean. The distance between the apices of the postorbital and antorbital processes is close to that in Monodon even though Odobenocetops is an animal approximately $15 \%$ smaller. Furthermore, the dorsal shifting of the process and the depth of the orbital notch clearly indicate that dorsal or anterior binocular vision was possible. Furthermore, good dorsal or anterior binocular vision is in agreement with the probable feeding posture of Odobenocetops (see "Scenario for the Feeding Mode of Odobenocetops peruvianus," below). 


\section{FEEDING ADAPTATIONS}

The modifications of the skull of Odobenocetops are correlated with major modifications of its musculature. Four aspects should be considered: mandibular movements, head movements, morphology of the palate, and inferred presence of an upper lip and vibrissae.

MANDIBULAR MOVEMENTS.-In Odobenocetops, the withdrawal of the maxillae and frontals from the dorsal side of the braincase has opened dorsally the temporal fossa, which in most odontocetes is roofed. The parietals are widely uncovered dorsally and secondarily increased in size so that they occupy most of the dorsal surface of the braincase. In the other delphinoids, the temporal fossa is roofed by a lateral expansion of the frontal and the maxilla. The parietals are small bones restricted to the lateral sides of the skull and do not contact each other. The temporalis is a small weak muscle whose origin is located on the parietal, on the lateral side of the skull, and whose insertion is on the coronoid process of the dentary. Its action is to raise the mandible to close the mouth. If muscle insertions and origins are at least partially related to particular bones (which is known to be not always true), the great development of the parietal of Odobenocetops might have led to a great extension of the temporalis on the dorsal side of the skull. Consequently, Odobenocetops probably was capable of much stronger adduction of the mandible than are other odontocetes.

Another important elevator of the mandible is the masseter. In the dog, the masseter is divided into three layers. The superficial and middle layers originate on the lateral side of the zygomatic arch (on the jugal and squamosal), and the deep layer originates on its medial side (Miller et al., 1964). As for the odontocetes, Howell (1927) described two layers in Neophocaena, superficialis and profundus, but only the former had a bony origin, on the zygomatic process of the squamosal and on the postorbital process of the frontal. The superficial layer inserts on the posteroventral angle of the mandible and the deep layer on the dorsal edge of the dentary in front of the insertion of the temporalis. In Odobenocetops, the large distance existing between the postorbital process of the frontal and the zygomatic process might indicate that the masseter was divided into two clearly defined elements. Several features suggest, however, that the masseter did not originate on the postorbital process, but rather that it was attached only on the strong zygomatic process of the squamosal. This structure is the very stout lateral wall of the squamosal gutter described above. It is a thick bony wall strongly attached to the skull all along its length. Furthermore, the squamosal-parietal contact is not squamous and vertical as in most other mammals; it is a very solid, transversely oriented, interdigitated suture apparently capable of resistance to strong anteroposterior stresses. Consequently, the architecture of the areas of origin of the masseter indicates a muscle much stronger than in the other delphinoids.

On the ventral side of the skull the pterygoid muscles also are mandibular adductors. In a terrestrial mammal (the dog, cf. Miller et al., 1964), both pterygoideus muscles (lateralis and medialis) originate on the lateral side of the skull, on the pterygoid but also on the orbitosphenoid. In Neophocaena, Howell (1927) observed a very reduced muscle originating on the pterygoid membrane and on the lateral edge of the pterygoid bone adjacent to it. The "insertion is not upon the mandible but on the tough tissue near the ear bone" (Howell, 1927:23). In Kogia, however, Schulte and Forest Smith (1918) observed two relatively strong pterygoid muscles (internus and externus) that insert upon the medial side of the dentary. Seagars (1982) found that in long-jawed delphinids with numerous teeth, the pterygoideus internus (=medialis) is in fact the dominant adductor muscle, followed in importance by the temporalis, masseter, and pterygoideus externus (=lateralis). In species with fewer teeth and broader jaws (Globicephala, Grampus), the temporalis is more powerful relative to the pterygoideus internus, and in Orcinus the temporalis is actually the dominant muscle (Murie, 1870, 1973). In Odobenocetops, the pterygoid shows a very strong laterally convex crest in the position of the pterygoideus medialis of the dog and Kogia, and of part of the undivided pterygoid of Neophocaena. This crest is more developed than any structure observed in the other odontocetes and indicates, in Odobenocetops, a pterygoid muscle much stronger than in the other delphinoids. Together with the evidence of a large temporalis cited above, this seems consistent with the pattern documented by Seagars (1982) in delphinids, which would lead us to expect a large temporalis and internal pterygoid in connection with the presumably short, toothless mandible of Odobenocetops.

The main mandibular depressor muscle in terrestrial mammals is the digastricus. In the dog it originates on the anterior side of the paroccipital process of the occipital and inserts upon the ventral border of the mandible (Miller et al., 1964). In the odontocetes, Howell $(1927,1930)$ termed it monogastricus, and the origin is on the anterolateral border of the thyrohyal and/or basihyal. Apparently there is no attachment to the skull. The tremendous thickening of the squamosal and, to a degree, of the occipital at the posterolateral angle of the skull in Odobenocetops, however, seems to indicate considerable muscular stress in that region. Although it is therefore possible that part or all of the digastricus muscle was attached to the posterolateral angle of the skull, a condition that would have to be regarded as a reversal, the neck muscles (see below) are more probably responsible (at least partially) for the strong development of that region of the skull.

The masticatory musculature of Odobenocetops thus seems to have been much more powerful than in any other odontocetes. Considering the lack of maxillary teeth, it indicates a very peculiar mode of feeding involving powerful movements of the lower jaw and perhaps of the tongue, gular, and hyoid musculature. Although there is no direct evidence of these latter muscle groups, the very deep and arched palate suggests a very large tongue and a consequently strong throat musculature (see below). 
HEAD Movements. - The muscles involved in head movements are numerous and strong. In odontocetes, the most important are the semispinalis, rectus capitis, splenius, multifidus, sternomastoideus, longissimus, and scaleni. The first four muscles insert on the occipital shield, and not much can be said about their morphology in Odobenocetops. The three latter muscles insert on the posterior border of the paroccipital process of the occipital and/or on the zygomatic process of the squamosal. The sternomastoideus and the longissimus insert on the posterior region of the sternomastoid fossa and the lateral edge of the paroccipital process. In Odobenocetops this region is greatly expanded ventrally and forms the tremendously thickened posterolateral angle of the squamosal. The enlargement of the area of insertion of these muscles and the stoutness of the bone in this region suggest that the sternomastoideus and longissimus of Odobenocetops were very powerful muscles. The same could be said about the scaleni, which insert on the posterior surface of the paroccipital process and basioccipital crests. The bony origin of the sternomastoideus is on the anterolateral edge of the sternum; the bony origin of the longissimus is on the transverse process of the anterior thoracic vertebrae (Pabst, 1990); origin of the scaleni (dorsalis and ventralis) is on the first ribs. These three muscles, if acting bilaterally, are depressors of the head, and if acting unilaterally, are lateral rotators of the head. The region of the nuchal crest located behind the sternomastoid fossa also is extremely thickened. In Neophocaena and Monodon the splenius and semispinalis capitis insert in this area. The lateral extremity of the insertion of these muscles also is on the posterior part of the upper part of the sternomastoid fossa. If acting bilaterally these muscles are levators of the head.

Consequently, the assumed strength of the sternomastoideus, longissimus, and scalenus in Odobenocetops would indicate strong and active vertical and transverse movements of the head or at least a need for a strong control of these movements This conclusion is in agreement with the morphology of the condyles and of the supracondylar fossa, which would allow significant vertical movements of the head (see above). It is further corroborated by the relatively large size of the semicircular and vestibular canals, in Odobenocetops as in Delphinapterus, which are apparently related to the mobility of the neck (see above).

PALATE MORPHOLOGY.-The palate of Odobenocetops is very wide, very deep, and arched. The morphology of its anterior part is dominated by the exceptionally developed premaxillae and the large vomer. The palate is very wide posteriorly because of the lateral expansion of the pterygoid, which forms a ventrolaterally oriented wing. The palatines also are very enlarged in the posterior region of the palate. Between the alveolar process of the premaxilla and the pterygoid wing, a deep, rounded notch forms the narrowest (middle) portion of the palate. This notch lies exactly in the path of a prolongation of the squamosal gutter and was obviously for the passage of the mandible. Seen ventrally, the notch is wide and almost semicircular; viewed along the axis of the squamosal gutter, though, it is much narrower, as the lateral plane of the palate is oblique in relation to a line joining the squamosal gutter to the apex of the rostrum, the supposed axis of the dentary. If the dentary of Odobenocetops was straight as it is in all the other odontocetes, then the dentary in its middle portion was only slightly thicker than in the other delphinoids; however, it was probably very high, as it needed to be strong to bear the stresses of the powerful musculature. The anterior part of the mandible probably was greatly thickened to partially fill the anterior region of the palate. Another possibility is that at their anterior ends, the dentaries were as high as the concave portion of the medial side of the premaxillary process (i.e., its proximal two-thirds, approximately $15 \mathrm{~cm}$ ) and formed two divergent processes or expansions complementary to those of the premaxillae. This mandibular morphology would some what resemble that observed in the borhyaenoid marsupial Thylacosmilus from the Pliocene of Argentina. Such a morphology would allow the apex of the lower jaw to fit perfectly in the anterior region of the palate, thereby allowing a perfect closing of the mouth.

An even slightly deep, wide, and/or vaulted palate is unknown among other cetaceans, so the morphology of Odobenocetops is unprecedented. In non-cetacean mammals, a deep, arched palate is known in the Odobenidae (Odobenus rosmarus, Valenictus chulavistensis) and in the Otariidae (Otaria flavescens and to a lesser extent Phocarctos hookeri). As mentioned above, the deep palate of Odobenocetops is consistent with a large tongue and consequently strong tongue muscles. Also, the gular musculature must have been fairly powerful, as it is related to the tongue and mandible movements.

UPPER LIP AND VIBRISSAE.-Muizon (1993a, 1993b) has suggested the presence in Odobenocetops of a strong upper lip. That hypothesis is maintained herein. Lips are known in several other odontocetes and are especially well developed in the beluga (Kleinenberg et al., 1969:80). Although these authors state that the lips of the beluga are devoid of musculature and not movable, figure 5 of Brodie (1989:132) seems to demonstrate considerable mobility of the beluga's lips. Furthermore, Mead (1975:39) mentioned that part of the lateral rostral muscle of the delphinoids is associated with the upper lip and stated that "[t]he lips of Cetacea are generally considered to be immobile, but in view of the great expanse of lip surface in animals such as Globicephala and Grampus and the relatively large mass of muscle inserting into the connective tissue of the lips in these forms, a certain amount of mobility may be present and may be important in feeding." A strongly developed, mobile upper lip in Odobenocetops could therefore result from the enlargement of a structure already existing in the other delphinoids.

We mentioned above the strong muscle attachments on the dorsal and anterior face of the apex of the rostrum. Given that the medial rostral muscle is inserted into the melon (Mead, 1975:10), which Odobenocetops lacks, both the medial and lateral portions of the rostral muscle might be implicated in upper lip movements in Odobenocetops. Consequently, the muscle arising from the subapical rims described above (passing laterally to the premaxillary foramina, converging at the apex of the 
rostrum, and enclosing the triangular area where, in other delphinoids, the nasal plug muscle is attached) would represent part of the medial portion of the rostral muscle. The remaining part of the medial portion of the rostral muscle, together with the lateral portion, would create the strong muscle attachments observed on the anterodorsal sides of the alveolar processes of the premaxillae. The whole rostral musculature of Odobenocetops would therefore be related to upper lip movements.

The occurrence of a large upper lip in Odobenocetops is consistent with the presence of the large neurovascular foramina observed on the anterior and ventral borders of the alveolar process and with the presence of the very large palatine foramen, which could have provided extensive blood and nerve supply to the ventral region of the lip. The dorsal region of the lip was irrigated and innervated via the very large maxillary (and probably premaxillary) foramina, which also were related to the blood and nerve supply of the pulp cavities of the tusks.

As noted above, the facial nerve of Odobenocetops is significantly larger than in the other delphinoids except Monodon (Table 3). The large diameter of the facial nerve canal in the periotic is consistent with the presence of a large upper lip and vibrissae.

Muizon (1993a, 1993b) suggested that the upper lip of Odobenocetops could have carried vibrissae, evolved convergently with those of the walrus. The extensive vascularization and innervation of the upper lip and the very spongy nature of the bone of the anterior side of the rostrum suggest that such structures could possibly have been present. Furthermore, vestigial vibrissae are well known in some adult cetaceans (mysticetes, Inia) and have been observed in several newborn or fetal delphinoids and Pontoporia (Bourdelle and Grassé, 1955; Yablokov and Klevezal, 1962; Tomilin, 1967; Best and da Silva, 1989). The vascularization of the anterior side of the rostrum of Odobenocetops also could be related to the lip only, however, so the presence of vibrissae remains undemonstrated.

COMPARISON WITH Odobenus.-Several features of Odobenocetops are convergent with the morphology of the walrus. They are (1) the large, deep, vaulted palate; (2) the presence of tusks; (3) the wide and low occipital, in posterior view, and the ventrolateral expansion of the ventrolateral angle of the skull; (4) the thickness and the extreme stoutness of the bone forming the ventrolateral angle of the skull and of the alisphenoid; (5) the well-developed upper lip and the presence of vibrissae (not certain in Odobenocetops); and (6) the presence of a rough, irregular, and expanded area for attachment of tough or horny tissue on the edges of the mouth (inferred for Odobenocetops).

The palate of Odobenocetops, however, differs strongly from that of Odobenus. It is much wider and deeper. It is composed of the premaxillae, palatines, vomer, and pterygoid, but the maxillae do not crop out on the palate as in most other mammals. There are no maxillary teeth in Odobenocetops, although it is known that some fossil odobenine walruses (Valenictus chulavistensis) also lacked maxillary teeth (Deméré, 1994). The vomer is very large and lozenge-shaped, as (but much larger than) in most other odontocetes. The tusks of Odobenoc- etops are premaxillary and strongly asymmetrical, whereas they are maxillary and symmetrical in Odobenus. The posteroventral angle of the skull is made up of the paroccipital process and the squamosal, whereas in Odobenus it is formed by the tremendously enlarged mastoid process of the periotic. The attachment area of tough tissue is located on the anterior edge of the premaxilla; in the walrus it is on the dorsal side of the mandibular symphysis.

Muizon (1993a, 1993b) regarded Odobenocetops peruvianus as a walrus-convergent bottom feeder. We have noted above that Odobenocetops and Odobenus share several strong similarities in their skull morphology. Functional comparisons will help determine whether the adaptations of Odobenocetops could fit with the walrus's mode of feeding.

The living walrus feeds mainly upon benthic invertebrates, such as thin-shelled bivalves ( $M y a$, other clams, and mussels), gastropods, molting crustaceans, holothurians, and tunicates, but rarely upon cephalopods, fish, or other vertebrates. Prey buried in the substrate, such as clams, are excavated by jetting water from the mouth (Kastelein and Mosterd, 1989; Kastelein et al., 1991). As suggested by Vibe (1950) and clearly expressed by Fay (1982), the walrus does not crush the shells of the mollusks it ingests; rather, it holds them between its lips and jaws at the front of the mouth and sucks out their siphons, using its mouth as a vacuum pump. Fay (1982:171) described the walrus mouth as follows: "The extraordinary vacuum pump of the walrus ... is powered by very large lingual retractors and depressors (M. styloglossus, hyoglossus, and genioglossus), complemented by the highly vaulted palate, the long firmly ankylosed mandibular symphysis, and the unusually powerful $\mathrm{m}$. tensores veli palatini and $\mathrm{m}$. buccinatorius, which provide rigidity to the walls of the 'cylinder.' The tongue is the 'piston.' The small rigid oral aperture, complemented by ample muscular lips, insure that the full effect of the vacuum is exerted only on objects held in the incisive area at the front of the mouth." Gordon (1984) confirmed that the vacuum is created by movement of the tongue directly rearward. Fay (1982:167) also stated, concerning the tough tissue covering the dorsal surface of the mandibular symphysis: "The rough cornified surface seems admirably suited for grasping and holding slippery prey; I believe that it functions also to hold molluscan shells while their contents are removed by suction."

When searching for food, the walrus moves along the bottom with its head down and its body at an angle to the bottom of about $10^{\circ}-45^{\circ}$ (Fay, 1982:164). The vibrissae are the sensitive organs that are constantly in contact with the bottom and transmit information to the animal. As mentioned by Fay (1982), the walrus feeds in darkness and "the eyes are comparatively smaller than those of other pinnipeds;" "they may be the least important as sensors" and "the animals probably locate their prey by vibrissal contact." Fay (1982:164) also mentioned that excavation of buried animals may be achieved by "rooting" with the snout: "the pattern of vibrissal abrasion, the greater cornification of the upper edge of the snout..., and the powerful cephalo-cervical musculature of the walrus are unlike those of 


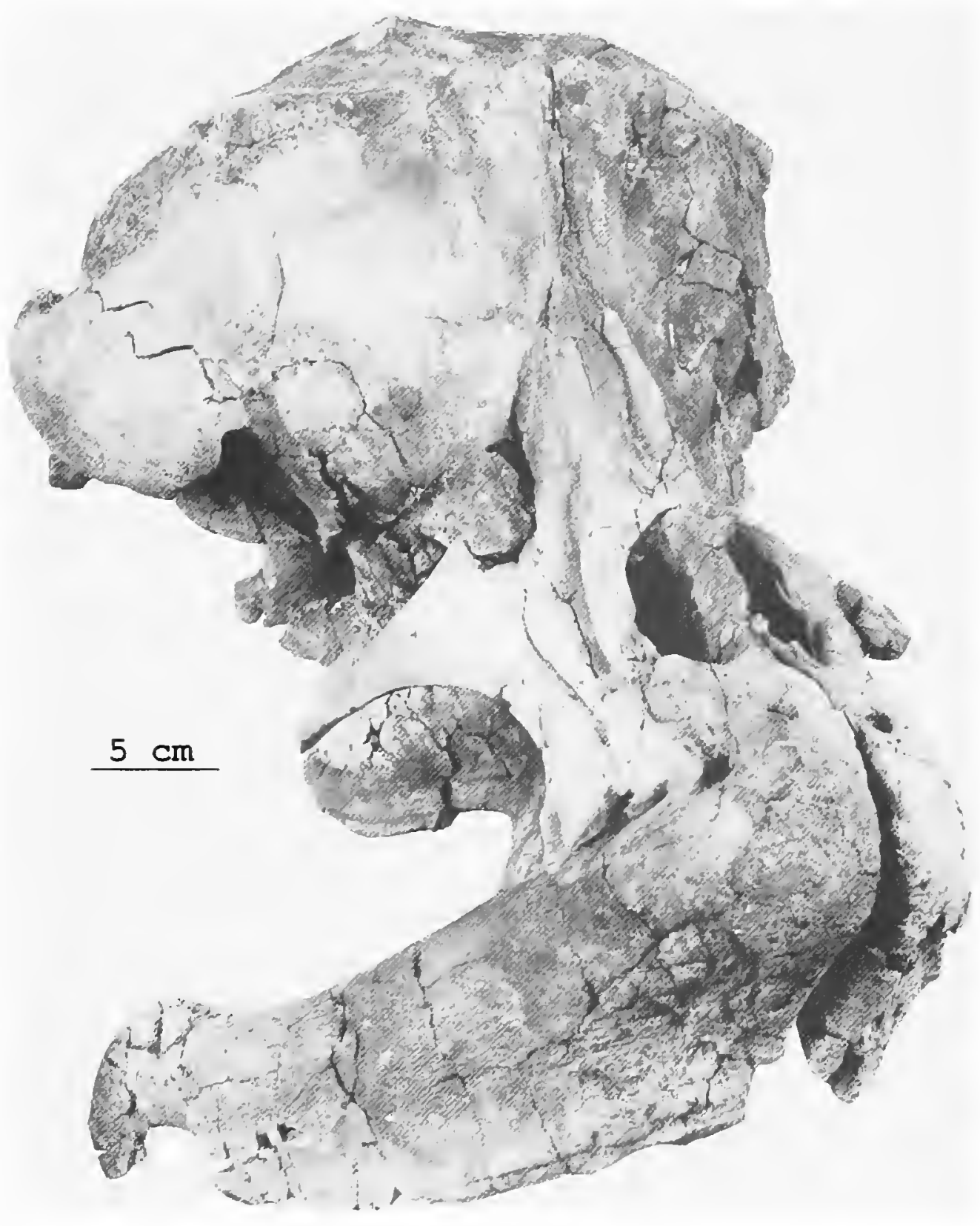

FIGURE 18 (left).-Odobenocetops peruvianus, holotype (USNM 488252): anterolateral view of the skull in a feeding position.

any other pinnipeds. Each points to frequent use of the snout as a digging organ." This mode of feeding creates long, sinuous furrows in the seafloor (Nelson and Johnson, 1987), each presumably representing a single bout of feeding by a walrus on a single dive.

In Odobenocetops, although the mandible is unknown, several aspects of the skull morphology are in perfect agreement with suction bottom feeding (see Figures 18, 20): The very large vaulted palate (even larger than in the walrus); the inferred cornified (or strongly fibrous) edge of the upper lip; the fairly well-developed masticatory musculature (for a cetacean), close, in strength, to that of the walrus; the powerful occipital musculature (at least the scalenus, sternomastoideus, and longissimus); and the significant atlanto-occipital movements denoted by the very convex and salient occipital condyles and the large supracondylar fossae. Contrary to walrus morphology, though, the eyes of Odobenocetops were large, and good binocular vision compensated for the probably poor echolocational ability. Even walruses have good anterodorsal binocular vision and seem to forage visually when water clarity permits, however (Kastelein and Wiepkema, 1989; Kastelein et al., 1993).

Odobenocetops had no maxillary teeth; like the living wal- rus, it was a sucking feeder that did not have the masticatory apparatus necessary to crush any hard exoskeleton of its prey. Fay (1982:166) has shown that the teeth of the living walrus are not used for crushing, and it is noteworthy that some fossil odobenids (Deméré, 1994) had lost the postcanine teeth altogether.

Another noteworthy feature of Odobenocetops is the strongly modified zygomatic process with a large squamosal gutter and a tremendously resistant parieto-squamosal suture. As it has no equivalent in any living mammal, this structure is difficult to interpret. If, however, this structure is related to the very strong masticatory musculature mentioned above, it likely permitted very powerful (though probably not very extensive) movements of the lower jaw. The exceptional strength of the mouth of Odobenocetops would thus have allowed it to maintain its prey extremely firmly in its mouth. The extreme development of the squamosal gutter and its high position are difficult to explain because the mandible is unknown.

Odobenocetops also shares with Odobenus the possession of tusks, but the large premaxillary alveolar processes of $O d o-$ benocetops are absent in the walrus. Fay (1982:136) stated that the tusks of the walrus are not related to feeding but instead 
play a social role. The same has been stated for the narwhal (Nishiwaki, 1972; Hay and Mansfield, 1989). Consequently, we assume that the tusks of Odobenocetops were used more as social organs than as feeding implements (see below for further discussion of the tusks). The deep premaxillary fossae bordering the anterior extremity of the vomer on the palate are absent in all the other odontocetes, and nothing similar is observed in the walrus. Their function has not been elucidated.

COMPARISONS WITH MARINE MAMMALS OTHER THAN Odobenus.-Delphinapterus leucas: Kleinenberg et al. (1969: 89-90) presented an interesting interpretation of the functions of the tongue of the beluga for feeding. According to these authors, the tongue is a very mobile and strong organ that has three functions. First the tongue orients the prey in the mouth. Second, the animal "draws its tongue back, pressing the prey to the palate and forcing it to the entrance of the pharynx." Third, "the tongue forces the water out of the mouth, preventing its entrance into the intestinal tract." The tongue thus appears to be a powerful and extremely specialized organ for food ingestion. It is therefore very probable that Odobenocetops, like all living odontocetes, had a powerful, enlarged (given the size of the palate) tongue, and that it could have been involved in a pumping feeding action as is observed in the walrus.

Bottom feeding is well established for belugas; worms and benthic animals are often found in their stomachs (Matthews, 1978). Belugas also are capable of powerful water-jetting similar to that observed in the walrus (D.P. Domning, pers. obs., and J.G. Mead, pers. comm., 1992). Bottom feeding also is known in Globicephala, and water-jetting in Orcinus and Globicephala (Werth, 1992).

Kolponomos clallamensis and K. newportensis: Tedford et al. (1994) described the skull of Kolponomos, an aquatic ursid from the early Miocene of Washington and Oregon. Among the most peculiar modifications of the skull of Kolponomos are the extremely enlarged mastoid processes, which are oriented ventrolaterally as is observed in the walrus. According to Tedford et al., Kolponomos could have fed upon benthic hard-shelled invertebrates, mainly mollusks but also echinoids. Consequently, the substantial and strong movements of the head must have necessitated strong neck musculature.

Furthermore, Kolponomos had anterior binocular vision, which assisted its search for food, as in Odobenocetops and Odobenus (Kastelein et al., 1993). Tedford et al. (1994) also suggested that Kolponomos could have had enhanced tactile sensitivity of the lips and the muzzle, possibly possessing a large upper lip and tactile vibrissae like the walrus. If that was actually the case, then Odobenocetops also would resemble Kolponomos, in having both good binocular vision and an enlarged, highly tactile upper lip. That bottom feeders could rely upon binocular vision and/or tactile sensibility of the upper lip and vibrissae is in agreement with the apparent lack (or reduction) of echolocational ability in Odobenocetops. Kolponomos, however, was very different from Odobenocetops in its mode of ingestion of prey. Kolponomos had very strong sea-otter-like crushing teeth, which were used to break the hard shells of benthic invertebrates (Tedford et al., 1994).

Desmostylians and Sirenians: Like Odobenocetops, most marine mammals that are believed to have dug for food in the seafloor possess large ventrolateral expansions of the posteroventral angle of the skull, which presumably reinforced the neck when the animal was searching for its food, with its head down and the body in an oblique position in the water. Desmostylians provide another example of this; they were evidently substrate-feeding herbivores (Domning et al., 1986) and all shared an enlarged paroccipital process (Ray et al., 1994). Furthermore, the peculiar sirenian Miosiren, which has been suspected of molluscivory on the basis of its dentition and reinforced palatal region, also has enlarged post-tympanic processes (Sickenberg, 1934). Other tusked sirenians, however, do not, and at least the most specialized of them may have used their jaw muscles instead of their neck muscles for digging (Domning, 1989).

The Holocene sirenian Dugong dugon (Müller) superficially resembles Odobenocetops in having a pair of slender, relatively straight, and open-rooted upper incisor tusks that are largely enclosed in prominent, downward-directed premaxillae. In the dugong, however, these tusks are symmetrical, are not strongly divergent, project at most a few centimeters outside the gum, and are directed anteroventrad rather than posteroventrad. Although tusks of fossil dugongids were surely used in feeding (probably to excavate sea grass rhizomes; Domning, 1989), those of the living species seem to have lost this function and have become relegated to purely social uses, such as fighting between males (Preen, 1989; Domning, unpubl. data). Evidently as a result of this restriction in function, tusks of $D$. dugon (uniquely among sirenians) have become sexually dimorphic, normally erupting only in the males (Marsh, 1980). It thus appears that the tusks of the herbivorous dugong can shed no additional useful light on the biology of the presumably carnivorous Odobenocetops.

Scenario for the Feeding Mode of Odobenocetops peruvianus: Odobenocetops lived in the early Pliocene on the coast of Peru, in the shallow waters of the bay of Sud-Sacaco, probably close to the shore (Marocco and Muizon, 1988). It was a sucking feeder preying upon benthic invertebrates such as thin-shelled mollusks and/or molting crustaceans, which were abundant in the Pisco Formation (Muizon 1981; Muizon and DeVries, 1985; Carriol et al., 1986). It searched for food using a position similar to that of the walrus. The head maintained contact with the bottom while the body was at an angle to the bottom, probably close to the angle of the premaxillary process with the anteroposterior axis of the skull $\left(\sim 45^{\circ}\right)$. The tail helped in keeping that position and, as in other cetaceans, provided propulsion (as mentioned by Fay (1982:164), the walrus also uses the posterior part of the body to move forward, but by means of the hind limbs). The forelimbs probably had a stabilizing role, as in the walrus, and would have helped to maintain the upper lip and vibrissae in contact with the bottom. It used its very good dorsal binocular vision and its large and 


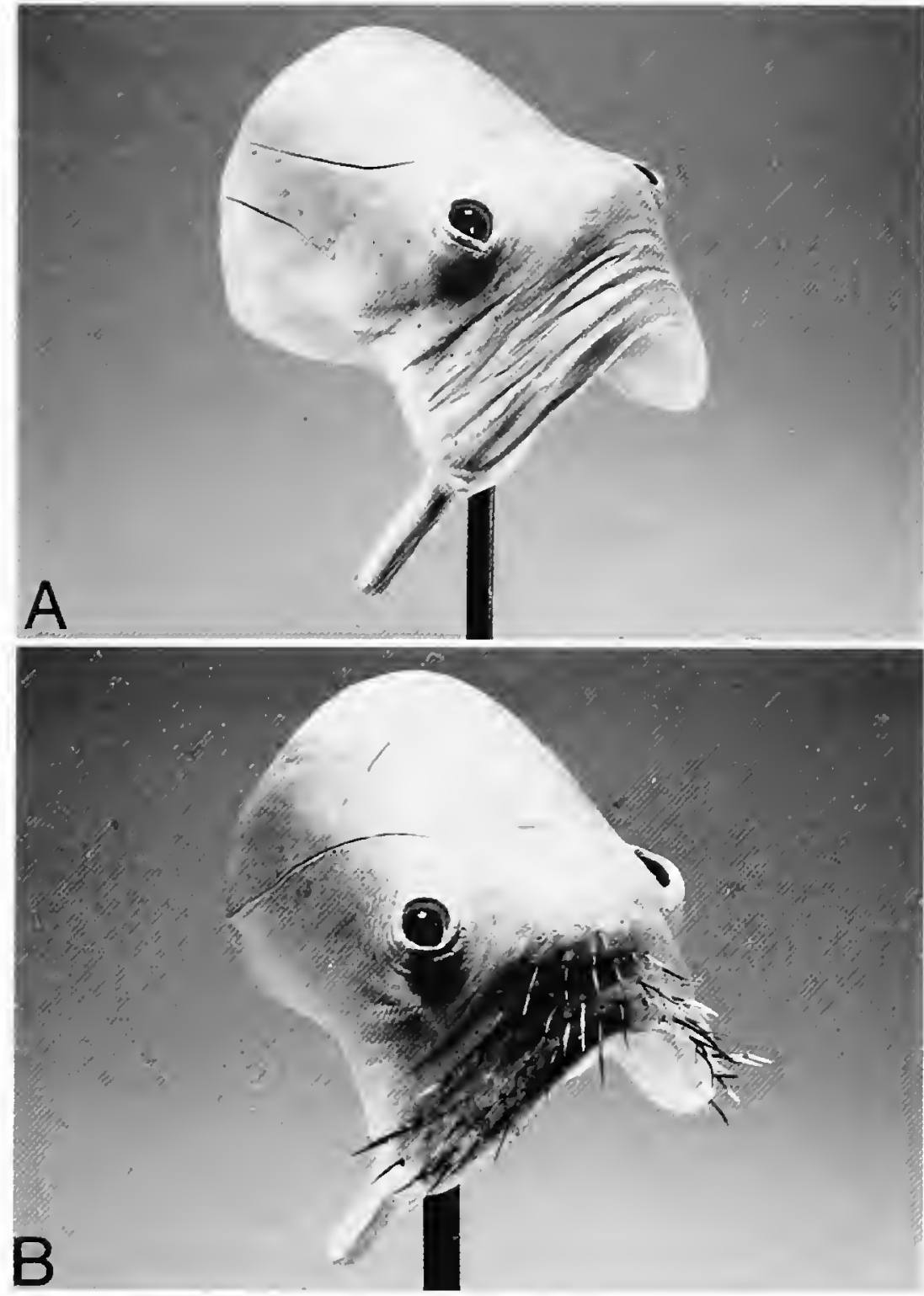

FIGURE 19.-Odobenocetops peruvianus, two possible reconstructions of the head: $a$, hypothesis without vibrissae, a "cetacean-like" interpretation; $b$, hypothesis with vibrissae, a "walrus-like" and more speculative interpretation (sculptures by Mary Parrish, Department of Paleobiology, NMNH).

highly sensitive upper lip, possibly assisted by strong vibrissae, to search for food (Figures 18-20). Most probably, little or no echolocation was involved. Once found, buried prey, such as clams, was probably excavated by water-jetting, as in the walrus, then caught in the anterior part of the mouth and strongly held in this position by the powerful lips and jaws. Then dorsoventral and/or anteroposterior movements of the tongue would have transformed the mouth into a sort of vacuum pump, and part of the prey was sucked out of its shell and ingested.

Consequently, Odobenocetops was a highly specialized cetacean that combined adaptations of both Odobenus (water-jetting and sucking) and Kolponomos (good binocular vision), and therefore was probably the best-adapted known bottomfeeding marine carnivore.

This proposed feeding scenario is not unexpected for an odontocete. Suction feeding has been reported many times in odontocetes (Kleinenberg, 1938; Wilke et al., 1953; Ray, 1966; Rae, 1973; Matthews, 1978; Crawford, 1981; Seaman et al.,

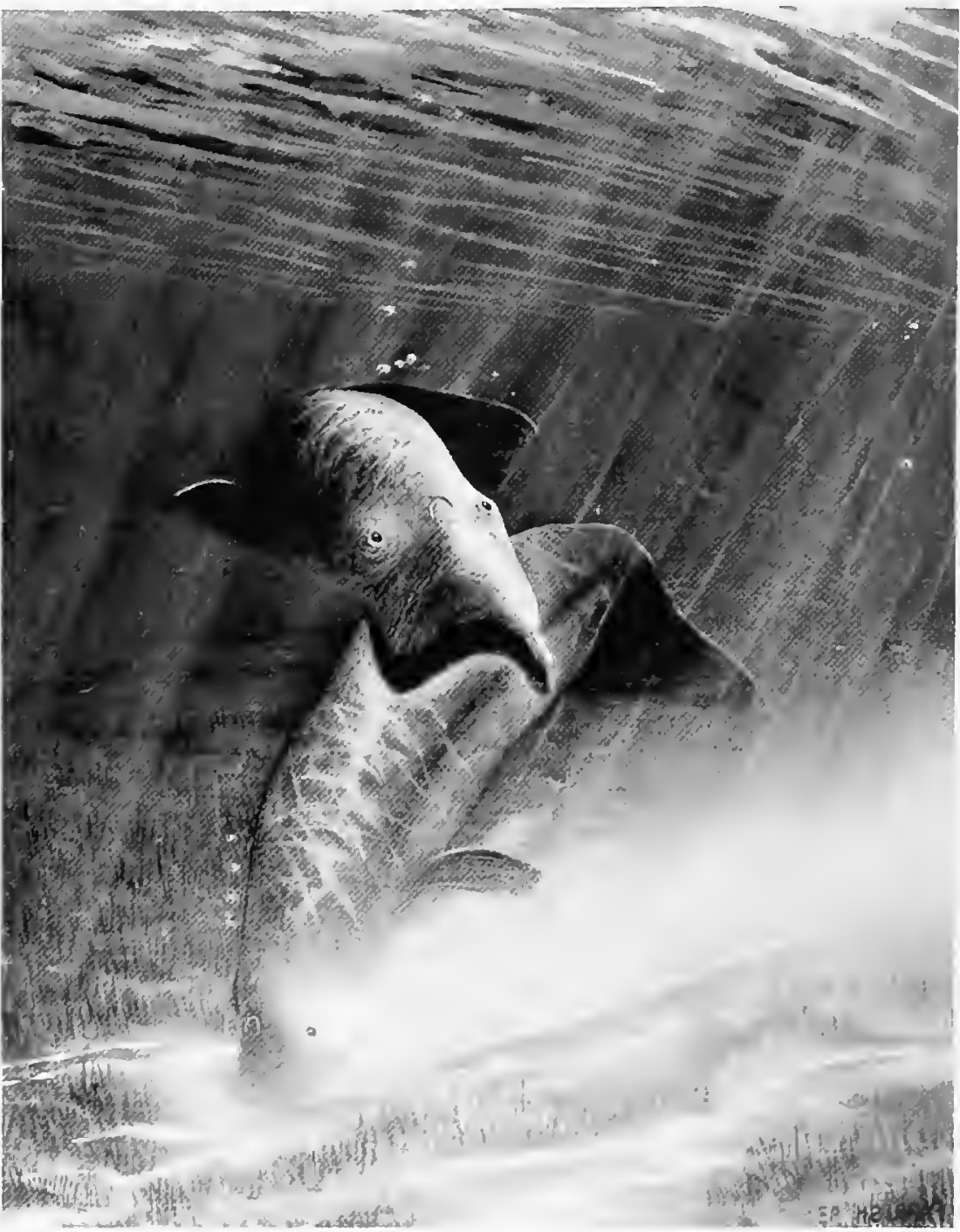

FIGURE 20.-Artist's reconstruction of Odobenocetops peruvianus in feeding position (original painting by Mary Parrish, Department of Paleobiology, NMNH).

1982; Martin, 1990; Heyning and Mead, 1996). An excellent review of the topic was presented by Werth (1992). According to Werth, it is in fact the absence of suction feeding that is unusual among odontocetes. Werth reported suction feeding in a number of species, both through direct observation: Delphinapterus leucas and Globicephala melaena; and inferred from anatomical or ecological evidence: Berardius bairdi, Mesoplodon layardi, Monodon monoceros, Phocoena phocoena, Phocoenoides dalli, Physeter macrocephalus, and Tursiops truncatus. Werth (1992:37) also reported a personal communication of W. Walker describing "a Tursiops stomach full of fresh, undigested siphons removed from clams; this type of diet (and inferred feeding method) is strikingly similar to that of suctionfeeding walruses." The observations made by Werth and others make the feeding adaptation inferred for Odobenocetops peruvianus much more likely than could be suspected at first glance.

\section{Possible Functions of the Tusks and Alveolar Processes}

The most striking and unexpected features of Odobenocetops are its tusks and the massive alveolar processes of the premaxillae that support them-features paralleled in no other ceta- 
cean. These structures, in our opinion, embody the twofold importance of Odobenocetops: Not only does the discovery of this new taxon dramatically extend the known morphological and ecological diversity of the Cetacea, but it also reopens the question of the function of tusks in true walruses.

After centuries of speculation and study, a consensus appears to have emerged that walruses use their tusks primarily in social (mostly agonistic) interactions, and secondarily for a variety of other purposes, but not to any significant extent in the course of their normal bottom-feeding (Fay, 1982; Nelson and Johnson, 1987; Kastelein and Mosterd, 1989; Kastelein et al., 1991). In other words, according to this view, walrus tusks are not feeding adaptations and do not form an integral part of the functional complex of feeding adaptations.

All who have examined the skull of Odobenocetops have been immediately struck by its gross resemblance to that of a walrus, most obviously in regard to the tusks. Moreover, this study has confirmed that the feeding behavior of Odobenocetops was walrus-like in that it consisted mainly of water-jetting and suction. This, however, raises a paradox: If walrus tusks are not feeding adaptations, then why should an animal whose feeding adaptations converge on those of a walrus be expected to have walrus-like tusks?

Fay (1982:137-138) proposed a plausible explanation of how walruses evolved large tusks. He hypothesized that "positive selective pressures and the potential for tusk development probably have existed in all polygynous pinnipeds from the beginning," but that the functional demands of pelagic piscivory, which required an unobstructed gape, precluded enlargement of the tusks beyond a certain point until odobenids took up feeding on benthic mollusks. Freed from the opposing selective pressure for a large gape, the animals were then able to respond to the preexisting social selection for hypertrophied tusks.

This explanation, however, would probably not apply to Odobenocetops. Early odontocete cetaceans, unlike pinnipeds, did not have enlarged caniniform teeth with obvious "potential for tusk development." Moreover, although some odontocetes that have become specialized for suction feeding have developed tusk-like upper or lower teeth (narwhals, ziphiids), others have developed similar specializations without any enlargement of teeth (belugas); "selective pressures for tusk development" thus seem not to have existed in all odontocetes. Furthermore, if any of the suction-feeding specializations in belugas, narwhals, and Odobenocetops were inherited from a common ancestor, they obviously did not coincide in time of evolution with any enlargements of teeth, because tusks are absent in the first and nonhomologous in the other two. It appears, then, that any net social selection for tusk enlargement in odobenocetopsids did not result directly from, nor was it correlated with, a shift from primitive piscivory to suction feeding.

This also may have been true in walruses. Protodobenus japonicus, a new odobenine from the early Pliocene of Japan, seems to have been principally a piscivore with incipient adaptations for suction feeding, but its upper canine is not nearly so enlarged as in Odobenus (Horikawa, 1995). At least the beginnings of the evolution of suction feeding thus apparently preceded tusk enlargement. The tusk of Protodobenus is openrooted, however, and apparently ever-growing, so it could be argued that this taxon also fulfills the prediction of Fay's hypothesis that tusk enlargement should have followed immediately upon a shift away from piscivory.

In Odobenocetops, tusk enlargement appears to have been correlated with the adoption of specifically Odobenus-like suction feeding, i.e., benthic suction feeding that involved continuous direct contact of the snout with the substrate, possibly with major dependence on tactile vibrissae. If, as believed by students of living walruses, this mode of feeding does not involve any use of, nor necessitate any enlargement of, the tusks, then the co-occurrence of benthic suction feeding and large tusks in both walruses and Odobenocetops is purely coincidental. If, on the other hand, this "explanation" is deemed unparsimonious, then we should look more closely for a functional connection between feeding and tusk enlargement in the modern walrus.

There is a wide range of possible functions for the tusks of Odobenocetops. Because the alveolar processes that support them are even more prominent than the tusks themselves, and differ from them in probably having been more nearly symmetrical, it is worthwhile to consider their possible functions separately.

Use of Tusks in Feeding: PRO: Tusks are teeth and primitively serve for food-gathering. Even a single, asymmetrical tusk directed downward and backward could be used for stabbing prey, and walruses may kill seals on occasion (Fay, 1982:153). On the other hand, most, if not all, dental specializations for feeding are symmetrical, but the tusks are asymmetrical. Asymmetry of feeding structures may occur in cetaceans. Fin whales have asymmetrical color patterns around the mouth that are possibly associated with feeding (Gamble, 1985). Tursiops preferentially bottom-feed on the right side and have an asymmetrical larynx (with the piriform recess wider on the right) that may make it easier to swallow with that side down (Joy S. Reidenberg, pers. comm., 1995).

CON: The tusks are asymmetrical; most, if not all, dental specializations for feeding are symmetrical. Asymmetry of feeding structures in cetaceans is not yet conclusively demonstrated and is not known to include the dentition.

Tusks as Ballast: PRO: The relatively dense tusks, by adding extra weight to the front of the head, may have helped keep the snout against the bottom during feeding. Walrus tusks and their supporting bone also may serve this function.

CON: If this was the primary function of the tusks, it is hard to explain why they were not equal in size. Also, it seems unlikely that tusks as small as those of Odobenocetops would have had a significant ballast effect in an animal that could have approached the mass of a narwhal (between 800 and 1000 $\mathrm{kg}$ ). The much larger tusk of a narwhal is not known to produce (either facultatively or obligately) a down-by-the-head attitude 
in that animal, even though it has a much greater moment for doing so than would have been the case in Odobenocetops.

Use of Tusks for Hauling Out: PRO: This is an important function of tusks in walruses.

CON: Post-Eocene cetaceans do not haul out. Tusks used in hauling out would be most useful if they were symmetrical and stronger than observed in Odobenocetops.

Use of Tusks in Piercing, Abrading, or Anchoring to Ice: PRO: Both walruses and narwhals use their tusks to make breathing holes, and walruses use them to anchor to ice (Fay, 1982:137).

CON: Sea ice did not exist in Peru in the early Pliocene. Although Odobenocetops may have lived in the Antarctic, it has not yet been found there.

Social Role of Tusks: PRO: In many species tusks play social roles, such as in combat, in courting or mating, and in visual display. This is true both in walruses and in narwhals, the sister group of Odobenocetops, in which they also are asymmetrical. In walruses, they are used for ritualized dominancethreat displays by both males and females (Fay, 1982: 135-136). Use for combat would be consistent with the tusks' orientation, which is suitable for a slashing attack to an opponent's flank, using powerful muscles attached to the paroccipital processes. If the opponent were always approached head-on (right side to right side), this also would be consistent with the tusks' asymmetry. Use for social roles also would predict that the tusks would be larger in some individuals than in others.

CON: The sex of the available specimen and the degree of intrapopulational variation in the size of tusks are unknown. The tusks may have had a role in actual contact with other animals, but they seem rather slender to have been used for extremely forceful contact. Neither do their downward-and-backward direction, unilateral enlargement, and slenderness seem optimized for an impressive visual display, especially under water.

Tusks as Primitive Retentions: PRO: The tusks may not have been adaptive in Odobenocetops itself, but merely retained from an earlier evolutionary stage.

CON: The weight, location, and external form of the tusks would probably have had deleterious hydrostatic and hydrodynamic effects on the animal's behavior and locomotion. Presumably, they would therefore have been eliminated quickly by selection in the absence of some positive selective value.

Alveolar Processes as Support for the Tusks: PRO: Any use of the tusks would likely result in bending stresses, which supporting sheaths would help resist.

CON: The alveolar processes were probably relatively symmetrical, whereas the tusks are grossly asymmetrical. An unerupted tusk could not be used for anything and therefore would require no extra support. Walruses use their tusks very forcefully in a variety of ways and do not have such elongate bony sheaths to support them. Rather, they have been strengthened by being made thicker. In Odobenocetops they are relatively slender, implying relatively little selection pressure for resistance to bending.
Alveolar Processes as Hydrofoils or Diving Planes: PRO: The processes were prominent features of the head, at the very front end of the body where control surfaces would be most effective. Their oblique orientation resembles that of cetacean flippers. The bottom-feeding behavior of Odobenocetops might well have benefited from hydrofoils to keep the snout pressed against the substrate.

CON: The processes may have been too small to have much effect as normal hydrofoils, especially if Odobenocetops was a relatively slow-swimming cetacean. Their angle of attack was not easily adjustable, so they would not have been as effective as the flippers. Other cetaceans manage without such control surfaces on the head. In cross section, the processes are thinner in front and thicker behind, hence not like that of an airfoil, so they would not have generated significant lift, even if they could have been held in a transverse rather than an oblique position. In bottom feeding, the alveolar processes would have lain against and parallel to the bottom (and hence in the same plane as the direction of advance) and would have had minimal effectiveness as hydrofoils. Moreover, their cross-sectional shape would, in that position, have tended to lift the head off the bottom rather than the contrary. If muscles or skin inserted on their posterior edges (see below), the processes plus attached soft tissues might have had the size and shape necessary to function as hydrofoils, but the other objections would still apply.

Alveolar Processes as Ballast: PRO: The extra mass of bone in the process, by adding weight to the front of the head, may have helped keep the snout against the bottom during feeding. Walrus tusks and their supporting bones also may serve this function.

CON: The bone of the processes is not denser than the rest of the skull, unlike the bone in the rostrum of the walrus. Furthermore, as is true for the tusks, the mass of the alveolar processes was not great when compared with that of the animal.

Use of Alveolar Processes for Sediment Displacement: PRO: The backward divergence of the processes would tend to produce a plowshare effect during feeding, shoving sediment to the sides and increasing the effective width of the path searched for prey. Cornified skin on the leading edge of the processes would be consistent with such use.

CON: The dorsolaterad slope (in head-down position) of the lateral surface of the processes is unlike the ventrolaterad slope of a plowshare, and would press sediment downward rather than digging in and lifting it. Increasing by this means the area searched for prey would presuppose the presence of vibrissae along the whole length of each process, which is questionable (see below).

Use of Alveolar Processes for Muscle Attachment: PRO: The processes would have provided highly effective lever arms for muscles (such as a modified platysma and/or cutaneus trunci) that flexed the neck and/or turned the head, both important actions in bottom feeding and in most of the conceivable uses of the tusks. The faint ridge on the posterior edge of the 
process might represent the insertion of a muscular aponeurosis.

CON: The large ventrolateral expansions of the occipital region would seem adequate for neck-muscle attachments, and such anterior muscle insertions are absent in walruses.

Use of Alveolar Processes for Skin Attachment: PRO: The faint ridge on the posterior side of each alveolar process could even more plausibly mark the attachment of a sheet of skin extending backward from the process. Such a sheet might have served as a barrier to keep churned-up mud and turbid water away from the eye during head-down bottom feeding. Although Odobenus lacks such a sheet of skin (and a bony strut to support it), it depends less upon vision during feeding, as suggested by its more lateral placement of the eyes compared with Odobenocetops. Walruses do sometimes use their vision in foraging, but they do not always do so (Kastelein et al., 1993).

CON: No contrary evidence is known.

Alveolar Processes as Restricting Size of Mouth Opening for Suction Feeding: PRO: In walruses, known suction feeders, the short bony sheaths of the tusks form rigid sides for the mouth opening and help concentrate the suctional force (see Fay, 1982:171, fig. 106).

CON: This also would be true for the most proximal parts of the alveolar processes of Odobenocetops, but not the distal parts, and so would not explain the great elongation of the processes. Both tusks of Odobenocetops seem large enough to have served this function even if supported only by short, walrus-like processes.

Alveolar Processes as Increasing Area and/or Breadth of Vibrissal Array: PRO: The symmetry and backward divergence of the processes increase the total width of the snout, which could, therefore, support an increased number of vibrissae. Cornified skin on the leading edge of the process would be consistent with such use.

CON: Large nutrient foramina are found only on the proximal, not the distal, portions of the alveolar processes (however, these foramina were not necessarily coextensive with the vibrissae). Moreover, it is not certain that vibrissae were in fact present.

Alveolar Processes as Orientation Guides and Stabilizers for the Mystacium: PRO: More-or-less symmetrical tusk-like bony processes could serve as guides, somewhat in the manner of sled runners, to maintain the proper orientation of the mystacium and vibrissal array to the substrate while the animal searched for food and to reduce the exertion of neck muscles. In Odobenocetops, the symmetry and backward divergence of the processes would have given them more leverage in countering roll and yaw, as well as pitch. The right tusk, at least, would have enhanced this leverage (but the advantage of this must have been small, or else both tusks would have been of similar length). The cross-sectional shape of each process would have caused it to ride over sediment rather than digging in, likewise stabilizing the head against roll. Cornified skin on the leading edge of the process would be consistent with such use. Odobe- nids with "walrus-like" morphotypes have analogous structures, i.e., long, symmetrical tusks with oval cross sections.

CON: No contrary evidence is known.

Use of Alveolar Processes in Combat: PRO: The large alveolar processes might have served a function in combat between males. This would be consistent with a social role for the tusks. The downward, backward, and lateral slope of the processes would serve, in a head-on collision, to guide an opponent's alveolar process and tusk ventrolaterad and away from the eye and flank. Cornified skin on the leading edge of the process would be consistent with such use.

CON: The sex of the available specimen is unknown.

Use of Alveolar Processes in Visual Display: PRO: This, too, would be consistent with a social role for the tusks. The processes are bulkier than the tusks themselves, and they would have accentuated and called attention to the presence and orientation of the tusks. In head-on view, they also would have made the entire animal look larger. Use for display would predict that the processes would be larger in some individuals than in others.

CON: The sex of the available specimen and the degree of intrapopulational variation in the size of the processes are unknown.

Alveolar Processes as Primitive Retentions: PRO: Enlarged alveolar processes of the tusk-bearing bones are a necessity in animals with enlarged tusks. If tusks (however oriented) were present in the ancestors of Odobenocetops, enlarged alveolar processes also would have been present (as in narwhals); hence, enlargement of the processes may call for no special adaptive explanation.

CON: For the reasons stated above, support for the tusks alone seems inadequate to account for the size of the processes. In any case, the enlarged processes of Odobenocetops relative to the rest of the skull are derived with respect to all other cetaceans, and this enlargement calls for explanation.

We conclude that the most plausible and important uses of the tusks of Odobenocetops were social ones. The alveolar processes probably also played social roles, incidentally as a support for the erupted tusk and perhaps more directly as weapons and/or shields in agonistic encounters, or in visual displays. Other functions, such as restricting the mouth opening for suction feeding or supporting an array of vibrissae, cannot be entirely ruled out and may even have been important in the early stages of evolutionary enlargement of the processes. Likewise, attached sheets of skin might have been useful in keeping suspended sediment out of the field of vision in later stages of the processes' enlargement. At all stages of evolution, the increased skeletal mass represented by both tusks and processes also would have had an incidental value in keeping the snout against the substrate during feeding.

We suggest, however, that the single most important function of the alveolar processes, and the one that may have controlled their evolution, was that of orientation guides for the mystacium and vibrissal array. This is the only hypothesis that 
seems to offer an explanation for the co-occurrence of benthic suction feeding and tusk-like structures in both Odobenocetops and walruses. Indeed, one of the most significant implications of the discovery of Odobenocetops is the fact that it reopens the question of whether the tusks of walruses are important in their feeding strategy.

As noted above, the work of Fay (1982) and others seemed to have answered this question in the negative, and the consensus today is that walrus tusks serve primarily in social behavior. In addition to their subsidiary functions, such as hauling out and opening holes in ice (Fay, 1982), perhaps walrus tusks also serve as orientation guides for the mystacium and vibrissae. An analogy can be drawn with sled-mounted undersea cameras that are designed to be dragged along the seafloor; the sled runners stabilize the sled in roll, pitch, and yaw, keeping the lights and cameras pointed in the right direction. Similarly, tusk-like structures would stabilize an animal's head and help maintain the mouth and vibrissal array in a fixed attitude relative to the bottom, increasing the efficiency of search by the sense organs and, possibly, the efficiency and accuracy of water-jetting and/or suction feeding.

If such orientation guides are important in the odobenine style of bottom feeding (and it should be possible to test this experimentally in living walruses), then we would expect both sexes to have them (as is the case with the tusks of Odobenus). The external form of such guides rather than their internal structure would be functionally important, however, so they would not necessarily have to be genuine tusks; for example, tusk-like bony structures would serve just as well, provided they were reasonably symmetrical and sufficiently long. Such structures would make real tusks redundant, and vice versa, so we would not expect to find both long, symmetrical tusks and bony equivalents of them in the same species. This is borne out by fossil odobenines such as Valenictus (Deméré, 1994), which resemble modern Odobenus in this regard-although this would of course be expected from their close relationship alone.

This hypothesis also is consistent with the ontogeny of walrus tusks. Weaning usually occurs in Odobenus at 14-27 months, and benthic feeding begins at 6-24 months (Fay, 1982:138-141). Tusk eruption also begins in the first year of life; the tusk begins to show signs of discoloration and wear by the age of two years, and at this time the tip of the crown extends below the ventral side of the mandible and usually 2-4 $\mathrm{cm}$ below the edge of the upper lip (Fay, 1982:105-107, fig. 71). It therefore seems possible that the tusks could be starting to function as guides even at this age.

What we find in Odobenocetops also is consistent with this interpretation. Although tusks are present, they are not symmetrical; indeed, only one of the pair may have erupted. Instead we find elongated, and probably much more symmetrical, alveolar processes of the premaxillae, which might very well have served as orientation guides for the snout. Their posterior divergence would have enhanced their effectiveness in this role. In fact, it is difficult to explain them merely as sheaths for the tusks, because walruses manage to wield much larger tusks very forcefully without the support of such elongated sheaths, and relatively symmetrical sheaths should not be needed for the highly asymmetrical (and, in the case of the unerupted tusk, functionless) teeth of Odobenocetops. We therefore posit a functional role for the alveolar processes independent of the tusks themselves.

This still leaves unexplained the evolution of tusks in Odobenocetops. Given their asymmetry and the unlikelihood of functions such as hauling-out or ice-breaking in the case of a cetacean living in Peru, it is probably safe to make an analogy with narwhal tusks and attribute to them a primarily social function. It would not be surprising if sister groups such as monodontids and odobenocetopsids evolved such analogous structures in parallel, albeit developing the tusks from canines and incisors, respectively.

\section{Conclusions}

It appears, then, that the resemblance between Odobenocetops and walruses is not merely superficial, but a genuine case of functional convergence in feeding adaptations-specifically, adaptations for suction feeding on infaunal benthic prey. Furthermore, from the fact that structures resembling walrus tusks evolved in an animal clearly convergent on walruses in other characters that are unquestionably feeding adaptations, we can surmise that the tusk-like structures are probably associated with feeding in both animals. Otherwise, the correlation of benthic suction feeding with tusk-like structures in both animals is merely a striking coincidence-a conclusion we regard as unparsimonious.

Apart from the tusks and alveolar processes, the features in which Odobenocetops resembles a walrus are its hourglassshaped skull, vaulted palate, enlarged paroccipital processes, possible vibrissae and sensitive upper lip, and possible horny covering of part of the upper lip. These features form a character complex apparently unique to odobenids and odobenocetopsids, and in the former are functionally related to a style of feeding documented in no other animals: powerful suction feeding on infaunal benthic prey. This character complex is wholly or partly absent in animals that prey on benthic invertebrates but are not suction feeders (e.g., sea otters), as well as in ones that are suction feeders but prey on animals that are freeswimming or merely rest upon the bottom (e.g., many odontocetes; A. Werth, pers. comm., 1992). It is thus only in association with this "benthic suction feeding" character complex that structures resembling walrus tusks are found-specifically in derived odobenines and in Odobenocetops.

If, instead, we attempt to explain the tusk-like structures in each case as having evolved mainly for social functions, we face an obvious problem. There is no apparent reason why fights or displays using such structures should occur always and only in benthic suction feeders. Moreover, it would be very 
surprising if both an odontocete and a pinniped were to evolve closely similar social displays, rituals, or modes of fighting that were used in and out of water, respectively, by animals of such very different body form.

If Fay (1982:137) is correct in attributing a social selective pressure for tusk enlargement to all polygynous pinnipeds (and this may well be true), then we might expect to find convergences on the walrus morphotype among other pinnipeds if we found them anywhere-yet this is not the case. We think Fay is correct in arguing that benthic suction feeding was the key adaptive shift that led to the enlargement of tusks in walruses. In view of the similar morphology seen in Odobenocetops, however, and the difficulty of applying the same social explanation to this otherwise very different animal, we propose that the utility of the tusk-like structures in both cases was primarily in feeding (as orientation guides for the mystacium) and only secondarily in social interactions. In other words, we consider the tusk-like structures to be an integral part of the "benthic suction-feeding" character complex, because we see no other plausible explanation for this striking correlation of characters.

Students of modern Odobenus should therefore reexamine its feeding behavior with the possibility in mind that the tusks may serve as orientation guides, as suggested herein. This hypothesis should be amenable to experimental tests.

\section{Addendum}

This paper was already in the editorial process when three new skulls of Odobenocetops were collected from the Pisco Formation, which justified the publication of a preliminary note (Muizon et al., 1999).

One of the skulls (SMNK 2491), referred to O. peruvianus, is from the Sud-Sacaco locality and from the SAS horizon (as was the holotype of $O$. peruvianus), which is earliest Pliocene in age. It is almost symmetrical and bears two small tusks; although the right is slightly larger than the left, it is still drastically smaller than the large tusk of the holotype. The alveolar sheaths are relatively small and of the same size. The two tusks are incomplete and their apices are missing. The right sheath is partly damaged at its apex, but because the preserved portion of the tusk is distinctly longer than the sheath as preserved, it is clear that the tusk was erupted. The left sheath and tusk also are incomplete, and the tusk is broken in the alveolus. It is therefore not possible to determine whether the left tusk was erupted. In the narwhal the unerupted tusks of the female are generally similar in size and definitely smaller than the large left tusk of the male, so this new skull of Odobenocetops peruvianus (SMNK 2491) was identified as a female.

The other two skulls (SMNK 2492 and MNHN SAO 202) come from the locality of Sacaco in the SAO horizon, which is slightly younger than the SAS horizon, in which the O.peruvianus specimens were found. They were referred by Muizon et al. (1999) to a different and new species, O. leptodon. The holotype (SMNK 2492) is a partially damaged skull that retains both tusks in situ. The right tusk is more than $1.35 \mathrm{~m}$ long as preserved (the apex was broken and worn during life), and its erupted portion measures $1.07 \mathrm{~m}$. The left tusk is small and slender and was approximately $25 \mathrm{~cm}$ long. Its apex bears a distinct wear facet, which indicates that the tooth was erupted. The presence of a very long right tusk and of an erupted left tusk in $O$. leptodon is an indication (not a proof) that this condition also could be present in $O$. peruvianus. This has to be confirmed by the discovery of new specimens of $O$. peruvianus, however.
The morphology of the snout of $O$. leptodon differs from that of $O$. peruvianus in being more rounded and wider in dorsal view and in lacking large premaxillary foramina. Furthermore, the dorsal face of the premaxilla bears a fossa for a premaxillary sac, and a pair of supplementary rostral bones is present at the anterodorsal apex of the snout. The anterodorsal edge of the orbit is only slightly concave in $O$. leptodon, whereas it is deeply notched in $O$. peruvianus. The presence of premaxillary sacs (which were probably absent in $O$. peruvianus) is probably an indication of the presence of a melon in O. leptodon. This organ, related to echolocation, was probably absent or vestigial in $O$. peruvianus. As stated above in the text, the inferred absence of a melon in $O$. peruvianus was probably compensated for by good anterodorsal binocular vision. Muizon et al. (1999) concluded that binocular vision was either reduced or absent in $O$. leptodon and that this was compensated for by echolocation abilities inferred from the probable presence of a melon.

The three new skulls have at least one tympanic and one periotic in situ. The characteristic morphology of these bones (especially the massiveness of the anterior process of the periotic) definitely confirms the referral of the periotics and tympanic described above to Odobenocetops peruvianus.

The holotype skull of Odobenocetops leptodon was associated with its atlas. The only occipital condyle preserved on the skull is damaged, which makes it difficult (but not impossible) to evaluate the position of the head relative to the axis of the body. An extrapolation could be done using the new skull of $O$. peruvianus (SMNK 2491), which has well-preserved condyles. The position of the atlanto-occipital articulation of Odobenocetops indicates that in swimming position the head was bent ventrally, bringing the dorsal plane of the skull into an anterodorsal orientation. With the head in this position, the long tusk was almost parallel to the long axis of the body. This interpretation is compatible with the length of the large tusk, as it is unlikely that such a long appendage could be at an angle of about $45^{\circ}$ to the body during swimming (Muizon et al., 1999, fig. 2). The head of Odobenocetops peruvianus in Figure 20 therefore 
should probably be bent slightly ventrally to make the long tusk parallel to the axis of the body.

To conclude, the new specimens of Odobenocetops indicate the following:

1. The long right tusk of $O$. peruvianus was probably longer than initially thought, although this needs to be confirmed by the discovery of new specimens of this species.

2. The small left tusk was probably erupted, but this also has to be confirmed by the discovery of new specimens.

3. The female of $O$. peruvianus had two small tusks, the right being only slightly larger than the left. This condition is likely to have also occurred in $O$. leptodon, although this has to be confirmed by additional specimens.

4. The new specimens confirm referral to $O$. peruvianus of the periotics and tympanic described above.

5. During swimming, the head of both species was bent ventrally and, in such a position, the long tusk was almost parallel to the axis of the body. Odobenocetops peruvianus (which has a deeply notched anterodorsal edge of the orbit) therefore had good dorsal (anterior) binocular vision when swimming.

\section{Literature Cited}

Bames, L.G.

1984. Fossil Odontocetes (Mammalia, Cetacea) from the Almejas Formation, Isla Cedros, Mexico. PaleoBios, 42:1-46.

Best, R.C., and V.M.F. da Silva

1989. Amazon River Dolphin, Boto: Inia geoffrensis (de Blainville, 1817). In S.H. Ridgway and R.J. Harrison, editors, Handbook of Marine Mammals, 4: River Dolphins and Larger Toothed Whales, pages 1-23. London: Academic Press.

Boenninghaus, Georg

1904. Das Ohr des Zahnwales, zugleich ein Beitrag zur Theorie der Schalleitung: Eine biologische Studie. Zoologische Jahrbücher, Abteilung für Anatomie und Ontogenie der Tiere, 19(2):189-360.

Bourdelle, E., and P.-P. Grassé

1955. Ordre des Cétacés (Cetacea Brisson 1762; Cete Linné 1758). In P.-P. Grassé, editor, Traité de Zoologie, Anatomie, Systématique, Biologie, 17(1):341-450. Paris: Masson.

Brill, R.L., M.L. Sevenich, T.J. Sullivan, J.D. Sustman, and R.E. Witt

1988. Behavioral Evidence for Hearing through the Lower Jaw by an Echolocating Dolphin (Tursiops truncatus). Marine Mammal Science, 4(3):223-230.

Brodie, P.F.

1989. The White Whale: Delphinapterus leucas (Pallas, 1776). In S.H. Ridgway and R.J. Harrison, editors, Handbook of Marine Mammals, 4: River Dolphins and Larger Toothed Whales, pages 119-144. London: Academic Press.

Brownell, R.L.

1989. Franciscana: Pontoporia blainvillei (Gervais et d'Orbigny, 1844). In S.H. Ridgway and R.J. Harrison, editors, Handbook of Marine Mammals, 4: River Dolphins and Larger Toothed Whales, pages 45-67. London: Academic Press.

Carriol, R.P., C. de Muizon, and S. Secrétan

1986. Les crustacés (Cirripedia, Decapoda) du Néogène de la formation Pisco (Pérou). Annales de Paléontologie, 73(3):137-164.

Cheneval, J.

1993. L'avifaune Mio-Pliocène de la formation Pisco (Pérou): Étude prèliminaire. Documents des Laboratoires de Géologie de la Faculié des Sciences de Lyon, 125:85-95.

Colbert, E.H.

1944. A New Fossil Whale from the Miocene of Peru. Bulletin of the American Museum of Natural History, 83(3):195-216.

Crawford, T.W.

1981. Vertebrate Prey of Phocoenoides dalli (Dall's Porpoise) Associated with the Japanese High Sea Salmon Fishery in the Northern Pacific Ocean. Master's thesis, University of Washington, College of Fisheries, Seattle.
Dal Piaz, G.

1916. Gli odontoceti del Miocene Bellunense; Squalodon. Memorie dell '/stituti Geologico della $(R)$ Università di Padova, part 2, 4: 1-79.

Deméré, T.A.

1994. Two New Species of Fossil Walruses (Pinnipedia: Odobenidae) from the Upper Pliocene San Diego Formation, Califomia. Proceedings of the San Diego Society of Natural History, 29:77-98.

Diercks, K.J., R.T. Trochta, C.F. Greenlaw, and W.E. Evans

1971. Recording and Analysis of Dolphin Echolocation Signals. Journal of the Acoustical Society of America, 49:1732-1732.

Domning, D.P.

1989. Fossil Sirenia of the West Atlantic and Caribbean Region, III: Xenosiren yucateca, gen. et sp. nov. Journal of Vertebrate Paleontology, 9(4):429-437.

Domning, D.P., C.E. Ray, and M.C. McKenna

1986. Two New Oligocene Desmostylians and a Discussion of Tethytherian Systematics. Smithsonian Contributions to Paleobiology, 59: $1-56$.

Dormer, K.J.

1979. Mechanism of Sound Production and Air Recycling in Delphinids: Cineradiographic Evidence. Journal of the Acoustical Society of America, 65:229-239.

Evans, W.E.

1967. Special Acoustic Problems in Cetacean Research, General Discussion. In W.N. Tavolga, editor, Marine Bio-Acoustics, 2:395-398. New York: Pergamon Press.

Evans, W.E., and P.F.A. Maderson

1973. Mechanisms of Sound Production in Delphinid Cetaceans: A Review of Some Anatomical Considerations. American Zoologist, 13:1205-1213.

Evans, W.E., and J.H. Prescott

1962. Observation of the Sound Capabilities of the Bottlenose Porpoise: A Study of the Whistles and Clicks. Zoologica, 47(3):121-126.

Fay, F.H.

1982. Ecology and Biology of the Pacific Walrus, Odobenus rosmarus divergens Illiger. North American Fauna, 74:1-279. Washington, D.C.: U.S. Department of Interior, Fish and Wildlife Service.

Fordyce, R.E.

1994. Waipatia maerewhenua, New Genus and New Species (Waipatiidae, New Family), an Archaic Late Oligocene Dolphin (Cetacea: Odontoceti: Platanistoidea) from New Zealand. Proceedings of the San Diego Society of Natural History, 29:147-176.

Fraser, F.C., and P.E. Purves

1960. Hearing in Cetaceans: Evolution of the Accessory Air Sacs and the Structure and Function of the Outer and Middle Ear in Recent Ceta- 
ceans. Bulletin of the British Museum (Natural History), Zoology, 7(1):1-140.

Fried, W.A., P.E. Nachtigall, and P.W.B. Moore

1990. Taste Reception in the Pacific Bottlenose Dolphin (Tursiops truncatus gilli) and the California Sea Lion (Zalophus californianus). In J.A. Thomas and R.A. Kastelein, editors, Sensory Abilities of Cetaceans: Laboratory and Field Evidence, pages 447-454. New York: Plenum Press.

Gamble, R.

1985. Fin Whale Balaenoptera physalus (Linnaeus, 1758). In S.H. Ridgway and R.J. Harrison, editors, Handbook of Marine Mammals, 3: Sirenians and Baleen Whales, pages 171-192. New York: Academic Press.

Gao, G., and K. Zhou

1995. Fiber Analysis of Vestibular Nerves in Small Cetaceans. In R.A. Kastelein, J.A. Thomas, and P.E. Nachtigall, editors, Sensory Systems of Aquatic Mammals, pages 447-453. Woerden, The Netherlands: De Spil Publishers.

Gordon, K.R.

1984. Models of Tongue Movement in the Walrus (Odobenus rosmarus). Journal of Morphology, 182:179-196.

Gray, O.

1951. An Introduction to the Study of the Comparative Anatomy of the Labyrinth. Journal of Laryngology and Otology, 65:681-703.

Hay, K.A.

1980. Age Determination of the Narwhal, Monodon monoceros, L. In W.F Perrin and C.A. Myrick, editors, Age Determination of Toothed Whales and Sirenians. Reports of the International Whaling Commission, Special Issue, 3:119-132.

Hay, K.A., and A.W. Mansfield

1989. Narwhal Monodon monoceros Linnaeus, 1758. In S.H. Ridgway and R.J. Harrison, editors, Handbook of Marine Mammals, 4: River Dolphins and Larger Toothed Whales, pages 145-176. London: Academic Press.

Heyning, J.E., and J.G. Mead

1996. Suction Feeding in Beaked Whales: Morphological and Observational Evidence. Contributions in Science, Natural History Museum of Los Angeles County, 464:1-12.

Horikawa, $\mathrm{H}$.

1995. A Primitive Odobenine Walrus of Early Pliocene Age from Japan. The Island Arc, 3:309-328.

Howell, A.B.

1927. Contribution to the Anatomy of the Chinese Finless Porpoise Neomeris phocaenoides. Proceedings of the United States National Museum, 70(13): 1-43.

1930. Myology of the Narwhal (Monodon monoceros). American Journal of Anatomy, 46(2):187-215.

Jansen, J., and J.K.S. Jansen

1969. The Nervous System of Cetacea. In H.T. Anderson, editor, The Biology of Marine Mammals, pages 175-252. New York: Academic Press.

Kastelein, R.A., N.M. Gerrits, and J.L. Dubbeldam

1991. The Anatomy of the Walrus Head (Odobenus rosmarus), Part 2: Description of the Muscles and of Their Role in Feeding and Haul-Out Behaviour. Aquatic Mammals. 17(3):156-180.

Kastelein, R.A., and P. Mosterd

1989. The Excavation Technique for Molluscs of Pacific Walruses (Odobenus rosmarus divergens) under Controlled Conditions. Aquatic Mammals, 15(1):3-5.

Kastelein, R.A., and P.R. Wiepkema

1989. A Digging Trough as Occupational Therapy for Pacific Walruses (Odobenus rosmarus divergens) in Human Care. Aquatic Mammals, 15(1):9-17.
Kastelein, R.A., R.C.V.J. Zweypfenning, H. Spekreijse, J.L. Dubbeldam, and E.W. Born

1993. The Anatomy of the Walrus Head (Odobenus rosmarus), Part 3: The Eyes and Their Function in Walrus Ecology. Aquatic Mammals, 19(2):61-92

Kellogg, R.

1923. Kentriodon pernix, a Miocene Porpoise from Maryland. Proceedings of the United States National Museum, 69(19):1-55.

1926. Supplementary Observations on the Skull of Zarhachis flagellator Copc. Proceedings of the United States National Museum, 67(28): I-18.

Ketten, D.R.

1984. Correlations of Morphology with Frequency for Odontocete Cochlea: Systematics and Topology. 335 pages. Doctoral dissertation, Johns Hopkins University, Baltimore, Maryland.

1992. The Marine Mammal Ear: Specializations for Aquatic Audition and Echolocation. In D. Webster, R. Fay, and A. Popper, editors, The Evolutionary Biology of Hearing, pages 717-754. New York: Springer-Verlag

Kctten, D.R., and D. Wartzok

1990. Three-dimensional Reconstructions of the Dolphin Ear. In J.A. Thomas and R.A. Kastelein, editors, Sensory Abilities of Cetaceans: Laboratory and Field Evidence, pages 81-105. New York: Plenum Press.

Kleinenberg, S.E.

1938. [Some Data on the Feeding of Tursiops tursio Fabr. in the Black Sea.] Byulleten Moskovskogo Obshchestva Ispytatelei Prirody, Otdel Biologicheskii [Bulletin of the Moscow Society of Researchers on Nature, Section of Biology], 47:406-413. [In Russian.]

Kleinenberg, S.E., A.V. Yablokov, B.M. Bel'kovich, and M.N. Tarasevich

1969. [Beluga (Delphinapterus leucas): Investigation on the Species.] 376 pages. Academy of Science of the USSR, A.N. Severtsov lnstitute of Animal Morphology. [In Russian. English translation by lsrael Program for Scientific Translations, Jerusalem.]

Kuznetzov, V.B.

1990. Chemical Sense of Dolphins: Quasi-Olfaction. In J.A. Thomas and R.A. Kastelein, editors, Sensory Abilities of Cetaceans: Laboratory and Field Evidence, pages 481-503. New York: Plenum Press.

Lawrence, B., and W.E. Schevill

1956. The Functional Anatomy of the Delphinid Nose. Bulletin of the Museum of Comparative Zoology, Harvard College, 114(4):103-151.

Lilly, J.C.

1961. Man and Dolphin. 312 pages. Garden City, New Jersey: Doubleday \& Co.

Lilly, J.C., and A.M. Miller

1961. Sounds Emitted by the Bottlenose Dolphin. Science, 5:1689-1693.

Lisson, C.I.

1898. Los fosfatos de Ocucaje. Boletin de Minas, Indüstria y Construcciones, 14(5):45-47.

Luo, Z., and K. Marsh

1996. Petrosal (Periotic) and Inner Ear of a Pliocene Kogiine Whale (Kogiinae, Odontoceti): 1mplications on Relationships and Hearing Evolution of Toothed Whales. Journal of Vertebrate Paleontology, 16(2):328-348.

Marocco, R., and C. de Muizon

1988. Los vertebrados del Neogeno de la costa Sur del Perú: ambiente y condiciones de fosilización. Bulletin de l'Institut Français d'Études Andines, 27(2):105-117.

Marsh, $\mathrm{H}$.

1980. Age Determination of the Dugong (Dugong dugon (Müller)) in Northern Australia and 1ts Biological Implications. Reports of the International Whaling Commission, Special Issue, 3:181-201. 
Martin, A.R.

1990. The Illustrated Encyclopedia of Whales and Dolphins. 192 pages. New York: Portland House.

Matthews, L.H

1978. The Natural History of the Whale. 219 pages. New York: Columbia University Press.

McCormick, J.G., E.G., Wever, and J. Palin

1970. Sound Conduction in the Dolphin Ear. Journal of the Acoustical Society of America, 48(6):1418-1428.

Mchedlidze, G.A., and G. Pilleri

1988. Kharthlidelphis diceros, a New Genus and Species from the Oligocene of Georgia (Caucasus, USSR). Investigations on Cetacea. $21: 9-15$.

Mead, J.G.

1975. Anatomy of the External Nasal Passages and Facial Complex in the Delphinidae (Mammalia, Cetacea). Smithsonian Contributions to Zoology, 207:1-72.

Miller, M.E., G.C. Christensen, and H.E. Evans

1964. Anatomy of the Dog. 941 pages. Philadelphia: W.B. Saunders.

Muizon, C. de

1981. Les vertébrés fossiles de la formation Pisco (Pérou), première partie: Deux nouveaux Monachinae (Phocidae, Mammalia) du Pliocène de Sud-Sacaco. Travaux de l'Institut Français d'Études Andines, 22: 160 pages. [Recherches sur les Grandes Civilisations, Mémoire 6. Paris: A.D.P.F.]

1983a. Pliopontos littoralis, un nouveau Platanistidae (Cetacea) du Pliocène de la côte péruvienne. Comptes Rendus Hebdomadaires des Séances de l'Académie des Sciences (Paris), series 2, 296: 1101-1104.

1983b. Un nouveau Phocoenidae (Cetacea) du Pliocène inférieur du Pérou. Comptes Rendus Hebdomadaires des Séances de l'Académie des Sciences (Paris), series 2, 296:1203-1206.

1983c. Un Ziphiidae (Cetacea) nouveau du Pliocène inférieur du Pérou. Comptes Rendus Hebdomadaires des Séances de l'Académie des Sciences (Paris), series 2, 297:85-88.

1984. Les vertébrés fossiles de la formation Pisco (Pérou), deuxième partie: Les odontocètes (Cetacea, Mammalia) du Pliocène inférieur de Sud-Sacaco. Travaux de l'Institut Français d'Études Andines, 25: 188 pages. [Recherches sur les Grandes Civilisations, Mémoire 50. Paris: A.D.P.F.]

1986. Un nouveau Phocoenidae (Odontoceti, Mammalia) du Miocène supérieur de la formation Pisco (Pérou). Comptes Rendus Hebdomadaires des Séances de l'Académie des Sciences (Paris), series 2, 303(16):1509-1512.

1987. The Affinities of Notocetus vanbenedeni, an Early Miocene Platanistoid (Cetacea, Mammalia) from Patagonia, Southern Argentina. American Museum Novitates, 2904: 27 pages.

1988a. Les vertébrés fossiles de la formation Pisco (Pèrou), troisième partie: Les odontocètes (Cetacea, Mammalia) Miocènes. Travaux de l'Institut Français d'Études Andines, 42: 244 pages. [Recherches sur les Grandes Civilisations, Mémoire 78. Paris: A.D.P.F.]

1988b. Le polyphylétisme des Acrodelphidae, odontocètes longirostres du Miocène européen. Bulletin du Muséum National d'Histoire Naturelle, series 4 , section C, 10(1):31-88.

1988c. Les relations phylogénétiques des Delphinida. Annales de Paléontologie, 74(4): 159-227.

1991. A New Ziphiid (Odontoceti, Mammalia) from the Early Miocene of Washington State (USA) and a Phylogenetical Analysis of the Major Groups of Odontocetes. Bulletin du Muséum National d'Histoire Naturelle, series 4, section c, 12:279-326.

1993a. Walrus-Like Feeding Adaptation in a New Cetacean from the Pliocene of Peru. Nature, 365:745-748.

1993b. Odobenocetops peruvianus, una remarcable convergencia de adaptación alimentaria entre morsa y delfín. Bulletin de l'Institut Français d'Études Andines, 22(3):671-683.
1994. Are the Squalodonts Related to the Platanistoids? Proceedings of the San Diego Society of Natural History, 29:135-146.

Muizon, C. de, and H. Bellon

1986. Nouvelles données sur l'âge de la formation Pisco (Pérou). Comptes Rendus Hebdomadaires des Séances de l'Académie des Sciences (Paris), series 2, 303(5):1401-1404.

Muizon, C. de, and T.J. DeVries

1985. Geology and Paleontology of Late Cenozoic Marine Deposits in the Sacaco Area (Peru). Geologisches Rundschau, 74(3):547-563.

Muizon, C. de, and D.P. Domning

2002. The Anatomy of Odobenocetops (Delphinoidea, Mammalia), the Walrus-like Dolphin from the Pliocene of Peru and Its Paleobiological Implications. Zoological Journal of the Linnean Society, 134(4):423-452.

Muizon, C. de, D.P. Domning, and M. Parrish

1999. Dimorphic Tusks and Adaptive Strategies in a New Species of Walrus-like Dolphin (Odobenocetopsidae) from the Pliocene of Peru. Comples Rendus de l'Académie des Sciences, series 2 (Sciences de la Terre et des Planètes), 329:449-455.

Murie, J.

1870. On Risso's Grampus, G. rissoanus (Desm.). Journal of Anatomy and Physiology, 5:118-138.

1873. On the Organization of the Caaing Whale, Globicephala melas. Transactions of the Zoological Society of London, 8(4):235-301.

Nelson, C.H., and K.R. Johnson

1987. Whales and Walruses as Tillers of the Sea Floor. Scientific American, 256(2):112-117.

Nishiwaki, $M$.

1972. General Biology. In S.H. Ridgway, editor, Mammals of the Sea: Biology and Medicine, pages 1-204. Springfield, Illinois: C.C. Thomas.

Norris, K.S.

1964. Some Problems in Echolocation in Cetaceans. In W.N. Tavolga, editor, Marine Bio-Acoustics, 1:317-355. New York: Pergamon Press.

1968. The Evolution of Acoustic Mechanisms in Cetaceans. In E.T. Drake, editor, Evolution and Environment, pages 297-324. New Haven: Yale University Press.

1969. The Echolocation of Marine Mammals. In H.T. Andersen, editor, The Biology of Marine Mammals, pages 391-423. New York: Academic Press.

Norris, K.S., K.J. Dormer, J. Pegg, and G.J. Liese

1971. The Mechanism of Sound Production and Air Recycling in Porpoises: A Preliminary Report. Proceedings of the Eighth Annual Conference on Biological Sonar and Diving Mammals, pages 113-129. Menlo Park, California: Stanford Research Institute.

Norris, K.S., and W.E. Evans

1967. Directionality of Echolocation Clicks in the Rough-tooth Porpoise, Steno bredanensis (Lesson). In W.N. Tavolga, editor, Marine BioAcoustics, 2:305-316. New York: Pergamon Press.

Norris, K.S., and G.W. Harvey

1974. Sound Transmission in the Porpoise Head. Journal of the Acoustical Society of America. 56(2):659-664.

Oelschläger, H.A., and E.H. Buhl

1985a. Development and Rudimentation of the Peripheral Olfactory System in the Harbor Porpoise Phocoena phocoena (Mammalia: Cetacea). Journal of Morphology, 184:351-360.

1985b. Occurrence of an Olfactory Bulb in the Early Development of the Harbor Porpoise (Phocoena phocoena L.). Fortschritte der Zoologie, 30:695-698.

Pabst, D.A.

1990. Axial Muscles and Connective Tissues of the Bottlenose Dolphin. In S. Leatherwood and R.R. Reeves, editors, The Bottlenose Dolphin, pages 51-67. San Diego: Academic Press.

Pilleri, G., editor

1989. Beiträge sur Paläontologie der Cetaceen Perus. Volume 1, 233 pages. Ostermundingen [Bern]: Hirnanatomisches Institut. 
1990. Beiträge sur Paläontologie der Cetaceen Perus. Volume 2, 248 pages. Ostermundingen [Bern]: Hirnanatomisches Institut.

Pilleri, G., and M. Ghir

1981. The Brain (Endocranial Cast) of Schizodelphis sulcatus and the Cephalization of Eoplatanista italica (Cetacea): Paleoneurological and Paleoecological Considerations. Memorie degli Istituti di Geologia e Mineralogia dell'Università di Padova, 34:387-440.

1982. The Brain and Cephalization of Schizodelphis sulcatus Gervais, 1861. Investigations on Cetacea, 13:13-25.

Preen, A.R.

1989. Observations of Mating Behavior in Dugongs (Dugong dugon). Marine Mammal Science, 5:382-387.

Purves, P.E.

1967. Anatomical and Experimental Observations on the Cetacean Sonar System. In R.-G. Busnel, editor, Animal Sonar Systems, Biology and Bionics, 1:197-270. Jouy-en-Josas: Laboratoire de Physiologie acoustique, INRA-CNRZ.

Rae, B.B.

1973. Additional Notes on the Food of the Common Porpoise (Phocoena phocoena). Journal of Zoology, 169:127-131.

Ray, C.

1966. Round Table: Practical Problems. In K.S. Norris, editor, Whales, Dolphins and Porpoises, page 671. Berkeley: University of California Press.

Ray, C.E., D.P. Domning, and M.C. McKenna

1994. A New Specimen of Behemotops proteus (Mammalia: Desmostylia) from the Marine Oligocene of Washington. Proceedings of the San Diego Society of Natural History, 29:205-222.

Ridgway, S.H., D.A. Carder, R.F. Green, A.S. Gaunt, L.L. Gaunt, and W.E. Evans

1980. Electromyographic and Pressure Events in the Nasolaryngeal System of Dolphins during Sound Production. In R.-G. Busnel and J.F. Fish, editors, Animal Sonar Systems [NATO Advanced Science Institute, series A (Life Science), Volume 28], pages 239-249. New York: Plenum Press.

Rodinov, V.A., and V.I. Markov

1992. Functional Anatomy of the Nasal System in the Bottlenose Dolphin. In J.A. Thomas, R.A. Kastelein, and A.Ya. Supin, editors, Marine Mammal Sensory Systems, pages 147-177. New York: Plenum Press. Schenkkan, E.J.

1973. On the Comparative Anatomy and Function of the Nasal Tracts in Odontocetes (Mammalia, Cetacea). Bijdragen tot de Dierkunde, 43(2):127-159.

Schevill, W.E.

1964. General Discussion. In W.N. Tavolga, editor, Marine Bio-Acoustics, 1:395-398. New York: Pergamon Press.

Schulte, H. von W., and M. de Forest Smith

1918. The External Characters, Skeletal Muscles, and Peripheral Nerves of Kogia breviceps (Blainville). Bulletin of the American Museum of Natural History, 38(2):7-72.

Seagars, D.J.

1982. Jaw Structure and Functional Mechanics of Six Delphinids (Cetacea: Odontoceti). 179 pages. Master's thesis, San Diego State University, San Diego.

Seaman, G.A., L.F. Lowry, and K.J. Frost

1982. Foods of the Belukha Whales (Delphinapterus leucas) in Western Alaska. Cetology, 44(Sept.):1-19.

Sickenberg, $O$.

1934. Beiträge zur Kenntnis Tertiärer Sirenen. Mémoires du Musée Royal d'Histoire Naturelle de Belgique, 63:1-352.

Sinclair, J.G.

1966. The Olfactory Complex of Dolphin Embryos. Texas Reports of Biological Medicine, 24:426-431.

Spoor, F.

1993. The Comparative Morphology and Phylogeny of the Human Bony Labyrinth. Doctoral dissertation, Universiteit Utrecht, Utrecht.

Tedford, R.H., L.G. Barnes, and C.E. Ray

1994. The Early Miocene Littoral Ursid Camivoran, Kolponomos: Systematics and Mode of Life. Proceedings of the San Diego Society of Natural History, 29:11-32.

Tomilin, A.G.

1967. Cetacea. In Mammals of the USSR and Adjacent Countries, 9: 717 pages. [Original in Russian, published 1957. Translated by lsrael Program for Scientific Translations, Jerusalem.]

Vibe, $\mathrm{C}$

1950. The Marine Mammals and the Marine Fauna in the Thule District (North-West Greenland) with Observations on Ice Conditions in 1939-41. Meddelelser om Grönland, 150(6):1-115.

Werth, A.J.

1992. Anatomy and Evolution of Odontocete Suction Feeding. xiii +313 pages. Doctoral dissertation, Harvard University, Cambridge, Massachusetts.

Wilke, F., T. Taniwaki, and N. Kuroda

1953. Phocoenoides and Lagenorhynchus in Japan, with Notes on Hunting. Journal of Mammalogy, 34(4):488-497.

Wood, F.G.

1964. General Discussion. In W.N. Tavolga, editor, Marine Bio-Acoustics, 1:395-398. New York: Pergamon Press.

Yablokov, A.V., and G.A. Klevezal

1962. [Whiskers of Whales and Seals and Their Distribution, Structure and Significance.] In S.E. Kleinenberg, editor, Morfologicheskie Osobennosti Vodnikh Mlekopitayushchikh [Morphological Characteristics of Aquatic Mammals], pages 48-81. Moscow: lzdatel'stvo "Nauka." [Translated from Russian by the Fisheries Research Board of Canada, 1969.] 



\title{
Paleopathology in a Miocene Kentriodontid Dolphin (Cetacea: Odontoceti)
}

\author{
Susan D. Dawson and Michael D. Gottfried
}

\begin{abstract}
A specimen of the kentriodontid dolphin Hadrodelphis calvertense, from the Miocene Calvert Formation of Maryland, exhibits pathological lesions on the ribs, vertebrae, and mandible. These lesions were imaged with both plain film radiography and computed tomography. Appearance of the rib lesions is consistent with fracture-callus formation. Two lumbar vertebrae exhibit vertebral spondylosis, which manifests itself as mild exostosis and lipping that does not involve the articular surfaces. These two pathologies are common findings in osteological collections of Holocene cetaceans. Such lesions are especially common among individuals that have reached skeletal maturity; however, this individual is skeletally immature.

The mandibular lesion consists of extensive periosteal new bone formation caudal to the tooth row, on the lateral aspect of the right mandibular ramus. Two large drainage fistulae are present, one of which reveals a bony sequestrum. New bone formation may result either from neoplastic or infectious processes-the etiology of the lesion appears to be infectious, possibly as a result of bacterial infection secondary to trauma. Mandibular osteomyelitis of this sort does not appear to be common in odontocetes, and new bone formation to this extent likely would have compromised echolocation. The combination of chronic infection and reduced echolocation abilities may have led directly to the demise of this individual.
\end{abstract}

\section{Introduction}

Contributions to the field of vertebrate paleopathology have increased dramatically in recent years (Rothschild and Martin, 1993) as a more sophisticated understanding of bone biology, along with modern veterinary and human medical techniques, has been applied to the fossil record. Relatively few pathological conditions have been described in fossil cetaceans, however-these include the identification of vertebral growth recovery lines in a fossil dolphin (Sebes et al., 1990); vertebral exostoses on Miocene "cetotheres" (Kellogg, 1969); and evi-

Susan D. Dawson, Department of Anatomy and Physiology, University of Prince Edward Island, Charlottetown, Prince Edward Island ClA 4P3, Canada. Michael D. Gottfried, MSU Museum, Michigan State University, East Lansing, Michigan 48824-1045, United States. dence of predation and/or scavenging by sharks (Deméré and Cerutti, 1982; Cigala-Fulgosi, 1990).

Our knowledge of disease processes in living cetaceans has been facilitated by stranding networks that recover cetacean carcasses, and by increasingly sophisticated observation and veterinary management of captive cetaceans. This knowledge base is an essential prerequisite for studies of pathologies in fossil cetaceans. Appropriate living models are necessary in order to diagnose a specific disease process based solely upon osteological remains, and, despite our detailed medical knowledge, the human model is not always appropriate.

The pathological odontocete described herein was collected from the Miocene Calvert Formation in Charles County, Maryland. The specimen is referred to Hadrodelphis calvertense Kellogg, 1966, a monotypic genus erected on the basis of a partial mandible. Hadrodelphis has been placed in the family Kentriodontidae (Dawson, 1996), a diverse assemblage of primarily Miocene delphinoids whose monophyly has been questioned (Muizon, 1988). The lack of fusion of vertebral and forelimb epiphyses indicates that this specimen is a subadult individual. It exhibits three distinct pathological lesions-on the ribs, vertebrae, and right mandible-that are the subject of this report. The lesions were examined and imaged with conventional radiography as well as with computed tomography (CT) scans, and the osteological collection of Holocene cetaceans at the National Museum of Natural History (NMNH), Smithsonian Institution, which subsumed the collections of the former United States National Museum (USNM), was surveyed to assess whether similar lesions occur in extant odontocetes.

ACKNOWLEDGMENTS.- - It is a great pleasure to participate in this volume commemorating Clayton Ray's many contributions to paleontology. Among his diverse activities, Clayton encouraged the development of a paleontology program at the Calvert Marine Museum (CMM), the repository for the specimen described herein and where much of the research for this paper was conducted.

We are very grateful to D. Jarvi, P. Barth, J. Gibson, S. White, and A. Panos, all of the Radiology Department at Calvert Memorial Hospital (Prince Frederick, Maryland) for radio- 
graphing and scanning the specimen. G. Daleo (Children's Hospital, San Diego) contributed valuable advice on scanning techniques. B. Rothschild (Arthritis Center of Northeast Ohio) and V. de Buffrénil (Museum National d'Histoire Naturelle, Paris) offered helpful reviews that improved the manuscript. $C$. Potter (NMNH) facilitated access to the NMNH cetacean collections.

Financial support was provided by CMM's Lincoln Dryden Paleontology Fund.

\section{Systematic Paleontology}

\section{Class Mammalia}

Order CETACEA

\section{Suborder ODONTOCETI}

Superfamily DELPHINOIDEA

Family KENTRIODONTIDAE

Subfamily LOPHOCETINAE

\section{Hadrodelphis calvertense Kellogg, 1966}

REFERRED MATERIAL.-Calvert Marine Museum CMM-V11, an associated specimen consisting of the skull, mandibles, complete vertebral column, ribs, partial right scapula, and right humerus, radius, and ulna.

LOCALITY.-CMM-V-11 was recovered in May, 1982, from Indian Creek, Charles County, Maryland, approximately $5 \mathrm{~km}$ northeast of the town of Charlotte Hall. The skeleton was partially exposed in the creek in a shell layer assigned to bed 14 of the Calvert Formation, Chesapeake Group. The initial discovery was made by H. Jackson and F. Granados, and the specimen was collected by them and D. Bohaska, N. Riker, C. Taylor, and W. Ashby.

Geological and Paleoenvironmental SetTing.-The Calvert Formation ranges from late early to middle Miocene in age, and in the Chesapeake region it is divided into 16 beds (referred to as "zones" by some authors), with bed 16 at the top of the formation. The nearshore marine clays, silts, and sands of the Calvert constitute one of the seven formations that make up the Chesapeake Group, a complex package of late Oligocene to Pliocene sediments deposited along the Middle Atlantic Coastal Plain. Climatic conditions during Calvert time were generally warmer than the region is at present, as reflected in the Calvert fauna, which includes very abundant and diverse invertebrates (especially mollusks), abundant sharks, and bony fish, sea turtles, crocodiles, seabirds, some land mammals, and an important assemblage of marine mammals.

Overviews of the geology and biota of the Calvert Formation can be found in Vogt and Eshelman (1987) and Ward (1992). The cetacean fauna has been summarized by Gottfried et al. (1994).

DESCRIPTION.-Ribs: Two ribs exhibit a circumscribed area of new bone formation located on each along the shaft of the rib. The larger of the lesions nearly doubles the diameter of the rib shaft, forming a distinct knobby swelling that blends smoothly with the normal cortex on the shaft proximal and distal to the lesion. The other lesion has a similar appearance but is smaller. The gross appearance of the cortex of the lesions is similar to that of the normal cortical bone. Radiographs of the larger lesion (Figure $1 a$ ) indicate periosteal new bone formation surrounding a central area of bone lysis. Radiographs also indicate a radiolucent line perpendicular to the long axis of the bone, around which is organized the periosteal new bone formation; this line may represent the original fracture site. Grossly similar lesions are commonly present on ribs of extant cetaceans (MDG, pers. obs., USNM collection). The rib lesions on CMM-V-11 are consistent with fracture-callus formation.

A series of short ( 6-9 mm), shallow, subparallel, transverse grooves incised into the rib shaft near the lesion shown in Figure $l a$ indicate possible predation and/or scavenging by sharks. This is a relatively common occurrence on fossil cetacean remains (e.g., Deméré and Cerutti, 1982; Cigala-Fulgosi, 1990), and similar scars also are present on other postcranial elements of the specimen.

Vertebrae: Two lumbar vertebral centra (about numbers 24 and 25) exhibit exostoses on their right dorsolateral surfaces. The exostosis on number 24 is relatively small and confined to a portion of the posterior right dorsolateral surface; that on number 25 is larger and extensively covers the right anterior dorsolateral surface of the centrum (Figure $1 b$ ). This excess bone growth does not involve the articular surfaces but extends outward from each of the affected centra. Grossly, the affected bone has an irregular, globular appearance. CT imaging of the larger exostosis on centrum 25 indicates that the new bone is dense and compact.

The incidence of vertebral pathology in cetaceans has provoked a fair amount of discussion (Paterson, 1984; Walker et al., 1986; Kompanje, 1993a). Vertebral exostosis and fusion in the lumbar and caudal regions is frequently observed in extant cetaceans. This condition has variously been termed ankylosing spondylosis, ankylosing spondylitis, spondylosis deformans, or spondylitis deformans (Kompanje, 1993a). These lesions are most commonly seen in older individuals. In humans, such lesions occur as part of the aging process and may be asymptomatic. The incomplete skeletal fusion, however, indicates that CMM-V-11 is a subadult rather than a mature individual.

Mandible: The right mandible exhibits an extensive area of new bone formation on the lateral aspect of the ramus (Figure $2 a$ ) posterior to the tooth row. The mandibles of Hadrodelphis are fused anteriorly along an extensive symphysis (equal to one-third of total mandibular length) and bear 19 alveoli each. The lesion appears to involve the posteriormost alveolus, but it is not localized around that point and extends about $20 \mathrm{~cm}$ caudad from the last alveolus. There is no evidence that the lesion led to tooth loss-37 of the total complement of 38 man- 


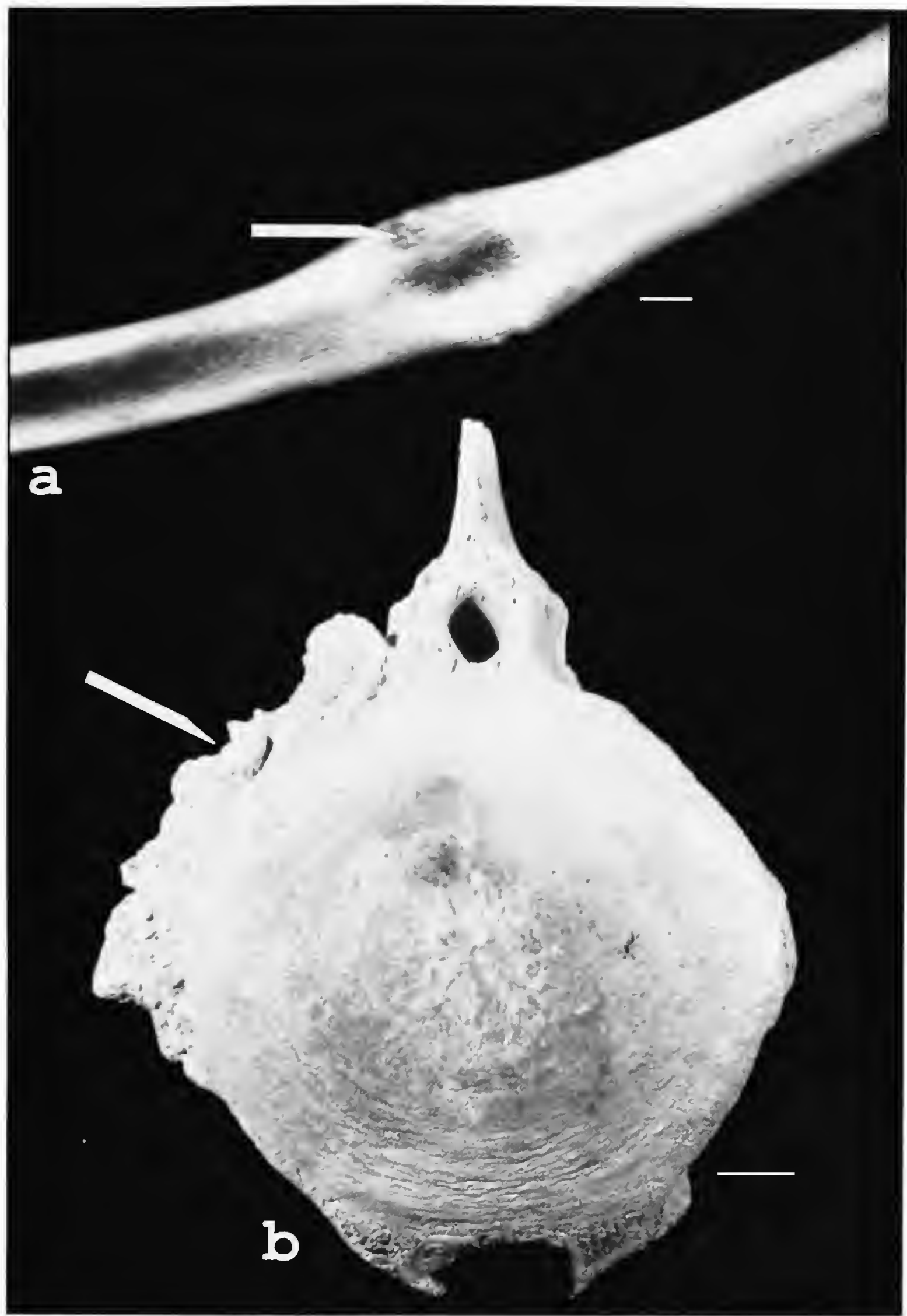

FIGURE 1.- $a$, Detail from radiograph of rib lesion of Hadrodelphis calvertense (CMM-V-11). This view shows a knob-like area of periosteal new bone formation surrounding a central area of lysis, and a radiolucent line (arrow) approximately transverse to the long axis of the rib, both consistent with a fracture callus. (Scale bar $=1$ $\mathrm{cm}$ ). $b$, Anterior articular view of lumbar vertebral centrum (about number 25) from CMM-V-11; the area of dense exostosis (arrow) is visible along the right dorsolateral margin of the centrum (note it does not include the articular face of the centrum). (Scale bar $=1 \mathrm{~cm}$.)

dibular teeth were found either in situ on the jaws or in the surrounding matrix.

The lesion, which blends relatively smoothly into the normal bone, involves the entire depth of the mandible, resulting in a very swollen and outwardly bowed appearance in the affected area (Figure $2 a$ ). The texture of the new bone is more porous than that of the normal mandible anterior to the lesion and on the corresponding portion of the normal left mandible. There is 


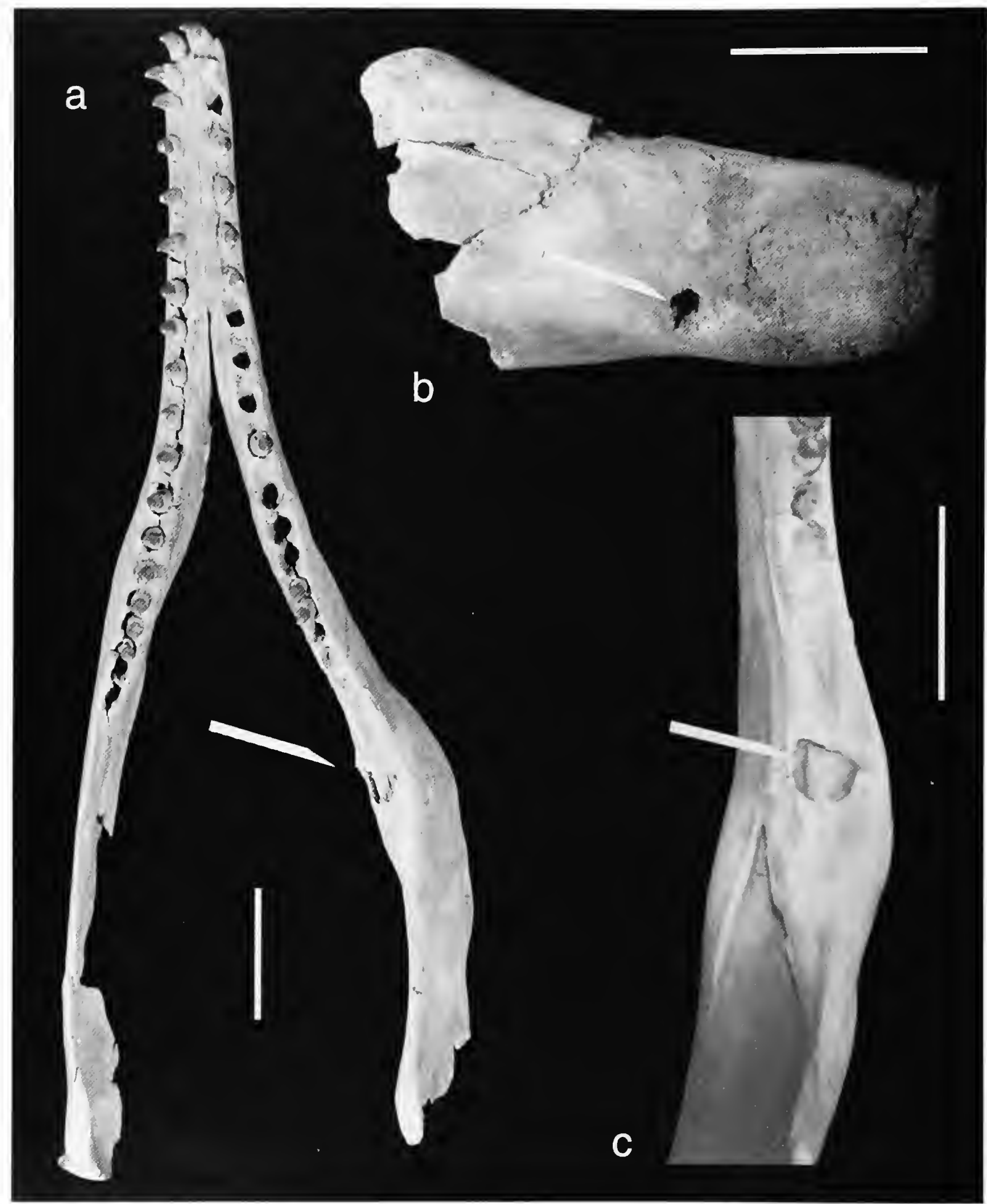

FIGURE 2. - a, Articulated mandibles of Hadrodelphis calvertense (CMM-V-11) in dorsal view; note swollen and bowed appearance of right mandible (arrow) (Scale bar $=10 \mathrm{~cm}$.) $b, c$, Detail of the mandibular lesion: in lateral $(b)$ and dorsal (anterior at top) (c) view; note drainage fistulae openings (arrows) in both views, and bony sequestrum within fistular opening in $c$. (Scale bars $=10 \mathrm{~cm}$.)

a subcircular opening, approximately $28 \mathrm{~mm}$ across and $20 \mathrm{~mm}$ high, located on the caudolateral aspect of the lesion (Figure $2 b$ ), and a similar, more nearly circular, opening approximately $26 \mathrm{~mm}$ in diameter on the dorsal surface of the lesion (Figure $2 c$ ). Both of these are interpreted as drainage fistulae, a conclusion supported by the presence of a sequestrum of isolated ne- crotic bone visible within the dorsal fistula (Figure $2 c$ ).

CT imaging (Figures 3,4 ) of the lesion confirms that the new bone formation is confined to the lateral aspect of the mandible; in a dorsal-view CT scan, the original mandibular bone is clearly visible, surrounding the mandibular canal (Figure 3). The periosteal new bone formation is extensive and encloses a 


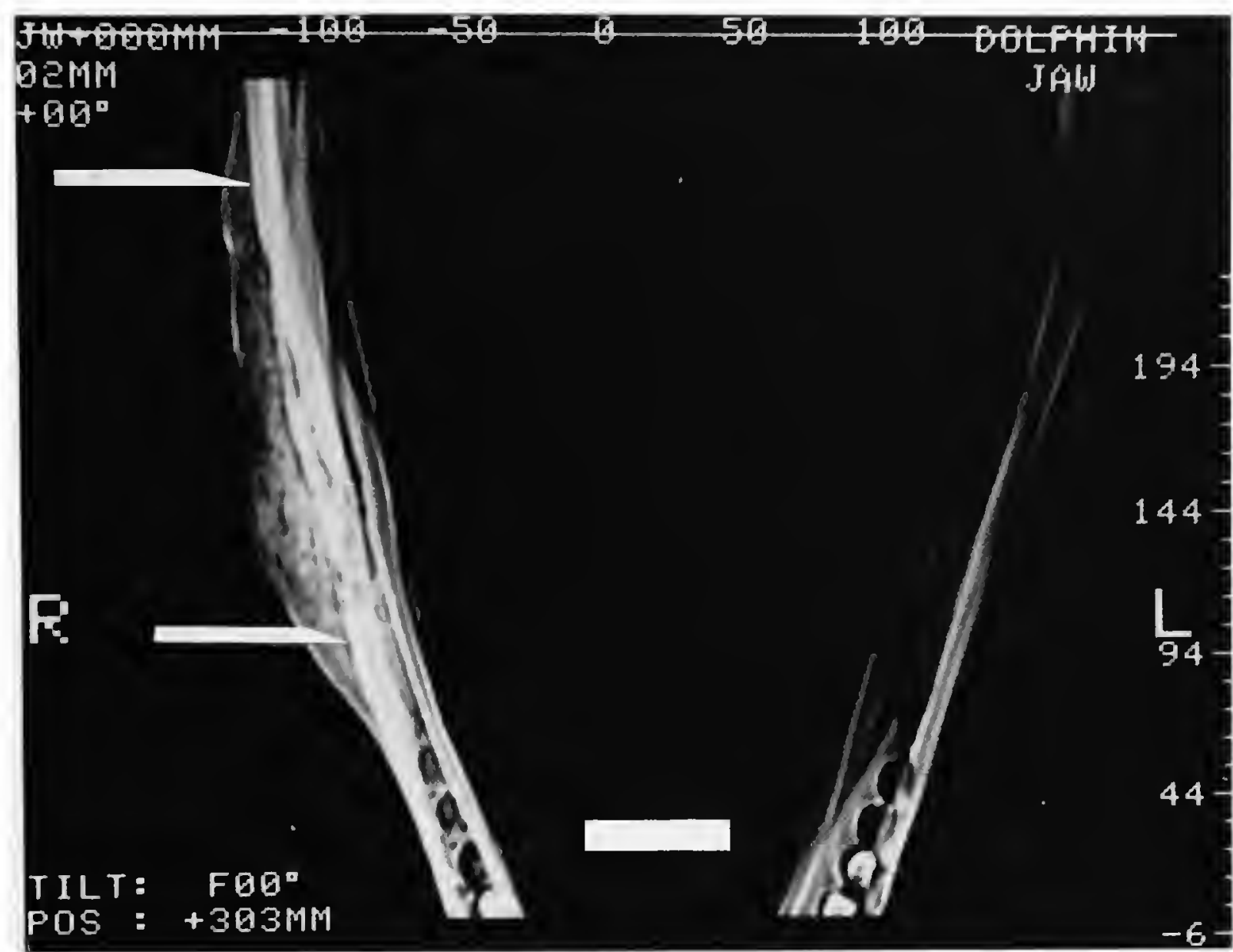

Figure 3.-Dorsal view computed tomography (CT) image (anterior to bottom) of mandibles of Hadrodelphis calvertense (CMM-V-11), showing extensive periosteal new bone formation on the lateral aspect of the right mandible caudal to the tooth row. Arrows indicate original normal lateral margin of mandible. Normal appearance and thickness of the bone can be seen on the corresponding portion of the left mandible. (Scale bar $=5 \mathrm{~cm}$.)

network of drainage tracts; the extent of new bone formation is particularly striking when compared with the normal appearance of this part of the mandible on the left ramus (Figure 3). The network of drainage tracts seen on CMM-V-11 is as expected in cases of chronic infectious processes, with new drainage tracts forming as older ones become blocked.

Lesions involving extensive new bone formation are typically the result of either neoplastic or infectious processes. Through radiologic and gross examination it is possible to distinguish between these two etiologies (Rothschild and Martin, 1993; Rothschild and Rothschild, 1995). We consider neoplasia the less likely of the two possibilities. Neoplasia may be caused by primary or secondary bone tumors: osteosarcoma, or primary bone tumor, is seldom reported in modern cetaceans and often involves lysis of bone; secondary bone tumors (metastases from other neoplastic lesions) are typically multifocal in distribution, but CMM-V-11 does not exhibit any other similar lesions.

The presence of a bony sequestrum and the two drainage fistulae strongly suggest osteomyelitis, an infectious process that may be bacterial or fungal in origin, as the cause of the mandibular lesion. One form of mandibular lesion called lumpy jaw (Jubb et al., 1993), most commonly seen in cattle, results from an actinomycosis infection thought to progress from trauma to periodontal tissue. Lumpy jaw does involve extensive peri- osteal new bone formation, but the gross appearance of the lesion in Hadrodelphis is inconsistent with lumpy jaw. A more likely pathogenesis is bacterial infection, introduced either by fracture or trauma to the teeth or periodontal tissue.

Fracture of the jaw itself can be excluded as the cause of the mandibular lesion. There is no displacement of segments of the mandible, nor is there any disruption of the continuity of the original outline of the mandible in the CT images (Figures 3 , 4 ), or in radiograph, as would be expected in a fracture. The lesion does not appear to have a locus of origin within an alveolus, and there is no evidence that it resulted from the bite of a predator. This process of elimination suggests trauma to periodontal tissue as the likeliest route of infection.

\section{Discussion}

The lesions in Hadrodelphis calvertense (CMM-V-11) represent three separate etiologies: healed rib fractures, idiopathic vertebral spondylosis, and chronic mandibular osteomyelitis following periodontal trauma. Gross and radiologic (Figure 1a) appearance of the rib lesion is consistent with a fracture callus. De Smet (1977) discussed skeletal pathologies observed in museum specimens of recent bottlenose dolphins (Tursiops truncatus); although the sample size was small $(n=12)$, rib fracture calluses were noted on half of both stranded and captive indi- 

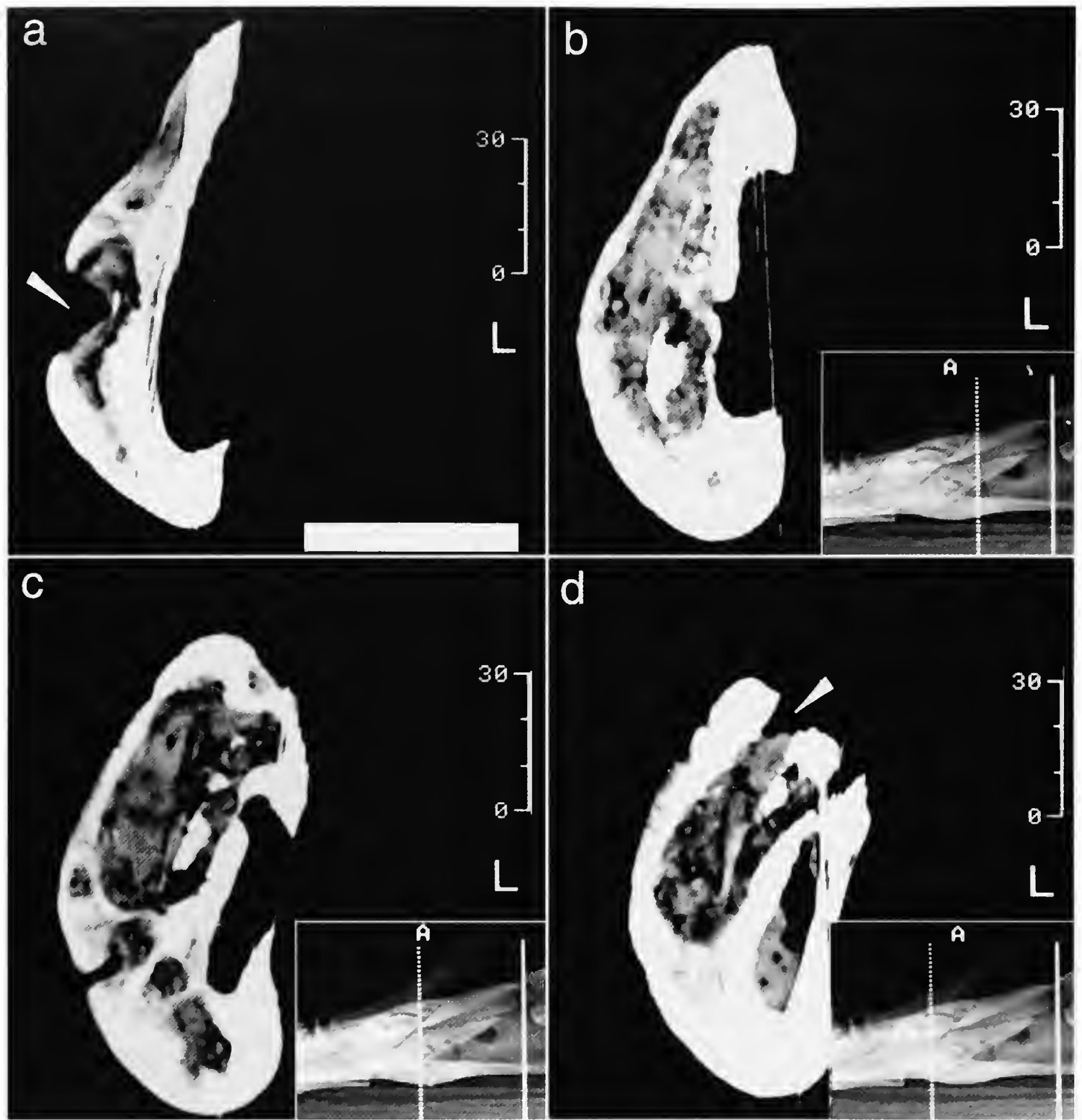

FIGURE 4. $-a-d$, Successive transverse cross-sectional CT scans through the mandibular lesion on Hadrodelphis calvertense (CMM-V-11). The lesion was imaged at $1 \mathrm{~mm}$ intervals; these are representative slices through the lesion, progressing from caudal to rostral (lateral to the left in each). Small inset images in $b-d$ show location of those slices. The large, laterally positioned fistula is clearly visible in $a$ (arrow), and the more dorsal fistula in $d$ (arrow); isolated areas of dense bone (which show as bright white) in $b-d$ represent sequestra. (Scale bar $=5 \mathrm{~cm}$.)

viduals. This high incidence of healed fractures suggests that rib fracture is not necessarily debilitating in odontocetes. Kompanje (1991) described a stranded killer whale (Orcinus orca) with exostoses on five ribs, which he concluded were caused by osteomyelitis secondary to fracture-evidence that rib fractures are not always resolved without complication.

Not only is exostosis on post-cervical vertebrae common in modern delphinids, but it also has been reported in fossil cetaceans, and it provided the etymological basis for the "cetothere" Thinocetus arthritus Kellogg, 1969. Kompanje (1993a) summarized some of the terms used in the literature to describe vertebral exostosis in cetaceans and made a convincing argument for diagnosing the condition as spondylosis deformans. He noted that in humans this condition is related to the aging process and is found in almost all geriatric human skeletons. The etiology of spondylosis involves degeneration of one or more vertebral disks, with new bone formation associated with sites of ligamentous attachments.

Kellogg (1969) referred to the exostoses on Thinocetus arthritus as both spondylitis deformans and osteophytosis (these were later referred to as ligamentous ossifications by Rothschild, 1987). Walker et al. (1986), in their study of the Pacific 
white-sided dolphin (Lagenorhynchus obliquidens), referred to vertebral pathologies as osteonecrosis, although their illustration appears consistent with exostosis indicative of spondylosis (sensu Kompanje). In a relatively large sample $(n=63$, of which 39 were stranded specimens), Walker et al. found a similarly high incidence of vertebral necrosis $(54 \%)$. They could not associate the pathologies with any predisposing factor, including age, however, and concluded that the observed pathologies did not contribute to the strandings. Paterson (1984) suggested that, although extreme cases of new bone formation in vertebrae may cause vertebral canal stenosis and associated neural deficits, most cases in cetaceans represent part of the normal aging process. Although the condition in Hadrodelphis appears most consistent with vertebral spondylosis (sensu Kompanje), the specimen is subadult, so non-age-related factors must have contributed to the new bone formation.

Although clearly less common than rib or vertebral pathologies, cetacean mandibular pathologies have been reported in the literature. Kompanje (1993b) described mandibular osteomyelitis in five stranded harbor porpoises (Phocoena phocoena) from the Netherlands. The cause of the infection in three of these cases can be attributed to fracture, as evidenced by clear discontinuities in the bones at the point of injury. In humans, infection introduced through dental or periodontal tissues (Topazian et al., 1987) - not fracture-is the most common cause of mandibular osteomyelitis. One of the porpoises described by Kompanje (1993b) may have become infected via periodontal tissues, which also are the likely route in Hadrodelphis; neither of these specimens exhibits tooth loss or any involvement of the alveoli.

Possible scenarios for the initial periodontal trauma in Hadrodelphis include predation attempts by sharks or some other predator, or trauma during feeding. Although shark predation on fossil and living cetaceans is well documented, we believe this is a relatively unlikely explanation. A comprehensive study of stranded bottlenose dolphins (Tursiops truncatus) found that most predatory attacks targeted the ventral region of the caudal peduncle, around the genital region (Mead and Potter, 1990). Corkeron et al. (1987) found evidence of shark bite wounds adjacent to the dorsal fins of a number of T. truncatus (in a study done as part of a photo identification project using dorsal-fin morphology). Long (1991) described a pygmy sperm whale (Kogia breviceps) that had been attacked on the anterior part of its caudal peduncle by a white shark (Carcharodon carcharias). Cigala-Fulgosi (1990) discussed a Pliocene dolphin (Tursiops cortesii) skeleton that, based upon the distinctive tooth marks, also had very likely been attacked by a white shark. Cigala-Fulgosi's description is perhaps the best-documented instance in the fossil record of a shark attack on a cetacean; the author found that the majority of the wounds were to the thoracic region (ribs, right forelimb, and right scapula) and to the lumbar vertebrae. No bites to the skull or jaws were recorded. Taken together, these reports suggest that shark attacks on cetaceans typically concentrate on the trunk and tail regions, not the head or jaws.

Shark predation also seems unlikely as the cause of death for CMM-V-11. As mentioned above, tooth marks are present on several elements of the skeleton, and the tip of a shark tooth is embedded in the transverse process of a lumbar vertebra. The lack of remodeling on the bone surrounding these marks implies postmortem scavenging, probably of a mild nature given the relative completeness of the skeleton.

Unlike the rib and vertebral pathologies, the mandibular lesion may well have contributed to this individual's demise. Chronic infection is often debilitating, and a painfully infected jaw may have inhibited feeding. Additionally, the extensive secondary bone formation on the lateral border of the mandible likely interfered with this part of the jaw's function as an "acoustic window" in echolocation, further affecting the animal's ability to capture prey and also causing general disorientation. Both debilitation and disorientation are factors in stranding, and in the case of CMM-V-11 the relatively complete nature of the skeleton is consistent with a stranded individual that was not subjected to extensive post-mortem disturbance.

Although living cetaceans are the most appropriate model for interpreting pathologies in fossil cetaceans, there are other factors must be considered when evaluating epidemiological features of disease frequency. Modern stranding networks are an invaluable source of basic information on cetacean biology, including parasites, toxicology, and incidence of trauma. Osteological lesions, however, are obviously the most relevant in a paleopathological context, and many such lesions may go undetected during typical necropsy procedures. Skeletal preparation is necessary to assess the frequency of skeletal lesions with confidence. This is particularly true for healed, nońdisplaced fractures and for idiopathic lesions, such as vertebral spondylosis. Unfortunately, complete skeletal preparation is not feasible in many cases.

Another complicating factor is the bias introduced by using museum collections as a source of specimens. The stranded specimens that frequently form the bulk of collections are often debilitated by disease and/or trauma; studies of disease frequencies based upon stranded specimens therefore probably do not reflect natural conditions in wild populations. Studies that include wild-caught or incidental-catch specimens, or that compare data between wild-caught and stranded specimens, are more likely to prove meaningful. It may be trivial to conclude that more study is needed, but clearly that is the case in cetacean paleopathology. Comprehensive comparative studies of pathologies in extant cetaceans will allow for more robust interpretations of disease processes in their fossil relatives. 


\section{Literature Cited}

Cigala-Fulgosi, F.

1990. Predation (or Possible Scavenging) by a Great White Shark on an Extinct Species of Bottlenosed Dolphin in the Italian Pliocene. Tertiary Research, 12(1):17-36.

Corkeron, P.J., R.J. Morris, and M.M. Bryden

1987. Interactions between Bottlenose Dolphins and Sharks in Moreton Bay, Queensland. Aquatic Mammals, 13(3):109-113.

Dawson, S.D.

1996. A Description of the Skull and Postcrania of Hadrodelphis calvertense Kellogg, 1966, and lts Position within the Kentriodontidae (Cetacea; Delphinoidea). Journal of Vertebrate Paleontology, 16(1): $125-134$

Deméré, T.A., and R.A. Cerutti

1982. A Pliocene Shark Attack on a Cetotheriid Whale. Journal of Paleontology, 6(6):1480-1482.

Gottfried, M.D., D.J. Bohaska, and F.C. Whitmore, Jr.

1994. Miocene Cetaceans of the Chesapeake Group. In A. Berta and T.A. Démére, editors, Contributions in Marine Mammal Paleontology Honoring Frank C. Whitmore, Jr. Proceedings of the San Diego Society of Natural History, 29:229-238.

Jubb, K.V.F., P.C. Kennedy, and N. Palmer

1993. Pathology of Domestic Animals. Fourth edition, volume 1, 780 pages. San Diego: Academic Press.

Kellogg, R.

1966. Fossil Marine Mammals from the Miocene Calvert Formation of Maryland and Virginia, Part 4: A New Odontocete from the Calvert Formation of Maryland. Bulletin of the United States National Museum, 247:99-101.

1969. Cetothere Skeletons from the Miocene Choptank Formation of Maryland and Virginia. Bulletin of the United States National Museum, 294:1-40.

Kompanje, E.J.O.

1991. Een oud Geval van Osteomyelitis bij een Orka Orcinus orca. Lutra, 34:71-76.

1993a. Vertebral Osteophytosis in Cetacea: Spondylosis or Spondylitis? Zeitschrift für Saugertierkunde, 58:316-318.

1993b. Osteomyelitis of the Mandible in Harbor Porpoises Phocoena phocoena from the Netherlands. Lutra, 36:39-46.

Long, D.J.

1991. Apparent Predation by a White Shark Carcharodon carcharias on a Pygmy Sperm Whale Kogia breviceps. United States Fishery Bulletin, 89:538-540.

Mead, J.G., and C.W. Potter

1990. Natural History of Bottlenose Dolphins along the Central Atlantic
Coast. In S. Leatherwood and R.R. Reeves, editors, The Bottlenose Dolphin, pages 165-196. New York: Academic Press.

Muizon, C. de

1988. Les relations phylogénétiques des Delphinida (Cetacea, Mammalia). Annales de Paléontologie, 74(4):159-227.

Paterson, R.A.

1984. Spondylitis Deformans in a Bryde's Whale (Balaeonoptera edeni Anderson) Stranded on the Southern Coast of Queensland. Journal of Wildlife Diseases, 20(3):250-252.

Rothschild, B.M

1987. Diffuse Idiopathic Skeletal Hyperostosis as Reflected in the Paleontologic Record: Dinosaurs and Early Mammals. Seminars in Arthritis and Rheumatism, 17:119-125.

Rothschild, B.M., and L.D. Martin

1993. Paleopathology: Disease in the Fossil Record. 386 pages. Boca Raton, Florida: CRC Press.

Rothschild, B.M., and C. Rothschild

1995. Comparison of Radiologic and Gross Examination for Detection of Cancer in Defleshed Skeletons. American Journal of Physical Anthropology, 96:357-363.

Sebes, J.1., B.M. Rothschild, J.W. Langston, and M.L. Gavant

1990. Growth Recovery Lines in Fossil Vertebrae. Journal of Vertebrate Paleontology, supplement, 19(3):41 A.

Smet, W.M.A. de

1977. The Fate of Old Bottle-nosed Dolphins, Tursiops truncatus, in Nature As Revealed by the Condition of Their Skeletons. Aquatic Mammals, 5(1):78-86.

Topazian, R.G., and M.H. Goldberg, editors

1987. Oral and Maxillofacial Infections: Osteomyelitis of the Jaws. Second edition, 473 pages. Philadelphia: W.B. Saunders.

Vogt, P.R., and R.E. Eshelman

1987. Maryland's Cliffs of Calvert: A Fossiliferous Record of Mid-Miocene Inner Shelf and Coastal Environments. Geological Society of America Centennial Field Guide, Northeast Section, pages 9-14.

Walker, W.A., S. Leatherwood, K.R. Goodrich, W.F. Perrin, and R.K. Stroud

1986. Geographical Variation of the Pacific White-sided Dolphin, Lagenorhynchus obliquidens, in the Northeastern Pacific. In M.M. Bryden and R. Harrison, editors, Research on Dolphins, pages 441-466. Oxford: Oxford Scientific Publishers.

Ward, L.W.

1992. Molluscan Biostratigraphy of the Miocene Middle Atlantic Coastal Plain of North America. Virginia Museum of Natural History Memoir, 2: 159 pages 


\title{
Paleontology of the Late Oligocene Ashley and Chandler Bridge Formations of South Carolina, 2: Micromysticetus rothauseni, a Primitive Cetotheriid Mysticete (Mammalia: Cetacea)
}

\author{
Albert E. Sanders and Lawrence G. Barnes
}

\begin{abstract}
Previously named fossil mysticete species in the extinct genus Cetotheriopsis Brandt, 1871, are C. lintianus (von Meyer, 1849), from Austria, and C. tobieni Rothausen, 1971, from Germany, both of late Oligocene (lower Chattian) age. Although each species is known only by a single braincase without a rostrum, both have been understood to be baleen-bearing, archaic mysticetes of the extinct family Cetotheriidae. Fossil baleen whales of this age are generally rare worldwide, and no Oligocene cetotheriids have been named previously from the eastern coast of North America. Elsewhere, we have established the family Eomysticetidae to accommodate two very primitive new mysticetes from the late Oligocene Chandler Bridge Formation near Charleston, South Carolina (Sanders and Barnes, 1999, 2002). In addition, two mysticete braincases without rostra from the underlying Ashley Formation near Charleston represent a new genus and new species in the Cetotheriidae. These specimens document a new taxon that is markedly different from Cetotheriopsis and is herein named Micromysticetus rothauseni, new genus, new species It is most similar to Cetotheriopsis tobieni Rothausen, 1971, which is herein referred to the new genus Micromysticetus. Micromysticetus rothauseni is a significant addition to the diverse Oligocene marine vertebrate assemblages from the Oligocene beds near Charleston. It constitutes the oldest known western North Atlantic records of the family Cetotheriidae and provides additional evidence of the archaeocete ancestry of the mysticetes.
\end{abstract}

\section{Introduction}

Tertiary marine deposits of South Carolina have yielded important fossil cetacean remains since 1845, when Robert W. Gibbes described the archaeocete Dorudon serratus from Eocene beds in the vicinity of the Santee River. Subsequent

Albert E. Sanders, The Charleston Museum, 360 Meeting Street, Charleston, South Carolina 29403. Lawrence G. Barnes, Natural History Museum of Los Angeles County, 900 Exposition Boulevard, Los Angeles, California 90007. discoveries have included two odontocetes, Agorophius pygmaeus (Müller, 1849) and Xenorophus sloanii Kellogg (1923b), both of which are known from holotype specimens found in the late Oligocene (ca. $30 \mathrm{Ma}$ ) Ashley Formation. In recent years, studies emanating from The Charleston Museum (ChM) have revealed a previously unrecognized rock unit overlying the Ashley Formation. Named the Chandler Bridge Formation by Sanders et al. (1982), this unit is slightly younger than the Ashley Formation, is also of late Oligocene age (ca. 28 $\mathrm{Ma}$ ), and has yielded a wealth of cetacean material that is providing critical new information about the evolution and systematics of Oligocene whales of the western hemisphere (Whitmore and Sanders, 1976; Sanders, 1980; Sanders et al., 1982; Weems and Sanders, 1986; Sanders and Barnes, 1989, 1991, 1999, 2002; Barnes and Sanders, 1990).

With the exception of the toothed mysticetes of the genera Aetiocetus Emlong, 1966, and Chonecetus Russell, 1968, from the northwest coast of the United States, Oligocene-age mysticetes from the Northern Hemisphere were formerly known only from Europe. In 1975 the remains of a primitive, archaeocete-like baleen whale were found in the late Oligocene Chandler Bridge Formation near Charleston, South Carolina, and were excavated by the Charleston Museum (Sanders and Barnes, 1989, 1999, 2002; Barnes and Sanders, 1990). We now describe and name an additional mysticete from Oligocene deposits near Charleston, a preliminary report of the holotype (ChM PV4844) having been made by Sanders and Barnes (1991). A partial braincase (ChM PV5933) referable to this taxon also has been found, and both specimens are conserved in the Charleston Museum collections. The purpose of this study is to report this newly recognized whale from South Carolina and to comment on its taxonomic affinities. We recognize that the family Cetotheriidae and the subfamily Cetotheriopsinae are greatly in need of review and definition, but that task is beyond the scope of this paper. 


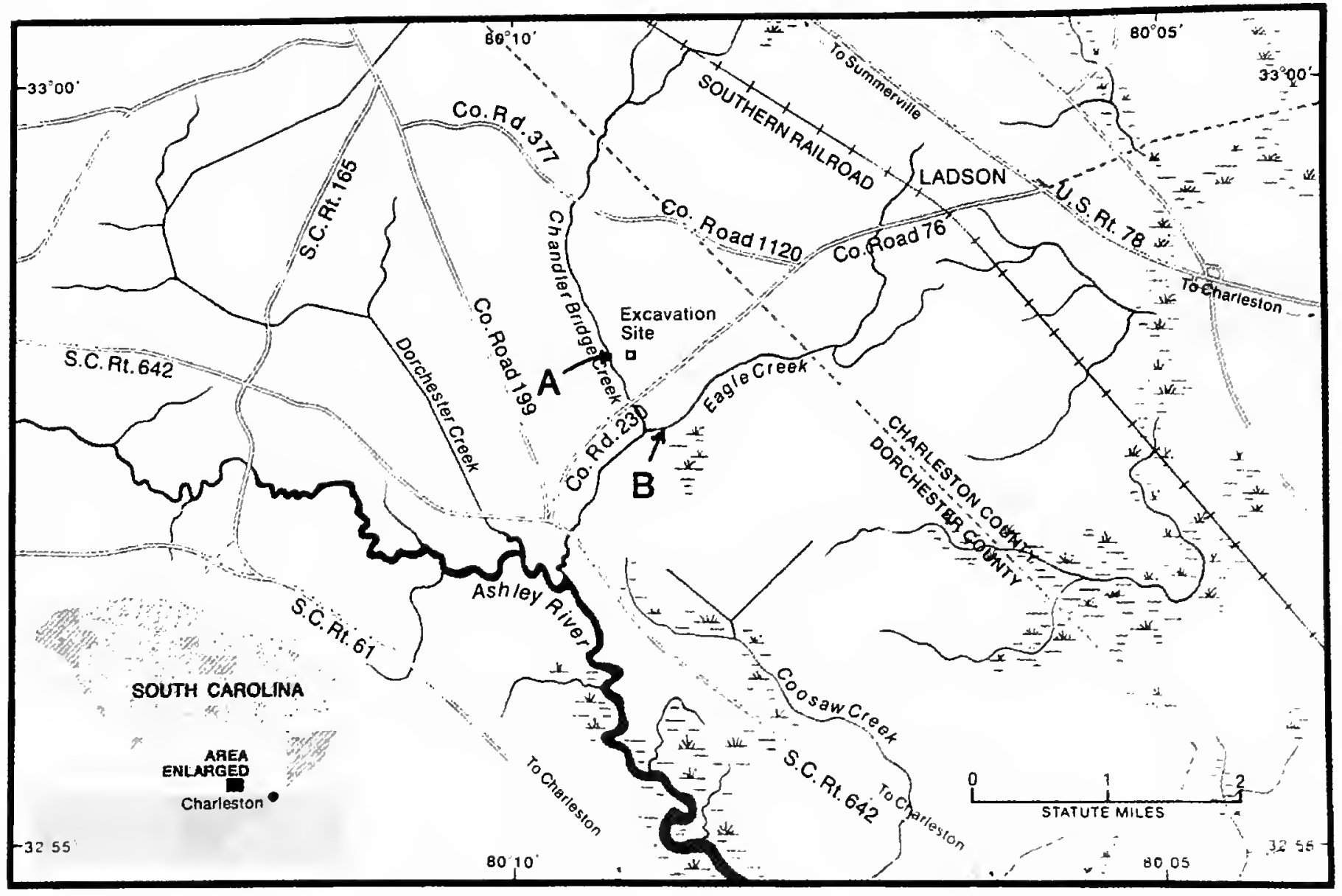

FIGURE I.-Map showing the localities for the holotype (A) and the paratype (B) of Micromysticetus rothauseni, new genus and new species, in Dorchester County, South Carolina, approximately 20 miles north of Charleston. (Base map from Sanders, 1980, courtesy of National Geographic Society.)

ACKNOWLEDGMENTS. - We appreciate this opportunity to recognize the contributions of our longtime friend and colleague Clayton Ray. For more than 25 years he has been ever helpful to us and, in his quiet, tactful manner, has often suggested an alternative answer to a question in such a way that one would wonder why that solution had not seemed evident in the first place. A thorough, meticulous worker, he also is one of the finest writers who has ever graced this profession, having the rare ability to transmit his findings with a lucidity that leaves little doubt about his interpretation of the data that he has presented. A veritable bulldog when in pursuit of an obscure or elusive subject, he leaves virtually no stone unturned until he either has found what he is seeking or is certain that it probably won't be found. One can truly say that if Clayton Ray has been over the ground, there probably isn't much left to find there. More importantly, he is a splendid human being, possessing many of the qualities that distinguished Joseph Leidy. We consider it a privilege to have known him and to have worked with him, for it is doubtful that we will see his like again in our lifetimes.

We thank Vance McCollum, the collector of the holotype of Micromysticetus rothauseni, and Billy Palmer, who collected the paratype, for their generosity in making these specimens available to science. We are especially grateful to Karlheinz Rothausen, now retired from the Institut für Geowissen-
schaften-Paläontologie, Johannes Gutenberg-Universität, Mainz, Germany, for the loan of his original drawings, photographs, and negatives of Micromysticetus (Cetotheriopsis) tobieni, for his review of our manuscript, and for many other favors. Bernhard Gruber of the Oberösterreichisches Landesmuseum in Linz, Austria, kindly permitted K. Rothausen and the first author to examine the holotype of Cetotheriopsis lintianus and other specimens in his care and made arrangements for the excellent photographs of the holotype of $C$. lintianus by the museum photographer Bernhard Ecker. Sanders extends thanks to the Deutsche Forschungsmeinschaft in Bonn, Germany, for financial assistance in a grant obtained by $\mathrm{K}$. Rothausen to cover lodging expenses incurred in the study of the European material involved in this study and in another study in which he and Rothausen are collaborating. The European segment of this study also was funded in part by a National Geographic Society grant to the first author in connection with his studies of other cetacean specimens at the Oberösterreichisches Landesmuseum in Linz. We also are grateful to the National Geographic Society for permission to use as the base map for our Figure 1 the map published as figure 1 in the first author's report of paleontological excavation activities carried out under the grants (numbers 954 and 1074) from the society (Sanders, 1980:603). 
The Charleston Museum and the Natural History Museum of Los Angeles County and its foundation provided facilities, salaries, and travel funds that made this study possible. AES produced the drawings. Bryan Stone produced all of the photographs except Figure 13C, made by Terry Richardson; Figures $11 \mathrm{~A}, \mathrm{~B}, 12 \mathrm{~A}-\mathrm{C}$, and 14, made by AES; and Figures 15-17, made by Bernhard Ecker. We thank David P. Whistler for comments on the manuscript and Zhexi Luo for his review of the text and figures of our description of the periotics of Micromysticetus rothauseni. Clayton E. Ray and Frank C. Whitmore, Jr., provided access to fossil cetacean material in the National $\mathrm{Mu}$ seum of Natural History and were helpful in numerous other ways.

\section{MATERIAL AND METHODS}

Terminology for cranial anatomy follows Kellogg (1938) and Fraser and Purves (1960). With some modifications required by the morphology of the specimens, cranial measurements follow Perrin (1975) and Kellogg $(1936,1965)$. The cranial reconstructions are in part mirror images of opposite sides of the specimens, and those of the two European taxa are based upon photographs of the holotypes and upon notes made from direct observations by Sanders. Broken lines represent areas of the skull not preserved in the actual specimen and thus are inferred or hypothetical configurations.

Geological interpretations of the rock units that yielded the holotype specimens are in accordance with the original description of the Chandler Bridge Formation (Sanders et al., 1982) and subsequent observations (Weems and Sanders, 1986).

Direct comparison of a cast of the holotype of Cetotheriopsis tobieni Rothausen, 1971, with the holotype of Cetotheriopsis lintianus (von Meyer, 1849) was made by K. Rothausen and one of us (AES) in July, 1992, and that material was compared with photographs of the holotype of the new taxon from South Carolina described in this paper. Where helpful, the fossils described herein have been compared with specimens of certain extant taxa.

ABBREVIATIONS.-The following abbreviations are used for institutions housing specimens used in this study:

\begin{tabular}{|c|c|}
\hline ChM & The Charleston Museum, Charleston, South Carolina \\
\hline FMNH & Field Museum of Natural History, Chicago, lllinois \\
\hline JGU & $\begin{array}{l}\text { Institut für Geowissenschaften-Paläontologie, Johannes Guten- } \\
\text { berg-Universität, Mainz, Germany }\end{array}$ \\
\hline LACM & $\begin{array}{l}\text { Natural History Museum of Los Angeles County, Los Angeles, } \\
\text { California }\end{array}$ \\
\hline UCMP & $\begin{array}{l}\text { University of California Museum of Paleontology, Berkeley, } \\
\text { California }\end{array}$ \\
\hline UO & University of Oregon, Eugene, Oregon \\
\hline USNM & $\begin{array}{l}\text { Collections of the National Museum of Natural History, Smith- } \\
\text { sonian Institution, Washington, D.C. (including the collections } \\
\text { of the former United States National Museum) }\end{array}$ \\
\hline
\end{tabular}

ABBREVIATIONS.-The following anatomical abbreviations are used in this study:

$\begin{array}{ll}\mathrm{Al} & \text { alisphenoid } \\ \mathrm{bc} & \text { basioccipital crest } \\ \mathrm{Boc} & \text { basioccipital } \\ \mathrm{Bs} & \text { basisphenoid } \\ \mathrm{ch} & \text { cranial hiatus } \\ \text { Eoc } & \text { exoccipital } \\ \mathrm{fm} & \text { foramen magnum } \\ \mathrm{fps} & \text { foramen pseudovale } \\ \mathrm{Fr} & \text { frontal bone } \\ \mathrm{gf} & \text { glenoid fossa } \\ \mathrm{hpt} & \text { hamular process of pterygoid } \\ \mathrm{jn} & \text { jugular notch } \\ \mathrm{Me} & \text { mesethmoid } \\ \mathrm{mea} & \text { external auditory meatus } \\ \mathrm{Na} & \text { nasal } \\ \mathrm{Oc} & \text { occipital condyle } \\ \mathrm{Pa} & \text { parietal } \\ \mathrm{Pal} & \text { palatine } \\ \mathrm{pgl} & \text { postglenoid process } \\ \mathrm{pop} & \text { paroccipital process } \\ \mathrm{Pt} & \text { pterygoid } \\ \mathrm{pts} & \text { fossa for pterygoid sinus } \\ \mathrm{Soc} & \text { supraoccipital } \\ \mathrm{Sq} & \text { squamosal } \\ \text { sqf } & \text { squamosal fossa } \\ \text { sqp } & \text { squamosal prominence } \\ \text { tf } & \text { temporal fossa } \\ \mathrm{Vo} & \text { vomer } \\ \mathrm{zps} & \text { zygomatic process of squamosal }\end{array}$

\section{Geologic SetTing}

Throughout the area near Charleston, the Chandler Bridge Formation is underlain by the Ashley Formation (Figure 2). Both formations are late Oligocene (early Chattian) marine units that are rich in fossil vertebrate material. The Chandler Bridge Formation was laid down approximately 28 million years ago (Sanders et al., 1982), and the Ashley Formation is considered to be about 30 million years old.

The holotype material of Micromysticetus rothauseni, new genus and new species (ChM PV4844), was found in the Ashley Formation at the bottom of a channelized stream only a few hundred feet west of the type locality of the Chandler Bridge Formation. The other specimen (ChM PV5933) was found relatively nearby, also in the Ashley Formation.

The uppermost portion of the Chandler Bridge Formation (Bed 3) is a beach facies from which a large number of marine vertebrate remains were recovered in a major excavation conducted by the Charleston Museum (Sanders, 1980). The site of that excavation is the type locality for the Chandler Bridge Formation and is $2.1 \mathrm{~km}$ southwest of the type locality of another Oligocene mysticete, the archaic Eomysticetus whitmorei Sanders and Barnes (2002).

The Chandler Bridge Formation unconformably overlies the late Oligocene Ashley Formation (ca. $30 \mathrm{Ma}$ ), a calcarenite that underlies the entire Charleston area. Together, these two formations have produced a comprehensive assemblage of Oligocene-age marine-associated vertebrates. Included are an extensive fish fauna; five taxa of sea turtles; a large crocodile, 


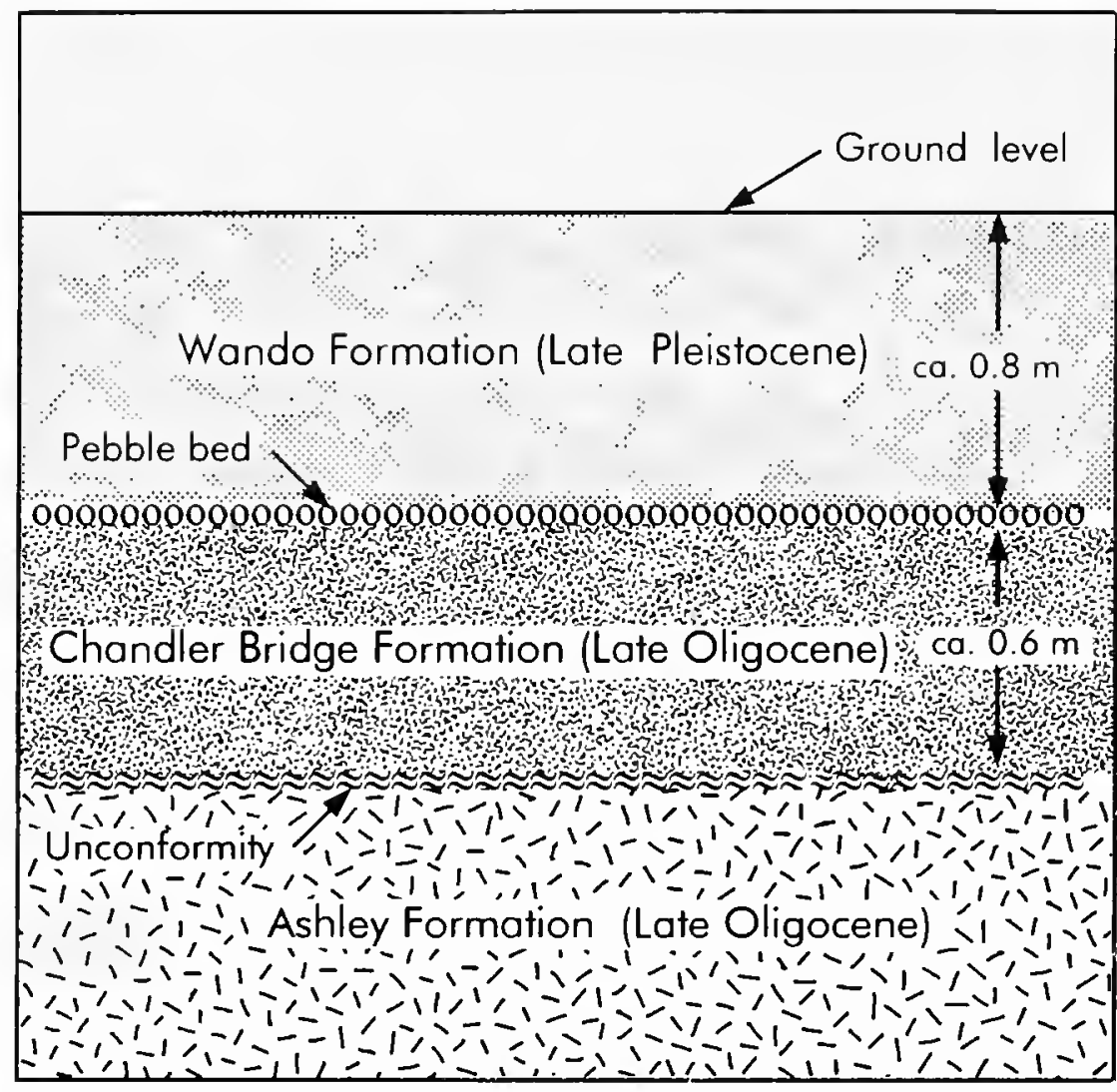

FIGURE 2.-Generalized stratigraphic section of late Oligocene (lower Chattian) beds along Chandler Bridge Creek and Eagle Creek near bridge on Ladson Road (County Road 230) in Dorchester County, South Carolina. Both the holotype and the paratype crania of Micromysticetus rothauseni, new genus and new species, were found in the Ashley Formation.

Gavialosuchus carolinensis Erickson and Sawyer (1996); several species of littoral and pelagic birds (including the largest and most nearly complete pseudodontorn yet found); at least two taxa of dugongids; and one of the largest and most diverse assemblages of cetacean remains yet recovered from any Oligocene deposit. Representatives of Mysticeti and Odontoceti have been found in the Chandler Bridge Formation, but squalodontoids and other primitive odontocetes are by far the most numerous, with mysticetes being relatively uncommon. To date, there has been no evidence of faunal assemblages or individual taxa that are positively restricted to either the Chandler Bridge or the Ashley Formation, although Micromysticetus rothauseni is presently known only from the Ashley. An early Chattian age for the Chandler Bridge Formation is indicated by the presence of undescribed squalodonts of the same evolutionary grade as Eosqualodon langewieschei Rothausen, 1968 (see Whitmore and Sanders, 1976; Sanders, 1980), which is from Eochattian sands (Chattian A) at Doberg, Germany. The Chattian A beds at Doberg have been referred to nannoplankton zone NP24 (Martini and Müller, 1975) and are considered to be of early Chattian age (Curry et al., 1978:46). A detailed appraisal of the age of the Chandler Bridge Formation is given by Sanders et al. (1982).

E. Martini (pers. comm., June 1990) examined nannoplankton from the underlying Ashley Formation at the type locality of the Chandler Bridge Formation and found the Ashley Formation to be referable to zone NP24. Because the same evolu- tionary grades and many of the same genera are represented among the cetaceans, sea turtles, and other vertebrate faunas of both the Ashley and the Chandler Bridge Formations, we consider that these two formations belong to the same biostratigraphic interval (NP24) and that very little time (perhaps only about $2 \mathrm{My}$ ) elapsed between the deposition of these two units.

\section{Systematic Paleontology}

Class Mammalia Linnaeus, 1758

Order Cetacea Brisson, 1762

Suborder MYSTICETI Flower, 1864

Superfamily BALAENOPTEROIDEA (Gray, 1868)

Family CetotheridDae (Brandt, 1872) Miller, 1923

Subfamily Cetotheriopsinae Brandt, 1872

\section{Micromysticetus, new genus}

Cetotheriopsis Brandt, 1871 [in part].-Rothausen, 1971:135.

DIAGNOSIS.-A genus of cetotheriopsine cetotheriids differing from Cetotheriopsis in the following characteristics: smaller size; cranium with an occipital shield shaped like a broad equilateral triangle, not an anteroposteriorly elongate triangle, medial crest on midline of occipital shield less prominent, squamosal fossa short anteroposteriorly, shallow, and interrupted by a protuberance-herein termed the squamosal prominence-extending posterolaterally to its posterior margin; exoccipital thick anteroposteriorly and narrow transversely; zygomatic process of squamosal elongate, deep, arched, and extending beyond apex of supraoccipital; glenoid fossa broad transversely with rounded posterointernal margin; basioccipital between basioccipital crests flat to slightly convex; sulcus for external acoustic meatus short and broad.

Adults with no prominent sulcus dorsal to occipital condyles on occipital shield,

ETYMOLOGY.-From mikros (Greek), small, and mystax (Greek), moustache, in reference to baleen; and from ketos (Greek), whale.

TYPE SPECIES.-Cetotheriopsis tobieni Rothausen, 1971.

INCLUDED SPECIES.-Micromysticetus tobieni (Rothausen, 1971) and Micromysticetus rothauseni, new species.

\section{Micromysticetus tobieni (Rothausen, 1971), new combination}

FIGURES 3-6

Cetotheriopsis tobieni Rothausen, 1971:135, figs. 2, 3, plates 1, 2.

EMENDED DIAGNOSIS.-A small species of Micromysticetus probably not exceeding $4.5 \mathrm{~m}$ in total length, differing from $M$. rothauseni, new species, by having large occipital condyles, occupying more than $45 \%$ of distance between outer margins 

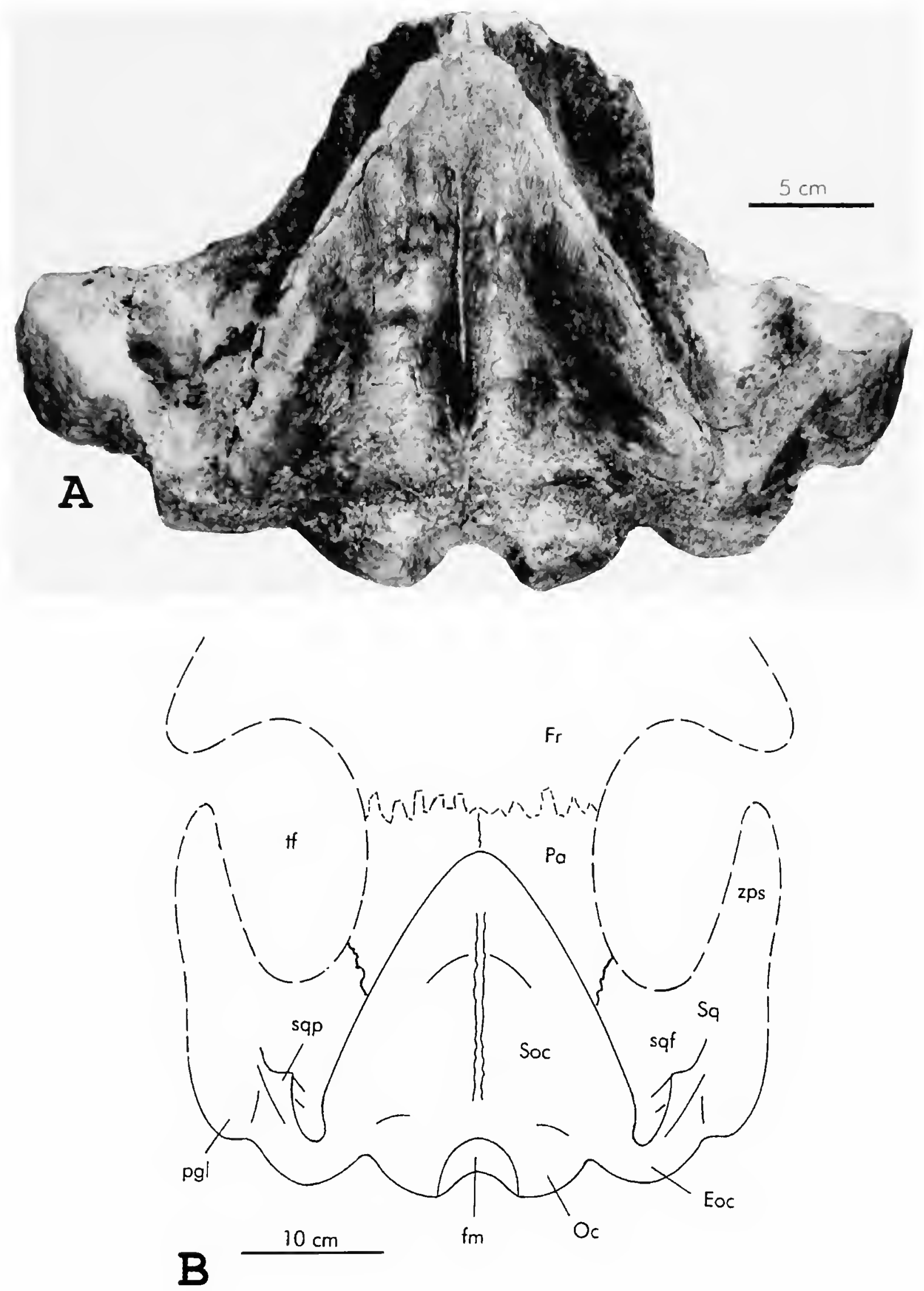

FIGURE 3.-Micromysticetus tobieni (Rothausen, 1971): A, holotype braincase (JGU P1289), dorsal view (from original photograph used in Rothausen 1971, table 1: fig. 1; courtesy of K. Rothausen); B, reconstruction. (Dashed lines indicate hypothetical configurations; abbreviations are explained in "Material and Methods.")

of exoccipitals. Lateral margins of supraoccipital almost straight in anterior two-thirds, then forming a slight angle in posterior portion; inner margins of basioccipital crests rounded and curving away from each other posteriorly, the space between them being slightly convex.
HOLOTYPE.-Partial braincase, JGU P1289, collection of Institut für Geowissenschaften-Paläontologie, Johannes Gutenberg-Universität, Mainz, Germany. Previously in the private collection of Fritz von der Hocht, Krefeld, Germany.

TYPE LOCALITY.-Kiesgrube Wilhelm Frangen, Lank-La- 

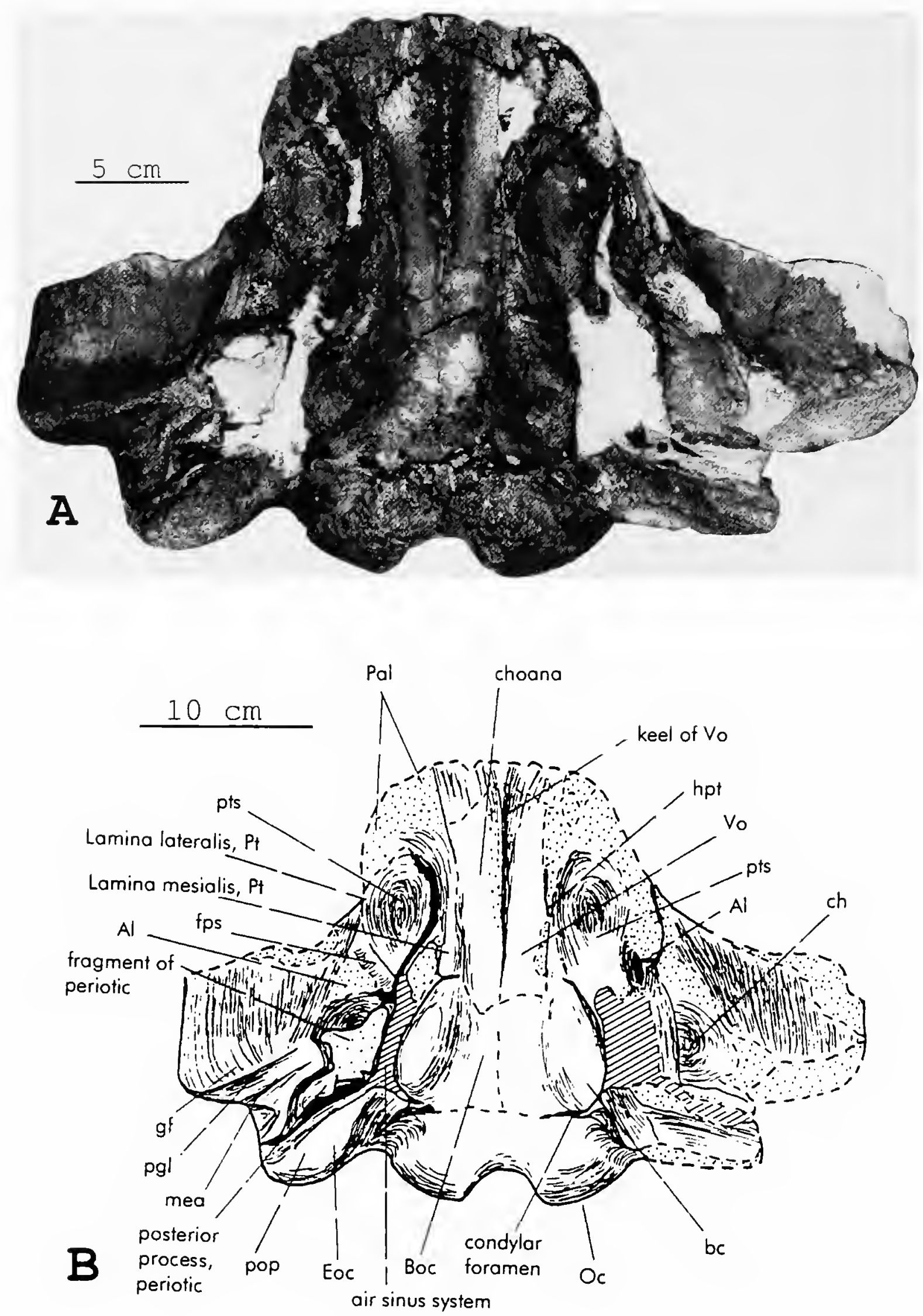

FIGURE 4.-Micromysticetus tobieni (Rothausen, 1971), holotype braincase (JGU P1289): A, posterior view (Rothausen 1971, table 1: fig. 3); B, left lateral view (Rothausen 1971, table 2: fig. 4). (From original photographs courtesy of K. Rothausen; abbreviations are explained in "Material and Methods.")

tum, WNW Dusseldorf-Kaiserwerth, Nordrhein-Westfalen, Germany.

FORMATION AND AGE.-Meeressande, upper "Chattian A" beds, nannoplankton zone NP24 (Martini and Müller, 1975), lower Chattian, late Oligocene.
REMARKS.-The holotype cranium of Micromysticetus tobieni lacks both of the zygomatic processes, but it seems apparent that had the anterior ends of those processes been preserved they would have extended beyond the anteriormost extent of the apex of the supraoccipital, as in M. rothauseni, new species, 

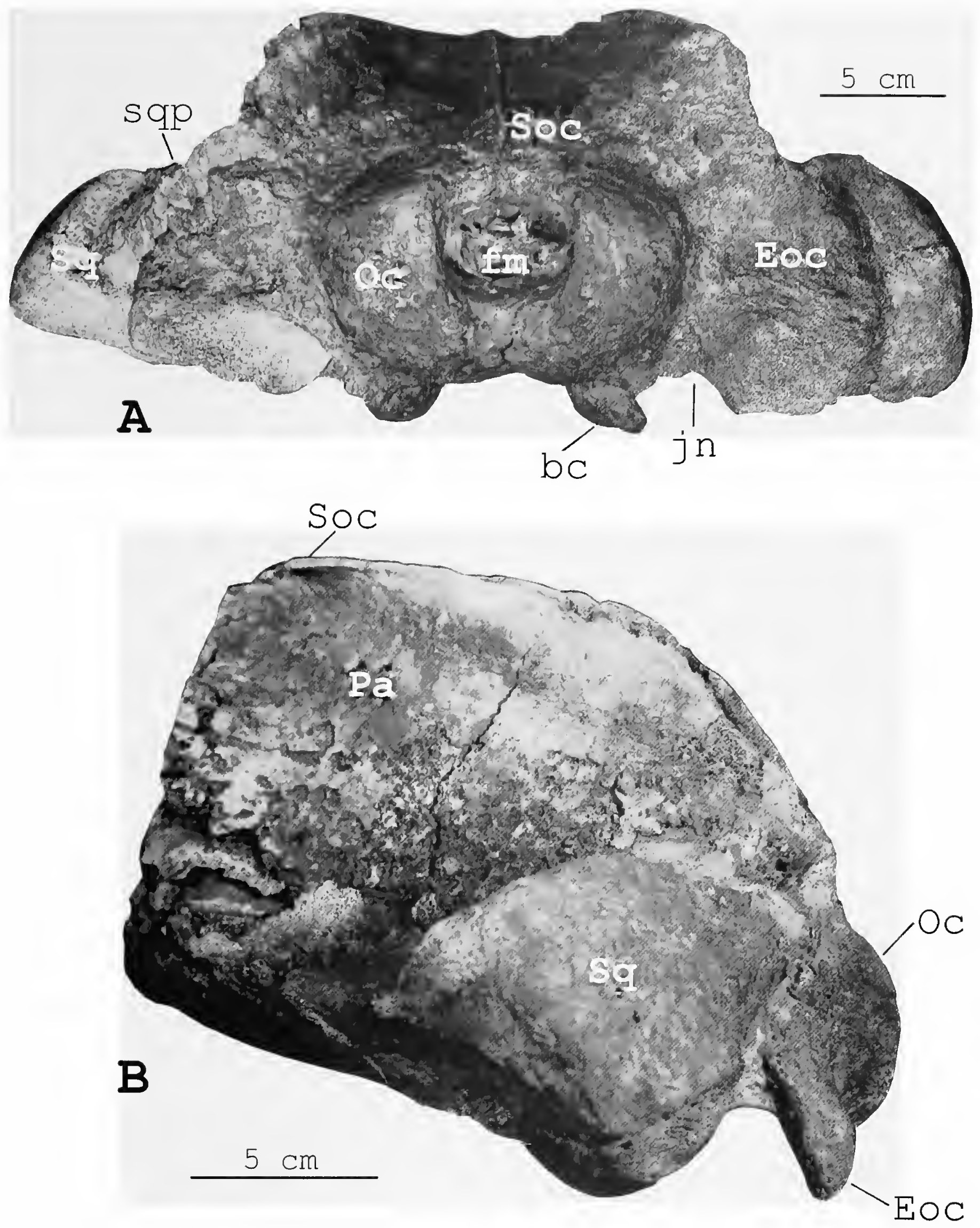

FIGURE 5.-Micromysticetus tobieni (Rothausen, 1971), holotype braincase (JGU P1289): A, posterior view (Rothausen 1971, table 1: fig. 3); B, left lateral view (Rothausen 1971, table 2: fig. 4). (From original photographs courtesy of K. Rothausen; abbreviations are explained in "Material and Methods.")

(Figures $3 \mathrm{~B}, 7$ ). The shape of the supraoccipital shield in the holotype is almost that of an equilateral triangle, the axes of the lateral margins intersecting the plane of the posterior margin of the occipital condyles at an angle of approximately $60^{\circ}$. The squamosal prominences are partly eroded but clearly evident and divide the floor of the squamosal fossa into two levels, as in $M$. rothauseni, new species, but not as conspicuously. The occipital condyles are quite large (Figure 8 ), occupying $46 \%$ of the space between the outer margins of the exoccipitals, but the condyles in $M$. rothauseni, new species, occupy a slightly 


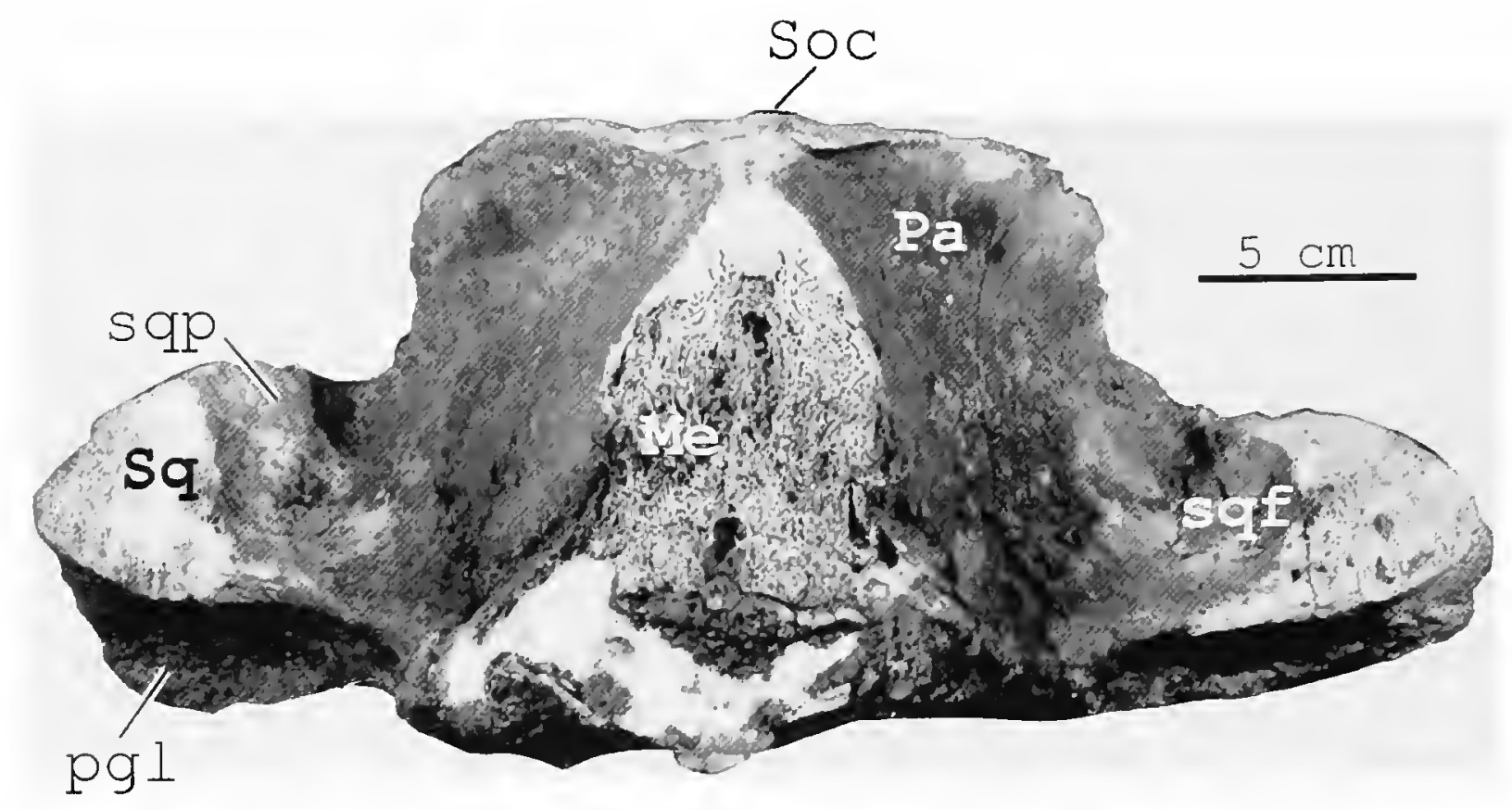

FIGURE 6.-Micromysticetus tobieni (Rothausen, 1971), holotype braincase (JGU P1289), anterior view. (Abbreviations are explained in "Material and Methods"; photograph courtesy of K. Rothausen.)

greater portion of the width of the exoccipital region $(48 \%$ in the holotype skull). Ventrally, the inner margin of the glenoid fossa bordering the cranial hiatus is more rounded than in $\mathrm{Ce}$ totheriopsis lintianus, in which the corresponding border is sharply angular (Figures 4, 16).

\section{Micromysticetus rothauseni, new species}

FIGURES $7-14$

Cetothere "possibly related to Cetotheriopsis."-Sanders and Barnes, 1991.

DIAGNOSIS.-A species of Micromysticetus differing from Micromysticetus tobieni in the following characteristics: cranium with more rounded posterior margin of squamosal fossa; median crest on supraoccipital not extending close to dorsal margin of foramen magnum; lateral margin of occipital shield more convex; exoccipital thicker anteroposteriorly and protruding more posteroventrally; basioccipital crests angular and not rounded as in $M$. tobieni, and with space between them flat and not convex.

HOLOTYPE.-ChM PV4844, braincase lacking the entire rostrum and the right zygomatic process of the squamosal; both periotics; and axis vertebra. Collected by Vance McCollum in March 1986.

TYPE LOCALITY.-South Carolina, Dorchester County; bottom of channelized bed of Chandler Bridge Creek in Hickory Hills housing development, $\sim 0.66 \mathrm{~km}(0.41 \mathrm{mi}$.) north of County Road 230 near S.C. Route 642, approximately $32 \mathrm{~km}$ (20 mi.) north of Charleston (Figure 1).

FormATION AND AGE.-Ashley Formation, late Oligocene, early Chattian correlative, nannoplankton zone NP 24, ca. 30 Ma. The skull and related specimens were found in the top of the Ashley Formation exposed in the streambed, approximately $30 \mathrm{~cm}$ below the contact with the overlying Chandler Bridge Formation, and only a few hundred meters west of the type locality of the Chandler Bridge Formation, marked as "Excavation Site" in Figure 1.

ETYMOLOGY.-The specific name is a patronym honoring Karlheinz Rothausen, in recognition of his many contributions to our knowledge of the Oligocene cetaceans of Europe.

PARATYPE.-ChM PV5933, partial braincase missing left side and most of basicranium. South Carolina, Dorchester County; bank of Eagle Creek, $\sim 152 \mathrm{~m}$ (500 ft.) northeast of confluence with Chandler Bridge Creek; County Road 230, $\sim 1.04 \mathrm{~km}(0.65 \mathrm{mi}$.) southwest of type locality of Micromysticetus rothauseni. Collected by Billy Palmer, November 1997.

DESCRIPTION.-Cranium: Although missing most of the zygomatic process of the right squamosal and a large section of the supraoccipital (Figure 7A), the holotype cranium of $\mathrm{Mi}$ cromysticetus rothauseni is well preserved otherwise, except where some of the dorsal surfaces have been eroded, especially along the lambdoidal crests and portions of the exoccipitals, occipital condyles, and zygomatic processes of the squamosals.

Micromysticetus rothauseni has a broad, triangular braincase; large and widely flaring zygomatic processes of the squamosals; and a narrow squamosal with a well-developed squamosal prominence (Figure 7). The parietals are joined at the midline and form the posterior portion of an intertemporal constriction with a narrowly rounded sagittal crest. This portion of the skull roof is preserved for a distance of $48 \mathrm{~mm}$ anterior to the apex of the supraoccipital and shows evidence of interdigitation with the frontals; thus, it is probable that most, if not all, of the parietal portion of the intertemporal region is preserved 

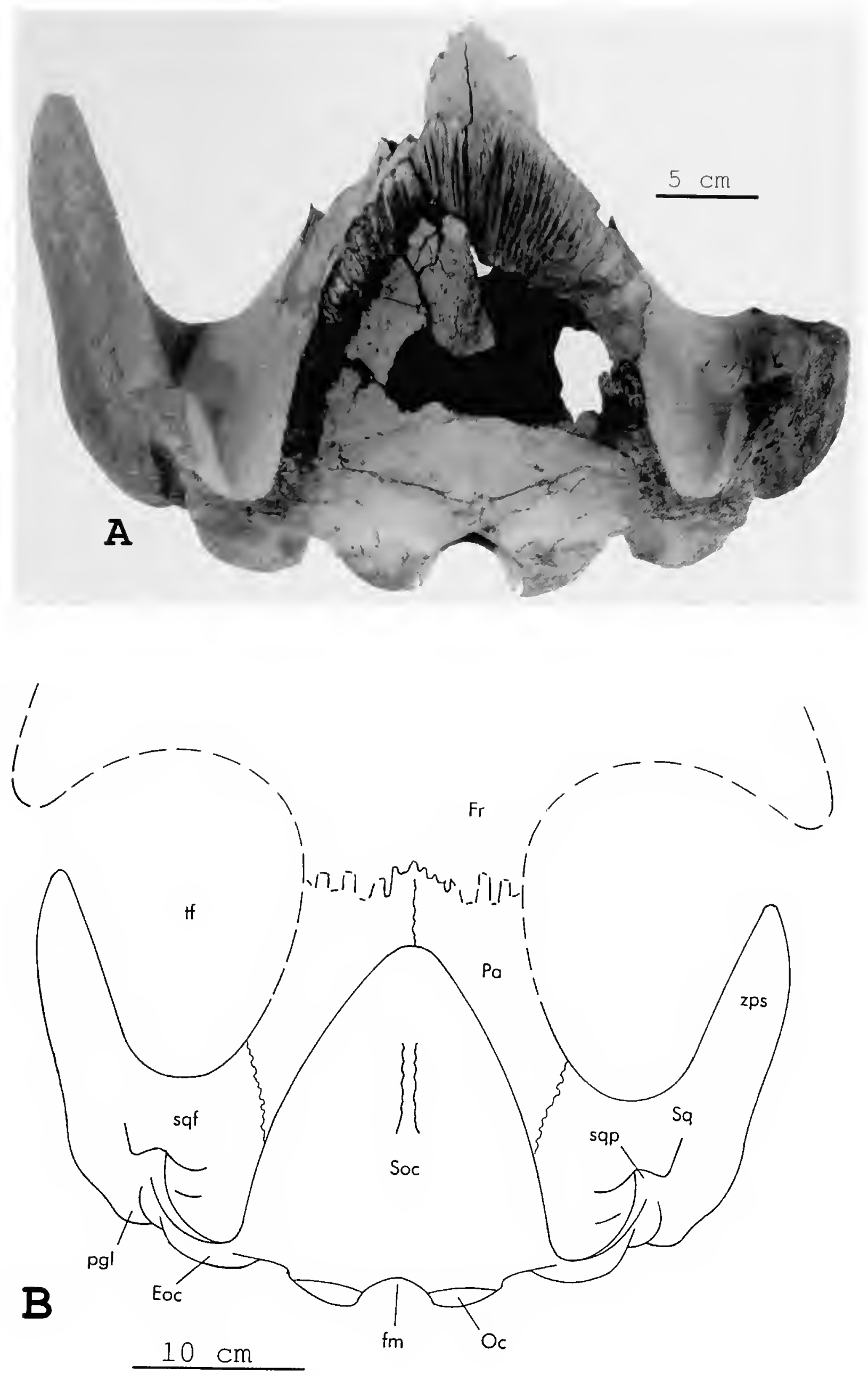

FIGURE 7.--Micromysticetus rothauseni, new genus and new species: A, holotype braincase, ChM PV4844, dorsal view; B, reconstruction. (Dashed lines indicate hypothetical configurations; abbreviations are explained in "Material and Methods.") 

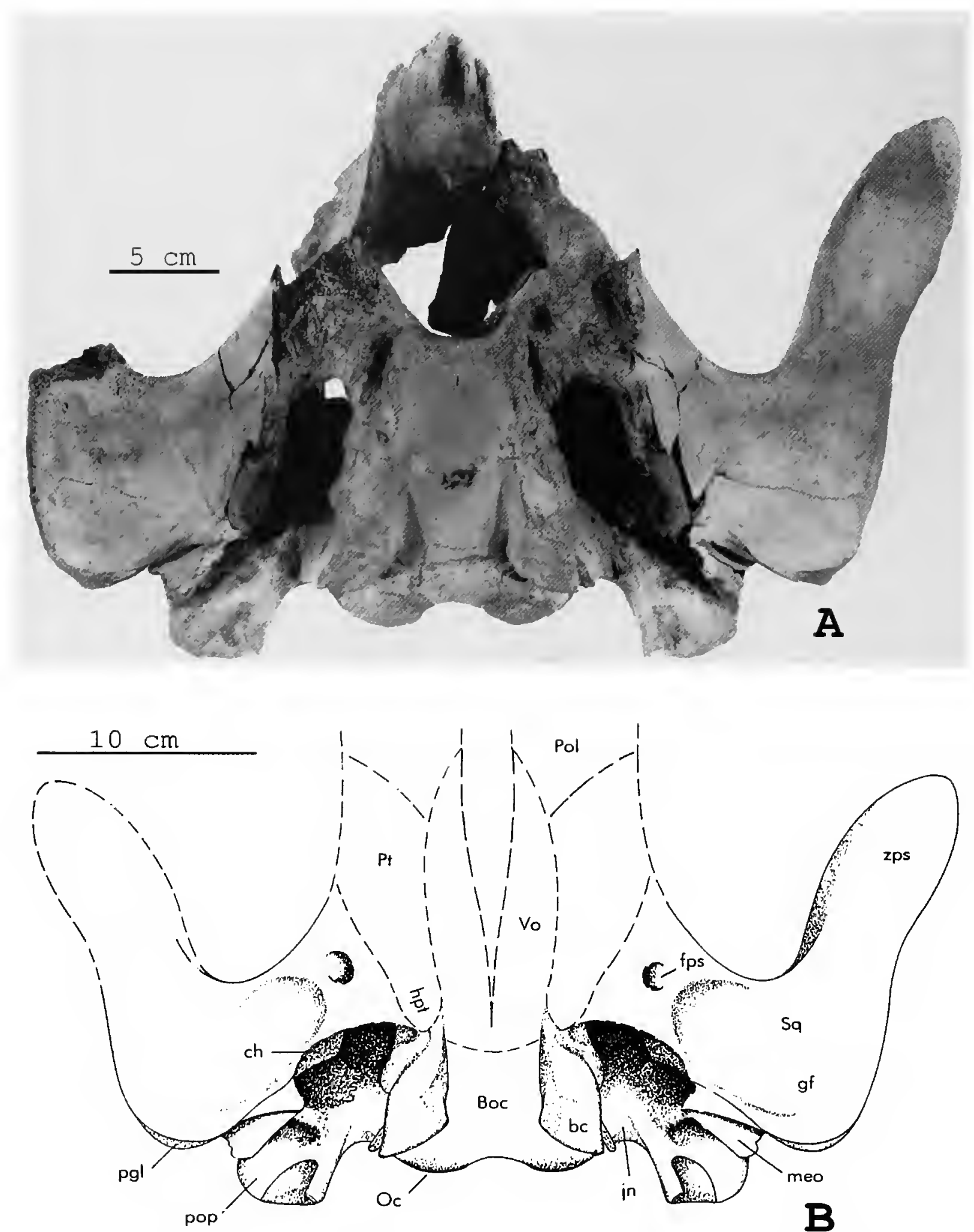

FIGURE 8.-Micromysticetus rothauseni, new genus and new species: A, holotype braincase, ChM PV 4844, ventral view; B, reconstruction. (Dashed lines indicate hypothetical configurations; abbreviations are explained in "Material and Methods.")

in the holotype. Details of that region anterior to the parietals are not known, but it seems likely that the frontals would have continued the constriction anteriorly for approximately the same distance as the length of the parietal portion. A moderately long, narrow, intertemporal region in the skull of this animal would have been necessary for the postorbital process of the frontal to clear the anterior tip of the zygoma.

The occipital shield is triangular and relatively broad and is slightly concave anterior to the foramen magnum and medial to the nuchal crest. Dorsal to the occipital condyles the surface of the occipital shield is flat to convex. The lateral and apical mar- gins of the supraoccipital are missing entirely, but the squamosal and parietal rims of the lambdoidal crests provide the outline of its original form. Laterally, they flare outward and overhang the temporal fossa. The axis of the left lambdoidal crest departs the plane of the posterior margins of the occipital condyles at an angle of approximately $75^{\circ}$ (at first nearly $90^{\circ}$ in M. tobieni, then bending anteriorly at an angle of about $60^{\circ}$ ). Anterodorsally, the margins of the lambdoidal crests curve inward toward the apex of the supraoccipital. In M. rothauseni, therefore, the margins of the supraoccipital are noticeably convex as they approach the apical region, whereas in $M$. tobieni 


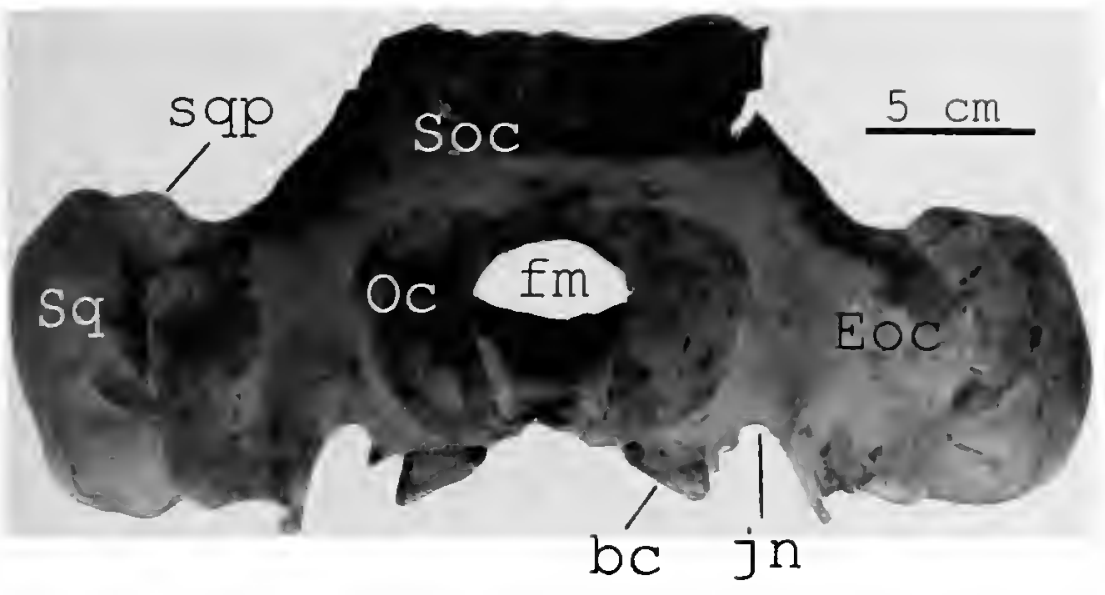

FIGURE 9.-Micromysticetus rothauseni, new genus and new species, holotype braincase, ChM PV 4844, posterior view. (Abbreviations are explained in "Material and Methods.")

the marginal curvature is more subtle and much less noticeable. Dorsally, there is a medial crest that extends posteriorly from the apical portion of the supraoccipital for about one-half the distance to the dorsal margin of the foramen magnum. In M.tobieni there is a similar crest that extends posteriorly for approximately three-fourths of the distance to the foramen magnum.

The occipital condyles are very large for a skull of such modest dimensions and are exceptionally broad transversely, occupying $48 \%$ of the distance $(256.6 \mathrm{~mm})$ between the outer margins of the exoccipitals. Despite their massive size, the condyles do not protrude prominently from the occipital shield. The plane of the dorsalmost margins of the condyles is on a level with the posterior margin of the floors of the squamosal fossae. In certain areas where they are least eroded, the articular surfaces of the condyles are punctate, suggesting that the specimen does not represent a fully mature individual. Although there is considerable variation in the amount of hori- zontal space taken up by the condyles in other species of cetotheres, that variation does not appear to be entirely a function of individual body size. In the holotype skull of the middle Miocene cetothere Cophocetus oregonensis Packard and Kellogg, 1934 (UO 305), the condyles occupy a mere $28 \%$ of the exoccipital region, although the anteroposterior length $(1.2 \mathrm{~m})$ of this specimen is only one-half the length $(2.5 \mathrm{~m})$ of the holotype skull (LACM 882) of the late Miocene cetotheriid Mixocetus elysius Kellogg, 1934a, in which the condyles occupy $34 \%$ of the exoccipital region. In the smallest known mysticete, represented by a partial cranium (UCMP 26502) from the late Miocene Towsley Formation (Barnes, 1977:329) of California and described as Nannocetus eremus by Kellogg (1929), who considered it to be a small cetothere, the condyles take up $49 \%$ of the distance between the outer margins of the exoccipitals (182 mm). In the considerably larger form M. rothauseni, however, they compose $48 \%$ of that distance $(256.6 \mathrm{~mm})$, nearly the same as in Nannocetus. It thus appears again that larger species do not necessarily have significantly smaller condyles than more diminutive taxa. There may be some ontogenetic variation in the size of the condyles relative to the transverse diameter of the exoccipital region, as suggested by the paratype of $M$. rothauseni (ChM PV5933), in which the condyles occupy $50 \%$ of the space between the exoccipital margins. That specimen is decidedly a much younger individual than the holotype. Nevertheless, the exceptionally large condyles of $M$. rothauseni seem to stand alone in comparison with other known cetotheres except Nannocetus and thus may be tentatively regarded as diagnostic for this species until proven otherwise by additional material. The condyles of $M$. tobieni also are comparatively large ( $46 \%$ of the width of the exoccipital region), which suggests that large condyles may in fact be characteristic of the genus Micromysticetus. Even if an allowance is made for allometric considerations, the condyles of these two
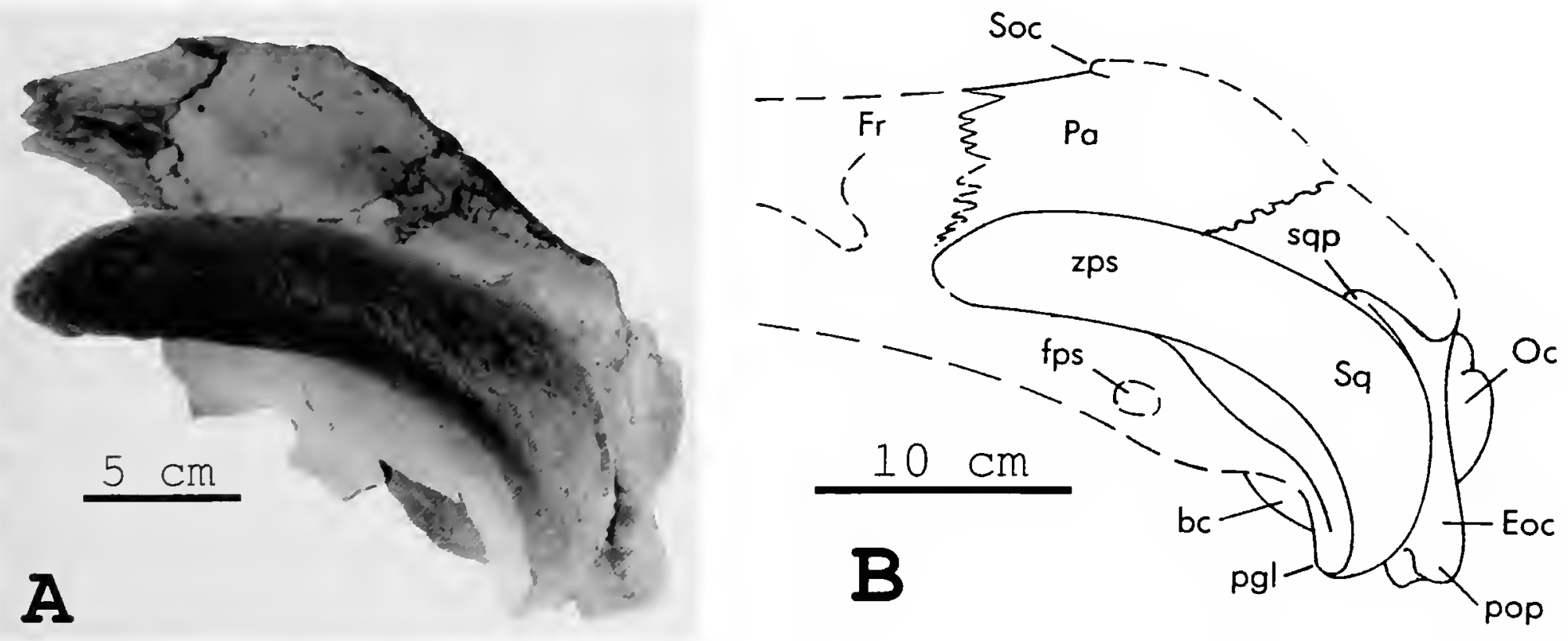

FIGURE 10.-Micromysticetus rothauseni, new genus and new species: A, holotype braincase, ChM PV4844, left lateral view; B, reconstruction. (Dashed lines indicate hypothetical configurations; abbreviations are explained in "Material and Methods.") 

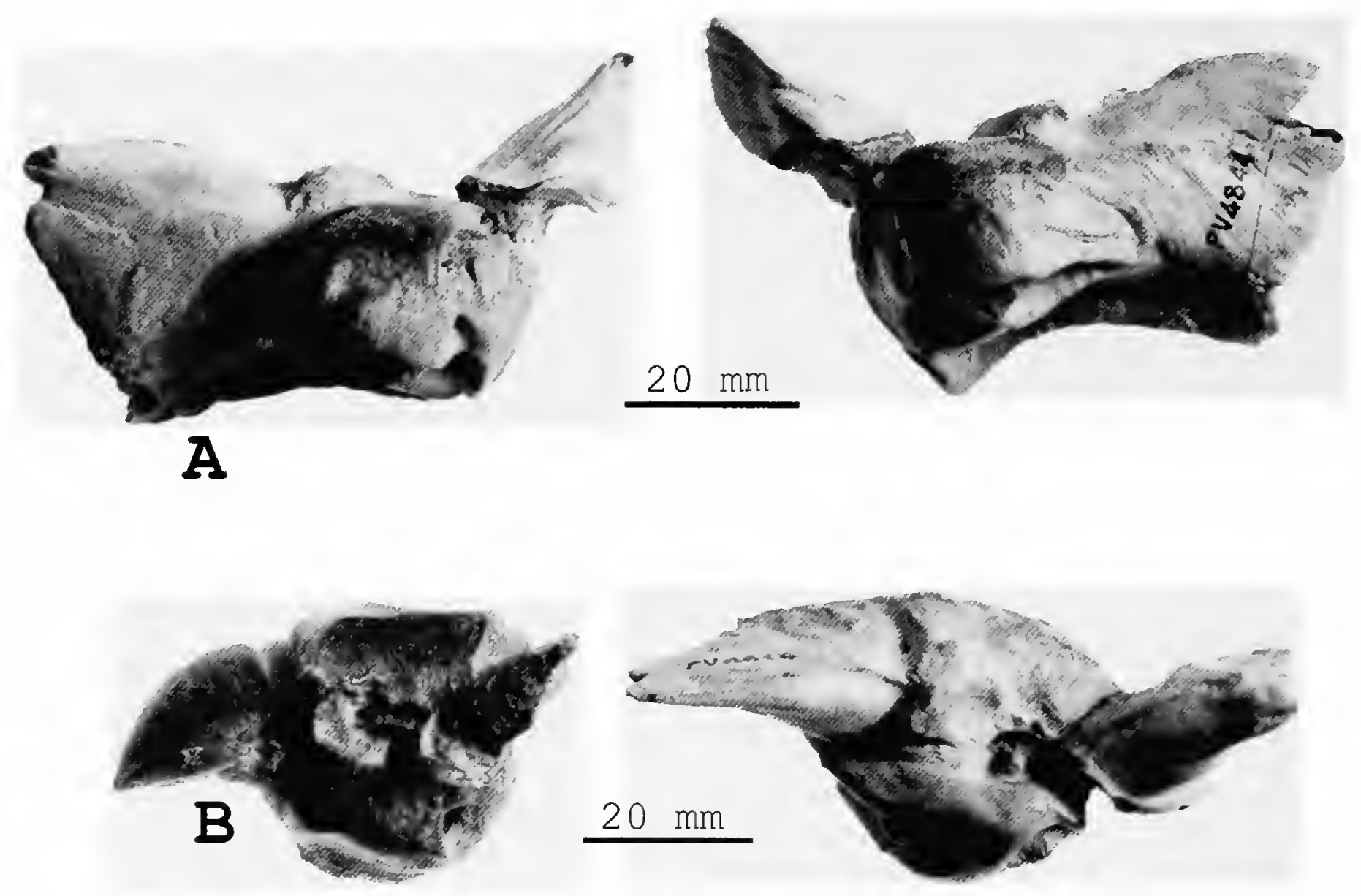

FIGURE 11.-A, Micromysticetus rothauseni, new genus and new species, holotype right and left periotics, ChM PV4844; B, left periotic of the archaeocete Zygorhiza kochii (ChM PV5065) (missing posterior process) from the late Eocene Harleyville Formation in Dorchester County, South Carolina (left), and the holotype left periotic of Micromysticetus rothauseni, new genus and new species (right).

taxa still are proportionately larger than those of most of the other cetotheres noted above.

Lateral to the condyle, the surface of each exoccipital is not concave as in Cetotheriopsis lintianus. The exoccipital portion of the occipital shield is thick, as is typical of most fossil and extant baleen whales. In its ventral part, however, the paroccipital process is exceptionally thick, and it extends posteroventrally.

Between the braincase and the zygomatic process, the squamosal fossa is shallow, anteroposteriorly short, and wide. Arising from the center of the floor of the squamosal fossa there is a knobby protuberance that we formally term the "squamosal prominence" (sqp). This prominence forms a scarp-like ridge that divides the floor of the squamosal fossa into two levels, the posterior level being elevated approximately $15 \mathrm{~mm}$ above the anterior level. Anteriorly from the anterior margin of the prominence, the floor of the fossa forms a narrow gutter that slopes ventrally to the anterior margin of the squamosal. The posterior level of the fossa is on a plane approximately parallel to the sagittal plane of the skull. A modified extension of the lambdoidal crest, the squamosal prominence is joined to the posterior part of the zygomatic process of the squamosal. The lateral wall of the braincase is nearly vertically oriented and slightly concave near its middle. It is not bowed laterally as is typical of most balaenopterids.

The zygomatic process of the squamosal is elongate, is very large relative to the size of the cranium, and diverges anterolaterally from the midline of the cranium. It arches anterodorsally in a broad curve and bends ventrally at its anterior extremity. The process is thick dorsoventrally and is of uniform thickness for most of its length, terminating in a rounded point anteriorly. The medial surface is uniformly smooth. The lateral surface is uniformly bowed outward, making its lateral side smoothly convex, and it flares slightly ventrolaterally at the ventral margin, especially so at the posterior end of the process, which is rounded dorsally and flattened ventrally to receive the posterior end of the jugal. The zygomatic process of the squamosal is slightly expanded dorsoventrally at its posterior end and arches slightly anteroposteriorly to create the large, anterodorsally inclined glenoid fossa.

At the posterior end of the lateral surface of the zygomatic process is a prominent, vertically oriented sternomastoid fossa. This fossa is inclined anterodorsally and is located immediately dorsal to the large paroccipital process. The latter is thick anteroposteriorly, is narrow transversely, and projects prominently ventrally and posteriorly from the occipital shield. 

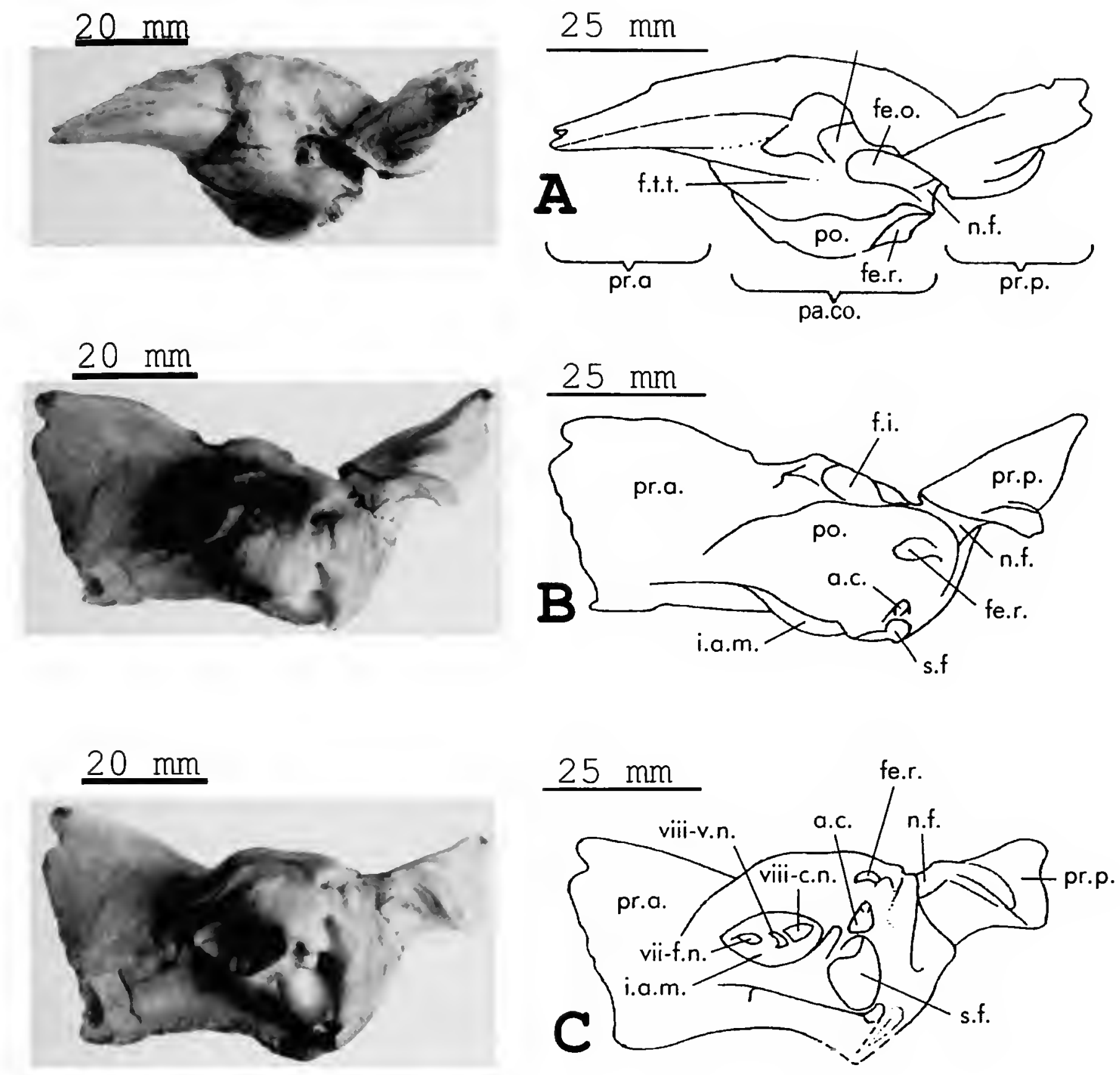

FIGURE 12.-Micromysticetus rothauseni, new genus and new species, holotype left periotic, ChM PV4844: A, ventral view; $B$, cerebral view; $C$, dorsolateral view. (Abbreviations: a.c.=aqueductus cochlearis; $c . n .=$ foramen for cochlear nerve; f.i.= fossa incudis; $f . n .=$ foramen for facial nerve; fe.o. $=$ fenestra ovalis; fe.r. $=$ fenestra rotunda; f.t.t. $=$ fossa for tensor tympani muscle; i.a.m.= internal auditory meatus; n.f. =notch for exit of facial nerve; pa. co. $=$ pars cochlearis; po $=$ promontorium; pr.a. $=$ anterior process; pr.p. $=$ posterior process; s.f. $=$ subarcuate fossa; v.n. =foramen for vestibular nerve.)
The recess for the external auditory meatus is deep, but short transversely and broad anteroposteriorly and is clearly defined between the postglenoid process of the squamosal and the paroccipital process.

The cranial hiatus, the recess between the squamosal and the basioccipital in which the periotic lies, is large and elongated anteroposteriorly. Anterolateral to the cranial hiatus and immediately posterior to the large, obliquely oriented foramen pseudovale is the falciform process. This process is thick and is connected to the postglenoid process of the squamosal by a very slender and low, transverse crest of bone. This crest marks the lateral border of a large pterygoid sinus extending anteriorly from the cranial hiatus. The ventral surface of the basioccipital is nearly flat. The basioccipital crests are broad, rectangular, and flattened ventrally, their inner margins paralleling the midline axis of the skull before breaking into divergent angles that terminate in narrow, rounded points posteriorly (Figure 7). As depicted by Rothausen (1971:137, pl. 3: fig. 5), the basioccipital crests (Alae Basioccipitalis in Rothausen, 1971) of Micromysticetus tobieni are rounded and knob-like, their inner margins curving away from each other posteriorly.

The glenoid fossa is broad transversely, with a nearly square articular surface, which is poorly delimited anteriorly. The innermost margin bordering the cranial hiatus is rounded, as in Micromysticetus tobieni. The postglenoid process is canted posterolaterally and is thickest laterally, where its ventral margin is convex, then becomes thinner medially, where it terminates at the margin of the pterygoid sinus.

Periotics: The holotype left and right periotics of Micromysticetus rothauseni (ChM PV4844) are well preserved (Figures 11,12 ). The left periotic is missing only the dorsalmost extension of the superior process, which is present in the right periotic and has been utilized in the reconstruction of the left one (Figure 12). The right one is chipped in several places. From the anteriormost point on the anterior process to the posteriormost point on the posterior process, the left periotic is 73 $\mathrm{mm}$ in length. The pars cochlearis is $28 \mathrm{~mm}$ in dorsoventral diameter, $36 \mathrm{~mm}$ anteroposteriorly, and $34 \mathrm{~mm}$ in transverse diameter. Its external face is strongly rugose. Immediately adja- 
cent to the dorsal end of the subarcuate fossa is a much smaller fossa that is reduced to a tiny pit in the right periotic; otherwise, these two bones are mirror images of each other and their measurements do not differ significantly. The anterior process is short, laterally compressed, and broadly expanded dorsoventrally. The posterior process also is short and is much smaller than both the anterior process and the pars cochlearis, quite unlike the periotics of most Miocene cetotheres, in which the posterior process is massive and greatly extended posteriorly (Kellogg, 1934a,b 1965, 1968a,b, 1969; Packard and Kellogg, 1934). The periotic of $M$. rothauseni bears little resemblance to those of Miocene cetotheres, and in ventral aspect it is most similar to the periotic of the late Eocene archaeocete Zygorhiza kochii (Reichenbach, 1847) as figured by Kellogg (1936:116, fig. 35a) and as seen in ChM PV5065, a left periotic of $Z y$ gorhiza (missing the posterior process) from Eocene beds in the Giant Portland Cement quarry near Harleyville, Dorchester County, South Carolina (Figure 11B). The anterior process of the periotic is more laterally compressed in Micromysticetus than in Zygorhiza and the posterior process is much smaller than in the latter (Kellogg, 1936:116, fig. 35a), but the relative positions of the fossa for the tensor tympani muscle, the fenestra ovalis, the fenestra rotunda, the canal for the facial nerve, the fossa incudis, and the subarcuate fossa are much the same in PV4844 and PV5065. In cerebral (internal) aspect, the anterior process is hatchet-shaped, like that of Zygorhiza, and in the left periotic it is $38.8 \mathrm{~mm}$ in dorsoventral diameter. The posterior process is small and narrow, measuring only $15.5 \mathrm{~mm}$ dorsoventrally. The great disparity in the size of these processes is exactly the opposite of their dimensions in most Miocene cetotheres, in which the anterior process has been drastically reduced and the posterior process greatly expanded.

Axis Vertebra: The holotype axis vertebra of Micromysticetus rothauseni (ChM PV4844, Figure 13, Table 1) is essentially complete, with only minor erosion of certain surfaces. Like the periotic, the axis vertebra most closely resembles its counterpart in the archaeocete Zygorhiza kochii, as figured by Kellogg (1936:133, fig. 41) from USNM 4679. The transverse processes are extremely short and, like those of the axis in $Z$. kochii, are "directed more backward than forward" (Kellogg 1936:132). They are extremely narrow anteroposteriorly and thus lack the vertebrarterial canal present in the axis of $Z y$ gorhiza. The anterior face of the axis slopes upward and posteriorly at a very slight angle. The anterior facets for articulation with the atlas vertebra are flat along their outer portions but curve upward onto the odontoid process. They are separated above the odontoid process by an interval of approximately 40 $\mathrm{mm}$. The odontoid process is broadly rounded ventrolaterally and slopes upward from the centrum to its anteriormost extent, where it abruptly assumes a vertical face $16.5 \mathrm{~mm}$ in width that ascends to the level of the dorsal surface of the centrum. On either side of the narrow rectangular vertical face there is a curvilinear excavation extending laterally to the inner margin of the articulating facets. In the upper inner corner of this excavation there is a declivity that notches out the area directly behind the anterior face. Both the dorsal surface of the centrum and the roof of the neural canal slope upward and backward. The neural canal is circular in profile, and in vertical diameter it is $35.3 \mathrm{~mm}$ anteriorly and $36.7 \mathrm{~mm}$ posteriorly. The posterior face of the centrum is $74.5 \mathrm{~mm}$ in transverse diameter and 60.6 $\mathrm{mm}$ in vertical diameter and is slightly concave. The epiphysis is well ankylosed to the centrum, but its outer margins have not yet reached the outer margins of the centrum. On the ventral face of the centrum there is a rectangular, tab-like prominence measuring $29.2 \mathrm{~mm}$ transversely and $22.4 \mathrm{~mm}$ anteroposteriorly. The neural spine is short, low, and conspicuously thickened at its base, which is anteroposteriorly elongated so that it overhangs the odontoid process, as in Zygorhiza kochii (Kellogg, 1936:133, fig. 41b). Its posterior face is vertically inclined, does not extend beyond the posterior face of the centrum, and bears a medial carina. Dorsally, the neural spine is divided medially by a sulcus that is narrow anteriorly but becomes increasingly wider and deeper posteriorly until it has divided the posteriormost portion of the dorsal surface of the spine into two low, knob-like prominences. The pedicles of the neural arch are thinnest anterolaterally and are flattened posteriorly below the postzygapophyses, which are inclined obliquely upward and have circular ventral postzygapophysial facets. The punctate surfaces of the anterior articular facets and the failure of the epiphysis to reach the margins of the posterior face indicate that this specimen was not a mature individual.

PARATYPE.-The paratype partial cranium (ChM PV5933, Figure 14) is missing virtually the entire left side except the condyle and upper portion of the parietal and the anterior margin of the supraoccipital. All of the basioccipital is missing except for the badly eroded remnant of the right basioccipital crest and the posterior portion of the pterygoid.

This specimen duplicates all of the characters of the holotype except in one regard. Approximately $37 \mathrm{~mm}$ anterior to the dorsal margin of the foramen magnum, a small sulcus about $5 \mathrm{~mm}$ in transverse diameter begins to traverse the surface of the supraoccipital posteriorly along the midline until it reaches a foramen that penetrates the occipital shield about $13 \mathrm{~mm}$ anterior to the dorsal edge of the foramen magnum. This feature is completely absent in the holotype braincase (obviously that of an older individual); the only trace of it is a small, shallow, almost unnoticeable depression at the midline.

DISCUSSION.-The archaeocete-like periotic and axis vertebra of Micromysticetus rothauseni suggest that it and M. tobieni are more primitive than the preserved elements of their cranial architecture might indicate. As previously noted, the length of the preserved portion of the intertemporal region in $M$. rothauseni is almost certainly only half of its original 


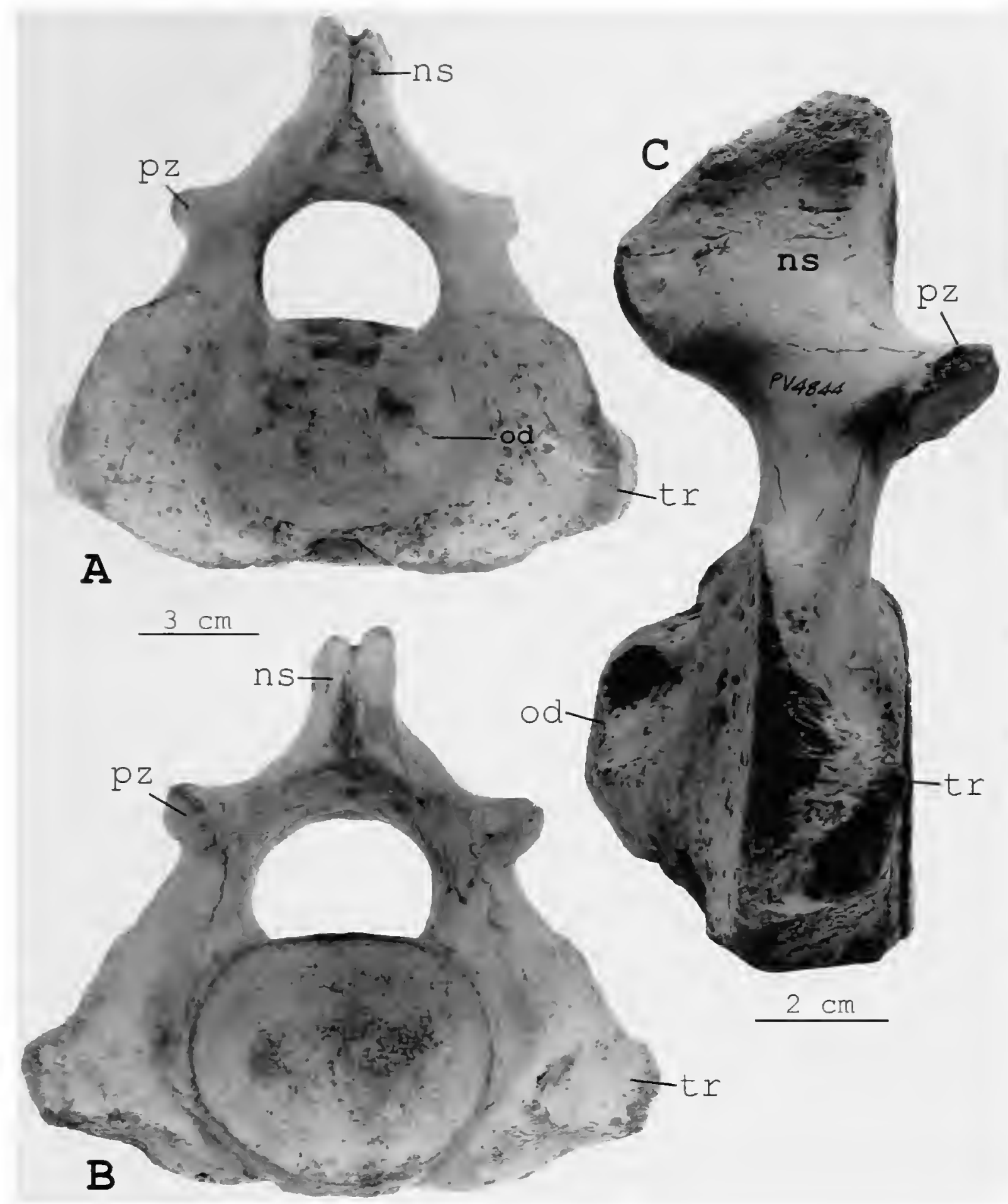

FIGURE 13.-Micromysticetus rothauseni, new genus and new species, holotype axis vertebra, ChM PV4844: A, left lateral view; B, anterior view; C, posterior view. (Abbreviations: ns.=neural spine; od.=odontoid process; pz.=postzygapophysis; $t \mathrm{t} .=$ transverse process.)

length, estimated to be approximately $95 \mathrm{~mm}$, and it seems probable that $M$. tobieni had an intertemporal constriction of similar length proportionate to its size. An intertemporal region of even greater proportionate length is present in the primitive Oligocene baleen whale family Eomysticetidae (Sanders and Barnes, 2002), a group that firmly establishes Archaeoceti as ancestors of Mysticeti. The striking similarities between the periotic and axis vertebra of $M$. rothauseni and those of $Z y$ gorhiza kochii provide additional evidence of archaeocetemysticete relationships and argue strongly in favor of a dorudontine archaeocete ancestry of the Mysticeti.
TABLE 1.-Measurements (in mm) of the holotype axis vertebra of Micromysticetus rothauseni, new genus and new species (ChM PV4844), from the late Oligocene of South Carolina. $\left({ }^{*}=\right.$ measurement is an estimate).

\begin{tabular}{l|r}
\hline Anteroposterior diameter of centrum & $49 *$ \\
Transverse diameter of centrum, anteriorly & 132 \\
Vertical diameter of centrum, anteriorly & 66 \\
Tip of neural spine to ventral face of centrum, anteriorly & 134 \\
Greatest vertical diameter of neural canal, anteriorly & 35 \\
Greatest transverse diameter of neural canal, anteriorly & 42 \\
Greatest distance between outer margins of transverse processes & 147 \\
Least anteroposterior diameter of right pedicle of neural arch & 13 \\
Greatest transverse diameter of centrum, posteriorly & 76 \\
Greatest vertical diameter of centrum, posteriorly & 59 \\
\hline
\end{tabular}



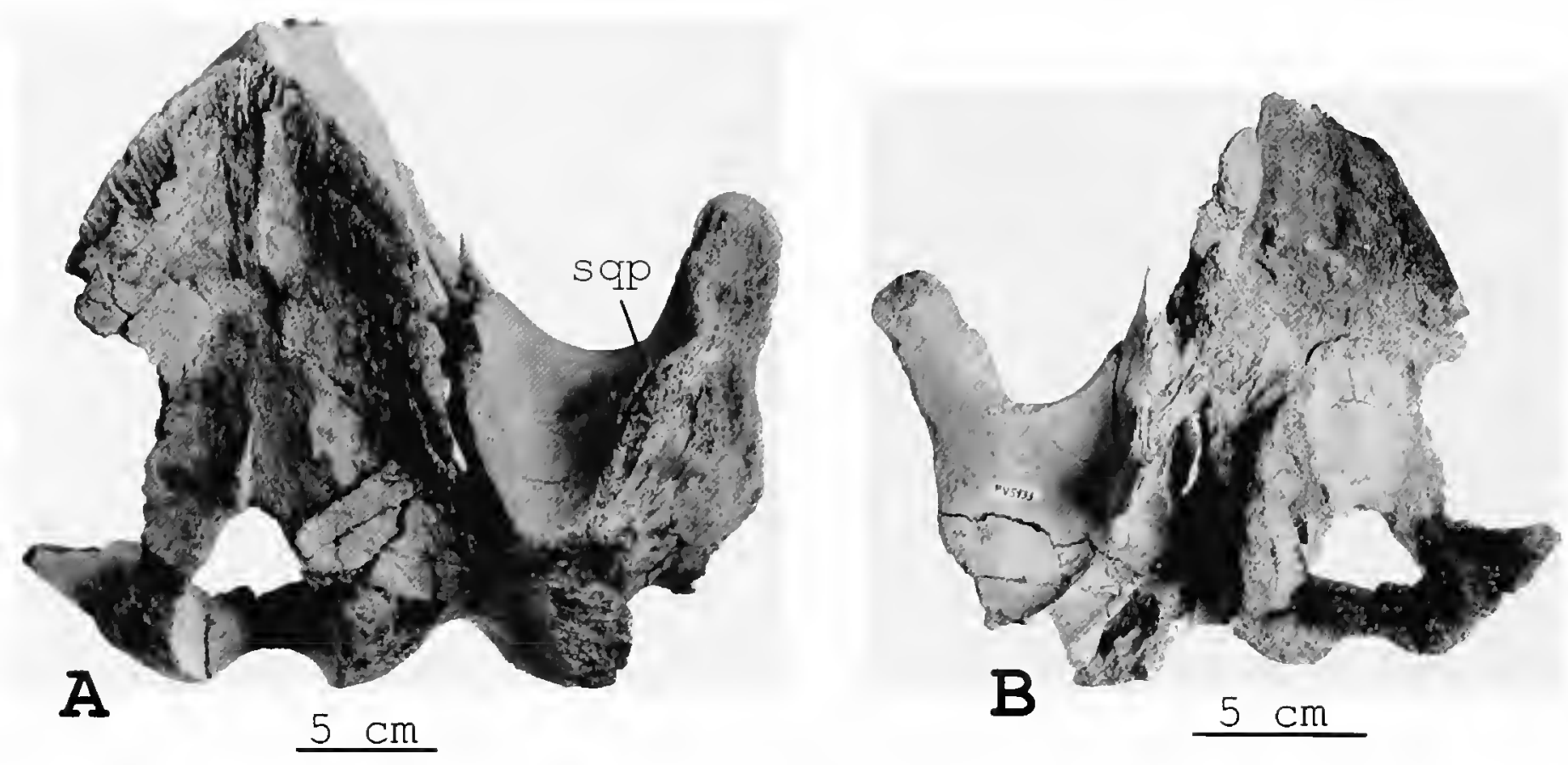

FIGURE 14,-Micromysticetus rothauseni, new genus and new species, paratype braincase, ChM PV5933: A, dorsal view; B, ventral view.

\section{Cetotheriopsis Brandt, 1871}

Balaenodon Owen, 1846 [in part].- Von Meyer, 1849:550; 1850:201

Stenodon Van Beneden, 1865 [based upon composite assemblage of specimens belonging to one or more unrelated animals].

Cetotheriopsis Brandt, 1871:566.-Brandt, 1873:40, pl. 19: figs. 1-4; 1874 6-11, pl. 1: figs. 1-16.-Winge, 1910:17-19.-Kellogg, 1923a:22-23; 1931: 307; 1934a:81.-Rothausen, 1971:131, 135, etc.-Whitmore and Sanders, 1976:318.-Fordyce, 1977:265; 1984, fig. 5b.

Aulocetus Van Beneden, 1875:537-539. [First latinized use of the name. "Aulocete" was used previously by Van Beneden (1861; see Kellogg, 1923a: 22-23). It is a junior synonym of Cetotheriopsis Brandt, 1871, because it has as its type species Balaenodon lintianus (see Winge, 1910:17-18; Kellogg, 1923a: 22-23); therefore, both genera, Aulocetus and Cetotheriopsis, have the same type species (see Kellogg, 1923a:22-23; 1931:307).]

D1AGNOS1S.-A genus of the subfamily Cetotheriopsinae differing from Micromysticetus in the following characteristics: larger size; cranium with occipital shield shaped like an anteroposteriorly elongate triangle; exoccipital broad transversely; glenoid fossa elongate anteroposteriorly and with an angular posterointerior margin; sulcus for external acoustic meatus long; zygomatic processes of squamosals not extending beyond apex of supraoccipital.

TYPE SPECIES.-Balaenodon lintianus von Meyer, 1849.

INCLUDED SPECIES.-Cetotheriopsis lintianus (von Meyer, 1849), late Oligocene, Austria.

\section{Cetotheriopsis lintianus (von Meyer, 1849)}

\section{FIGURES $15-17$}

Balaenodon lintianus von Meyer, 1849:550.-Von Meyer, 1850:201.

"Aulocete" Van Beneden, 1861

Stenodon lintianus Van Beneden, 1865:73-79, text fig. 2 [see Kellogg, 1923a: 22-23].

Cetotheriopsis lintianus Brandt, 1871:196.-Brandt, 1873:40, pl. 19: figs. 1-4; 1874:6-11, pl. 1: figs. 1-16.-Kellogg, 1923a:22-23; 1928:185-187, fig. 18; 1931:307; 1934a:81; 1969:1.—Slijper, 1936:209.-Rothausen, 1971:132.—
Whitmore and Sanders, 1977:314.-Fordyce, 1984, fig. 5b [photo of dorsal view of holotype].

Cetotheriopsis linziana Brandt, 1873 [in part, based upon the holotype of $\mathrm{Ce}$ totheriopsis lintianus and other specimens].-Brandt, 1874.

Squalodon linzianus Brandt, 1871. [A tympanic bulla that Brandt (1873) reassigned to Squalodon ehrlichi and Abel (1913) referred to Patriocetus ehrlichi.

Aulocetus lintianus Van Beneden, 1861, 1875. [=Balaenodon lintianus; see Winge, 1909:17-18; Kellogg, 1923a:22-23; 1931:307.]

Aulocetus linzianum Van Beneden, 1875 [see Kellogg, 1923a:22-23].

HOLOTYPE.-Cranium missing the entire rostrum; possibly associated atlas and another vertebra (see Kellogg, 1923a:22-23). The tooth and tympanic bulla that were originally included in the type material by von Meyer (1849) were later removed from it (von Meyer, 1850:202; Kellogg, 1923a:22-23); they were thought by Van Beneden (1865) to belong to a squalodont and subsequently were referred to "Squalodon" ehrlichii by Brandt (1873, 1874). Oberösterreichisches Landesmuseum, Linz/Donau, Austria.

TYPE LOCALITY.--The holotype was found in the Sandgrube Bauernberg near Linz, Austria (Rothausen, 1971:140).

FORMATION AND AGE.-Linz Sands, upper Chattian, uppermost Oligocene, nannoplankton zone NP25 (Rabeder and Steininger, 1975:177).

EMENDED DIAGNOSIS.-A relatively small mysticete probably not exceeding $5 \mathrm{~m}$; supraoccipital with well-developed medial crest on anterior half and deep, basin-like depression in posterior half; apex narrow and acute. Crest lying below level of adjacent lambdoidal crests in medial trough extending from depressed center of supraoccipital anteriorly almost to apex; apex elevated slightly above posterior portion of supraoccipital (Figure 16B). In posterior view, vertex of braincase strongly depressed below lambdoidal crests (Kellogg, 1928:187); lambdoidal crests prominently developed and overhanging temporal 

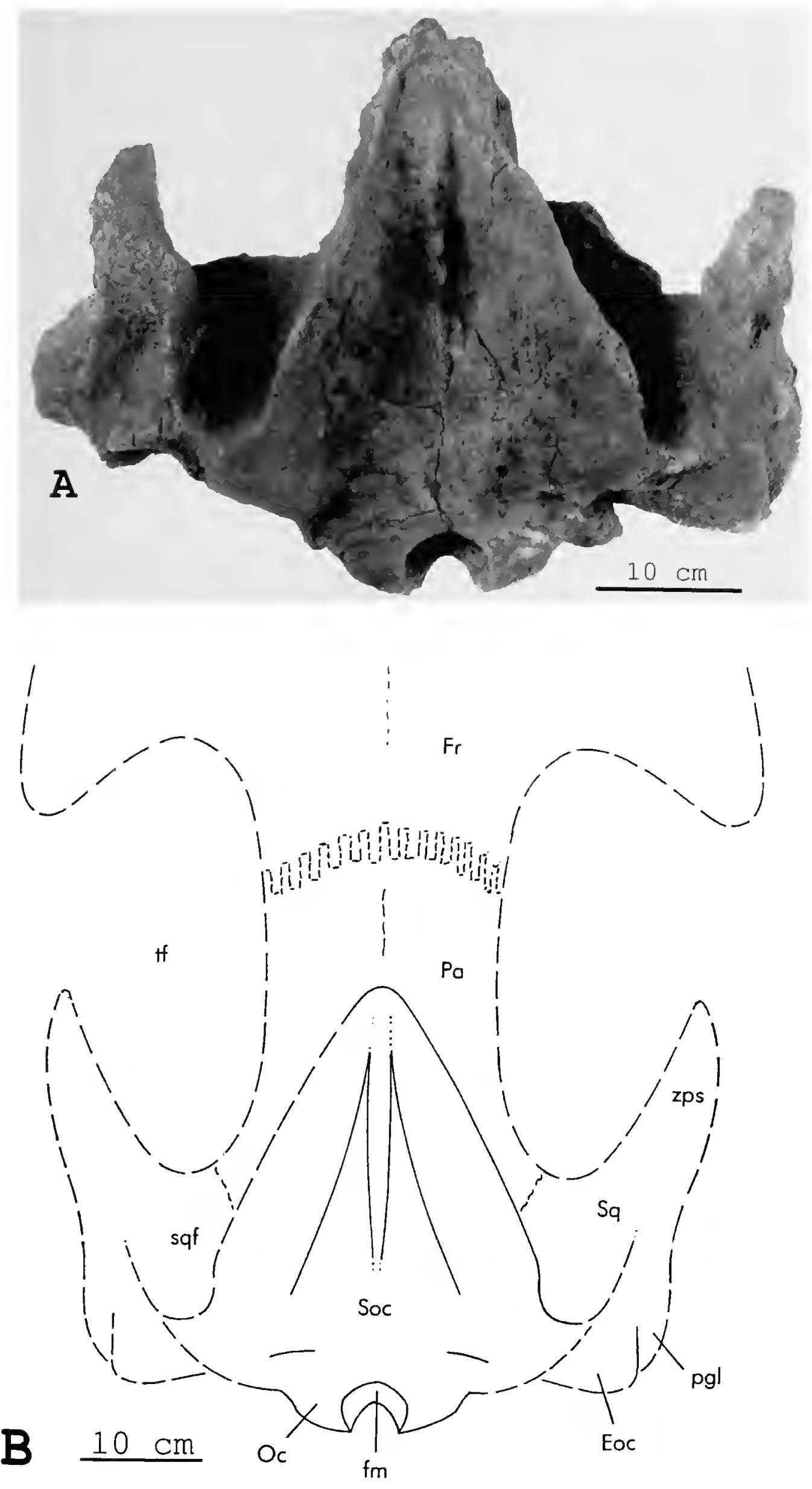

FIGURE 15.-Cetotheriopsis lintianus (von Meyer, 1849): A, holotype braincase, dorsal view (Oberösterreichisches Landesmuseum photograph by B. Ecker); B, reconstruction. (Dashed lines indicate hypothetical configurations; abbreviations are explained in "Material and Methods.")

fossae. Exoccipitals broadly rounded and sloping posteroventrally from posterior margin of squamosal fossae, but outer margins too badly eroded to permit reliable transverse measurement. Occipital condyles massive and with dorsal margins situated well below level of floors of squamosal fossae; squamosal fossae elongate and deeply excavated. Zygomatic pro- cesses of squamosal roughly parallel to axis of skull midline and not conspicuously directed outward.

REMARKS.- The holotype skull is so badly eroded in the squamosal and exoccipital regions that it is difficult to determine their details. The ventral side of the skull (Figure 16A) has not been prepared, and virtually the entire basicranium is 

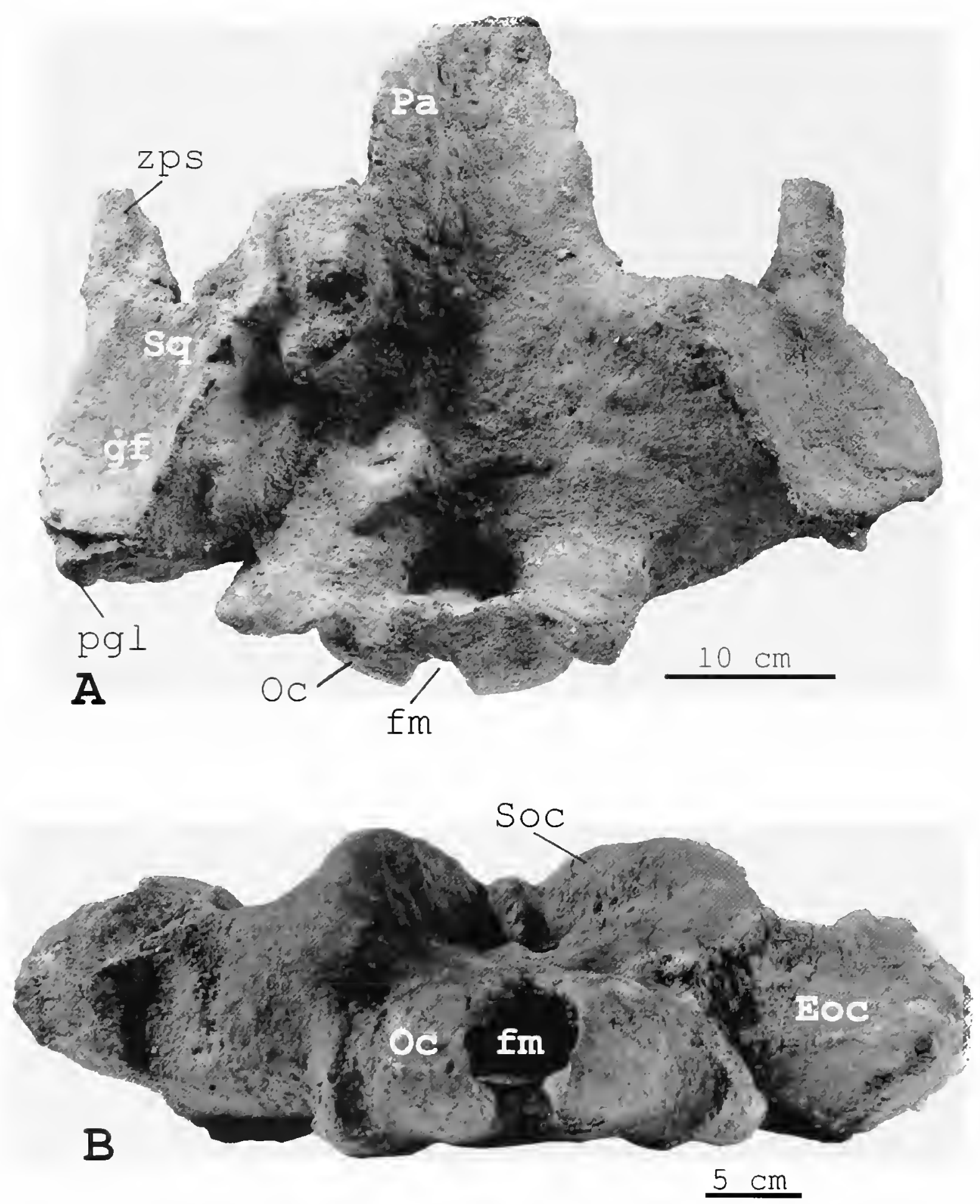

FIGURE 16.-Cetotheriopsis lintianus (von Meyer, 1849), holotype braincase: A, ventral view; B, posterior view (Oberösterreichisches Landesmuseum photographs by B. Ecker). (Abbreviations are explained in "Material and Methods.")

missing. The specimen is covered with fine quartz sand grains like those that have long hindered studies of the odontocetes Patriocetus ehrlichi (Van Beneden, 1865) and Agriocetus incertus (Brandt, 1874), also from the Linz Sands. Kellogg (1928:187) noted that this species has "elongate zygomatic processes, that do not reach forward to the level of the apex of the supraoccipital shield." These processes are so badly eroded that it is difficult to be certain about their original length, but in view of the greatly elongated supraoccipital and relative length of the zygomatic processes in Eomysticetus (Sanders and Barnes, 2002), it seems highly unlikely that the zygomata of $C$. lintianus extended beyond the apex of the supraoccipital, if in fact they even reached that point. Probably through deformation by the weight of overlying sediments, the left squamosal has been twisted out of its proper orientation, the lateral face having been turned upward into the dorsal plane of the skull, thus causing the glenoid fossa to be abnormally visible in lateral aspect (Figure 17). In our reconstruction of this specimen (Figure 15B), we have followed the orientation suggested by the right squamosal and the remains of its zygomatic process; the form and lateral angle of the left squamosal in the actual specimen and the reconstruction are therefore noticeably different (Figure 15A,B). Our reconstruction of the portion of the skull anterior to the apex of the supraoccipital is based upon 
FIGURE 17.-Cetotheropsis lintianus (von Meyer, 1849), holotype braincase, left lateral view (Oberösterreichisches Landesmuseum photograph by B. Ecker).

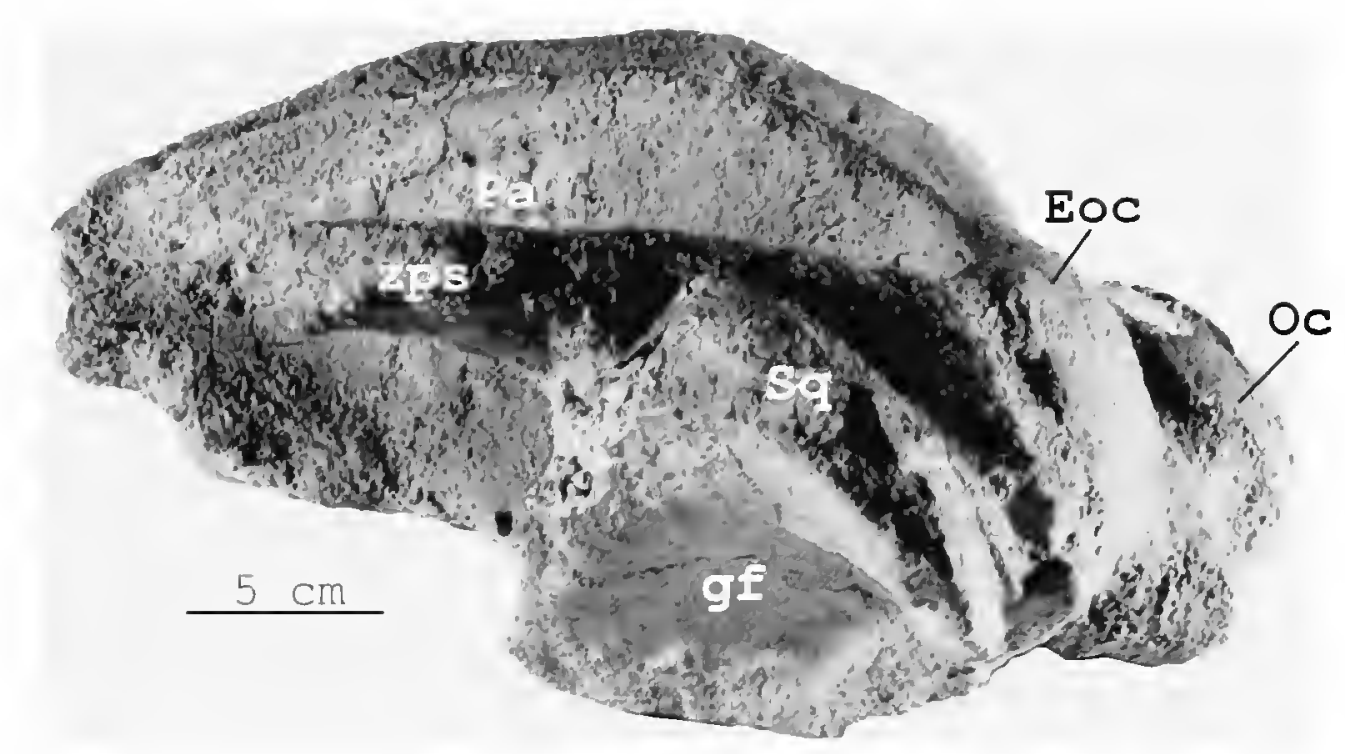

features manifested in the holotype cranium of the archaic mysticete Eomyticetus whitmorei (Sanders and Barnes, 2002), which has an elongate intertemporal region and a supraoccipital thrust strongly forward like that of $C$. lintianus.

\section{Discussion}

Until recently, Micromysticetus tobieni (Rothausen, 1971), from lower Chattian beds near Dusseldorf, Germany (Figures 3-6), and Cetotheriopsis lintianus (von Meyer, 1849), from uppermost Oligocene sands at Linz, Austria (Figures 15-17), represented the only toothless baleen-bearing, fossil mysticete specimens reported from Oligocene beds in the Northern Hemisphere. Despite the absence of rostra on these specimens, they have been accepted as true, baleen-bearing mysticetes and have been classified in the family Cetotheriidae Brandt, 1872. The family Cetotheriidae differs from the families Balaenopteridae, Eschrichtiidae, and Balaenidae by having a skull with an elongate intertemporal region formed by the parietals and a gradual lateral slope from the cranial vertex to the dorsal surface of the supraorbital process. The laterally projecting zygomatic processes in all three of the species of the subfamily Cetotheriopsinae discussed herein suggests the presence in each of a wide supraorbital process and a broad rostrum consistent with the development of baleen and the filter-feeding method used by the true mysticetes. In view of the elongate intertemporal region in all four specimens, their assignment to the family Cetotheriidae corresponds with previous classifications of such animals and is supported by our present, although somewhat limited, knowledge of the group.

A comparison of the measurements of the holotype skulls of Micromysticetus tobieni and Cetotheriopsis lintianus with those of Micromysticetus rothauseni (Table 2) reveals three principal points about these three species. First, Micromysticetus tobieni and Micromysticetus rothauseni are approximately comparable in size, $M$. tobieni being slightly larger, and both are smaller than the holotype of Cetotheriopsis lintianus. Second, the skull of $C$. lintianus is the largest of all three of the ho- lotypes. Third, and most important, the anteroposterior lengths of the supraoccipitals separate the three specimens into two sets, one in which the supraoccipital is narrow and greatly elongated (C. lintianus) and the other in which it is considerably shorter anteroposteriorly (M. tobieni and M. rothauseni).

The set of curves in Figure 18 graphically demonstrates the morphometric separation between the two groups of speci-

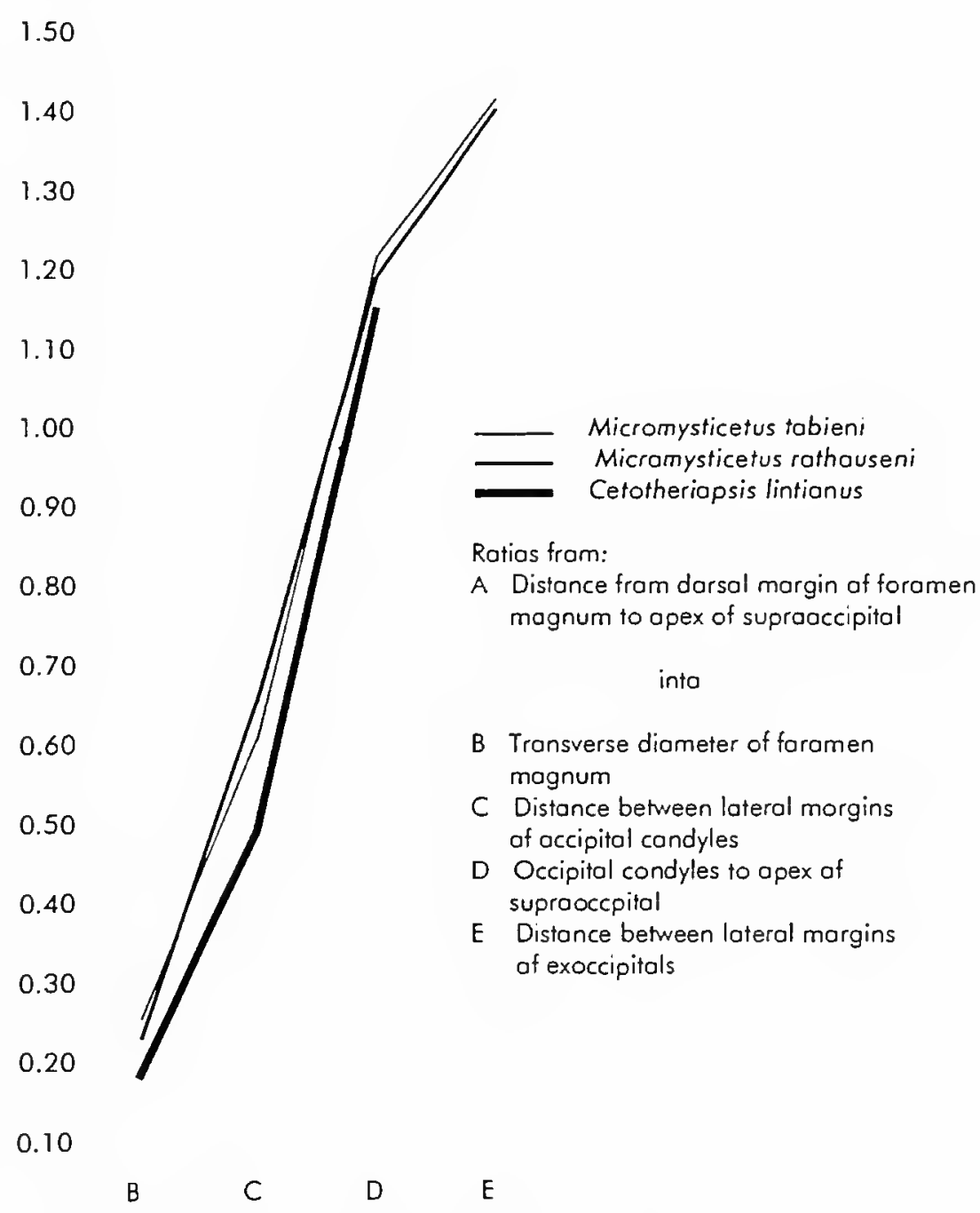

FIGURE 18.-Morphometric comparison of the holotype crania of Micromysticetus tobieni (Rothausen, 1971), Micromysticetus rothauseni. new genus and new species, and Cetotheriopsis lintianus (von Meyer, 1849), using ratios derived from five selected cranial measurements. 
TABLE 2.-Measurements (in mm) of the holotype (ChM PV4844) and paratype (ChM PV5933) skulls of Micromysticetus rothauseni, n. gen. n. sp., from the late Oligocene of South Carolina, and of the holotype skulls of Micromysticetus tobieni (Rothausen) (JGU P 1289) and Cetotheriopsis lintianus (von Meyer) from the late Oligocene of Europe. Except as noted below, measurements of $M$. tobieni and C. lintianus are from Rothausen (1971, table 1). (Measurements in parentheses are estimates; ${ }^{*}=$ measurement from cast of Micromysticetus tobien $; \dagger=$ measurement from holotype of Cetotheriopsis lintianus; -= no data.)

\begin{tabular}{|c|c|c|c|c|}
\hline Character & $\begin{array}{l}\text { M. rothausen } \\
\text { (holotype) }\end{array}$ & $\begin{array}{l}\text { M. rothauseni } \\
\text { (paratype) }\end{array}$ & $\begin{array}{l}\text { M. tobieni } \\
\text { (P1289) }\end{array}$ & C. lintianus \\
\hline Occipital condyles to plane of anteriormost end of specimen, as preerved & 256.4 & 214.2 & 267 & 340 \\
\hline Dorsal edge of foramen magnum to apex of supraoccipital & 182.5 & $(156)$ & 199 & $287 \dagger$ \\
\hline Occipital condyles to apex of supraoccipital & 224.5 & 200.2 & 247 & 325 \\
\hline Occipital condyles to posterior end of vomer & - & - & 110 & - \\
\hline Greatest width across zygomatic processes of squamosals & $(398)$ & $(370)$ & 403 & 505 \\
\hline Distance between lateral margins of exoccipitals & 256.6 & $(230)$ & $278^{*}$ & - \\
\hline Distance between lateral margins of occipital condyles & 124.4 & 115 & $126^{*}$ & 145 \\
\hline $\begin{array}{l}\text { Greatest distance between lateral margins of basioccipital processes } \\
\text { (Alae Basioccipitalis in Rothausen, 1971) }\end{array}$ & 94.7 & - & 116 & - \\
\hline Transverse diameter of foramen magnum & 44.4 & $(43)$ & 54 & $55.5+$ \\
\hline Vertical diameter of foramen magnum & 36.3 & - & 45 & $41 \dagger$ \\
\hline Vertical diameter of right occipital condyle & 67 & $(54)$ & $78.5^{*}$ & $84 \dagger$ \\
\hline Greatest transverse diameter of right occipital condyle & 41 & (37) & $49^{*}$ & $55 \dagger$ \\
\hline $\begin{array}{l}\text { Distance from inner margin of right occipital condyle to outer edge of } \\
\text { right exoccipital }\end{array}$ & 109.6 & $(97)$ & 112 & - \\
\hline $\begin{array}{l}\text { Maximum length of left zygomatic process, extremity of postglenoid } \\
\text { process to anterior end of zygoma }\end{array}$ & 192 & - & & - \\
\hline Width of temporal fossa & 122 & $(103)$ & - & - \\
\hline Greatest internal height of braincase at midline & 82 & $(70)$ & - & - \\
\hline
\end{tabular}

mens. To obtain these ratios, we divided measurement $A$, the distance from the dorsal margin of the foramen magnum to the apex of the supraoccipital, into four other measurements: B, the transverse diameter of the foramen magnum; $C$, the distance between the lateral margins of the occipital condyles; $\mathrm{D}$, the distance from the occipital condyles to the apex of the supraoccipital; and E, the distance between the lateral margins of the exoccipitals. Although poor preservation prevents the taking of measurement $\mathrm{E}$ in the holotype of Cetotheriopsis lintianus, measurements of B, C, and D place the curve for that species well away from those for Micromysticetus tobieni and Micromysticetus rothauseni.

Although $M$. rothauseni and $M$. tobieni are similar in general appearance, there is considerable difference in the shape of the basioccipital crests in these two specimens. In M. tobieni the basioccipital crests have rounded margins, whereas in $M$. rothauseni the margins of these processes are decidedly angular, their inner margins paralleling each other before breaking into divergent angles that terminate in narrow, rounded points posteriorly. Micromysticetus rothauseni thus represents a species that is distinct from $M$. tobieni, but the variability between other species in polytypic mysticete genera and particularly the presence of squamosal prominences in both forms support their referral to the same genus.

\section{Conclusions}

Two mysticete braincases without rostra, from the late Oligocene Ashley Formation (lower Chattian) near Charleston,
South Carolina, represent a new genus and new species herein named Micromysticetus rothauseni. Micromysticetus rothauseni is distinct from the European Cetotheriopsis tobieni at the specific level, but the presence of a previously unrecognized character uniting these two species requires that $C$. tobieni be reassigned to the new genus Micromysticetus.

Micromysticetus tobieni (Rothausen, 1971) and M. rothauseni differ from Cetotheriopsis lintianus (von Meyer, 1849) principally in having an anteroposteriorly shorter supraoccipital, the apex of which terminates behind the anteriormost extent of the zygomatic process of the squamosal. That feature is in contrast with the condition in the skull of $C$. lintianus, in which the apex of the supraoccipital seems almost certainly to have reached the level of the anterior tip of the zygoma. Micromysticetus also is characterized by the presence of a knob-like eminence (the squamosal prominence) on the squamosal. Both genera are classified in the family Cetotheriidae.

Micromysticetus rothauseni constitutes the oldest western North Atlantic records of the family Cetotheriidae; previous specimens of cetotheres from this region were found in Miocene sediments (Kellogg, 1924, 1965, 1968a-c, 1969). It further documents that this genus of cetotheriids was present on both sides of the North Atlantic during late Oligocene time. In their archaeocete-like morphologies, the periotic and axis vertebra of Micromysticetus rothauseni greatly resemble those structures in the Eocene archaeocete Zygorhiza kochii (Reichenbach, 1847), lending further support to the idea that the ancestry of the suborder Mysticeti is tied to the subfamily Dorudontinae of the archaeocete family Basilosauridae. 

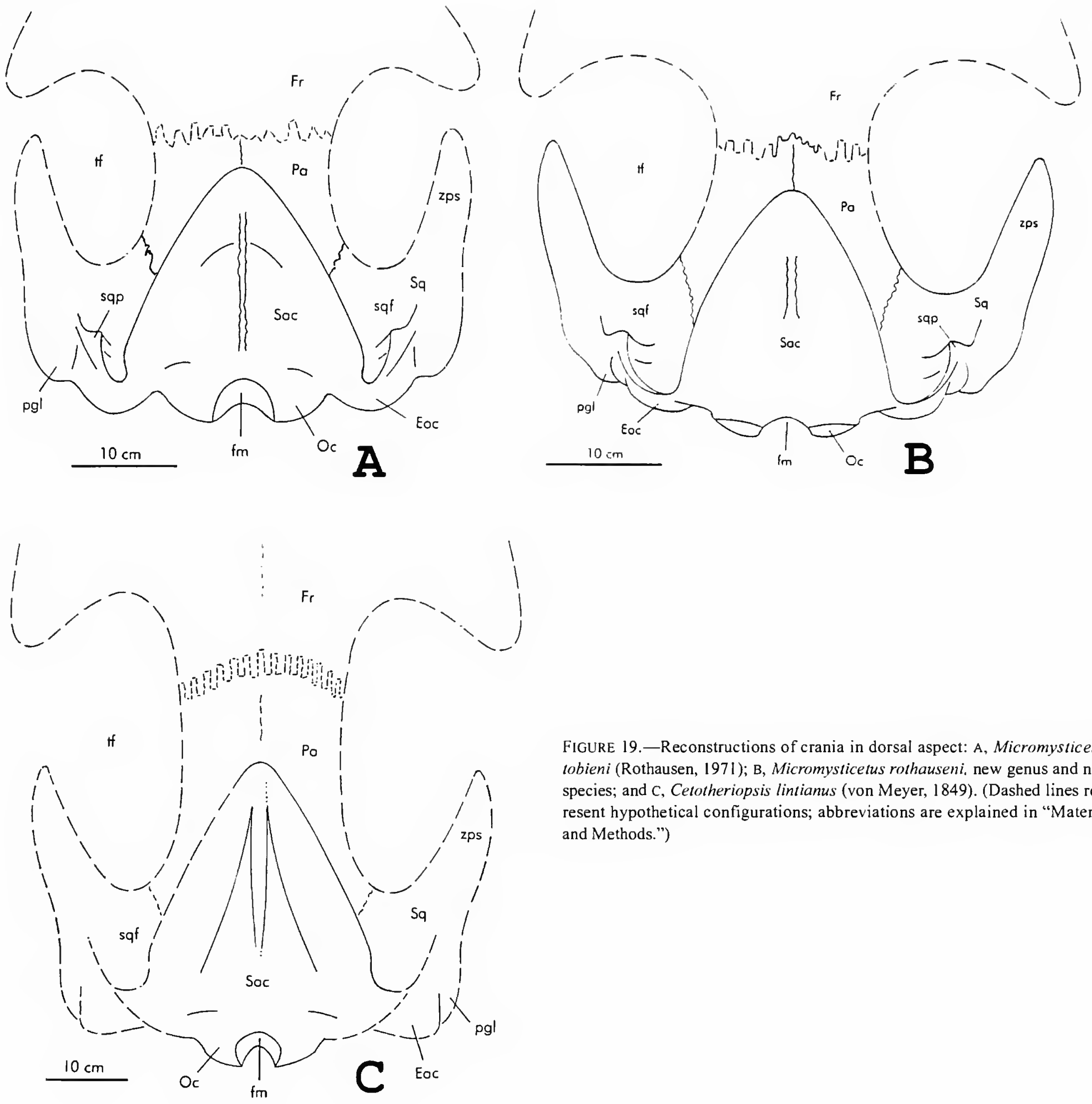

FIGURE 19.- Reconstructions of crania in dorsal aspect: A, Micromysticetus tobieni (Rothausen, 1971); B, Micromysticetus rothauseni, new genus and new species; and C, Cetotheriopsis lintianus (von Meyer, 1849). (Dashed lines represent hypothetical configurations; abbreviations are explained in "Material and Methods.")

\section{Literature Cited}

Abel, 0

1913. Die Vorfahren der Bartenwale. Denkschriften der Akademie der Wissenschaften, Wien. Mathematisch-Naturwissenschaftliche Klasse, 90:155-224, plates 1-12.

Barnes, L.G.

1977 ("1976"). Outline of Eastern North Pacific Fossil Cetacean Assemblages. Systematic Zoology, 25(4):321-343. [Date on title page is 1976; actually published in 1977.]

Barnes, L.G., and A.E. Sanders

1990. An Archaic Oligocene Mysticete from South Carolina. Journal of Vertebrate Paleontology, supplement, 9(3):14A.
Beneden, P.J. Van

1861. Un mammifère nouveau du Crag d'Anvers. Bulletin de l'Académie Royale des Sciences de Belgique, series 2, 12:22-28.

1865. Recherches sur les ossements provenant du Crag d'Anvers: Les squalodons. Mémoires de l'Académie Royale des Sciences, des Lettres et des Beaux-Arts de Belgique, series 2, 35(3):1-85, plates $1-4$.

1875. Le squelette de la baleine fossile du Musée de Milan. Bulletin de l'Académie Royale des Sciences de Belgique, series 2, 40:736-758.

Brandt, J.F. von

1871. Bericht über den Fortgang meiner Studien über die Cetaceen, 
welche das grosse zur Tertiärzert von Mitteleuropa bis Centralasien hinein ausgedehnte Meeresbecken bevölkerten. Bulletin de l'Académie Impériale des Sciences de St. Pétersbourg. series 3, 16:563566.

1872. Über eine neue Classification der Bartenwale (Balaenoidea) mit berücksichtigung der untergegangenen Gattungen derselben. Bulletin de l'Académie Impériale des Sciences de St. Pétersbourg, series 3, 17:113-124.

1873. Untersuchungen über die Fossilen und Subfossilen Cetaceen Europas. Mémoires de l'Académie Impériale des Sciences de St. Pétersbourg, series 7, 20(1): vii +372 pages, 24 plates.

1874. Ergangzunge zu den fossilen Cetaceen Europas. Mémoires de l'Académie Impériale des Sciences de St. Pétersbourg, series 7, 21(6): iv +54 pages, 5 plates.

Brisson, M.J.

1762. Regnum animale in classes IX distributum sive synopsis methodica. Revised edition, 296 pages Leiden: Theodorus Haak.

Curry, D., C.G. Adams, M.C. Boulter, F.C. Dilley, F.E. Eames, B.M. Funnell, and M.K. Wells

1978. A Correlation of Tertiary Rocks in the British Isles. Geological Society of London, Special Report, 12:1-72.

Emlong, D.R.

1966. A New Archaic Cetacean from the Oligocene of Northwest Oregon. Bulletin of the Museum of Natural History, University of Oregon, 3: 51 pages.

Erickson, B.R, and G.S. Sawyer

1996. The Estuarine Crocodile Gavialosuchus carolinensis n. sp. (Crocodylia: Eusuchia) from the Late Oligocene of South Carolina, North America. Monograph of the Science Museum of Minnesota. Paleontology, 3: 47 pages.

Flower, W.H.

1864. Notes on the Skeletons of Whales in the Principal Museums of Holland and Belgium, with Description of Two Species Apparently New to Science. Proceedings of the Zoological Society of London. 1864:384-420.

Fordyce, R.E.

1977. The Development of the Circum-Antarctic Current and the Evolution of the Mysticeti (Mammalia: Cetacea). Palaeogeography, Palaeoclimatology, Palaeoecology, 21:265-271.

1984. Evolution and Zoogeography of Cetaceans in Australia. In M. Archer and G. Clayton, editors, Vertebrate Zoogeography and Evolution in Australasia, pages 929-948. Carlisle, Australia: Hesperian Press.

Fraser, F.C., and P.E. Purves

1960. Hearing in Cetaceans: Evolution of the Accessory Air Sacs and the Structure and Function of the Outer and Middle Ear in Recent Cetaceans. Bulletin of the British Museum (Natural History), Zoology. 7(1):1-140 pages, frontispiece, plates 1-53.

Gray, J.E.

1868. Synopsis of the Species of Whales and Dolphins in the Collection of the British Museum. 10 pages, 37 plates. London: Bernard Quaritch.

Kellogg, R.

1923a. Description of Two Squalodonts Recently Discovered in the Calvert Cliffs, Maryland, and Notes on the Sharktoothed Cetaceans. Proceedings of the United States National Museum, 62(16):1-69, plates $1-20$.

1923b. Description of an Apparently New Toothed Cetacean from South Carolina. Smithsonian Miscellaneous Collections, 76(7): 7 pages, 2 plates.

1924. Description of a New Genus and Species of Whalebone Whale from the Calvert Cliffs, Maryland. Proceedings of the United States $\mathrm{Na}$ tional Museum, 63: 14 pages, 6 plates [publication 2482].

1928. The History of Whales: Their Adaptation to Life in the Water. Quarterly Review of Biology, 3:29-76, 174-208.

1929. A New Cetothere from Southern California. University of Southern
California Publications, Bulletin of the Department of Geological Sciences, 18(15):449-457.

1931. Pelagic Mammals from the Temblor Formation of the Kern River Region, California. Proceedings of the California Academy of Sciences, series 4, 19(12):217-397.

1934a. The Patagonian Fossil Whalebone Whale, Cetotherium moreni (Lydekker). In Contributions to Paleontology: Marine Mammals. Carnegie Institution of Washington Publication, 447:63-81.

1934b. A New Cetothere from the Modelo Formation at Los Angeles, California. In Contributions to Paleontology: Marine Mammals. Carnegie Institution of Washington Publication, 447:83-104.

1936. A Review of the Archaeoceti. Carnegie Institution of Washington Publication, 482: $\mathrm{xv}+366$ pages, 37 plates.

1938. Adaptation of Structure to Function in Whales. Carnegie Institution of Washington Publication, 501:649-682.

1965. Fossil Marine Mammals from the Miocene Calvert Formation of Maryland and Virginia, Part 1: A New Whalebone Whale from the Miocene Calvert Formation. Bulletin of the United States National Museum. 247:1-45, plates 1-21.

1968a. Fossil Marine Mammals from the Miocene Calvert Formation of Maryland and Virginia, Part 5: Miocene Calvert Mysticetes Described by Cope. Bulletin of the United States National Museum, 247:103-132, plates 46-48.

1968b. Fossil Marine Mammals from the Miocene Calvert Formation of Maryland and Virginia, Part 6: A Hitherto Unrecognized Calvert Cetothere. Bulletin of the United States National Museum, 247: 133-161, plates 49-57.

1968c. Fossil Marine Mammals from the Miocene Calvert Formation of Maryland and Virginia, Part 7: A Sharp-Nosed Cetothere from the Miocene Calvert. Bulletin of the United States National Museum, 247:163-173, plates 58-63.

1969. Cetothere Skeletons from the Miocene Choptank Formation of Maryland and Virginia, Part 1: The Skeleton of a Miocene Choptank Cetothere. Bulletin of the United States National Museum, 294: 1-24, plates 1-15.

Martini, E., and C. Müller

1975. Calcareous Nannoplankton from the Type Chattian. Proceedings of the Sixth Congress on Neogene Mediterranean Stratigraphy, Bratislava, Yugoslavia, 1975,1:37-41.

Meyer, H. von

1849. [Untitled.] Neues Jahrbuch für Mineralogie, Geognosie, Geologie, und Petrefakten-Kunde (Stuttgart), 1849:547-550.

1850. [Untitled.] Neues Jahrbuch für Mineralogie, Geognosie, Geologie. und Petrefakten-Kunde (Stuttgart), 1850:195-204.

Miller, G.S., Jr.

1923. The Telescoping of the Cetacean Skull. Smithsonian Miscellaneous Collections, 76(5): 1-71, 8 plates.

Müller, J.

1849. Über die fossilen Reste der Zeuglodonten von Nordamerica, mit Rücksicht auf die europäischen Reste aus dieser Familie. iv +38 pages, 27 plates. Berlin: Verlag von G. Reimer.

Owen, R.

1846. A History of British Fossil Mammals and Birds. xlvi +560 pages, 237 figures. London: John Van Voorst.

Packard, E.L., and A.R. Kellogg

1934. A New Cetothere from the Miocene Astoria Formation of Newport, Oregon. In Contributions to Paleontology: Marine Mammals. Carnegie Institution of Washington Publication, 447:1-62.

Perrin, W.F.

1975. Variation of Spotted and Spinner Porpoise (Genus Stenella) in the Eastern Pacific and Hawaii. Bulletin of the Scripps Institute of Oceanography, University of California, 21:1-206.

Rabeder, G., and F. Steininger

1975. Die direkten biostratigraphischen korrelationsmoglichkeiten von Saugetierfaunen aus dem Oligo-Miozän der Centralen Paratethys 
Proceedings of the Sixth Congress on Mediterranean Neogene Stratigraphy, Bratislava. Yugoslavia, 1:177-183.

Reichenbach, H.G.L.

1847. In C.G. Carus, Resultate geologischger, anatomischer und zoologischer Untersuchungen über das unter dem Namen Hydrarchos von der A.C. Koch zuerst nach Europa gebrachte und in Dresden ausgestellte grosse fossile Skellet, pages 1-15, plates 1-7. Dresden and Leipzig.

Rothausen, K.

1968. Die systematische Stellung der europäischen Squalodontidae (Odontoceti, Mamm.). Paläontologische Zeitschrift. 42(1/2):83-104, plates $11,12$.

1971. Cetotheriopsis tobieni n. sp., der erste paläogene Bartenwal (Cetotheriidae, Mysticeti, Mamm.) nördlich des Tethysraumes. Abhandlungen des Hessische Landesamtesn für Bodenforschung, 60:131148, plates 1-3.

Russell, L.S.

1968. A New Cetacean from the Oligocene Sooke Formation of Vancouver lsland, British Columbia. Canadian Journal of Earth Science, 5:929-933.

Sanders, A.E.

1980. Excavation of Oligocene Marine Fossil Beds near Charleston, South Carolina. National Geographic Society Research Reports. 12:601-621.

Sanders, A.E., and L.G. Barnes

1989. An Archaic Oligocene Mysticete from South Carolina, U.S.A. $A b$ stracts, Eighth Biennial Conference on the Biology of Marine Mam- mals, Pacific Grove, California. December, 1989, page 58.

1991. Late Oligocene Cetotheriopsis-Like Mysticetes (Mammalia, Cetacea) from near Charleston, South Carolina. Journal of Vertebrate Paleontology, supplement, 11(3):54A.

2002. Paleontology of the Late Oligocene Ashley and Chandler Bridge Formations of South Carolina, 3: Eomysticetidae, a New Family of Primitive Mysticetes (Mammalia: Cetacea). In R. Emry, editor, Cenozoic Mammals of Land and Sea: Tributes to the Career of Clayton E. Ray. Smithsonian Contributions to Paleobiology, 93:313-356.

Sanders, A.E., R.E. Weems, and E.M. Lemon, Jr.

1982. Chandler Bridge Formation: A New Oligocene Stratigraphic Unit in the Lower Coastal Plain of South Carolina. U.S. Geological Survey Bulletin. 1529-H:105-124, figures 24-27.

Slijper, E.J.

1936. Die Cetaceen: Vergleichend-anatomisch und systematisch. Capita Zoologica, $6(1-2): x v+590$ pages.

Weems, R.E., and A.E. Sanders

1986. The Chandler Bridge Formation (Upper Oligocene) of the Charleston, South Carolina, Region. In T.L. Neathery, editor, Geological Society of America Centennial Field Guide, Southeastern Section, pages 323-326.

Whitmore, F.C., Jr., and A.E. Sanders

1977. Review of the Oligocene Cetacea. Systematic Zoology. 25(4):304-320. Winge, H.A.

1909. Om Plesiocetus og Squalodon fra Danmark. Videnskabelige Meddelelser, Dansk Naturhistorisk Foreninq, Kobenhavn, 7(1):1-38, plates $1,2$. 



\title{
Balaena ricei, a New Species of Bowhead Whale from the Yorktown Formation (Pliocene) of Hampton, Virginia
}

\author{
James W. Westgate and Frank C. Whitmore, Jr.
}

\section{ABSTRACT}

Fossil species of Balaena have previously been named on the basis of material from the Western Hemisphere, but all are founded upon undiagnostic material. The holotype of $B$. ricei new species consists of a partial skull, partial mandible, all major flipper bones, and representatives of all types of vertebrae, allowing comparison with the two best-known European species.

This study, together with the known occurrence of Balaena species in the Pliocene of Europe, strengthens the conclusion that bowhead whales were present on both sides of the North Atlantic Ocean at that time. By contrast, remains of Balaena have not been reported from Miocene deposits of the Atlantic coast of North America.

\section{Introduction}

In September 1960 William Rice discovered the skull and skeleton of a large bowhead whale while excavating materials from his borrow pit in Hampton, Virginia (Figure 1). This was the first recorded occurrence of a bowhead whale from the Yorktown Formation (U.S. Geological Survey, 1962, 1965). Another bowhead whale was found in 1985 at the old Hampton Landfill on Magruder Boulevard (G.H. Johnson, pers. comm., 1985). It consists of a set of fused cervical vertebrae, two mandibles, the rib cage, six dorsal vertebrae, and both scapulae, ulnae, and radii. The specimen, of late Yorktown age, is in the collections of the Department of Geology, College of William and Mary, Williamsburg, Virginia.

The family Balaenidae, the bowhead and right whales, has a narrow, highly arched rostrum and fused cervical vertebrae that

\footnotetext{
James W. Westgate, Department of Geology, Lamar University, Beaumont, Texas 77710. Frank C. Whitmore, Jr., Research Associate, Department of Paleobiology, National Museum of Natural History, Smithsonian Institution, Washington, D.C. 20560-0121.
}

allow ready identification of the members of the family; both characters are seen in the present specimen. The fossil record of the family goes back to the earliest Miocene (McLeod et al., 1993), but the record is sparse until the late Miocene and the Pliocene, when fossil occurrences indicate widespread, perhaps global, distribution of balaenids. Despite the wide distribution of the family, its generic and specific diversity have always been low. Today the family is represented by two monotypic genera: Eubalaena, the right whale, and Balaena, the bowhead. Several extinct genera of Balaenidae have been described, but only one, Balaenula Van Beneden (1872), is now generally accepted.

The specimen described differs from Eubalaena in having a larger head, whose profile has a continuous curve from the occipital condyles to the anterior end of the rostrum, and in possessing a coracoid process on the scapula (True, 1904; McLeod et al., 1993). It differs from Balaenula in its greater size.

Many fossil species have been described and assigned to the genus Balaena. Most of these were published in the nineteenth century, and many are based upon undiagnostic material. Of the many nominal species, McLeod et al. (1993) recognized four as valid species of Balaena: $B$. affinis Owen, 1844; B. etrusca Capellini, 1873; B. montalionis Capellini, 1904; and $B$. primigenias Van Beneden, 1872.

In modern times, bowhead whales lived in great numbers along the Atlantic coast of North America. In spite of this, no balaenid remains have yet been found in the Miocene Calvert, Choptank, St. Marys, or Eastover Formations, or in the late Pliocene Chowan River Formation, all of the Chesapeake Group (Table 1). The occurrence of the Rice's Pit bowhead whale in the upper Yorktown Formation, however, establishes proof that bowhead whales inhabited the waters off eastern North America during middle Pliocene times.

ACKNOWLEDGMENTS.-Thanks are due to the Research Intern Program, Office of Academic Studies, Smithsonian Institution, which provided funds and related expenses for this 


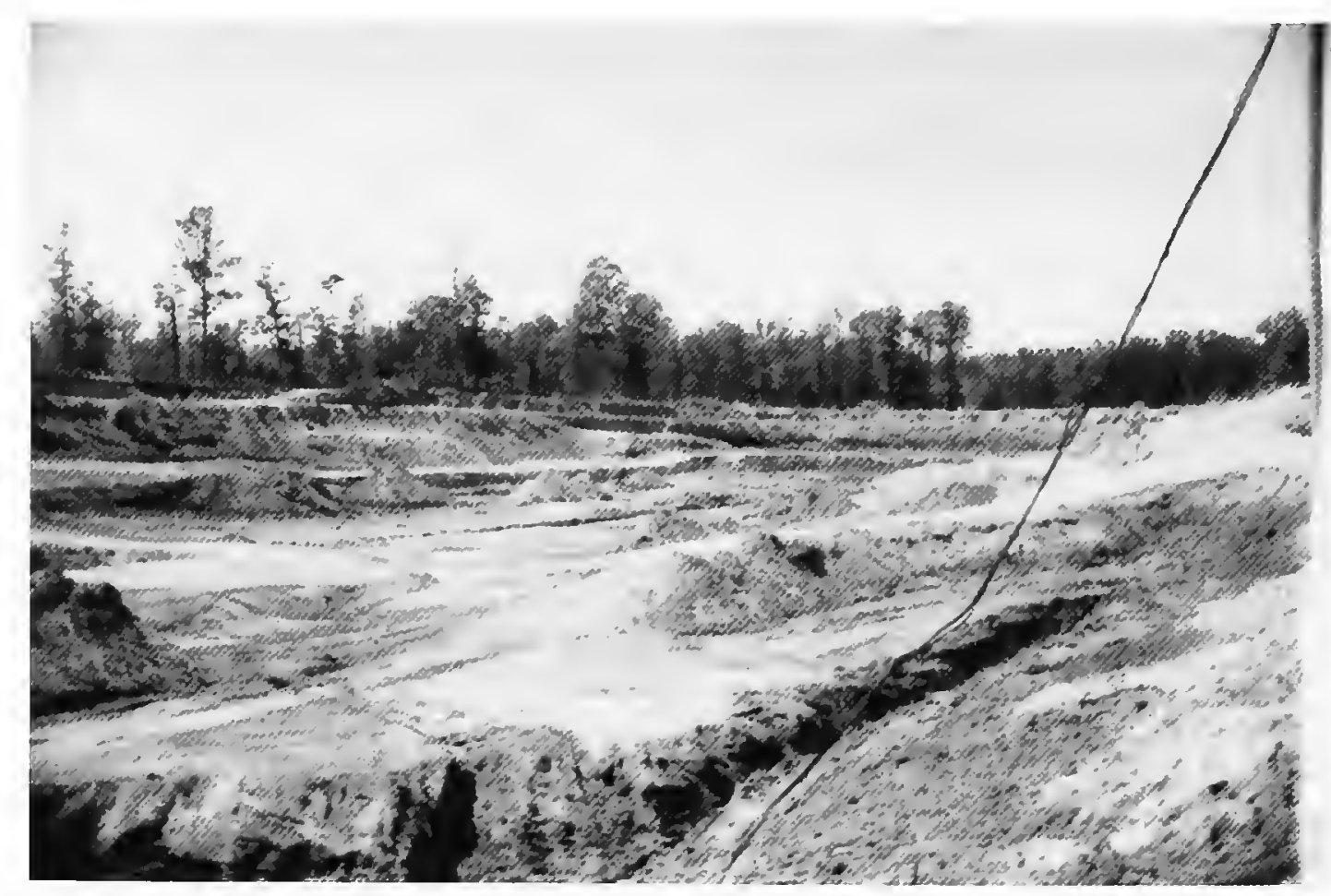

FIGURE 1.-Rice's Pit, Hampton, Virginia. (W.M. Rice photo.)

study during the summers of 1972 and 1974; to the late William M. Rice for his cooperation in the removal of the specimen from his borrow pit and for his generous donation of the specimen to the National Museum of Natural History; to Gerald H. Johnson of the Department of Geology, College of William and Mary, for his time and assistance with writing the manuscript; to David J. Bohaska for his help in preparing the manuscript for publication, and especially for his advice in orienting and labeling the ear ossicles; to Samuel A. McLeod for a helpful review of the manuscript; to the late Robert McKinney of the United States Geological Survey, who photographed all of the bones except the ear ossicles, which were taken by Victor Krantz; to the members of the Department of Paleobiology, Smithsonian Institution, who put up with the inconveniences a specimen of this size creates; and to each person who aided in the tedious job of typing the various stages of the manuscript.

Thanks must also be given to Clayton E. Ray of the Department of Paleobiology, Smithsonian Institution, who acted as Westgate's advisor during the two summers in which he was a participant in the Research Intern Program.

\section{GEOLOGIC SETTING}

Rice's Pit, which is about $13.2 \mathrm{~m}$ (43.5 ft.) deep, is located on the Hampton Flat and is excavated into the Yorktown and overlying Tabb Formations. The Tabb Formation is composed of a fining upward sequence with a basal thin pebble sand that grades upward into a well-sorted, light gray, quartzose sand and into a surficial heterogeneous mixture of clay, silt, and fine sand. It is about $1.7 \mathrm{~m}(5.6 \mathrm{ft}$.) thick on the eastern side of the pit. The Tabb was deposited in an ancestral Chesapeake Bay during the late Pleistocene.
The Yorktown Formation exposed in Rice's Pit is a fully marine sequence that coarsens and becomes more carbonate-rich upward. At the base of Rice's Pit, the Yorktown is a sparsely fossiliferous, quartzose, clayey, fine sandy silt with less than $20 \%$ carbonate. It grades to a moderately fossiliferous, massive-bedded, fine to medium sand near the top of the formation. The uppermost $20-110 \mathrm{~cm}(0.6-3.3 \mathrm{ft}$.) is leached and partially oxidized to a soft, slightly compressive, clayey and silty fine sand.

The stratum from which the whale was removed is a medium gray, silty fine sand. The dominant minerals are quartz (56\%), aragonite and calcite ( $41 \%$ collectively), and small amounts of glauconite, heavy minerals, and mica.

The associated fauna contains a diverse assemblage of bivalves, gastropods, and echinoderms. Barnacles, bryozoans, corals, endolithic sponges, and inarticulate brachiopods are common to rare. Foraminifers and ostracodes (Hazel, 1971) are abundant and moderately diverse. The dead right whale came to rest on the floor of a shallow shelf swept by gentle currents (Figure 2).

\section{StRATIGRAPHIC POSITION}

\section{TABLE I}

The age assignment and stratigraphic framework of the Yorktown Formation has changed with time. Lyell (1845), Rogers (1881), Clark and Miller (1912), Mansfield (1944), and others until the early 1970s assigned a Miocene age to the Yorktown. Subsequently, it was placed in the Pliocene on the basis of the foraminiferal (Akers, 1972; Berggren, 1973), ostracode (Hazel, 1971), and molluscan assemblages (Ward and Blackwelder, 1980; Campbell, 1993). The whale came from 


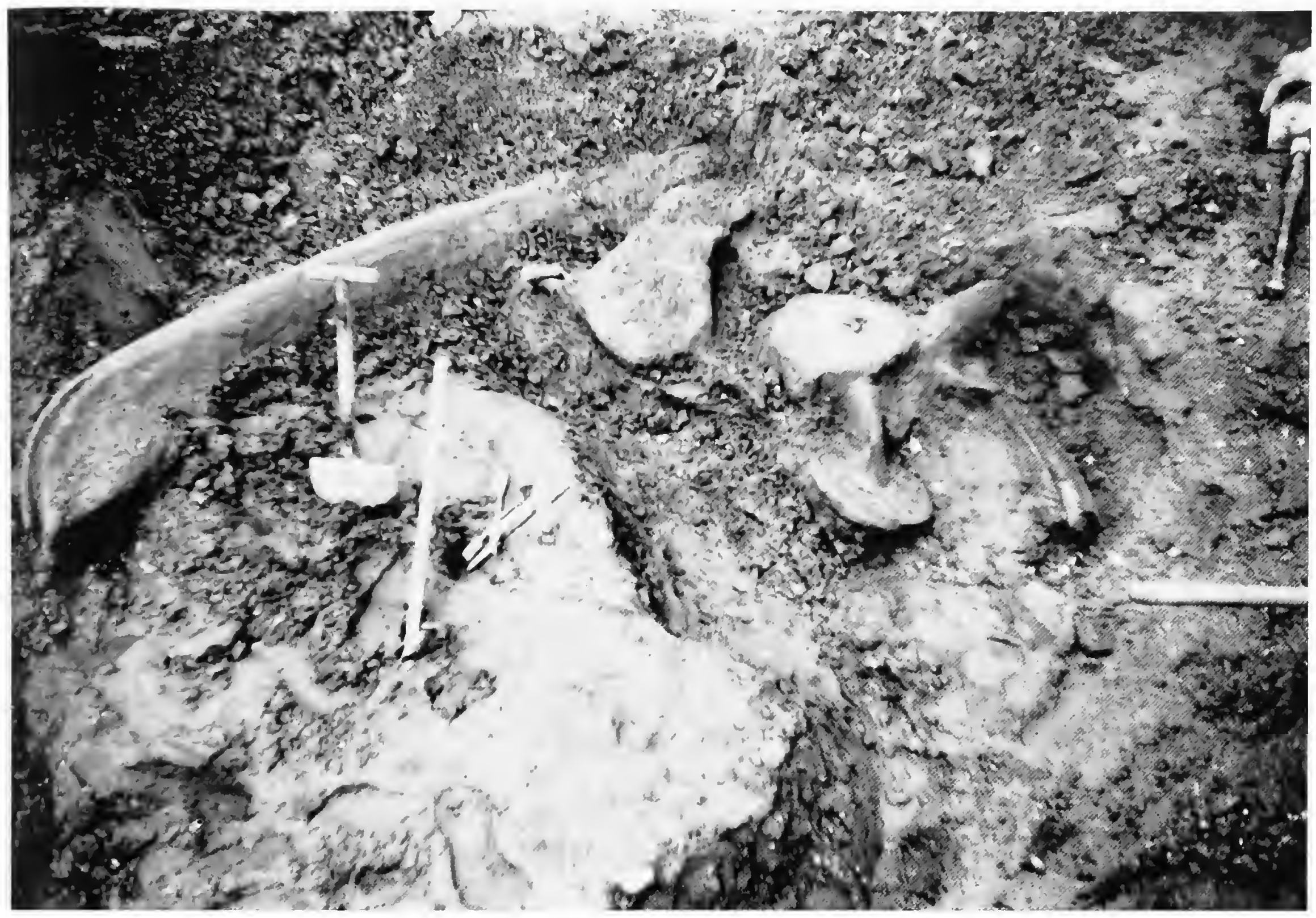

FIGURE 2.- Mandible of USNM 22553 during excavation in Rice's Pit. (F.C. Whitmore photo.)

the Turritella alticostata Zone (Zone 2) of Mansfield (1944), the Orionina vaughani zone of Hazel (1971), the molluscan M5 Zone of Blackwelder (1981), and planktonic Zone N19 of Blow (1969) (Akers, 1972).

The stratigraphic placement of the whale-bearing unit within the Yorktown is somewhat problematic because of the great lateral variation in thickness and lithology of late Tertiary formations in southeastern Virginia. These changes resulted from syn- and postdepositional deformation in the terrace zone of the Chesapeake Bay impact structure on the York-James penin-

TABLE 1.-Stratigraphic setting of Rice's Pit, Hampton, Virginia.

\begin{tabular}{|c|c|c|c|}
\hline EPOCH & FORMATION & MEMBER & SECTION AT RICE'S PIT \\
\hline Pleistocene & Tabb & & Tabb Formation \\
\hline \multirow{5}{*}{ Pliocene } & Chowan River & & \\
\hline & \multirow{4}{*}{ Yorktown } & Moore House & \\
\hline & & Mogarts Beach & \\
\hline & & Rushmere & \\
\hline & & Sunken Meadow & \\
\hline
\end{tabular}

sula (G.H. Johnson, pers. comm., 1997). Rice's Pit is in a gently tilted, erosionally truncated fault block in the outer terrace zone of the Chesapeake Bay impact structure. The whale-bearing bed is probably equivalent to the middle upper Yorktown: the silty fine sand facies of Johnson $(1969,1976)$ and the Morgarts Beach Member of Ward and Blackwelder (1980). The sequence of beds in Rice's Pit spans the boundary between the Rushmere and Morgarts Beach Members of the Yorktown Formation, according to Campbell (1993).

\section{Systematics}

\section{Balaena ricei, new species}

TYPE SPECIMEN.-USNM 22553. Right maxilla, vomer, dorsal half of cranium, right periotic with auditory ossicles, right and left mandibles both lacking posterior ends, seven cervical vertebrae, three partial thoracic vertebrae, two lumbar vertebrae, 16 caudal vertebrae, 10 chevron bones (haemal arches), sternum, right scapula, right humerus, right radius, right ulna, four metacarpals, and eight ribs. Collected by Frank C. Whit- 


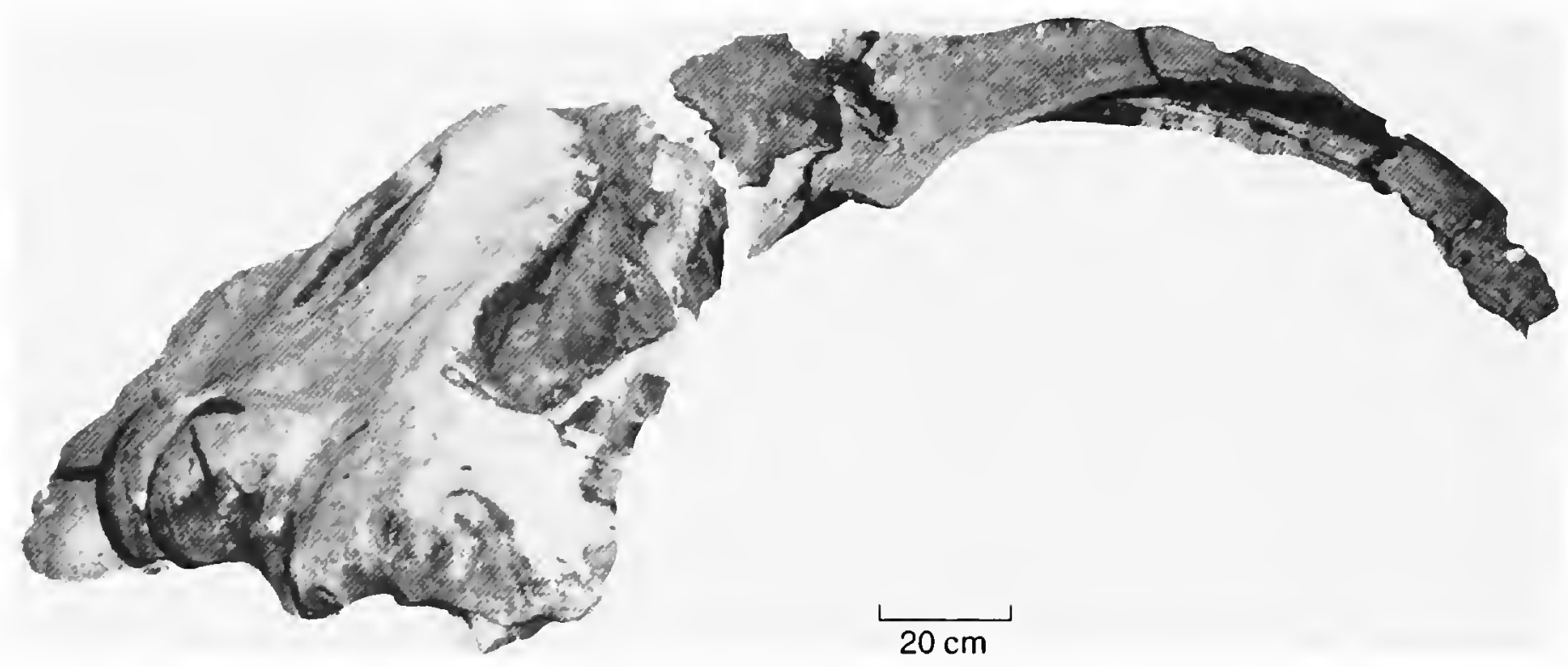

FIGURE 3.-Skull, right posterolateral view.

more, Jr., Nicholas Hotton III, Kurt Hausschildt, and party, September 1960. Donated by William M. Rice.

ETYMOLOGY.-Named after William M. Rice, owner of the borrow pit from which the type specimen was collected.

DiAGNOSIS.-A species of Balaena that differs from B. mysticetus in having humerus longer relative to length of forearm, in having transverse processes present on first 11 caudal vertebrae, in having foramina piercing the transverse processes only in caudal vertebrae posterior to the fourth caudal, having an opening in the atlas shaped like a figure eight-the upper half for the spinal cord and the lower half for the odontoid process

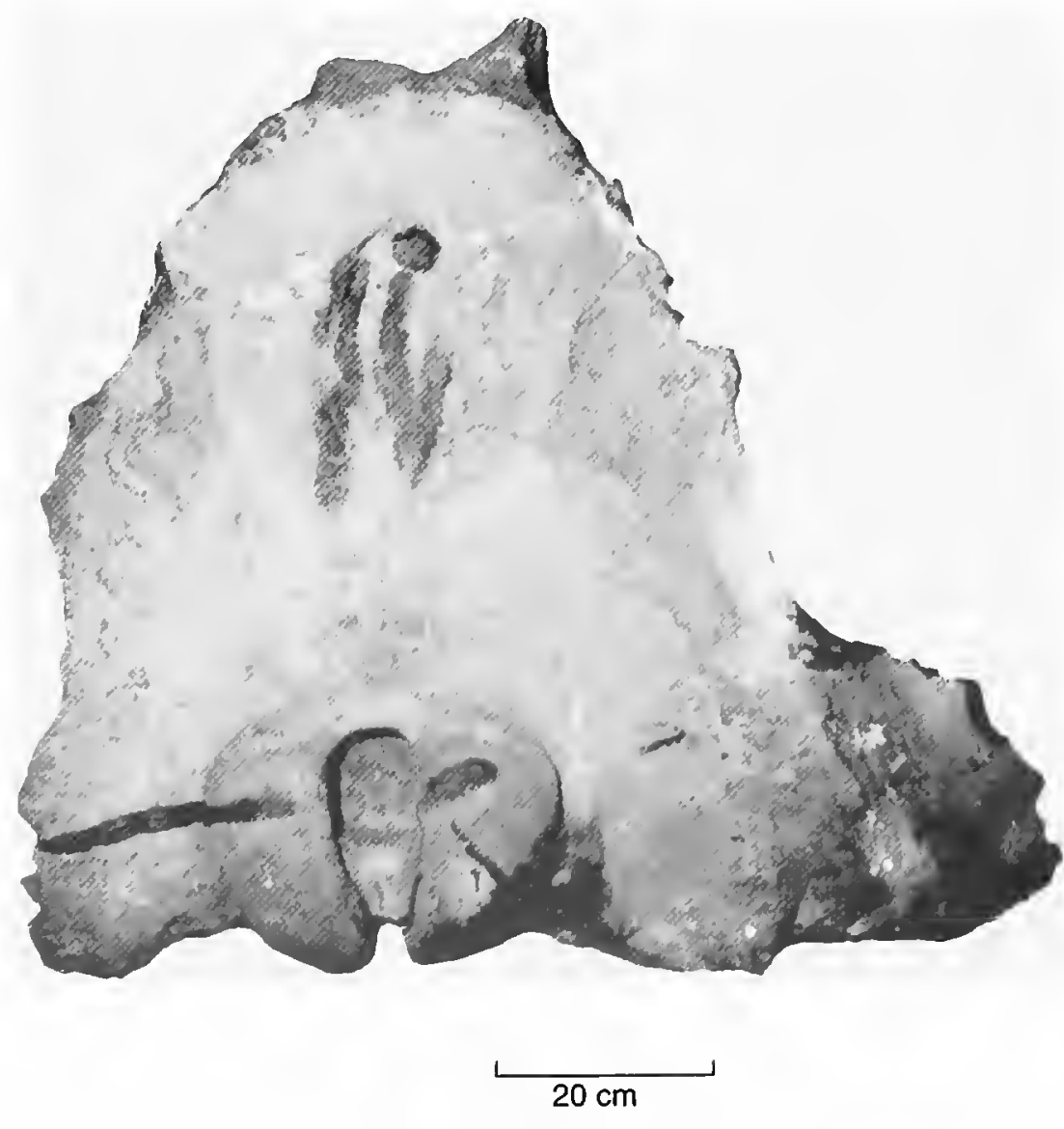

FIGURE 4.-Cranium, posterior view. of the axis; differs from $B$. etrusca in having figure-eightshaped opening in atlas, and in smaller size; differs from $B$. montalionis in shape of supraoccipital shield.

DESCRIPTION (all measurement in centimeters unless otherwise noted).-Cranium (Figures 3, 4): Distance from dorsal edge of foramen magnum to anterior border of supraoccipital, 67.0 ; breadth of supraoccipital at temporal fossa, 78.0; dorsoventral height of occipital condyle, 25.0; breadth of occipital condyle, 15.5; height of foramen magnum, 13.0; breadth of foramen magnum, 8.5.

The lateral surfaces of the cranium are too broken to allow the delineation of the parietal bones, and the extent of the frontal bone cannot be determined because only the base of the right supraorbital process has been preserved.

The supraoccipital extends upward at approximately a $75^{\circ}$ angle. Near the apex of the supraoccipital is a wide, laterally sloping medial ridge. Posteroventrally, this ridge is abruptly replaced by a $4 \mathrm{~cm}$ deep, $\mathrm{U}$-shaped depression that has a prominent lateral ridge on each side. These lateral ridges gradually diminish posteroventrally for $20 \mathrm{~cm}$. At this point the supraoccipital possesses no relief in the midsection. Another prominent ridge, typically found in modern balaenids, forms the lateral border of the supraoccipital along the temporal fossa. This ridge is created by upward curvature of the overhanging border of the occipital shield.

Only the base of the squamosal bone is preserved. The $35 \mathrm{~cm}$ section present extends anterolaterally from the supraoccipital at a $60^{\circ}$ degree angle. The entire ventral surface of the cranium was destroyed by heavy machinery when the operator was removing fill material from the borrow pit. Fortunately, the right periotic and the associated malleus, incus, and stapes became disarticulated from the cranium, allowing close inspection of the periotic and these infrequently recovered auditory ossicles.

Maxilla (Figures 3, 5): Length, 224.0; length along curve, 240.0 ; breadth at nasal region, 20.0 ; breadth at anterior end, 10.0; height at nasal region, 32.0; height at anterior end, 0.2 . 


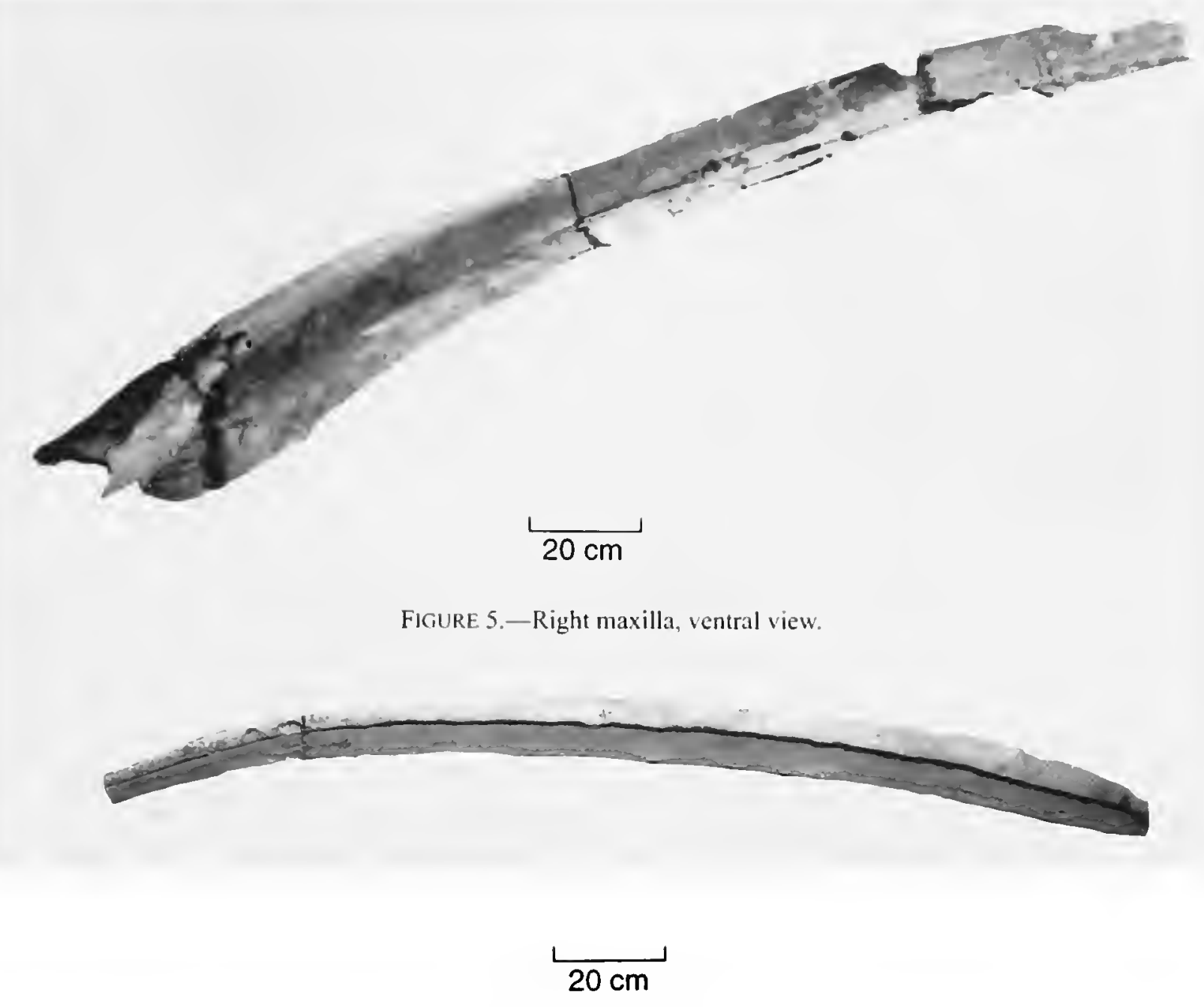

Figure 6.-Vomer.

The maxilla extends forward from the anterior edge of the supraoccipital region in a well-rounded arc. The maxilla gradually loses its triangularity, flattening anteriorly into a thin and narrow but ventrally convex projection of bone. The external side is flat, having almost no lateral curvature. Four foramina lie on this side near the junction with the frontal.

The dorsal surface of the posterior part of the maxilla exhibits a prominent ridge along the external side bordered internally by a flat shelf upon which the premaxilla rests (Figure 3 ). On the inner margin of this shelf the maxilla curves downward, forming the lateral wall of the vomerine trough. At about onethird the length of the maxilla, the ridge converges with and displaces the shelf. The ridge gradually diminishes and disappears in the anterior mid-region of the maxilla. Therefore, the anterior two-thirds of the maxilla is characterized by a thin, ventrally curved and ventrally sloping surface.

Combined with the $75^{\circ}$ slope of the occipital shield, the exaggerated curvature of the maxilla creates a very highly arched rostrum. The arch of the rostrum in conjunction with the long jaws forms an immense buccal cavity capable of engulfing huge volumes of marine organisms.

Vomer (Figure 6): The vomer is a delicate $\mathrm{V}$-shaped bone having a curvature comparable to that of the maxilla. At the internal vertex of the " $V$," the thin sides unite at about half the dorsal height, forming a thickened and sturdy interior. In cross section the vomer resembles an inverted "A," being solid from the crossbar to the apex.
Periotic (Figures 7, 8): Viewed from the lateral aspect, the most prominent part of the periotic is the pars cochlearis. The length of the pars cochlearis is approximately twice its width. The surface between the fenestra rotunda and the pterygoid fossa is nearly flat with slight curvature near its edges and two shallow grooves on its face.

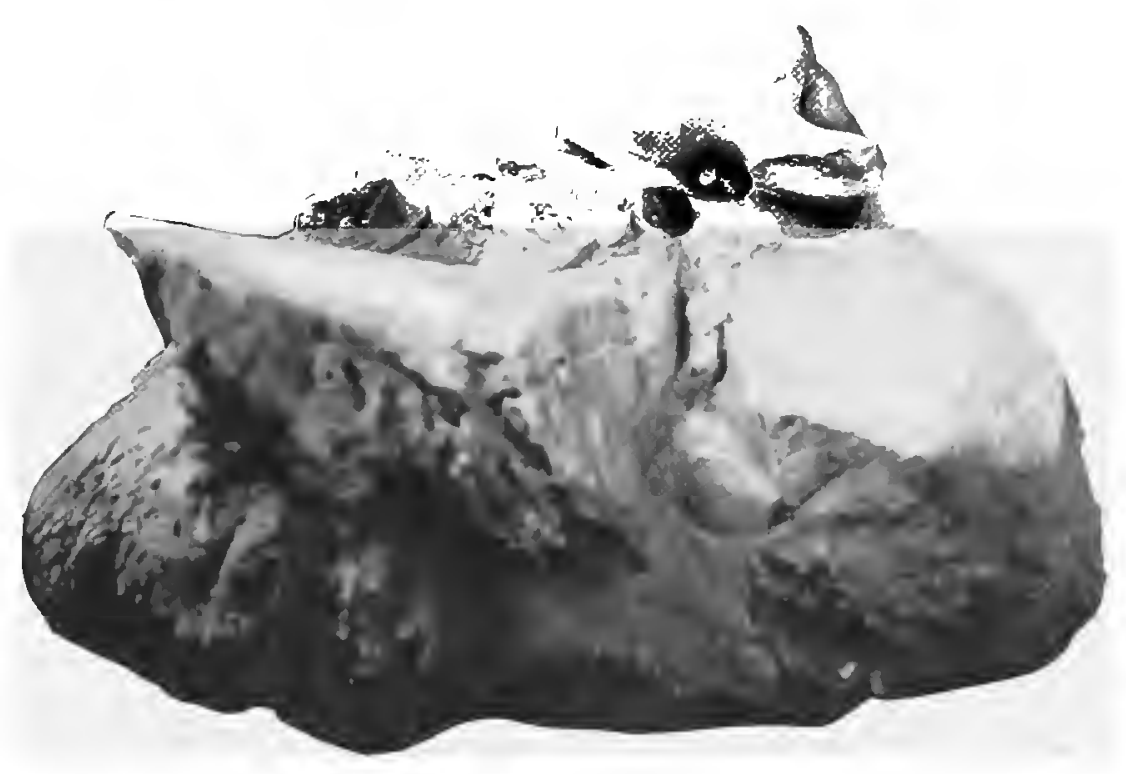

FIGURE 7.-Right periotic, ventral or tympanic view. 


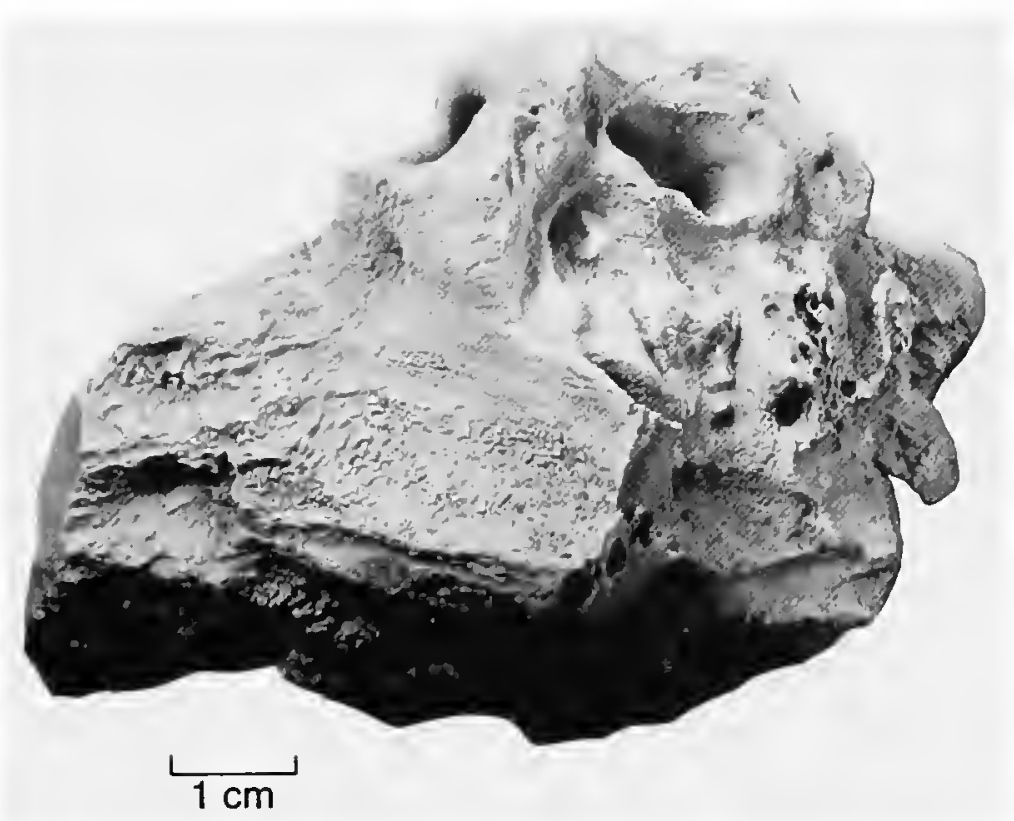

ant. p.

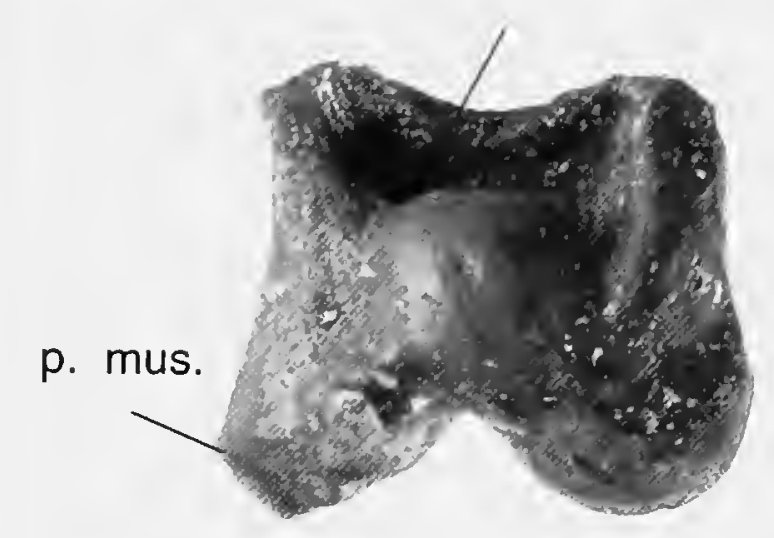

a

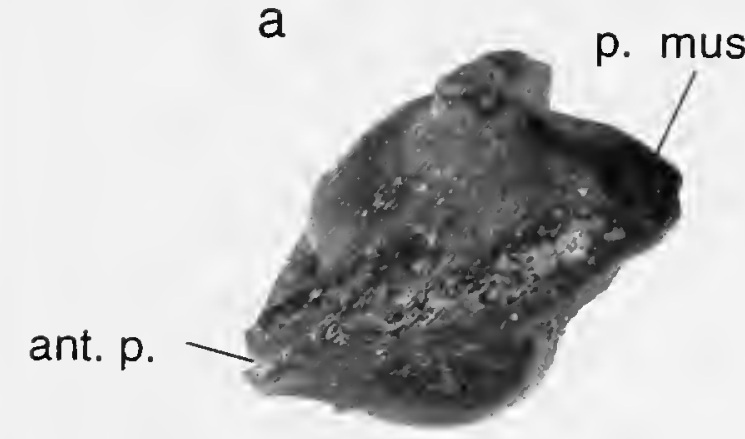

C

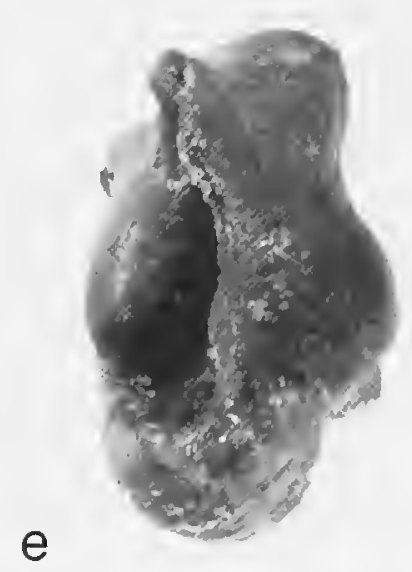

$1 \mathrm{~cm}$
FIGURE 8 (left).--Right periotic, internal or cranial view.

FIGURE 9 (below).--Right malleus: $a$, dorsal view; $b$, ventral view; $c$, medial view; $d$, lateral view; $e$, anterior view; $f$, posterior view. (ant.p. $=$ broken base of anterior process; he.f.=hemicircular facet; ho.f.=horizontal facet; p.mus.=processus muscularis.)

b
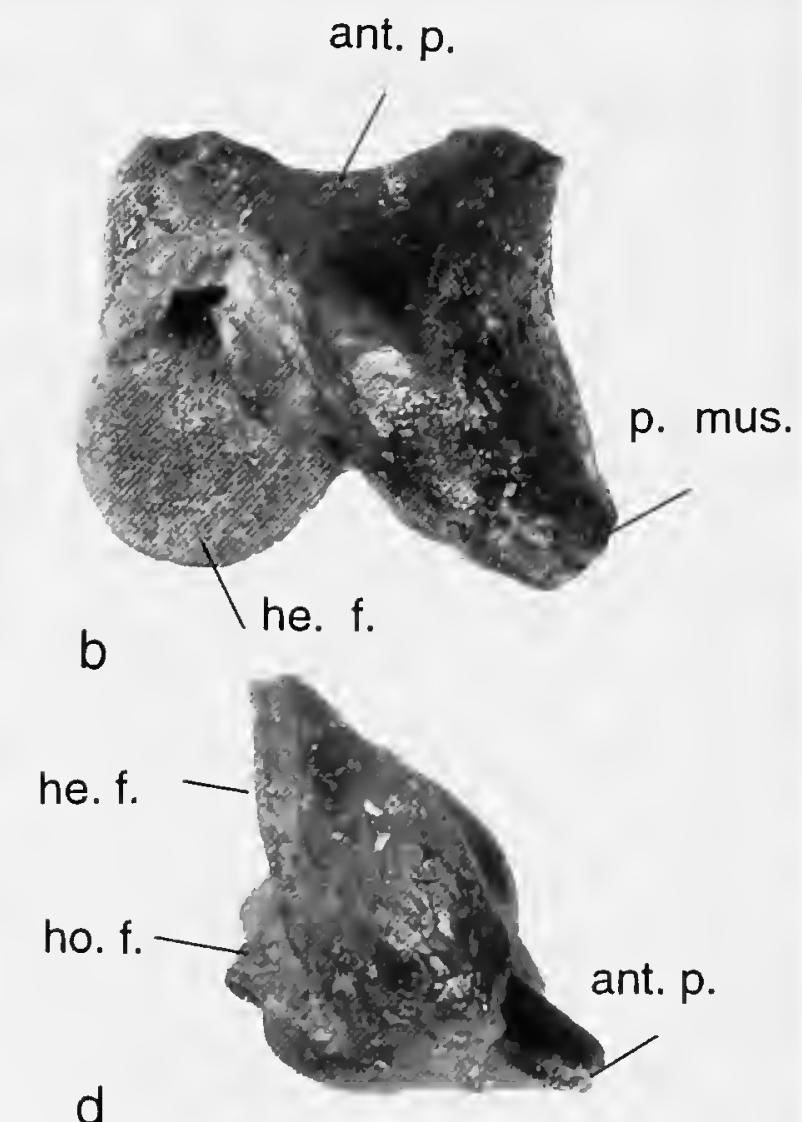

d

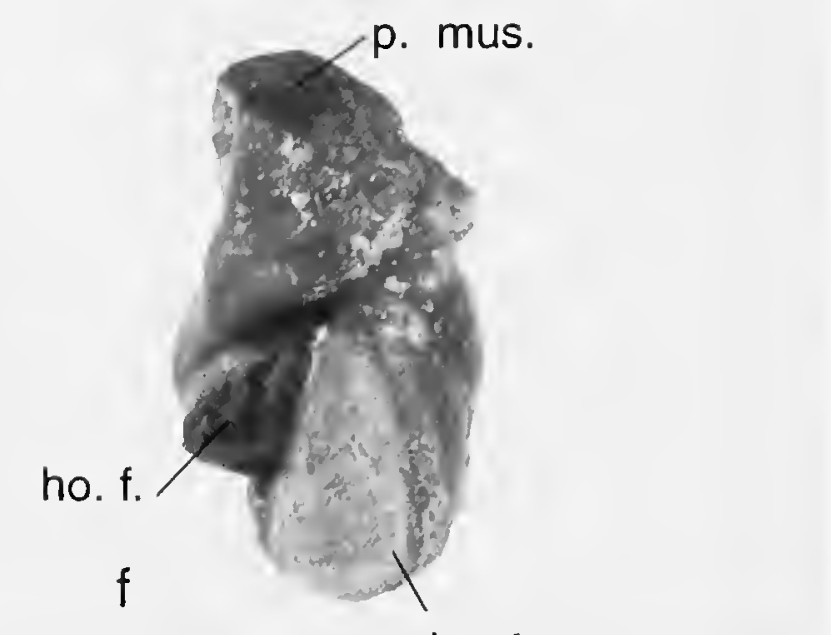

he. f. 
c. b.

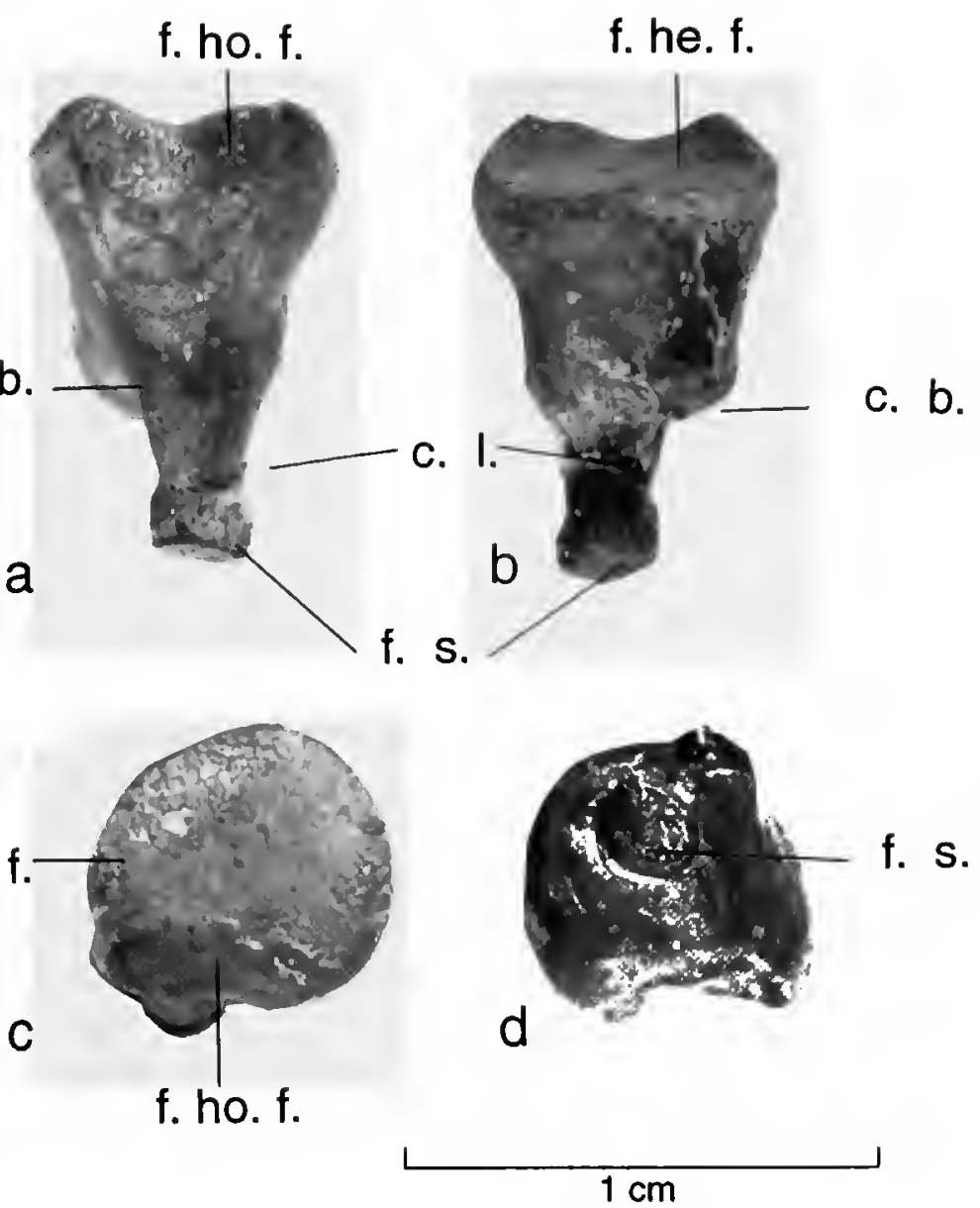

FIGURE 10.-Right incus: $a$, view showing facet for horizontal facet of malleus, and crus longum; $b$, view showing facet for hemicircular facet of malleus; $c$, view showing articular facets for malleus; $d$, view showing articular facet for stapes. (c.l.=crus longum; c.b. $=$ crus breve (broken); f.he.f. $=$ facet for hemicircular facet of malleus; f.ho.f. $=$ facet for horizontal facet of malleus; f.s. $=$ facet for stapes.)

The groove for the facial nerve and the fallopian aqueduct forms a wide channel that begins at the base of the posterior process and curves forward below and just beyond the fenestra ovalis. The fenestra ovalis is blocked by the foot plate of the stapes, which cannot be removed without damage to it. The anterior process is nearly flat, with very slight grooves radiating from its base. Only the base of the posterior process remains.

Malleus (Figure 9): Length, $19 \mathrm{~mm}$; width, $16 \mathrm{~mm}$. The delicate anterior process is broken, but its structure is still discernible through inspection of the cross section of the process at the point of fracture. It is apparent that the anterior process had an interior flat-bottomed groove and a rounded exterior. Posteriorly, the minutely convex hemicircular facet and the sig-

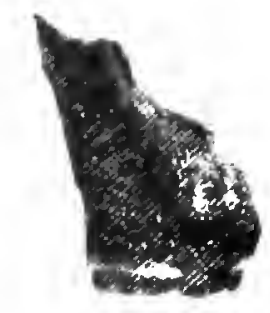

FIGURE 11 (right).-Right stapes: $u$, medial vicw; $b$, ventral view, showing articulation for incus.

\section{b}

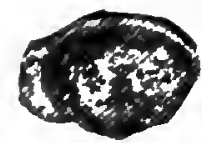

$5 \mathrm{~mm}$

nificantly smaller horizontal facet, which join at nearly a right angle, form the contact for the incus.

Incus (Figure 10): Length, $12 \mathrm{~mm}$; width, $9 \mathrm{~mm}$. The two facets of the incus that are adjacent to the malleus are both concave, the smaller much more so than the other. The horseshoeshaped larger facet meets the smaller facet at an acute angle adjacent to the cleft of the larger facet. The crus breve is missing, but the crus longum is complete. The crus longum is thin and short. At its end is a small circular facet that serves as the point of contact between the incus and the stapes.

Stapes (Figure 11): The facet on the head of the stapes and adjacent to the incus is larger and more nearly oval than that of the crus longum of the incus. The foot plate of the stapes cannot be removed from the fenestra ovalis of the periotic. The midsection of the stapes was destroyed with the breaking of the stapes head from the main body of the stapes.

Mandible: Length (partial), 310.0; length along curve (partial), 340.0; height (anterior), 35.5; height (posterior), 10.0; width (posterior), 20; width (anterior), 11.

The posterior sections of the mandibles are absent (Figures 12-14). Although the most diagnostic part of the mandible is missing, the remaining part can be informative.

The following section refers to the right mandible only. Throughout most of its preserved three meters, the mandible projects in a straight line, curving inward only in the most anterior $60 \mathrm{~cm}$. At the distal end, the mandible twists inward and slightly upward. The residual dental groove extends from ap-

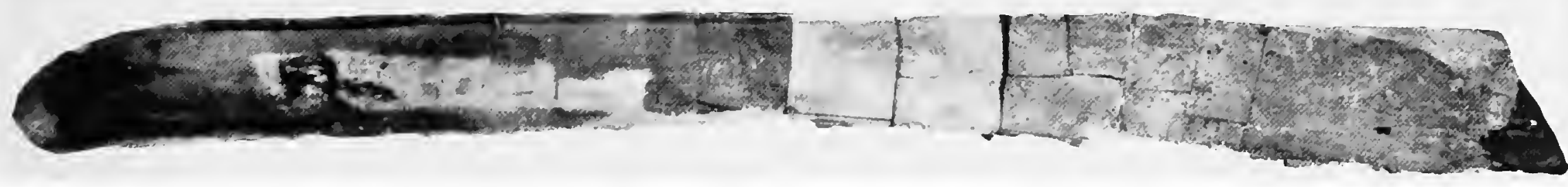




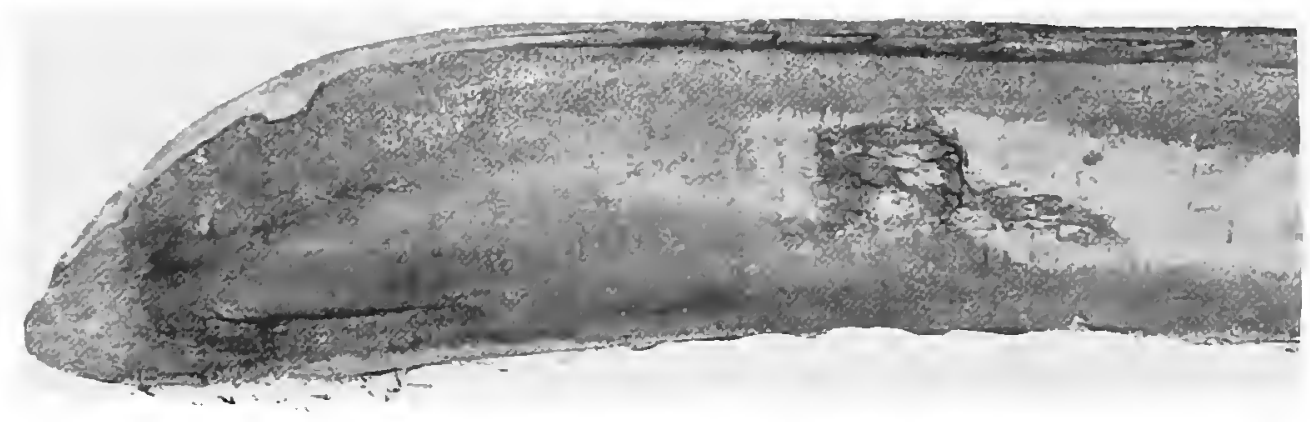

$20 \mathrm{~cm}$

FIGURE 13.-Right mandible (anterior end).

proximately the middle to the distal end of the preserved portion of the mandible, immediately below and internal to the narrow, rounded dorsal edge. From a width of $1 \mathrm{~cm}$ at the preserved proximal end, this groove rapidly widens to $4 \mathrm{~cm}$ at the anterior extremity of the jaw. The depth of the dental groove correspondingly increases from $3 \mathrm{~cm}$ to $5 \mathrm{~cm}$. At the most proximal point, the dental groove is positioned at the midline of the mandible and is a wide notch separating two terminal projections of bone.

From the distal end of the mandible extending posteriorly along the internal face, $5 \mathrm{~cm}$ above the lower edge of the jaw is a broad swollen ridge, $1 \mathrm{~cm}$ high and $35 \mathrm{~cm}$ long. On the external side near the dorsal surface of the mandible are five large foramina spaced 16 to $25 \mathrm{~cm}$ apart along the length of the jaw. The most anterior foramen is the largest. It is the posterior end of an anteriorly directed canal that is $25 \mathrm{~cm}$ long, $4 \mathrm{~cm}$ wide, and $2 \mathrm{~cm}$ deep. The foramen itself is round, $1 \mathrm{~cm}$ in diameter; it lies $110 \mathrm{~cm}$ from the distal end of the mandible (measuring along the external curvature).

The height and width of the mandible increase greatly in the posterior direction. In cross section, the anterior end is small in comparison to the posterior.

Cervical Vertebrae (Figures 15-18): Transverse breadth of atlas, 54.0; vertical height of atlas, 38.0; transverse breadth of articular surface of atlas, 39.0; transverse breadth of articular surface (right facet), 16.0; vertical height of articular surface (right facet), 27.0; depth of articular concavity, 9.0; transverse

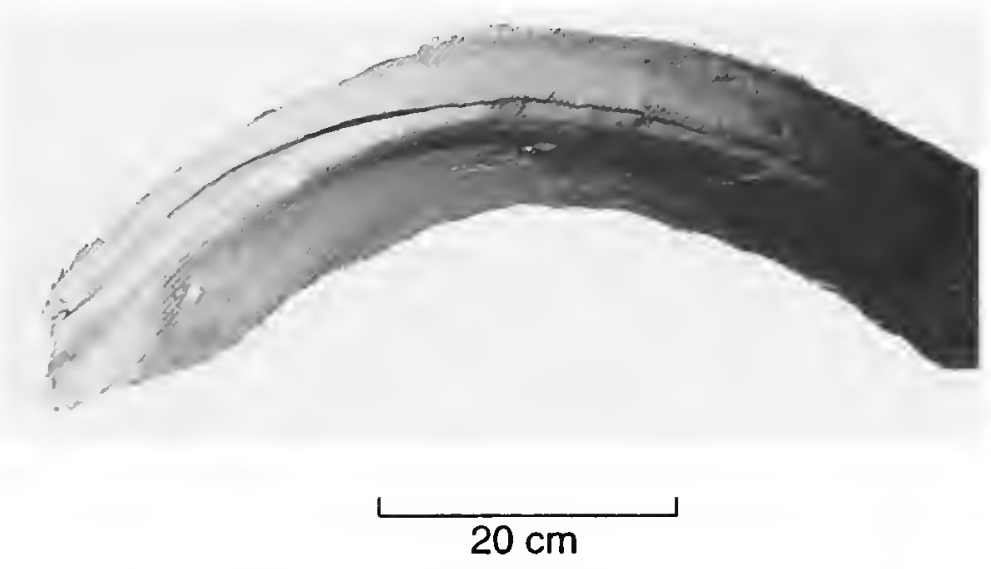

FIGURE 14,-Dorsal view of anterior end of right mandible. breadth of spinal canal (anteriorly), 10.5; transverse breadth of spinal canal (posteriorly), 20.0; vertical diameter of spinal canal (anteriorly), 9.5; vertical diameter of spinal canal (posteriorly), 10.0; ventral length of atlas, 12.5 ; ventral length of atlas with axis, 16.0; ventral length of cervical region, 26.0.

The seven cervical vertebrae are fused together, forming one compact mass. The fusion of the cervicals and the pancake-like thinness of the five posterior cervicals, both of which allow a shortening and strengthening of the neck, are characteristic of all of the balaenids. The development of this condition may be an adaptation to accommodate the intensified amount of water resistance and skull weight caused by the extreme arching of the rostrum and the heaviness of the large mandibles.

No other group of mysticetes possesses a cervical region in which all or most of the vertebrae are fused, although fusion of cervical vertebrae to a lesser extent is a common feature of many odontocetes (Eschricht and Reinhardt, 1866:107).

All of the dorsal transverse processes on the cervical vertebrae are broken. The left halves of the last five neural arches and the right half of the last neural arch in the cervical region also are broken. The remaining portions of neural arches on the

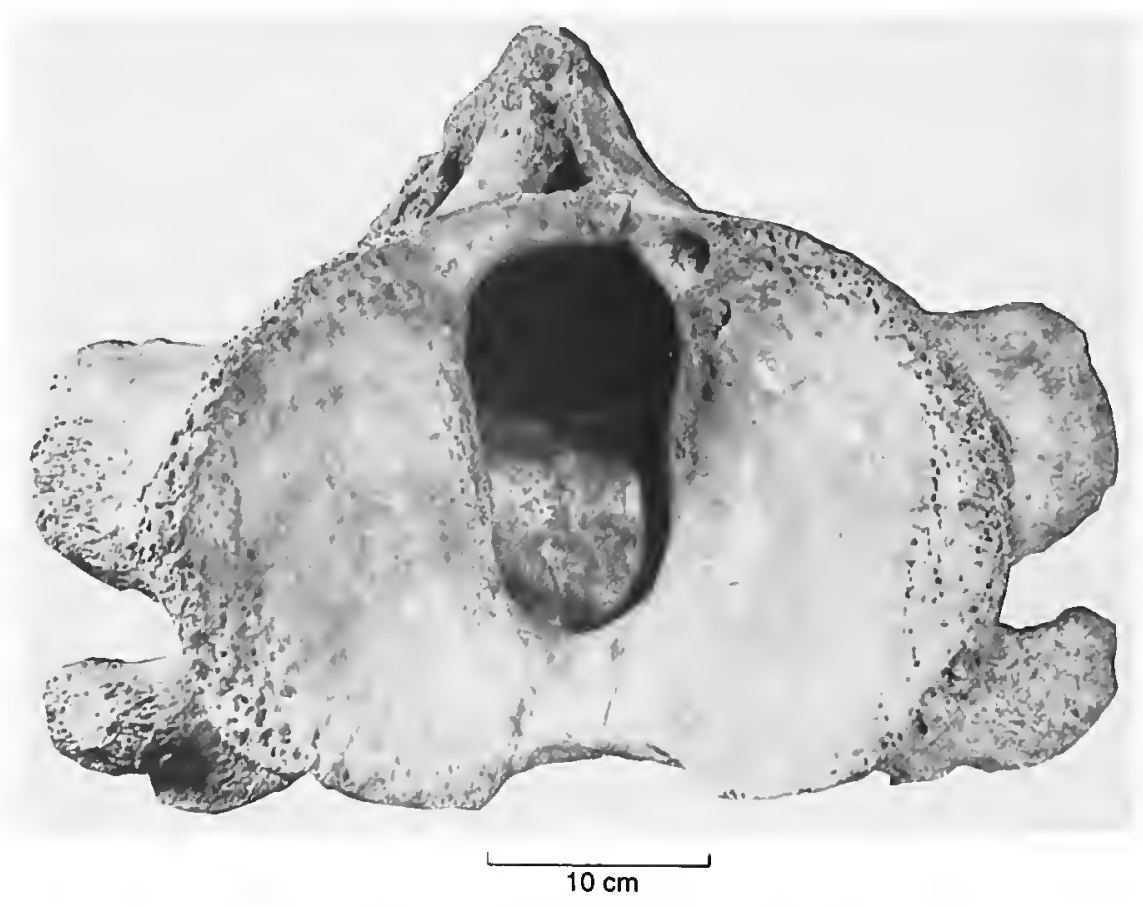

FIGURE 15.-Cervical vertebrae, anterior view. 


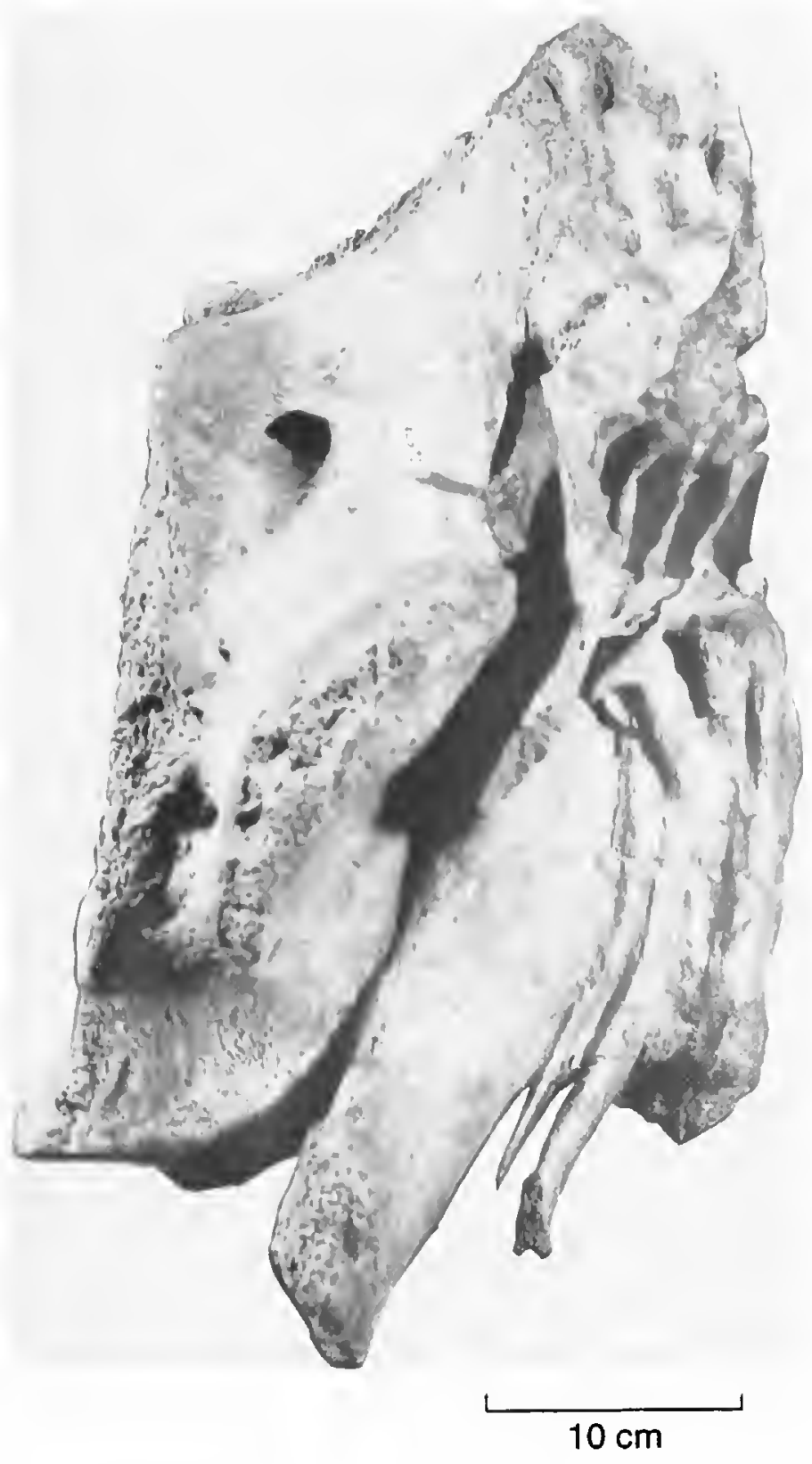

FIGURE 16.-Cervical vertebrae, left lateral view.

last six cervicals are thin, wide, dorsolaterally oriented projections. They unite in an osseous mass that forms the roof of the spinal canal, which in turn is surmounted by a spinal ridge con- sisting of the dorsal processes of these neural arches and the osseous growth uniting them. Of the processes on the atlas, only the dorsal process is fused to the axis. This leaves a wide gap between the atlas and axis on the lateral borders of the neural canal.

On the axis and third cervical vertebra, both ventral transverse processes are present but broken. The base of the left ventral transverse process remains on the fourth cervical and that of the right ventral transverse process on the fifth cervical. Other ventral transverse processes may once have been present, but because the surfaces of several centra are broken, their traces are absent.

The nearly flat dorsal surface of the fused centra, which is the floor of the spinal canal, is interrupted by transverse grooves that represent the lines of fusion between the vertebrae. The spinal canal changes from a subcircular opening at the atlas to an oval that is nearly twice as wide as high at the third cervical.

The second through the sixth cervical vertebrae are ventrally covered by a wide, smooth bone growth, which forms a low ridge down the midline and originates at the anterior edge of the axis (Figure 17). The lateral edges of this growth extend almost to the bases of the inferior transverse processes, where the individual vertebrae may be distinguished. This growth terminates posterior to the atlas, where a distinct transverse groove separates the ventral surface of the atlas from that of the axis.

The atlas is the largest of the seven cervical vertebrae. Its length alone constitutes almost half the length of the cervical region and, combined with the axis, forms the anterior twothirds of the cervical region. The opening in the atlas for the spinal cord and for the odontoid process of the axis is in the shape of an inverted figure eight having a slightly constricted midsection (Figure 15). Just posterior to the dorsal margin of each articular facet of the atlas lies a bridged-over transverse arterial canal (Eschricht and Reinhardt, 1866:108). These canals are $2 \mathrm{~cm}$ wide and nearly $2 \mathrm{~cm}$ high, and they are bridged

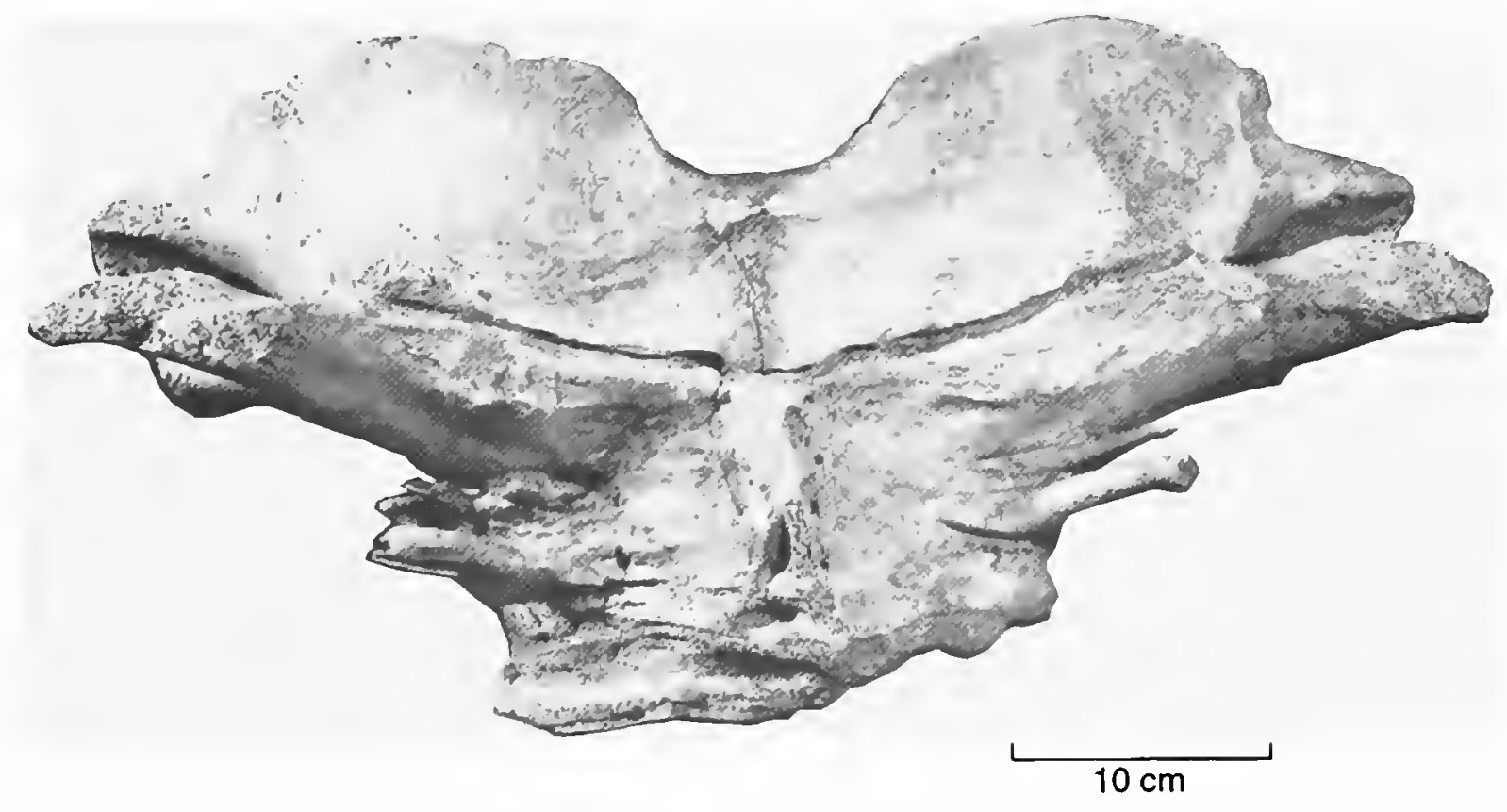

FIGURE 17.-Cervical vertebrae, ventral view. 


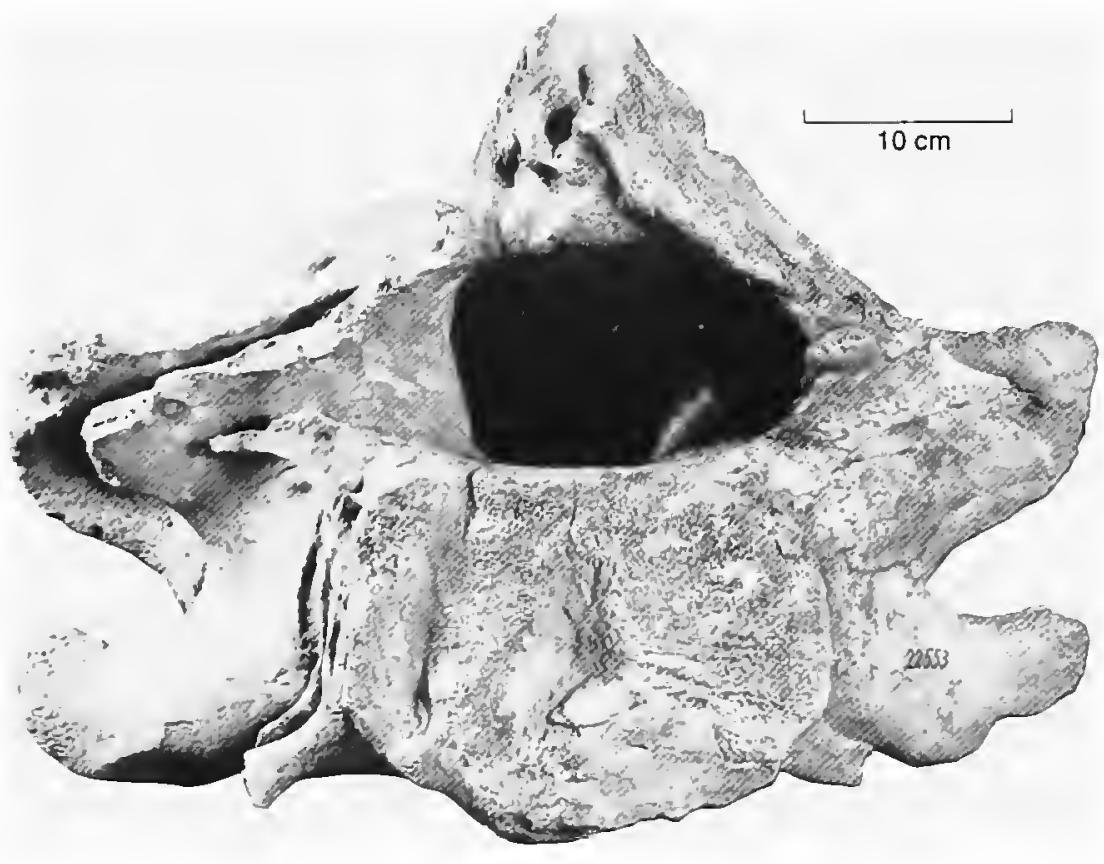

FIGURE 18--Cervical vertebrae, posterior view.

over for a transverse distance of $5 \mathrm{~cm}$ on the right canal and 6 $\mathrm{cm}$ on the left (Figure 16). A large posteriorly directed pit $3 \mathrm{~cm}$ in diameter lies at the base of the dorsal process of the atlas (Figure 15). This large cavity may have been the site of cartilage that did not ossify. The transverse processes of the atlas are thick and broad, but their length cannot be ascertained because the ends are broken.

The dorsal transverse processes of the axis are much more delicate than those of the atlas (Figure 16). These axial processes are almost as wide vertically but are about one-third as thick as those of the atlas. The length is indeterminable because both processes are broken. The ventral transverse processes of the axis are approximately $16 \mathrm{~cm}$ long, but their ends are worn and may not be complete. An upward curvature at the ends of the ventral transverse processes and a corresponding down- ward curvature of the dorsal transverse processes form an incomplete ring through which the vertebral artery passed (Eschricht and Reinhardt, 1866:108).

The third through seventh cervicals are almost identical in shape and dimension. All have extremely delicate transverse processes except at the point where they meet the osseous mass that is the roof of the spinal canal. The centra of these cervicals are thin and flat; each is about $1 \mathrm{~cm}$ thick and $16 \mathrm{~cm}$ high, although the seventh is thicker than its predecessors.

Thoracic Vertebrae: Three badly weathered thoracic vertebrae are present. None of these vertebrae possess fused epiphysial disks, and all are too eroded to allow accurate measurements or diagnosis.

Lumbar Vertebrae (Figures 19, 20): Only two lumbar vertebrae have been preserved. Because their exact position in the vertebral column is uncertain, the more anterior vertebra has been designated lumbar- $\mathrm{A}$ and the more posterior is lumbar-B. Vertical diameter of centrum (anterior), (A) 21.5, (B) 23.5; transverse diameter of centrum (anterior), (A) 24.0, (B) 26.0; anteroposterior length of centrum, (A) 15.5, (B) 17.5; height to top of dorsal process, (A) $57+$, (B) $55+$; transverse diameter of neural canal (anterior), (A) 12.0, (B) 9.0; vertical diameter of neural canal (anterior), (A) 7.0, (B) 5.0; transverse length of transverse processes, (A) $33+$, (B) $26+$.

The transverse processes of lumbar-A are longer than twice the anteroposterior length of the centrum, and they are directed slightly anteriorly. The neural spine of the vertebra is broken but is $27 \mathrm{~cm}$ in height and is directed posterodorsally at about a $70^{\circ}$ angle. Neither vertebral epiphysis has fused to the centrum of lumbar-A.

The dimensions of lumbar-B are similar to those of lumbar$\mathrm{A}$, but the processes and neural canal are smaller, although the centrum is larger in diameter. The anterior epiphysis may have fused to the centrum of lumbar- $\mathrm{B}$, but this is uncertain because

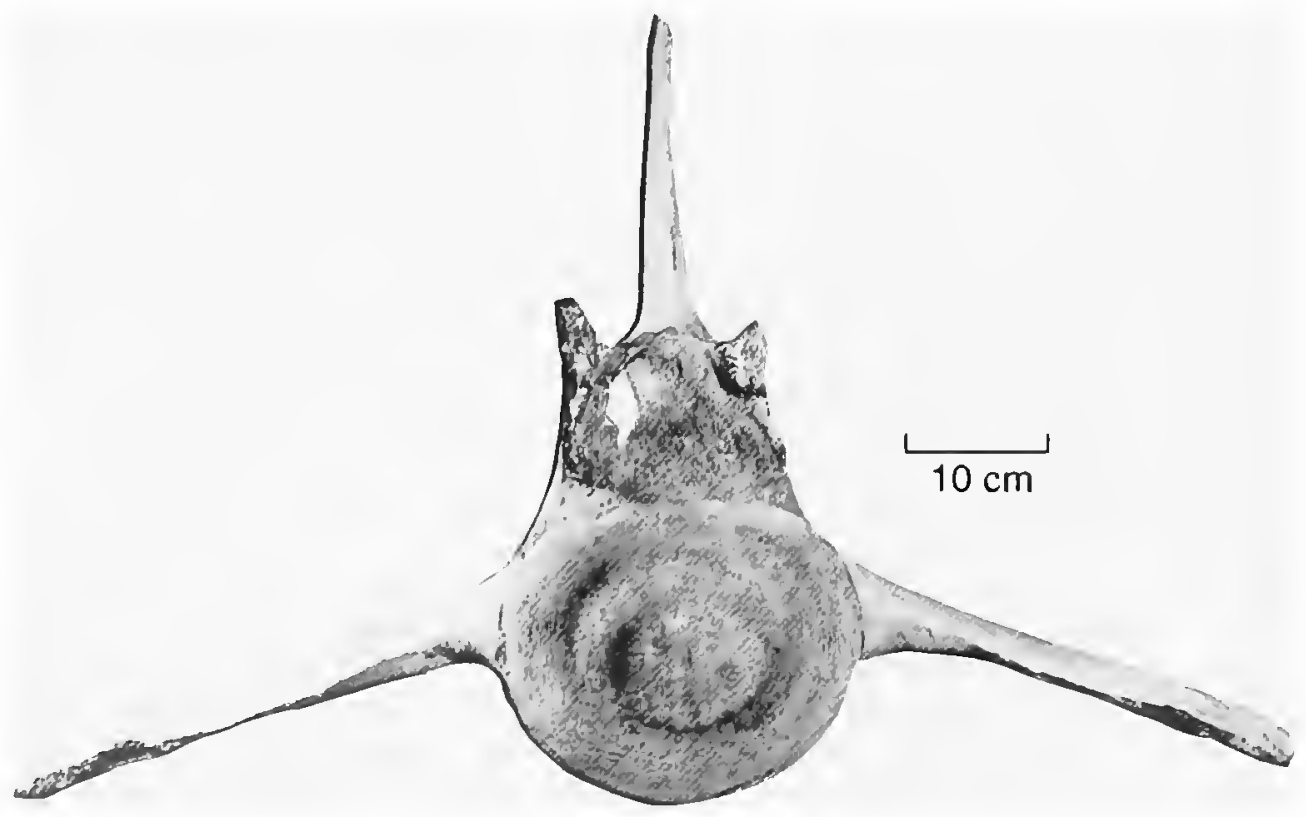

FIGURE 19.-Lumbar vertebra, anterior view. 


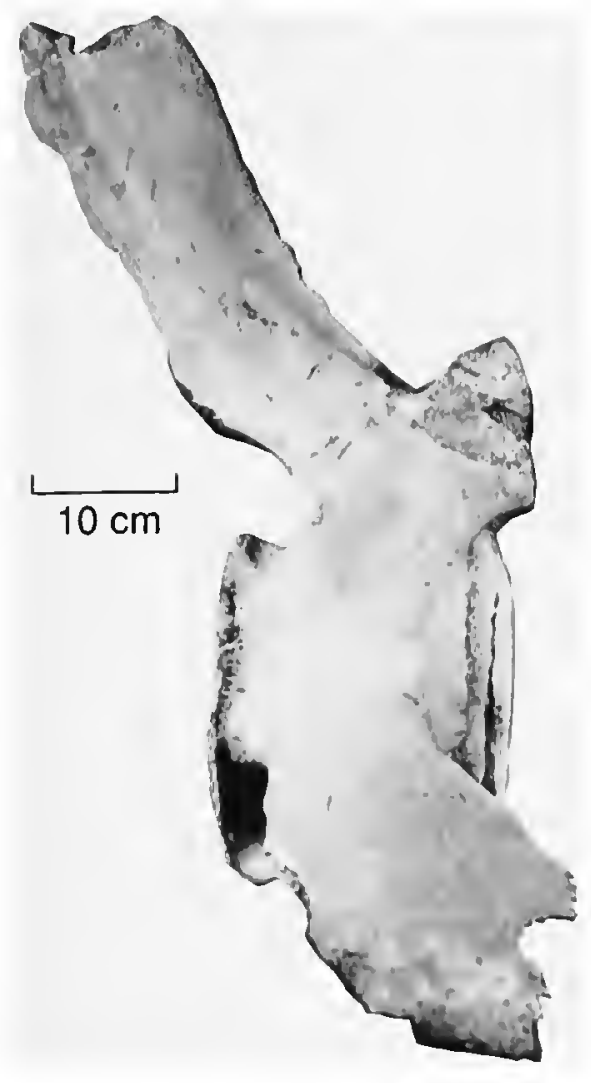

a distinct suture exists in the entire circumference between the two.

Caudal Vertebrae (Figures 21, 22, Table 2): Measurements of the first caudal vertebra (see Table 2 for others): Vertical diameter of centrum (anterior), 24.0; transverse diameter of centrum (anterior), 26.0; anteroposterior length of centrum, 20.0; height to top of dorsal process, 55+; transverse diameter of neural canal, 8.5; vertical diameter of neural canal (anterior), 5.0; transverse length of transverse processes, $24+$.

The first caudal vertebra is herein defined as the most anterior vertebra possessing a contact with a chevron bone. Sixteen caudal vertebrae are present and range in length from $20 \mathrm{~cm}$ to $6 \mathrm{~cm}$. The most anterior caudal vertebrae resemble the posterior lumbar vertebra, but these caudals have larger centra, shorter processes, and neural spines that are more vertically directed than the posterodorsally slanted spine of the posterior lumbar. Posteriorly, the vertebral processes diminish rapidly in size so that on the last eight caudal vertebrae present, no transverse processes exist at all, and the $11^{\text {th }}$ caudal present is the last vertebra possessing a neural arch. The first foramina in the transverse processes appear in the sixth caudal vertebra. The foramen on the right transverse process of this vertebra measures more than twice the diameter of the foramen on the left

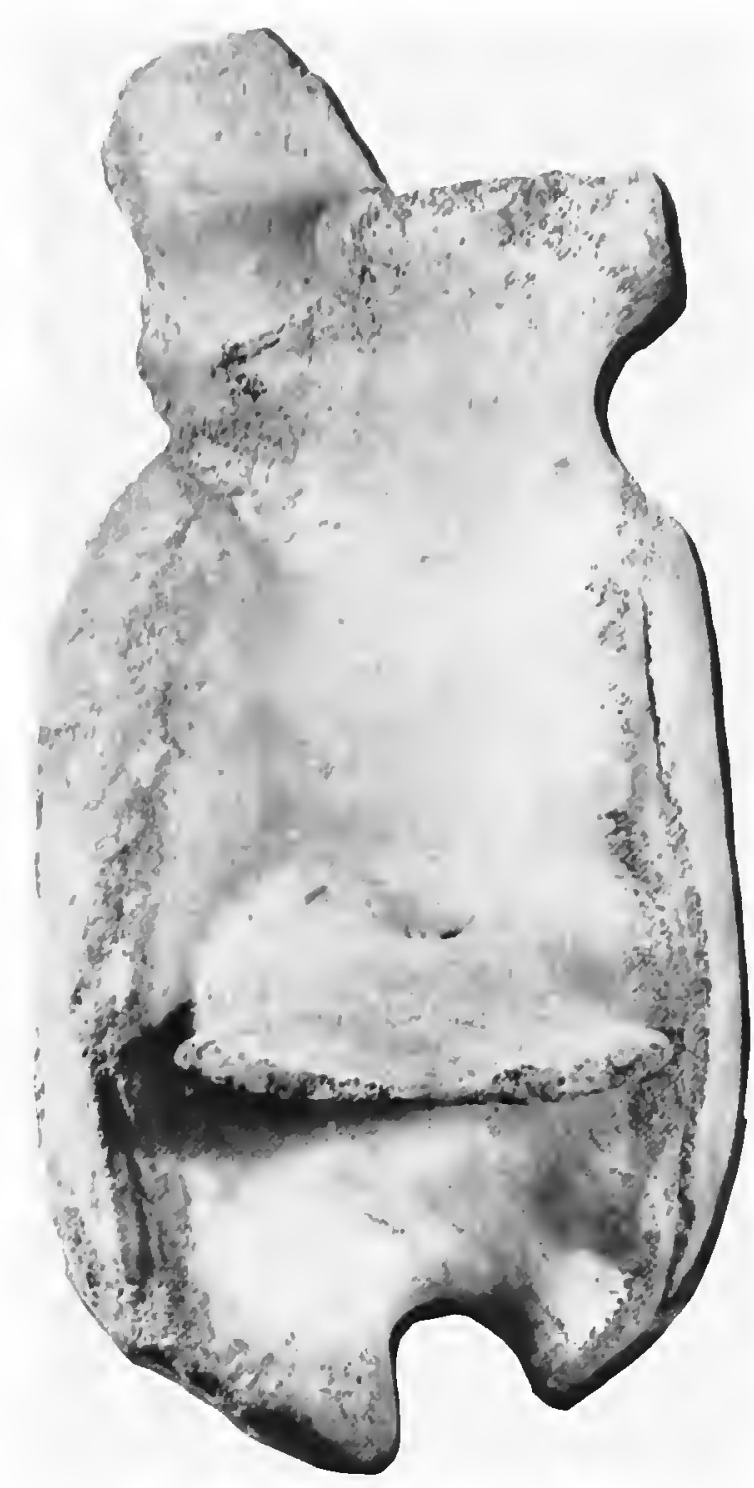

$10 \mathrm{~cm}$

transverse process. On the ventral surface of the caudals, the articular facets for the haemal arches turn increasingly inward on the more posterior vertebrae. By the ninth caudal these facets join to make two foramina, each $3 \mathrm{~cm}$ in diameter. Between these ventral foramina and those of the transverse processes lies a broad, ventrally directed groove on the surface of the centrum. A similar groove extends from the transverse process to the reduced neural arch, where another foramen has formed allowing passage transversely into the neural canal through the sides of the neural arch. Posteriorly, the grooves on the centra gradually become bridged over by bone, and the foramina lengthen into tunnel-like structures. In the $13^{\text {th }}$ caudal present, which is devoid of processes, the tunnel structures are intercon-

TABLE 2.-Caudal vertebraeof Balaena ricei (measurements in $\mathrm{cm}$ ).

\begin{tabular}{|c|c|c|c|c|c|c|c|c|c|c|c|c|c|c|c|}
\hline \multirow{2}{*}{ Measurement } & \multicolumn{15}{|c|}{ Caudal vertebral number } \\
\hline & 2 & 3 & 4 & 5 & 6 & 7 & 8 & 9 & 10 & 11 & 12 & 13 & 14 & 15 & 16 \\
\hline Vertical diameter of centrum (anterior) & 24.5 & 25.0 & 26.0 & 26.0 & 26.0 & 26.0 & 27.0 & 26.5 & 26.0 & 25.5 & 24.5 & 19.0 & 19.0 & 11.5 & 9.0 \\
\hline Transverse diameter of centrum (anterior) & 27.0 & 27.5 & 28.0 & 28.0 & 29.0 & 28.0 & 29.5 & 28.0 & 27.0 & 25.5 & 28.0 & 21.0 & 18.0 & 12.5 & 9.5 \\
\hline Anteroposterior length of centrum & 18.0 & 22.0 & 21.5 & 19.5 & 20.0 & 19.5 & 20.0 & 19.0 & 18.5 & 18.0 & 17.5 & 12.5 & 10.5 & 8.0 & 6.0 \\
\hline Height to top of dorasl process & 54.0 & $53+$ & 52.0 & $49+$ & $45+$ & $43+$ & $41+$ & 39.0 & 35.0 & 33.5 & $29+$ & 21.0 & 17.0 & 12.0 & 9.0 \\
\hline Transverse length of transverse length & 22.5 & 20.5 & $17+$ & 12.5 & 10.0 & 6.0 & $5+$ & $2+$ & - & - & - & - & - & - & - \\
\hline
\end{tabular}




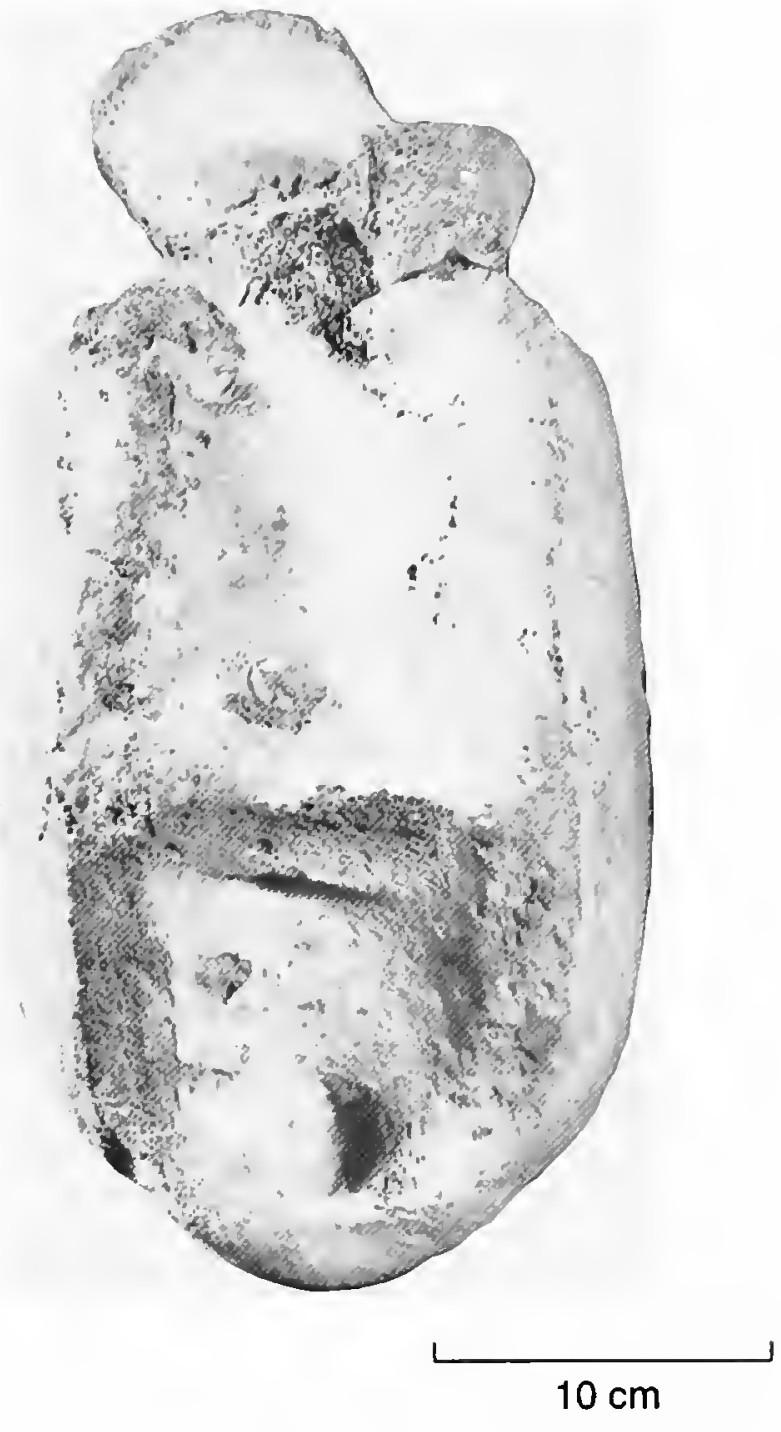

nected, completely encircling the centrum, and are exposed exteriorly only through five moderately sized foramina.

Haemal Arches (Figure 23): The chevrons decrease in height from $24 \mathrm{~cm}$ in the anteriormost to $10 \mathrm{~cm}$ in the posteriormost. Only slight morphological variation exists between the individual chevrons. The intermediate chevrons gradually decrease in size posteriorly, and the smallest have not fused at their vertices. The largest chevrons possess a ventral process but the smallest consist of only an arch.

Sternum: Anteroposterior length, 30.0; transverse breadth, 23.0; thickness, 5.0. Sterna of Balaenidae are characteristically variable (True, 1904). The sternum of Balaena ricei is shaped like an elongated, flat shield (Figure 24). The external surface is convex transversely, giving the appearance of having a low ridge along the midline. Longitudinally, the internal surface is nearly flat with a broad depression at the anterior end. Collectively, these features produce an anteroposterior cross section that is relatively thin anteriorly and posteriorly but thick in the midsection. On the lateral edges of this thickened section is a rough surface indicative of the presence of cartilage. This surface served as the point of articulation for the first pair of ribs.

Ribs (Figure 25): Only one rib remains complete. This also is the only rib with an articulating tubercular process, and it probably belongs to the first pair. The tubercular process is 12 $\mathrm{cm}$ long with a flat end indicative of a point of articulation. The distance from the tubercular process to the distal end is $109 \mathrm{~cm}$,

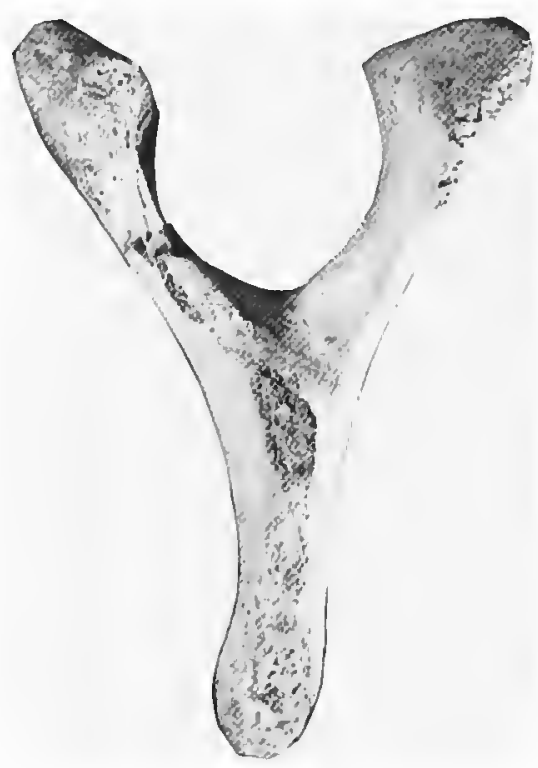

$10 \mathrm{~cm}$

and the external curvature is about $170 \mathrm{~cm}$. The distal end is nearly flat, $13 \mathrm{~cm}$ wide, and $4 \mathrm{~cm}$ thick. The most distal surface is flat to allow articulation with the sternum.

Scapula: Height (glenoid fossa to middle of convex margin), 69.0; greatest anteroposterior length, 86.0; smallest anteroposterior length (at neck), 23.0; glenoid fossa (anteroposterior length), 25.0; glenoid fossa (transverse breadth), 22.0; acromion length (ventral surface), 19.0; coracoid length (dorsal surface), 11.0 .

The presence of the prominent coracoid process on the scapula (Figures 26,32) of Balaena ricei is similar to that of the scapula of B. mysticetus and unlike that of Eubalaena glacialis, which lacks the coracoid process (True, 1904). The $7 \mathrm{~cm}$ high coracoid process of $B$. rice $i$ extends anteriorly for $10 \mathrm{~cm}$ with a slight upward and outward orientation. This process is stout, is

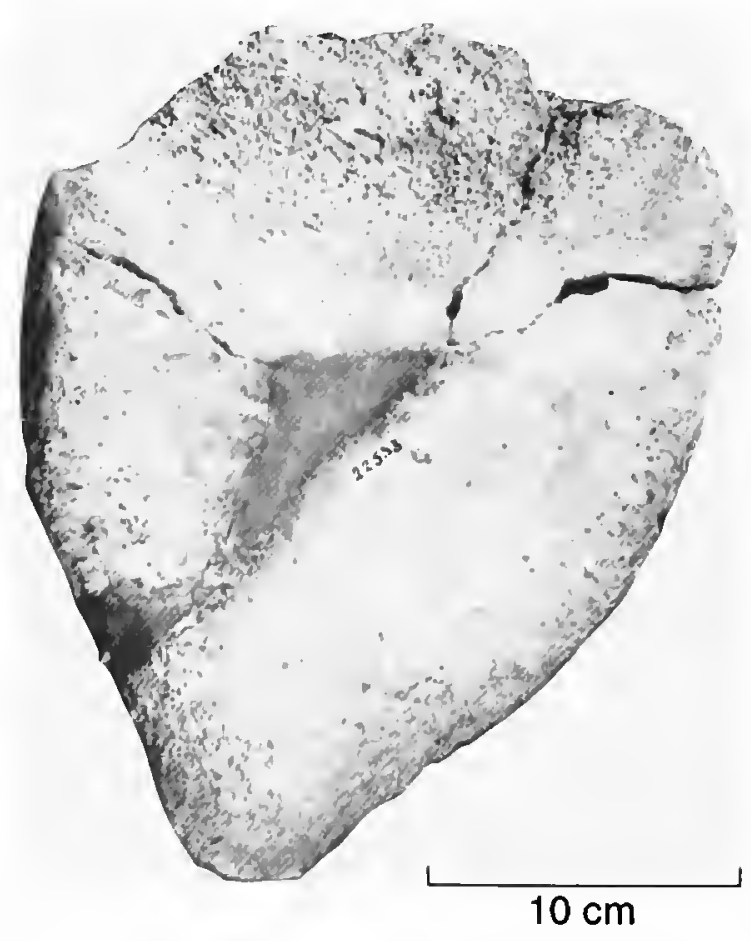

FIGURE 24.--Sternum, dorsal view. 


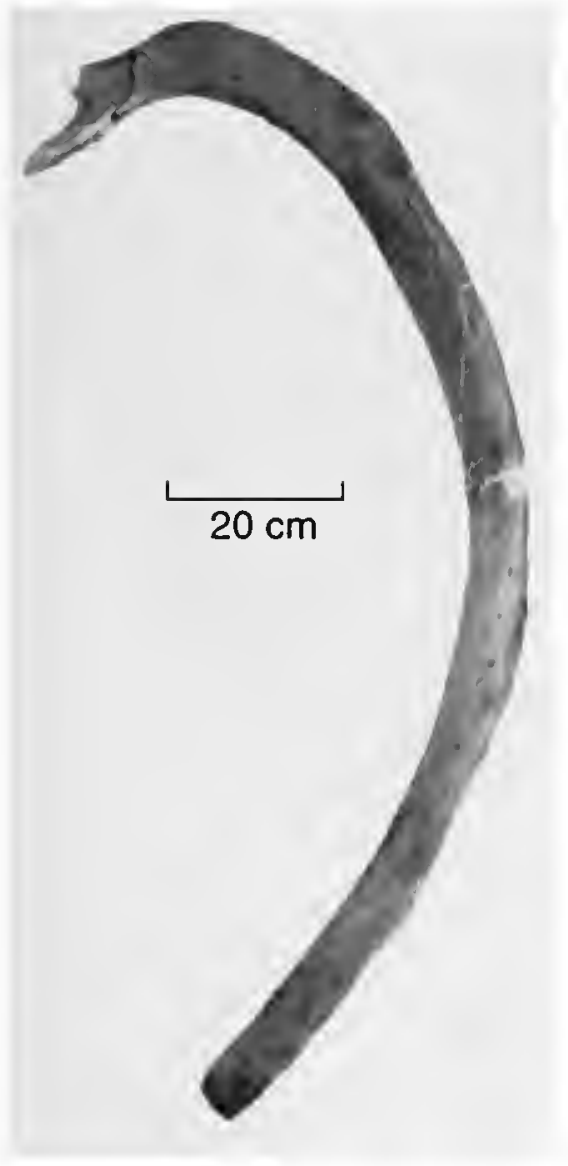

Figure 25 (left).-Right first rib, posterior view.

FIGURE 26 (right).-Right scapula, lateral view.

ovate in cross section, and has a width more than one-half its height.

The acromion process is larger than the coracoid process, but proportionately it is not as sturdy. The acromion curves internoventrally for $21 \mathrm{~cm}$ from its origin above the coracoid process to the acromion's anterior end. At this point the acromion is parallel to the coracoid process. The spina scapulae extends as a sharp ridge from the dorsal midsection of the acromion process to the external anterior edge of the scapula, meeting it at mid-height. The anterior edge of the scapula is $4 \mathrm{~cm}$ wide and shallowly convex at this point.

The anteroposterior length of the scapula is $20 \%$ greater than its height. The breadth of the neck is about $27 \%$ of the maximum anteroposterior length of the scapula. The neck of the scapula of $B$. rice $i$ is thus more robust than that of $B$. mysticetus, which possesses a scapular neck having a breadth only about $21 \%$ of the convex margin (Eschricht and Reinhardt, 1866).

The posterior edge of the scapula is rounded and about $3 \mathrm{~cm}$ thick. The glenoid fossa is elliptical in circumference and shallowly concave at the center where the head of the humerus articulates with it.

Humerus (Figures 27, 28, 32): Length, 48.5; greatest transverse diameter (proximal), 21.5; anteroposterior diameter (proximal), 28.0; greatest transverse diameter (distal), 13.0; anteroposterior diameter (distal), 23.5; least circumference of shaft, 49.0 .

The humerus is similar in design and structure to the humeri of the other mysticetes. The head of the humerus is large and rounded, tilting outward and backward to allow the maximum amount of freedom from restraint at the point of contact with the glenoid fossa of the scapula. There is a shallow groove be-

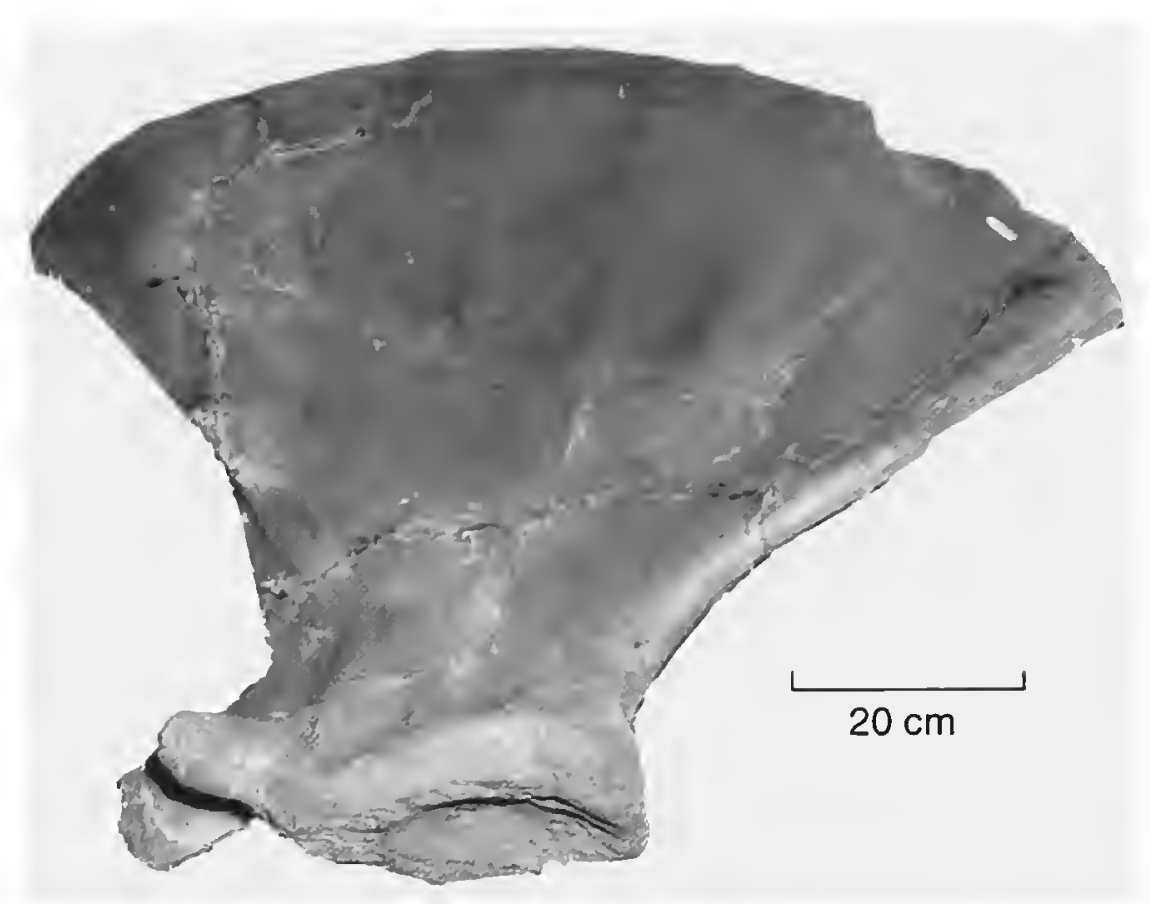

tween the head and the shaft, indicating that fusion of the proximal epiphysis was not yet complete in this specimen. The midsection of the shaft is straight and has only slight lateral curvature, whereas the anterior and posterior sides of the shaft are rounded. At its distal end, the humerus flares out, forming a broad point of contact for the radius and ulna. At this contact, the base of the humerus is $\mathrm{V}$-shaped. The $\mathrm{V}$ forms a $130^{\circ}$ angle, and at the vertex the humerus is $13 \mathrm{~cm}$ thick, transversely. Another $\mathrm{V}$-shaped angle of articulation is situated at the posterior edge of the point of articulation between the ulna and the humerus. This is the contact point for the olecranon process of the ulna where it abuts the posterior edge of the distal end of the humerus. This surface forms a $140^{\circ}$ angle with the contact for the main proximal articular face of the ulna.

Radius (Figures 29, 32): Length, 52.0; transverse diameter (proximal), 12.0; anteroposterior diameter (proximal), 19.0; transverse diameter (distal), 10.5; anteroposterior diameter (distal), 22.5; least anteroposterior diameter of shaft, 17.5.

The radius is flatter and slightly longer than the humerus. The proximal end of the radius is thicker transversely and narrower anteroposteriorly than the distal end, which is flat and widened anteroposteriorly to accommodate the carpals. The distal ends of the ulna and radius form a broader articular surface for the carpals $(45 \mathrm{~cm})$ than the distal end of the humerus, which is only $26 \mathrm{~cm}$ wide. The anterior edge of the radius curves outward anteriorly, widening the bone considerably and flattening the edge into a comparatively thin border. The posterior edge is concave, creating a $6 \mathrm{~cm}$ gap internally between the midsections of the radius and ulna when these bones are articulated.

Ulna (Figures 30-32): Length, 49.0; transverse diameter (proximal), 10.0; anteroposterior diameter (proximal), 16.0; transverse diameter (distal), 7.0; anteroposterior diameter (distal), 21.0; least anteroposterior diameter of shaft, 9.5 .

The ulna is lacking its distal epiphysis but is only slightly shorter than the radius, which is complete. At the proximal end of the ulna, the olecranon process also is lacking. This process 


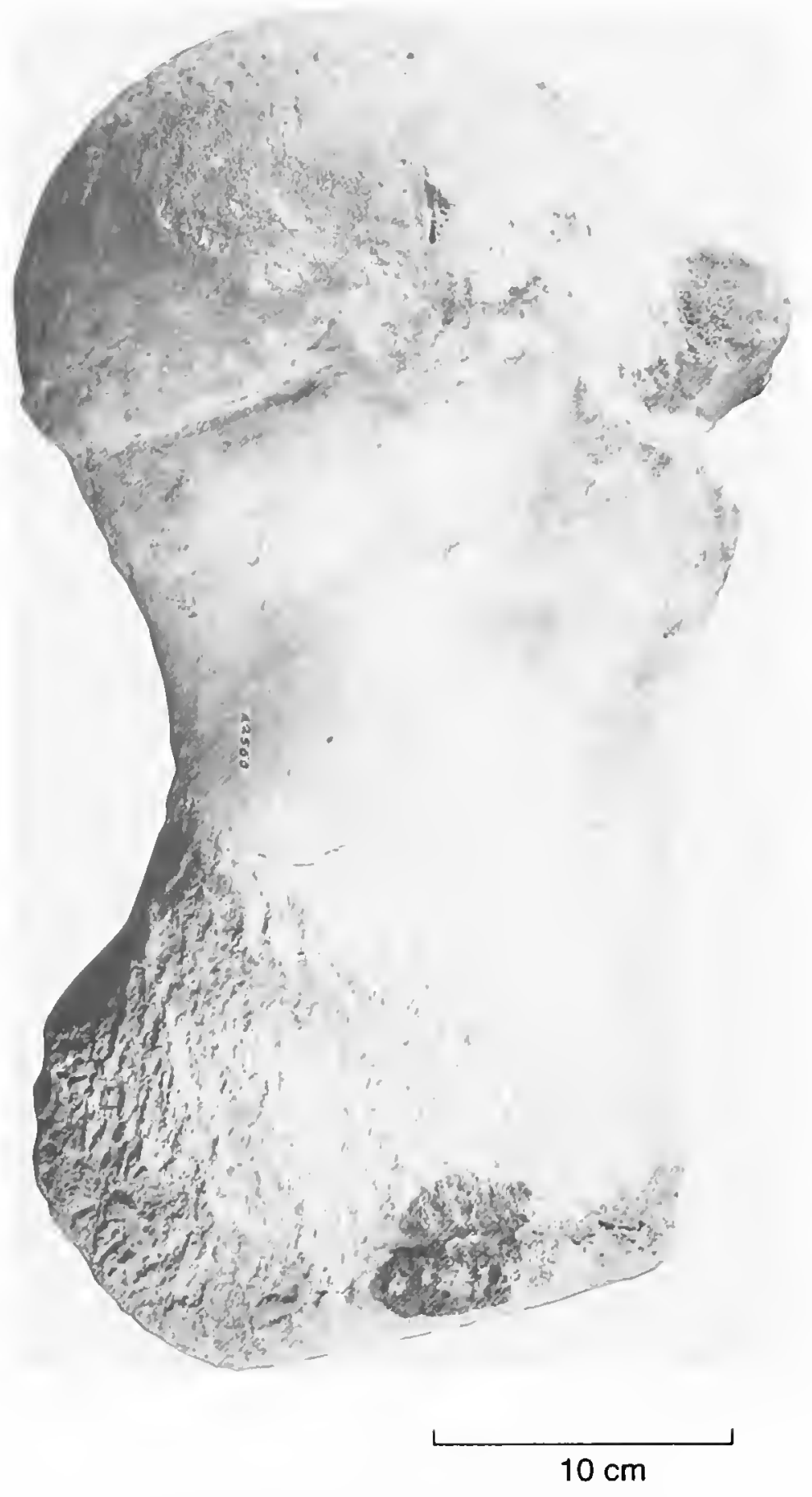

FIGURE 27.--Right humerus, lateral view.

probably had not yet fused to the main body of the ulna, but it also may not have ossified bcfore the animal died. When the olecranon process is present, the ulna is nearly immobilized in its contact with the humerus and radius. This locking fit gives the flipper rigidity against the resistant water pressures met during swimming. As in the radius, the distal end of the ulna is flared, providing a wide carpal area of contact and creating a broader external surface toward the extremity of the flipper. The anterior edge of the ulna extends from the distal flare in a nearly straight diagonal line to the base of the proximal contact against the radius. The posterior edge is curved in a wellrounded, anteriorly directed arc.

Metacarpals (Figure 33): The only bones of the manus present are the four largest metacarpals. The metacarpals are basically similar in shape (Table 3 ), and size is the principal characteristic distinguishing them. Each metacarpal resembles

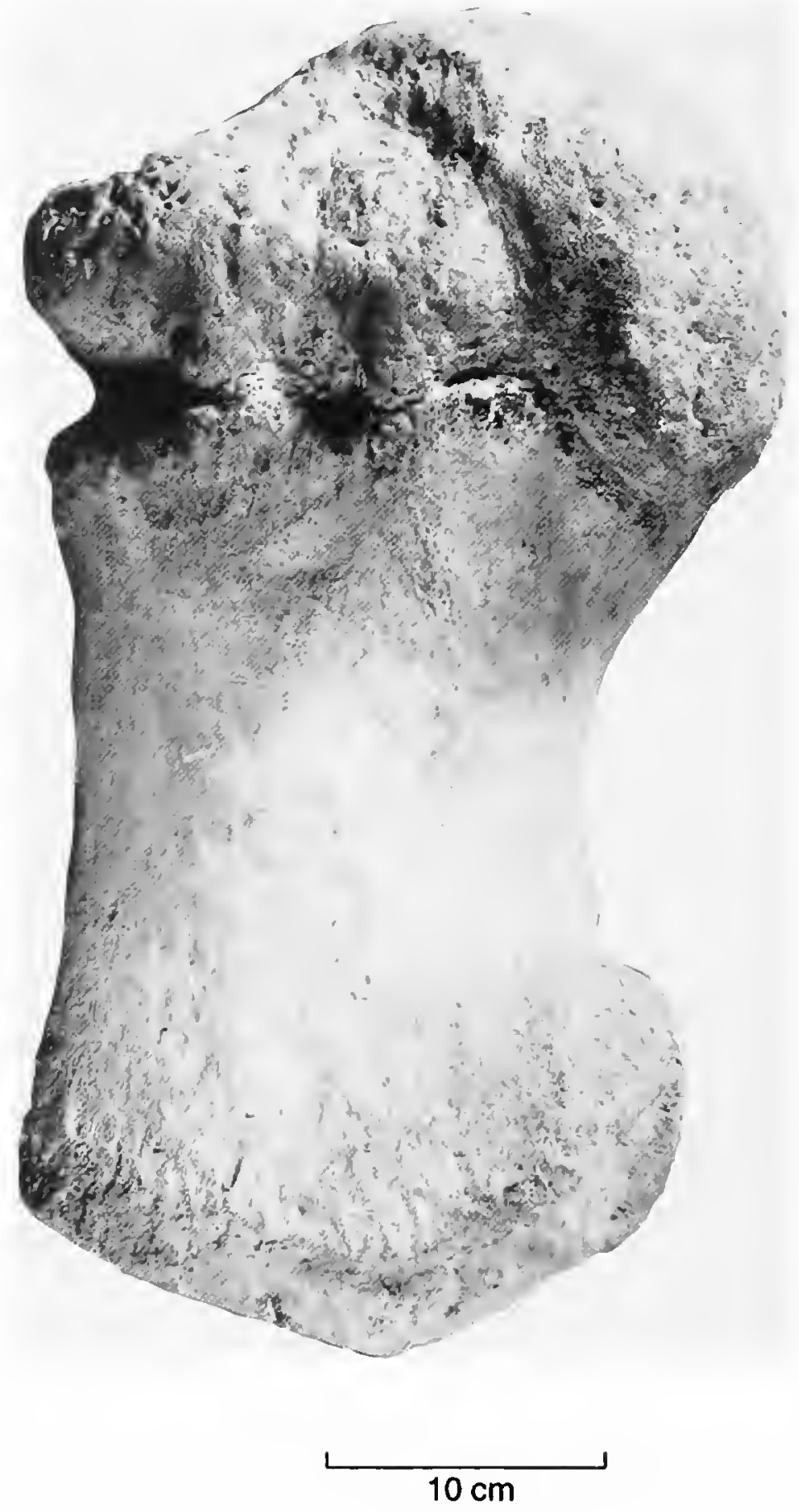

FigURE 28.-Right humerus, medial view.

a flattened cylinder with a flared proximal end. All ends have the rough porous appearance that cartilage-covered bone possesses.

Discussion.-This specimen closely resembles Balaena mysticetus but on a smaller scale. Some differences are notable, but, as many of the most advanced characteristics of B. mysticetus (such as the lack of a coronoid process on the mandible) have not been preserved in this specimen, a complete comparison is prevented. The mysticete flipper illustrates another struc-

TABLE 3.-Measurements of metacarpals (in cm).

\begin{tabular}{c|cccc}
\hline Metacarpal & Length & Proximal width & Distal width & Proximal thickness \\
\hline 2nd & 10.5 & 9.0 & 7.0 & 5.5 \\
3rd & 13.5 & 10.0 & 8.0 & 6.0 \\
4th & 9.5 & 10.0 & 7.0 & 5.0 \\
5th & 7.5 & 8.5 & 5.0 & 4.0 \\
\hline
\end{tabular}




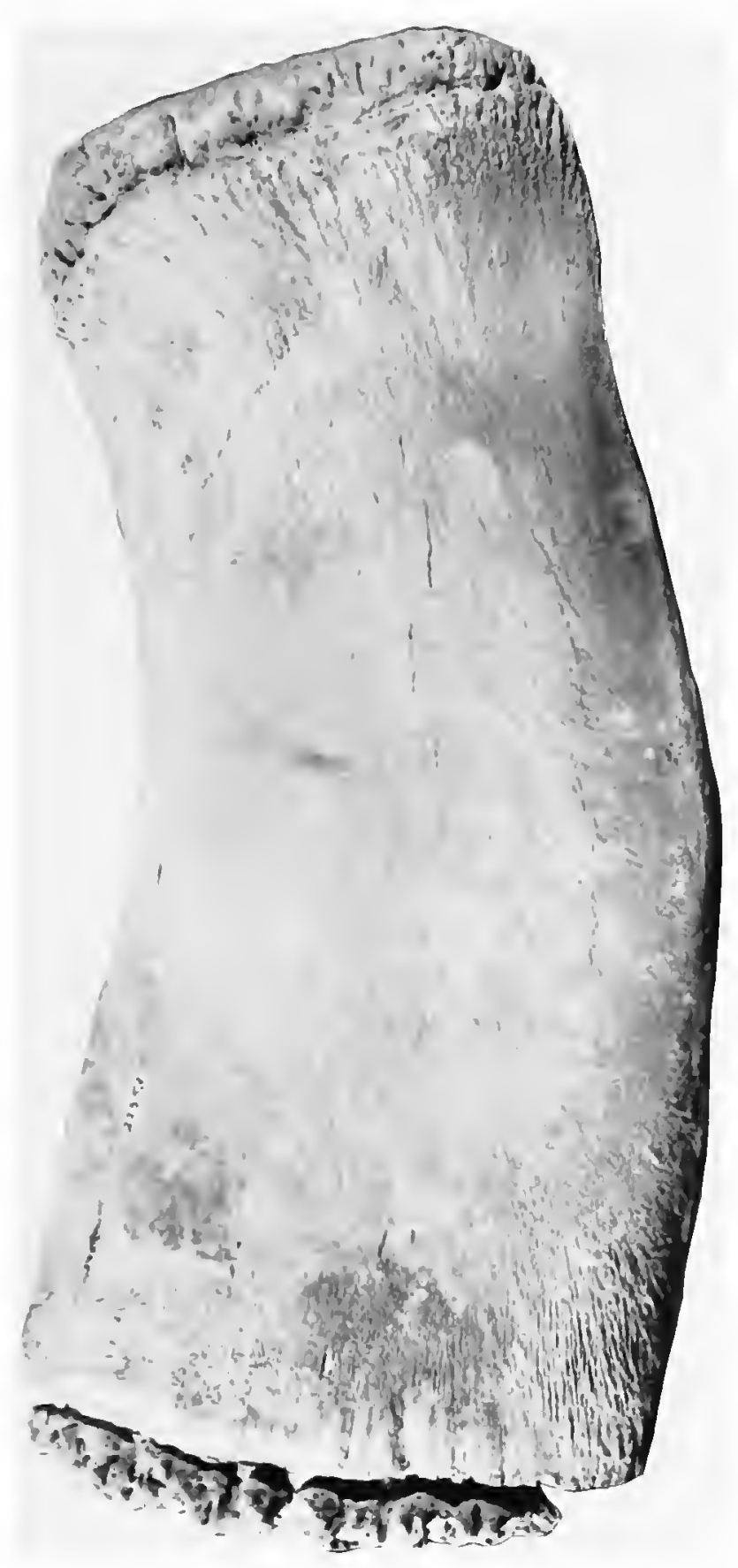

FIGURE 29 (left).-Right radius, lateral view.

FIGURE 30 (right).--Right ulna, medial view.

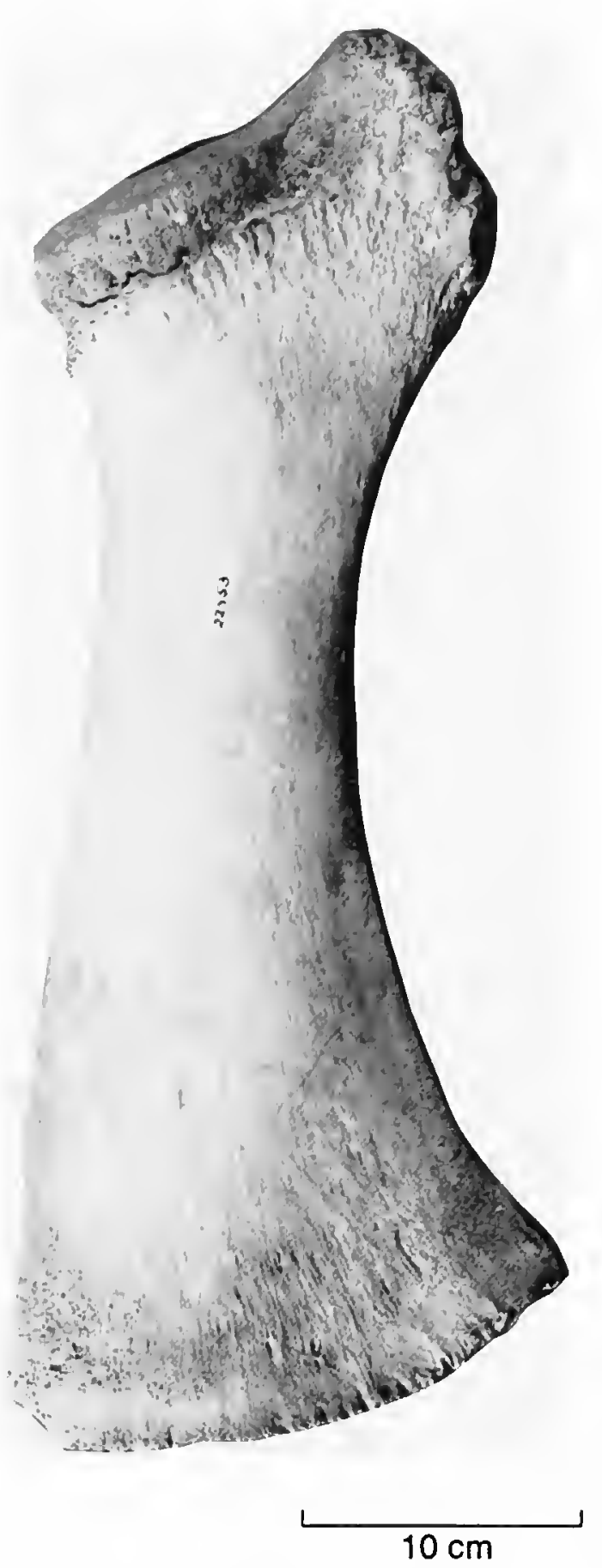

$10 \mathrm{~cm}$

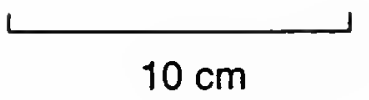

ture that has undergone extreme modification. The lengthening of the radius and ulna in comparison with the humerus is evidenced in most of the genera of whalebone whales, including Balaena. The relationship of the length of the forearm to that of the humerus in $B$. mysticetus is approximately 3 to 2 , whereas in $B$. ricei it is about 1 to 1 . The humerus of $B$. mysticetus has been described as "very short and thick, almost as broad as long (as 4 to 5)" (Eschricht and Reinhardt, 1866:129). That of $B$. ricei is much more elongate and narrow, the thick proximal end being only a little more than one-half as wide as the bone is long, a width-to-length ratio of about 1 to 2 . In the caudal region more distinctions may be noted between B. mysticetus and $B$. ricei. In $B$. mysticetus the anterior caudals have very diminished traverse processes, and foramina for the branches of the aorta may be present on the transverse processes of the second caudal (Eschricht and Reinhardt, 1866:124). In B. ricei, however, the transverse processes are not completely absent until the $12^{\text {th }}$ caudal, and foramina on the transverse processes do not appear before the fifth caudal. A major point of distinction between $B$. mysticetus and $B$. ricei may be observed in comparing the atlas vertebrae. The atlas of $B$. ricei possesses a figureeight-shaped opening, the upper one-half for the spinal cord and the lower half for the odontoid process of the axis (Figure $15)$. From an anterior view, therefore, the odontoid process is clearly visible. The atlas of $B$. mysticetus possesses no opening for the odontoid process of the axis, and from the anterior view the only visible portion of the centrum of the axis is that which is incorporated in the floor of the neural canal. The same is true of B. etrusca Capellini, 1873, which is much larger than $B$. ricei: its fused cervical vertebrae measure $260 \mathrm{~mm}$ anteroposteriorly as opposed to $166 \mathrm{~mm}$ for $B$. ricei.

Balaena mysticetoides Emmons, 1858, was based upon a tympanic bulla from the Yorktown Formation of North Caro- 


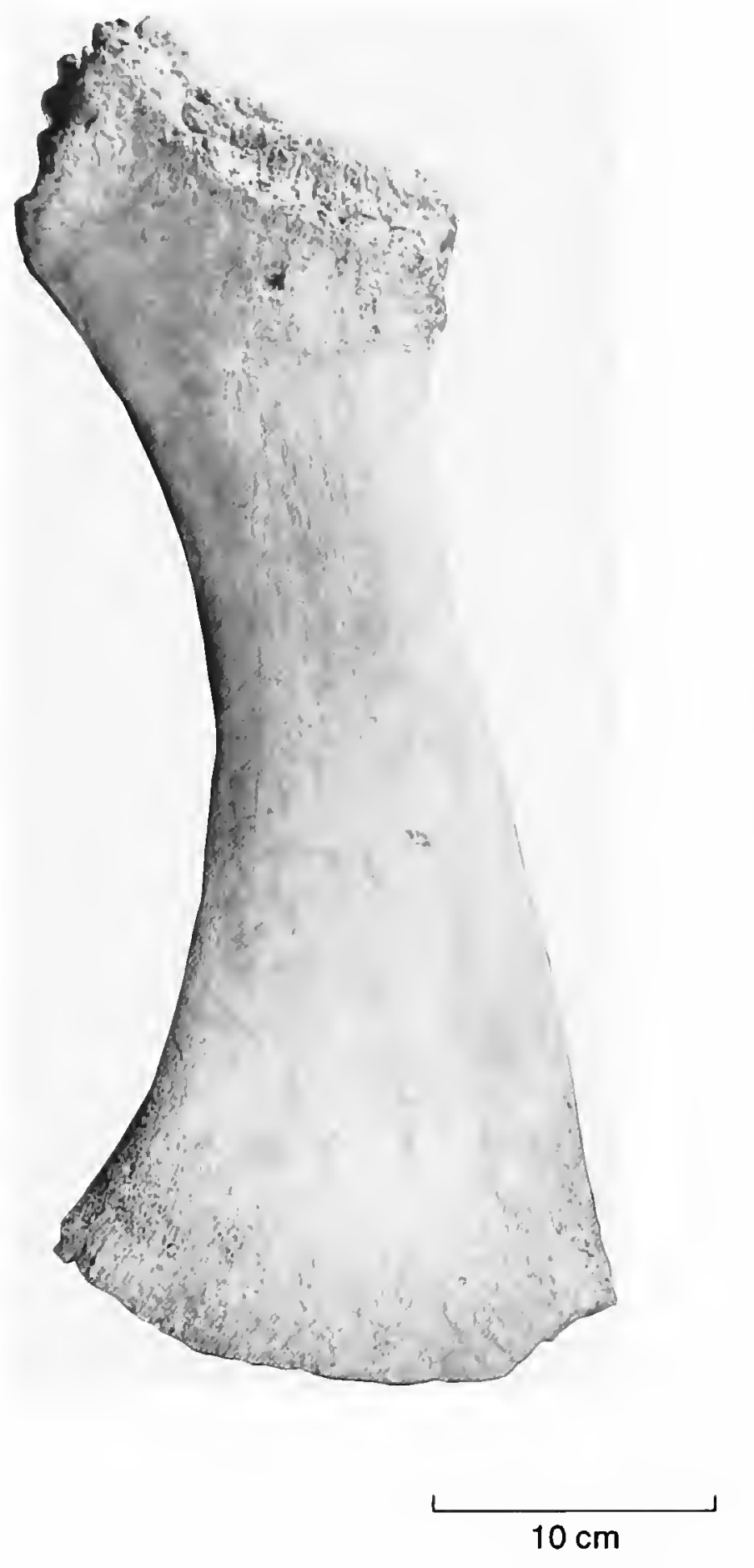

lina (McLeod et al., 1993). The holotype specimen has been lost, but the figure presented by Emmons (1858, fig. 26) is of a nondiagnostic tympanic bulla of an indeterminate mysticete.

Balaena svedenborgii Lilljeborg, 1867 , possesses a distinctly different caudal section from that of $B$. ricei. According to Lilljeborg, foramina do not appear in the transverse processes until the $10^{\text {th }}$ caudal (fifth in B. ricei), and the lower channel for the branches of the aorta at the point of attachment for the haemal arches does not become a closed canal until the $15^{\text {th }}$ caudal (eighth in B. ricei; Figure 22). McLeod et al. (1993:52) synonymized $B$. svedenborgii with $B$. mysticetus.

Balaena primigenia Van Beneden, 1872, is based upon only a posterior sphenoid, several tympanic bullae, a complete rib, and a phalanx. This species thus has no diagnostic parts comparable with $B$. ricei.

In 1852, Leidy described B. palaeatlantica and B. prisca. Balaena palaeatlantica, from the Miocene at City Point on the
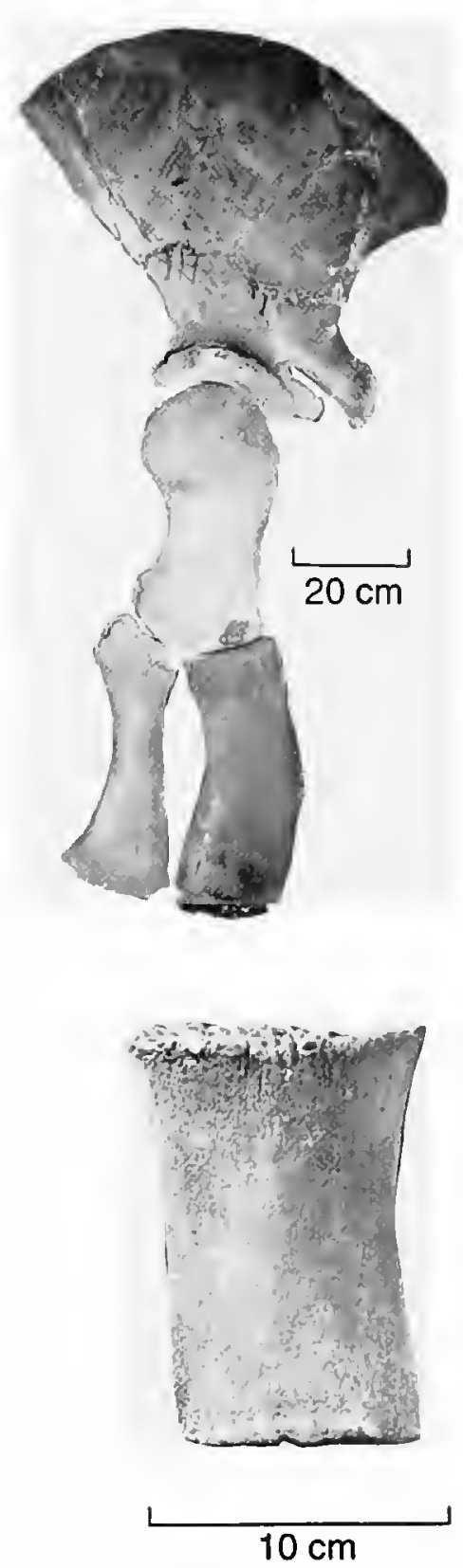

James River in Virginia, is based upon an $81 \frac{1}{2}$ in. $(21.6 \mathrm{~cm})$ fragment of mandible, some vertebrae, and a zygomatic process. (The term Miocene as used by Leidy in 1852 includes beds that we would now designate as Pliocene.) The transverse measurements of the mandibular fragment are 2 in. $(5.2 \mathrm{~cm})$ anteriorly and $23 / 4$ in. $(7.0 \mathrm{~cm})$ posteriorly. The height is $3 \frac{3}{4} \mathrm{in}$. $(9.5 \mathrm{~cm})$ anteriorly and $4 \frac{1}{2} \mathrm{in}$. $(11.4 \mathrm{~cm})$ posteriorly. Balaena prisca is based upon a mandibular fragment 14 in. $(35.5 \mathrm{~cm})$ long. The vertical diameter is $3 \mathrm{in} .(7.6 \mathrm{~cm})$ and the transverse diameter, 2 in. $(5.0 \mathrm{~cm})$. Kellogg (1968) regarded this specimen as undiagnostic. These mandibular fragments represent species much smaller than $B$. ricei, and the holotype of $B$. prisca was considered by both Cope and Kellogg (Kellogg, 1968:125) to be from a cetothere.

Balaena simpsoni Philippi, 1887 , is based upon a badly broken occipital shield, which Philippi admitted could not be accurately diagnosed. It represents an adult estimated to be 20-25 ft. (6-7.5 m) long. Donoso-Barros (1976) placed this species in the genus Caperea. Fordyce (1984) regarded it as undiagnostic.

Balaena affinis Owen, 1844, B. definita Owen, 1844, and $B$. pampaea Ameghino, 1891, are based upon tympanic bullae 
TABLE 4.-Measurements of the supraoccipital shield of Balaena montalionis and B. ricei (in $\mathrm{cm}$ ).

\begin{tabular}{l|cc}
\hline \multicolumn{1}{c|}{ Mcasurement } & $\begin{array}{c}\text { Balaena } \\
\text { montalionis* }\end{array}$ & $\begin{array}{c}\text { Balaena } \\
\text { ricei }\end{array}$ \\
\hline From superior margin of foramen magnum to apex of occipital shield & 53.0 & 67.0 \\
Width at level of superior margin of foramen magnum & $66.0^{\dagger}$ & 78.0 \\
Width 150 mm anterior to foramen magnum & 52.5 & 71.0 \\
Width 300 mm anterior to foramen magnum & 43.0 & 67.5 \\
Width 400 mm anterior to foramcn magnum & 30.5 & 56.6 \\
\hline * Mcasurements from Capellini (1904)
\end{tabular}

* Mcasurements from Capellini (1904).

${ }^{\dagger}$ This measurement erroneously given by Capellini as $0.066 \mathrm{~m}$.

and thus cannot be compared with $B$. ricei. Balaena definita is based upon a balaenopterid bulla (McLeod et al., 1993).

Balaena montalionis Capellini, 1904, from the Pliocene of Tuscany is based upon a partial skull including a complete occipital shield, squamosals, left supraorbital process of the frontal, nasals, partial maxilla, basioccipital, and basisphenoid (Capellini, 1904, pl. 1). Capellini (1904) stated that the holotype of $B$. montalionis is too incomplete to allow comparison with other fossil balaenids of Tuscany, but that it differs markedly from $B$. mysticetus in the conformation of the supraoccipital. In this respect $B$. montalionis also differs from $B$. ricei ( $\mathrm{Ta}$ ble 4), a difference sufficient to differentiate the two species.

\section{Conclusions}

The cosmopolitan occurrence of Balaena in Pliocene time was part of the appearance of the modern whale fauna, dominated by large baleen whales, sperm whales, and the many gen- era of the family Delphinidae (Fordyce, 1989; Whitmore, 1994). This faunal change has been attributed to changes in ocean currents resulting from the growth of the West Antarctic ice sheet, the cutting off of warm water flowing into the Atlantic from the Mediterranean, and the rise of the Isthmus of Panama.

Late Miocene and Pliocene fossils of Balaena are associated in Europe and North America with remains of Balaenula, a smaller genus now extinct (Van Beneden, 1872; Whitmore and Kaltenbach, MS). The relationship between these two genera is on tenuous ground because of the paucity of good fossil material, as is the question of the number of species of Balaena that existed during the Pliocene. This number may be reduced when we know more about size range and intraspecific variation in Pliocene Balaena; but, considering the number of species of Balaenoptera in modern seas, five species of Pliocene Balaena may not be an unreasonable number.

\section{Literature Cited}

Akers, W.H.

1972. Planktonic Foraminifera and Biostratigraphy of Some Neogene Formations, Northern Florida and Atlantic Coastal Plain. Tulane Studies in Geology and Paleontology, 9: 139 pages

Ameghino, $\mathrm{F}$.

1891. Caracteres diagnósticos de cincuenta especies nuevas de mamíferos fósiles argentinos. Revista Argentina de Historia Natural (Buenos Aires), 1(3a):129-167, figs. 26-75.

Berggren, W.A

1973. The Pliocene Time Scale: Calibration of Planktonic Foraminiferal and Calcareous Nannofossil Zones. Nature, 243:391-397.

Blackwelder, B.W.

1981. Late Cenozoic Stages and Molluscan Zones of the United States Middle Atlantic Coastal Plain. Paleontological Society Memoir, 2: $1-34$.

Blow, W.H

1969. Late Middle Eocene to Recent Planktonic Foraminiferal Biostratigraphy. In P. Brönnimann and H.H. Renz, editors, Proceedings of the First International Conference on Planktonic Microfossils, Geneva, 1967, pages 199-422, plates 1-54. Leiden: E.J. Brill.

Campbell, L.D.

1993. Pliocene Molluscs from the Yorktown and Chowan River Formations in Virginia. Publications of the Virginia Division of Mineral Resources, 127: 259 pages, 43 plates.
Capellini, G.

1873. Sulla Balaena etrusca. Memorie dell'Accademia delle Scienze dell'Instituto di Bologna, series 3a, 3:313-331.

1904. Balene Fosili Toscane, 11: Balaena montalionis. Memorie dell'Accademia delle Scienze dell'Instituto di Bologna, series 6, 1:47-54.

Clark, W.B., and B.L. Miller

1912. The Physiography and Geology of the Coastal Plain Province of Virginia. Bulletin of the Virginia Geological Survey, 4: 274 pages.

Donoso-Barros, $\mathrm{R}$.

1976 ("1975"). Contribución al conocimiento de los Cetaceos vivientes y fosiles del territorio de Chile. Guyana, Zoologia, 36:1-127. [Date on title page is 1975; actually published in 1976.]

Emmons, E.

1858. Report of the North Carolina Geological Survey: Agriculture of the Eastern Counties, Together with a Description of the Fossils of the Marl Beds. 314 pages.

Eschricht, D.F., and J. Reinhardt

1866. On the Greenland Right Whale, (Balaena mysticetus Linnaeus). [Publications of the] Ray Society, London, 1866: 150 pages, 106 plates.

Fordyce, R.E.

1984. Evolution and Zoogeography of Cetaceans in Australia. In M. Archer and C. Clayton, editors, Vertebrate Zoogeography and Evolution in Australia, pages 929-948. Perth, Western Australia: Hesperian Press. 
1989. Origins and Evolution of Antarctic Marine Mammals. In J.A. Crame, editor, Origins and Evolution of the Antarctic Biota. Geological Society (London), Special Publication, 47:269-281.

Hazel, J.E.

1971. Ostracode Biostratigraphy of the Yorktown Formation (Upper Miocene and Lower Pliocene) of Virginia and North Carolina. U.S. Geological Survey Professional Paper, 704: 13 pages.

Johnson, G.H.

1969. Guidebook to the Geology of the Lower York-James Peninsula and South Bank of the James River. Guidebook, 1: 33 pages. Williamsburg, Virginia: Department of Geology, College of William and Mary.

1976. Geology of the Mulberry 1sland, Newport News North and Hampton Quadrangles. Virginia Division of Mineral Resources Report of Investigations, 41: 72 pages.

Kellogg, R.

1968. Fossil Marine Mammals from the Miocene Calvert Formation of Maryland and Virginia, Part 5: Miocene Calvert Mysticetes Described by Cope. Bulletin of the United States National Museum. 247:103-132, plates 46-48.

Leidy, J.

1852 ("1851"). [Description of Balaena prisca and B. palaeatlantica.] Proceedings of the Academy of Natural Sciences of Philadelphia. 5(12):308-309. [Date on title page is 1851; published in 1852.]

Lilljeborg, W.

1867. On Two Subfossil Whales Discovered in Sweden. 48 pages, 11 plates. Uppsala: W. Schultz.

Lyell, C.

1845. On the Miocene Tertiary Strata of Maryland, Virginia, and of North and South Carolina. Quarterly Journal of the Geological Society of London, 1:413-427, appendix.

Mansfield, W.C.

1944. Stratigraphy of the Miocene of Virginia and the Miocene and Pliocene of North Carolina. In Julia Gardner, Mollusca from the Miocene and Lower Pliocene of Virginia and North Carolina. U.S. Geological Survey Professional Paper, 199-A:1-16.

McLeod, S.A., F.C. Whitmore, Jr., and L.G. Barnes

1993. Evolutionary Relationships and Classification. In J.J. Burns, J.J.
Mantague, and C.J. Cowles, editors, The Bowhead Whale. Society for Marine Mammalogy, Special Publication, 2:45-70.

Owen, Richard

1844. Appendix to Professor Henslow's Paper, Consisting of a Description of the Fossil Tympanic Bones Referable to Four Species of Balaena. Proceedings of the Geological Society of London, 4:283-286.

Philippi, R.A.

1887. Die Tertiären und Quartären Versteinerungen Chiles. 266 pages, 58 plates. Leipzig: F.A. Brockhaus.

Rogers, B.

1881. A Reprint of Annual Reports and Other Papers on the Geology of the Virginias. 832 pages. New York: D. Appleton \& Co.

True, F.W.

1904. Whalebone Whales of the Western North Atlantic Compared with Those Occurring in European Waters, and Some Observations on the Species of the North Pacific. Smithsonian Contributions to Knowledge. 33: 332 pages, 50 plates.

U.S. Geological Survey

1962. Paleontology, Evolution [Finding of 50-foot Fossil Whale]. In Geological Survey Research 1962. U.S. Geological Survey Professional Paper, 450A:474.

1965. Significant Finds of Vertebrate Fossils in Virginia and Florida. In Geological Survey Research 1965. U.S. Geological Survey Professional Paper, 525A:71.

Van Beneden, P.J.

1872. Les baleines fossiles d'Anvers. Bulletin de l'Académie Royale des Sciences, des Lettres, et des Beaux-Arts de Belgique (Bruxelles), series 2, 34:6-20.

Ward, L.W., and B.W. Blackwelder

1980. Stratigraphic Revision of Upper Miocene and Lower Pliocene Beds of the Chesapeake Group, Middle Atlantic Coastal Plain. U.S. Geological Survey Bulletin, 1482-D: 61 pages.

Whitmore, F.C., Jr.

1994. Neogene Climate Change and the Emergence of the Modern Whale Fauna of the North Atlantic Ocean. Proceedings of the San Diego Society of Natural History, 29:229-238.

Whitmore, F.C., Jr., and J.A. Kaltenbach

MS. Neogene Cetacea of the Lee Creek Phosphate Mine, North Carolina. 


\title{
Paleontology of the Late Oligocene Ashley and Chandler Bridge Formations of South Carolina, 3: Eomysticetidae, a New Family of Primitive Mysticetes (Mammalia: Cetacea)
}

\author{
Albert E. Sanders and Lawrence G. Barnes
}

\begin{abstract}
A new family of relatively large, archaic fossil mysticetes, the Eomysticetidae, is based upon a new genus and new species, Eomysticetus whitmorei, from the late Oligocene Chandler Bridge Formation in the vicinity of Charleston, South Carolina, USA. With the exception of the primitive mysticete Micromysticetus rothauseni Sanders and Barnes (2002), all previously named Cetacea from these deposits are odontocetes. Eomysticetus whitmorei, known by much of an associated skeleton, is a baleen-bearing mysticete having rostral features that are characteristically associated with baleen-whale feeding adaptations. The rostrum is relatively broad and flat, the palate has nutrient foramina associated with baleen development, and the dentaries are elongate, oval in cross section, and edentulous. This whale shares many cranial features with Archaeoceti, e.g., the narrow, elongate intertemporal region, narrow supraorbital processes of the frontals, elongate zygomatic processes of the squamosals, and small cochlear portion and narrow anterior process of the periotic. The numbers and structure of the vertebrae and ribs are intermediate between archaeocetes and cetotheriid mysticetes, and the relative length of the humerus compared with that of the distal limb bones (radius and ulna) is intermediate between those of archaeocetes and Neogene mysticetes.

A second, more highly evolved species, Eomysticetus carolinensis, described herein, is represented by a partial skull also from the Chandler Bridge Formation. The osteology of Eomysticetidae strongly reinforces the ancestral-descendant relationship of Archaeoceti to Mysticeti and helps to substantiate the theory of the monophyly of the Cetacea. Eomysticetus whitmorei is the most archaic baleen-bearing mysticete yet described and survived into late Oligocene time as a relict form. In its degree of cranial telescoping it is more primitive than the contemporaneous toothed mysticetes of the family Aetiocetidae and contemporaneous baleen-bearing members of the Cetotheriidae. The presence of the second species, E. carolinensis, in the same formation demon-
\end{abstract}

Albert E. Sanders, The Charleston Museum, 360 Meeting Street, Charleston, South Carolina 29403. Lawrence G. Barnes, Natural History Museum of Los Angeles County, 900 Exposition Boulevard, Los Angeles, California 90007. strates the newly recognized evolutionary diversity of the Oligocene Cetacea and the fact that multiple lineages of various groups evolved simultaneously. The family Eomysticetidae is the presumed sister taxon to all of the more-derived baleen-bearing Mysticeti.

\section{Introduction}

The Tertiary marine deposits of the South Carolina coastal plain have furnished important fossil cetacean remains since 1845, when Robert W. Gibbes described the archaeocete Dorudon serratus from Eocene beds in the vicinity of the Santee River. Subsequent discoveries have included two odontocetes, Agorophius pygmaeus (Müller, 1849) and Xenorophus sloanii Kellogg, 1923, both of which were described from holotypes found in the Ashley Formation near Charleston. As demonstrated by Whitmore and Sanders (1976), the Ashley Formation is of late Oligocene age, and not Eocene as had been supposed by previous authors. In recent years, studies emanating from the Charleston Museum have disclosed a previously unrecognized formation overlying the Ashley. This rock unit, the Chandler Bridge Formation of Sanders et al. (1982), also is of late Oligocene age (ca. 28 million years ago (Ma)) and has produced a wealth of cetacean material that is providing critical new information about the evolution and systematics of Oligocene Cetacea (Whitmore and Sanders, 1976; Sanders, 1980; Sanders et al., 1982; Weems and Sanders, 1986; Sanders and Barnes, 1989; Barnes and Sanders, 1990).

In October 1975, a Charleston Museum party under Sanders's direction excavated the remains of the first baleen whale to be found in the Oligocene beds around Charleston. The specimen was recovered from the Chandler Bridge Formation in Dorchester County, South Carolina, approximately 20 miles $(32.2 \mathrm{~km})$ north of Charleston. Subsequently, another baleenbearing mysticete was found in this formation, and these two specimens are the subject of this paper. Previously described Oligocene mysticetes from the North Atlantic and Tethys re- 
gions had consisted of two taxa, Cetotheriopsis lintianus (von Meyer, 1849) from Linz, Austria, and Cetotheriopsis tobieni Rothausen, 1971, from the North Sea Basin near Dusseldorf, Germany. Those taxa and the new form Micromysticetus rothauseni are discussed elsewhere in this volume (Sanders and Barnes, 2002).

The first South Carolina specimen is a partial skeleton representing a new genus and new species with cranial characters that are in many ways intermediate between those of previously described members of the suborders Archaeoceti and Mysticeti (Sanders and Barnes, 1989; Barnes and Sanders, 1990). The cranium and dentaries of this specimen are nearly complete and were associated with vertebrae, ribs, and the right forelimb. The second specimen is a partial skull representing another species in the genus.

Two of the most intense subjects of current debate about cetacean evolution are their place of origin and ancestry and whether they are monophyletic, diphyletic, or triphyletic. The descriptions of the new fossil cetaceans in this study shed light on the second of these questions and reinforce the theory that the Cetacea are monophyletic. New morphologic and taxonomic interpretations and subordinal definitions are proposed, and comparisons are made with relevant previously named fossil species.

ACKNOWLEDGMENTS.-Initial thanks must go to Catherine Key, who discovered the holotype of Eomysticetus whitmorei and reported it to Sanders. She and Mary Worley contributed many hours of assistance with the excavation work, to which Chaz Duc and Joel Padgett also made valuable contributions. We thank Leroy Blackwell for permission to excavate the holotype on his property and for furnishing a backhoe and operator to remove the Pleistocene overburden from the site. A considerable portion of the preparation work was made possible by a grant from the Charleston Scientific and Cultural Educational Fund; the remainder was funded by the Charleston Museum. For their assistance with the preparation of the holotype we thank Barry Albright, Daniel Davis, Jonathan Geisler, Chester Linder, Aaron Stokes, Mark Taylor, and Robert E. Weems (USGS). Jonathan Durst-Glenn assisted in proofreading the manuscript.

We are particularly grateful to Vance McCollum and Barry Albright, the collectors of the holotype of Eomysticetus carolinensis, for their generosity and interest, and we appreciate $\mathrm{Mr}$. McCollum's assistance in the preparation of that specimen. Tanya Elston also aided with the preparation work. Bryan Stone produced all of the photographs except those in Figures $9,10,11,12$, and $17 \mathrm{C}$, which were made by the first author with assistance from Aaron Stokes. Chris Olm prepared the drawing for Figure 3B, to which the first author added final details. The remainder of the line drawings were produced by the first author. Peter Laurie made the vertebral measurements for Figure 28, and Clyde White assisted with the tabulations. Milton Rhodes assisted with tabulations for Figure 29. The Charleston Museum and the Natural History Museum of Los
Angeles County and its foundation provided facilities, salaries, and travel funds for the authors that made this study possible. Ewan Fordyce reviewed the manuscript and provided helpful comments. Clayton E. Ray and Frank C. Whitmore, Jr., provided access to fossil cetacean material in the NMNH and were helpful in numerous other ways.

In our description of Micromysticetus rothauseni elsewhere in this volume, we have recorded our appreciation of Clayton Ray and his many contributions to vertebrate paleontology. We wish now to acknowledge another long-time friend and colleague, Frank C. Whitmore, Jr., whom we have honored with the patronym Eomysticetus whitmorei. We can think of no paleocetologist more deserving of patronymic recognition, but it is at best a very inadequate means of expressing to him our sincere thanks for his friendship and encouragement over the years. We have been the beneficiaries of his wise counseling and sound advice on many occasions, but as much as anything we have appreciated his ever-cheery disposition, even in the face of recent visual difficulties that would have defeated a less courageous person. Admired and respected by all who know $\mathrm{him}$, he is at once an excellent scientist and a valued friend, and we consider it a privilege to have worked with him. Thank you, Frank, for everything.

\section{MATERIAL AND METHODS}

Terminology for cranial anatomy follows Kellogg (1927) and Fraser and Purves (1960). With some modifications required by the morphology of the specimen, cranial measurements follow the methodology of Perrin (1975) and of Kellogg $(1936,1965)$. For the measurements of the mandibles, vertebrae, and forelimb we have followed Kellogg $(1936,1965$, $1968,1969)$, also with required modifications. The reconstruction of the skull is based upon photographs of the specimen.

Geological interpretations of the unit that produced the holotype specimen are in accordance with the original description of the Chandler Bridge Formation (Sanders et al., 1982) and with subsequent observations about that unit (Weems and Sanders, 1986).

Authorships of modern taxa mentioned in the text follow Rice (1984), and synopses of living species, genera, and suprageneric groups and their authorships may be found there and in Hershkovitz (1966).

ABBREVIATIONS-Institutional abbreviations used in this paper are as follows:

$\begin{array}{ll}\text { ChM } & \text { The Charleston Museum, Charleston, South Carolina } \\ \text { NMNH } & \text { National Museum of Natural History, Smithsonian Institution, } \\ & \text { Washington, D.C. } \\ \text { USGS } & \begin{array}{l}\text { United States Geological Survey } \\ \text { USNM }\end{array} \\ & \begin{array}{l}\text { collections of the National Museum of Natural History, includ- } \\ \text { ing collections of the former United States National Museum }\end{array}\end{array}$

Anatomical abbreviations used in this paper are as follows:

$\begin{array}{ll}\text { aon } & \text { antorbital notch } \\ \text { bc } & \text { basioccipital crest }\end{array}$




$\begin{array}{ll}\text { Boc } & \text { basioccipital } \\ \text { ch } & \text { cranial hiatus } \\ \text { Eo } & \text { exoccipital } \\ \text { fm } & \text { foramen magnum } \\ \text { fps } & \text { foramen pseudovale } \\ \text { Fr } & \text { frontal } \\ \text { gf } & \text { glenoid fossa } \\ \text { hpt } & \text { hamular process of pterygoid } \\ \text { jn } & \text { jugular notch } \\ \text { lc } & \text { lambdoidal crest } \\ \mathrm{Max} & \text { maxilla } \\ \mathrm{mea} & \text { eaxternal auditory meatus } \\ \mathrm{mf} & \text { mandibular foramen } \\ \mathrm{mrg} & \text { mesorostral groove } \\ \mathrm{Na} & \text { nasal } \\ \mathrm{Oc} & \text { occipital condyle } \\ \mathrm{Pa} & \text { parietal } \\ \mathrm{Pal} & \text { palatine } \\ \mathrm{pgl} & \text { postglenoid process } \\ \mathrm{Pmx} & \text { premaxilla } \\ \mathrm{pop} & \text { paroccipital process } \\ \mathrm{Pt} & \text { pterygoid } \\ \mathrm{pts} & \text { fossa for pterygoid sinus } \\ \mathrm{Soc} & \text { supraoccipital } \\ \text { sop } & \text { supraorbital process } \\ \mathrm{Sq} & \text { squamosal } \\ \mathrm{sqf} & \text { squamosal fossa } \\ \mathrm{ssf} & \text { secondary squamosal fossa } \\ \mathrm{tf} & \text { temporal fossa } \\ \mathrm{Vo} & \text { vomer } \\ \mathrm{zps} & \text { zygomatic process of squamosal } \\ & \end{array}$

\section{Systematic Paleontology}

Class Mammalia Linnaeus, 1758

Order Cetacea Brisson, 1762

Suborder MYSTICETI Flower, 1864

\section{Superfamily EOMYSTICETOIDEA, new superfamily}

INCLUDED SUPERFAMILIES.-Eomysticetoidea, new superfamily; Balaenopteroidea (Gray, 1868) sensu Mitchell, 1989; Eschrichtoidea (Ellerman and Morrison-Scott, 1951) sensu Mitchell, 1989; Balaenoidea Brandt, 1873 (sensu Mitchell, 1989).

INCLUDED FAMILY.—Eomysticetidae, new family, only.

\section{Family EOMYSTICETIDAE, new family}

DIAGNOSIS.-The same as for the genus.

TYPE AND ONLY INCLUDEd GenUS.-Eomysticetus, new genus.

\section{Eomysticetus, new genus}

DiagNosis.-A mysticete differing from all other baleenbearing Mysticeti by having an elongate and narrow intertemporal region and floor of squamosal fossa with small pit-like depressions herein termed "secondary squamosal fossae"; dif- fering from members of Aetiocetidae by the absence of teeth in adulthood; differing from Cetotheriidae, Balaenopteridae, Balaenidae, Neobalaenidae, and Eschrichtiidae by having elongate anterolateral processes of nasal bones, extremely long zygomatic processes of squamosals, very thin blade-like anterior process of periotic and small posterior process with well-defined facet for articulation with tympanic bulla, and humerus as long as radius and ulna. Differs from Balaenopteridae, Balaenidae, Neobalaenidae, and Eschrichtiidae by having naris near mid-length of rostrum, exceptionally elongate nasal bones, parietals exposed along intertemporal region between frontals and apex of supraoccipital, periotic with transversely compressed anterior process and no dorsal process on cochlear portion, and large coronoid process of dentary and posterior edge of coronooid elevated above anterior edge.

The two known species of Eomysticetus share the following similarities: exoccipital thick and posteriorly flared; condyles broad and not protruding from skull; basioccipital slightly vaulted transversely; basioccipital crests short anteroposteriorly and wide transversely; large recess for posterior process of periotic; postglenoid process short, thin anteroposteriorly, and continuous with falciform process medially; glenoid fossa with oblique ridge from anteromedial to postlateral; dorsal curvature of zygoma; flattened ventral surface of glenoid fossa; large foramen pseudovale; wide jugular notch; narrow intercondylar notch; asymmetrical and interfingering frontoparietal suture; sagittal crest present on apex of parietals in intertemporal region; sagittal crest on apex of supraoccipital at right of midline; secondary anteroposterior crest flanking each side of sagittal crest at apex of occiput; paroccipital process not extending laterally as far as lateral edge of zygoma; floor of squamosal fossa with a pit-like depression herein termed the "secondary squamosal fossa."

TYPE SPECIES.-Eomysticetus whitmorei, new species.

INCLUDED SPECIES.-Eomysticetus whitmorei, new species, and Eomysticetus carolinensis, new species. Late Oligocene, South Carolina, USA.

ETYMOLOGY.-From $\alpha \omega \varsigma$ (eos) (Greek), dawn, and $\mu \imath \varsigma \tau \alpha \kappa o$ (mystako) (Greek), whisker or mustache, in reference to the baleen plates in mysticete whales; and from cetus or cete (Latin, from Greek ketos), whale.

\section{Eomysticetus whitmorei, new species}

FIGURES 3-17

Diagnosis.-A species of Eomysticetus differing from $E$. carolinensis, n. sp., in having transversely thicker basioccipital crests; zygomatic process of squamosal thicker, more nearly parallel to sagittal plane, and extending beyond apex of supraoccipital; a facet on ventral surface of distolateral end of zygoma for articulation with jugal; lambdoidal crests more dorsally directed and not overhanging temporal fossae; parietals nearly vertical on either side of intertemporal region rather than sloping ventrolaterally; sagittal crest on parietals in intertempo- 


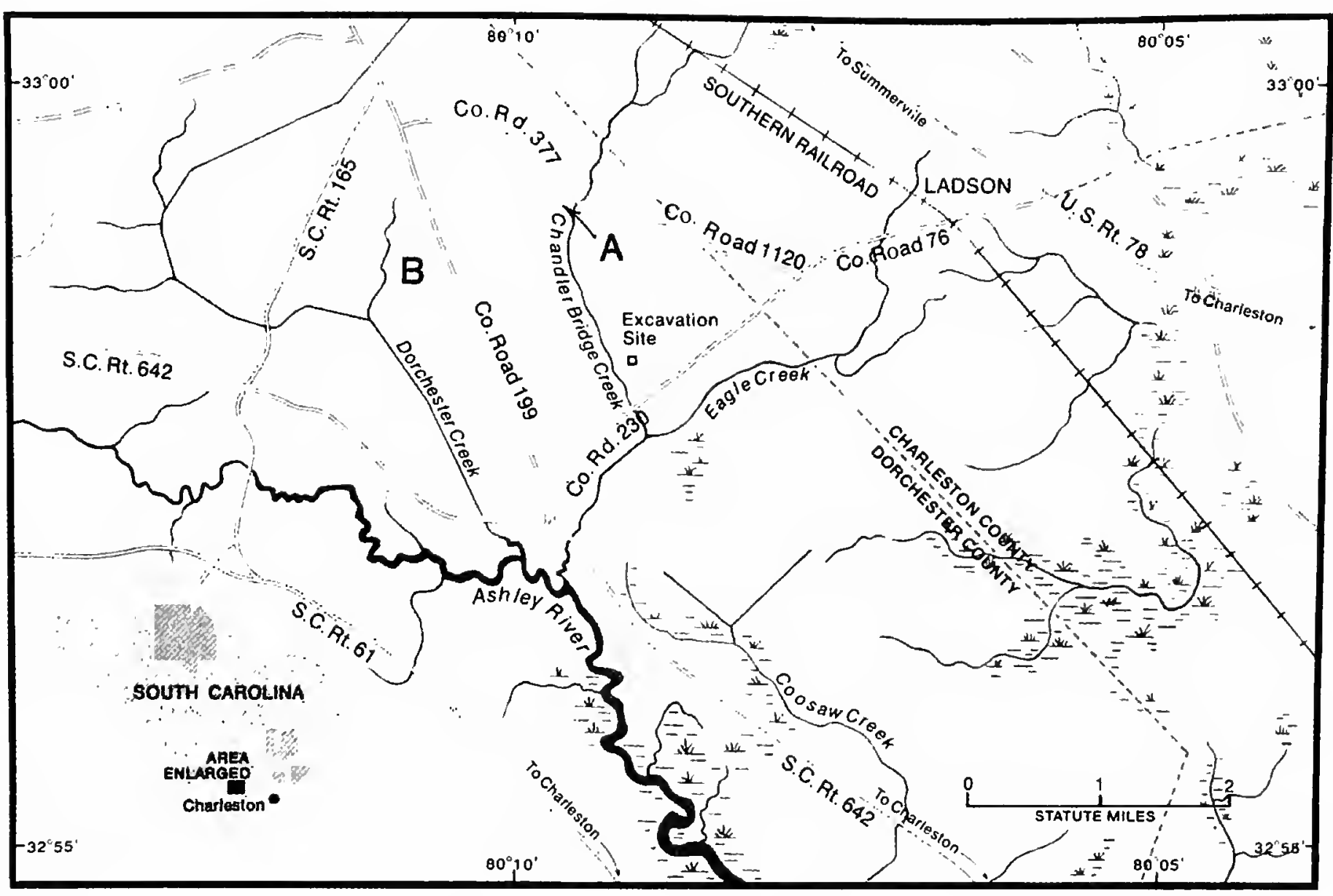

FIGURE 1.-Map showing the type localities of Eomysticetus whitmorei, new genus and new species (A), and Eomysticetus carolinensis, new species (B), near Charleston, South Carolina. ("Excavation site" on map is location of Charleston Museum excavation of the Chandler Bridge Formation (Sanders, 1980). Base map from Sanders I980, courtesy of National Geographic Society.)

ral region blade-like posteriorly and not rounded; dorsal exposure of parietal along midline of intertemporal region $50 \%$ longer; dorsomedial surface of zygomatic process of squamosal convex rather than flat; deeper supracondylar fossa; articular surfaces of occipital condyles more protuberant posteriorly and more distant from occipital surface.

HOLOTYPE. - ChM PV4253; skull, both periotics, both tympanic bullae, both dentaries; seven cervical vertebrae, seven thoracic vertebrae, two lumbar vertebrae, and one possible caudal vertebra; parts of at least 17 ribs and a possible sternal rib; right scapula, humerus, radius, and ulna; collected by Albert E. Sanders and party, October 1975.

TYPE LOCALITY (Figure 1).- South Carolina, Dorchester County, Greenhurst Subdivision, west bank of drainage ditch at junction with Chandler Bridge Creek, $0.16 \mathrm{~km}$ southwest of Jamison Road (County Road 377), approximately $32^{\circ} 52^{\prime} 54^{\prime \prime} \mathrm{N}$ and $80^{\circ} 09^{\prime} 30^{\prime \prime} \mathrm{W}$ (USGS, Stallsville $7.5^{\prime}$ topographic quadrangle). Elevation of dorsal surface of cranium $5.7 \mathrm{~m}$ (18.58 ft.) above mean sea level.

Formation AND Age (Figure 2).-Bed 3 of the Chandler Bridge Formation, a late Oligocene (Chattian) marine unit laid down approximately $28 \mathrm{Ma}$ (Sanders et al., 1982). The uppermost portion of the Chandler Bridge Formation, bed 3, is a beach zone from which a large number of marine vertebrate remains were recovered in a major excavation conducted by the

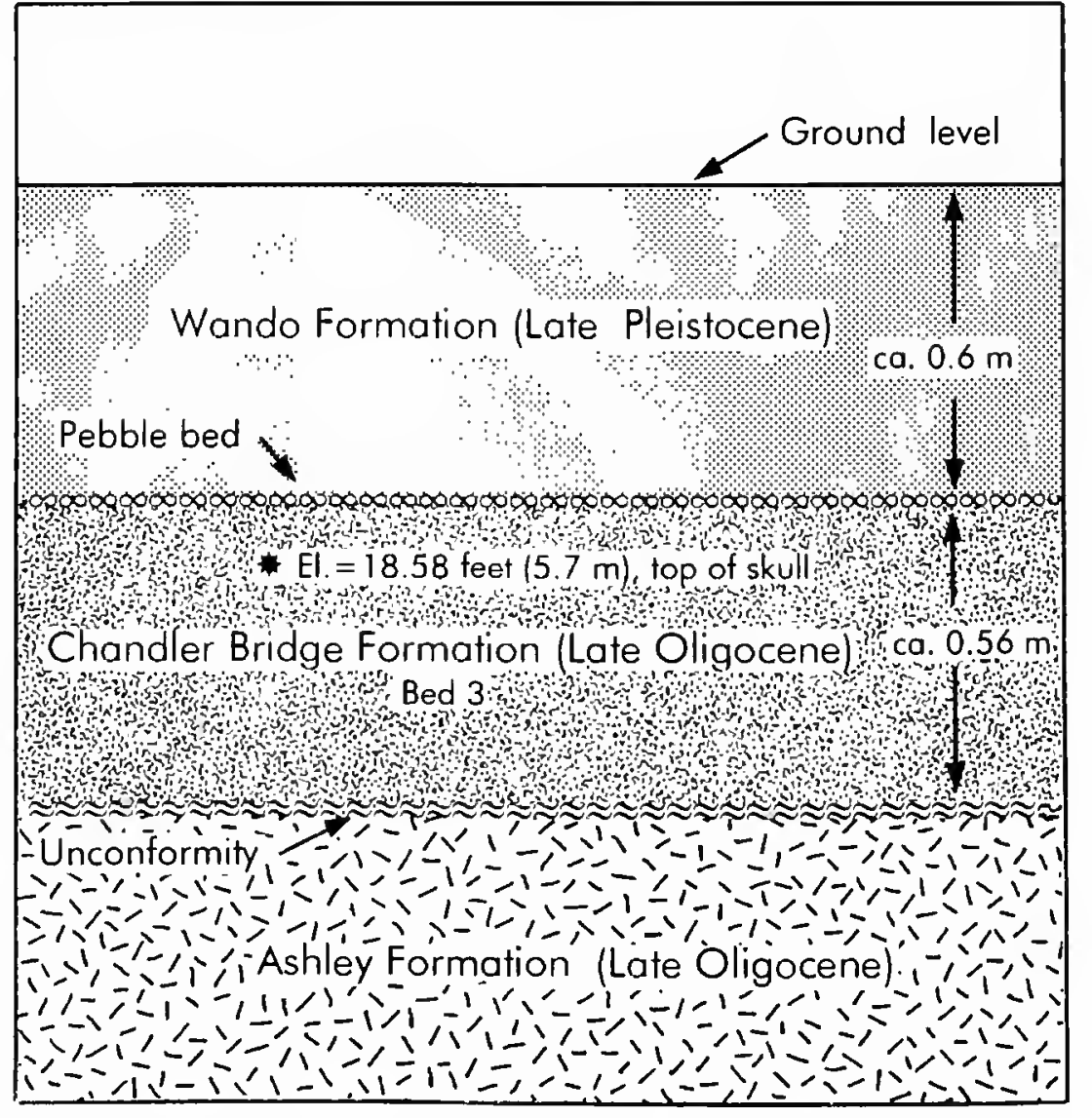

FIGURE 2.-Stratigraphic section at the type locality of Eomysticetus whitmorei, new genus and new species, from the Chandler Bridge Formation. (Not to scale.) 
Charleston Museum (Sanders, 1980). The site of that excavation is the type locality for the Chandler Bridge Formation and is $2.1 \mathrm{~km}(1.3 \mathrm{mi}$.) southeast of the type locality of Eomysticetus whitmorei.

The Chandler Bridge Formation unconformably overlies the late Oligocene Ashley Formation (ca. $30 \mathrm{Ma}$ ), a calcarenite that underlies the entire Charleston area. Together, these two formations have produced one of the largest and most diverse assemblages of cetacean remains recovered from Oligocene deposits. Squalodontoids and other primitive toothed cetaceans are by far the most numerous, whereas mysticetes are relatively rare. An early Chattian age for the Chandler Bridge Formation is indicated by the presence in this formation of undescribed squalodonts of the same evolutionary grade as Eosqualodon langewieschei Rothausen, 1968 (see Whitmore and Sanders, 1976; Sanders, 1980), found in Eochattian sands (Chattian A) at Doberg, Germany, that have been referred to nannoplankton zone NP24 (Martini and Müller, 1975) and are considered to be of early Chattian age (Curry et al., 1978:46). A detailed appraisal of the age of the Chandler Bridge Formation was given by Sanders et al. (1982). As the latter authors have noted, "Because the Chandler Bridge Formation is thin and permeable and thus leached of carbonate, attempts to recover a calcareous microfauna or microflora have been either unsuccessful or equivocal in that the few specimens obtained may represent material reworked from the underlying Ashley Member [now Ashley Formation] . . . into bed 1" (Sanders et al., 1982:H114). E. Martini, however, recently examined the nannoplankton in samples of the Ashley Formation from the type locality of the Chandler Bridge Formation and found the Ashley to be referable to zone NP24 (pers. comm., E. Martini to K. Rothausen, Rothausen to A.E. Sanders, June 1990). Because the same evolutionary grades and many of the same genera are represented in the cetaceans, phocids (Koretsky and Sanders, 2002), sea turtles, a new crocodilian (Erickson and Sawyer, 1996), and other vertebrate faunas of the Ashley and the Chandler Bridge Formations, we consider that these two formations belong to the same biostratigraphic interval (NP24) and that very little time (probably no more than about $2 \mathrm{My}$ ) elapsed between the deposition of these two units. The age of the Chandler Bridge Formation is placed at approximately $28 \mathrm{Ma}$ and the underlying Ashley Formation at about $30 \mathrm{Ma}$. Those estimates are suggested by (1) the primitive aspect of the cetacean fauna of the two units, among which are three undescribed toothed mysticetes with archaeocete-like dentition (Barnes and Sanders, 1996), several relatives of the most-archaic known odontocete, Xenorophus sloanii Kellogg (1923), from the Ashley Formation; and the archaic Eomysticetus whitmore $i$ and $E$. carolinensis described in this paper; but primarily by (2) biostratigraphic correlation of the Ashley Formation with nannoplankton zone NP24.

ETYMOLOGY.-The species is named in honor of Frank C. Whitmore, Jr., formerly of the USGS, who has contributed greatly to the study of fossil cetaceans and who has supported us in our efforts in innumerable ways.

DESCRIPTION.-Skull: The skull of Eomysticetus whitmore $i$ is very long and has a flat, narrow rostrum; a narrow, triangular braincase; large and widely placed zygomatic processes of the squamosals; and an elongate and greatly constricted intertemporal region (Figure 3, Table 1). We have estimated the length of the skull at $1590 \mathrm{~mm}$ by articulating the complete right dentary with the right glenoid process and leaving $5 \mathrm{~mm}$ clearance for connective tissue.

The rostrum is composed mostly of maxilla on the dorsal surface, as in other mysticetes. The ventral surface of the rostrum lacks development of nutrient grooves, as is typical of other mysticetes. The mesorostral gutter is open dorsally for only a short distance immediately anterior to the narial opening. The premaxillae converge at a point $180 \mathrm{~mm}$ anterior to the nasals, and at this location they are a mere $10 \mathrm{~mm}$ apart. From that point anteriorly they are closely approximated on the anterior portion of the rostrum, effectively roofing over the mesorostral groove in that region. Anterior to the naris the premaxillae expand anteriorly and are convex transversely, but adjacent to the narial region the premaxillae are narrower and more convex along their midlines. On the right side, adjacent to the narial opening, a piece of the right maxilla attaches to the premaxilla. It laps both dorsally and ventrally to the lateral margin of the premaxilla, and its dorsal surface is convex. Posteriorly, the premaxillae diverge posteriorly at the nares and curve around the lateral margins of the nasal bones, producing a slightly convex surface that slopes ventrolaterally away from the nasals. Adjacent to the anterolateral corner of the naris, the premaxilla is elevated, as in Aetiocetidae, and then slopes anteroventrally (Figure 4). The premaxillae widen posteriorly, extending into the interorbital area and terminating a few millimeters anterior to the posterior tip of the nasals. Breakage of the posterior ends of the premaxillae and nasals prohibits an exact measurement of the latter distance. The posterior termination of each premaxilla appears to have tapered between the ascending process of the frontal and the posterior end of the nasal and probably terminated at the same point as the nasals.

The nasal bone is $300 \mathrm{~mm}$ in length, exceeding that of any other described mysticete. It extends posteriorly to a point between the temporal crests and constitutes approximately $18.7 \%$ of the estimated total length of the skull. At its midline, the anterior margin of the nasal is virtually straight across transversely, then is slightly concave laterally. Farther laterally, toward the margin of the premaxilla, the anterior edge of the nasal puts forth a small process that is directed farther anteriorly and is sutured into a recess along the medial side of the premaxilla (Figure 3).

The right and left nasals are joined at the midline by an irregular, meandering suture. They are arched transversely, and at the apex of the narial opening they are slightly upturned. From the edge of the narial opening the nasals slope gently downward and backward into a shallow but quite noticeable swale 


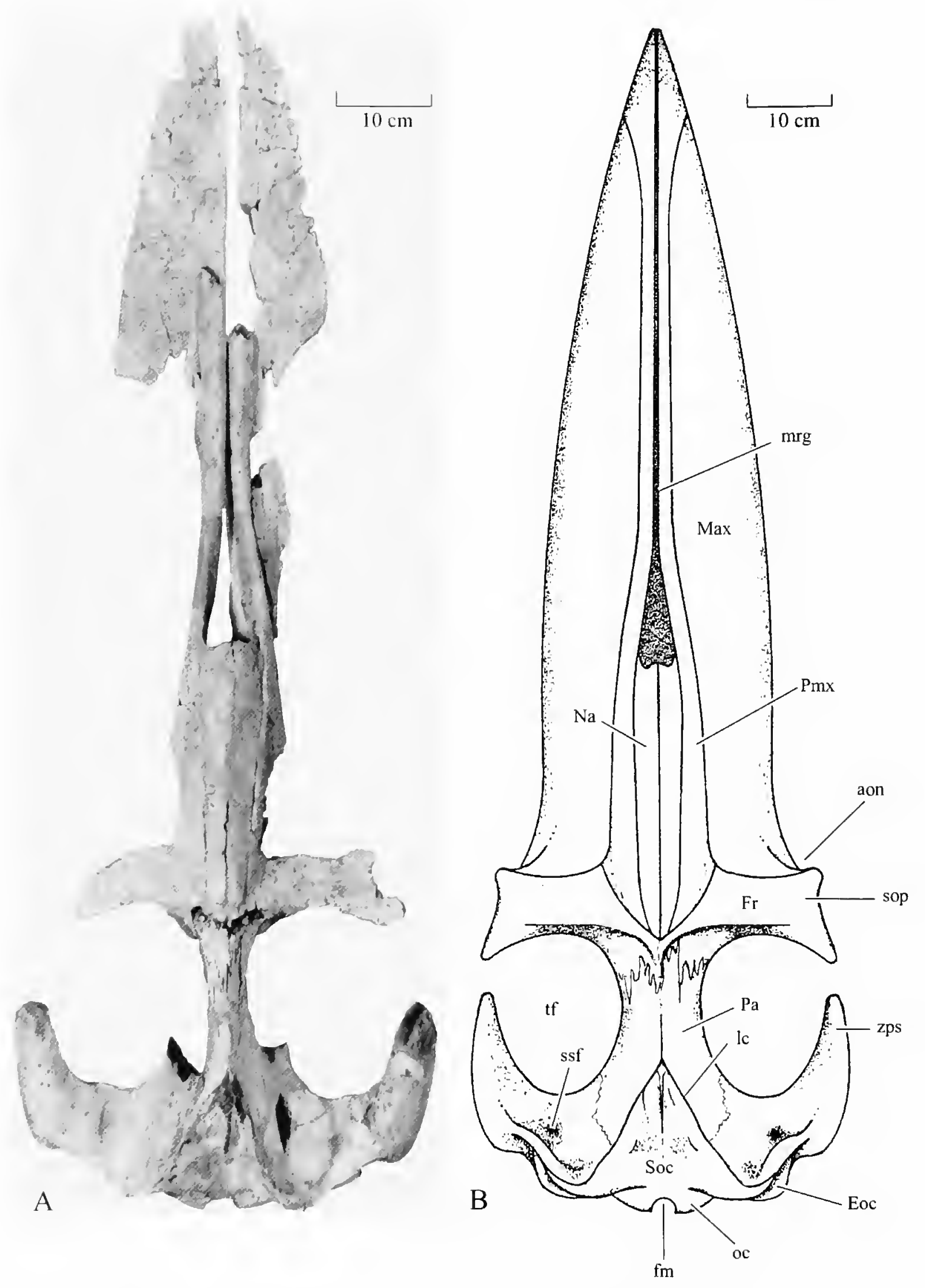

FIGURE 3.-Eomysticetus whitmorei, new genus and new species: A, holotypc, ChM PV4253, skull, dorsal view; $\mathrm{B}$, reconstruction of skull based upon holotype, dorsal view. (Solid lines in areas of missing bone (see Figure 3A) are hypothetical configurations. Abbreviations are explained in "Material and Methods.")

that extends posteriorly from the anterior margins of the nasals as far as the apex of the supraoccipital (Figure 4). The nasals are widest anteriorly, tapering posteriorly as they overlap the frontals, terminating posteriorly slightly behind the point of the temporal crests.

The supraorbital processes of the frontals are incomplete on the holotype. Their posterior margins are preserved, but the an- terior and lateral margins are missing on both sides. The right supraorbital process of the frontal is more complete than the left one and seems to have been relatively narrow in comparison with most mysticetes, although that appearance might be an artifact of preservation. The posterior margin is concave, and the anterior margin is mostly incomplete, so that the relationship with the maxilla is not clear. The distal margin of each 
TABLE 1.-Mcasurements (in mm) of the holotype skulls of Eomysticetus whitmorei, new genus and new species (ChM PV4253), and Eomysticetus carolinensis, new spccies (ChM PV4845). Parcntheses denote estimated measurements.

\begin{tabular}{|c|c|c|}
\hline Character & E. whitmorei & E. carolinensis \\
\hline Condylobasal length & $(1590)^{*}$ & - \\
\hline Length of rostrum & $(1147)$ & \\
\hline $\begin{array}{l}\text { Preserved portion of skull, broken end of left premaxilla to posterior surface of left occipital } \\
\text { condyle }\end{array}$ & 1035 & - \\
\hline Anterior end of left premaxilla to apcx of supraoccipital & $820+$ & - \\
\hline Greatest length of left premaxilla & $640+$ & - \\
\hline Greatest width of right maxilla (preserved portion) & 56 & - \\
\hline Anterior end of right premaxilla to anterior end of right nasal bonc & $350+$ & - \\
\hline Anterior end of right nasal bone to apex of supraoccipital & 469 & - \\
\hline Deepest point of swale between tip of nasals and apex of supraoccipital & 37 & - \\
\hline Greatest length of right nasal bone at midline & $(300)$ & - \\
\hline Anterior width of right nasal bone & 35 & - \\
\hline Combined width of nasal bones, anteriorly & 71 & - \\
\hline Combined width of nasal bones, posteriorly & $(40)$ & - \\
\hline Length of anterolateral extension of left nasal bone from plane of anterior end of nasals & (26) & - \\
\hline Height of anterior ends of nasal bones above plane of premaxillae at nasal opening & $(23)$ & - \\
\hline Greatest width of external nares & 49 & - \\
\hline $\begin{array}{l}\text { Transverse distance between outside margins of premaxillae at level of anterior ends of nasal } \\
\text { bones }\end{array}$ & $95+$ & - \\
\hline Length of intertemporal region, temporal crest to plane of apex of supraoccipital & 192 & - \\
\hline Transverse distance between outside margins of preserved portions of supraorbital processes & 373 & - \\
\hline Greatest width across zygomatic processes of squamosals & 480 & $(510)$ \\
\hline $\begin{array}{l}\text { Maximum length of right zygomatic process, extremity of postglenoid process to anterior end } \\
\text { of zygoma }\end{array}$ & 261 & 233 \\
\hline Length of temporal fossa & 357 & - \\
\hline Width of temporal fossa & 170 & 183 \\
\hline Dorsal margin of foramen magnum to apex of supraoccipital & 229 & 236 \\
\hline Transverse diameter of foramen magnum & (32) & 43 \\
\hline Vertical diameter of foramen magnum & 46.7 & 44.2 \\
\hline Greatest distance between lateral margins of occipital condyles & 142 & 134.5 \\
\hline Vertical diameter of right occipital condyle & 76 & 84 \\
\hline Greatest transverse diameter of right occipital condyle & 58 & 53 \\
\hline Distance from inner margin of right occipital condyle to outer edge of right exoccipital & 163 & 147.5 \\
\hline Distance between lateral margins of exoccipitals & $(350)$ & $(342)$ \\
\hline Vertical distance from basisphenoid to apex of supraoccipital & $(168)$ & \\
\hline Greatest distance between lateral margins of basioccipital crests & $132+$ & 131 \\
\hline Intemal length of braincase & $(120)$ & $(100)$ \\
\hline Internal height of braincase, left cerebral cavity & 80 & - \\
\hline Internal height of braincase, right cerebral cavity & 81 & - \\
\hline Greatest internal height of braincase at midline & 87 & 87 \\
\hline Greatest internal width of braincase & 157 & - \\
\hline
\end{tabular}

"Estimated with complete right dentary articulated

supraorbital process is incomplete but is slightly upturned. A well-defined temporal crest extends transversely across the posterodorsal surface of the supraorbital process and reaches nearly to the midline of the skull, converging with the posterior margin of the supraorbital process and continuing laterally onto the dorsal surface of the process. This crest is highest at its medial part.

The intertemporal region is greatly elongate and narrow and is composed dorsally of a relatively short exposure of the frontals and the anteroposteriorly more elongate parietal bones. The frontals and parietals are joined by irregularly and randomly interdigitating sutures (Figure 5). The intertemporal constriction ascends toward the apex of the occipital shield, and the posterior half of the parietals form a short blade-like sagittal crest
(Figures 6,7).

The sagittal crest diverges at the juncture with the apex of the supraoccipital, and the remaining bone surface indicates that it was confluent with the lateral margins of the occipital shield. Anteriorly, the supraoccipital is triangular and relatively small and has a prominent sagittal crest beginning approximately at the middle and extending toward the apex. The anterior region of the occipital shield is elevated, but immediately posterior to the sagittal crest it is concavely depressed. Mediolateral to this depression there is a thickened tuberosity on the supraoccipital next to the inner wall of each lambdoidal crest. At that point, the supraoccipital begins to flare outward ventrolaterally. More posteriorly, the surface of the occipital shield is flat to convex dorsal to the foramen magnum, and a condyloid fossa is 


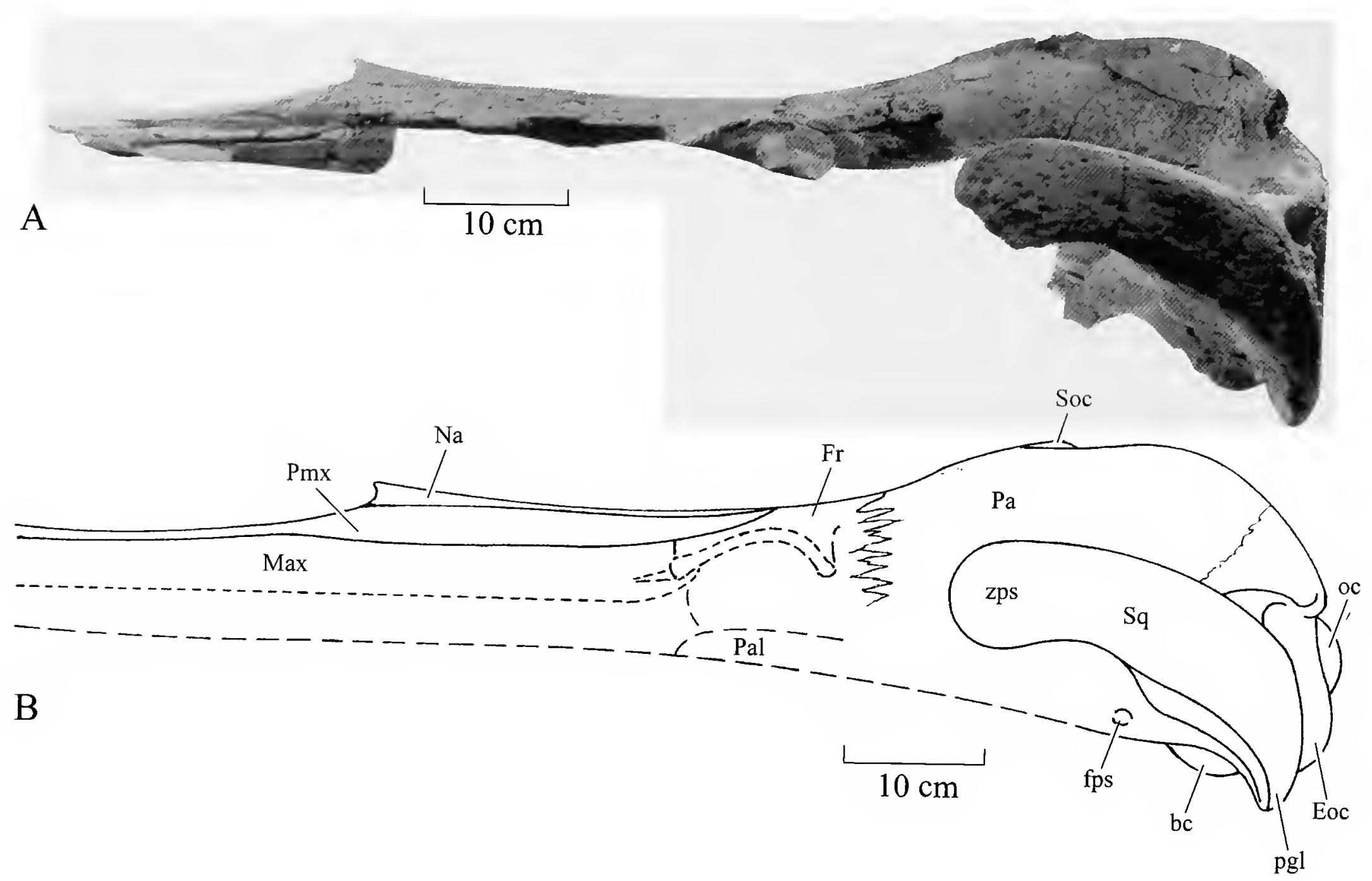

FIGURE 4.-Eomysticetus whitmorei, new genus and new species: A, holotype, ChM PV4253, skull, left lateral view; B, reconstruction of skull based upon holotype, left lateral view. (Dashed lines represent hypothetical configurations. Abbreviations are explained in "Material and Methods.")

present above each condyle. The occipital condyles are large, are located relatively low on the occipital shield, and are broad transversely. Lateral to the condyles, the surface of each exoccipital is unusually convex. As in most fossil and extant baleen whales, the exoccipital is mostly thick. In its lateral portion, however, the paraoccipital is thin anteroposteriorly and does not extend laterally farther than the middle of the postglenoid process.

The lambdoidal crest forms the lateral margin of the occipital shield and descends posteriorly and ventrally toward the back of the squamosal fossa. It is continuous with a prominent and narrow ridge-like structure that extends onto the dorsal surface of the zygomatic process of the squamosal. This ridge walls in the posterior end of the squamosal fossa, overhangs the secondary squamosal fossa, and is higher than in later mysticetes. A flexure in this crest is the homologue of the squamosal prominence of Micromysticetus rothauseni (Sanders and Barnes, 2002).

Between the braincase and the zygomatic arch, the squamosal fossa is deep, anteroposteriorly elongate, and wide. The posterior end of the fossa ascends steeply to meet the lateral part of the lambdoidal crest. This oblique part of the crest is prominent and spans to the posterior part of the zygomatic process of the squamosal. At the posterior end of the squamosal fossa, adjacent to the base of the zygomatic process of the squamosal, is a small, circular, pit-like fossa, herein named the secondary squamosal fossa (Figures 3,5 ). The lateral wall of the braincase is nearly vertical, is slightly concave near the middle, and is not bowed laterally as in most of the highly evolved taxa of Mysticeti.

The zygomatic process of the squamosal is very large relative to the size of the cranium, is elongate, and diverges only slightly from the midline of the cranium. It arches anterodorsally in a broad curve and bends ventrally at its anterior extremity. The medial face of the process is composed of dense bone and is divided into two planes, one upper and one lower. Its lateral surface is uniformly and smoothly convex and flares slightly ventrolaterally at the ventral margin, especially so at the anterior end of the process. In the ventral tip of the process there is a recess for articulation of the jugal bone (Figure 8). Lateral to this recess, the margin of the zygomatic process flares ventrolaterally. The arch is slightly expanded dorsoventrally at its anterior end and also arches slightly anteroposteriorly to create the large, anterodorsally inclined glenoid fossa.

At the posterior end of the lateral surface of the zygomatic process there is a prominent, transversely oriented sternomastoid fossa. This fossa is inclined anterodorsally and is located immediately lateral to the small paroccipital process. The latter 


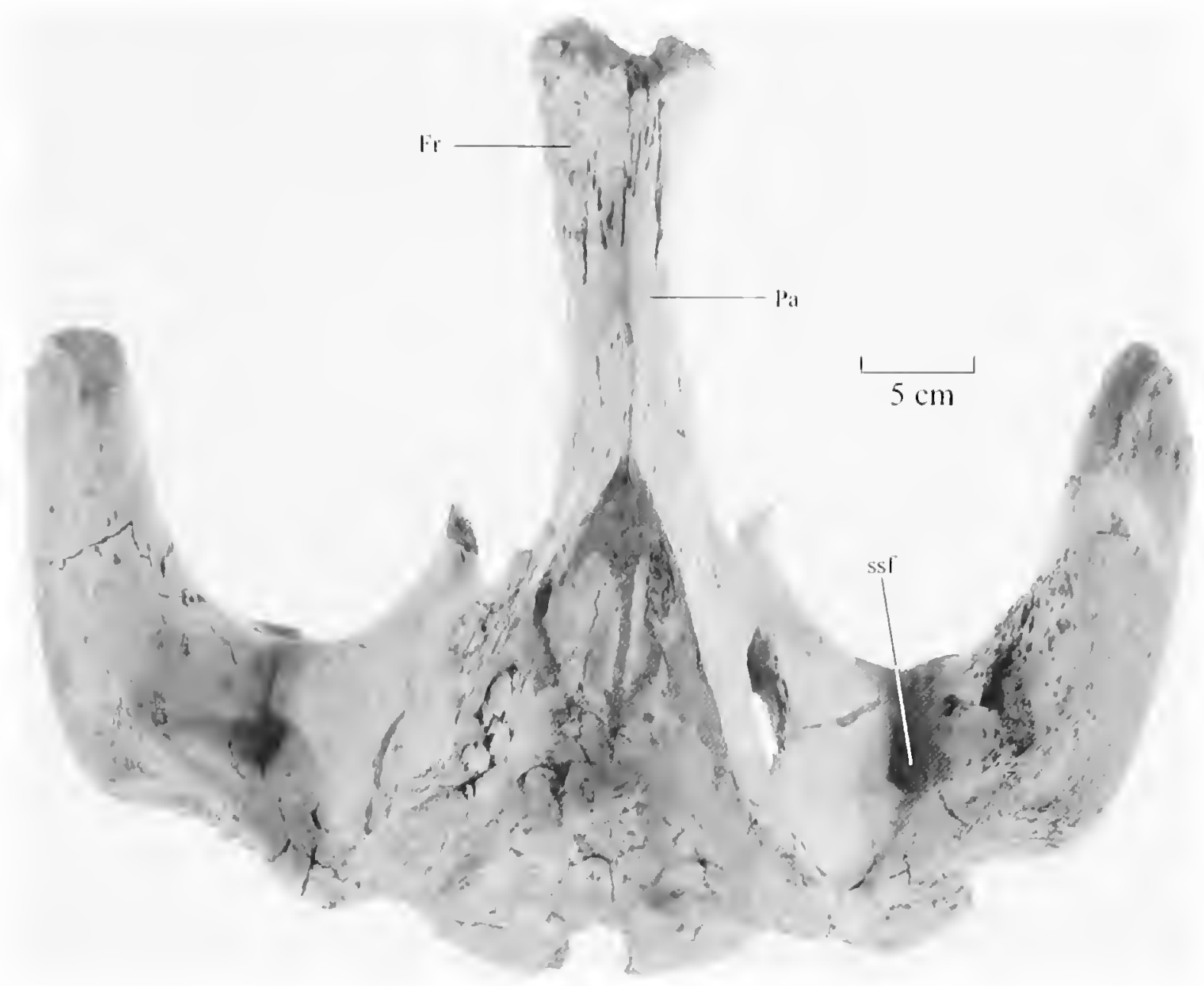

FIGURE 5--Eomysticetus whitmorei, new genus and new species, holotype, ChM PV4253, skull: enlarged view of braincase showing frontoparietal suturing and secondary squamosal fossa. (Abbreviations are explained in "Material and Methods.")

projects slightly ventrally and posteriorly from the occipital shield.

The recess for the external acoustic meatus is deep and is clearly defined between the postglenoid process of the squamosal and the paroccipital process. The mastoid process (posterior process of the bulla) is short and occupies all of the recess.

For a mysticete, Eomysticetus whitmorei has a relatively small cranial hiatus, the recess between the squamosal and the basioccipital in which the periotic lies. Lateral to the cranial hiatus and immediately posterior to the large, obliquely oriented foramen pseudovale is a rather thick falciform process of the squamosal that is bridged to the postglenoid process of the squamosal by a thin wall of bone. This wall of bone is a structure unique to Eomysticetus and marks the lateral border of a large peribullary sinus that extends anteriorly from the cranial hiatus, but it is not possible to determine its anterior extent because of breakage of bone in the area. On the lateral wall of the cranial hiatus, dorsal to the medial end of the mastoid process, is an epitympanic recess. As in Micromysticetus (Sanders and Barnes, 2002) and other primitive mysticetes, the ventral surface of the basioccipital is arched transversely, a form that is considered to be a primitive character. The basioccipital crests are thick and knob-like.

The glenoid fossa is broad transversely with a nearly square articular surface that is delimited anteriorly by a transverse margin extending laterally from the anterior edge of the squamosal fossa. The postglenoid process is relatively short and thin and is thickest laterally, where its ventral margin is convex; it then becomes more thin medially, where it terminates at the margin of the peribullary fossa.

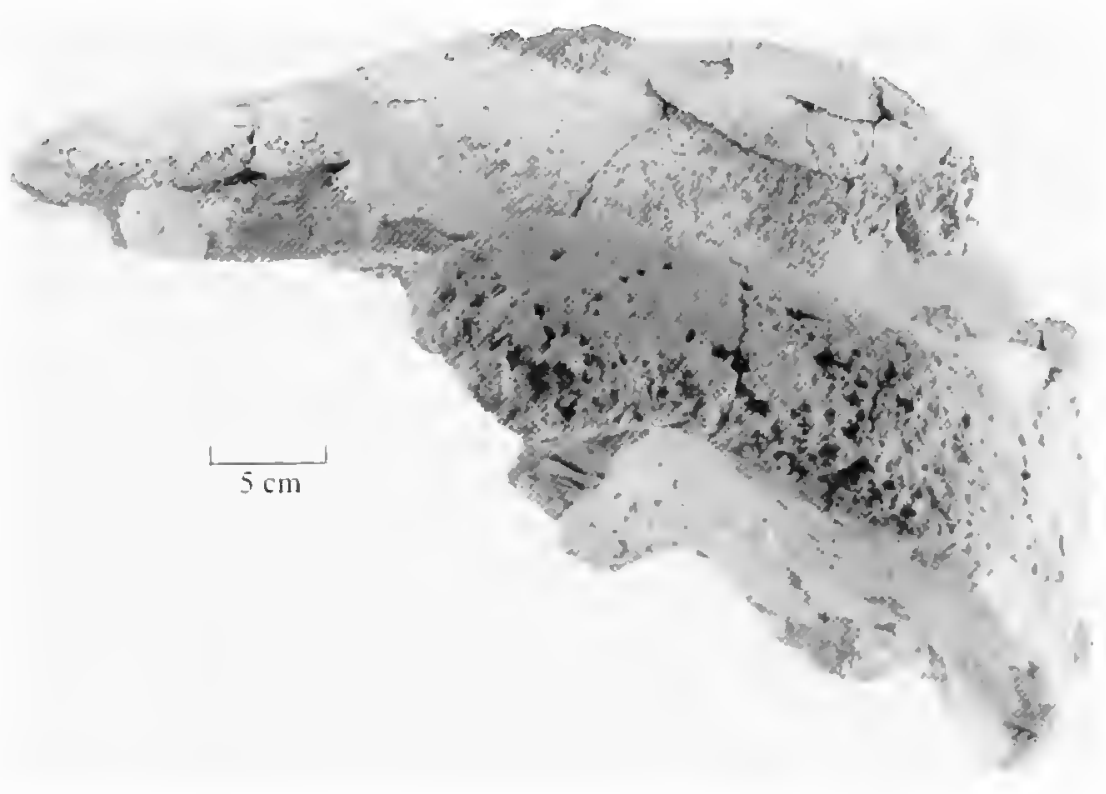

Figure 6.-Eomysticelus whitmorei, new genus and new species, holotype, ChM PV4253, braincase, left lateral view. (Abbreviations are explained in "Material and Methods.") 

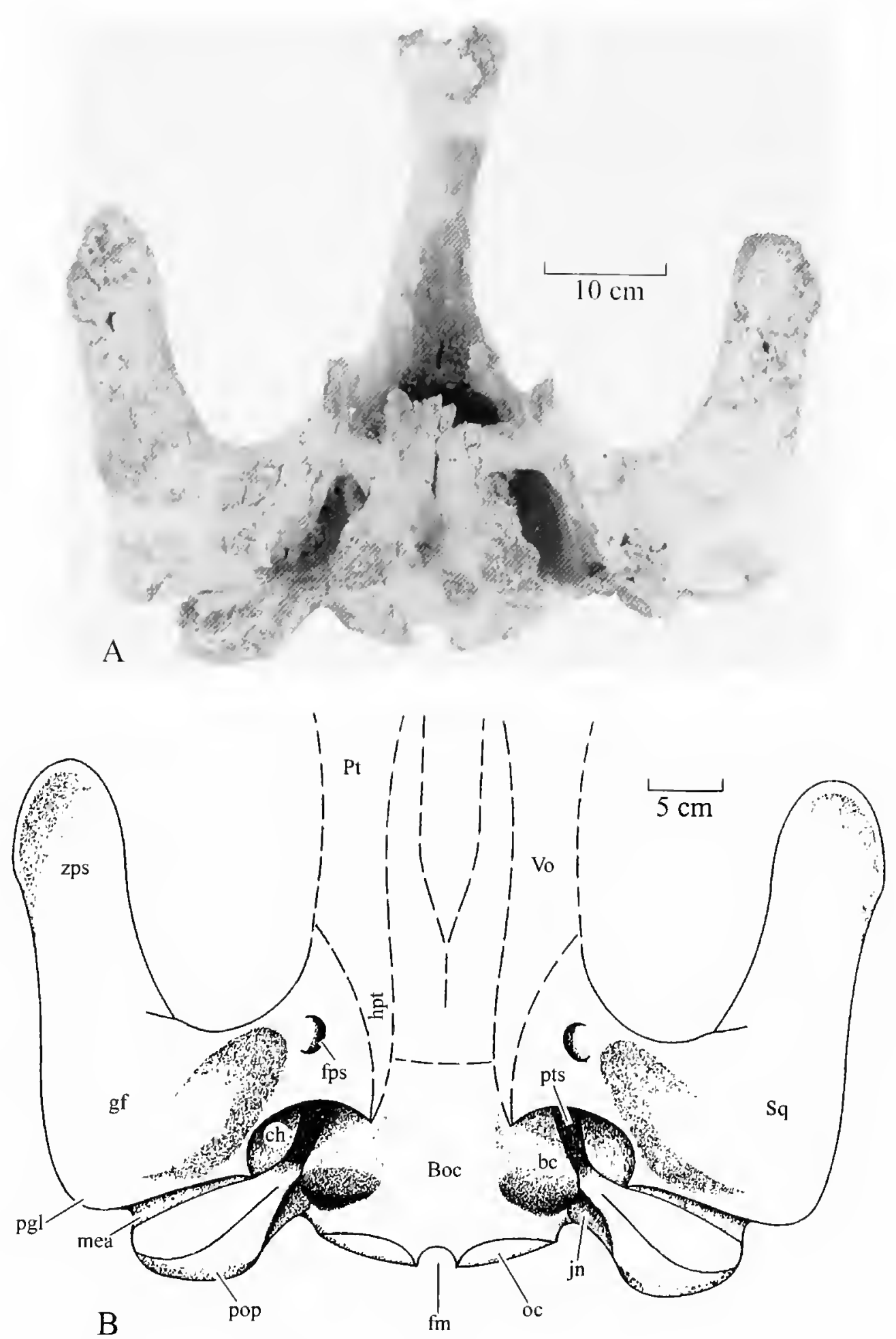

FIGURE 7.-Eomysticetus whitmorei, new genus and new species: A, holotype, ChM PV4253, cranium, ventral view; $B$, reconstruction of holotype cranium, ventral view. (Dashed lines represent hypothetical configurations. Abbreviations are explained in "Material and Methods.")

Periotic: Both of the periotics of Eomysticetus whitmorei are preserved and are relatively small for a mysticete (Figure 9). The left one is virtually complete, but the right one is missing approximately one-half of the pars cochlearis. The holotype left periotic measures $78 \mathrm{~mm}$ from the anteriormost point of the anterior process to the posteriormost extent of the posterior process. The pars cochlearis is $38 \mathrm{~mm}$ in anteroposterior length, 25 $\mathrm{mm}$ in dorsoventral diameter, and $31 \mathrm{~mm}$ in transverse diameter. At the anterior end of the cochlear portion the bone is deeply incised by the fossa for the tensor tympani muscle.

The anterior process is extremely compressed transversely and broadly expanded dorsoventrally (Figure 10). The poste- rior process is much shorter and is laterally expanded dorsally but more laterally compressed ventrally. The cochlear portion is relatively small, does not project very far medially from the body of the bone, and is not as globose as that of Micromysticetus rothauseni (Figure 10; see also Sanders and Barnes, 2002, fig. 12). A large dorsal process, such as is typical of the more highly evolved mysticetes, is not present, but the bone around the internal acoustic meatus is slightly convex, especially lateral to the meatus. In its overall proportions, the periotic resembles those of the basilosaurid Archaeoceti more than the inflated periotics of the derived Mysticeti (Figure 11).

In the primitive character state (e.g., Basilosauridae such as 


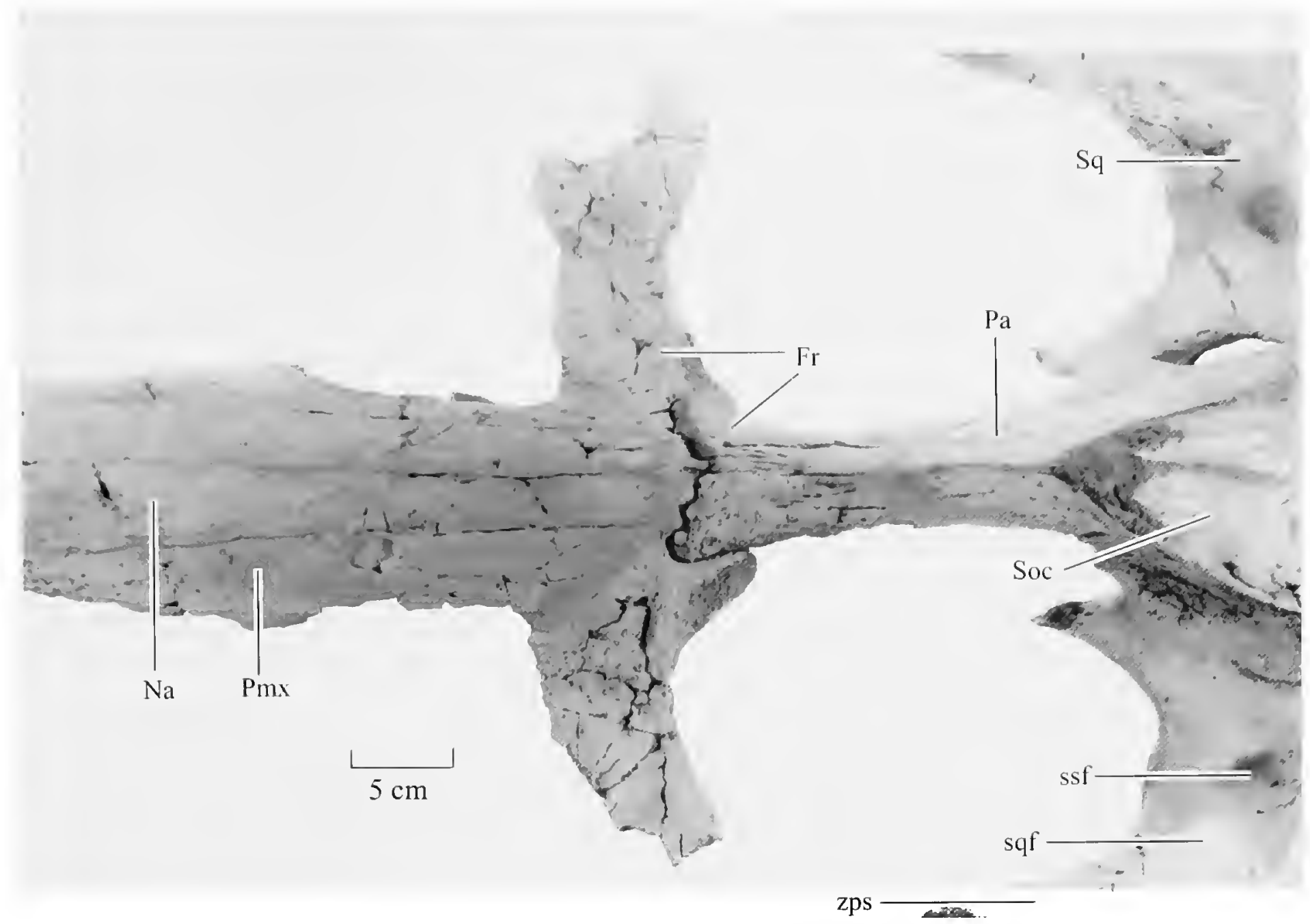

FIGURE 8.-Eomysticetus whitmorei, new genus and new species, holotype, ChM PV4253, enlarged view of intertemporal region of cranium, dorsal view. (Abbreviations are explained in "Material and Methods.")

Zygorhiza), the internal acoustic meatus on the cochlear portion of the periotic is a single large aperture, and included within it are the foramina for the facial nerve (VII), the vestibular nerve (=foramen singulare) (VIII), and the cochlear nerve (=tractus spiralis foraminosus) (VIII). This primitive condition also is widespread among the odontocetes.

In E. whitmorei, however, the internal acoustic meatus is divided into two parts separated by a thick, dorsally projecting transverse septum of bone that isolates the large foramen for the facial nerve from the foramina for the vestibular nerve and the cochlear nerve (Figure 10C). This situation also is present in such primitive Cetotheriidae as Herpetocetus spp., and in the more derived Cetotheriidae. In the Balaenopteridae the same bony septum is very prominent and extends very far cranially, and its extensive development is correlated with the extreme dorsal enlargement of the dorsal tuberosity and the bone around it.

The presence of the septum dividing the originally single internal acoustic meatus is an autapomorphy of Eomysticetidae and of most other Mysticeti beyond it.

The loss of a distinct sinuous dorsal crest on the periotic, originally traversing from the center of the cochlear portion to the anterior process, is related to the inflation of the cerebral surface of the periotic and development of a dorsal tuberosity.

More extreme cerebral or dorsal extension of the dorsal tuberosity, associated with dorsal extension of the transverse sep- tum dividing the internal acoustic meatus and also of other bone surrounding the internal acoustic meatus, is an autapomorphy of the Balaenopteridae.

The septum dividing the internal acoustic meatus in E. whitmorei is curiously missing in Micromysticetus rothauseni. That taxon has the primitive character state of the single, large, ovoid internal acoustic meatus (Sanders and Barnes, 2002, fig. 12). Micromysticetus rothauseni also has a well-defined sinuous dorsal crest that traverses the pars cochlearis, also a primitive character. Only a weak suggestion of that crest is present in E. whitmorei. Most likely, these features in Micromysticetus are character reversals or relict conditions. Because Micromysticetus is otherwise more highly derived than Eomysticetus whitmorei (and we have classified it among the Cetotheriidae), and doubtless was a baleen-bearing mysticete, it is very unlikely that Micromysticetus represents some different lineage of Mysticeti that evolved separately from archaeocete-like primitive mysticetes and was convergent with the Cetotheriidae.

Tympanic Bulla: Both tympanic bullae are present. The bulla is proportionally small for a mysticete. The involucrum is tapered anteriorly and is not composed of thick bone. As is typical of mysticetes, the sigmoid process is large and convex. In overall shape, the bulla is ovoid and very much like that of archaeocetes of the family Basilosauridae.

Dentaries (Table 2): The virtually complete right dentary is relatively long and slender with a slight lateral curvature, a dis- 
TABLE 2.-Measurements (in $\mathrm{mm}$ ) of the holotype dentaries of Eomysticetus whitmorei, new genus and new species, ChM PV4253. Parentheses indicate estimated measurements.

\begin{tabular}{|c|c|c|}
\hline Character & Left & Right \\
\hline Total length (straight line) as preserved & 894 & 1513 \\
\hline Greatest vertical diameter $100 \mathrm{~mm}$ behind anterior end of ramus, as preserved & 90 & $63+$ \\
\hline Greatest transverse diameter $100 \mathrm{~mm}$ behind anterior end of ramus, as preserved & 50 & 32.5 \\
\hline $\begin{array}{l}\text { Greatest transverse diameter } 500 \mathrm{~mm} \text { behind anterior end of ramus ( } 394 \mathrm{~mm} \text { anterior to posterior } \\
\text { face of condyle), as preserved }\end{array}$ & 91 & - \\
\hline $\begin{array}{l}\text { Greatest vertical diameter } 500 \mathrm{~mm} \text { behind anterior end of ramus ( } 394 \mathrm{~mm} \text { anterior to posterior } \\
\text { face of condyle), as preserved }\end{array}$ & 45 & - \\
\hline Greatest vertical diameter $500 \mathrm{~mm}$ behind anterior end of ramus & - & 72.5 \\
\hline Greatest transverse diameter $500 \mathrm{~mm}$ behind anterior end of ramus & - & 53 \\
\hline Greatest vertical diameter $1000 \mathrm{~mm}$ behind anterior end of ramus & - & $83+$ \\
\hline Greatest transverse diameter $1000 \mathrm{~mm}$ behind anterior end of ramus & - & 54 \\
\hline Greatest vertical diameter through coronoid process & $(200)$ & - \\
\hline Horizontal distance from center of coronoid process to posterior face of condyle & (216) & 221 \\
\hline Horizontal distance across base of coronoid process & 300 & - \\
\hline $\begin{array}{l}\text { Horizontal distance from posteriormost extent of condyle to beginning of anterior edge of coro- } \\
\text { noid }\end{array}$ & 390 & 389 \\
\hline Horizontal distance from posteriormost extent of condyle to end of posterior edge of coronoid & 100 & - \\
\hline $\begin{array}{l}\text { Greatest distance from posteriormost extent of condyle to internal margin of orifice for mandibu- } \\
\text { lar canal }\end{array}$ & $(210)$ & $(225)$ \\
\hline Greatest vertical diameter of posterior end including condyle & (185) & - \\
\hline Greatest transverse diameter of condyle & 46 & 49 \\
\hline Greatest vertical diameter of condyle & 101 & - \\
\hline
\end{tabular}

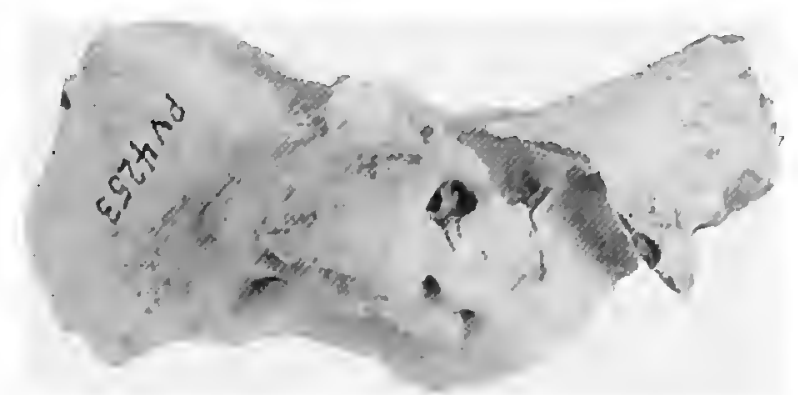

A

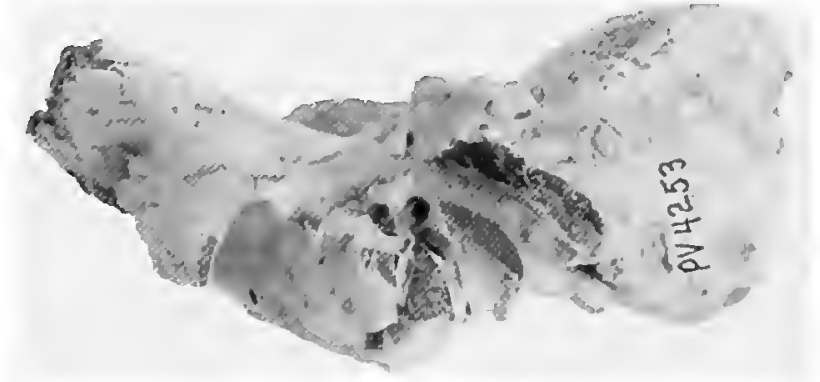

B
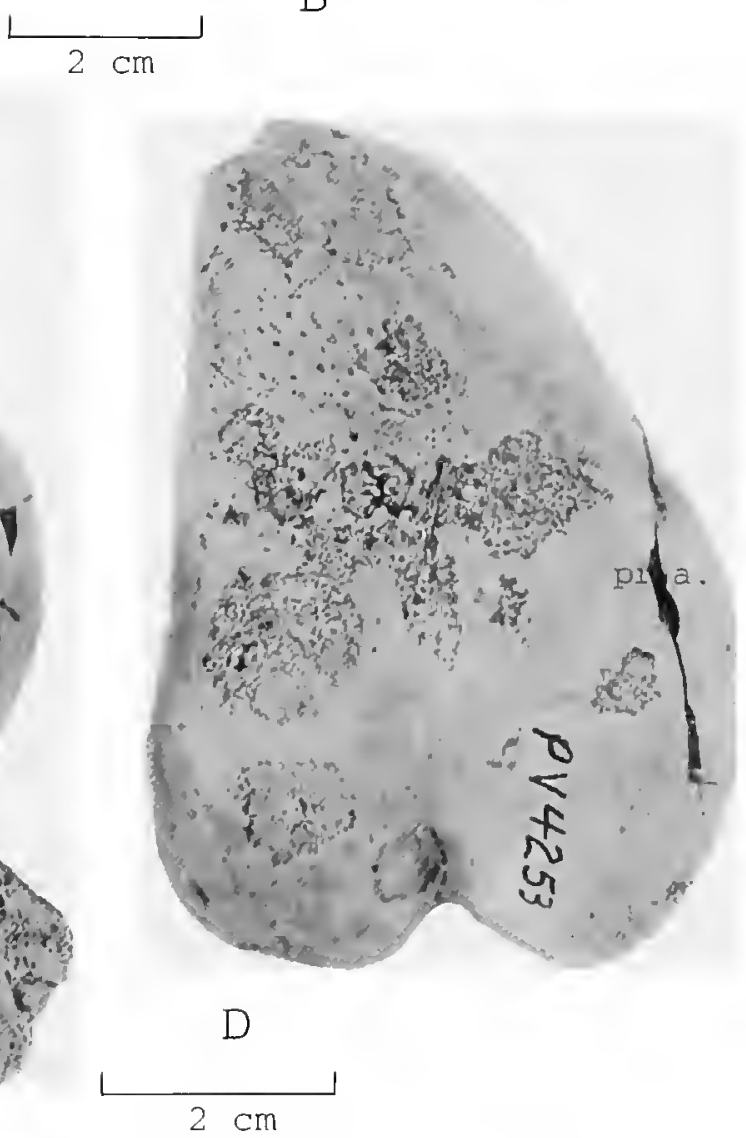

FIGURE 9.-Eomysticetus whitmorei, new genus and new species, holotype, ChM PV4253: A, left periotic; B, right periotic; $C$, right tympanic bulla in ventral vicw; D, left tympanic bulla in cerebral or dorsal view. 

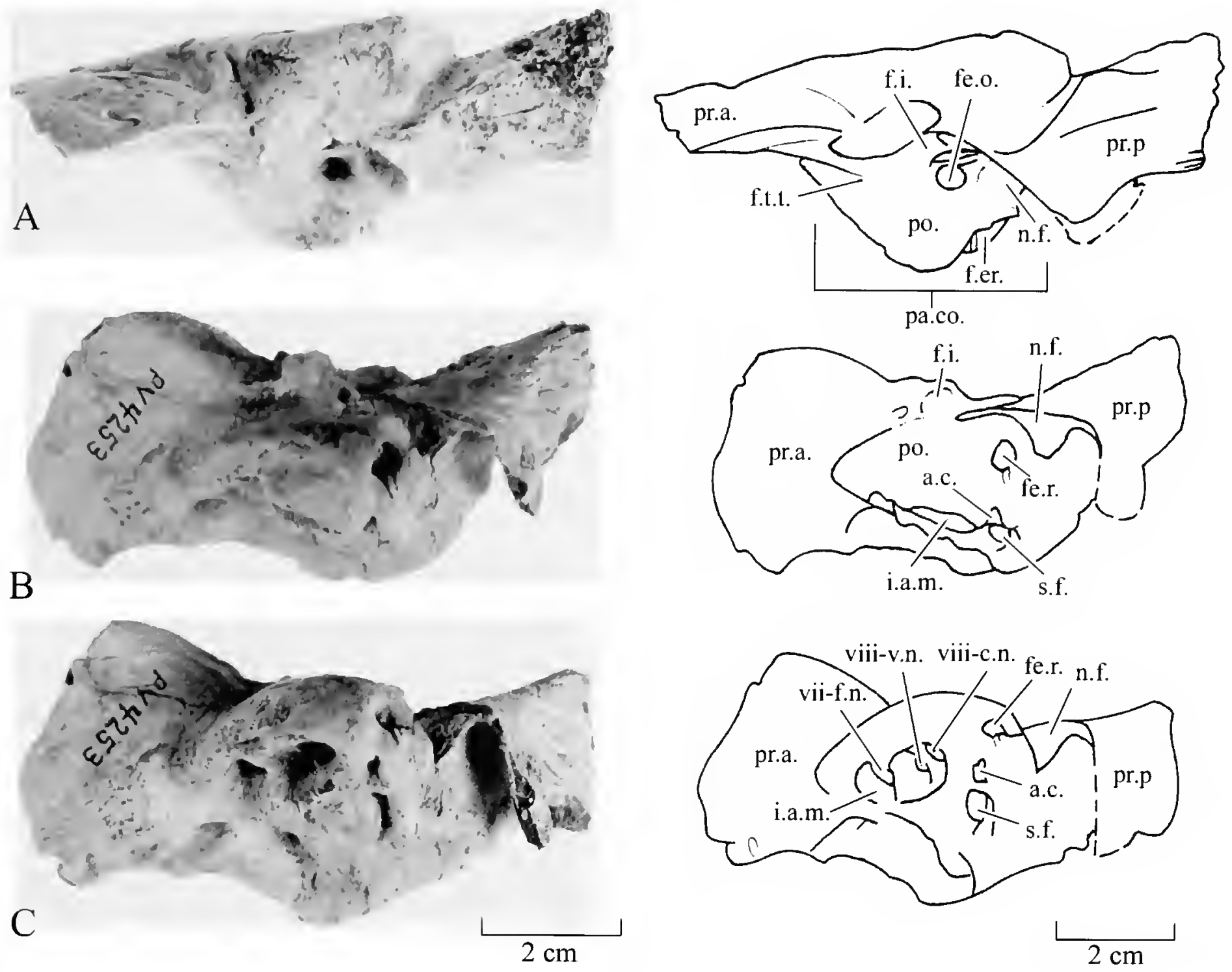

FIGURE 10.-Eomysticetus whitmorei, new genus and new species, holotype, ChM PV4253, left periotic: A, ventral view; B, cerebral or dorsal view; C, dorsolateral view. (Dashed lines represent hypothetical configurations; a.c.=aqueductus cochlearis; $\mathrm{c} . n .=$ foramen for cochlear nerve (VIII); f.i. $=$ fossa incudis; .n. $=$ foramen for facial nerve (VII); fe.o.=fenestra ovalis; fe.r. $=$ fenestra rotunda; f.t.t. $=$ fossa for tensor tympani muscle; i.a.m. $=$ internal auditory meatus; $n$.f. $=$ notch for exit of facial nerve; pa. co. $=$ pars cochlearis; po. =promontorium; pr.a. $=$ anterior process; pr.p.=posterior process; s.f.=subarcuate fossa; v.n. $=$ foramen for vestibular nerve (VIII).)

tinct downward bend anteriorly, a large and laterally deflected coronoid process, and a small posteriorly directed condyle (Figure 12). Approximately $60 \%$ (894 mm) of the left dentary is preserved (Figure 13). Most of the posterior end is present in both dentaries, but the anterior end is missing in the left one. The posterior end of the left dentary is complete except for the lower angle, which is missing in both dentaries. The coronoid process is preserved only on the right side and is relatively large and has a high apex. There is a large mandibular foramen, and, as is typical of mysticetes, the dentary is elongate and lacks alveoli. On the external (labial) surface of the nearly complete right dentary is a series of 10 mental foramina begin-

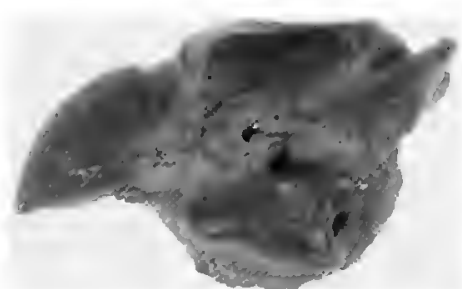

A

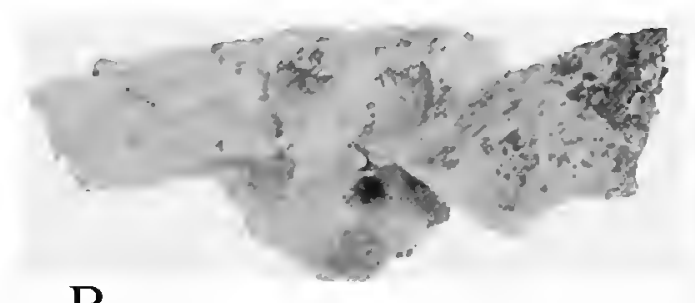

B

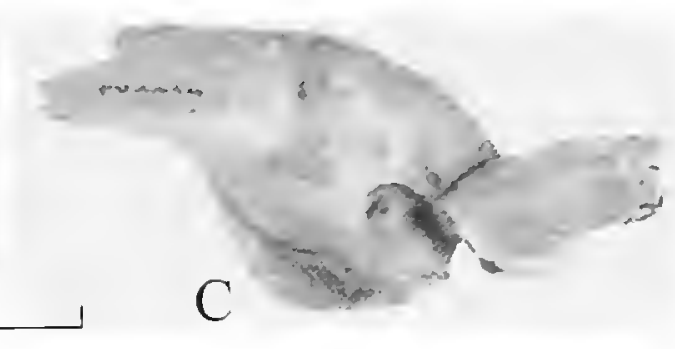

$3 \mathrm{~cm}$

FIGURE 11.--Left periotics: A, Zygorhiza kochii (Reichenbach), ChM PV5065; B, Eomysticetus whitmorei, new genus and new species, holotype, ChM PV4253; C, Micromysticetus rothauseni Sanders and Barnes, holotype, ChM PV4844. 


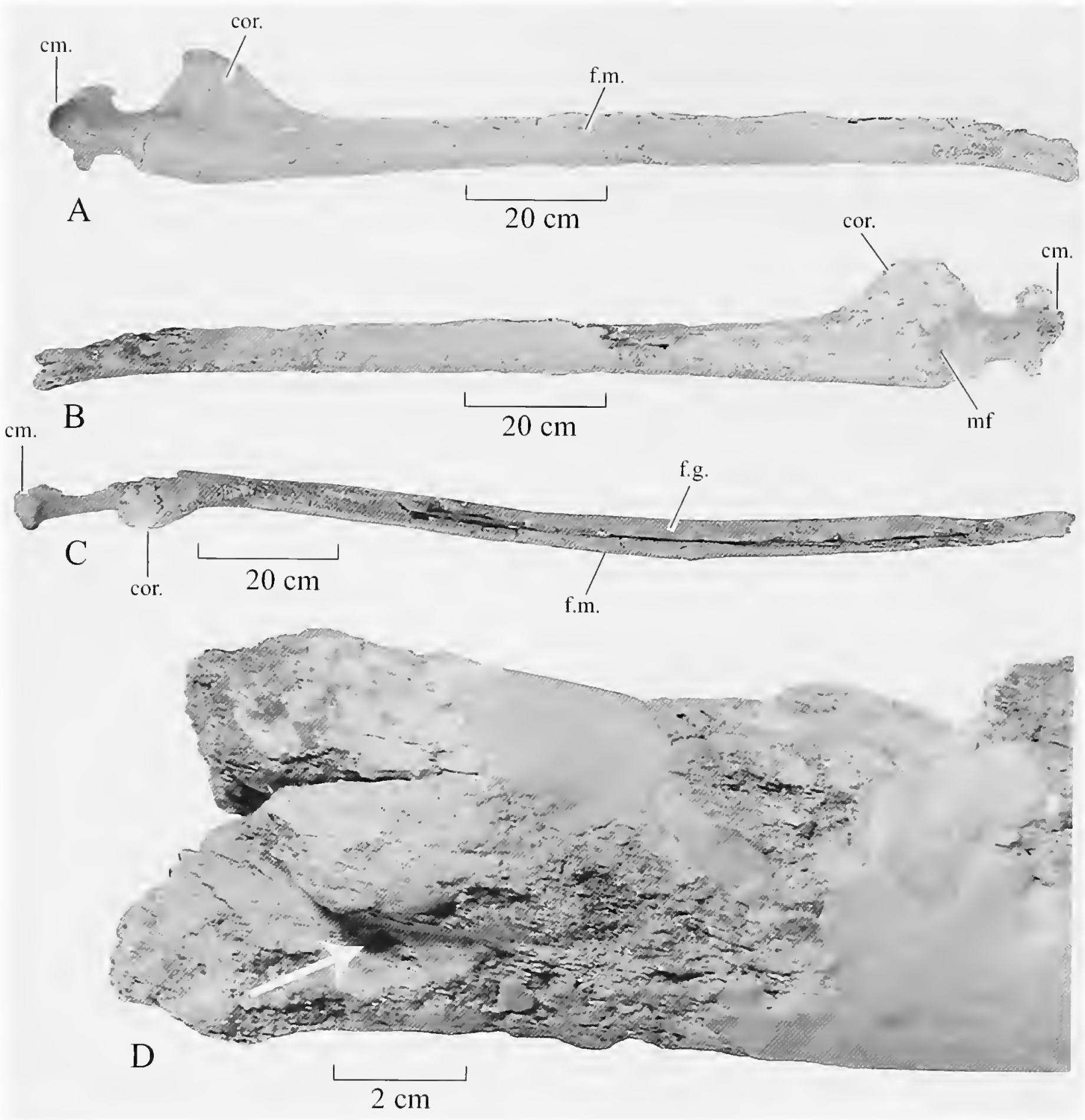

FigURE 12.-Eomysticetus whitmorei, new genus and new species, holotype ChM PV4253, right dentary: A, labial view; B, lingual view; C, dorsal view; D, distal end showing groove for symphyseal ligament. (cm.=mandibular condyle; cor.=coronoid process; f.g.=gingival foramen; f.m.=mental foramen; $m . f .=$ mandibular foramen.)

ning at $95 \mathrm{~mm}$ anterior to the anteriormost edge of the coronoid and appearing thereafter at $155,280,410,490,580,660,750$, 870 , and $940 \mathrm{~mm}$ from that point. The posteriormost foramen opens posteriorly. Though badly broken and eroded, a remnant of the gingival groove is preserved on the dorsal margin of the dentary. The groove for the symphyseal ligament begins about $20 \mathrm{~mm}$ posterior to the anterior end of the dentary and is approximately $43 \mathrm{~mm}$ in anteroposterior length (Figure 12D). It is situated in the ventral one-third of the dentary height and bends slightly dorsally at its anterior end. The ligamentary groove is quite distinct and is indicative of the typical ligamental mandibular symphysis of the more highly evolved mysticetes, such as cetotheriids and balaenopterids.
For approximately $600 \mathrm{~mm}$ of its length anterior to the coronoid, the right dentary is almost entirely straight (Figure 12C). From there forward, the anterior part tapers in uniform dorsoventral diameter for the remaining length of the bone. Approximately $600 \mathrm{~mm}$ from the anterior end, the horizontal ramus begins to bend noticeably downward and is of almost uniform dorsoventral diameter from that point to its anterior terminus. Unlike the mandibles of most Neogene mysticetes, which are bowed laterally between the level of the coronoid process and the anterior end, the lateral curvature of the dentary in $E$. whitmorei is restricted to the anterior half and forms a much flatter arc than in such forms as Pelocetus calvertensis Kellogg (1965, fig. 6), Mesocetus siphunculus Cope, 1895 (see 


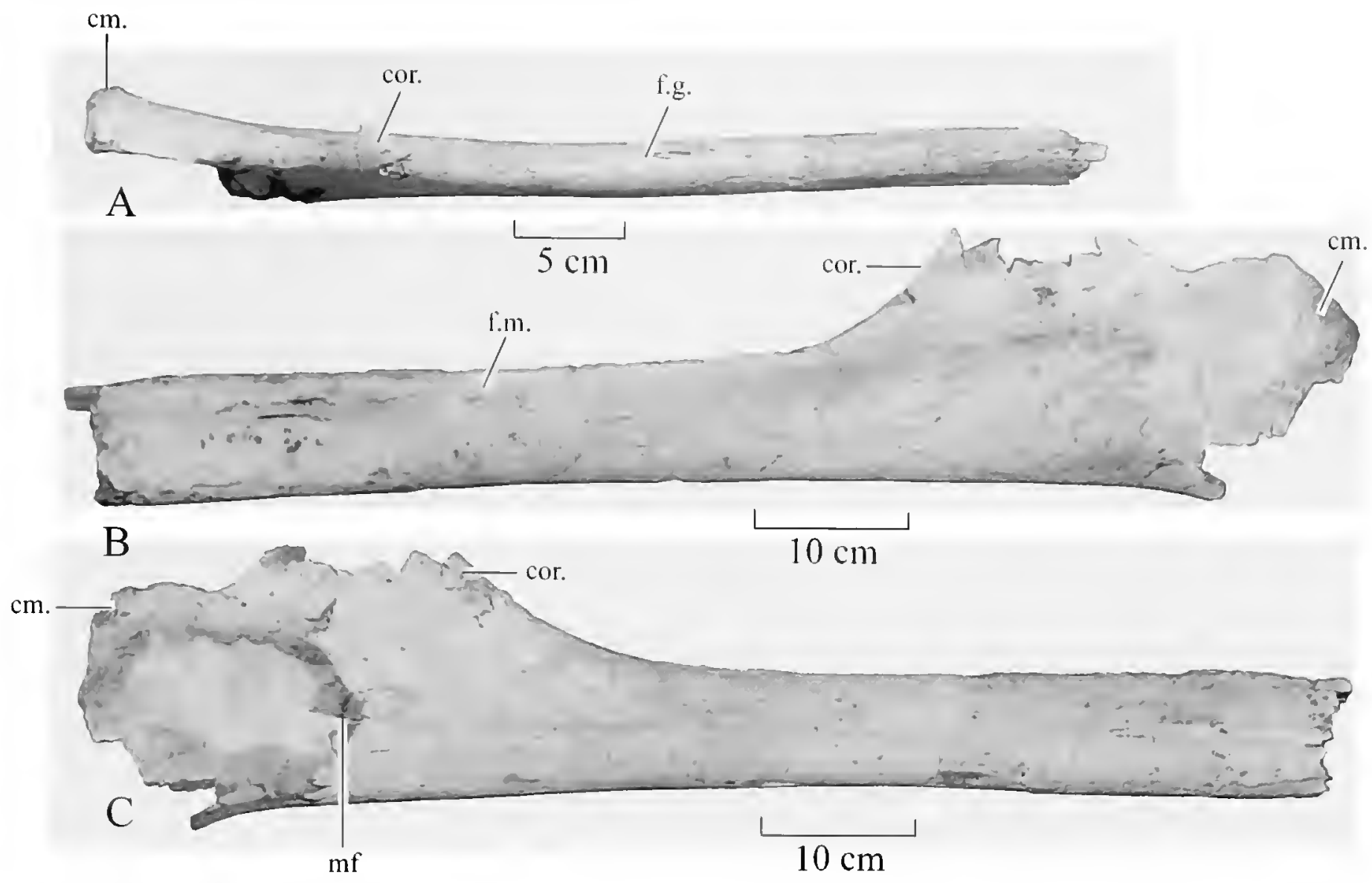

FIGURE 13.-Eomysticetus whitmorei, new genus and new species, holotype, ChM PV4253, left dentary: A, dorsal view; B, labial view; $\mathrm{C}$, lingual view. (For abbreviations, see Figure 12.)

Kellogg, 1968, fig. 49), and Parietobalaena palmeri Kellogg (1968, fig. 89), all from Miocene deposits of Virginia. The flattened curvature of the mandible of $E$. whitmore $i$ is most nearly like that of Diorocetus hiatus Kellogg (1968, fig. 59), in which the curvature is reduced to conform to the narrow, strongly tapered rostrum in that species, which also is from Miocene deposits of Virginia. The length and slight degree of convexity in the mandible of Eomysticetus demonstrates the presence of a long, narrow rostrum in this new Oligocene mysticete, as indicated also by the narrowness of two large anterior fragments of the left and right maxillae.

Posteriorly and in dorsal aspect, the external wall of the mandible follows a broad, laterally directed (concave) curve between the level of the anterior end of the coronoid and the posterior edge of the condyle (Figure 12C). To our knowledge, that configuration of the posterior region of the dentary is not known in any other mysticete. In most previously described taxa, the lateral surface follows a convex line and is then sharply recurved in the area between the apex of the coronoid and the condyle, thus placing the posterior edge of the coronoid further medial than the anterior edge. In E. whitmorei the posterior edge is on the same long, concave curve as the anterior edge and is not offset medially. Along the base of the coronoid process, the lateral surface of the ramus sweeps dorsally in a broad curve that terminates at the anterior edge of the mandibular condyle, which lies approximately $60 \mathrm{~mm}$ above the plane of the dorsal margin (Figures 12A, 13B). Extended posteriorly, the axis of the dorsal margin bisects the condyle approximately at the center of its vertical diameter. The condyle is thus seated extremely high on the posterior end of the mandible. A similar situation exists in the dentaries of Mesocetus siphunculus (see Kellogg, 1968, fig. 49) and Diorocetus hiatus (see Kellogg, 1968, fig. 59), but in neither of these forms is the condyle elevated nearly so high as in $A$. whitmorei. In all three taxa, however, the condyle is located much higher than in Parietobalaena palmeri and Pelocetus calvertensis, the anterior face being only slightly above the plane of the dorsal edge in the latter forms. Of the four Miocene cetotheriids mentioned herein, the mandible of Diorocetus hiatus most nearly resembles that of Eomysticetus whitmorei in the moderate degree of convexity of the ramus and in the dorsoventral height of the anterior face of the condyle. The mandibular foramen is relatively large and opens posteriorly. Its anteriormost margin is aligned approximately with the apex of the coronoid process, and the anterior margin is a broad curve. The lateral wall within the foramen is thin and dense.

The coronoid process is exceptionally large for a mysticete and more nearly resembles that of the archaeocete Zygorhiza kochii (Reichenbach, 1847) (see Kellogg, 1936, fig. 31a). It has a relatively broad base anteroposteriorly and a high, rounded apex. The apex is present on the right dentary of $E$. whitmore but is missing in the left one (Figures 12,13). It is thick anteriorly and thinner posteriorly. As seen in Figure 12, the dorsal half of the coronoid is curved laterally in a gentle arc so that it is angled dorsolaterally as in many Neogene mysticetes, but not to such an extreme as in the latter forms (e.g., Parietobalaena 
TABLE 3.-Measurements (in mm) of the cervical vertebrae of Eomysticetus whitmorei, new genus and new species, ChM PV4253. Parentheses indicate estimated measurements.

\begin{tabular}{l|ccccccc}
\hline \multicolumn{1}{c|}{ Character } & Atlas & Axis & C.3 & C.4 & C.5 & C.6 & C.7 \\
\hline Anteroposterior diameter of centrum & 57 & $66^{*}$ & 39 & 33 & 36 & 40 & 40 \\
Transverse diameter of centrum, anteriorly & 137 & 127 & 102 & 97 & $(100)$ & 98 & 95 \\
Vertical diameter of centrum, anteriorly & 73 & $(48)$ & 84 & - & $(95)$ & $(83)$ & 83 \\
Tip of neural spine to ventral face of centrum, anteriorly & $(128)$ & - & - & - & - & - & $(170)$ \\
Greatest vertical diameter of neural canal, anteriorly & 73 & - & - & - & - & $(43)$ & $(45)$ \\
Greatest transverse diameter of neural canal, anteriorly & 46 & 50 & - & - & - & $(41)$ & $(89)$ \\
Greatest distance between outer ends of diapophyses & - & - & - & - & - & $(156)$ & $(196)$ \\
Greatest distance between outer ends of parapophyses & - & - & - & - & $(186)$ & $(182)$ & $(124)$ \\
Least anteroposterior diameter of right pedicle of neural arch & 54 & 15 & - & - & - & 19 & 20 \\
Greatest transverse diameter of centrum, posteriorly & $(127)$ & 112 & 105 & 99 & $(96)$ & 94 & 97 \\
Greatest vertical diameter of centrum, posteriorly & $(65)$ & 83 & 92 & 90 & 92 & $(88)$ & 88 \\
Anteroposterior diameter into transverse diameter, centrum (anteriorly) & 2.40 & 1.92 & 2.62 & 2.94 & 2.78 & 2.45 & 2.38 \\
Anteroposterior diameter into vertical diameter, centrum (anteriorly) & 1.32 & 0.76 & 2.15 & - & 2.64 & $(2.08)$ & 2.08 \\
\hline
\end{tabular}

*Includes odontoid process.

palmeri Kellogg (1968, fig. 89)). In E. whitmorei, there also is a proportionately shorter distance between the anterior edge of the condyle and the terminus of the posterior edge of the coronoid, which also is situated well above the dorsal margin of the ramus.

Cervical Vertebrae: All seven of the cervical vertebrae are preserved (Table 3). None is ankylosed with any of the others in the series; however, the posterior face of the axis vertebra is deeply concave and closely encloses the anterior face of the third cervical, apparently presaging the eventual ankylosis of these two vertebrae in some Neogene mysticetes. The anterior face of the third cervical vertebra is slightly concave transversely, except for its upper portion, which is thickened anteroposteriorly so that it projects anteriorly to fit into a concavity along the dorsal margin of the posterior face of the axis vertebra. In all of the other cervical vertebrae following the axis, the anterior face of the centrum is flat and the posterior face is concave. The epiphyses are firmly ankylosed to the centra in all of the cervical vertebrae, indicating the physical maturity of the specimen.

The atlas is missing both of its transverse processes, but the size of the broken areas at their bases on the centrum suggests that the processes were of modest size and apparently were not large enough to have enclosed a transverse foramen (Figure 14B). They were situated relatively high on the centrum, directly upon the juncture of the dorsal and lateral surfaces. The transverse diameter of the anterior face is broadest at that point $(137 \mathrm{~mm})$ and narrowest across the ventral margin $(86 \mathrm{~mm})$. The facets for articulation with the occipital condyles of the cranium are deeply concave and somewhat angular along their lateral margins. Vertically, they are $86 \mathrm{~mm}$ in diameter and extend above the level of the dorsal surface of the centrum to a point just below the roof of the neural canal, their dorsal margins forming the anterior edges of the pedicles of the neural arch. The dorsal margins of the facets extend anteriorly beyond the level of the ventral margins. Twelve millimeters behind the anterior margin of the neural arch, each of the pedicles is pierced by a large (13 $\mathrm{mm}$ on right, $15 \mathrm{~mm}$ on left), laterally di- rected arterial foramen, or canal, that emerges into a shallow groove on the dorsal surface of the centrum. The spine is missing from the neural arch, but it may not have been much more than an elevated, knob-like continuation of the low, median ridge present on the anterior portion of the arch. The lower portion of the neural canal is deeply concave, the ventral margin being only $44 \mathrm{~mm}$ above the ventral surface of the centrum. Anteriorly, its lateral margins are formed entirely by the lateral margins of the articular facets; the transverse diameter of the canal is $42 \mathrm{~mm}$ dorsally and $17.5 \mathrm{~mm}$ ventrally. The margins of the posterior face of the atlas are not well preserved and provide only an approximate measurement of the transverse diameter, which was at least $127 \mathrm{~mm}$. The facets for articulation with the axis vertebra are much smaller than the anterior facets, their dorsal margins lying well below the dorsal surface of the centrum. The right one is the best preserved of the two and is greater in vertical diameter $(\sim 60 \mathrm{~mm})$ than in transverse diameter $(\sim 47 \mathrm{~mm})$. The ventral margin of the posterior face is preserved sufficiently to determine that a hyapophysis is not present on the atlas of $E$. whitmorei.

The axis vertebra is missing the neural arch (Figure 14C). The stumps of the pedicles are directed posteriorly at an angle and are flattened anterolaterally. The transverse processes are short and blunt, are imperforate, and are bent posteriorly. The ends are upturned and thus do not project below the level of the ventral surface of the centrum. The anterior face of the axis slopes posteriorly at a slight angle. The anterior facets for articulation with the atlas are concave transversely and are separated above the odontoid process by an interval of approximately $52 \mathrm{~mm}$ across the midline of the centrum. The odontoid process is broadly rounded ventrally; dorsally, it is flattened on either side of a median ridge that extends posteriorly onto the dorsal surface of the centrum. Between the pedicles of the neural arch, two foramina are situated on each side of the bony ridge. The posterior face is deeply excavated both transversely and dorsoventrally, but more so in the former direction and especially along the dorsal margin.

The neural arch and most parts of the elements of the trans- 


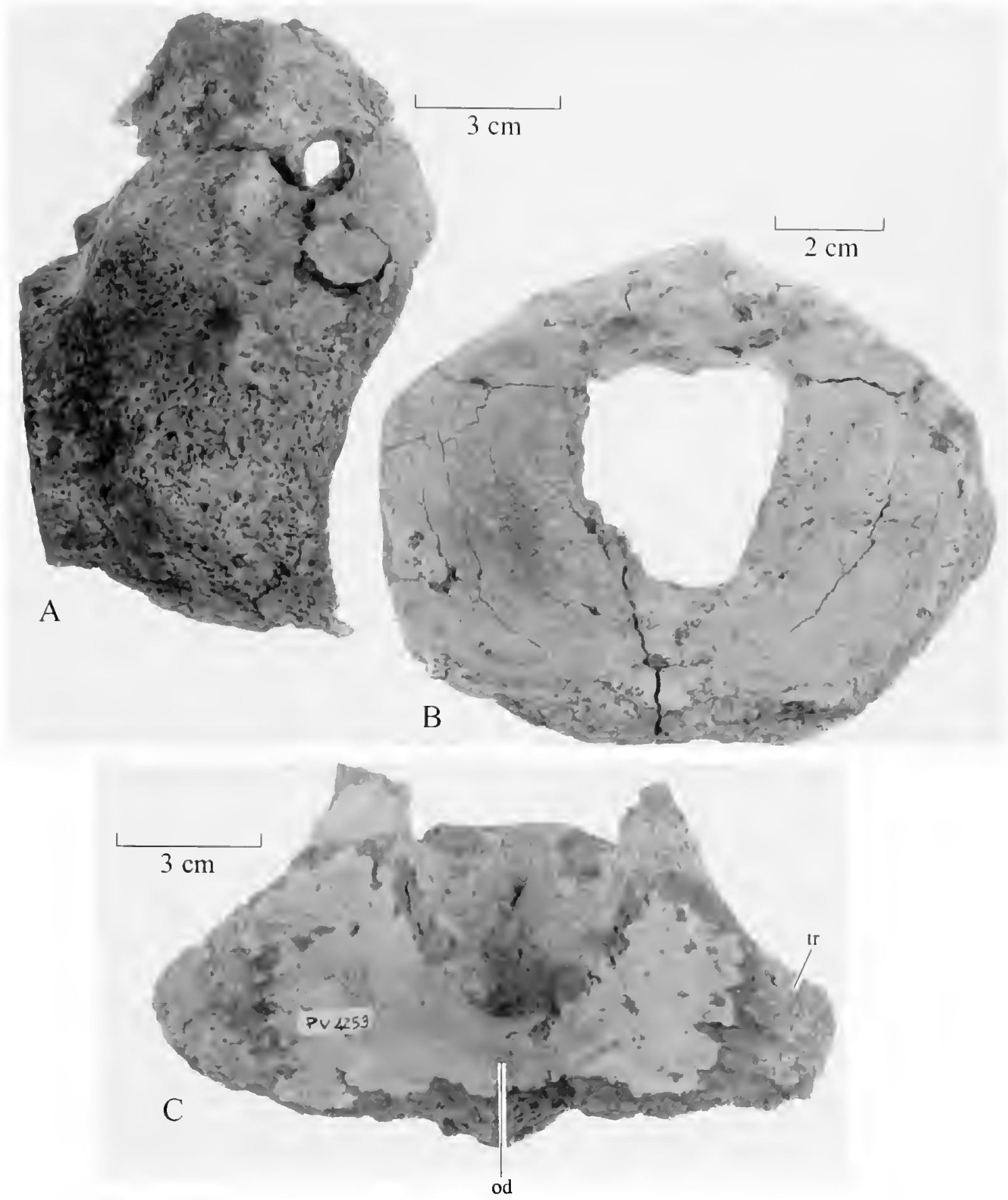

FIGURE 14.-Eomysticetus whitmorei, new genus and new species, holotype, ChM PV4253: A, atlas vertebra in anterior view; B, same, right lateral view; $C$, axis vertebra, anterior face. (od.=odontoid process; tr. $=$ transverse process.)

verse processes are missing on the third, fourth (Figure 15), and fifth cervical vertebrae. The left lower transverse process is present on the third cervical, and both of the lower processes are preserved on the fourth cervical. On the dorsal surface of the centrum of each of these three vertebrae there is a pair of foramina at the midline. On the third through the seventh cervical vertebrae, the profile of the anterior face of the centrum is approximately that of a flattened circle, the greatest diameter occurring transversely on a level coinciding with the dorsal margin of the base of the parapophyses. The profile of the posterior face is of the same general conformation, with the exception of the third cervical. In that vertebra, the ventral margins of the posterior face assume a triangular shape, sloping sharply from the widest point of the anterior face to a broadly rounded angle at the edge of the ventral surface of the centrum. This angle projects below the ventral margin of the parapophyses, which extend below the ventral margin of the anterior face.

On the sixth cervical vertebra, the neural spine and the left half of the neural arch are missing (Figure 16A). From the preserved right portion it can be seen that the anterior profile of the neural canal was that of a triangle with rounded angles. The ventral articular facet of the postzygapophysis has the form of a truncated ellipse, is $23 \times 20 \mathrm{~mm}$ in dimension, and projects posteriorly $5 \mathrm{~mm}$ beyond the centrum. The diapophysis is much more slender than the parapophysis, the base of which is larger in this cervical than in any of the others, extending approxi- 


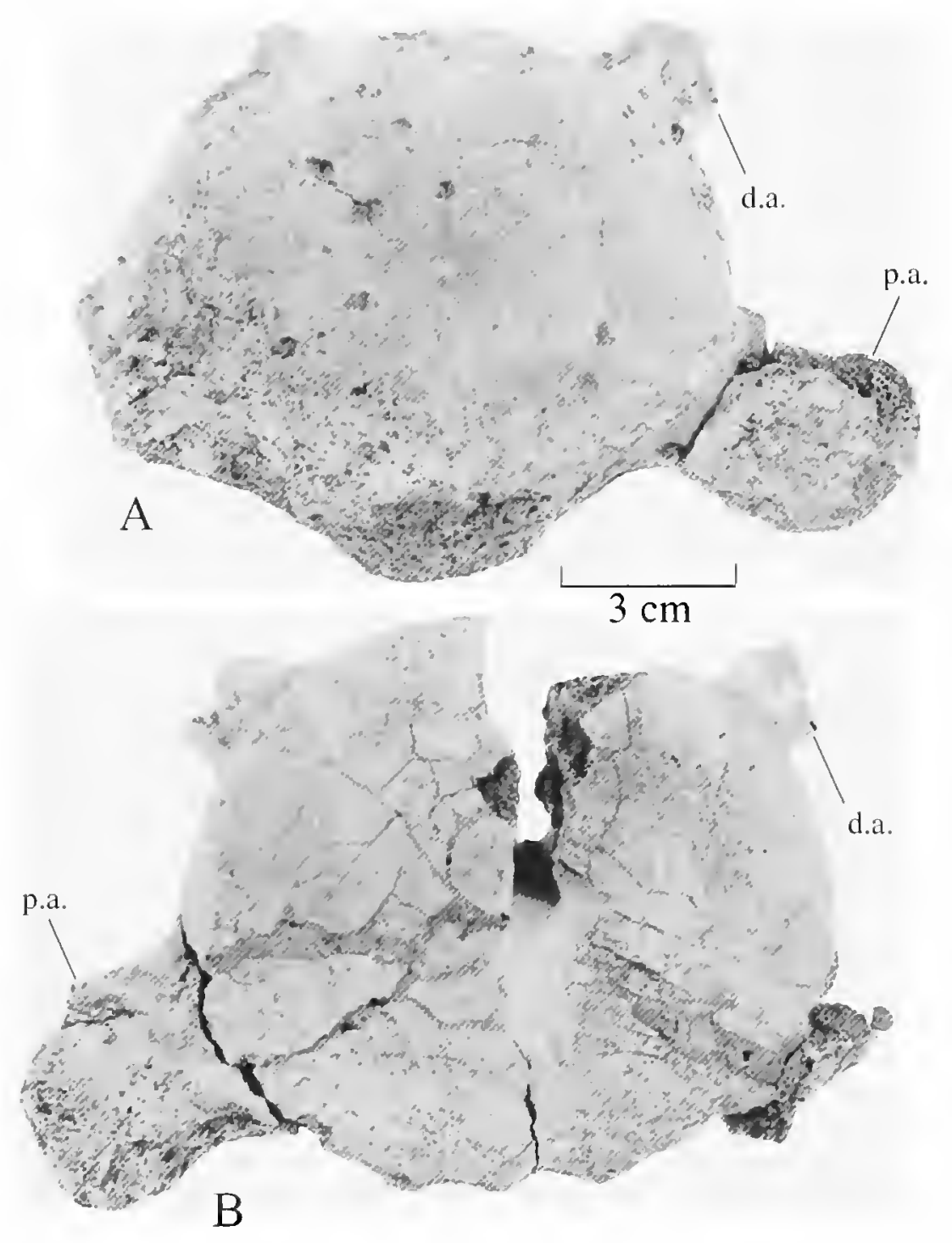

FIGURE 15.-Eomysticetus whitmorei, new genus and new species, holotype, ChM PV4253, cervical vertebrae, anterior views: A, third cervical; B, fourth cervical. (d.a.=diapophysis; p.a.=parapophysis.)

mately $17 \mathrm{~mm}$ below the ventral surface of the centrum. The vertical diameter of the lateral foramen is $46.6 \mathrm{~mm}$, greater than that of any of the other cervical vertebrae. The articulating portions of the diapophyses and the parapophyses are missing.

On the seventh cervical vertebra, the neural arch is complete and the neural canal is triangular in anterior profile (Figure $16 \mathrm{~B})$. The pedicles of the arch are considerably larger than those of the other cervical vertebrae and are noticeably asymmetrical in dorsoventral diameter, the right one being $33 \mathrm{~mm}$ and the left one $28 \mathrm{~mm}$. There also is a striking difference in the dimensions of the ventral facets of the postzygapophyses, the right one being approximately $40 \times 16 \mathrm{~mm}$ and the left one approximately $31 \times 11 \mathrm{~mm}$. Both are much longer anteroposteriorly and more narrow transversely than corresponding facets of the sixth cervical. The upper and lower transverse processes are more complete on the right side than on the left, the entire right parapophysis being missing. The articulating portions of the right processes are not preserved. In contrast to the sixth cervical, the diapophysis is much larger than the parapophysis, which is greatly reduced from the size of its preceding counterpart. The increased dorsoventral width of the pedicles has de- creased the size of the lateral foramen; the vertical diameter of the right one is only $36 \mathrm{~mm}$, compared with $46.6 \mathrm{~mm}$ on the sixth cervical. At the greatest transverse width of the posterior face of the centrum there are demifacets for the articulation of the first rib. These features are best observed when this vertebra is placed in normal articulating position with the first thoracic vertebra, which has a corresponding demifacet opposite each of those on the last cervical.

Thoracic Vertebrae: Seven thoracic vertebrae are preserved, among them the first three and the fifth, seventh, eighth, and the possible $15^{\text {th }}$ in the thoracic series. Lacking direct evidence of the total number of thoracic vertebrae normally present in $E$. whitmore $i$, we assume that there were no fewer than 12, based upon Kellogg's (1968:175) comments about the number of dorsal (thoracic) vertebrae in fossil mysticetes from the Miocene Calvert Formation in Maryland and Virginia. Eomysticetus whitmorei appears to have had at least 15 pairs of ribs, however, and thus would have had 15 thoracic vertebrae. As shown in Table 4, the anteroposterior diameter of the centrum in the preserved thoracic vertebral series increases from the first through the last, and the transverse diameters are consistently greater than the vertical diameters. Ratios of lengths and widths of the thoracic vertebral centra are diagrammed in Figure 29 and are interpreted in the "Discussion" section below.

The anteroposterior length of the centrum of the first thoracic vertebra (Figure 17A) is only $10 \mathrm{~mm}$ greater than that of the seventh cervical vertebra. The spinous process is preserved on the first thoracic vertebra, but the right and left sides of its neural arch are missing. The spinous process slopes anteriorly at an angle of approximately $60^{\circ}$ from the plane of the roof of the neural arch, and from that plane to its tip the process is $81 \mathrm{~mm}$ in vertical thickness. On the lateral margins of the centrum, the anterior demifacet for the capitulum of the first rib is situated below the level of the posterior demifacet for the capitulum of the second rib.

The second thoracic vertebra (Figure 17B) is essentially complete, with only its left transverse process, the margins of its neural arch, and the posterior edge of its spinous process showing appreciable degrees of erosion. The profile of the neural canal continues the triangular shape that is present on the seventh cervical. The apex of the neural spine is intact, the vertical height of this process being $137 \mathrm{~mm}, 56 \mathrm{~mm}$ greater than that of the first cervical. The pedicles are markedly different in their transverse dimensions, the right one being $33 \mathrm{~mm}$ and the left one $29 \mathrm{~mm}$. They are much narrower anteroposteriorly, the right one being $22.5 \mathrm{~mm}$ and the left one $20 \mathrm{~mm}$ in greatest diameter. Arising from the base of the pedicle, the transverse process projects dorsolaterally at an angle of approximately $35^{\circ}$ from the center of the anterior face of the centrum and anteriorly to a point about $40 \mathrm{~mm}$ beyond the centrum, placing the articular facet for the tuberculum of the second rib on a level with the roof of the neural arch and well anterior to the anterior face of the centrum. The somewhat elliptical prezygapophysial 


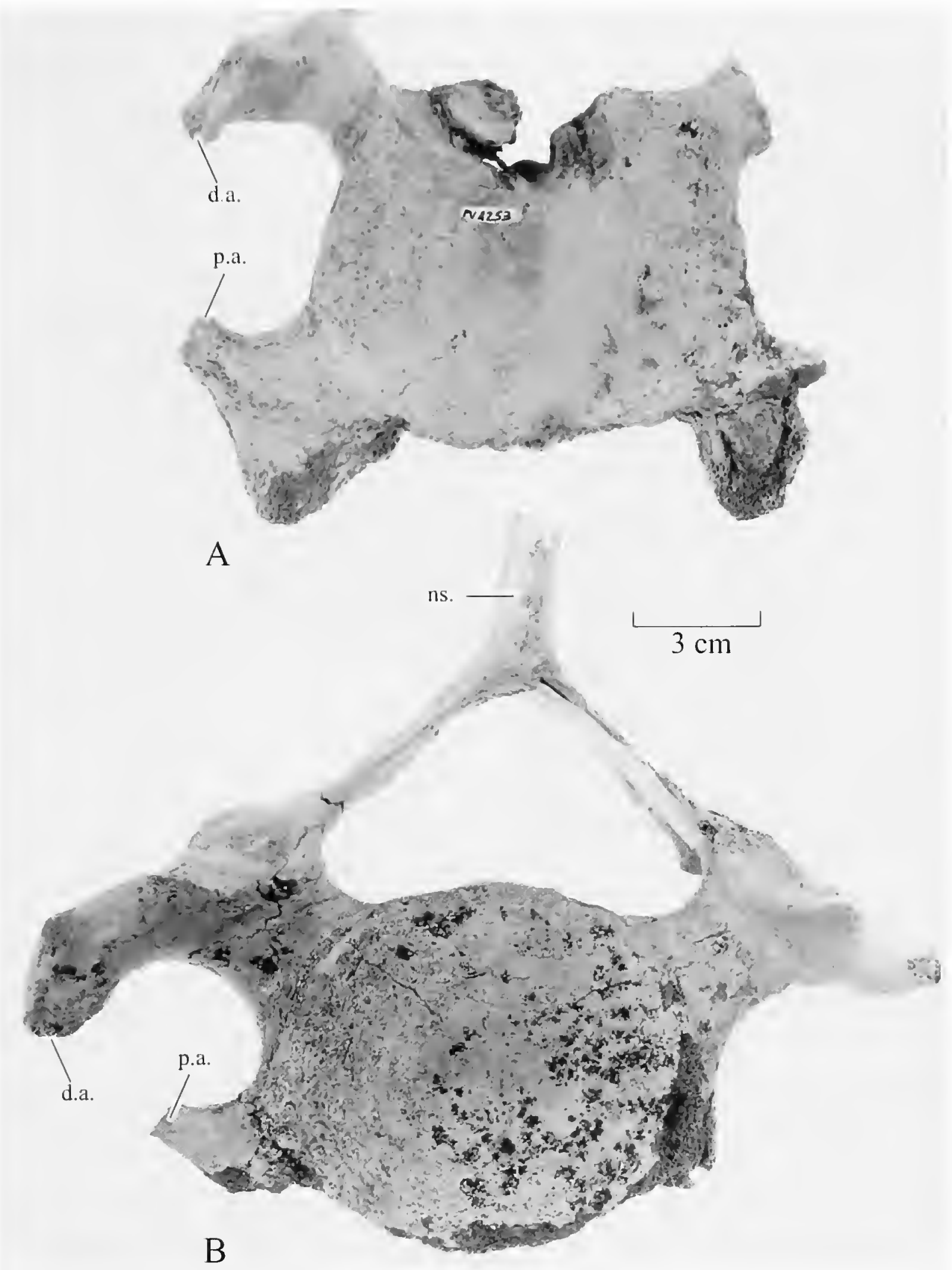

FIGURE 16.-Eomysticetus whitmorei, new genus and new species, holotype, ChM PV4253, cervical vertebrae, anterior views: A, sixth cervical; B, seventh cervical. (For abbreviations, see Figure 15.)

facet is situated on the dorsal surface of the diapophysis, forming a shallow depression approximately $37 \mathrm{~mm}$ in length. The postzygapophysis extends $9 \mathrm{~mm}$ beyond the posterior face of the centrum. Its ventral articular facet is elliptical in form and measures $26 \times 16 \mathrm{~mm}$. On the lateral margins of the centrum, the anterior facet for the capitulum of the second rib is located slightly ventral to the posterior facet for the capitulum of the third rib.

The third thoracic vertebra (Figure 17C) is similar in form and preservation to the second one, both having a neural spine 


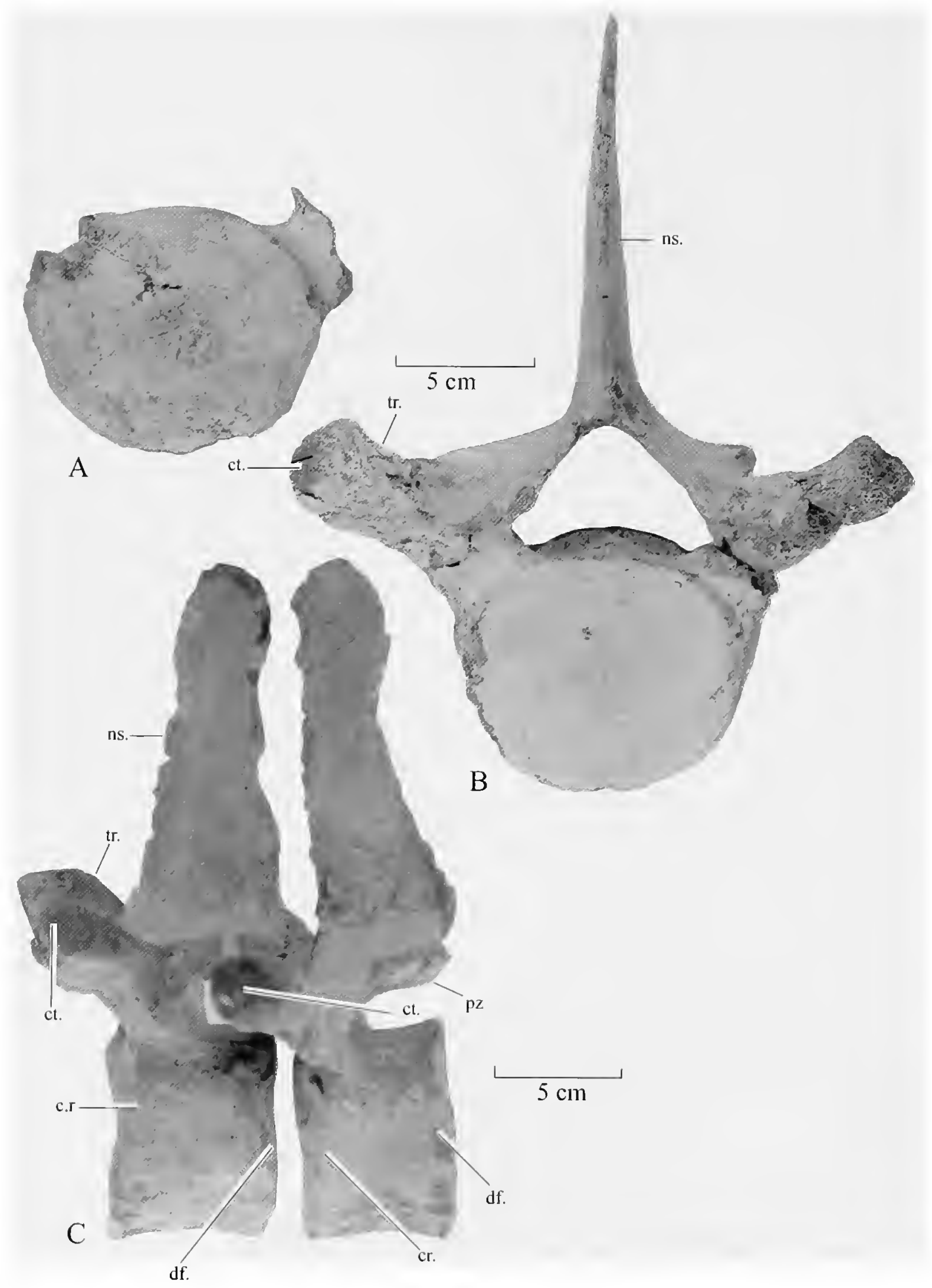

FIGURE 17.-Eomysticetus whitmorei, new genus and new species, holotype, ChM PV4253, thoracic vertebrae: $\mathrm{A}, \mathrm{B}$, first and second thoracics, respectively, in anterior view; C, second and third thoracics (left to right) in lateral view. ( $c r .=$ anterior demifacet for capitulum of rib; $c t$. =facet for tuberculum of rib; df. =posterior demifacet for capitulum of rib; $\mathrm{mp} .=$ metapophysis; $\mathrm{ns} .=$ neural spine; $\mathrm{pz} .=$ postzygapophysis; $\mathrm{tr} .=$ transverse process.)

that is comparatively slender anteroposteriorly. The dorsal tip of the spinous process is missing only a millimeter or two, its vertical dimension being approximately $143 \mathrm{~mm}$ with that allowance. Posteriorly, its base has two facets to receive the anterior end of the base of the neural spine of the fourth thoracic. The neural canal is triangular in anterior view, but its apex is not as acute as that of the second thoracic, from which it differs also by being $3 \mathrm{~mm}$ less in vertical diameter. The transverse processes project dorsolaterally, but in this vertebra the axis of each process passes through the ventral margin of the centrum, rather than through the center as in the second thoracic. The right process extends anteriorly approximately $38 \mathrm{~mm}$ beyond the anterior face of the centrum. It is the best preserved of the two, the extremity of the left one having been eroded away. 


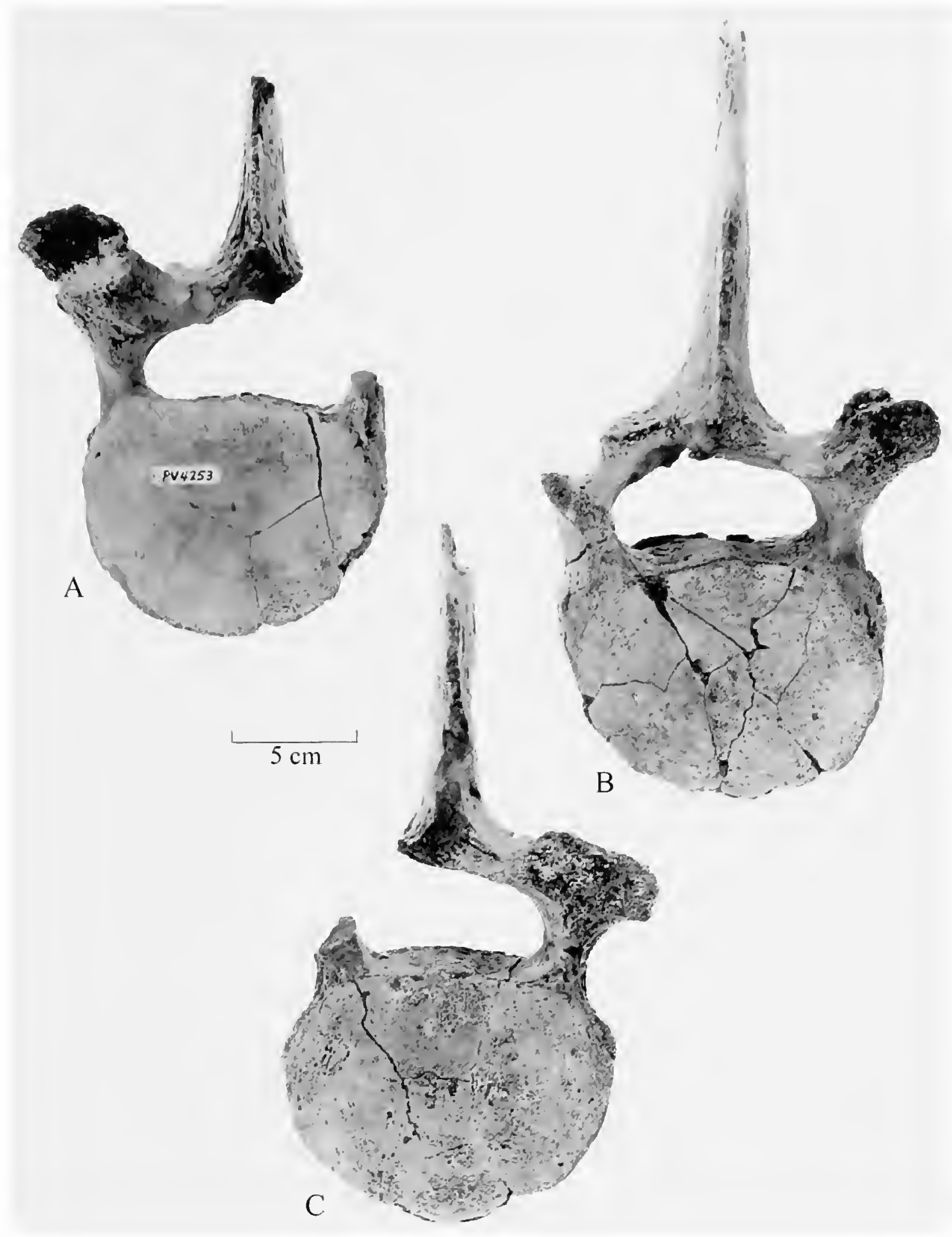

FIGURE 18.-Eomysticetus whitmorei, new genus and new species, holotype, ChM PV4253, thoracic vertebrae, anterior views: A, fifth thoracic; B, seventh thoracic; C, eighth thoracic.

The articular facet for the tuberculum of the right third rib is well preserved and measures $32 \times 26 \mathrm{~mm}$. The center of this facet is approximately $6 \mathrm{~mm}$ above the level of the roof of the neural canal. On the centrum the anterior facet for the capitulum of the third rib is positioned slightly more ventrally than the posterior facet for the capitulum of the fourth rib. As in the second thoracic, the transverse diameter of the right pedicle of the neural arch exceeds that of the left, the right being $21.5 \mathrm{~mm}$ and the left approximately $18 \mathrm{~mm}$, with allowance for erosion of the external surface of the left pedicle. The prezygapophysial facets are not well preserved along their outer edges, but the left one is sufficiently intact to determine its length as $43 \mathrm{~mm}$.
The postzygapophysis extends approximately $4 \mathrm{~mm}$ beyond the posterior face of the centrum. Its ventral facet is too badly eroded to yield a measurement.

The vertebra that we have identified as the fifth thoracic (Figure 18A) qualifies for that position by virtue of the anteroposterior length of its centrum $(76 \mathrm{~mm})$ compared with that of the other thoracics (see Table 4). In this specimen, the right side of the neural arch and approximately one-half of the vertical diameter of the spinous process are preserved. The anterior profile of the neural canal is not so triangular as it is on the second and third thoracic vertebrae, the vertical diameter being 4 $\mathrm{mm}$ less than that of the third thoracic (see Table 4). The right 
TABLE 4.-Measurements (in mm) of the thoracic vertebrae of Eomysticetus whitmorei, new genus and new species, ChM PV4253. (Parentheses indicate estimated measurements.)

\begin{tabular}{l|ccccccc}
\hline \multicolumn{1}{c|}{ Character } & T.1 & T.2 & T.3 & T.5 & T.7 & T.8 & T.15(?) \\
\hline Anteroposterior length of centrum & 49 & 56 & 63 & 76 & 81 & 84 & 93 \\
Transverse diameter of centrum, anteriorly & 96 & 90 & 91 & 93 & 96 & 102.6 & $(101)$ \\
Vertical diameter of centrum, anteriorly & 82 & 78 & 81 & 76 & $(79)$ & 81 & 87 \\
Minimum anteroposterior length of pedicle of neural arch & 19 & 20 & 27 & - & 42 & 49 & - \\
Transverse diameter of neural canal, anteriorly & - & 63 & 72 & $(64)$ & 67 & $(59)$ & - \\
Vertical diameter of neural canal, anteriorly & - & 40 & 37 & 33 & 32 & 32 & - \\
Distance between ends of transverse processes & - & 190 & $(176)$ & - & $(162)$ & - & - \\
Dorsal edge of metapophysis to ventral face of centrum, anteriorly & - & 27 & 30 & - & 31 & - & - \\
Tip of neural spine to ventral face of centrum, anteriorly & - & 176 & $(177)$ & - & $(190)$ & - & - \\
Transverse diameter of centrum, posteriorly & 92 & 94 & 94 & - & $(106)$ & 102 & 110 \\
Vertical diameter of centrum, posteriorly & 82 & 82 & 83 & $(84)$ & $(84)$ & $(85)$ & 94 \\
Anteroposterior length into transverse diameter of centrum, anteriorly & 1.97 & 1.55 & 1.52 & 1.22 & 1.19 & 1.22 & 1.09 \\
Anteroposterior length into vertical diameter of centrum, anteriorly & 1.68 & 1.39 & 1.35 & 1.00 & $(0.98)$ & 0.96 & 0.94 \\
\hline
\end{tabular}

transverse process projects dorsolaterally, but not at as great an angle as those of the second and third thoracic vertebrae. Unlike the latter vertebrae, the pedicles are not angled outward with the transverse process but instead arise almost directly vertical to the plane of the dorsal surface of the centrum. The end of the transverse process is badly eroded, but it is clear that the articular facet for the tuberculum of the fifth rib is well above the roof of the neural canal. The anterior end of the prezygapophysis is broken off, its preserved portion extending approximately $15 \mathrm{~mm}$ beyond the anterior face of the centrum. The posterior end of the postzygapophysis also is missing, but apparently it did not project much beyond the posterior face of the centrum. Its ventral facet is canted ventrolaterally and appears to have been more rounded than its counterparts on the second and third thoracic vertebrae.

The seventh thoracic vertebra (Figure 18B) continues a trend of progressive increase in the anteroposterior diameter of the centrum in the thoracic series (see Table 4). Concomitantly, it continues a gradational trend in the decrease in the vertical diameter of the neural canal. Much of the spinous process is preserved, but it lacks the dorsal tip and portions of the anterior and posterior edges. The left transverse process is badly eroded but extends at least $9 \mathrm{~mm}$ beyond the anterior face of the cen- trum. The right transverse process is entirely missing. The postzygapophysis extends only slightly beyond the posterior face of the centrum.

The eighth thoracic vertebra (Figure 18C) has most of its spinous process but lacks the tip and sections of the anterior and posterior margins. The left transverse process is preserved but is badly eroded and is incomplete anteriorly. Both the right transverse process and its pedicle are absent. At this position in the thoracic series, the transverse processes are still situated high on the flanks of the neural arch, the articular facet for the tuberculum of the rib being about level with the roof of the neural canal. As seen in Table 4, this vertebra reflects three progressive anterior-to-posterior trends in certain dimensions of the thoracic vertebrae: (1) a progressive increase in the anteroposterior length of the centrum; (2) a corresponding increase in the anteroposterior dimension of the pedicles of the neural arch; and (3) a reduction in the height of the neural canal. Commonly seen in cetacean vertebral columns, these trends are nothing more than accommodations for the disparate sizes of the cervical and lumbar series.

On the probable $15^{\text {th }}$ thoracic vertebra (Figure 19) the transverse processes are located at a midlateral position on the centrum, clearly indicating that it is one of the last in the thoracic
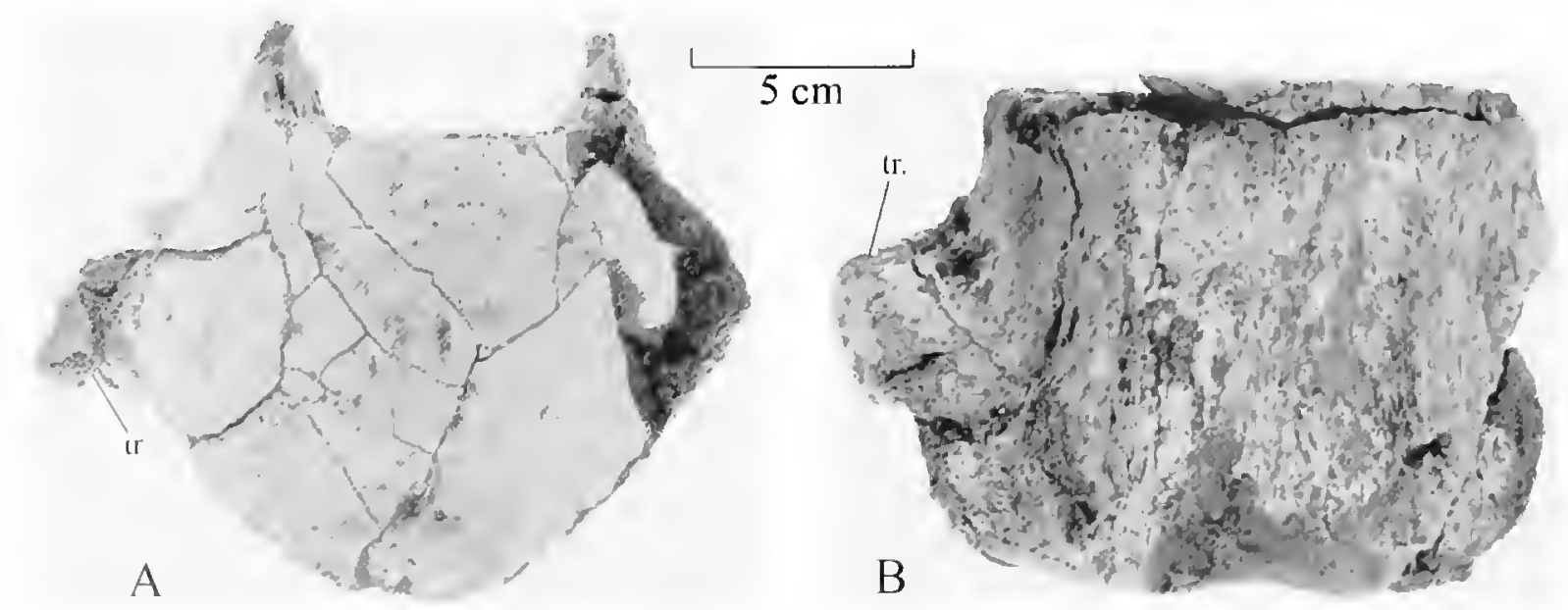

FIGURE 19.-Eomysticetus whitmorei, new genus and new species, holotypc, ChM PV4253, probable fifteenth thoracic vertebra: A, antcrior vicw; B, dorsal view. (tr.=transverse process.) 
TABLE 5.-Measurements (in $\mathrm{mm}$ ) of the lumbar vertebrae and probable first caudal vertebra of Eomysticetus whitmorei, new genus and new species, ChM PV4253. Parentheses indicate estimated measurements.

\begin{tabular}{l|ccc}
\hline \multicolumn{1}{c|}{ Character } & Lumbar A & Lumbar B & First caudal (?) \\
\hline Anteroposterior length of centrum & 126 & $(127)$ & 125 \\
Transverse diameter of centrum, anteriorly & 118 & $(128)$ & $(115)$ \\
Vertical diameter of centrum, anteriorly & $(119)$ & $(114)$ & $(114)$ \\
Minimum anteroposterior length of pedicle of neural arch & 76 & $(73)$ & 61 \\
Transverse diameter of neural canal, anteriorly & 31 & $(20)$ & 21 \\
Vertical diameter of neural canal, anteriorly & - & - & 36 \\
Distance across ends of transverse processes & $(330)$ & - & $(258)$ \\
Dorsal edge of metapophysis to ventral face of centrum, anteriorly & - & - & 195 \\
Tip of neural spine to ventral face of centrum, anteriorly & - & - & $(252)$ \\
Transverse diameter of centrum, posteriorly & $(114)$ & $(127)$ & $(123)$ \\
Vertical diameter of centrum posteriorly & $(108)$ & $(128)$ & $(110)$ \\
Anteroposterior length into transverse diameter of centrum, anteriorly & 0.94 & $(1.01)$ & 0.92 \\
Anteroposterior length into vertical diameter of centrum, anteriorly & $(0.94)$ & $(0.90)$ & 0.92 \\
\hline
\end{tabular}

series. Furthermore, its very short and blunt transverse process is additional evidence that this vertebra is the last thoracic. This vertebra exemplifies the archaeocete-like characters that are evident in the thoracic vertebrae of $E$. whitmorei. The entire neural arch, including the spinous process, is missing, as is the left transverse process. Only the posterior half of the right transverse process is preserved, but that portion is sufficient to demonstrate that the transverse processes on this vertebra are short and are positioned midlaterally on the centrum, as in the last seven thoracic vertebrae of the archaeocete Zygorhiza kochii (see Kellogg, 1936:139-142). In the Miocene cetotheres Pelocetus calvertensis (see Kellogg, 1965, pl. 12), Diorocetus hiatus (see Kellogg, 1968, pl. 54), and Thinocetus arthritus (see Kellogg, 1969, pl. 6), the transverse processes of the last three or four thoracic vertebrae extend from the centrum, but they are much more elongate than in either Eomysticetus whitmorei or Zygorhiza kochii. These latter species also differ from the aforementioned cetotheres by having the articular facet for the tuberculum of the ribs positioned above the level of the roof of the neural canal on the third through the seventh thoracics. In Pelocetus calvertensis and Thinocetus arthritus, two species of cetotheriids for which there is sufficient material for comparison, the facet for the tuberculum does not extend dorsal to that level and is usually situated ventral to it (Kellogg, 1965, pls. 5-9; 1969, pl. 6).

Lumbar Vertebrae: Only two lumbar vertebrae were found with the holotype skeleton of Eomysticetus whitmorei. Both are missing the neural arch, and in the absence of other lumbar vertebrae, it is difficult to place these vertebrae in their exact positions in the vertebral column. We therefore believe it best to refer to these vertebrae only as lumbar " $A$ " and lumbar " $B$."

Lumbar vertebra " $A$ " (Figure 20A) is the anteriormost of the two and seems clearly referable to the anterior one-third of the series, judging from the length and form of the right transverse process, the only one preserved on this specimen (see Table 5). The transverse process is elongate and flattened, with a slightly expanded and dorsally curved distal extremity, showing that it did not articulate with a rib. As in vertebrae of the Archaeoceti, the transverse processes of this vertebra are directed ventrolat- erally, not horizontally as in typical Mysticeti. The centrum is nearly cylindrical, its height and width being nearly equal. Compared with more highly evolved Mysticeti, such as Cetotheriidae (e.g., Thinocetus arthritis), the centrum is relatively more elongate, and in this regard it is reminiscent of the lumbar vertebrae of basilosaurine archaeocetes. It is relatively shorter than in dorudontines, its length being somewhat intermediate between basilosaurines and dorudontines. The base of the pedicle is elongate anteroposteriorly and narrow transversely, indicating that the pedicle was typical of the condition in Mysticeti.

Lumbar vertebra "B" (Figure 20B) is from a more posterior location in the vertebral column than the one that we have labeled as lumbar vertebra "A." Judging by the disparity in size and shape between it and lumbar vertebra " $A$," several vertebrae undoubtedly separated the two. It also suffered from severe weathering and is fractured and lacks its processes. It has a longer centrum, of greater diameter, and this is typical of the more posterior lumbar vertebrae in species of Mysticeti. Its neural canal also is of smaller diameter, in agreement with a narrower nerve cord posteriorly in the body. Also, as with lumbar vertebra " $A$," the centrum is relatively more elongate than is typical in species of Mysticeti.

Possible Caudal Vertebra: The posteriormost vertebra of the holotype skeleton is possibly a caudal vertebra (Figure 20C). It is definitely from a position more posterior in the body than any of the aforementioned vertebrae. Its centrum is larger, its neural process shorter, its transverse processes shorter and more ventrally directed, and its neural canal narrower (Table 5 ). The parts of the ventral surface of the centrum that would have borne facets for articulation with chevron bones have been abraded away; therefore, we cannot definitely place this bone in the caudal series, but it could be either a posteriormost lumbar or an anterior caudal. In its overall morphology, this vertebra resembles posterior lumbar and anterior caudal vertebrae of archaeocetes (see Kellogg, 1936, fig. 60 for Zygorhiza kochii, and pl. 5 for Basilosaurus cetoides).

The dorsal process is longer than those in this part of the column in $B$. cetoides, but the metapophyses extend dorsolaterally as in the same species. The distal end of the intact left trans- 


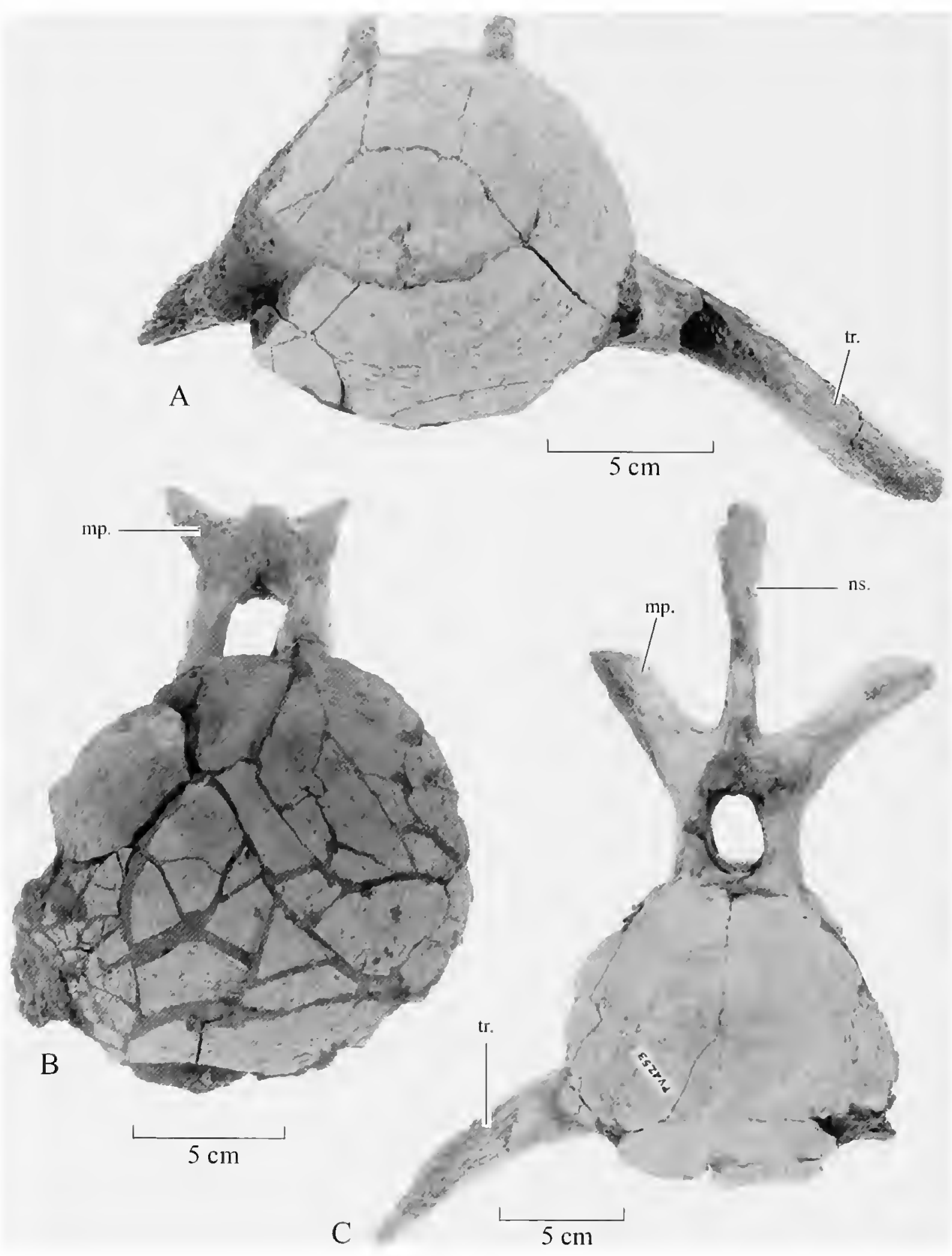

FIGURE 20.-Eomysticetus whitmorei, new genus and new species, holotype, ChM PV4253, lumbar and caudal (?) vertebrae in anterior view: A, lumbar "A"; B, lumbar "B"; C, probable anterior caudal vertebra. (For other abbreviations see Figure 17.)

verse process bends ventrally at its extremity, not dorsally as in the lumbar vertebra "A" described above. On the dorsal surface of the transverse process is an oblique crest of bone, representing a muscle scar, that is typically seen on vertebrae in the anterior part of the caudal series in species of modern Cetacea.

Ribs: The ribs of the holotype as they were found in the excavation were not in anatomical position, and the field occurrence did not therefore indicate the sequence in life. We have determined the apparent positions of the ribs using comparisons with other fossil and extant Cetacea (see Figure 21). Because it is typically short and broad in cetaceans, the first rib is the only one that is definitely identifiable. All the other positions that we indicate are approximations and might be inaccurate by one or two positions. The ribs that have both the tuberculum and the capitulum are identifiable as right or left by the posteroventral slope of the facet on the tuberculum, by the an- 


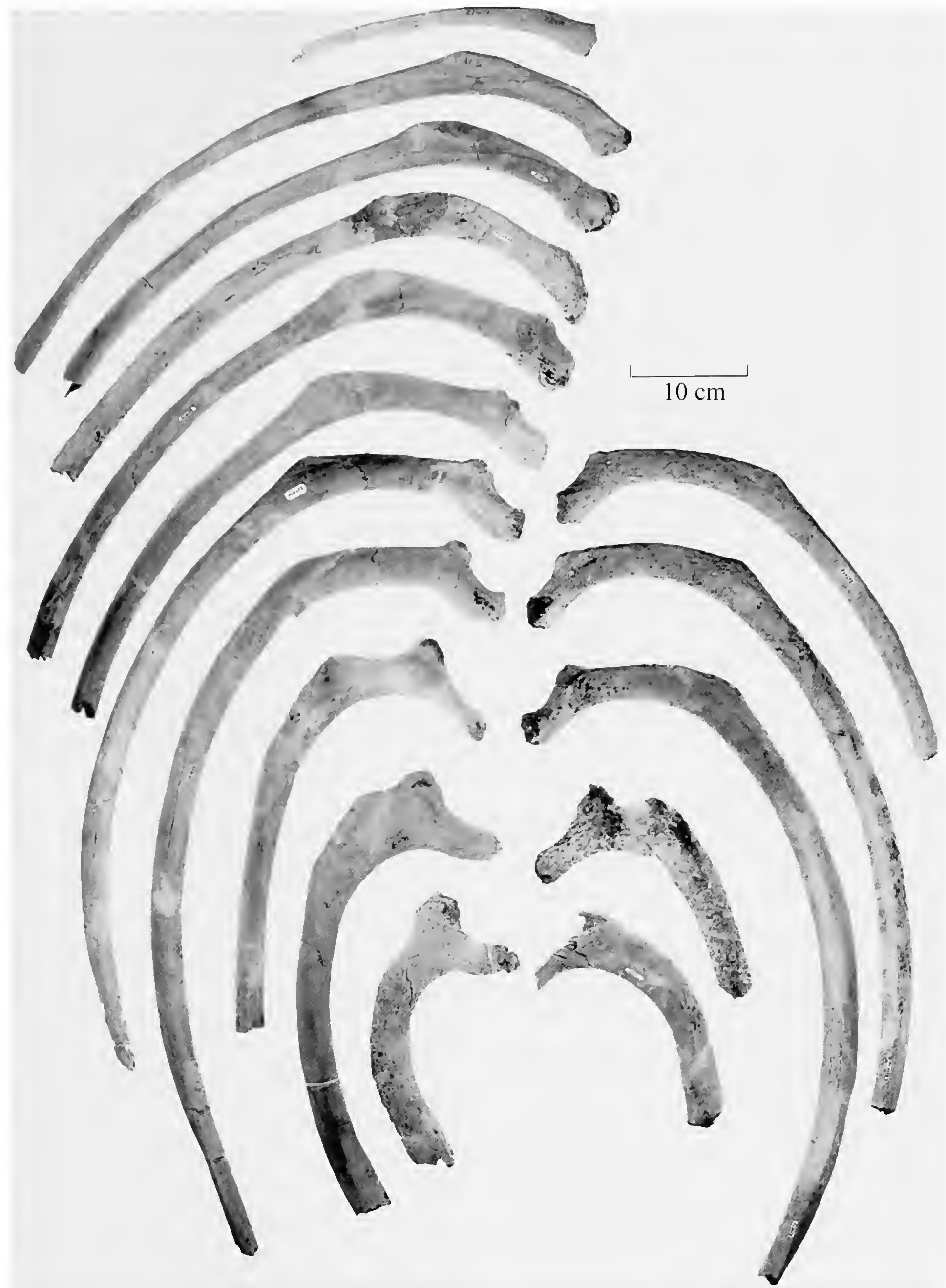

FIGURE 21.-Eomysticetus whitmorei, new genus and new species, holotype, ChM PV4253; ribs in anterior view. 
terior twist of the neck and capitulum, and by the direction of the prominence and strut at the change in angle of the shaft of the rib. The posterior ribs, which lack the capitulum and terminate proximally in only an irregular facet, are less certainly identified as right or left; however, except for the posteriormost one, the ribs from the right and left sides are probably identified correctly. The determination of the sequence of the ribs after the first rib on each side was based upon (1) progressive lengthening and thickening of the shaft toward the middle of the series, (2) progressive shortening of the neck and reduction in size of the capitulum posteriorly, and (3) loss of head and reduction in overall size of the posteriormost ribs.

According to these generalizations, there are at least 15 different rib positions among the bones of the skeleton. This judgment assumes that the smallest rib, which is not complete, is a posteriormost rib, and that the slightly mismatched pair that we have identified as the right and left seventh ribs are in fact a pair. This number is equal to the 15 ribs that are present in species of Archaeoceti and is more than the typical 12 of cetotheriids (see Kellogg, 1968:175). If the mismatched ribs we identify as the right and left seventh ribs in fact represent different positions, then the holotype of Eomysticetus whitmorei may have had 16 ribs on each side.

Only the first rib on the left side is present, and it is missing part of its head. It is short, broad, and flat, its proximal end is strongly curved, and the shaft is short with a definite rugose articular facet distally.

The probable right second rib is not complete. It is not as broad and flat as the first, and it is definitely longer than that rib, even though it is broken distally.

The probable right and left third ribs are not complete. The one from the right side is the better preserved of the two and is longer. The left one seems to match it well, but its surface is badly eroded. Each of these ribs is not so curved as the previous one, and each has a prominent angle, a prominent tuberculum, and a long head.

The possible fourth rib, represented only in the right series, is less curved proximally, is more slender, and has a shorter neck between the tuberculum and capitulum compared with the previous rib.

The probable fifth rib, present only in the right series, is more elongate and has a more cylindrical cross section and a shorter neck than the previous rib.

Both the right and left probable sixth ribs are present, and they differ from the previous one in the following ways: they are more elongate, the head is smaller, the neck is shorter and more slender, and the tuberosity at the change in angle is located farther distally on the shaft of the rib. We are cautious about the assignment of both ribs to the same location, because the left one has a slightly more slender head.

The possible left seventh rib is slightly thicker than the previous one at the proximal end.

The probable left eighth rib differs from the previous one by having a shorter neck.
The probable ninth rib is represented on the right side only. It has a shorter neck, and the tuberosity at the change in angle is located farther distally on the shaft of the rib.

The rib that we believe to be the $10^{\text {th }}$ is represented on the right side only. Compared with the previous rib, the neck is much shorter, the head has a large and flat articulation, and the tuberosity at the change in angle is located farther distally on the shaft of the rib.

The possible $11^{\text {th }}$ rib is represented on the right side only. Compared with the previous rib, it has a less prominent tuberosity at the change in angle of the shaft, a very short neck, and barely separate tuberculum and capitulum.

The possible $12^{\text {th }}$ rib also is represented on the right side only. Compared with the previous rib, the tuberosity at the change in angle of the shaft is less prominent. It is the first rib without a capitulum, and the tuberculum has a rounded, blunt articulation.

The possible $13^{\text {th }}$ rib also is represented on the right side only. Compared with the previous rib, it is more slender and has a less prominent tuberosity at the change in angle of the shaft. It also lacks a capitulum, and the tuberculum has a smaller, blunt articulation.

The possible $14^{\text {th }}$ rib is represented on the left side only. It is more slender than the previous rib and has a less prominent tuberosity at the change in angle of the shaft. Like the previous two ribs, it lacks a capitulum and the tuberculum has even a smaller articulation.

The presumed $15^{\text {th }}$ is the smallest of the preserved ribs. It appears to be from the right side, and it is missing the proximal end. By its curvature, it appears similar to the posteriormost ribs of extant Cetacea.

Forelimb: The anterior limb in Eomysticetus whitmorei is represented by a partial right scapula, the right humerus, the right ulna, and the right radius (Figure 22). The scapula is preserved only in the area immediately above the glenoid cavity and for a distance of $200 \mathrm{~mm}$ along the posterior edge. Although lacking its anterior external and internal edges, the glenoid cavity is subovate $(60 \times 90 \mathrm{~mm})$, shallow, and somewhat flattened transversely. The articular head and glenoid cavity are distinctly elongate rather than ovoid, as in the Miocene cetotheres Pelocetus calvertensis, Diorocetus hiatus, and Thinocetus arthritus, for example. Anteriorly, the articular head extends well forward of the base of the anterior edge and acromion and curves sharply inward. The posterior edge of the scapula rises directly from the posterior end of the articular head and projects backward in a low arc for a distance of 122 $\mathrm{mm}$ along the plane from the head to the terminus of the arc. Midway along that distance the edge is $33 \mathrm{~mm}$ thick, but in the space of only $40 \mathrm{~mm}$ above the edge, the scapula thins to $9 \mathrm{~mm}$ in transverse diameter. A similar but more concave arc is described by the posterior edge of the scapula of the late Oligocene odontocete Sulakocetus dagestanicus Mchedlidze, 1976 (see Mchedlidze, 1976, fig. 1, table 16) from the northern Caucasus region of Dagestan. 


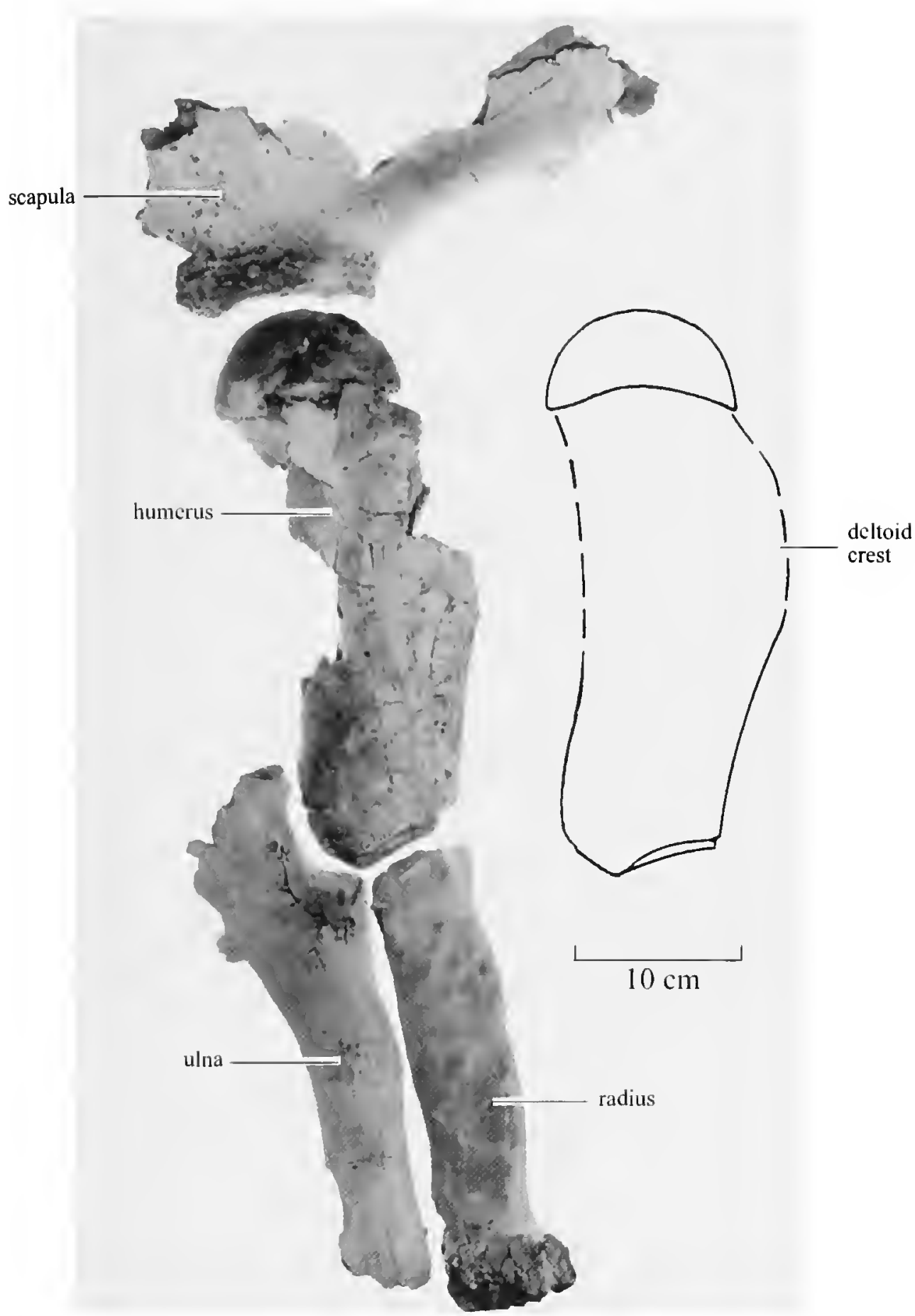

FIGURE 22 (left).-Eomysticetus whitmorei, new genus and new species, holotype, ChM PV4253, right forelimb in lateral view, with reconstruction of humerus at right. (Dashed lines represent hypothetical configurations.)

The humerus is incomplete, lacking the lateral edges of the head, the region of the radial tuberosity, most of the posterior face, and approximately $80 \mathrm{~mm}$ of the proximal portion of the medial side. The head is smooth and is directed obliquely laterally and posteriorly, the greater portion of it being positioned posterior to the long axis of the bone, which passes through the convergence of the radial and ulnar facets. It is flattened along its external side and is decidedly less globose than the heads of the humeri of Pelocetus calvertensis, Diorocetus hiatus, and Thinocetus arthritus. At the distal end of the humerus, the lateral portion of the juncture of the radial and ulnar facets is preserved, permitting an accurate measurement of the length of this bone at its greatest distal extent. As in all non-archaeocete Cetacea, the radial and ulnar facets converge to form an obtuse angle, approximately $125^{\circ}$ in this individual. The shaft of the humerus is quite different from those of Neogene mysticetes, being considerably longer, more robust, and of an entirely different configuration. The preserved portion above the ulnar facet is rounded, and immediately above the proximal margin of that facet there is a shallow gutter, above which the bone begins to widen transversely. Anteriorly, the lateral and medial sides of the shaft are greatly flattened distally and converge to form a narrow keel for a distance of approximately $90 \mathrm{~mm}$ along the preserved portion of the anterior face. The keel arises from the proximal border of the radial facet and angles upward along a tangent of approximately $55^{\circ}$ from the axis of the radial facet, a line approximately paralleling the anterodistal angle from the lower end of the deltoid crest in archaeocete humeri. This feature can thus be termed the anterodistal angle of the humerus in E. whitmorei. Although the region above it is missing in the holotype, the slope of this angle suggests the presence of a prominent deltoid crest in humeri of Eomysticetidae (Figure 22). At a point approximately $148 \mathrm{~mm}$ from the distal end of the humerus, the anterior face begins to broaden proximally toward the head. 
TABLE 6.-Measurements (in $\mathrm{mm}$ ) of the holotype right humerus of Eomysticetus whitmorei, new genus and new species, ChM PV4253. Parentheses indicate estimated measurements.

\begin{tabular}{l|c}
\hline Greatest length & 329 \\
Anteroposterior diameter of head & $110+$ \\
Transverse diameter of head & $93+$ \\
Anteroposterior diameter of shaft in valley above ulnar facet & 95 \\
Anteroposterior diameter of shaft, $120 \mathrm{~mm}$ above distal tip & 103 \\
Transverse diameter of shaft at same level & 63 \\
Transverse diameter of anterior face of shaft at same level & 16 \\
Transverse diameter of posterior face of shaft at same level & 47 \\
Anteroposterior diameter of external portion of radial facet & 54 \\
Anteroposterior diameter of distal end at level of anterior margin & 77 \\
$\quad$ of radial facet & \\
Transverse diameter of distal end & $(84)$ \\
\hline
\end{tabular}

The humerus of $E$. whitmorei displays a remarkable combination of archaeocete and mysticete characters but is most similar to humeri of Archaeoceti (e.g., Basilosaurus cetoides and Zygorhiza kochii (see Kellogg, 1936:65-66, 161-162)) in three major respects: (1) the greatest anteroposterior diameter of the shaft exceeds that of the distal end; (2) there is a pronounced anterodistal angle characteristic of archaeocetes but unknown in previously described mysticete humeri; and (3) the extreme length of the shaft, compared with humeri in Neogene mysticetes (Table 6). The most distinctive non-archaeocete character is the presence of separate, flattened radial and ulnar facets, instead of the rounded trochlea and capitulum that are typical of humeri of archaeocetes and other mammals. That is the difference between the rotational elbow joint of archaeocetes and the nonrotational joint of the modernized Cetacea.

The radius was badly shattered by compaction of sediments but has been restored closely enough to its proper form to yield a reasonably accurate measurement of its greatest length, which is $268 \mathrm{~mm}$. Proximodistally, the anterior and posterior margins of the shaft do not appear to have been as strongly curved as those of the radii of archaeocetes and of Miocene cetotheriids (see Kellogg, 1936, fig. 72; 1965, fig. 23; 1968, fig. $73 ; 1969$, pl. 3). Although the distal end of the radius is badly crushed and incomplete, the preserved portion shows that it was expanded both transversely and anteroposteriorly. The distal epiphysis is missing. The proximal end is bent posteriorly to articulate with the radial facet of the humerus. The facet for articulation with the ulna was not preserved, and the medial face immediately below the radial facet also is missing. Approximately $50 \mathrm{~mm}$ below the anterior edge of the proximal end, the transverse diameter of the shaft abruptly increases, marking the proximal termination of a broad, flat area that extends proximodistally along the anterior face for a distance of about 65 $\mathrm{mm}$, at which point it diminishes into the normal transverse diameter and rounded form of this face of the shaft. This feature seems to be homologous with the "elliptical rugose area" noted by Kellogg (1936:162) in his description of the radius of $Z y$ gorhiza kochii. Kellogg (1936:162) presumed it to be the area for the insertion of the pronator teres muscle, which may still have been slightly functional in $Z$. kochii, considering the prim-
TABLE 7.-Measurements (in $\mathrm{mm}$ ) of the holotype right ulna of Eomysticetus whitmorei, new genus and new species, ChM PV4253.

Length of preserved portion (from $13 \mathrm{~mm}$ above proximal portion of 327 greater sigmoid cavity to distal end)

Greatest diameter of greater sigmoid cavity

Greatest transverse diameter of proximal portion of greater sigmoid cavity

Greatest transverse diameter of distal portion of greater sigmoid cavity

Greatest length of anterior face of shaft below greater sigmoid cavity

Anteroposterior diameter of shaft at $85 \mathrm{~mm}$ below greater sigmoid cavity

Transverse diameter of shaft at same level

itive structure of its elbow joint. If present in Eomysticetus, it is doubtful that that muscle would have been functional at all in view of the more highly specialized, nonrotational elbow joint in this form.

The ulna (Table 7) is missing the posterior portion of the olecranon process and a large area of its internal side proximal to the shaft. Also missing are the distal sections of the anterior and posterior faces and the distal sections of the medial face. The shaft is transversely compressed and is broadly curved proximodistally. It is transversely expanded at both the distal and the proximal ends. The proximal portion of the greater sigmoid cavity is slightly concave, the distal portion being broadly convex transversely. As with the radius, the distal epiphysis is not present.

\section{Eomysticetus carolinensis, new species}

FIGURES 24-28

Cetothere "similar to C. tobieni."-Sanders and Barnes, 1991.

DIAGNOSIS.-A species of Eomysticetus separated from $E$. whitmorei by the following characters: intertemporal region shorter; parietals one-third less in length along midline; apex of supraoccipital extending farther anteriorly (by approximately $38 \mathrm{~mm}$ ); anterior portion of supraoccipital heavily corrugated; lambdoidal crests more laterally oriented and overhanging temporal fossa; parietals sloping from intertemporal region more laterally and not so vertically directed; sagittal crest of parietals in intertemporal region rounded, not blade-like; squamosal fossa narrower; zygomatic process of squamosa thinner and more divergent from sagittal plane; distal end of zygoma extending to or slightly behind plane of apex of supraoccipital and lacking a prominent ventral facet for articulation with jugal; dorsomedial side of zygoma not convex but flat to slightly concave; basioccipital crests trasversely thinner, more ventrally extended, and more knob-like; foramen ovale of larger diameter and more elongate; anterior border of glenoid fossa broadly curving, not angular; glenoid fossa more square and deeper anteroposteriorly; postglenoid process thicker and deeper; supracondylar fossae shallower; intercondylar notch (between occipital condyles) shallower; jugular notch bilobed (not preserved in E. whitmore). 
HOLOTYPE. - ChM PV4845, braincase lacking the entire rostrum and missing the left exoccipital and squamosal. Collected by Barry Albright and Vance McCollum during the summer of 1988.

TYPE LOCALITY.-Found in a ditch in the Irongate subdivision, Dorchester County, South Carolina, approximately 33.8 $\mathrm{km}(21 \mathrm{mi}$.) north of Charleston and about $2.6 \mathrm{~km}$ (1.6 mi.) northwest of the type locality of Micromysticetus rothauseni Sanders and Barnes (2002).

FORMATION AND AGE.-Chandler Bridge Formation, bed 2, lower Chattian correlative, late Oligocene, nannoplankton zone NP24 (by inference), ca. $28 \mathrm{Ma}$ (Figure 23).

ETYMOLOGY.-The specific name recognizes South Carolina as the origin of the holotype.

DESCRIPTION.-Lacking the left squamosal and exoccipital regions and all of the ventral portion of the postorbital region anterior to the basisphenoid, the holotype cranium of Eomysticetus carolinensis is not as complete as the holotype of $E$. whitmorei, but the surfaces are well preserved and the basicranium and most of the dorsal surface of the intertemporal region are present Figures 24-26).

The lambdoidal crests are incompletely preserved in the apical region and elsewhere are missing altogether, making it difficult to determine the original shape of the supraoccipital. Nonetheless, the curvature and angle at which the preserved remnant of the left lambdoidal crest extends posteriorly from the apex of the supraoccipital permit a reasonably close approximation of the shape of the occipital shield (Figure 24B), which evidently is narrow and elongate, more so than in $E$. whitmorei. Also unlike the condition in E. whitmorei, the supraoccipital extends beyond the plane of the anterior tips of the zygomae. The dorsal surface of the supraoccipital in $E$. carolinensis is divided into two elevations, the posterior portion being a shallow depression beginning approximately 40 $\mathrm{mm}$ anterior to the posterior margin of the supraoccipital and extending forward to the posterior margin of the parietals. At that point the supraoccipital abruptly ascends the parietals to a plateau formed by the parietals and slopes upward and forward to the apex, a distance of approximately $130 \mathrm{~mm}$. A conspicuous rounded eminence on each side of the midline marks the point of contact between the supraoccipital and the parietals during an earlier stage of ontogeny when the bone of the supraoccipital was thinner and more plastic. A prominent medial crest traverses virtually the entire length of the supraoccipital, extending from a point near the apex to the posterior margin of the lower, excavated area, dividing that area into two sections. The crest achieves its maximum height on the plateau formed by the parietals, where it rises almost to the height of the adjacent lambdoidal crests. In this region the crest is flanked by two short crests, each of which is bordered on both sides by an elongate gully-like depression. The resulting pattern of alternating ridges and grooves produces a corrugated effect over most of the elevated portion of the supraoccipital (Figure 24).

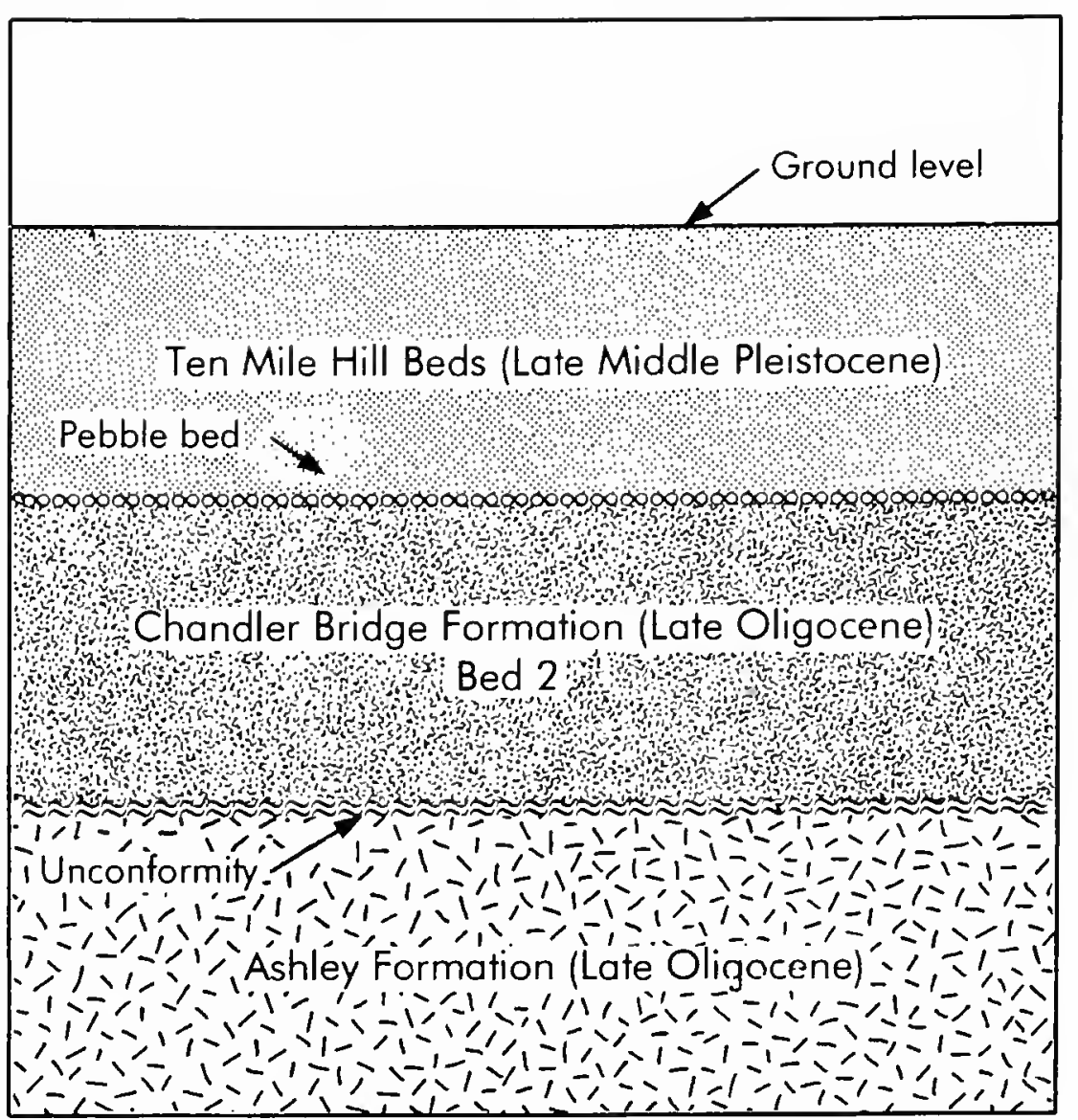

FIGURE 23.- Stratigraphic section at type locality of Eomysticetus carolinensis, new species, ChM PV4845. (Not to scale.)

The holotype of E. carolinensis represents a mature individual, as indicated by the smooth articular surfaces of the occipital condyles. The dorsal margins of the condyles of E. carolinensis lie only slightly below the level of the floors of the squamosal fossae (Figure 27). The vertical diameter of the foramen magnum exceeds the transverse diameter. The exoccipital is broad and does not extend very far posteroventrally, and most of the paroccipital process is missing. The lateral wall of the braincase is concave, the squamosal inclining posteriorly to the posterior margin of the lambdoidal crest along the inner flank of the squamosal fossa. The floor of the squamosal fossa is interrupted by the secondary squamosal fossa, a deep, circular, pit-like depression approximately $18 \mathrm{~mm}$ in diameter at its deepest point. The posterior wall of this pit receives a narrow gutter that steeply ascends to the floor of the squamosal fossa and extends to its posteriormost margin. Anterior to the pit, the floor of the fossa is broadly concave. The zygomatic process of the squamosal diverges more abruptly from the sagittal plane, is rather long, is tapered anteriorly, and is not so strongly arched as that of $E$. whitmorei. It is angled sharply outward from the long axis of the skull and extends forward to a point slightly behind the plane of the apex of the supraoccipital. A relatively small, shallow, and anterodorsally inclined sternomastoid fossa occupies the posterior face of the squamosal near the suture with the exoccipital.

On the ventral side of the cranium the basioccipital is well preserved. It is dorsally arched transversely and has large, 


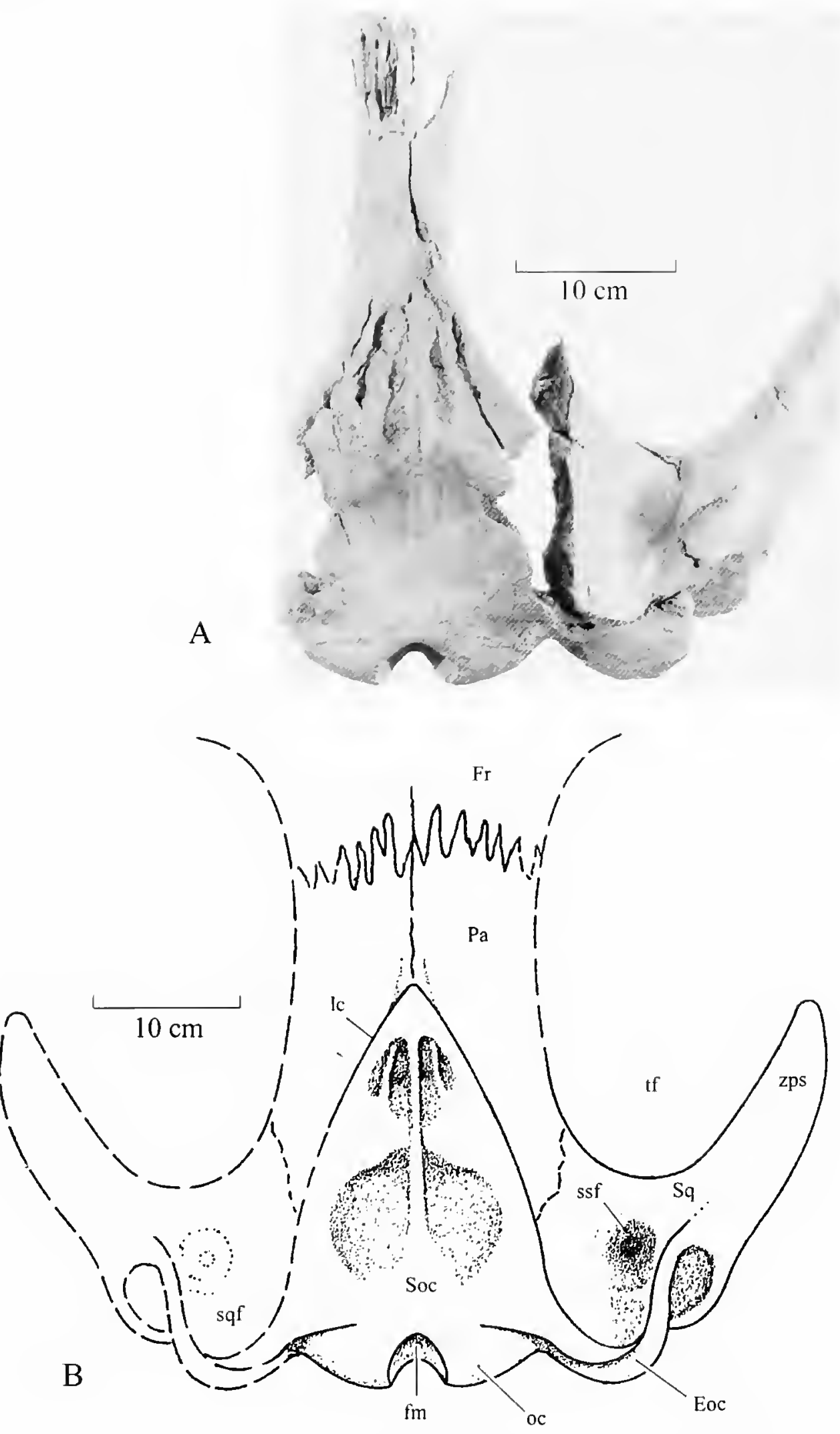

FIGURE 24 (left).-Eomysticetus carolinensis, new species, holotype, ChM PV4845: A, cranium, dorsal view; B, reconstruction of cranium based upon holotype, dorsal view. (Dashed lines and solid lines in areas of missing bone (see Figure 24A) represent hypothetical configurations. Abbreviations are explained in "Material and Methods.")

somewhat rounded basioccipital crests that are sharply divergent posteriorly and descend prominently from the basicranium. Extending forward from the anterior slope of the basioccipital crest and along the lateral margin of the basisphenoid there are large, elongate, and obliquely oriented interdigitations that form the suture for the hamular process of the pterygoid. The glenoid fossa is large and almost rectangular in form, its transverse width $(102.7 \mathrm{~mm})$ nearly equaling its anteroposterior length $(106 \mathrm{~mm})$. Slightly posterior to the cranial hiatus, the innermost margin of this fossa forms an acute angle. The glenoid process is elongate transversely and is very narrow anteroposteriorly. There is a correspondingly long external auditory meatus.

The most noticeable features of the holotype cranium of $E$. carolinensis are the elongate supraoccipital shield and the long intertemporal region. The preserved portion of this region is $135 \mathrm{~mm}$ in length anterior to the apex of the supraoccipital and consists primarily of the parietals, which interdigitate with a narrow posterior extension of the frontals over a broad area anteroposteriorly. Dorsally, a finger of the frontals extends backward to within $60 \mathrm{~mm}$ of the apex of the supraoccipital. Laterally, the parietals project forward for a distance of at least 110 $\mathrm{mm}$ anterior to the apex, overlapping the posterior end of the frontals for a distance of at least $50 \mathrm{~mm}$. Although only a 78 $\mathrm{mm}$ portion of the frontals is preserved, the degree to which the left side of this section has begun to flare outward anteriorly indicates that a forward extension of approximately $50 \mathrm{~mm}$ along a line of intensifying outward curvature would bring it into 

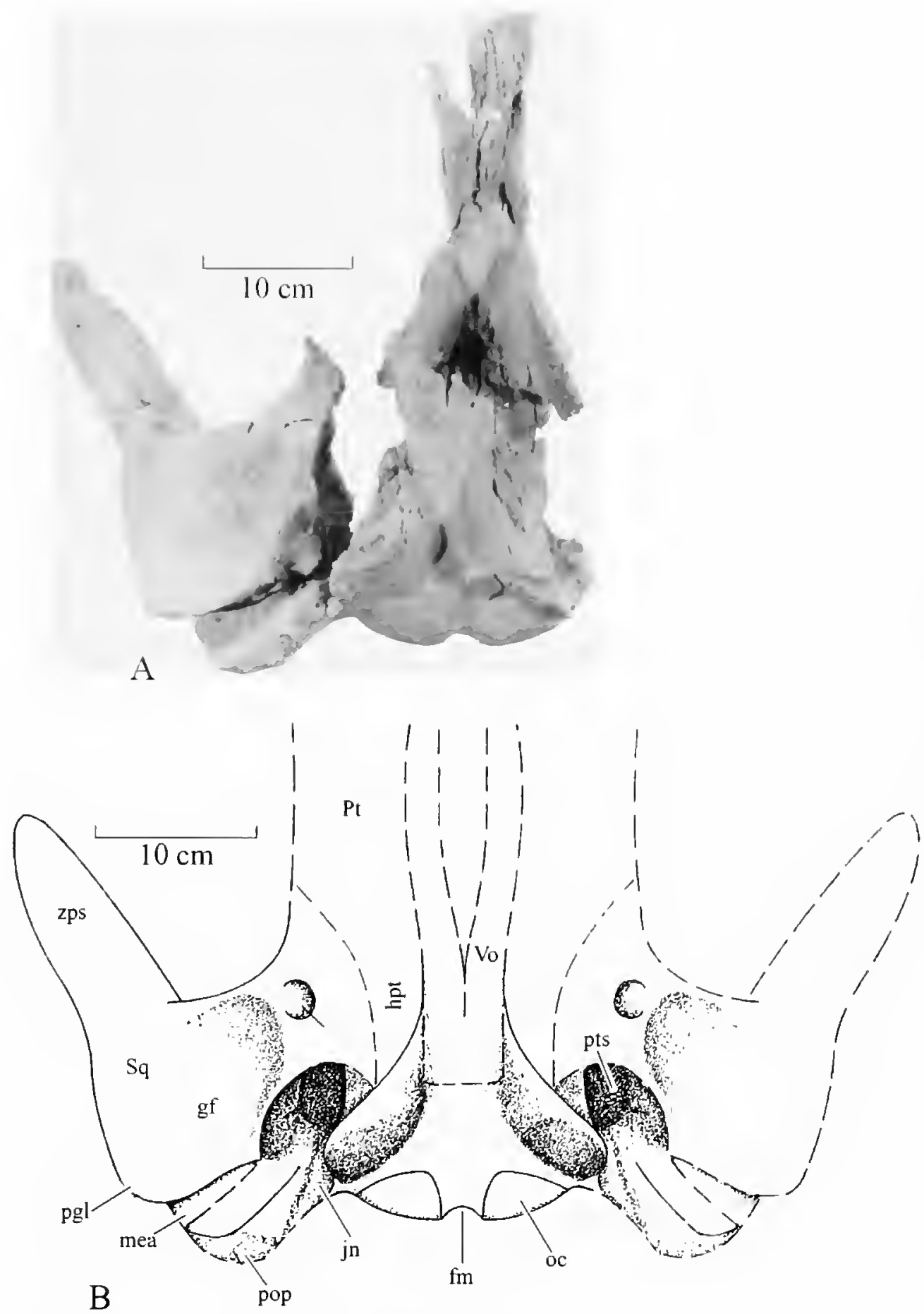

FIGURE 25 (left)--Eomysticetus carolinensis, new species, holotype, ChM PV4845: A, cranium, ventral view; B, reconstruction of skull based upon holotype, ventral view. (Dashed lines and solid lines in areas of missing bone (see Figure 24A) represent hypothetical configurations. Abbreviations are explained in "Material and Methods.") contact with the posterior margin of the supraorbital processes of the frontal. We estimate that the distance between the apex of the supraoccipital and the level of the posterior edges of the supraorbital process was approximately $165 \mathrm{~mm}$. The distance from the posterior margin of the temporal fossa to the apex of the supraoccipital is about $195 \mathrm{~mm}$; thus, the anteroposterior length of the temporal fossa in this specimen can be conservatively estimated as approximately $360 \mathrm{~mm}$.

Although no portion of the rostrum was preserved, we believe that the nasals of $E$. carolinensis must have been elongated as in $E$. whitmorei, and it is not unreasonable to think that the rostrum was long and narrow like that of $E$. whitmorei.

\section{Discussion}

\section{COMPARISONS WITH OTHER CETACEAN TAXA}

General evolutionary trends within the suborder Mysticeti are toward progressively large body size, relatively large heads, short necks, grooves in the throat region, and telescoping of the cranial elements with an emphasis on movement of occipital bones anteriorly over the braincase. In its forward progress through the various grades of telescoping (Miller, 1923), the acute anterior margin of the supraoccipital shield seems to have wedged between the parietals and gradually forced them apart, producing well-developed lambdoidal crests that usually overhang the temporal fossae in Oligocene and primitive mysticetes. In most later mysticetes of Neogene time the dorsal portion of the parietals has been reduced to a small area in the anterior region of the skull roof. In Eomysticetus whitmorei and E. carolinensis the parietals occupy a prominent portion of the intertemporal region of the skull.

The braincase of $E$. whitmorei shares more characters with archaeocetes than does any other described mysticete skull. The same could probably be said for E. carolinensis were more of the skull preserved. Comparison of the skulls of the late Eocene archaeocete Zygorhiza kochii, the late Oligocene Eomysticetus whitmorei, the late Oligocene "Mauicetus" lopho- 


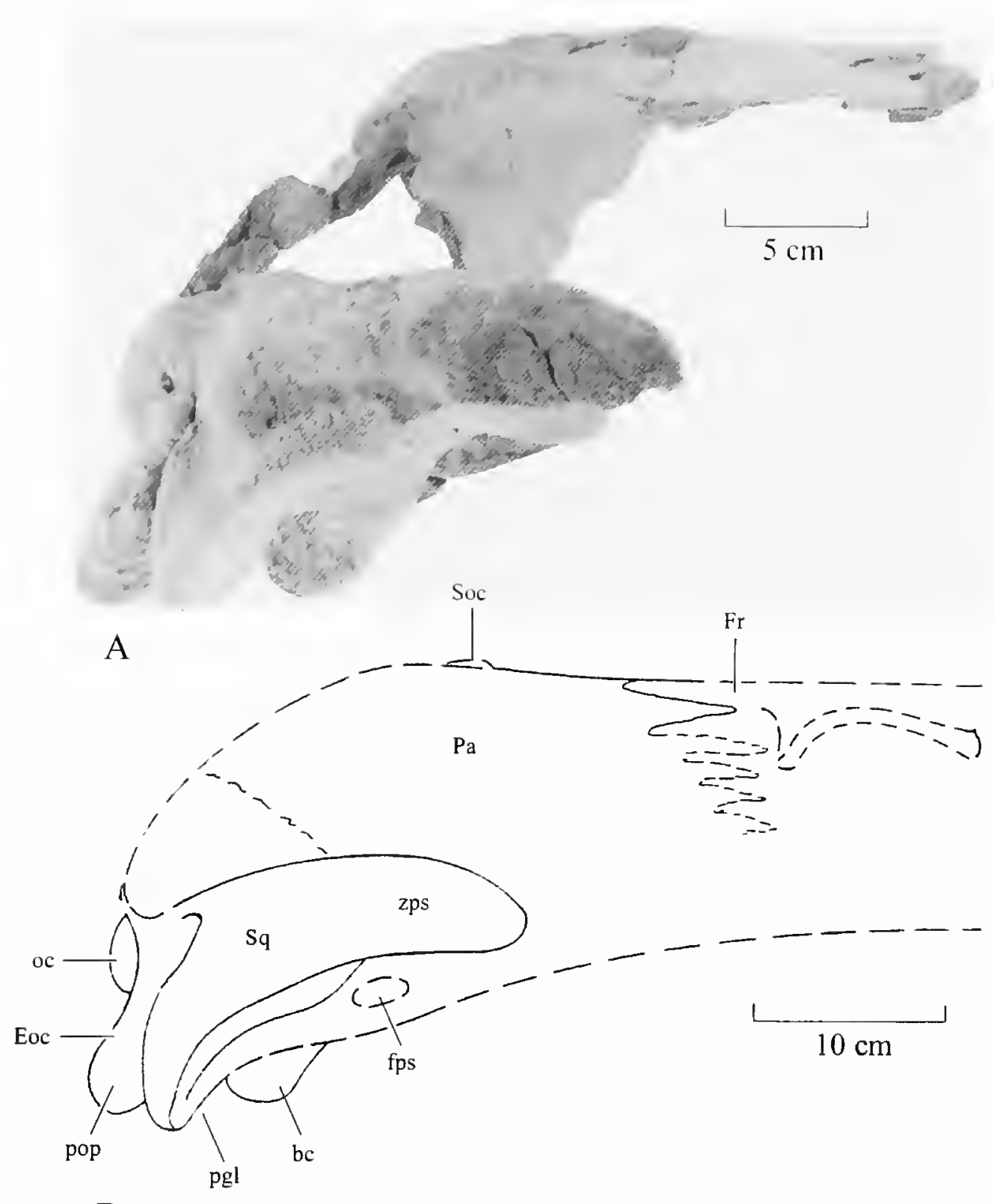

FIGURE 26 (left).-Eomysticetus carolinensis, new species, holotype, ChM PV4845: A, cranium, right lateral view; B, reconstruction of skull based upon holotype, right lateral view. (Dashed lines represent hypothetical configurations. Abbreviations are explained in "Material and Methods.")

B

cephalus Marples, 1956, the early Miocene Aglaocetus moreni (Lydekker, 1894), the late Miocene Cetotherium rathkii (Brandt, 1873), and the late Oligocene toothed mysticete Aetiocetus cotylalveus Emlong, 1966, shows a general progression from the non-telescoped archaeocete skull represented by $Z y$ gorhiza kochii through the telescoping of the cranial elements in the grades represented by Eomysticetus, "Mauicetus lophocephalus," Aglaocetus, and Cetotherium. The most striking evolutionary changes in the crania of those four taxa are the shortening of the intertemporal region and a corresponding reduction in the length of the nasal bones. Although more primitive in rostral characters and presence of teeth, Aetiocetus cotylalveus actually has a more highly telescoped cranium than does either Eomysticetus or Mauicetus, and it really does not fit into the progression of telescoping in the mysticetes. That observation lends strong support to Kellogg's (1969:1) doubt that Aetiocetus was an antecedent of the baleen-bearing whales and to the suggestions of Barnes $(1987,1989)$ and Barnes et al. (1995) that it is unlikely that any of the aetiocetid mysticetes were involved with the ancestry of modern mysticetes. True baleen-bearing Mysticeti were contemporaneous with the Aetiocetidae and in fact occur even earlier in the fossil record than any known aetiocetid. Those facts, coupled with the presence of autapomorphies in aetiocetids that are not shared with the earliest baleen-bearing Mysticeti (for example the comparatively shorter and wider intertemporal region of the Aetiocetidae), confirm that all known Aetiocetidae were relict taxa. Likewise, Eomysticetus whitmorei and E. carolinensis were in their time also relict taxa, for they have cranial characters that are more primitive than some earlier-occurring baleen-bearing mysticetes. It seems most probable that the Aetiocetidae and the Mammalodontidae are side branches of Mysticeti in which baleen was never developed, the retention of teeth into adulthood perhaps being a paedomorphic character that became firmly entrenched. Whether the same can be suggested for the third family of toothed mysticetes, the Llanocetidae, is a question that must await knowledge of the cranial characters of species in that group.

Among currently known fossil and living mysticetes, the extremely long nasal bones in Eomysticetus whitmorei are approached in length by those of "Mauicetus" lophocephalus (see Crowley and Barnes, 1996). A comparison of the measurements of the nasals of $E$. whitmorei with those of the holotype of "M." lophocephalus (see Marples, 1956:568) can be decep- 


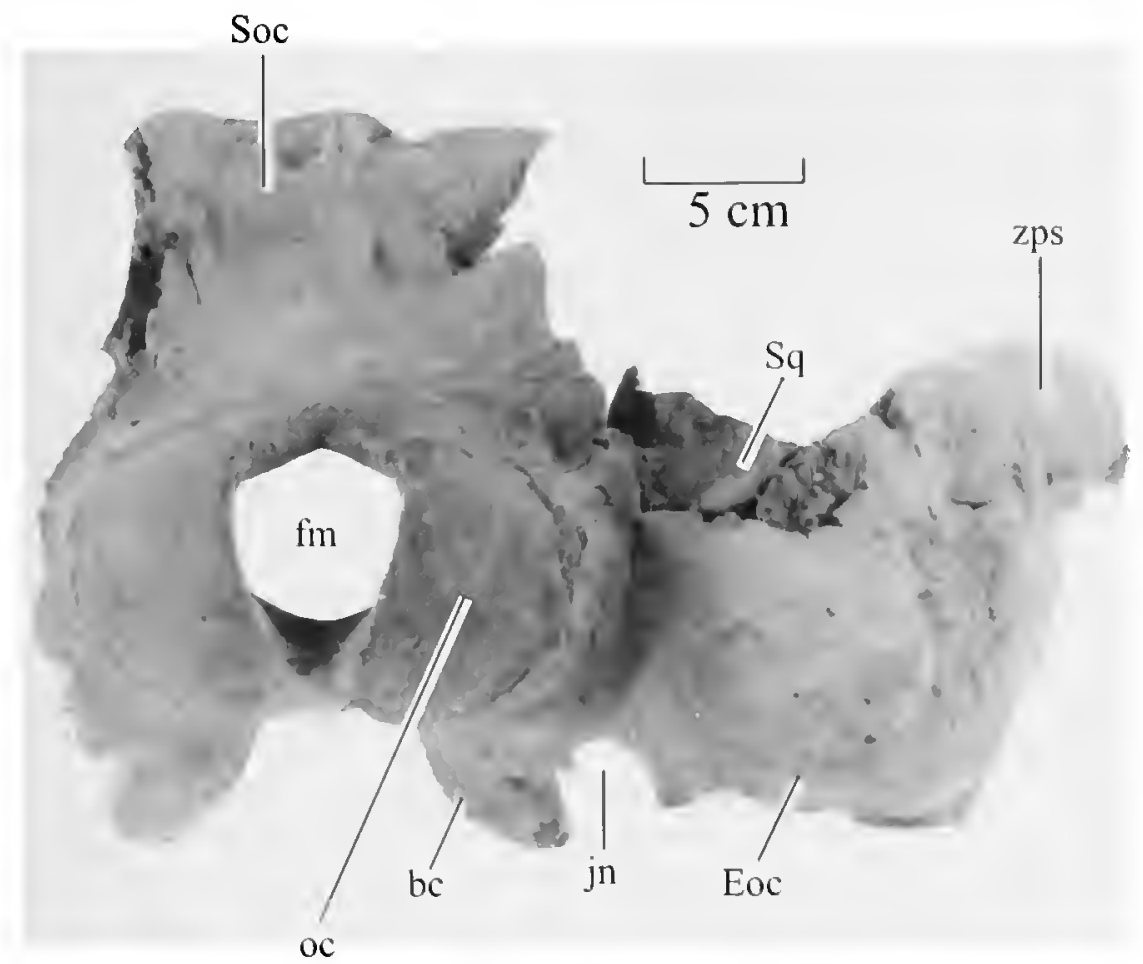

FIGURE 27.-Eomyslicelus carolinensis, new species, holotype, ChM PV4845, cranium, posterior view. (Abbreviations are explained in "Material and Methods.")

tive if the differences in sizes between the respective skulls are not taken into account. The nasal bones in $E$. whitmorei are approximately $300 \mathrm{~mm}$ long, whereas those of the holotype of " $M$." lophocephalus are given (by Marples) as $350+\mathrm{mm}$ in length. The distance between the lateral margins of the exoccipitals is $495 \mathrm{~mm}$ in " $M$." lophocephalus but only $340 \mathrm{~mm}$ in $E$ whitmorei, demonstrating that the holotype skull of " $M$." $l o-$ phocephalus is approximately $30 \%$ larger. Consequently, if the skull of Eomysticetus whitmorei were as large as the New Zealand specimen, the nasals would measure about $393 \mathrm{~mm}$, exceeding those of the latter. Compared directly, the length of the nasals is $88 \%$ of the distance between the lateral margins of the supraoccipitals of Eomysticetus whitmorei, but only $71 \%$ of the same distance in the holotype skull of " $M$." lophocephalus. Unfortunately, we find that comparisons of the nasal bones of these two specimens based upon the original description of "M." lophocephalus seem uncertain at best because of the discrepancy between the figured length of the nasals in Marples's (1956:567, fig. 1c) reconstruction and their apparent length in photographs $\mathrm{A}$ and $\mathrm{B}$ of his plate 1 . In the reconstruction, the nasals and the premaxillae are shown to terminate at the anterior edge of the frontals, whereas in both of the two published photographs (A, the prepared specimen, and $B$, the skull in place) the nasals appear to extend posteriorly onto the frontals as in Eomysticetus and other, more typical baleen whales. Not having seen the holotype of " $M$." lophocephalus, we cannot venture a qualified opinion as to which of the two alternatives is correct. Apparently that question will never be settled, because the holotype cranium of " $M$." lophocephalus has been lost (E. Fordyce, pers. comm., July 1994). Among other cetaceans, the length of the nasal in Eomysticetus whitmorei appar- ently is matched by that of Remingtonocetus harudiensis (Kumar and Sahni, 1986:331-332, figs. 3, 4). The anterior portion of the nasals are missing in the figured paratype of the latter taxon, but their length was estimated as $310 \mathrm{~mm}$ (Kumar and Sahni, 1986:333, table 1).

The presence of a temporal crest on the dorsal surface of the supraorbital process is one of the defining features of mysticetes. In Odontoceti, the temporal line is at the posterior margin of the process. The fact that the temporal crest in E. whitmorei merges with the middle part of the posterior margin of the supraorbital process indicates that this is a very primitive position for the structure. The intertemporal region is elongate and narrow, exceedingly so in comparison with most other fossil and extant Cetacea. The structure of the intertemporal region of $E$. whitmorei is a primitive condition for a cetacean, especially for a baleen whale. The prominent sagittal crest on the upper part of the occipital shield also is present in some species of the family Cetotheriidae (e.g., Micromysticetus rothauseni Sanders and Barnes, 2002). The condition of the paroccipital processbeing thin laterally and only extending laterally as far as the middle part of the postglenoid process-is primitive among Cetacea and also is present in extant gray whales (Eschrichtius robustus). The pit-like secondary squamosal fossa, described above, is known to occur only in E. whitmorei and E. carolinensis. For a mysticete, Eomysticetus whitmorei has a relatively small cranial hiatus, another primitive character.

The periotic of $E$. whitmorei closely resembles that of $M i-$ cromysticetus rothauseni (Sanders and Barnes, 2002, figs. 12, 13) in having a large, flattened, hatchet-shaped anterior process and a short, stubby posterior process. That form is very similar to the configuration of the periotic of the archaeocete $Z y$ gorhiza kochii. The dentary of Eomysticetus whitmorei is unique among known mysticetes, the posterior end being massive in size compared with Neogene forms. In its shape, dorsoventral height, anteroposterior length, and elevation of the end of the posterior edge above the anterior edge, the coronoid process of $E$. whitmorei is more nearly like that of an archaeocete than a mysticete and thus appears to represent a transitional stage between the configuration of the coronoid in Eocene archaeocetes, such as Zygorhiza kochii, and that of the Miocene cetotheres, such as Parietobalaena palmeri. In lateral aspect, the dentary displays the parallel dorsal/ventral profiles characteristic of Mysticeti.

The vertebral column of $E$. whitmorei also exhibits features intermediate between archaeocetes and mysticetes. Interestingly, the vertebrae are more like those of the archaeocete $Z y$ gorhiza kochii than their counterparts in other baleen whales. In the third through the seventh thoracic vertebrae the articular facet for the tuberculum is situated above the level of the roof of the neural canal, as in Z. kochii. The transverse processes of the lumbar and caudal vertebrae bend ventrolaterally as in Archaeoceti, rather than extending horizontally as in more highly evolved Mysticeti. In size and relative length/width ratios of their centra, the thoracic, lumbar, and caudal vertebrae of $E$. 


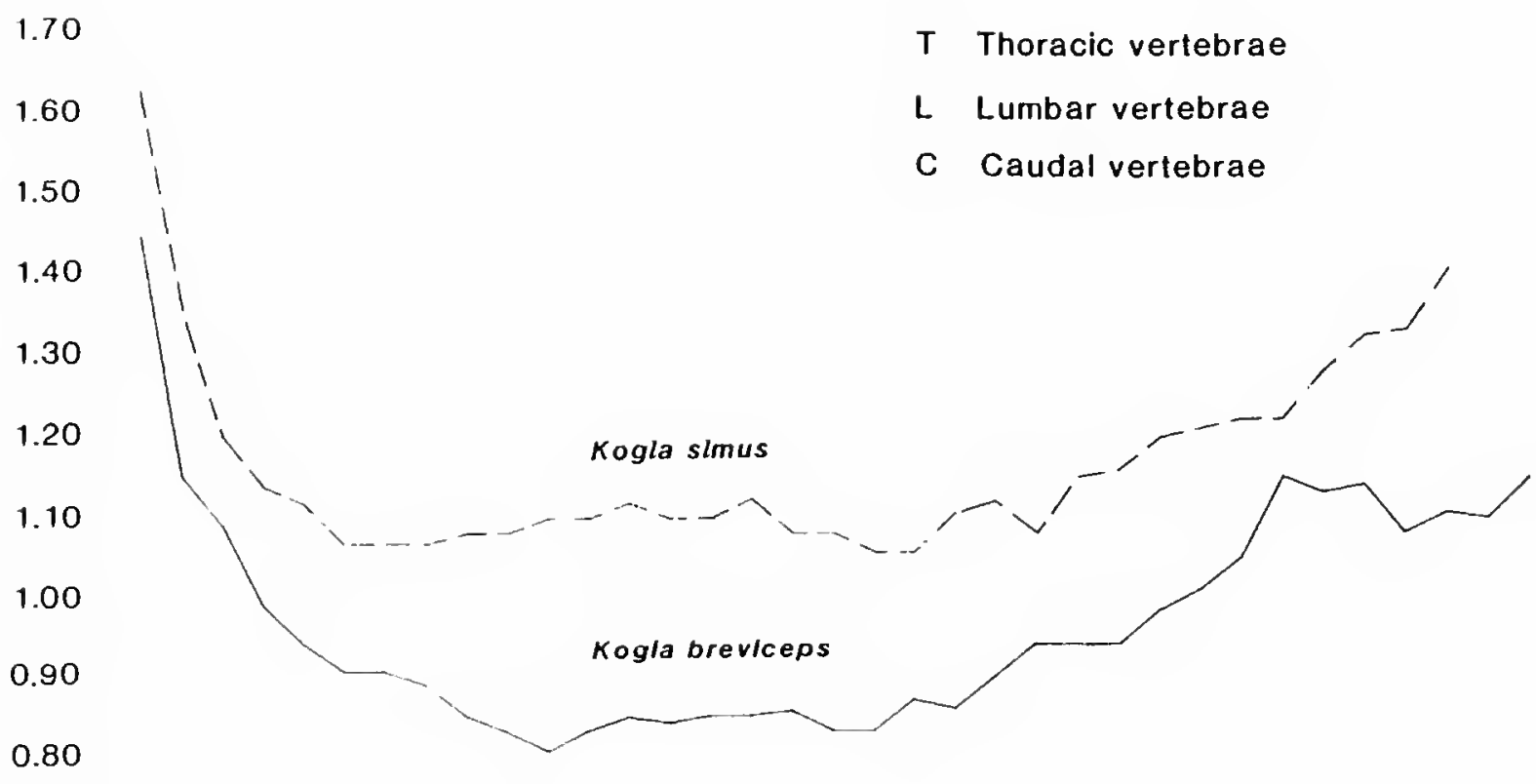

0.70

$$
\begin{aligned}
& \text { - }
\end{aligned}
$$

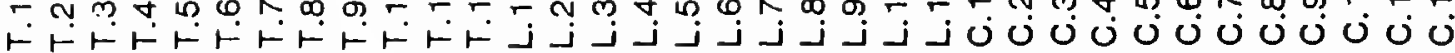

FIGURE 28. - Curves of mean values of vertebral width/length ratios of five specimens of extant Kogia breviceps and four specimens of extant Kogia simus.

whitmorei are intermediate between those of dorudontine archaeocetes and cetotheriid mysticetes (Figure 29).

Unpublished studies initiated by Sanders have shown that the two living species of the odontocete genus Kogia (K. breviceps and $K$. simus) have distinctly different vertebral length/width ratios (Figure 28), making it possible to identify isolated vertebrae of these two taxa. We have used this method in comparisons of the vertebrae of Eomysticetus whitmorei with those of selected archaeocetes and mysticetes to see how those forms might be sorted out on the basis of vertebral ratios. In Figure 29 we compare the curves of ratios obtained by dividing the transverse width of the anterior end of the centrum by the anteroposterior length of the centrum in the thoracic vertebrae of $E$. whitmorei, three Eocene archaeocetes (Zygorhiza kochii (Reichenbach, 1847), Dorudon stromeri Kellogg, 1936, Basilosaurus cetoides (Harlan, 1845)), and three Miocene cetotheres (Pelocetus calvertensis Kellogg, 1965, Thinocetus arthritus Kellogg, 1969, and Halicetus ignotus Kellogg, 1969). The thoracic vertebrae were selected because only two lumbar vertebrae and one caudal vertebra are available for Eomysticetus. As illustrated by the curve for the thoracics of Basilosaurus cetoides, lower ratios reflect elongate centra; thus, the low range of the extremely elongate vertebrae of that taxon does not permit plotting of the entire thoracic series within the vertical limits of Figure 29, the ratio for the 15 th thoracic vertebra being 0.49 .

As seen in Figure 29, the anterior portion of the curve for the thoracic vertebrae of Eomysticetus whitmorei falls between those of the archaeocetes Zygorhiza kochii and Basilosaurus cetoides below it, and those of the three cetotheriids above it. From the fifth thoracic vertebra posteriorly through the sev- enth, eighth, and $15^{\text {th }}(?)$, the Eomysticetus whitmorei curve most closely follows the curves of the two specimens of $Z y$ gorhiza kochii (USNM 4679, USNM 11962) for which measurements of thoracic vertebra were available (Kellogg, 1936: 143). Noting that the anterior portions of the curves of the three cetotheres form a discrete group separate from the curves of Eomysticetus whitmorei, Zygorhiza kochii, and Basilosaurus cetoides, we suggest that vertebral width/length ratios may be useful as indicators of broad phenetic relationships.

In Figure 29 the first six thoracic vertebrae furnish the best indices for comparison of the taxa shown. Of the eight individuals represented, the curves of three of them (Pelocetus, Halicetus, and one of the Zygorhiza specimens) converge within the range of 1.34 and 1.37 at the seventh thoracic vertebra. At the eighth thoracic all but three of the curves (Basilosaurus cetoides, Thinocetus arthritis, and Dorudon stromeri) converge between 1.20 and 1.26. Thereafter, the curves diverge again as they approach the lumbar vertebrae. The position of the eighth thoracic as the focal point for five of the eight curves shown indicates that it is in this vertebra that dramatic increases in the anteroposterior length of the centrum begin to take place. In the series of 15 thoracic vertebrae that is characteristic of the archaeocetes reviewed by Kellogg (1936), the eighth one is at the direct numerical center of the series. Anterior to that point, the first seven thoracics tend to reflect the shorter anteroposterior lengths of the cervical vertebrae, whereas those posterior to the eighth thoracic reflect the proportionately greater lengths of the lumbar centra. Recognition of the eighth thoracic vertebra as the commencement point of anteroposterior lengthening of the centra in the thoracic vertebrae of ancestral cetaceans (i.e., the Archaeoceti) suggests that the reduction in the number of tho- 


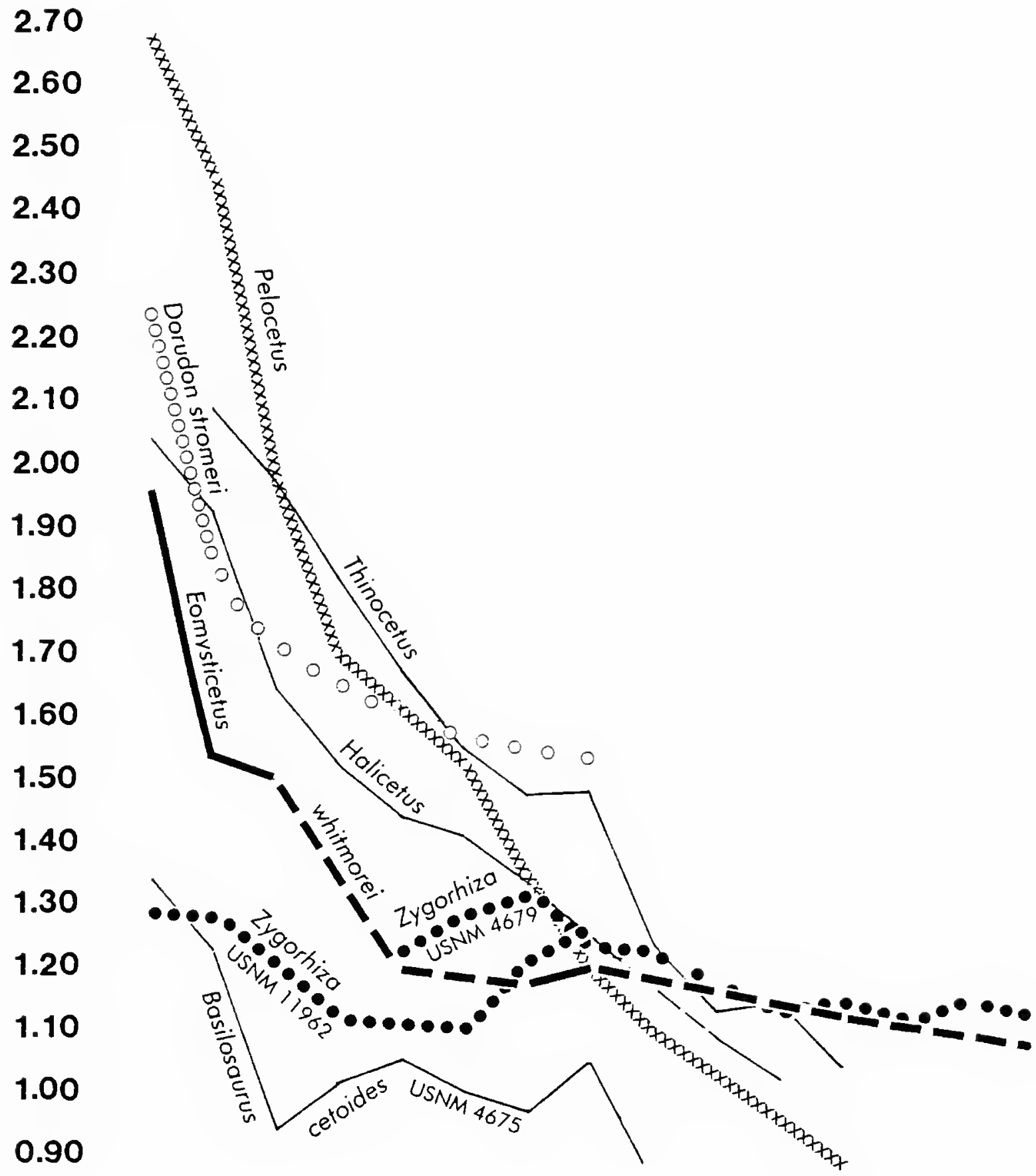

$$
\text { r }
$$

FIGURE 29.-Curves of width/length ratios of holotype thoracic vertebrae of Eomysticetus whitmorei, new genus and new species (late Oligocene); the late Eocene archaeocetes Basilosaurus cetoides, Dorudon stromeri, and Zygorhiza kochii; and the middle Miocene cetotheres Halicetus ignotus, Pelocetus calvertensis, and Thinocetus arthritus. (Lower values reflect more elongate vertebrae. Dashed lines and widely separated symbols indicate absence of specimens at those points in the column. See "Discussion" for sources of measurements used in these curves.)

racic vertebrae from 15 in archaeocetes to 12 in cetotheres took place in the posterior region of the thoracic series. The reason for that reduction is probably rooted in the adaptive economics of cetacean evolution.

Among modern mysticete taxa, Balaenoptera musculus and $B$. physalus have 15 thoracic vertebrae, $B$. borealis has 13-14, B. acutorostrata has 11, and Eschrichtius robustus, Megaptera novaeangliae, and Eubalaena glacialis all have 14 thoracic vertebrae (Kellogg, 1968:175). Kellogg (1968:175) also noted that "skeletons of adult Recent mysticetes are not only larger, with one exception, but are also comprised of more vertebrae than the Calvert Miocene cetotheres. This increase in the number of vertebrae occurs notably in the caudal series." In view of the numerous affinities that Eomysticetus whitmorei shares with archaeocetes, including certain morphological features of the thoracic vertebrae, it is not entirely surprising to find that this animal apparently carried a higher complement of thoracic vertebrae than the Miocene cetotheres that it preceded, and that they would be closer in number to the 15 thoracic vertebrae present in both Basilosaurus cetoides and Zygorhiza kochii 
(Kellogg, 1936:46, 143). The presence of 15 thoracic vertebrae in this archaic Oligocene mysticete seems almost certainly to be a primitive character, quite unrelated to the increased number of thoracic vertebrae in extant mysticetes as discussed by Kellogg (1968:175).

That premise is supported by the fact that the heads of the ribs of Eomysticetus have capitular articulations with the centra in the first through the ninth thoracic vertebrae, whereas capitular articulation among the extant balaenopterids has been reduced to the first three or four pairs of anterior ribs (Kellogg, 1968:175). In the late Eocene dorudontine archaeocete $Z y$ gorhiza kochii, 10 of the anterior ribs have both the capitular and tubercular articulations (Kellogg, 1936:167), and in the Calvert cetotheres the heads of only seven or eight of the anterior ribs have the two articular surfaces (Kellogg, 1968:175).

The ribs of Eomysticetus whitmorei are of a normal cetacean type. They are neither pachyostotic nor osteosclerotic. They bow strongly laterally, indicating a full-bodied animal. The anteriormost rib is short and broad as is typical of derived Cetacea.

The most striking feature of the forelimb in Eomysticetus whitmorei is the large size of the humerus in comparison with the radius and the ulna, a condition more characteristic of Archaeoceti than of either the Mysticeti or the Odontoceti, the humerus in archaeocetes being considerably longer and more robust than the radius and the ulna. In all known Neogene Cetacea, the humerus is much shorter than the radius and the ulna, reflecting evolutionary trends toward the shortening of the humerus as the forelimb becomes more highly specialized as a flipper-like structure. As seen in Table 8, the relative proportions of the humerus and the radius and ulna in Eomysticetus whitmorei are intermediate between those of the middle Eocene archaeocete Basilosaurus cetoides (USNM 4675; Kellogg, 1936) and the middle Miocene cetothere Thinocetus arthritus (USNM 23794; Kellogg, 1969). Archaic limb proportions apparently were characteristic of many late Oligocene odontocetes as well. The humerus is longer than the radius and ulna $(130 \mid 100,102)$ in the primitive odontocete Sulakocetus dagestanicus Mchedlidze, 1976 (see Mchedlidze, 1976:50-51) and greatly exceeds the length of the lower arm bones in the squalodontid Kelloggia barbarus Mchedlidze, 1976 (see Mchedlidze, 1976, pl. 26) from Azerbaijan. More-advanced trends are seen in two other late Oligocene odontocetes from the Caucasus region. The humerus and radius-ulna complex are about equal in length in Ferecetotherium kelloggi Mchedlidze, 1970 (Mchedlidze, 1976:15, pl. 5), a sperm whale (see Barnes, 1985), and the humerus is slightly shorter in Oligodelphis azerbajdzanicus Mchedlidze and Aslanova, 1968 (Mchedlidze, 1976, pl. 11), a probable kentriodontid dolphin (see Barnes, 1985). In both Mysticeti and Odontoceti, therefore, late Oligocene time appears to have been a period of transition between the archaeocete type of forelimb and the various kinds of more highly adapted limb structure of Neogene Cetacea, the
TABLE 8.-Greatest proximodistal lengths of humerus, radius, and ulna in the late Eocene archaeocete Basilosaurus cetoides (USNM 4675; Kellogg, 1936:64, 67, 68, tables 13-15), the late Oligocene mysticete Eomysticetus whitmorei (holotype, ChM 4253), and the middle Miocene mysticete Thinocetus arthritus (USNM 23794; Kellogg, 1969:9, 10, tables 9-11), all from North America.

\begin{tabular}{l|ccc}
\hline \multicolumn{1}{c|}{ Specimen } & Humerus & Radius & Ulna \\
\hline Basilosaurus cetoides (USNM 4675) & $490 \pm$ & 250 & 334 \\
Eomysticetus whitmorei (holotype, ChM PV4253) & 329 & 268 & 327 \\
Thinocetus arthritus (USNM 23794) & 260 & 385 & 398 \\
\hline
\end{tabular}

shortened humerus having evolved convergently in the two extant groups.

Eomysticetus whitmorei exemplifies a more primitive grade of telescoping than the late Oligocene species of Mauicetus of New Zealand. Apparently, it was one of the last members of a line that preceded Mauicetus, and it probably demonstrates the general appearance of the skull in the earliest baleen-bearing mysticetes. The progenitors of the line that it represents would seem quite evidently to have been forms that were in evolutionary transition from Archaeoceti to Mysticeti.

The Archaeoceti is the most archaic suborder of Cetacea and includes three families, ranging from the most primitive Protocetidae through the more highly evolved Remingtonocetidae and Basilosauridae. Typical Eocene forms are characterized principally by nontelescoped skulls, the nares being situated anteriorly on the anterior part of the rostrum, and by a distinctive dental formula and morphology. The Protocetidae are the oldest and most primitive archaeocetes and include early and middle Eocene animals from North Africa, India, and Pakistan in the Tethys region (e.g., Gingerich et al., 1983, 1990, 1995) and two new protocetids from Georgia (Hulbert et al., 1998) and South Carolina (Geisler et al., 1996). The South Carolina animal is currently under study at The Charleston Museum. All were less than $4 \mathrm{~m}$ long, had the normal mammalian dental formula, had fully movable (but reduced) hind limbs, and had the petrosal still located within the braincase. The Basilosauridae include the medium-sized, generalized Dorudontinae and the more divergent, large Basilosaurinae. Species in this family have been discovered around the world, but no unquestionable basilosaurid represented by a skull has been recorded in rocks younger than late Eocene age. Like the Protocetidae, their skulls were not telescoped, but their molars and premolars were more highly evolved because none were three-rooted, there were accessory denticles on the anterior and posterior edges, and because M3 was lost. Generalized dorudontines may have been the ancestors of the mysticetes and the odontocetes (Barnes and Mitchell, 1978; Fordyce, 1980; Barnes and Sanders, 1996).

Although most of the major steps in cetacean evolution are represented in the fossil record, previously described material has not included skulls evincing transitional grades between archaeocetes and mysticetes or between archaeocetes and odontocetes. Characters derived from archaeocetes are evident in 
early members of both of the modern suborders (e.g., Barnes and Mitchell, 1978), but the long absence of skulls of advanced archaeocetes showing trends toward specific odontocete or mysticete characters has led some authors to dismiss the Archaeoceti as being the possible ancestors of the living Cetacea.

Kleinenberg and Yablokov (Kleinenberg, 1958, 1959; Kleinenberg and Yablokov, 1958; Yablokov, 1964) have argued that modern baleen and toothed whales must have had separate origins because they are such dissimilar animals now and because they both differ so greatly from archaeocetes. Rice (1966, 1984) and some authors of other general works have accepted such arguments and have classified the archaeocetes, odontocetes, and mysticetes as separate mammalian orders. Van Valen (1968) rebutted the arguments for triphyly by Yablokov, Kleinenberg, and others, and his conclusion that archaeocetes should be accepted as the ancestors of modern whales has been supported by statements by Fordyce (1980), Gaskin (1982), and Rothausen (1985).

Proponents of the theory of polyphyletic origin of cetaceans have unknowingly rested much of their case upon unsound stratigraphic ground. Yablokov and others have argued that the "earliest" odontocetes from Charleston, South Carolina, i.e., Agorophius pygmaeus (Müller, 1849) and Xenorophus sloanii Kellogg, 1923, which had figured prominently in paleontological analyses, were late Eocene in age, contemporaries of the archaeocetes, and therefore could not possibly be considered as their descendants; however, the deposits that produced these early odontocetes have now been reinterpreted as late Oligocene in age (Whitmore and Sanders, 1976), which makes them millions of years younger than ancestral Eocene archaeocetes and places them in an intermediate position both chronologically and anatomically. Unfortunately, few summary articles have incorporated that information.

One of the major shortcomings of Yablokov and Kleinenberg's triphyletic argument is that the extremely different characters of modern mysticetes and odontocetes show only that they have diverged in their evolutionary history, not necessarily that they had separate origins. Additionally, many of those authors' arguments are simply based upon incorrect or incomplete data. Because archaeocetes are known only as fossils, skeletal structures are the only presently available characters that are useful when comparing them with living odontocetes and mysticetes. The early, primitive odontocetes and mysticetes have few of the skeletal features that some mammalogists, working only with living taxa, often consider to be important and/or diagnostic for the living groups. When considering only the cetaceans of the Oligocene, however, we find odontocetes and mysticetes that are remarkably similar to one another as well as to archaeocetes, and that, in fact, have many osteological characters that are intermediate between archaeocetes and primitive members of the other two suborders. Of these, Eomysticetus whitmorei provides the most dramatic example of shared archaeocete and mysticete characters and should put to rest any further claims of polyphyly in cetacean phylogeny.

\section{The Primitive Phylogenetic Position of} Eomysticetus whitmorei

Eomysticetus whitmorei was demonstrably a baleen-bearing mysticete. There are no dental alveoli on its palate nor on its dentaries, the palatal surface of its maxilla has sulci that indicate the presence in life of blood vessels that would have nourished baleen, the horizontal rami of the dentaries are elongate and parallel-sided, and a line of nutrient foramina along the dorsal (gingival) border of each dentary marks the former row of mandibular dental alveoli and their associated nutrient foramina. All of these features are typical of baleen-bearing mysticetes that use a bulk-feeding mode.

Eomysticetus whitmorei represents a previously undocumented stage in the evolutionary history of baleen-bearing mysticetes, and at present it and E. carolinensis are the only named members of a previously unreported clade of Mysticeti recognized herein as the family Eomysticetidae. Other primitive baleen-bearing mysticetes of a similar, but slightly more derived grade of evolution have been reported, but as yet most of them are either unnamed and/or uncertainly assigned to a family. Some or all of these may, upon future study, be determined to belong as well to the family Eomysticetidae.

Autapomorphies that define Eomysticetus whitmorei and the family Eomysticetidae (Figure 30 ) include (1) the extremely narrow intertemporal region (not to be confused with the anteroposteriorly elongate intertemporal, a primitive character retained from Archaeoceti); (2) the narrow, elongate rostrum; (3) the elongate nasal bones; (4) the small, pit-like secondary squamosal fossae; (5) the elongate zygomatic processes of the squamosals diverging anterolaterally from the sagittal plane of the skull (E. carolinensis); (6) the spatulate anterior end of the zygomatic process of the squamosal (E. whitmorei); (7) the bladelike anterior process of the periotic that is compressed transversely and expanded dorsoventrally ( $E$. whitmorei and probably E. carolinensis as well); and (8) the length of the humerus, which equals the length of the radius and ulna.

Otherwise, Eomysticetus whitmorei has the most primitive cranial morphology of any named primitive baleen-bearing mysticete. The morphologic sequence arranged from $E$. whitmorei to Eomysticetus carolinensis to Micromysticetus rothauseni to Cetotheriidae to Balaenopteridae, in general demonstrates development or enhancement of the following derived character states among Mysticeti: anteroposterior shortening of the frontal and parietal in the intertemporal region, anteroposterior shortening and concomitant transverse widening of the occipital shield, more horizontal extension of the lambdoidal crests, loss of the secondary squamosal fossa, increase in size of the squamosal prominence, shortening of the zygomatic process of the squamosal, increase in lateral displacement of the anterior end of the zygomatic process of the squamosal, widening of the intercondylar notch, and more ventrolateral flaring of the lateral wall of the braincase. 


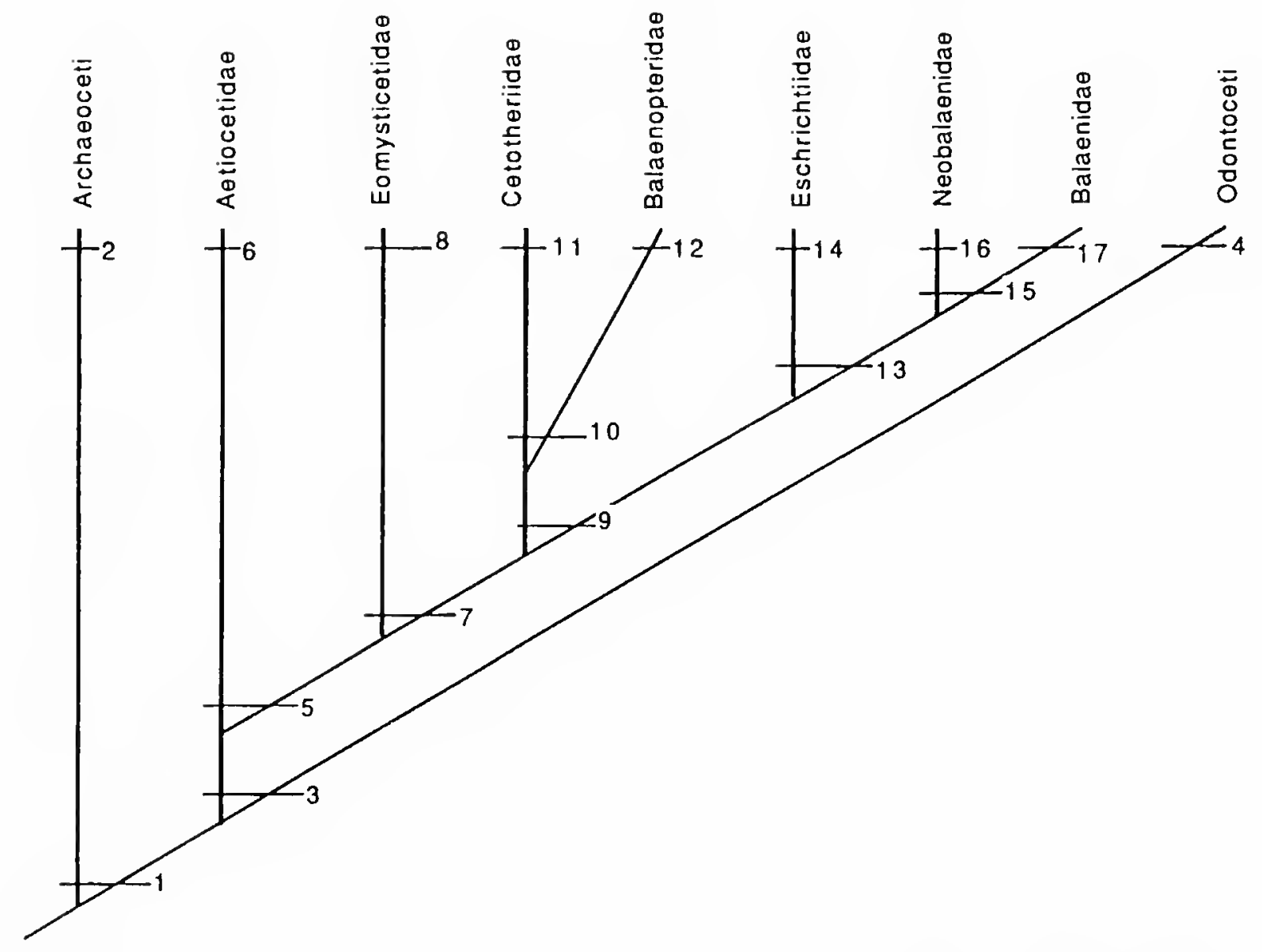

FIGURE 30.-Cladogram showing relationships of Eomysticetus whitmorei to other Cetacea. In part from Bames, 1990; Barnes and McLeod, 1984; McLeod et al., 1989, 1992. The nominal families Llanocetidae and Mammalodontidae are omitted because their characters are poorly known. Characters at dichotomies are as follows:

Node 1=Order Cetacea: 1, Facial region of skull elongated; 2, Intertemporal region narrow and elongated; 3, Sagittal and lambdoidal crests high; 4, Incisive (anterior palatine) foramina lost; 5, Tympanic bulla involuted and inflated; 6 , Supraorbital process of frontal enlarged; 7, Basioccipital crest enlarged; 8, Falciform process of squamosal present lateral to anterior process of periotic; 9 , Periotic and tympanic bulla separated on their medial sides from the basioccipital; 10, Tympanic bulla separated posteriorly from the exoccipital; 11, Hypoglossal foramen in basioccipital located either at the apex of or inside the jugular notch; 12, Peribullary sinus and pterygoid sinus present as diverticula of middle ear sinus; 13, Incisors and canines not transverse, but aligned anteroposteriorly with the cheek-tooth row; 14, Central cusp of both upper and lower cheek teeth transversely compressed; 15, Mandibular foramen enlarged; 16, Scapula with supraspinatus fossa reduced and with acromion and coracoid processes parallel and directed anteriorly; 17, Postzygapophyses on thoracic and lumbar vertebrae reduced.

Point 2=Archaeoceti: Apparently paraphyletic; defined primarily by primitive characters.

Node 3=Mysticeti plus Odontoceti: 1, Bones of cranium telescoped; 2, Multiple maxillary foramina derived from infraorbital foramen; 3, Elongate (laterally) supraorbital process of frontal; 4, Vomer exposed on basicranium and extending posteriorly to cover basisphenoid/basioccipital suture; 5 , Zygomatic process of the squamosal contacting postorbital process of frontal and/or connected to it by a ligament; 6 , Posterior part of dentary thin and dense in area of mandibular foramen (the "pan bone"); 7, Monophylodonty; 8 , Elbow joint nonrotational, with anteroposterior position of radius and ulna and formation of discretc flattened articular facets on distal end of humerus (one for radius, two for ulna); 9 , Olecranon fossa of humerus lost; 10, Hyperphalangy.

Point 4=Odontoceti: 1, Premaxillary foramen present (as an aperture of infraorbital foramen complex) with anteromedial, posteromedial and posterolateral sulci emanating from it; 2, Spiracular plate present on premaxilla anterolateral to nares (for premaxillary sac, a diverticulum of the narial passage); 3, Ascending process of maxilla expanding posteriorly over supraorbital process of frontal; 4, Antorbital notch present; 5, Pterygoid sinus extending anteriorly and around lateral side of narial passage; 6 , Middle sinus present; 7, Lachrymal and jugal bones fused.

Node 5=Mysticeti: 1, Flat (tabular) supraorbital process of frontal with knob-like postorbital process; 2 , Antorbital process of maxilla present (antorbital process extending posterolaterally from dorsal surface of rostrum along antcrior margin of supraorbital process); 3, Maxilla extending posteriorly ventral to supraorbital process of frontal; 4, Lateral margin of maxilla becoming thin; 5 , Temporal crest moved to dorsal surface of supraorbital process of frontal; 6 , Basioccipital and basisphenoid becoming thickened dorsoventrally; 7, Mandibular symphysis loose, with elongate ligamental groove at symphysis; 8 , Atlas with single transverse process. 
Point $6=$ Family Aetiocctidae: 1, Intertemporal region shortened anteroposteriorly and widened transversely; 2, Protuberance present on premaxilla at anterolateral corner of nasal bone; 3, Squamosal fossa shortened anteroposteriorly; 4 , Elongate notch present in posterior border of palatine at posterior end of palate.

Node 7=Family Eomysticctidae plus all other Mysticeti: 1, Functional teeth lost in adult; 2, Baleen present in postfetal stage; 3 , Gingival foramina present and enlarged along dorsal margin of horizontal ramus of dentary; 4, Sulci present on palatal surface of maxillae marking paths of nutrient vessels that nourish baleen plates; 5 , Vomer forming a prominent ventral kecl along midline of palate.

Point $8=$ Eomysticetus (=Family Eomysticetidae): 1, Intcrtemporal region extremely narrowed; 2 , Nasal bones elongated; 3, Zygomatic process of squamosal clongated; 4, Zygomatic process of squamosal diverging anterolaterally from sagittal plane of skull; 5 , Anterior process of periotic compressed transversely and expanded dorsoventrally ("blade-like").

Node 9=All Mysticeti beyond Family Eomysticetidae: 1, Nasal bones shortened anteroposteriorly; 2, Supraorbital process of frontal widened anteroposteriorly; 3, Intertemporal region shortened anteroposteriorly so that zygomatic process of squamosal contacts postorbital process of frontal; 4 , Anterior process of periotic thickened transversely; 5, Posterior process of periotic fused to posterior (mastoid) process of tympanic bulla; 6 , Humerus shorter than radius or ulna.

Node $10=$ Family Cetotheriidae plus Family Balaenopteridae (=Superfamily Balaenopteroidea): 1, Transversely aligned gap present between posterior margin of ascending process of maxilla and anterior margin of supraorbital process of frontal; 2 , Ascending process of premaxilla tapered between posterior ends of nasal and maxilla; 3, Zygomatic process of squamosal relatively shortened and blunt; 4, Postglenoid process globose.

Point 11 =Cetotheriidae: 1 . Ascending process of maxilla tapered posteriorly between frontal and ascending process of premaxilla.

Point 12=Family Balaenopteridae: 1, Cleft present along alisphenoid/squamosal suture in lateral wall of braincase; 2, Dorsal surface of supraorbital process of frontal depressed ventrally relative to intertemporal region; 3, Rostral bones (maxillae, premaxillae, nasals) extending posteriorly toward occipital shield anteroposteriorly compressing frontals and parietals; 4, Mandibular canal and mandibular foramen reduced in diameter; 5 , Bone of mandible porous and inflated; 6 , Numerous throat grooves present; 7. Four digits in manus.

Node $13=$ Family Eschrichtiidae plus Superfamily Balaenoidea: 1, Rostrum arched dorsally (at least $10^{\circ}$ ) (from Barnes and McLeod, 1984); 2, Nasal bones wide and "blocky"; 3, Bones around narial region of skull elevated; 4 , Horizontal ramus of dentary torsioned in anterior part; 5, Mandibular condyle enlarged and nearly spherical; 6, Horizontal ramus of dentary expanded and arched dorsoventrally; 7 , Coronoid process of dentary reduced.

Point 14=Family Eschrichtiidae: 1, Premaxillary foramen present on either or both premaxillae lateral to narial opening (convergence with Odontoceti); 2, Premaxillae wide posteriorly and excluding maxillae from exposure on cranial vertex; 3 , Nasal bones large and forming highest part of skull; 4, Tubercles for muscle attachment present on both sides of occipital shield; 5, Baleen plates thick anteroposteriorly; 6, Baleen plates cream in color; 7, Dorsal fin lost.

Node 15=Superfamily Balaenoidea: 1, Zygomatic process of squamosal and glenoid fossa positioned far ventrally on the skull; 2, Pterygoids extending far posteriorly beneath basicranium; 3 , Baleen plates numerous and thin; 4 , Cervical vertebrae fused.

Point 16=Family Neobalaenidae: 1, Body size reduced; 2, Rostrum arched about 17 degrees; 3, Occipital shield extended anteriorly; 4, Zygomatic process of squamosal short; 5, Nasal bones small; 6 , Horizontal ramus of dentary deep dorsoventrally; 7, Humerus shortened.

Point 17=Family Balaenidae: 1, Head greatly enlarged, approximately one-third of body length; 2, Rostrum transversely compressed; 3 , Rostrum greatly arched dorsally, premaxillae forming highest part of skull; 4, Baleen plates greatly elongated; 5 , Supraorbital process of frontal sloping and greatly elongate (extended laterally); 6, Zygomatic process of squamosal flaring anterolaterally; 7 , Involucrum of tympanic bulla flattened dorsoventrally; 8 , Dorsal fin lost.

\section{Other Primitive BaleEn-Bearing Mysticetes}

A primitive baleen-bearing mysticete, represented by a remarkably complete skull and skeleton, was preliminarily reported by Okazaki (1995) from a late Oligocene deposit on the island of Kyushu in Japan. This unnamed whale is quite similar to Eomysticetus whitmorei but is more highly derived. The two species share similar overall size, a narrow and elongate intertemporal region capped by a narrow sagittal crest, elongate and narrow nasal bones, a secondary fossa within the squamosal fossa, a relatively small but transversely expanded postglenoid process, a relatively small occipital shield, elongate and anterolaterally flaring zygomatic processes of the squamosals, a tubercle-like posterior end of the basioccipital crest, an anteroposteriorly thick exoccipital, elongate and relatively flat rostrum, relatively straight horizontal ramus of the dentary, and a large and dorsally lobate coronoid process of the dentary. The 
unnamed Oligocene mysticete from Kyushu differs from Eomysticetus whitmorei by having the following derived character states (derived polarity determined in relation to the condition in Archaeoceti): a wider rostrum, an anteroposteriorly wider supraorbital process of the frontal, an anteroposteriorly shorter intertemporal region, larger and wider occipital shield that flares laterally over the temporal fossa rather than flaring dorsally, transversely narrower but more anteroposteriorly extensive squamosal fossa, and a relatively deeper horizontal ramus of the dentary. The unnamed mysticete from Kyushu also differs from $E$. whitmorei by having more convex occipital condyles. Although this might be a primitive character state, because it is shared with the Archaeoceti, we interpret it as a derived character state in comparison with $E$. whitmorei and, therefore, as a reversal. The elongate intertemporal region of $E$. whitmorei is a primitive character state that is shared with archaeocetes, and for this reason (as with the archaeocetes) the zygomatic process of the squamosal makes no contact with the postorbital process of the frontal. In the Kyushu specimen, with its anteroposteriorly shorter intertemporal region, the zygomatic process of the squamosal contacts the postorbital process of the frontal (see Okazaki, 1995, fig. 1b), and this is the derived character state. That derived condition exists as well in all other (more derived) mysticetes, except in "Mauicetus" lophocephalus, as illustrated by Marples (1956, fig. 1c; see also Barnes and McLeod, 1984, fig. 3c). The gap between the anterior tip of the zygomatic process and the squamosal and the postorbital process of the frontal is smaller in " $M$." lophocephalus than it is in E. whitmorei. In that regard, among the Mysticeti E. whitmorei is the form most like the Archaeoceti, and "M." lophocephalus approaches the condition in various derived groups of mysticetes, such as the Cetotheriidae, Balaenopteridae, Eschrichtiidae, Neobalanidae, and Balaenidae.

Late Oligocene Mauicetus is a problematic taxon. It is usually classified in the family Cetotheriidae, although Barnes and McLeod (1984:16) noted that it does not have autapomorphic characters that distinguish the type genus of the family Cetotheriidae, the late Miocene genus Cetotherium. Of the nominal species in the genus Mauicetus, only "M." lophocephalus is known by a relatively complete skull, and the illustrations of this skull (e.g., Marples, 1956, fig. 1c; Barnes and McLeod, 1984, fig. 3c) are based upon interpretations of its morphology prior to its being completely removed from sediment. If we restrict our interpretation of the skull morphology to the specimen illustrated by Marples (1956), it is clear that " $M$." lophocephalus is a relatively primitive baleen-bearing mysticete, although it is not nearly so primitive as Eomysticetus whitmorei. In some characters (e.g., zygomatic process of squamosal not contacting postorbital process of the frontal, smaller supraoccipital shield) "M." lophocephalus is more primitive than the unnamed baleen-bearing mysticete reported by Okazaki (1995) from Kyushu. It does not have the elongate and flaring zygomatic process of the squamosal that the unnamed mysticete from Kyushu shares with $E$. whitmorei, and it is not so closely related to either of these taxa as they are to each other. Whether " $M$." lophocephalus is ultimately determined to belong to the Cetotheriidae or to some other clade, it is not inclusive within the clade containing Eomysticetus whitmorei and the unnamed mysticete from Kyushu.

Crowley and Barnes (1996) reported yet another type of unnamed primitive baleen-bearing mysticete of late Oligocene age from the Olympic Peninsula of Washington. This whale is not closely related to " $M$." lophocephalus, nor does it belong to the family Eomysticetidae. Although that specimen, Eomysticetus whitmorei, and the unnamed mysticete from Kyushu all have a sagittal crest and an extensive exposure of the parietals in the intertemporal region, as well as a large and dorsally lobate coronoid process of the dentary, these are shared primitive characters and do not necessarily indicate close relationship. The late Oligocene mysticete from Washington has autapomorphic characters-such as a short and medially curved zygomatic process of the squamosal, a relatively anteroposteriorly shorter and wider intertemporal region, and a shorter rostrumthat serve to distinguish it from Eomysticetus whitmorei.

From late Oligocene deposits in southern Baja California Sur, Mexico, have been reported other primitive baleen-bearing mysticetes (Barnes, 1998) that appear to share characters with Eomysticetus whitmorei: elongate nasal bones, elongate and divergent zygomatic process of the squamosal, and a small supraoccipital shield whose margins flare dorsally rather than laterally. These specimens have not yet been completely cleaned from their enclosing matrix, and only preliminary studies of them have been made.

The specimens from Baja California Sur, along with the unnamed mysticete reported from Kyushu by Okazaki (1995), demonstrate that primitive baleen-bearing mysticetes of the Eomysticetus grade, and possibly belonging to the family Eomysticetidae, were widespread in late Oligocene time. With apparent records of this group in the western North Atlantic, the eastern North Pacific, and the western North Pacific, the group might have been essentially cosmopolitan in late Oligocene time.

\section{ClassificATION}

Within the classification of mysticetes we recognize the families Aetiocetidae, Eomysticetidae, Cetotheriidae, Balaenidae, Neobalaenidae, Balaenopteridae, and Eschrichtiidae. Barnes (1984) and Barnes et al. (1985) proposed classifications of Cetacea that embraced both fossil and extant taxa, and Mitchell (1989) offered a new arrangement of Archaeoceti and Mysticeti accompanying his description of Llanocetus denticrenatus, an enigmatic, primitive late Eocene toothed mysticete from Antarctica. Our establishment of the new taxon Eomysticetus whitmorei necessitates further reappraisal of mysticete systematics. In the revised classification of Mysticeti presented below, subfamilies are used where they have become commonly recognized. In instances where the family group name is not used 
at the same rank as originally proposed, the original author is listed in parentheses followed by the author(s) who used the emended rank. Our classification differs from Mitchell's (1989) arrangement principally in our avoidance of the use of infraorders to group primitive, toothed mysticetes (i.e., Llanocetus, Aetiocetus, Mammalodon) about which too little is known to warrant such definitive hierarchical assignments, especially in the case of Llanocetus denticrenatus, which Mitchell (1989) described from only a fragment of the right dentary and a cranial endocast.

The two archaeocete-like teeth preserved in the mandibular fragment of Llanocetus denticrenatus and the wide diastema between them differ considerably from dental morphology and tooth spacing in Aetiocetus cotylalveus Emlong, 1966, and Mammalodon colliveri Pritchard, 1939, but these differences do not necessarily indicate the absence of shared similarities in cranial morphology. We therefore propose the new superfamily Aetiocetoidea as a group to accommodate all of the few known Paleogene toothed mysticetes, and we accordingly refer the Llanocetidae of Mitchell (1989) to that superfamily pending knowledge of the cranial anatomy of llanocetids.

In the following classification, a $\dagger$ in front of a taxonomic group indicates that it is extinct.

Order Cetacea Brisson, 1762

Suborder Mysticeti Flower, 1864

†Superfamily Aetiocetoidea, new superfamily

†Family Aetiocetidae Emlong, 1966

$\dagger$ Subfamily Chonecetinae Barnes, Kimura, Furusawa, and Sawamura, 1995

$†$ Family Llanocetidae Mitchell, 1989

$†$ Family Mammalodontidae Mitchell, 1989

†Superfamily Eomysticetoidea, new superfamily

$\dagger$ Family Eomysticetidae, new family

Superfamily Balaenopteroidea (Gray, 1868) Mitchell, 1989

$†$ Family Cetotheriidae (Brandt, 1872) Miller, 1923

†Subfamily Cetotheriopsinae Brandt, 1872

†Subfamily Cetotheriinae Brandt, 1872

Family Balaenopteridae Gray, 1864

Subfamily Megapterinae (Gray, 1866) Gray, 1868

Subfamily Balaenopterinae (Gray, 1864) Brandt, 1872

Superfamily Eschrichtioidea (Ellerman and Morrison-Scott, 1951) Mitchell, 1989

Family Eschrichtiidae Ellerman and Morrison-Scott, 1951

Superfamily Balaenoidea (Brandt, 1873) Mitchell, 1989

Family Neobalaenidae Gray, 1874

Family Balaenidae Gray, 1825

Absent from the foregoing arrangement and from most of the recent classifications of the Mysticeti are several taxa once thought to be mysticetes or to be mysticete ancestors. Commenting on the primitive late Oligocene cetacean Squalodon pygmaeus (Müller, 1849) from South Carolina, Gervais (1871:138) proposed that $S$. pygmaeus actually belonged among the rorquals. In erecting the new genus Agorophius for S. pygmaeus, Cope (1895:139) noted that "the form of the skull in this genus approaches distinctly that of Cetotherium ... and the permanent loss of the teeth would probably render it necessary to refer it to a Mystacocete." Subsequent authors (e.g.,
True, 1907, 1908; Abel, 1913; Miller, 1923; Kellogg, 1928) correctly placed Agorophius pygmaeus in the Odontoceti. Patriocetus ehrlichi (Van Beneden, 1865), from the late Oligocene sands at Linz, Austria, was figured incorrectly by Abel (1913; see also Kellogg, 1928), who suggested that it was a primitive toothed mysticete. Miller (1923:44) recognized its true affinities with the Odontoceti, and Rothausen (1968) illustrated the correct form of the rostrum and referred Patriocetus to the Squalodontidae.

Archaeodelphis patrius Allen, 1921, known by a partial cranium without locality data but thought to be of late Eocene age (Allen, 1921), was assigned to the odontocete family Agorophiidae by Miller (1923:40). Kellogg (1928) placed Archaeodelphis in Odontoceti incertae sedis, but suggested it as a possible mysticete ancestor, as did Dechaseaux (1961:881). Rothausen (1968:97-98) included Archaeodelphis in the Agorophiidae, but Whitmore and Sanders (1976) returned it to incertae sedis. We have considered the morphology of the holotype (MCZ 15749) of Archaeodelphis patrius in some detail and agree with Fordyce (1981:1042) that it is clearly an odontocete and had nothing whatsoever to do with the ancestry of the mysticetes.

Following Emlong (1966) in regarding Aetiocetus cotylalveus as a member of the Archaeoceti, Mchedlidze (1976) suggested that Ferecetotherium kelloggi Mchedlidze, 1970, and Mirocetus rjabinini Mchedlidze, 1970, belonged with Aetiocetus in the family Aetiocetidae, which he concluded was the archaeocete family that gave rise to the Mysticeti. Many authors (e.g., Barnes and Mitchell, 1978; Fordyce, 1980; Barnes, 1985, 1987, 1989; Barnes et al., 1995; Evans, 1987; Sanders and Barnes, 1989), however, agree with Van Valen's (1968) interpretation of Aetiocetus cotylalveus as a primitive toothed mysticete, thus leaving in question the other two taxa assigned to the Aetiocetidae by Mchedlidze. Barnes (1985) proposed that Ferecetotherium kelloggi is actually a primitive sperm whale, its slender, conical teeth constituting a homodont dentition quite unlike the dental characteristics of Archaeoceti. As for Mirocetus rjabinini, independent examinations of its holotype by Sanders and by Rothausen produced concurrent opinions: that the maxillae ascend well onto the frontals and probably overspread most of the supraorbital processes, and that Mirocetus rjabinini therefore belongs in the Odontoceti (Rothausen to Sanders, pers. comm., 1976, 1990).

In summary, our opinions regarding the subordinal positions of the genera discussed above are as follows:

\footnotetext{
Suborder Mysticeti

Aetiocetus

Llanocetus

Mammalodon

Suborder Odontoceti

Agorophius

Archaeodelphis

Ferecetotherium

Mirocetus

Patriocetus
} 


\section{Conclusions}

Eomysticetus whitmorei is an archaic, baleen-bearing mysticete of late Oligocene age. The length of the skull and the size of the vertebrae indicate that it was of moderate size $(\sim 8 \mathrm{~m}$ long) in life, and although its rostrum and mandibles are edentulous as in other mysticetes, it has a braincase very much like that of an archaeocete. The stage of its cranial telescoping is unlike that of any other mysticete yet described. The palatal surface of its maxilla has sulci that indicate the presence in life of blood vessels that would have nourished baleen, but the palatal surface was not highly vascularized, as is typical of highly evolved mysticetes, so the baleen probably was not very long. The coronoid process of the dentary is very large, and the temporal musculature was extensive.

In many characters, E. whitmorei is morphologically transitional between archaeocetes and mysticetes, which demonstrates clearly the direct ancestral-descendant relationship between the two groups and helps to refute the arguments for cetacean polyphyly.

Eomysticetus whitmorei is a relict taxon, however, because baleen-bearing mysticetes with a higher degree of cranial telescoping are known earlier in the Oligocene and also were contemporaneous with $A$. whitmorei in Chandler Bridge (lower
Chattian) time. Its morphology demonstrates the stage of cranial telescoping that was probably achieved in the early Oligocene by other lineages of mysticetes. The species was contemporaneous with, and perhaps sympatric with, at least two other species of mysticetes (cetotheriopsine cetotheriids; Sanders and Barnes, 2002), a diversity of primitive odontocetes, and some new and as-yet-undescribed toothed mysticetes from South Carolina (Barnes and Sanders, 1996). It also is broadly contemporaneous with relict tooth-bearing aetiocetid mysticetes and with several other lineages of primitive mysticetes that existed elsewhere in the world in late Oligocene time. Some of these other mysticetes had teeth, some had baleen, some had highly evolved crania, and some had primitive crania.

The skull of Eomysticetus whitmorei exhibits the most primitive cranial features known in a fossil baleen-bearing mysticete whale. Its prominent archaeocete-like characters-such as the location of the nasal opening far anterior to the vertex of the skull-provide new insights into the origin of baleen whales and suggest that a presently unknown line of Archaeoceti branched directly toward Mysticeti and that Odontoceti evolved from Archaeoceti along an entirely separate evolutionary pathway.

\section{Literature Cited}

Abel, $\mathrm{O}$

1913. Die Vorfahren der Bartenwale. Denkschriften der Akademie der Wissenschaften, Wien, Mathematisch-Naturwissenchaftliche Klasse, 90:155-224, 12 plates.

Allen, G.M.

1921. A New Fossil Cetacean. Bulletin of the Museum of Comparative Zoology at Harvard College, 65(1):1-14, 3 figures, 1 plate.

Barnes, L.G.

1984. Search for the First Whale: Retracing the Ancestry of Cetaceans. Oceans, 17(2):20-23.

1985. Review: G.A. Mchedlidze, General Features of the Paleobiological Evolution of Cetacea, 1984. [English translation.] Marine Mammal Science, 1(1):90-93.

1987. Aetiocetus and Chonecetus, Primitive Oligocene Toothed Mysticetes and the Origin of Baleen Whales. Journal of Vertebrate Paleontology, supplement, 7(3): 10A.

1989. Aetiocetus and Chonecetus (Mammalia: Cctacca); Primitive Oligocene Toothed Mysticetes and thc Origin of Baleen Whales. In Fifth International Theriological Congress, Rome, 22-29 August 1989, Abstracts of Papers and Posters, 1:1:479.

1990. The Fossil Record and Evolutionary Relationships of the Genus Tursiops. In S. Leatherwood and R.R. Rcevcs, editors, The Bottlenose Dolphin, pages 3-26. New York: Academic Press.

1998. The Sequence of Fossil Marine Mammal Assemblages in México. In O. Carranza-Castañeda and D.A. Córdoba-Mćndez, editors, Avances en Investigación: Paleontología de Vertebrados. Instituto de Investigaciones en Ciencias de la Tier, Universidad Autónoma del Estado de Hidalgo, Publicación Especial, 1:26-79

Barnes, L.G., D.P. Domning, and C.E. Ray

1985. Status of Studies on Fossil Marinc Mammals. Marine Mammal Science, 1(1):90-93.
Bames, L.G., M. Kimura, H. Furusawa, and H. Sawamura

1995. Classification and Distribution of Oligocene Aetiocetidae (Mammalia; Cetacea; Mysticeti) from Western North America and Japan. The Island Arc, 3(4):392-431.

Bames, L.G., and S.A. McLeod

1984. The Fossil Record and Phyletic Relationships of Gray Whales. In M.L. Jones, S. Swartz, and S. Leatherwood, editors, The Gray Whale: Eschrichtius robustus, pages 3-32. New York: Academic Press.

Barnes, L.G., and E.D. Mitchell

1978. Cetacea. In V.J. Maglio and H.B.S. Cooke, editors, Evolution of African Mammals, pages 582-602. Cambridge, Massachusetts: Harvard University Press.

Barnes, L.G., and A.E. Sandcrs

1990. An Archaic Oligocene Mysticete from South Carolina. Journal of Vertebrate Paleontology, supplement, 10(3): 14A.

1996. The Transition from Archaeocetes to Mysticetes: Late Oligocene Toothed Mysticctes from near Charleston, South Carolina. In J.E. Repetski, editor, Abstracts of Papers, Sixth North American Paleontological Convention, Smithsonian Institution, Washington, D.C., Junc 9-June 12, 1996. Paleontological Society. Special Publication, $8: 24$.

Brandt, J.F. von

1872. Über eine neuc Classification der Bartenwale (Balaenoidea) mit bcrücksichtigung der untergegangenen Gattungen derselben. Bulletin de l'Académie Impériale des Sciences de St. Pétersbourg, series 3, 17:113-124.

1873. Untersuchungen ubcr die fossilen und subfossilen Cetaccen Europas. Mémoires de l'Académie Impériale des Sciences de St. Pétersbourg, series 7, 20(1): viii +372 pages, 34 plates.

Brisson, M.J.

1762. Regnum animale in classes $I X$ distributum sive synopsis methodica. 


\section{Cope, E.D.}

Editio actior, 296 pages. Leiden: Theodorus Haak.

1895. Fourth Contribution to the Marine Fauna of the Miocene Period of the United States. Proceedings of the American Philosophical Society, 34:135-155, 1 plate.

Crowley, B.E., and L.G. Bames

1996. A New Late Oligocene Mysticete from Washington State. In J.E. Repetski, editor, Abstracts of Papers, Sixth North Amcrican Paleontological Convention, Smithsonian Institution, Washington, D.C., June 9-June 12, 1996. Paleontological Society, Special Publication, 8:90.

Curry, D., C.G. Adams, M.C. Boulter, F.C. Dilley, F.E. Eames, B.M. Funnell, and M.K. Wells

1978. A Correlation of Tertiary Rocks in the British Isles. Geological Society of London. Special Report, 12:1-72, 5 figures.

Dechaseaux, C.

1961. Encephales de Cetaces fossiles. In J. Piveteau, editor, Traité de Paléontologie, 6(1):881-886. Paris: Masson.

Ellerman, J.R., and J.C.S. Morrison-Scott

1951. Checklist of Palaearctic and Indian Mammals, 1938-1946. 810 pages. London: British Museum (Natural History).

Emlong, D.R.

1966. A New Archaic Cetacean from the Oligocene of Northwest Oregon. Bulletin of the Museum of Natural History. University of Oregon, 3:1-51, 15 figures.

Erickson, B.R., and G.S. Sawyer

1996. The Estuarine Crocodile Gavialosuchus carolinansis n. sp. (Crocodylia: Eusuchia) from the Late Oligocene of South Carolina, North America. Monograph of the Science Museum of Minnesota. Paleontology. 3: 47 pages.

Evans, P.G.H

1987. The Natural History of Whales and Dolphins. xvi +343 pages. New York: Facts on File Publications.

Flower, W.H.

1864. Notes on the Skeletons of Whales in the Principal Museums of Holland and Belgium, with Description of Two Species Apparently New to Science. Proceedings of the Zoological Society of London, 1864:384-420.

Fordyce, R.E.

1980. Systematics of the Odontocete Whale Agorophius pygmaeus and the Family Agorophiidae (Mammalia: Cetacea). Journal of Paleontology, 55(5): 1028-1045.

1981. A Review of Australian Fossil Cetacea. Memoirs of the National Museum of Victoria, 43:43-58, 2 plates.

Fraser, F.C., and P.E. Purves

1960. Hearing in Cetaceans: Evolution of the Accessory Air Sacs and the Structure and Function of the Outer and Middle Ear in Recent Cetaceans. Bulletin of the British Museum (Natural History), Zoology,

Gaskin, D.E. $7(1): 1-140$, frontispiece, plates 1-53.

1982. The Ecology of Whales and Dolphins. xii +459 pages, 99 figures. London: Heinemann Educational Books.

Geisler, J., A.E. Sanders, and Z. Luo

1996. A New Protocetid Cetacean from the Eocene of South Carolina, U.S.A.; Phylogenetic, and Biogeographic Implications. In J.E. Repetski, editor, Abstracts of Papers, Sixth North American Paleontological Convention, Smithsonian Institution, Washington, D.C., 9-12 June 1996. Paleontological Society, Special Publication, 8:139.

Gervais, $P$.

1871. Remarques sur l'anatomie des cétacés de la division des balénidés tirées de l'examen des pièces relatives a ces animaux qui sont conservées au museum. Nouvelles Archives du Museum d'Histoire Naturelle, Paris, 7:65-146, 7 plates.

Gingerich, P.D., M. Arif, and W.D. Clyde

1995. New Archaeocetes (Mammalia, Cetacea) from the Middle Eocene Domanda Formation of the Sulaiman Range, Punjab (Pakistan).
Contributions from the Museum of Paleontology, University of Michigan, 29(11):291-330.

Gingcrich, P.D., and D.E. Russell

1990. Dentition of Early Eocene Pakicetus (Mammalia, Cetacea). Contributions from the Museum of Paleontology, University of Michigan, 28(1): $1-20$

Gingerich, P.D., N.A. Wells, D.E. Russell, and S.M.1. Shah

1983. Origin of Whales in Epicontinental Remnant Seas: New Evidence from the Early Eocene of Pakistan. Science, 220:403-406, 2 figures.

Gray, J.E.

1825. Outline of an Attcmpt at the Disposition of the Mammalia into Tribes and Families with a List of the Genera Apparently Appertaining to Each Tribe. Philosophical Annals, 26:337-344.

1864. Notes on the Whalebone-Whales, with a Synopsis of the Species. Annals and Magazine of Natural History, series 3, 14:345-353.

1866. Catalogue of the Seals and Whales in the British Museum. Second edition, 402 pages, 102 figures. London: British Museum.

1868. Synopsis of the Species of Whales and Dolphins in the Collection of the British Museum. 10 pages, 37 plates. London: Bernard Quaritch.

1874. List of Seals, Whales, and Dolphins of New Zealand. Transactions and Proceedings of the New Zealand Institute, 1873, 6(Article 16):87-89 [Transactions for 1873, published in 1874.]

Hershkovitz, P.

1966. Catalog of Living Whales. Bulletin of the United States National Museum, 246: viii + 259 pages.

Hulbert, R.C., R.M. Petkewich, G.A. Bishop, D. Bukry, and D.P. Aleshire

1998. A New Protocetid (Mammalia: Cetacea: Archaeoceti) and Associated Biota from the Middle Eocene of Georgia. Journal of Paleontology, 72:907-927.

Kellogg, $R$.

1923. Description of an Apparently New Toothed Cetacean from South Carolina. Smithsonian Miscellaneous Collections, 76(7): 7 pages, 2 plates.

1927. Study of the Skull of a Fossil Sperm-Whale from the Temblor Miocene of Southern California. Carnegie Institution of Washington Publication, 346:1-23.

1928. The History of Whales-Their Adaptation to Life in the Water Quarterly Review of Biology, 3:29-76, 174-208.

1936. A Review of the Archaeoceti. Carnegie Institution of Washington Publication, 482: xv +366 pages, 88 figures, 37 plates.

1965. Fossil Marine Mammals from the Miocene Calvert Formation of Maryland and Virginia, Part 1: A New Whalebone Whale from the Miocene Calvert Formation. Bulletin of the United States National Museum, 247:1-45, plates 1-21.

1968. Fossil Marine Mammals from the Miocene Calvert Formation of Maryland and Virginia, Part 6: A Hitherto Unrecognized Calvert Cetothere. Bulletin of the United States National Museum, 247: 133-161, plates 49-57.

1969. Cetothere Skeletons from the Miocene Choptank Formation of Maryland and Virginia, Part 1: The Skeleton of a Miocene Choptank Cetothere. Bulletin of the United States National Museum, 294:124 , plates $1-15$.

Kleinenberg, S.E.

1958. K voprosu o proiskhozhdenii kitoobraznykh. [On the Problem of Origin of Cetaceans.] Doklady Akademia Nauk SSSR, 122(5):950952. [In Russian.]

1959. On the Origin of Cetacea. In H.R. Hewer and N.D. Riley, editors, Proceedings of the Fifteenth International Congress of Zoology, 1958, London, pages 445-447.

Kleinenberg, S.E., and A.V. Yablokov

1958. O morfologii verkhnikh dykhatel'nykn putei kitoobrazhynykh. [The Morphology of the Upper Respiratory Passages in the Cetaceans.] Zoologischeskii Zhurnal, 37:1091-1099.

Koretsky, 1.A., and A.E. Sanders

2002. Paleontology of the Late Oligocene Ashley and Chandler Bridge Formations of South Carolina, 1: Paleogene Pinniped Remains; the 
Oldest Known Seal (Carnivora: Phocidae). In R. Emry, editor, Cenozoic Mammals of Land and Sea: Tributes to the Career of Clayton E. Ray. Smithsonian Contributions to Paleobiology, 93:179-183.

Kumar, K., and A. Sahni

1986. Remingtonocetus harudiensis, New Combination, a Middle Eocene Archaeocete (Mammalia, Cetacea) from Western Kutch, India. Journal of Vertebrate Paleontology, 6(4):326-349, 10 figures.

Marples, B.J.

1956. Cetotheres from the Oligocene of New Zealand. Proceedings of the Zoological Society of London, 126(4):565-580.

Martini, E., and C. Müller

1975. Calcareous Nannoplankton from the Type Chattian. Proceedings of the Sixth Congress on Neogene Mediterranean Stratigraphy, Bratislava, Yugoslavia, 1975, 1:37-41.

Mchedlidze, G.A.

1970. Nekotorye obshchie cherty istorii kitoobraznykh, Chast' I. [Some Features of the Historical Development of Cetacea, Part 1.] 112 pages. Tbilisi, Georgia: Akademia Nauk Gruzinskoi S.S.R., Institut Paleobiologii, "Metsniereba" Publishers. [In Russian.]

1976. Osnovnyye cherty paleobiologicheskoy istorii kitoobraznykh. [Basic Features of the Paleobiological History of Cetaceans.] 136 pages, 32 plates. Tbilisi, Georgia: Akademia Nauk Gruzinskoi S.S.R., Institut Paleobiologii, "Metsniereba" Publishers. [In Russian, English summary.]

McLeod, S.A., R.L. Brownell, and L.G. Barnes

1989. The Classification of Cetaceans: Are All Whales Related? In Fifth International Theriological Congress, Rome, 22-29 August 1989, Abstracts of Papers and Posters, 1:490.

McLeod, S.A., F.C. Whitmore, Jr., and L.G. Barnes

1992. Evolutionary Relationships and Classification. In J.J. Bums, J.J. Montague, and C.J. Cowles, editors, The Bowhead Whale. Society for Marine Mammalogy, Special Publication, 2:45-70.

Meyer, H. von

1849. [Untitled.] Neues Jahrbuch für Mineralogie, Geologie, und Paläontologie, 1849:547-550. Stuttgart

Miller, G.S., Jr.

1923. The Telescoping of the Cetacean Skull. Smithsonian Miscellaneous Collections, $76(5): 1-71,8$ plates.

Mitchell, E.D.

1989. A New Cetacean from the Late Eocene La Meseta Formation, Seymour 1sland, Antarctic Peninsula. Canadian Journal of Fisheries and Aquatic Sciences, 46(12):2219-2235, 4 figures.

Müller, J.

1849. Über die fossilen Reste der Zeuglodonten von Nordamerica, mit Rücksicht auf die europäischen Reste aus dieser Familie. iv + 38 pages. Berlin: Verlag von G. Reimer.

Okazaki, Y.

1995. A New Type of Primitive Baleen Whale (Cetacea; Mysticeti) from Kyushu, Japan. The Island Arc, 3(4):432-435.

Owen, R.

1839. Observations on the Basilosaurus of Dr. Harlan (Zeuglodon cetoides, Owen). Transactions of the Geological Society of London. series 2, 6:69-79.

Perrin, W.F.

1975. Variation of Spotted and Spinner Porpoise (Genus Stenella) in the Eastern Pacific and Hawaii. Bulletin of the Scripps Institute of Oceanography, University of California, 21:1-206.

Pritchard, B.G

1939. On the Discovery of a Fossil Whale in the Older Tertiaries of Torquay, Victoria. Victorian Naturalist, 55(9):151-159.

Reichenbach, H.G.L.

1847. In C.G. Carus, Resultate geologischger, anatomischer und zoologischer Untersuchungen üher das unter dem Nainen Hydrarchos von $\operatorname{der}$ A.C. Koch zuerst nach Europa gebrachte und in Dresden aus- gestellte grosse fossile Skellet, pages 1-15, plates 1-7. Dresden and

Rice, D.W Leipzig.

1966. Cetaceans. In S. Anderson and J.K. Jones, Jr., editors, Recent Mammals of the World: A Synopsis of Families, pages 291-324. New York: The Ronald Press Co.

1984. Cetaceans. In S. Anderson and J.K. Jones, Jr., editors, Orders and Families of Recent Mammals of the World, pages 447-490. New York: John Wiley and Sons.

Rothausen, $\mathrm{K}$.

1968. Die systematische Stellung der europäischen Squalodontidae (Odontoceti, Mamm.). Paläontologische Zeitschrift. 42:83-104, 3 figures, 2 plates.

1971. Cetotheriopsis tobieni n. sp., der erste paläogene Bartenwal (Cetotheriidae, Mysticeti, Mamm.) nördlich des Tethysraumes. Abhandlungen des Hessischen Labdesamtes für Bodenforschung, 60:131148, 3 figures, 3 plates

1985. The Early Evolution of Cetacea. Fortschritte der Zoologie, 30: $143-147$

Sanders, A.E

1980. Excavation of Oligocene Marine Fossil Beds near Charleston, South Carolina. National Geographic Society Research Reports, 12:601621,8 figures.

Sanders, A.E., and L.G. Bames

1989. An Archaic Oligocene Mysticete from South Carolina, U.S.A. $A b-$ stracts, Eighth Biennial Conference on the Biology of Marine Mammals, Pacific Grove, California, 7-11 December 1989, page 58

1991. Late Oligocene Cetothriopsis-like Mysticetes (Mammalia, Cetacea), from near Charleston, South Carolina. Journal of Vertebrate Paleontology, supplement, 11(3):54A.

2002. Paleontology of the Late Oligocene Ashley and Chandler Bridge Formations of South Carolina, 2: Micromysticetus rothauseni, a Primitive Cetotheriid Mysticete (Mammalia: Cetacea). In R. Emry, editor, Cenozoic Mammals of Land and Sea: Tributes to the Career of Clayton E. Ray. Smithsonian Contributions to Paleobiology, 93:271-292

Sanders, A.E., R.E. Weems, and E.M. Lemon, Jr.

1982. Chandler Bridge Formation-A New Oligocene Stratigraphic Unit in the Lower Coastal Plain of South Carolina. U.S. Geological Survey Bulletin, 1529-H:105-124, 4 figures.

True, F.W.

1907. Remarks on the Type of the Fossil Cetacean Agorophius pygmaeus (Müller). Smithsonian Institution Publication, 1694: 8 pages, 1 plate.

1908. On the Classification of the Cetacea. Proceedings of the American Philosophical Society, 47(189):385-391.

Van Valen, L.

1968. Monophyly or Diphyly in the Origin of Whales. Evolution, 22(1): $37-41$.

Weems, R.E., and A.E. Sanders

1986. The Chandler Bridge Formation (Upper Oligocene) of the Charleston, South Carolina, Region. In T.L. Neathery, editor, Geological Society of America Centennial Field Guide, Southeastern Section. pages 323-326, 1 figure. Tulsa, Oklahoma; Society of Economic Palcontologists and Mincrologists.

Whitmore, F.C., Jr., and A.E. Sanders

1977 ("1976"). Review of the Oligocene Cetacea. Systematic Zoology, 25(4):304-320. [Date on title page is 1976; actually publishcd in 1977.]

Yablokov, A.V.

1964. Konvergentsiya ili parallelizm $v$ razvitii kitoobraznykh. [Convergence or Parallelism in the Evolution of Cetaceans.] Paleontologicheskii Zhurnal, 1964, (1):97-106. [In Russian. Translated in International Geology Review. 17(8):1461-1468.] 


\title{
Plates for Joel Asaph Allen's Unpublished Monograph on the Mammalian Orders Cete and Sirenia and a Record of the Search for the Manuscript
}

\author{
James G. Mead and Rosemary G. Dagit
}

\section{ABSTRACT}

In 1882 Joel Asaph Allen published his "Preliminary List of Works and Papers Relating to the Mammalian Orders Cete and Sirenia" as a Bulletin of the United States Geological and Geographical Survey of the Territories. That list, consisting of 1013 bibliographic records in chronological order from 1495 to 1840 , was said to be one-third of the actual bibliography of a monograph on cetacean and sirenians on which Allen was working. Extensive archival searching has produced only the unpublished plates of the work. We have concluded that the monograph does not reside in any of the logical archival repositories.

\section{Introduction}

Joel Asaph Allen is perhaps best known for his work with the American Ornithological Union while curator at the American Museum of Natural History. Less well known, but by no means less significant, is his work on mammals. In 1882, "The Preliminary List of Works and Papers Relating to the Mammalian Orders of Cete and Sirenia" was published in the Bulletin of the United States Geological and Geographical Survey of the Territories, volume 6 . This annotated bibliography contains 1013 titles extending from 1495 to 1840 . Allen had received a copy of the galley proofs of the remaining titles, covering the years 1840 to approximately 1880 . Because of a number of factors to be explained in this paper, that portion of the work was never published. The purpose of this research paper was to try to locate the missing portion of that work.

INSTITUTIONAL ABBREVIATIONS.-The following institutional abbreviations are used:

AMNH American Museum of Natural History, New York

James G. Mead, Division of Mammals, National Museum of Natural History, Smithsonian Institution, Washington, D.C. 20560-0108. Rosemary G. Dagit, 19989 Sischo Drive, Topanga, California 90290.

\author{
GPO Government Printing Office, Washington, D.C. \\ MCZ Museum of Comparative Zoology, Harvard University, Cam- \\ bridge, Massachusetts \\ USGS United States Geological Survey \\ USNM Collections of the National Museum of Natural History, in- \\ cluding those of the former United States National Museum, \\ Washington, D.C.
}

ACKNOWLEDGMENTS.--None of this would have been possible without the generous help of the archival community. In particular we want to express our thanks to the following: Carol Spawn, Academy of Natural Sciences, Philadelphia; Steve Cartlett, American Philosophical Society; Christine Raggeri, College of Physicians, Philadelphia; Linda Stanley, Historical Society of Philadelphia/The Library Company; Head Librarian, MCZ; William Cox, Smithsonian Institution Archives; Mary Rabbitt, Historian, George Goodwin, Head Librarian, and Cliff Nelson, Invertebrate Paleontologist, USGS; Michele Pacifico, USGS Records, and Edward Shamel, GPO Records, United States National Archives; James Dallet, Archivist, University of Pennsylvania Archives, Philadelphia; and all of the following at the AMNH: Pam Haas, Main Archivist; Mary Lecroy, Science Assistant, Ornithology; Marie Lawrence, Mammals Librarian; Charlotte Holton, Osborn Librarian.

\section{History of Allen's Work}

Joel Asaph Allen was born in Springfield, Massachusetts, on 19 July 1838 (Allen, 1916). He entered the Wilbraham Academy as a student in 1858 and started his academic publishing career with a series of articles on the birds of New England, which appeared in the New England Farmer starting on $11 \mathrm{Au}-$ gust 1860 . He entered the Lawrence Scientific School at Harvard in February 1862 under the tutelage of Louis Agassiz at the Museum of Comparative Zoology. Allen distinguished himself as a general naturalist, although his tendencies lay in the studies of birds and mammals, with which he was to be- 
come an expert in later years. He went with Agassiz to Brazil in 1865 and, with few interruptions, was employed as an assistant to Agassiz at the MCZ until he resigned that post to take up a curatorship at the American Museum of Natural History in New York in May of 1885. One of these interruptions was his assistantship to Spencer Fullerton Baird, then Assistant Secretary of the Smithsonian Institution, to lead an expedition to the Yellowstone Territory in 1873.

\section{INVOLVEMENT WITH UNITED STATES GEOLOGICAL AND GEOGRAPHICAL SURVEY OF THE TERRITORIES}

Extended research into the Hayden Survey of the Territories and the history of the United States Geological Survey, as well as Allen's life, was necessary. In his autobiography Allen (1916:32) stated that he was a "special collaborator" with the Hayden Survey from 1876 to 1882 . He was primarily headquartered at the MCZ. He also received payment "for services rendered as naturalist" for four months, February-May 1879. During his association with the Survey, he published a monograph on North American Rodentia with Elliott Coues as coauthor in 1877. Allen corresponded frequently with Spencer Baird at the Smithsonian concerning specimen exchange and acquisition. In May 1876, he wrote asking for permission from Baird to give Hayden a chance to publish his work on North American mammals. This correspondence suggests that the Smithsonian had some interest in the work but does not indicate how Allen became associated with the Hayden publications. January of 1877 found Allen "hard at work on the Sciuridae for Hayden" (archival reference $\mathrm{H}$ ) and asking to use the Smithsonian collection to finish his pinniped work.

Allen continued to work on the "History of North American Pinnipeds, a Monograph of the Walruses, Sea-Lions, Sea-Bears and Seals of North America," which finally appeared as number 12 of the Miscellaneous Publications of the Geological and Geographical Survey in 1880. Records exist indicating payment and correspondence connected with proofing both copy and plates.

In May 1880, Allen wrote to Baird discussing his current work on cetaceans (letter from Allen to Baird dated 11 May 1880; archival reference E). As of September 1881, he had completed the bibliography (some of which was in the hands of the printer) and designed eight original plates to illustrate the monograph text (letter from Allen to Baird dated 26 September 1881; archival reference F). T. Sinclair and Sons produced the plates, a total of 12 , which were drawn by James Henry Blake.

In 1881, Baird wrote to Allen (archival reference F) asking if he had received the cetacean proofs that Baird forwarded from the public printer. Allen replied in the affirmative. It is not clear why the proofs were originally sent to Baird (archival reference I).

\section{ILLNESS}

Allen came down with a "serious attack of pleurisy" (Allen, 1916:32) in December of 1881. Allen's poor health took him to Colorado for several months and there is correspondence from both Hayden and Coues asking him to publish the edited portion of the bibliography and to finish the remainder when he regained his health. Following the publication of part of the work, correspondence continued, including a letter from Alexander Agassiz to Baird concerning a missing manatee plate from Allen's work (Smithsonian Archives RU 30, box 1).

It was clear that Allen's illness strongly affected his working ability. In his autobiography (Allen, 1916:33) he noted that on returning to Cambridge in September of 1882 (after spending the summer in Colorado Springs on the advice of his physicians) he learned that his medical difficulties were caused by a "nervous breakdown." Considering the state of psychiatry in 1882, that diagnosis could encompass a number of disorders. He continued to work part-time at the MCZ until the spring of 1885 .

\section{CURATORSHIP AT THE AMERICAN MUSEUM OF NATURAL HISTORY}

In 1885 the financial affairs of the Museum of Comparative Zoology took a downward turn (Allen, 1916:33). At that time three opportunities presented themselves: (1) Allen could continue to work at the $\mathrm{MCZ}$ but at the risk of the position's being terminated because of lack of money; (2) he could accept a position on the United States Geological Survey; or (3) he could accept a curatorship that had been offered to him by the American Museum of Natural History. He chose the last alternative, and in his autobiography he indicated that this was with the blessing of Agassiz (Allen, 1916:33).

This assertion of Agassiz's approval is in contrast to the sentiments Agassiz expressed in a note appended to Allen's letter of resignation (25 April 1885; archival reference $G$ ) from his post at the MCZ. In that note Agassiz indicated that he had allowed Allen to remain on full salary for the past three years while he recovered from his illness with the expectation that Allen would resume his post at the MCZ.

A note written by Allen in 1908 in his "North Atlantic Right Whale and its near Allies" (pp. 279-280) indicates that, following the reorganization of the USGS, there was no money to publish the remaining zoological work begun under Hayden. He also indicates that although ill health was initially the impediment to finishing the work, other interests later took precedence. The AMNH had obtained considerable material of the North Atlantic right whale through the efforts of Roy Chapman Andrews and the shore whalers of southern Long Island (Andrews, 1908). This prompted Allen to publish the right whale section of his monograph (Allen, 1908). 


\section{DEMise of the United STATES GeOlogical AND GEOGRAPHICAL SURVEY OF THE TERRITORIES}

The United States Geological and Geographical Survey of the Territories, led by F.V. Hayden, was charged with exploring and assessing the geological and agricultural prospects of the areas now known as Colorado, Wyoming, North and South Dakota, Nebraska, and Michigan (Nelson et al., 1981). The results of the survey were published in several forms, as annual reports, bulletins, maps, and miscellaneous publications. Hayden was personally involved in the printing of most works and corresponded frequently with both the authors and the printers. Thomas Sinclair and Sons, in Philadelphia, did almost all of the plates associated with the survey publications.

On 30 June 1879, the Hayden Survey of the Territories was officially merged with the Powell and King Surveys into the United States Geological Survey, with Clarence King as director (Records of the 45th Congress; see Appendix). The politics surrounding the merger were quite unpleasant, and Hayden was disappointed at not being named director. He did, however, stay on as a geologist. Congress designated $\$ 20,000$ to finish the publications begun under Hayden.

In 1886, Hayden retired from the USGS and moved to Philadelphia, where he died on 22 December 1897. His wife, Emma Woodruff Hayden, lived until 1934 but did not deposit his personal papers with any institution. Edward Woodruff Johnson, her nephew, was beneficiary in her will. There remained a close friendship between the Hayden/Woodruff families and the Allen family, as shown by a gift of Allen's personal copy of his autobiography from his wife, Susan Allen, to one of the Woodruffs. This copy is currently in the library of the AMNH. It is possible that the manuscript has been preserved in the Woodruff family papers, but to eliminate this possibility would require extensive genealogical work and contacting collateral descendants.

To establish the preceding chain of events, we carefully examined the records of the USGS. All incoming and outgoing correspondence of the Hayden Survey as well as the new Geological Survey under King were examined for the years 1874-1882. Few references to Allen exist. The only letters from him are in support of Hayden's appointment as director or in reference to the rodent or pinniped works. No mention was made of the cetacean work. Hayden wrote and received many letters from both the public printer and T. Sinclair and Sons, none of which mention Allen. Records of the USGS (Record Group 57) show accounts and appointments. Hayden's appointment as geologist is included as well as his notes acknowledging receipt of his paycheck. Most of these records are on microfilm. The loose papers yet to be photographed also were examined and yielded nothing more. No mention was made of Allen's being commissioned or receiving payment for his work on cetaceans. Perhaps this explains why the funds specified by Congress for printing the remaining Hayden works did not include Allen's bibliography. The publication records of the Hayden Survey indicated that all printing was done through the
Government Printing Office, so the archival material in Record Group 157, containing all GPO records, also were examined. This included incoming and outgoing correspondence and records of orders for printing. The public printers during the years $1880-1882$ were John D. Defrees and S.P. Rounds. The chief clerk, involved in most correspondence, was A.F. Childs. In the large volume of correspondence between $\mathrm{T}$. Sinclair and Sons and the GPO, no letters pertain to Allen's work.

Among the records of Orders for Executive Printing, however, is a reference to an order for 3000 copies of "Bulletin Vol. VI, no. 3," dated 3 October 1881. A later entry (17 July 1882) mentions an order for 200 copies of "Hayden's bull. vol. 6, no. 3 (Allen)." This could be the author's reprint request. Each order at the GPO was given its own folder, called a "white jacket," which contained all the information pertaining to that job. Unfortunately these have all been destroyed.

Dr. Elliott Coues, an Army surgeon, took over as "acting director of the ex-Survey" (letter from Coues to Leidy dated 15 July 1879). He also was named Honorary Curator of Mammals at the Smithsonian and seemed to use that office to discharge his duties as editor of the Hayden Survey publications. There are several references by Coues concerning proofs being sent to both Allen and a proof reader, Mr. Young (letter from Coues to Leidy dated 20 January 1879). He maintained a consistent correspondence with both LeConte and Leidy, as well as with Allen. Coues and Allen had coauthored a monograph on North American rodents for the Survey and were close personal friends.

All correspondence for 1880-1882 was checked and, other than the above notes, there was no mention of the Allen manuscript. No letters to or from Allen were found. Coues seems to be the major correspondent concerning Hayden's reports but mentions only volumes 13 and 14 . Hayden remained involved until 1880 , mostly working on the copy and prints for the 1878 annual report and final report, volume 8 . There was some problem with timing and funding and Sinclair was asked to hold up work on the plates until Hayden came forth with the copy. The time lags and sequences of printing the survey material were quite erratic. It is somewhat curious that Allen is not mentioned at all, as the pinniped work came out in 1880 and the first part of the cetacean bibliography in 1882 .

Some correspondence refers to proofs but there is only one letter specifically addressing the cetacean bibliography (archival reference D). It also is curious to note that Coues does not appear on the USGS payroll but continued to use the United States Geological and Geographical Survey of the Territories letterhead for related correspondence until at least 1882 .

It is not clear how the payment of authors or engravers was handled. One reference (letter from Coues to LeConte dated 19 November 1879) indicates that Coues sent the bills and originals to Hayden. A letter from Hayden to LeConte in February 1879 said that he was not able to pay for a commissioned article at that time. A later letter from Hayden to the director of the USGS in December 1879 indicates that he was trying to finally 
settle survey accounts with the treasury department. There were no other ledger accounts except Hayden's salary after 1880.

\section{ARCHIVAL SOURCES CONSULTED}

None of the archival sources yielded the actual manuscript or contained more than limited references to it. It seems curious that, during a time noted for frequent correspondence between colleagues, Allen is not better represented in the papers of Leidy, LeConte, Hayden, or Baird. The material in the National Archives pertaining to the USGS and the GPO has been carefully searched and all relevant facts have been discussed above. It is not worth looking there any further. All Philadelphia sources have been covered with the exception of Edward Woodruff Johnson, a descendant of Hayden, who may still be alive and possibly in possession of some of Hayden's personal papers. Letters to other archival holdings of Hayden' papers have revealed little. Tracing the plates through Thomas Sinclair and Sons provided information indicating that any letter copy was done by the GPO.

\section{Plates for the Allen Monograph}

While the senior author (Mead) was a student at Yale University in the mid-1960s, he developed a rapport with the staff of the MCZ in Cambridge. Mead was collecting loose lithographic plates that Othniel Charles Marsh, of the Yale Peabody Museum, had produced. Mead followed a lead given him by William D. Sill, a student in Vertebrate Paleontology at the $\mathrm{MCZ}$, and approached the librarian of that museum, who was rumored to have several sets of loose lithographic plates for sale. This turned out to be the case and Mead bought one set. When he opened it he was delighted to find that it contained several Marsh plates that he did not have plus some other miscellaneous plates. It was common practice in the late nineteenth century for authors of monographs to have the plates printed separately from the text and to make extra copies of them to give to colleagues. It was not until Mead was going through the miscellaneous plates in the mid-1970s that he discovered a complete set of the plates for Allen's monograph on the Cetacea. The plates were printed as quarto illustrations, indicating that Allen had planned a quarto monograph and not an octavo, as was the case with his monograph on pinnipeds. They are reproduced herein (with the exception of Plate VIII, which was not found), and as complete a description of them as possible is given in the plate legends. The legends include the scientific names as they appear on the original plates, with the currently recognized names in brackets.

\section{CONCLUSIONS}

Some facts definitely have been established: (1) The monograph was assigned to be volume 6, part 3 of the Bulletin of the United States Geological and Geographical Survey of the Territories (Hayden Survey). The first part of the Bibliography was published under this reference. (2) Printing of the bulletin was done by the GPO. It is unclear who printed the reprint of Allen's partial bibliography, but most probably it, too, was printed in Washington, D.C. Reference was found to a law against printing anything at government expense except by the GPO. (3) Both Baird and Allen had access to the galley proofs at one time. Probably Coues and Hayden maintained copies also. Anything sent back to the GPO was either printed or destroyed. (4) A copy of the proofs was still in Allen's possession as late as 1916, as he mentions it in his autobiography and bibliography.

Most of Allen's personal papers are located at the AMNH. The main archives have two scrapbooks as well as miscellaneous correspondence, none of which pertains to the cetacean bibliography. Some manuscripts have been cataloged in the main library, but Allen's is not among them. The Ornithology Department has several file drawers full of Allen's correspondence. These were searched thoroughly, but unsuccessfully, for the manuscript and for letters to Coues, Hayden, Baird, and Thomas Sinclair and Sons. The archives of the Ornithology Department has a large collection of letters between Allen and Coues. It was here that mention was made of the bibliography and of Allen's health problems. The Osborn Library in Vertebrate Paleontology has copies of the plates but no manuscript.

The Mammalogy Department archives have recently been reorganized and, although the actual manuscript was not found, several interesting facts appeared. In 1921, all of Allen's books were purchased by the department for $\$ 200$. Cleveland Allen wrote in the 1930s asking for permission to look at his father's letters and papers. Dr. Frederick Lucas petitioned to have another of Allen's papers published posthumously. There also was a request from the South Dakota State College library for letters between Coues and Allen. It is certainly worth checking with them for further leads.

The authors would like to note that they have found Allen's published bibliography (Allen, 1882) so useful that they have put it into computer-readable format and used the extensive annotations to keyword it. It is available on-line as a part of the Smithsonian Institution Research Information System (SIRIS). 


\section{Appendix}

\section{Archival References}

A. Geological Survey, Records of the 45th Congress, Session III, Chapter 182, 1879, pages 394-395.

B. Letter from Elliott Coues to Joseph Leidy, dated 15 July 1879, in the Leidy Collection of the Hayden Papers (567), Academy of Natural Sciences, Philadelphia.

C. Letter from Elliot Coues to Joseph Leidy, dated 20 January 1879, in the Leidy Collection of the Hayden Papers (567), Academy of Natural Sciences, Philadelphia.

D. Letter from Elliott Coues to John LeConte, dated 19 November 1879, in the Elliott Coues Papers, American Philosophical Society, Philadelphia.

E. Letter from Joel Allen to Spencer Baird, dated 11 May 1880 , in the records of the Office of the Secretary (Spencer F. Baird), 1879-1882 (Smithsonian Archives, RU 28, box 14).

F. Letter from Joel Allen to Spencer Baird, dated 26 September 1881, in the records of the Office of the Secretary
(Spencer F. Baird), 1879-1882 (Smithsonian Archives, RU 28 , box 37 , folder 19 ).

G. Letter from Joel Asaph Allen to Louis Agassiz, dated 25 April 1885, resigning Allen's position at the Museum of Comparative Zoology; with a note in Agassiz's hand expressing dismay at the letter (Special Collections, MCZ, bag 33.10.1).

H. Letter from Joel Asaph Allen in Cambridge, Massachusetts, to Spencer Fullerton Baird, Assistant Secretary of the Smithsonian Institution, dated 9 January 1877, in the records of the office of the Assistant Secretary (Smithsonian Archives, RU 52, box 38, folder 192).

I. Letter from Spencer Fullerton Baird to Joel Asaph Allen, dated 14 December 1881, about the proofs that Baird received from the public printer and was forwarding to Allen (Smithsonian Archives, RU 33, file 115b-480).

\section{Literature Cited}

Allen, J.A.

1880. History of North American Pinnipeds: A Monograph of the Walruses, Sea-lions, Sea-bears and Seals of North America. United States Geological and Geographical Survey of the Territories, F. V. Hayden, Geologist-in-Charge, Miscellaneous Publications, 12: xvi +785 pages, 60 woodcuts

1882. Preliminary List of Works and Papers Relating to the Mammalian Orders Cete and Sirenia. Bulletin of the United States Geological and Geographical Survey of the Territories, 6(3):399-562. [Reprinted by Arno Press, New York, 1974.]

1908. The North Atlantic Right Whale and Its Near Allies. Bulletin of the American Museum of Natural History, 24:277-329.
1916. Autobiographical Notes and a Bibliography of the Scientific Publications of Joel Asaph Allen. xi +215 pages. New York: American Museum of Natural History.

Andrews, R.C.

1908. Notes upon the External and Internal Anatomy of Balaena glacialis Bonn. Bulletin of the American Museum of Natural History, 24(10): 171-182.

Nelson, C.M., M.C. Rabbitt, and F.M. Fryxell

1981. Ferdinand Vandeveer Hayden: The U.S. Geological Survey Years, 1879-1886. Proceedings of the American Philosophical Society, 125(3):238-243. 


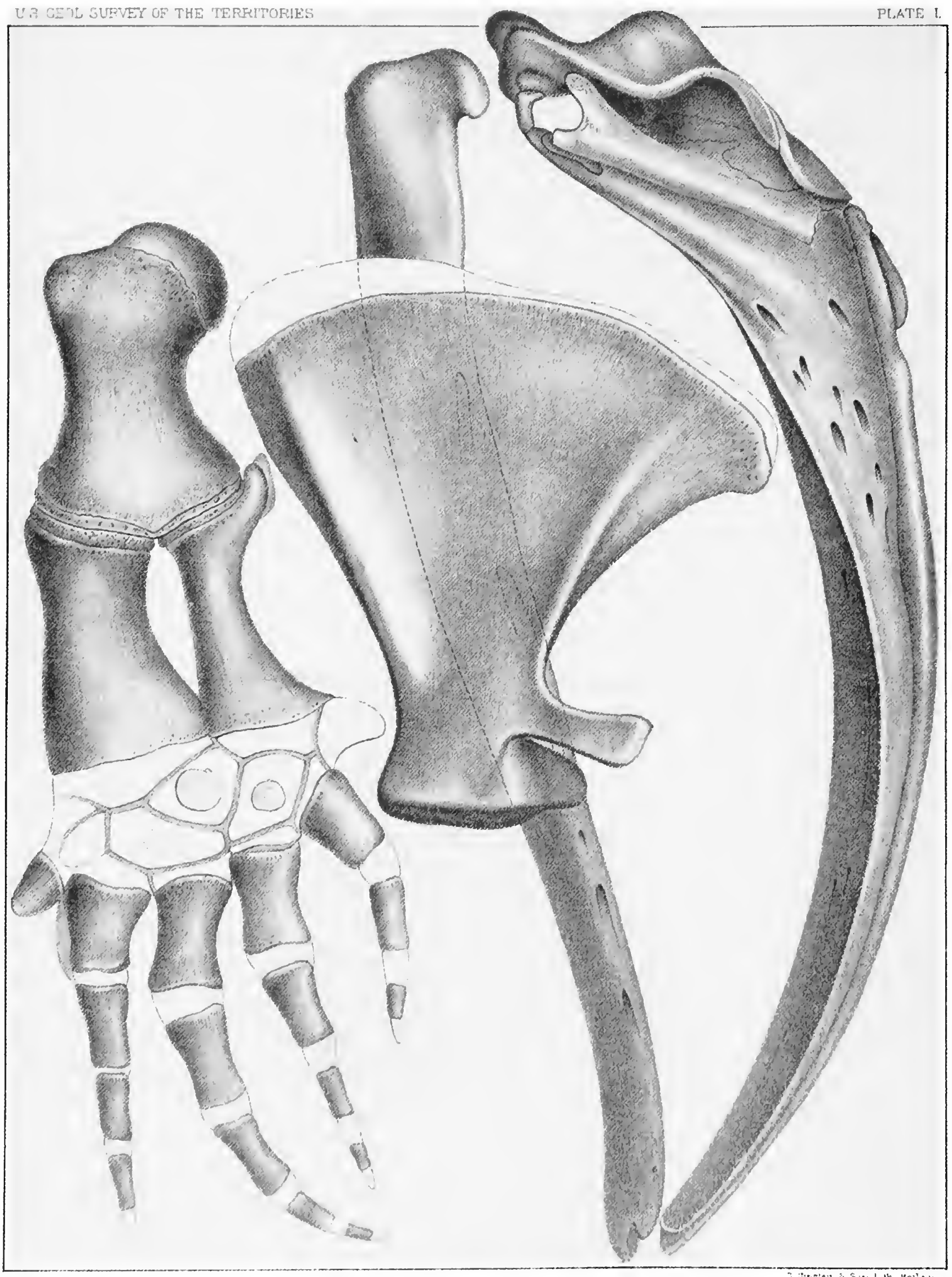

if H thake del

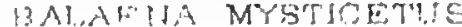

PLATE I.-Balaena mysticetus: Right lateral view of skull and mandible; lateral view of right scapula; medial view of right flipper. Specimen unknown. 


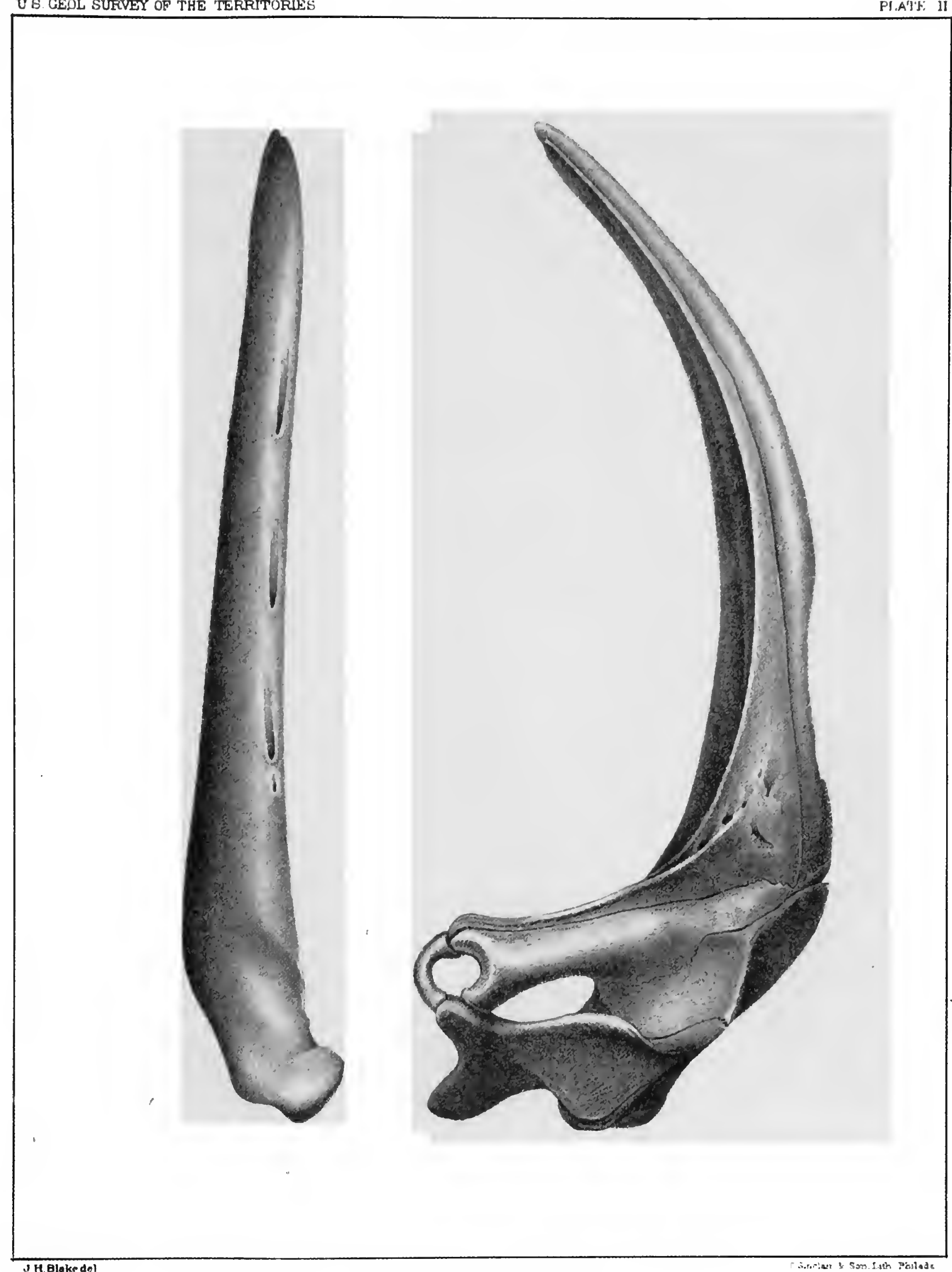

PLATE I1.-Balaena cisarctica [Eubalaena glacialis]: Left lateral view of skull and mandible. Skull in MCZ, taken in April 1864 at Provincetown, Massachusetts. Reproduced as Plate XIX in Allen, 1908. 


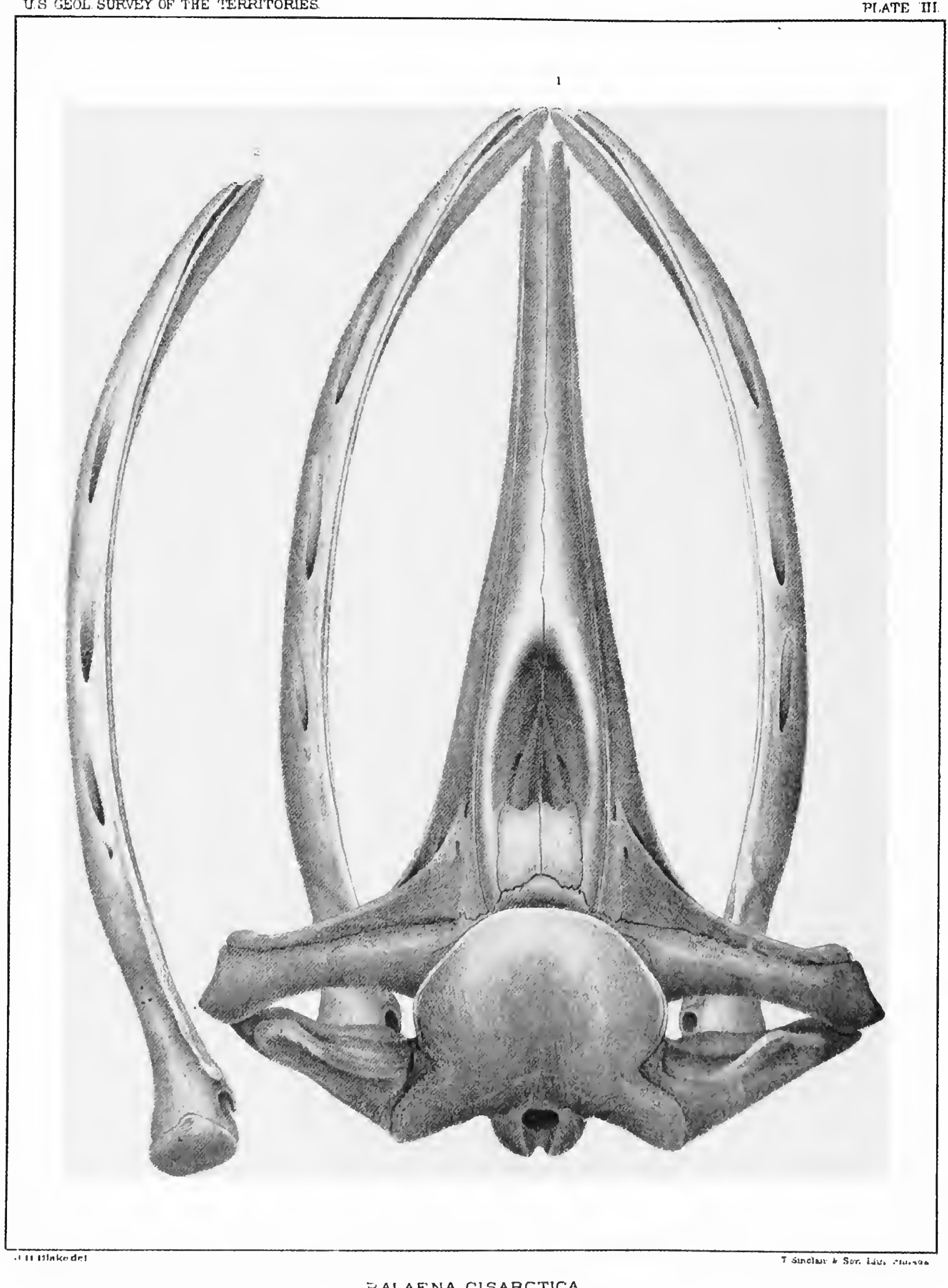

BALAENA CISARCTICA

PLATE 111.-Balaena cisarctica [Eubalaena glacialis]: 1, dorsal view of skull and mandibles; 2, dorsal view of left mandible. Skull in MCZ, taken in April 1864 at Provincetown, Massachusetts. Reproduced as Plate XX in Allen, 1908. 


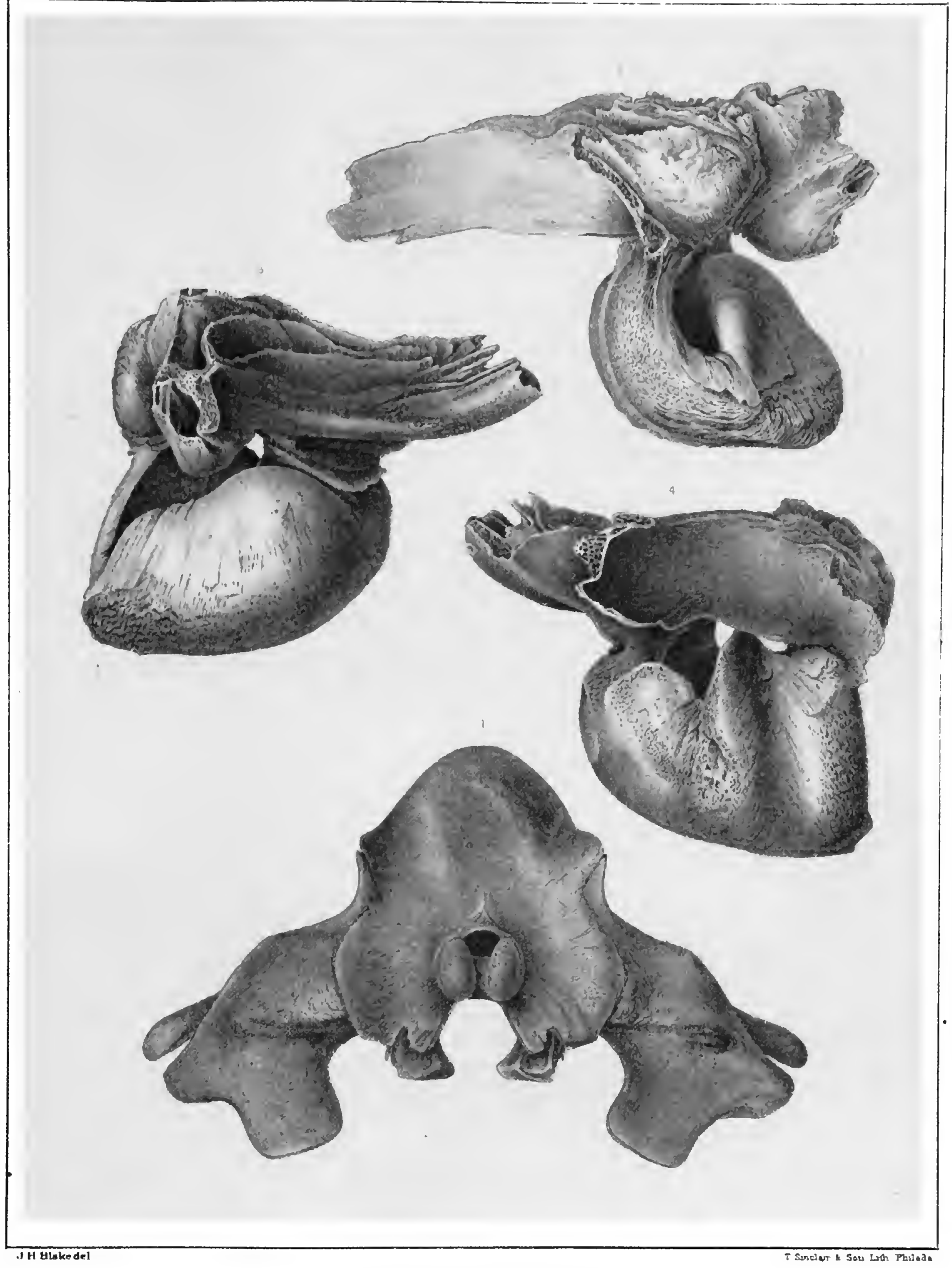

BALAENA CISARCTICA

PLATE IV.-Balaena cisarctica [Eubalaena glacialis]: 1, posterior view of skull and mandibles; 2, anterior view of right tympanoperiotic; 3, medial view of right tympanoperiotic; 4 , lateral view of right tympanoperiotic. Skull in MCZ, taken in April 1864 at Provincetown, Massachusetts. Reproduced as Plate XXI in Allen, 1908. 


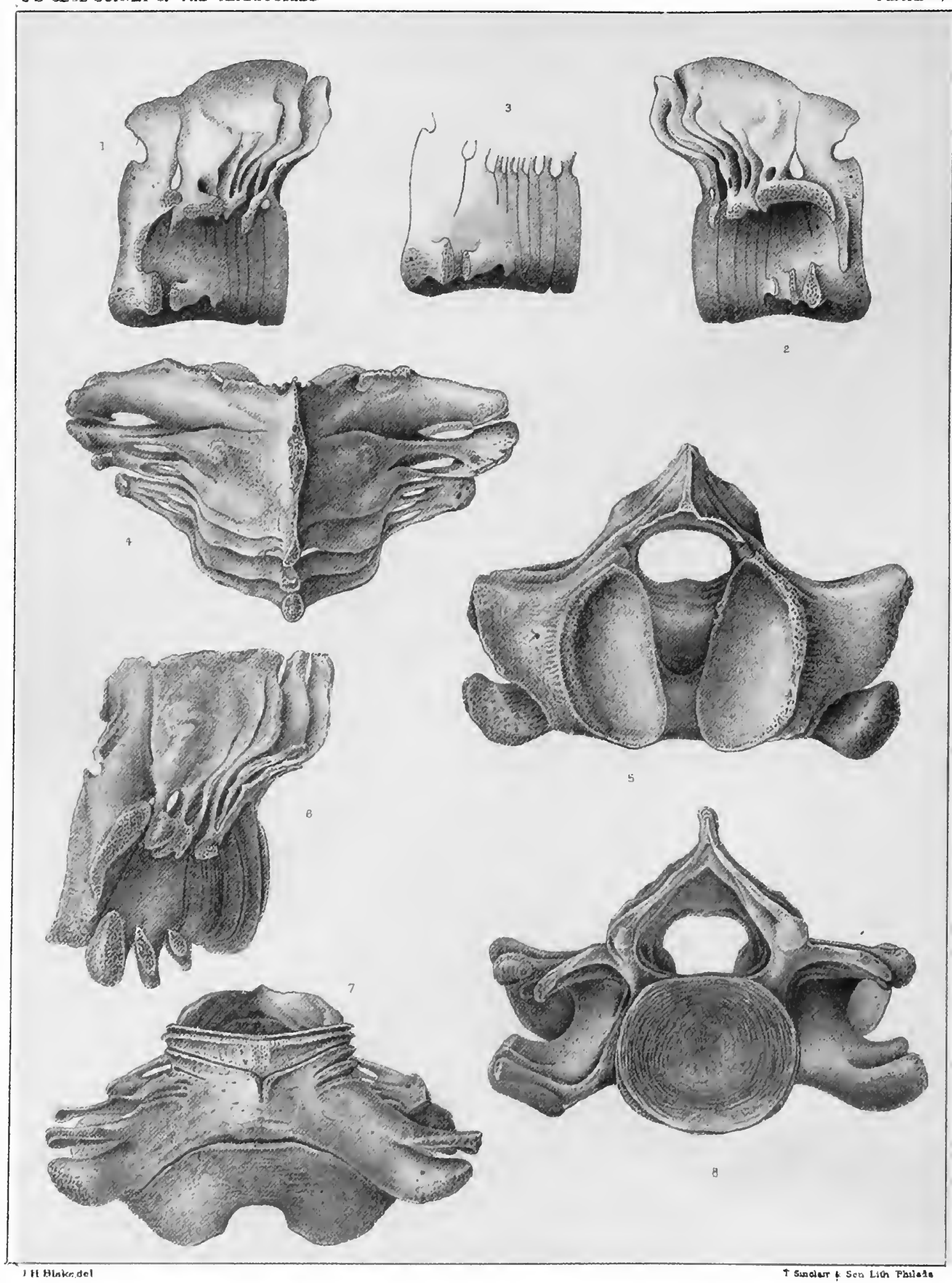

BALAENA CISARCTICA

PLATE V.-Balaena cisarctica [Eubalaena glacialis]: 1, left lateral view of the cervical vertebrae; 2 , left lateral view of the cervical vertebrae with dorsal processes hidden; 3 , right lateral view of the cervical vertebrae; 4 , dorsal view of the cervical vertcbrae; 5 , anterior view of the cervical vertebrae; 6 , left lateral view of the cervical vertebrae; 7 , ventral view of the cervical vertebrae; 8 , posterior view of the cervical vertebrae. 1-3, Holotype of Balaena cisarctica (USNM 301637); 4-8, specimen in MCZ, taken in April 1864 at Provincetown, Massachusetts. Reproduced as Plate XXIl in Allen, 1908. 


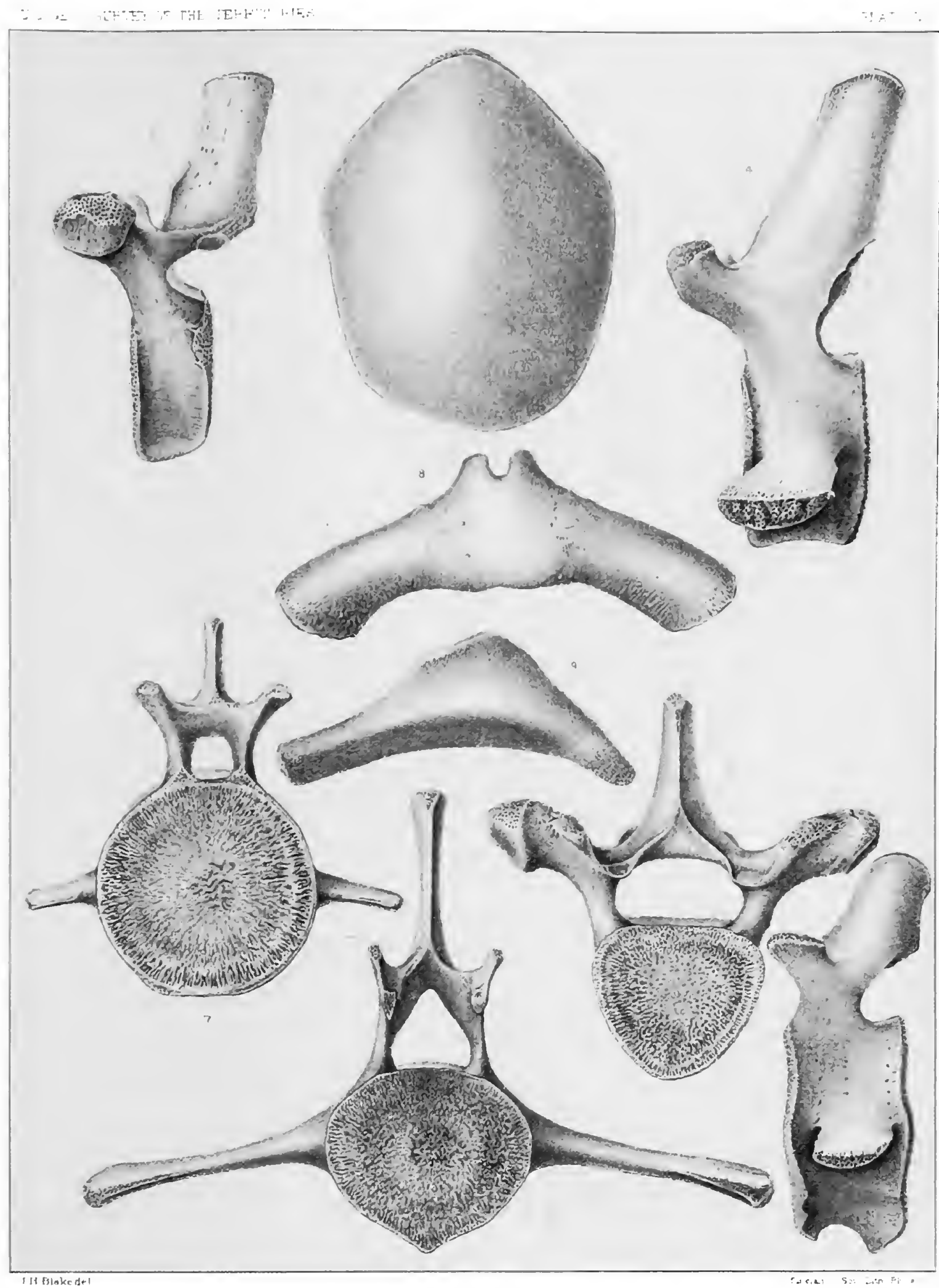

5.AENA : EAHCTICA

PLATE VI.-Balaena cisarctica [Eubalaena glacialis]: 1, ventral view of sternum; 2, left lateral view of sixth thoracic vertebra; 3 , anterior view of sixth thoracic vertebra; 4 , left lateral view of sixth lumbar vertebra; 5 , anterior view of sixth lumbar vertebra; 6 , left lateral view of sixth caudal vertebra; 7 , anterior view of sixth caudal vertebra; 8 , ventral(?) view of the fused basihyal and thyrohyal; 9 , external view of left pelvic vestige, anterior to the right, ventral to the top. Specimen in MCZ, taken in April 1864 at Provincetown. Massachusetts. Reproduced as Plate XXIII in Allen, 1908 . 


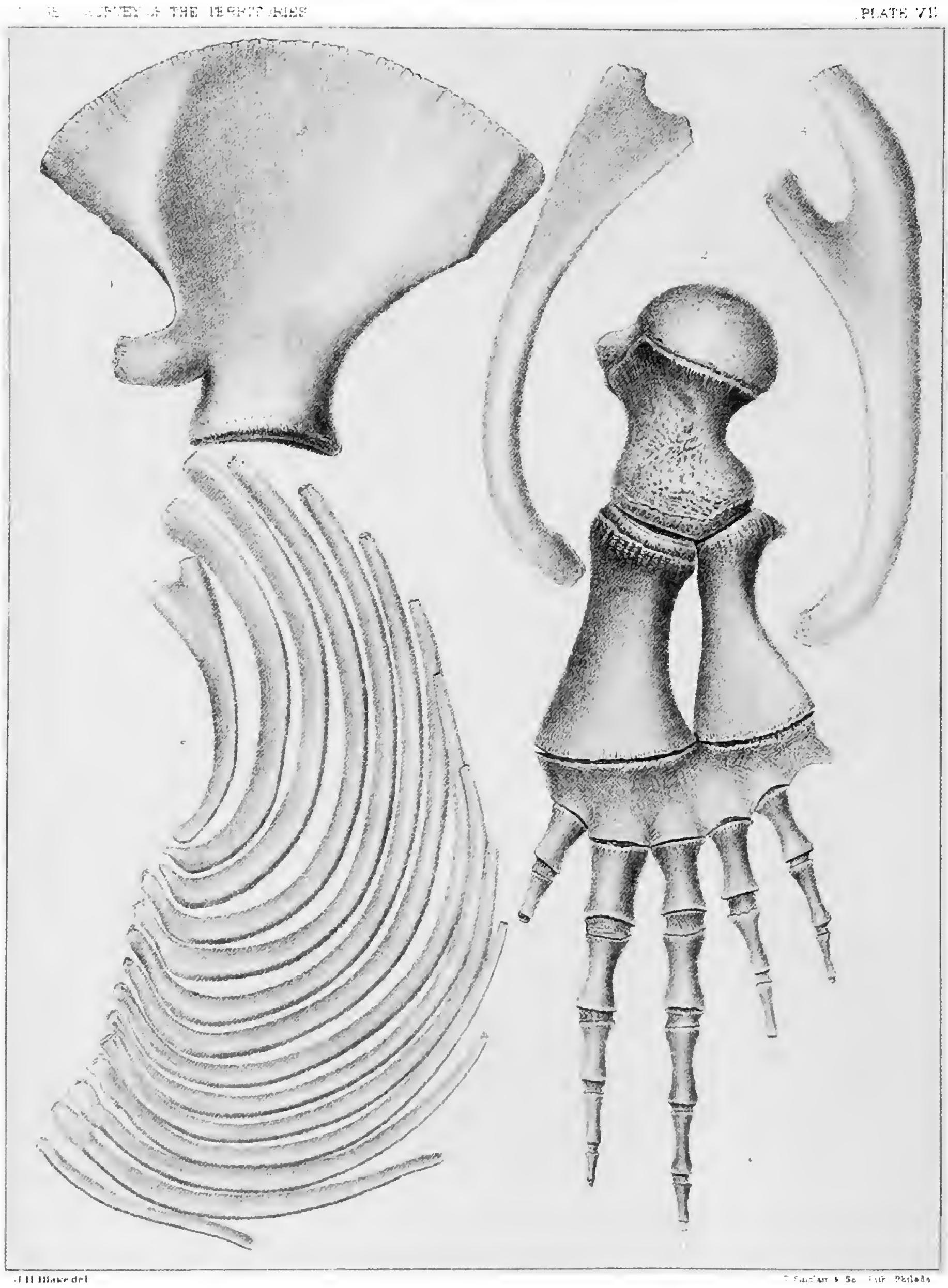

GALAENA USARCTICA

PLATE V11.-Balaena cisarctica [Eubalaena glacialis]: 1, lateral view of left scapula, anterior to the right; 2, lateral view of left flipper; 3, posterior view of the left first rib; 4, anterior view of the right first rib, ventral at top; 5, posterior view of right ribs, ventral at top. Speeimen in MCZ, taken in April 1864 at Provincetown, Massaehusetts. Reproduced as Plate XXIV in Allen, 1908. 


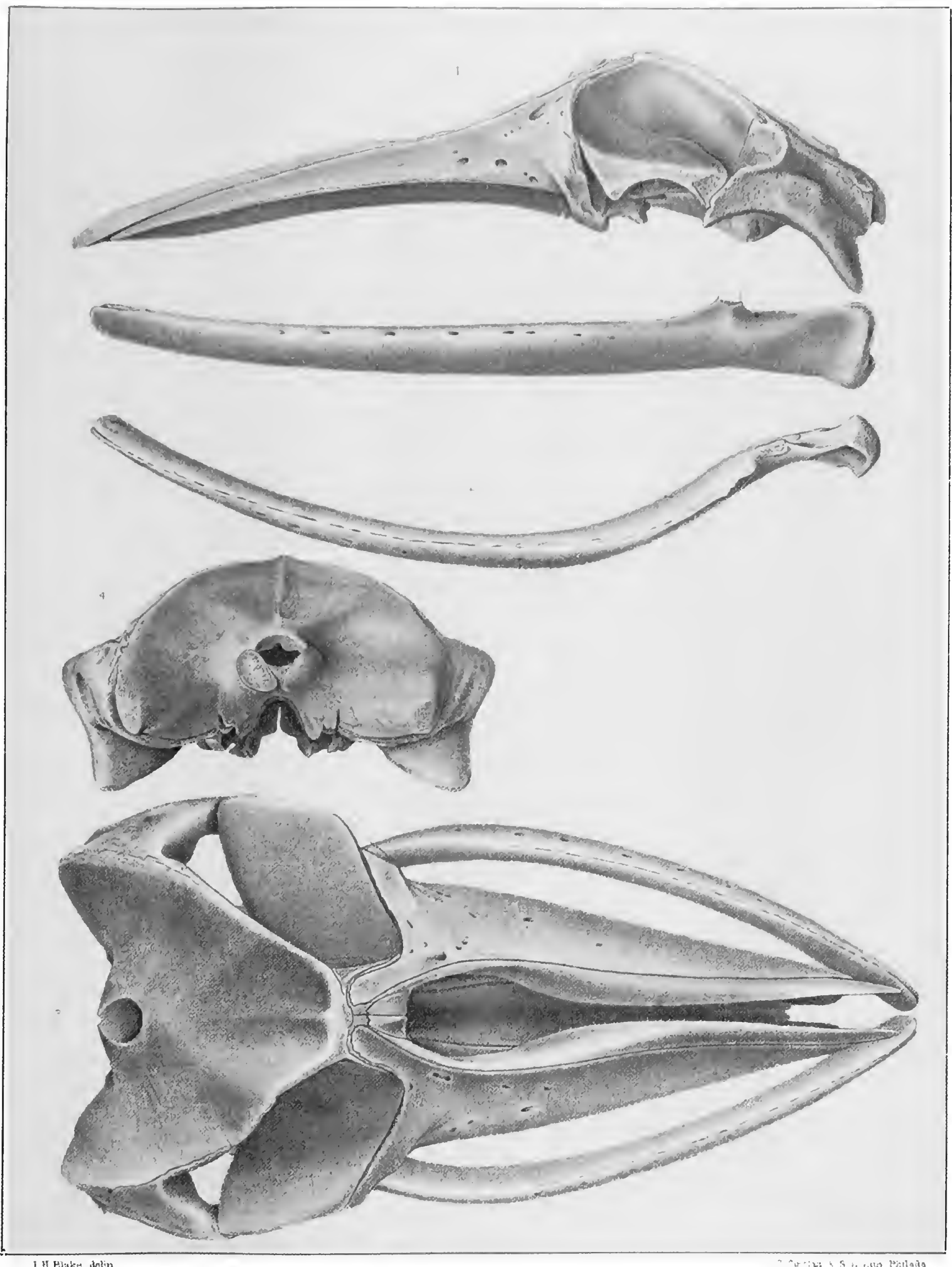

J 3t Elakts, delin

BALAENJPIERA ROSWTAY

[PLATE VIII.-(Not found.) The missing manatee plate referred to in letter to Agassiz from Allen dated 9 June 1886, which was enclosed in a letter from Agassiz to Baird (Smithsonian Archives RU 30, box 1).]

PLATE IX.-Balaenoptera rostrata [Balaenoptera acutorostrata]: 1, left lateral view of skull and mandible; 2, dorsal view of mandible; 3 , dorsal view of skull and mandibles; 4 , posterior view of skull. Specimen unknown. 


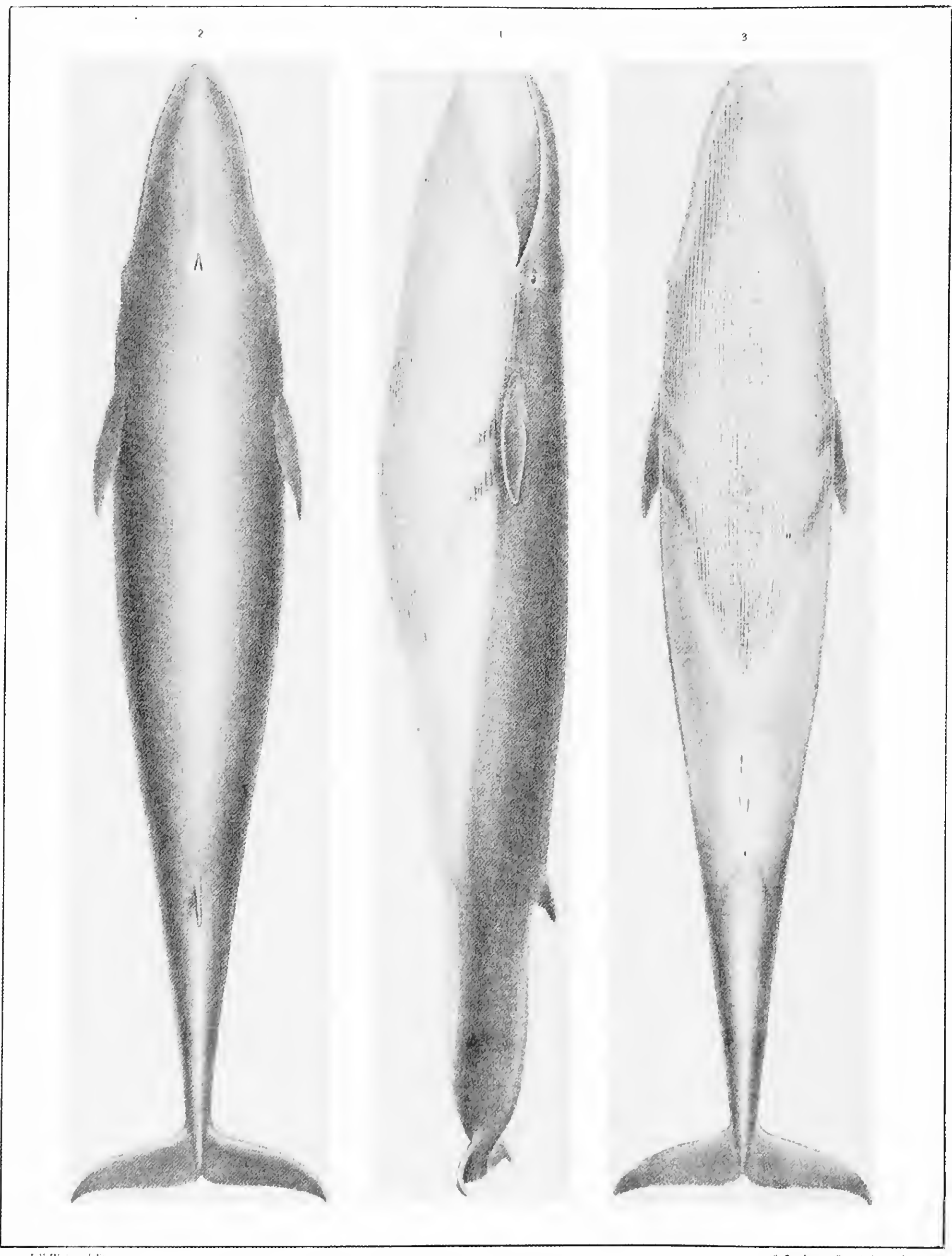

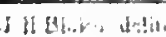

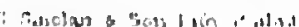

Plate X.-[Balaenoptera physalus], external view of whole animal: I, left lateral view; 2, dorsal view; 3, ventral view. Specimen unknown. 


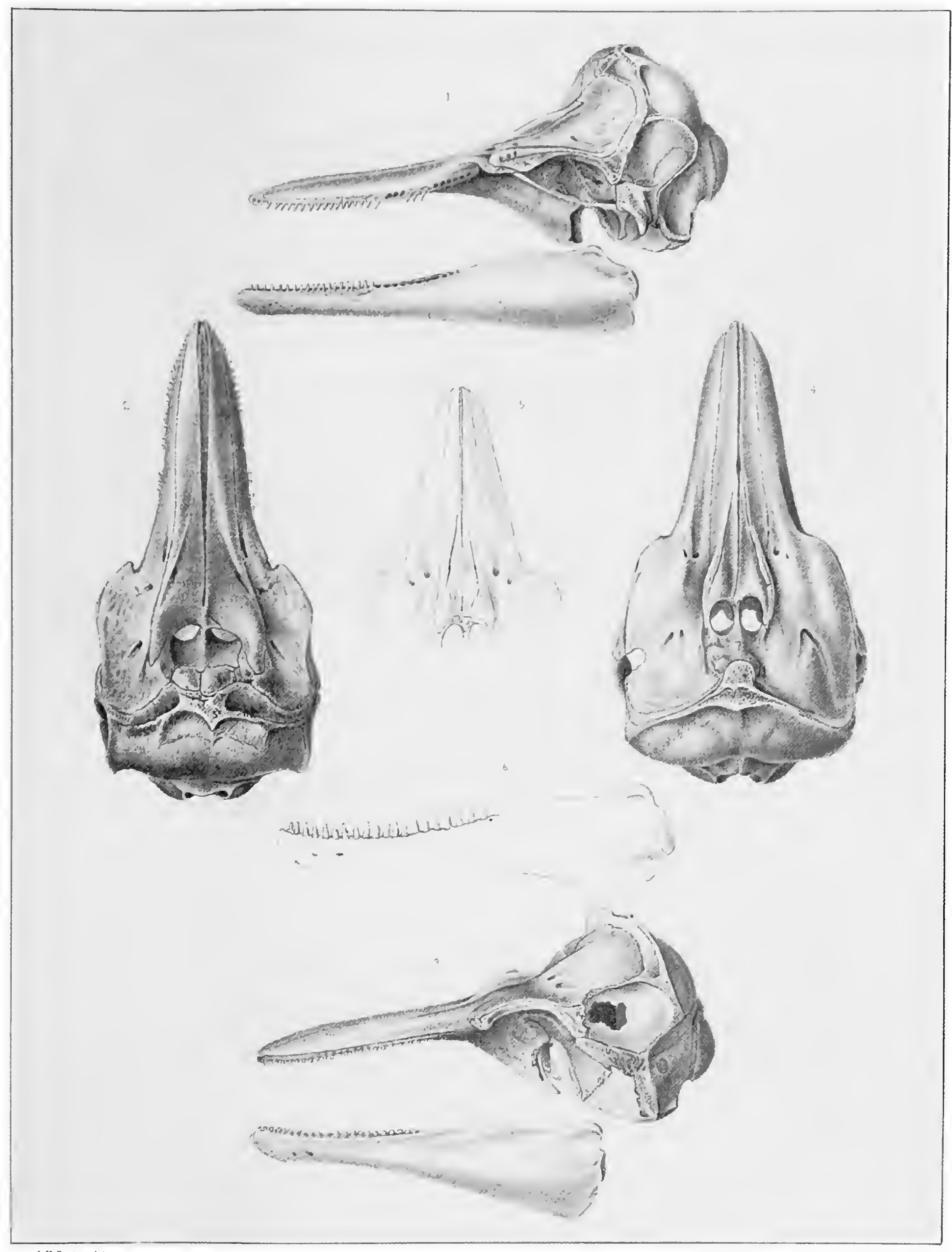

\&

PLATE XI.-1, 2 [Lagenorhynchus acutus]: 1, left lateral view of skull and mandible; 2, dorsal view of skull. 3-5 [Phocoena phocoena]: 3, left lateral view of skull and mandible; 4 , dorsal view of skull; 5 , dorsal view of rostrum. 6 [Tursiops truncatus]: left lateral view of mandible. Specimens unknown. 


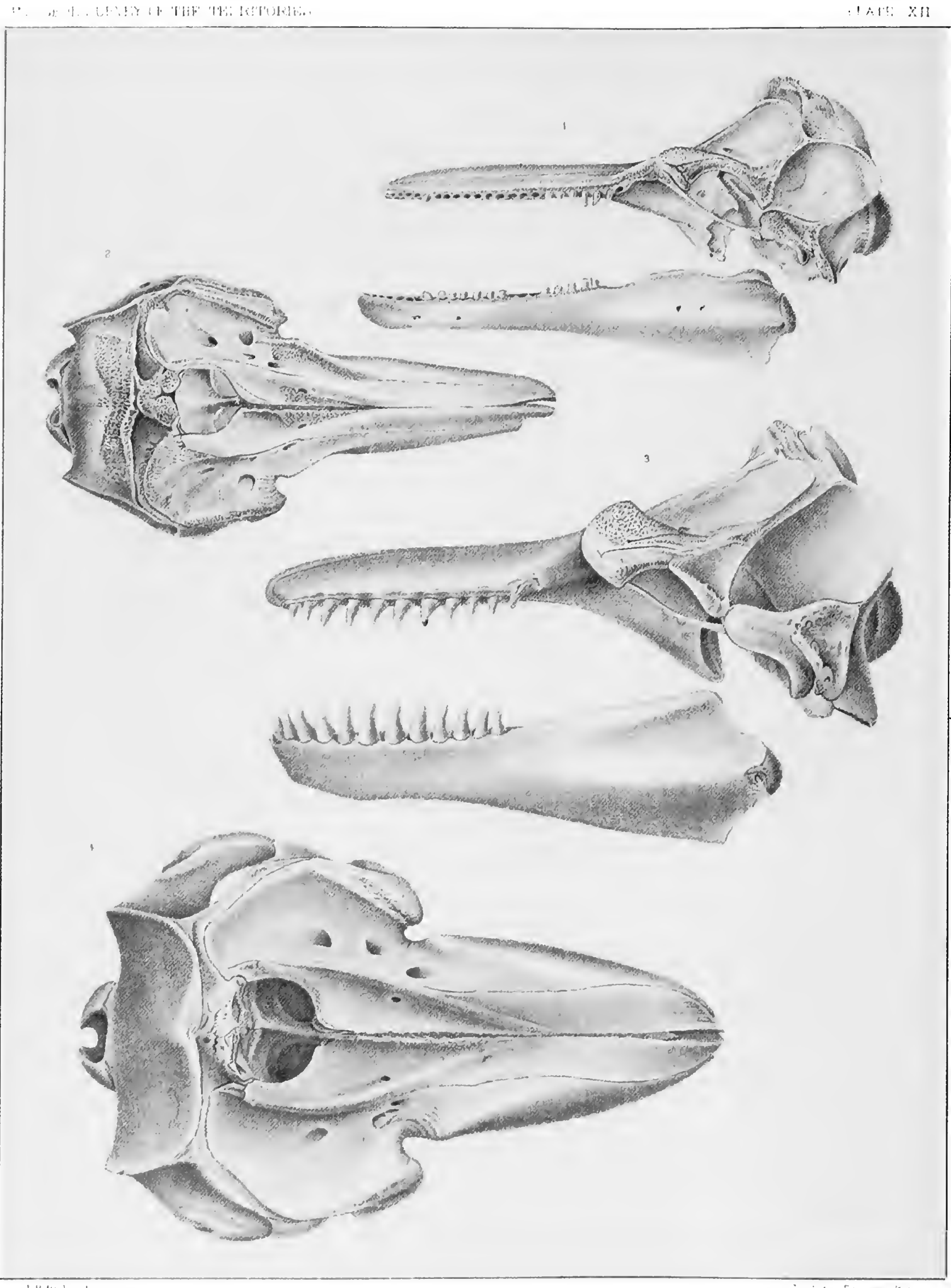

$141+16.4$

PLATE XII.-1, 2 [Tursiops truncatus] : I, left lateral view of skull and mandible; 2, dorsal view of skull. 3, 4 [Orcinus orca]: 3 , left lateral view of skull and mandible; 4 , dorsal view of skull. Specimens unknown. 




\section{REQUIREMENTS FOR SMITHSONIAN SERIES PUBLICATION}

Manuscripts intended for series publication receive substantive review (conducted by their originating Smithsonian museums or offices) and are submitted to the Smithsonian Institution Press with Form SI-36, which must show the approval of the appropriate authority designated by the sponsoring organizational unit. Requests for special treatment-use of color, foldouts, case-bound covers, etc.-require, on the same form, the added approval of the sponsoring authority.

Review of manuscripts and art by the Press for requirements of series format and style, completeness and clarity of copy, and arrangement of all material, as outlined below, will govern, within the judgment of the Press, acceptance or rejection of manuscripts and art.

Copy must be prepared on typewriter or word processor, double-spaced, on one side of standard white bond paper (not erasable), with $11 / 4^{\prime \prime}$ margins, submitted as ribbon copy (not carbon or xerox), in loose sheets (not stapled or bound), and accompanied by original art. Minimum acceptable length is 30 pages.

Front matter (preceding the text) should include: title page with only title and author and no other information; abstract page with author, title, series, etc., following the established format; table of contents with indents reflecting the hierarchy of heads in the paper; also, foreword and/or preface, if appropriate.

First page of text should carry the title and author at the top of the page; second page should have only the author's name and professional mailing address, to be used as an unnumbered footnote on the first page of printed text.

Center heads of whatever level should be typed with initial caps of major words, with extra space above and below the head, but no other preparation (such as all caps or underline, except for the underline necessary for generic and specific epithets). Run-in paragraph heads should use period/dashes or colons as necessary.

Tabulations within text (lists of data, often in parallel columns) can be typed on the text page where they occur, but they should not contain rules or numbered table captions.

Formal tables (numbered, with captions, boxheads, stubs, rules) should be submitted as carefully typed, double-spaced copy separate from the text; they will be typeset unless otherwise requested. If camera-copy use is anticipated, do not draw rules on manuscript copy.

Taxonomic keys in natural history papers should use the aligned-couplet form for zoology and may use the multi-level indent form for botany. If cross referencing is required between key and text, do not include page references within the key, but number the keyed-out taxa, using the same numbers with their corresponding heads in the text.

Synonymy in zoology must use the short form (taxon, author, year:page), with full reference at the end of the paper under "Literature Cited." For botany, the long form (taxon, author, abbreviated journal or book title, volume, page, year, with no reference in "Literature Cited") is optional.

Text-reference system (author, year:page used within the text with full citation in "Literature Cited" at the end of the text) must be used in place of bibliographic footnotes in all Contributions Series and is strongly recommended in the Studies Series: "(Jones, $1910: 122)$ " or "...Jones (1910:122)." If bibliographic footnotes are required, use the short form (author, brief title, page) with the full citation in the bibliography.

Footnotes, when few in number, whether annotative or bibliographic, should be typed on separate sheets and inserted immediately after the text pages on which the references occur. Extensive notes must be gathered together and placed at the end of the text in a notes section.

Bibliography, depending upon use, is termed "Literature Cited," "References," or "Bibliography." Spell out titles of books, articles, journals, and monographic series. For book and article titles use sentence-style capitalization according to the rules of the language employed (exception: capitalize all major words in English). For journal and series titles, capitalize the initial word and all subsequent words except articles, conjunctions, and prepositions. Transliterate languages that use a non-Roman alphabet according to the Library of Congress system. Underline (for italics) titles of journals and series and titles of books that are not part of a series. Use the parentheses/colon system for volume (number):pagination: "10(2):5-9." For alignment and arrangement of elements, follow the format of recent publications in the series for which the manuscript is intended. Guidelines for preparing bibliography may be secured from Series Section, SI Press.

Legends for illustrations must be submitted at the end of the manuscript, with as many legends typed, double-spaced, to a page as convenient.

Illustrations must be submitted as original art (not copies) accompanying, but separate from, the manuscript. Guidelines for preparing art may be secured from the Series Section, SI Press. All types of illustrations (photographs, line drawings, maps, etc.) may be intermixed throughout the printed text. They should be termed Figures and should be numbered consecutively as they will appear in the monograph. If several illustrations are treated as components of a single composite figure, they should be designated by lowercase italic letters on the illustration; also, in the legend and in text references the italic letters (underlined in copy) should be used: "Figure 9b." Illustrations that are intended to follow the printed text may be termed Plates, and any components should be similarly lettered and referenced: "Plate 9b." Keys to any symbols within an illustation should appear on the art rather than in the legend.

Some points of style: Do not use periods after such abbreviations as "mm, ft, USNM, NNE." Spell out numbers "one" through "nine" in expository text, but use digits in all other cases if possible. Use of the metric system of measurement is preferable; where use of the English system is unavoidable, supply metric equivalents in parentheses. Use the decimal system for precise measurements and relationships, common fractions for approximations. Use day/month/ year sequence for dates: "9 April 1976." For months in tabular listings or data sections, use three-letter abbreviations with no periods: "Jan, Mar, Jun," etc. Omit space between initials of a personal name: "J.B. Jones."

Arrange and paginate sequentially every sheet of manuscript in the following order: (1) title page, (2) abstract, (3) contents, (4) foreword and/or preface, (5) text, (6) appendices, (7) notes section, (8) glossary, (9) bibliography, (10) legends, (11) tables. Index copy may be submitted at page proof stage, but plans for an index should be indicated when the manuscript is submitted. 
